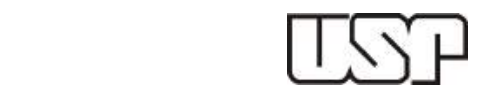

UNIVERSIDADE DE SÃO PAULO

FACULDADE DE FILOSOFIA, LETRAS E CIÊNCIAS HUMANAS PROGRAMA DE PÓS-GRADUAÇÃO EM HISTÓRIA ECONÔMICA

\title{
"O lápis é mais pesado que a enxada": reforma agrária no Chile e pedagogias camponesas para transformação econômica (1955-1973)
}

\author{
Versão Final Corrigida \\ Joana Salém Vasconcelos
}




\section{UNIVERSIDADE DE SÃO PAULO}

FACULDADE DE FILOSOFIA, LETRAS E CIÊNCIAS HUMANAS

PROGRAMA DE PÓS-GRADUAÇÃO EM HISTÓRIA ECONÔMICA

\section{"O lápis é mais pesado que a enxada": reforma agrária no Chile e pedagogias camponesas para transformação econômica (1955-1973)}

\section{Versão Final Corrigida}

Joana Salém Vasconcelos

Tese para obtenção do título de Doutora em História Econômica no Programa de Pós-Graduação em História Econômica do Departamento de História da Faculdade de Filosofia, Letras e Ciências Humanas da Universidade de São Paulo.

Orientador: Prof. Dr. Jorge Grespan

São Paulo 
Catalogação na Publicação

Serviço de Biblioteca e Documentação

Faculdade de Filosofia. Letras e Ciências Humanas da Universidade de São Paulo

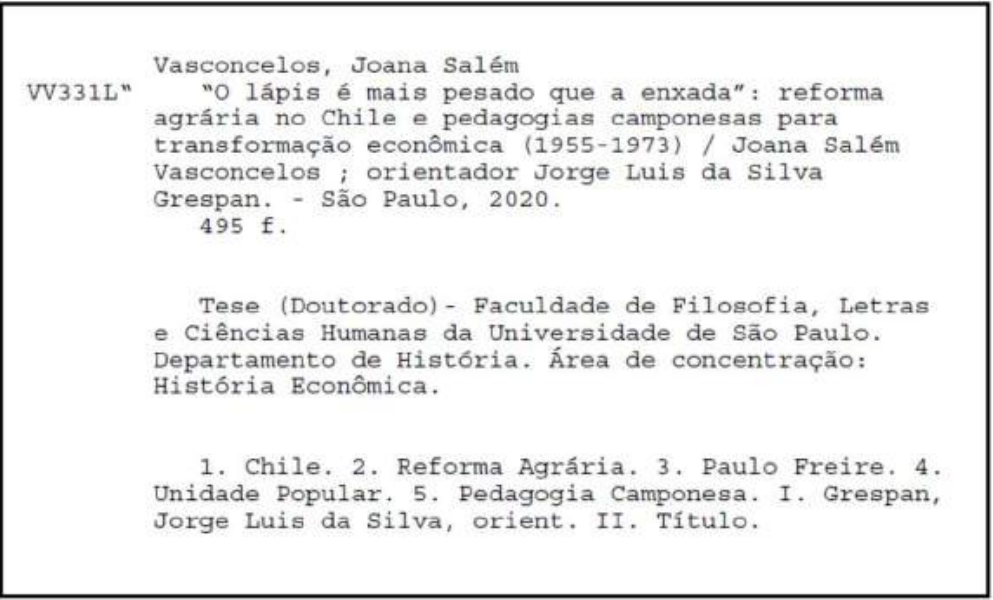




\section{(") $f f l c h$ UNIVERSIDADE DE SÃO PAULO \\ ㄱf Ch FACULDADE DE FILOSOFIA, LETRAS E CIÊNCIAS HUMANAS}

\section{Termo de Ciência e Concordância do orientador}

Nome do (a) aluno (a): Joana Salém Vasconcelos

Data da defesa: 17/12/2020

Nome do Prof. (a) orientador (a): Jorge Luis da Silva Grespan

Nos termos da legislação vigente, declaro ESTAR CIENTE do conteúdo deste EXEMPLAR CORRIGIDO elaborado em atenção às sugestões dos membros da comissão Julgadora na sessão de defesa do trabalho, manifestando-me plenamente favorável ao seu encaminhamento e publicação no Portal Digital de Teses da USP.

São Paulo, 10/02/2021

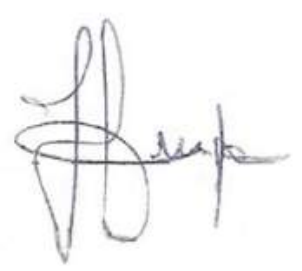


Para Jacques Chonchol, Alicia Muñoz, Oscar Torres e Pancha Rodríguez, lutadores da vida inteira pela reforma agrária.

Para todos os camponeses e camponesas do Chile que batalharam pela conquista da terra $\mathrm{e}$ foram reprimidos pela ditadura. 


\section{Agradecimentos}

Esta tese é resultado de cinco anos de trabalho e de uma teia de relações de aprendizado. Muitas pessoas generosas e parceiras contribuíram para que minha pesquisa pudesse ser construída, superasse desafios e encontrasse seu curso.

Agradeço a meu orientador Jorge Grespan, que permaneceu leve, confiante e rigoroso. À historiadora Heidi Tinsman, que supervisionou meu estágio doutoral na Universidade da Califórnia, me disponibilizou suas caixas-arquivo chilenas e me desafiou a encontrar um caminho mais amplamente alicerçado em fontes primárias. Ao professor Rolando Álvarez, da USACH, que além de me orientar em minhas estadias no Chile, me levou para conhecer San Clemente e entrevistar personagens fascinantes da reforma agrária. A Tinsman e Álvarez também agradeço pelos comentários rigorosos e elogiosos na Banca de Defesa, com os quais muito me honraram, ao lado do professor Lincoln Secco (USP), que desde minha graduação foi um grande parceiro. Agradeço à professora Márcia Cury e ao professor Luiz Bernardo Pericás, pelo diálogo construtivo na Banca de Qualificação em agosto de 2018. Aos professores de Geografia Agrária da USP, Valeria de Marco e Ariovaldo Umbelino, que provocaram interações histórico-geográficas na minha pesquisa e me motivaram a aprofundar minha compreensão do sujeito camponês.

Agradeço à FAPESP (processo 2016/13432-4), cujo financiamento e apoio foram imprescindíveis para viabilizar uma pesquisa ancorada em sete arquivos de três países (Chile, EUA, Brasil) e conduzida em regime de dedicação exclusiva. Aos funcionários do Programa de Pós-Graduação em História Econômica da USP, especialmente ao Nelson Caetano. À equipe do Instituto Paulo Freire em São Paulo, sobretudo Lutgardes Freire e Ângela Biz Antunes. Aos acolhedores funcionários da Biblioteca Nacional e do Archivo Nacional de la Administración (ARNAD), em Santiago do Chile. Aos funcionários do Departamento de História da UC Irvine, na pessoa de Yuting Wu.

Agradeço a Jacques Chonchol, que me recebeu em sua casa mais de sete vezes com sua habitual generosidade enquanto a tese era produzida. A primeira vez que o entrevistei em Santiago, em julho de 2011, eu desenvolvia meu mestrado e estava interessada na sua experiência da reforma agrária em Cuba. Poucos dias depois da minha visita, sua esposa, a brasileira Maria Edy Ferreira, faleceu. Cinco anos mais tarde compreendi que as pesquisas de Maria Edy eram uma fonte preciosa para meu doutorado. Não a conheci, mas também me sinto profundamente grata a ela.

Quando morei no Chile em 2017 e retornei ao país em 2018 e 2019, tive a sorte de encontrar o apoio de dezenas de pessoas, a quem devo meus agradecimentos. Ao professor Claudio Robles Ortiz, que me convidou para compor o Centro de Estudos de História Agraria da América Latina (CEHAL). A Diego Romero, que me ajudou com a coleta de fontes na BN. Ao solícito professor Octavio Avendaño, que me emprestou livros raros sobre a reforma agrária e me indicou os sebos da "Persa Bio Bio". Ao amigo Jaime Navarrete Vergara, que compartilhou comigo seus conhecimentos sobre o MCR e a esquerda chilena atual. Ao historiador Sergio Grez Toso, sempre disponível ao diálogo, à troca de 
análises e à solidariedade militante. A Daniela Zubicueta, que em seu mestrado encontrou fontes que eu procurava e me ofereceu materiais com a generosidade dos verdadeiros freirianos. Ao jovial Cristóbal Kay, que me compartilhou diálogos gravados de 1973 entre camponeses assentados, ele próprio e Peter Winn. A Cristóbal Bize, que me deu fotos das aulas de marxismo para camponeses pelo MIR.

A Vanderlei Vazelesk e a Clarinha, meus parceiros viajantes de duas Santiago, em dois continentes. A amiga e historiadora Elisa Borges, professora excelente, hospitaleira, que me ajudou com contatos chilenos desde 2015 e seguiu me estimulando. Em 2019, escrevemos juntas um capítulo sobre a visita de Fidel Castro no Chile de Salvador Allende, sem dúvida um dos meus trabalhos preferidos.

Agradeço às mais de quarenta pessoas que entrevistei no Chile durante os últimos cinco anos. Primeiramente, a Oscar Torres, atencioso, inteligente e ótimo narrador, que rapidamente se tornou um grande amigo. A Marcela Gajardo e a Rolando Pinto, que compartilharam comigo suas histórias de vida ao lado de Paulo Freire, com que viveram a experiência originária da Pedagogia do oprimido nos assentamentos da reforma agrária chilena. A Alicia Muñoz, Pancha Rodríguez e Jacqueline Arriegada, lideranças da Asociación Nacional de Mujeres Rurales e Indígenas (ANAMURI), que me acolheram várias vezes para entrevistas com once na sede da organização. A Sergio Gómez, da FAO, que gentilmente me ofereceu materiais pouco acessíveis e fundamentais para minha pesquisa. A Carmen Gloria Aguayo, que me contou suas histórias com Paulo Freire nos idos de 1965. A Pancha, Alicia, Oscar, Marcela, Rolando, Sergio e Carmen também agradeço por aceitarem o convite para que relatassem suas memórias no livro La Vía Chilena al Socialismo 50 Años Después: Historia y Memoria (CLACSO, 2020), que coorganizei enquanto terminava a tese ${ }^{1}$.

Agradeço a Jaime Gazmuri, Maria Emilia Palma, Maria Elena Cruz, Liliana Barria, bem como a turma da CORA de Los Angeles, Juan Aedo, Hugo Cumsille, Octavio Fritz, Miguel Mattus e Carlos Contreras, que me contaram pacientemente suas experiências como funcionários do agro durante a reforma agrária chilena em diferentes territórios, me deram caronas, me ofereceram almoços e me emprestaram diversos materiais. Aos camponeses Martim Vásquez, Ovídio Diaz Diaz, Oscar Valladares, Leonel Abarca e Guillermo Carrasco, que me relataram suas histórias de vida. Aos professores de camponeses Arnaldo Cáceres, Rogelio Correa e Manuel Herrera, sagazes e apaixonados pela profissão. Ao ex-mirista Victor Yáñez e sua companheira Verónica, que me acolheram por uma noite em San Carlos. Ao padre Fernando, mapucista que me recebeu em Chillán. A José Bengoa, Mario Garcés, Andrés Pascal Allende, Brian Loveman, Almino Affonso e Zilah Branco, intelectuais comprometidos e sujeitos da história, que responderam às minhas perguntas com paciência. Agradeço também aos seis profissionais que transcreveram meus quilômetros de entrevistas.

Ao professor Sergio Fuenzalida, que aceitou conversar sobre os relatórios da contrarreforma agrária encomendados pelo governo Lagos que encontrei nas gavetas de Chonchol e eram praticamente

\footnotetext{
${ }^{1}$ Tomos I e II disponíveis na Biblioteca Digital CLACSO: http://biblioteca.clacso.edu.ar/clacso/se/20201201031842/La-viachilena-al-socialismo-Tomo-I.pdf e http://biblioteca.clacso.edu.ar/clacso/se/20201201032252/La-via-chilena-al-socialismoTomo-II.pdf
} 
desconhecidos. Passados dois anos de trabalho, essa história foi desdobrada em um artigo acadêmico e duas reportagens. À Claudia Urquieta, pela parceria na realização das reportagens com o CIPER (Historia de un despojo I e II). Em 2017, fomos juntas aos arquivos da CORA e à hacienda Rio Colorado entrevistar camponeses que perderam a terra para as Forças Armadas. A ela também agradeço pela ótima companhia e pela hospitalidade durante o semestre que moramos juntas.

Às lindas amizades feitas no Chile: Lina Magalhães, Clara González, Felipe Correa, Clécio Mendes, Jaime Vergara, Nico Romero e las chicas de Maturana 16 (Maya, Isa e Cony), que tornaram minhas viagens de trabalho muito mais divertidas. A Felipe também pela digitalização de dezenas de documentos, por me emprestar sua bicicleta e me ensinar Run Run se fue pa'l Norte no charrango.

Nos Estados Unidos, também fui acolhida por diferentes pesquisadores, que fizeram toda diferença em minha trajetória. Agradeço especialmente aos membros do coletivo editorial da revista Latin American Perspectives (LAP) da UC Riverside, que me surpreenderam ao convidar-me para compor seu carismático grupo: sobretudo Ronald e Frances Chilcote, Rhonda Neugebauer, Rosalind Bresnahan, Marjorie Bray, Bill Bollinger e George Leddy. A Andrew Smolski (LAP) e Daniela Grandón, pelo trio de trabalho que formamos à distância, pelos projetos realizados e (ainda) não realizados. Aos brilhantes pesquisadores da UC-Cuba Conference, na pessoa do generoso Raul Fernández. Aos colegas de Latin American Studies da UCI.

Às poucas e boas amizades feitas nos Estados Unidos: a quase brasileira Kat Cosby e a chileníssima Javiera Letelier, parceiras de todas as horas. Ao comunista queer Jon-David, que me ajudou em momentos estratégicos.

Aterrissando de volta ao Brasil, agradeço aos camaradas do GMarx (USP), que completa doze anos de estudos coletivos e debates. O GMarx está cada vez mais forte e persistente. Continua sendo minha casa, mesmo quando estou ausente. Em especial agradeço a Lincoln, Ciro, Vivian, Rosa, Ramone André, Jullyana e Adriana. Aos colegas do NECAD (USP), minha pequena enciclopédia viva da TMD: Fabio Maldonado, Isa Guerrero, Antônio Mota, e todos os demais. Agradeço aos ótimos diálogos com a turma do GT História e Marxismo da ANPUH, sobretudo nos simpósios de Brasília e Recife.

Aos participantes do Programa Realidade Latino-Americana da UNIFESP, pelas pesquisasmochileiras e a prática coletiva da pedagogia da viagem, sobretudo em Cuba (2016) e Chile (2017). Agradeço especialmente a Fabio Luis, Fabiana Dessotti, Rafael Lima e Bruna Muriel, equipe que coordenou o $1^{\circ}$ Curso de Extensão Realidade Latino-Americana em 2019.

Muchas gracias aos companheiros do Pulso Latino Podcast, com quem aprendo a misturar pesquisa, comunicação e militância. A série Caminhos Latinos foi eletrizante e recompensadora, um desafio inventado durante a escrita final dessa tese, em parceria com a turma do parágrafo anterior e os queridos Tadeu Breda e Bianca Oliveira da editora Elefante - a quem também agradeço. Projetos de comunicação como o Pulso Latino oferecem novos e melhores sentidos à pesquisa acadêmica.

Aos meus amores e amoras da Rede Emancipa de Educação Popular, especialmente da Universidade Emancipa, minha trincheira. Não tenho palavras para dizer como essa Rede é importante. 
Obrigada à mulherada que coordenou o curso "Entender o Mundo Hoje - Pandemia e Periferias" em 2020, com seus 18 mil alunos (!) e infinitos certificados: Dani Mussi, Eli Alves, Laisa Stroher, Claudia Hardagh, Naiara do Rosário, Maria Letícia Correa, Silvana Lousada, Ana Laura, Sara Azevedo, Tati Poggi, e tantas outras, junto com os queridos André Lopes (meu par de "equipe técnica"), Juliano Niklevicz, Danilo Prisco, Dani Ribeiro e Maurício Costa. É surreal mobilizar tanta gente sem dispor de um centavo: um tsunami de estímulo moral. Também agradeço a Cibele Assensio, Taline Chaves, Danylo Amilcar e Anita Ferreira, porque não tem fim a lista de emancipas que eu amo.

Aos maravilhosos vizinhos do Pompeia Sem Medo, que me fazem acreditar na utopia da comunidade, na luta afetiva, no vira-voto e na reabertura do Hospital Sorocabana (já!). Nesses anos, foram muitas batalhas ombro a ombro, do bairro ao país, do país ao bairro, nas travessas, ladeiras, carnavais e panfletagens, com a vibração da luta prazerosa.

Às incondicionais e insubstituíveis Cata Pedroso, Thalie Drummond e Nati Dória, minhas amigonas do peito, bê-efe-efes, que estão perto de mim onde quer que estejam. Intimidade é isso.

Aos meus amigos da vida inteira, com quem eu brinco desde os anos 1990: Ju R, Zé, Tita, Tatá, Bê, Aninha, Ju S, Gabi, Guga, Thiego, Sô, Juli... Amizades-vinho, que envelhecem e não param de melhorar. Admiro e me inspiro há duas décadas e meia.

Aos meus amigos do chão da escola: Livia Andreosi, Claudio Cretti, Renée Avigdor, Ilan Lapyda, Mauro Pontes, Fabio Franco, Pedro BH e Livia Botim, com quem sempre aprendi tanto. A Rejane Hoeveler e Luan Auiá, com quem compartilho a paixão de pesquisar o Chile, os áudios longos e as interações brachilenas, como o Enlace Brasil-Chile.

A Dea, Fê e Pa, minhas roomies, que tornaram o cotidiano da pandemia muito mais alegre e me ajudaram tanto nos momentos difíceis.

Aos meus amores da primeira fila, aqueles que tem as cadeiras reservadas. A minha mãe, Suzana, que me ensinou a ser eu mesma. A meu pai (Mingo) e a Isis, pelo carinho, pela cumplicidade e pela coragem. A Marcos, Kinha, Jasmim e Caetano, raios de amor que iluminam os espaços da vida. A Lívia, meia-irmã que está sempre inteira. A Manô e a Sô pela nossa micro-rede de apoio. Aos Salém e aos Vasconcelos, meus clãs cheios de tios, tias, primos, primas e agregados maravilhosos. E no comando, duas mulheres. Agradeço a velhinha inquieta, vovó Dulce, fortaleza de 97 anos. E a velhinha serena, vovó Martha, sabedoria de 99. Minhas avós brilham no exemplo. Em fevereiro de 2021, foram vacinadas (viva o SUS).

Por fim, agradeço ao João, meu eterno romance, meu editor, meu melhor amigo, meu parceiro de montanha russa. Obrigada por tudo. $<3$ 
"Sem cultura, não há produção."

E. P. Thompson (2002: 258)

“É mais fácil liquidar o latifúndio no Chile de 1972, do que o latifúndio cultural"

Paulo Freire (1972: 16)

"Não existem territórios materiais que não estejam associados a territórios imateriais"

Rosset \& Martínez Torres (2016: 280) 


\section{Resumo}

Esta tese investiga a história da reforma agrária no Chile a partir de um olhar dialético entre economia e cultura, sugerindo que as hierarquias de acesso à terra eram também hierarquias epistemológicas. No Chile de 1955 , somente $7 \%$ dos proprietários controlavam $78 \%$ da superfície agrícola, enquanto o analfabetismo rural alcançava $60 \%$ da população adulta. Argumento que a concentração da terra e a exclusão educacional eram parte da mesma estrutura de dominação e acumulação capitalista dependente. A necessidade de transformação dessa estrutura ativou diversas iniciativas de educação camponesa que visavam formar novos sujeitos para nova agricultura. Entre 1955 e 1973, três projetos urbanos para transformação agrária entraram em confronto e disputaram hegemonia rural: a modernização tecnocrática; a reforma agrária estrutural democrata-cristã; e a revolução agrária da via chilena ao socialismo. As diferentes pedagogias camponesas para transformação econômica buscavam formar subjetividades produtivas (economias morais) apropriadas a distintos regimes de propriedade e trabalho. Tais pedagogias foram interpeladas por lutas, agências e experiências heterogêneas de um campesinato cada vez mais organizado. A presença de Paulo Freire no Chile (1964-1968) e sua influência nos organismos da reforma agrária é um componente-chave desta narrativa. Sustento que a reforma agrária iniciada em 1967 pelo governo da Democracia Cristã e acelerada pela Unidade Popular alterou estruturas agrárias e culturais em diferentes temporalidades, desestabilizando hierarquias sociais da terra e do conhecimento. Cada capítulo da tese possui um corpus documental próprio, com objetivo de narrar estratégias pedagógicas específicas para transformação agrária. A tese se baseia em fontes primárias de sete arquivos em três países (Chile, EUA, Brasil), entre os quais estão materiais didáticos, relatórios de educadores rurais, relatórios de pesquisadores para Fundação Ford e Rockefeller, documentos do Instituto de Educação Rural, do INDAP, da CORA, do FEES, do ICIRA, programas de cursos camponeses, transcrições de círculos de cultura com vozes camponesas, imagens utilizadas nas pedagogias freirianas, diversos veículos de imprensa, sessões parlamentares, atas de reuniões de organismos do agro, discursos presidenciais, documentos partidários, fotografias e mais de quarenta entrevistas de história oral.

Palavras-Chave: Chile, Reforma Agrária, Paulo Freire, Unidade Popular, Pedagogia Camponesa. 


\title{
"The pencil is heavier than the hoe": agrarian reform in Chile and peasant pedagogies for economic transformation (1955-1973)
}

\begin{abstract}
This $\mathrm{PhD}$ dissertation investigates the history of agrarian reform in Chile from a dialectical perspective between economics and culture, suggesting that the hierarchies of access to land were also epistemological hierarchies. In Chile of 1955 , only $7 \%$ of landowners controlled $78 \%$ of the agricultural land, while rural illiteracy reached $60 \%$ of the adult population. I argue that land concentration and educational exclusion were part of the same structure of domination and dependent capitalist accumulation. The need to transform this structure triggered several peasant education initiatives that aimed to train new subjects for the new agriculture. Between 1955 and 1973, three urban projects for agrarian transformation clashed and disputed rural hegemony: technocratic modernization; ChristianDemocratic structural agrarian reform; and the agrarian revolution from the Chilean road to socialism. The different peasant pedagogies for economic transformation sought to form productive subjectivities (moral economies) appropriate to distinct regimes of property and labor. Such pedagogies were challenged by struggles, agencies, and heterogeneous experiences of an increasingly organized peasantry. Paulo Freire's presence in Chile (1964-1968) and his influence on agrarian reform institutions is a key component of this narrative. I maintain that the agrarian reform initiated in 1967 by the government of Christian Democracy and accelerated by Popular Unity changed agrarian and cultural structures at different temporalities, destabilizing social hierarchies of land and knowledge. Each chapter of the thesis has its own documentary corpus, to narrate specific pedagogical strategies for agrarian transformation. The research is based on primary sources from seven archives in three countries (Chile, USA, Brazil), including teaching materials, reports from rural educators, reports from researchers to the Ford and Rockefeller Foundations, documents from the Institute of Rural Education, INDAP, CORA, FEES, ICIRA, peasant course programs, transcriptions of culture circles with peasant voices, images used in Freirean pedagogies, various press vehicles, parliamentary sessions, minutes of meetings of agricultural institutions, presidential speeches, party documents, photos and more than forty oral history interviews.
\end{abstract}

Keywords: Chile, Agrarian Reform, Paulo Freire, Popular Unity, Peasantry pedagogy. 


\section{"El lápiz es más pesado que la pala": reforma agraria en Chile y pedagogías campesinas para la transformación económica (1955-1973)}

\section{Resumen}

Esta tesis investiga la historia de la reforma agraria en Chile a partir de una mirada dialéctica entre economía y cultura, sugiriendo que las jerarquías de acceso a la tierra eran también jerarquías epistemológicas. En Chile de 1955, solamente 7\% de los terratenientes controlaban 78\% de la superficie agrícola, mientras el analfabetismo rural alcanzaba $60 \%$ de la población adulta. Argumento que la concentración de la tierra y la exclusión educacional eran parte de la misma estructura de dominación y acumulación capitalista dependiente. La necesidad de transformación de esta estructura ha activado diversas iniciativas de educación campesina que visaban formar nuevos sujetos para la nueva agricultura. Entre 1955 y 1973, tres proyectos urbanos para la transformación agraria entraron en conflicto y disputaron hegemonía rural: la modernización tecnocrática, la reforma agraria estructural democratacristiana; y la revolución agraria de la vía chilena al socialismo. Las diferentes pedagogías campesinas para la transformación económica buscaban formar subjetividades productivas (economías morales) apropiadas a distintos regímenes de propiedad y trabajo. Tales pedagogías fueron desafiadas por luchas, agencias y experiencias heterogéneas de un campesinado cada vez más organizado. La presencia de Paulo Freire en Chile (1964-1968) y su influencia en los organismos del agro es un elemento clave de esta narrativa. Sostengo que la reforma agraria iniciada en 1967 por el gobierno de la Democracia Cristiana y acelerada por la Unidad Popular ha alterado estructuras agrarias y culturales en diferentes temporalidades, desestabilizando jerarquías sociales de la tierra y del conocimiento. Cada capítulo de la tesis tiene un corpus documental propio, con objetivo de narrar estrategias pedagógicas específicas para la transformación agraria. La tesis está basada en siete archivos en tres países (Chile, EUA, Brasil), entre los cuales están materiales didácticos, informes de educadores rurales, informes de académicos para la Fundación Ford y Rockefeller, documentos del Instituto de Educación Rural, del INDAP, de la CORA, del FEES, del ICIRA, programas de cursos campesinos, transcripciones de círculos de cultura con voces campesinas, imágenes utilizadas en las pedagogías freirianas, discursos presidenciales, documentos partidarios, fotografías y más de cuarenta entrevistas de historia oral.

Palabras-Clave: Chile, Reforma Agraria, Paulo Freire, Unidad Popular, Pedagogía Campesina. 


\section{Lista de Siglas}

ACR - Acción Católica Rural

AIA - American International Association for Economic and Social Development

ANAMURI - Asociación Nacional de Mujeres Rurales e Indígenas

ANOC - Asociación Nacional de Organizaciones Campesinas

ARNAD - Archivo Nacional de la Administración

ASICH - Asociación Sindical Chilena

CARE - Cooperativa Americana de Remesas al Exterior

CCC - Consejo Comunal Campesino

CEPAL - Comissão Econômica para América Latina e Caribe (ONU)

CERA - Centro de Reforma Agraria

CEPRO - Centro de Producción

CEREN - Centro de Estudios de la Realidad Nacional (U. Católica)

CESO - Centro de Estudios Socioeconómicos (U. Chile)

CIA - Central Intelligence Agency

CIDA - Comité Interamericano de Desarrollo Agrícola

$\mathrm{CNC}$ - Consejo Nacional Campesino

CNC - Confederación Nacional Campesina

CORA - Corporación de Reforma Agraria

CPC - Consejo Provincial Campesino

CTCN - Comité Técnico Nacional de Capacitación Campesina

CUT - Central Única de Trabajadores

DIRINCO - Dirección de Industria y Comercio

FAO - Food and Agriculture Organization (ONU)

FCI - Federación Nacional Campesina e Indígena

FEES - Fondo de Educación y Extensión Sindical

FECH - Federación de Estudiantes de la Universidad de Chile

FEUC - Federación de Estudiantes de la Universidad Católica

FEUTE - Federación de Estudiantes de la Universidad Técnica del Estado

FISA - Feria Internacional de Santiago

HRB - Hectáreas de Riego Básico

ICIRA - Instituto de Capacitación e Investigación para la Reforma Agraria

IER - Instituto de Educación Rural

IICA - Instituto Interamericano de Cooperação para Agricultura

INACAP - Instituto Nacional de Capacitación Profesional

INDAP - Instituto de Desarrollo Agropecuario

ITT - International Telephone and Telegraph

JAP - Junta de Abastecimiento y Precios

LTC - Land Tenure Center (U. Wisconsin-Madison)

MAPU - Movimiento de Acción Popular Unitaria

MCI - Movimiento de Campesinos Independientes

MCR - Movimiento Campesino Revolucionario

MINAGRI - Ministério de Agricultura

MINEDUC - Ministério de Educação Pública

MIR - Movimiento Izquierda Revolucionaria

ODENA - Oficina de Normalización Agrícola

ODEPA - Oficina de Planificación Agrícola

OEA - Organização dos Estados Americanos

ONSEV - Oficina Nacional de Servicios Voluntarios

PC (PCCh) - Partido Comunista de Chile

PCB - Partido Comunista Brasileiro

PDC (DC) - Partido Democracia Cristiana

PS - Partido Socialista de Chile 
PN - Partido Nacional

RAC - Rockefeller Archive Center

SAG - Servicio Agrícola Ganadero

SARA - Sociedad de Reforma Agraria

SNA - Sociedad Nacional de Agricultura

UCC - Unión de Campesinos Chilenos

UOC - Unidad Obrero Campesina

UP - Unidad Popular

USAID - United States Agency for International Development

UTE - Universidad Técnica del Estado 


\section{Sumário}

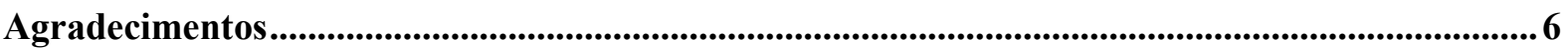

Resumo

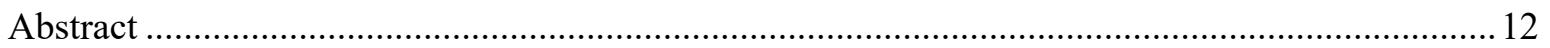

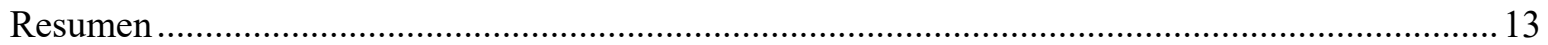

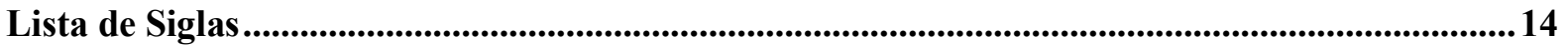

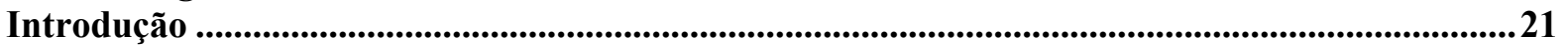

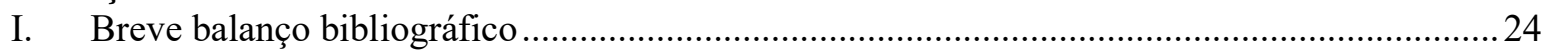

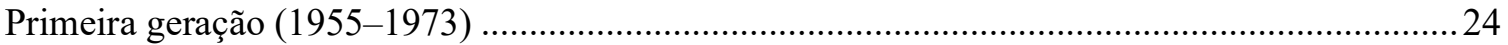

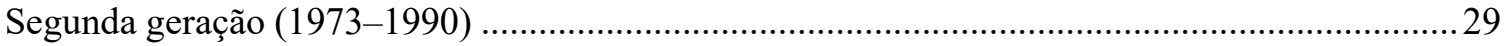

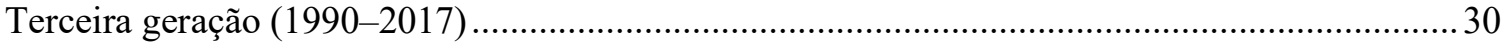

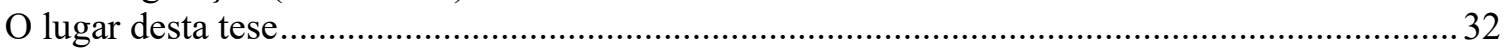

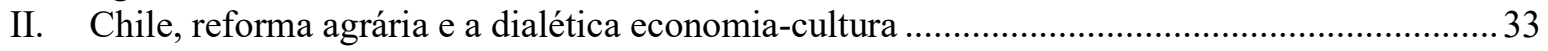

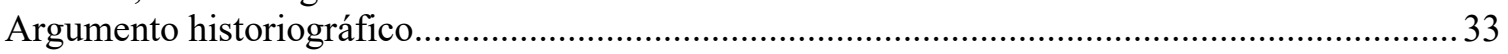

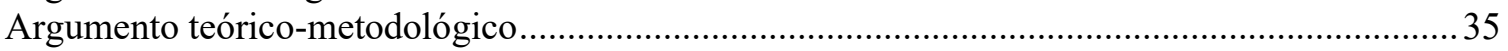

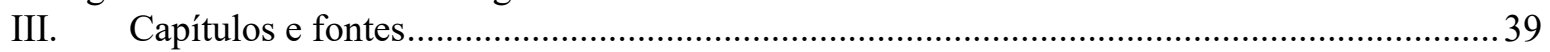

IV. Por fim: nota sobre brasileiros da reforma agrária chilena .................................................45

Capítulo 1 - Questão agrária no Chile entre 1955 e 1973: formas econômicas, batalhas culturais

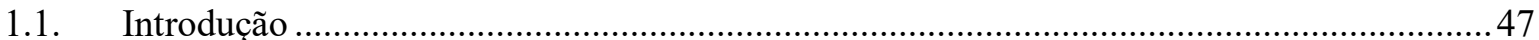

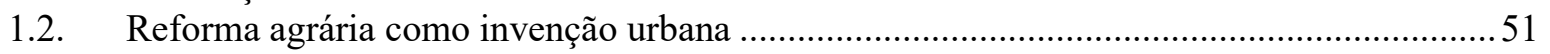

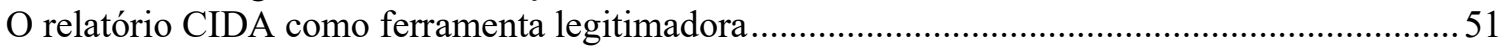

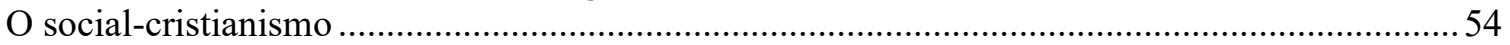

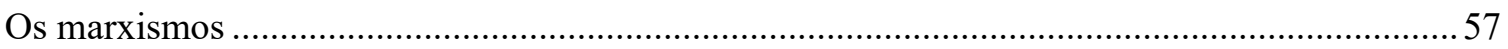

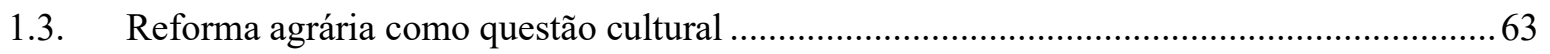

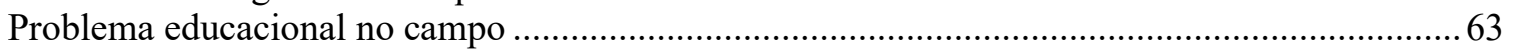

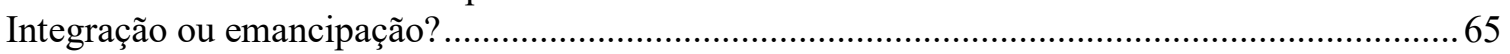

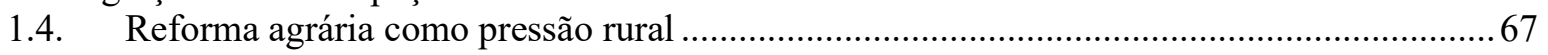

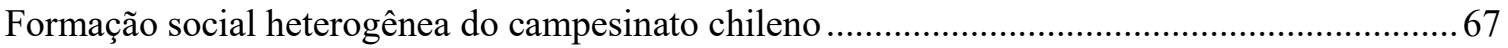

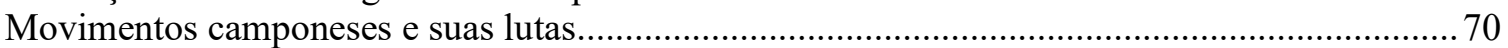

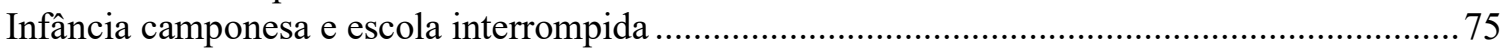

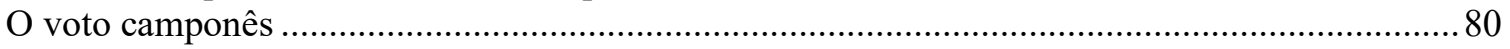

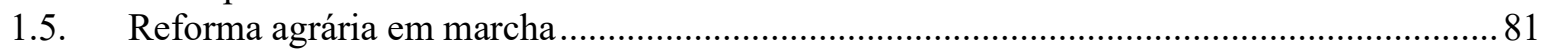

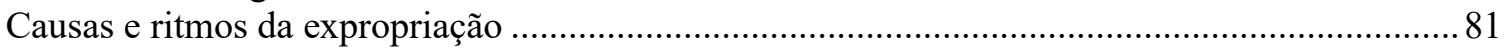

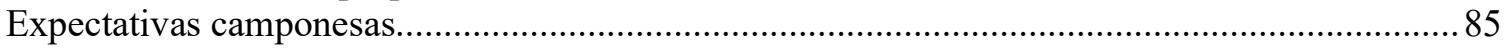

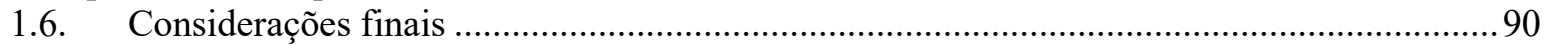

Capítulo 2 - Plantando conceitos: a atuação dos Estados Unidos na educação agrária do Chile91

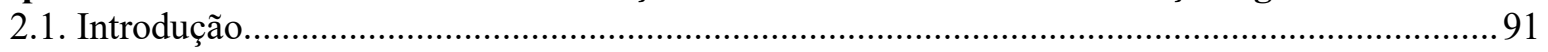

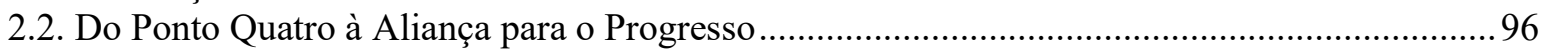

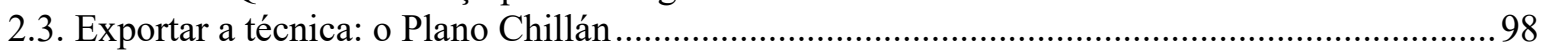

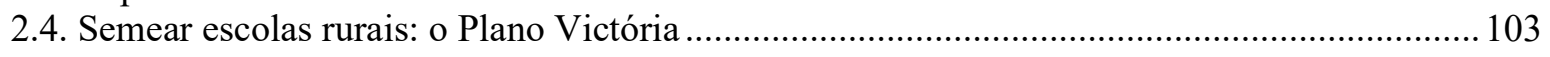

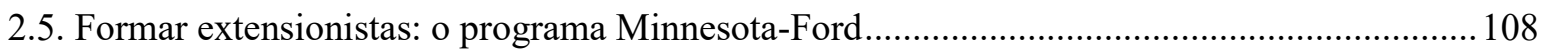

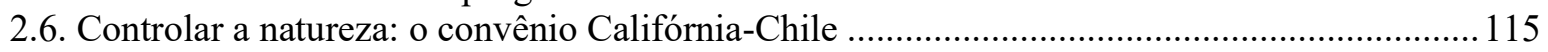

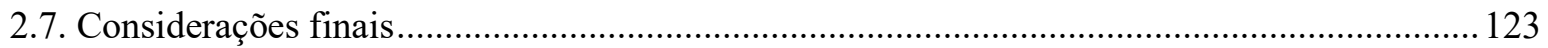

Capítulo 3 - A terra para quem a merece: a pedagogia do sacrifício do Instituto de Educação

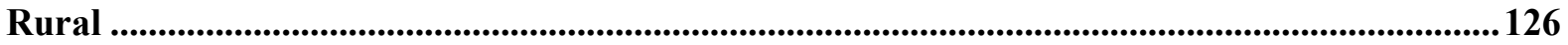

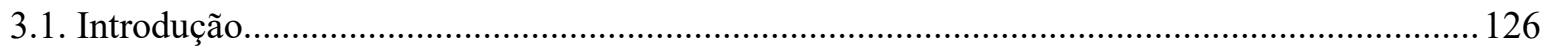

3.2. Uma grande família camponesa: os fundamentos afetivos da hegemonia .............................. 130

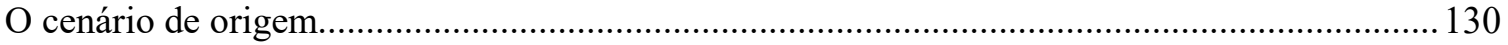

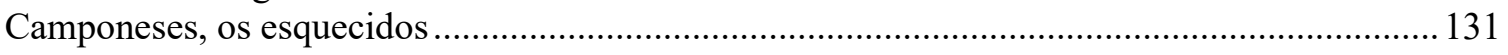

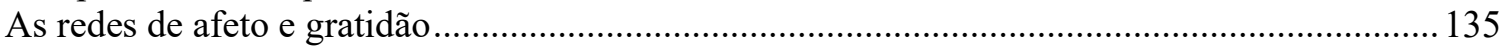

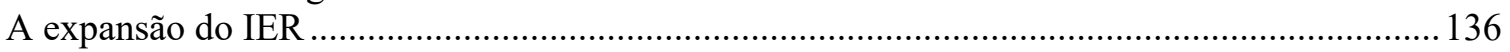

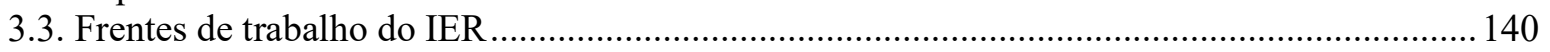


Centros de Capacitação: um circuito político-pedagógico multiplicador...................................... 140

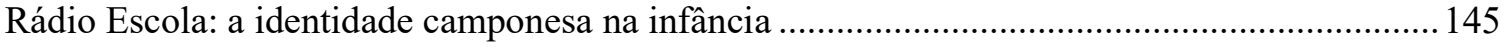

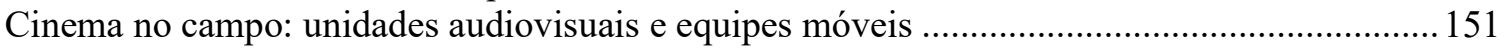

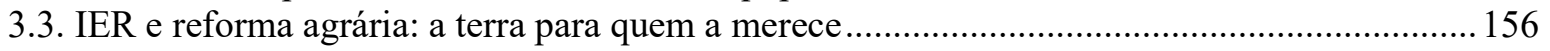

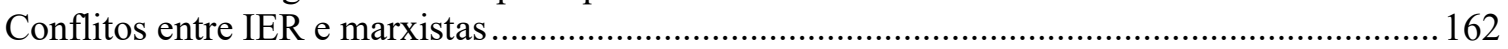

Cooperativa anticomunista: formas econômicas, batalhas culturais............................................ 166

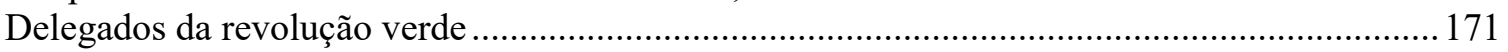

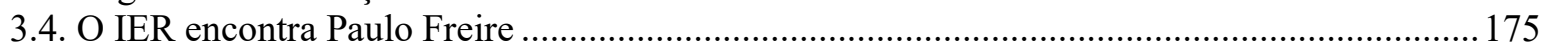

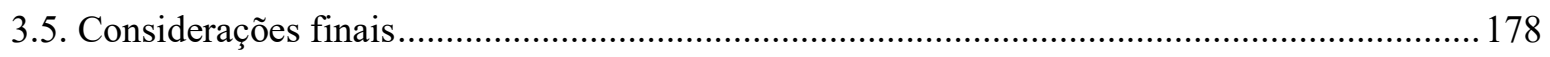

Capítulo 4 - Semeadores de palavras: Paulo Freire, a reforma agrária chilena e a pedagogia do

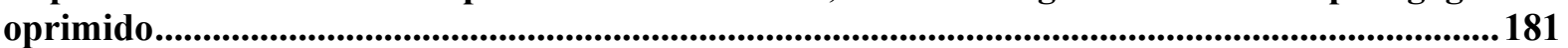

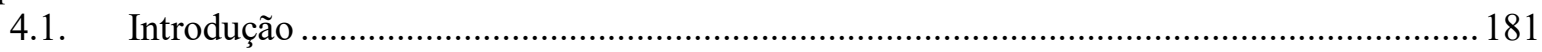

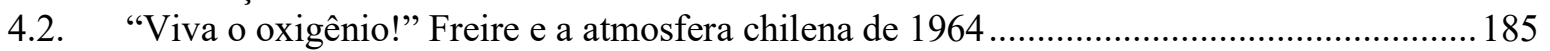

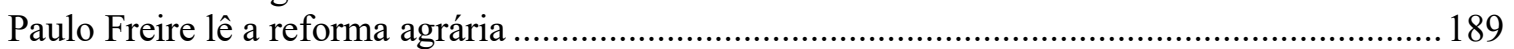

4.3. O método psicossocial se espalha pelo campo: adaptações do Ministério da Educação .... 191

Formas mortas da educação de adultos e método psicossocial....................................................... 193

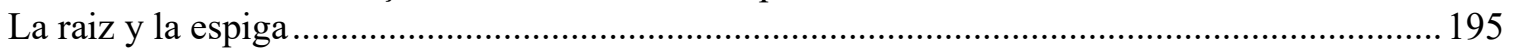

4.4. Paulo Freire no INDAP: ação cultural com comitês camponeses.......................................205

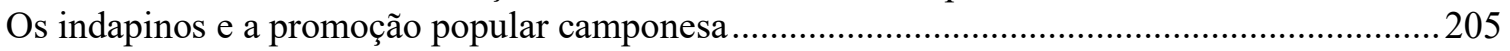

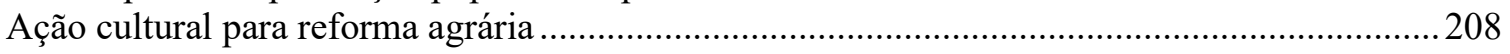

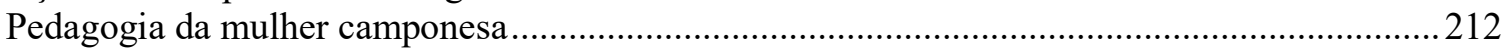

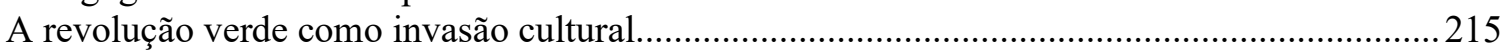

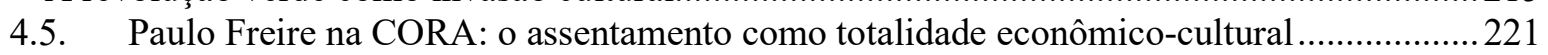

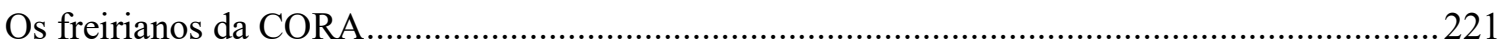

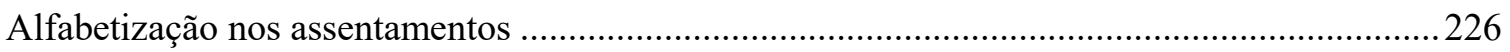

Camponeses professores: autocapacitação como hipótese ……………………..........................22

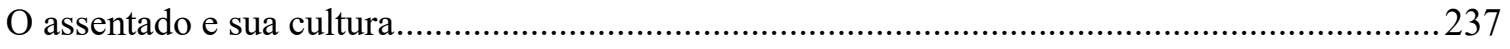

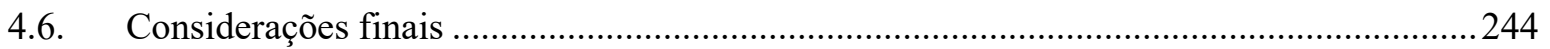

Capítulo 5 - Pedagogia do território: protagonismo camponês, poder e produção ......................246

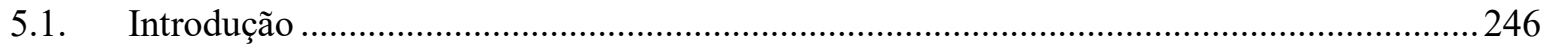

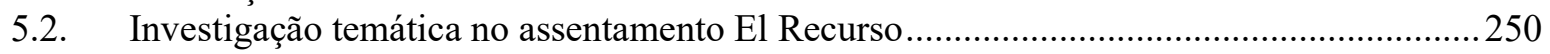

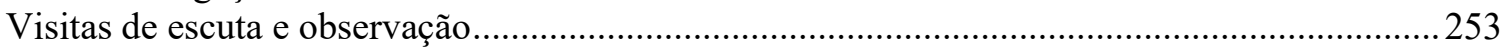

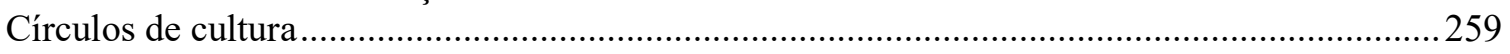

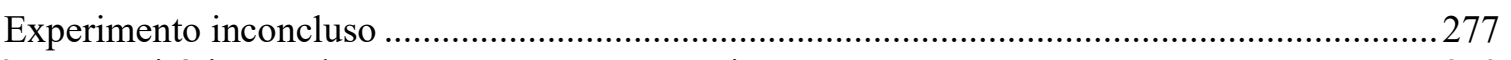

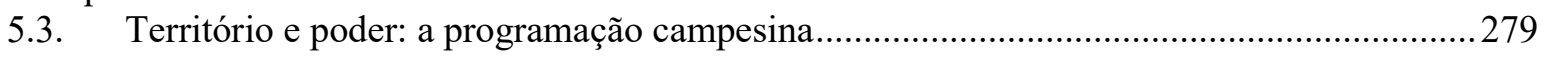

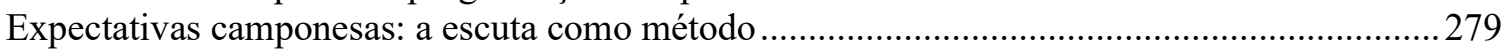

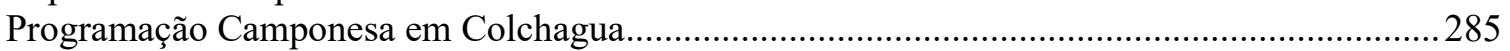

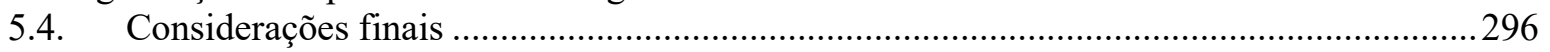

Capítulo 6 - Pedagogia da reivindicação: sindicalismo camponês e educação política ...............298

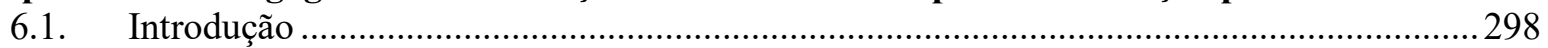

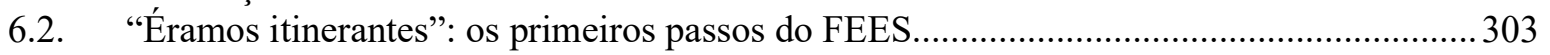

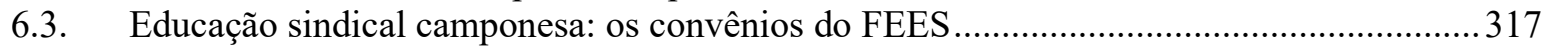

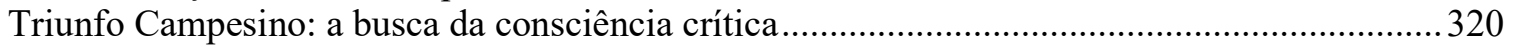

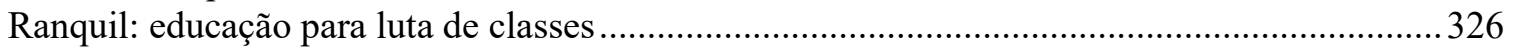

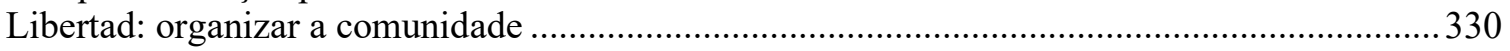

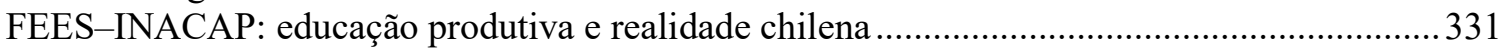

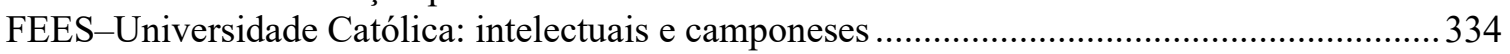

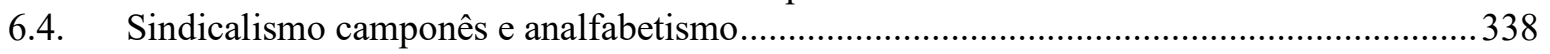

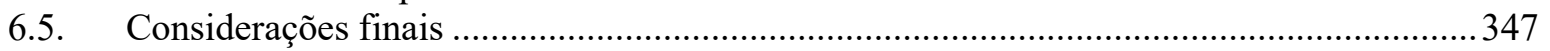

Capítulo 7 - Unidade Popular e a reforma agrária: batalha da produção, batalhas da

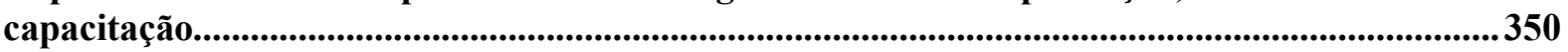

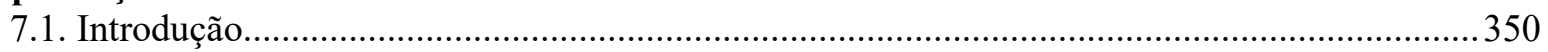

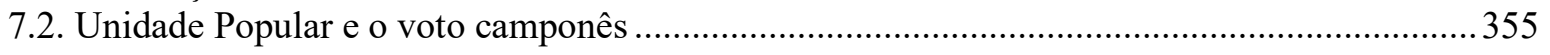

7.3. Política agrária da Unidade Popular: três dilemas desafiam a capacitação .................................359

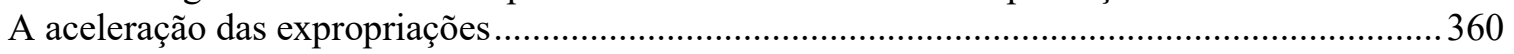




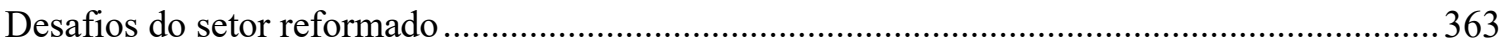

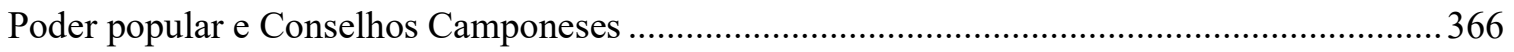

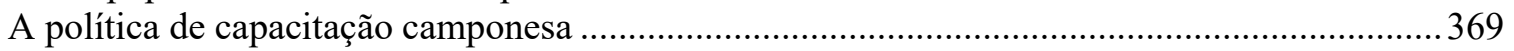

7.4. O CTNC e a arquitetura da capacitação camponesa da UP ......................................................370

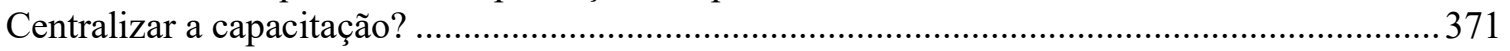

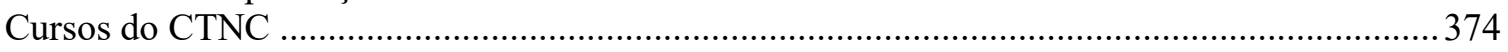

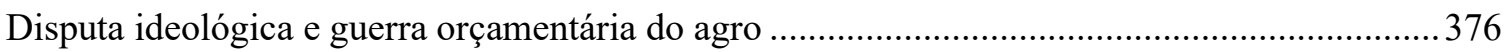

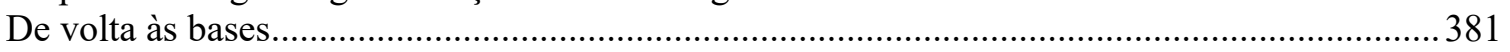

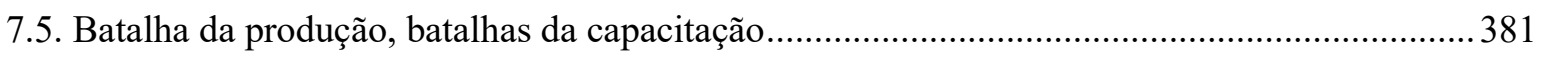

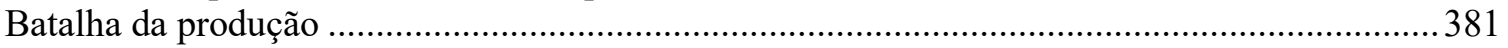

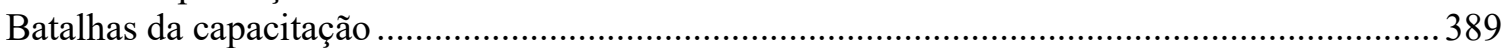

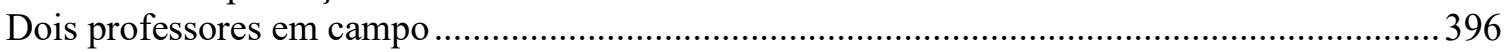

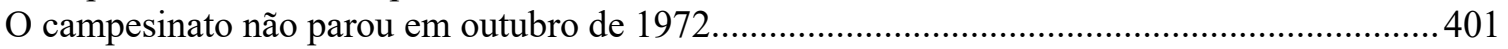

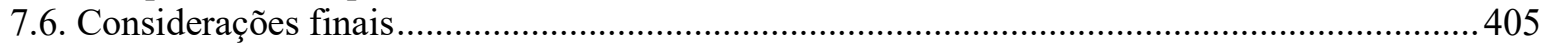

Capítulo 8 - Alfabetização camponesa e trabalho voluntário na Unidade Popular: diálogos entre

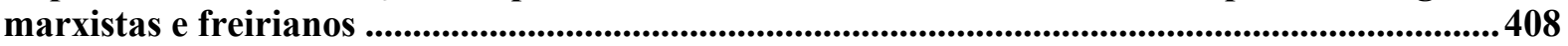

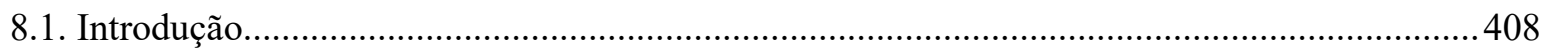

8.2. Voluntários para alfabetização rural: a aliança camponesa-estudantil .......................................412

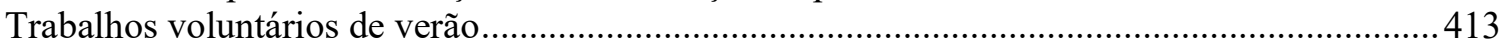

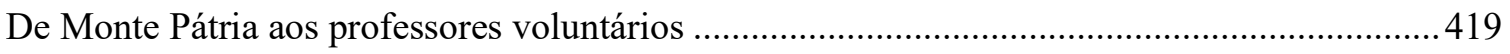

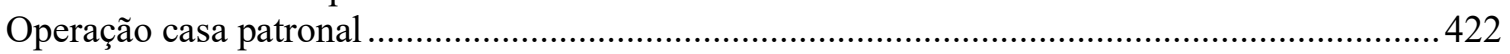

8.3. Pedagogia freiriana e adaptações marxistas: o guia da UP para alfabetização.......................... 426

Sugestões para alfabetização: uma adaptação marxista do método psicossocial............................426

Paulo Freire no Chile em 1972: diálogos com a revolução chilena..............................................443

8.4 Conselhos Camponeses e os desafios da pedagogia do território ...............................................448

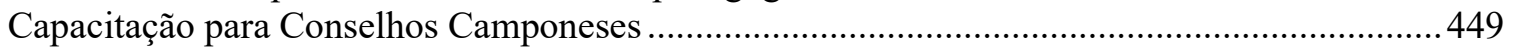

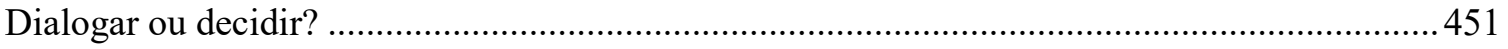

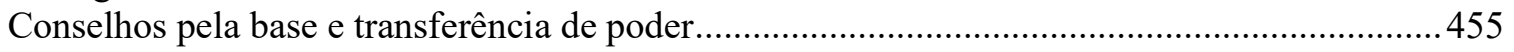

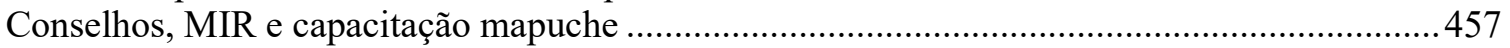

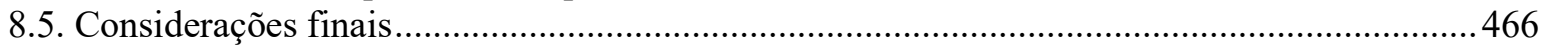

Epílogo …......................................................................................................................................................468

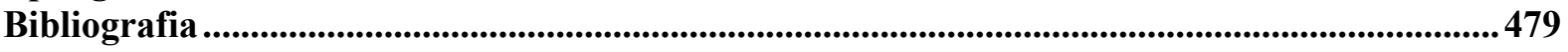

Fontes primárias ………....................................................................................................................................485

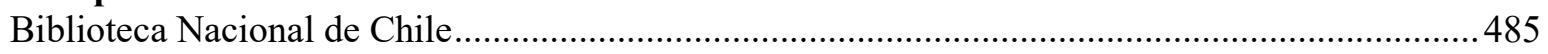

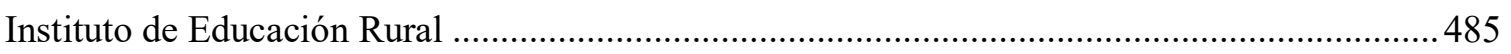

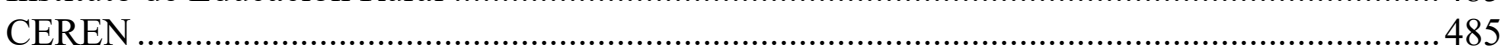

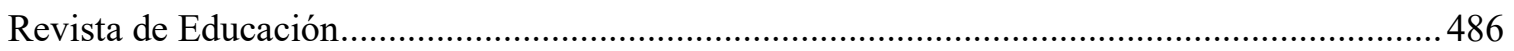

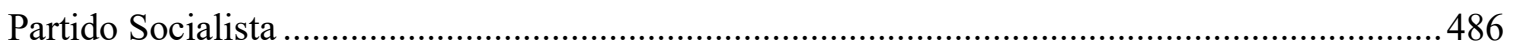

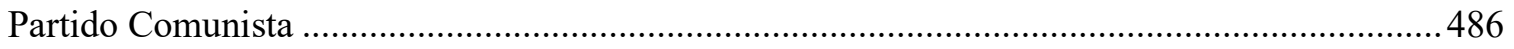

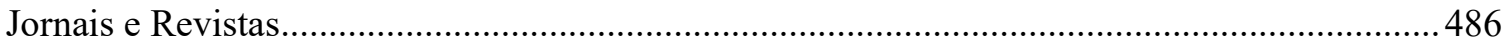

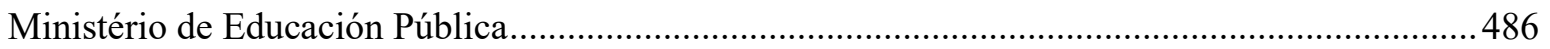

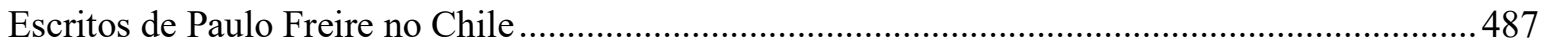

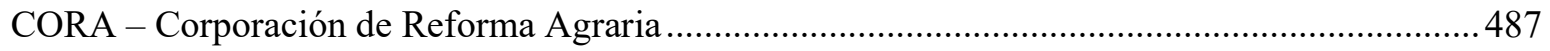

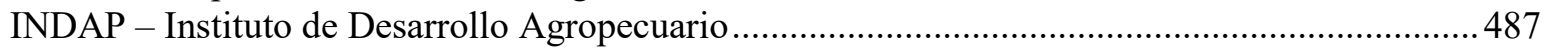

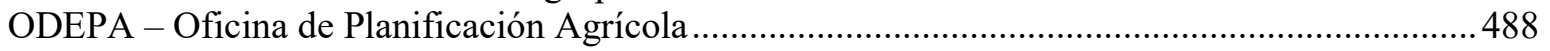

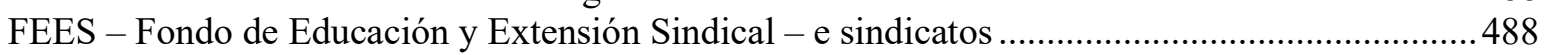

ICIRA - Instituto de Capacitación e Investigación de Reforma Agraria ...........................................48

PIIE - Programa Interdisciplinar de Investigación en Educación (U. Católica) ................................489

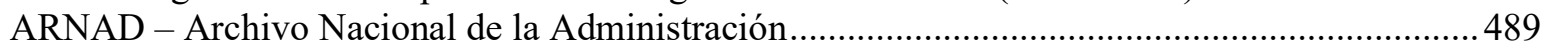

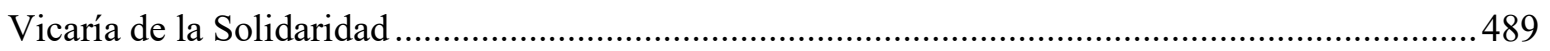

CRPF - Centro de Referência do Instituto Paulo Freire .................................................................490

LTC - Land Tenure Center (University of Wisconsin-Madison) …...............................................490

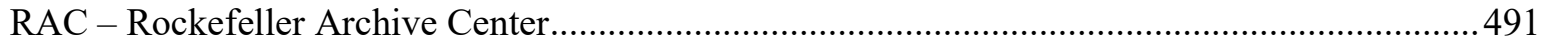

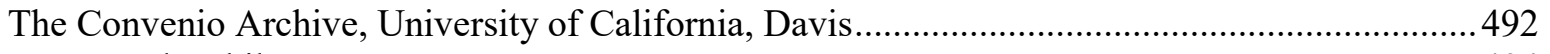

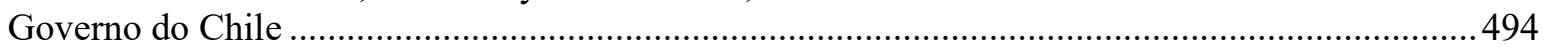


Publicações do sistema ONU

494

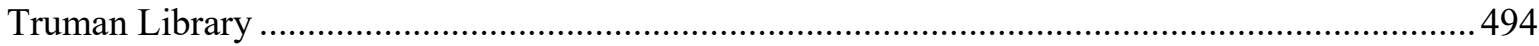

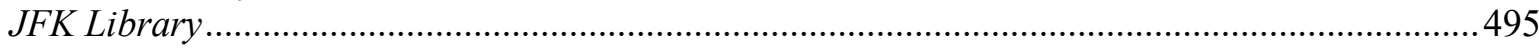

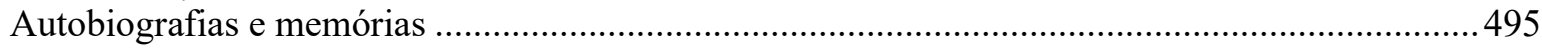

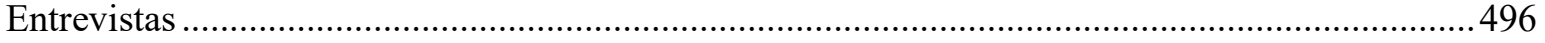




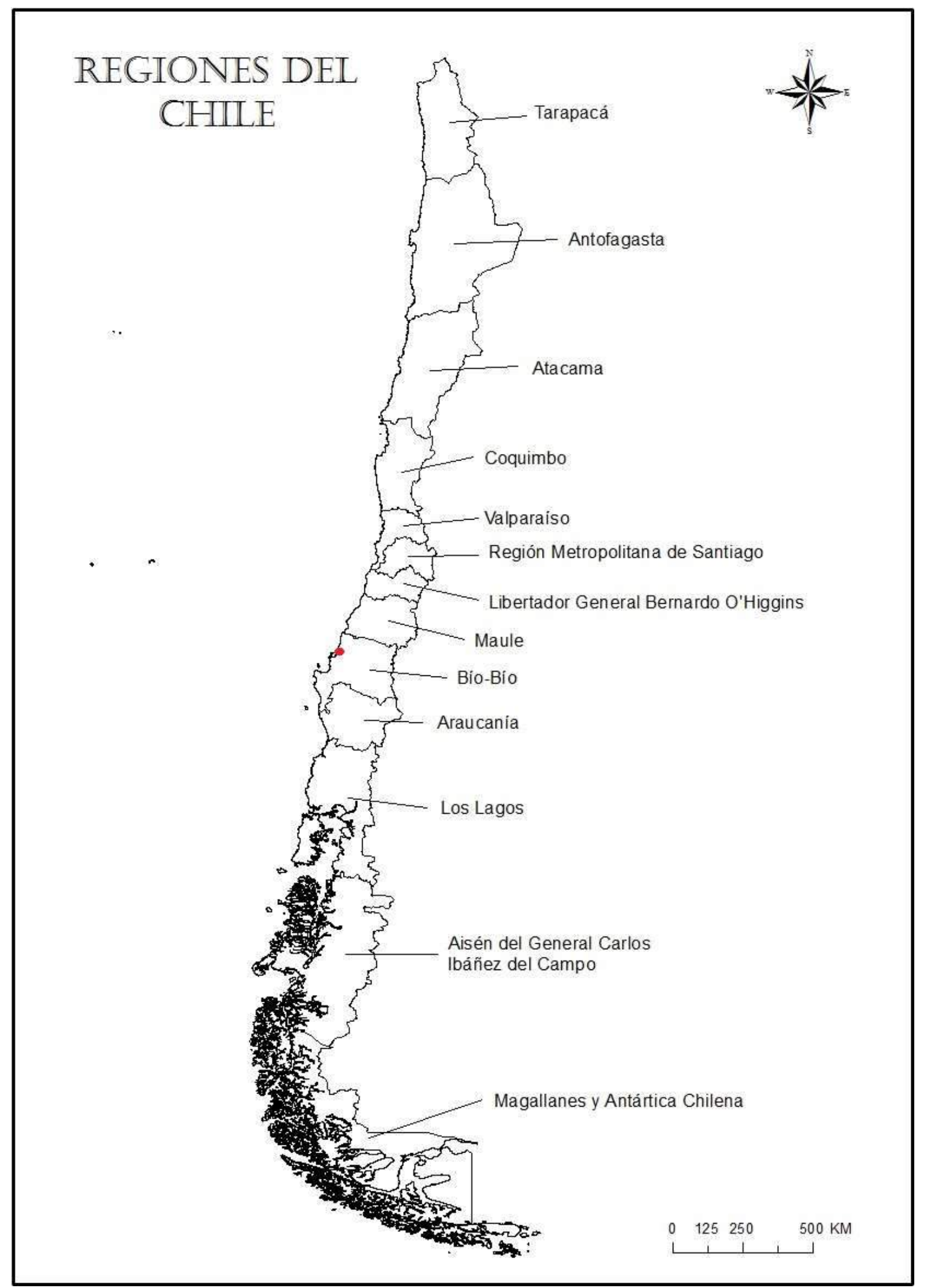

Este mapa é meramente ilustrativo e não corresponde à divisão territorial administrativa do Chile no período em que ocorre a narrativa desta pesquisa. 


\section{Introdução ${ }^{2}$}

“A pedagogia dominante é a pedagogia das classes dominantes".

Ernani Maria Fiori. Santiago, 1968 $^{3}$

Em 1968, camponeses de um assentamento da reforma agrária no Chile localizado na comuna de Lampa, a 40 quilômetros de Santiago, participavam de um processo de alfabetização organizado pela Corporação de Reforma Agrária (CORA), que então realizava uma experiência pedagógica com o "método psicossocial" de Paulo Freire. Com dificuldade de aprender as letras, um camponês explicou à professora Juana Vargas: "o lápis é mais pesado que a enxada". Essa metáfora nos ajuda a começar esta história da reforma agrária chilena, ou melhor, das pedagogias camponesas para transformação econômica da agricultura do país, entre os anos de 1955 e 1973. Com tão poucas palavras, o camponês de Lampa dava conta de explicar o peso da dominação cultural e das hierarquias do conhecimento que oprimiam o trabalhador rural, tanto quanto o latifúndio.

A cultura letrada, para muitos camponeses chilenos daquela época, representava um poder que emanava de outro mundo, no qual vigoravam as epistemologias urbanas, isto é, as linguagens, paradigmas e dispositivos técnicos da chamada "modernidade". ${ }^{5}$ Em um país no qual 7\% dos proprietários controlava 78\% da superfície agrícola (CIDA, 1966), a hierarquia social de acesso à terra estava organicamente vinculada à hierarquia de acesso ao conhecimento escrito e ao poder multidimensional da cultura letrada. No Chile de 1960, quase 60\% da população rural maior de 15 anos era analfabeta. ${ }^{6} \mathrm{O}$ analfabetismo rural e o latifúndio eram problemas estruturais profundamente articulados, que juntos explicavam as desigualdades sociais, a exploração do trabalho, a dominação cultural, o subdesenvolvimento chileno e os pactos entre oligarquias do campo e da cidade.

Quando a reforma agrária foi alçada ao centro do debate político nacional no fim dos anos 1950, um abismo separava a experiência social camponesa, seu trabalho, suas formas de viver e resistir à dominação da classe proprietária, em relação à experiência do mundo urbano, suas estruturas culturais, laborais e mentais. No entanto, foram as epistemologias urbanas e o aparato crítico do

\footnotetext{
${ }^{2}$ Todas as citações desta narrativa que estão referenciadas na bibliografia em espanhol e inglês foram traduzidas livremente ao português pela autora. Essa pesquisa foi realizada com apoio da FAPESP, processo 2016/13432-4.

${ }^{3}$ Ernani Maria Fiori apud Paulo Freire, “Aprender a escrever sua palavra”. Prefácio à Pedagogia do Oprimido, 2018 , p. 11.

${ }^{4}$ Relatório de Juana Aravena Vargas, Algunas experiencias en la supervisión de educación básica. In: Paulo Freire, Alfabetización Funcional en Chile. Informe UNESCO. Santiago: ICIRA (mimeo.), 1968a.

${ }^{5}$ Utilizo o conceito de epistemologia urbana para me referir às estruturas de conhecimento e poder que organizam as formas de pensar, sentir e ver o mundo de uma ampla coletividade. Nesse caso, as epistemologias urbanas eram dominantes frente às epistemologias rurais porque impunham de maneira hierárquica seus dispositivos cognitivos e técnicos perante a realidade do campo. Inspiro-me em Boaventura de Sousa Santos $(2007,2009)$ para manejar o conceito, compreendendo a possibilidade de batalhas entre diferentes epistemologias e considerando as relações sociais e políticas como fundamentalmente epistemológicas, ou seja, baseadas em hierarquias de saberes.

${ }^{6}$ Os dados do censo de 1960 indicavam 34\% de analfabetismo rural (CIDA, 1966), mas considerando o analfabetismo funcional, o índice alcançava 59\%. (Waldemar Cortés Carabantes, "Formas muertas y dinámicas en nuestra educación de adultos". Revista de Educación, n. 93, 1963).
} 
desenvolvimentismo que formularam os termos técnicos das reformas agrárias para o país, interpeladas de maneira crescente pela agência camponesa, que se apropriou das ferramentas disponíveis e inventou novas táticas de luta para fazer avançar suas próprias aspirações. No mundo urbano, três projetos políticos antagônicos de "reforma agrária" rivalizavam: a modernização tecnocrática, a reforma capitalista e a revolução socialista. ${ }^{7}$ Já no mundo rural, a formação de um campesinato heterogêneo, com múltiplas trajetórias sociais, migratórias, étnicas e territoriais, gerava diferentes aspirações e expectativas a respeito da redistribuição das terras, pendulando entre a parcela individual e o cooperativismo, mas compartilhando uma economia moral camponesa guiada pelo desejo de autonomia e bem-estar (Scott, 1976), frequentemente traduzido na expressão "vivir en lo propio". Em uma estrutura latifundiária que parecia imóvel, as tensões intracamponesas de gênero, raça e classe permaneciam latentes. Quando a mudança estrutural deu partida, uma pluralidade de subjetividades camponesas emergiu, atuando sobre a reforma agrária das mais diversas maneiras. Reconhecer a heterogeneidade do processo social e a complexidade do processo político da reforma agrária chilena é, portanto, nosso marco zero.

Esta tese narra a história das pedagogias para transformação agrária no Chile entre 1955 e 1973 com objetivo de analisar como as diferentes estratégias educacionais do mundo urbano concorriam para formação de novos sujeitos camponeses, destinados a participar de uma nova estrutura agrária. A educação camponesa refletia projetos antagônicos de reforma agrária e modelos de sociedade que emanavam das epistemologias urbanas. Constituíram um terreno privilegiado para a disputa da consciência e da subjetividade da população rural e formaram iniciativas determinantes das batalhas culturais para transformação econômica do campo. Além disso, tais pedagogias representaram diferentes estratégias culturais para a própria reforma agrária, iluminando as articulações entre subjetividade popular, trabalho rural e produção. Por meio das pedagogias da reforma agrária, o mundo urbano e o mundo rural, que antes pareciam distantes, agendaram um encontro sem precedentes: uma variedade de experiências sociais inéditas foi desencadeada a partir da relação entre camponeses e educadores, técnicos extensionistas, agrônomos, sociólogos, psicólogos, estudantes, como parte constitutiva de uma das mais profundas mudanças estruturais vivenciadas pelos chilenos no século XX. Nesse sentido, argumentarei que as pedagogias da reforma agrária foram o elo mais importante da relação contraditória entre estrutura e experiência. ${ }^{8}$

O fio condutor desta narrativa é a história social de uma sequência de projetos pedagógicos para transformação agrária no Chile, incluindo múltiplas iniciativas e diferentes tipos de fontes primárias. A observação de tais experiências nos permite analisar os nexos entre a mudança econômica

\footnotetext{
${ }^{7}$ Os fundamentos programáticos de cada uma dessas reformas agrárias podem ser encontrados respectivamente em Sotomayor (1966); CIDA (1966); PC (1966) e PS (1961).

${ }^{8}$ Como sinalizado nos trabalhos teóricos de Emilia Viotti da Costa $(1990,1994)$, a história social seria dialética conforme lograsse analisar os nexos entre estrutura e experiência, evitando o estruturalismo frio que limita o papel dos sujeitos na transformação histórica; bem como a subjetividade frívola, na qual a vontade dos sujeitos flutua sem os pés ancorados nos limites estruturais.
} 
e a mudança subjetiva, bem como as intencionalidades de diferentes partidos e instituições, nacionais e internacionais, na agenda da educação camponesa como parte imprescindível da reforma agrária. As pedagogias camponesas para reforma agrária atuavam sobre as hierarquias de saber que, por sua vez, eram hierarquias ativas nas relações sociais de produção. Tratavam de "modernizá-las" por meios de novas técnicas de produção, ou de "integrar" o campesinato à cultura urbana e à sociabilidade moderna, ou de efetivamente "emancipar" os trabalhadores rurais dos poderes proprietários, sem com isso dispensar a disciplina laboral. Argumentarei que tais pedagogias representavam múltiplas estratégias de transformação econômica da agricultura no âmbito das subjetividades produtivas.

Como investigou Paulo Freire ao percorrer os assentamentos da reforma agrária chilena entre 1964 e 1968, quando era um brasileiro exilado, a mudança estrutural da agricultura seria mais exitosa conforme emanasse da própria subjetividade camponesa, do seu poder de autodeterminação, evitando que os dispositivos técnicos da reforma agrária e da transformação produtiva se convertessem em procedimentos de "invasão cultural" (Freire, 1969). Os saberes campesinos e sua cultura, para Freire, deveriam se emancipar dos constrangimentos do latifúndio e protagonizar a mudança das formas de propriedade, de produção e de trabalho no campo. Para isso, era necessário viabilizar um diálogo horizontal entre epistemologias hierarquicamente constituídas, o que não era uma tarefa simples. Os sujeitos políticos e técnicos da reforma agrária, lastreados no paradigma desenvolvimentista e em nome de projetos modernizadores, reformadores ou revolucionários, precisariam amadurecer uma nova capacidade de escuta ativa dos camponeses e valorização dos seus conhecimentos historicamente inferiorizados. Mas, no Chile, como em outras partes da América Latina, os donos de terras e os donos de livros tinham a supremacia da objetificação do outro. Para Paulo Freire, que ocupa o duplo papel de protagonista desta história e referencial teórico desta tese, a reforma agrária era um processo que exigia a quebra das hierarquias epistemológicas entre campo e cidade e a inédita valorização dos saberes de sujeitos analfabetos.

Argumentarei que a transformação da estrutura econômica da agricultura chilena entre 1955 e 1973 requeria uma profunda mudança cultural e epistemológica das formas hierárquicas da vida camponesa, bem como das habituais hierarquias entre campo e cidade. Aqui, o objetivo mais amplo é iluminar a interdependência dialética entre transformação econômica e subjetividade popular por meio do estudo das estratégias pedagógicas para reforma agrária. Assim, pretendo iluminar os nexos entre economia (estrutura) e subjetividade (experiência) na transformação agrária chilena, que encadeou conflituosamente os projetos de modernização, de reforma e de revolução agrária dentro do nosso recorte temporal. O estudo das pedagogias camponesas e da educação produtiva configuram o recorte teórico-metodológico que escolhi para conduzir a narrativa e a análise. 


\section{Breve balanço bibliográfico}

Antes de apresentar as escolhas teórico-metodológicas, as fontes e os objetivos específicos de cada capítulo, cumprirei a tarefa de localizar esta tese dentro de um contexto bibliográfico sobre a reforma agrária do Chile, formado por estudos de diferentes áreas do conhecimento: história, economia, sociologia, agronomia, pedagogia, ciência política e geografia. Optei por um "balanço bibliográfico", mais amplo do que um "balanço historiográfico", considerando que o tema agrário mobiliza conhecimentos multidisciplinares e muitos autores que inspiram nosso trabalho não são historiadores. A seguir, navegarei por um corpus bibliográfico volumoso e heterogêneo, de difícil sistematização. Diante do desafio, proponho uma periodização que considera três gerações de estudos sobre a reforma agrária chilena, sendo que todas contribuem, à sua maneira, para impulsionar esta tese, com destaque especial para alguns conjuntos específicos de trabalhos na primeira e na terceira. A periodização bibliográfica que criei é uma possibilidade entre várias, que não deve ser lida de modo determinista.

\section{Primeira geração (1955-1973)}

A primeira geração de estudos sobre a reforma agrária chilena pertence ao próprio tempo da reforma agrária, entre os anos 1950 e 1973, e é formada pelo que caracterizei como "pesquisas militantes". Seus autores utilizavam a pesquisa como ferramenta do debate político e da transformação da realidade. Os diagnósticos e investigações agrárias dessa geração serviam diretamente às batalhas de uma reforma agrária ainda em aberto. Para nosso trabalho, as pesquisas militantes têm um valor peculiar, pois são fontes híbridas, simultaneamente primárias e secundárias. Considero os pesquisadores militantes como sujeitos ativos da história da reforma agrária chilena e, seus pensamentos políticos, parte determinante do processo. Ao mesmo tempo, são autores de uma bibliografia que emprega metodologias científicas e se constitui simultaneamente como fonte secundária.

As pesquisas militantes tinham em comum o objetivo de viabilizar a reforma agrária estrutural e fazê-la avançar no caminho da eliminação do latifúndio, do aumento da produtividade, da criação de cooperativas camponesas e da capacitação dos trabalhadores rurais. Engajavam-se diretamente nas controvérsias sobre os ritmos das expropriações, a necessidade ou não de uma nova lei e os caminhos da via chilena ao socialismo. Em alguns casos, eram trabalhos que davam ampla abertura de escuta e registro das vozes do campesinato, sendo estes os que mais receberam atenção.

Dividi a primeira geração em três conjuntos de trabalhos multidisciplinares, que se enfocam nas áreas de (1) a economia e a agronomia, (2) a sociologia e (3) a pedagogia. Sua marca comum é a intervenção na luta política e nas batalhas técnicas. O primeiro conjunto se destaca pelos manifestos e estudos fundamentais de Jacques Chonchol (1951, 1964, 1965, 1970), engenheiro agrônomo e dirigente do alto escalão dos governos da Democracia Cristã (DC) e da Unidade Popular (UP), que produziu as principais sínteses sobre o que deveria ser o programa da reforma agrária no Chile. Junto com ele, com 
igual importância técnica e política, estão os diagnósticos e relatórios de Solon Barraclough (1962, 1965a, 1965b), economista e dirigente da FAO no Chile, que coordenou o relatório do Comitê Interamericano de Desenvolvimento Agrícola (CIDA, 1966), além de seu livro de intervenção escrito com José A. Fernández (Barraclough \& Fernández, 1974) e de seu ensaio síntese com Almino Affonso (Barraclough \& Affonso, 1973). Tais estudos se transformaram em cânones consagrados e guias do processo de mudança na reforma agrária chilena, estruturando a argumentação econômica e agronômica legitimadora das diretrizes políticas que deveriam ser adotadas.

Um segundo conjunto de pesquisas militantes se inseria no campo da sociologia, começando com o emblemático livro de Almino Affonso, Sergio Gómez, Emilio Klein e Pablo Ramirez (1970) sobre movimento camponês chileno. Este livro se transformou imediatamente em uma referência, utilizado nos cursos das confederações camponesas e nas aulas sobre história do movimento campesino para dirigentes sindicais. Ele demonstrava a diversidade de repertórios de luta do campesinato e explicava a historicidade das organizações camponesas. O conjunto sociológico se destaca pela preocupação com a via chilena ao socialismo na agricultura, durante o governo de Salvador Allende. ${ }^{9}$ Um grupo expressivo de pesquisas sociológicas analisou os problemas de produtividade no setor reformado, a luta de classes no campo, as tomas e expropriações, o cautinazo e a luta mapuche pela recuperação das terras usurpadas, as greves camponesas e a sindicalização rural, os desafios dos conselhos camponeses e do poder popular, as sabotagens patronais, a escassez de canais estatais de comercialização agrária, enfim, assuntos prementes do debate político da transformação revolucionária. ${ }^{10}$ Esses trabalhos esmiuçaram sociologicamente os desafios mais prementes da revolução chilena na agricultura, conformando um corpus bibliográfico que deu conta de explicar em detalhes e em diversos ângulos quais foram os problemas da política agrária da UP.

Com ênfase na sociologia econômica e objetivos militantes bem definidos, é difícil encontrar assuntos não abordados por esses autores. Mas foi possível. De maneira geral, este conjunto e o anterior não deram atenção suficiente aos desafios da capacitação camponesa na reforma agrária. Em muitas dessas pesquisas, os problemas econômicos foram priorizados em si mesmos e tratados de maneira separada com relação à questão cultural e educacional da reforma agrária. Em defesa de uma dialética entre economia e cultura, nesta tese, propomos articular o olhar econômico ao olhar pedagógico sobre o problema agrário. Aliás, é bastante simbólico que no livro canônico de Affonso et al. (1970), Marta Zaballeta, que poderia ter sido sua única autora mulher, elaborou um estudo sobre capacitação camponesa que foi excluído da publicação final, ausência informada em um despreocupado preâmbulo.

\footnotetext{
${ }^{9}$ Produzimos uma análise dos dilemas agrários da Unidade Popular (UP) com base na leitura dos pesquisadores militantes aqui: Vasconcelos (2020a).

${ }^{10}$ Entre eles, se destacam Sergio Gómez (1972, 1973), Gómez \& Klein (1972), Cristóbal Kay (1974), Kay e Peter Winn (1972, 1974), Hugo Zemelman (1971a, 1971b), Petras \& Zemelman (1972), Saavedra (1972, 1975), Barrera (1973), José Bengoa (1973), Ian Roxborough (1974, 1977), Brian Loveman (1976) e Kyle Steenland (1977). Também estão nesse conjunto as pesquisas dos Cuadernos do CEREN: Affonso, 1969; Lehman, 1970; Barraclough, 1970, 1971; Barraclough \& Affonso, 1973; Chonchol; 1970; Zemelman, 1971; Castillo \& Larraín, 1971; Maffei \& Billaz, 1972; Cantoni, 1972a; Ribeiro, 1972; Maffei \& Marchetti, 1972b; Crispi, 1973. Entre outros.
} 
Para não cometermos injustiças, alguns pesquisadores desse conjunto sociológico se debruçaram sobre a questão da consciência camponesa no processo de reforma agrária, ainda dentro do enfoque econômico, mas sem adentrar nos desafios pedagógicos. Realizaram enquetes sociológicas e coletaram as vozes camponesas de maneira qualitativa e quantitativa, o que lhes permitiu escutar a heterogeneidade de percepções campesinas sobre a reforma agrária. Lehman (1970) e Petras \& Zemelman (1972) criam "tipologias da consciência camponesa". Lehman (1970: 39, 40) fez um "mapeamento antropológico" do discurso camponês e classificou três tipos de consciência com base em enquetes feitas em catorze propriedades rurais: a consciência dependente ou paternalista (nos latifúndios), a consciência de classe (nos sindicatos) e a consciência campesina (nos assentamentos e cooperativas). Petras \& Zemelman (1972), depois de conversar com assentados em Colchagua, classificaram três tipos de consciência: de dirigentes, que protagonizam a luta; de seguidistas, que apoiam a luta sem protagonismo; e a consciência do opositor, expressa pelos capatazes (mayordomos) que perderam privilégios. Nesse mesmo sentido, Chinchilla \& Sternberg (1974) analisaram as preferências partidárias do campesinato e suas aspirações a respeito da propriedade individual e coletiva, igualmente circunscritos ao período da UP. Tais pesquisas sobre a consciência camponesa permitiram, mais que os demais estudos do conjunto sociológico, registrar vozes camponesas, mas não chegaram a dialogar com a questão pedagógica.

O terceiro conjunto é composto, pois, de estudos pedagógicos sobre a reforma agrária, que correspondem às pesquisas militantes da primeira geração mais desconsideradas pela historiografia. Para esta tese, porém, representam um foco prioritário de análise. Eram trabalhos de educadores, psicólogos e sociólogos que praticavam as pedagogias da capacitação camponesa, formados por equipes que atuaram diretamente com Paulo Freire no Instituto de Desenvolvimento Agropecuário (INDAP) e no Instituto de Capacitação e Investigação para Reforma Agrária (ICIRA), entre 1964 e 1969. Alguns deles prosseguiram atuando na educação camponesa durante o governo da UP. Em primeiro lugar, se destacam os ensaios de Paulo Freire escritos no Chile, que considero um corpus fundamental da bibliografia da reforma agrária chilena, tanto os livros célebres, quanto seus artigos e relatórios dispersos. ${ }^{11}$ Não é comum considerar Paulo Freire como um pesquisador da reforma agrária. Essa leitura é, possivelmente, um ângulo original da tese, atrelada à compreensão que o próprio Freire apresentava da subjetividade na mudança estrutural. O brasileiro sugere o enfoque cultural para atuação na reforma agrária, mas sem com isso perder um olhar estruturalista. Alguns de seus escritos chilenos eram destinados aos educadores da reforma agrária, com sugestões sobre como conduzir um círculo de cultura com camponeses, o que é a investigação temática em assentamentos, a importância dos diálogos

\footnotetext{
${ }^{11}$ Agradeço à Marcela Gajardo e Rodrigo Aravena por disponibilizarem alguns originais mimeografados de Paulo Freire em versão digital, que deveriam estar organizados no fundo documental José María Arguedas da Biblioteca Nacional, que tem arquivos do ICIRA, mas permaneceu fechado durante todo tempo desta pesquisa. Outros originais encontrei no caderno de formação n. 25 do Centro Intercultural de Documentación (CIDOC), organizada por Ivan Illich no México, em 1968. Os ensaios originais mimeografados são: Freire, 1967b, 1968a, 1968b, 1968c, 1968d, 1968e, 1968f, 1968g, 1968h, 1968i, 1968j, 1968k, 1969, 1972; com Velozo, 1968. Os livros famosos de Freire escritos no Chile são: Freire, 1967, 1981, $2011,2018$.
} 
alfabetizadores e como analisar as imagens dos temas geradores. Outros escritos eram relatórios oficiais para Unesco, registrando a recepção camponesa do método e outras informações de pesquisa em campo. Outros ainda eram pesquisas que se consolidaram em livros, como a Pedagogia do Oprimido, uma obra cuja matéria prima é a reforma agrária chilena, muito embora não costume ser lida dessa forma. $\mathrm{Ou}$ ainda Comunicação ou Extensão?, que revela as tensões de Freire com os técnicos extensionistas rurais em plena reforma agrária chilena, conceitua a "invasão cultural" e reflete sobre a temporalidade da mudança subjetiva no processo produtivo. São livros que recebem, nesta pesquisa, o duplo tratamento de fontes primárias e de referenciais teóricos.

Junto com Freire, uma equipe de aguerridos pesquisadores militantes produziu trabalhos no conjunto pedagógico da primeira geração. Este grupo é pouco considerado pelos estudos agrários posteriores, porque não realizou publicações oficiais e editadas, embora tenha produzido uma grande quantidade de relatórios no ICIRA sobre suas experiências pedagógicas freirianas no decorrer da reforma agrária. Entre eles, os registros mais preciosos das vozes camponesas que pude encontrar são as transcrições de círculos de cultura, que faziam parte do método psicossocial. As transcrições eram parte do método, isto é, eram um material de trabalho, análise e compartilhamento das falas dos camponeses entre os pesquisadores. As equipes freirianas se preocupavam em ler a inteligência camponesa, estudando seu pensamento como jamais outra pesquisa militante havia feito. Destacam-se as fontes inéditas que trato de analisar nesta tese, formadas pelos relatórios do assentamento El Recurso, em Buín, e a experiência de programação territorial camponesa em três comunas de Colchagua (Palmilla, Perallillo e Chépica). ${ }^{12}$ Essas fontes contêm o maior volume de vozes camponesas sem mediação secundária de todo período da reforma agrária que pude encontrar.

Além disso, vale destacar a produção de Maria Edy Ferreira, brasileira e pesquisadora no ICIRA (1967-1969), que além de liderar as iniciativas freirianas mencionadas, com Liliana Barria, Sergio Villegas, Marcela Gajardo e José Luis Fiori, também desdobrou os métodos freirianos em pesquisas sociológicas e em um método de estudo das expectativas e aspirações camponesas durante a mudança estrutural (Ferreira, 1968, 1970). Seu trabalho também é uma fonte inédita, nunca examinada pela historiografia. Outra pesquisadora de destaque deste conjunto foi Marcela Gajardo (1969, 1973a, 1973b, 1973c), que deu continuidade a uma agenda de pesquisa com tonalidade freiriana sobre capacitação camponesa, sobretudo no âmbito sindical durante o governo da UP, e depois escreveu dois volumes sobre a educação camponesa da década de 1960.

$\mathrm{Na}$ impossibilidade de mencionar todos os estudos da primeira geração, que são caudalosos como as polêmicas agrárias chilenas, nos falta identificar os principais centros de produção da pesquisa militante. O mais importante deles foi o ICIRA, criado em 1964 em um convênio do governo chileno com a Food and Agriculture Organization (FAO), que concentrou a maior quantidade de publicações. ${ }^{13}$

\footnotetext{
${ }^{12}$ Sobre El Recurso: Ferreira \& Fiori, 1969. Sobre a programação territorial: Ferreira, Barria \& Villegas, 1969; Ferreira \& Barria, 1971. Oscar Domingues, do ICIRA, também pesquisou as aspirações camponesas (Domínguez, 1966).

${ }^{13}$ Só na bibliografia desta tese há mais de 30 títulos editados pelo instituto. Sobre a história do ICIRA, ver FAO (2017).
} 
Os pesquisadores do ICIRA repercutiram diferentes tendências políticas, passando pela esquerda da DC, o social-cristianismo, o pensamento freiriano, o comunitarismo e o marxismo. Foi uma instituição plural, cuja atividade investigativa acompanhou os desafios da política agrária chilena até o golpe de 1973.

Outro organismo foi o Centro de Estudos da Realidade Nacional da Universidade Católica (CEREN), que entre 1970 e 1973 publicou os Cuadernos del CEREN. Era um núcleo cosmopolita de pesquisadores, fundado por Jacques Chonchol, que agregava a intelectualidade próxima do "socialismo comunitário" e foi um importante fórum das pesquisas militantes. ${ }^{14}$ Além deles, outra plataforma do pensamento agrário chileno foi a Revista Agraria, dirigida por Gonzalo Arroyo, que constituía um suplemento mensal do hebdomadário Chile Hoy, dirigido por Marta Harnecker. A Revista Agraria foi publicada em 1972 e 1973, e combinava pesquisa militante e jornalismo investigativo, com ensaios políticos e reportagens baseadas em experiências de campo. ${ }^{15}$ Por fim, também cumpriu um breve papel a revista Sociedad y Desarrollo do Centro de Estudos Socioeconômicos (CESO) da Universidade do Chile, integrado por intelectuais que desenvolveram a teoria marxista da dependência (TMD). ${ }^{16}$

Além disso, não posso ignorar a importância de alguns centros de pesquisa estrangeiros nessa primeira geração de estudos da reforma agrária chilena. O Land Tenure Center (LTC) da Universidade de Wisconsin-Madison (EUA), com patrocínio da USAID, se tornou um centro de excelência sobre a reforma agrária latino-americana. Fundado em 1962, o LTC enviou mais de quinze pesquisadores para desenvolver teses de doutorado sobre a agricultura chilena nos anos 1960, coordenados pelo economista William Thiesenhusen. ${ }^{17}$ Havia também o convênio da Universidade do Chile com a Universidade da Califórnia (1965-1975), com um ramo nas ciências agrárias, patrocinado pela Fundação Ford, e outras iniciativas estadunidenses que atuaram na produção de conhecimento engajado sobre transformações produtivas agrícolas no Chile. ${ }^{18}$

Em suma, a primeira geração de pesquisas reúne um conjunto plural de correntes políticas e um volume torrencial de interesses e engajamentos, nacionais e internacionais, na reforma agrária chilena.

\footnotetext{
${ }^{14}$ Os Cuadernos contêm ao menos 19 artigos sobre temas agrários em seus 18 números publicados de 1970 a 1973 . O CEREN era dirigido por Jacques Chonchol, Armand Mattelard (demógrafo belga), Frank Hinkelammert (economista alemão), Manuel Antonio Garretón (politólogo chileno) e Hernán Valdés (escritor chileno) (Chonchol \& Robles, 2016: 276).

${ }^{15}$ Editada pelo Centro de Estudos Agrários da Universidade Católica (Santiago e Talca), a Revista Agraria tinha em seu conselho editorial homens influentes durante o governo da UP: Jacques Chonchol (Ministro de Agricultura de Allende) e David Baytelman (vice-presidente da CORA), junto de pesquisadores-militantes como José Bengoa, Jorge Echeñique, José A. Fernandez, Sergio Gómez, Raúl Iturra, Daniel Vidart. O grupo pertencia a uma esquerda acadêmica que orbitava ao redor do MAPU.

${ }^{16}$ Há que se sublinhar que entre os pesquisadores do CESO e da TMD, poucos deram atenção ao problema agrário, destacadamente Cristóbal Kay e José Bengoa. Participavam os brasileiros exilados Theotonio dos Santos, Vania Bambirra, Ruy Mauro Marini, Emir Sader e Marco Aurélio Garcia, junto com os chilenos Orlando Caputo, Roberto Pizarro, Cristobal Kay, André Gunder Frank, Pio Garcia, Alexander Schejtman, José Bengoa, Gonzalo Arroyo, e outros (Cárdenas Castro, 2015). Mas sua revista só publicou três números, um deles dedicado à questão agrária.

${ }^{17}$ Entre eles, dedicaram-se à reforma agrária chilena: Brown $(1965,1968)$; Chinchilla (1973); Chinchilla e Sternberg, (1974); Dorner (1966a, 1966b); Garret (1976, 1978); McCoy (1969); Stanfield (1973); Roxborough (1974, 1977); e principalmente o coordenador do LTC no Chile, William Thiesenhusen (1965a, 1965b, 1965c, 1966a, 1966b, 1966c, 1966d, 1966e, 1966f, 1967, 1971, 1974).

${ }^{18}$ Convênio este que formou os chamados "Californian Boys", como demonstrou Heidi Tinsman (2016), em contraponto aos "Chicago Boys".
} 
Em comum, buscavam subsidiar e influenciar os rumos da mudança no campo. Tal efervescência foi interrompida pelo golpe de 11 de setembro de 1973, quando o processo repressivo atingiu diretamente a vida dos pesquisadores militantes.

\section{Segunda geração (1973-1990)}

Em contraste com a pluralidade e liberdade da primeira geração, a segunda geração realizou pesquisas agrárias em tempos de ditadura, em condições adversas para o pensamento científico, driblando a repressão entre 1973 e 1990. Nesse período, segundo a Comissão Nacional de Verdade e Reconciliação (Rettig), foram assassinados e desaparecidos 324 camponeses e 51 técnicos da reforma agrária. Mais de 50 mil camponeses foram excluídos da terra que tinham conquistado nos anos anteriores, além de milhares de trabalhadores rurais terem sido presos e torturados. ${ }^{19}$ Os investigadores agrários que adentravam o campo para realizar suas pesquisas testemunharam a brutalidade da contrarreforma agrária, mas ainda assim, corajosamente, publicaram uma quantidade importante de estudos críticos.

A segunda geração produziu três tipos de trabalhos. Primeiro, as pioneiras análises críticas da modernização autoritária na agricultura, que demonstravam os impactos sociais e territoriais da contrarreforma agrária, a nova pobreza rural e as poblaciones callampa nas beiras de estrada, integrando estudos econômicos e sociológicos sobre as consequências da política agrária da ditadura. $\mathrm{O}$ valor político desses trabalhos é enorme, e seus autores foram fundamentais para que se reunissem informações sobre a agricultura durante a ditadura, sem os quais muito poderia ter sido perdido e obscurecido por narrativas oficiais. ${ }^{20}$ Alguns desses trabalhos foram desenvolvidos dentro do Grupo de Investigações Agrárias (GIA), criado em 1978 para investigar políticas agrárias da ditadura, com apoio do Land Tenure Center e da Academia del Humanismo Cristiano, fundada pelo Cardeal Silva Henríquez. O segundo tipo de obra foi elaborado no Centro de Estudos da Mulher (CEM), criado em 1983, que inovou com a metodologia dos relatos de vida e valorizou de maneira inédita a voz das mulheres camponesas sobre sua experiência na reforma agrária chilena, ao publicar suas memórias e reflexões. Foram trabalhos pioneiros em apontar as tensões de gênero no seio da reforma agrária chilena e no uso abundante da metodologia da história oral das trabalhadoras rurais. ${ }^{21}$

Um terceiro tipo de trabalho foi buscar no passado agrário chileno e na história social do século XIX interpretações de longo prazo sobre as dificuldades vividas na reforma agrária dos anos 1960 e

\footnotetext{
${ }^{19}$ Sobre a contrarreforma agrária da ditadura de Pinochet e a repressão ao campesinato, produzimos uma investigação paralela publicada em Vasconcelos, 2020c. A contabilização por setores da sociedade não é feita nos relatórios oficiais, mas foram contabilizadas pela autora. Ver Informe de la Comisión Nacional de Verdad y Reconciliación (Rettig), 1990; Informe de la Comisión Nacional sobre Prisión Política y Tortura (Valech 1), 2005; e Informe de la Comisión Presidencial Asesora para la Calificación de Detenidos Desaparecidos, Ejecutados Políticos y Víctimas de Prisión Política y Tortura (Valech 2), 2011. ${ }^{20}$ Entre eles, se destacam: Cereceda \& Dahe, 1980; Gómez, 1981a, 1981b, 1982, 1986; Rivera \& Cruz, 1984; Ortega, 1987; Gómez \& Echeñique, 1988.

${ }^{21}$ Sobretudo Acuña, 1986; Valdéz, Mack \& Matta, 1986 e Valdéz, 1988.
} 
1970, valorizando as agências populares..$^{22}$ Por fim, um quarto tipo emergiu no fim da ditadura, com dois livros de posicionamentos políticos antagônicos, que tiveram em comum o primeiro esforço de síntese panorâmica da história da reforma agrária. Ambos buscaram explicar a reforma agrária para as gerações que não a viveram. Huerta (1989) sistematizou uma narrativa muito completa sobre os múltiplos projetos em disputa, identificando seus proponentes, embates, intenções, obstáculos, os limites do Estado e, sobretudo, as tensões entre as elites políticas e a realidade camponesa. Enquanto isso, Garrido, Guerrero \& Valdés (1988) escreveram uma história oficialista, na qual a reforma agrária aparecia como uma continuidade evolutiva da política de colonização, o governo Allende era descrito como um caos de ilegalidades rurais e a política agrária da ditadura como exata, bem-sucedida e normalizadora. Esses autores reabilitavam o conceito de reforma agrária sem mudança estrutural, derrotado nos anos $1960 .{ }^{23}$

Apesar da repressão, os valentes pesquisadores agrários que permaneceram no Chile durante a ditadura fundaram e articularam novos espaços institucionais para seguir seu trabalho (o GIA, o GEA, o CEM, a FLACSO). Em que pese as adversidades, os críticos da ditadura conseguiram produzir investigações agrárias mais difundidas e relevantes que os estudiosos pró-regime.

\section{Terceira geração (1990-2017)}

Os movimentos de democratização e a queda da ditadura abriram um novo ciclo entre 1990 e 2017, que mapeei como terceira geração de estudos da reforma agrária chilena, desenvolvidos predominantemente por historiadores. A maior liberdade para busca de documentos e uma onda de novas abordagens, olhares e metodologias colaboraram para criatividade historiográfica. $\mathrm{O}$ distanciamento favorecia novas perspectivas. Esta geração foi aberta pelo livro coletivo de Kay \& Silva (1992), que aproveitaram o novo contexto democrático para reunir pesquisas da história agrária chilena do século XIX à crítica da ditadura. Ao mesmo tempo, uma historiografia inspirada em Peter Winn (1986) e em sua tese sobre as duas revoluções chilenas (desde cima e desde baixo) inspirou trabalhos sobre a reforma agrária que iluminavam diferentes territórios e experiências atravessados por tensões semelhantes. Os trabalhos de Heidi Tinsman (2002) e Florencia Mallon (2004), referenciados em E.P. Thompson (2002), Joan Scott (1999) e Raymond Williams (2005), buscaram esmiuçar a experiência popular camponesa nas suas tensões concretas de gênero, raça e classe, enfatizando as particularidades territoriais dessas tensões e driblando as metanarrativas características das pesquisas militantes da primeira geração.

Tinsman (2002) estudou as hierarquias de gênero e o conceito de família nas políticas de reforma agrária da DC e da UP, e analisou fenômenos como a masculinidade sindical camponesa, o mutualismo

\footnotetext{
${ }^{22}$ Ver Salazar, 1985; Bengoa, 1985, 1988, 1990. Juntos, esses livros alcançaram cerca de 17 edições.

${ }^{23} \mathrm{Um}$ dos autores, José Garrido, foi presidente do Colégio de Agrônomos quanto este atuou em favor do paro patronal de outubro de 1972, ocasião em que suspendeu a carteira profissional do então ministro da agricultura, Jacques Chonchol (Andanzas de la Orden Agronómica. Revista Agraria n.1, Chile Hoy n. 25, Dic./1972).
} 
de gênero na convocatória ao apoio cívico das mulheres rurais, as tensões matrimoniais provocadas pela mudança estrutural no campo, e as restrições que a reforma agrária impunha às mulheres. Já Mallon (2004), depois acompanhada por Correa, Molina \& Yáñez (2005), Suazo (2013), Redondo (2017) e Navarrete Vergara (2018), se dedicou à experiência da reforma agrária em terras mapuche, sobretudo em Cautín, por diferentes ângulos. Tais pesquisas analisaram a história do Movimento Campesino Revolucionário (MCR), das tomas e corridas de cerco e das tensões étnicas e políticas implicadas na rebelião indígena do cautinazo, colaborando com novas compreensões sobre a historicidade indígena.

Nesse novo ciclo, o historiador Thomas Klubock (2014) inovou com uma história florestal do Chile, utilizando instrumentos da história ambiental para analisar a política das monoculturas florestais de pinos e eucaliptos durante a reforma agrária em diferentes governos. Sobre o mesmo território florestal, Claudio Robles Ortiz (2017) produziu uma pesquisa sobre a "revolução desde baixo" no Complexo Florestal de Panguipulli. Também foram publicados dois trabalhos na área de ciência política: o estudo de Oscar Oszlak (2016) sobre a Sociedade Nacional de Agricultura (SNA) durante a reforma agrária, que contribuiu para as pesquisas sobre as classes latifundiárias e suas trajetórias; e o livro de Octavio Avendaño (2017), que analisou detalhadamente como os partidos políticos atuaram na reforma agrária chilena entre 1946 e 1973 e construíram relações entre a política parlamentar e a política camponesa. Ademais, há três autores que percorreram os estudos agrários chilenos da primeira até a terceira geração em uma maratona de vida inteira: Cristóbal Kay (2002), Sergio Gómez (2002) e José Bengoa (2016).

Por último, mas não menos importante, uma nova onda de publicações fez parte da efeméride do aniversário de 50 anos da lei de reforma agrária (16.640 de 1967), que estimulou livros, documentários e dossiês temáticos. Em 2017, dezenas de debates sobre a reforma agrária ocorreram em todo país, nas universidades, sindicatos e centros culturais, expandindo o contato com o tema, que antes parecia restrito a circuitos especializados. A efeméride serviu para recolocar a história da reforma agrária no debate público, ao menos durante aquele ano. Entre os novos estudos estimulados pela data, se destacaram um dossiê da revista Annales da Universidade do Chile, que trouxe investigações recentes e originais junto com trabalhos de memória; ${ }^{24}$ um dossiê da revista Polis da Universidade de Los Lagos, ${ }^{25}$ uma publicação comemorativa da Biblioteca do Congresso Nacional de Chile (Corvera, 2017); um livro de Faiguenbaum (2017) sobre a história do Instituto de Desenvolvimento Agropecuário (INDAP); e outro, editado pela Universidade de Talca, motivado pelos 50 anos da reforma agrária (Rojas \& Manríquez, 2017). Por fim, com coerência e persistência, aos 91 anos, Jacques Chonchol (2018) se atreveu a escrever o livreto Por una nueva reforma agraria para Chile, que tece um fio entre passado e presente. Esses novos trabalhos tiveram em comum a motivação da efeméride, mas também

\footnotetext{
24 "A 50 años de la reforma agraria", Annales, n. 12, U. Chile, 2017.

25 "Reformas agrarias en América Latina y Chile: lecciones aprendidas sobre la controversia de la propiedad de la tierra", Polis, n. 47, U. Los Lagos, 2017.
} 
os enfoques territoriais locais da reforma agrária, explorando as possibilidades investigativas da história regional.

\section{O lugar desta tese}

O tema das pedagogias camponesas, da ação cultural para reforma agrária, da alfabetização, da capacitação e da educação produtiva aparece de maneira residual na maior parte dessa bibliografia, com exceção do conjunto pedagógico da primeira geração de pesquisas militantes, que formam um corpus primário para esta pesquisa; e de Heidi Tinsman (2002), que se aprofunda na análise de processos educacionais relacionadas com a família e as hierarquias de gênero da reforma agrária. De certa maneira, o aspecto residual da educação camponesa em tantos trabalhos indica um ponto cego, sobre o qual pretendo lançar luz ao analisar as hierarquias culturais e epistemológicas da reforma agrária que conectam as formas de produzir às formas de conhecer. O nexo entre economia e cultura, entre produção e conhecimento não havia sido até aqui suficientemente investigado pela bibliografia, a não ser por Paulo Freire e suas equipes da primeira geração, que são nossos principais inspiradores.

Um trabalho bastante próximo do objeto desta tese não foi incluído no balanço bibliográfico porque $n a \tilde{o}$ se trata de um estudo da reforma agrária chilena. É a dissertação de mestrado de Daniela Zubicueta (2019), que tratou da experiência social da alfabetização freiriana junto a camponeses da reforma agrária, circunscrita ao período em que Paulo Freire esteve no Chile e à alfabetização, sem analisar outros ramos da capacitação camponesa e sem vincular a pedagogia à questão econômica. Zubicueta propõe um bonito encontro entre história social e história da educação, e descobriu fontes primárias preciosas, cujo paradeiro até então eu desconhecia, embora as tenha procurado. ${ }^{26}$ Este trabalho coincide com Zubicueta no ângulo da história social, na análise da experiência educacional camponesa, mas o faz de maneira diferente ao propor uma tentativa de "história econômica thompsoniana" ou "história das economias morais", ${ }^{27} \mathrm{em}$ busca do nexo entre experiência e estrutura econômica. Nesse sentido, sugeri outros encontros teórico-metodológicos, da história social com a história econômica, da história da agricultura com a história da cultura, abarcando uma periodização mais ampla, delimitada pelas principais iniciativas educacionais para transformar a estrutura produtiva

\footnotetext{
${ }^{26}$ Trata-se das imagens da alfabetização camponesa da CORA, localizadas pela historiadora no Museo Casa Eduardo Frei; e das imagens da capacitação de mulheres camponesas do INDAP, do arquivo pessoal de Carmen Gloria Aguayo. Agradeço aos achados de Daniela Zubicueta, com quem troquei referências e dialoguei em 2019.

${ }^{27}$ James Scott argumentou que a "economia moral camponesa" frequentemente é guiada por uma "ética da subsistência", para a qual o sentimento popular e a experiência da exploração nem sempre coincide matematicamente com o processo de maior extração de mais valia: "A ética da subsistência está enraizada nas práticas econômicas e trocas sociais da sociedade camponesa. Como um princípio moral, como um direito à subsistência (...). Um sistema de propriedades que proveja seu proprietário com a garantia mínima de retorno é usualmente experimentado como menos explorador do que um sistema que dele extraia em média até menos [trabalho], mas não alcance suas necessidades como consumidor primário (...). O teste da subsistência oferece uma perspectiva muito diferente sobre a exploração do que teorias que se sustentam unicamente no critério da mais valia expropriada" (Scott, 1976, p. 6-7). Inspiro-me também no conceito de economia moral de E.P. Thompson: "a visão consistente e tradicional das normas e obrigações sociais e das funções econômicas apropriadas para cada uma das partes de uma comunidade" (Thompson, 1971: 79). Tais "obrigações" e "funções" são também chamadas pelo autor de "normas surdas" (Thompson, 2002: 235).
} 
da agricultura chilena. Por isso, essa história começa ainda antes da reforma agrária, quando estrategistas estadunidenses desembarcaram no Chile para "plantar o conceito" da "revolução verde" em $1955 .^{28}$

\section{Chile, reforma agrária e a dialética economia-cultura}

Nesta tese, busquei desenvolver dois argumentos gerais, um de ordem historiográfica e outro de ordem teórico-metodológica, justificados a seguir.

\section{Argumento historiográfico}

O argumento historiográfico sugere que os projetos de transformação econômica da agricultura chilena empreenderam pedagogias camponesas e dispositivos técnico-científicos de educação produtiva porque reconheciam que as mudanças precisavam abarcar não apenas a reorganização tecnológica, do regime de propriedades, das relações de trabalho, mas também transformar as formas de conhecer, de saber, de sentir e de compreender o mundo. Em uma palavra, essas pedagogias atuavam nas formas de consciência popular camponesa, e buscavam fomentar o surgimento dos "novos sujeitos" para uma "nova agricultura". Longe de ser um "aspecto" da reforma agrária, a questão pedagógica era seu cerne, uma vez que atuava sobre as subjetividades produtivas do campesinato, suas estruturas de sentimento, suas visões a respeito dos sentidos do seu próprio trabalho e as nuances da economia moral de cada fração da classe camponesa.

Nesse percurso, valorizei as fontes que expressavam as vozes camponesas sem mediações, na tentativa de analisar tais pedagogias a contrapelo, ou seja, a interação do campesinato com os processos educacionais que os interpelaram, bem como as alianças e tensões entre educadores, técnicos e camponeses. Isso ocorre, como já explicamos, no contexto de encontros e desencontros entre epistemologias urbanas, utopias modernizadoras, saberes camponeses e as aspirações populares de transformação da vida no campo. Por exemplo: em uma pesquisa sobre aspirações campesinas, Oscar Domínguez entrevistou 105 trabalhadores rurais em cinco comunas rurais próximas à Santiago. O pesquisador escutou variadas percepções e aspirações dos camponeses de 1965. "Nunca protestei, aqui o patrão é bom, tratável, se preocupa com os doentes", dizia um camponês de Melipilla. "O patrão é bom, tudo o que pedimos, favores, dinheiro, conseguimos com ele”, dizia outro (apud Domínguez,

\footnotetext{
${ }^{28}$ A chamada "revolução verde" foi o processo de deslocamento técnico-econômico da indústria da guerra para produção agropecuária ocorrida logo após a II Guerra. A mecanização da agricultura e o uso de pesticidas se disseminou a partir dos anos 1950, incrementando continuamente um modelo intensivo de produção agrária, cujos efeitos nocivos e mortíferos foram criticados pelo menos desde 1962 pela bióloga Rachel Carson (1969). A revolução verde foi um processo político consciente, que envolveu estratégias educacionais de longo prazo para modificação de padrões produtivos, como veremos no caso do Chile. O termo "revolução verde" foi criado como parte da estratégia de apaziguamento dos danos causados por tais tecnologias ao meio ambiente. O paradigma se consolidou como modelo produtivo das grandes corporações até hoje.
} 
1966: 24). Por outro lado, também escutou: “o patrão é malvado: cobra tudo, não se ajusta à lei do descanso e das 8 horas de trabalho" e "nos latifúndios é impossível subir de vida, temos poucas regalías e baixos salários" e também "aqui sempre empobrecemos, trabalhamos só para sobreviver" (apud Domínguez, 1966: 20,27). As variadas percepções que os camponeses tinham da sua própria realidade laboral influíram na subjetividade produtiva dos assentamentos. Como indicava Maria Edy Ferreira (1968, 1970), a percepção camponesa sobre as vantagens e desvantagens do assentamento seria determinante na sua escolha em favor da parcela individual ou da cooperativa camponesa, modelando, portanto, a fisionomia econômica do regime de propriedades no país na consolidação da reforma agrária. O processo transitório do assentamento, determinado pela lei 16.640, durava de 3 a 5 anos, nos quais camponeses formavam uma sociedade com a CORA (a Sociedade da Reforma Agrária, SARA). Era um momento chave da transformação e reorganização da economia moral camponesa, no qual a experiência seria capaz de influenciar a estrutura de propriedades. As pedagogias para reforma agrária eram a principal iniciativa política com capilaridade sobre estas subjetividades.

A periodização desta pesquisa começa na década de 1950, porque foram encontradas evidências de que a educação camponesa foi determinante em projetos de transformação econômica prévios à reforma agrária de 1967. Desde a década de 1950, as pedagogias para mudança produtiva eram uma preocupação aguda das multinacionais da revolução verde, dos aparelhos públicos e privados da hegemonia estadunidense que atuava na agricultura latino-americana, tais como Fundação Rockefeller, Fundação Ford, USAID e um corpo de cientistas das Universidades de Minnesota, de WisconsinMadison e da Califórnia. Também se constatou a grande importância do Instituto de Educação Rural, fundado em 1954, na atuação pedagógica sobre a subjetividade produtiva, ao interpelar o campesinato e estimular determinados valores morais, uma década antes da reforma agrária estrutural. Dada a importância histórica de tais iniciativas e a escassa investigação a respeito, o argumento historiográfico dessa pesquisa se expandiu para década de 1950. As fontes anteriores à reforma agrária de $1967 \mathrm{o}$ corroboravam fortemente e, portanto, pareciam fundamentais para a linha da investigação. Como resultado, estudei uma grande quantidade de sujeitos educacionais que promoveram variados projetos de transformação cultural no seio da transformação agrária no Chile entre 1955 e 1973.

Nesse sentido, me identifico com a estratégia historiográfica de Tinsman (2002, 2008), que buscou identificar as particularidades do processo social da mudança agrária na experiência vivida do campesinato. Tinsman identificou as hierarquias de gênero como estruturas produtoras das estratégias políticas, não como um "aspecto" do processo histórico. Concordando com Joan Scott (1999), Tinsman argumentou que tais hierarquias eram essenciais nas batalhas políticas da reforma agrária chilena, isto é, não observá-las significava perder de vista a totalidade.

Nesse mesmo sentido, argumentarei que a produção das hierarquias dos saberes produtivos, considerados mais ou menos válidos pela cultura econômica dominante, formam um eixo substantivo da história da reforma agrária e da revolução chilena. Abstrair a questão pedagógica da transformação econômica é perder de vista um eixo totalizante do processo. Por isso, busquei esmiuçar as 
intencionalidades pedagógicas da transformação agrária desde um ângulo historiográfico que nos permita investigar a dialética entre economia e cultura.

\section{Argumento teórico-metodológico}

O segundo argumento geral é de ordem teórico-metodológica. Procurei defender que a economia, ao contrário do que as teorias mecanicistas advogam, é também uma estrutura subjetiva. Com isso, naveguei pelas trilhas do marxismo de Thompson (2002), Williams (1979) e Winn (1971) ao apostar que as estruturas de produção estão repletas de estruturas de sentimentos, economias morais e formas de entender a própria vida, que são determinantes dos processos de transformação econômica, especialmente quando relacionadas à reorganização das relações de trabalho e ao desaparecimento do capataz.

Descontente com o marxismo que considerava mecanicista e dogmático, Thompson escreveu, em 1977:

A analogia "base e superestrutura" é radicalmente inadequada. Não tem conserto. Está dotada de uma inerente tendência ao reducionismo ou ao determinismo econômico vulgar, classificando atividades e atributos humanos ao dispor alguns destes na superestrutura (lei, arte, religião, "moralidade"), outros na base (tecnologia, economia, as ciências aplicadas), e deixando outros ainda a flanar, desgraçadamente, no meio (linguística, disciplina do trabalho). Nesse sentido, possuem um pendor para aliar-se com o pensamento positivista e utilitarista, isto é, com posições centrais não do marxismo, mas da ideologia burguesa. (...) É preciso dizer: sem cultura, não há produção $(2002: 256,258)$.

Thompson demonstrou, em sua historiografia sobre a classe trabalhadora da Inglaterra, os limites teórico-metodológicos do "estruturalismo" de Althusser e da correspondente historiografia, que tinha um potencial reificador dos sujeitos motivado pela priorização das estruturas econômicas e das abstrações metanarrativas levadas às últimas consequências. O estruturalismo em excesso corria o risco de obliterar a luta de classes e a agência dos sujeitos históricos, suas experiências e potencialidades.

Thompson também foi um crítico das práticas e discursos leninistas que projetavam sobre a classe trabalhadora realmente existente uma ideia de proletariado teoricamente imaginada, que se encaixava em padrões de comportamento revolucionário nem sempre correspondentes à experiência de classe efetiva. Como consequência, tais abordagens favoreciam o moralismo político e a frustração vanguardista. Nas palavras de Thompson, esse problema era fruto do "leninismo platônico". Contra esse procedimento idealista e reificador dos sujeitos trabalhadores realmente existentes, o historiador inglês afirmava o conceito de classe como experiência:

A classe se delineia segundo o modo como homens e mulheres vivem suas relações de produção e segundo a experiência de suas situações determinadas, no interior do conjunto de suas relações sociais, com a cultura e as 
expectativas a eles transmitidas e com base no modo pelo qual se valeram destas experiências em nível cultural (Thompson, 2002: 277).

A "história vista de baixo" requeria, no programa historiográfico de Thompson, um imperativo metodológico: a busca de fontes primárias que oferecessem as vozes dos debaixo por si mesmos, sem intérpretes ou mediadores, em um volume suficiente que permitissem ao historiador investigar a inteligência popular, os sentidos da sua experiência de classe e a "economia moral das multidões" (Thompson, 1971). "A classe acontece", escreveu, "quando alguns homens, como resultado de experiências comuns (herdadas ou partilhadas), sentem e articulam a identidade de seus interesses entre si, e contra outros homens cujos interesses diferem (e geralmente se opõem) dos seus" (Thompson, 1987:10). Ou seja,

A experiência de classe é determinada, em grande medida, pelas relações de produção em que os homens nasceram - ou entraram involuntariamente. A consciência de classe é a forma como essas experiências são tratadas em termos culturais: encarnadas em tradições, sistemas de valores, ideias e formas institucionais" (Thompson, 1987:10).

Investindo em uma aposta teórica semelhante, Raymond Williams (1979) se voltou para análise marxista da literatura e da cultura como manifestação estrutural da experiência humana. Entre suas contribuições mais versáteis estão os conceitos de "estrutura de sentimento" e "estrutura de experiência", que podem servir como um esteio dialético das investigações históricas, consolidando o lugar estrutural das subjetividades na história. As estruturas de sentimento, Williams define, são os "elementos especificamente afetivos da consciência e das relações, e não de sentimento em contraposição ao pensamento, mas de pensamento tal como sentido e de sentimento tal como pensado" (1979: 134). E reforça:

Estamos definindo esses elementos como uma "estrutura": como uma série, com relações internas específicas, ao mesmo tempo engrenadas e em tensão. Não obstante, estamos também definindo uma experiência social que está ainda em processo, com frequência ainda não reconhecida como social, mas como privada, idiossincrática, e mesmo isoladora, mas que na análise (e raramente de outro modo) tem suas características emergentes, relacionadoras e dominantes, e na verdade suas hierarquias específicas

Considerando as diferentes temporalidades subjetivas no interior das formações sociais, Williams avalia que o marxismo até ali se dedicou a examinar os fenômenos "consolidados" da cultura, mas deixou de lado os fenômenos "em processo", que anunciam potenciais formas culturais do futuro, tanto quanto as batalhas políticas que atravessam tais formas culturais, ou seja, os processos transitórios de mudança subjetiva. Por isso, explica que: "as estruturas de sentimento podem ser definidas como experiências sociais em solução, distintas de outras formações semânticas sociais que foram precipitadas e existem de forma mais evidente e imediata" (Williams, 1979: 136). Se as relações de classe, de produção, de trabalho que ocorrem na materialidade social estão necessariamente implicadas em estruturas de sentimento e experiências de classe, transformar estruturas econômicas significa 
impreterivelmente transformar a subjetividade popular. E para Thompson e Williams, a transformação da consciência popular só poderia acontecer por meio da experiência autodeterminada de sujeitos.

Esse giro epistemológico interno ao marxismo, impulsionado por Thompson e Williams resultou em um novo programa historiográfico novo que ascendeu nos anos 1980 e destacava as particularidades da experiência de classe, valorizando as expressões da subjetividade como fonte histórica. Diante dessa nova historiografia e da polarização por ela deflagrada dentro do marxismo, Emília Viotti da Costa $(1990,1994)$ fez um alerta: os estudos da estrutura precisavam encontrar a experiência, e os estudos da experiência não deveriam perder de vista a estrutura. Em dois artigos emblemáticos, referências-chave para as escolhas teórico-metodológicas desta tese, a historiadora brasileira examinou os caminhos da historiografia do trabalho nos anos 1980, durante a polarização historiográfica entre estrutura e experiência. Tal polarização, se encarada com sectarismo, poderia desgastar a substância dialética da agenda de Thompson e Williams, alertou a autora. Afinal, a dialética entre economia e cultura, trabalho e sentimento, era a condição investigativa rumo ao aprimoramento marxista da historiografia.

Assim, segundo explicou Viotti da Costa, se por um lado o estruturalismo havia eventualmente produzido uma historiografia sem sujeitos, também os estudiosos da "agência" podiam perder os esteios estruturais e seus imprescindíveis fundamentos explicativos. "Tanto uma postura quanto a outra me parecem igualmente equivocadas", registrou a historiadora:

Uma porque se recusa a integrar a teoria às transformações extraordinárias quer ocorreram no mundo contemporâneo nos últimos trinta anos, apegandose a esquemas teóricos que não dão mais conta do real (...); a outra, porque no seu afã de originalidade, ao inverter simplesmente os postulados da historiografia dos anos $60 \mathrm{em}$ vez de integrá-los numa síntese mais rica, corre (...) o risco de recriar, sob aparência do novo, um tipo de história bastante tradicional (...) [e] deixar de lado aspectos fundamentais para compreensão da vida do indivíduo em sociedade (Costa, 1994: 10).

Nesse sentido, Viotti sugere uma historiografia que almeje a dialética entre estrutura e experiência: "os estudos mais bem-sucedidos", sintetizou, "são exatamente aqueles em que o autor conseguiu estabelecer uma ponte entre esses dois tipos de abordagem, que outros consideraram irreconciliáveis" (Costa, 1990: 8).

Nesta tese, ao nos debruçarmos sobre as diferentes temporalidades da transformação econômico-produtiva (do desenvolvimento) e a transformação subjetiva (das consciências) no processo de mudanças agrárias no Chile, estava em busca da ponte indicada por Viotti da Costa. Percebemos, ademais, que na reforma agrária chilena, a necessidade da autodeterminação camponesa na mudança de sua consciência gerava um impasse entre a velocidade da transformação econômica na estrutura de propriedades, os imperativos da produtividade do trabalho e as diferentes temporalidades que estão contidas nas lutas. 
A “invasão cultural” criticada por Paulo Freire (1969), que também nos ancora em termos teórico-metodológicos, era um procedimento padrão do projeto tecnocrático modernizador da agricultura, que inferiorizava o campesinato. Mas também poderia ser um efeito da velocidade revolucionária, cuja temporalidade "atropelasse" o diálogo revolucionário entre seus múltiplos sujeitos, impondo o ritmo de uns sobre outros. "Manipulação e conquista, como fases da invasão cultural e como instrumentos para preservá-la, não são caminhos de libertação. São caminhos de domesticação. O verdadeiro humanismo não pode aceitá-las, em nome de nada", escreveu Freire (1969: 33). E completava:

Não se pode pensar na capacitação técnica de camponeses, com vistas a uma maior produtividade de seu trabalho, em uma perspectiva humanista e científica, se nessa tentativa se vê ingenuamente o problema da técnica (...). As técnicas não aparecem por acaso. As técnicas bem acabadas e elaboradas são a aplicação da ciência, que por sua vez implica ter uma consciência do mundo (...). O saber científico, no qual a intencionalidade da ciência se apresenta no máximo grau do metódico, não pode ser visto fora de seus condicionamentos histórico-sociológicos (1969: 28-29).

Não por acaso, Freire dedicou parte dos seus escritos chilenos na elaboração de uma "crítica das vanguardas sectárias", porque identificava que poderiam incorrer em invasão cultural tanto quanto as empresas capitalistas, os aparelhos culturais da burguesia ou o Estado. "A ação cultural como a entendemos não pode, de um lado, sobrepor-se à visão do mundo dos camponeses e invadi-los culturalmente; de outro, adaptar-se a ela", escreveu no artigo de 1968, Ação cultural para reforma agrária (Freire, 1981: 30). Ao colocar a questão pedagógica como porta de entrada do debate econômico sobre a transformação das subjetividades produtivas, Freire elaborou uma crítica políticopedagógica do produtivismo moderno: "a paciência também é uma virtude revolucionária, que tem, como seu oposto, a impaciência revolucionarista (...). Sem o conhecimento sério, responsável, de como estas populações transformam, na sua prática, sua fraqueza em força, é impossível uma comunicação válida com elas". E completou: "Sem este conhecimento, o que fazemos, enquanto intelectuais pequeno-burgueses, é invadi-las, em termos distintos da invasão que as classes dominantes já fazem, mas invasão sempre - uma espécie de 'colonialismo revolucionário"” (Freire, 1981: 47).

A sincronia entre a mudança econômica e a mudança cultural se tornou um grande problema filosófico da Pedagogia do Oprimido. Tradicionalmente, esse livro foi lido como maior referência da pedagogia moderna, mas desvinculado da dimensão econômica. Os estudos históricos sobre Pedagogia do Oprimido, como Holst (2006), Kirkendall (2010) e Gajardo (2019), aprofundaram de maneira primorosa as correlações entre vida e obra de Freire, identificando como os aspectos teórico-políticos de seus escritos se entrelaçavam à sua experiência biográfica. Sobretudo, tais autores indicaram como Freire atuou de maneira inigualável nas fissuras da Guerra Fria, impulsionando um programa de alfabetização que, ao desequilibrar as hierarquias do conhecimento e promover a reciprocidade nas relações desiguais entre educadores e educandos, atuava a contrapelo de todos os verticalismos, fossem 
capitalistas ou socialistas. Ou seja, Freire atuava dentro de uma agenda marxista de tipo autogestionária, bastante coerente com a historiografia de Thompson e com os estudos culturais de Williams. Nesse sentido, considero um aspecto original desta tese a proposta de uma "leitura econômica" da Pedagogia do Oprimido, a partir da qual formulei o conceito de "subjetividade produtiva", que com efeito, nos parece lexicalmente mais exato que "economia moral".

\section{Capítulos e fontes}

Explicarei a seguir as linhas gerais de cada um dos capítulos que compõem a tese, incluindo ao final do parágrafo as fontes utilizadas e as imagens selecionadas. É necessário justificar que o uso abundante de imagens nesta tese tem uma razão de ser: as imagens são textos para camponeses analfabetos, portanto fontes que explicam o cerne das minhas investigações sobre pedagogia e comunicação política entre cidade e campo.

\section{Capítulo 1 - Questão agrária no Chile entre 1955 e 1973: formas econômicas, batalhas culturais}

Quais eram os contornos da questão agrária chilena no periodo estudado, considerando as correntes de pensamento político da reforma agrária como invenção urbana e as dinâmicas autodeterminadas do movimento camponês, suas aspirações e expectativas?

O Capítulo 1 tem como objetivo narrar a história da reforma agrária no Chile pela identificação de um duplo movimento: as epistemologias urbanas, em suas diversas correntes modernizadoras, reformadoras e revolucionárias; e as epistemologias rurais, entendidas por meio da experiência da luta camponesa e de suas práticas de reivindicação da terra. Para isso, esmiucei o que seria a "reforma agrária como invenção urbana", de onde partiam diferentes horizontes modernos e antagônicos de mudança; e a "reforma agrária como pressão rural", que mapeia panoramicamente as estratégias camponesas desde baixo. Também é desdobrado o conceito de "reforma agrária como questão cultural" por meio da análise da relação entre o latifúndio e o analfabetismo rural, bem como da apresentação do cenário educacional do campo nos anos 1950 e 1960: a escassez de escolas rurais e o trabalho compulsório das crianças camponesas, retiradas da escola com 9 anos para integrar os quadros da mão de obra das haciendas. Por fim, do encontro entre a invenção urbana e as pressões rurais a reforma agrária é posta em marcha. Discutimos, em linhas gerais, o processo expropriatório, a intensidade da mobilização camponesa durante a reforma e alguns dilemas da revolução agrária. As fontes do Capítulo 1 são estudos agrários dos pesquisadores militantes da primeira geração; documentos de partidos políticos; a Revista de Educación do Ministério da Educação Pública do Chile; entrevistas com camponeses no âmbito da história oral. As imagens selecionadas são a capa do emblemático relatório CIDA que documenta com exatidão o que conceituei como epistemologias urbanas da reforma agrária; ilustrações de cartilhas 
partidárias destinadas a dialogar com camponeses quando a reforma agrária era debatida no parlamento (1965 a 1967); e uma foto do agrônomo Jacques Chonchol conversando com camponeses quando era vice-presidente do INDAP.

\section{Capítulo 2 - Plantando conceitos: a atuação dos Estados Unidos na educação agrária do Chile}

Quais eram as estratégias educacionais dos múltiplos agentes estadunidenses para transformação da agricultura chilena? Como se relaciona educação produtiva e revolução verde?

O Capítulo 2 recua um pouco no tempo e começa a narrativa em 1955, quando aparelhos de hegemonia estadunidenses, públicos e privados, se instalam no Chile com projetos de educação agrária em variadas dimensões. Esse capítulo mapeou fontes primárias até aqui bem pouco investigadas pela historiografia, e identificou quais instituições estadunidenses atuaram na educação agrária chilena. Educação agrária, e não "pedagogias camponesas", porque muitos desses projetos se dedicavam a alteração de currículos de agronomia e de técnicos agrícolas, mais preocupados com a educação dos funcionários da agricultura do que dos camponeses. Esse capítulo narra as iniciativas da USAID, da Fundação Rockefeller e da Associação Internacional Americana para o Desenvolvimento Econômico e Social (AIA) na construção de escolas rurais no sul do Chile e as estratégias dessas mesmas instituições de penetração no Ministério da Agricultura por meio do Departamento Técnico Interamericano de Cooperação Agrícola. Também analisa a atuação de acadêmicos da Universidade de Minnesota, especialistas em extensão rural e financiados pela Fundação Ford, na criação de estações experimentais agrícolas e na estruturação de departamentos de extensão rural nas faculdades de agronomia. E, por fim, o Capítulo 2 esmiúça os projetos e as intenções de agrônomos, botânicos, pomólogos e entomólogos da Universidade da Califórnia (Davis e Riverside) nas suas investigações sobre pragas agrícolas e prescrições de pesticidas. Associei todas essas iniciativas a uma estratégia educacional sofisticada a serviço da revolução verde e da modernização tecnocrática da agricultura, cuja principal estratégia era a invasão cultural. As fontes do Capítulo 2 são provenientes de diferentes arquivos: os relatórios da AIA sobre as escolas rurais no Chile, os documentos das fundações Ford e Rockefeller são do Rockefeller Archive Center; os documentos do Convênio Chile-Califórnia provêm do The Convenio Archive (UC, Davis); alguns discursos presidenciais vêm da Truman Library e da JFK Library. As imagens selecionadas são fotografias da construção de escolas rurais chilenas no início dos anos 1960 com financiamento estadunidense, que pertencem ao Rockefeller Archive Center.

\section{Capítulo 3 - A terra para quem a merece: a pedagogia do sacrifício do Instituto de Educação Rural}

Quais eram as estratégias educacionais do Instituto de Educação Rural para o campesinato chileno e como articulavam sua pedagogia do sacrificio ao processo de lutas pela reforma agrária? 
O Capítulo 3 trata de analisar a história do IER desde sua fundação, em 1954, até o começo do governo Allende. Analisei as estratégias do instituto para capacitação camponesa, os conteúdos e valores priorizados em seus programas, a importância social e afetiva da experiência no instituto para uma grande quantidade de camponeses, a ascensão social que conquistavam depois dos cursos. O IER foi pioneiro em criar centrais de capacitação para camponeses adultos, se espalhando rapidamente por todo território rural chileno. Também foram inovadoras na criação de uma Rádio Escola para educação primária, adotada em milhares de escolas rurais do país, e que evocava uma cultura produtiva camponesa e cristã nas crianças rurais. Sem dúvida, foram vanguardistas na criação de unidades audiovisuais itinerantes, furgões doados pela USAID que percorreram o país com capacitação para homens e mulheres do campo. O IER era parceiro dos Peace Corps e frequentemente elogiado pelos aparelhos de hegemonia estadunidenses que atuavam na educação agrária chilena. Sua "pedagogia do sacrifício" imprimia uma compreensão meritocrática da reforma agrária, que sugeria a terra como "mérito" com base em uma trajetória de sacrifícios e não como "direito". Essa foi a economia moral com a qual combatia a agitação comunista e socialista no campesinato. A compreensão de reforma agrária do IER, embora anticomunista, era defensora da propriedade cooperativa, contradição que debateremos. As fontes do Capítulo 3 estão concentradas na revista Surco y Semilla do IER, destinadas aos camponeses, que percorri integralmente entre 1962 e 1968: das cartas de leitores aos editoriais e reportagens. Também estudei as fichas de aulas da Radio Escola Surco y Semilla, tal como eram entregues aos professores rurais, realizei entrevistas com professores do IER e examinei documentos dos convênios do IER com o Mineduc no Arquivo Nacional da Administração (ARNAD Chile). As imagens selecionadas são fotografias da revista Surco y Semilla com situações educacionais do IER e fac-símiles de cartas de camponeses leitores.

\section{Capítulo 4 - Semeadores de palavras: Paulo Freire, a reforma agrária chilena e a Pedagogia do Oprimido}

Como a pedagogia de Paulo Freire influenciou as estratégias educacionais do Estado chileno para reforma agrária durante o governo Frei? Como tal influência se multiplicou em diferentes organismos de Estado para reforma agrária de maneira diversa, gerando experiências sociais diferentes?

O Capítulo 4 trata da multiplicação da influência da pedagogia de Paulo Freire na reforma agrária chilena por meio dos órgãos de Estado: Mineduc, INDAP e CORA. Narrei a chegada de Freire no país, seu encontro integrador com brasileiros exilados, as situações profissionais que viveu, e articulei em torno do seu método, de modo inédito, instituições chilenas normalmente apartadas, como Mineduc e Minagri. Expliquei como seu método na alfabetização camponesa foi desenvolvido pelo Mineduc, analisei os materiais didáticos e os relatórios de experiências educacionais com os 
camponeses. Também examinei os materiais do INDAP e da CORA, buscando mostrar que cada instituição realizou inflexões específicas do método freiriano, de acordo com as nuances políticas internas à própria DC. Alguns relatórios de educadores internos aos relatórios gerais que Freire fazia à Unesco foram analisados pela primeira vez na historiografia. Para este capítulo, as descobertas das imagens da CORA e do INDAP feitas por Daniela Zubicueta foram bastante enriquecedoras. Aqui, o principal objetivo foi relacionar pedagogia freiriana e reforma agrária chilena como um campo de influências recíprocas, no qual a reforma agrária foi modificada pela ação cultural freiriana, mas Paulo Freire também foi transformado pelo contato com o campesinato do país, tal qual previsto na sua pedagogia. Ao fim, expliquei as tensões políticas que geraram a não renovação do contrato de Freire e sua opção por sair do país. As fontes do Capítulo 4 são os escritos chilenos de Paulo Freire, que se encontram dispersos e fragmentados, mas foram sistematizados com grande esforço a fim de viabilizar a organização de um corpus integrado. Busquei mapear, por meio dos seus textos, as situações concretas vividas por Freire em diálogos pedagógicos com os camponeses. Igualmente dispersos, os estudos e pesquisas das equipes freirianas (o conjunto pedagógico da primeira geração de pesquisadores militantes) também representou uma tarefa de organização de corpus bastante desafiadora. Ademais, me embasei nos materiais pedagógicos do método psicossocial elaborados pelo Mineduc, pela CORA e pelo INDAP; e em diversas entrevistas de história oral com educadores e camponeses. As imagens desse capítulo são as várias sequências de codificações do método psicossocial, utilizadas em círculos sobre o conceito antropológico de cultura, nas etapas de alfabetização e pós-alfabetização camponesa.

\section{Capítulo 5 - Pedagogia do território: protagonismo camponês, poder e produção}

Como os experimentos das equipes freirianas junto ao campesinato chileno levaram educadores e camponeses ao diálogo que resultou na pedagogia do território?

O Capítulo 5 não estava previsto no plano original desta tese, mas precisei criá-lo por coerência metodológica: dar a atenção devida às fontes das equipes freirianas, com volumoso registro dos círculos de cultura transcritos. Trata-se de um mergulho em duas experiências pontuais e bastante específicas de pedagogias camponesas que, no entanto, ofereciam a chave para solucionar vários dilemas econômico-culturais da reforma agrária na via chilena ao socialismo. O primeiro foi a investigação temática no assentamento El Recurso, coordenada por Maria Edy Ferreira, que assinou o relatório da pesquisa com José Luis Fiori. A segunda experiência era a programação camponesa, uma experiência inovadora conduzida por Maria Edy, Sergio Villegas e Liliana Barria, na qual se articulava técnicas freirianas de diálogo com repertórios desenvolvimentistas da investigação sociológica, resultando na apropriação epistemológica do campesinato sobre seu território comunal. "Pedagogia do território" não foi um termo usado pelos autores do método, que o chamavam de "programação camponesa", mas sim foi uma expressão criada na tese para localizar tal iniciativa específica no contexto mais amplo das 
pedagogias da reforma agrária. O método inaugurava uma instância de negociação inédita entre agendas desenvolvimentistas e subjetividade popular camponesa, gerando ferramentas completamente novas de empoderamento territorial e de organização camponesa em nível comunal. Tratava-se de uma iniciativa pedagógica territorial para dar vazão aos nós dialéticos da economia/cultura. As fontes do Capítulo 5 foram os relatórios das experiências freirianas que somam mais de 400 páginas de transcrição de círculos de cultura: uma enxurrada de vozes camponesas sem mediação. São dois relatórios sobre a investigação temática de El Recurso, um deles do arquivo do Instituo Paulo Freire e outro da biblioteca da U. Chile. Há também dois relatórios sobre a experiência de programação camponesa, um encontrado na biblioteca da Universidade da Califórnia, Irvine, e outro na biblioteca da U. Chile. Também aqui utilizei entrevistas de história oral. As imagens desse capítulo são as lâminas codificadoras utilizadas pelos círculos, e algumas páginas da programação camponesa que ajudam a ilustrar o método que conceituei como "Pedagogia do território".

\section{Capítulo 6 - Pedagogia da reivindicação: sindicalismo camponês e educação política}

Como o Fundo de Educação e Extensão Sindical desenvolveu pedagogias para reinvindicação sindical camponesa e luta por direitos dos trabalhadores rurais? Quais os seus desafios e problemas?

O Capítulo 6 trata da educação sindical camponesa financiada pelo Fundo de Educação e Extensão Sindical (FEES). É surpreendente que até hoje o FEES tenha passado completamente desapercebido pela historiografia, sendo esta a primeira tentativa de narrar sua história. Criado pela lei de sindicalização camponesa (1967), interpretei o FEES como uma política de reparação educacional ao campesinato, depois uma longa história de exclusão da terra e da escola. Analisei as cartilhas laborais do FEES, que visavam difundir o conhecimento sobre leis e direitos trabalhistas no campo. Também examinei os conteúdos dos programas educacionais de cada uma das confederações sindicais camponesas que firmaram convênios com o FEES, analisando sua estratégia pedagógica no contexto das lutas camponesas em curso (com destaque para as greves provinciais). Também contei a história de construção do FEES, relatei sua precariedade infraestrutural e o caráter militante evocado pelos seus funcionários para cumprir a tarefa educativa. $\mathrm{O}$ método psicossocial aparece também na alfabetização dos sindicatos, mas se destacam os cursos sobre legislação e direitos laborais, reforma agrária, sindicalismo camponês, formação de dirigentes, técnicas de comunicação e formação de camponeses educadores. A classe patronal resistiu à arrecadação do FEES, e as reuniões do seu Conselho demonstravam uma permanente tensão orçamentária. Também analisei a presença de camponeses analfabetos nas assembleias de fundação de sindicatos e as estratégias não escritas de ensino, como o uso de um filme que ficou famoso à época: El Chacal de Nahueltoro, de Miguel Littín. As fontes do Capítulo 6 são as cartilhas laborais do FEES distribuídas entre os camponeses; os relatórios das 
confederações camponesas sobre os cursos realizados e serviços de assistência prestados aos filiados; a imprensa que cobria conflitos laborais no campo, especialmente La Nación e El Siglo; as atas de reuniões do conselho do FEES (Ministério do Trabalho, ARNAD); atas de fundações de sindicatos camponeses com impressões digitais dos analfabetos (Direção do Trabalho, ARNAD); entrevistas de história oral; e o filme de Miguel Littín. As imagens do capítulo são ilustrações das cartilhas laborais; recortes de imprensa utilizados em aulas para camponeses; as atas sindicais com impressões digitais; frames e cartazes do filme mencionado.

\section{Capítulo 7 - Unidade Popular e a reforma agrária: batalha da produção, batalhas da capacitação}

Como a Unidade Popular articulou a batalha da produção agrária à batalha da capacitação camponesa na via chilena ao socialismo? Qual era o lugar da capacitação na política agrária da UP e seus obstáculos?

O Capítulo 7 explica como a capacitação camponesa se inseria em duas das três principais polêmicas agrárias da UP para a via chilena ao socialismo: (1) o ritmo das expropriações, a necessidade de uma nova lei que reduzisse o tamanho da propriedade privada de $80 \mathrm{HRB}$ para $40 \mathrm{HRB}$ e eliminasse a reserva patronal; e (2) a batalha da produção no setor reformado e a organização do trabalho em assentamentos e Centros de Reforma Agrária (CERA). A terceira polêmica está no capítulo seguinte. Esse capítulo explica a política de capacitação camponesa da UP e a criação do Conselho Técnico Nacional de Capacitação Camponesa (CTNC) em 1971, que empreendeu a tentativa de reestruturação territorial da capacitação camponesa na reforma agrária, mas se frustrou por uma série de problemas. Também examinei a relação entre a batalha da produção agrária e a batalha da capacitação, evidenciando os problemas da organização do trabalho no setor reformado e o choque entre a economia moral camponesa (de subsistência e bem-estar), com a moral econômica da revolução chilena (produtivista, disciplinada e acumuladora). A batalha da produção pressionava pela necessidade de uma vitória econômico-estrutural do processo revolucionário, que em algumas circunstâncias se chocava com a experiência e a subjetividade produtiva do campesinato, portanto, o que chamei de "batalha da capacitação" foi o front desse choque. As fontes do Capítulo 7 foram a imprensa que tratava da batalha da produção e das sabotagens patronais (La Nación, Chile Hoy e El Siglo, principalmente), as pesquisas militantes da primeira geração, com destaque para o diagnóstico de Barraclough \& Fernández e seu olhar instrumental da capacitação, diversas entrevistas de história oral com professores de camponeses que atuaram em diversas instituições, sobretudo militantes do PC e do MAPU. As imagens selecionadas são recortes de imprensa que ilustram os desafios da batalha da produção e da revolução chilena no campo.

Capítulo 8 - Alfabetização camponesa e trabalho voluntário na Unidade Popular: diálogos entre marxistas e freirianos 
Como se deu a alfabetização camponesa durante o governo da UP e quais diálogos entre freirianos e marxistas se desenrolaram a partir desta experiência revolucionária? Como os trabalhos voluntários, a aliança estudantil-camponesa, a capacitação mapuche e os conselhos camponeses se articulavam como poderes revolucionários e educacionais desde baixo?

O Capítulo 8 trata da alfabetização camponesa durante o governo de Allende e do papel do trabalho voluntário da juventude nesse processo. Destaquei as campanhas de alfabetização dos trabalhos voluntários de verão, que chamei de "aliança estudantil-campesina", bem como o esforço militante e a solidariedade da juventude com a mudança cultural e econômica do campo. Analisei detidamente a adaptação da UP para o método psicossocial, buscando identificar as alianças e conflitos entre a corrente marxista que influenciou as Sugerencias para la Alfabetización e a pedagogia de Freire para revolução no campo. Para isso, examinei os conteúdos do método freiriano adaptado pela UP e contextualizei as viagens de Freire ao Chile de Allende, seus diálogos com marxistas críticos e sua percepção sobre as vanguardas de tipo sectário. Em três viagens, Freire dialogou com universitários e camponeses. Por fim, analisei a terceira polêmica agrária da UP e relacionei a capacitação camponesa com a construção do poder popular dos conselhos camponeses, isto é, os cursos e o processo político que impulsionavam tais conselhos. Destaquei o protagonismo indígena na criação de conselhos comunais na Araucanía ao explorar também as estratégias da UP de capacitação mapuche e a educação política agenciada pelo MIR no mesmo território. As fontes do Capítulo 2 são diversas: a imprensa que tratou de alfabetização camponesa e trabalhos voluntários de verão (Revista de Educación, La Nación, El Siglo, Chile Hoy); as entrevistas de Paulo Freire quando foi ao Chile; as Sugerencias para la Alfabetización, material adaptado da UP para o método psicossocial, utilizado na alfabetização camponesa. Também utilizei entrevistas de história oral. As imagens selecionadas são as codificações fotográficas do Sugerencias, utilizadas em "comitês de alfabetização" (já não mais “círculos"), recortes de imprensa e fotografias de cursos de marxismo do MIR para camponeses, provenientes do Centro Cultural Museo y Memoria de Neltume, que foram disponibilizadas por Cristóbal Bize, a quem agradeço.

\section{Por fim: nota sobre brasileiros da reforma agrária chilena}

Foi marcante a presença de brasileiros que participaram diretamente na reforma agrária chilena, como pesquisadores militantes, "funcionários do agro" e dedicados colaboradores daquele projeto de transformação. A maioria desses brasileiros foi perseguida e estava exilada pelo golpe de 1964 no Brasil. Eles carregaram os fios da história interrompida da reforma agrária brasileira até a vibrante força da reforma agrária chilena. Ou, como expressou Almino Affonso, ministro do trabalho do governo de João Goulart e professor do ICIRA: "vivemos no Chile o que havíamos amado ter no Brasil, mas não pudemos" (Affonso, 2020). 
Centenas de dirigentes e intelectuais da esquerda brasileira desembarcaram em Santiago depois de 1964. Gostaria de homenagear esses brasileiros e brasileiras que se empenharam no trabalho diligente da reforma agrária do Chile, porque seu engajamento era genuíno, profissional, generoso e sensível. Onde quer que estivessem, se posicionaram em luta contra a exploração social, especialmente do campesinato. O Chile os recebeu calorosamente até 1973.

O sonho de uma América Latina sem latifúndios, com a terra para quem a trabalha, também era uma "estrutura de sentimento" compartilhada por esses brasileiros. Era o espírito comunitário e combativo de um tempo de revoluções e contrarrevoluções. Como pode ser observado na bibliografia dessa tese, as contribuições teóricas e práticas de tais brasileiros sobre a reforma agrária no Chile contém muitas lições. Talvez a mais importante seja a capacidade de exercer a solidariedade sem fronteiras e colocar sua inteligência a serviço de um projeto popular e latino-americanista de mudança social. Eram anos paradoxais das suas vidas, com a melancolia do exílio e a alegria de uma militância criativa e plural, dedicados aos camponeses de um país que não era o seu. Embrenharam-se completamente em uma luta agrária que, depois deles, nenhum brasileiro investigou.

Por isso, gostaria de homenageá-los com este trabalho: Maria Edy Ferreira, Paulo Freire, Almino Affonso, Plínio de Arruda Sampaio, Wilson Cantoni, Zilah Branco, Ivan Ribeiro, Ernani Maria Fiori e José Luis Fiori. Seus caminhos também nos convocam à compreensão dessa complexa mistura de utopia e distopia, esperança e desgraça, que atravessou o destino dos camponeses latino-americanos entre as décadas de 1950 e 1970. 


\title{
Capítulo 1 - Questão agrária no Chile entre 1955 e 1973: formas econômicas, batalhas culturais
}

\begin{abstract}
"Muitos pensam que a reforma agrária é um processo domesticado de mudança, que pode ser controlado à vontade. Apertando-se um botãozinho podemos fazer que as coisas cheguem até certo ponto e apertando outro, que se detenham (...). Estão profundamente equivocados. (...) Ninguém, inclusive aqueles que iniciam um processo dessa natureza, sabem no fundo até onde devem ir, de que forma vão operar e onde vão parar".
\end{abstract}

- Jacques Chonchol, 1962, na Universidade do Chile ${ }^{29}$

"Só recentemente foi possível falar sobre reforma agrária de forma aberta na América Latina. Há dois anos, (...) a Escola de Verão da Universidade do Chile incluiu um curso sobre reforma agrária e isso foi considerado uma inovação atrevida. Este ano, (...) parece perfeitamente natural. Nenhum partido político, de nenhuma cor, se atreve hoje a dizer que se opõe ao princípio da reforma agrária. (...) No entanto, como adverte Doreen Warriner: 'um resultado do debate mundial sobre a reforma agrária é que agora há uma confusão em torno ao que a reforma agrária realmente significa"".

- Solon Barraclough, 1962, na Universidade do Chile ${ }^{30}$

"A reforma agrária vai nos beneficiar porque vamos poder levar as crianças na escola".

- Camponês da zona rural da Região Metropolitana, $1965^{31}$

\subsection{Introdução}

Em 1962, uma conferência na Universidade do Chile reuniu economistas e agrônomos para debater a reforma agrária. Na ocasião, o economista estadunidense Solon Barraclough, que vivia no Chile há dois anos, ofereceu uma palestra intitulada "O que é a reforma agrária", na qual alertou para a polissemia que a expressão vinha adquirindo, cada vez mais portadora de conteúdos diversos e antagônicos, e delimitou o conceito de reforma agrária que ele considerava necessária. O engenheiro agrônomo Jacques Chonchol, à época com 36 anos e funcionário na Food and Agriculture Organization (FAO), falou sobre as "Razões econômicas, sociais e políticas da reforma agrária". Chonchol tinha acabado de voltar de uma missão oficial da FAO em Cuba, onde conheceu Fidel Castro e assessorou a revolução durante alguns meses, além de ter participado ativamente dos debates entre seus dirigentes. ${ }^{32}$ Amadurecia em toda América Latina uma intelectualidade favorável às mudanças estruturais da agricultura, junto com forças políticas cada vez mais dispostas a realizar mudanças profundas no campo, fosse para evitar uma revolução, fosse para começar uma. Foi nesse contexto que o Chile colocou em

\footnotetext{
${ }^{29}$ Chonchol, 1965: 104.

${ }^{30}$ Barraclough, 1965: 127.

${ }^{31}$ Apud Domínguez, 1966: 15.

32 Em 2011, realizei uma entrevista com Chonchol sobre sua missão agrária em Cuba. Ver Vasconcelos \& Chonchol, 2012. Sobre a história agrária da revolução cubana, ver Vasconcelos, 2016a.
} 
prática uma das reformas agrárias mais complexas da América Latina em termos técnicos e legislativos, dialogando com um campesinato heterogêneo e cada vez mais mobilizado. A reforma agrária chilena refletia a polissemia da expressão, abrindo uma disputa política entre diferentes projetos, ancorados em diferentes imaginários sobre um futuro agrário "moderno".

Este primeiro capítulo tem como objetivo apresentar o debate sobre a questão agrária chilena desde a década de 1950 até o golpe de 1973, período no qual o tema esteve no centro da política e da esfera pública no país. Naquele tempo, uma intelectualidade urbana cada vez mais hegemônica elaborou projetos de reforma agrária concomitantemente ao acirramento das pressões dos sujeitos camponeses por melhorias em suas condições de vida. Pretendo aqui explicar o triplo movimento no qual sujeitos urbanos provenientes de uma elite intelectual cosmopolita, partidos políticos de diferentes ideologias e com expressivo enraizamento popular, e organizações camponesas representativas de populações predominantemente analfabetas se engajaram na luta por diferentes projetos de reforma agrária estrutural, o que resultou em uma experiência política repleta de encontros, desencontros, alianças e tensões.

Acompanhando Gunder Frank (1965) e Quijano (1971), identifico três projetos de reforma agrária provenientes do mundo urbano e das elites intelectuais da América Latina, que disputavam os rumos da mudança rural em todo continente durante as "décadas da reforma agrária". ${ }^{33}$ Essas três propostas de reforma agrária correspondiam a projetos políticos radicalmente diferentes para a agricultura, porém tinham em comum uma epistemologia urbana, uma linguagem técnica e política típica das cidades. Em poucas palavras, na batalha entre tais projetos de reforma agrária, cada horizonte de mudança podia ser sintetizado em um dos três verbos: modernizar, reformar ou revolucionar o campo. Cada vertente propunha uma associação própria entre mudança técnico-produtiva e mudança social.

O projeto de exclusiva "modernização" agrária implicava mudanças técnicas sem alteração da estrutura de propriedades e sem a figura jurídica da "expropriação", protegendo a concentração fundiária a fim de modernizar o capitalismo preservando suas disparidades estruturais. Tal projeto de modernização é datado dos anos 1950, e está dentro do contexto do Ponto Quarto de Harry Truman, uma política dos Estados Unidos para tecnificação da agricultura latino-americana que patrocinou a conversão da indústria da guerra para indústria dos insumos agrícolas: a chamada revolução verde. A modernização agrária, ou revolução verde, agenciou novas relações entre agricultura e conhecimento, propondo uma "reeducação técnica" dos agrônomos, técnicos, proprietários e camponeses. No Chile, pelo menos desde 1955, os Rockefeller, a Fundação Ford e outros aparelhos de hegemonia dos Estados Unidos passaram a financiar projetos de educação rural, com objetivo de expandir os mercados da revolução verde por meio de um programa de modernização agrária. O recorte temporal desta tese começa em 1955 porque foi nesse ano que a Fundação Rockefeller instalou uma sede em Santiago para

\footnotetext{
${ }^{33}$ Em um trabalho anterior, chamei as décadas de 1950, 1960 e 1970 de "décadas da reforma agrária", quando a necessidade de mudança estrutural na agricultura foi alçada ao centro do debate político em todos os países da América Latina (Vasconcelos, 2017).
} 
atuar no Ministério da Agricultura durante o governo de Carlos Ibañez del Campo. A reforma agrária do presidente conservador Jorge Alessandri, implementada pela lei 15.020 de 27 de novembro de 1962, foi uma síntese política desse projeto de modernização técnica e conservadorismo social, que resultou da reacomodação das oligarquias rurais frente a um novo paradigma produtivo, fartamente propagandeado pelos aparelhos de hegemonia estadunidense, públicos e privados.

Mas não demorou para que uma nova hegemonia fosse construída para a mudança agrária nos anos 1960, influenciada pelos ventos da revolução cubana e da sua contraface: a resposta estadunidense a Cuba, plasmada na Aliança para o Progresso, em 1961. Depois da derrota da invasão de Playa Girón em Cuba, em abril de 1961, a administração de John Kennedy inaugurou uma nova estratégia de gestão ideológica da Guerra Fria, por meio de um novo tipo de "reformismo imperialista", cujo principal documento programático foi a Carta de Punta del Este. ${ }^{34}$ No Chile, um novo bloco de poder foi constituído pela Democracia Cristã, que ganhou as eleições presidenciais de 1964, a qual, por sua vez, foi sustentada por parcela expressiva do voto camponês e patrocinada pelos empréstimos da USAID. Entre 1960 e 1970, os Estados Unidos investiram mais de 1,5 bilhão de dólares no Chile "para mantêlo vinculado a seu sistema econômico-militar", segundo Joan Garcés (1993: 100), assessor político da presidência de Salvador Allende. A Comissão Econômica para América Latina e Caribe (CEPAL) e a intelectualidade desenvolvimentista chilena também exerceram enorme influência política nesse contexto, e tornaram-se coautores do projeto de reforma agrária consolidado na lei 16.640 de 28 de julho de 1967. Essa lei colocou o Chile na rota da mudança estrutural do regime de propriedades agrárias, inaugurando o teste de um segundo projeto.

Como veremos, a reforma agrária do presidente Eduardo Frei Montalva (DC) intencionava genuinamente pela melhoria das condições agrárias do capitalismo periférico, ao proibir propriedades privadas maiores que 80 hectareas de riego básico $(\mathrm{HRB})^{35}$ e qualquer propriedade abandonada ou mal explorada. No mesmo pacote mudancista, foi aprovado um novo sistema de sindicalização camponesa, pela lei 16.625 de 29 de abril de 1967, que pela primeira vez na história fortaleceu a organização sindical do mundo rural como direito reconhecido pelo Estado. A reforma agrária da DC incorporava a modernização técnica, mas agregava um sentido de justiça social no campo, promovendo a utopia de um capitalismo agrário eficiente, conduzido por camponeses empresários e trabalhadores rurais amparados por direitos. Mas essa promessa esbarrava nos interesses da classe proprietária e das oligarquias, com as quais a DC mantinha vínculos orgânicos, o que foi percebido e ressentido pelos próprios movimentos camponeses. Em 1970, uma onda sem precedentes de mobilizações do

\footnotetext{
${ }^{34}$ Sobre a reforma agrária, o objetivo 6 da Carta dizia: "Impulsionar, dentro das particularidades de cada país, programas de reforma agrária integral, orientada à efetiva transformação das estruturas e injustos sistemas de propriedade e produção da terra, com vistas a substituir o regime de latifúndio e minifúndio por um sistema justo de propriedades, de tal maneira que, mediante o complemento de crédito oportuno e adequado, a assistência técnica e a comercialização e distribuição dos produtos, a terra constitua, para o homem que a trabalha, a base da sua estabilidade econômica, fundamento de seu progressivo bemestar e garantia de sua liberdade" (OEA, 1961).

${ }^{35}$ Hectárea de Riego Básico (HRB) era uma unidade de superfície que correspondia à fertilidade de um hectare físico de terra irrigada do Vale de Maipo, e era apresentado junto com uma tabela de conversão, criada pelo Departamento de Agricultura dos Estados Unidos (CIDA, 1966: 24).
} 
campesinato chileno e dos indígenas mapuche da Araucanía passou a exigir radicalização da reforma agrária e recuperação de terras usurpadas, o que fortaleceu Salvador Allende no pleito e, junto com outros setores das classes trabalhadoras, pavimentou seu caminho até vitória eleitoral.

O terceiro projeto de reforma agrária era a revolução. Incorporava a mudança técnica e a mudança do regime de propriedades, mas era cético sobre a possibilidade de qualquer justiça social plena no capitalismo periférico, em função do poder patronal preservado da estrutura anterior. O projeto revolucionário de reforma agrária da Unidade Popular acelerou a mudança no campo e levou ao limite a lei gestada no governo anterior. Allende expropriou mais de 6 milhões de hectares em três anos, enquanto seu antecessor havia expropriado 3,5 milhões em seis (Barraclough \& Fernández, 1974). Quando o golpe de 11 de setembro de 1973 destruiu a democracia e a via chilena ao socialismo, os partidos da esquerda e grande parte das organizações camponesas estavam convictos da necessidade de uma nova lei de reforma agrária revolucionária, que coibisse o poder das burguesias agrárias detentoras de propriedades entre 40 e $80 \mathrm{HRB}$ e eliminasse as reservas patronais. Naquele instante, o campesinato chileno e os partidos de esquerda desenvolviam um sistema de poder popular rural por meio dos conselhos camponeses, que prometiam ser uma ferramenta revolucionária decisiva na nova sociedade. Os conselhos comunais camponeses ${ }^{36}$ demandavam que o Estado lhes transferisse prerrogativas de decisões políticas e produtivas, conduzidas pelas mãos calejadas daqueles que efetivamente trabalhavam a terra.

Durante o processo histórico que colocou em choque três projetos urbanos para transformação agrária - modernização, reforma, revolução - os movimentos camponeses manifestaram crescente protagonismo, disputando desde baixo os sentidos da mudança que afetava diretamente a sua vida. A organização camponesa cresceu e amadureceu em sindicatos, cooperativas, assentamentos, Centros de Reforma Agrária (CERA), conselhos camponeses, comitês e comandos. Em 1973, mais da metade do campesinato adulto estava organizado em alguma instituição coletiva, e movimentava diretamente a história agrária do Chile com suas exigências. A reforma agrária chilena foi gestada sob tremenda pressão rural, na qual subjetividades camponesas se associavam de diferentes maneiras às epistemologias urbanas pela mudança estrutural.

Argumento ao longo da tese que os três projetos para mudança agrária chilena, que entraram em construção e conflito entre 1955 e 1973, produziram pedagogias para o campesinato e executaram agendas de educação produtiva, buscando conduzir a subjetividade dos trabalhadores da terra no rumo do seu projeto de futuro. Defendo que a educação rural foi uma das estratégias mais importantes dos diferentes programas econômicos para transformação da agricultura. Variadas pedagogias para transformação econômica pretendiam consolidar no campesinato economias morais "adequadas" aos modelos de sociedade em luta. Por isso, a educação camponesa para reforma agrária conforma um

\footnotetext{
${ }^{36}$ O Decreto 481 de 21 de dezembro de 1970 criou três níveis de atuação para os conselhos campesinos: o comunal, o provincial e o nacional, que correspondiam aos níveis político-administrativos do Estado chileno.
} 
recorte de observação privilegiado para a análise das disputas de valores e dos conteúdos subjetivos das diferentes formas de propriedade e de organização do trabalho.

\subsection{Reforma agrária como invenção urbana}

\section{O relatório CIDA como ferramenta legitimadora}

Em 1966, foi publicado o estudo mais emblemático sobre a questão agrária chilena até aquele momento, constituindo um marco da nova hegemonia reformista. O relatório Tenencia de la tierra y desarrollo socioeconómico del sector agrícola foi patrocinado pelo Comitê Interamericano de Desenvolvimento Agrícola (CIDA), um conglomerado de instituições internacionais que reunia a CEPAL, a FAO, o Banco Interamericano de Desenvolvimento (BID) e o Instituto Interamericano de Cooperação para Agricultura da Organização do Estados Americanos (IICA/OEA). O CIDA foi criado em 1961, na reunião de Punta del Este que fundou a Aliança para o Progresso, como parte de um projeto internacional de

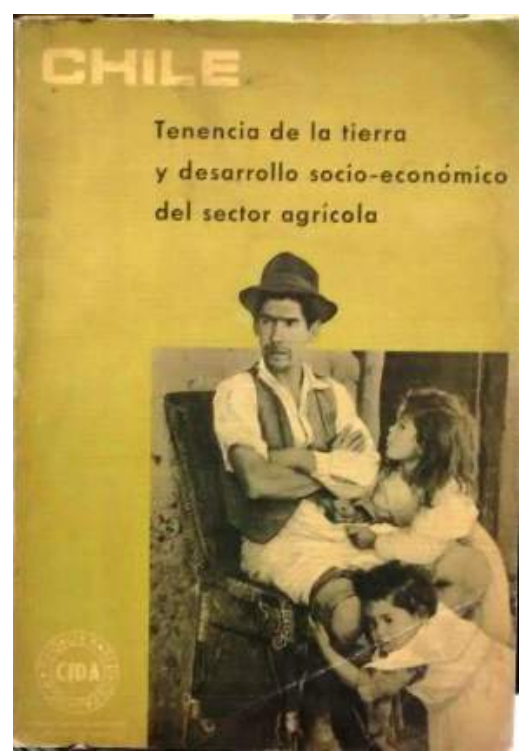

Capa do Relatório CIDA, 1966 enfrentamento das condições que geraram a revolução cubana. Como lembrou Thomas Carroll, economista do BID, em 1964: "na América Latina, enfrentamos o seguinte dilema: onde a reforma agrária é seriamente realizada torna-se um assunto explosivo e imprevisível, mas a situação é ainda mais explosiva e imprevisível quando a reforma não é feita" (Carroll, 1965: 148).

O relatório era um diagnóstico enciclopédico sobre as condições geográficas, econômicas e sociais da agricultura chilena, com tom pragmático e programático sobre o que, afinal, deveria ser a reforma agrária. Dentro dessa agenda, relatórios equivalentes foram produzidos em outros seis países: Brasil, Argentina, Colômbia, Equador, Guatemala e Peru. No Chile, foi coordenado por Barraclough, com uma equipe de 42 profissionais ( 37 homens, 5 mulheres), predominantemente engenheiros agrônomos. Segundo seus autores, se "reuniu e estudou praticamente toda a informação disponível a respeito" da agricultura chilena (CIDA, 1966: 268). O documento consolidava, em termos científicos, o enfrentamento ao latifúndio no desdobrar da polêmica a respeito do estancamento da agricultura chilena, que havia polarizado as classes dirigentes do país por uma década.

Desde 1953, a resolução 66 da CEPAL indicava que "todo regime de produção agrária deve moverse para o melhoramento das condições de vida da população rural" e que "a reforma agrária deve ser considerada como um elemento básico dos estudos de planificação e desenvolvimento" (CEPAL, 1953: 
35). Logo ganharam projeção as argumentações de Ahumada (1958) e Pinto (1959), economistas da CEPAL, que apontavam o estancamento agrário como maior obstáculo ao desenvolvimento chileno. Acreditavam que o país atravessava uma "crise integral" (Ahumada, 1958: 13), decorrente de uma série de desequilíbrios estruturais gerados por uma agricultura "atrasada" e "feudal". Entre 1925 e 1955, a participação agrícola na renda nacional havia caído de 19,2\% para 16,7\% (Pinto, 1959: 115) enquanto a população chilena aumentara extraordinários 66\% (Ahumada, 1958: 63). O processo de urbanização e industrialização alterava aceleradamente os comportamentos e demandas de consumo da sociedade, o que exigia da agricultura maior produtividade.

A incapacidade do setor agrário para responder a essa demanda, segundo a tese de Pinto e Ahumada, gerava dois problemas. Por um lado, um processo inflacionário dos alimentos com enorme potencial conflitivo, uma vez que os trabalhadores urbanos pressionavam por aumentos salariais correspondentes às perdas inflacionárias, enquanto os proprietários agrícolas exigiam preços mais altos para sua produção; e por outro, a redução da capacidade de importar bens de capital e de consumo, pressionada pelo crescimento sem precedentes das importações agroalimentares, cujo valor se expandiu $87 \%$ entre 1947 e 1954 (Pinto, 1959: 155). Assim, avaliavam os cepalinos, que a insuficiente produtividade agrícola obstruía a expansão industrial, único caminho que poderia atenuar a dependência chilena do cobre em um contexto de "crise do desenvolvimento para fora". A criação de um novo paradigma, de "desenvolvimento para dentro", segundo Ahumada, era fundamental para arrefecer a ameaça comunista: "se não se destroem ao mesmo tempo as fontes das quais se nutre o entusiasmo comunista, que são a ignorância e a pobreza, as bordoadas só contribuirão para fortalecê-lo" (1958: 60). A reforma agrária refletia, portanto, preocupações ideológicas (combater o comunismo) e técnico-econômicas (desencadear o "desenvolvimento para dentro" a partir da produtividade agrícola).

Fazendo coro com essa compreensão, o relatório CIDA avançava em determinar que "os sistemas de propriedade prevalecentes na agricultura chilena constituem um obstáculo ao desenvolvimento econômico e social" e "os ajustes espontâneos são insuficientes para solucionar os problemas derivados dos atuais regimes de propriedade da terra" (CIDA, 1966: 40). Qualquer rota na direção do desenvolvimento, portanto, deveria passar por uma reforma massiva do sistema de propriedades no campo. Essa diretriz refletia o projeto de reforma agrária sustentado por Solon Barraclough, economista da FAO que coordenou o relatório CIDA e exerceu grande influência na transformação agrária chilena durante a década em que viveu no país. Ele dizia: "reforma agrária significa, essencialmente, reforma do regime de propriedades da terra e implica a redistribuição dos direitos de propriedade da terra em favor dos pequenos cultivadores, trabalhadores camponeses sem-terra e do Estado". E completava: "Por definição, a reforma agrária implica três objetivos: maior justiça social, uma modificação da estrutura de poder político e um melhor desenvolvimento econômico" (Barraclough, 1965: 145).

Segundo os dados do censo de 1955, apresentados no relatório, $78,5 \%$ da superfície agrícola chilena era comandada por somente $6,9 \%$ dos proprietários, que controlavam 10.400 grandes unidades latifundiárias. Do outro lado, $77 \%$ dos pequenos proprietários, isto é, 116.200 minifundistas e 
camponeses, se aglomeravam em somente $11,1 \%$ da superfície. Para as instituições do CIDA, o complexo latifúndio-minifúndio, característico da estrutura agrária da maior parte da América Latina, foi visto como um obstáculo à modernização capitalista. Sobre os usos e cultivos, o relatório CIDA alertava que apenas $38,7 \%$ das terras agricultáveis chilenas estavam efetivamente utilizadas, sendo que $52,5 \%$ estavam tomadas por "pastos naturais", em situação de ociosidade ou subutilização, e $8,8 \%$ por barbechos. ${ }^{37} \mathrm{~A}$ estrutura de propriedade da terra no Chile de 1955 pode ser vista em detalhe na Tabela 1.

\begin{tabular}{|c|c|c|c|c|}
\hline \multicolumn{5}{|c|}{ Tabela 1 - Estrutura de propriedades agrárias no Chile (1955) } \\
\hline \multirow{2}{*}{ Tamanho } & \multicolumn{2}{|c|}{$N^{0}$ de propriedades } & \multicolumn{2}{|c|}{ Superfície agrícola } \\
\hline & Unidade & $\%$ & Hectares & $\%$ \\
\hline $\begin{array}{l}\text { Propriedade } \\
\text { subfamiliar }\end{array}$ & 55.800 & 37,0 & 67.400 & 0,3 \\
\hline Propriedade familiar & 60.400 & 40,0 & 1.762 .800 & 8,1 \\
\hline $\begin{array}{c}\text { Propriedade } \\
\text { multifamiliar média }\end{array}$ & 24.400 & 16,1 & 2.823 .000 & 13,1 \\
\hline $\begin{array}{c}\text { Propriedade } \\
\text { multifamiliar grande }\end{array}$ & 10.400 & 6,9 & 16.983 .900 & 78,5 \\
\hline Total & 151.000 & 100 & 21.637 .100 & 100 \\
\hline
\end{tabular}

O CIDA classificava quatro tipos de propriedade rural: (1) a unidade multifamiliar grande, ou latifúndio, que dispunha de terras suficientes para empregar permanentemente um número de trabalhadores "muito maior" que os membros da família proprietária e requeria divisão hierárquica de trabalho; (2) a unidade multifamiliar média, que dispunha de terras suficientes para dar emprego permanente a um número de trabalhadores "maior" que os membros da família, mas não tantos que se requeressem capatazes; (3) a unidade familiar, cujas terras eram suficientes para manter uma família em nível satisfatório de subsistência com o trabalho exclusivo dos seus membros; e (4) a unidade subfamiliar, cujas terras eram insuficientes para satisfazer as necessidades mínimas de uma família e para permitir a utilização do seu trabalho por todo ano (CIDA, 1966: VII-IX). Apesar do verniz técnico, tal classificação ocultava a verdadeira extensão das propriedades em hectares, o que difícultava a conceituação do latifúndio e do minifúndio em termos de tamanho. Isso porque era imprecisa ao classificar as unidades com as expressões "maior" e "muito maior" para se referir à quantidade de trabalhadores permanentemente empregados nas propriedades multifamiliares, sem delimitar uma quantidade específica de trabalhadores que diferenciasse tais explorações. Além disso, desconsiderava que uma expressiva quantidade de latifúndios permanecia ocioso, enormes haciendas com escassos trabalhadores permanentes, gerando distorções nas variáveis de classificação em relação à realidade. De toda forma, o diagnóstico apontava a necessidade de uma reforma agrária estrutural.

\footnotetext{
37 Terras em preparação ou descanso para serem cultivadas em sistema de rotação, segundo a definição do Censo AgrícolaGanadero de 1955 (CIDA, 1966: 147).
} 
Embora o relatório fosse uma resposta a diversos impulsos políticos mudancistas, nacionais e internacionais, urbanos e rurais, é notável que sua produção mobilizou um aparato institucional formado por profissionais da cidade, engenheiros agrônomos e economistas, que desenvolveram parâmetros técnicos para atingir determinados objetivos internos à sua epistemologia. Esse é um dos motivos para que o historiador José Bengoa afirme que "a reforma agrária chilena foi uma reforma agrária urbana, ou seja, foi pensada na cidade". ${ }^{38}$ Embora houvesse fortes pressões rurais pela reforma agrária, a lei foi redigida em "termos urbanos", com uma linguagem e tecnicalidade pertencentes a um universo epistemológico distante do campo. Consequentemente, os pressupostos epistemológicos da reforma agrária se chocaram com práticas, linguagens, aspirações e expectativas do campesinato.

Para exemplificar, o conceito de HRB, que lastreava todo processo expropriatório da lei 16.640, foi largamente incompreendido pelo campesinato, especialmente no sul do país onde $80 \mathrm{HRB}$ podia corresponder a mais de 350 hectares físicos de terra. A resistência social a esse conceito técnico ocupou um papel central nos conflitos expropriatórios (Steenland, 1977; Gómez, 1973). O coeficiente de fertilidade medido pelo HRB tinha origem no Soil Conservation Services do Departamento de Agricultura dos Estados Unidos, e pode ser considerado um símbolo da tecnicalidade da "reforma agrária urbana", alheia à população rural, ou em outras palavras, uma metonímia do poder técnico que as epistemologias urbanas impuseram ao processo de reforma agrária. Mas o campesinato soube fazer o uso contra-hegemônico das epistemologias hegemônicas.

\section{O social-cristianismo}

Paralelamente à narrativa cepalina da modernização, mas estabelecendo com ela pontos de contato, também foram publicados no Chile dos anos 1950 e 1960 manifestos da doutrina social-cristã que analisavam a realidade chilena e apontavam a reforma agrária como caminho para superação da crise. O engenheiro agrônomo Jacques Chonchol e o advogado Julio Silva Solar publicaram dois livros pioneiros, nos quais inauguraram seu pensamento: Hacia un mundo comunitário (1951) e El desarrollo de la nueva sociedad en América Latina (1965). Neles, entregavam um diagnóstico sobre a crise do mundo moderno e, particularmente, do subdesenvolvimento latino-americano, buscando se diferenciar simultaneamente do reformismo da CEPAL e do marxismo. O livro de 1951 era um manifesto da corrente de pensamento que se pode caracterizar como "social-cristianismo revolucionário", orientada por dois princípios básicos: primeiro, que o proletariado deveria ser protagonista na luta anticapitalista por sua libertação e, segundo, que a forma econômica desejada para transformação revolucionária era a propriedade comunitária. Era uma proposta alternativa frente às duas formas de propriedade que representavam idealmente os polos da Guerra Fria: a individual-capitalista e a estatal-socialista. Jacques Chonchol protagonizou o debate agrário chileno dos anos 1960 e 1970 não apenas porque ocupou cargos

\footnotetext{
${ }^{38}$ Entrevista com José Bengoa. Santiago, 04 de maio de /2017.
} 
de alto comando na estrutura do Estado, mas pela complexidade e representatividade do seu pensamento político, e pela maneira como juntou sabedoria técnica com o programa da sociedade comunitária e da economia cooperativa. Como engenheiro agrônomo, possuía trânsito e credibilidade nas principais instituições internacionais interessadas nas reformas agrárias latino-americanas daquele período: a CEPAL, a OEA e a FAO.

Com pais agnósticos de origem judia, Jacques Chonchol tornou-se católico por influência externa à família, envolvendo-se nos anos 1930 com a militância Falangista, uma seção independente da juventude do Partido Conservador, que mais tarde daria origem ao PDC. Inspirados por filosofias do social-cristianismo francês, como o "humanismo integral" de Jacques Maritain, a ação de "economia e humanismo" do Padre Lebret e a filosofia do "personalismo" de Emmanuel Mounier, Chonchol e Silva Solar desenvolveram um sistema doutrinário próprio, atravessado por conceitos marxistas e desenvolvimentistas, porém sem adesão aos seus programas políticos: "o social-cristianismo luta pela abolição total do sistema de vida capitalista", escreveram (Chonchol \& Solar, 1951: 4).

Apesar de afirmarem-se "não marxistas" em termos programáticos, a influência teórica de Marx era explícita em seu livro-manifesto de 1951: "Marx aponta, com razão, a espoliação, a escravização, as violências mais escancaradas e brutais do direito de propriedade e, em geral, a violência inaudita dos meios empregados para estabelecer os cimentos do regime capitalista" e "a sociedade está cindida em duas classes: uma proprietária das riquezas e meios de produção (...) e outra submetida e despossuída, cujo espírito revolucionário se avoluma na medida em que toma consciência de sua dignidade e força" (Chonchol \& Solar, 1951: 16: 26).

Uma década mais tarde, apresentaram o termo "socialismo comunitário" para sintetizar sua filosofia política e seu programa: "a economia comunitária é um requisito para que todos os homens se integrem em uma verdadeira comunidade fraternal. A ideia comunitária é, por isso, uma ideia de libertação humana" (Chonchol \& Solar, 1969: 25). O socialismo comunitário, para seus formuladores, se afirmava como terceira via, nem liberal, nem estatista, rechaçando ao mesmo tempo o individualismo burguês e o autoritarismo das fórmulas do socialismo real. ${ }^{39}$ A propriedade comunitária, célula do novo sistema social que imaginavam, seria uma empresa autogestionária, coletiva e fraternal, na qual os trabalhadores encontrariam igualdade de oportunidades e poder, o que representaria "um passo decisivo rumo à sociedade sem classes" (Chonchol \& Solar, 1969: 50).

Os estudos agrários de Jacques Chonchol desse período acompanhavam em linhas gerais o diagnóstico econômico da CEPAL a respeito do desequilíbrio entre produtividade rural, crescimento demográfico e urbanização, apontando igualmente o "estancamento agrário" como a origem do déficit externo e suas consequentes obstruções do desenvolvimento. Contudo, articulava seus referenciais

\footnotetext{
${ }^{39} \mathrm{Na}$ entrevista ao historiador Claudio Robles, Chonchol recordou: "Havia a direita, que era reacionária e conservadora. E havia uma esquerda que era fundamentalmente marxista. E falávamos entre nós sobre o comunitarismo e uma sociedade em que se desenvolvem os corpos intermédios, entre o indivíduo e o Estado. Víamos a esquerda como fundamentalmente estatista. A direita como individualista. E a sociedade comunitária como a sociedade dos corpos intermédios" (Chonchol \& Robles, 2016: 58).
} 
cepalinos com o comunitarismo, uma ética tomista e uma crítica cristã da propriedade privada. A propriedade comunitária era sua proposta mais original para a integração do campesinato aos benefícios da modernização. ${ }^{40}$

O agrônomo também se contrapunha à tese de que o processo de amadurecimento educacional seria um pré-requisito prévio às transformações estruturais na agricultura latino-americana. Ao contrário, Chonchol em seus textos e palestras nos anos 1960, advogava por reformas que articulassem dialeticamente as transformações culturais e econômicas: "As mudanças estruturais e a educação devem vir conjuntamente" (1965: 119). Ele acreditava que, embora por óbvio devesse ser combatido, o analfabetismo rural em si não era o maior obstáculo para a transformação do campesinato, marcado pela desconfiança frente às mudanças vindas de fora de seu meio cultural:

Essa população não só é analfabeta, mas também tradicionalista, no sentido de permanecer apegada a sistemas de produção que vêm se repetindo de pais para filhos e manifesta, ao mesmo tempo, certa desconfiança a tudo que possa modificá-los. A tarefa educacional consiste em tirar essa população da sua mentalidade tradicional (Chonchol, 1965: 73, 76).

Para sublinhar sua diferença com a modernização capitalista da agricultura, que tecnificava a produção e preservava a estrutura de propriedades concentradas, Chonchol criou um slogan bemsucedido, replicado pelos movimentos camponeses durante os anos seguintes: "a reforma agrária na América Latina deve ser um processo massivo, rápido e drástico de redistribuição dos direitos sobre a terra e sobre a água" (Chonchol, 1965: 119). A velocidade e a massividade da transformação agrária eram fundamentais para evitar que as classes proprietárias restaurassem seu poder. Seu caráter "rápido, drástico e massivo" deveria esvaziar os mecanismos de poder da contrarreforma, criando uma estrutura alternativa de poder e controle sobre a terra que contivesse os contragolpes.

$\mathrm{Na}$ prática, essa radicalidade era contraditória, e desencadeou uma intensa variedade de conflitos políticos e tensões sociais que constituem o terreno principal dos estudos sobre a reforma agrária chilena. Além da velocidade e amplitude, outra diferença importante do pensamento de Chonchol com relação à reforma agrária de vertente tecnocrática era a aceitação do descontrole como parte intrínseca e desejável da mudança: "Muitos pensam que a reforma agrária é um processo domesticado de mudança, que pode ser controlado à vontade. Apertando-se um botãozinho podemos fazer que as coisas cheguem até certo ponto e apertando outro, que se detenham", continuou em sua palestra na Universidade do Chile em 1962: “Estão profundamente equivocados. (...) Ninguém, inclusive aqueles que iniciam um processo dessa natureza, sabem no fundo até onde devem ir, de que forma vão operar e onde vão parar" (Chonchol, 1965: 104).

\footnotetext{
${ }^{40}$ Em 2017, perguntei a Chonchol sobre a possível contradição entre sua perspectiva comunitarista, crítica ao estatismo, e o protagonismo do Estado-investidor na industrialização cepalina. "Esas dos cosas se fueron conjugando de alguna manera", respondeu. Entrevista com Jacques Chonchol, Santiago, 11 de abril de 2017. A publicação que mais expressava sua visão cepalina naquele período El desarrollo de América Latina y la reforma agrária (1964), era uma genuína articulação entre estes social-cristianismo e desenvolvimentismo anticapitalista.
} 
Essa posição demarcava uma linha divisória nítida entre estratégias tecnocráticas e democráticas da mudança social no campo. As pressões sociais pela mudança não seriam domesticadas, e as decisões sobre os contornos de um processo de reforma agrária deveriam absorver essas pressões e admitir, portanto, que a reforma agrária se iniciava sem que se soubesse quando, onde e como iria "terminar". Nesse caminho atuariam forças políticas desde cima e movimentos populares desde baixo, sendo variadas as alianças e tensões entre vanguardas urbanas e efervescência camponesa. A educação camponesa, novamente, cumpria uma função fundamental no imaginário da modernização, isto é, o amortecimento dos conflitos e a condução cultural do processo destinado a um fim desejado pelas diferentes narrativas desenvolvimentistas.

\section{Os marxismos}

Os intelectuais e políticos marxistas que estudaram e vivenciaram o Chile dos anos 1950 e 1960 também produziram compreensões desenvolvimentistas sobre a reforma agrária, concatenadas em duas caracterizações diferentes da mudança revolucionária e que, mais tarde, se confrontariam no seio da via chilena ao socialismo. Em um primeiro momento, as concepções da reforma agrária entre comunistas, socialistas e cepalinos partiam de um diagnóstico crítico semelhante sobre o estancamento da agricultura e da urgência de uma reforma agrária que alterasse a estrutura de propriedades e desatasse a armadilha do subdesenvolvimento. Tal semelhança permitia um ponto de partida comum para projetos de reforma agrária distintos, que projetavam formas de propriedade e organização do trabalho camponês também diferentes. Até meados dos anos 1960, a CEPAL e as correntes marxistas compartilhavam o olhar histórico-estrutural do problema agrário, advogando por uma plataforma de reforma agrária e industrialização comum.

Em dezembro de 1961, o documento "Bases de uma Política Socialista Frente ao Problema Agrário" foi apresentado ao Pleno do XIX Congresso do PS, indicando a necessidade de uma "autêntica reforma agrária", frente ao diagnóstico do estancamento agrícola como fator preponderante da crise econômica, da incapacidade de avançar com a industrialização e do aprofundamento da miséria social. Apontavam o contraste entre o aumento de 1,6\% da produção agropecuária entre 1946 e 1957 e o crescimento de $2,5 \%$ da população no mesmo período: "a absoluta incapacidade da agricultura para crescer a um ritmo maior que o crescimento demográfico significou uma piora da situação alimentar da maioria da população", ${ }^{41}$ alertavam os socialistas. "Existe fome (...) e um estado de progressiva desnutrição que acomete nosso povo", registrava o Departamento de Estudos do PS. O documento acusava a classe latifundiária e as oligarquias políticas chilenas de formarem uma "classe dirigente cega e egoísta, contra todo sentido de progresso". ${ }^{42}$

\footnotetext{
${ }^{41}$ PS, Bases de uma Politica Socialista Frente ao Problema Agrário. Departamento de Estudos do Comitê Central. Pleno do XIX Congresso do Partido Socialista. Santiago, 1961.

42 Idem.
} 
Para os socialistas, o problema se originava na concentração de terras e na concentração do poder, que eram fenômenos sobrepostos, mas não idênticos. Também registravam que o "estado de ignorância e dependência da grande massa camponesa tem sido um obstáculo para toda tentativa de progresso, impedindo que o indivíduo do campo expresse sua potencialidade criadora, oculta sob essa camada de indiferença, ressentimento e passividade". ${ }^{43} \mathrm{O}$ documento afirmava que "a reforma agrária não é uma panaceia", pois deveria ser parte de uma agenda radical de distribuição de renda nas cidades, de controle de preços alimentares e de industrialização estatal. Também era necessário, segundo o PS, "fomentar e estimular a transformação do caráter sociológico do campesinato", promovendo sua "capacidade, engenho e habilidade diretiva que jaz de forma potencial em um terço da população chilena". Para tanto, indicavam campanhas de cultura e alfabetização, saúde e construção habitacional, que permitisse a conquista de uma vida melhor ao campesinato. $\mathrm{O}$ documento enfim alertava: "somente guerras, revoluções ou crises já balizaram tais mudanças", ${ }^{44}$ matizando sua diferença em relação ao desenvolvimentismo "ordeiro" do paradigma cepalino, que não pretendia fomentar conflitos de classe, mas promover uma mudança pactuada e técnica por cima.

A concepção socialista da reforma agrária previa a necessidade de "mobilizar o campesinato como força social revolucionária, em estreita aliança com a classe operária" para modificar radicalmente o regime de propriedades e de trabalho no campo, rumo a uma economia socializada, planificada e formada predominantemente por propriedades cooperativas e estatais. Tal expropriação deveria ocorrer com base no tamanho da propriedade privada e não de sua produtividade. Entre os desafios desse caminho socialista, estavam o analfabetismo rural e a mentalidade camponesa, vítima de um "sistema autoritário, ou autoritário-paternalista". Os camponeses não poderiam, dizia o PS, "da noite para o dia, atuar racionalmente como homens totalmente livres. Séculos de atraso mental conspirarão contra suas possibilidades de autodemocratização instantâneas", resumia. Por isso, previa-se que a escola rural teria um papel fundamental a cumprir, promotora de um impulso cultural e educacional ao campesinato, junto do fomento às modernas técnicas agrárias, qualificando-o enquanto trabalhadores e sujeitos da revolução.

Nos seus Congressos subsequentes, em Linares (1965) e Chillán (1967), o PS enfatizou uma tendência à radicalidade revolucionária, afirmando que um processo insurrecional era inevitável para construir a mudança que pretendiam. Em 1966, Aniceto Rodríguez, líder socialista do mundo rural em Linares, discursou ao Pleno do PS: "nos qualificaram de agitadores e demagogos. Porém, os camponeses nos entregaram seu estímulo generoso e, pouco a pouco, foram compreendendo a profunda verdade da nossa mensagem". ${ }^{45}$ Ele alertava que "a reforma agrária não está na ordem do dia porque o capitalismo está se tornando mais justo e menos explorador, mas sim porque a combatividade e a

\footnotetext{
43 Idem.

${ }^{44}$ Idem.

${ }^{45}$ Aniceto Rodríguez, 1966, año de la organización y de las luchas campesinas. Informe al Pleno Nacional del PS. Santiago, 1966.
} 
insurgência revolucionária das massas ameaçam minar todo o sistema". ${ }^{46}$ Em Chillán, em 1967, as resoluções do partido concluíram que "a violência revolucionária é inevitável e legítima" e "constitui a única via que conduz à tomada do poder" (apud Altamirano \& Salazar, 2011: 211).

Em uma Cartilla Campesina de 1966, os socialistas tentavam se comunicar com os camponeses ilustrando que seus dirigentes eram aliados confiáveis, com quem poderiam contar em suas batalhas. Além de 80 páginas de textos sobre os direitos dos trabalhadores rurais e as estratégias da sindicalização, algumas figuras ajudavam a tornar o material mais compreensível para maioria, como estas reproduzidas a seguir.

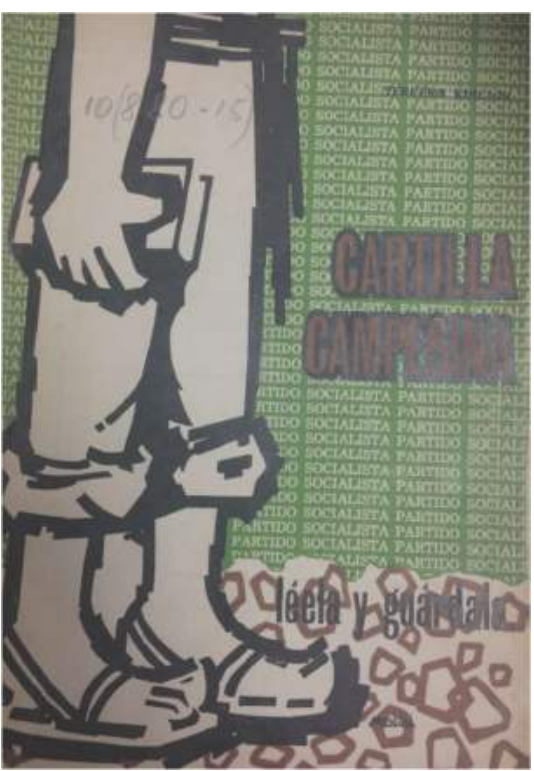

PS, Cartilla Campesina, 1966

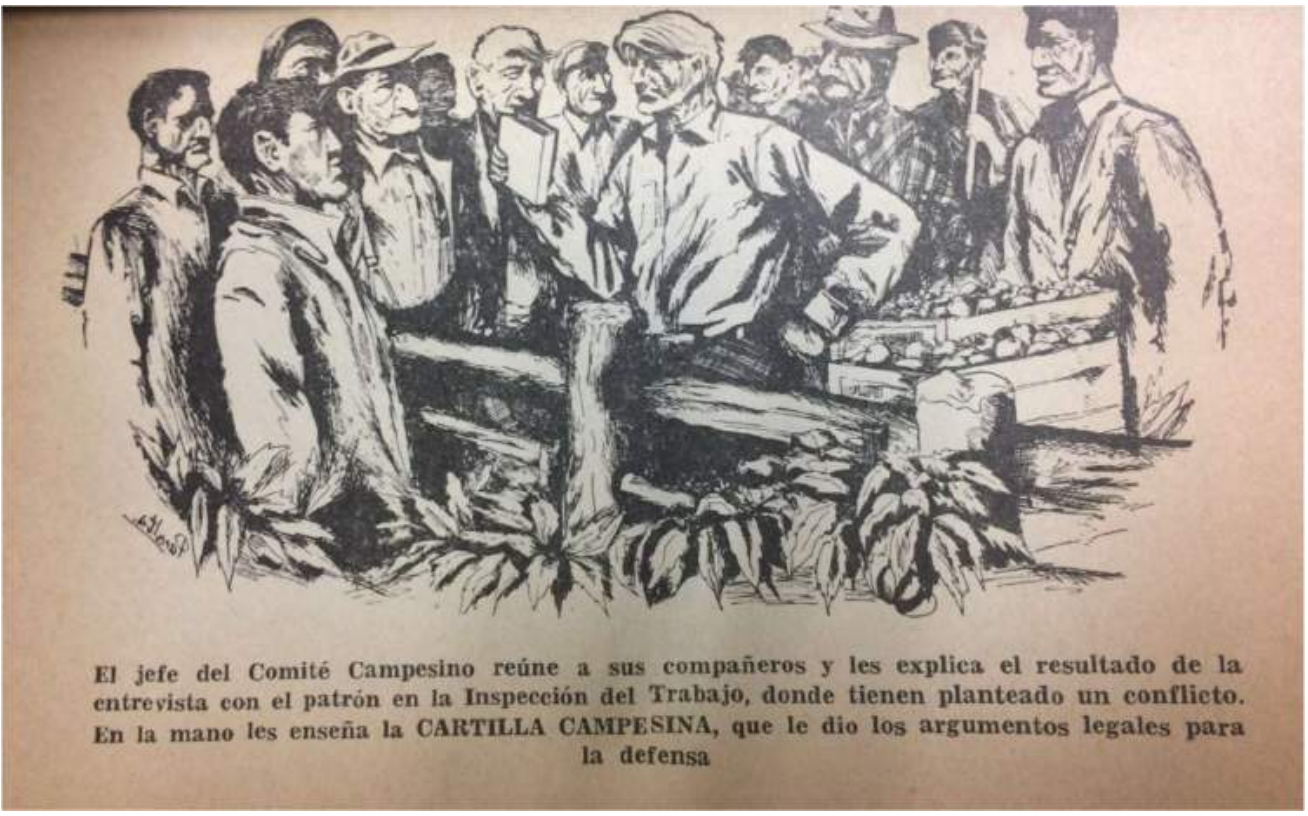

"O chefe do Comitê Campesino reúne seus companheiros e lhes explica o resultado da entrevista com o patrão na Inspetoria do Trabalho (...). Em sua mão, a Cartilha Campesina lhe deu argumentos legais para defesa”. PS, Cartilla Campesina, 1966

\footnotetext{
${ }^{46}$ Idem.
} 


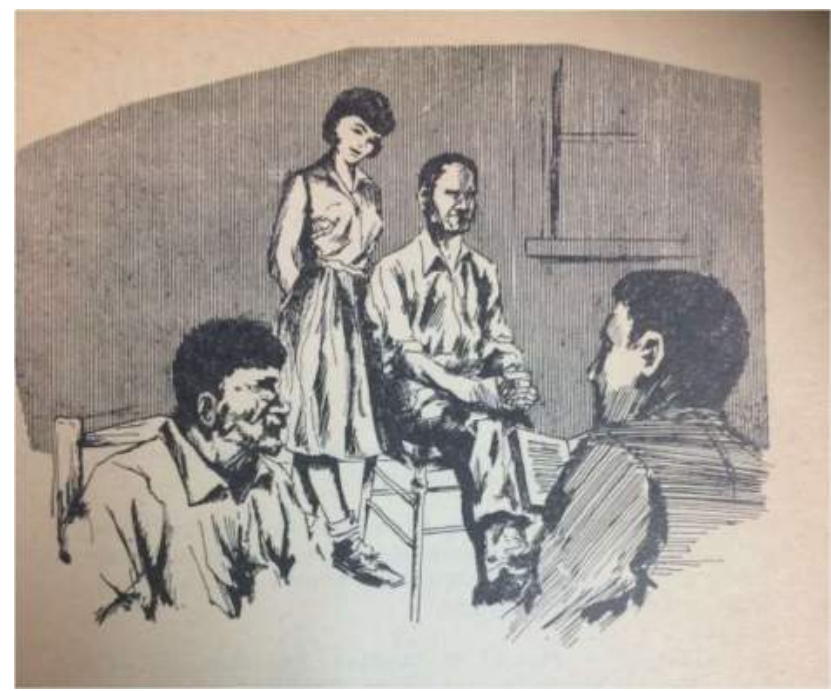

"Na choza campesina, Don Panta e sua família escutam o chefe do núcleo socialista do latifúndio vizinho, que lhes explica que o PS fará a reforma agrária para felicidade dos camponeses". PS, Cartilla Campesina, 1966

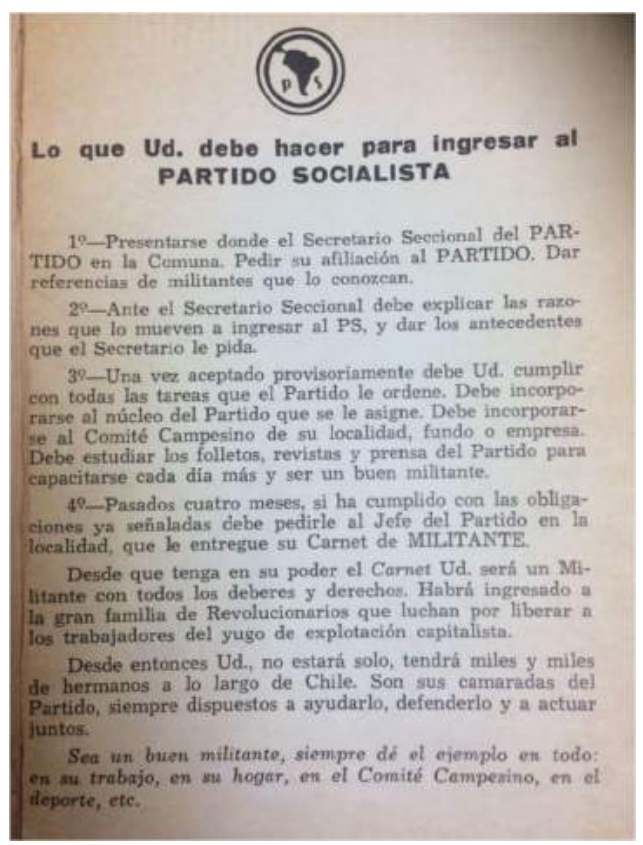

“O que você deve fazer para ingressar no PS". PS, Cartilla Campesina, 1966

Desde 1958, o Partido Comunista formalizou a possibilidade de uma revolução sem armas. Nos anos 1960, apesar de manter uma boa relação com os líderes da revolução cubana, os comunistas seguiam alinhados à URSS, num constante empenho de adaptação às particularidades da realidade

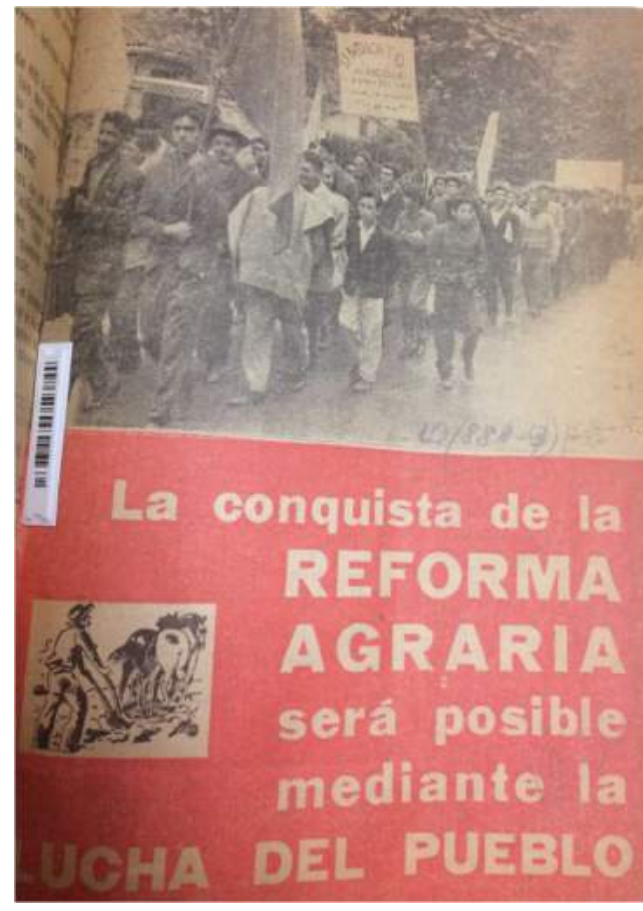

PC, La conquista de la reforma agraria será posible mediante la lucha del pueblo. nacional chilena (Corvalán, 2003). Apesar de ser reconhecido como um partido de tradição "legalista", durante décadas o PC desenvolveu um trabalho de sindicalização e greves camponesas "fora da lei" junto aos movimentos rurais, pelo menos desde os anos 1930, além de ter experimentado a clandestinidade forçada durante a vigência da Ley de Defensa Permanente de la Democracia (mais conhecida como Lei Maldita), entre 1948 e 1958, que o proscreveu. Em 1966, um documento do PC chamado "A Conquista da Reforma Agrária será possível mediante a luta do povo", os comunistas reforçavam seu compromisso de fomento e apoio à luta dos trabalhadores rurais como único caminho para "estraçalhar as manobras 
dos latifundiários e de todos os direitistas". ${ }^{47}$ Em uma mensagem às suas bases camponesas, os cinco senadores comunistas ${ }^{48}$ indicaram as sete mudanças que propuseram ao projeto de lei da reforma agrária de Eduardo Frei no Senado: ${ }^{49}$

1) O limite máximo de $40 \mathrm{HRB}$ para propriedade privada, "de modo que seja possível entregar terra a um maior número de camponeses". Denunciavam que o projeto de lei do governo deixava dez vezes mais terras aos grandes proprietários e patrões do que aos camponeses beneficiários da reforma.

2) A inexpropriabilidade de propriedades menores que $40 \mathrm{HRB}$, mesmo quando estivessem mal exploradas, e oferta adequada de crédito e insumos.

3) A expropriação do gado e dos bens de capital para reforma agrária, que no projeto de lei do governo eram preservados com os proprietários originais.

4) O fim do reajuste aos títulos de reforma agrária, que já pagavam juros de $3 \%$, e quando reajustados gerariam inflação.

5) Defesa e aumento das regalías dos camponeses para aqueles que ficariam excluídos da reforma agrária. A regalía eram as formas não salariais de remuneração do trabalho camponês, sendo a mais desejada a regalía de terra, na qual os trabalhadores podiam cultivar nos seus dias livres. "Além da lentidão com que a reforma agrária caminha, ela deixa pelo menos outras 100 mil famílias camponesas à margem do direito à terra", registravam os senadores comunistas. Por isso, "o PC considera indispensável que na lei de reforma agrária se incluam agora mesmo benefícios à grande massa dos camponeses" dela excluída, entre eles uma regalía mínima de 1/2 hectare.

6) Os comunistas também defenderam o aumento do direito à talaje, o pasto dos animais dos camponeses em terrenos determinados nas terras do patrão.

7) A última emenda dos senadores comunistas à lei defendia que os camponeses fossem incorporados em todos os organismos da reforma agrária, para que fossem escutados e participassem da condução das políticas agrárias.

"Os senadores do PC estão convencidos de que estas propostas tendem a tornar a reforma agrária mais profunda e efetiva e de que têm um caráter construtivo e realista", ${ }^{50}$ diziam. Denunciavam, ademais, que no Vale Central existiam ao menos 500 mil hectares ociosos nos latifúndios, enquanto 185 mil camponeses permaneciam sem terras. $O$ folheto seguia explicando as características da lei de reforma agrária debatida no parlamento, definia o que eram os assentamentos, explicava quem poderia ser assentado e como os camponeses se tornariam beneficiários diretos da terra. O documento também

\footnotetext{
${ }^{47} \mathrm{PC}$, La conquista de la reforma agrária será posible mediante la lucha del pueblo. Santiago, 1966.

${ }^{48}$ Eram Julieta Campusano, Carlos Contreras Labarca, Víctor Contreras, Volodia Teitelboim e Luis Corvalán.

${ }^{49} \mathrm{Idem}$. As aspas contidas nos sete pontos correspondem ao mesmo documento.

${ }^{50}$ Idem.
} 
apresentava uma página com gráficos e ilustrações sobre a concentração fundiária do país, parcialmente reproduzidos a seguir, em um esforço didático de abordagem de temas complexos.
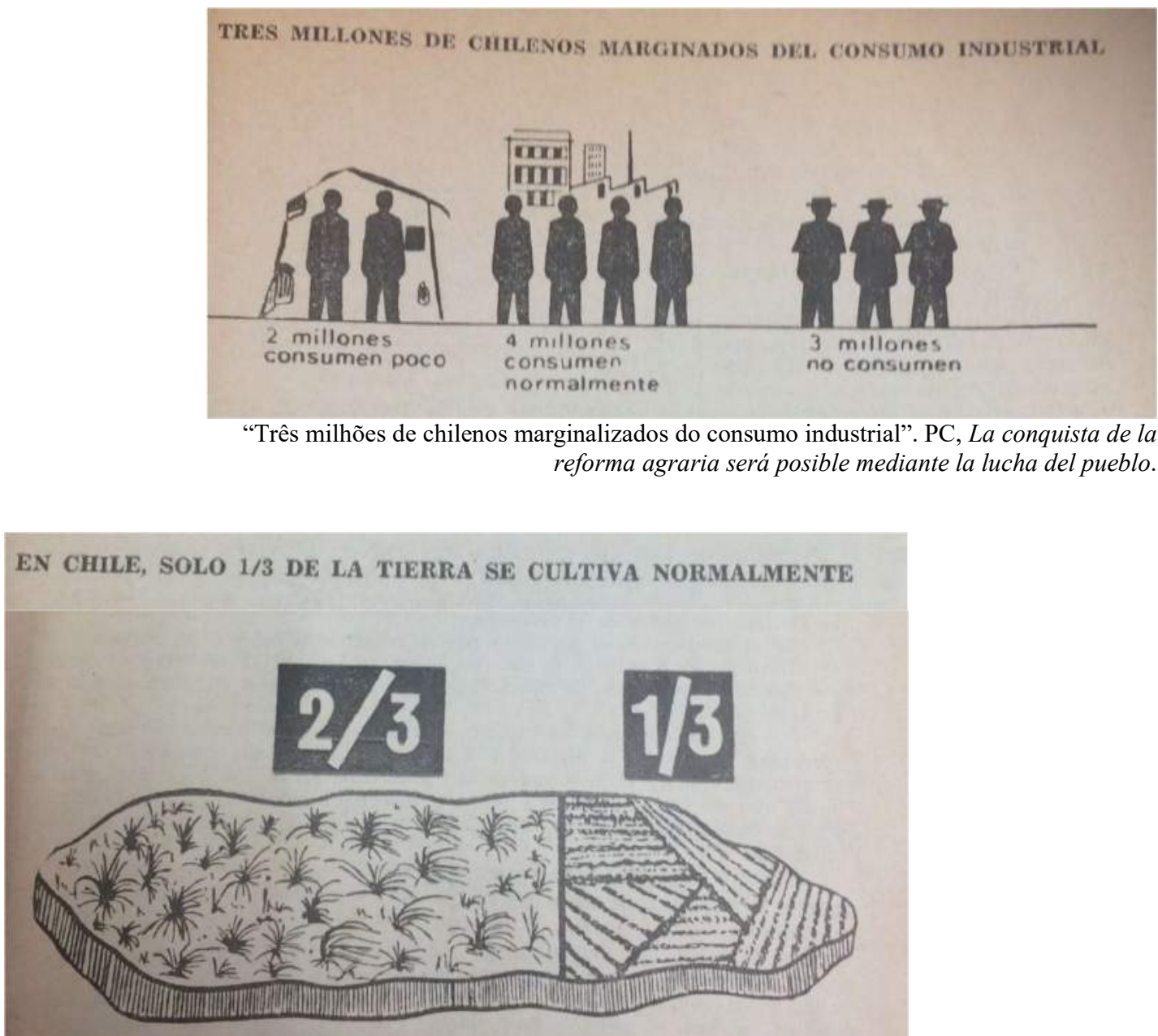

"No Chile, só um terço da terra se cultiva normalmente". PC, La conquista de la reforma agraria será posible mediante la lucha del pueblo.

Os comunistas avaliavam que o principal problema do projeto de lei de reforma agrária da DC era a "falta de confiança no camponês" como sujeito econômico da mudança agrária: "os inimigos das mudanças estruturais no campo são, antes de tudo, céticos sobre a eficácia e a responsabilidade do camponês (...). Mas existem cálculos que desmentem tal desconfiança”, concluíam os comunistas: “o Comitê Interamericano de Desenvolvimento Agrícola (CIDA) assinalou que enquanto as grandes empresas agrícolas produzem 83 escudos $\left(\mathrm{E}^{\circ}\right)$ por hectare agrícola, as demais produzem 391 ". ${ }^{51}$ Dentro da mesma racionalidade do informe CIDA, os comunistas comprovavam "a surpreendente capacidade de nossos camponeses", ${ }^{52}$ merecedores de toda confiança.

\footnotetext{
${ }^{51}$ Idem.

${ }^{52}$ Idem.
} 
Paralelamente à atuação de apoio e pressão dos partidos marxistas em favor da reforma agrária da DC, o debate intelectual se aquecia com a polêmica sobre o caráter feudal ou capitalista da agricultura chilena, que tinha implicações políticas imediatas nos caminhos de uma revolução socialista. Em 1966, o economista alemão André Gunder Frank cunhou o termo "desenvolvimento do subdesenvolvimento" (1966), para criticar os programas desenvolvimentistas da CEPAL e de frações das classes dominantes latino-americanas, argumentando que não existia espaço para humanizar o capitalismo na periferia, e que toda reforma estaria contribuindo para aprofundar o mesmo fosso de problemas do subdesenvolvimento que se pretendia superar. No ano seguinte, Gunder Frank publicou seu livro Capitalismo y subdesarrollo en América Latina, com um estudo de caso sobre o Chile, no qual polemizava com os cepalinos Aníbal Pinto e Jorge Ahumada. Poucos anos depois, intelectuais marxistas chilenos e brasileiros exilados em Santiago fizeram coro com tais formulações enquanto fundavam o Centro de Estudos Socioeconômicos (CESO) da Universidade do Chile, que mais tarde entrou para a história da teoria marxista da dependência. Uma corrente cada vez mais expressiva do marxismo chileno passou a vocalizar a crítica aos limites das reformas estruturais cepalinas no contexto do capitalismo dependente, ecoando a radicalidade de agrupamentos como o Movimiento de Izquerda Revolucionaria (MIR), também criado em 1965 a partir de um racha da juventude do PS. Parte dessa crítica também se dirigia à sociologia funcionalista e sua teoria da marginalidade e da integração.

\subsection{Reforma agrária como questão cultural}

\section{Problema educacional no campo}

Embora o desafio econômico ganhasse maior projeção nas epistemologias urbanas do desenvolvimento da agricultura, tanto para reformadores democrata-cristãos, quanto para revolucionários marxistas, a reforma agrária era também uma questão cultural. Em 1953, o analfabetismo rural no Chile chegava a 66\% da população do campo (Ponce de León, 2018b: 104). A média da escolaridade total da população rural em 1960 era 2,4 anos, metade da escolaridade da população urbana (Ponce de León, 2018a: 84). Em 1961, segundo o censo, o analfabetismo atingia 34\% da população rural, mais de 900 mil pessoas (CIDA, 1966: 13, 199). O CIDA alertou para o caráter subestimado desse número: "a desigualdade se agrava (...) pois se considera que uma pessoa lê e escreve quando reconhece as letras, pode formar palavras e sabe assinar seu nome", contabilizando-se como alfabetizados milhares de camponeses que eram "analfabetos por desuso" (CIDA, 1966: 199). Ainda que fosse difícil de mensurar o analfabetismo funcional, Waldemar Cortés Carabantes registrou em 1963 que o analfabetismo rural, na realidade, alcançava $59 \%$ da população maior de 15 anos. ${ }^{53}$

Os estudos agrários gestado nas cidades identificavam a falta de educação camponesa como um importante obstáculo ao desenvolvimento. O relatório CIDA alertava que $46,6 \%$ dos habitantes rurais

\footnotetext{
${ }^{53}$ Waldemar Cortés Carabantes, Formas muertas y dinámicas en nuestra educación de adultos. Revista de Educación, n. 93 , 1963.
} 
com 6 a 14 anos não frequentava sequer o primeiro ano escolar, chamados de "inescolares absolutos", aqueles que nunca pisaram em uma sala de aula. Entre as crianças camponesas que frequentavam escolas rurais na província de Santiago, somente $13,5 \%$ chegavam ao $6^{\circ}$ ano primário (CIDA, 1966: 198). A evasão escolar era o normal da vida no campo. O censo de 1955 contabilizava 41 mil crianças menores de 15 anos trabalhando na agricultura em caráter permanente e cotidiano. ${ }^{54}$

"Ignorância" e "falta de qualificação" eram expressões frequentes dessa narrativa modernizadora para descrever a miséria camponesa e sua subordinação às autoridades patronais. "Esta estrutura, para funcionar", registrava o relatório CIDA, "necessita de uma grande massa camponesa sem iniciativa e de baixos níveis de educação, tecnificação e especialização, que obedeça sem discutir às ordens emanadas desde cima por um patrão providente e onipresente" (CIDA, 1966: 192). De modo geral, o retrato de uma população rural obediente, passiva e sem iniciativa compunha a compreensão que esses setores da intelectualidade urbana desenvolveram sobre o campesinato do país. Nesse cenário, tornou-se um lugar-comum entre os intelectuais do desenvolvimento a imagem de um "campesinato ignorante". Essa imagem estava associada às taxas de analfabetismo, ao seu isolamento geográfico e cultural, a um comportamento submisso, ao tradicionalismo e ao desconhecimento de alguns códigos urbanos que lhes permitiriam alcançar melhorias técnicas e cidadania cultural. Como parte de um novo "consenso modernizador", consolidou-se a ideia de que a falta de educação da população camponesa era parte determinante do cenário de "atraso nacional". ${ }^{55}$ Para vocalizar essa concepção, Jorge Ahumada sintetizou: "salvo modificações de importância secundária, o sistema educacional chileno se conserva como se concebeu quando o país ainda era uma grande comunidade rural. Seu maior defeito reside em ser aristocratizante". E concluiu: "A escola primária não está orientada para prover a educação mínima necessária (...) para que se conviva dignamente e de forma civilizada" (1958: 25).

Em 1964, nos últimos meses do governo Alessandri, a imprensa oficial resumiu sua visão sobre o problema: "é fundamental aumentar a produção agrícola e isso só pode ser conseguido mediante uma eficiente assimilação dos procedimentos científicos e técnicos que assegurem rendimentos ótimos", no processo que nomearam "aculturação camponesa". ${ }^{56}$ Esses termos eram representativos do projeto de modernização agrária sem mudança social, que percebia o camponês como um objeto do processo econômico, bem como a mudança de paradigma produtivo como um processo mecanicista. Ao contrário, a DC e o social-cristianismo eram mais sofisticados na sua proposição da reforma agrária como questão cultural.

\footnotetext{
${ }^{54}$ Para efeitos de comparação, nas cidades, as crianças "inescolares absolutas" correspondiam a 9,9\%. Em Santiago, 60\% das que entravam no ensino primário, não chegavam a conclui-lo (CIDA, 1966: 199).

${ }_{55}$ Propulsor do mesmo leit motiv, o objetivo 7 da Carta de Punta del Este sugeria "eliminar o analfabetismo nos adultos do hemisfério e, para 1970, assegurar um mínimo de seis anos de educação primária a toda criança em idade escolar na América Latina; modernizar e ampliar os meios de ensino secundário, vocacional, técnico e superior; aumentar a capacidade para pesquisa pura e aplicada, e prover a mão de obra capacitada que requerida pelas sociedades em rápido desenvolvimento" (OEA, 1961: 623).

${ }^{56}$ Culturización campesina. La Nación, 12/05/1964.
} 
Os impulsionadores da reforma agrária cepalina consideravam decisivo criar uma nova classe de agricultores modernos com espírito empresarial, redistribuir terra e combater a pobreza rural, integrando o campesinato aos mercados consumidores, à cultura moderna e à coletividade nacional. Em um artigo chamado Estructura Agrária y Educación en América Latina, Barraclough (1962) pontuou: "em uma economia em desenvolvimento, os camponeses precisam de mais educação, tanto em benefício próprio como para melhorar sua condição econômica e social. Já não aceitarão a condição de ignorância”. A reforma agrária entendida como questão cultural combinava a defesa do direito à educação com a demanda pragmática por mão de obra qualificada: "devemos nos perguntar como as necessidades educacionais mudam conforme muda o regime de propriedade agrária (...) e quanta mão de obra capacitada adicional será requerida na próxima década" (Barraclough, 1962: 1, 6).

A doutrina da DC propunha que a crise integral precisaria ser solucionada por um "desenvolvimento integral", ou como sintetizou Gajardo, uma "ruptura com a ordem sem promover conflitos sociais, através da modernização do acesso às funções e aos benefícios sociais e de uma maior organização e participação política dos setores marginalizados" (1973a: 27). Nesse caminho, a doutrina da DC aplicava ao campesinato o conceito de "marginalidade" que precisava ser "integrada" por meio da capacitação. A capacitação camponesa da reforma agrária, nessa chave, seria sinônimo de integração à ordem capitalista moderna.

\section{Integração ou emancipação?}

O par marginalidade/integração teve duas origens. A primeira, a doutrina social-cristã repousada nas formulações do jesuíta Roger Veckemans, para quem a radicalização dos "marginalizados" seria consequência da falta de educação: "é preciso educar, formar, preparar os marginais para que possam se organizar e sustentar sua própria organização" (Veckemans apud Gajardo, 1973a: 28). Ele prosseguia: "capacitar é preparar o indivíduo para que possa se organizar entregando-lhe os meios necessários para isso e produzindo uma mutação cultural", ou seja, "uma mudança profunda de mentalidade capaz de criar novos sistemas de associação, de valores culturais e de motivações que permitam assumir seu papel de participante efetivo na tomada de decisões que afetam sua própria existência". A segunda matriz estava na sociologia funcionalista e no controverso conceito de "massa marginal" proposto por José Nun (1969) para definir os "desintegrados" ao sistema. Nesse sentido, o desenvolvimento integral estaria associado à criação de canais de "integração" dos camponeses à sociedade moderna. Consequentemente, a marginalidade era um "conceito indispensável para compreender o tipo de atividades educativas desenvolvidas por estes setores" (Gajardo, 1973a: 28).

Quando Paulo Freire conviveu e trabalhou com alfabetização camponesa no Chile, se confrontou com noções fortemente hierárquicas sobre a ignorância camponesa dentro da matriz 
desenvolvimentista. Na Pedagogia do Oprimido, Freire argumentou: "os chamados marginalizados, que são os oprimidos, jamais estiveram fora de. Sempre estiveram dentro de. Dentro da estrutura que os transforma em 'seres para outro"”. E indicava: "Sua solução, pois, não está em 'integrar-se', em 'incorporar-se' a esta estrutura que os oprime, mas em transformá-la para que possam fazer-se 'seres para si"” (Freire, 2018: 84-85). Havia então uma divergência sobre o objetivo da educação camponesa no contexto da reforma agrária, que podia ser resumida em duas palavras: "integrar" ou "emancipar"? A integração, como criticou Paulo Freire, era um procedimento de objetificação do outro, predispondo ao camponês um papel pré-determinado no "mundo moderno": o empresário self made.

Ao criticar as elites da modernização chilena, vivenciando na prática as experiências educacionais da reforma agrária do país, o brasileiro formulou o conceito de "alienação da ignorância", que seria um dispositivo de poder visível nas tensões entre as culturas urbana e rural. No famoso ensaio Comunicação ou Extensão?, escrito para técnicos extensionistas rurais do Chile da reforma agrária, Freire explicou:

Para que os homens simples sejam tidos como absolutamente ignorantes, é necessário que haja quem os considere assim. Estes, como sujeitos desta definição, necessariamente se classificam a si mesmos como aqueles que sabem. Absolutizando a ignorância dos outros, na melhor das hipóteses relativizam a sua própria ignorância. Realizam deste modo o que chamamos "alienação da ignorância", segundo a qual esta se encontra sempre no outro, nunca em quem a aliena (Freire, 1969: 36). ${ }^{57}$

Do ponto de vista epistemológico, os projetos de modernização capitalista do Chile tendiam à alienação da própria ignorância quando absolutizavam a ignorância do outro: o camponês. Matizes no pensamento desenvolvimentista variavam entre uma compreensão mais tecnocrática sobre o mundo rural, que convertia sujeitos camponeses em objetos do desenvolvimento, e proposições mais empáticas com a subjetividade e agência dos camponeses, que defendiam sua autodeterminação na tomada de decisões sobre a transformação da agricultura. Nesse sentido, os marxismos buscavam desconstruir a teoria da marginalidade e a agenda da "integração ao sistema", substituindo a projeção de um camponês empresário com realizações econômicas particulares pelo camponês revolucionário, abnegado, cujo trabalho fosse movido pelo sentimento de solidariedade radical. A capacitação camponesa da reforma agrária era uma disputa por diferentes economias morais e por valores e sentimentos que dariam substância às novas formas de propriedade e trabalho da nova sociedade.

No entanto, como afirmou um camponês em Colchagua sobre a lei de reforma agrária do governo da DC, em 1969: "essa lei tem muitos erros porque foi feita para os camponeses, mas os camponeses não participaram de sua elaboração". ${ }^{58}$ Além da reforma agrária criada pelas epistemologias urbanas, o movimento camponês amadurecia sua organização e seu repertório tático em

\footnotetext{
${ }^{57}$ Publicado em 1969 no Chile, chama atenção que Comunicação ou Extensão? tenha obtido sua primeira edição brasileira apenas em 2013.

${ }_{58}$ Transcrição de círculo de cultura com camponeses em Maria Edy Ferreira \& Liliana Barria. Hacia un método de programación campesina. ICIRA/INDAP: Santiago de Chile, 1971.
} 
uma trajetória de lutas com dinâmica própria, que embora estivesse articulada às agendas partidárias, também mostrava uma dose expressiva de autodeterminação.

\subsection{Reforma agrária como pressão rural}

\section{Formação social heterogênea do campesinato chileno}

As epistemologias urbanas da reforma agrária eram hegemonizadas pela imagem de um campesinato passivo, ingênuo, ignorante e desinteressado. Em contraponto, algumas pesquisas da época identificavam os pobres do campo como sujeitos históricos dinâmicos e ativos lutadores, e sugeriam enfoques atentos à agência camponesa para análise do problema agrário. Ao mesmo tempo, para os modernizadores, reformadores ou revolucionários, era cada vez mais importante compreender a heterogeneidade da formação social camponesa no Chile que tornava a reforma agrária um desafio mais complexo do que em outros países, pela multiplicidade de situações socioterritoriais em que se implicava.

Uma das obras inovadoras nesse sentido, que explorou a complexidade do campesinato chileno em sua potência e heterogeneidade estrutural, foi o estudo de Góngora (1960), que buscou decifrar a formação histórica da estratificação camponesa, suas tensões com o latifúndio e seus lugares no sistema hacendal, percebendo os camponeses como subalternos, mas sem subestimar sua condição de agentes. O estudo de Góngora tratava da origem da inquilinaje e se inseria no debate sobre a existência (ou não) do feudalismo no Chile. Ao contrário do que afirmava a historiografia até então, Góngora argumentou que a inquilinaje era uma relação de produção que surgira a partir da crise da encomienda, isto é, como parte do processo de modernização da agricultura e avanço do capitalismo no século XIX. Nesse sentido, o autor buscou demarcar o caráter capitalista originário daquela relação de produção, ainda predominante no Chile dos anos 1950 e 1960 . Os inquilinos eram os trabalhadores que moravam dentro dos latifúndios com suas famílias, remunerados com uma composição de regalías e salário. As regalías eram formas de pagamento não monetário, como parcelas de terra, direitos de pasto (talaje), animais ou sementes. As parcelas de terra dos inquilinos, chamadas goces ou huertos, eram a regalía mais desejada, uma vez que viabilizavam a independência da economia campesina com relação à hacienda. Era comum o patrão fornecer galletas aos trabalhadores como refeição, uma bolacha de farinha de trigo de má qualidade, além de endividá-los nas pulperías, lhes remunerando com vales que só poderiam ser utilizados no armazém interno ao latifúndio.

O trabalho de Góngora foi importante porque caracterizava historicamente algumas ambivalências da relação hacendado-inquilino e tensões entre inquilinos-afuerinos, que posteriormente vieram à tona nos conflitos desencadeados pela reforma agrária. Segundo ele, os camponeses que se tornaram inquilinos no início do século XIX eram geralmente espanhóis pobres, que ocuparam pedaços 
de terra em arrendamentos semicontratualizados com latifundiários, que os utilizavam como estratégia de controle do território. A origem não indígena de muitos desses inquilinos e sua relação ambígua com o proprietário, que ora the via como aliado, ora como adversário, ajudavam a explicar alguns conflitos de classe que emergiram na reforma agrária posteriormente.

Outro camponês muito importante na agricultura chilena eram os chamados afuerinos, trabalhadores temporários externos aos latifúndios, absorvidos periodicamente pela hacienda em períodos de colheita, contratados por tarefas (faenas) ou por dia. Os afuerinos pertenciam ao mundo externo, eram circulantes. Muitos passaram a vida migrando em busca de melhores condições. $\mathrm{O}$ sociólogo Hugo Zemelman (1971) argumentou que uma das modalidades mais comuns de migração era impulsionada pela "absoluta falta de alternativas" para os camponeses pobres, decorrente da "crise do sistema tradicional" (1971: 42, 68). Zemelman produziu uma etnografia do migrante rural, que resultou na sugestão de alguns tipos:

a) O migrante tradicional empresarial: usava a regalía ou minifúndio como fonte de capitalização, mas experimentava a perda relativa de sua independência. Era impulsionado a recuperar um status de subprodutor independente em outro lugar, objetivo muitas vezes frustrado devido à crise agrária estrutural.

b) O migrante tradicional marginal: não usava a regalía ou minifúndio como fonte de capitalização. Sua decisão de migrar advinha de situações-limite, do desespero, da miséria, da fome e da falta de alternativas de subsistência. Experimentava circuitos abusivos de "migração intrarrural" e se deslocava como um reflexo de sobrevivência.

c) O migrante por influência urbana instrumental: eram trabalhadores rurais geralmente não subordinados às relações paternalistas de dependência com o proprietário, tais como medieros (meeiros), minifundistas, tratoristas ou comerciantes. Tendiam a preferir o pagamento em salário em vez das regalías e, embora fossem bem integrados à cultura rural, buscavam cidades como meio de ascensão.

d) O migrante por influência cultural urbana: ocupava um lugar menos dependente na estratificação campesina, normalmente alfabetizado e jovem, mas já não se identificava com a cultura rural e desenvolvia um perfil discordante, contestador, menos submisso aos patrões. Acessava meios de comunicação de massa e desejava participar do modo de vida urbano.

Para além da tipologia e da diversidade da circulação afuerina, o método etnográfico de Zemelman expressou diretamente a voz camponesa, suas histórias, sensibilidades e expectativas em um livro. Na tabela 2 a seguir, a população rural está identificada por formas de trabalho, segundo o censo de 1955. 


\begin{tabular}{|l|c|c|}
\hline \multicolumn{3}{|c|}{ Tabela 2 - População agrícola por localização no processo produtivo (1955) } \\
\hline \multicolumn{2}{|c|}{ Número de pessoas } & \% \\
\hline Proprietários de unidades multifamiliares grandes & 46.800 & 2,4 \\
\hline Proprietários de unidades multifamiliares médias & 111.800 & 5,8 \\
\hline Administradores, técnicos e profissionais & 23.000 & 1,2 \\
\hline Proprietários de unidades familiares & 367.400 & 19 \\
\hline Comunidades indígenas ou sucessórias & 336.200 & 17,4 \\
\hline Proprietários de unidades subfamiliares & 150.000 & 7,8 \\
\hline Medieros & 134.500 & 7,0 \\
\hline Capatazes (empleados ou mayordomos) & 147.000 & 7,6 \\
\hline Inquilinos e inquilinos-medieros & 494.400 & 25,6 \\
\hline Trabalhadores sem-terra (afuerinos) & 122.500 & 6,3 \\
\hline \multicolumn{2}{|c|}{ Fonte: CIDA, $1966: 42}$. \\
\hline
\end{tabular}

Além dos inquilinos e afuerinos, um personagem importante do campesinato chileno eram os minifundistas, que representavam $37 \%$ das unidades produtivas, aglomeradas em $0,3 \%$ da superfície agrícola. Uma pesquisa de Baraona, Aranda e Santana (1961) analisou a complexidade das relações entre sociedade e natureza no vale do rio Putaendo, um afluente do rio Aconcagua, a fim de desvendar as origens do minifundismo, a vida social camponesa e o dinamismo da relação dos trabalhadores rurais com a terra e com a hacienda. Embora engajados com a agenda modernizadora, os autores se apresentaram na contramão da narrativa hegemônica ao dedicar especial atenção aos saberes camponeses, investindo na ambivalência da palavra cultura, cujo emprego acionava as acepções de cultivo agrícola e de prática social. "Nosso desejo de mudança, de passar do subdesenvolvimento ao desenvolvimento, admite um grande número de versões que, em última instância, depende dos nossos povos (...) Atrás do nome do camponês ou pobre rural se esconde uma vida complexa, rica, cheia de aspectos inesperados", escreveram (Baraona et al, 1961: XIII-XIV, XVI).

Esse enfoque aparecia na valorização do conhecimento popular rural sobre a natureza, indicando, por exemplo, que por necessidade de sobreviver, os camponeses pobres aprenderam a cultivar as piores terras: "a habilitação de pedregais para cultivo é uma arte de camponeses pobres" e "o reconhecimento das modalidades de clima local e seus efeitos na agricultura requerem considerável agudez" (Baraona et al, 1961: 7, 8). Os autores também valorizavam a agência camponesa manifestada em sua sagacidade produtiva: "o camponês do Vale de Putaendo, ao viver preocupado com o clima, desenvolve uma grande habilidade para tomar decisões oportunas", analisavam os autores (Baraona et al, 1961: 12).

$\mathrm{Na}$ investigação sobre os camponeses de Putaendo, nada se menciona sobre uma "grande massa campesina sem iniciativa" (CIDA, 1966: 192) ou "desarticulada e desinteressada" (Barraclough, 1962: 17). Ao contrário, com um olhar antropológico sobre a vida camponesa, o estudo lançava luz sobre suas racionalidades próprias, suas práticas não utilitárias que escapavam ao produtivismo e algumas preferências indecifráveis aos códigos modernizadores urbanos. Entre elas, os autores alertavam para a simbologia e importância do huerto no bem-estar camponês: 
O huerto, ao constituir um elemento essencialmente prazeroso da vida camponesa, só é parcialmente orientado pelos ditames técnicos da arboricultura frutífera. Os fatores que o plasmam são tanto estéticos, como utilitários, enquanto nas plantações de frutas propriamente ditas, dominam amplamente estes últimos. Os requisitos para um bom huerto derivam do bem viver camponês e oferecem possibilidades de expressão pessoal que desafiam a adoção de padrões rígidos (Baraona et al, 1966: $48)$.

Os minifundistas de Putaendo, nesse sentido, foram caracterizados como "homens múltiplos" (Baraona et al, 1961: 289), cuja vida estava baseada em um complexo de atividades distintas, relacionadas à plantação e a outros 58 tipos de trabalhos, do artesanato à mineração, do comércio às tarefas agrícolas a jornal nas haciendas. A compreensão sobre a importância do huerto na vida camponesa, possivelmente influenciada pela perspectiva de Chayanov (2014a), também levou Rafael Baraona a desenvolver a "teoria do assédio interno e externo" para explicar as tensões entre economia camponesa e empresa patronal. ${ }^{59}$

A busca de ampliação do acesso à terra levava o inquilino, o mediero, o afuerino e o minifundista, historicamente, a se aproveitarem dos momentos de crise da agricultura haciendal (nos ciclos de queda das exportações, por exemplo) para expandir seus goces por dentro do latifúndio (assédio interno) ou de seus minifúndios por fora (assédio externo), pressionando o controle patronal sobre a terra e expandindo o território da empresa campesina. Nos séculos XIX e XX, os mecanismos que determinaram a pulsação de poder sobre a terra entre camponeses e latifundiários no Chile dependeram da atratividade das minas de salitre para a mão de obra camponesa, da capacidade dos proprietários em oferecer melhores remunerações que as minas, os preços dos minérios no mercado mundial, os ciclos de exportação de trigo e, evidentemente, as duas guerras brutais de territorialização do Estado chileno (a Guerra do Pacífico, ao norte, entre 1879 e 1883; e a Guerra da Araucanía, ao Sul, entre 1883 e 1889). A alta mobilidade dos camponeses no território era paradoxal, pois revelava ao mesmo tempo a miséria da condição dos pobres do campo e a impossibilidade das classes patronais em controlá-las em sua circulação.

\section{Movimentos camponeses e suas lutas}

À heterogeneidade social se somava a multiplicidade política do campesinato que, ao longo do século XX, constituiu diversas organizações fundamentais nas pressões rurais pelo direito à terra. Um estudo paradigmático sobre a história do movimento camponês chileno foi escrito pelo brasileiro Almino Affonso junto com os chilenos Sergio Gómez, Emílio Klein e Pablo Ramírez, durante o governo Frei, e publicado em $1970 .{ }^{60}$ Até ali, muito pouco se conhecia da história das organizações camponesas no país e tal obra foi uma descoberta histórica e política fundamental para a reforma agrária. Como se

\footnotetext{
${ }^{59}$ Baraona coordenou o relatório CIDA para o Equador e sua teoria foi apresentada a partir destes estudos.

${ }^{60}$ Almino Affonso contou a história de escrita deste livro em um depoimento de memória publicado em Affonso (2020).
} 
verá adiante, logo que foi publicado, os conteúdos do livro entraram nos cursos de capacitação camponesa das confederações sindicais e organismos do agro, participando diretamente da formação da consciência histórica da classe camponesa durante a revolução chilena de 1970-1973. Os autores de Movimiento Campesino Chileno foram os primeiros a narrar, de maneira sistemática, a história do massacre de camponeses em Ranquil (1934), da greve de Molina (1953) e das lutas dos camponeses do Vale de Choapa (1965), propondo um fio condutor entre esses acontecimentos dentro do mesmo processo: a constituição de uma cultura diversificada de lutas no campo e o caráter processual da conquista de direitos camponeses, que culminava com a sindicalização, a reforma agrária e a revolução.

Contrariando o senso comum sobre a ausência de movimentos campesinos importantes antes da lei de sindicalização campesina ( ${ }^{\circ} 16.625$ de 1967), os autores argumentavam que os camponeses chilenos estavam em processo de organização ilegal pelo menos desde a década de 1920. Para isso tinham enfrentado obstáculos diversos: repressão de carabineiros, violência patronal, demissões, listas de lideranças marcadas pelos patrões, inspetores do trabalho aliados de parlamentares latifundiários e o aparato de vigilância da SNA. Entretanto, clandestinamente, os campesinos criaram "comitês sindicais", "uniões livres", federações e confederações sob constante ataque. Por meio de petições oficiais, tomas de terreno e greves ilegais, diversos grupos camponeses na primeira metade do século XX desenvolveram lutas que geravam uma pressão social cada vez menos ignorável pela inteligência urbana. Os autores sugeriam que, para as classes dominantes do campo e da cidade, era prioritário reprimir as organizações campesinas, o que foi garantido, inclusive, com conivência de partidos da esquerda no contexto da Frente Popular. ${ }^{61}$ Expor a força das lutas camponesas por meio da história e retirá-la da invisibilidade transmitia uma mensagem política inequívoca no debate da "via chilena ao socialismo", inaugurada no ano da sua publicação.

Os autores narraram a história das principais organizações camponesas de escala nacional que ainda estavam ativas em 1967, momento da aprovação da lei de sindicalização (objeto do capítulo 6 desta tese). Analisaram as origens, ideologias, estratégias políticas, formas de financiamento, instâncias

\footnotetext{
${ }^{61}$ A sindicalização camponesa estava contemplada pelo Código Laboral de 1931, mas foi obstruída e reprimida pelo governo, que a tratou como um caso "excepcional" por pressão dos latifundiários. Nos marcos dos governos da Frente Popular encabeçados pelo Partido Radical (Pedro Aguirre Cerda, de 1938 a 1941, e Gabriel Gonzalo Videla, de 1946 a 1952 ), os comunistas e a ala "frentista" dos socialistas adotaram uma estratégia legalista de negociação que legitimou a continuidade da proscrição. Aguirre Cerda, eleito com a promessa de ampliar os direitos laborais, suspendeu o direito à sindicalização camponesa com a ordem ministerial 34, em março de 1939, na qual se lia: "os partidos que apoiam o atual governo declaram que continuar a constituição de sindicatos camponeses pode dificultar o estudo e solução deste importante problema (Chile, 1939). Oito anos mais tarde, o trâmite institucional em que apostaram aqueles setores da esquerda resultou na aprovação da Lei 8.811 de 1947, que ficou conhecida como "lei de travas à sindicalização". Com ela, a sindicalização foi legalizada, mas sujeita a requisitos impraticáveis, o que até mesmo Eduardo Frei reconheceu, em 1967, que era o mesmo que perpetuar a proibição. Entre as travas, destacavam-se três mecanismos: os membros do sindicato deveriam estar há mais de um ano no mesmo latifúndio, o que entregava o destino da organização ao poder demissionário do patronal, pois não existia imunidade sindical; exigia-se ao menos 10 membros letrados, o que era um enorme desafio dado o analfabetismo rural massivo; e proibiase a participação de "outros elementos" externos ao latifúndio na reunião de sua fundação, deixando os campesinos sujeitos a procedimentos detalhistas e burocráticos incompreensíveis sem a assessoria de advogados. Segundo os autores, essas e outras restrições faziam com que apenas $13 \%$ do campesinato estivesse apto para formação de sindicatos legais. Prova disso é que durante a vigência da lei somente 24 sindicatos legais foram criados, dos quais em 1967 apenas 14 estavam em funcionamento em todo o país (Affonso et al, 1970: 35, 49, 52).
} 
de poder, relações com as bases, com a reforma agrária e com a educação campesina de seis organizações camponesas com poder de convocatória social. Eram as seguintes:

- UCC: A União de Campesinos Cristãos (UCC), criada em 1960, a partir do departamento camponês da Associação Sindical Chilena (ASICH), uma organização cristã tributária da greve de Molina em 1953.

- FCI/Ranquil: A Federação Nacional Campesina e Indígena (FCI), fundada em 1961 a partir de organizações comunistas e socialistas de luta pela terra. Em 1967, foi nomeada Confederação Ranquil em homenagem aos camponeses reprimidos em um massacre em 1934

- ANOC: Em 1962, em Lautaro, foi criada Associação Nacional de Organizações Campesinas (ANOC) a partir da Ação Católica Rural (ACR) e do Instituto de Educação Rural (IER), que segundo os autores, eram um braço da SNA no movimento camponês (ver capítulo 3);

- MCI: Em 1964, com funções explicitamente eleitorais, foi criado o Movimento de Campesinos Independentes (MCI) para engajar as bases rurais na campanha de Eduardo Frei;

- CNC: Em 1965, a Confederação Nacional Campesina unificou a ANOC e a UCC;

- INDAP/Libertad: embora fosse um organismo governamental, os autores analisam a criação do INDAP como ativo organizador de sindicatos camponeses durante o governo Frei, muitos dos quais foram posteriormente incorporados à Confederação Libertad, ligada a grupos cristãos independentes (Affonso et al, tomo 1, 1970)

Ficava claro que existia uma complexa rede de rivalidades entre marxistas e cristãos na disputa política por bases camponesas desde os anos 1930 e que partidos e sindicatos urbanos eram ativos propulsores desse processo (Affonso et al, tomo 1, 1970). A batalha entre cristãos e marxistas tornouse ainda mais acirrada com a reforma da legislação eleitoral de 1958, sobre a qual se falará em breve.

Além disso, os autores produziram uma análise detalhada dos métodos de luta camponesa e do perfil dos seus dirigentes (Affonso et al, tomo 2, 1970). Cada forma de luta foi associada à ênfase em demandas por regalías, salários, melhorias nas casas ou direitos trabalhistas. As lutas foram mapeadas conforme documentos da Direção do Trabalho, com destaque aos pliegos de peticiones (abaixoassinados), greves e tomas.

Entre 1960 e 1966, foram contabilizadas 1.001 petições camponesas à Direção do Trabalho, das quais $74 \%$ demandavam mais terras na forma de regalías. No mesmo período, ocorreram 826 greves camponesas em onda crescente, saltando de 3 greves em 1960 a 586 em 1966. Entre as greves, 60\% tiveram duração de um dia e $73 \%$ tinham causas salariais. Foram registradas 22 tomas no período, todas 
as quais mesclavam demandas que exigiam salários, regalías e cumprimento da legislação social, na fórmula "melhoria das condições de vida e trabalho". Metade delas ocorreu na província de Santiago. Assim, notavam os autores, era precipitado afirmar uma "demanda preferencial" do campesinato (terras ou salários). De certa maneira, o próprio Estado atuou no sentido do assalariamento rural quando, entre 1953 e 1967, obrigou progressivamente os patrões a remunerarem seus trabalhadores com mais salários e menos regalías. Em 1953, se determinou que os patrões deveriam pagar os camponeses $50 \%$ em regalías de terra, 25\% regalías de consumo e 25\% em dinheiro. Em 1963, uma nova lei determinou que os salários se expandissem a $35 \%$ da remuneração, com $20 \%$ de regalías de consumo e $45 \%$ de terra. No ano seguinte, se exigiu que 50\% fosse remunerado em dinheiro e em 1967, 100\% (Ramírez, 1968). Segundo Petras \& Zemelman (1972), os camponeses sentiram falta da regalía de terra e utilizaram a própria reforma agrária para recuperá-la. A relação entre forma de luta e tipo de reivindicação entre 1960-1966 pode ser visualizada na tabela 3 a seguir.

\begin{tabular}{|l|c|c|c|}
\hline \multicolumn{5}{|c|}{ Tabela 3 - Petições, greves e tomas camponesas (1960-1966) } \\
\hline & Quantidade & Por melhorias salariais & Por terra (regalías) \\
\hline Petições & 1.001 & $26 \%$ & $74 \%$ \\
\hline Greves & 826 & $73 \%$ & $27 \%$ \\
\hline Tomas & 22 & Melhores condições de vida (luta híbrida) \\
\hline \multicolumn{4}{|c|}{ Elaboração própria com base em: Affonso et al, tomo 2, 1970: $21,36,58,133}$. \\
\hline
\end{tabular}

Entre suas conclusões, registravam que: "há uma significativa experiência urbana entre os dirigentes camponeses, que se distinguem fundamentalmente do resto do campesinato quanto à sua educação formal" (Affonso et al, 1970, tomo 2: 227). A educação e a cultura urbanas eram, além disso, o que explicava a função de muitos "agentes externos" no processo de organização camponesa, vinculados a uma cultura política das capitais: militantes de partidos, sindicatos e Igreja, parlamentares e uma expertise técnica das universidades.

As diferentes narrativas da modernização construíam braços de apoio e contato com as lutas camponesas e rompiam paulatinamente o isolamento do inquilino. Nesse sentido, um dado revelador da proeminência urbana na sindicalização camponesa era a participação intensa de trabalhadores e funcionários das cidades nas suas direções. Dos dez membros da direção da UCC, sete eram de extração urbana. Seu Comitê Executivo Nacional foi formado com quatro trabalhadores da cidade e sem camponeses. Da mesma maneira, a larga estabilidade das direções comunistas da FCI indicava que seus membros já não eram mais trabalhadores rurais, mas sim sindicalistas profissionais. Já a ANOC, ao contrário, possuía uma direção composta de lideranças de origem camponesa (Affonso et al, 1970: 86, 137, 179).

Outro trabalho decisivo sobre a trajetória de lutas camponesas que antecederam a reforma agrária foi o livro do cientista político estadunidense Brian Loveman (1976), que narrou o acúmulo de experiências da luta camponesa, sua longa trajetória de petições e greves ilegais entre 1919 e 1973. Loveman morou em Santiago entre 1971 e 1972, quando encontrou arquivos ainda intocados da Direção 
do Trabalho. O órgão recebia todas as petições e cartas campesinas desde a existência do Código do trabalho de 1931, formando um valioso acervo dessa múltipla cultura de luta. "Esse arquivo estava literalmente embaixo do rio Mapocho, no subterrâneo", nos contou Loveman: "Eu tirei algas e ervas que embrulhavam os volumes". ${ }^{62}$ Nos volumes cobertos de umidade, mas protegidos por embalagens plásticas, encontrou toda correspondência entre camponeses e Estado, o registro das petições coletivas, demandas pelo cumprimento do Código do Trabalho, denúncias de falta de pagamentos e péssimas condições nas haciendas, alertas contra os abusos dos patrões. Com isso analisou uma variedade de respostas dos inspetores do trabalho para tais demandas, seu comportamento político, sua relação com poderes de Estado e latifundiários, a falta de estrutura mínima para fiscalização social e as pressões exercidas por parlamentares em diferentes direções.

No mesmo arquivo, Loveman também descobriu uma grande quantidade de cartas redigidas por camponeses para os presidentes da República, explicando-lhes seus problemas e necessidades em primeira pessoa. ${ }^{63}$ Ao analisar todas essas correspondências e petições, Loveman também ajudou a combater o mito de que o Estado chileno teria sido o "criador" do movimento camponês. Os arquivos revelavam uma teia de conflitos e negociações constantes. No entanto, à diferença do trabalho coordenado por Almino Affonso, que focalizava o papel das organizações, Loveman iluminou a ação camponesa com coloração espontânea, fruto de uma autodeterminação que até então parecia invisível. Os camponeses eram pragmáticos, se apoiavam em "agentes externos", políticos e partidos quando lhes convinha, mas apenas uma minoria era ideologicamente engajada. Os partidos, por seu lado, ampliavam territórios de trabalho de base. Segundo Avendaño (2017), marxistas e cristãos concorriam com os mesmos métodos, sintetizados em um "tripé tático": as lutas sindicais, a educação e a assistência técnica-social.

A principal tese de Loveman, posteriormente repercutida em muitos outros trabalhos, identificava que, entre a Constituição de 1925 e a lei de reforma agrária de 1967, a estabilidade política chilena foi avalizada por um pacto entre classes dominantes do campo e da cidade, no qual as primeiras concediam preços mais baixos aos alimentos, evitando conflitos com os trabalhadores urbanos, ao passo que as segundas lhe asseguravam a exclusão dos camponeses do Código Laboral de 1931, isto é, do direito de sindicalização e do sistema de seguridade social. O marco institucional desse pacto teria sido a suspensão (1939) e inviabilização legal (1947) dos sindicatos campesinos justamente pelos governos da Frente Popular.

Como registrado por Affonso (et al, 1970), comunistas e socialistas apoiadores da Frente Popular ("frentistas") compactuaram com a exclusão camponesa ao confiar nos mecanismos legais de negociação dispostos pelos governos de Aguirre Cerda (1939-1941) e Gonzalo Videla (1946-1952). Já Loveman enfatizou a história do único setor político da esquerda que se manteve fora do pacto de

\footnotetext{
62 Entrevista com Brian Loveman, Solana Beach (Califórnia), 03/11/2017.

${ }^{63}$ Uma seleção dessas cartas foi publicada pelo ICIRA com título El campesino chileno le escribe a su Excelencia (Loveman, 1970).
} 
dominação: a Liga Nacional de Campesinos Pobres, fundada em 1935 e considerada a primeira organização camponesa nacional. Sua principal representação no meio institucional era Emílio Zapata, de inclinação trotskista, fundador do Partido Obreiro Socialista, que posteriormente se fundiu ao PS. $\mathrm{Na}$ avaliação de Loveman, a presença de Zapata como parlamentar para apoiar a luta camponesa teria sido a mais constante e com finalidades menos eleitoreiras e mais genuínas se comparada a outros partidos. Entre 1932 e 1968, Zapata foi o único parlamentar que realizou mais investigações em terreno de abusos patronais, fora do seu distrito eleitoral (59\%), infiltrando latifúndios "impenetráveis" e territórios trancados pela hacienda. Outros partidos apresentavam engajamento majoritário em seus próprios distritos. Os parlamentares comunistas realizaram 38\% das suas investigações e apoios fora dos seus distritos; os socialistas apenas 27\% e os falangistas/DC, 17\% (Loveman, 1976: 212).

Por último, mas não menos importante, a socióloga Patrícia Garret (1978) foi além das teses de Loveman: mostrou que o arranjo campo/cidade de dominação social não se sustentava meramente na exclusão dos direitos laborais aos camponeses, e sim mais especificamente no trabalho feminino de subsistência. Garret argumentou pioneiramente que a "empresa campesina" (huertos ou minifúndios) sustentava a reprodução da vida dos trabalhadores rurais. $\mathrm{O}$ trabalho das mulheres nos huertos garantia a efetiva subsistência dos camponeses e, portanto, constituía o pilar sustentador do rebaixamento geral de salários e preços dos alimentos. Eram as mulheres rurais, comandantes da empresa campesina, que aportavam trabalho gratuito na reprodução da vida da massa trabalhadora e sustentavam o conjunto do pacto social sobre seus ombros. Na época, Garret também alertou que as mulheres, assim como os huertos, eram um importante ponto cego dos estudos agrários, historicamente enfocados na hacienda. O trabalho não remunerado de "mulheres múltiplas" era o último elo de sustentação do arranjo de forças estabilizadoras do capitalismo chileno; mulheres que articulavam em seu cotidiano a produção no huerto, o processamento de alimentos, o pastoreio, a ordenha, o trabalho doméstico, o artesanato, o cuidado dos filhos e a subsistência dos homens (Garret, 1978: 95).

Para Loveman (1976), as duas leis de 1967 compuseram uma ruptura incontornável e descontrolada do pacto de estabilidade entre latifundiários e burguesias urbanas. Para Garret (1978), essa irrupção conservou as estruturas patriarcais. A reforma agrária atingia homens e mulheres do campo de maneira muito distinta.

\section{Infância camponesa e escola interrompida}

Apesar da falta de escolas rurais, nos anos 1950, o Plano de Educação de Emergência do Ministério da Educação priorizou a construção de escolas urbanas, alegando que existiam escolas rurais subutilizadas em razão dos processos migratórios. ${ }^{64}$ Mas a realidade mostrada pelo historiador Rodrigo Mayorga era outra. Circulares do Ministério da Educação entre 1931 e 1951 descreviam cenas de abandono e precariedades nas escolas rurais, em geral padecendo de problemas elementares: falta de

\footnotetext{
${ }^{64}$ Entre 1942 e 1950, 250 mil pessoas do campo chegaram a Santiago (Loyola, 2018: 146).
} 
carteiras e mobília, escassez de livros e materiais básicos, escolas sem água encanada, professores sem diploma (mais de um terço), escolas sem professores ou com um único e sobrecarregado profissional, inúmeras deficiências de transportes no trajeto até a escola, infraestrutura de deslocamento quase inexistente em alguns povoados, entre outras (Mayorga, 2018b: 250). A precariedade da escola rural era evidente quando colocada lado ao lado dos sonhos de modernização econômica do país.

A pobreza das crianças rurais comprometia o aprendizado. A historiadora Francisca Rengifo (2018) conta que a fome foi uma das maiores causas da evasão escolar entre 1930 e 1960. Ao analisar o depoimento de professores de escolas rurais para Revista de Educación, Rengifo concluiu que muitas crianças do campo iam para a escola quase sem roupas, sem sapatos e muitas vezes passando fome. Eram convocadas a trabalhar muito cedo e habitavam lares camponeses sem banheiro ou água encanada. O professor rural Daniel Navea, por exemplo, escreveu em 1941: "250 mil filhos de camponeses recebem no Chile uma cultura tão inferior que bem poderia ser comparada ao ideal educativo dos tempos coloniais" (Navea apud Rengifo, 2018: 167). Até os anos 1960, a questão do trabalho infantil ainda era uma constante na agricultura chilena. Não por acaso, a experiência dos camponeses que tratarei a seguir coincidem nesse mesmo ponto: foram retirados da escola para trabalhar quando tinham de 10 a 12 anos.

O camponês Martim Vásquez nasceu em 1939, filho de inquilinos que viviam dentro de um latifúndio em Colchágua, em um lugar chamado Pueblo Chico, depois Nilahue Cornejo. Ele começou a trabalhar aos 10 anos junto ao pai. Da infância, ele se lembra da má alimentação que recebiam dos patrões: "uma galleta de manhã, feita de pão integral e o trigo quase inteiro, com puro sal. E ao meiodia, feijão com mote de trigo, mas às vezes o mote se queimava e saia com gosto de cinzas", ${ }^{65}$ recordou. Durante sua adolescência, nos anos 1940 e 1950, Vasquez se recorda, "as escolas rurais eram escassíssimas e éramos analfabetos de forma quase generalizada". ${ }^{66}$ Algumas escolas rurais eram privadas e pertenciam ao próprio latifundiário. Assim, a criança camponesa sequer saia da propriedade: era mantida na escola interna à hacienda até a idade em que o patrão a considerava apta ao trabalho, exercendo um controle quase absoluto sobre a reprodução da força de trabalho do latifúndio.

"O currículo que os patrões queriam ensinar aos trabalhadores era que aprendessem a assinar, ainda que não soubessem ler, para que dessem o voto a eles. Essa era a missão", criticou Vasquez. "Em alguns latifúndios era até proibido ter aparelhos de rádio a pilhas, porque os camponeses iriam escutar que havia um mundo para além daquele onde viviam presos. Eram proibidos de ter relógio, porque só o capataz podia controlar o tempo". ${ }^{67}$ As informações sobre reforma agrária em 1962 circularam quando os poucos alfabetizados, como era o caso do pai de Martim, liam jornais aos analfabetos e contavam o que estava acontecendo na capital. Martim aprendeu a ler com seu pai, dentro de casa, por isso pulou o $1^{\circ}$ ano e frequentou a escola por dois anos, somente até o $3^{\circ}$ primário. Depois, foi obrigado a trabalhar

\footnotetext{
${ }^{65}$ Entrevista com Martim Vásquez, Santiago, 28/04/2017.

${ }^{66}$ Idem.

${ }^{67}$ Idem.
} 
com o pai. Outro camponês que se lembrou do trabalho na infância foi o dirigente sindical Oscar Valladares, lenhador desde os 14 anos em Mellipilla. ${ }^{68}$ Também Ovídio Diaz, de San Clemente, nasceu dentro do fundo Vieja Unión e começou a trabalhar aos 14 anos como ajudante no trato dos animais. ${ }^{69}$

Foi aos 9 anos que Alicia Muñoz começou a servir a casa patronal da hacienda Água Fria, em Curicó. "Fazia tortillas, harina tostada, ajudava com o mote, já tinha responsabilidades na casa camponesa, sabia fazer as coisas como uma mulher, mas era uma criança”, lembra Alicia. "Antes de trabalhar, eu estudava em uma escolinha que existia no campo. Um dia, chegaram as patroas e disseram a minha mãe que precisavam que eu fosse trabalhar nas casas patronais da hacienda, para recolher verduras e levar à cozinha". ${ }^{70}$ Sua mãe imediatamente objetou: "não, ela ainda está na escola e meu filho já está trabalhando pela família". As patroas não se alteraram: "nós precisamos da sua filha a partir de hoje, você tem essa casa aqui e tem obrigações a pagar. Ela também vai trabalhar". ${ }^{71}$ Era 1955.

No trabalho doméstico, Alicia se recorda que o patrão do fundo Água Fria era um assediador, que pedia às meninas para levar água quente para que tomasse banho e as recebia nu no banheiro: "eu tinha muito asco", recorda Alicia. "Sua forma de saciar-se era mostrar seu corpo". Jovem, ela tremia de medo quando era escalada para cumprir a tarefa de levar a água do banho do patrão. Também se lembra que um dos irmãos do patrão, quando vinha passar um tempo na casa patronal, invadia o quarto onde dormiam as seis ou sete nanas, as camponesas recrutadas para o trabalho doméstico, e lhes arrancava os lençóis durante a madrugada para ver seus corpos (Muñoz, 2020). "Eles agiam como se fossem nossos donos", ${ }^{72}$ acusa Muñoz. Além de tudo, sua remuneração era controlada pelo sistema da pulpería, o armazém do patrão: "me pagavam com um vale, que eu só podia gastar na venda do patrão, onde tudo era muito caro e de péssima qualidade", ${ }^{73}$ explicou. Para piorar, a pequena Alicia era obrigada a morar na casa dos patrões durante dias e semanas, passando muito tempo sem ver sua família na casa campesina. Para visitar sua mãe em sua própria casa, precisava pedir permissão. A mãe de Alicia era analfabeta e durante anos foi obrigada a trabalhar sem remuneração, como parte das obrigações do seu marido inquilino. Alicia observava sua mãe ajudando alguns camponeses a formar sindicatos clandestinos, lhes levando algo para comer nas reuniões secretas durante a noite, antes de 1967. Esses camponeses que voltavam do Norte, das minas de salitre, exerceram grande influência em Alicia: "muito pequena, escutei três camponeses importantes que tinham ido ao Norte para salitreira", contou a camponesa. "Voltavam com um conhecimento sindical novo. (...) Como menina pequena, aquilo me impactava muito e eu queria encontrar um jeito de trabalhar nesse sindicato clandestino" (Muñoz, 2020). Eram os camponeses que José Bengoa chamou de federados, porque tinham participado da Federación Obrera de Chile na primeira metade do século XX: "a mina foi a escola de muitos

\footnotetext{
${ }^{68}$ Entrevista com Oscar Valladares, Santiago, 30/06/2017.

${ }^{69}$ Entrevista com Ovídio Diaz, San Clemente, 27/05/2017.

${ }^{70}$ Entrevista com Alicia Muñoz, Santiago, 14/05/2017.

71 Idem.

72 Idem.

73 Idem.
} 
camponeses" (Bengoa, 2016: 16). Nas minas, os trabalhadores desenvolviam uma consciência de classe e uma prática sindical inexistente no campo. Ciclicamente, mais tarde circulavam pelo território como afuerinos e disseminavam essa cultura política pelos campos.

"Nesse tempo, os inquilinos tinham que ser submissos", explicou o camponês Leonel Abarca, que começou a trabalhar aos 12 anos, "não existia esse tema do trabalho infantil". ${ }^{74}$ Os meninos começavam "quando estavam mais ou menos em condições de operar um cavalo ou um boi", ${ }^{75}$ contou. Victor Yañez, que nasceu em 1951, também se lembra da comida que entregavam aos camponeses: "nesse tempo se trabalhava de sol a sol. (...) Os que iam para o latifúndio recebiam uma marula, um pão de trigo que não era bem limpo, era moído com partes de palha". ${ }^{76}$ Filho de minifundistas da região de Bio Bio, Victor teve a chance de estudar na cidade de San Carlos, mas chegou a ver crianças nas faenas agrícolas: "um menino pequeno sabe quebrar choclos, amontoá-los, sabe jogá-los em cima do carro", ${ }^{77}$ relatou.

Até 1967, ainda existiam inquilinos mantidos isolados nos latifúndios, impedidos de sair sem permissão do patrão. Como lembrou a agrônoma Camila Montecinos, "nessa época, o direito de sair da propriedade ainda era determinado pelo patrão. Ninguém podia se mover sem permissão patronal, não podiam circular pelos caminhos. Por isso, o campeonato de futebol era chave, porque era um momento em que se podia juntar a todos e conversar" ${ }^{78}$ explicou. Havia casos de camponeses que perdiam familiares e amigos por doenças fáceis de curar, porque o patrão não os levava ao hospital. Gustavo Marín, militante mirista que se juntou aos mapuches de Cautín para fazer a revolução agrária em 1970, também fundador do Movimento Campesino Revolucionário (MCR), conheceu uma indígena que viveu uma experiência dramática: "ela tinha 40 anos, não era velha, mas tinha poucos dentes. E me contou: 'Tive dois filhos que faleceram porque o patrão não me deixou levá-los ao hospital em Lautaro'", 79 contou com lágrimas e muita raiva.

Tais experiências ajudam a enxergar com mais vivacidade o que os números revelavam sobre infância, trabalho, analfabetismo e escolaridade camponesa no Chile anterior à reforma agrária. Como vimos, segundo Carabantes, em 1963, o analfabetismo da população rural maior de 15 anos alcançava $59 \%$, incluindo os funcionais. ${ }^{80}$ Sobre a escolarização da infância rural, vale retomar alguns dados do relatório CIDA: 46\% das crianças camponesas não frequentava nem o primeiro ano escolar e 41 mil crianças trabalhavam na agricultura em caráter permanente e cotidiano (CIDA, 1966: 198-199). Somado a isso, a fome estava entre as principais causas da evasão escolar nacional, que nos anos 1950 chegou a escandalosos 70\% das matrículas (Rengifo, 2018: 157-208).

Outro grave problema da escolarização camponesa era a falta de professores. Em 1958, a educadora Luz Vieira Mendez relatou para Revista de Educación que "as escolas normais rurais são insignificantes

\footnotetext{
${ }^{74}$ Entrevista com Leonel Abarca, Santiago, 02/05/2017.

75 Idem.

${ }^{76}$ Entrevista com Victor Yañez, San Carlos, 19/05/2017.

77 Idem.

${ }^{78}$ Entrevista com Camila Montecinos, Santiago, 14/05/2017.

${ }^{79}$ Entrevista com Gustavo Marin, Santiago, 20/04/2017.

${ }^{80}$ Waldemar Cortés Carabantes. Formas muertas y dinámicas de nuestra educación de adultos, op. cit.
} 
em seu número frente às urbanas (preparam, em geral, professores com menor número de anos de estudos, portanto de inferior qualificação profissional)". ${ }^{81}$ Naquele ano, existiam 4.187 estabelecimentos escolares públicos no país, sendo $22 \%$ deles rurais, embora a população rural alcançasse $30 \%{ }^{82}$ Isso significava uma única escola para cada 3 mil habitantes do campo. ${ }^{83}$ A educadora Mendez relatava que os professores rurais arcavam com um conjunto tão diversificado de responsabilidades e trabalhos que era como se tocassem todos os instrumentos de uma orquestra:

Sobretudo nas zonas mais afastadas (...), um bom professor rural representou e ainda representa uma espécie de factótum, ou algo como um homem orquestra: constrói a casinha para escola e para si mesmo, produz as carteiras, ensina o alfabeto às crianças da comunidade, ensina a plantar e também a confeccionar uma vassoura e, em caso de extrema urgência, dá um jeito de tornar-se enfermeiro e até parteiro. ${ }^{84}$

Disso também se lembra Alicia. A escola fiscal próxima ao latifúndio onde vivia era tão precária que tinha uma única sala, "era uma fila de bancos para cada ano" na mesma sala, narrou Muñoz (2020): "as crianças chegavam até o $5^{\circ}$ ano primário e ali paravam". Raras vezes, as famílias camponesas tinham recursos para enviar um filho ao ensino secundário na cidade mais próxima. Quando isso ocorria, muitas vezes esses filhos nem voltavam.

Em 1963, eram 3.220 escolas rurais no Chile, sendo que 35\% delas possuíam somente um professor - ou melhor, um "professor orquestra" - e 26\%, dois professores (CIDA, 1966: 285, 286). O principal crescimento, contudo, foi do setor privado em razão da lei 9.864 de 1951, a Lei de Subvenções, que inaugurou um sistema de repasses do Estado para estabelecimentos educacionais privados. $\mathrm{O}$ Instituto de Educação Rural (IER) foi um dos maiores beneficiários, como se verá no capítulo 3. Por conta dela, nos anos 1950, pela primeira vez as escolas primárias privadas expandiram enquanto o número de estabelecimentos públicos foi reduzido. Se em 1950, o Estado chileno investia 3,5 milhões de escudos nas escolas privadas, em 1961 esse valor já alcançava 50 milhões (Ponce de León, 2018b: $110,117)$. Se comparado com as escolas primárias, o sistema secundário era desproporcionalmente pequeno. Em termos de desigualdade de gênero, na educação técnica agrária do setor privado, $97 \%$ das matrículas eram masculinas (Loyola, 2018: 138, 142, 144).

Como bem lembrou Martim Vásquez, o sistema de exclusão educacional dos camponeses funcionava, entre outros propósitos, como um procedimento de controle político eleitoral.

\footnotetext{
${ }^{81}$ Luz Vieira Mendez. La situación del maestro en América Latina. Revista de Educación, n.74-75, 1958.

${ }^{82}$ Waldemar Cortés Carabantes, ibid.

${ }^{83} \mathrm{Em}$ 1960, a população rural total no Chile era de 2.650 .500 pessoas. Alberto Aleite Astorga, Reformas estructurales y planeamiento educacional. Revista de Educación, n. 95, 1964.

${ }^{84}$ Idem.
} 


\section{O voto camponês}

Em meados da década de 1950 o sistema partidário chileno atravessava um momento de mudanças, de reacomodação de alianças, pressionado por novas agendas desenvolvimentistas, como a reforma agrária. A criação da Federação Social-Cristã, em 1953, e posterior formação do Partido Democrata Cristão, em 1957, instalaram de maneira contundente a doutrina social-cristã na cena política do país. No mesmo período, em 1955, ocorreu a reunificação do Partido Socialista, que esteve formalmente dividido durante quase uma década. Em 1958, foi derrogada a Lei Permanente de Defesa da Democracia (ou Lei Maldita), que proscrevia o Partido Comunista da legalidade desde 1947 (Avendaño, 2017: 153).

Junto com a legalização do comunismo, outras três leis teriam contribuído, segundo Avendaño (2017), para uma inflexão no sistema político-partidário do Chile em 1958, abrindo espaço para uma nova correlação de forças. A primeira foi a lei 12.899, que estabeleceu uma cédula eleitoral única, emitida pelo Estado. Antes disso, os latifundiários e oligarquias locais tinham o poder de fabricação descentralizada de cédulas eleitorais e a prática do cohecho (voto de cabresto) era uma constante. "Até a reforma do sistema eleitoral de 1958, os latifundiários tinham enorme poder porque controlavam o voto camponês, sobretudo dos inquilinos e das pessoas que viviam dentro do latifúndio", 85 explicou Jacques Chonchol, que trabalhava no Departamento de Economia Agrária do Ministério da Agricultura durante o governo de Carlos Ibañez. "Cada partido fabricava seu próprio voto, entregava ao eleitor que o depositava na urna. Nos campos, quando chegavam as eleições, os patrões juntavam todos os camponeses, lhes entregavam os votos já marcados, os subiam nos caminhões e os levavam a votar", 86 recordou. Quando a cédula única "liberou" o voto camponês da coerção direta do latifundiário e coibiu o cohecho, o empenho na conquista eleitoral do campesinato se intensificou entre todos os partidos.

A segunda mudança de 1958, como indicou Avendaño, foi a obrigatoriedade do voto. Isso expandiu a participação eleitoral das populações rurais e das mulheres. E a terceira foi a proibição de coligações locais que não correspondessem às coligações nacionais, o que impôs às comunas um vínculo direto com as querelas partidárias de Santiago, o que limitava a atuação do caudillismo local (Avendaño, 2017: 169). Essas três medidas ampliaram a participação eleitoral no campo e acirraram a concorrência dos partidos pelo voto camponês.

Por isso, a reforma eleitoral impactou o padrão histórico de votos da direita (coligação de Conservadores e Liberais) nas eleições parlamentares nas zonas rurais, que despencou de 38,9\% em 1957 para 19,1\% em 1965. No mesmo período, o PDC saltou de 5,8\% para 38,4\% e a esquerda (PC e PS), de 10\% para 16,5\% (Avendaño, 2017: 179). "Proporcionalmente, a partir de 1961 os partidos de esquerda cresceram mais nas comunas rurais que no resto do país", contabilizou o cientista político (Avendaño, 2017: 179).

\footnotetext{
${ }^{85}$ Entrevista com Jacques Chonchol, Santiago, 15/04/2016.

${ }^{86}$ Idem.
} 
Enquanto o Partido Nacional e o Partido Radical perderam influência no eleitor camponês na virada dos anos 1950 para os 1960, seus votos se reposicionaram em favor das alternativas DC e FRAP (Frente de Ação Popular, antecessora da UP, também encabeçada por Allende). Nas eleições de 1953 a 1969, segundo os dados contabilizados pelo autor, os votos camponês, de inquilinos, medieros, afuerinos e peones foram distribuídos como mostra a tabela 4 a seguir.

\begin{tabular}{|l|l|l|l|l|l|}
\hline \multicolumn{5}{|c|}{ Tabela 4 - Voto camponês no Chile (1953-1969) } \\
\hline Votos de inquilinos e medieros em eleições parlamentares \\
\hline & $\mathbf{1 9 5 3}$ & $\mathbf{1 9 5 7}$ & $\mathbf{1 9 6 1}$ & $\mathbf{1 9 6 5}$ & $\mathbf{1 9 6 9}$ \\
\hline PN (PL-PC)* & 38,6 & 43,9 & 29,9 & 14,2 & 14,6 \\
\hline PR & 15,1 & 20,5 & 20,6 & 13,4 & 10,8 \\
\hline DC & 3,2 & 8,3 & 14 & 34,6 & 34,6 \\
\hline FRAP (PS-PC)** & 9,6 & 6,3 & 17,8 & 28,8 & 34,6 \\
\hline Votos de afuerinos e peones em eleições parlamentares \\
\hline \multicolumn{5}{|c|}{} \\
\hline PN (PL-PC)* & $\mathbf{1 9 5 3}$ & $\mathbf{1 9 5 7}$ & $\mathbf{1 9 6 1}$ & $\mathbf{1 9 6 5}$ & $\mathbf{1 9 6 9}$ \\
\hline PR & 30 & 38,4 & 18,7 & 18,7 & 24,2 \\
\hline DC & 15,5 & 20,7 & 16,4 & 16,4 & 16,7 \\
\hline FRAP (PS-PC)** & 8,6 & 14 & 37,4 & 37,4 & 27 \\
\hline * Partido Conservador / ** Partido Comunista \\
\hline \multicolumn{6}{|c|}{ Fonte: Avendaño, 2017: $186-187$} \\
\hline
\end{tabular}

Essas dinâmicas permitiram a criação de um novo bloco de poder nos anos 1960, que viabilizou a reforma agrária.

\subsection{Reforma agrária em marcha}

\section{Causas e ritmos da expropriação}

O agrônomo chileno Hugo Trivelli, diretor do CIDA, se tornou ministro da agricultura no governo da DC. Como ministro, Trivelli compartilhou com Rafael Moreno (vice-presidente da CORA) e Jacques Chonchol (vice-presidente do INDAP até 1969), a autoria do projeto de lei de reforma agrária enviado ao parlamento pelo presidente Eduardo Frei em 1965, aprovado depois de dois anos de tramitações e de longos debates parlamentares. O relatório CIDA foi utilizado recorrentemente no contexto da disputa parlamentar pela reforma agrária como fonte legitimadora das posições reformistas. ${ }^{87}$ Àquela altura, os opositores da reforma por expropriação, adeptos da modernização técnica sem mudança social, se viram atrincheirados na Sociedade Nacional de Agricultura (SNA) e nos partidos oligárquicos (Liberal e Conservador), cada vez mais isolados.

A "revolução em liberdade" de Eduardo Frei Montalva, consolidava a hegemonia da DC no meio rural e abria um período efervescente de polêmicas sobre a reforma agrária, que encontraram um ponto

\footnotetext{
${ }^{87}$ Cámara de Diputados, Legislatura Extraordinaria. Sesión 90a, 19/05/1966.
} 
de consenso relativamente amplo na lei 16.640, com colaboração e pressão dos partidos marxistas e das organizações camponesas. Era um documento de 160 páginas, pactuado entre um amplo arco de partidos políticos e que contemplava diferentes projetos da modernização, apoiada por democratacristãos, cepalinos, social-cristãos, comunitaristas, socialistas e comunistas, e representava, de certa forma, uma materialização dos pressupostos do relatório CIDA (1966). Antes que fosse aprovada a nova reforma agrária, contudo, foi necessário modificar o artigo 10 da Constituição de 1925, que proibia qualquer tipo de expropriação. Naquele contexto, o debate sobre o direito à propriedade motivado pela reforma constitucional do artigo 10 antecipou o núcleo principal das divergências e convergências partidárias que estavam por vir, além de abrir oficialmente o caminho para a reforma agrária expropriatória. ${ }^{88}$

$\mathrm{Na}$ lei 16.640, os critérios de expropriação eram múltiplos e ocupavam mais de dez artigos. Deveriam ser expropriadas, segundo os artigos de 3 a 13 (Chile, 1967b):

(a) Todas as propriedades maiores que $80 \mathrm{HRB}$ (tabela de conversão no artigo 172);

(b) propriedades subdivididas depois de 4 de novembro de 1964 e que antes possuíam mais de $80 \mathrm{HRB}$;

(c) propriedades que permanecessem "mal exploradas" após 3 anos de aprovação da lei (sem definir com exatidão o que isso significava);

(d) todas as propriedades de pessoas jurídicas, com exceção das cooperativas camponesas, após seis meses de aprovação da lei;

(e) propriedades com contratos irregulares de arrendamento;

(f) propriedades de qualquer tamanho oferecidas em doação para CORA por seus donos;

(g) propriedades em territórios que o Estado pretendesse realizar obras de irrigação.

Nos artigos 16 a 19, estabeleciam-se as regras para o direito à reserva patronal de $80 \mathrm{HRB}$, que incluía a preservação de todos os bens de capital (máquinas, plantações e instalações) ao proprietário. Os artigos de 42 a 55 regulamentavam as indenizações. Os artigos 66 e 67 determinavam que as terras seriam redistribuídas na forma transitória de assentamento por 3 a 5 anos e posteriormente atribuídas aos camponeses em três tipos de propriedade: cooperativas, parcelas individuais ou propriedades mistas. $\mathrm{O}$ artigo 67 representou o maior foco de polêmica no desenrolar da reforma, uma vez que estabelecia que os assentamentos seriam parcelados de maneira individual, mas simultaneamente definia que a decisão final poderia ser tomada pelos próprios camponeses.

O período transitório do assentamento representava a janela da capacitação camponesa, na qual os sujeitos da reforma agrária deveriam ser "transformados" em termos epistemológicos e

\footnotetext{
${ }^{88}$ Interessante notar que, nesse debate, a Tradição, Família e Propriedade (TFP) brasileira influenciou explicitamente os católicos conservadores da Fiducia chilena, por meio do livro Reforma agrária. Questão de consciência, que propunha a doutrina contrária à reforma agrária de João Goulart. O livro foi traduzido e difundido no Chile a partir de 1963. Em defesa da expropriação, a DC reivindicava argumentos jusnaturalistas sobre o direito natural à propriedade, enquanto comunistas e socialistas advogavam pela função social da propriedade (Avendaño, 2017: 276).
} 
antropológicos. A capacitação era o lugar de transformação da economia moral do campesinato, no qual cada projeto modernizador agiu com objetivos próprios. A lei definia os múltiplos órgãos capacitadores do campesinato para a reforma agrária, que atuavam com programas de alfabetização, capacitação técnica e cursos de formação política e sindical. Esse conjunto complexo de processos educacionais experimentado pelo campesinato é o objeto central dessa tese. As possibilidades subjetivas abertas pela mudança agrária deram origem a um fenômeno sem precedentes de encontros e desencontros entre os formuladores urbanos da reforma agrária e seus múltiplos projetos, e os camponeses, sujeitos rurais da reforma, que também possuíam aspirações e expectativas próprias. A educação camponesa foi escolhida como locus social privilegiado para a observação das batalhas culturais pela reforma agrária, as disputas em torno a diferentes economias morais e subjetividades orientadas para diferentes projetos de futuro.

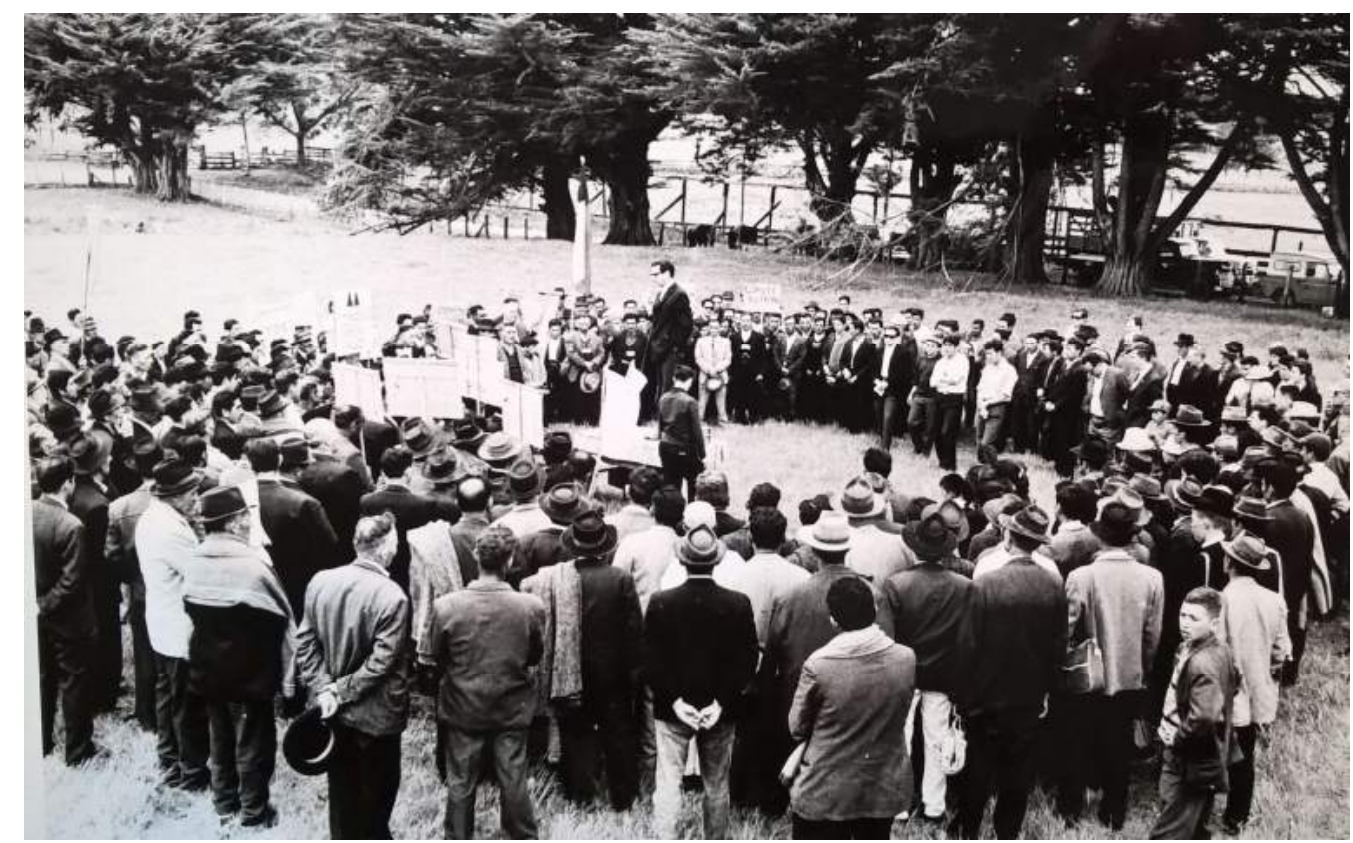

Jacques Chonchol, vice-presidente do INDAP, se reúne com camponeses, 1967. Arquivo pessoal de Jacques Chonchol

Os beneficiários da reforma agrária precisavam cumprir os seguintes requisitos: ser chileno, camponês, maior de 18 anos, não ser proprietário, ser casado ou chefe de família. $\mathrm{O} 72^{\circ}$ estabelecia os critérios de pontuação que ranqueava beneficiários preferenciais:

(a) trabalhadores permanentes vinculados à propriedade nos anteriores 3 anos;

(b) ocupantes sem violência;

(c) minifundistas que trabalhassem diretamente a terra (incluindo comunidades indígenas com títulos de mercê);

(d) quem demonstrasse "maior capacidade para o trabalho" (Chile, 1967b).

Os critérios de seleção dos beneficiários da reforma agrária davam conta de que não seriam todos os camponeses incluídos na mudança social. A reforma excluía mulheres e afuerinos e não considerava as particularidades do direito mapuche à recuperação das terras usurpadas, o que favorecia um setor 
específico de inquilinos, homens e huincas. ${ }^{89}$ Essa conta seria cobrada mais tarde e viria a gerar mudanças pelo governo da UP no sentido da abertura do acesso à terra para os setores excluídos pela DC, além de sérios conflitos intracamponeses (Tinsman, 2002; Mallon, 2004).

Segundo Barraclough e Affonso, a reforma agrária no Chile entre 1967 e 1973, amparada pela lei 16.640, foi o processo mais massivo de expropriações por vias legais do mundo, por meio de uma conjugação sem precedentes de radicalidade, profundidade e respeito às instituições, o que diz muito sobre a especificidade da via chilena ao socialismo do triênio de Salvador Allende. Escreveram:

Se comparamos o processo de reforma agrária no Chile com processos parecidos em outros países da América Latina ou do mundo, ficamos impressionados com o êxito relativo alcançado até aqui. A grande maioria das reformas agrárias chamadas não revolucionárias, como na Colômbia, Equador ou Itália, não afetou mais que 5 ou $10 \%$ da terra agrícola. Já na maioria dos casos em que as reforma agrárias foram tão massivas e profundas como no Chile, por exemplo no México, Bolívia, União Soviética, China e Cuba, resultaram de revoluções violentas (Barraclough \& Affonso, 1973: 12).

Entre 1967 e 1972, o setor reformado havia se expandido de 1,9\% a 35\% da superfície agrícola do país, enquanto as propriedades maiores que $80 \mathrm{HRB}$, tamanho limite imposto pelo artigo $3^{\circ}$ da lei, foram reduzidas de $55,3 \%$ da superfície para $2,9 \%$. Por outro lado, o minifúndio permanecia estável: as unidades menores que $5 \mathrm{HRB}$ seguiram representando em torno de $80 \%$ das propriedades e ocupando inalterados $9,7 \%$ da superfície, o que revela uma das insuficiências da lei na superação do sistema latifúndio-minifúndio (Barraclough \& Fernández, 1974: 38). A profundidade e o ritmo dessa excepcional "revolução agrária dentro da lei" podem ser dimensionados na tabela 5.

\begin{tabular}{|c|c|c|c|c|}
\hline \multicolumn{5}{|c|}{$\begin{array}{c}\text { Tabela } 5 \text { - Expropriações da reforma agrária no Chile } \\
(1965-30 / 06 / 1972)\end{array}$} \\
\hline Por ano & Propriedades & opriadas & Superfície & hectares) \\
\hline 1965 & \multicolumn{2}{|c|}{99} & \multicolumn{2}{|c|}{541.183} \\
\hline 1966 & \multicolumn{2}{|c|}{264} & \multicolumn{2}{|c|}{526.276} \\
\hline 1967 & \multicolumn{2}{|c|}{217} & \multicolumn{2}{|c|}{285.026} \\
\hline 1968 & \multicolumn{2}{|c|}{220} & \multicolumn{2}{|c|}{657.247} \\
\hline 1969 & \multicolumn{2}{|c|}{315} & \multicolumn{2}{|c|}{870.208} \\
\hline 1970 & \multicolumn{2}{|c|}{293} & \multicolumn{2}{|c|}{684.613} \\
\hline 1971 & \multicolumn{2}{|c|}{1.378} & \multicolumn{2}{|c|}{2.555 .506} \\
\hline 1972 & \multicolumn{2}{|c|}{1.904} & \multicolumn{2}{|c|}{2.741 .250} \\
\hline Total & \multicolumn{2}{|c|}{4.690} & \multicolumn{2}{|c|}{8.860 .310} \\
\hline Por governo & Propriedades & $\%$ & Hectares & $\%$ \\
\hline $\begin{array}{c}\text { Governo Frei } \\
(1965-1970)\end{array}$ & 1.408 & 30 & 3.563 .554 & 40 \\
\hline $\begin{array}{c}\text { Governo } \\
\text { Allende } \\
(1971-1972)\end{array}$ & 3.282 & 70 & 5.296 .756 & 60 \\
\hline
\end{tabular}

\footnotetext{
${ }^{89}$ São chamados huincas os povos brancos colonizadores. Etimologicamente, a palavra vem de "novo inca".
} 
A aceleração da reforma agrária foi um ingrediente importante para vitória eleitoral de Salvador Allende em setembro de 1970. A via chilena ao socialismo acirrou a polarização política e a reforma agrária tornou-se um dos principais eixos da revolução chilena. Nesse contexto, foram desatadas três polêmicas fundamentais: sobre o ritmo do processo expropriatório e o tamanho máximo da propriedade privada; sobre as formas de propriedade e a organização do trabalho no setor reformado, bem como a inclusão de mulheres, mapuche e afuerinos no acesso à terra; e sobre os conselhos camponeses como órgãos de poder popular ${ }^{90}$ (Chonchol, 1976).

\section{Expectativas camponesas}

Para se dimensionar a "revolução camponesa" vivida pelo Chile entre 1967 e 1973, vale visualizar o crescimento do volume de greve, tomas e camponeses sindicalizados entre 1967 e 1973 na tabela 6 a seguir.

\begin{tabular}{|c|c|c|c|}
\hline \multicolumn{5}{|c|}{ Tabela 6 - Sindicalização Campesina, Greves e Tomas (1967-1973) } \\
\hline Ano & Camponeses sindicalizados & Greves & Tomas \\
\hline $\mathbf{1 9 6 7}$ & 50.309 & 693 & 9 \\
\hline $\mathbf{1 9 6 8}$ & 71.721 & 648 & 26 \\
\hline $\mathbf{1 9 6 9}$ & 103.643 & 1.127 & 148 \\
\hline $\mathbf{1 9 7 0}$ & 140.293 & 1.580 & 456 \\
\hline $\mathbf{1 9 7 1}$ & 253.531 & 1.758 & 1.276 \\
\hline $\mathbf{1 9 7 2}$ & 279.628 & 796 & 307 \\
\hline $\mathbf{1 9 7 3}$ & 313.700 & 316 & - \\
\hline \multicolumn{4}{|c|}{ Fontes: Saavedra, 1975: 205; Huerta, 1986: 337; Gómez, 2002; Loveman, 1976: 264; Gómez, 1981: 11.} \\
\hline
\end{tabular}

A explosividade social no campo e as diferentes tentativas de influência promovidas pelas vanguardas partidárias representavam uma colisão imprevisível entre os projetos da modernização (as reformas agrárias como invenção urbana) e o complexo universo de expectativas de um campesinato altamente estratificado (que colocava em marcha variadas reformas agrárias como pressão rural). Os gráficos desse processo social permitem visualizar que enquanto a organização sindical camponesa experimentava um crescimento contínuo entre 1967 e 1973, as greves e tomas foram massivas no ano eleitoral de 1970 e atravessaram um pico de mobilizações entre 1970 e 1971. Isso pressionou Allende pela aceleração da reforma agrária e tornou-se a força social motriz das expropriações.

\footnotetext{
${ }^{90}$ Esses eixos foram detalhados em dois capítulos de livro de minha autoria, publicados este ano (Vasconcelos, 2020a, 2020b).
} 

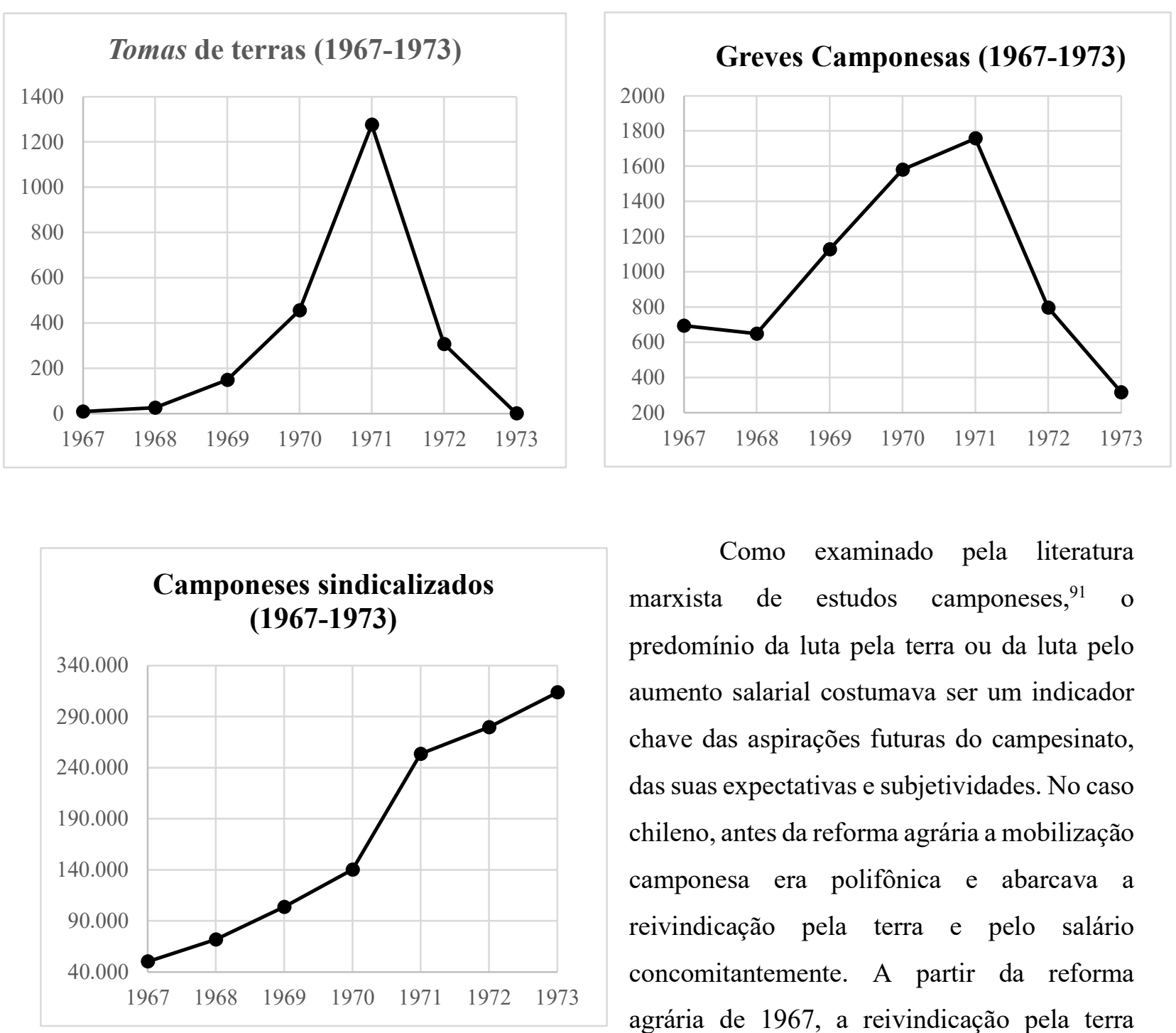

Como examinado pela literatura marxista de estudos camponeses, ${ }^{91}$ o predomínio da luta pela terra ou da luta pelo aumento salarial costumava ser um indicador chave das aspirações futuras do campesinato, das suas expectativas e subjetividades. No caso chileno, antes da reforma agrária a mobilização camponesa era polifônica e abarcava a reivindicação pela terra e pelo salário concomitantemente. A partir da reforma agrária de 1967 , a reivindicação pela terra ganhou projeção e tornou-se o centro das mobilizações. As greves, que antes foram um método de luta salarial, passaram a ser um método de luta pela terra. Os estudos das subjetividades camponesas realizados àquela época por alguns pesquisadores, como Maria Edy Ferreira, Paulo Freire, Hugo Zemelman, James Petras, Oscar Dominguez, Marcela Gajardo e José Luis Fiori, muitos dos quais serão analisados detalhadamente nesta tese, apontavam ao menos três desencontros entre a reforma agrária "urbana" e as aspirações do campesinato. O primeiro desencontro se relacionava aos arranjos e tensões entre a propriedade individual e a propriedade coletiva. O segundo ocorria no âmbito das hierarquias das relações sociais de produção e organização do trabalho. E o terceiro desencontro, derivado dos

\footnotetext{
91 No início do século XX, emergiram duas visões opostas dentro do marxismo sobre o desenvolvimento histórico do campesinato. A primeira, preconizada por Lênin (1979), defendia que o campesinato inevitavelmente atravessaria um processo de diferenciação, isto é, alguns camponeses se tornariam proprietários e outros trabalhadores assalariados, indicando que a evolução do capitalismo tendia a eliminar essa classe social, considerada um resíduo pré-capitalista. A segunda, fundamentada em Chayanov (2014) e posteriormente associada à teoria da acumulação de Luxemburgo (1985), acreditava que a diferenciação, que efetivamente ocorria, não era um fenômeno absoluto e não eliminaria o campesinato enquanto classe. A classe camponesa poderia ser preservada pelo capital como estratégia de controle territorial, tanto quanto poderia resistir à diferenciação, lutando para preservar seu modo de vida comunitário e sua economia familiar. Esse debate foi sintetizado por Sevilla Guzmán \& Molina (2004), em perspectiva latino-americana.
} 
anteriores, residia na relação do campesinato com o excedente da produção e com o imperativo econômico do aumento da produtividade, que se impôs de maneira ainda mais contundente na batalha da produção da revolução chilena. Tais desencontros alcançaram o paroxismo durante a via chilena ao socialismo, tensionados pela polarização ideológica e pelo acirramento da luta de classes no campo.

O primeiro desencontro foi investigado por Ferreira em uma pesquisa empírica e dialógica junto a camponeses assentados de Culiprán..$^{92} \mathrm{O}$ assentamento resultou de um conflito entre inquilinos e patrão da hacienda Culiprán que começara em 1965, quando o patrão quis reduzir a regalía de terra em função da normativa do governo, que determinava mínimo de $50 \%$ de remuneração salarial. A propriedade tinha 7.126 hectares e "os camponeses se encontravam em condições muito precárias devido à exploração inadequada das terras, seu baixo rendimento e a utilização insuficiente dos recursos naturais", ${ }^{93}$ constatou a brasileira. Entre as 133 famílias e 854 camponeses que ali viviam, $40 \%$ nunca havia saído do latifúndio para visitar amigos ou conhecer a cidade de Melipilla, que ficava a apenas 12 quilômetros dali. O contato com o mundo exterior era feito pelo rádio, que $53 \%$ das famílias possuiam em casa, e pelos jornais, lidos por $60 \%$ dos alfabetizados.

O latifúndio foi expropriado pelo governo Frei, por tamanho e má exploração. Em 1967, durante a lenta tramitação da reforma, Ferreira entrevistou os assentados de Culiprán, entre os quais $28 \%$ não sabia o que era reforma agrária: "não sei nada, porque nunca ninguém me explicou", disse um camponês; "não sou capaz de dizer" e "não sei para que deve servir", ${ }^{44}$ responderam outros. Entre os entrevistados, $38 \%$ responderam não saber o que era a CORA, $9 \%$ pensavam que CORA e reforma agrária eram a mesma coisa e outros $9 \%$, que entre ambos não havia relação. Mas os dados mais importantes para o mapeamento deste primeiro desencontro era que $63 \%$ dos assentados de Culiprán afirmavam com segurança que as terras seriam parceladas. A perspectiva da cooperativa camponesa, ainda que mista, parecia não estar no horizonte daqueles assentados específicos. Ademais, era fundamental perceber que $81 \%$ dos assentados consideravam que seus direitos como assentados eram "equivalentes às antigas regalías, mas ampliadas". 95

A socióloga brasileira sinalizou que a aspiração do camponês pela parcela individual era inegociável, ainda que compatível com a propriedade coletiva. "Nos períodos de mudança estrutural, como no assentamento, o camponês é levado a reestruturar seu campo de percepções, porque se encontra diante de novas circunstâncias e novos fatos que reorganizam seu campo de ação", estudou Ferreira. "Com que perspectivas o camponês encara [os projetos da CORA], que valores o guiam, quais são suas metas?", questionava. Sua hipótese principal era que, apesar do predomínio da tendência individual, o desempenho do assentamento em termos de vantagens do trabalho coletivo poderia reverter essa tendência pela prática. Se as estruturas coletivas funcionassem, poderiam suplantar a tendência ao

\footnotetext{
${ }_{92}$ Maria Edy Ferreira, Expectativas campesinas y asignación de tierras de Culiprán. Santiago (mimeo), 1968.

${ }^{93}$ Idem: p. 1.

94 Idem: p. 9.

${ }^{95}$ Idem: p. 35.
} 
individual. Ferreira alertou, portanto, que os operadores políticos e técnicos da reforma agrária não deveriam subestimar a importância do huerto na subjetividade camponesa e o desejo de vivir en lo propio. A experiência de classe precisava ser um dado fundamental para reforma agrária. Como classe, os camponeses há décadas praticavam o "assédio interno" como forma de resistência, lutando para ampliar sua produção autônoma no interior do latifúndio. A tendência era que seguissem buscando uma meta individual no interior dos assentamentos. A reforma agrária abria caminho para a reversão do processo de proletarização do camponês e podia ser experimentada como nada mais que a recuperação da regalía, isto é, um retorno melhorado à estrutura anterior de relações sociais de produção (Ramírez, 1968). Até mesmo camponeses do Partido Socialista viviam essa aspiração, como expressou um dirigente entrevistado por Petras \& Zemelman: "pensamos que devemos trabalhar em comunidade, dois ou três anos, pelo assentamento. E depois virá a divisão. Se andamos bem, não dividimos nada. Mas eu acredito que as pessoas vão querer a divisão, cada um quer sua parcelinha" (apud Petras \& Zemelman, 1972: 97).

O segundo desencontro foi analisado por Paulo Freire e seus parceiros de pesquisa no Chile entre 1964 e 1969. Efetivamente, o desencontro sobre as hierarquias de trabalho e produção foi o objeto concreto de Pedagogia do Oprimido, escrito durante a observação e vivência de Freire com os camponeses chilenos que precisavam aprender a produzir sem o capataz (chamado no campo chileno de mayordomo ou empleado) e a reestruturar sua percepção sobre o mundo no caminho da autodeterminação. A Pedagogia do Oprimido é um livro sobre a reforma agrária chilena, embora isso quase nunca seja lembrado. A ideia da "aderência ao opressor" ou da repetição de hierarquias laborais nas quais novos personagens ocupam os antigos papéis era um tema fulcral dos estudos de Freire em seu exílio. Ferreira, amiga de Freire e sua colega de trabalho, também desenvolveu uma agenda de pesquisas nesse sentido.

Após realizar entrevistas em 80 assentamentos com 3.164 assentados a respeito das tendências de poder dentro do setor reformado, Ferreira (1970) notou que as hierarquias laborais da hacienda se reproduziam subjetivamente na nova estrutura de propriedades. No assentamento, portanto, as antigas hierarquias patronais poderiam se refletir na "formação de uma oligarquia burocrática constituída por dirigentes camponeses reeleitos para cargos de autoridade dentro do assentamento" (Ferreira, 1970: 22). Petras e Zemelman realizaram um estudo com metodologia da escuta também na zona de Melipilla em 1971. Explicaram o peso da figura patronal na vida camponesa: "seus valores, suas ideias sobre o mundo, até mesmo seu sentido de prestígio pessoal, estão intimamente ligados aos valores e preferências do patrão", escreveram (Petras \& Zemelman, 1972: 27). Algumas tipologias da consciência camponesa foram criadas nesse contexto. Petras \& Zemelman falaram de três tipos: a consciência de dirigente, que atua como sujeito construtor do processo de reforma agrária; a consciência seguidista, que apoia a reforma, mas atua sem protagonismo, como base dos dirigentes; e a consciência do opositor, geralmente expressa entre capatazes (mayordomos e empleados), cujas vantagens com relação aos 
inquilinos advinham das hierarquias criadas pelo próprio patrão, o que se dissolvia na nova estrutura do assentamento e gerava perdas materiais a este segmento.

Por fim, o terceiro desencontro entre reforma agrária e subjetividade camponesa era a consequência dos dois primeiros desencontros anteriores: a reforma dependia da disciplina laboral do campesinato, mas este nem sempre encontrava motivos suficientes para trabalhar com o mesmo empenho e intensidade que antes. O grande desafio da reforma agrária seria conciliar o aumento da produção agropecuária com o processo expropriatório mais vasto da história do país, que modificava profundamente o trabalho no campo. Esse desafio ganhou dimensões revolucionárias nos mil dias da UP. Como advertiam Jacques Chonchol (1964) e Sólon Barraclough (1970, 1971), era inevitável que a alteração estrutural do regime de propriedades desencadeasse um processo de desorganização produtiva. Entre 1967 e 1973, foram 9 milhões de hectares expropriados e quase 100 mil camponeses organizados em um sistema laboral completamente novo. Embora a reforma agrária incorporasse uma grande quantidade de terras ociosas dos latifúndios à produção, as novas relações sociais de trabalho não seriam estabilizadas automaticamente. Muito menos considerando que o processo expropriatório resultou de uma avalanche de lutas camponesas que alterou em definitivo a experiência de vida daqueles trabalhadores e sua percepção sobre o próprio trabalho e as hierarquias laborais. Isso sem falar das atividades de sabotagem de segmentos da classe proprietária rural.

O desafio de organizar o trabalho coletivo nas propriedades do setor reformado envolvia dialogar com a economia moral do campesinato, deslocando-a da subsistência para a acumulação. Os estímulos materiais ao trabalho coletivo nem sempre foram suficientes, fazendo com que muitos camponeses perseguissem melhores condições de vida pelo "assédio interno" no assentamento ou Centro de Reforma Agrária (CERA). Petras e \& Zemelman (1972: 24) formularam: "a economia moral anterior trazia a ideia semirreligiosa de que cada homem devia ganhar o suficiente para manter sua família, sustentando-se contra a ideia 'moderna' de aumentar o excedente ao máximo". O desejo de trabalhar para si mesmo, notavam os autores, muitas vezes correspondia ao aprofundamento da economia moral da subsistência, na contramão da produtividade moderna anunciada por todas as correntes ideológicas que sustentaram a reforma.

Além disso, a organização do trabalho no setor reformado enfrentava o desafio do analfabetismo rural de quase 1 milhão de pessoas. Os procedimentos de gestão cooperativa do assentamento requeriam alfabetização para que se pudesse ler os folhetos sobre seus direitos, gerenciar créditos e preços sem intermediários e organizar os planos de produção. A reforma agrária também convocava o campesinato ao aprendizado democrático, ao uso das assembleias de assentamento como ferramenta organizativa dos planos de produção. Os trabalhadores rurais estavam muito mais habituados a receber ordens de trabalho do que a tomar decisões laborais com autonomia, e isso imprimia marcas profundas na sua subjetividade, além de afetar as condições objetivas de trabalho e produção na agricultura.

Essas condições viabilizaram as mais variadas alianças entre partidos políticos e frações de classe camponesa, configurando uma rede complexa de tensões políticas, econômicas e sociais. A 
heterogeneidade social e territorial do campo chileno e a pluralidade das forças partidárias em ação produziram as mais diversas situações educacionais, como espaço de encontro entre mundo urbano e rural.

\subsection{Considerações finais}

Argumentei, neste capítulo, que a reforma agrária chilena foi parte de uma agenda de modernização nacional de diferentes partidos políticos, que atuaram com objetivos vários e às vezes contrapostos. $\mathrm{Ou}$ ainda, que a reforma se tratava de programas mudancistas internacionais, sujeitos às tensões da Guerra Fria. Os projetos de exclusiva modernização técnica da agricultura, de reforma estrutural capitalista e de revolução agrária e camponesa disputaram cada palmo do processo de transformação econômica chilena entre 1955 e 1973. Busquei oferecer um panorama do debate sobre a questão agrária chilena desse período, protagonizado por intelectuais das cidades com diferentes colorações ideológicas. Ao mesmo tempo, apresentei um olhar sobre a pressão camponesa que vinha debaixo, rejeitando a tese de que o movimento camponês teria surgido junto com a reforma a partir do resgate das pesquisas que demonstram a vitalidade da luta camponesa anterior a efervescência de 1967 a 1973.

Retratou-se a situação educacional e laboral das crianças camponesas, mostrando histórias de vida de pessoas que foram retiradas da escola na infância para serem incorporados ao trabalho rural, com remunerações precárias ou inexistentes. Viu-se que havia um abismo educacional e cultural entre os formuladores urbanos da reforma agrária e os camponeses. A reforma agrária fez esses mundos tão distantes se encontrarem e desencontrarem em alianças e colisões que serão estudadas adiante nesta tese. Nesse sentido, a reforma agrária chilena representou uma revolução cultural para o campesinato, sobretudo no campo da educação de adultos, nos ramos da capacitação técnica, produtiva, da alfabetização, da pós-alfabetização e da educação sindical. Uma pluralidade de atores, detalhados no decorrer dos próximos capítulos, buscaram desenvolver estratégias de educação camponesa no sentido da modernização, da reforma capitalista e da revolução socialista. Experiências de autoeducação camponesa foram criadas, métodos de planificação econômica democrática foram testados, uma grande quantidade de experiências educacionais heterogêneas movimentou o processo social da mudança agrária. Demonstraremos, no decorrer da narrativa, que a economia moral do campesinato esteve em disputa por meio da educação ou da capacitação camponesa, em todas as suas ramificações.

São essas as tarefas que me propus a realizar nos capítulos a seguir. 


\title{
Capítulo 2 - Plantando conceitos: a atuação dos Estados Unidos na educação agrária do Chile
}

\begin{abstract}
"O propósito do trabalho com extensão é a educação. (...) Para ser bemsucedida, não pode se confundir com uma operação regulatória ou policialesca. Lançar os extensionistas em funções policialescas, desviando de seus objetivos educacionais básicos, é colocar em risco a integridade do serviço. (...) Dar ao extensionista o poder de impor a lei de reforma agrária (...) é arriscar destruir a confiança existente entre o agente da extensão como consultor educacional e o agricultor, como recipiente voluntário da informação educacional".
\end{abstract}

- S.O. Berg, L.E. Hanson \& W.P Martim, U. Minnesota, 1963 ${ }^{96}$

"Um maior crescimento econômico dos países em desenvolvimento serve aos interesses e propósitos nacionais dos Estados Unidos (...). Enquanto os lessdeveloped coutries não desenvolverem suas próprias faculdades $\mathrm{e}$ universidades, os EUA precisam ajudá-los a preencher essa lacuna (...). A genialidade da educação agrária nos EUA foi conectar o vazio entre o laboratório e o campo".

- Charles M. Hardin, UC Davis, 1966 $^{97}$

"O problema não é diagnosticar deficiências [na agricultura], o problema é como plantar o conceito dessas deficiências amplamente entre os agricultores chilenos".

- Martin M. Barnes, UC Riverside, $1969^{98}$

\subsection{Introdução}

Em 1955, a Fundação Rockefeller instalou uma sede em Santiago do Chile com o propósito de atuar junto ao Ministério da Agricultura, por meio de uma oficina de estudos especiais. ${ }^{99}$ Desde 1953, os Rockefeller financiavam o Plano Chillán, uma operação piloto de transformação das práticas produtivas de médios agricultores por meio da educação agrária. Segundo um estudo financiado pela Fundação Ford uma década mais tarde, o Plano Chillán teria sido "um amplo experimento de extensão agrária, treinamento e educação" 100 aplicado nas províncias de Nuble, Maule e Concepción, financiado em parceria com a USAID (Agência dos Estados Unidos para o Desenvolvimento Internacional).

O programa pretendia preparar extensionistas agrários para difundir novas tecnologias, transmitir aos produtores os conhecimentos de pesquisas científicas e capacitar trabalhadores rurais com cursos de curta duração, seminários e demonstrações em estações experimentais. Segundo o mesmo

\footnotetext{
${ }^{96}$ S. O. Berg, L.E. Hanson \& W.P Martin. Chilean agriculture. A report on Chilean agriculture and agricultural education to the Ford Foundation. Ford Foundation Catalogued Reports. Report 001718, 1963: 85.

${ }^{97}$ LDC são "países menos desenvolvidos" (less developed countries). Charles Hardin, The idea of an International Service Faculty. The Convenio Archive (box 1, AR 01-05). Shields Library Special Collections. University of California, Davis, 1966. ${ }_{98}$ M. M. Barnes, Statement of M. M. Barnes to Agricultural Sciences Subcommittee UC-UC Ford Foundation Program, August, 5th, 1969 [classified]. The Convenio Archive (box 1, AR 01-06). Shields Library Special Collections. University of California, Davis, 1969.

${ }^{99}$ S. O. Berg, L. E. Hanson \& W.P. Martin,, ibid., p. 79.

${ }^{100}$ Id., ibid., p. 25.
} 
estudo, o Plano Chillán teria sido "razoavelmente bem-sucedido em alterar os métodos de produção agrária na área de Chillán. A população rural recebeu bem o programa e as atividades dos clubes da juventude" ${ }^{101}$ Fazia parte da estratégia de transformação produtiva, tanto a modernização técnica das estações experimentais agrícolas para aprimorar a pesquisa científica, quanto a criação de centros rurais comunitários para jovens, lugares de socialização, educação e cultura. A Estação Experimental La Platina, por exemplo, era uma fazenda de 301 hectares próxima a Santiago, que recebeu investimentos do Plano Chillán. Em seus laboratórios se investigavam os cultivos de milho, trigo, feijão, oleaginosas, forragens e nutrição animal, variedades de frutas resistentes, além de métodos de irrigação, uso de fertilizantes e pesticidas. ${ }^{102} \mathrm{~A}$ criação dos clubes de juventude e dos programas de educação no campo indicavam que os Rockefeller compreendiam as conexões intrínsecas entre "sistemas culturais", da natureza e da sociedade.

Alguns anos depois, em 1960, a AIA (Associação Internacional Americana para o Desenvolvimento Econômico e Social) deu início ao Plano Victoria, que propunha a construção de 14 escolas rurais e cursos de formação de professores na comuna de Victoria, província de Malleco, que naquele ano havia sido atingida pelo grande sismo de Valdivia. ${ }^{103}$ Em função do Plano Victoria, a AIA negociou o surgimento de uma Comissão Especial de Educação Rural na CORFO (Corporação de Fomento da Produção), a principal instituição desenvolvimentista do Estado chileno, criada em 1947. Em sua primeira reunião, em janeiro de 1962, a Comissão contou com a presença de Ernest E. Maes, representante da AIA, além de Guillermo Jul, diretor de agricultura da CORFO, e Domingo Valenzuela, diretor de educação normal do Ministério da Educação. ${ }^{104}$ Evidenciava-se assim o poder que tinham esses financiadores estrangeiros para moldar instituições e políticas de desenvolvimento relacionados à educação rural no Chile naquele momento.

Em 1964, a AIA já havia subsidiado a construção de oito escolas rurais com apenas 245 mil dólares, o que articulou o engajamento das comunidades envolvidas, com suas Juntas de Vecinos e Centros de Madres. ${ }^{105}$ Além disso, foi criada uma equipe, financiada pela AIA, para confecção de livros didáticos rurais e organização de cursos para professores, que ocorriam na Escola Normal Experimental Rural de Victoria e chegavam a turmas de 50 docentes provenientes de sete escolas rurais da província de Malleco. ${ }^{106}$ O Plano Victoria foi considerado um sucesso em 1964 por seus parceiros, os Rockefeller

\footnotetext{
${ }^{101}$ Idem, p. 25.

102 Ibid, p. 44.

${ }^{103}$ Com grau 9 na escala Richter e com epicentro em Lumaco, o sismo ocorrido em 1960 provocou uma sequência devastadora de terremotos e tsunamis, matou 5700 pessoas e feriu 2 milhões, sendo até hoje o deslocamento tectônico mais violento já registrado.

${ }^{104}$ AIA (American International Association for Economic and Social Development). The Rural Education Program - Chile - Quarterly Report. Box 42, Folder 310, 1962-1963.

${ }^{105}$ As Juntas de Vecinos e os Centros de Madres são instituições comunitárias fundamentais na história do Chile, cuja participação na reforma agrária foi analisada criticamente por Garret (1976) e Tinsman (2009).

106 AIA, ibid.
} 
(novamente), que se dispuseram a replicá-lo na província de Ñuble no ano seguinte, com assistência da USAID. ${ }^{107}$

A USAID, em 1962, realizou também uma parceria com a Universidade de Wisconsin-Madison para inaugurar o Land Tenure Center (LTC). ${ }^{108} \mathrm{O}$ LTC era um centro de estudos econômicos agrários sobre países subdesenvolvidos, dentro do qual se formariam muitos especialistas em agricultura chilena. Alguns anos mais tarde, jovens de Wisconsin desenvolveram teses de doutorado sobre a subjetividade econômica da reforma agrária no Chile, e participaram in loco da experiência camponesa no setor reformado, além de terem analisado seus diferentes níveis de engajamento e compromisso com o processo produtivo, o debate sobre as novas formas de propriedade e os desafios da reorganização do trabalho. Os economistas e sociólogos do LTC estiveram atentos à tensão entre a mudança do regime de propriedades e a demanda de aumento da produtividade agrícola, bem como aos conflitos sociais provocados pelo abalo das hierarquias de trabalho e gênero decorrentes da reforma. ${ }^{109}$

O economista Willian Thiesenhusen, coordenador do LTC, passou a década de 1960 no Chile, e lá investigou maneiras de aumentar a produtividade em meio à transformação estrutural do regime de propriedades e estudou diferentes tipos de incentivos ao trabalho rural. Junto com Peter Dorner, pressupôs a necessidade de participação dos Estados Unidos nas reformas agrárias latino-americanas: “devido a seu tamanho, riqueza, poder e compromisso, os Estados Unidos são parte da situação (...). Assuntos em discussão como a reforma agrária não são exclusivamente internos aos países em desenvolvimento". ${ }^{110}$ Sugeriam aos economistas uma agenda de pesquisa focada no estudo das transformações estruturais e dos novos arranjos de poder e propriedade durante reformas agrárias dos países subdesenvolvidos, sendo o caso chileno um bom exemplo.

No mesmo período, em 1963, três acadêmicos da Universidade de Minnesota patrocinados pela Fundação Ford percorreram o Chile durante dois meses para investigar a situação educacional agrária e o sistema de extensão rural do país. O relatório desta viagem ${ }^{111}$ tornou-se a principal base para $\mathrm{o}$ Minnesota Agriculture Extension Project, que atuou no Chile durante os anos seguintes. ${ }^{112} \mathrm{O}$ convênio Minnesota-Ford se inseriu no recém-fundado Instituto de Investigações Agropecuárias (IIA), uma

\footnotetext{
${ }^{107}$ RAC. Rockefeller Family Public Relations Department, Chile Rural Education Project of the RBF. Series 13 (FA1193). Box 18, folder 108, 1964.

${ }^{108}$ Eugene A Havens. The Land Tenure Center: its establishment and activities. Madison: Land Tenure Center, University of Wisconsin, 1963.

${ }^{109}$ Entre as teses e publicações do LTC com relatos de experiências da reforma agrária se destacam Roxborough, 1974, 1977; Garret, 1976, 1978; Chinchilla, 1973; Chinchilla \& Sternberg, 1974. Em geral, tiveram como orientador William Thiesenhusen (1965a, 1965b, 1965c, 1966a, 1966b, 1966c, 1966d, 1966e, 1966f, 1967, 1974) ou Peter Dorner (1966a, 1966b). Ver também Dorner \& Thiesenhusen (1964).

${ }^{110}$ Peter Dorner \& William Thiesenhusen, Relevant Research Programs to be Conducted in Developing Countries. Journal of Farm Economics, v. 46, n. 5, dez., 1964.

111 S. O. Berg, L. E. Hanson \& W.P. Martin, op. cit.

112 Sobre o Minnesota Agriculture Extension Project in Chile, ver Rockefeller Archive Center (RAC), Ford Foundation Catalogued Reports: W. M. Myers, Report on a trip to Chile. Report 000285, 1964; William E. Wilhelm, Agricultural education development in Argentina and Chile. Report 002626, 1964; C.A. Simkins, Progress Report. Minnesota Agricultural Extension Project in Chile. 1/10/1964 - 30/09/1965. Report 001703, 1965; Francis Boddy; James M. Kingsley; E.W. McDiarmid; H. T. Morse, Report of visit to the University of Concepcion, Chile, by a Special Team from University of Minnesota, 10/11/1964 - 5/12/1964. Report 000110, 1965; Willard W. Cochrane, University of Minnesota Agriculture Extension and Education Project in Chile, 1966-67: proposed work plan and budget. Report 001697, 1966.
} 
instituição semiautônoma do Ministério da Agricultura, dentro do qual organizaram o Departamento de Educação Produtiva. Além de recomendar a reestruturação do sistema de extensão e educação rural, os acadêmicos de Minnesota criaram novos cursos e modificaram currículos das Faculdades de Agronomia da Universidade de Concepción e da Universidade Católica (Cochrane, 1966).

O principal objetivo do projeto Minnesota-Ford era desenvolver pontes educacionais entre a pesquisa científica universitária e os produtores rurais e formar extensionistas que estivessem habilitados para a tarefa da "educação produtiva". Isso significava, basicamente, desenvolver técnicas de transposição dos conhecimentos gerados em laboratório para a realidade agrária, gerando ganhos de produtividade e aquecendo o mercado de insumos. Essa transposição convocava o desafio da comunicação e da mudança cultural, para "modernizar" dois fenômenos intrinsecamente associados: as técnicas de cultivar e as formas compartilhar conhecimento.

Os extensionistas de Minnesota foram frequentemente elogiados pelos cientistas da Universidade da Califórnia, que em 1965 assinaram um convênio com a Universidade do Chile, também sob patrocínio da Fundação Ford. "The Convenio", seu apelido oficial em spanglish, foi um empreendimento milionário e de longo prazo ou, como diziam, de "10 milhões durante 10 anos". ${ }^{113}$ Mais precisamente, 9.410.448 dólares, dos quais $27 \%$ foram destinados ao subcomitê de agricultura e medicina veterinária. ${ }^{114} \mathrm{O}$ convênio priorizava a pesquisa científica, a coleta e classificação de novas espécies vivas em campo e a recomendação de insumos. Sob o patrocínio da Ford, estações experimentais rurais foram modernizadas no Chile, currículos agrários foram remodelados e linhas de pesquisa inéditas foram inauguradas. Surgiu assim um intenso fluxo de cientistas entre as duas universidades. Considerado o mais exitoso setor do convênio, o subcomitê de agricultura e medicina veterinária desenvolveu investigações nas áreas de fruticultura, entomologia (estudos dos insetos), nematologia (estudo dos nematoides, mais conhecidos como lombrigas), fitopatologia (enfermidades das plantas geradas por fungos, bactérias ou vírus), nutrição animal e nutrição de solos, entre outros.

Operando com tentáculos, os pesquisadores do convênio UC-UC trabalharam em variadas parcerias: com a USAID, com os Rockefeller, com o IIA, com a CORFO, com a Universidade de Minnesota, com o INDAP e com a CORA. Se dedicaram especialmente ao fortalecimento da Estação Experimental La Rinconada da Universidade do Chile, uma fazenda de 1200 hectares que se encontrava sucateada e tornou-se o local prioritário de atuação dos cientistas da Califórnia. ${ }^{115}$ Financiado até 1975 , as agendas científicas do convênio UC-UC atravessaram as turbulências da reforma universitária, da reforma agrária, da revolução socialista e os impactos do golpe de 11 de setembro de 1973.

\footnotetext{
${ }^{113}$ John Netherton, University of Chile - University of California Collaboration. Ford Foundation Catalogued Reports. Report $004824,1968$.

114 THE CONVENIO. 1974-1975 Annual Report. University of California - Universidad de Chile. The Convenio Archive (box 1). Shields Library Special Collections. University of California, Davis.

115 THE CONVENIO. 1965-1967 Annual Report. University of California - Universidad de Chile. The Convenio Archive (box 1). Shields Library Special Collections. University of California, Davis.
} 
Como se vê, havia uma profusão de iniciativas educacionais e científicas dos Estados Unidos para o Chile na área da agricultura naquele período. Por que, afinal, USAID, Rockefeller, Ford, AIA e várias universidades estadunidenses comprometeram tanto dinheiro, trabalho e empenho na modernização da agricultura chilena? Por que se engajaram especificamente na educação? Nas palavras do entomólogo da UC, Davis, Martin M. Barnes em um memorando confidencial para Fundação Ford, a missão dos cientistas estadunidenses no Chile era "plantar conceitos"116 - o que seria mais difícil do que apenas plantar trigo, uvas ou beterrabas com emprego de novas técnicas. Plantar conceitos exigia o desenvolvimento de sistemas científico-institucionais de assistência técnica, pesquisa, educação e extensão que alterassem as formas do conhecimento produtivo na agricultura. Exigia o implante de novos dispositivos político-culturais para "semear" e "cultivar conceitos", para criar as condições do seu florescimento. Apesar da sua relevância, a articulação dos projetos de educação rural e transformação produtiva oferecida dos Estados Unidos para o Chile ainda não foram explorados pela historiografia da reforma agrária. ${ }^{117}$

Neste capítulo, argumento que plantar conceitos foi parte fundamental da estratégia dos Estados Unidos durante a Guerra Fria, praticada com ao menos dois objetivos: primeiro, dinamizar processos de transformação agrária sob sua tutela, com intuito de diluir tensões sociais e desativar os gatilhos camponeses das revoluções socialistas na América Latina; e segundo, alterar os paradigmas de conhecimento agrário como uma etapa imprescindível na política de expansão dos mercados de insumos da revolução verde. Como veremos, os investidores estadunidenses percebiam que a mudança cultural requerida para transformação produtiva no campo era um processo de longo prazo. Ou seja, os conceitos plantados naquele momento só seriam consolidados e colhidos pelas próximas gerações. A estratégia educacional agrária dos Estados Unidos assumiu muitas aparências e foi construída por sujeitos movidos por várias intenções, que encontraram no Chile um ambiente receptivo e sintonizado às narrativas da modernização. Era parte do alinhamento entre CEPAL e Aliança para o Progresso.

Embora tivessem suas nuances e atuassem de modo mais ou menos discreto, as iniciativas educacionais dos Rockefeller, Ford, AIA e USAID, junto aos cientistas de Minnesota, Califórnia e Wisconsin passaram a disputar na prática os sentidos da revolução chilena, por exemplo, oferecendo

\footnotetext{
116 M. M. Barnes, The Convenio Archive, 1969, op. cit.

${ }^{117}$ Com exceção de Tinsman (2016), que destrinchou a história dos propósitos econômicos condutores do convênio UC-UC na área da fruticultura, não existem trabalhos na historiografia sobre os programas mencionados. Tinsman argumenta que antes do golpe que levou os Chicago Boys ao poder em 1973, o Chile foi influenciado pelo paradigma dos "Californian Boys", dentro do qual o convênio representaria a consolidação de um intercâmbio de saberes e técnicas sugerido desde os anos 1920, em decorrência da importante similaridade climática, ecossistêmica e agrária entre Califórnia e Chile. A autora demonstra que o convênio UC-UC ofertou atenção especial para indústria frutícola, setor que foi só viabilizado devido ao arranjo keynesiano de investimentos, no qual o mercado dependia de incentivos estatais. Nas suas palavras: "o boom da fruta foi muito mais que uma consequência da aplicação dos princípios de Chicago à agricultura. Os vínculos entre o Chile e a Universidade da Califórnia se estabeleceram nas décadas de 1950 e 1960 e se articularam através de modelos keynesianos e até socialistas. Ainda que a disseminação do emprego de tecnologias agrárias da Califórnia no Chile tenha resultado especialmente condizentes com os modelos de mercado livre, nunca esteve ligada ao neoliberalismo, nem tampouco ao seu serviço" (Tinsman, 2016: 104-5)
} 
significados próprios para reforma agrária. ${ }^{118} \mathrm{Com}$ diferentes escopos, todos atuaram no terreno da subjetividade produtiva, isto é, dos conhecimentos que afetavam diretamente as formas de produzir e as consciências capazes de mover a economia. Ao mesmo tempo, a educação agrária passou a ocupar um terreno cada vez mais central na luta política por hegemonia, no momento em que revoltas camponesas aceleravam a revolução chilena e que o regime de propriedade rural se tornou um importante campo de batalha para todos os partidos. ${ }^{119} \mathrm{O}$ acirramento das greves, a onda de tomas e os novos enfrentamentos com a classe proprietária mostravam a emergência de novos sujeitos camponeses - os mesmos trabalhadores rurais considerados, pelos cientistas de Minnesota, "recipientes voluntários da informação educacional". ${ }^{120}$

\subsection{Do Ponto Quatro à Aliança para o Progresso}

Harry Truman anunciou seu plano em 20 de janeiro de 1949 com este nome: Point Four. Era um conjunto de medidas de educação científica e tecnológica implementadas pelos Estados Unidos para frear a influência da União Soviética nos países do terceiro mundo. A Guerra Fria entrava em seus primeiros atos quando Truman propôs "um incisivo e novo programa para tornar disponíveis os benefícios dos nossos avanços científicos e progresso industrial para o crescimento das zonas subdesenvolvidas". ${ }^{121}$ Dizia ele: "os recursos materiais que podemos oferecer como assistência para outros povos é limitado. Porém, nossos imponderáveis recursos em conhecimentos técnicos estão em constante crescimento e são inesgotáveis". ${ }^{122}$ Entre os eixos prioritários do Ponto Quatro estava a exportação de serviços de assistência técnica para agricultura latino-americana, o que deu partida a um conjunto de conexões acadêmicas novas entre Estados Unidos e Chile, responsáveis por empregar centenas de cientistas, técnicos, políticos, professores, pesquisadores e burocratas da agricultura, os quais, por sua vez, estavam dedicados a construir novos nexos entre campo e cidade em âmbito internacional.

Centenas de chilenos foram acolhidos em universidades dos Estados Unidos para apreender técnicas de pesquisa da agricultura e voltar ao Chile. Dezenas de profissionais estadunidenses viveram no Chile e criaram vínculos estreitos com o país. Um fluxo de pesquisadores agrários ia e vinha todos os anos financiado por agências públicas e privadas dos Estados Unidos, as quais estavam sincronizadas

\footnotetext{
118 Petras \& Laporte (1971) elaboraram um estudo sobre as políticas de reforma agrária dos Estados Unidos para o Chile impulsionada a partir da Aliança para o Progresso, a construção das ambiguidades retóricas do reformismo imperialista e os conflitos entre diferentes agentes políticos estadunidenses no decorrer dos anos 1960. Não é isso que interessa enfocar aqui, mas sim a dimensão cultural-educacional dessa estratégia econômica, em geral esquecida pela historiografia.

${ }^{119}$ Sobre as mobilizações camponesas no período da revolução chilena, ver: Loveman, 1976; Roxborough, 1977; Steenland, 1977; Mallon, 2004; Tinsman, 2009; Klubock, 2014; Bengoa, 2016; Redondo, 2017; Robles-Ortiz, 2018; Navarrete Vergara, 2018. Sobre o debate agrário entre os partidos políticos chilenos ver Avendaño, 2017. Sobre as polêmicas em torno à organização do trabalho nos assentamentos, ver Barraclough \& Affonso, 1973; Bengoa, 1973; Barraclough \& Fernández, 1974; Collarte e Pérez, s/d; Gómez, 1994.

${ }^{120}$ S. O. Berg, L. E. Hanson \& W. P. Martin, op. cit., p. 85.

${ }^{121}$ Harry S. Truman, Inaugural Address. January 20th, 1949.

122 Idem.
} 
à mesma política. A despeito das nuances ideológicas desse universo plural de intelectuais, havia uma missão compartilhada por todos: a ciência deveria ser posta a serviço da produtividade, deveria ser aplicada à economia agrária, transpor os muros do conhecimento acadêmico, conquistar fazendas e assentamentos, plantar novos conceitos. No contexto da Guerra Fria, isso significava proporcionar à América Latina uma modernização agrária em harmonia com interesses dos Estados Unidos, o que forjaria uma agricultura integrada à cosmovisão capitalista e tecnocrática que emulavam.

Para Truman, era urgente combater "as falsas doutrinas que defendem que o caminho para o progresso são as tiranias". ${ }^{123}$ Ao fim e ao cabo, um conjunto de instituições milionárias se engajaram na exportação de um sistema cultural, tecnológico e educacional, entendido como ferramenta ideológica para combater o comunismo. Isso exigia investimentos de longo prazo para moldar estruturas institucionais científicas e educacionais, públicas e privadas, como universidades, currículos, laboratórios e práticas de extensão rural. Demandava financiar o deslocamento de muitas famílias, criar redes acadêmicas, convênios de cooperação científica, enviar equipes de pesquisadores a campo, coordenar investimentos, influenciar a configuração de faculdades agrárias, desenvolver mecanismos eficientes educação rural, e o mais importante, construir novos elos educacionais entre campo e cidade. Em suma, tratava-se de uma grande operação de reciclagem da “colonialidade do saber" (Lander, 2000), um investimento cultural que traria benefícios econômicos incalculáveis de longo prazo para as grandes corporações de insumos. Pouco a pouco, o implante da "modernização" produziria novos mercados para fertilizantes, herbicidas, pesticidas, nematicidas, inseticidas, sementes, variedades resistentes, maquinaria e laboratórios científicos. E o que era mais importante, selaria novos laços de dependência com relação ao ativo econômico que, na narrativa de Truman, era inesgotável: o conhecimento. ${ }^{124}$ "Se a produtividade e o poder de compra desses países se expandem", dizia Truman, "nossa própria indústria e agricultura serão beneficiadas". ${ }^{125}$

Em uma reunião ocorrida em janeiro de 1950, o comitê do Ponto Quatro previa encontrar obstáculos. Pautavam métodos para responder às pressões coletivas dos "povos contrários à exploração econômica das zonas subdesenvolvidas". ${ }^{126}$ Enquanto isso, no Chile, a CEPAL se alinhava a uma visão anticomunista do progresso. Em ambos os países, a educação agrária e a capacitação rural foram vislumbradas por intelectuais proeminentes como recurso chave para barrar revoluções (como Ahumada, 1958; Pinto, 1959).

Com a revolução cubana de 1959, a política de exportação científica-educacional dos Estados Unidos para América Latina ganhou contornos de urgência geopolítica e recebeu mais recursos. John F. Kennedy anunciou, em 20 de janeiro de 1961: "para nossas repúblicas irmãs, ao sul da fronteira, oferecemos um compromisso: converter nossas boas palavras em bons atos, em uma nova aliança para

\footnotetext{
${ }^{123}$ Harry S. Truman, Special Message to the Congress Recommending Point Four Legislation. Truman Library.

${ }^{124}$ Como veremos, o discurso de Truman evoca o procedimento de domínio sobre outros povos que a historiadora Mary Louise Pratt chamou de "anti-conquista" (Pratt, 1992).

125 Idem.

${ }^{126}$ Point Four Information Service, Memorandum. Report of Meeting, Point Four Committee. Truman Library.
} 
o progresso". No mesmo discurso, prometeu o investimento de 20 bilhões de dólares da USAID para América Latina. São conhecidos os objetivos 5, 6 e 7 da Carta de Punta del Este, que definiram as diretrizes do aumento da produtividade agrícola, da reforma agrária e da modernização educacional, incluindo a erradicação do analfabetismo e a formação de "pessoal capacitado que requer as sociedades em rápido desenvolvimento". ${ }^{127}$ Nem sempre, contudo, esses objetivos foram analisados de maneira orgânica como estavam sendo aplicados. Sugiro, neste capítulo, que no universo da modernização capitalista da técnica palpitava uma constelação de "ideologias científicas", dispositivos de transformação do conhecimento produtivo que carregavam consigo novas relações sociais de poder e produção, envelopadas pela neutralidade da ciência. Sobre esses dispositivos, suas tensões e intenções tratarei adiante.

\subsection{Exportar a técnica: o Plano Chillán}

Em 1952, Chillán era um departamento com 92 mil habitantes (INE, 1952), o maior da província de Ñuble, entre o Vale Central e a zona da Fronteira entrecortada pelo rio Biobío. ${ }^{128}$ O plano Chillán, financiado pelos Rockefeller e pela USAID entre 1954 e 1960, foi um marco de inauguração do Ponto Quatro na agricultura chilena. Supervisionado pelo Departamento Técnico Interamericano de Cooperação Agrícola (DTICA), criado em 1951, o plano costurava um acordo entre a Universidade de Concepción, a Universidade do Chile e a FAO. Seus objetivos eram promover a "educação produtiva" na área de Chillán a partir de dois eixos: primeiro, formar extensionistas habilitados para instruir os agricultores a respeito dos "desenvolvimentos tecnológicos recentes da agricultura" 129 e prestar serviços de assistência técnica de maneira articulada às pesquisas científicas; e segundo, capacitar diretamente os agricultores e trabalhadores rurais com cursos, cartilhas, folhetos, seminários, demonstrações e visitas a estações experimentais. O Plano Chillán teria inaugurado no Chile um novo paradigma de extensão. ${ }^{130}$

Uma das suas primeiras medidas foi instalar um novo campus da Escola de Agricultura da Universidade de Concepción em Chillán, onde estudariam os alunos de engenharia agrônoma nos três anos finais da carreira, dedicados a aplicações e práticas de extensão. Em 1956, foi construída uma nova biblioteca, com um acervo volumoso financiado pela USAID e um espaço apropriado para cursos diversos. Foi considerada a melhor biblioteca de agronomia do país pela Fundação Ford nos anos 1960.

\footnotetext{
${ }^{127}$ Estes objetivos foram textualmente citados no capítulo 1 (OEA, 1961: 623).

${ }^{128}$ A região chilena conhecida como "La Fronteira", demarcada pela travessia do rio Biobío, se refere à zona de conflito entre espanhóis e povos mapuche desde o período colonial. Em 1641, foi assinado o Tratado de Quillin, no qual os espanhóis reconheceram a autonomia territorial mapuche. Em 1825, foi firmado o Tratado de Tapihue entre chilenos e indígenas, que renovou o princípio da autonomia recíproca. Durante o século XIX, os mapuche chamavam de "o país" o território ao norte do rio Bíobío de e diziam "a terra" para seu lado (Correa; Molina; Yáñez, 2005). Apesar dos tratados de paz, a fronteira esteve quase permanentemente em guerra, com ciclos de maior ou menor intensidade, que culminou com a chamada guerra da pacificação da Araucanía entre 1862 e 1883, quando o Estado chileno empreendeu uma política de extermínio, invadiu e consolidou seu controle sobre o território indígena (Bengoa, 2014).

${ }^{129}$ S.O. Berg, L.E. Hanson \& W.P. Martin, op. cit.,p. 32.

${ }^{130}$ Idem, p. 25.
} 
Em 1962, o campus de Chillán contava com um quadro de 33 professores e seguia financiado por agências estadunidenses. ${ }^{131}$

Os Rockefeller e a USAID também investiram na melhoria de duas estações experimentais do Ministério de Agricultura (La Platina e Temuco), bem como na construção da nova estação experimental de Chillán em parceria com a universidade. Fortalecia-se a ideia de que a ciência poderia ser uma ferramenta redentora da agricultura. "A solução para o problema do aumento da produção de trigo para atingir as necessidades chilenas", alertavam os cientistas de Minnesota, "não deve ser apenas uma preocupação do geneticista do trigo ou do agricultor, mas também do fitopatólogo, do pedólogo, do especialista em cultivos, do extensionista, dos economistas, engenheiros de produção e do bioquímico". ${ }^{132}$ A ideia de uma modernização agrária comandada pela ciência, colocava os proprietários, os camponeses e os trabalhadores rurais no papel de aplicadores da inteligência dos outros. Era preciso plantar o conceito, nas comunidades rurais, de que os cientistas eram os sujeitos propulsores da modernização. Na tabela 7 , é possível ver o conjunto de fazendas experimentais agrícolas existentes no Chile em 1963.

\begin{tabular}{|c|c|c|c|c|}
\hline \multicolumn{5}{|c|}{ Tabela 7 - Estações experimentais agrícolas no Chile (1963) } \\
\hline Estação & $\begin{array}{c}\text { Comuna, } \\
\text { Região }\end{array}$ & $\begin{array}{l}\text { A quem } \\
\text { pertence }\end{array}$ & $\begin{array}{l}\text { Superfície } \\
\text { (ha) }\end{array}$ & Pesquisas \\
\hline $\begin{array}{l}\text { Estação } \\
\text { Central La } \\
\text { Platina }\end{array}$ & $\begin{array}{ll}\text { Próxima } & \text { a } \\
\text { Santiago, } \\
\text { Região } \\
\text { Metropolitana }\end{array}$ & $\begin{array}{l}\text { Min. } \\
\text { Agricultura }\end{array}$ & 301 & $\begin{array}{l}\text { Milho, cereal, feijão, } \\
\text { oleaginosas, nutrição animal, } \\
\text { irrigação, fertilizantes }\end{array}$ \\
\hline $\begin{array}{l}\text { Estação Sul } \\
\text { Trianon }\end{array}$ & $\begin{array}{l}\text { Temuco, } \\
\text { Araucanía }\end{array}$ & $\begin{array}{l}\text { Min. } \\
\text { Agricultura }\end{array}$ & 210 & $\begin{array}{l}\text { Cereal, batata, forragem, } \\
\text { oleaginosas, herbicidas }\end{array}$ \\
\hline $\begin{array}{l}\text { Estação } \\
\text { Centro-Sul } \\
\text { Tres } \\
\text { Hijuelas }\end{array}$ & Chillán, Ñuble & $\begin{array}{l}\text { Min. } \\
\text { Agricultura e } \\
\text { U. } \\
\text { Concepción }\end{array}$ & 300 & $\begin{array}{l}\text { Milho, cereal, forragem, } \\
\text { oleaginosas, nutrição animal, } \\
\text { herbicidas e fertilizantes }\end{array}$ \\
\hline Anibal & $\begin{array}{l}\text { Ovalle, } \\
\text { Coquimbo }\end{array}$ & $\begin{array}{l}\text { Min. } \\
\text { Agricultura }\end{array}$ & 103 & Cereais e forragem \\
\hline Porvenir & $\begin{array}{l}\text { Caquenes, } \\
\text { Maule }\end{array}$ & $\begin{array}{l}\text { Min. } \\
\text { Agricultura }\end{array}$ & 352 & $\begin{array}{l}\text { Gestão de biomas, vegetais, } \\
\text { recursos florestais }\end{array}$ \\
\hline $\begin{array}{l}\text { Canal Bajo e } \\
\text { Barro } \\
\text { Blanco }\end{array}$ & $\begin{array}{l}\text { Osorno, Los } \\
\text { Lagos }\end{array}$ & $\begin{array}{l}\text { Min. } \\
\text { Agricultura }\end{array}$ & 198 & Cereal e forragem \\
\hline Human & $\begin{array}{l}\text { Los Angeles, } \\
\text { Biobío }\end{array}$ & $\begin{array}{l}\text { Min. } \\
\text { Agricultura }\end{array}$ & 787 & $\begin{array}{l}\text { Trigo, beterraba, forragem, } \\
\text { maças e pecuária }\end{array}$ \\
\hline Fruticula & $\begin{array}{l}\text { Vicuña, } \\
\text { Coquimbo }\end{array}$ & $\begin{array}{l}\text { Min. } \\
\text { Agricultura }\end{array}$ & 105 & Frutas, forragem e vegetais \\
\hline Vivero & $\begin{array}{l}\text { La Serena, } \\
\text { Coquimbo }\end{array}$ & $\begin{array}{l}\text { Min. } \\
\text { Agricultura }\end{array}$ & 4 & Frutas e floresta \\
\hline EI Sauce & $\begin{array}{l}\text { Los Andes, } \\
\text { Valparaíso }\end{array}$ & $\begin{array}{l}\text { Min. } \\
\text { Agricultura }\end{array}$ & 133 & $\begin{array}{l}\text { Cebola, tomate e feijão. } \\
\text { Inseticidas. }\end{array}$ \\
\hline $\begin{array}{ll}\text { Santa } & \\
\text { Teresa de } \\
\text { Viluco }\end{array}$ & $\begin{array}{l}\text { Paine, Região } \\
\text { Metropolitana }\end{array}$ & $\begin{array}{l}\text { Min. } \\
\text { Agricultura }\end{array}$ & 120 & $\begin{array}{l}\text { Feijão, trigo, milho } \\
\text { oleaginosas }\end{array}$ \\
\hline
\end{tabular}

${ }^{131}$ Idem, p. 63, 70 .

132 Idem, p. 83. 


\begin{tabular}{|l|l|l|c|l|}
\hline El Fiscal & $\begin{array}{l}\text { Collipulli, } \\
\text { Araucanía }\end{array}$ & $\begin{array}{l}\text { Min. } \\
\text { Agricultura }\end{array}$ & 421 & Forragem \\
\hline Centinela & $\begin{array}{l}\text { Puerto Octay, } \\
\text { Los Lagos }\end{array}$ & $\begin{array}{l}\text { Min. } \\
\text { Agricultura }\end{array}$ & 435 & Batata \\
\hline $\begin{array}{l}\text { La } \\
\text { Rinconada }\end{array}$ & $\begin{array}{l}\text { Maipu, Região } \\
\text { Metropolitana }\end{array}$ & $\begin{array}{l}\text { Universidad } \\
\text { e do Chile }\end{array}$ & 1200 & $\begin{array}{l}\text { Milho cereal, vinícolas e } \\
\text { frutas, forragem e pecuária }\end{array}$ \\
\hline Pirque & $\begin{array}{l}\text { Pirque, Região } \\
\text { Metropolitana }\end{array}$ & $\begin{array}{l}\text { Universidad } \\
\text { e Católica }\end{array}$ & 300 & $\begin{array}{l}\text { Milho cereal, vinícolas e } \\
\text { frutas, forragem, aves e } \\
\text { pecuária }\end{array}$ \\
\hline Austral & $\begin{array}{l}\text { Valdívia, Los } \\
\text { Rios }\end{array}$ & $\begin{array}{l}\text { Universidad } \\
\text { e Austral }\end{array}$ & 375 & $\begin{array}{l}\text { Batata e forragem, pecuária, } \\
\text { fertilizantes }\end{array}$ \\
\hline
\end{tabular}

Fonte: adaptada de BERG, S.O., HANSON, L.E. \& MARTIN, W.P. Op. cit. p. 44-45

O Plano Chillán abarcava as províncias de Ñuble, Maule (Vale Central) e Concepción (Fronteira). As duas primeiras, Ñuble e Maule, possuíam aproximadamente 38\% de terras irrigadas, um índice mais baixo do que outras regiões do Vale Central, como Aconcágua e Colchagua, que chegavam a $63 \%$ e $67 \%$. Segundo o ICIRA, 88 propriedades de Ñuble eram de "grande potencial produtivo", promissores para modernização, correspondendo a $26 \%$ da superfície da província. Na tabela 8 a seguir, é possível observar a estrutura de propriedades agrárias separadamente, em três zonas geográficas do país.

\begin{tabular}{|c|c|c|c|c|c|c|}
\hline \multicolumn{7}{|c|}{ Tabela 8 - Estrutura de propriedades agropecuárias no Chile por zona $(\%)-1955$} \\
\hline & $\%$ & $\begin{array}{l}\text { Multifamiliares } \\
\text { grandes }\end{array}$ & $\begin{array}{l}\text { Multifamiliares } \\
\text { médias }\end{array}$ & Familiares & Subfamiliares & $\begin{array}{l}\text { Superfície } \\
\text { agrícola total } \\
\text { (hectares) }\end{array}$ \\
\hline \multirow{2}{*}{$\begin{array}{c}\text { Vale } \\
\text { Central }\end{array}$} & $\begin{array}{c}\mathrm{N}^{0} \mathrm{de} \\
\text { propriedades }\end{array}$ & 7,6 & 12,2 & 32,1 & 48,1 & \multirow{2}{*}{6.219 .300} \\
\hline & $\begin{array}{c}\text { Superfície } \\
\text { agrícola }\end{array}$ & 86,6 & 8,2 & 4,6 & 0,6 & \\
\hline \multirow{2}{*}{ Fronteira } & $\begin{array}{c}\mathrm{N}^{0} \mathrm{de} \\
\text { propriedades }\end{array}$ & 9,4 & 21,3 & 46,4 & 22,9 & \multirow{2}{*}{4.040 .623} \\
\hline & $\begin{array}{c}\text { Superfície } \\
\text { agrícola }\end{array}$ & 73,6 & 18,1 & 8,1 & 0,2 & \\
\hline \multirow{2}{*}{$\begin{array}{l}\text { Los Lagos } \\
\text { e Chiloé }\end{array}$} & $\begin{array}{c}\mathrm{N}^{0} \text { de } \\
\text { propriedades }\end{array}$ & 3,9 & 22,4 & 54,7 & 19,0 & \multirow{2}{*}{3.799 .066} \\
\hline & $\begin{array}{c}\text { Superfície } \\
\text { agrícola }\end{array}$ & 65,4 & 26,7 & 7,6 & 0,3 & \\
\hline
\end{tabular}

Nas províncias de Ñuble e Maule (ao sul do Vale Central, quase zona da Fronteira), aproximadamente $34 \%$ da superfície de cultivos era explorada por relações de mediería. Dentro das grandes propriedades, $47 \%$ dos trabalhadores eram peões ou afuerinos, $26 \%$ inquilinos e $8,7 \%$ medieros, somando cerca de 48 mil pessoas (CIDA, 1966: 14, 49, 53, 148). Compunham o público final almejado pelo plano Chillán. Os Rockefeller patrocinaram 120 clubes de juventude nessas províncias, 
projetados como locais aglutinadores das comunidades rurais receptoras das novas práticas, com atividades educativas e culturais diversas, incluindo demonstrações produtivas de novos produtos. ${ }^{133}$

As demonstrações desenvolvidas visavam melhorar as técnicas de produção dos cultivos de trigo, arroz, milho, forragem, oleaginosas, feijão, lentilha, madeira, além de modernizar as áreas de zoopatologia, nutrição animal, fertilidade do solo, controle de pragas, herbicidas, inseticidas e maquinaria agrária. Enquanto isso, Concepción representava um polo urbano e industrial importante, funcionando como fornecedora de estrutura universitária e intelectual para o plano. Segundo os cientistas de Minnesota que chegaram ao Chile uma década mais tarde, existiam "poucas dúvidas de que o Plano Chillán contribuiu enormemente para a promoção da eficiência da produção agrária na região". ${ }^{134}$

$\mathrm{O}$ rápido aumento dos rendimentos agrícolas teria sido consequência de duas práticas consideradas básicas e incentivadas pelas agências dos Estados Unidos: a expansão da superfície irrigada e o uso de fertilizantes. O compromisso da USAID com a CORFO teria sido alcançar um crescimento de 5,5\% da produtividade no prazo de uma década. ${ }^{135}$ Naquele contexto, estudos realizados nas estações experimentais de Temuco e Chillán demonstraram que a aplicação sistemática de fertilizantes modernos para alfafa, cultivada para alimentação animal, gerava rendimentos 3 a 5 vezes maior do que o custo dos novos insumos, e no caso da batata e beterraba, os rendimentos eram de 5 a 10 vezes mais altos. ${ }^{136}$

As demonstrações sobre as vantagens dos fertilizantes nos rendimentos agrícolas abriam um novo mercado para os Estados Unidos. Entre 1956 e 1965, o Chile expandiu a aplicação de fertilizantes nos cultivos a uma taxa de 10\% ao ano. Em 1965, a ODEPA (Oficina de Planificação Agrícola do Ministério da Agricultura) projetava o aumento de $72 \%$ do uso de fertilizantes e de $54 \%$ dos pesticidas para 1971. No entanto, apenas $10 \%$ desses insumos eram produzidos no país, enquanto os Estados Unidos figuravam com o maior produtor mundial. ${ }^{137}$ Assim, se por um lado a modernização agrícola se encaixava em praticamente todas as narrativas políticas chilenas para superação do subdesenvolvimento, a alavanca necessária para livrar o país do peso das importações de alimentos e o melhor caminho para destravar a estagnação agrária, por outro, levar a modernização agrícola a cabo gerava novos encargos à balança comercial devido à necessidade de importar novos insumos que o Chile ainda não produzia. Segundo propôs Ortega (1987), o Plano Chillán foi o marco inaugural de um programa de tecnificação agrária paradigmático e transversal, ou seja, defendido por reformistas, marxistas e até setores da oligarquia. Entre 1950 e 1964, o número de tratores utilizados no campo chileno cresceu 48\%, de 7200 a 22 mil. Já a importação de pesticidas, que custava ao país 4 milhões de

${ }^{133} \mathrm{~W}$ Wilhelm. Agricultural education development in Argentina and Chile. Ford Foundation Catalogued Reports. Report $002626,1964$.

${ }^{134}$ S.O. Berg, L. E. Hanson \& W. P. Martin, op. cit., p. 33.

${ }^{135}$ Idem, p. 34.

${ }^{136}$ Id. ibid., p. 82.

${ }^{137}$ ODEPA, Plan de desarrollo agropecuario 1965-1980, p. 57, 104. 
dólares em 1960, se expandiu para 10 milhões de dólares em 1965 e depois 16 milhões em 1975 (Ortega, 1987: 17, 19).

Para além da transformação produtiva local, os cientistas de Minnesota avaliavam que o plano Chillán tinha sido relativamente bem-sucedido em exportar o modelo institucional estadunidense para organizar um sistema de extensão rural no Chile. Foi criado um organismo estatal de extensão, o Departamento de Extensão Agrária do Ministério da Agricultura, com oficinas descentralizadas no território. Para comandar essa arquitetura, os Rockefeller alojaram seu escritório de estudos especiais dentro do Ministério da Agricultura. ${ }^{138}$ O Plano Chillán também levou o Ministério a criar o Departamento de Conservação e Assistência Técnica (DECAT), para atuar da gestão de solos. Em 1963, o Departamento de Extensão Agrária possuía 63 escritórios pelo país, mas apenas 47 tinham funcionários contratados e somente 39 agrônomos disponíveis. ${ }^{139} \mathrm{Em} 3$ de julho de 1963, a lei 15.205 aboliu o Departamento de Extensão Agrária e transferiu suas funções para o recém-criado INDAP (Instituto de Desenvolvimento Agropecuário). O INDAP também assumiu as atribuições do DTICA, entre elas a articulação de convênios internacionais de assistência técnica e extensão.

O Plano Chillán, porém, teve seus pontos fracos. "Não estavam suficientemente enraizados em pesquisas", segundo os avaliadores de Minnesota, e "os fundos de ajuda do Ponto Quatro foram removidos cedo demais". ${ }^{140}$ Sua curta duração (6 anos) não permitiu o desenvolvimento de um processo educacional mais amplo e efetivo. Além disso, sua dimensão foi pequena para as metas anunciadas e, como os próprios reconheceram, o staff técnico dos Estados Unidos não estava preparado para atuar na complexa estrutura agrária e cultural do campo chileno. Tampouco havia profissionais nacionais suficientes para realizar com competência e amplitude a construção de novas pontes educacionais entre o mundo urbano e o mundo rural, requeridas para a transformação produtiva.

Outro elemento problemático foi a dificuldade de comunicação entre técnicos da cidade e produtores do campo. "Agricultores são particularmente desconfiados e confiam em poucas pessoas, menos ainda naqueles que possuem considerável educação", ${ }^{141}$ constataram no relatório para Fundação Ford. Por outro lado, "os instruídos pelo Instituto de Educação Rural (IER) conseguem ganhar confiança mais facilmente destes agricultores do que os graduados em Faculdades de Agronomia". ${ }^{142}$ De origem camponesa, os técnicos capacitados pelo IER se desempenhavam melhor como extensionistas do que os mais bem formados agrônomos da cidade, uma vez que possuíam trânsito, confiança e comunicação natural entre seus pares do campo.

O IER está desempenhando um excelente trabalho de extensão agrícola com pequenos proprietários e suas famílias e com pequenas comunidades agrícolas. Suas escolas para treinamento de líderes comunitários agrícolas por

\footnotetext{
${ }^{138}$ S. O. Berg, L.E. Hanson \& W. P. Martin, p. $27,79$.

${ }^{139}$ Id. ibid, p. 93, 102.

${ }^{140}$ Id. ibid, : p. 99.

${ }^{141}$ Id. ibid., p. 53.

${ }^{142}$ Uma análise sobre o papel do IER e dos cristãos na educação agrária chilena será objeto exclusivo de um próximo capítulo. Id. ibid., p. 53.
} 
todo país são, em geral, respeitadas, e também o são seus programas de rádio, campanhas visuais e cursos curtos. ${ }^{143}$

Em sinal de reconhecimento e alinhamento ideológico, os Estados Unidos financiavam vários programas do IER, especificamente a escola Abrahan Lincoln - "é um excelente trabalho e merece o apoio da USAID". ${ }^{144}$ A barreira hierárquica entre campo e cidade era o desafio cultural mais importante da educação agrária. Agrônomos de origem urbana, formados em universidades de elite, tinham dificuldades para fazer essa transposição. Na maioria dos casos, porque emanavam um espírito de superioridade acadêmica, simbólica e social que não combinava com a atividade educativa e não inspirava confiança ao agricultor. Como indicou Thiesenhusen, "tornar-se uma pessoa que ensina ao invés de mandar - rompendo com a atitude noblesse oblige - não é uma tarefa pequena e nem todos são favoráveis" (Thiesenhusen, 1965a: 18-19). Ao mesmo tempo, os técnicos agrícolas, de estratos médios, eram insuficientes para a dimensão da tarefa extensionista que as agências estadunidenses propunham.

Era fato que, na perspectiva da modernização técnica, a agricultura chilena estava "sendo punida porque quase nenhum agrônomo bem treinado tem origens rurais e para eles é muito difícil trabalhar efetivamente com a população rural precariamente educada". ${ }^{145}$ Mas o olhar de longo prazo das agências estadunidenses na formação dos mercados de insumos as fazia atuar pacientemente, semeando seus conceitos no terreno germinal do sistema social: as escolas primárias. A educação agrária para transformação produtiva ia muito além do Plano Chillán e do foco na assistência técnica. Os projetos de expansão das escolas primárias rurais, visando o aumento da base das crianças camponesas alfabetizadas e a produção de materiais didáticos, estavam no radar do investimento externo.

\subsection{Semear escolas rurais: o Plano Victória}

Em 1963, segundo constataram agentes estadunidenses, 42\% dos habitantes rurais ainda não sabiam ler ou escrever. No segmento específico da população rural de 15 anos de idade, $36 \%$ eram analfabetos, índice altíssimo para faixa etária. ${ }^{146}$ No olhar da agenda estadunidense para transformação produtiva, o analfabetismo rural não era apenas um problema social, mas também um obstáculo à plantação dos conceitos, um problema educacional que emperrava as possibilidades de transformação técnica da agricultura nos anos subsequentes. Transpor esse obstáculo, isto é, alfabetizar crianças rurais e expandir a rede de escolaridade no campo, significava atacar a "questão social", mas também ampliar os canais de interação e as possibilidades de diálogo entre campo e cidade por meio do letramento. Esses canais eram vitais ao projeto de transformação produtiva levado a cabo pelas agências e universidades dos Estados Unidos na América Latina e se encontravam emperrados por séculos de

\footnotetext{
143 Id. ibid, p. 37.

${ }^{144}$ Id. ibid., p. 52.

${ }^{145}$ Id. ibid., p. 57.

146 Id. ibid., p. 49.
} 
abandono educacional do campo. Não porque o campo estivesse isolado, como problematizou Pascal Allende (1971), mas sim porque a modernização agrária era um projeto de reestruturação das relações campo-cidade, que propunha substituir a dominação oligárquica e a produção extensiva pela dominação tecno-empresarial e a produção intensiva. Isso só poderia ser levado a cabo por novos sujeitos-nexo, que não existiam a priori: era preciso formá-los e essa era uma tarefa de longo prazo.

A promessa anunciada pelo governo de Jorge Alessandri foi viabilizar o ingresso de 40 a 60 mil crianças nas escolas primárias por ano, somando campo e cidade. ${ }^{147}$ Mas essa promessa não atacava o verdadeiro problema. Entre 1930 e 1960, a matrícula das crianças chilenas na escola primária cresceu de $59 \%$ para $82 \%$ da população entre 7 e 14 anos. No entanto, $70 \%$ a $80 \%$ das crianças ingressantes evadiam e nunca terminavam o primário (Loyola, 2018: 151; Rengifo, 2018: 161). No caso das crianças rurais, a evasão era ainda maior, considerando que, em média, começavam a trabalhar no campo regularmente com 8 ou 9 anos de idade. ${ }^{148}$

No ensino secundário rural, a situação era ainda pior. Em 1962, existiam apenas 16 escolas rurais secundárias públicas no país e 25 privadas. ${ }^{149} \mathrm{O}$ caso do secundário técnico em agricultura, então, era ainda mais restrito. Em 1939, as matrículas gerais no ensino técnico alcançaram 25\% do total das escolas secundárias. Contudo, apenas $1 \%$ dessas correspondiam à escola técnica agrária. $\mathrm{O}$ tema preocupava os agentes estadunidenses: "a educação agrária é de longe a parte menos efetiva do ensino secundário no Chile. Apenas 2.600 alunos estão nesse nível de treinamento e 2.200 deles recebem uma péssima instrução. (...) Os professores são mal qualificados e mal pagos". ${ }^{150}$ Essa realidade não se alterou até 1960, quando a escola técnica agrária correspondia $2 \%$ do total das matrículas públicas do ensino secundário.

Existiam três níveis de formação técnica secundária para agricultura no Chile, destinados a jovens de estratos médios ou médios-baixos, que concluíam os seis anos da escola primária, mas em geral eram excluídos pelos sistemas elitistas de ingresso nas universidades. O curso mais básico, de 3 anos, formava auxiliares do campo e era oferecido por apenas 8 escolas públicas em todo país. Depois, havia um curso de 5 anos oferecido por 4 escolas públicas, que formava os práticos agrícolas. O terceiro e mais longo, requeria de 6 a 7 anos de estudo e o diploma de prático para ingresso. Apenas uma escola pública em San Felipe oferecia essa modalidade, na qual se formavam técnicos agrícolas. "A educação agrícola nos níveis intermediários é um campo inexplorado na América Latina", constatava Solon Barraclough (Barraclough, 1962:15).

A escola de técnicos de San Felipe era altamente seletiva. Recebeu somente 41 alunos novos em 1960. Em 1963, aprovou a entrada de 60 e reprovou 35 candidatos na admissão. Eram cerca de 100

\footnotetext{
${ }^{147}$ Id. ibid., p. 50.

${ }^{148}$ Como confirmado no depoimento de camponeses sobre sua experiência de trabalho infantil regular na roça ou em serviços domésticos. Entrevistas com Martim Vázquez, Santiago, 28/04/2017; Leonal Abarca, Santiago, 02/05/2017; Alice Muñoz, Santiago, 14/05/2017; Ovídio Díaz, San Clemente, 27/05/2017.

${ }^{149}$ S. O. Berg, L. E. Hanson \& W. P. Martin, op. cit., p. 54.

${ }^{150}$ Id. ibid, p. 54-55.
} 
alunos para quatro professores em tempo integral, e cinco instrutores em tempo parcial. ${ }^{151}$ No nível de formação de professores, não era diferente: existiam somente 14 escolas normais em todo país, das quais 7 eram rurais. ${ }^{152}$ Tudo isso, a despeito do que afirmou a historiadora Carolina Loyola: "a taxa de investimento em capital humano que o país efetuou entre 1940 e 1960 foi, de longe, a mais ampla registrada até então" (Loyola, 2018: 145). Loyola argumenta ainda que a expansão do sistema escolar ocorrida em 1950 e 1960 teria sido mais acelerada do que a mudança da estrutura econômica, dando origem a uma nova camada de pessoas escolarizadas, que não encontravam empregos correspondentes ao seu nível de formação em razão da lentidão dos projetos modernizadores da estrutura econômica. ${ }^{153}$ $\mathrm{Se}$, em termos econômicos, a agricultura chilena havia sido relegada ao segundo plano na estratégia de desenvolvimento, situação que só foi alterada com a reforma agrária de 1967, em termos educacionais, a escola rural e o ensino técnico agrário estavam igualmente abandonados, ficando muito aquém das expectativas da modernização cultural. Essa situação preocupava os agentes estadunidenses, que o explicitaram para Fundação Ford.

Foi nesse cenário que a parceria da AIA, dos Rockefeller e da CORFO deu origem à Comissão Especial para Educação Rural no Chile, com objetivo de ampliar a infraestrutura educacional do campo, construir escolas rurais, atuar na formação de professores e na produção de materiais didáticos. A importância deste experimento para a família Rockefeller não era pequena. O plano Victória, "cujo nome foi dado pelos próprios chilenos para nosso programa de educação rural", ${ }^{154}$ contam, incluía a construção de 14 escolas primárias rurais no departamento de Victória, província de Malleco. Rodman Rockefeller, filho mais velho do Nelson Rockefeller, esteve em Concepción em 1962. Além de reunirse com os membros da Comissão Especial para Educação Rural, pretendia deslocar-se em pessoa para comuna de Victoria, a $210 \mathrm{~km}$ dali, e conferir o terreno do seu experimento, como contava seu funcionário Ernest Maes em carta para John R. Camp. ${ }^{155}$ Em 1947, os Rockefeller haviam fundado a International Basic Economic Corporation, uma empresa de comercialização genética e agronegócio que atuava na América Latina. Foi por meio dela que a revolução verde se esparramou por diferentes países do mundo subdesenvolvido. Cinco anos depois da sua visita à Victória, Rodman tornou-se vicepresidente da IBEC, e passou a se dedicar prioritariamente à questão agrária e ao mercado de insumos. Seu interesse em escolas rurais e educação agrária nas profundezas do Chile, portanto, não era mero voluntarismo.

O professor Enrique Salinas, da escola rural normal de Copiapó, se associou ao plano Victória e tornou-se Secretário Executivo da Comissão Especial para Educação Rural. Foi uma pessoa chave na articulação orçamentária entre AIA e CORFO e, mais importante, na execução de uma das metas-chave

\footnotetext{
${ }^{151}$ Id. ibid., p. 55.

152 Id. ibid., p. 50.

153 "Tanto as reformas parciais elaboradas durante os governos da Frente Popular, como os planos integrais de Alessandri e Frei, se bem enraizaram a orientação econômica da educação, não conseguiram impedir a desarticulação entre a formação e a capacitação da mão de obra e as exigências do mercado laboral" (Loyola, 2018: 146).

${ }^{154}$ AIA, op. cit.

${ }^{155}$ Id. ibid.
} 
do projeto: proporcionar o engajamento comunitário no plano, estimular clubes de juventude e incentivar a participação de juntas de vecinos, centros de madres e associações rurais na construção das escolas. “A Comissão Especial para Educação Rural está fazendo todo possível para integrar o programa em seus dois aspectos, como indicado no acordo básico, construção de escolas e desenvolvimento técnico, realizados pelos próprios chilenos", reportou Ernst Maes em abril de 1962. ${ }^{156}$ A AIA se preocupava conectar a expansão do sistema escolar rural, comandada pela comissão da CORFO, com a inserção de pedagogias rurais diferenciadas, novos materiais, nova organização curricular e a formação de docentes alinhados com as mudanças. Almejavam o máximo engajamento possível das bases comunitárias rurais.

Em um relatório de 1963, Maes afirmou que "o maior desafio dessa conexão era prover ao programa de educação rural no Chile uma orientação mais funcionalista em termos de necessidades da criança rural. Isso está sendo feito com a adição de práticas vocacionais agrícolas e cursos sobre mercados agropecuários no currículo elementar". ${ }^{157}$ Em outras palavras, o que se propunha era uma intervenção no currículo das crianças rurais por meio da inserção de duas horas de práticas agrícolas na escola todos os dias a partir dos 9 anos de idade. Era, sem margem a dúvidas, um dispositivo pedagógico para treinar, capacitar e disciplinar os futuros trabalhadores rurais desde a infância. Segundo Maes, "os chilenos ficaram deslumbrados" 158 com os materiais apresentados em um workshop sobre educação vocacional agrária para crianças. Ao mesmo tempo, a AIA reportava a necessidade de "eliminar o sistema antipedagógico de ditado nas séries elementares usados agora devido à escassez de materiais", atuando, ainda que discretamente, no debate das reformas pedagógicas do país. ${ }^{159}$

Transcorrido pouco mais de um ano, em julho de 1963, a construção de oito escolas estava em fase final. Eram elas: Lilás, Colo, Rosario, San Gregorio, Las Cardas, California, Quino, Coihueco. Todas as comunidades tinham se engajado no projeto, como mostram as fotos. ${ }^{160}$

\footnotetext{
156 Id. ibid.

${ }^{157}$ Id. ibid.

158 Id. ibid.

${ }^{159}$ Sobre as reformas pedagógicas e as escolas experimentais chilenas dos anos 1930 aos 1960, ver Mayorga, $2018 \mathrm{~b}$.

${ }^{160}$ AIA, Series 1027. AIA Photographs. Subseries 3: Chile. Box 6. Folder 139. Folder Title: 233: School in Las Lilas; $238 ?$ School at San Gregorio; 256: School at Colo; 261: Las Cardas, Chile; 262: Las Cardas, Chile. Data: 1963, 1964.
} 


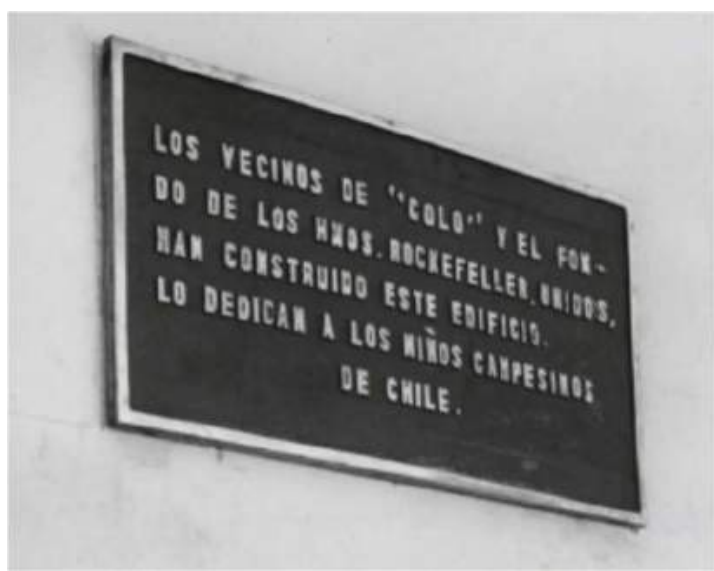

"Os vecinos de Colo e o Fundo dos Irmãos Rockefeller, unidos, construíram este edifício. $\mathrm{O}$ dedicam às crianças camponesas do Chile". Colo, 1963/1964

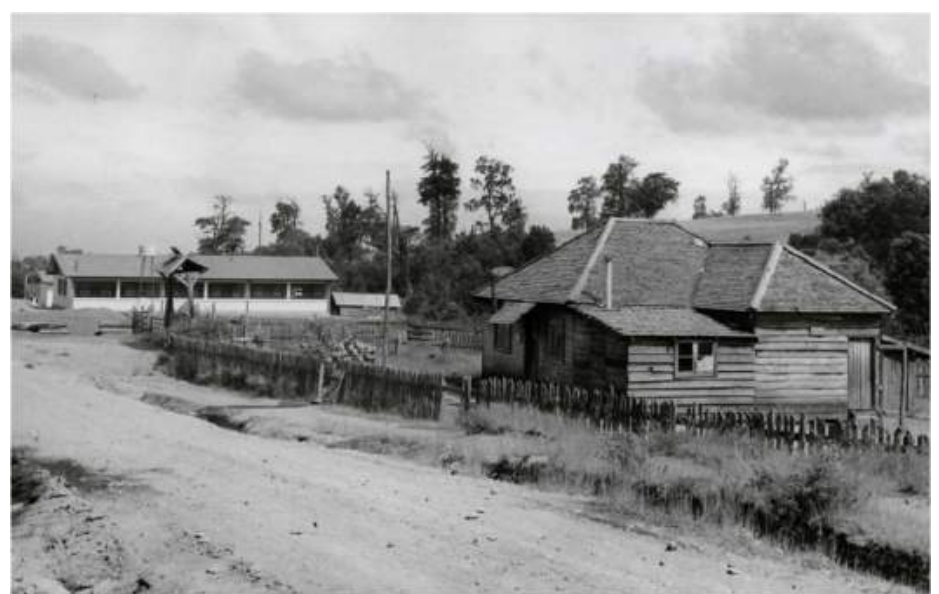

$\mathrm{Na}$ frente, a velha escola adaptada de uma casa. No fundo a nova escola do Plan Victória, para 150 alunos. San Gregorio, 1963/1964

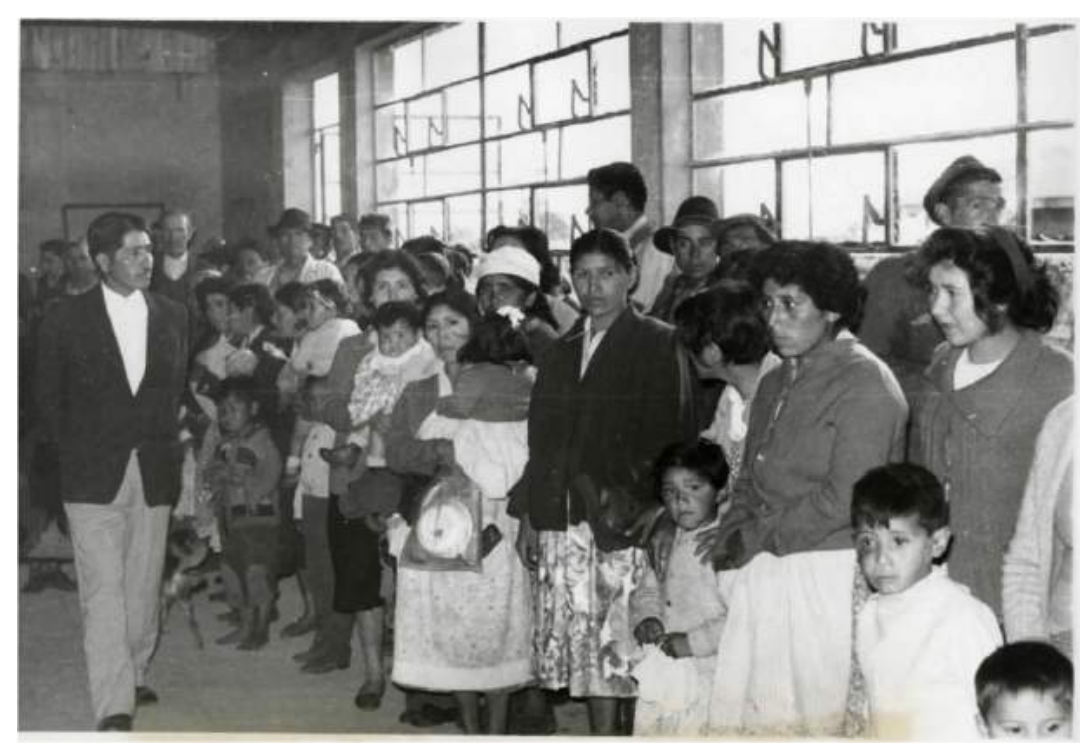

Plan Victória em Las Cardas, 1963/1964
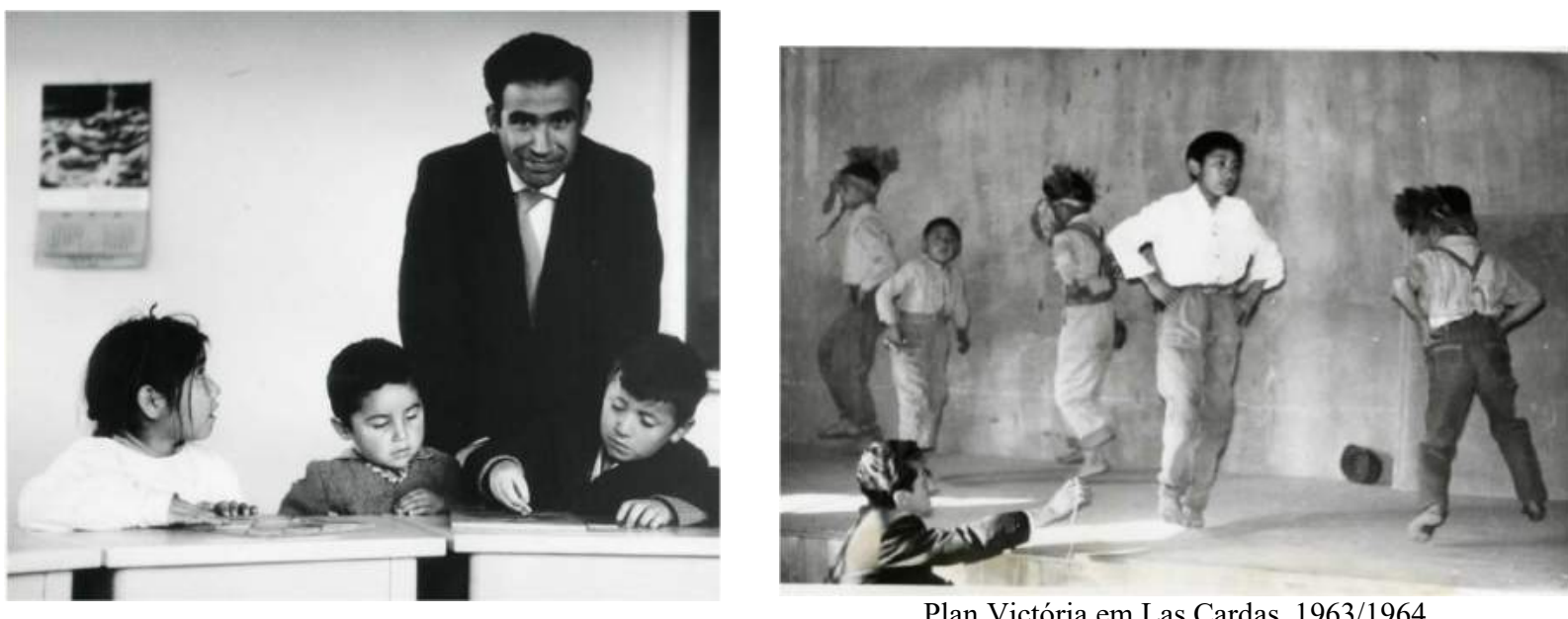

Plan Victória em Las Cardas, 1963/1964

"Plan Victória. Escola Las Lilas. Professor com seus pupilos na nova escola", Las Lilas, 1963/1964 
Concomitantemente, as equipes de produção de materiais didáticos tinham adquirido livros para as bibliotecas com os 9 mil escudos da AIA destinados a isso, e estavam criando oficinas de marcenaria rural para jovens. Eram três tipos de escola em construção: as chamadas do tipo A, tinham $426 \mathrm{~m}^{2}$ e 4 salas de aula, para comunidades pequenas; as escolas tipo B, com $696 \mathrm{~m}^{2}$ e seis salas de aulas; e as escolas tipo C, com $823 \mathrm{~m}^{2}$ e oito salas de aulas. O investimento médio da AIA era de 80 escudos por $\mathrm{m}^{2}$.

Não eram apenas de livros, cimento e tijolos que os investimentos eram feitos. Projetos de articulação social que conectavam "técnicas escolares" com "centros juvenis" e "trabalhos nas comunidades" eram edificados. Em setembro de 1963, todas as comunidades engajadas demonstravam pressa para receber suas escolas, e então a Comissão Especial da CORFO decidiu liberar o uso das instituições antes mesmo da inauguração oficial. A carência era profunda e o engajamento foi geral. Em 1964, além de projetarem outras seis escolas do plano Victória, sinalizaram a replicação do método como Plano Nuble. ${ }^{161}$

É interessante notar que a temporalidade dos investimentos educacionais agrários dos Rockefeller, dos Ford, da USAID e da AIA eram longas. Ao apostar em escolas primárias e formação vocacional de crianças rurais, demonstravam que suas estratégias de mercado se sincronizavam com o tempo lento da mudança cultural, que poderia levar gerações até produzir resultados palpáveis. Mas a atuação no médio prazo também era crucial, como mostra o projeto de formação de agrônomos extensionistas chilenos, acordado entre Fundação Ford e Universidade de Minnesota.

\subsection{Formar extensionistas: o programa Minnesota-Ford}

Em suas oito semanas de viagem pelo Chile, entre 23 de setembro e 22 de novembro de 1963, Berg, Hanson e Martin, da Universidade de Minnesota, reuniram-se sistematicamente com o staff agrário dos Estados Unidos no Chile e com dezenas de acadêmicos de universidades chilenas, alguns com doutorado na Califórnia ou Chicago. Foram 14 encontros com a Fundação Rockefeller, 12 reuniões com oficiais da USAID, 7 conversas com membros da missão Chile-Califórnia (USAID), 2 reuniões com a UNESCO sobre educação rural e 16 dias dedicados integralmente a encontros com autoridades de quatro das sete Faculdades de Agronomia existentes no país. A expressiva presença de agentes estadunidenses atuando na educação agrária chilena àquela altura era resultado de duas gerações de esforços.

As diferentes iniciativas paralelas dos Estados Unidos na educação agrária chilena foram pouco a pouco sendo sincronizadas: "Ford e Rockefeller devem trabalhar juntos em extensão e pesquisa, enquanto Califórnia e Minnesota devem complementar-se uma à outra", ${ }^{162}$ propuseram. Os pioneiros do projeto Minnesota recomendaram que a Fundação Ford criasse um escritório especial de extensão

\footnotetext{
${ }^{161}$ AIA, op. cit.

162 S.O. Berg, L.E. Hanson \& W.P. Martin, op. cit., p. 95, 98-99.
} 
rural dentro do Ministério da Agricultura, a exemplo da AIA na CORFO e dos Rockefeller no mesmo Ministério. ${ }^{163}$ Nesse sentido, a Fundação Ford já atuava dentro da Comissão de Planejamento Educacional do Ministério da Educação. ${ }^{164}$

As principais recomendações de Berg, Hanson e Martin foram em seguida convertidas em objetivos do Projeto Minnesota de Extensão Agrícola no Chile (Minnesota Agriculture Extension Project in Chile). Entre elas, se propunha uma assessoraria ao governo chileno na estruturação de um sistema nacional de extensão rural, que incluia uma nova carreira para extensionistas e dava-lhes salários mais estimulantes e veículos de trabalho para percorrer o país. A falta de veículos fazia com que mais de $75 \%$ dos profissionais da extensão permanecessem no escritório. ${ }^{165}$ Esse novo sistema deveria seguir um paradigma de "extensão orientada pela pesquisa", de modo a aproximar cientistas de extensionistas em coordenação com as estações experimentais. Essas deveriam ser modernizadas e os primeiros esforços deveriam se concentrar em pesquisas sobre como cultivo de cereais, forragem e nutrição animal. Também recomendavam aprimorar os métodos de extensão e comunicação, para que o conhecimento proveniente dos laboratórios e universidades penetrasse nas práticas dos agricultores e trabalhadores rurais. Para isso sugeriam convênios entre Minnesota, as Universidades de Concepción e Católica e as agências agrárias do governo. Seria necessário criar parcerias acadêmicas, oferecer bolsas de pesquisa para chilenos nos Estados Unidos e ampliar a oferta de cursos curtos. Também seriam apresentados planos de alterações curriculares nas Faculdades de Agronomia pela inserção de práticas de campo e especialização para extensionistas (área que simplesmente não existia). Destacavam também o patrocínio para novas bibliotecas e a produção de materiais educativos, folhetos e campanhas visuais, além programas de rádio e TV. Consideravam primordial que tudo isso fosse feito através das autoridades chilenas, ou seja, que a Fundação Ford se inserisse dentro dos ministérios e agências produtivas e educacionais, assim como os cientistas de Minnesota se inseriam nas universidades e nas estações experimentais. Por fim, recomendavam a replicação de experiências como o plano Chillán, atrelando estações experimentais a clubes de juventude rural como terreno de demonstrações. ${ }^{166}$

A partir dessas recomendações, o programa Minnesota de Extensão Agraria no Chile partiu com seis objetivos:

1) Estabelecer um setor de educação produtiva dentro do Instituto de Investigações Agropecuárias.

2) Produzir materiais educativos sintetizando resultados de pesquisas do IIA para agricultores.

3) Prover treinamento técnico baseado em pesquisa para o staff de extensionistas das agências agrárias públicas e privadas.

4) Pesquisar novas metodologias de educação produtiva e assistência técnica adaptadas para as condições chilenas.

\footnotetext{
163 Id. ibid., p. 95.

${ }^{164}$ W. M. Myers, Report on a trip to Chile. Report 000285, 1964.

${ }^{165}$ S.O Berg, L.E. Hanson \& W.P. Martin, op. cit., p. 3

${ }^{166}$ Id. ibid., p. 89-94.
} 
5) Conectar pesquisadores do IIA com profissionais em campo.

6) Colaborar com a Universidade na alteração curricular e no treinamento profissional superior. ${ }^{167}$

Para alavancar o programa, a Fundação Ford disponibilizou 518 mil dólares para que um staff de oito pesquisadores de Minnesota vivessem no Chile durante três anos, sob o comando do agrônomo Charles A. Simkins, do administrador rural Eugene F. Pilgrim e o especialista em comunicação Milton E. Morris. ${ }^{168}$ Em 1966, esse orçamento saltou para 825 mil dólares. ${ }^{169}$ Uma das primeiras tarefas cumpridas foi um convênio da Universidade de Minnesota com a Universidade de Concepción, com objetivo de estruturar a formação de extensionistas na Escola de Agricultura de Concepción e Chillán. Abarcava bolsas de intercâmbio, reformas curriculares e exportação de expertise. A ideia era desenvolver a especialidade de extensionista dentro da carreira de engenheiro agrônomo. Para que a política fosse executada pelos próprios chilenos, diziam, "será fornecido pela Universidade de Minnesota um Conselheiro Educacional para o Reitor [da Universidade de Concepción], que será a figura chave para o sucesso das operações (...). Ele deve se manter coordenado e integrado aos outros esforços educacionais da Fundação Ford no Chile, incluindo o contato com professor Barlett, especialista em programas educacionais da Fundação, que trabalha na Comissão de Planejamento Educacional". ${ }^{170}$

Naquele ano, a Fundação Ford possuía 4,5 milhões de dólares investidos em projetos no Chile, 80\% disso atrelado diretamente a educação e ciência. ${ }^{171}$ No projeto Minnesota-Ford, também seriam enviados especialistas em bibliotecas com uma verba de 25 a 50 mil dólares para compra de livros. $\mathrm{O}$ staff alertou, no entanto, que a verba de biblioteca era excessiva porque "as publicações sobre esse tema simplesmente não existem nesta escala". ${ }^{172}$ Tratava-se de abrir o caminho para uma nova área de pesquisa aplicada.

No setor de pesquisa aplicada, o programa de Minnesota atrelou-se ao Instituto de Investigações Agropecuárias (IIA), uma instituição semiautônoma criada em 1963, com orçamento originado de um terço do INDAP, um terço da CORFO e um terço do Tesouro. O IIA foi o principal laboratório para o programa Minnesota-Ford e, segundo relatavam, "o maior motivo para seu estabelecimento foi remover os esforços de pesquisa o mais longe possível da política e tornar viável a contratação e demissão de funcionários de acordo com o mérito. O serviço governamental hoje não permite essa flexibilidade". ${ }^{173}$ Em 1965, o IIA possuía cerca de 100 pesquisadores, no entanto estava "sob grande pressão de outros

\footnotetext{
${ }^{167}$ Cochrane, op. cit., p. 12.

${ }^{168}$ C.A Simkins, Progress Report. Minnesota Agricultural Extension Project in Chile. October 1, 1964 - September 30, 1965. Ford Foundation Catalogued Reports. Report 001703, 1965: 14. E também Cochrane, op. cit., p. 77.

${ }^{169}$ Cochrane, op. cit., p. 4.

${ }^{170}$ A influência de Minnesota sobre as estruturas de poder da Universidade de Concepción era perceptível, por exemplo, quando o reitor acatou a proposta de Myers para a nova direção do Instituto de Física, junto com uma oferta de incremento do seu salário pela Fundação Ford, e ainda solicitou recomendações de algum acadêmico estadunidense para assumir a direção do Instituto de Biologia. W. M. Myers, op. cit., 3, 4.

171 W. Wilhelm, op. cit.

${ }^{172}$ Cochrane, op. cit., p. 66.

${ }^{173}$ S. O. Berg, L. E. Hanson \& W. P. Martin, op. cit., p. 80.
} 
órgãos, como a CORA, a CORFO, o INDAP (...). Sente-se entre algumas pessoas que o instituto oferece uma contribuição pequena para agricultura chilena". ${ }^{174}$

O programa também criou departamentos de educação produtiva nas estações experimentais La Platina, Chillán e Carillanca, cujo objetivo era "sintetizar os resultados das pesquisas do IIA com materiais educacionais úteis". ${ }^{175}$ Ao menos 15 pesquisadores chilenos de La Platina e 7 em Catrillanca passaram a cooperar com a equipe de Minnesota, nas pesquisas sobre cultivos, irrigação, entomologia, virologia e apicultura. ${ }^{176}$ Além disso, 8 chilenos foram contratados diretamente para educação produtiva, 4 em La Platina, 2 em Temuco e 2 em Chillán. ${ }^{177}$ Esses profissionais seriam responsáveis por identificar as melhores metodologias de ensino e extensão, além de trazer do campo ao laboratório as necessidades práticas de pesquisa. $\mathrm{O}$ trigo, o milho e a pastagem foram rapidamente identificados como os mais fáceis para incremento produtivo por meio de procedimentos simples de fertilização.

A estruturação de um novo sistema governamental de extensão chegou ao impasse da proximidade das eleições de 1964. O relatório para Ford alertava: "não parece sábio atrelar nosso projeto a nenhum governo específico". ${ }^{178}$ Como já falamos, a estratégia educacional estadunidense para transformação produtiva chilena precisava ser coordenada no longo prazo. Havia também uma preocupação sobre a possibilidade de desequilíbrio de ritmos da formação de profissionais extensionistas antes que houvesse empregabilidade no Estado.

Sob o governo de Eduardo Frei, em 1965, o diretor Charles A. Simkins, agrônomo de Minnesota, reuniu-se com Jacques Chonchol, presidente do INDAP, órgão que havia herdado as atribuições do Departamento de Extensão Agrária, e com seu diretor técnico, Hernan Mery. ${ }^{179}$ Definiram que o INDAP iria colaborar com a distribuição de circulares técnicas preparadas pelo IIA. A primeira delas, 1500 cópias sobre produção de milho, já teria sido "bem recebida". ${ }^{180}$ Pactuaram também que seriam ministrados cursos sobre extensão para os agrônomos do INDAP. No entanto, a precariedade do órgão e suas outras prioridades tornava a atividade da extensão menos intensiva do que o programa requeria: “o Sr. Mery insistiu que sua organização está muito ocupada ofertando e coletando empréstimos para realizar tanto trabalho de extensão. Comentou que menos de $25 \%$ dos funcionários do órgão tem transporte para trabalhos de campo". ${ }^{181}$

Nas primeiras quatro atividades de "demonstração produtiva" do programa, participaram respectivamente 55, 37, 74 e 82 agricultores [farmers]. No entanto, os agrônomos extensionistas ali

\footnotetext{
${ }^{174}$ C. A. Simkins, op. cit., p. 4.

175 Id. ibid., p. 1.

${ }^{176}$ Id. ibid., p. 5.

177 Cochrane, op. cit., p. 12.

${ }^{178}$ W. M. Myers, op. cit., p. 10.

${ }^{179}$ Hernán Mery foi assassinado em abril de 1970, quando executava uma expropriação pela CORA na fazenda La Piedad, em Longaví, onde se instalou um confronto entre os camponeses. Um grupo de camponeses "apatronados" ou "amarillos" ocupou o terreno contra a CORA para impedir a reforma agrária, enquanto outro grupo lutava pela expropriação. Um camponês "amarillo" lhe deu um golpe na cabeça e Mery faleceu na hora. Segundo Octavio Avedaño, "o assassinato de Hernán Mery constituiu, sem dúvida, a ação mais desleal e grave ocorrida desde que se foi iniciado o processo de reforma agraria" (Avendaño, 2017: 244).

${ }^{180}$ C. A. Simkins, op. cit., p. 3.

${ }^{181}$ Id. ibid., p. 3
} 
presentes, segundo avaliou Simkins, "não eram vistos com muito respeito". ${ }^{182}$ Apesar do tom paternalista e da unilateralidade da missão, a equipe de Minnesota admitia que tinha muito o que aprender com os chilenos e que os primeiros três meses foram usados praticamente para entender a heterogeneidade geográfica, produtiva e social da agricultura daquele pequeno país. "Aumentar a produtividade da agricultura chilena requer muitos anos de esforço. Precisamos aprender o máximo possível sobre os problemas deles para desenvolver as soluções", 183 escreveram. Além disso, a escassez de profissionais de nível superior tornava tudo mais difícil: "a competição por jovens engenheiros agrônomos no Chile têm sido severa. Precisamos competir com grande número de agências com programas de ação pelos melhores", ${ }^{184}$ alertavam.

Fazia falta aos engenheiros agrônomos os conhecimentos específicos sobre educação e comunicação. As disciplinas de sociologia, pedagogia e antropologia, que formavam "a base das boas técnicas de trabalho com o povo", ${ }^{185}$ eram escassas ou inexistentes nas sete Faculdades de Agronomia do país, tornando os engenheiros pouco familiarizados com os sujeitos que compunham a realidade social do campo. A carreira de agronomia da Universidade do Chile, por exemplo, contava com $2 \%$ a $6 \%$ do currículo para ciências sociais. A Universidade Católica alcançava entre $2 \%$ e $10 \%$ e a Universidade de Concepción entre 0 e $3 \% .{ }^{186}$ A transformação produtiva proposta pelas agências estadunidenses e almejada pelos agentes chilenos da modernização exigia maior amplitude e sofisticação das habilidades comunicativas. O agrônomo não poderia contar sempre com técnicos, práticos ou auxiliares com ensino secundário para intermediar seu trabalho. Deveria ser competente para comunicar-se com capatazes das fazendas, com os inquilinos, com afuerinos, com pobres e analfabetos do campo, aqueles que viviam com as mãos na terra. "Consolidar um programa de informação requer (...) um conhecimento sociológico, cultural e do ambiente econômico das audiências rurais", ${ }^{187}$ diziam para Fundação Ford. Para preencher essa "lacuna curricular", profissionais de comunicação, sociologia e extensão rural da Universidade de Minnesota criaram novos cursos e um programa de especialização para as Universidades Católica e de Concepción, para que os agrônomos aprendessem a "traduzir sua expertise tecnológica em ação". ${ }^{188}$

A Universidade Católica formava $43 \%$ dos engenheiros agrônomos do país. Com assessoria de Minnesota, foi inaugurado em 1966 um Departamento de Educação e Extensão Rural. Entre seus objetivos estavam "identificar e estabelecer os métodos mais eficientes de extensão, educação e comunicação que levem à adoção de novas tecnologias". ${ }^{189}$ Foram criadas cinco disciplinas de educação

\footnotetext{
${ }^{182}$ Id. ibid., p. 3

${ }^{183}$ Id. ibid., p. 7.

${ }^{184}$ Cochrane, op. cit., p. 5.

185 Id. ibid., p. 26.

${ }^{186}$ S. O. Berg, L. E. Hanson \& W. P. Martin, op. cit., p. 73.

${ }^{187}$ Cochrane, op. cit., p. 16

188 Id. ibid., p. 27.

${ }^{189}$ Id. ibid., p. 30.
} 
extensionista na Universidade Católica sob responsabilidade de professores de Minnesota, como mostra a tabela 9 .

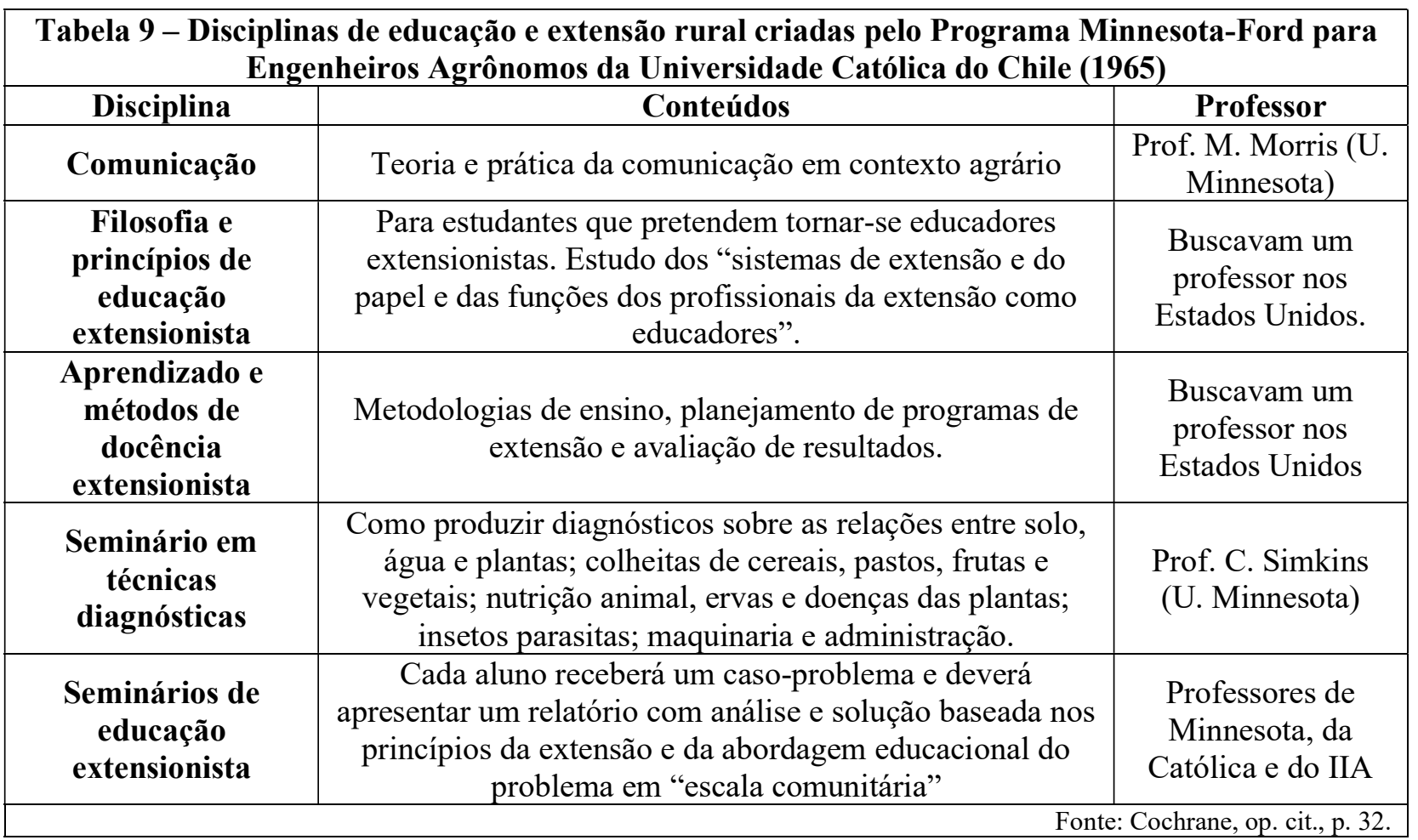

Na U. Católica também foi criada uma Faculdade de Docência específica para educação extensionista, com um público de outros cursos que não agronomia. Um primeiro curso, que seria testado em 1966, teria de 6 a 8 semanas de trabalho de campo, coordenador por um professor de Minnesota. No mesmo ano foram iniciados cursos com professores de Minnesota para funcionários da CORA e do INDAP. ${ }^{190}$

Os estadunidenses demonstravam relativo desprezo pelo potencial dos profissionais chilenos de comunicação e duvidavam da sua versatilidade: “o comunicador rural, como profissão, não existe no Chile, e isso torna o problema de recrutamento especialmente difícil". ${ }^{191}$ Nesse sentido, uma pergunta levantada pela equipe de Minnesota era: como garantir que aquilo que foi comunicado fosse praticado? "Existe uma diferença entre comunicar e convencer. Um bom programa de comunicação não fará o trabalho sozinho", ${ }^{192}$ refletiam.

Paralelamente, em 1967 a Fundação Ford financiava um projeto de educação televisiva no Chile. Em uma viagem de três semanas, o consultor Bernard Queenan reuniu-se com emissoras de TV, universidades (que eram gestoras de canais) e com o Ministério da Educação, concluindo que não havia

\footnotetext{
${ }^{190}$ Id. ibid., p. 40, 55.

${ }^{191}$ Id. ibid., p. 60.

192 Id. ibid., p. 61.
} 
"nenhuma evidência sobre tentativas de financiar projetos de educação aplicados à televisão". ${ }^{193}$ Diagnosticou que as iniciativas de programas de TV educativos eram "descoordenadas e esporádicas", sem que houvesse plano de modernização técnica do sistema de televisivo nacional. Diante desse vazio, recomendou um convênio entre o Center of Educational Television Overseas (CETO) e o Ministério da Educação chileno, para formar profissionais em televisão educativa e criar estúdios educativos de TV articulados às universidades. ${ }^{194}$ A educação televisiva era um ponto importante da agenda da Aliança para o Progresso.

Com o intuito de expandir os veículos de comunicação educativa, a Fundação Ford também patrocinava a produção de novos materiais didáticos para escola primária e manuais para professores no Chile, paralelamente à AIA. Em 1966, o consultor de mercado editorial William Laird se reuniu com o ministro da Educação, conversou com autores de livros didáticos chilenos e visitou quatro editoras: Zig-Zag, Lord Cochrane e as editoras das Universidades do Chile e Católica. Em seu relatório para Ford, analisava detalhadamente a cadeia de produção, impressão e distribuição dos livros escolares, com foco especial nos manuais de alfabetização para escola primária Adelante (36 páginas) e Sigamos (60 páginas). "O principal problema em avançar com o livro Adelante, ou com qualquer outro produto, do estágio experimental para a distribuição em massa para as escolas parece ser a falta de fundos", argumentava, convocando a USAID para investir. ${ }^{195}$ A Ford realizou orçamentos para 300 mil exemplares em 5 editoras, públicas e privadas. "O crescimento da população leitora seguramente levará a efeitos de longo prazo no mercado de livros, revistas e literatura técnica", ${ }^{196}$ avaliou. Explicitando os interesses estadunidenses no novo mercado, concluía: “o ministro [da Educação] atua no negócio editorial com planejamento, preparação e produção dos materiais escolares. Não concordamos com isso para o longo prazo, mas sim para permitir o início do programa. Esperamos que em algum momento o governo se retire do negócio editorial" ${ }^{197}$ O silabário chileno mais utilizado para população rural desde 1942 se chamava Mi Tierra e será discutido em um próximo capítulo.

Outro avanço da Fundação Ford sobre os livros didáticos chilenos havia ocorrido em 1965, quando o consultor Abraham Fischler entregou exemplares de um livro de ciências dos Estados Unidos para que fosse traduzido e utilizado nas escolas primárias chilenas no prazo de dois anos: "espero que através deles meus amigos chilenos vejam como é possível produzir materiais que incorporem um ponto de vista e uma filosofia que pode encorajar professores à mudança", ${ }^{198}$ escreveu. Sua segunda missão era estruturar, pela Comissão de Planejamento Educacional do Ministério da Educação, um centro de

193 Bernard P. Queenan, Visit to Chile $23^{\text {rd }}$ April-15 th May 1967. Letters addressed to John P. Netherton, Ford Foundation representative in Chile \& Confidential Annex. Centre for Educational Television Overseas (CETO). Ford Foundation Catalogued Reports. Report 001921, 1967.

${ }^{194}$ Id. ibid.

195 William J. Laird, Report on visit to Chile, March $24^{\text {th }}-$ April $5^{\text {th }}$, 1965. Ford Foundation Catalogued Reports. Report 000045, 1965: 6 .

${ }^{196}$ Id. ibid., p. 7.

${ }^{197}$ Id. ibid., p. 11.

198 Abraham S. Fischler, Visit to Chile April 19-30 ${ }^{\text {th }}$. Educational Planning Commission efforts. Ford Foundation Catalogued Reports. Report 000064, 1965. 
ensino de ciências que promovesse novas abordagens pedagógicas e metodológicas. Fischler chegou a encontrar-se com Irma Salas, uma das mais importantes pedagogas chilenas formada no Teachers College em Nova Iorque, além de manter contatos com a USAID (Mayorga, 2018a).

Os projetos da Fundação Ford para educação e extensão rural abarcavam uma visão entrelaçada do sistema cultural e econômico chileno, atuando no longo prazo pela expansão da sociedade rural alfabetizada, apta a adotar novas tecnologias agrárias. A extensão rural era chave, na medida em que modelava os novos canais pelos quais atuaria um batalhão de novos homens-nexo e mulheres-nexo, agentes da educação produtiva na agricultura chilena, ou ainda, plantadores de conceitos.

\subsection{Controlar a natureza: o convênio Califórnia-Chile}

Em seu livro Imperial Eyes, a historiadora Mary Louise Pratt (1992) analisa os relatos de viajantes europeus na América Latina e na África ao longo do século XIX, a partir do processo que ela conceituou como "anticonquista". Anticonquista, para ela, foram "as estratégias de representação através das quais os sujeitos burgueses da Europa buscavam assegurar sua inocência no mesmo momento em que garantiam a hegemonia europeia" (Pratt, 1992: 7). O protagonista da anticonquista, segundo Pratt, era a figura aparentemente passiva do "observador", ou seja, os viajantes intelectuais brancos que tinham como principal atividade observar e registrar o que viam. Eles alegavam expandir as fronteiras do conhecimento dos seus povos a respeito dos outros povos e paisagens, da natureza e da cultura das terras distantes. Normalmente, não demonstravam impor nenhum projeto de poder, apenas observar, registrar e narrar.

Uma revolução do pensamento naturalista em fins do século XVIII e o advento do cientificismo moldaram novas narrativas de anticonquista dos viajantes, correspondentes às mentalidades imperiais próprias do XIX. Pratt analisa o impacto da publicação do livro Systema Naturae (1735), do naturalista sueco Carl Linnaeus, que propôs uma taxonomia botânica universal, o primeiro sistema europeu de classificação da natureza com uma linguagem passível de ser aplicada em todas as partes do mundo. Linnaeus depois publicou Philosopbia Botanica (1751) e Species Plantarum (1753), obras que se disseminaram pela Europa e originaram um novo paradigma de conhecimento da natureza e, consequentemente, das práticas de domínio dos ecossistemas pela "coleta e classificação". ${ }^{199}$ Nesse sentido, a autora analisa "a emergência da história natural como uma estrutura de conhecimento e, também, como um momento voltado para o interior" da identidade do próprio colonizador (Pratt, 1992: 9). Para ela, "as ideologias dominantes fazem uma clara distinção entre a busca (interessada) da riqueza e a busca (desinteressada) do conhecimento (...). Sistematizar a natureza, como sugiro, é um projeto

\footnotetext{
${ }^{199}$ Nos anos 1770, Linnaeus organizou uma grande expedição científica para diversas partes do globo, cuja importância poderia ser comparada às cruzadas cristãs. Dessa vez, sonhavam em controlar "enciclopedicamente" a natureza, com procedimentos de coleta e classificação que reproduziam, no nível da cognição, a mesma operação da conquista territorial (Pratt, 1992: 25, 27)
} 
europeu de novo tipo, uma nova forma daquilo que podemos chamar de 'consciência planetária' entre europeus"(Pratt, 1992: 18).

$\mathrm{O}$ argumento de Pratt sobre a anticonquista ajuda a iluminar nosso tópico porque identifica as narrativas provenientes dos procedimentos de coleta e classificação da natureza. Ela mostra como esse modo de pensar "enciclopédico", era um correspondente epistemológico da própria conquista, uma vez que se apropriava e acumulava a partir das sociedades e naturezas colonizadas para produzir identidades hierarquicamente desiguais. Isso implicava, por exemplo, a "coleta e classificação" de saberes da humanidade e a exclusão de formas populares e orais de conhecer do universo de saberes "válidos".

Uma das principais missões do Convenio entre a Universidade da Califórnia e a Universidade do Chile, financiado pela Fundação Ford entre 1965 e 1975 era precisamente coletar e classificar a natureza chilena. Esse gesto fazia parte de uma busca aparentemente desinteressada pela expansão do conhecimento, porém se atrelava inevitavelmente à busca interessada pelo poder econômico, territorial e cultural de um povo sobre outros.

$\mathrm{O}$ argumento promovedor do Convenio coincidia com os motivos econômicos básicos da reforma agrária. Nos relatórios para Fundação Ford, justificavam a empreitada apresentando o aumento da produtividade agrícola como uma necessidade imperativa. O Chile gastava 200 a 275 milhões de dólares ao ano para importar alimentos e "os cultivos chilenos podem crescer enormemente com desenvolvimento intensivo dos recursos da terra e da água". ${ }^{200}$ Para isso, os cientistas do convênio apresentavam uma solução: "com o plantio de variedades de espécies melhoradas, expandindo o uso de fertilizantes apropriados, aprimorando a eficiência da irrigação, controlando insetos destrutivos e doenças nas plantas, reduzindo plantas com melhoria dos estoques e práticas processamentos". Desinteressado, o discurso científico estava genuinamente sintonizado com as narrativas da modernização nacionais, apontando a urgência da modernização agrária como chave-mestra da superação do subdesenvolvimento. Se a Califórnia possuía 18 milhões de habitantes e produzia alimento para 25 milhões, tinham algo a ensinar ao Chile, que com 8 milhões de habitantes não conseguia alimentar-se a si. ${ }^{201}$ Nesse escopo, aportavam com ciência à produtividade agrícola, como uma benfeitoria.

O entomólogo Evert Schlinger, da UC Riverside, relatou à Fundação Ford que entre abril de 1966 e julho de 1967 sua equipe havia coletado mais de 1 milhão de espécies de insetos, aranhas e ácaros em território chileno "para estudos futuros". ${ }^{202}$ A coleta foi realizada por um grupo de 24 taxonomistas chilenos e estadunidenses, além da presença de cientistas da Argentina, Canadá e Holanda. Foram contabilizadas 20 mil espécies de aranhas coletadas em 200 áreas do país, de

\footnotetext{
${ }^{200}$ Convenio. 1965-1967 Annual Report. University of California - Universidad de Chile. The Convenio Archive (box 1). Shields Library Special Collections. UC, Davis: 14.

${ }^{201}$ UC-UC, Study Committee. Commission of agricultural sciences. The Convenio Archive (box 1, AR 01-05). Shields Library Special Collections. University of California, Davis, 1964.

${ }^{202}$ Evert I. Schlinger, Studies in neotropical agroceridae, part 1. The Convenio Archive (box 1, AR 01-02). Shields Library Special Collections. UC, Davis, 1967.
} 
Antofagasta até Valdivia, proporcionando um aumento de $200 \%$ na fauna conhecida de aracnídeos. "Nenhuma aranha parasita jamais foi pesquisada na América do Sul, os resultados que obtivemos terão um significado especial", comemorou Schlinger em 1967. Também foram coletadas 300 espécies de moscas therevidae, todas parasitas das vinícolas, entre as quais 279 eram totalmente desconhecidas na comunidade científica mundial. "A América do Sul como um todo não possuía nenhum registro anterior de moscas therevidae", reportou. A análise das therevidae conduziu à descoberta da mosca da fruta mediterrânea, cuja erradicação, apontavam, seria um "tremendo benefício para produção agrícola e seu retorno econômico". ${ }^{203}$ Isso gerou consequências para a entrada de frutas chilenas nos Estados Unidos: "depois da descoberta da mosca mediterrânea no Chile em 1966, foi requerido que todas as frutas que entrassem nos EUA fossem fumigadas com Methyl Bromide e mantidas a menos de $35^{\circ} \mathrm{F}$ durante 14 dias", escreveram. ${ }^{204}$ Isso já era feito com as uvas da própria Califórnia. "A indústria frutícola chilena em grande medida empregou como modelo as práticas desenvolvidas na Califórnia", assegurou Heidi $\operatorname{Tinsman}^{205}$ (Tinsman, 2016: 103). Ademais, entre os 90 tipos de ácaros levados ao laboratório da estação La Rinconada, 50 eram parasitas de cultivos. Essa coleta dobrou o número de ácaros identificados no Chile e multiplicou em $400 \%$ os parasitas conhecidos. "Alguns destes podem ser importantes na importação de programas para Califórnia", ${ }^{206}$ sugeriu o entomólogo.

Concomitantemente, a equipe de nematologia reportava resultados com o mesmo entusiasmo. M. W. Allen e E. M. Noffsinger, nematólogos da UC Davis, pesquisaram 84 cultivos agrícolas, entre os quais $64 \%$ estavam infectados por 42 espécies de lombrigas. Entre os cítricos, $62 \%$ estavam infectados. ${ }^{207}$ Seus objetivos eram coletar, classificar, testar métodos de controle químico, além de "instruir e treinar chilenos em taxonomia de nematoides e nematologia aplicada, isto é, o controle das pragas". ${ }^{208}$ A prioridade era disseminar novos métodos de controle químicos nas plantações de cítricos. O principal produto testado foi o DBCP (dibromo-cloropropano), conhecido no mercado como Nemagon. A aplicação de DBCP no Vale Central da Califórnia foi muito comum até ser proibida, em 1979, em todo território dos Estados Unidos. Nesse ano, a agência estadunidense de proteção ambiental (United States Environmental Protection Agency) acatou o resultado de pesquisas que comprovaram a toxidade do produto e as enfermidades decorrentes, como esterilidade e câncer ${ }^{209}$. A aplicação de

\footnotetext{
${ }^{203}$ Convenio. 1965-1967 Annual Report, op. cit.

${ }^{204}$ Project CC 2460, Progress report F. Cordon Meyer. The Convenio Archive (box 1, AR 01-04). Shields Library Special Collections. UC, Davis, 1967.

${ }^{205}$ Uma das ironias dessa história foi analisada pela historiadora Heidi Tinsman: nos anos 1980, movimentos sociais da Califórnia se uniram para boicotar a uva chilena, entre outros motivos, por causa da toxidade do Methyl Bromide, cuja fumigação foi recomendada por cientistas californianos duas décadas antes. Entre eles, estavam o United Farm Workers (sindicato de trabalhadores rurais e camponeses da Califórnia, liderado por César Chaves), o Chile Solidarity Movement (que lutava contra a ditadura de Augusto Pinochet desde os EUA) e movimentos ambientalistas de consumidores. Ver Tinsman, 2016, capítulo 4.

${ }^{206}$ E. I. Schlinger, op. cit.

${ }^{207}$ M.W. Allen\& E. M. Noffsinger, Final Report. Nematology Investigation in Chile. The Convenio Archive (box 1, AR 0102). Shields Library Special Collections. UC, Davis, 1969.

208 Id. ibid.

${ }^{209} \mathrm{O}$ DBCP (fórmula $\mathrm{C}_{3} \mathrm{H}_{5} \mathrm{Br}_{2} \mathrm{Cl}$ ) foi um dos primeiros agrotóxicos a ser retirado do mercado pelas agências de vigilância sanitária. Nos Estados Unidos, comprovou-se em 1975 que gerava enfermidades como esterilidade, câncer e má formação; em 1977 sua autorização foi suspensa e em 1979 a substância foi proibida. É um produto persistente, o que significa que pode
} 
Nemagon, segundo atestaram os cientistas do convênio UC-UC, era capaz de gerar recordes de rendimentos, além de aumentar o tamanho das frutas.

Em 17 de dezembro de 1968, Allen e Noffsinger publicaram um artigo no El Mercurio para demonstrar aos produtores a utilidade dos tratamentos com DBCP no aumento da produção de cítricos danificados pela infeção de nematoides. "A produção dos limoeiros aumentou $40 \%$ em um ano, com um tratamento de 5 escudos por árvores", comemoraram. ${ }^{210}$ Ao mesmo tempo que exaltavam os recordes de rendimentos obtidos por meio de 3 a 4 aplicações, previam também que após três anos ocorreria um declínio na produção das árvores tratadas: "nesse caso, sugerimos uma nova dose". ${ }^{211}$ Também publicaram artigos na revista El Campesino da SNA. As vinícolas Concha y Toro e Trapiche, por exemplo, foram tratadas com DBCP em 1968, que foi aplicado diretamente por cientistas do convênio UC-UC para combater o nematoide Meloidogyne incognita. Em março de 1969, essas empresas obtiveram recordes de rendimentos nas vinícolas.

Em 1968 e 1969, Allen, Noffsinger e sua equipe de sete chilenos fizeram visitas de aplicação do produto em aproximadamente 70 comunas, ${ }^{212}$ onde coletaram pragas e demonstraram técnicas de controle químico. Visitavam predominantemente propriedades privadas de fora do setor reformado, onde chegaram a depositar 93 litros de Nemagon e 560 litros de DD por hectare com uso de tratores. A espécie mais comum de nematoides presente em quase todos os cultivos infectados era o Tylenchulus semipenetrans. Além desse volumoso trabalho em campo, os nematólogos da Califórnia também ministravam aulas das Universidades do Chile e Católica, no SAG e no IIA, com demonstrações do DBCP e de outros produtos. Em meados de 1969, diagnosticaram: "tratamentos comerciais estão agora sendo adotados por alguns agricultores", influenciados pela propaganda, pelos resultados econômicos e pela aura científica do produto. ${ }^{213}$

Outros agrotóxicos foram introduzidos no Chile por influência dos cientistas da Califórnia. Após uma pesquisa em todo Vale Central, do Aconcágua ao Bíobio, foi encontrado o "vírus

permanecer contaminante da terra por cerca de 200 anos. A Shell, a Standard Food Company, a Dow Chemical e a Dole Food Company foram processadas por trabalhadoras das plantações de banana na Nicarágua, que os acusaram de intoxicá-las com DBCP, apesar da proibição de seu uso no país. As trabalhadoras sofreram câncer de útero, traumas neurológicos, abortos prematuros e esterilidade. A Shell, Dow Chemical e Dole Food Co. foram condenadadas a pagar 490 milhões de dólares para 600 trabalhadores nicaraguenses, mas se negaram a cumprir a sentença. Segundo o Atlas da Justiça Ambiental, ainda existem 20 mil nicaraguenses contaminados por DBCP que aguardam indenizações. Ver: Lewgoy, 1983 e https://ejatlas.org/conflict/afectados-por-el-nemagon-nicaragua

${ }^{210}$ M. W. Allen \& E. M. Noffsinger, Los nematodos, factor limitante en la producción de cítricos. El Mercurio, 17/12/1968. The Convenio Archive (box 1, AR 01-02). Shields Library Special Collections. University of California, Davis, 1968.

${ }^{211}$ Id. ibid.

${ }^{212}$ Entre setembro de 1968 e fevereiro de 1969, por exemplo, o Nemagon da Shell foi aplicado nas propriedades La Rosa (Peumo), Esmeralda (Pica), de Sergio Silva (Chiñihue), Castillo (Paine), Trapiche (Longotoma), La Primavera, Chaca La Nana, San José de Tocornal (Santiago), entre outras. Outras comunas visitadas pelos aplicadores de DBCP foram: Maipu, Pucón, Rancagua, Quillagua, Terma de Mamiña, La Serena, Calera de Tango, Buín, Curicó, Chillán, San Vicente, Chiñinue, Mallarauco, Valdivia de Paine, Coinco, Laguna de Aculeo, Rangue, La Chimba, Quillota, Talca, Copequen, San Felipe, Las Mercedes, Valle de Lluta, Requiinoa, Arica, Mallarauco, Melipilla, La Cruz, Fray Jorge, La Calera, Hijuelas, San Fernando, Pichidegua, Olmué, Las Condes, Casablanca, Pirque, Palmilla, Santa Cruz, Pocuro, La Cruz, El Monte, Romeral, Lo Herrera, Santa Ana, Cunaco, Hospital, Llay Llay, Zuñiga, Huechurada, Andalucía, Lontué, Ovalle, Santa Sofia, Tagalante, Curacaví e Las Cabras. M.W. Allen, E. M. NOFFSINGER e A. Valenzuela et al.. Control of citrus nematode (Tylenchulus semipenetrans) on living lemon trees. Nematology Project - Chile. The Convenio Archive (box 1, AR 01-02). Shields Library Special Collections. UC, Davis, 1968-1969.

${ }^{213}$ M.W. Allen \& E. M. Noffsinger, Final Report, op. cit. 
potencialmente mais destrutivo das beterrabas já conhecido": o Paratanus Exitiosus. ${ }^{214}$ Além da produção de variedades resistentes, os pesquisadores recomendaram a realização de testes de controles químicos em La Rinconada, com os inseticidas DDT, Diazinon, Malathion, Sevin, Metasystox. Desde 1962, a partir da publicação do livro Primavera silenciosa de Rachel Carson (1969), sabia-se que o DDT era um produto altamente tóxico e que não existiam níveis seguros de aplicação. Abriu-se uma polêmica na comunidade científica, na qual o setor ecologista sofreu tentativas de silenciamento. ${ }^{215}$

Um impacto similar foi promovido pelo programa de fitopatologia do convênio, na investigação dos vírus e bactérias que geravam enfermidades nas plantas. Tinham como objetivo detectar novas doenças nos cultivos e em seguida lançar o programa "Chile livre de pragas", que aplicava dois métodos de controle: a introdução de novas variedades estrangeiras resistentes e os agrotóxicos. O fitopatólogo Harley English, da UC Davis, coordenou uma coleta de campo em um território correspondente a um terço do Vale Central, entre Vallenar (Atacama) e Valdívia (Los Ríos), e observou 13 cultivos de frutas e castanhas. Descobriram 200 doenças causadas por fungos e bactérias, sendo metade nunca antes registrada. Os principais cultivos prejudicados eram peras, maçãs, amêndoas, pêssegos, nectarinas, nozes e chirimoias. Em um campo conduzido em Maipu e Buin, afirmaram ter encontrado uma "séria destruição" nos cultivos de frutas, com uma ampla contaminação fúngica de Monilia laxa e Phytophthora infestans (conhecido como tizón no Chile e como requeima no Brasil). ${ }^{216}$ Em análises de 756 árvores na Estação Experimental de La Platina, encontraram cítricos, amêndoas e pêssegos infectados.

Em outra pesquisa, conduzida pelos fitopatólogos L.G. Weathers e L. Sánchez, foram examinadas 1300 árvores em 75 propriedades entre janeiro e fevereiro de 1969, no setor que abarcava 95\% da área cítrica do país. ${ }^{217} \mathrm{Na}$ Estação La Rinconada, analisaram um conjunto de árvores contaminadas pelo vírus da tristeza, cuja disseminação ainda estava restringida a Peumo, na região de O’Higgins. "Até agora se acreditava que o Chile era um dos poucos países do mundo que permanecia livre da tristeza dos cítricos", ${ }^{218}$ lamentaram. Considerado o vírus mais perigoso para os cítricos em todo mundo, os sintomas da tristeza eram flacidez e morte das folhas. As árvores contaminadas em

${ }^{214}$ C. W. Bennet, F. J. Hills, R. Ehrenfeld et al., Yellow wilt of sugar beet. Journal of American Society of Sugar Beet Technologists. Jan/1967. The Convenio Archive (box 1, AR 01-03). Shields Library Special Collections. University of California, Davis, 1967.

${ }^{215}$ No mesmo ano, um artigo de ameaça à Rachel Carson foi publicado com o título “Silence, Miss Carson!”, de B. Darby, na revista Chemical and Engineering News. Foram várias tentativas de silenciamento, pois os consensos da comunidade científica naquele momento se alinharam com a revolução verde. A recepção da obra de Carson desde uma perspectiva de gênero da história da ciência foi analisada em Smith, 2001.

${ }^{216}$ W. H. English, A. P. Torres, J. Kirk, Reconocimiento de especies del género Monilinia em frutales de carozo y en trembrillo de flor en Chile. Revista Agricultura Técnica, v. 29, n’2. The Convenio Archive (box 1, AR 01-03). Shields Library Special Collections. UC, Davis, 1966.

${ }^{217}$ Comunas de La Cruz, Quillota, San Felipe, Los Andes, Buin, Paine, Hospital, Maipo, El Monte, Malleco, Melipilla, Mallarauco, San Vicente de Tagua-Tagua, El Tambo, Tunca, Zuñíga, Peumo, Pichedegua, Almahue, Santa Cruz, Cunaco e Santiago.

218 L. Sanchez, L. G. Weathers, Distribution of tristeza virus in commercial trees in Chile. 1968-1969 Annual Report. The Convenio Archive (box 1, AR 01-03). Shields Library Special Collections. UC, Davis, 1969. Id., La amenaza de la tristeza de los cítricos em Chile. In. Revista Agricultura Técnica, v.30, n.3, s/d. The Convenio Archive (box 1, AR 01-03). Shields Library Special Collections. UC, Davis. Id., Tristeza Disease of Citrus in Chile. Plant Disease Reporter. v. 54, n. 7, July/1970. The Convenio Archive (box 1, AR 01-03). Shields Library Special Collections. UC, Davis, 1970. 
Peumo tinham sido todas importadas dos Estados Unidos desde 1947. A recomendação dos fitopatólogos era colocar as árvores infectadas em quarentena. "Um surto desse vírus de rápida disseminação seria desastroso para a produção de laranjas (...). Para erradicar os reservatórios do vírus tristeza medidas drásticas precisam ser tomadas". ${ }^{219}$ Todos os limões Meyer testados em La Rinconada estavam contaminados, assim como algumas tangerinas Satsuma. Além da quarentena, 27 variedades de cítricos resistentes foram criadas na estação experimental como forma de controle biológico. 220

Os fitopatólogos da Califórnia também se propuseram a desenvolver programas de extensão rural e formação superior, constatando que o principal problema enfrentado era a escassez de chilenos especializados na área. ${ }^{221}$ Os cursos de fitopatologia ministrados por pesquisadores da UC Davis na Universidade do Chile contavam com $25 \%$ a $30 \%$ dos conteúdos dedicados ao "controle químico". 222 Além disso, produziram cartilhas para agricultores, buscando dirimir a escassez de extensionistas: "aconselhamos a ênfase na preparação de publicações para distribuir entre fruticultores, ao invés de dedicar mais tempos às demonstrações nas propriedades, que provavelmente ficarão inconclusas devido à ausência de profissionais chilenos", ${ }^{223}$ recomendavam.

A área de pomologia (estudo das árvores frutíferas) também teve destaque no convênio. Coordenados pelos pomólogos Kay Ryugo e Claron Hesse (UC Davis), 5 especialistas da Califórnia participaram de criação de variedades melhoradas e livres de doenças, apostando na via do controle biológico. Nas estações experimentais La Rinconada e La Platina foram iniciados berçários de aperfeiçoamento das variedades. Em dois anos, pelo menos 28 das 219 novas variedades de frutas importadas e criadas em berçários já estavam plantadas em campo. O problema da importação de variedades não era apenas a inversão climática das estações do ano, já que geralmente vinham do hemisfério norte. Além disso, era quase inevitável que as novas plantas trouxessem também novos fungos e bactérias da Europa e dos Estados Unidos para o Chile, potencialmente destrutivos de variedades locais.

Uma carta de Ulises Abascal, funcionário do SAG, para Claron Hesse nos anos 1970 agradecia: “muitas das variedades que você nos trouxe na década de 1960 (1965, 1966, 1967) são agora aceitas pelos agricultores e os berçários estão trabalhando com eles. Não foi uma transformação rápida, mas como pode ver, seu trabalho foi muito útil para nós". ${ }^{224}$ Ou seja, em um futuro próximo, os países exportadores de variedades frutíferas poderiam ser beneficiados também porque suas frutas carregavam

\footnotetext{
${ }^{219}$ Id., Distribution of tristeza virus in commercial trees in Chile, op. cit.

${ }^{220}$ Convenio. 1965-1967 Annual Report, op. cit.

${ }^{221}$ W. H. English, Plant Pathology Program. The Convenio Archive (box 1, AR 01-03). Shields Library Special Collections. UC, Davis, 1967. W.H. English, J. W. Moller, S. F. Nome, New records of fungus diseases of fruit crops in Chile. Plant Diseases Reporter. v. 51, n. 3, 1967. The Convenio Archive (box 1, AR 01-03). Shields Library Special Collections. UC, Davis, 1967.

222 S.F. Nome, L. D. Leach, Progress Report. Plan Pathology Program. The Convenio Archive (box 1, AR 01-03). Shields Library Special Collections. University of California, Davis, 1967.

${ }^{223}$ H. J. O'reilly, J. Kirk, R. Krause, R. Gonzalez, L. Campos, S.F. Nome, A. P. Torres, M. Legarraga, A. Lizana, F. Kocher, N. Frtich, Investigation of Fungues and Bacterial Diseases of Deciduous Fruits. Annual Report. UCD, July-Nov/1968. The Convenio Archive (box 1, AR 01-03). Shields Library Special Collections. University of California, Davis, 1968.

${ }^{224}$ C. Hesse, Progress Report. Pomology in Chile. Jan/1967, Jan/1968, Aug/1968-Jul/1969, April-May/1979. The Convenio Archive (box 1, AR 01-04). Shields Library Special Collections. UC, Davis.
} 
consigo um novo "pacote" de fungos e bactérias, que poderiam disseminar novas doenças nas variedades locais, para as quais o controle químico seria requerido novamente de fora. ${ }^{225}$ Em outras palavras, os procedimentos de controle biológico por introdução de variedades estrangeiras potencialmente também promoviam a indústria química dos países centrais. Dessa empreitada participava a Foundation Plant Materials Service (FPMS), uma agência de coleta de pragas e criação de variedades resistentes na Califórnia. ${ }^{226}$

O dr. Kay Ryugo recomendava a fumigação da terra dos berçários de variedades com inseticidas e nematicidas como método de prevenção: "fumigar as terras para mudas antes de plantar não é uma prática comum ou é aplicada de maneira inadequada devido à falta de maquinaria apropriada. Por isso os nematoides são o problema mais sério do comércio de mudas". ${ }^{227}$ Os pomólogos da Califórnia também eram experts de nutrição dos solos, o que colaborava para difusão do uso de fertilizantes. ${ }^{228} \mathrm{O}$ aumento de importação de fertilizantes inevitavelmente favorecia os mercados da revolução verde: "o uso exclusivo de um nitrato como fertilizante $\left(\mathrm{NaNO}_{3}\right)$ vai causar deterioração do solo", alertava o cientista R.G. Platt. ${ }^{229}$ Os fertilizantes de solo foram também um recurso para o ramo da nutrição animal, na produção de pastagem e alfafa. No mesmo relatório que se posicionavam favoráveis à reforma universitária de 1968 no Chile, os cientistas da Califórnia contavam que a Faculdade de Medicina Veterinária havia comprado a fazenda San Ricardo para construir uma nova estação experimental, cujo foco seriam pesquisas sobre a mastite, uso de hormônios nas reses leiteiras e outros temas de saúde e nutrição animal. ${ }^{230}$

Fica evidente, pela documentação analisada, que o controle químico era uma metodologia prioritária para a ampla maioria da comunidade científica engajada na modernização agrária. Quase todas as investigações do subcomitê agrícola e veterinário contemplavam, em alguma etapa do seu desenvolvimento, a aplicação de inseticidas, herbicidas, nematicidas, fungicidas, bactericidas, hormônios ou antibióticos. ${ }^{231}$ Além disso, todos se engajaram no ensino universitário e se queixaram

${ }^{225}$ Nos berçários de La Rinconada e La Platina, em 1969, existiam as seguintes variedades em teste (com correspondente origem): 46 variedades de pêssegos (40 dos EUA, 6 alemãs) 36 variedades de cítricos (EUA), 31 variedades de uvas (EUA), 26 de maçãs (24 dos EUA, 2 alemãs); 15 ameixas (13 dos EUA, 2 alemãs); 15 cerejas (EUA); 12 berries (EUA); 10 nozes (EUA); 7 morangos (EUA); 7 peras (1 dos EUA, 6 alemãs); 4 nêsperas (EUA); 4 papayas (EUA); 3 variedades de amêndoas (EUA); 2 castanhas (EUA); 1 apricot (EUA). Esse detalhamento está em R.S. Bringhurst, Final Report Projects CC 2458, CC 2459, CC 2460. Department of Pomology, UCD. July, 1, 1967 - June, 30, 1968. The Convenio Archive (box 1, AR 01-04). Shields Library Special Collections. University of California, Davis, 1968.

${ }^{226}$ K. Ryugo. \& C.O Hesse, Research Project. The Convenio Archive (box 1, AR 01-05). Shields Library Special Collections. UC, Davis.

${ }^{227}$ K. Ryugo, Final Report CC 2458, CC 2459, CC 2460. The Convenio Archive (box 1, AR 01-04). Shields Library Special Collections. UC, Davis, 1967.

${ }^{228}$ Claron Hesse. Orchard Soil Management. 1968-1969 Annual Report, Project CC 2459. The Convenio Archive (box 1, AR 01-04). Shields Library Special Collections. UC, Davis, 1969.

${ }^{229}$ R.G. Platt, Report of Citrus and Avocado Culture in Chile, UC-UC Program, Jan. $8^{\text {th }}$ to Feb. $3^{\text {rd }}$, 1967. The Convenio Archive (box 1, AR 01-05). Shields Library Special Collections. UC, Davis, 1967.

${ }^{230}$ Convenio. 1969-1970 Annual Report. University of California - Universidad de Chile. The Convenio Archive (box 1). Shields Library Special Collections. UC, Davis.

${ }^{231}$ Todos os relatórios a seguir, por exemplo, apresentavam o controle químico como centro das soluções dos problemas encontrados: R.S. Bringhurst, Fruticulture. The Convenio Archive (box 1, AR 01-06). Shields Library Special Collections. UC, Davis, 1968; F. Carrol, E. Porte, E. Haardt, M. Godoy, J. Robb, D. Torell, Garcia, Xinema, H. Castellano, The Efficiency of utilization of land and feed resources for livestock production in Chile. The Convenio Archive (box 1, AR 01-06). Shields Library Special Collections. UC, Davis, 1968; W.H. English, H. J. O'Reilly, Investigation of fungus and bacterial disease of 
da precariedade da extensão rural chilena. Falava-se, entre os californianos e a Fundação Ford, da "péssima reputação do Serviço de Extensão no Chile". ${ }^{232}$ Quase todos os cientistas da Califórnia manifestaram por escrito sua preocupação sobre o risco de que seus trabalhos em laboratórios não conseguissem se disseminar como realidade e prática no campo. Por isso, alertavam, "os profissionais de pesquisa no Chile devem considerar extensão e educação como parte dos seus deveres regulares. Grandes mudanças terão que ocorrer no programa de extensão atual do Chile antes que os extensionistas assumam exclusivamente seu papel". ${ }^{233}$ Percebiam um grande descompasso entre seu fazer científico e a realidade educacional do campo, o que lhes gerava ansiedade. Claron Hesse vocalizava a angústia sentida também pelos acadêmicos de Minnesota: “[a extensão] é uma área crítica, que envolve prática, ética e organização profissional de agricultores no Chile. A necessidade de uma equipe muito maior de extensionistas e um vínculo muito mais próximo entre profissionais de extensão e pesquisa é primordial". 234

O acadêmico Charles Hardin criou um projeto preliminar ousado para solucionar esse problema: a Escola de Agricultura da Universidade da Califórnia deveria criar uma Faculdade de Serviços Internacionais (Foreign Service Faculty), responsável por estender a extensão, isto é, oferecer serviços de aplicação, ensino, distribuição e disseminação da sua tecnologia. Hardin via a América Latina como um grande laboratório. Ele dizia: "nós buscamos adaptar e aplicar nos países menos desenvolvidos (less developed countries) a tecnologia que nos permitiu continuar avançando na produção agrícola americana, em pequenas propriedades e com a força de trabalho em declínio. A capacidade de estender tecnologia agrícola para o exterior está alojada em agências de ensino e pesquisa". E por isso, era preciso "construir um sistema de ensino e pesquisa ajustado às necessidades agrícolas dos LDC". ${ }^{235}$ Argumentava que seria um sistema de ganhos recíprocos, uma vez que "ambos, californianos e estudantes dos países menos desenvolvidos vão aprender a adaptar a ciência aos problemas dos LDC". ${ }^{236}$ Além disso, considerava que as experiências em outros países eram saudáveis para os rumos da ciência, pois "um profissional que não aplica sua pesquisa em outros contextos pode sofrer da ausência de oportunidades efetivas para "expandir as fronteiras do conhecimento". ${ }^{237} \mathrm{O}$ custo

deciduous fruits (1967-1968). The Convenio Archive (box 1, AR 01-06). Shields Library Special Collections. UC, Davis, 1968; W.H. Hart, E.M. Noffsinger, M. W. Allen, Nematode investigations in Chile. The Convenio Archive (box 1, AR 0106). Shields Library Special Collections. UC, Davis, 1968; H. Kido, Hugue, A. Marin, A study of the biology and control of Margarodes vitium Girad. Sep. 15, 1967 - Feb. 8, 1968. The Convenio Archive (box 1, AR 01-06). Shields Library Special Collections. UC, Davis, 1968; G. Nyland, R. Krause, M. Ochoa, M. Legarraga, Virus Disease of Stone and Pome Fruits and Nursery Improvement Program. The Convenio Archive (box 1, AR 01-06). Shields Library Special Collections. UC, Davis, 1968.

${ }^{232}$ UC-UC, Study Committee. Commission of agricultural sciences, op. cit.

${ }^{233}$ Id. ibid.

${ }^{234}$ C Hesse. Report on a trip to Chile. UC-UC Program. Jan. 5th to Jan. 30th, 1967. The Convenio Archive (box 1, AR 0105). Shields Library Special Collections. University of California, Davis, 1967.

${ }^{235}$ Charles Hardin, A proposal for a Foreign Service Faculty centered in The College of Agriculture of The University of California [Preliminary - Comments Welcome]. The Convenio Archive (box 1, AR 01-05). Shields Library Special Collections. UC, Davis, s/d.

${ }^{236}$ Id. ibid.

${ }^{237}$ Id. ibid. 
estimado da sua proposta era 2 milhões de dólares para um teste com 15 pesquisadores extensionistas no exterior.

Em 1968, foi feita uma solicitação formal para Ford Foundation para que o subcomitê de agricultura e medicina veterinária abrisse um ramo prioritário para serviços de extensão. 238 "Os serviços de extensão estão sendo reestruturados nesse momento no Chile. Propomos que o papel da U. Chile nas atividades de extensão seja reexaminado no próximo ano". Mencionavam o trabalho desenvolvido junto ao programa Minnesota-Ford de extensão rural e dois empréstimos do BID obtidos pela Universidade do Chile especificamente destinados às melhoras em La Platina e La Rinconada. "Nós estamos tentando trabalhar mais próximos da Universidade de Minnesota, pois esta busca desenvolver a formação de extensionistas. Dr. Brown concorda que precisamos de um intenso esforço de extensão. Nenhuma pesquisa será significativa sem isso". 239

\subsection{Considerações finais}

Como sugeriu Heidi Tinsman, "a longa interação entre Chile e a agroindústria dos Estados Unidos, como suas instituições de estudos agrários, foi chave para a transformação do campo chileno" (Tinsman, 2016: 104). Ela se referia especificamente ao convênio UC-UC. Nesse capítulo, expliquei que foram diversas agências financiadoras, universidades e cientistas dos Estados Unidos que se envolveram no projeto de modernização agrária no Chile nos anos 1950 e 1960 . Apresentado como aporte solidário ao desenvolvimento alheio, aqueles projetos tecno-educacionais faziam parte de uma agenda muito mais ampla e de longo prazo, cuja meta era a criação de novos mercados dependentes dos insumos da revolução verde em todo hemisfério sul.

A agenda estadunidense de educação rural e pesquisa agrária no Chile penetrava dentro do Estado chileno: no Escritório de Estudos Especiais dos Rockefeller dentro do Ministério da Agricultura, na Comissão Especial de Educação Rural da AIA dentro da CORFO ou na participação da Fundação Ford na Comissão de Planejamento Educacional do Ministério da Educação. Os Rockefeller, os Ford, a AIA, a USAID, as universidades se encontravam conversavam e costuravam seus propósitos sistematicamente no Chile. Inauguravam instituições de Estado, conduziam as prioridades científicas do Instituto de Investigações Agropecuárias, empregavam os melhores técnicos e equipamentos das estações experimentais, nomeavam diretores na Universidade de Concepción, eram amigos do reitor da Universidade do Chile, enfim, se misturavam aos programas de modernização do país. Afinal, a maioria dos partidos chilenos, entre marxistas, cristãos e oligárquicos, estava de acordo com o imperativo da

\footnotetext{
${ }^{238}$ Convenio, A request submitted to the Ford Foundation for a continuation of funding for the UC-UC cooperative program for the period from April, 1st, 1968 to June, 30, 1970. The Convenio Archive (box 1, AR 01-05). Shields Library Special Collections. University of California, Davis, 1968.

${ }^{239}$ Agricultural Subcommittee. Minutes of the meeting. The Convenio Archive (box 1, AR 01-05). Shields Library Special Collections. UC, Davis, 1966.
} 
produtividade. E, portanto, de acordo com a necessidade de plantar novos conceitos modernos na consciência dependente e atrasada do campesinato e até mesmo da classe proprietária.

Como sugere Pratt, a "anticonquista" era a construção discreta e desinteressada das narrativas de legitimação da conquista. Charles Hardin, agrônomo da Califórnia, assim o explicitava:

O crescimento econômico incrementado dos países em desenvolvimento serve aos interesses e propósitos nacionais dos Estados Unidos (...). Enquanto os LDC não desenvolverem suas próprias faculdades e universidades, os EUA precisam ajudá-los a preencher essa lacuna (...). Para que os EUA ajudem a reduzir a brecha no número de pessoas treinadas, é preciso projetar suas ciências aplicadas para o mundo em desenvolvimento como jamais ocorreu antes. $^{240}$

Apesar de atuar mais perto das elites políticas e intelectuais do país, o projeto estadunidense para agricultura chilena se preocupava com o tecido social comunitário desde os anos 1950, o que se mostrou nítido no Plano Chillán e no Plano Victória. Foram criados clubes da juventude e centros de formação comunitária, o que engajou os sentimentos políticos das populações rurais na construção de novas escolas e no aprendizado produtivo. Como diziam os expertos de Minnesota: "o distintivo da extensão é o fato de ser uma educação continuada que serve a uma clientela (sic) que vai da juventude em clubes de trabalho [clubwork] ao mais idoso produtor ou inquilino ativamente engajado na agricultura". ${ }^{241}$ Todos deveriam ser mentalmente transformados: os conceitos da modernização agrária poderiam penetrar e se reproduzir sem preconceitos de raça, gênero, idade ou classe social.

No fim dos anos 1960, a revolução chilena se acelerava. Com a proximidade das eleições de 1970 e a radicalização dos trabalhadores nas suas demandas para o governo Eduardo Frei, a polarização política interna do país se tornava cada vez mais entusiasmada. A extensão rural tinha um enorme potencial para propaganda política. Sobre isso, os acadêmicos de Minnesota também refletiram:

É extremamente tentador para as agências públicas recrutar os olhares ávidos no mecanismo fácil dos serviços de extensão e capturar servos para propagar suas ideias ou vender seus programas. (...) Nos Estados Unidos, durante os anos 1930, o Departamento de Agricultura (USDA) foi acusado de usar cooperativas de extensão federais para promover a política agrária do New Deal. Recentemente, o USDA tentou explicitamente 'usar' os serviços de extensão para persuadir agricultores a apoiar as políticas do governo para produção e comercialização de trigo. Esses esforços precisam ser fortemente desencorajados e evitados, caso se queira que os serviços de extensão floresçam como um instrumento poderoso do processo educacional de uma nação. ${ }^{242}$

A revolução chilena, porém, não deixava nenhuma ilusão em pé sobre a neutralidade da ciência, da técnica ou da transmissão de saberes. Os economistas estadunidenses Solon Barraclough e William Thiesenhusen colocavam no centro das suas preocupações a tensão (social e educacional) gerada entre

\footnotetext{
${ }^{240}$ Charles Hardin, op. cit.

${ }^{241}$ S. O. Berg, L. E. Hanson \& W. P. Martin, op. cit., p. 85.

${ }^{242}$ Id. ibid., p. 85.
} 
a mudança do regime de propriedades e a necessidade de aumentar a produtividade. "Devemos perguntar como as necessidades educacionais serão alteradas em relação às mudanças de regime de propriedades (...). Quanta mão de obra capacitada adicional será necessária durante a próxima década para realizar as mudanças estruturais?”, convocava Barraclough (1962: 6). A mudança do regime de propriedades abalava e alterava o processo educacional agrário. Investigando as relações de trabalho no setor reformado, Thiesenhusen afirmava: "todas as evidências indicam que a assistência técnica deve ser coercitiva o suficiente para que a produção permaneça alta, o que será necessário para o sucesso da reforma. Por isso, é inseguro quando o líder da cooperativa e o técnico são a mesma pessoa" (Thiesenhusen, 1965c: 36).

Os alertas e as recomendações dos cientistas da Califórnia e de Minnesota a respeito da necessidade urgente de criar pontes entre o laboratório e o campo sequer mencionavam, em nenhum documento, a grande transformação promovida pela reforma agrária no regime de propriedades. Tampouco pareciam se importar com o boom da sindicalização camponesa, a partir de abril de 1967, ou com a eclosão de greves e ocupações dos trabalhadores da terra. ${ }^{243} \mathrm{O}$ dispositivo científico da "anticonquista" convocava com urgência os mensageiros mais competentes para disseminar suas descobertas ao mundo rural. No entanto, o mundo rural vivia suas próprias descobertas - e bem longe dos laboratórios.

${ }^{243}$ As dimensões numéricas do levante camponês entre 1967 e 1973 (sindicalização, greves e tomas) estão expostas no capítulo 1. 


\section{Capítulo 3 - A terra para quem a merece: a pedagogia do sacrifício do Instituto de Educação Rural}

"Nesse lugar afastado da maior parte dos benefícios da cultura, a chegada do IER é esperada com justificada ansiedade e renovado interesse, devido ao seu material informativo e às ideias que aporta para a comunidade rural".

Pedro Rossel, Escola Rural n¹8, Sara de Lebu, 1962 ${ }^{244}$

"Aqueles que esperam tudo do alto do céu, muito preenchidos por sua preguiça e comodidade, aguardando que a sorte venha golpear sua porta, esses não merecem ajuda de ninguém".

- IER. Conquistemos una vida mejor, $1963^{245}$

"O camponês merece um destino melhor, mas tem que conquistá-lo, tem que saber encontrá-lo. E nesse mundo de tanto progresso, o homem mais educado é o que terá melhor porvir"

- IER. Educación para los campesinos de Chile, $1964^{246}$

"Os que estavam no poder eram os próprios patrões e a lei era conveniente a eles. Agora existem duas perspectivas: ou cristianismo, ou marxismo"

- Ulises Días, dirigente do MCI, 1967247

\subsection{Introdução}

Em setembro de 1962, o Instituto de Educação Rural (IER) denunciou que o Congresso da Central Unitária de Trabalhadores do Chile (CUT), instituição com maioria comunista e socialista, havia impedido que 350 "autênticos camponeses" participassem do evento. O editorial da revista Surco y Semilla, órgão de imprensa do IER, acusava que "os célebres comunistas e marxistas (...) deixaram entrar 2500 delegados, dos quais 2400 eram operários e somente 100 camponeses. Claro que todos esses 100 camponeses eram comunistas". E questionava: "Por acaso a classe camponesa não merece tanto respeito como a classe operária?". ${ }^{248}$ Naquela ocasião, os dirigentes camponeses colocados para fora organizaram um evento paralelo, o Congresso Camponês Livre que, segundo o IER, contava com mais representantes rurais que todo congresso da CUT, no qual os camponeses seriam uma "minoria insignificante frente à massa de operários e ninguém entendia as brigas, insultos, golpes e armadilhas". ${ }^{249}$ Enquanto isso, o clima no evento paralelo teria sido de "verdadeiro estudo, verdadeira irmandade" 250 e busca de soluções para a vida no campo. "Parabenizamos aos camponeses que não se diminuíram e deram uma lição aos politiqueiros da cidade", ${ }^{251}$ concluíam. O setor expulso da CUT

\footnotetext{
${ }^{244}$ Carta do Centro de Padres y Apoderados. ¿Qué trae el correo? Surco y Semilla, n. 84, Nov/1962.

${ }^{245}$ Editorial. Surco y Semilla, n. 89, Ago/1963.

${ }^{246}$ Editorial. Surco y Semilla, n. 6, Mar./1964

${ }^{247}$ La ley de sindicalización. Surco y Semilla, n. 136, Jul./1967

${ }^{248}$ Nuestro pensamiento. Surco y Semilla, n. 82, Sep./1962.

${ }^{249}$ Id. ibid.

250 Id. ibid.

${ }^{251}$ Id. ibid.
} 
havia recém-criado a Associação Nacional de Organizações Camponesas (ANOC), com base na militância rural cristã, que funcionaria como um braço ativista do IER (Affonso et al, 1970: 100).

Em termos gramscianos, é possível dizer que o Instituto de Educação Rural foi um importante aparelho privado de hegemonia, que operava um projeto político no mundo rural chileno por meio de uma estratégia pedagógica e religiosa. Desde 1954, os Centros de Capacitação do IER ofereciam cursos gratuitos para jovens e adultos camponeses e também atuavam com o desenvolvimento cultural no campo, o que, no governo de Eduardo Frei Montalva (1964-1970), passou a ser chamado "promoção popular". ${ }^{252}$ Além disso, desde 1958 o instituto oferecia cursos via Rádio Escola para escolas primárias rurais, com alcance de dezenas de milhares de crianças. Embora se declarasse "fora da política de partidos", 253 em setembro de 1964 a revista do IER não hesitou em estampar o rosto de Eduardo Frei e comemorar a vitória eleitoral da Democracia Cristã (DC), com a solene manchete: "Presidente Campesino". ${ }^{254}$ Esse e outros materiais que analisarei evidenciavam a afinidade ideológica do IER àquele partido, embora sua origem também o conectasse com setores mais conservadores e oligárquicos do mundo político.

Durante as décadas de 1960 e 1970, o Instituto de Educação Rural participou de constantes polêmicas com as esquerdas. Frequentemente associava seus rivais marxistas a "agitadores profissionais" da cidade, ou a "extremistas de escritório", ${ }^{255}$ que chegavam ao campo com soberba e desconhecimento da realidade rural. "Os camponeses devem estar vigilantes, para que ninguém tente dirigi-los de fora", 256 alertavam. Para se diferenciar, lembravam que "os fundadores do IER pensaram que a transformação tinha que ser feita ali mesmo, no campo, com elementos existentes do próprio meio". ${ }^{257}$ No entanto, na sua origem, as cúpulas fundadoras do instituto conformavam uma aliança entre dois setores também "externos" ao campesinato: o episcopado nacional chileno, criador da Ação Católica Rural, em 1952, e com vocação apostólica, e um segmento da classe patronal, representada pela Sociedade Nacional de Agricultura (SNA), que tinha interesses em incutir no campesinato seus próprios critérios ideológicos, sendo o mais relevante deles a sacralização da propriedade privada.

\footnotetext{
${ }^{252}$ Sobre o conceito e as contradições da "promoção popular" no campo, ver Garret (1978) e Tinsman (2002).

${ }^{253}$ IER, ¿Qué es el IER?, 1972.

${ }^{254}$ Capa Presidente Campesino. Surco y Semilla, n.102, Set/1964.

255 Nuestro pensamiento. Surco y Semilla, n. 79, Maio/1962.

${ }^{256}$ Nuestro pensamiento: la libertad de los campesinos. Surco y Semilla, n. 89, Ago/1963.

${ }^{257}$ Meta del IER para transformar el agro. Surco y Semilla, n. 96, Mar/1964.
} 


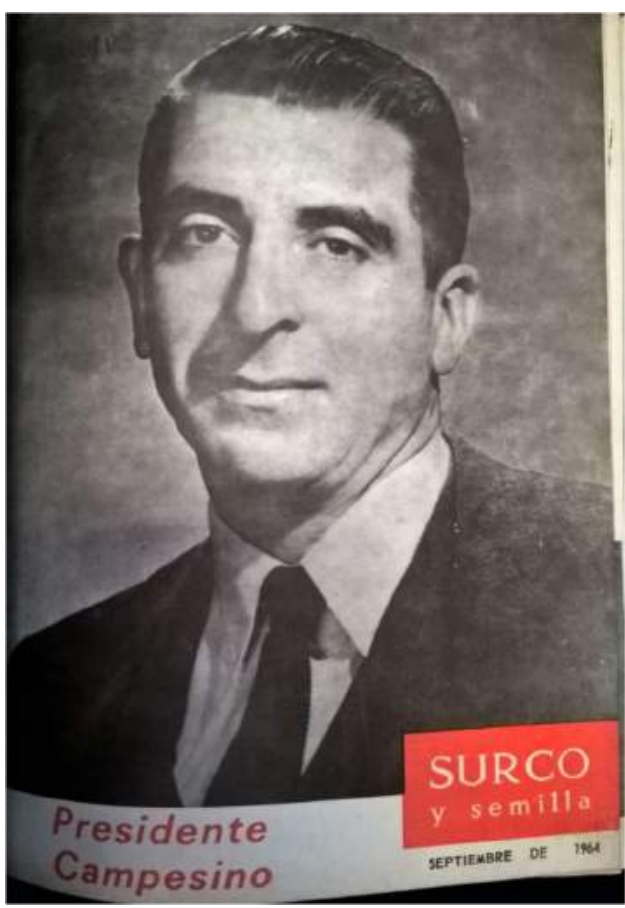

"Presidente Campesino". Capa da edição que comemorou a vitória eleitoral de Eduardo Frei Montalva (Surco y Semilla, n.102, Sep/1964.)

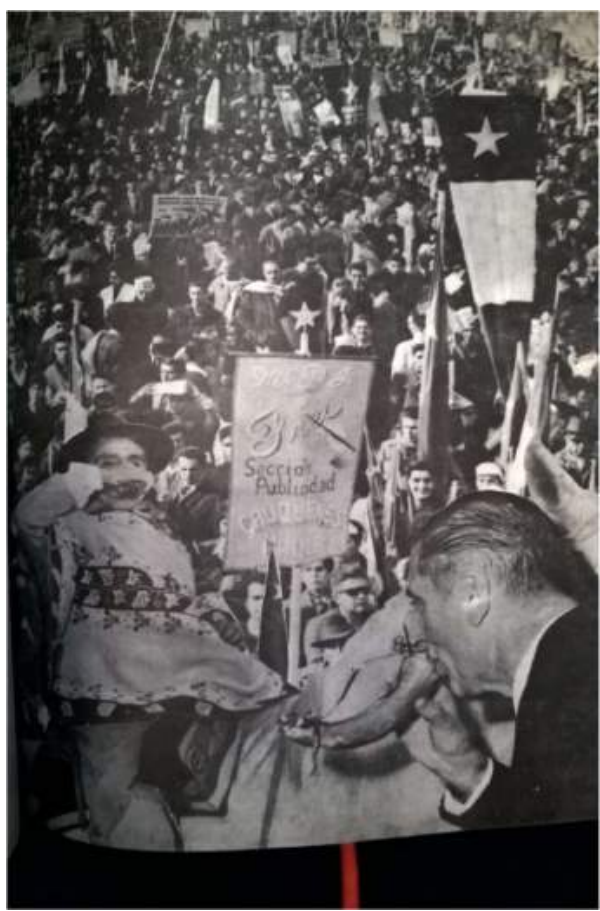

Eduardo Frei recém-eleito presidente, em cerimônia com camponeses (Bienvenido el nuevo presidente de Chile. Surco y Semilla, n.103, Out/1964.)

Nesse capítulo, argumentarei que o IER foi uma instituição relevante e decisiva na história da reforma agrária chilena por duas razões. A primeira delas foi a atuação cotidiana nas bases camponesas, oferecendo ao trabalhador rural aquilo que lhe era escasso: educação formal e capacitação técnica certificada. Dessa maneira, o instituto construiu uma grande rede de confiança político-pedagógica entre os setores populares do campo, vocalizando sua subjetividade e seus valores, mas também exercendo o poder de lhes entregar o certificado dos seus saberes, papeis timbrados que lhes ampliavam as chances de acesso à terra. A segunda razão foi o fato de o IER participar do debate público em torno da reforma agrária atuando como uma instituição-nexo ${ }^{258}$ entre as bases do campesinato e a política nacional, por meio de uma experiência social e pedagógica multiplicadora. Nesse sentido, seus Centros de Capacitação representavam o laboratório de criação de um "novo camponês", que deveria se tornar o sujeito de um projeto modernizador, comunitário e cristão de reforma agrária. Muitos ex-alunos do IER se espalharam pelos rincões do mundo rural e atuaram como tecedores desse projeto. Em outras

258 Desloco para "instituição-nexo" o conceito que Pascal Allende desenvolveu sobre os "homens nexo" no estudo da ruralidade do Vale Hurtado. Os homens-nexo desempenham "papeis intermediários entre a localidade e os níveis mais altos da estrutura de dependência nacional" (Pascal Allende, 1971: 51). O autor também os chama de "notáveis" ou "intermediários" e explica: "Esse caráter de nexo é, em nosso ver, o elemento básico do grupo de notáveis. Os indivíduos que compõem esse grupo social podem variar em suas ocupações: podem ser comerciantes, professores, policiais, funcionários dos Correios e Telégrafos etc. Mas todos eles desempenham de alguma maneira o papel de intermediários. Variam também quanto à origem de seu caráter de nexos. (...) Podem variar quanto ao grau em que concentram papeis de nexo. Há notáveis que são intermediários somente em uma área da vida social (educação, economia, política etc.) e para um número reduzido de pessoas. Outros, não obstante, tem uma preocupação específica, concentram papeis de homens nexo em outras áreas da vida social e para um grande número de camponeses". Desempenham "papeis de intermediários entre a localidade e os níveis mais altos da estrutura de dependência nacional" (Pascal Allende, 1971: 50-51). 
palavras, as tensões políticas inerentes ao processo de modernização econômica da agricultura chilena requeriam aparatos para batalha cultural.

Argumento também que a política-pedagógica do instituto conformava uma economia moral e, portanto, interferia diretamente no debate sobre as formas de propriedade da reforma agrária. ${ }^{259}$ Essa economia moral era formada por três componentes fundamentais. O primeiro e mais importante deles era o sacrifício. Na narrativa do IER, apenas os camponeses sacrificados obteriam a terra, isto é, aqueles que demonstrassem aceitar a dureza do trabalho no campo e que não se impacientassem ao almejar a velocidade dos atalhos - apresentados, estes, pelos "agitadores marxistas". Nessa pedagogia, todo sacrifício seria recompensado, mas era preciso esperar a hora certa. Por isso, a irmã do sacrifício era a virtude da paciência. Juntos, esses dois valores se politizavam uma agenda lenta e restritiva para reforma agrária. O segundo componente da economia moral do IER era o mérito da educação. A terra era para quem a merecesse e estes eram os camponeses estudiosos e capacitados, cultivados no espírito e disciplinados no trabalho. "Até pouco tempo, os camponeses tinham bem poucas esperanças de chegar a ser proprietários. Agora, todos apresentam projetos para a reforma agrária. Os camponeses mais preparados e produtivos serão proprietários em curto prazo", ${ }^{260}$ prometia um editorial. Vale frisar que a educação certificada representava uma das formas pelas quais o IER exercitou seu poder no processo da reforma agrária, sob a forma de um poder educacional. ${ }^{261} \mathrm{E}$ o terceiro componente da sua economia moral era o cooperativismo. Embora o sacrifício e o mérito da educação fossem atributos conquistados pelo indivíduo, o IER se referenciava na doutrina social-cristã, dotada de um profundo sentido comunitário. Sem nunca deslegitimar o desejo da propriedade individual, o instituto empreendia uma série de estratégias pedagógicas em defesa da forma cooperativa, como se verá adiante.

Por último, no cenário político chileno, a atuação do IER se destacou por algumas particularidades que serão ressaltadas. Entre elas, o fato de oferecer educação a partir do setor privado religioso, com tintura abertamente anticomunista; o fato de haver sido fundado treze anos antes da lei 16.640 de reforma agrária, que só em 1967 colocou a capacitação camponesa como elo chave da distribuição de terras; nesse mesmo sentido, se destaca seu vanguardismo na formação de dirigentes rurais e na construção de infraestrutura educacional do campo ainda nos anos 1950, quando o tema não estava em pauta; o fato de receber doações da USAID e de ser admirado pelos agentes estadunidenses de educação agrária atuantes no país; e por fim, sua notável coesão político-pedagógica, calcada na moral sacrificial, no sentimento identitário de uma "grande família camponesa" em contraponto a um "mundo externo".

\footnotetext{
${ }^{259}$ Sobre o conceito de "economia moral", ver Scott (1976).

${ }^{260}$ Nuestro pensamiento. Surco y Semilla, n. 80, Jul/1962 (grifo da autora). Nesta passagem, referiam-se à lei de reforma agrária 15.020, do presidente conservador Jorge Alessandri (1958-1964), conhecida como "reforma agrária de macetero", resposta às pressões da Aliança para o Progresso. Macetero significa cachepô ou vaso de plantas, palavra usada para criticar a insignificância da reforma agrária de Alessandri no conjunto da agricultura chilena. Sobre ela, ver Huerta (1987) e Faiguenbaum (2013).

${ }^{261}$ Diversas outras instituições, como o INDAP, a CORA, o FEES, o ICIRA, o INACAP, as Escolas Agrícolas e os sindicatos ofereciam cursos certificados aos camponesas durante a reforma agrária dos governos de Eduardo Frei (1965-1970) e Salvador Allende (1970-1973). Porém, como veremos, o IER foi o pioneiro nessa estratégia. A prática pedagógica de alguns desses organismos será analisada em outros capítulos.
} 
Para desenvolver tais argumentos e aprofundar a narrativa sobre essas particularidades, me perguntei qual foi o lugar do IER nas batalhas culturais e econômicas da reforma agrária e da revolução chilena. Quais eram as estratégias pedagógicas, cursos e projetos que permitiram a constituição de sua base social? Quais valores morais eram veiculados em seus materiais e experiências didáticas? Que metodologias empregavam? Qual reforma agrária defendiam? Quais formas de propriedade e trabalho projetavam? Como os camponeses se engajavam ao seu projeto? Quem financiava suas agendas? Para construir uma narrativa sobre essas questões, consultei fontes primárias e bibliográficas, complementadas por narrativas orais obtidas por entrevistas.

\subsection{Uma grande família camponesa: os fundamentos afetivos da hegemonia}

\section{O cenário de origem}

Criado em 1954 pela Ação Católica Rural, sob a liderança do Monsenhor Rafael Larraín, o IER preencheu um espaço vazio da educação camponesa do Chile. Chamado de "primeiro forjador do novo camponês", Larraín era celebrado como mentor e guia do instituto. Na edição comemorativa da sua primeira década, a revista Surco y Semilla recordava que “em 1954, nem técnicos, nem recursos se

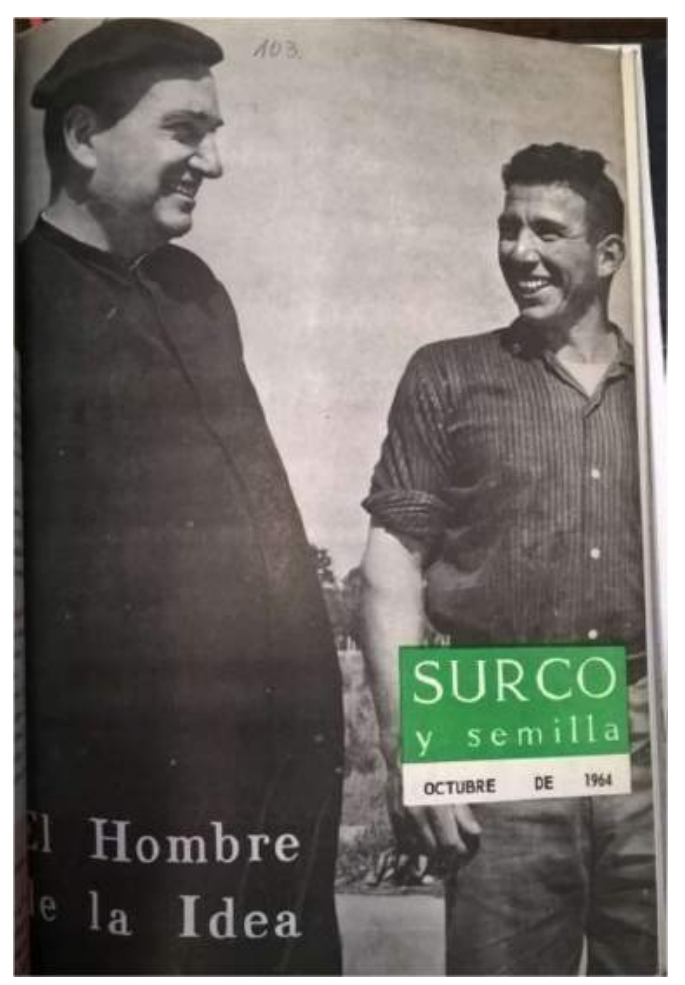

Capa da edição comemorativa dos 10 anos do IER: Rafael Larraín ao lado de um camponês (El hombre de la idea. Surco y Semilla, n.103, Out/1964) voltavam ao campo; era um setor abandonado". Na sua imprensa, o instituto exaltava seu próprio pioneirismo, e lembrava que antes, "ano a ano, 80 mil crianças camponesas deixavam a escola sem nenhuma expectativa para seu futuro. O conjunto da juventude rural, entre os 15 e 25 anos formava a impotente soma de 800 mil jovens desorientados e angustiados". ${ }^{262}$ De fato, nos anos 1950, a frequência escolar rural média era de apenas 2,5 anos e as crianças rurais começavam a trabalhar muito cedo. ${ }^{263}$

O IER inaugurou seu empreendimento na educação rural baseado em duas frentes. A primeira era formada pelos Centros de Capacitação de jovens e adultos, voltados para educação básica, rudimentos de ofícios, especializações e formação de líderes

\footnotetext{
${ }^{262}$ Diez años de labor. Surco y Semilla, n. 103, Out/1964.

${ }^{263}$ IER, ¿Qué es el IER?, 1972.
} 
comunitários. A segunda era a Rádio Escola Surco y Semilla, um sistema de ensino radiofônico para escolas primárias rurais, que se espalhou com uma velocidade impressionante: "a escassez de recursos e de estímulos faz o professor se sentir desamparado no campo", ${ }^{264}$ percebiam. Depois, nos anos 1960, o IER se desdobrou em uma frente produtiva, com trabalhos de assistência para cooperativas e assentamentos; e ainda uma frente comunitária de promoção popular, que assessorava organismos de base, como Juntas de Vecinos, Centros de Madres, Centros Campesinos e Clubes Esportivos.

O primeiro Centro de Capacitação do IER foi inaugurado em Santa Ana, perto de Santiago, em 1954. "Nos quatro primeiros anos, tivemos que romper a barreira do desconhecido e até o sétimo ano, a barreira da falta de pessoal", ${ }^{265}$ rememorou Rafael Larraín. A secretária do IER, Isabela Valenzuela, confessou que os primeiros chefes do instituto vinham do mundo cristão urbano, e embora muitos fossem nascidos no campo, não trabalhavam com a terra. $\mathrm{O}$ abismo cultural entre campo e cidade era profundo. Só depois de alguns anos os dirigentes do instituto se "ruralizaram", com a profissionalização das lideranças formadas por seus próprios cursos. ${ }^{266}$

Mesmo sem ter formação superior, o professor Rogelio Correa começou a dar aulas no IER em 1958. Segundo se lembra, o que permitiu que pessoas sem título acadêmico se tornassem professores do instituto teria sido a Lei de Educação Fundamental: "eu tinha o estudo secundário, o estudo de filosofia no seminário, que não concluí, e essa formação espiritual, que também era muito importante (...). Me dei conta no seminário que tinha vocação pedagógica e não para padre", ${ }^{267}$ explicou. Como ele, muitos dos primeiros professores do IER foram recrutados dos seminários.

\section{Camponeses, os esquecidos}

"Um esquecido: o camponês", estampava a manchete de uma matéria da revista do IER em 1964. Superando as dificuldades iniciais, o instituto foi bem recebido entre os camponeses. A sessão de cartas de leitores da revista Surco y Semilla postava mensagens de gratidão, com histórias em primeira pessoa da transformação pessoal vivida pelos alunos do IER devido ao processo educativo. Joaquim Contreras, por exemplo, aluno do primeiro curso do IER em Linderos, inaugurado em abril de 1956, escreveu: "aprendi a ser melhor, trabalhando para os demais. Estou comprando um terreninho por aqui para viver en lo próprio (...). Me tornei outro por causa da educação que o instituto me deu". ${ }^{268} \mathrm{O}$ Cotrerita, como era chamado, trabalhou como delegado do IER em Curacaví, onde se casou com outra delegada. ${ }^{269}$ Ele encarnava um bom exemplo do progresso pessoal impulsionado pelo instituto: como resultado dos seus cursos, apesar da baixa escolaridade, ascendeu ao posto de administrador agrícola no Centro de

\footnotetext{
${ }^{264}$ Diez años de labor. Surco y Semilla, n. 103, Out/1964.

${ }^{265}$ El hombre de la idea. Surco y Semilla, n. 103, Out/1964.

${ }^{266}$ Isabelita. Surco y Semilla, n. 104, Nov./1964.

${ }^{267}$ Entrevista com Rogelio Correa, Santiago, 30/05/2019.

${ }^{268}$ Contrerita, un campesino formado en el IER. Surco y Semilla, n. 103, Out/1964.

269 Eram chamados "delegados" os funcionários que atuavam nas bases camponesas do instituto, com atribuição de organizadores, educadores, líderes comunitários e às vezes responsáveis pela abertura de novos centros.
} 
Capacitação La Sanchina, em Rancagua. Como ele, 30 estudantes da Escola Agrícola Gonzalo Correa, em Molina, organizados no Centro Estudantil de Jovens Cristãos, agradeciam:

Estamos aprendendo algumas coisas úteis para ensinar aos nossos companheiros camponeses sobre o atraso em que vivem. Mesmo que não faça muito tempo que conhecemos o IER, felicitamos seu trabalho com um coração de camponeses sinceros e cristãos. É a única instituição que se preocupa conosco. ${ }^{270}$

Em outubro de 1964, o canal 13 transmitiu um programa de televisão sobre o IER, com a presença de dois ex-alunos. Um deles era Sergio Cisternas, que até os 20 anos havia vivido como inquilino dentro de um latifúndio e com estreita mobilidade. Na televisão, contou que fez um curso do IER e "quando voltou à comunidade a qual pertencia, o lugar onde havia sido inquilino, (...) seus companheiros o escutavam com a boca aberta, assombrados pela prodigiosa mudança produzida em seus conhecimentos e em sua visão mais ampla da vida. Eu era outro homem!". ${ }^{271}$ Depois de fazer mais cursos, Cisternas se tornou delegado nacional do IER e chegou a viajar à Europa representando os camponeses chilenos, em um vertiginoso processo de ampliação de horizontes. Em 1966, o ex-inquilino foi escolhido presidente do instituto.

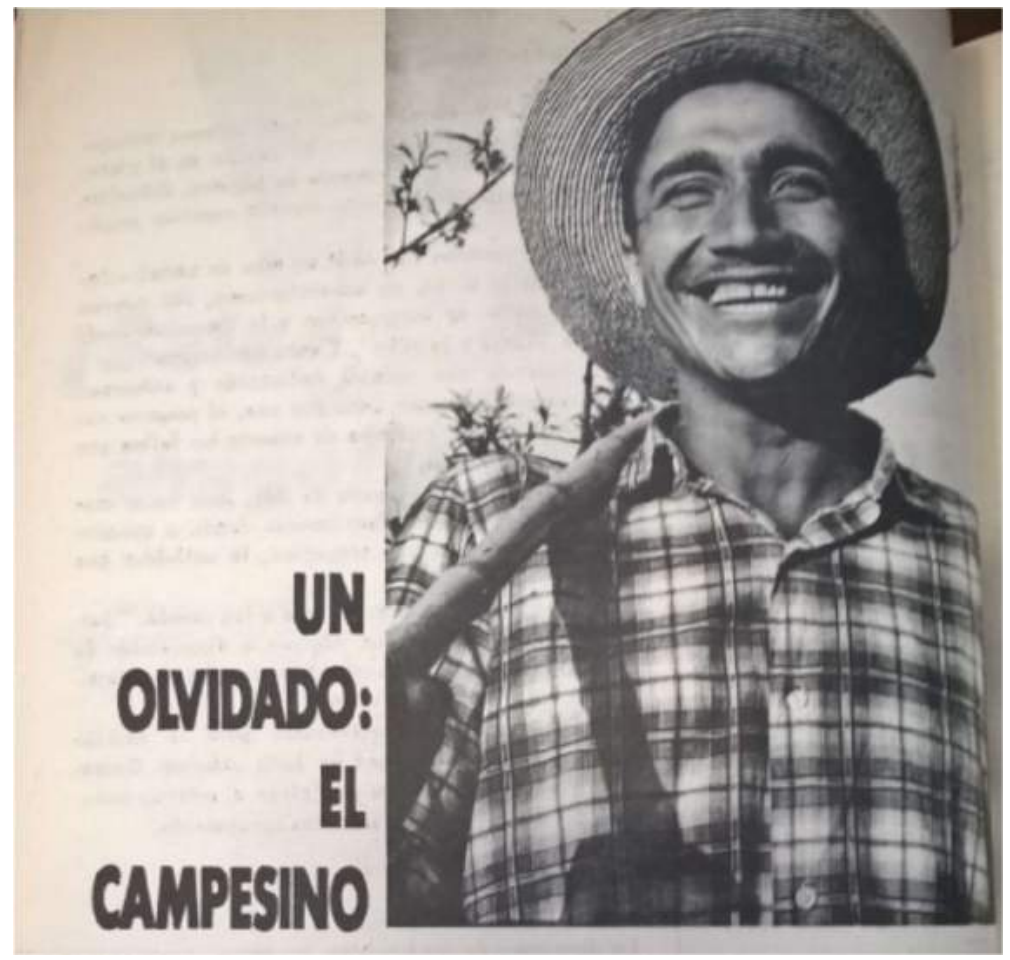

A narrativa do IER, confirmada por alguns camponeses, era que teriam sido pioneiros no acolhimento de um campesinato desamparado (Un olvidado: el campesino. Surco y Semilla, n.98, Maio/1964.)

\footnotetext{
${ }^{270}$ ¿Qué trae el correo? Surco y Semilla, n. 82, Set./1962.

${ }^{271}$ IER en televisión. Surco y Semilla, n. 104, Nov./1964.
} 
Entre as manifestações de apreço, em 1964 os trabalhadores do Centro Campesino El Carmen escreveram um poema-homenagem chamado "Versos ao instituto", que dizia: ${ }^{272}$

"Los campesinos de Chile

Estaban abandonados

Por falta de Centrales

Para ser capacitados.

(...) Yo creo que en todo el mundo

No habrá otra institución

Que ayude a los campesinos

$\mathrm{Y}$ enseñe a vivir mejor.
(...) A todos los campesinos

Yo los miro como hermanos

Y que unas nuestras fuerzas

Para todo superarnos.

Gracias, querido Instituto

Por todos tus sacrificios

Que te preocupas de nosotros

Para que aprendamos el oficio"

A revista Surco y Semilla dispunha de 10 mil exemplares mensais em 1962 e era uma importante plataforma de trocas de experiências e de memórias dos camponeses participantes do IER. ${ }^{273}$ Os exemplares circulavam com programas de assinaturas, que estimulavam seus leitores a se tornarem vendedores voluntários de lotes maiores, com campanhas para expansão do público. A revista sempre recebia elogios. Jovens camponeses de Malloco, por exemplo, escreveram: "graças ao seu sacrifício e constantes desvelos, ela [a revista] chegou a ser o que hoje realmente representa a expressão mais sincera dos pensamentos e das ideias da classe camponesa do Chile". ${ }^{274}$ A camponesa Honoria C. de Burgos, do fundo Turquia, dizia: "a revista (...) traz tudo o que me interessa: jardim, hortaliças, abonos". ${ }^{275}$ Mas também publicava algumas críticas. A camponesa Hortensia V. de Flores, de Combarbalá, reclamou: "a revista (...) chega a mim muito atrasada, devido a isso não consigo guiar-me pelas instruções de cultivo (...) e o mesmo ocorre com meu filho". ${ }^{276}$ Em 1967, após uma mudança da direção editorial e do layout, algumas leitoras protestaram: "nos disseram que agora Surco y Semilla estava "muito para homens"', contaram os editores, e que queriam de volta a Página del Hogar e a seção para crianças.

O engajamento dos leitores, tratados como participantes ativos da publicação, era estratégia de comunicação bem-sucedida e fundamental para seu enraizamento. "Não somos capazes de aumentar a tiragem? Claro que somos", convocava um editorial, "mas para isso precisamos de uma decidida colaboração de vocês. Porque vocês, amigos leitores, formam parte viva dessa revista". ${ }^{277}$ Entre os vendedores voluntários, havia camponeses que se mostravam dispostos a se endividar entregando exemplares gratuitamente aos vizinhos mais pobres. Em 1962, a camponesa Olga Albornoz reclamou: "estou muito brava com vocês porque a revista de maio ainda não chegou. Eu aqui trabalho para vender-

\footnotetext{
${ }^{272}$ Versos al Instituto. Surco y Semilla, n. 103, Out./1964.

${ }^{273}$ ¿Qué trae el correo? Surco y Semilla, n.82, Set/1962.

274 Id. ibid.

275 ¿Qué dicen? Surco y Semilla, n. 80, Jul./1962.

276 Id. ibid.

${ }^{277}$ Estimados amigos. Surco y Semilla, n. 101, Ago./1964.
} 


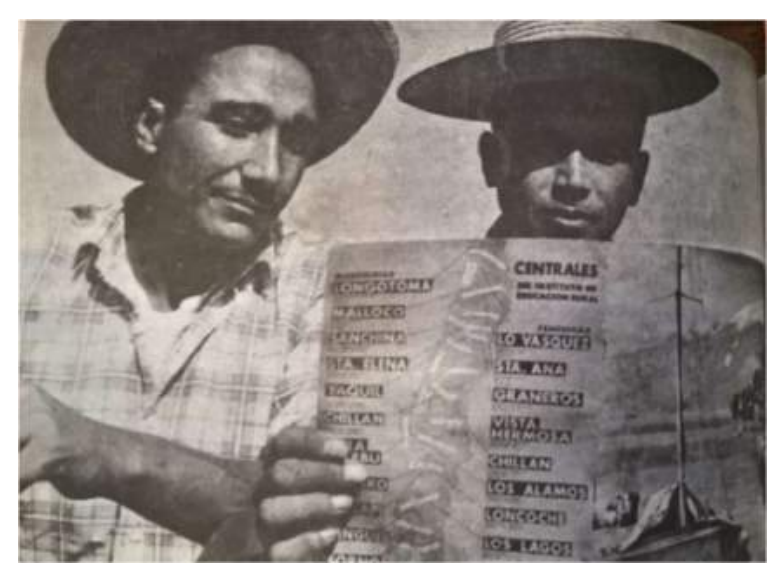

Camponeses lendo Surco y Semilla (La aurora de los campesinos. Surco y Semilla, n. 100, Jul./1964)

lhes mais, porém se chegam de forma tão irregular, como responderei à confiança das pessoas?". ${ }^{278}$ Alguns enviavam cartas sobre seu compromisso: "quero que não sobre nenhuma família camponesa neste ano que não me compre um exemplar da revista, este é meu ideal", ${ }^{279}$ dizia Elvia Navarrete, de Colliguay. Já a camponesa Elisa Salazar, de Cauquenes, lamentava que não conseguia aumentar seus lotes porque "muitas famílias não sabem ler". 280

Se considerarmos que um exemplar solto, naquele ano, custava 12 centavos de escudo e a assinatura anual era $1,20 \mathrm{E}^{\mathrm{o}}$, é provável que o custo financeiro da revista fosse um obstáculo menor do que a própria exigência leitora. ${ }^{281}$ Outros leitores compartilhavam sua prática de ler a revista do IER em voz alta para os analfabetos. Roberto Sanhueza, de Cherquenco, escreveu: "li o Consultório de Ño Matusalén aos huasos. Ficaram encantados. Simplesmente, o máximo. Tratarei, esse ano, de fazer toda propaganda possível da revista" ${ }^{282}$ Referiase à sessão que dava conselhos sobre relacionamentos.

Carta campesina: "Por intermédio dessa revista, tão importante para o setor que até pouco tempo atrás estava tão abandonado, me refiro ao setor camponês, quero dar meus agradecimentos às estimadas professoras do Centro Feminino de Malloco, por aquilo que adquiri nesse curso, que me fez experimentar a mudança que eu tanto desejava e que servirá também aos meus irmãos camponeses. De antemão dou meus agradecimentos e ao mesmo tempo felicito a Surco y Semilla pelos ensinamentos que dá para nós, camponeses. Saudações atenciosas, da aluna do Centro de Malloco. Teresa Bermúdez, de Colliguay" (Buzón de Surco y Semilla. Surco y Semilla, n. 118, Ene./1966.)

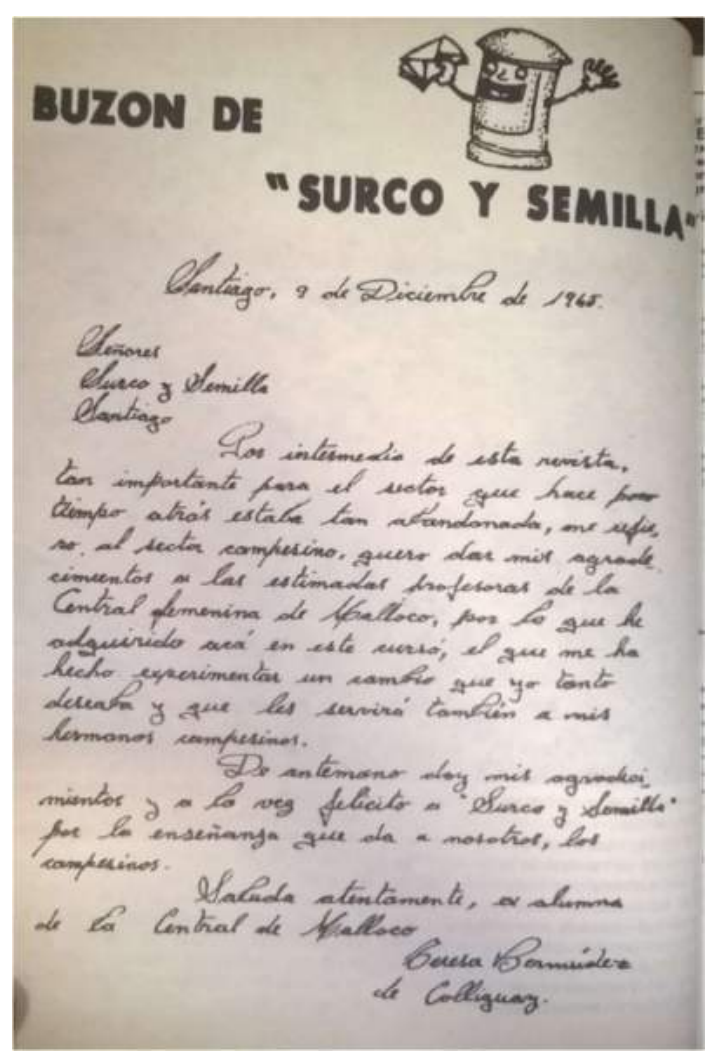

\footnotetext{
${ }^{278}$ ¿Qué dicen?, op. cit.

279 ¿Qué trae el correo? Surco y Semilla, n. 82, Sep./1962.

280 Id. ibid.

${ }^{281}$ O salário mínimo agrícola diário em 1962 girava em torno de 95 centavos de escudo $(25 \%$ obrigatoriamente entregue em dinheiro). Reajuste de salarios. Surco y Semilla, n.82, Set/1962.

${ }^{282}$ Huaso é a palabra usada no Chile, com tom que pode ser pejorativo, para se referir aos pobres do campo. ¿Qué dicen? Surco y Semilla, n. 80, Jul./1962.
} 


\section{As redes de afeto e gratidão}

O IER proporcionava aos seus alunos redes de cumplicidade afetiva para toda a vida. Em uma cueca campesina inventada por uma ex-aluna, por exemplo, o lugar social recém-criado do "camponês estudante", partícipe da comunidade educacional do instituto, era mobilizado como um ativo de sedução amorosa: 283
Me gustan las manzanas,
También las peras
Me gustan las chicuelas
Cuando solteras.
Cuando solteras, ay sí,
así les canto.
"Los libros del Instituto
Me gustan tanto".

As redes afetivas e amorosas que circulavam no IER muitas vezes se consolidaram em casamentos, que eram estimulados e celebrados na coluna social. Em março de 1964, dois ex-alunos, Sergio Caro, mecânico rural por La Sanchina, e Josefina Ponce, formada em Talca, se casaram em Molina e viraram notícia: "O IER os uniu", dizia a manchete, "a grande família camponesa que se formou ao redor do IER se une à alegria do jovem casal". ${ }^{284}$ Em abril de 1965, outro casamento foi comemorado no Centro de Capacitação de Longotoma, em La Ligua. A revista dizia: "a festa foi todo um êxito, já que os noivos, padrinhos, cunhados e sogros contam com a simpatia de toda essa grande família que é o IER". ${ }^{285}$ Entre dezembro de 1965 e fevereiro de 1966, mais 5 casamentos do IER foram comemorados. O professor chefe do Centro de Capacitação de Castro se casou com uma voluntária da Central de Los Lagos. Um mês depois, um dirigente do Movimento Campesino Independente se casou com a professora chefa de Chillán, mesmo dia que a chefa do Centro de Capacitação de Graneros se casava com o chefe do Centro de Lipingue. Semanas depois, um professor de Yáquil casou-se com uma ex-aluna de Santa Ana. "O Espírito Santo esteve muito ativo nos últimos meses", 286 festejaram.

Como argumentou a historiadora Heidi Tinsman, o ideal do casamento camponês, baseado na divisão nítida dos papeis de gênero, ocupou um lugar central no projeto político da Democracia Cristã, que associava a estabilidade familiar e os matrimônios bem-sucedidos à paz social e ao progresso da nação. Em referência aos programas do IER, Tinsman explicou que "a responsabilidade social da mulher era definida no domínio espiritual e ético do lar, em contraste com o terreno masculino da política e da mudança social” (Tinsman, 2002: 137). O casamento interno à comunidade do próprio instituto, portanto, era tanto uma consequência natural do convívio, como também uma peça-chave de um projeto político rural, baseado na valorização de uma "grande família camponesa", alimentada por

\footnotetext{
${ }^{283}$ Buzón de Surco y Semilla. Surco y Semilla, n. 118, Jan../1966.

${ }^{284}$ El IER los unió. Surco y Semilla, n. 99, Jun./1964.

${ }^{285}$ Buzón de Surco y Semilla. Surco y Semilla, n. 102, Jul./1965.

${ }^{286}$ Buzón de Surco y Semilla. Surco y Semilla, n. 119, Fev./1966.
} 


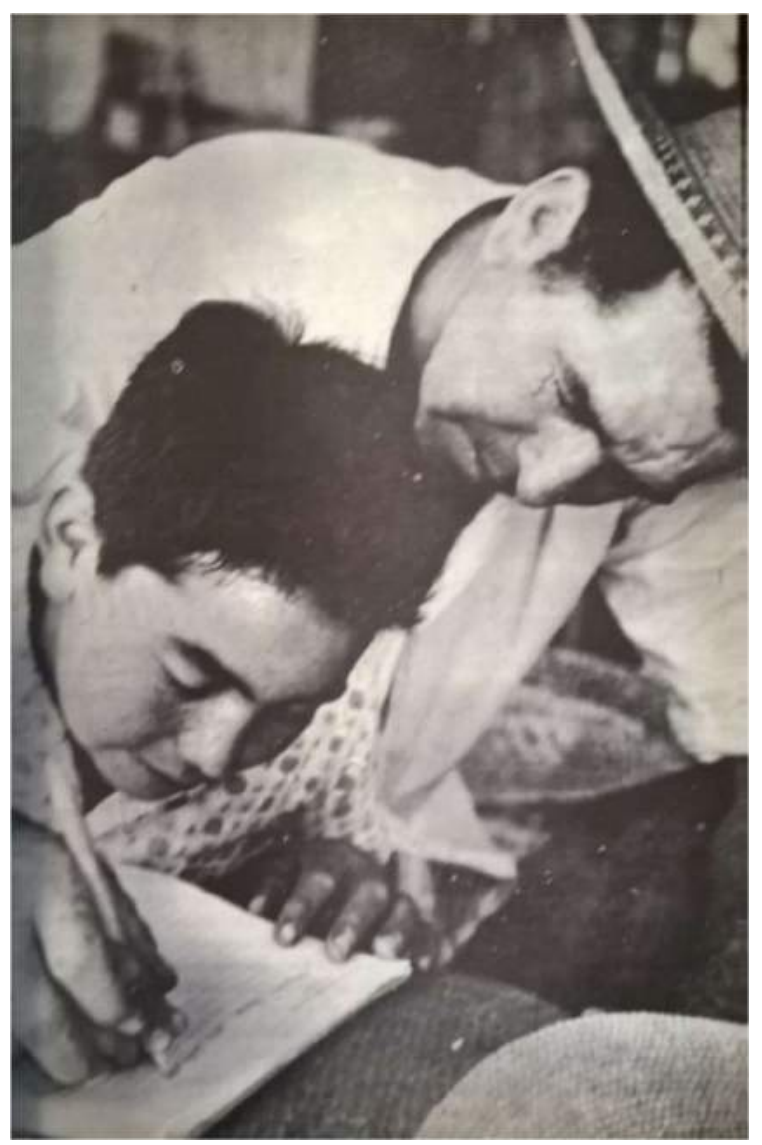

"O campesinato despertou para a educação através do IER". Buena Siembra, Buenos frutos. Surco y Semilla, n. 108, Mar/1965. laços de confiança pedagógica. Os afetos podem funcionar, afinal, como a substância mais importante da hegemonia.

O ex-aluno Luis Sandoval, por exemplo, lembrava com nostalgia da sua vida no Centro de Capacitação de Chilllán, em que compartilhou "estudos, alegrias, problemas e intimidades". ${ }^{287}$ Ele testemunhou que o Centro "nos brindou com seu teto tão amigavelmente como se fôssemos seus filhos (...). Ainda que partamos para muito longe daqui, nunca esqueceremos o Centro, seus distintos professores (...), a generosa "Mamy" e as boas "Tias" (...). Reconheceremos sempre seus sacrifícios". ${ }^{288}$ Era nítido, portanto, como os papeis de gênero da família camponesa cristã eram projetados sobre a sociabilidade educacional, multiplicando "mães", "pais", "tias" no decurso da aprendizagem.

\section{A expansão do IER}

O crescimento do IER foi vertiginoso. Se em 1960 o instituto possuía apenas 6 Centros de Capacitação, que reuniam um total de 847 alunos (Affonso et al., 1970: 168), no ano de 1963 já administrava 16 centros com cerca de 2.100 egressos anuais, seus promotores executaram serviços de extensão rural em 503 comunidades, lideravam a organização de 73 cooperativas com 3.800 famílias e possuíam 1.478 escolas rurais inscritas no programa da Rádio Escola Surco y Semilla. ${ }^{289}$ Pouco a pouco, o instituto edificava um silencioso poder cultural, enraizava seus projetos, aprimorava suas metodologias, criava inovações pedagógicas e envolvia dezenas de milhares de famílias camponesas em suas redes.

No início, a Igreja era o principal financiador do IER. Mas o Estado também lhe fornecia recursos públicos. Desde 1956, recebia subvenções do Ministério da Educação, quando se tornou oficialmente

\footnotetext{
${ }^{287}$ Buzón de Surco y Semilla. Surco y Semilla, n. 104, Nov./1964.

${ }^{288}$ Id. ibid.

${ }^{289}$ Una mirada hacia tras. Surco y Semilla, n. 86, Mar/1963.
} 
um "cooperador da função educacional do Estado" ${ }^{290}$ condição atrelada à gratuidade dos seus cursos. Uma figura importante no trabalho de angariar subvenções foi Isabel Valenzuela, a Isabelita. Secretária de Rafael Larrain desde 1945 e braço direito do IER, era descrita como uma mulher eficiente, jovial e inovadora. Havia participado da Juventude Obreira Católica e era responsável pelos apoios internacionais, pela expansão de novos centros e pela política institucional. A secretária se lembrava da batalha para que o IER fosse contemplado pela lei de subvenções ( ${ }^{\circ} 9.864$, de 1951), que determinava transferência de recursos públicos para instituições educacionais privadas: "a luta por uma lei que subvencionasse os cursos gratuitos foi possível graças ao telefone e à minha bicicleta, na qual eu ia e vinha da Central de Oficinas Públicas ou ao Correio (...). Sem dúvida, um dos momentos mais importantes [da minha carreira] foi a aprovação da lei", ${ }^{291}$ declarou.

O Ministério da Agricultura, também aportava recursos ao IER. Em 1964, por exemplo, o subsidiou com 300 mil escudos. ${ }^{292}$ Naquele ano, o instituto já contava com 22 Centros de Capacitação distribuídos pelo território chileno, incluindo dois Centros de formação de líderes (um masculino, em Malloco; um feminino, em Santa Ana), uma especialização mecânica (Sanchina) e uma escola de carpintaria (Osorno), além de 18 Centros de Capacitação básica. Em 1965, foi inaugurado o Centro de Chiñígue, especificamente para formação de delegados do IER. ${ }^{293}$ Os delegados eram ex-alunos empregados no instituto, que assumiam atribuições de liderança comunitária nas atividades de promoção popular camponesa.

Segundo Rogelio Correa, professor do Centro de Capacitação de Lautaro, os centros da Araucanía tinham maioria de alunos mapuches. As aulas, contudo, eram em castelhano e nunca em mapudumgum, devido à Lei de Educação Fundamental, que condicionava a subvenção do Estado às diretrizes curriculares huincas. "Uma das autocríticas que me faço", confessou Correa,

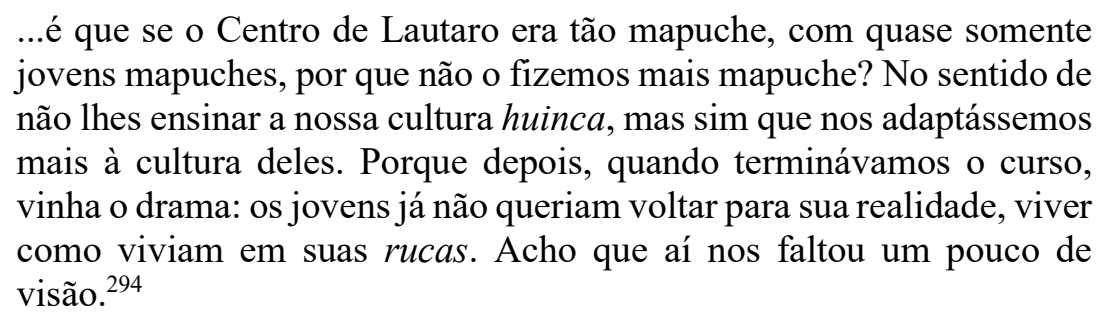

Ou seja, o IER expandia os horizontes de muitos campesinos, mas também era portador de uma condição colonizadora e catequizadora, ainda que seu cristianismo fosse mais pedagógico, que apostólico e priorizasse mais os valores que as liturgias. A chamada "educação básica complementar", obrigatória em castelhano, era o que garantia as receitas do Estado. Em 1965, o instituto recebeu do Ministério da Educação 128.589,12 escudos correspondente à subvenção de cursos de educação

\footnotetext{
290 IER, Escuela Agrícola de Adultos Princesa Paola de Bélgica, 1971.

${ }^{291}$ Isabelita. Surco y Semilla, n. 104, Nov./1964. A lei de subvenções públicas para a educação gratuita privada promoveu importante crescimento do setor educacional privado (Ponce de León, 2018:109).

292 ARNAD, Minagri, v. 1600.

${ }^{293}$ Delegados del IER. Para Chile. Surco y Semilla, n. 112, Jul/1965.

${ }^{294}$ Entrevista com Rogelio Correa, Santiago, 30/05/2019.
} 
fundamental em 15 dos seus centros de capacitação, com alunos entre 16 e 52 anos, 34\% mulheres, incluindo as Centrais de Lautaro, Lloncoche e Huiscapi, com forte presença de alunos indígenas. ${ }^{295}$ Nesses Centros, "ensinar o idioma castelhano era praticamente alfabetizar", ${ }^{296}$ porque quase todos os jovens de 15 anos tinham saído da escola muito cedo e seu idioma era mapudumgum.

Em 1966, o IER havia alcançado sua máxima expansão e gerenciava 31 centrais de capacitação em 18 províncias, com 3.170 alunos em regime de internato, 5.365 alunos em regime externato e serviços permanentes de extensão rural em mais de 400 comunidades. ${ }^{297}$ Naquele ano, o instituto assinou um convênio com a monarquia belga e criou uma Escola Agrícola de Adultos, chamada "Princesa Paola de

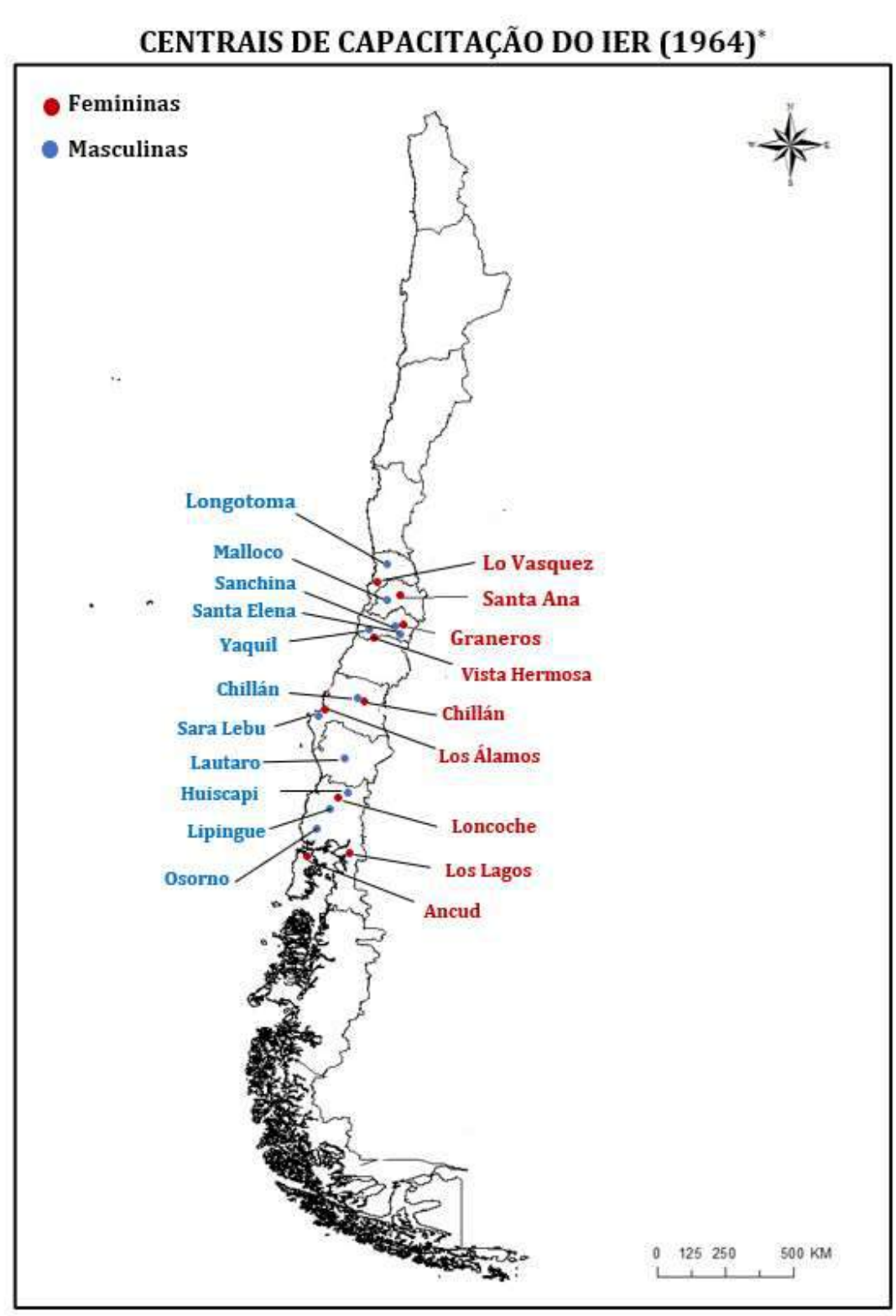
Bélgica" para formação de instrutores rurais. A figura do instrutor rural não existia nas carreiras agrícolas chilenas e foi criada pelo próprio IER, misturando características dos práticos agrícolas com os pedagogos, buscando combinar os conhecimentos técnicos do primeiro, com as habilidades sociais e comunicacionais dos segundos. ${ }^{298}$ A Escola oferecia um curso de quatro anos exclusivo para camponeses com curso secundário completo, sendo os três primeiros anos de agricultura e um ano completo de pedagogia. O IER chegou ao fim dos anos 1960 com cerca de 500 promotores contratados para desenvolvimento comunitário (com uma missão diferente à

-Informações em Surco y Semilla, n. 95, Feb/1964.

295 ARNAD, Mineduc, v. 26134.

296 Entrevista com Rogelio Correa, Santiago, 30/05/2019.

${ }^{297}$ ¿Qué es el IER? Novas centrales a servicio del campesino. Surco y Semilla, n.136, Jul/1967.

298 IER, Escuela Agrícola de Adultos Princesa Paola de Bélgica, 1971; Recordando a nuestro IER. Surco y Semilla, n. 120, Mar./1966. 
dos professores), ${ }^{299}$ que assessoravam cerca de 1.000 organizações camponesas, que representavam 28 mil sócios. ${ }^{300} \mathrm{O}$ IER possuía também quatro equipes móveis com unidades audiovisuais, que funcionavam como centros de capacitação itinerantes. O mapa abaixo mostra a distribuição territorial dos centros de capacitação do IER no Chile, em 1964.

O instituto também expandiu suas atividades para o Peru. Em 1964, mais de 80 jovens estrangeiros já tinham sido capacitados nos Centros de Promotores de Malloco (masculino) e Santa Ana (feminino). O camponês peruano Enrique Velázquez, ex aluno do IER em Malloco, voltou ao seu país e fundou, em 1963, o Centro de Capacitação de Huaura, onde foi professor chefe. Aquele não era o primeiro. Desde 1960, o IER possuía um Centro de Capacitação em Sayen (Peru), onde trabalhavam duas assessoras chilenas. Outros centros foram abertos em Cajamarca e em Puno, o que totalizava cinco Centros do IER no país vizinho. ${ }^{301}$

O instituto recebia contribuições importantes dos Estados Unidos, país com quem manteve uma relação direta e prioritária. No contexto da Aliança para o Progresso, a USAID realizou doações financeiras e materiais; os Peace Corps enviaram brigadas de trabalhadores voluntários estadunidenses diretamente ao IER - chamados pelos chilenos do instituto de "piscorinos"; e a Cooperativa Americana de Remessas ao Exterior (CARE) transferia tecnologia, doando radiotransmissores, carros modernos e projetores audiovisuais. A participação dos Estados Unidos nas estratégias político-pedagógicas do

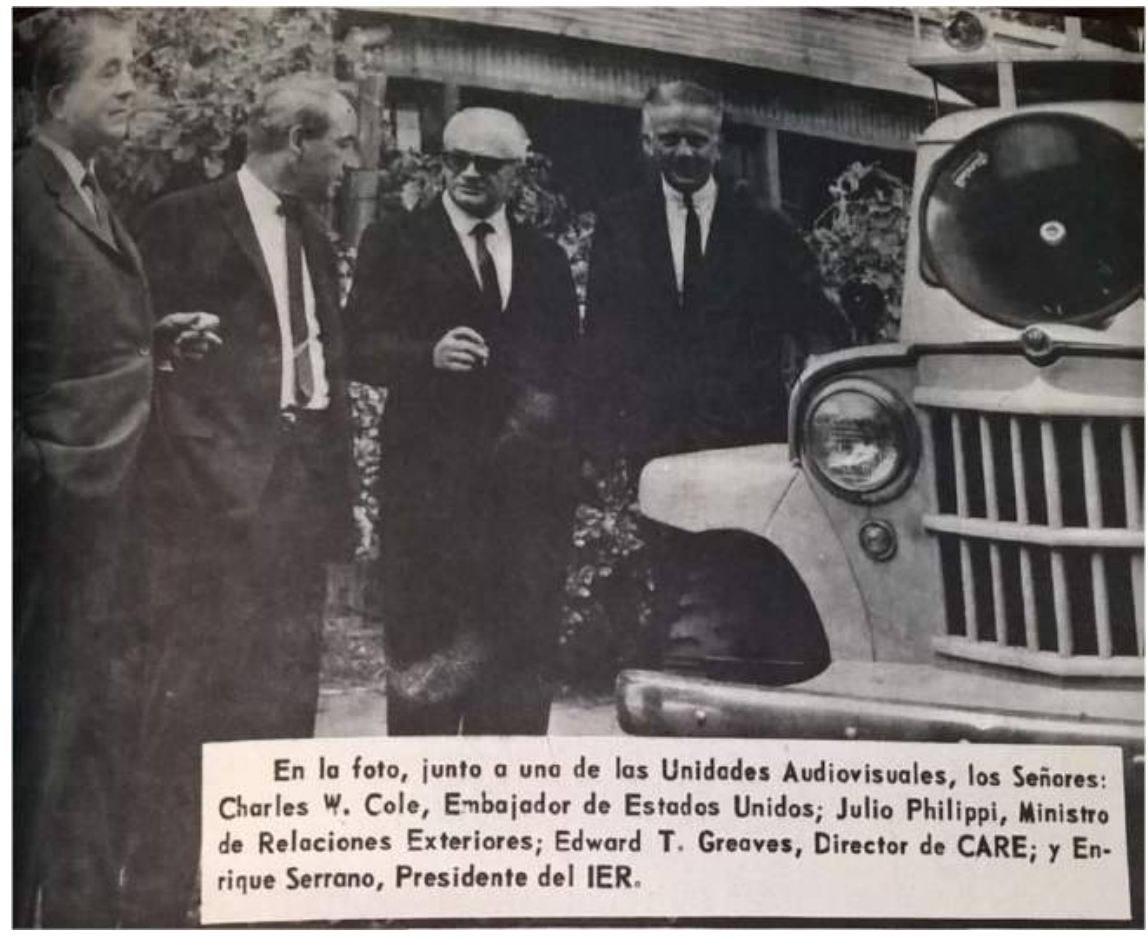

Cerimônia de doação das Unidades Audiovisuais do CARE e da USAID ao IER. Presentes o embaixador dos EUA, o Ministro de Relações Exteriores, o Diretor da CARE e presidente do IER. (Unidades Audiovisuales. Surco y Semilla, n. 98, Maio/1964).

\footnotetext{
${ }^{299}$ IER, ¿Qué es el IER?, 1972.

300 ¿Qué es el IER? Novas centrales a servicio del campesino. Surco y Semilla, n. 136, Jul/1967.

${ }^{301}$ Una semilla chilena da sus frutos en Peru. Surco y Semilla, n. 105, Dic./1964.
} 
IER, obviamente, não era um altruísmo. Como argumentei no capítulo anterior, a educação camponesa na América Latina era parte da geopolítica de Guerra Fria, em decorrência da centralidade das tensões agrárias nos processos de rebelião social e revolução.

Essa hegemonia estadunidense se construía por meio de diferentes métodos e canais. O IER os interpretava como gente solidária e generosa. "A que vinham?", perguntava sua revista sobre os Peace Corps: "A servir, simplesmente". ${ }^{302}$ Em outubro de 1963, quando o diretor dos Corpos de Paz no Chile voltou para os Estados Unidos com uma delegação, o instituto o cobriu de elogios com letras maiúsculas: "Grande Chefe, Perfeito Diretor e verdadeiro Pai dos Piscorinos, o mais inteligente e leal enlace entre sua organização e o instituto: Mr. Walter Langford" ${ }^{303}$ E ofereciam o Chile como sua "segunda Pátria".

Com o passar dos anos, os cursos do IER ligaram os pontos dos seus Centros de Capacitação e criaram uma rede comunitária e afetiva entre camponeses nascidos em territórios que antes pareciam incomunicáveis. Num contexto de isolamento e escassez, o papel de socialização educacional do campesinato construído pelo IER adquiriu relevância afetiva e política, anterior aos sindicatos e assentamentos da reforma agrária emergidos em 1967. Essa sociabilidade educacional se baseou em estratégias pedagógicas e metodologias que analisarei a seguir.

\subsection{Frentes de trabalho do IER}

\section{Centros de Capacitação: um circuito político-pedagógico multiplicador}

No organograma do instituto, existiam três tipos de Centros: os centros de orientação (educação básica e ofícios), os centros de capacitação (cursos especializados) e os centros de promotores (para formação de delegados e professores do IER). ${ }^{304}$ Os cursos, oferecidos em regime de internato, costumavam durar cinco meses e, às vezes, depois de uma pausa, outros cinco meses. $\mathrm{O}$ circuito de formação e retorno às comunidades realizado pelos alunos do IER foi esquematizado na figura a seguir. ${ }^{305}$

\footnotetext{
302 ¡Adiós piscorinos! Surco y Semilla, n. 88, Jul./.1963.

303 Id. ibid.

304 ¿Qué es una Central del IER? Surco y Semilla, n. 96, Mar/1964.

305 Desenho fotografado pela autora com autorização da Biblioteca Nacional do Chile: ¿Qué es una central del IER? Surco y Semilla, n. 96, Mar/1964.
} 


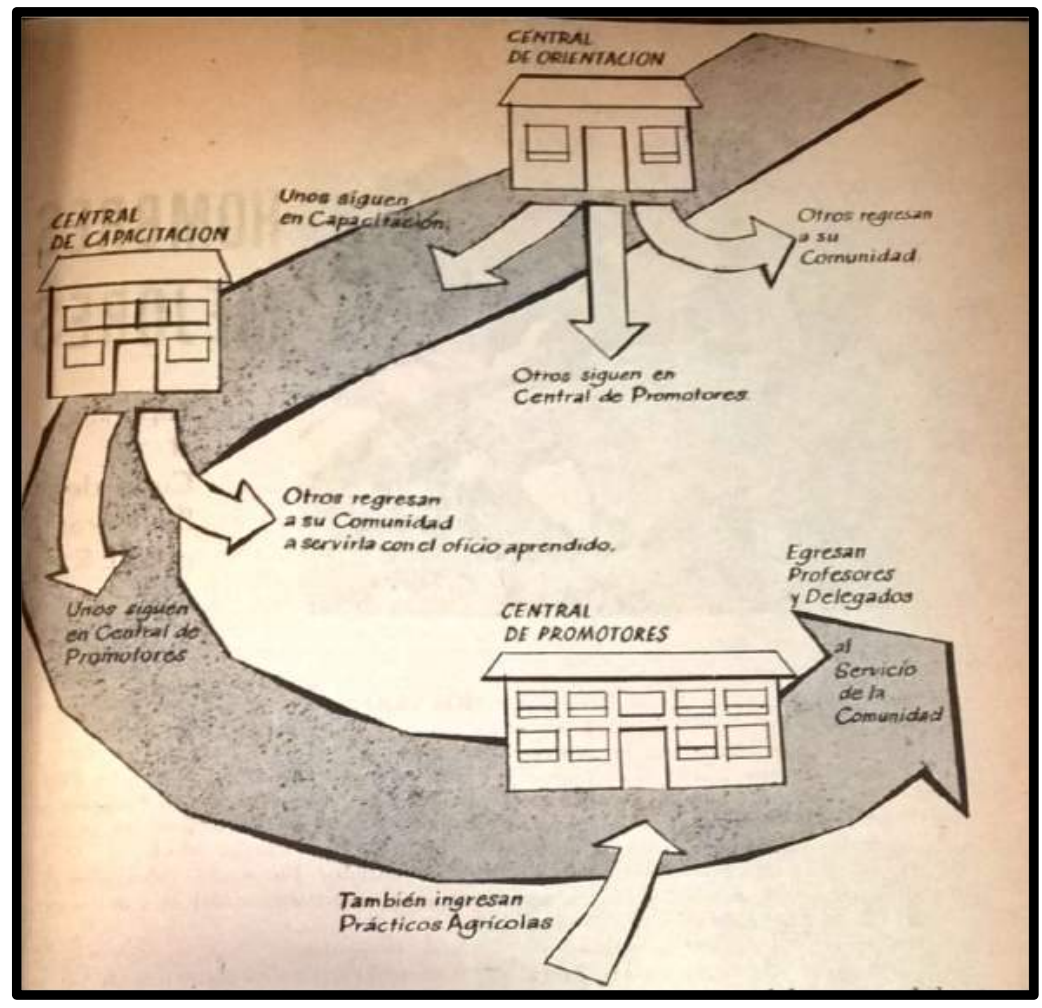

A ênfase no retorno dos ex-alunos às suas comunidades era a essência de um processo de multiplicação político-pedagógica. A passagem pelos cursos do IER costumava ser uma experiência transformadora e marcante na vida dos camponeses. A rede afetiva e as transformações vividas no processo pedagógico criavam os fundamentos de uma subjetividade política nova.

A capacitação era separada por gênero e eram raros os cursos mistos, embora não fossem inexistentes. ${ }^{306}$ Algumas grades curriculares dos centros de orientação, que ofereciam educação básica, apareciam nos documentos oficiais enviados pelo IER para o Estado, na prestação de contas das subvenções. Os centros de orientação ofereciam cursos em modalidade intensiva (cerca de 3 semanas) ou extensiva ( 5 meses). A estrutura dos cursos fundamentais era compartilhada por centros masculinos e femininos, mas em seu interior, ocorriam separações de conteúdos por gênero, sobretudo nos rudimentos de ofícios, que ocupava de $50 \%$ a $60 \%$ da carga didática, como sintetizado na tabela 10 a seguir. ${ }^{307}$

\footnotetext{
${ }^{306}$ A capacitação de homens e mulheres tinha conteúdos diferentes. Sobre as tensões entre classe e gênero na reforma agrária chilena, ver Garret (1978), Acuña (1986) e Tinsman (2002 ou 2009).

307 ARNAD, Mineduc, v. 26134. Plan del curso gratuito e intensivo de educación fundamental para jóvenes campesinos. Expedientes n. 57 a 71 do IER. Longotoma, Chillán, Tahuinco-Choapa (móvil), Malloco, Misquihué (móvil), Graneros, Chiñigue, Yaquil, Los Alamos, Sara de Lebu, Lautaro, Osorno, Castro, 1965.
} 


\begin{tabular}{|l|l|}
\hline Tabela 10 - Conteúdos didáticos dos Centros de Orientação do IER & HORAS \\
\hline (A) Educação para Saúde & 10 a 40 \\
\hline (B) Educação social e cívica & 7 a 40 \\
\hline Educação econômica (cooperativas) & 7 a 40 \\
\hline Educação familiar & 5 a 40 \\
\hline Ciências sociais & 7 a 40 \\
\hline Educação moral & 6 a 40 \\
\hline Desenvolvimento da comunidade & 20 a 100 \\
\hline (C) Educação básica: castelhano, matemática, história e geografia. & 5 a 100 \\
\hline $\begin{array}{l}\text { (D) Recreação: educação física e esportes, folclore e artes, práticas } \\
\text { recreativas. }\end{array}$ & 90 a 760 \\
\hline (E) Rudimentos de ofícios (em grupos optativos paralelos) & $\mathbf{1 6 0 h}$ a 1.200h \\
\hline TOTAL (intensivo / extensivo)
\end{tabular}

As mensagens cristãs permeavam os materiais. Um livreto de Educação para Saúde, por exemplo, introduzia: "é uma opinião unânime, na qual todos coincidem, que o homem é o ser mais perfeito da criação. Foi criado à imagem de Deus, e todos os bens da terra devem se ordenar em função do homem, ao centro e acima de todos estes". ${ }^{308} \mathrm{O}$ livreto expunha reflexões cristãs sobre a existência, para logo explicar o processo biológico de reprodução da vida, as partes e funções dos órgãos genitais masculinos e femininos, definições sobre a maternidade e a paternidade e informações sobre doenças venéreas. Enquanto isso, as aulas de Educação econômica eram focadas no cooperativismo. Ensinavam a história do movimento cooperativista inglês do século XIX, com uma lição de moral explícita: a partir da humilde contribuição financeira de cada um, os pequenos negócios podem crescer. Os camponeses chilenos poderiam se tornar verdadeiros empresários cooperativistas. A história era apresentada em tom de parábola e incorporada como um grande exemplo a ser seguido. Junto dela, ensinava-se os sete princípios do cooperativismo e a diversidade das formas cooperativas que poderiam ser adotadas pelos alunos, de acordo com sua realidade. ${ }^{309}$ Outra disciplina importante era o Desenvolvimento da comunidade. Fundamentada na doutrina social-cristã, que postulava que as empresas comunitárias eram os corpos intermediários que precisavam ser fortalecidos como ideal de sociedade, a disciplina incentivava a construção de escolas, hospitais, estradas e centros de recreação, que permitissem a melhoria da qualidade de vida da coletividade camponesa. Segundo documentos internos do instituto, entre 1960 e 1969, seus cursos de educação básica contaram com 29.618 alunos. ${ }^{310}$

Já nos cursos de especialização, os conteúdos se diferenciavam por gênero de maneira mais pronunciada, de acordo com ofícios tipicamente atribuídos à divisão sexual do trabalho rural. Entre os

\footnotetext{
${ }^{308}$ IER, Cuaderno de Educación Fundamental. Educación para la salud. Serie Contenidos, s/f.

${ }^{309}$ Las cooperativas, una realidad histórica. Surco y Semilla, n. 82, Set./1962; Los pilares del edificio cooperativo. Surco y Semilla, n. 82, Nov./1962; IER, Cuaderno de Educación Fundamental. Educación Económica. Serie Contenidos, s/f.

${ }^{310}$ IER, Memoria Anual. 1968-1969.
} 
cursos para mulheres destacavam-se os de Corte e Costura, Chefia de Ateliês Cooperativos, Indústria Caseira, Artesanato Camponês, Educação para o Lar, Economia Doméstica, Jardinaria, Cuidados com a Horta e Cestaria. ${ }^{311}$ Já os homens, tinham cursos de Cultivos, Técnicas Agropecuárias, Criação de Animais, Apicultura, Carpintaria Rural, Administração Agrícola, Mecânica Agrícola, Construção Rural, Operador de Maquinaria, Tratorista, Gerente de Cooperativa, Eletricidade, entre outros. ${ }^{312}$ Como argumentou Tinsman (2002: 138), "ainda que essa capacitação oferecesse a ambos, homens e mulheres, habilidades para incrementar sua renda, as contribuições femininas eram realizadas de dentro de casa, enquanto as contribuições masculinas estavam mais claramente conectadas à produção comercial".

Em 1964, existiam apenas dois Centros de Promotores, um masculino (Malloco) e outro feminino (Santa Ana), onde eram realizados os cursos mais sofisticados, de Aperfeiçoamento de professores, Técnicas pedagógicas, Orientação econômica, Orientação vocacional, Cooperativismo e Desenvolvimento comunitário. ${ }^{313}$ Os alunos eram ou tornavam-se quadros intermediários ou nacionais na estrutura educacional do IER, como professores, chefes de Centros, delegados ou promotores populares, encontrando melhores oportunidades de emprego dentro do próprio instituto. Fechava-se assim um circuito cultural e econômico de edificação de um projeto político.

As mulheres podiam alcançar posições destacadas de chefia no IER, embora no contexto de uma separação prévia dos papeis de gênero. Cada um dos mais de dez centros de capacitação feminina, por exemplo, foi comandado por uma professora-chefa, que tinha sob sua ordem uma considerável infraestrutura pedagógica. Além disso, as equipes dos Centros de Capacitação Móveis foram chefiadas por duas mulheres, que frequentemente eram reconhecidas pela sua competência: a assistente social Elba Bruna e a pedagoga Dalila Pacheco. ${ }^{314}$ Em setembro de 1966, um ex-aluno do Centro Móvel de Misquihue agradeceu especialmente à 'professora Elbita': “todas essas pessoas estão desenvolvendo uma enorme campanha de ensinamentos que, por aqui, nunca se esperava", 315 disse.

Seguindo a lógica do mutualismo de gênero da promoção popular camponesa, analisado por Tinsman (2002), o IER, em geral, convocava as mulheres para participação cívica e comunitária dentro dos contornos delimitados pela construção do gênero, sempre voltadas para as tarefas da "sensibilidade" e do "cuidado". "A mulher camponesa está incorporada as lutas e esforços organizados para mudar o modo de vida no campo", 316 convocava o instituto, ao mesmo tempo que determinava seu destino: "a poupança do lar, quem faz é a mulher" ${ }^{317} \mathrm{O}$ mutualismo de gênero era, como mostrou Tinsman, uma política de modernização dos papeis de gênero no ativismo cívico e convocava homens e mulheres à participação ativa na "revolução em liberdade". Nesse mesmo sentido, o IER recrutava homens e

${ }^{311}$ Cursos del IER en 1964. Surco y Semilla, n. 97, Abr/1964; Central de Capacitação Feminina de Ancud. Surco y Semilla, n.102, Set/1964.

312 Cursos del IER en 1964. Surco y Semilla, n. 97, Abr/1964; Educación en progreso. Surco y Semilla, n. 107, Fev/1965.

${ }^{313}$ Educación en progreso. Surco y Semilla, n. 107, Fev/1965.

${ }^{314}$ Un nuevo estilo de trabajo. Surco y Semilla, n. 110, Maio/1965; Primer año de trabajo de los equipos móviles. Surco y Semilla, n. 118, Jan/1966.

315 Buzón de Surco y Semilla. Surco y Semilla, n. 126, Set./1966.

316 Señor presidente, nosotros pedimos. Surco y Semilla, n. 102, Set/1964.

${ }^{317}$ El ahorro del hogar lo hace la mujer. Surco y Semilla, n. 113, Set/1965. 
mulheres rurais à construção ativa de um projeto de transformação agrária, defendendo o protagonismo camponês, o comportamento econômico poupador, a disciplina laboral, a empresa cooperativa e o casamento cristão como bases subjetivas da nova agricultura. Como sintetizou Tinsman (2002: 146), "os homens seguiriam sendo patriarcas, mas deveriam ser modernos e benevolentes. Ainda que de forma hierárquica, eles também deveriam dividir o palco com as mulheres".

Os valores de iniciativa e o protagonismo camponês se fortaleciam no fluxo de alunos do IER que viajavam aos cursos e retornavam às suas comunidades, para colocar em prática o que aprenderam. Um grupo de ex-alunas do IER, por exemplo, ao retornar para sua comunidade em Cerro Colorado, inaugurou um Centro Feminino e um Centro de Madres, com cursos para suas vizinhas sobre Primeiros socorros, Confecção de móveis caseiros, Corte e costura, Puericultura, Educação familiar e Educação para saúde. ${ }^{318}$ Em novembro de 1965, Carlos Calbuco e Margarita Manquepillán, dois delegados formados pelo IER, contaram ter organizado uma jornada de estudos em Huichaco, onde viviam, para tratar de Administração agrícola, Educação familiar, Promoção popular, Cuidados do adolescente, Cooperativas camponesas, Desenvolvimento da comunidade, Reforma agrária, Avicultura e apicultura, em uma parceria com o INDAP. ${ }^{319}$ Em junho de 1966, ex-alunos do IER se reuniram em Bíobio para retomar seus debates sobre Cooperativismo, Organização sindical e Desenvolvimento da comunidade. Como desdobramento, inauguraram uma oficina de criação animal para rapazes, um ateliê de costura cooperativa para garotas e agendaram um concurso de beleza que elegeria uma "rainha" entre as moças de diferentes comunidades rurais. ${ }^{320}$

No programa de televisão do Canal 13 transmitido em outubro de 1964, a ex-aluna Alicia Miranda, além de explicar o papel da capacitação feminina - "em todos os aspectos sociais, culturais e econômicos" - ressaltou especialmente a importância dos ex-alunos do IER voltarem às suas comunidades de origem para "despertar inquietações, ajudar a compreender seus problemas e buscar os meios de solucioná-los". ${ }^{321}$ Para comprovar seu argumento, contou a anedota de uma comunidade que ela mesma visitou como delegada, onde muitas crianças morriam por doenças estomacais. Depois de consultar o Serviço Nacional de Saúde, confirmou o que suspeitava: "bastava ferver a água!", 322 exclamou. Miranda atribuiu esse saber tão singelo aos cursos de Educação para Saúde que recebeu no IER.

A camponesa Teresa Bermúdez, de Colliguay, teve sua carta de próprio punho reproduzida numa edição de 1966, na qual expressava o processo pedagógico multiplicador:

Por intermédio desta revista, tão importante para o setor que até pouco tempo atrás estava tão abandonado (...) quero dar meus agradecimentos às estimadas professoras da Central Feminina de Malloco, por aquilo que adquiri nesse

\footnotetext{
${ }^{318}$ Buzón de Surco y Semilla. Surco y Semilla, n. 117, Dez/1965.

${ }^{319}$ Id. ibid.

${ }^{320}$ Buzón de Surco y Semilla. Surco y Semilla, n. 127, Out./1966.

${ }^{321}$ IER en televisión. Surco y Semilla, n. 104, Nov./1964.

${ }^{322}$ Id. ibid.
} 
curso, que me fez experimentar uma mudança que eu tanto desejava e que servirá também aos meus irmãos camponeses. ${ }^{323}$

Outro depoimento sobre a multiplicação intergeracional dos ensinamentos aprendidos nos centros de capacitação foi do camponês Gastón Vasquez: "O IER me transformou totalmente. Me tornou consciente do vasto trabalho por realizar entre a classe camponesa (...). Devemos tudo ao IER, porque o que podemos dar ao nosso filho, quem nos deu foi o IER". 324

O delegado do IER em Loncoche, Sergio Alarcón, escreveu que na sua região foram criados quatro centros de ex-alunos, com objetivo de aprofundar estudos, rever colegas e colocar em prática os conhecimentos. A Adela del Tránsito, inquilina de Chacayal, expressava seu sentimento sobre a necessidade do campesinato progredir coletivamente: "quero dizer aos nossos queridos camponeses que temos um longo caminho a percorrer, temos muito que mudar em nós mesmos, em nosso espírito de esforço e respeito aos demais, para poder colocar em marcha essa comunidade que somos, os camponeses do Chile". ${ }^{325}$

Em 1965, a revista Surco y Semilla verificou o paradeiro de 33 ex-alunos do Centro de Capacitação de Longotoma. Entre os 27 ex-alunos localizados, 9 deles tinham se tornado ajudantes de professores no próprio centro onde estudaram; quatro viraram delegados do IER; 5 deles voltaram ao trabalho agrícola nas suas comunidades de origem; 6 se tornaram dirigentes profissionais, sendo dois da ANOC e quatro do MCI (Movimento Campesino Independente); dois estavam fazendo um novo curso no Centro de Promotores; e apenas um foi morar em Santiago. Com essa pequena mostra, era possível notar que o IER tinha vocação para transformar camponeses em professores e dirigentes orgânicos ao meio rural, que seguiam atuando no terreno da cultura, da construção da hegemonia e da promoção popular. ${ }^{326}$ Não há dúvidas, portanto, que os Centros de Capacitação do IER eram impulsionadores de um processo de mudança cultural com impactos econômicos, viabilizando novas práticas de organização camponesa, técnicas de produção e coesão comunitária em torno aos seus valores.

\section{Rádio Escola: a identidade camponesa na infância}

A Rádio Escola Surco y Semilla foi uma inovação tecnológica que colocou o IER a frente de qualquer outro organismo privado no enraizamento pedagógico no campo. Ela foi inaugurada em 1958 e no ano seguinte foi recomendada por decreto pelo governo de Jorge Alessandri para escolas primárias rurais. Em 1964, já eram 1.750 escolas que aderiam aos cursos radiofônicos, atendendo a 92 mil alunos,

\footnotetext{
${ }^{323}$ Buzón de Surco y Semilla. Surco y Semilla, n. 118, Jan./1966.

${ }^{324}$ Forjadores del IER. Surco y Semilla, n. 104, Nov./1964.

${ }^{325}$ Buzón de Surco y Semilla. Surco y Semilla, n. 111, Jun./1965.

${ }^{326}$ Longotoma. Surco y Semilla, n. 109, Abr./1965.
} 
por meio de 42 emissoras privadas que transmitiam os conteúdos em módulos, das 9 horas da manhã às 16 horas. ${ }^{327}$ A Rádio Corporação América vendia equipamentos baratos aos lares camponeses e a USAID doava os transmissores para as escolas, via Aliança para o Progresso. Bastava que os professores rurais se inscrevessem gratuitamente para que recebessem os livretos da Rádio Escola, específicos para condução das aulas radiofônicas. No começo da década de 1960, o instituto se orgulhava de já ter produzido 9 mil horas de programas. ${ }^{328}$

Não era apenas nas escolas rurais que os programas eram escutados, mas também dentro das casas. Em 1962, a camponesa Lorna Castillo, de Calama, escreveu: "quero expressar quão feliz me sinto ao escutar os programas da Rádio Escola Surco y Semilla, e por isso mesmo quero assinar a revista". ${ }^{229}$ Já o inquilino Luis Enrique Fuentealba, de Bulnes, agradeceu pelo equipamento de rádio que ganhou do instituto: "vivo muito longe do povoado, aqui não chega nenhuma notícia. No mercado não poderia adquirir uma rádio de tanta qualidade, porque seu preço é elevado. Eu digo a todos os meus amigos e família que o instituto é um grande futuro e ajuda para os camponeses". ${ }^{330}$ A professora Maria Teresa Pousa, da Escola Particular $n^{\circ} 7$ de Curimon e San Felipe, ao fim do ano fez questão de "agradecer-lhes por todos os favores que nos outorgaram durante o ano escolar de 1965. As alunas aproveitaram ao máximo as interessantes lições que vocês nos proporcionaram por meio da Rádio Escola". ${ }^{331}$

Os cursos radiofônicos tinham dois níveis: o Curso A para os primeiros anos e o Curso B para os anos finais da escola primária. Ambos compartilhavam quatro matérias: Educação Agropecuária; Educação moral; Educação manual e Educação para o lar. O Curso B contava com uma quinta disciplina, chamada Iniciação cultural, que tratava de cooperativismo, folclore e América Latina. Nos livretos recebidos pelos professores, cada aula ocupava 2 a 3 páginas, com instruções sobre os objetivos e as melhores formas de condução daquele conteúdo. O programa radiofônico durava de 15 a 20 minutos. Depois de escutá-lo, a aula prosseguia com o suporte que os livretos ofereciam ao professor.

$\mathrm{O}$ material às vezes continha dicas sobre didática. Na aula de Educação moral sobre responsabilidade escolar, por exemplo, o material sugeria "que o professor procure inovar o sistema de tarefas, reduzindo-as ao mínimo e dando-lhes maior variedade" ou "é aconselhável que a educação (...) se aproxime cada vez mais da realidade das crianças, seus interesses e sua vida". ${ }^{332}$ Em termos metodológicos, existiam cinco tipos de aulas: formação de conceitos, fixação de conceitos, formação de hábitos, apreensão de mecanismos, aplicação de mecanismos. As aulas de Educação moral trabalhavam com parábolas cristãs que acionavam diferentes valores, como a responsabilidade escolar, a conduta com a família e com os amigos, como evitar brigas e obedecer às regras. A parábola "História de um homem que quis gozar de suas riquezas" criticava aqueles que privilegiavam as riquezas

\footnotetext{
${ }^{327}$ Diez años de labor. Surco y Semilla, n. 91, Out/1963; Radio Escuela, Surco y Semilla, n. 100, Jul/1964; Una morada hacia al futuro. Surco y Semilla, n. 87, Jun/1963; Radio Escuela Surco y Semilla. Surco y Semilla. n. 96, Mar/1964.

${ }^{328}$ Diez años de labor. Surco y Semilla, n.91, Out/1963.

${ }^{329}$ ¿Qué dicen? Surco y Semilla, n. 80, Jul./1962.

330 ¿Qué trae el correo? Surco y Semilla, n. 82, Sep./1962.

${ }^{331}$ Buzón de Surco y Semilla. Surco y Semilla, n. 118, Jan./1966.

332 IER, Radio Escuela Surco y Semilla. Curso A, Maio/1964.
} 
materiais em detrimento do cultivo espiritual. A "História de um homem que não soube perdoar" estimulava as crianças à prática do perdão, ao mesmo tempo que retomava os sentimentos de respeito e submissão a Deus. Já "Os farsantes" era uma parábola que estimulava as crianças a ajudar os demais sem esperar recompensa. Em "A moeda para pagar impostos", explicavam porque Jesus era fiel a Deus sem desobedecer às leis do império romano, a fim de estimular o "desejo de cumprir a lei" ${ }^{333} \mathrm{~A}$ aplicação prática desses aprendizados era traduzida no combate à preguiça, na defesa de uma conduta obediente e trabalhadora, na delimitação dos papeis de cada membro dentro da família, junto com a valorização da solidariedade, do humanismo e da humildade. Em "A primeira pedra", que contava como Jesus salvou a mulher adúltera condenada por fariseus, ensinavam às crianças como "é fácil condenar aos demais. Difícil é condenar-se a si mesmo, reconhecer que todos somos pecadores". 334 A parábola do Bom Samaritano, da aula "O poço de água viva", ensinava às crianças sobre a universalidade do amor divino, que abarcava a todos os povos do mundo. Em "A grande surpresa" ensinavam às crianças que no juízo final Jesus premiaria àqueles que aplicaram a universalidade do amor divino na sua vida ao amparar os necessitados e oferecer sua generosidade aos humilhados: "Jesus ensina que todos os homens são iguais, porque são filhos do mesmo Pai". Por isso, teria dito: "Se desprezas teu irmão que tem fome, é a mim que desprezas. Se eres indiferente ao teu irmão que está nu e doente, é a mim que rechaças". ${ }^{335}$ A proposta moral da aula passava por "estimular os alunos a que se ajudem mutuamente". 336

Para aproximar as crianças rurais do personagem de Jesus Cristo, algumas aulas descreviam sua infância como de um menino camponês comum e corrente, um huaso chileno, que ia para escola, brincava no bosque e aprendia o ofício da carpintaria com José, seu "pai adotivo". Entre os redatores dessas adaptações da bíblia à ruralidade chilena, estava Rogelio Correa, que antes de ser professor de Centro de Capacitação de Lautaro em 1961, foi quem escreveu programas de rádio e livretos de Educação Moral. "Eu criei uma aldeia imaginária dentro do Chile, que se chamava Pueblo Grande. Nessa aldeia ocorriam as histórias que Ele contou. As parábolas. Eram dramatizadas. O instituto tinha uma equipe excelente de rádio, era gente muito profissional. Eles gravavam os livros", recordou-se Correa. "Fiz uns cem ou mais livretos radiofônicos", ${ }^{337}$ calculou. Suas histórias eram destinadas aos camponeses de 6 a 12 anos. "Eu recebia cartas que as crianças me enviavam. Tinham personagens protagonistas que se repetiam. Um deles se chamava Pancho, um menino. O Pancho era amigo desse outro menino, que era Jesus. Então eles queriam conhecer o Pancho", recordou.

Nas aulas de Educação agropecuária, valorizava-se o conhecimento posto em prática. Quase todas as aulas ensinavam melhorias no âmbito da pequena empresa campesina, isto é, na produção do huerto familiar, que era um trabalho geralmente executado pelas crianças desde muito cedo na companhia das

\footnotetext{
${ }^{333}$ Educación Moral. Material pedagógico de la Radio Escuela Surco y Semilla, Maio.-Nov./1965.

${ }^{334}$ Id. ibid.

${ }^{335}$ Id. ibid.

${ }^{336}$ Id. ibid.

${ }^{337}$ Entrevista com Rogelio Correa, Santiago, 30/05/2019.
} 
suas mães. Como costumava ocorrer com as atividades femininas, o huerto não era considerado propriamente um trabalho. Em sua tese, Patrícia Garret (1978) mostrou como o trabalho feminino e infantil dos huertos no Chile era invisibilizado e não remunerado, sendo a base que sustentava o barateamento geral dos custos de reprodução da vida, uma vez que, ao permitir que trabalhadores rurais resistissem aos baixos salários com a alimentação de suas próprias roças, o reduzido custo de produção rural gerava um rebaixamento dos preços dos alimentos que, por sua vez, se transmitia aos baixos salários urbanos. A socióloga estadunidense criticava que $85 \%$ das mulheres camponesas foram classificadas como "economicamente inativas" pelo Censo Agropecuário entre 1955 e 1965, embora fossem elas as incansáveis produtoras dos alimentos da família nos huertos (Garret, 1976: 13). Essa invisibilidade econômica do trabalho feminino, porém, se contrastava com o protagonismo do huerto no âmbito pedagógico.

A Educação Agropecuária da Rádio Escola ocupava mais de 40\% dos conteúdos radiofônicos e as aulas desse ramo se relacionavam quase integralmente com os trabalhos da empresa camponesa, dirigida por mulheres e acompanhada por crianças: "Preparando um canteiro", "Plantando hortaliças", "Enxerto", "Videiras de jardim", "Variedades de batatas resistentes às pragas", "Prepare sua composteira”, eram alguns títulos das aulas. Também havia uma preocupação particular com a vida das abelhas, consideradas insetos especiais por se organizarem em sociedade. Na aula "Importância das Abelhas", as crianças aprendiam sobre o valor alimentício e medicinal do mel, sobre a vantagem econômica da apicultura e o caráter fundamental da polinização para o ciclo da vida. O livreto definia: "a apicultura não é outra coisa que uma sociedade formada entre o homem e as abelhas para que trabalhem em conjunto". 338

Para os redatores da Rádio Escola, as abelhas exemplificavam os valores morais que se pretendia difundir na cultura camponesa: eram trabalhadoras, disciplinadas, cooperativas e generosas. O livreto do professor ensinava: "as abelhas estão entre os seres mais organizados do mundo e podem servir de exemplo aos humanos na questão do trabalho cooperativo". ${ }^{339}$ Seus inimigos naturais também eram estudados na aula "As formigas arruínam as colmeias". Outro tópico frequente da Educação agropecuária era a criação animal, com aulas sobre cuidados com porcos, alimentação de cavalos e bois, vacinações e vacas leiteiras. Como vimos, tanto a Rádio Escola, como a Revista praticavam uma "pedagogia produtiva", que tinha desdobramentos práticos no incremento da renda da empresa campesina.

As aulas de Educação manual eram direcionadas para os meninos; enquanto as de Educação para o lar para as meninas. Embora ambas exercitassem as habilidades das crianças para produzir manualmente objetos de utilidade rural, lúdica ou decorativa, como mesas, brinquedos de madeira, roupas e panos de prato, os temas dos meninos remetiam ao mundo da produção agrícola ou da brincadeira fora de casa,

\footnotetext{
${ }^{338}$ Educación Agropecuaria. Material pedagógico de la Radio Escuela Surco y Semilla, Maio.-Nov./1965.

${ }^{339}$ Id ibid.
} 
enquanto os temas das meninas variavam entre cuidados domésticos e lições espirituais sobre os sentimentos da coesão familiar. ${ }^{340}$

Entre 1958 e 1963, o IER distribuiu gratuitamente 1.276 receptores de radiodifusão para as escolas. A maior parte havia sido patrocinada pela Braden Copper Co., que 1964 doou 9 mil escudos em uma cerimônia que celebrava "os vínculos de amizade que unem a Braden ao nosso instituto". ${ }^{441}$ A Braden Copper pertencia à Kennecott Copper Corporation, proprietária da mina de cobre El Teniente até sua estatização em 1971. ${ }^{342}$ A Rádio Escola também contou com o trabalho dos voluntários dos Peace Corps, com quem mantinham uma estreita relação. A chegada e a partida das brigadas de "piscorisnos" motivava festas, cerimônias de despedida, homenagens públicas e agradecimentos. Em junho de 1964, a revista noticiou a despedida de Kay Partidge, uma "simpática gringuita", que trabalhou no IER durante um ano escrevendo as páginas de Educação para Saúde da própria revista Surco y Semilla, além de um Manual de primeiros socorros e enfermaria do lar. ${ }^{343}$

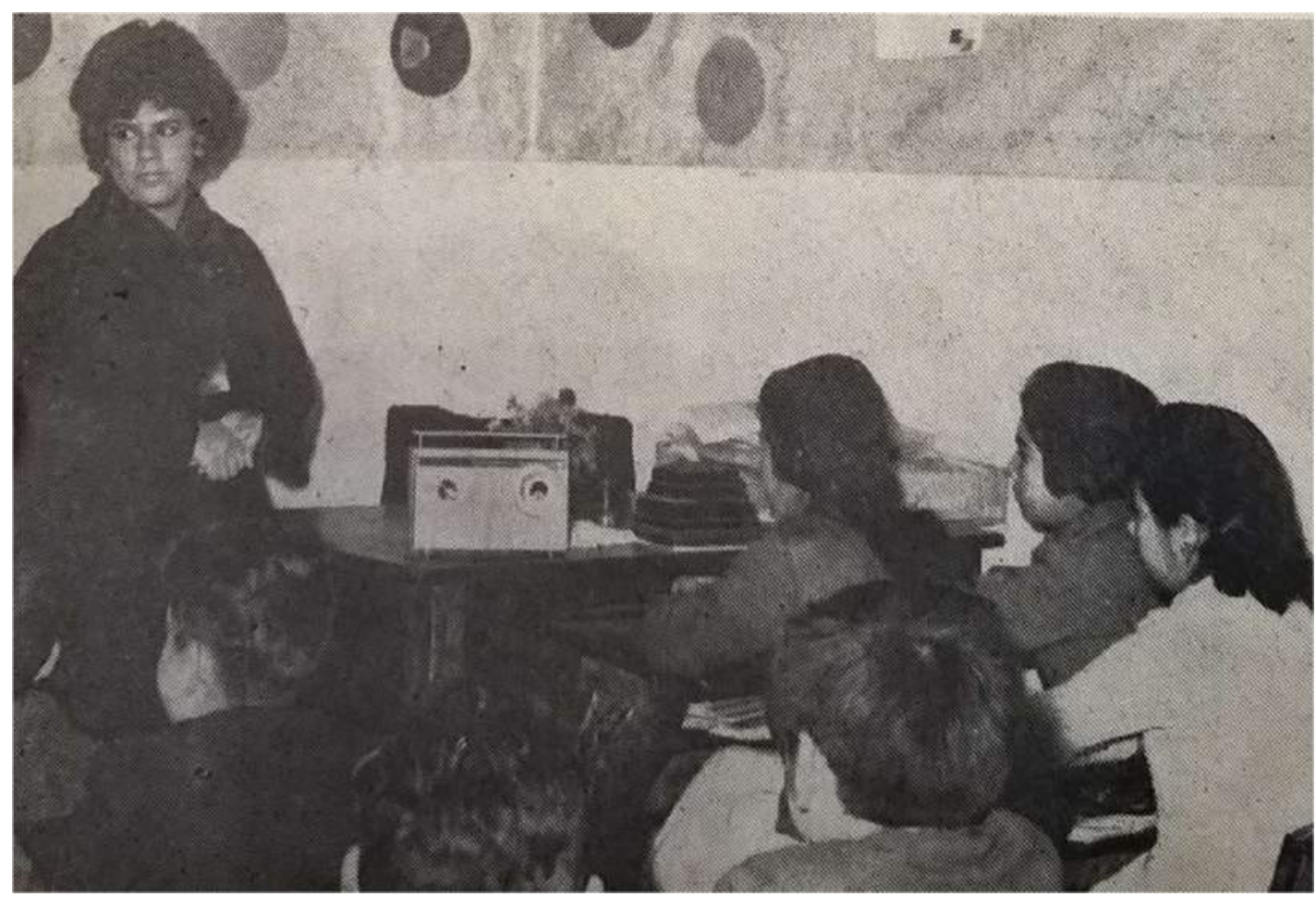

Alunos de escola rural escutam o programa do IER pelo rádio (Radio Escuelas del IER. Surco y Semilla, n. 89, Ago./1963)

\footnotetext{
${ }^{340}$ Educación Manual. Material pedagógico de la Radio Escuela Surco y Semilla, Maio.-Nov./1965; Educación para el Hogar. Material pedagógico de la Radio Escuela Surco y Semilla, Maio.-Nov./1965;

${ }^{341}$ Vida en el IER. Surco y Semilla, n. 91, Out/1963

342 A companhia Braden Copper teve 51\% das suas ações compradas pelo governo de Eduardo Frei em 1967 e foi completamente estatizada sem indenizações em 1971.

343 ¡Chaíto, Kay! Surco y Semilla, n. 99, Jul./1964.
} 


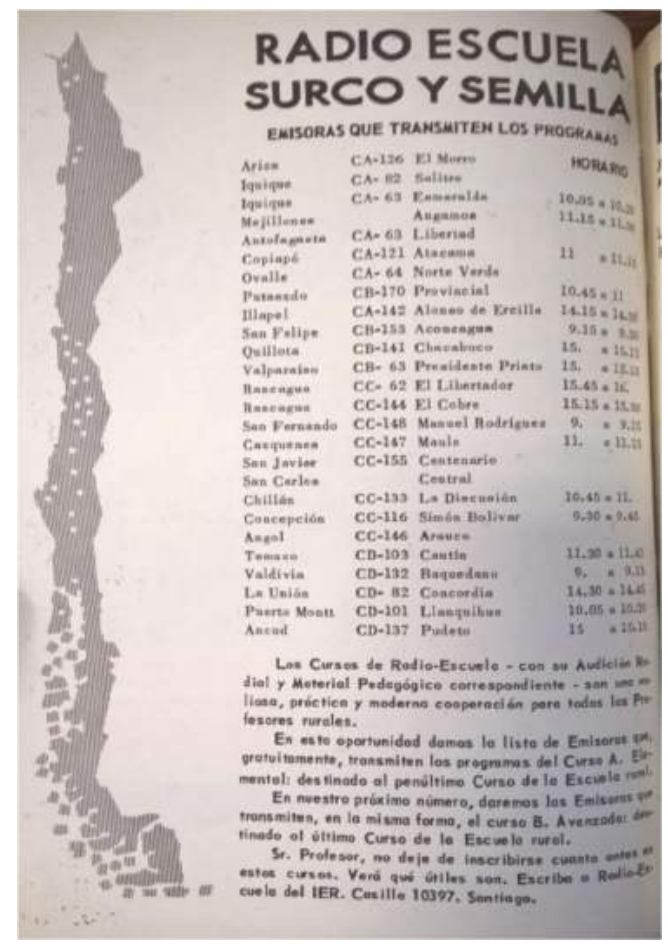

"Damos a lista de emissoras que transmitem gratuitamente os programas do curso (...) Sr. Professor, não deixe de se inscrever o quanto antes nestes cursos, verá com são úteis" (Radio Escuela Surco y Semilla, Surco y Semilla, n. 100, Jul/1964)

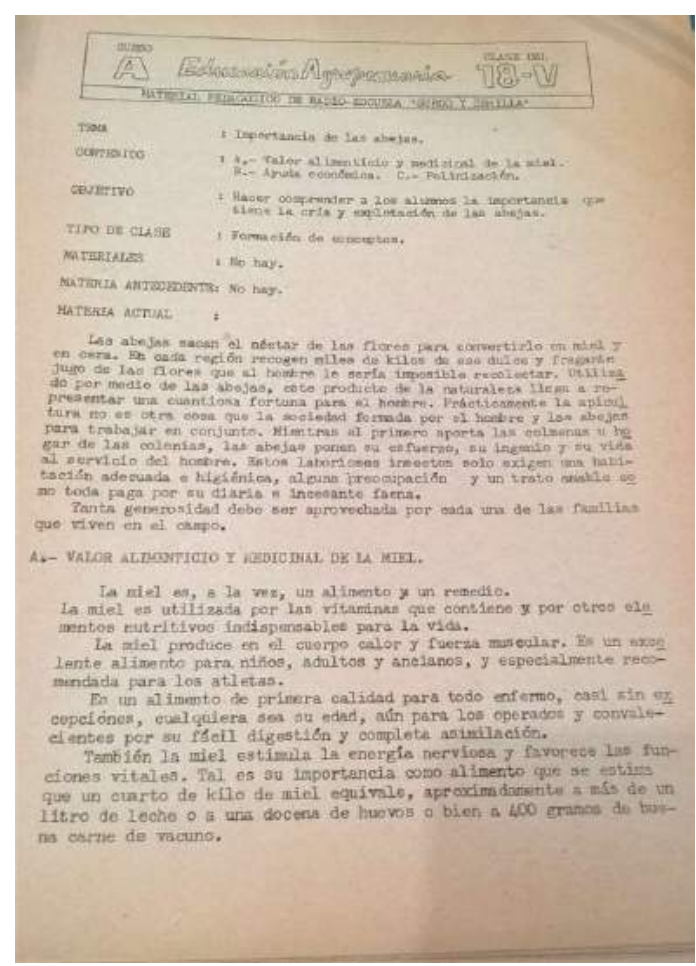

Livreto da Radio Escola recebido pelos professores primários. Aula de Educação agropecuária sobre o tema "Importância das abelhas". (Material pedagógico de la Radio Escuela Surco y Semilla, Maio.-Nov./1965.)

A primeira missão dos Corpos de Paz ao IER foi formada por 43 jovens que chegaram em outubro de 1961. Em dezembro de 1963, outros 30 jovens estadunidenses se incorporaram aos trabalhos do IER, ministrando aulas, auxiliando serviços comunitários, se inserindo em equipes de jornalismo, produzindo programas de rádio, entre outras atividades. ${ }^{344}$ "Nosso departamento de Difusão e Rádio Escola tem uma dívida especial com quatro piscorinos que colaboraram ombro a ombro, com sua alma", 345 agradecia o instituto. Eram Roger Marshall, que cuidava da fotografia; Sarah Patterson, ilustradora e diagramadora; William Fox, que visitou dezenas de escolas rurais distribuindo mapas, livretos e receptores de rádios; e Martim Ronan, encarregado da biblioteca e do audiovisual. Os piscorinos participaram também diretamente da criação das Unidades Móveis Audiovisuais do IER, considerado o empreendimento pedagógico mais ousado e moderno que alcançou o Chile rural daqueles tempos.

${ }^{344}$ Vida del IER. Surco y Semilla, n. 88, Jul/1963; Vida del IER. Surco y Semilla, n. 93, Dez/1963. Entre os "piscorinos" que foram ao Chile (mas não ao IER), estavam Brian Loveman e sua companheira Sharon, que trabalharam em Trovolhue, Cautín, entre 1965 e 1968. Sharon ministrava aulas nos Centros de Madres e ambos ajudavam os camponeses a reconstruir o povoado destruído pelo terremoto de 1960. Nos anos seguintes, Brian Loveman produziu seu doutorado sobre história camponesa chilena com os arquivos do Departamento Laboral em Santiago (Loveman, 1976).

${ }^{345}$ Vida del IER. Surco y Semilla, n. 88, Jul./1963. 


\section{Cinema no campo: unidades audiovisuais e equipes móveis}

As Unidades Audiovisuais do IER foram um presente da Cooperativa Americana de Remessas ao Exterior (CARE). Em abril de 1964, dois furgões Willys Jeep com projetores de filmes foram "doados pelo povo dos Estados Unidos", ${ }^{346}$ e deram origem a essa nova frente de capacitação itinerante: as Equipes móveis, que viajavam para "regiões do Chile cujos habitantes sequer conhecem o cinema". 347 $\mathrm{O}$ ato de doação foi transformado em um evento solene com autoridades, o que demonstrava mais uma vez a relevância do IER na estratégia geopolítica estadunidense da Guerra Fria. Uma fotografia capturou Charles W. Cole, embaixador dos Estados Unidos, ao lado de Julio Phillippi, ministro de Relações Exteriores do governo de Jorge Alessandri, junto com Edward T. Greaves, diretor do CARE e Enrique Serrano, presidente do IER. Além deles, estavam presentes no evento William Moffet, recémempossado diretor dos Peace Corps no Chile, e Rafael Larraín, presidente de honra do instituto. Como seu antecessor, Moffet foi enfaticamente elogiado pelo IER por conhecer "profundamente a mentalidade dos povos latino-americanos" e por ter usado seu primeiro mês no Chile para percorrer diversos centros de capacitação e projetos comunitários das bases do instituto. ${ }^{348}$ A doação daqueles dois furgões poderia parecer apenas um detalhe, mas era parte de uma agenda diplomática internacional na qual a geopolítica estadunidense da Guerra Fria para educação rural se atrelava pedagogicamente às bases do campesinato chileno. O que confirmava, mais uma vez, o papel projetado para o IER pelos seus patrocinadores.

Em junho, um terceiro furgão foi doado pelos Peace Corps, mesmo mês em que mais 19 jovens voluntários estadunidenses chegaram para trabalhar no instituto. ${ }^{349}$ Ao dar a partida, cada centro móvel de capacitação contava com dois professores, duas professoras e um motorista, todos chefiados pela assistente social Elba Bruna. Com os jeeps, o IER conseguiu percorrer zonas distantes dos seus centros de capacitação, que às vezes sequer possuíam escolas primárias. A ideia era "chegar mais perto dos Pais de Família e das Donas de Casa que, pelas responsabilidades próprias de seu trabalho e seu lar, não podem receber os benefícios da educação", 350 diziam. Ao alcançar uma comunidade, as equipes móveis ofereciam aulas e palestras gratuitas, quase sempre separadas por gênero. Os temas se repetiam: Técnica agropecuária, Educação para o lar, Higiene, Saúde, Cooperativas, Corte e costura, Desenvolvimento comunitário. Além disso, ofereciam entretenimentos culturais, como danças e folclore, junto com um excepcional acesso à indústria cultural moderna por meio do cinema. A mistura da cultura popular e tipicamente camponesa, como a cueca, com a linguagem moderna do dispositivo audiovisual, não poderia deixar de gerar fascínio. Com isso, o IER tinha em mãos um poderoso recurso de sedução

\footnotetext{
346 Unidades Audiovisuales. Surco y Semilla, n. 98, Maio./1964.

${ }^{347}$ La otra cara de los equipos móviles. Surco y Semilla, n. 127, Out/1966.

${ }^{348}$ Bienvenido Sr. Moffet. Surco y Semilla, n. 97, Abr./1964.

${ }^{349}$ Nuevos voluntarios. Surco y Semilla, n. 100, Jul./1964

${ }^{350} \mathrm{La}$ otra cara de los equipos móviles. Surco y Semilla, n. 127, Out/1966.
} 
cultural que lhes amplificava a potência pedagógica. E nunca deixavam de vender assinaturas da revista. ${ }^{351}$

Desde 1958, o IER promovia o Festival Campesino. Com as equipes móveis, em outubro de 1964, o festival ganhou uma modalidade itinerante em dez comunidades rurais (Melipilla, O'Higgins, Aconcágua, Talca, Chillán, Cañete, Temuco, Valdivia, Osorno, Ancud), em uma agenda que chamaram de programa folclórico massivo. ${ }^{352} \mathrm{~A}$ chegada do cinema levado pelas equipes móveis nos setores mais isolados do campo chileno gerava um forte impacto na subjetividade rural. Em junho de 1965, um garoto camponês de 10 anos, da comunidade de Salto Chico, escreveu uma carta que expressava o elemento básico do fascínio: "o que vi no filme 'Um vaso de leite', passado aqui graças à Equipe móvel do IER, me fez aprender o que é um filme", ${ }^{353}$ contava. Na sequência, compôs uma resenha do seu conteúdo. Era um vídeo educativo sobre pasteurização do leite. "Estou muito contente que o IER esteja aqui e torço para que sempre se lembrem das crianças de Salto Chico", ${ }^{354}$ completava o pequeno Juan Barría Ojeda, aluno do $4^{\circ}$ ano da escola rural $n^{\circ} 37$. Entre os objetivos das equipes móveis, estavam: motivar as comunidades a "participar ativamente no conhecimento e solução dos seus problemas"; "proporcionar técnicas agrícolas, econômicas e domésticas"; e oferecer educação básica. "Os professores do IER cumprem distintas tarefas (...), alguns ensinando técnicas de enxerto, outros vacinando e outros fazendo visitas domiciliares", ${ }^{355}$ explicavam.

Entre outubro de 1965 e janeiro de 1966, duas equipes móveis circularam em quatro povoados distantes. O primeiro jeep foi para El Transito (Atacama) e Choapa (Coquimbo), no Norte Chico, com uma equipe pedagógica chefiada por Dalila Pacheco e composta de seus companheiros Octavio Boettner, Teresa Peñaloza, Luis Fuentes, Gustavo Araya e José Gonzalez. A segunda percorreu Salto Chico e Misquihué (Llanquihue), na região dos Lagos (ao sul), encabeçada por Elba Bruna, e formada por Edmundo Ramírez, Alida Mera, Francisco Villegas, Heriberto Quiroz e Enedina Bascuñán. Em Misquihué, a equipe móvel do IER conseguiu realizar suas aulas dentro de uma escola pública, por meio de uma parceria com a diretora Yolanda de Paredes. As classes de folclore e dança foram as mais cheias. Também produziram juntos, em oficinas de educação manual, objetos para cozinha, roupas e teares. ${ }^{356}$

No Vale de Choapa, a equipe se instalou por três meses em um antigo rancho dentro do assentamento de Taihuinco, onde ministraram aulas para 70 pessoas. A equipe ensinou às mulheres de Choapa novas técnicas de costura, enquanto aos homens foram oferecidas oficinas sobre galinheiro e cooperativismo. Também projetaram sessões de cinema na comunidade e ofereceram práticas de folclore. Choapa era uma região camponesa com forte influência do Partido Comunista. Taihuinco foi

\footnotetext{
${ }^{351}$ El IER em marcha. Surco y Semilla, n. 100, Jun/1964; Un nuevo estilo de trabajo. Surco y Semilla, n. 110 , Maio/1965.

352 Festival del campesino. Surco y Semilla, n. 103, Out./1964.

353 Buzón de Surco y Semilla. Surco y Semilla, n. 111, Jun./1965.

354 Id. ibid.

${ }^{355}$ La otra cara de los equipos móviles. Surco y Semilla, n. 127, Out/1966.

356 Id. ibid.
} 
o primeiro assentamento da reforma agrária chilena e representava uma inovação da Democracia Cristã na implementação da lei de reforma agrária do governo anterior. Em fevereiro de 1965, o governo de Eduardo Frei decidiu fazer a reforma agrária na hacienda Choapa, uma propriedade de 250 mil hectares que pertencia ao Serviço Nacional de Saúde e fora transferida para CORA. Lá viviam 1500 famílias camponesas com pouco acesso à educação. "Os funcionários da CORA falavam um idioma um pouco intrincado para os camponeses. Assentamento, Comitê, Conselho. 'Que diabos seria isso?", 357 narrava um livreto da própria CORA sobre a história do primeiro assentamento de reforma agrária. Depois de serem convencidos pela CORA de que o assentamento seria vantajoso com relação ao parcelamento individual completo, os camponeses de Choapa organizaram uma eleição de um Comitê de Assentamento: "cada um dos chefes de família assinou a Ata do Assentamento. Os que sabiam assinar escreveram com seu nome, os demais com o dedo". 358

O cientista político Octavio Avedaño interpreta que a escolha do governo Democrata Cristão em inaugurar o modelo de assentamento em Choapa não era um acaso, mas sim uma tentativa de apaziguamento da hegemonia comunista no território: "a decisão de intervir no Vale de Choapa gerou uma reação imediata dos dirigentes do PC, que criticaram abertamente a iniciativa e o modo como o governo assumiria a titulação de terras nessa zona" (2017: 251). Com o assentamento em construção, "os sindicatos controlados pelo PC mantiveram a tensão com base nas supostas imposições efetuadas pelos profissionais e técnicos da CORA, assim como pelo poder que foram perdendo devido ao modo que se organizavam os assentamentos", escreveu o autor (2017: 252). Em um território onde a rivalidade entre DC e PC já estava enraizada, a equipe móvel do IER foi inicialmente recebida com desconfiança: "os camponeses no começo acreditaram que era uma nova campanha de convencimento e doutrinação política", relatavam os delegados, "mas se despediram manifestando o desejo de que alguma vez voltássemos por essas bandas".359

O IER se orgulhava de que sua capacitação fosse útil à toda classe camponesa, independente das colorações político-ideológicas. Ou seja, sua oferta pedagógica, generosa e gratuita também funcionava como um método de fabricação do ativo político mais valioso da construção da hegemonia: a confiança popular. Por meio de suas aulas, transmitia um ideal do camponês respeitoso das leis, produtivo, paciente, sacrificado e criativo. Naquele mesmo ano, atendendo aos pedidos, o IER firmou um convênio com a CORA para realização de quatro novos cursos via equipe móvel, com 300 horas de aulas para 1.200 famílias dos assentamentos de Choapa. ${ }^{360}$

\footnotetext{
${ }^{357}$ CORA, Los asentamientos de la reforma agraria. Una realidad chilena. S/f.

358 Id. ibid.

${ }^{359}$ Primer año de trabajo de los equipos móviles. Surco y Semilla, n. 118, Jan./1966.

${ }^{360}$ Convenio IER y CORA. Surco y Semilla, n. 122, Maio/1966.
} 

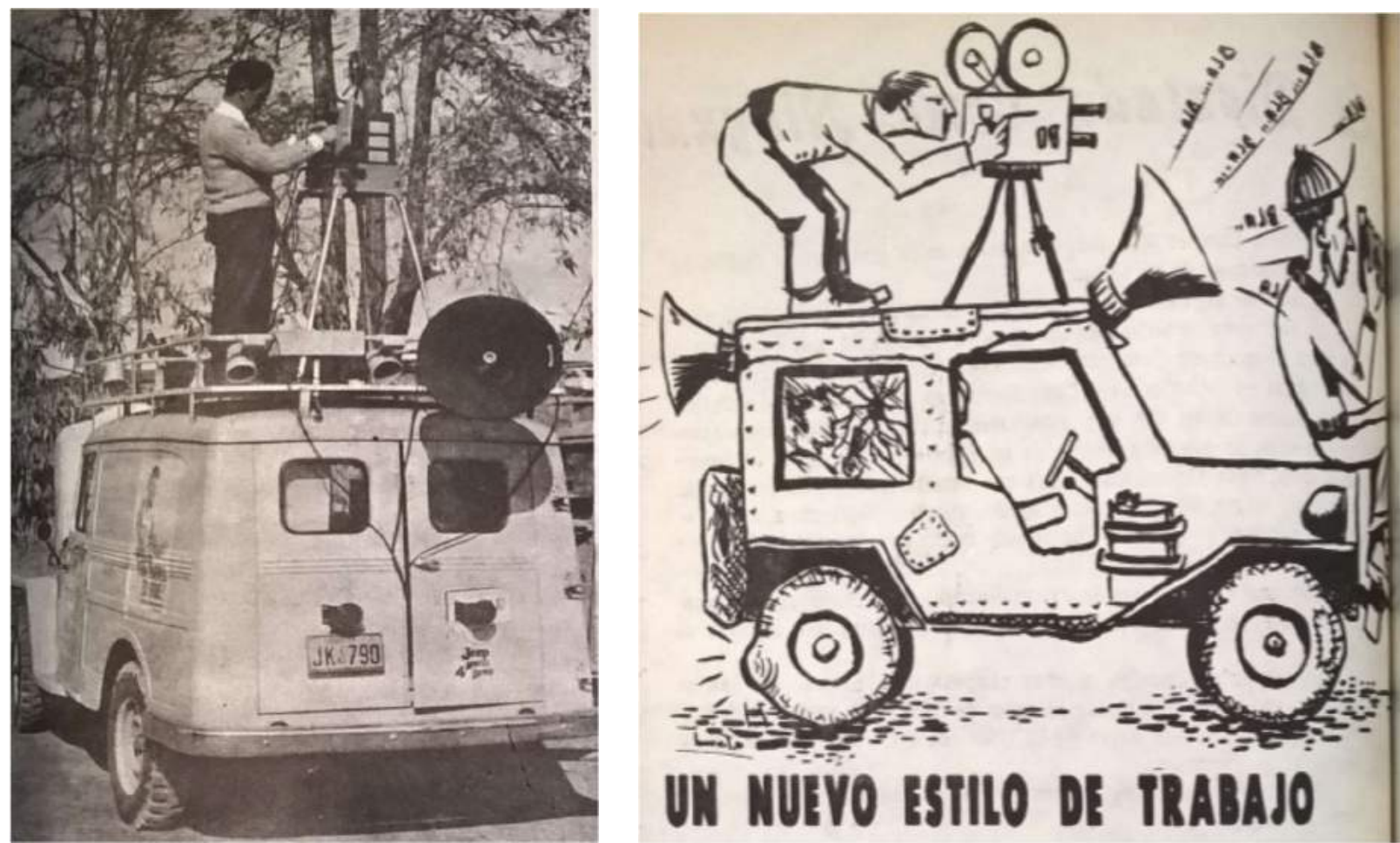

Unidade audiovisual e equipe móvel do IER (Un nuevo estilo de trabajo. Surco y Semilla, n. 110, Maio/1965.)

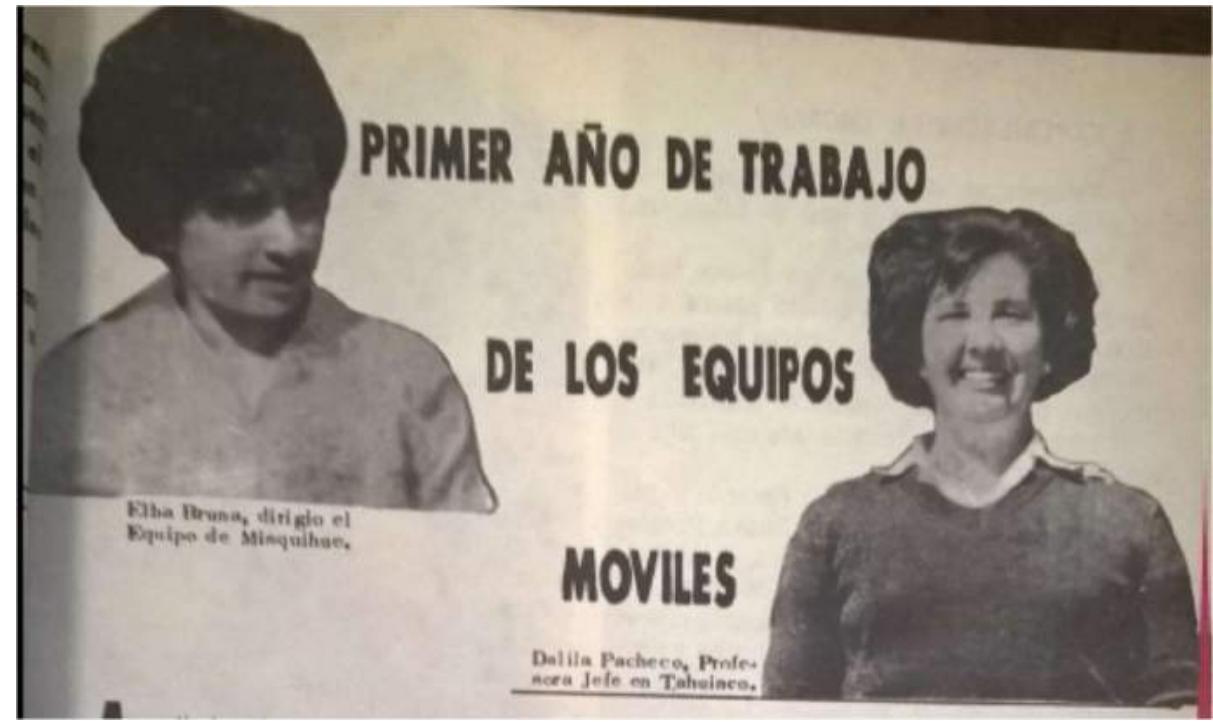

Reconhecimento de Elisa Bruna e Dalila Pacheco, dirigentes das equipes móveis do IER (Primer año de trabajo de los equipos móviles. Surco y Semilla, n. 118, Jan./1966.) 


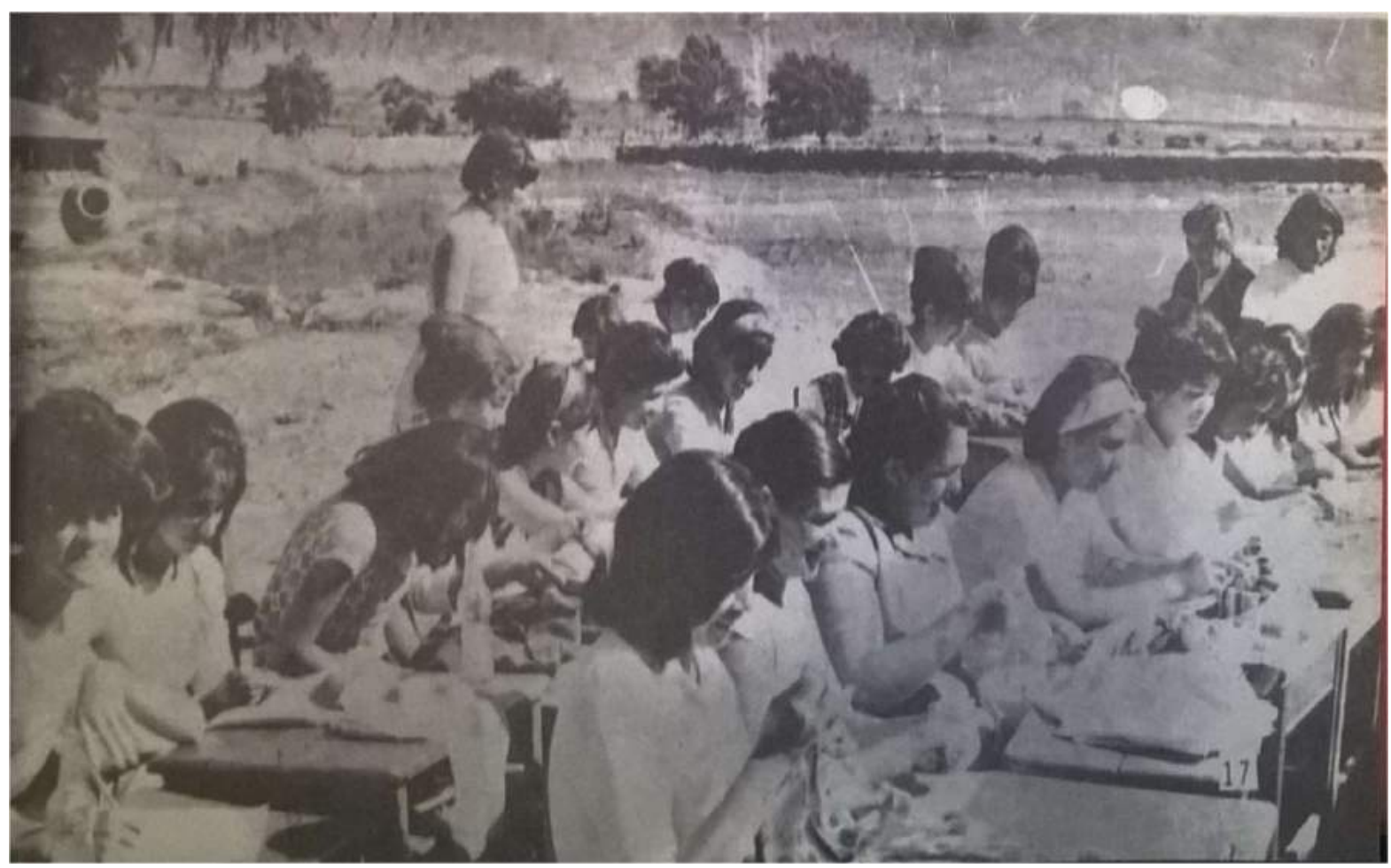

Primer año de trabajo de los equipos móviles. Surco y Semilla, n. 118, Jan./1966.

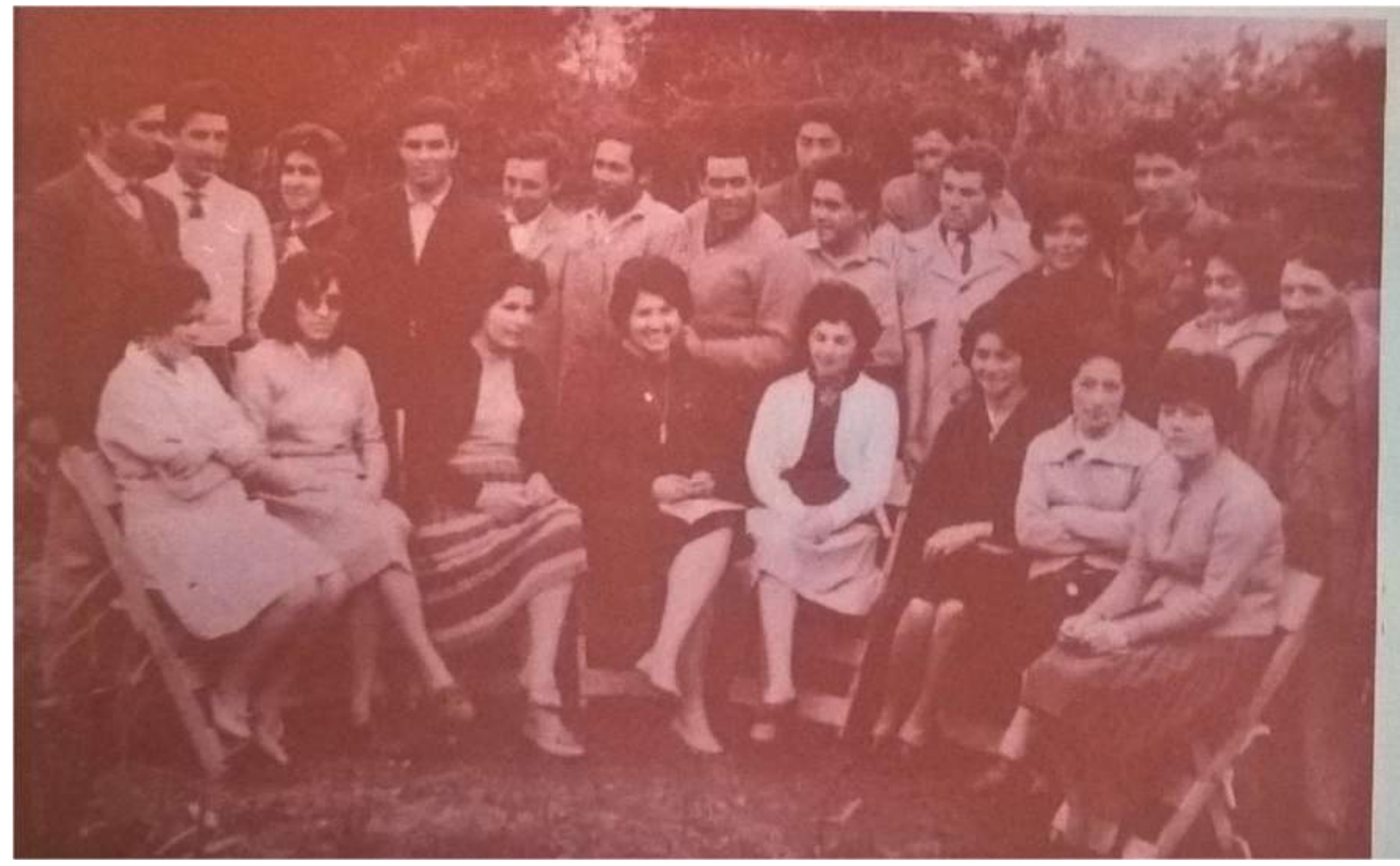

Equipe regional de Los Angeles junto à Equipe móvel na reunião prévia de organização do Festival Campesino 1964, em Bíobio (Buzón de Surco y Semilla. Surco y Semilla, n. 106, Jan/1965.) 


\subsection{IER e reforma agrária: a terra para quem a merece}

A postura do IER com relação à reforma agrária se alterou ao longo dos anos, em uma inflexão semelhante ao processo adaptativo da SNA à nova correlação de forças político-eleitoral (como esmiuçou Oszlak, 2016), mas a ultrapassou rumo a um reformismo substantivo, como imperativo transformador que emanava das suas próprias bases e se alinhava melhor ao progressismo da DC. Em 1960, a revista do IER escreveu um editorial incisivo sobre os riscos da reforma agrária: "é muito infantil acreditar que os problemas do Chile se resolverão apenas com a repartição das terras. É preciso escolher bem os futuros proprietários agrícolas; é preciso capacitá-los e lhes dar assistência técnica e econômica". ${ }^{361}$ Lembravam que, no passado, a política de colonização não levou em conta as debilidades técnico-produtivas dos colonos, que por falta de educação, passaram fortes privações. Em 1962, com a aprovação da lei 15.020, o IER se mostrou esperançoso e satisfeito com a reforma agrária de macetero. Não parecia querer ir além. Em outro editorial, exagerava a credibilidade da promessa de Alessandri, de que a cada ano seriam entregues 5 mil parcelas aos camponeses. A tensão era depositada na escolha dos beneficiários. Quem eram os verdadeiros merecedores?

Para o IER havia dois riscos. O primeiro, que se entregassem parcelas como chácaras de veraneio para pessoas da cidade, seguindo dinâmicas do clientelismo político. A isso, respondiam: "a ANOC e o IER estarão de olhos abertos e vão defender que a terra seja para quem realmente a vá trabalhar. Nada de novos patrões miniatura. Os camponeses devem estar vigilantes". ${ }^{362} \mathrm{O}$ segundo risco era que se entregassem parcelas para camponeses "preguiçosos" e "despreparados": os flojos. Anunciavam que “mesmo entre os camponeses (...), não haverá tantas [parcelas] para todos (...). Ao país convém que sejam proprietários primeiro os que mais merecem, com seu esforço, poupança e experiência. Esses terão todo apoio do IER e da ANOC". ${ }^{363} \mathrm{O}$ instituto oferecia sua estrutura pedagógica e sua revista para auxiliar os interessados em ser proprietários com os trâmites documentais e o cumprimento dos requisitos da lei 15.020 .

Esse auxílio representava um lugar de poder dotado somente às instituições-nexo. Por um lado, a linguagem técnica das políticas de reforma agrária eram parte de um dispositivo cultural urbano, que exigia uma compreensão aguçada dos códigos da cidade. Para a maior parte dos camponeses interessados, era impossível acessar aqueles códigos sem a existência de "tradutores políticos" e "pessoas-nexo" que manejassem simultaneamente a encriptação da linguagem urbana e a subjetividade rural. O IER estava bem posicionado para isso, graças à rede de confiança político-pedagógica construída durante anos.

\footnotetext{
${ }^{361}$ Surco y Semilla, n. 52, Mar./1960. Apud Affonso et al, 1970: 171.

${ }^{362}$ Nuestro pensamiento. Surco y Semilla, n. 83, Out./1962.

${ }^{363}$ Id. ibid. A ANOC surgiu em 1962, depois que os camponeses das organizações de base cristãs foram proibidos de entrar no III Congresso da CUT, episódio que abriu esse capítulo. Consolidaram suas posições no Congresso de Camponeses Livres realizado como evento paralelo.
} 
No procedimento de "tradução", a instituição-nexo imprimiria seus valores, suas tendências, suas ideologias. Por exemplo, o IER tornou-se um otimista da reforma agrária de macetero, tanto quanto um entusiasta da reforma agrária da Igreja: "a reforma agrícola propiciada pelo Arcebispado de Santiago já começa a dar seus frutos. Há camponeses que já são donos das terras que trabalham. Há famílias camponesas que olham com esperança o amanhã”. ${ }^{364}$ Esse otimismo era um subterfúgio, por um lado, contra a crescente insatisfação rural e, por outro, contra o fortalecimento da reforma agrária estrutural entre os modernizadores urbanos, que alteraria o sistema de propriedades e eliminaria o latifúndio, cuja legitimidade técnica e política culminou com o relatório CIDA (1966). A narrativa estruturalista da CEPAL e dos marxistas colidia com o latifúndio. Já o IER combateu essa linguagem por meio da pedagogia do sacrifício.

Merecer a terra, para o IER, era um dizer que se vinculava a um conceito moral específico. O camponês merecedor era sacrificado no trabalho, certificava sua educação e esperava pacientemente o momento de receber a parcela. Uma estratégia de argumentação frequente do instituto era a narrativa de histórias de vida reais que fortaleciam sua economia moral. Para convencer o campesinato sobre a temporalidade inevitavelmente lenta da reforma, por exemplo, o IER narrava a história de Galvarino Pazoa Sánchez, sua esposa e seus quatro filhos, que esperaram durante oito anos até conquistar sua parcela da CORA. Junto com outras 217 famílias, deveriam pagar em 30 anos por seis hectares na antiga hacienda Hospital, agora Colônia Presidente Kennedy. Mas a própria voz do camponês entrevistado criava tensão com a narrativa do instituto: "a colheita de batatas somente deu para pagar a primeira parcela", contava Galvarino, que trabalhava "sozinho", porque seus filhos estudavam na escola agrícola privada Pascual Baburizza em Los Andes. "E vocês está contente, dom Galvarino?", perguntava o repórter do IER. "Sorriu. Não quer expressar demasiado entusiasmo, mas bastava olhar a plantação, as aves e a casa que a gente percebe que sem dúvida é um grande passo a frente", ${ }^{365}$ dizia o próprio entrevistador, diante do silêncio constrangido do parceleiro. E Galvarino, então, se queixava: "Gostaria que fosse maior. O terreno é bom, mas em seis hectares não se faz muito". ${ }^{366}$ A revista do IER então justificava que aquele tamanho correspondia à "unidade econômica familiar" e era tecnicamente adequado.

$\mathrm{O}$ instituto e seus braços ativistas (ANOC e MCI) insistiam que a batalha pelo merecimento não deveria ser feita de agitação, greves, tomas e confrontos, como propunham os marxistas, mas sim de sacrifício pessoal, paciência e espiritualidade. Essa disputa pelo merecimento da terra e as formas de conquistá-la encapsulavam uma economia moral projetada para o futuro, que preenchia de sentimentos as formas de propriedade em luta. Assim, embora pregasse sobre a "universidade do amor divino" nas aulas de Educação moral, quando o tema era reforma agrária, o IER dividia a humanidade pelo mérito

\footnotetext{
364 ¿Qué trae el correo? Surco y Semilla, n. 84, Nov./1962. Sobre a organização do trabalho e a produtividade na reforma agrária da igreja, o economista William Thiesenhusen, do Land Tenure Center, escreveu um par de artigos.

${ }^{365}$ La tierra mía. Surco y Semilla, n. 108, Mar/1965.

${ }^{366}$ Id. ibid.
} 
e incutia nos camponeses uma hierarquia implacável, na qual os mais sacrificados eram mais merecedores, ao passo que os "preguiçosos" nada mereciam. Eram preguiçosos aqueles que agitavam confrontos, pois almejavam uma rota "mais fácil" rumo à propriedade. Assim dizia um editorial em 1966:

O progresso não tem que ser feito com um gesto amargo, de revolta e de vingança (...). Se o povo está frustrado e não consegue enxergar seus valores, esse é o cenário ideal para provocar amarguras sociais, revoltas e destruições. Mas o verdadeiro amigo do camponês lhe ensina quais são os seus valores. ${ }^{367}$

No ano eleitoral de 1964, o instituto abandonou seu otimismo com a lei de Alessandri, e preparou o terreno para narrativa da reforma agrária mais próxima da DC. "Não se pode falar ainda, no Chile, de um impacto da reforma agrária, porque proporcionalmente são tão poucos os beneficiários que a massa camponesa sente que ficará de mãos vazias", ${ }^{368}$ criticaram. "O camponês tem que começar, através de suas organizações, a exigir um plano (...). Mas sem política, deve resistir aos que os envolvam e os utilizem nas contendas políticas para depois esquecê-lo". ${ }^{369}$ Foi naquele ano que o instituto inaugurou seu primeiro curso anual de administradores agrícolas de Longotoma, com 34 alunos, selecionados entre os filhos de pequenos proprietários e colonos. O conteúdo das aulas era Administração de parcelas, Custos de produção, Contabilidade rural, Planificação de cultivos, Comercialização e cooperativismo. Afirmavam: "existe em nosso camponês uma verdadeira vontade de aprender e progredir, sobretudo quando é chamado a assumir a responsabilidade que lhe corresponde na agricultura do país". ${ }^{370}$

Quando Frei foi eleito, o IER seguiu convocando os camponeses ao protagonismo e à atividade comunitária. "Esperamos muito de um bom novo governo, mas daí a esperar tudo e esperarmos sentados há uma grande distância", avisaram. "Mas sempre nosso destino está em primeiro lugar em nossas próprias mãos". ${ }^{371}$ Essa retórica ativista do instituto resultava de uma compreensão de que a disputa por hegemonia, em um contexto de acirrada concorrência com as forças rivais, também dependia de um dinamismo constante das próprias bases. A DC e os marxistas despontavam como novas maiorias políticas no meio rural e qualquer apassivamento poderia representar a perda da batalha cultural. "Os camponeses agora são como uma garota bonita: todos querem namorá-la", 372 dizia um editorial do instituto sobre a Lei de Sindicalização Camponesa, promulgada em abril de 1967.

Diante do acirramento dos conflitos rurais, a estratégia político-pedagógica do IER, embora efetivamente ampliasse as oportunidades profissionais e culturais dos seus alunos, buscava também construir empatia com a classe latifundiária. A ideia era criar identidades relativas entre proprietários e aspirantes a proprietários, o que estava conectado à pedagogia do sacrifício. "A SNA está disposta a apoiar os camponeses que sejam vítimas. O que é preciso evitar é que um caso injusto daqueles que

\footnotetext{
${ }^{367}$ Un camino abierto al progreso. Surco y Semilla, n. 121, Abr./1966.

${ }^{368}$ Un olvidado: el campesino. Surco y Semilla, n. 98, Maio./1964.

369 Id. ibid.

${ }^{370}$ Una 'manito' a la reforma agraria. Surco y Semilla, n. 99, Jun./1964.

371 Nuestro pensamiento. Surco y Semilla, n. 103, Out./1964.

${ }^{372}$ La lei de sindicalización. Surco y Semilla, n. 136, Jul./1967.
} 
sofreram abusos seja desviado, fazendo com que outros se levantem para se apresentar como se todos fossem vítimas de injustiças". ${ }^{373}$ Não era coincidência que a voz da SNA aparecesse por dentro do editorial do IER. Para o instituto, tudo que lembrasse a "luta de classes" seria combatido. Mas isso não representava apassivamento - ao contrário, era outra estratégia de mobilização.

A correlação entre a conquista da terra e o esforço pessoal era parte orgânica da construção políticopedagógica do instituto. No instante de acirramento das tensões da reforma agrária, a narrativa já estava armada por meio de uma moral cristã de tipo meritocrático. A generosidade e a solidariedade frente aos desamparados, nessa hora, dava lugar à agressividade contra os flojos. "Os que esperam tudo do alto do céu, muito preenchidos por sua preguiça e comodidade, aguardando que a sorte venha golpear sua porta, esses não merecem ajuda de ninguém", ${ }^{374}$ apregoavam. Na pedagogia do sacrifício, a propriedade camponesa que se tornaria possível com a reforma agrária era resultado do suor, do empenho e do estudo, e nunca do conflito com os patrões. Os marxistas atuavam na mesma linha dos flojos porque buscavam enganar ao camponês propagandeando que lhes era de direito que "chegasse uma riqueza de repente, repartindo os bens dos outros". ${ }^{375}$ Os marxistas lhes prometiam a terra sem esforço, pela revolta vingativa contra outros proprietários. Esse cuento de niños, diziam, envenenava o sentimento do campesinato sobre a justa demanda da terra, fazendo com que já não se quisesse mais trabalhar e muito menos aprender novas técnicas.

Essa narrativa ocultava dois problemas estruturais que se tornariam inevitáveis a partir da implementação dos assentamentos, especialmente com a nova reforma agrária em 1967: primeiro, o problema das desigualdades internas ao próprio campesinato, elemento que se tornou inescapável no momento em que a lei 16.640 privilegiou inquilinos em relação aos afuerinos, homens em relação a mulheres e winkas em relação a mapuches: ${ }^{376} \mathrm{em}$ segundo, a concentração estrutural do sistema de propriedades rurais, que correspondia à concentração de poder das oligarquias, sendo a reforma agrária, portanto, uma luta com contornos de classe.

Mas apesar de comandado politicamente por setores da SNA, as intenções do instituto nem sempre foram acatadas pela classe proprietária. Essa tensão se expressava no depoimento de Isabelita, a secretária que operava o aparato: "é uma tarefa importante nos fazermos compreender pelos patrões. Disso depende que os delegados possam chegar aos latifúndios para conquistar uma verdadeira superação. Alguns patrões compreenderam, mas muitos temem as greves e agitações". ${ }^{377}$ Ela elogiava a ajuda do proprietário Jorge Saelzer, ministro da agricultura do governo de Jorge Alessandri, que chegou a ser presidente do Consórcio de Agricultores do Sul (CAS), organização proprietária que mais tarde protagonizaria o golpe contra Allende na região da Araucanía. "O Centro de Capacitação de

\footnotetext{
${ }^{373}$ Nuestro Pensamiento. Surco y Semilla, n. 113, Ago./1965.

${ }^{374}$ Conquistemos una vida mejor. Surco y Semilla, n. 89, Ago/1963.

${ }^{375}$ Nuestro Pensamiento. Surco y Semilla, n. 81, Ago./1962.

${ }^{376}$ A literatura sobre reforma agrária chilena que trata destes conflitos foi apresentada no capítulo 1 .

${ }^{377}$ Isabelita. Surco y Semilla, n. 104, Nov/1964.
} 
Huicapi está construído num terreno doado pelo senhor Jorge Saelzer de sua própria terra", lembrava Isabelita, revelando a simpatia que setores da direita tiveram pelo IER.

No contexto das transformações estruturais, a aliança da classe proprietária com o IER esbarrava em alguns limites que se manifestaram, por exemplo, quando a classe proprietária resistiu a cumprir as novas leis laborais e colocou o campesinato do MCI em confronto direto com a própria SNA. Em maio de 1966, foram demitidos 81 trabalhadores agrícolas e suas famílias em treze fundos de Melipilla. No mesmo mês, o ministro do Trabalho de Frei, William Thayer, admitiu que outras 718 demissões possivelmente ilegais eram investigadas. Na sede do MCI, em 48 horas foram listados 200 nomes de trabalhadores despedidos em 20 fundos, em Santiago, Rancagua e Talca. Era uma revolta patronal contra a lei 16.465, que estabelecia direitos laborais aos camponeses, incluindo a proibição da demissão sem justa causa. Ulises Diaz, o anti-marxista presidente do MCI, fez um discurso contra os patrões:

Os patrões se queixam da agitação nos campos. Choram como crianças (...) e correm de um Ministério a outro quando os camponeses, cansados de esperar uma resposta para suas petições, se declaram em greve. Para eles não importa como vivem seus trabalhadores, em alojamentos de 40 quartos para 40 famílias, como no fundo Santa Inés, em São Bernardo. E em outras partes, como na Isla de Maipo, há famílias vivendo nas coxias dos animais. ${ }^{378}$

Mas Erasmo Martínez, secretário geral do MCI, em seguida acalmava os ânimos: "pedimos a suspensão das greves camponesas, mesmo que nos acusem de proceder precipitadamente". ${ }^{379}$ A greve não era o caminho do IER, do MCI e da ANOC. Se alguma vez as apoiavam é porque precisavam responder à rebelião da sua base. A capacitação e o sacrifício, no imaginário político propagado pelo IER, eram mecanismos suficientes para abertura das oportunidades, para que os mais capazes se tornassem os novos proprietários, o que evitava a menção ao enfrentamento dos interesses patronais.

Entre 1965 e julho de 1967, enquanto o congresso debatia a nova lei de reforma agrária, a demanda por terras foi tão espraiada que mesmo com escassas possibilidades de conseguir acessar uma parcela, os camponeses pediam ajuda do IER para que "traduzissem" a linguagem cifrada da reforma de macetero para códigos apreensíveis. Em fevereiro de 1965, o inquilino Luis Varas, do fundo Santa Sofía, escreveu em carta: "Señorita Silvia Alarcón (...) peço se poderia me apresentar uma solução sobre a reforma agrária. Desejo saber se tenho direito a uma casa ou parcela familiar por pontos. Quantos pontos são necessários? (...) Peço esse favor à revista preferida dos camponeses". ${ }^{380}$ A diretora da revista respondeu que em razão do grande volume de solicitações como aquela, no próximo número publicariam uma simplificação dos requisitos da pontuação. Esse sistema de pontuação era uma forma de quantificar a meritocracia e hierarquizar os merecedores da terra. Os requisitos da lei 15.020, traduzidos pela revista no número seguinte, estão sintetizados na tabela 11 a seguir.

\footnotetext{
${ }^{378}$ Los despidos campesinos, nueva fuente de tensión. Surco y Semilla, n. 122, Maio./1966.

379 Id ibid.

${ }^{380}$ Silvia Alarcón era a diretora da revista. Buzón de Surco y Semilla. Surco y Semilla, n. 107, Fev./1965.
} 


\begin{tabular}{|c|c|}
\hline 1 & $\begin{array}{l}\text { Comprovar ser chefe de família, ou seja, provedor (casado, viúvo ou solteiro). Os solteiros } \\
\text { deveriam enviar duas declarações autenticadas em cartório, em que os dependentes declarem } \\
\text { não receberem renda maior que um salário vital anual e o postulante que os mantém. }\end{array}$ \\
\hline 2 & $\begin{array}{l}\text { Ter entre } 21 \text { e } 65 \text { anos de idade (os maiores de } 65 \text { que queiram postular, devem apresentar uma } \\
\text { declaração de que possuem um parente de mais de } 17 \text { anos que o sustenta) }\end{array}$ \\
\hline 3 & "Ser saudável e de bons costumes". Enviar certificados de antecedentes. \\
\hline 4 & $\begin{array}{l}\text { Comprovar que trabalha no campo no mínimo há } 5 \text { anos antes da postulação. Apresentar } \\
\text { contratos de trabalho, certificado de seguro social, comprovante de mediería ou arrendamento. }\end{array}$ \\
\hline 5 & Certificado que comprove a honra do postulante e suas aptidões para atividades agrícolas \\
\hline 6 & Número de contribuinte de impostos e certificado de pagamentos. \\
\hline 7 & Indicação da zona onde pretende receber a parcela. \\
\hline 8 & Um selo de $0,10 \mathrm{E}^{\mathrm{o}}$ \\
\hline
\end{tabular}

Os ecos da pedagogia do sacrifício podiam ser escutados desde os mais profundos rincões. Talvez replicá-los também podia servir como estratégia do próprio camponês para ser escutado. O mesmo Luis Varas, que perguntou sobre seu direito à terra, enviou um poema sobre o sacrifício do trabalho no campo, que louvava o esforço brutal com alegria. Alguns trechos diziam:

$$
\begin{aligned}
& \text { (...) Yo brindo por mi camisa } \\
& \text { impregnada de sudor } \\
& \text { porque me hace en mi labor } \\
& \text { hombre de mucho valer, } \\
& \text { porque mi hijo y mi mujer } \\
& \text { coman su pan con honor. } \\
& \text { (...) Brindo por el coraje } \\
& \text { del mozo que, en la jornada, } \\
& \text { como noble camarada } \\
& \text { golpea el yunque conmigo } \\
& \text { con alma de llamarada. } \\
& \text { Brindo al fin por mi trabajo } \\
& \text { que tanto bendito y quiero. } \\
& \text { Ay Dios! Que casi me rajo, } \\
& \text { Me agrada pelar el ajo } \\
& \text { Desde que comienza el día. } \\
& \text { Con gusto y con alegría } \\
& \text { ves esquirlas en mis manos }
\end{aligned}
$$

\footnotetext{
${ }^{381}$ Algumas palavras do poema traduzidas: Yunque: bigorna. Llamarada: labareda. Rajarse: quebrar-se. Pelar el ajo: trabalhar com empenho e dedicação. Esquirlas: lascas. Buzón de Surco y Semilla. Surco y Semilla, n. 107, Fev./1965.
} 
Era uma espécie de ode ao sacrifício laboral, na qual o patrão era inexistente e o trabalhador chegava ao exaurimento das suas forças por vontade própria. A moral do sacrifício crescia a cada estrofe, partindo da construção da honra do trabalhador disciplinado perante sua família até chegar em um êxtase viril do homem que "quase se quebra" de tanto se esforçar e que, com alegria, trabalha até ferir as mãos. Nesse mesmo sentido, seguidos editoriais do IER cresciam em agressividade contra os flojos e em estigmatização do "campesino preguiçoso", que era um arquétipo do camponês não merecedor da parcela: "não existe força humana capaz de aumentar a colheita de um flojo, ainda que o encham de crédito e ajudas financeiras, os empréstimos do flojo nunca serão pagos", ${ }^{382}$ denunciavam. "Nada pode substituir o esforço, a preparação (...). A pessoa sem formação se aproveita dos recursos e se afunda ainda mais na flojera". ${ }^{383} \mathrm{O}$ flojo era uma espécie de inimigo imaginário, que legitimava os propósitos excludentes da pedagogia do sacrifício.

\section{Conflitos entre IER e marxistas}

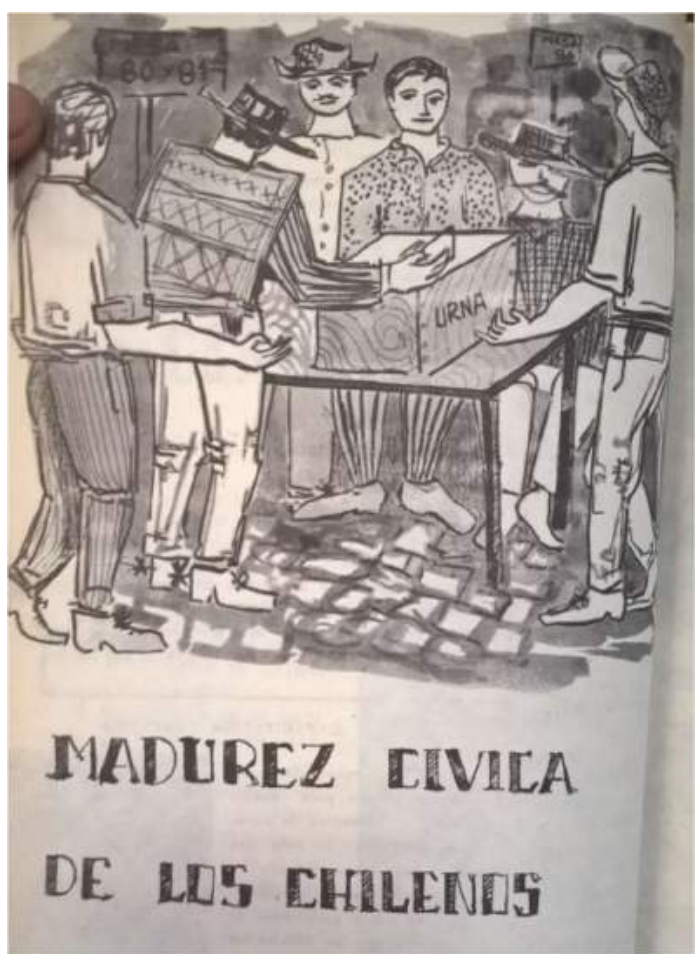

A disputa do voto camponês torna-se proeminente a partir de 1958 (La madurez cívica de los chilenos. Surco y Semilla, n. 109, Abr/1965.)
Quando o IER foi criado, as haciendas ainda funcionavam como unidades fundamentais de controle eleitoral. A rivalidade entre a DC e os partidos marxistas no campo deslocava o IER para uma retórica repetitiva a respeito dos perigos do comunismo. Em seu estudo sobre o movimento campesino chileno, Affonso, Gómez, Klein e Ramiro enfatizavam que o Conselho Diretivo do IER tinha forte presença patronal, além de senadores e ministros latifundiários ligados à SNA (Affonso et al., 1970: 169). Do ponto de vista eleitoral, o instituto ocupava um lugar dúbio. Tinha vínculos fundacionais com as oligarquias do Partido Nacional (SNA), mas em sua política pedagógica pendia para a doutrina social-cristã, e adotava uma narrativa inclinada à DC. Nos anos 1960, os segmentos da oligarquia que compunham a cúpula do IER pareciam praticar uma política de contenção de danos, criando um colchão amortecedor para reforma agrária que estava por vir. Em sua

\footnotetext{
382 Valores humanos, bases del cambio. Surco y Semilla, n. 107, Fev./1965.
}

${ }^{383}$ Id. ibid. 
prática pedagógica nas bases, o IER atuava pelo desenvolvimento comunitário e pelo protagonismo camponês, ao mesmo tempo que recebia apoio direto e constante da SNA e da USAID.

Seu projeto político-pedagógico se articulava a uma via mudancista selada por princípios anticomunistas, que assim encontrava aliados ideológicos e econômicos em diferentes frações das classes dominantes. Em síntese, o instituto representava uma confluência de interesses político eleitorais: da Ação Rural Católica, da Democracia Cristã, de segmentos da classe latifundiária e política, da SNA, da USAID e, nas bases da sociedade chilena, de educadores rurais de localidades heterogêneas, camponeses engajados aos seus cursos, leitores de sua revista e uma grande zona de influência nas escolas rurais primárias. Os pesquisadores do ICIRA apontavam para sua contradição: "ainda que o IER busque impulsionar a autodeterminação da população rural para solucionar seus problemas, considera indispensável (...) incorporar o setor patronal a todo processo de desenvolvimento da comunidade" (Affonso et al, 1970: 168).

Fundada em 1962, a ANOC funcionou como um braço político do IER, para onde enviavam delegados com maior vocação ativista. Seu papel era absorver a crescente impaciência camponesa, oferecendo atividades de tipo agitador e organizativo-sindical, embora fosse uma organização de organizações, e não de pessoas. Como no IER, tanto conservadores, como democrata-cristãos apostaram na construção da ANOC. Outra contradição revelada no estudo do ICIRA (Affonso et al, 1970: 179) foi que o trabalho pedagógico pioneiro do instituto gerou uma situação paradoxal na qual a organização camponesa com mais evidentes vínculos patronais (ANOC) fosse, ao mesmo tempo, aquela que mais camponeses possuía em seus organismos dirigentes: os delegados do IER. O motivo não era outro que a eficiência da sua estrutura político-pedagógica, que funcionava também como uma escola de quadros camponeses. Assim, ANOC e IER se complementavam.

Em 1964, frente à crescente politização do campesinato, os cristãos resolveram fundar um quarto instrumento, o Movimento Campesino Independente (MCI), que atuaria mais explicitamente na campanha eleitoral. A demanda partiu de setores de delegados do próprio IER, que não se sentiam à vontade para fazer campanha explícita nas estruturas do instituto e que vivenciavam algum desconforto de manejar organizações que se diziam "apolíticas" no meio de uma onda politizadora. O principal objetivo do MCI era combater o marxismo no processo eleitoral de 1964. Para trabalhar no novo movimento, foram contratados 200 promotores do IER, que receberam um curso de preparação específico. Com função explicitamente eleitoral, o MCI formou 532 comitês camponeses, presentes em quase todas as províncias, e realizaram mais de cem jornadas de formação com objetivos eleitorais (Affonso et al, 1970: 201-202). Dessa maneira, o IER podia manter suas atividades pedagógicas na batalha dos valores, sem expor o nome da instituição ao corpo a corpo mais duro da campanha eleitoral. Para isso, tinham o MCI.

Nas eleições de 1964, os editoriais da Surco y Semilla admitiam que tanto Frei como Allende eram candidatos que reconheciam os problemas estruturais do campo. Contudo, "Allende quer mudanças que levam ao marxismo; e Frei quer mudanças dentro da liberdade da democracia" e "os camponeses devem 
ter clareza que (...) um melhoramento econômico que custe a liberdade e a democracia não é um autêntico melhoramento". ${ }^{384}$ Independentemente de quem saísse vitorioso, enfatizavam que "os camponeses devem se preparar (...) também para assumir cada vez maiores responsabilidades" e que os "funcionários do futuro governo terão que ouvir e respeitar o camponês, já que ele 'sabe onde o sapato aperta"'.385

De toda forma, a comemoração do triunfo da DC foi enfática e não deixava margem para dúvidas: Eduardo Frei era o presidente do IER, que refletia o "grande despertar da personalidade camponesa". 386 $\mathrm{Na}$ construção do amedrontamento anti-marxista, afirmaram que "o Chile sentiu um imenso alívio de saber, nessa tarde, que estaria em boas mãos". ${ }^{387} \mathrm{O}$ instituto se considerava parte direta na mudança subjetiva rural que gerou o triunfo de Eduardo Frei: "todas essas mudanças de mentalidade e atitude social ocorreram em muito pouco tempo (...). Ficou para trás a época da indiferença social do campesinato (...). E a eleição presidencial deu um novo impulso a este despertar". ${ }^{388}$ Ao mesmo tempo que apoiava o novo governo, o instituto organizou uma lista de demandas baseadas em uma enquete feita com 30 dirigentes camponeses de oito províncias. A enquete apresentava sete problemas e solicitava que fossem ordenados em prioridade. A primeira delas foi a "justa distribuição da terra", a segunda "educação adequada e ao alcance das famílias camponesas", ${ }^{389}$ a terceira era atendimento médico adequado e a quarta, melhores condições de moradia. $\mathrm{O}$ topo da lista mostrava que a reforma agrária já era uma demanda hegemônica na própria estrutura do IER, uma questão impostergável. Analisarei a seguir como o IER conduziu o tema da reforma agrária.

Do outro lado da batalha ideológica, estavam os aparelhos de hegemonia marxista, que criaram suas próprias instituições-nexo. Uma das críticas preferidas das esquerdas contra o IER era sua notória aliança com setores da classe latifundiária e com autoridades oficiais dos Estados Unidos. Um dirigente da Federação Campesina e Indígena Ranquil, em 1962, escreveu na revista Unidad Campesina:

Uma das principais escoras do imperialismo ianque e dos latifundiários é o IER. Com promessas enganosas pretendem deter a luta dos camponeses, cuja rebeldia e firmeza lhes causa espanto. Com o pretexto de preparar especialistas em agricultura e de proporcionar diversos conhecimentos, o IER levantou vários Centros no país, com apoio do governo, dos gerentes e latifundiários e com dinheiro e outros aportes de diversas organizações estadunidenses e do governo imperialista dos Estados Unidos. Esse instituto antipopular, inimigo hipócrita dos camponeses, (...) educou uns 4 mil jovens para seus obscuros fines de manter os camponeses oprimidos, e tem uns 2 mil ativistas de prontidão (...), junto com uns 70 agentes do imperialismo chamados Corpos de Paz, conquistando vontades para as causas dos exploradores do campesinato (apud Affonso et al, 1970: 142).

\footnotetext{
${ }^{384}$ La hora de la clase campesina. Surco y Semilla, n. 100, Jul/1964.

${ }^{385}$ Id. ibid.

${ }^{386}$ Nuestro pensamiento: ¡de pie campesinos! Surco y Semilla, n. 101, Ago/1964.

${ }^{387}$ Bienvenido el nuevo presidente. Surco y Semilla, n. 104, Out./1964.

${ }^{388}$ Id. ibid.

${ }^{389}$ Señor presidente, nosotros pedimos. Surco y Semilla, n. 102, Set./1964.
} 
Os vínculos com a USAID e os Peace Corps motivaram os deputados comunistas Carlos Rosales e Cipriano Rodrigues, em 1966, a acusaram o IER de ser uma "instituição estrangeira". Como resposta, o deputado Narciso Irureta desafiou os comunistas que visitassem um Centro de Capacitação e conhecessem a realidade das bases do IER. Em seguida, o deputado camponês Gilberto Canales fez um depoimento emocionado sobre sua trajetória como delegado do IER, onde aprendeu tudo aquilo que o postulou para ocupar aquela tribuna. ${ }^{390}$

O contexto de rivalidades e o avanço da luta por uma reforma agrária estrutural, que eliminasse o latifúndio, gerou expurgos internos no IER. Um deles resultou na expulsão do professor chefe do Centro de Capacitação de Lautaro, Rogelio Correa, demitido por razões políticas em 1965. Sua lembrança desse episódio desconstrói a narrativa de protagonismo camponês emulada da imprensa oficial do instituto: "eles queriam que fizéssemos uma educação amorfa, inocente, inofensiva. Quando já estávamos completamente conscientizados de que não era assim (...). Demitiram mais de 100 pessoas ao mesmo tempo", ${ }^{391}$ lembrou-se. Funcionário do IER desde 1958, Correa já fazia parte Assembleia de Sócios, um órgão de poder interno que poucos professores conseguiam acessar. Na Assembleia de Sócios participavam patrões, padres, professores e camponeses. Era, segundo nos contou Correa, um organismo dirigido de cima, pela mão forte da igreja e dos patrões: "uma democracia dirigida", explicou. "Bastava o que dissesse dom Rafael Larraín, que era um homem muito habilidoso, de grandes valores, mas que dirigia o 'dote', como dizemos aqui". ${ }^{392}$ Afinal, a chave do cofre do instituto continuava sendo clerical.

Rogelio Correa sintetizou a crise política que despertou sua demissão da seguinte maneira:

O IER, em seu valor, na sua condução superior, na sua autoridade, era uma instituição que buscava o que a bíblia diz sobre 'juntar o leão com o cordeiro'. A conciliação. (...). Mas nós [professores] vamos percebendo, por acompanhar as próprias lutas, que não é assim. O direito é o direito e é preciso ter consciência dele e defendê-lo (...). Por isso, necessariamente vamos entrar em conflito. Os patrões não queriam a reforma agrária e os patrões financiavam o IER. ${ }^{393}$

No mesmo ano em que foi demitido do IER, Correa foi contratado pela CORA e seguiu trabalhando como educador rural. Os pesquisadores do ICIRA confirmavam o conflito político vivido por Correa: "é evidente que a Ação Católica Rural e o IER não se propunham a cumprir tarefas que significassem uma mudança na estrutura do sistema de propriedades da terra. Nem tampouco (...) capacitar camponeses para que impusessem seus direitos diante dos abusos patronais" (Affonso et al, 1970: 174). Rogelio Correa, que nunca foi filiado à DC, a partir de 1969 resolveu participar do MAPU, por identidade com as posições de Jacques Chonchol.

\footnotetext{
${ }^{390}$ Falta de valor moral. Surco y Semilla, n. 125, Ago./1966.

${ }^{391}$ Entrevista com Rogelio Correa, Santiago, 30/05/2019.

${ }^{392}$ Id. ibid.

${ }^{393}$ Id. ibid.
} 
O IER assumiu que as batalhas ideológicas se acentuavam. Em 1968, acusavam os marxistas de não terem origem camponesa e atuarem como "agitadores externos", enquanto o próprio instituto se autoproclamava genuinamente camponês, partícipes originários de uma cultura rural e de seus valores. "Propiciando a formação de mentalidades com critério próprio, com ideias claras, com capacidade de se auto-organizar e de se dirigir, [o IER] é um entrave àqueles que, movidos por interesses alheios ao campesinato, pretendem manipulá-lo com a agitação passageira", 394 afirmava a cúpula do IER em documento interno. "Os próximos anos são decisivos na livre tomada de posições ideológicas e a livre adesão a determinadas correntes ou grupos, seja de tipo gremial, cooperativistas, político ou de vizinhos", ${ }^{395}$ calculavam. Para empreender sua batalha ideológica, ampliou seus programas externos e serviços comunitários nos tempos da reforma agrária. Apenas em 1969, por exemplo, alcançou 15.883 camponeses em projetos culturais, sociais e econômicos. ${ }^{396}$

Junto da pedagogia do sacrifício e da meritocracia educacional, oferecida como ferramenta de poder do IER perante sua "família campesina", se construía uma defesa cada vez mais nítida da propriedade cooperativa como forma superior de progresso econômico e espiritual. Enquanto se debatia a nova lei de reforma agrária no congresso, o IER também alertava aos camponeses já beneficiários da reforma, sobretudo aqueles que, a partir da experiência de Choapa em 1965, a obtiveram em forma coletiva de assentamento. Por isso, o instituto argumentava:

Os camponeses que já trabalham em assentamentos têm uma enorme responsabilidade perante todo o campesinato. Devem provar que a terra em mãos do campesinato produz mais e é melhor cuidada. (...) Devem colocar mais empenho que nunca para obter um rendimento tão alto que deixem calados para sempre os que alegavam que o camponês não era capaz (...). Por trás de tudo isso, há uma profunda mudança de mentalidade dos camponeses. ${ }^{397}$

Nas querelas sobre as formas de propriedade, a pedagogia do sacrifício do IER ganhava contornos cooperativistas. Os cursos sobre Cooperativas eram os mais frequentes nas diferentes frentes de trabalho do instituto. O seu cooperativismo, entretanto, era permeado de anticomunismo. É o que será examinado a seguir.

\section{Cooperativa anticomunista: formas econômicas, batalhas culturais}

Em abril de 1965, o camponês Fernando Mery, que durante 15 anos trabalhou como minifundista, escreveu uma "carta ao pequeno proprietário", publicada na revista Surco y Semilla. Nela buscava compartilhar as dificuldades de ser um pequeno parceleiro agrícola, e apresentava argumentos sobre as

\footnotetext{
${ }^{394}$ IER, Memoria Anual. 1966-1967.

${ }^{395}$ Id. ibid.

${ }^{396}$ IER, Memoria Anual. 1968-1969.

${ }^{397}$ Campesinos propietarios. Surco y Semilla, n. 117, Dez./1965.
} 
vantagens das formas coletivas de propriedade e produção: "Com a cooperativa, você e seus vizinhos contarão com uma fonte segura de créditos oportunos (...), que lhes permitirão comprar boas sementes, adubos, desinfetantes, ferramentas e fazer chegar até máquinas agrícolas às propriedades comunitárias", 398 assegurava. Um artigo do IER em 1966 alertava: "aqueles que querem que cada um tenha sua parcela também precisam partir da base de que é necessário haver uso cooperativo da água, das máquinas, e saber que as parcelas individuais custam muito mais caro". ${ }^{399}$ Assim, explicavam aos trabalhadores rurais que "os camponeses serão os donos de onde haja assentamento, mas terão que trabalhar em conjunto como uma cooperativa, ou individualmente usando serviços cooperativos". 400

O IER priorizava a propriedade comunitária e cooperativa em seus textos e materiais pedagógicos, em seus cursos e oficinas. Mas defendia a propriedade individual da casa e do huerto familiar, combinado com variados arranjos de cooperativas (de produção, de crédito, de maquinarias, de serviços). A proposta da "cooperativa mista" estava contemplada em uma das três possibilidades de saída do assentamento na lei 16.640 de reforma agrária. ${ }^{401}$ Ao mesmo tempo que o instituto propagandeava a forma cooperativa, tinha absoluta certeza da necessidade de combiná-la com as parcelas, por conhecer as aspirações íntimas da sua "grande família", que tanto queria vivir en lo proprio. Apegada a isso, a ANOC sintetizava uma linha um pouco mais individualista para reforma agrária, considerando que "não é justo e nem moralmente conveniente que uma maioria obrigue à minoria a um sistema de vida comunitário (...). É moralmente inconveniente" (apud Affonso et al, 1970: 190). Para a Associação, a propriedade deveria ser coletiva somente por unanimidade.

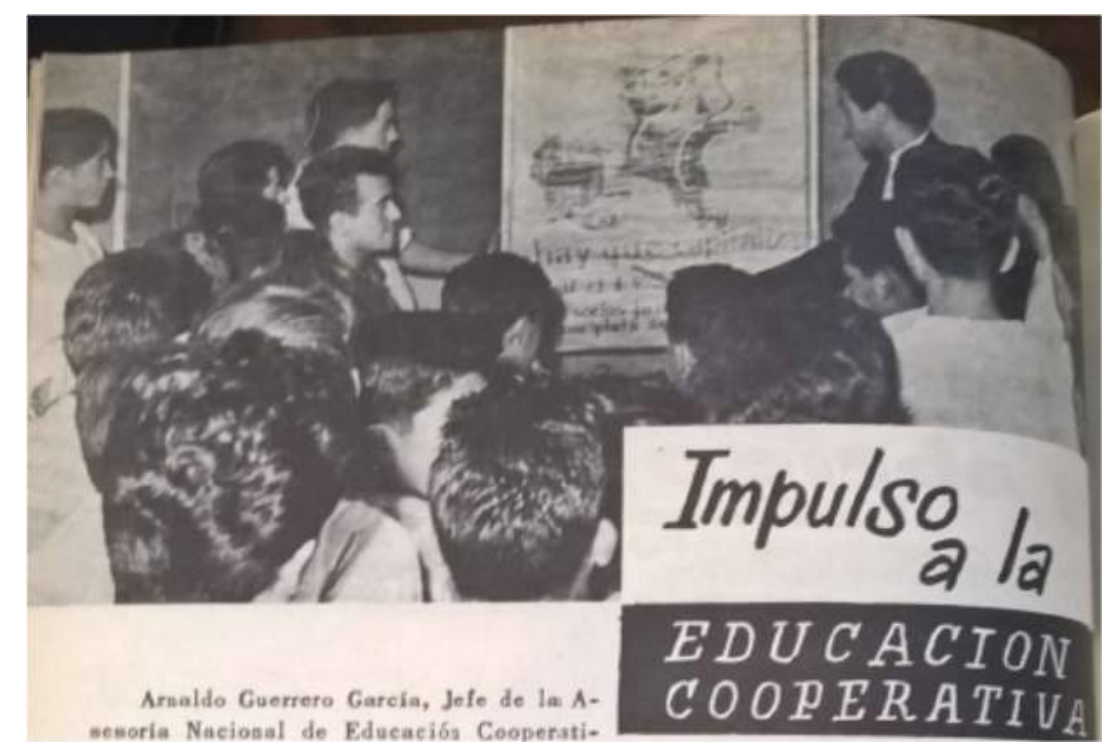

Dentro da doutrina social-cristã, o IER era defensor das formas cooperativas, mas permeadas pelo anticomunismo (Impulso a la educación cooperativa. Surco y Semilla, n. 98, Maio/1964.)

\footnotetext{
${ }^{398}$ Carta a un pequeño propietario. Surco y Semilla, n. 109, Abr./1965.

${ }^{399}$ Vivir en lo propio. Surco y Semilla, n. 125, Ago./1966.

${ }^{400}$ Id. ibid.

401 “As terras poderão ser assinadas em domínio exclusivo para cooperativas camponesas ou de reforma agrária ou em copropriedade de camponeses e de cooperativas camponesas ou de reforma agrária" (artigo 67) e "as terras e direitos que formem parte das titulações mistas que derivem da aplicação do artigo 67 formarão parte de um todo indivisível" (artigo 69). Chile, $1967 \mathrm{~b}$.
} 
A defesa simultânea da parcela individual e da cooperativa a mista permitia que IER e ANOC colassem à imagem dos marxistas a de "agitadores antiparcela", favoráveis a uma propriedade exclusivamente coletiva e do Estado. Como mostrou o primeiro capítulo, a realidade da disputa política pelas formas de propriedade era repleta de cortinas de fumaça (Roxborough, 1974, 1977). No entanto, embora a acusação do IER fosse relativamente falsa, durante anos representou a mais frequente e enraizada denúncia contra a esquerda: “o comunismo não quer que ninguém, nem pequeno, nem grande, tenha um pedaço de terra", falsificava um editorial. "O lobo anda entre as ovelhas. Cuidado com o revoltoso que nunca constrói nada", ${ }^{402}$ conspiravam. A imprensa do IER assegurava que muitos "falsos amigos" chegavam ao campo para utilizar as demandas camponesas com propósitos nefastos de ódio, agitação e egoísmo. Em 1966, a revista acusava: "o IER suporta violentos ataques ao seu trabalho, que geralmente partem dos comunistas e seus aliados. (...) Esse partido precisa encontrar elementos desesperados, sem preparação, aos quais seja fácil ensinar o ódio e a luta de classes", ${ }^{403}$ diagnosticavam. Também associavam o comunista ao excesso de discursos, à retórica vazia e à preguiça: “o comunista no campo é um grande blablablá, campeão em palavras de ódio e que incitam a lutar contra tudo, mas nunca construiu nada positivo, nem para as pessoas, nem para os lugares, nem famílias, nem escolas". 404

Durante o debate sobre a lei de reforma agrária do governo Frei, o clima de incerteza fez acirrar a rivalidade entre IER e marxistas no campo. "Periodicamente o IER deve suportar violentos ataques ao seu trabalho, que geralmente partem dos comunistas e seus aliados", ${ }^{405}$ lamentavam. "O IER tem um estilo de trabalhar silencioso. Sempre acreditou que os fatos valem mais que as palavras (...). Terão os comunistas conversado com os milhares de camponeses ex-alunos do IER?", ${ }^{406}$ desafiavam. E confrontavam: "o IER o considera seu principal inimigo". ${ }^{407}$ Outra acusação contra a esquerda era que esta defendia a ausência de indenização aos proprietários e propunha a entrega gratuita da terra ao campesinato. "Os amigos comunistas andam por aí exigindo que os camponeses fiquem com a terra sem pagar nada por ela. Isso é para que não haja reforma agrária. Se ninguém paga pela terra, como seguir fazendo parcelas?", ${ }^{408}$ se indignavam. E ainda alertavam: "abram bem os olhos para enxergar se a ovelha que se aproxima é de verdade, ou não é um lobo com pele de ovelha". ${ }^{409} \mathrm{O}$ comunista era assim mimetizado ao arquétipo do flojo, àquele que queria terra sem trabalhar, sem pagar por ela, sem se sacrificar, cortando caminhos pelo clientelismo político.

Mas apesar do anticomunismo mordaz, o ativismo cooperativista do IER era orgânico às suas práticas pedagógicas, que tinham um forte sentimento de coletividade. Cooperativa, para o IER, não era

\footnotetext{
402 Nuestro pensamiento. Surco y Semilla, n. 77, Mar/1962.

${ }^{403}$ Ataques al IER. Surco y Semilla, n. 125, Ago/1966.

${ }^{404}$ Sindicalización: una responsabilidad nueva. Surco y Semilla, n. 125, Ago/1966.

${ }^{405}$ Ataques al IER. Surco y Semilla, n. 125, Ago./1966.

${ }^{406}$ Id. ibid.

${ }^{407}$ Id. ibid.

${ }^{408}$ Claridad en la confusión. Surco y Semilla, n. 120, Mar./1966.

${ }^{409}$ Id. ibid.
} 
apenas um slogan. Era um ensinamento espiritual, era um modo de vida, era uma prática. Os cursos de educação econômica cooperativa correspondiam a cerca de $20 \%$ do módulo de educação social e cívica dos Centros de Capacitação básica. O instituto possuía um Departamento de Cooperativas, responsável por viabilizar formas coletivas de trabalho às centenas. ${ }^{410}$

Em seus materiais, ensinavam a história do movimento cooperativo inglês no século XIX como quem conta uma parábola cristã, baseada no heroísmo de dois homens. O primeiro era Owen, o industrial que se compadeceu de seus trabalhadores e introduziu reformas em suas fábricas, criando a proposta "que os operários possuam as máquinas, mas sem nunca encontrar o meio de torná-lo realidade" ${ }^{411}$ O segundo, King, um médico que ficou conhecido como "doutor dos pobres" e para ajudar os trabalhadores publicava uma revista chamada $O$ cooperador, que difundia ideias de trabalhos coletivos. Com base nas idealizações desses dois "cavalheiros altruístas" ${ }^{412}$ um grupo de tecelões de Rochdale juntou suas pequenas poupanças e criou um armazém cooperativo. O sucesso da empreitada fez o capital do grupo crescer, até que se tornassem, de antigos operários miseráveis, bem-sucedidos proprietários coletivos de uma fábrica. Com base no exemplo inglês, os materiais do IER explicavam os pilares do cooperativismo: ${ }^{413}$

1) Livre adesão (ou portas abertas);

2) Controle democrático: eleições dos dirigentes, sendo cada pessoa um voto, independente das disparidades de participação em capital; igualdade de direitos e deveres; assembleias gerais ordinárias cm voz para todos; conselhos de administração com escuta; máximo de $10 \%$ de capital concentrado em um único sócio;

3) Lucro limitado, para evitar que pessoas fizessem proveito individual do trabalho coletivo;

4) Justa distribuição do excedente, segundo o trabalho efetivamente realizado por cada membro.

"Estes princípios", anunciava Surco y Semilla, "encerram uma verdadeira doutrina social que, posta em prática, será uma verdadeira revolução no campo econômico-social. Essa doutrina é o comunitarismo". ${ }^{414}$ Se uma das características do instituto era converter seus princípios e doutrinas em processos político-pedagógicos, com isso não seria diferente.

Em 1963, o IER ofereceu um conjunto de textos de Educação pré-cooperativa na sua revista, para que fosse utilizado como módulos de um curso ministrado por seus delegados e delegadas campo adentro. O manual era um "passo a passo" para criação de uma cooperativa. O primeiro módulo ensinava a investigar o território: avaliar a extensão e os tipos de trabalhos que podem ser convertidos em cooperativas, o número adequado de trabalhadores necessários, estudar a qualidade do solo, a

\footnotetext{
${ }^{410}$ Una mirada hacia al futuro. Surco y Semilla, n. 87, Jun./1963.

${ }^{411}$ Id. ibid.

${ }^{412}$ Las cooperativas, una realidad histórica. Surco y Semilla, n. 82, Set./1962.

${ }^{413}$ Nesse texto, prometem sete pilares, mas só explicam quatro. Os últimos três deveriam ter sido apresentados no número seguinte, mas isso não acontece. (Los pilares del edificio cooperativo. Surco y Semilla, n. 82, Nov/1962.)

${ }^{414}$ Id. ibid. Nosso grifo.
} 
história e os antecedentes de outras cooperativas locais, escutar os moradores sobre tais experiências, compreender os fluxos de transporte e comércio. ${ }^{415} \mathrm{O}$ segundo módulo consistia em estudar os princípios do cooperativismo, seus diferentes métodos e compreender as possibilidades e escopos mais adequados para aquele território. Um dos objetivos era compreender como colocar "o dinheiro a serviço do homem, e o homem a serviço da comunidade". ${ }^{416} \mathrm{O}$ terceiro módulo tratava da organização interna. Instruíam aos campesinos que enviassem uma solicitação ao Departamento de Educação e Desenvolvimento Comunitário do IER, especificamente à Secretaria de Educação Cooperativa, comunicando seu interesse em criar uma e receber assessoria direta do instituto.

O grupo se consolidaria como comité pré-cooperativa, dividido em subcomitês de finanças, legalização e educação. O IER então convocaria uma Junta Geral Constitutiva para oficializar a cooperativa. ${ }^{417}$ No módulo seguinte, ensinavam a conformação da personalidade jurídica. "O futuro de qualquer trabalho cooperativo se baseia em muita educação e maturação", ${ }^{418}$ predicavam. Em 1965, o IER proporcionou um encontro de 12 pré-cooperativas de diferentes Centros de Capacitação em Longotoma, para que compartilhassem experiências e desafios. O encontro terminou com o fornecimento de crédito e materiais do instituto para que os grupos se consolidassem. ${ }^{419} \mathrm{Ou}$ seja, o IER também era efetivamente uma grande incubadora de cooperativas camponesas.

O IER caminhava entre o comunitarismo e o anticomunismo, entre a universalidade do amor divino e a meritocracia da reforma agrária, de maneira que o próprio instituto vocalizou dúvidas sobre a possibilidade de tornar real um sistema agrário cooperativista no Chile. Afinal, não eram todos que estavam preparados, nem todos os que mereciam. Seu ódio contra a flojera estremecia o funcionamento da cooperativa, quando se admitia a escassa probabilidade de que o sacrifício dos seus membros fosse um ativo moral homogêneo, em qualquer comunidade:

A cooperativa supõe amadurecimento de cada pessoa, que não vai folgar às custas do demais (...). É preciso ombrear um ao outro com o mesmo empenho, e sabemos que isso ainda não existe tão nitidamente, porque sempre alguns se distinguem e outros são enroladores e faltam no trabalho. A cooperativa precisa educar muito para conseguir um esforço semelhante, ou organizar-se tão bem que os frutos do trabalho se repartam em proporção ao esforço e eficácia empreendidos por cada um. Supõe que as pessoas sejam muito justas. ${ }^{420}$

Em fins de 1966, o IER realizou um novo curso para formar Chefes de Assentamentos em convênio com a CORA e o ICIRA. O piloto foi realizado na hacienda Lampa, perto de Santiago. ${ }^{421}$ Segundo a historiadora Daniela Zubicueta (2019: 116), o método adotado nesse curso foi o de Paulo

\footnotetext{
${ }^{415}$ Cooperativa: primeros pasos, parte I. Surco y Semilla, n. 88, Jul./1963.

${ }^{416}$ Cooperativa: primeros pasos, parte II. Surco y Semilla, n. 89, Ago./1963.

${ }^{417}$ Cooperativa: primeros pasos, parte III. Surco y Semilla, n. 90, Sep./1963.

${ }^{418}$ Vivir en lo propio. Surco y Semilla, n. 125, Ago./1966.

${ }^{419}$ Nuevos talleres. Surco y Semilla, n. 109, Abr./1965.

${ }^{420}$ Id. ibid.

${ }^{421}$ Aquí conversamos. Surco y Semilla, n. 131, Fev./1967.
} 
Freire (tema que discutirei no próximo capítulo). Durante o governo de Eduardo Frei, o instituto seguiu uma linha propagandista dos assentamentos, afirmando que a renda familiar camponesa das famílias assentadas havia crescido de 2 mil escudos anuais para 7.200 entre 1966 e 1967. Referia-se aos 130 assentamentos existentes antes da lei 16.640, nos quais 50\% dos assentados seriam analfabetos. ${ }^{422}$ "Os assentados têm, agora, que responder à esperança do país", ${ }^{423}$ escreveram. O presidente do IER, Enrique Serrano expressava seu apoio aos assentamentos para que os camponeses se tornassem "cada vez mais merecedores". ${ }^{424}$

Pouco a pouco, a forma assentamento consolidou-se na construção da nova lei de reforma agrária. As vacilações do IER sobre a propriedade coletiva ganharam mais concretude. O problema não seria a forma coletiva em si, que sempre foi impulsionada pelo instituto, nem propriamente a situação quase inevitável de trabalhadores que se empenham com intensidades diferentes. O problema seria mais diretamente ideológico: o aparelhamento do marxismo nas propriedades coletivas. "Grupos políticos estão usando o nome dos camponeses de Choapa para se opor a uma reforma agrária que dê a cada família um lote de terra", ${ }^{425}$ denunciaram. "Essa é uma hora de aspirações de todos para melhorar vida e oxalá chegar a serem proprietários, mas com base em poupança e merecimento. Não é uma mágica, nem é uma pesca milagrosa". ${ }^{426}$ Ou seja, o assentamento ganhava mais ou menos legitimidade conforme fosse dirigido por grupos mais ou menos afinados com seu projeto. Ao mesmo tempo, a demanda pela parcela individual transformou-se, para o IER, em uma exigência diferenciadora cada vez mais importante no combate de um comunismo antiparcela, o lobo entre os cordeiros, que não deixaria nenhum camponês ser dono da sua própria terra.

\section{Delegados da revolução verde}

Por último, mas não menos importante, embora os materiais pedagógicos do instituto priorizassem o fortalecimento da empresa camponesa, com ensinamentos para ampliar a rentabilidade autônoma por meio do huerto, da saúde animal, das indústrias caseiras, da fabricação de móveis e de roupas, tudo isso convivia com a defesa da modernização técnica e dos aparatos da revolução verde. $O$ uso de antibióticos, pesticidas, herbicidas, nematicidas e fertilizantes e outros insumos era incentivado e elogiado com entusiasmo pelo instituto. Quando o cultivador de sementes Miguel Navarro Diaz, de El Monte, por exemplo, comentou ao repórter de Surco y Semilla sobre os melhores herbicidas e pesticidas para suas variedades, o entrevistador exclamou: “Dom Miguel é um homem 100\% progressista!”. ${ }^{427}$

\footnotetext{
${ }^{422}$ Ley de reforma agraria. Surco y Semilla, n. 137, Ago./1967.

${ }^{423}$ Reforma agraria. Surco y Semilla, n. 140, Nov./1967.

${ }^{424}$ El hombre de la reforma agraria. Surco y Semilla, n. 119, Fev./1967.

${ }^{425}$ Nuestro pensamiento. Surco y Semilla, n. 113, Ago./1965.

${ }^{426}$ Id. ibid.

${ }^{427}$ Un agricultor progresista. Surco y Semilla, n. 95, Fev./1964
} 
Em uma reportagem de 1962, mesmo ano da publicação de Primavera silenciosa, de Rachel Carson, o instituto exclamava em tom alarmista: "os insetos estão por toda parte! (...) Causam enorme prejuízo para as árvores frutíferas e todos os cultivos. (...) Você pode se livrar deles, ou ao menos diminuir as perdas que ocasionam, aplicando produtos químicos em suas árvores". ${ }^{428}$ Traçados como inimigos desproporcionais, o artigo criava um clima de pânico generalizado a respeito dos insetos, como se fossem um fator novo da vida rural: "os insetos não atacam só os vegetais, afetam também o homem, os animais, as casas, as bodegas e os alimentos (...). No Chile, os danos causados [pelos insetos] podem ser avaliados em mais de 2 milhões de escudos por ano". ${ }^{429}$ Na mesma página, o anúncio publicitário mostrava a solução: chegou Isotox, inseticidas e herbicidas para hortaliças, da California Spray Chemical Corporation.

É interessante notar que enquanto a retórica da guerra ou da luta era evitada nos temas sociais, nos quais se buscava a amistosidade do campesinato com os patrões, o IER mostrava uma beligerância desatada contra os insetos nos anúncios de venenos. Em um artigo sobre a "guerra contra a mosca do mediterrâneo", encontrada no Chile pelo pesquisador estadunidense James Haley, em 1962, anunciavam em tom dramático: "a campanha [contra a mosca] só poderá ser suspensa quando o perigo estiver total e definitivamente controlado". 430

Em outras vezes, traziam as instruções para desinfecção preventiva de frutas no inverno: pêssegos, amêndoas, acerolas, peras etc. O discurso proporcionava uma aura de magia aos insumos químicos:

A desinfecção preventiva invernal tem como objetivo eliminar uma série de pestes que atacam as árvores de frutas. Com ela, se obtém plantas mais vigorosas, (...) com frutas de qualidade o ano inteiro, aumento da colheita e se evita o debilitamento das plantas, o que aumenta a vida produtiva dos pomares (...) O líquido desinfetante deve banhar totalmente o tronco, os galhos e ramos da árvore. ${ }^{431}$

Entre os serviços prestados pelo Departamento de Cooperativas do IER estava a assistência sobre herbicidas, pesticidas, nematicidas e outros insumos. ${ }^{432}$ Insistia-se na importância dos herbicidas em quase todos os números da revista: "o uso de produtos chamados herbicidas oferece muitas vantagens (...). O mais importante é que reduz os gastos das jornadas empregadas em combater pragas por meios mecânicos". ${ }^{433}$ Propagandeavam que o herbicida mais usado no país era o 2,4-D, mas ao mesmo tempo indicavam uma variedade de produtos disponíveis nos mercados, como o 2,4; 5-T; MCP, DNBP, CIPC, Dalapón, Diurón, entre outros. As propagandas da Bayer eram muito comuns nas páginas da revista: "colha êxitos com Bayer", diziam os anúncios, ao lado de uma lista de herbicidas e pesticidas da empresa: Agallol, Lonacol, Antracol (para tomates e batatas); Folidol, Gusathion (para cítricos, avocados, olivas); Morestan, Eradex (vinhas); Photoxin (grãos). Também anunciavam antibióticos para

\footnotetext{
428 ¡Los insectos están por todas partes! Surco y Semilla, n. 84, Nov./1962.

429 Id. ibid.

${ }^{430}$ Chile en guerra aérea contra peligrosa mosca. Surco y Semilla, n. 122, Maio./1966

431 Desinfecte sus frutales durante el invierno. Surco y Semilla, n. 88, Jul./1963.

432 Departamento de cooperativas. Um servicio del IER a las cooperativas campesinas. Surco y Semilla, n. 97, Abr./1964

433 Mata malezas o herbicidas. Surco y Semilla, n. 99, Jul./1964.
} 
animais: "Você cria porcos? Cynamid para porcos" trazia uma lista de sete possibilidades de remédios porcinos.

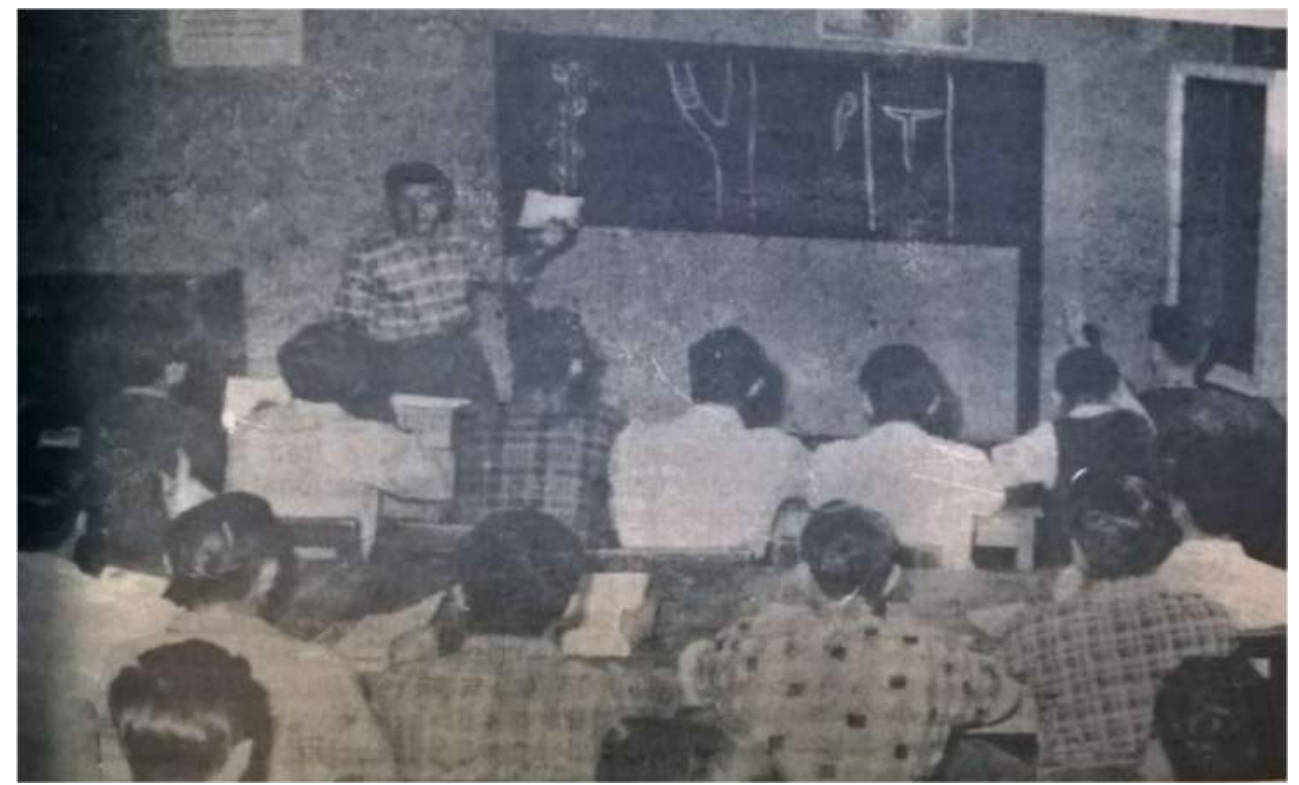

Aula masculina de Educação agropecuária (Ataques al IER. Surco y Semilla, n. 125, Ago/1966.)

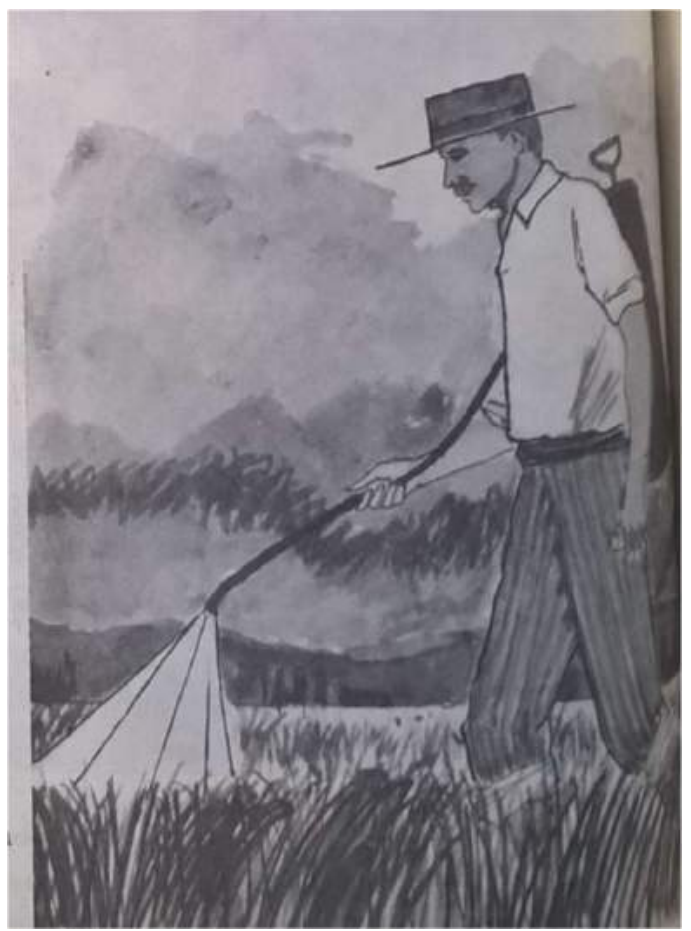

"O uso de produtos chamados herbicidas oferece muitas vantagens" (Mata malezas o herbicidas. Surco y Semilla, n. 99, Jul./1964.)
O IER era decididamente entusiasta da revolução verde e promovia a difusão de agrotóxicos (predominantemente estrangeiros) com sua pedagogia produtiva e com assessoria técnica. Contudo, em alguns casos também indicava os riscos dos produtos que recomendava: "alguns são muito venenosos e podem ocasionar sérios danos aos aplicadores ou pessoas que trabalham com isso. Por esse motivo, o Serviço de Extensão Agrícola recomenda produtos que não causem dano", como seriam, supostamente, os Metoxyclor, Malatión e Ferbam: "inofensivos". ${ }^{434}$ Em 1966, a ênfase no cuidado e na capacitação havia aumentado. "Apesar do êxito obtido por esses produtos nos últimos anos no controle de pestes $\mathrm{e}$ enfermidades, seu uso por pessoas pouco

${ }^{434}$ Pulverización de frutales. Surco y Semilla, n. 111, Jun./1965. 
capacitadas causa uma série de acidentes, muitos deles fatais". ${ }^{435}$ Em seguida descreviam situações de intoxicação e alguns sintomas que deveriam estimular a procura de atendimento médico.

O pedagogo Rolando Pinto, que foi educador da CORA durante os anos da reforma agrária, nos contou que a aplicação dos produtos venenosos se tornou usualmente uma incumbência das mulheres. Provavelmente, segundo se recordava, porque era considerado um trabalho "leve", ou seja, que supostamente não exigiria tanta força bruta, mas sim detalhismo e atenção. Segundo se lembra, pensavase que as mulheres acertariam as doses de agrotóxicos melhor que os homens por serem "mais cuidadosas". Mas não só por isso: também porque a aplicação exigia a leitura dos rótulos e das instruções de uso e, de maneira geral, as mulheres eram mais alfabetizadas que os homens. ${ }^{436}$ Segundo nos explicou Pinto:

$\mathrm{Na}$ tradição inquilina, eram as filhas e as mulheres donas dos latifúndios, ou as esposas dos donos, que educavam as mulheres camponesas. Inclusive, com pequenas escolinhas na propriedade. Mas ao contrário, o inquilino era um homem bruto que trabalhava a terra. Que estava 'transformado em coisa', como dizia Paulo Freire. (...) Jamais o patrão se preocupou em dar-lhe maior educação. (...) Por isso, as mulheres que aplicavam os produtos. (...) Depois muitas delas começaram a ter problemas de infertilidade, resultante desses químicos que respiravam, mesmo com máscaras. (...) Segundo, porque os homens consideravam que era um trabalho leve. Não era um trabalho duro. (...) Ou seja, era uma concepção machista.

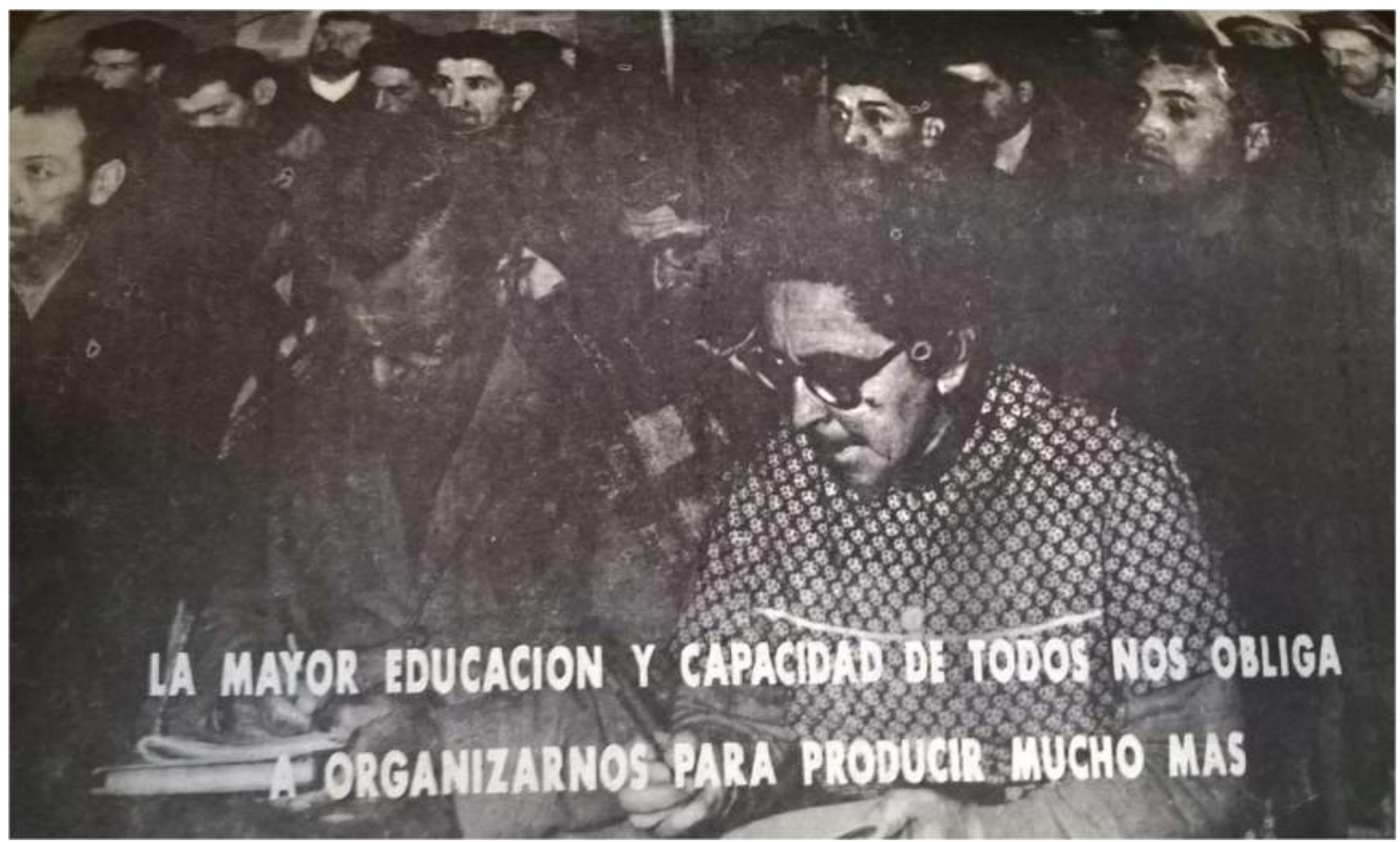

"A maior educação e capacidade de todos nos obriga a nos organizarmos para produzir muito mais". Surco y Semilla, n. 114 , Set/1965.

${ }^{435}$ Tenga cuidado con el uso de los pesticidas. Surco y Semilla, n. 120, Mar/1966.
${ }^{436}$ Entrevista com Rolando Pinto Contreras, Santiago, 23/05/2019. 
Voltarei à relação entre educação técnica e insumos químicos em outros capítulos. As polêmicas de maior intensidade nas quais o IER esteve envolvido, como vimos, não dizia respeito aos temas técnicos. Ao contrário, os procedimentos da revolução verde, naquele tempo, eram um consenso entre praticamente todos os setores políticos da América Latina, com raríssimas exceções de incipientes movimentos ambientalistas. A hegemonia do produtivismo, que abarcava todo espectro partidário, alinhava inimigos políticos inconciliáveis na mesma agenda tecnológica da modernização agrícola. Por último, apresentarei algumas evidências da interação do IER com a pedagogia de Paulo Freire depois que o brasileiro chegou ao Chile em novembro de 1964.

\subsection{O IER encontra Paulo Freire}

Embora a pedagogia do sacrifício do IER estivesse forjada por valores rígidos, que correspondiam a uma economia moral da obediência à ordem, da paciência e da disciplina laboral da classe camponesa, e favorecesse uma reforma agrária restritiva, lenta e controlada de cima para baixo, existiam ocasiões em que o instituto manifestava seu apreço pelo conhecimento próprio da cultura popular e apresentava a potência dos saberes camponeses na produtividade. Em fevereiro de 1964, sua revista estampava a manchete "Os camponeses ensinam agricultura", em reportagem que contava a história dom Miguel Navarro Diaz, um "agricultor progressista", cultivador de sementes, elogiado por seus conhecimentos que não vieram da educação formal: "Não tenho estudos especiais, feitos em um colégio sobre sementes, mas estou há 30 anos trabalhando com isso e algo se aprende" ${ }^{437}$ explicou o camponês. "Tenho umas maquininhas feitas por nós mesmos, são simples, mas servem tão bem como as complicadas, querem vê-las?”, prosseguiu, mostrando sua própria criação tecnológica para seleção de sementes. A reportagem descrevia:

A máquina é um barril deitado e suspenso a certa altura, com uma manivela para girar. Tem uma pequena porta para colocar e retirar as sementes; as 'engrenagens' não são mais do que 30 pedras arredondadas que separam as sementes do resto da planta. Dessa máquina, as sementes passam para outra, não menos original. Feita de madeira, latas, engenhosidade e parafusos, funciona como um ventilador elétrico. ${ }^{438}$

A tecnologia caseira de dom Miguel era descrita detalhadamente pelo IER, que valorizava a perspicácia da sua criação. Dona Rosita, sua esposa, aproveitou a ocasião para expressar o quanto que desejava que a filha do casal, de 17 anos, estudasse em um Centro de Capacitação do IER.

Antes mesmo que Paulo Freire chegasse ao Chile, em março de 1964, o instituto manifestava interesse por metodologias de ensino mais horizontais, especialmente nas circunstâncias de formação

${ }^{437}$ Un agricultor progresista. Surco y Semilla, n. 95, Fev./1964.
${ }^{438}$ Id. ibid. 
pedagógica dos próprios professores: "os professores preparados no Centro Christa Mock estão colocando em prática um método diferente de ensino", ${ }^{439}$ relatavam em Surco y Semilla. "Desaparece aqui a tradicional figura do possuidor de conhecimentos, que os distribui do alto de um púlpito para um alunado receptivo. O professor se integra a uma equipe com seus próprios alunos, na busca da verdade. Naquele instante, TODOS são professores", ${ }^{440}$ enfatizavam. O evento era a Universidade Popular de Verão, no Centro de Capacitação de Graneros, na qual participaram 103 professores que, durante 5 semanas e jornadas de 14 horas diárias de trabalho, vivenciaram 72 aulas e atividades de aperfeiçoamento. Não eram apenas do IER, mas também professores de Escolas Normais chilenas e alguns pedagogos estrangeiros (estadunidenses, alemães, espanhóis). ${ }^{441}$ "Deu-se ênfase a uma característica do professorado do IER: a mística que alivia o trabalho" ${ }^{442}$ contavam. A Universidade Popular de Verão contou com aporte da OIT.

A valorização dos saberes camponeses, da criatividade popular para novas tecnologias de produção, tanto quanto de metodologias de ensino mais horizontais, proporcionava um ponto de encontro entre o IER e Paulo Freire. Por isso, quando este chegou ao Chile, exilado pelo golpe de 1964, despertou atenção e entusiasmo dos educadores cristãos que trabalhavam com camponeses há mais de uma década. "Muito inovador é um método que estão usando para ensino de leitura e escritura aos que não sabem", anunciaram na revista do instituto. "Em cada escola fazem reuniões entre os alunos - os que não sabem ler nem escrever - com um professor. Este lhes mostra alguns desenhos ou uma fotografia de uma situação no campo. (...) Desse quadro, retiram-se muitas experiências (...), conclusões e palavras básicas", explicaram, sem esconder seu fascínio. Em seguida, segundo o novo método, o professor escolhia uma palavra da conversa dos próprios camponeses e escrevia na lousa. Assim, "em pouco tempo, quase sem se dar conta, vão aprendendo a ler e escrever, em aulas muito divertidas e que deixam muitos ensinamentos, por exemplo, que é muito mais fácil retirar um tronco diante da casa com ajuda dos compadres e vizinhos", porque afinal, "a união faz a força, isso é pura verdade" ${ }^{443} \mathrm{O}$ instituto se referia ao programa de alfabetização da Chefatura de Planos Extraordinários para Educação de Adultos, do Ministério de Educação Pública, que havia incorporado o método de Paulo Freire, que o governo chileno nomeou "método psicossocial". Em dois anos, o Ministério ergueu mais de mil escolas para alfabetizar trabalhadores e paralelamente formar 5 mil professores seguindo as diretrizes da pedagogia ensinada pelo brasileiro.

A relação entre o IER e Paulo Freire, a princípio, foi amistosa. Como nos contou Marcela Gajardo, que trabalhou junto com Freire em uma equipe multidisciplinar do ICIRA, "Paulo dava aulas no IER. Convidavam-no toda hora. (...) O que ele tratava de demonstrar era como seu método tinha mais vantagens que o deles. Eles não se fechavam para escutar e eventualmente adotavam algumas

\footnotetext{
${ }^{439}$ Hombres mejores. Surco y Semilla, n. 96, Mar./1964.

440 Id. ibid.

${ }^{441}$ Id. ibid.

442 Id. ibid.

${ }^{443}$ La educación avanza en el campo. Surco y Semilla, n. 127, Out./1966.
} 
dessas ideias" ${ }^{444}$ A aura teológica de Freire e sua proximidade relativa com a DC foram, certamente, fatores iniciais de confiança para o IER, que recebeu, refletiu e incorporou internamente aspectos do método de alfabetização de Paulo Freire. Em um relatório intitulado "Instituto de Educação Rural. Curso de Alfabetização e Cultura Popular. Professor Paulo Freire - INDAP", ${ }^{445}$ o instituto produziu uma circular interna baseada em registros de uma aula com Paulo Freire. Nessa circular, resumiam as etapas e significados do "método psicossocial" do brasileiro e as diretrizes práticas para sua aplicação no campo chileno. Além de resumir a proposta de Freire, o documento revelava que o IER iniciou uma investigação própria do universo vocabular camponês a fim de replicar o método de Freire por conta própria em dois locais: Cañete (província de Maule) e Huentelolen (província de Arauco).

Nessa investigação, registraram algumas frases dos camponeses que lhes pareceram relevantes para extrair palavras geradoras e temas para círculos de cultura. Algumas delas, eram "queremos a terra para nós para não termos que entregar nossos pulmões aos ricos" (inquilino de Cañete); "estamos vendidos ao fundo, somos como animais escravos" (inquilino de Cañete); "a terra não dá para tanta família" (mapuche de Huentelolen); "se tivéssemos muita terra, muita colheita - pouca terra, pouca colheita" (mapuche de Huentelolen), entre outras. Perguntados por que queriam aprender a ler e escrever, os inquilinos e mapuches responderam: "para ter dinheiro", "para que não nos enganem", "para pensar mais", "para que não nos apontem com o dedo". ${ }^{446}$ O relatório do IER que incorporava a pedagogia do Paulo Freire também indicava que "além de frases e expressões, devem ser selecionadas as palavras mais usadas, sobretudo aquelas com maior conteúdo emocional. (...) Algumas são regionais, outras locais, como: ñocha, troyo, pega, huinca, reducto, mote (Arauco), chupalla, mingaco, ruca, ojota, chalaco, sopaipilla (Maule)". No processo de investigação vocabular, segundo os registros do IER, "é importante não anotar na frente do interlocutor", ${ }^{447}$ alertavam, pois isso intimidava e alterava comportamentos. Outra indicação sensível indicada no documento do IER tratava da necessidade de evitar que na mesma aula de alfabetização estivessem analfabetos absolutos e semianalfabetos, o que poderia gerar constrangimentos.

O IER também tomou nota de princípios da pedagogia freireana relacionados à valorização dos saberes populares não escolarizados. No momento do círculo sobre o conceito antropológico de cultura, que antecedia o processo alfabetizador, o IER ressaltava: "o homem simples vai perceber que na verdade não é ignorante absoluto, ainda que seja analfabeto. Descobrirá a relatividade da sua ignorância, ignorância que antes lhe oprimia por ser considerada absoluta". ${ }^{448} \mathrm{E}$, por fim, os registros do IER destacavam a importância, para a funcionalidade do método, de que "todas as atividades de leitura e escritura estejam vinculadas com as situações reais do educando (...). Só assim a participação dos

\footnotetext{
${ }^{444}$ Entrevista com Marcela Gajardo, 04/12/2018.

${ }^{445}$ Fundo Documental José María Arguedas. Biblioteca Nacional. Instituto de Educação Rural. Curso de Alfabetização e Cultura Popular. Professor Paulo Freire - INDAP, sem data (s/d).

${ }^{446}$ Id. ibid.

447 Id. ibid.

${ }^{448}$ Id. ibid.
} 
alfabetizandos será dinâmica, natural, consciente e crítica". Isso porque, "quanto mais reais forem as situações de aprendizagem, maior será a aplicação do aprendido nas soluções dos problemas do indivíduo, da comunidade regional e nacional". ${ }^{449}$ Enfim, a influência de Paulo Freire nas instituições educadoras chilenas, do campo e da cidade, foi avassaladora. Como se verá no próximo capítulo, o pedagogo brasileiro foi incorporado de maneira decisiva nos processos educacionais do país, particularmente aqueles relacionados à reforma agrária. Nem o IER passou imune.

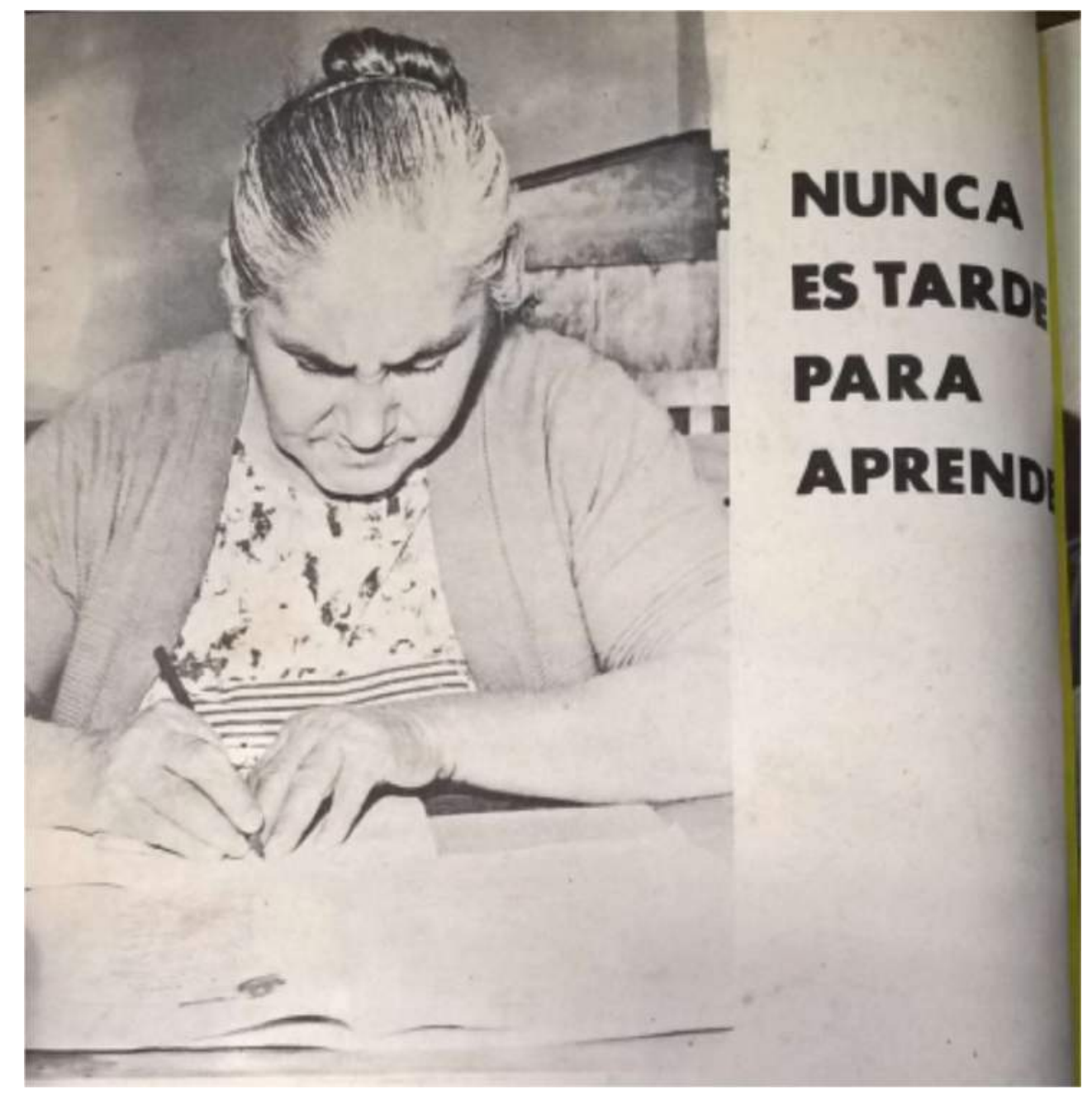

Carmen Salamanca, camponesa alfabetizada aos 78 anos (Nunca é tarde para aprender. Surco y Semilla, n. 96, Mar/1964.)

\subsection{Considerações finais}

Como vimos, o Instituto de Educação Rural foi uma instituição pioneira na educação camponesa do Chile, concebida em 1954 pelo Episcopado Chileno, apoiada por setores latifundiários

${ }^{449}$ Id. ibid. 
como a Sociedade Nacional de Agricultura (SNA), patrocinada pela USAID via Aliança para o Progresso, com importante peso diplomático e fluxo de voluntários estadunidenses dos Peace Corps. Nos anos 1960, o instituto estreitou seus vínculos com a Democracia Cristã. Embora fosse uma organização pensada a partir das classes dominantes e setores de cúpula do poder político do país, o instituto ofereceu oportunidades educacionais e culturais gratuitas e conquistou amplos setores do campesinato para desenvolver novos projetos de vida semeados dentro de seus centros de capacitação. A Rádio Escola e a revista Surco y Semilla cumpriram um papel fundamental no enraizamento dos trabalhos do IER em diferentes territórios, conectando escolas primárias e comunidades que antes eram consideradas incomunicáveis.

Dessa forma, o IER conseguiu difundir o sentimento de participação em uma "grande família camponesa", como pode-se apreender dar inúmeras cartas de camponeses recebidas pelo instituto e das redes de afeto, amizade, companheirismo e matrimônios ativadas e criadas pela sociabilidade educacional da própria organização. Essa "grande família” conformou também as bases sociais de um projeto político específico, em um contexto de acirramento eleitoral da concorrência entre cristãos (DC) e marxistas (FRAP/UP) nos anos 1960. Para tornar sua base educacional politicamente operativa, o IER participou da criação da ANOC (1962) e do MCI (1964), receptores das lideranças formadas nos centros de capacitação que apresentavam um perfil mais ativista. O IER se tornou, nesse sentido, uma usina pedagógica de dirigentes camponeses, criando uma simbiose entre educação e política por meio de ferramentas comunitárias que, como mostram as vozes de seus alunos, eram portadoras de uma significativa capacidade de transformação existencial e afetiva. Materializa-se, nesse processo, um silencioso poder cultural, no qual as redes de afeto e o sentimento da "grande família camponesa" se convertem em hegemonia para um projeto de poder econômico, durante o período em que a reforma agrária se deslocava para o centro do debate chileno e latino-americano.

O IER utilizou seu poder cultural para difundir uma economia moral relacionada a uma pedagogia do sacrifício, difundindo valores que vangloriavam o esforço, o trabalho duro, o suor e, no limite, a própria exploração social. Junto do sacrifício, as virtudes da paciência e da obediência eram articuladas a uma conduta moral de respeito às leis, em uma nítida tentativa de apaziguamento das tensões sociais cada vez mais explosivas entre a classe camponesa e a classe patronal rural. Em algumas circunstâncias, contudo, o IER se viu esmagado pelo conflito de classe. Assim, por um lado, a organização tentava criar laços de alianças e negociações pacíficas entre camponeses e patrões. Por outro, na medida em que o governo de Eduardo Frei avançava na aplicação da reforma agrária e na garantia dos direitos laborais dos trabalhadores rurais, e os patrões respondiam com desobediência às leis, novos conflitos rurais eclodiam e envolviam as bases sociais do próprio instituto, obrigando os dirigentes da ANOC, do MCI e do próprio IER a apoiar temporariamente algumas greves e lutar contra demissões em massa. Amortecer essa luta tornou-se uma tarefa cada vez mais desafiadora e praticamente inconciliável. Como se verá, a intensificação das lutas sociais no campo fez parte do 
processo popular que engendrou a eleição de Salvador Allende em 1970, e o aprofundamento da reforma agrária pela Unidade Popular passou a desafiar ainda mais as posições conciliadoras do IER.

Por fim, naquele mesmo contexto do governo de Eduardo Frei, o pedagogo Paulo Freire chegou ao Chile e foi incorporado como referencial em diversos programas de alfabetização e de educação camponesa, ocupando um espaço fundamental nas batalhas pedagógicas da reforma agrária chilena. $\mathrm{O}$ IER não fechou as portas a essa influência, recebeu Paulo Freire para aulas dentro do instituto e realizou exercícios de aplicação do seu método de alfabetização e ação cultural. No entanto, a influência de Paulo Freire na educação camponesa se fez mais contundente e espraiada nos organismos públicos do próprio Estado chileno, o que será tratado no próximo capítulo. 


\section{Capítulo 4 - Semeadores de palavras: Paulo Freire, a reforma agrária chilena e a Pedagogia do oprimido}

"Agrônomos, técnicos agrícolas, cooperativistas, alfabetizadores, todos nós temos muito o que aprender com os camponeses e se a isto nos recusarmos, nada a eles podemos ensinar"

- Paulo Freire, Santiago, $1968^{450}$

"O camponês, quando não duvida, é um pedagogo nato" - Julio Salgado, supervisor de educação básica da CORA, $1968^{451}$

"Em algumas áreas do Chile onde estava ocorrendo a reforma agrária, os camponeses que participavam dos programas de alfabetização escreveram palavras com suas ferramentas nos caminhos de terra onde trabalhavam, (...) com as combinações silábicas que estavam aprendendo. "Estes homens são semeadores de palavras', me disse Maria Edy Ferreira".

- Paulo Freire, $1971^{452}$

\subsection{Introdução}

As pinturas originais que Paulo Freire utilizou em seu primeiro experimento pedagógico de alfabetização camponesa, em Angicos (RN) em 1962 e com financiamento da USAID, foram criadas pelo artista recifense Francisco Brennand. Eram dez quadros, cujos originais foram presenteados a Freire depois de terem sido transformados em slides, que seriam projetados em lençóis brancos nas centenas de círculos de alfabetização que se espalharam pelo Nordeste do Brasil no ano seguinte. As pinturas retratavam situações existenciais tematizadas a partir da realidade de analfabetos rurais e urbanos brasileiros, que se desdobrariam em reflexões coletivas e palavras geradoras. Em um dos quadros, havia um trabalhador rural com uma espingarda de caça, que correspondia à situação existencial número 4, chamada: "caçador letrado (ou cultura letrada)". ${ }^{453}$ Freire guardava os quadros presenteados por Brennand em sua sala do Serviço de Extensão Cultural da Universidade do Recife. Depois do golpe de 1964, oficiais do Exército vasculharam seus pertences e apreenderam as obras.

\footnotetext{
450 “Os camponeses e seus textos de leitura". Freire, 1981: 23. Publicado no México em 1968 com o título "Los campesinos también pueden ser los autores de sus propios textos de lectura". In: Paulo Freire, Educação e Conscientização. Cuadernos Cidoc - Centro Intercultural de Comunicación, n. 25. Cuernavaca: Cidoc, 1968.

${ }^{451}$ Relatório de Julio Salgado Moya dentro de Paulo Freire, Alfabetización Funcional en Chile. Informe UNESCO. Santiago: ICIRA (mimeo.), 1968a.

452 Paulo Freire, El proceso de alfabetización adulta como acción cultural para la libertad. Revista de Educación, n. 34 , Mar./1971.

${ }^{453}$ Em Educação como Prática da Liberdade, em que Paulo Freire narra sua experiência em Angicos, a situação existencial número 4 vem acompanhada da seguinte explicação: "4a SITUAÇÃO. Caçador letrado (cultura letrada). Ao ser projetada esta situação, identificam o caçador como um homem de sua cultura, ainda que possa ser analfabeto. Discute-se o avanço tecnológico representado na espingarda em confronto com o arco e a flecha. Analisa-se a possibilidade crescente que tem o homem de, por seu espírito criador, por seu trabalho, nas suas relações com o mundo, transformá-lo cada vez mais. E que esta transformação, contudo, só tem sentido na medida em que contribuir para a humanização do homem. Na medida em que se inscrever na direção da sua libertação. Analisam-se finalmente implicações da educação para o desenvolvimento" (Freire, 1967: 130).
} 
Segundo se lembra, a pintura da espingarda entrou como peça do inquérito policial-militar que o acusava de subversão: "dizia-se que aquilo era a maneira com que se treinavam guerrilheiros. Imagina! O fato é que perdi os originais do Brennand”, lamentou (Freire \& Guimarães, 1987: 93).
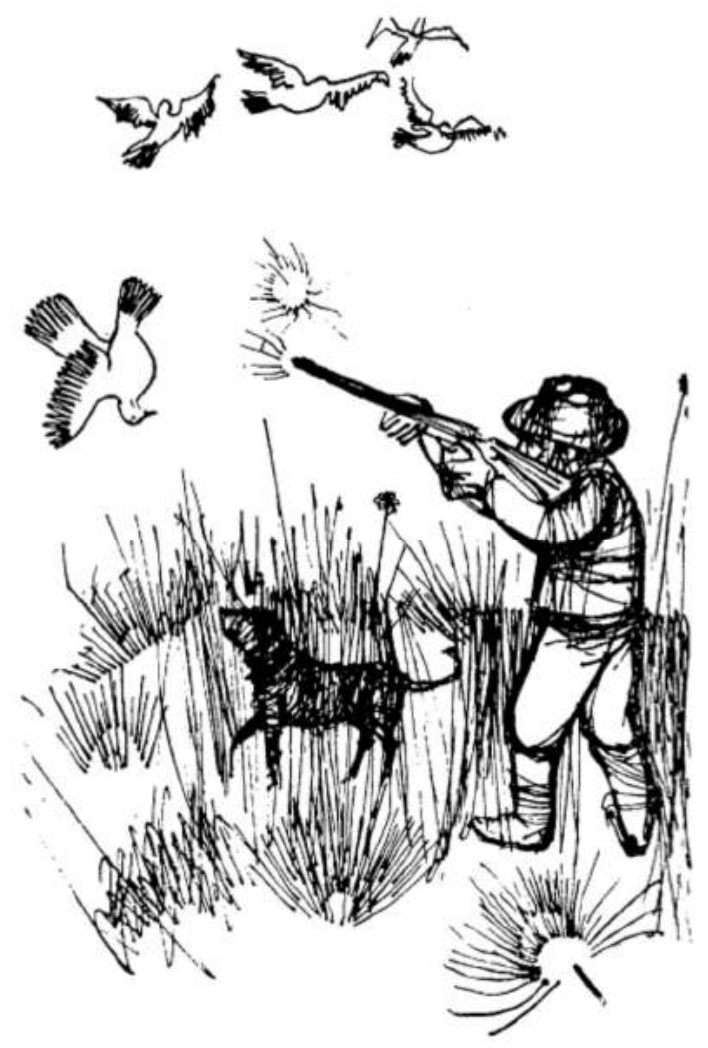

Em Educação como Prática da Liberdade, Freire pediu que o artista Vicente de Abreu reinventasse as imagens das situações existenciais, originalmente pintadas por Brennand. Essa foi a recriação da $4^{\text {a }}$ situação existencial: "O caçador letrado (cultura letrada)”. A espingarda motivou os militares brasileiros a acusar o método de alfabetização de "subversivo" (Freire, 1967: 130131).

Em 2019, a historiadora Daniela Zubicueta concluiu uma pesquisa sobre a pedagogia de Paulo Freire no Chile, em que reuniu uma importante quantidade de imagens produzidas por artistas chilenos para tematizar situações existenciais e palavras geradoras nos círculos de alfabetização e pósalfabetização com método psicossocial. Esse foi o nome como passaram a se referir ao que no Brasil já se conhecia como "método Paulo Freire". ${ }^{454}$ Zubicueta entrevistou dois artistas que acompanharam as equipes interdisciplinares do Instituto de Desenvolvimento Agropecuário (INDAP), coordenadas pelo brasileiro durante os primeiros anos do seu exílio em Santiago. Eram Julio Zuñiga e Paz Vial. Ao contrário de Brennand, eram artistas desconhecidos. Paz contou à Zubicueta que "Paulo Freire buscava gente que não tivesse pintado antes, para poder formar. Não queria pintores, para que não viessem com 'vícios"” (Vial apud Zubicueta, 2019: 151).

Zeloso da potência imagética da sua pedagogia, Freire incentivava que os jovens artistas lessem livros de filosofia e incorporassem nas suas pinturas a profundidade do método: "Ele nos dava livros para ler. Me lembro que nos fez ler Eric Fromm, $A$ arte de amar. Tudo isso era maravilhoso para uma

\footnotetext{
${ }^{454}$ As pinturas reunidas no trabalho de Zubicueta foram encontradas no Museu Casa Eduardo Frei Montalva e no arquivo pessoal de Carmen Gloria Aguayo. Uma parte delas também se encontra no Centro de Referência do Instituto Paulo Freire, em São Paulo, local onde eu as obtive.
} 
garota jovem como eu, porque além de tudo, a qualquer dúvida que tivéssemos, ele se sentava junto e explicava", prosseguiu Paz Vial. Julio Zuñiga, por sua vez, contou que Paulo Freire "trazia uma versão muito linda de um artista brasileiro, Francisco Brennand, que eram as [imagens] originais. A ideia era reconstruir toda a sequência do Conceito Antropológico de Cultura, o primeiro que se discutia" (Zuñiga apud Zubicueta, 2019: 151). É possível que Freire tenha conseguido trazer no exílio alguns slides das primeiras pinturas de Angicos. "Paz e eu viajamos muitas vezes a distintos pontos do país e a partir daí começamos a trabalhar nas telas", contou Zuñiga à historiadora chilena.

As pinturas de Paz Vial e Julio Zuñiga retratavam situações existenciais camponesas, baseadas em observação da vida rural chilena. Durante o governo de Eduardo Frei, foram utilizadas nos círculos de cultura impulsionados pelas equipes freirianas do INDAP, que atuavam junto a comitês camponeses, associações de proprietários pequenos impulsionadas pelo governo da Democracia Cristã (DC). O exílio chileno de Paulo Freire coincidiu com a chamada revolução em liberdade, o programa de reformas estruturais da DC durante o governo Eduardo Frei Montalva. Entre 1964 e 1967, Freire trabalhou como consultor da Unesco para o INDAP, presidido por Jacques Chonchol, atuando na ação cultural. Outras instituições aproveitaram a expertise do pedagogo e desenvolveram programas de alfabetização de adultos camponeses com seu método. Depois, em 1967 e 1968, Freire atuou no ICIRA, onde desenvolveu experiências inovadoras de investigação temática em assentamentos. Examinarei adiante os desdobramentos da pedagogia de Paulo Freire na educação camponesa da reforma agrária chilena.

Como consultor, embora estivesse formalmente alocado no Ministério da Agricultura, Freire circulou por diferentes instituições, o que fez com que costurasse uma massiva rede de adesão à sua pedagogia no Ministério da Educação. A socióloga Marcela Gajardo, amiga de Freire e jovem colega dos tempos de ICIRA, nos contou que os ministérios eram formalmente desarticulados e foi ele quem "facilitou a intersetorialidade. (...) Estava contratado no INDAP, mas transitava com muita facilidade pela CORA e pelo Ministério da Educação", explicou. ${ }^{455}$ Jacques Chonchol confirmou: as pastas da agricultura e da educação "eram caminhos separados. A única relação foi o Paulo Freire (...). Não tínhamos programas comuns". ${ }^{456}$ A capacidade de Freire de circular por diferentes corredores do governo Frei e influenciar setores políticos diversos (às vezes rivais) sinaliza o peso e a multiplicidade da sua influência na educação camponesa durante a reforma agrária do Chile.

Nesse capítulo, argumento que a atuação de Paulo Freire em diferentes instituições públicas chilenas engendrou um processo de transformações multiplicadoras. De um lado, o próprio Freire foi transformado pela realidade chilena, especialmente pelo contato com as profundezas da vida rural. Não é por acaso que a subjetividade camponesa e ação cultural da reforma agrária chilena estejam nos fundamentos experimentais da Pedagogia do oprimido. ${ }^{457} \mathrm{O}$ substrato histórico de um dos livros mais traduzidos no mundo, que o torna embebido pela reforma agrária chilena, não costuma ser um aspecto

\footnotetext{
${ }^{455}$ Entrevista com Marcela Gajardo, Santiago, 04/12/2018.

${ }^{456}$ Entrevista com Jacques Chonchol, Santiago, 26/11/2018.

${ }^{457}$ A experiência das transformações agrárias chilenas está especificamente desenvolvida no capítulo 3 (Freire, 2018).
} 
suficientemente destacado. ${ }^{458} \mathrm{O}$ pesquisador John Holst (2006) defende que Pedagogia do oprimido (1968), em comparação com Educação como prática da liberdade (1967), documenta a inflexão política que Freire viveu ao ser interpelado pela efervescência chilena. Concordando com Holst, acrescento que Pedagogia do oprimido, na sua qualidade de fonte documental, também pode ser compreendido como um documento da reforma agrária chilena, escrito ao calor de um amplo diálogo estabelecido entre Freire, as equipes interdisciplinares do INDAP, CORA, ICIRA, o Ministério da Educação (Mineduc), os professores, o mundo sindical e os camponeses dos mais diferentes territórios do país, no contexto da aprovação da lei de reforma agrária em julho de 1967 e, portanto, da expansão do horizonte subjetivo e objetivo das mudanças estruturais. Para desenvolver esse argumento, os textos de Paulo Freire escritos no Chile participarão desta narrativa a partir daquilo que revelam sobre a experiência político-pedagógica rural e que informam sobre a subjetividade camponesa e a consciência transitiva da reforma agrária. ${ }^{459}$ Muitos argumentos construídos por Freire, como se verá, resultam da vivência de situações educacionais concretas, diretamente relacionadas com as transformações estruturais na agricultura.

De outro lado, argumento que os chilenos se apropriaram da metodologia freiriana de múltiplas maneiras e reinventaram sua aplicação em diversas frentes de alfabetização camponesa e ação cultural ao experimentarem sua potencialidade com contornos variados. A flexibilidade criativa do método psicossocial foi utilizada como estratégia para revolucionar as metodologias organizadoras do poder entre pessoas-nexo ou instituições-nexo ${ }^{460}$ e os territórios camponeses. A pedagogia do oprimido, de certa forma, se propunha a implodir as hierarquias (tradicionais ou modernas) do próprio nexo de dependência entre o campesinato, considerado "ignorante absoluto", e a cultura urbana letrada, alienada da sua própria ignorância. ${ }^{461}$ Mas só poderia implodir hierarquias na medida em que potencializasse os saberes camponeses, fomentando um novo poder que emanasse no coração do processo políticopedagógico, produzido pela autoconsciência camponesa sobre sua própria agência.

\footnotetext{
${ }^{458}$ Um volume imenso de obras se referencia na filosofia educacional da Pedagogia do oprimido, mas até aqui desconheço a existência de trabalhos que leiam esse livro como fonte primária com enfoque na reforma agrária e nos desafios econômicoculturais. Entre os trabalhos que analisam especificamente a passagem de Freire no Chile, se destacam Williamson (1989); Holst (2006); Kirkedall (2010); Fauré Polloni (2011); Aravena \& Díaz-Diego (2016); e Zubicueta (2019). Para análises e testemunhos de quem conviveu diretamente com ele no país: Fernández (1998), Gajardo (2019), Osorio Vargas (2019). Para biografias panorâmicas, ver Gadotti (1996); Souza (2001) e Haddad (2019).

${ }_{459}$ Em Educação como prática da liberdade, Paulo Freire define que "consciência transitiva significa (...) o reconhecimento da consciência histórica. As massas estão dentro do jogo, agora não mais exclusivo das elites, e os temas em luta não lhes são estranhos. Pelo contrário, vários destes temas - o poder, a democracia, a liberdade etc. — aparecem no cenário político assinalados por ideologias que buscam interpretar o sentimento popular. As classes populares se encontram presentes, ainda que algumas vezes em forma aparentemente passiva, e a pressão que exercem se configura como uma força real no sentido da afirmação da liberdade" (Freire, 1967: 17).

${ }^{460}$ Aqui, como nos capítulos anteriores, a ideia de pessoas-nexo ou instituições-nexo entre a estrutura nacional e a localidade camponesa é inspirada no estudo de Pascal Allende (1971).

461 Em Extensão ou comunicação?, escrito no Chile para agrônomos, Paulo Freire propõe o conceito de "alienação da ignorância" como estado de consciência daquele que desconhece a limitação de seu próprio saber: "Para que os homens simples sejam tidos como absolutamente ignorantes, é necessário que haja quem os considerem assim. Estes, como sujeitos dessa definição, necessariamente se localizam a si mesmos (...) como quem sabe. Absolutizando a ignorância daqueles, na melhor das hipóteses, relativizam sua ignorância. Desse modo realizam o que chamamos de "alienação da ignorância", segundo a qual esta se encontra sempre no outro, nunca em que a aliena" (Freire, 1969: 36). Para Freire, a existência de um "ignorante absoluto" é um mito, peça chave da pedagogia do opressor. Ou seja, ninguém sabe tudo, tanto quanto ninguém não sabe nada.
} 
A multiplicação da pedagogia do oprimido deixou seus registros. As instituições públicas chilenas que atuavam na educação camponesa produziram pinturas de situações existenciais, manuais para alfabetização com método psicossocial, criaram diferentes listas de palavras geradoras para o campo e para cidade e registraram relatórios de investigações temáticas. Nesse capítulo, tratarei das experiências freirianas no âmbito do Mineduc, do INDAP e da CORA (os experimentos freirianos com ênfase no ICIRA serão tratados no próximo capítulo). Darei especial importância à pedagogia da pergunta, às imagens e textos de leitura, à investigação temática e à formação de professores camponeses como recursos do protagonismo camponês, que fundamentavam seu fortalecimento como sujeito popular - em contraste com as práticas de "invasão cultural" e "ação antidialógica", que por vezes estavam misturadas nas mesmas instituições.

Quais eram os critérios de diferenciação entre as várias apropriações do método freiriano, das equipes do Mineduc, da CORA, do INDAP? O que foi ação dialógica e o que foi ação antidialógica na educação camponesa desses organismos? Como os vestígios documentais nos permitem inferir tais contrastes? Ao fim e ao cabo, argumento que aqueles que adotaram a investigação temática, a pedagogia da pergunta e se preocuparam com a autoalfabetização ou autocapacitação como hipótese, permitindo a expansão da escuta do campesinato pelas pessoas-nexo, representaram uma corrente política-pedagógica específica, programaticamente freiriana, que atuou nas bases de todas as instituições. Essa "corrente freiriana" era plural e tinha em comum a sensibilidade política que priorizava a escuta e a horizontalidade. Essa característica a tornou relativamente invisível perante as estridentes batalhas das vanguardas. Com isso, conduzirei o capítulo pelo argumento central da tese, de que a pedagogia ocupou um lugar estratégico nas batalhas da economia moral e, portanto, nos diferentes projetos de futuro que estavam em confronto.

\section{2. "Viva o oxigênio!" Freire e a atmosfera chilena de 1964}

Quando Paulo Freire pisou no Chile, em novembro de 1964, estava na rota de fuga de dois golpes militares consecutivos: o brasileiro, que lhe perseguiu e encarcerou durante mais de 70 dias, incluindo a passagem por uma estreita solitária; e o boliviano, que lhe surpreendeu quatro dias depois da sua chegada a La Paz, inviabilizando seu emprego no Ministério da Educação e o forçando ao "exílio do exílio". ${ }^{462}$ Freire desembarcou sem passaporte em Arica, a primeira cidade próxima da fronteira da Bolívia com o Chile, em razão das articulações dos amigos Plinio Sampaio, Paulo de Tarso e Thiago de Mello, este último adido cultural brasileiro em Santiago. Ao descer ao nível do mar, depois de duas semanas de angústia e falta de ar na altitude de La Paz, Paulo Freire agradeceu à atmosfera: "viva o oxigênio!". ${ }^{463}$ Embora a exclamação fosse literal, pela dificuldade que teve de se adaptar à altura dos

\footnotetext{
${ }^{462}$ A memória de Paulo Freire sobre sua prisão e fuga do Brasil em 1964 estão detalhadas em Freire \& Guimarães, 2010. Itinerários biográficos podem ser lidos em Holst (2006); Kirkendall (2010); Haddad (2019).

${ }^{463}$ A interjeição a esmo no aeroporto de Arica foi relatada por Paulo Freire em Freire \& Guimarães (1986: 88) e em Pedagogia da Esperança (Freire, 2011: 48).
} 
Andes, sua dimensão metafórica era igualmente importante. O brasileiro "respirou" da atmosfera chilena e se misturou ao clima de grandes expectativas com as reformas estruturais da Democracia Cristã e crescente mobilização popular. "Minha prática de exílio me politizou intensamente. Foi o Chile, inclusive, que fez isso", avaliou em 1986 (Freire \& Guimarães, 2010: 25). Em 1991, de volta ao país para um evento em sua homenagem, confessou: "me tornei quase chileno" (Freire, 2018: 160). Não por acaso, um dos períodos mais produtivos da trajetória do pedagogo foi quando morou em Santiago: concluiu Educação como prática da liberdade (1967), escreveu Pedagogia do oprimido (1968) e redigiu no mínimo treze textos mimeografados, entre orientações práticas para círculos de cultura, debates pedagógicos com educadores, diálogos com agrônomos, sugestões metodológicas e reflexões sobre a reforma agrária. Esse corpus está esparramado em diferentes publicações, sendo que parte dele nunca sequer foi publicado. ${ }^{464}$

Em novembro de 1968, quem buscou Paulo Freire no aeroporto de Santiago foi o jovem Francisco Weffort, à época com 28 anos, que logo depois prefaciaria Educação como prática da liberdade (Freire, 1967) e se tornaria seu genro. Com a vitória eleitoral de Eduardo Frei em setembro de 1964, o entusiasmo popular reformista estava em pleno impulso, a despeito das críticas da esquerda marxista. "Comecei a trabalhar imediatamente", lembrou Paulo Freire: "o contexto do exílio até me deu uma possibilidade enorme de aprender mais e de aprofundar as coisas que já vinha fazendo no Brasil" (Freire \& Magalhães, 2010: 90). Mais tarde, relembrando sua experiência, afirmou:

O Chile nos ensinou América Latina (...). Percorri grande parte do país em que aprendi realmente muito. Aprendi fazendo parte, ao lado de educadores e educadoras chilenos, de cursos de formação para quem, nas bases, nos assentamentos da reforma agrária, trabalharia com camponeses e camponesas a questão fundamental da leitura da palavra, sempre precedida pela leitura do mundo (Freire, 2011: 49, 60).

A relação de Paulo Freire com a reforma agrária chilena foi mais orgânica e impactante do que a literatura brasileira costuma explorar. Poucos dias depois da sua entrada no país, Jacques Chonchol, recém empossado diretor do INDAP, o contratou para trabalhar na Unidade de Metodologia e Estudos do Departamento de Capacitação do órgão que dirigia, por meio de um convênio com a Unesco (Faiguenbaum, 2017: 96). O INDAP havia sido criado em 1962, pela lei de reforma agrária de macetero do presidente Jorge Alessandri, e executava funções de oferta de crédito e assistência técnica para

\footnotetext{
${ }^{464}$ Os treze textos de Paulo Freire mimeografados no Chile se encontram esparramados, e parte dessa pesquisa foi constituilos como corpus coerente. Em 1968, o filósofo e educador Ivan Illich editou, no México, uma brochura mimeografada com textos de Paulo Freire, quase todos inéditos, com exceção do capítulo 4 de Educação como prática da liberdade, que já havia sido publicado no Brasil pela Paz e Terra no ano anterior. Entre os materiais, estavam o manuscrito Extensión o Comunicación?, publicado pelo ICIRA em 1969; três textos transformados em capítulos do livro Ação cultural para liberdade em 1975 (Freire, 1968a, 1968d, 1968e); dois publicados em Educação e mudança em 1979 (Freire, 1968j, 1968k); outros oito artigos aparentemente nunca publicados em português (Freire, 1967, 1968a, 1968b, 1968c, 1968f, 1968g, 1968h, 1968i); e um co-escrito com Raul Veloso (Freire \& Velozo, 1968), também inédito até hoje. Dos oito nunca publicados, três foram também encontrados em versão mimeografada interna do ICIRA, disponibilizados por Marcela Gajardo e Rodrigo Aravena em formato digital, pois pertenciam à Sessão José Maria Arguedas da Biblioteca Nacional, que está fechada por tempo indeterminado. Por fim, um quarto texto disponibilizado por Gajardo e Aravena da Sessão Arguedas é exclusivo, ou seja, não foi encontrado em nenhum outro local (Freire, 1968a).
} 
pequeno proprietário, com um orçamento que variava de 25 a 35\% do Ministério da Agricultura (Faiguenbaun, 2017: 207). No governo de Eduardo Frei, o órgão recebeu novas atribuições vinculadas ao conceito de promoción popular campesina e inseriu diretrizes culturais e educacionais no seio das políticas agrárias. Tal concepção seria consolidada com as leis de reforma agrária (16.640) e de sindicalização camponesa (16.625) em 1967.

A velocidade com que Paulo Freire foi incorporado ao staff reformista do Chile estava relacionada tanto a afinidades pessoais, como políticas. Paulo de Tarso e Plinio Sampaio eram militantes da Democracia Cristã no Brasil e já conheciam Jacques Chonchol, o que os permitiu ser rapidamente incorporados à estrutura do ICIRA com cargos estáveis. "Quando Paulo Freire chegou ao Chile eu não o conhecia", lembrou Chonchol, "mas estavam aqui dois brasileiros, Plínio Sampaio e Paulo de Tarso, que me apresentaram a ele e disseram 'por que você não o contrata?'. Eu o contratei". ${ }^{465}$ Já Almino Affonso, que não tinha qualquer relação com a DC, amargou alguns meses de desemprego antes de ser acolhido pela socióloga brasileira Maria Edy Ferreira, sua antiga companheira de movimento estudantil na União Estadual dos Estudantes de São Paulo, que era casada com Chonchol. ${ }^{466}$ Entre 1964 e 1973 , pelo menos dez brasileiros exilados estiveram empregados em instituições da reforma agrária chilena, sobretudo no ICIRA, com atribuições de pesquisa e docência, trabalhando em contato com funcionários do Estado, educadores, agrônomos, extensionistas, sociólogos, psicólogos, administradores rurais e diretamente com camponeses. ${ }^{467}$ " A influência intelectual dos brasileiros do exílio foi enorme no debate social e político chileno", ${ }^{468}$ apontou Marcela Gajardo.

Logo após chegar em Santiago, em um jantar com brasileiros e chilenos, Paulo Freire narrou sua experiência de alfabetização no Nordeste e projetou slides com as pinturas de Brennand. Em dois dias, o anfitrião do jantar, Thiago de Mello, lhe telefonou para declamar o poema Canção para os fonemas da alegria, publicado em 1967 como epígrafe de Educação como prática da liberdade:

Peço licença para algumas coisas.

Primeiramente para desfraldar este canto de amor publicamente.

Sucede que só sei dizer amor quando reparto o ramo azul de estrelas que em meu peito floresce de menino.

Peço licença para soletrar, no alfabeto do sol pernambucano, a palavra ti-jo-lo, por exemplo,

\footnotetext{
${ }^{465}$ Entrevista com Jacques Chonchol, Santiago, 14/04/2016.

${ }^{466}$ Entrevista com Almino Affonso, São Paulo, 07/08/2018.

${ }^{467}$ Sem incluir Maria Edy Ferreira, que já vivia no Chile e atuou como ponte de acolhimento, os brasileiros que trabalharam na reforma agrária chilena, em diferentes períodos, foram: Paulo de Tarso (ICIRA), Paulo Freire (INDAP, ICIRA via Unesco), Plinio Sampaio (ICIRA via FAO), Almino Affonso (ICIRA via OIT), Wilson Cantoni (FEES), José Luis Fiori (ICIRA, contratado por Paulo Freire), João Zacariotti (ICIRA), Zilah Branco (ICIRA, contratada por Almino Affonso), Odilo Friedrich (ICIRA) e Evelyn Zingue (INDAP). O primeiro emprego de Ernani Maria Fiori no exílio, em 1966, foi no IER (depois chegou a ser reitor da Universidade Católica).

${ }^{468}$ Entrevista para Beca et al, 2013: 1024.
} 
e poder ver que dentro dela vivem paredes, aconchegos e janelas, e descobrir que todos os fonemas

são mágicos sinais que vão se abrindo constelação de girassóis gerando em círculos de amor que de repente estalam como flor no chão da casa.

Às vezes nem há casa: é só o chão. Mas sobre o chão quem reina agora é um homem diferente, que acaba de nascer:

porque unindo pedaços de palavras aos poucos vai unindo argila e orvalho, tristeza e pão, cambão e beija-flor,

e acaba por unir a própria vida no seu peito partida e repartida quando afinal descobre num clarão

que o mundo é seu também, que o seu trabalho não é a pena que paga por ser homem, mas um modo de amar - e de ajudar

o mundo a ser melhor. Peço licença para avisar que, ao gosto de Jesus, este homem renascido é um homem novo:

ele atravessa os campos espalhando a boa-nova, e chama os companheiros a pelejar no limpo, fronte a fronte, contra o bicho de quatrocentos anos, mas cujo fel espesso não resiste a quarenta horas de total ternura.

Peço licença para terminar soletrando a canção de rebeldia que existe nos fonemas da alegria:

canção de amor geral que eu vi crescer nos olhos do homem que aprendeu a ler.

O poema representava muito mais do que um arroubo criativo de um amigo poeta. Representava a sólida ponte de acolhimento que se estendia para as experiências pedagógicas freirianas na comunidade brasileira exilada no Chile. Simbolizava sua sintonia com o progressismo chileno e com o momento político otimista que vivia o país vizinho. Sinalizava também a potência interrompida do seu trabalho no Brasil e o encontro com um ambiente propício para novos desdobramentos, onde poderia desfrutar de uma atmosfera pluralista e democrática de mudanças, testando as variadas novas formas da sua política pedagógica. Paulo Freire respiraria o oxigênio chileno até 1969, quando novos 
"sufocos", junto com excelentes convites de trabalho nos EUA e em Genebra, o fizeram partir para outros exílios.

\section{Paulo Freire lê a reforma agrária}

Em Pedagogia da esperança, Paulo Freire lembrou de suas incursões ao mundo camponês chileno: "viajando quase todo o país, acompanhado sempre por jovens chilenos, na sua maioria progressistas, ouvi camponeses e discuti com eles sobre aspectos de sua realidade", narrou. "Debati com agrônomos e técnicos agrícolas uma compreensão político-pedagógica democrática de sua prática; debati problemas gerais da política educacional com os educadores" (Freire, 2011: 57).

Impedido de atuar na esfera político-partidária, Freire levou muito a sério sua distância de qualquer ativismo político formal no país e evitou tratar suas divergências em público: "Isso aprendi com Lênin", disse a Sergio Guimarães duas décadas depois: "Lênin sempre respeitou o país em que esteve exilado" (Freire \& Guimarães: 2010: 105). Mas conforme o brasileiro se tornava importante e influente no Chile, atuante no seio de um processo reformista cada vez mais polarizado, parecia quase inevitável que não expressasse, na natureza do seu próprio trabalho, uma concepção e uma posição a respeito da reforma agrária.

A leitura que Paulo Freire fazia da reforma agrária chilena era bastante autoral e não era unânime. Consequentemente, encontrou entusiastas e críticos resistentes. Se houve alguma batalha visível travada pelo brasileiro no Chile, no corpo a corpo do processo educacional de reforma agrária, ela ocorreu junto aos setores do funcionalismo estatal que se impacientavam com o tempo pedagógico do seu método e reivindicavam a primazia do aumento da produtividade acima das peculiaridades subjetivas do campesinato. "O aumento da produção no processo de reforma agrária é eminentemente cultural", insistiu o pedagogo, "o aumento indispensável da produção não pode ser visto como algo separado do universo cultural em que ocorre". 469

No debate sobre o tempo pedagógico e a pressa por aumentar a produtividade, Freire se posicionava a favor do ritmo da subjetividade camponesa, alegando que qualquer atropelo para ganhar tempo seria, ao contrário, uma perda: "tanto a técnica, como o procedimento empírico do camponês, são manifestações culturais e (...) não podem ser mecanicamente substituídos (...). [Alguns técnicos] terminam por cair nessa irônica contradição: 'para não perder tempo', o que fazem é perdê-1o", 470 criticou Freire, em março de 1968. No debate com a tecnocracia agrícola chilena, o brasileiro desenvolveu alguns dos conceitos mais importantes da sua filosofia educacional, como "invasão cultural", "cultura do silêncio" e "ação antidialógica". ${ }^{471}$ O quarto e último capítulo de Pedagogia do

\footnotetext{
${ }^{469}$ Freire, 1968a: 6.

${ }^{470}$ Paulo Freire, El compromiso del profesional con la sociedad. In: Educação e conscientização. Cuaderno $n^{\circ} 25$, Cuernavaca, México: Centro Intercultural de Documentación (CIDOC), 1968k.

${ }^{471}$ Estes conceitos alcançaram densidade no ensaio Comunicación o extensión? (1969), destinado a dialogar com técnicos agrônomos e extensionistas da reforma agrária chilena: "mesmo reconhecendo que não todos os agrônomos chamados extensionistas façam invasão cultural, não é possível ignorar a conotação invasora cultural do termo extensão (...). Manipulação
} 
oprimido, tratava justamente da teoria da ação antidialógica, elaborada a partir de seus embates pedagógicos na reforma agrária chilena (Freire, 2018: 167).

"Os camponeses não rechaçam o diálogo porque sejam ontologicamente avessos a ele. Existem razões de ordem histórico-sociológica, cultural e estrutural, que explicam sua negativa ao diálogo", alertava Freire: "sua experiência existencial se constitui nos marcos do antidiálogo. O latifúndio, como estrutura vertical e fechada é, em si mesmo, antidiálogo (...). Não será com antidiálogo que romperemos o silêncio camponês, mas com diálogo que problematize o silêncio e suas causas" (Freire, 1969: 3738). A paciência pedagógica perante situações de silêncio camponês seria uma condição necessária para abertura disruptiva, porém lenta, da sua condição de sujeito protagonista da reforma agrária.

A principal estratégia freiriana para romper o silêncio camponês eram os círculos sobre o conceito antropológico de cultura, interpretados como "perda de tempo" por alguns técnicos chilenos. O conceito antropológico de cultura era a primeira etapa do processo de alfabetização por conscientização, também chamada pré-alfabetização, e foi também um recurso chave da investigação temática e da ação cultural. ${ }^{472}$ Por meio do diálogo sobre imagens que correlacionavam natureza, trabalho e sociedade, o coordenador do círculo sobre conceito antropológico de cultura tinha como objetivo desconstruir o mito de que os analfabetos fossem pessoas incultas ou ignorantes. Com isso, se dilatava a compreensão dos camponeses analfabetos sobre sua condição de sujeito produtor de cultura, material e imaterial. Na verdade, o diálogo sobre o conceito antropológico de cultura proporcionava uma mudança conscientizadora de mão dupla: ao mesmo tempo que desativava a cultura do silêncio camponês, demonstrando a riqueza da sua propulsão subjetiva, se combatia a alienação da ignorância dos "invasores culturais", que deveriam relativizar seu próprio saber perante os outros saberes do analfabeto camponês.

Nesse sentido, o processo pedagógico necessário à reforma agrária, tal como proposto por Freire, implicava uma crítica da visão tecnicista da transformação estrutural na agricultura e um embate com setores produtivistas impacientes. Em relatório para Unesco, após três anos de contrato, o brasileiro alertou:

Mecanicismo, tecnicismo, economicismo são dimensões de uma mesma visão acrítica e antidialética do processo de reforma agrária, implicando a minimização do homem, que se torna mero objeto da mudança. O equívoco fundamental dessa visão acrítica ou a percepção distorcida do processo é que se pretende operar no domínio histórico-cultural, especificamente humano, no qual se dá a reforma agrária, como quem se comporta no domínio das coisas. ${ }^{473}$

\footnotetext{
e conquista, como fases da invasão cultural e como instrumentos para preservá-la, não são caminhos de libertação. São caminhos de domesticação. O verdadeiro humanismo não pode aceitá-las, em nome de nada" (Freire, 1969: 33).

472 A investigação temática consistia em uma etapa prévia (e constante) do método de alfabetização de Freire, realizada através de visitas dos educadores para escuta e compreensão do universo vocabular e cultural dos camponeses. Dessa investigação, sairiam as palavras geradoras. A investigação não deixava de ocorrer após a escolha das palavras; era componente contínuo do método. Existiam muitas formas de ação cultural, entre elas os círculos sobre o conceito antropológico de cultura desvinculados da alfabetização propriamente dita.

${ }^{473}$ Paulo Freire, Alfabetización Funcional en Chile, informe UNESCO. Santiago: ICIRA (mimeo.), 1968a (p. 2).
} 
Freire lia a reforma agrária como um processo de transformação econômico-cultural, pois as relações de trabalho e as técnicas de produção se assentavam sobre condições existenciais e culturais. Quando os camponeses eram relutantes a novas técnicas de produção e a novas formas de organizações do trabalho (mais cooperativas e menos hierárquicas, por exemplo), isso decorria de uma objeção subjetiva que não seria alterada sem um trabalho consciente de ação cultural. Em outras palavras, a transformação estrutural da técnica, da propriedade e do trabalho não ocorreria mecanicamente, porque a cultura era substância estruturante da economia, tanto quanto a economia era estruturante da cultura. Mas sua visão dialética da transformação estrutural estava na contramão das epistemologias dominantes, impregnadas de economicismo.

Frequentemente, Freire se defendeu de críticas a respeito de seu "culturalismo" e "idealismo" inclusive vindas de setores marxistas. ${ }^{474}$ Mas seu olhar dialético sobre os nexos entre economia e cultura o permitia explicar com precisão "a manutenção de grande parte das manifestações culturais características da estrutura latifundiária, na estrutura transitória do assentamento. Só um mecanicista não consegue entender que a superestrutura não se transforma automaticamente com a mudança da infraestrutura", advertia em seu relatório para Unesco. ${ }^{475}$

$\mathrm{Na}$ leitura freiriana da reforma agrária, era prioritário fortalecer o sujeito popular camponês como parte indispensável da estruturação autônoma dos assentamentos, das novas relações de propriedade e trabalho. Como se verá adiante, alguns marcadores do método de Paulo Freire ajudavam a identificar a maior ou menor organicidade que cada instituição desenvolveu com o fortalecimento do sujeito popular camponês. Os círculos sobre o conceito antropológico de cultura, a investigação temática das palavras geradoras, a pedagogia da pergunta, a formação de camponeses alfabetizadores e a autoria camponesa dos textos para pós-alfabetização seriam algumas das principais marcas do protagonismo popular proposto no método. Nesses marcadores, a diferença entre diálogo e proselitismo era fundamental. Em razão das nuances do processo político chileno, particularmente as cisões que pouco a pouco se pronunciavam no interior da DC, cada organismo de Estado incorporou a pedagogia de Paulo Freire de maneira criativa e específica.

\subsection{O método psicossocial se espalha pelo campo: adaptações do Ministério da Educação}

Em 1966, o estudante de filosofia e sociologia Rolando Pinto Contreras foi matriculado por sua então namorada, Olga Grau, em um curso para Coordenadores de Alfabetização de Adultos, oferecido pela

\footnotetext{
${ }^{474}$ As críticas da esquerda a Paulo Freire serão analisadas no capítulo sobre educação camponesa durante o governo da Unidade Popular. Algumas delas podem ser encontradas na entrevista: Paulo Freire, ¿Una dimensión política de la educación? Una conversación con Paulo Freire. In: Cuadernos de Educación, Serie Orientaciones (1971-1973). Santiago: Universidad de Chile, 1972.

${ }^{475}$ Paulo Freire, Alfabetización Funcional en Chile, op. cit., p. 5.
} 
Chefatura de Planos Extraordinários de Educação de Adultos em parceria com a Federação de Estudantes da Universidade do Chile (FECH). Embora tivesse mais interessado em música e esportes, o estudante escutou sua polola: "já é hora de você começar a se dedicar a coisas importantes da vida". O curso oferecia duas turmas de 100 alunos, cada uma com 9 horas de aulas por semana, entre setembro e dezembro daquele ano. "A verdade é que no início eu não estava bem no curso", ${ }^{476}$ confessou Rolando Pinto. Junto de Manuel Garretón, que lecionou sobre reforma agrária, havia "um senhor que falava péssimo portunhol, eu não entendia direito, embora fosse muito cálido e carismático...”. Era Paulo Freire, que ocupava a maior parte do curso explicando seu conceito de alfabetização por conscientização, o método que havia experimentado no Brasil, bem como sua filosofia educacional. "Então o homem foi me cativando. Fui me posicionando no seu método até ser o mais aplicado da turma e me tornar muito amigo de Paulo", lembrou Rolando Pinto. Treze anos mais tarde, concluiu um doutorado em Educação em seu exílio na Bélgica, após uma dramática fuga do Chile ditatorial viabilizada por Freire, que vivia em Genebra desde 1970. Como muitos outros jovens chilenos daquela época, Rolando Pinto sentiu-se transformado ao tomar contato com a pedagogia de Paulo Freire em 1966: "as orientações filosóficas e metodológicas que sustentavam o método simplesmente nos cativaram" (Pinto Contreras, 2018: 136).

Um encantamento semelhante se deu com a então jovem estudante de pedagogia da Universidade Católica, Marcela Gajardo. Como parte da sua militância na Federação de Estudantes (FEUC), Marcela desenvolvia um trabalho de educação popular nas poblaciones, que posteriormente se tornou o tema de sua monografia de fim de curso. "Conheci Freire em 1966, quando o escutei falar. Interessou-me tanto que fui conversar com ele e pedi que viesse dar uma conferência na Universidade Católica, para o movimento estudantil. Eu era porta-voz de Extensão Cultural da FEUC", ${ }^{477}$ contou. "Disseram-me que como dirigente estudantil, podia me conectar com José Serra, que era a pessoa que estava coordenando os estudantes para participar das campanhas de alfabetização". Depois, Marcela pediu a Paulo Freire que a orientasse na sua tese de conclusão de curso, intitulada Institutos Populares de Educação: uma alternativa de trabalho com os setores populares e ele aceitou, registrando uma dedicatória carinhosa em sua defesa, em $1969 .{ }^{478}$

Em janeiro e fevereiro de 1967, equipes de alfabetizadores formadas por jovens como Rolando Pinto e Marcela Gajardo, capacitadas por Paulo Freire e por outros profissionais do Mineduc, da CORA e do INDAP, foram deslocadas para diferentes regiões do país, onde foram inaugurados círculos de alfabetização e de cultura. O jovem Rolando Pinto foi para o Vale de Salamanca, perto da cordilheira de Illapel, na província de Limarí (IV região), onde 180 camponeses se inscreveram para os cursos. Os camponeses eram, em sua maioria, minifundistas empobrecidos que trabalhavam em terras não irrigadas de secano, mas também havia inquilinos da Hacienda Illapel, que posteriormente se tornou um

\footnotetext{
476 Entrevista com Rolando Pinto Contreras, Santiago, 11/12/2018.

${ }^{477}$ Entrevista com Marcela Gajardo, Santiago, 04/12/2018.

478 Idem.
} 
assentamento da reforma agrária. Os camponeses eram subdivididos em círculos de aproximadamente 20 pessoas, cada um coordenado por um alfabetizador formado nos cursos de Paulo Freire (Pinto Contreras, 2018: 136).

Entre 1965 e 1966, o método psicossocial inspirou a produção de diferentes materiais didáticos, com imagens e palavras geradoras que variaram de acordo com o perfil de cada equipe dos quatro organismos que o incorporaram (no setor agrário: INDAP, CORA, ICIRA; além do Mineduc). Durante os dois primeiros anos de exílio de Freire no Chile, foram capacitados 6 mil alfabetizadores com o método psicossocial, por meio de cursos intensivos com duas semanas a três meses. Em 1967, a Unesco premiou o Estado chileno pela "promoção de novas metodologias de ensino", em decorrência do treinamento massivo impulsionado pela presença de Paulo Freire no país (Williamson, 1989: 22; Kirkendall, 2010: 74). Como analisou Zubicueta: “o Ministério da Educação Pública apostou em uma massiva mobilização humana. O método era simples, mas implicava a capacitação de milhares de pessoas dispostas a ir aos territórios, conectar-se com as comunidades, dedicar seu tempo e se envolver" (Zubicueta, 2019: 73).

\section{Formas mortas da educação de adultos e método psicossocial}

O material de alfabetização desenvolvido pelo Mineduc se intitulava La raiz y la espiga e sua elaboração foi coordenada por Waldemar Cortés Carabantes, que convocou uma equipe para adaptar as palavras geradoras do Nordeste brasileiro para o Chile. ${ }^{479}$ Diretor da Chefatura de Planos Extraordinários de Alfabetização de Adultos desde a eleição de Eduardo Frei, Cortés Carabantes era um educador democrata-cristão, que procurou Paulo Freire logo que soube da sua presença em Santiago. "Nos tornamos grandes amigos", contou, "e Paulo autorizou que eu e minha equipe atualizássemos esse método e o adaptássemos à realidade chilena e ao idioma espanhol". ${ }^{480}$ Além de batizá-lo como método psicossocial, Carabantes e sua equipe logo se desfizeram da primeira palavra geradora brasileira (tijolo), que no espanhol (ladrillo) não representava uma boa escolha. Crítico dos sectarismos, Waldemar se orgulhava de incorporar pessoas de todo espectro político em sua gestão: “formei uma equipe (...) pluralista: trabalhei com elementos de extrema esquerda, de centro e de direita, com a única bandeira de servir ao adulto marginal (...). Conseguimos um trabalho interpartidário”, lembrou. ${ }^{481}$ Ainda assim, escutou com atenção uma advertência: "Paulo Freire me indicou que tivéssemos cuidado, porque devido

\footnotetext{
${ }^{479}$ Segundo a historiadora Daniela Zubicueta (2019: 73), a equipe responsável por adaptar o método freiriano de alfabetização de adultos para o Chile, convocada pela Chefatura de Planos Extraordinários de Educação de Adultos, foi composta por Verónica Alegría Hernández (bióloga da U. Chile); Sergio Sepúlveda (geógrafo da U. Chile); Amalia Villarroel Vascopé (matemática e física da Direção de Educação Secundária); Nancy Duchens (historiadora da U. Chile); Luis Tamayo Salazar (desenhista e professor primário); e Carlos Fernando Berroeta (desenhista e professor de costura).

${ }^{480}$ Entrevista de Waldemar Cortés Carabantes para Robert Austin, janeiro de 1993 (Austin, 2004: 4).

${ }^{481}$ Idem.
} 
à aplicação do mesmo método tinha sido expulso do Brasil (...). O acusaram de aplicar um método marxista". ${ }^{482}$

Já há algum tempo, Carabantes criticava o uso de metodologias e materiais da educação infantil para alfabetizar adultos. ${ }^{483}$ Em 1963, escreveu um artigo chamado Formas muertas y dinámicas en nuestra educación de adultos, publicado na Revista de Educación do ministério, no qual criticava "a falácia de algumas campanhas de alfabetização", ${ }^{484}$ tais como o Corpo Cívico de Alfabetização Popular, criado em 1944, cujo orçamento havia sido drasticamente reduzido de 1,2 milhão de escudos em 1953 para 11 mil em 1962. "Fracassaram todas aquelas campanhas baseadas no mero entusiasmo de alfabetizadores inexperientes, sem conhecimento sobre técnicas didáticas, sem material e sem constância", ${ }^{485}$ avaliava Carabantes. Além da precariedade das escolas estatais noturnas - para ele, "formas mortas de educação de adultos" - o educador também correlacionava o fosso educacional à estrutura econômica, alertando que pouco ou nada adiantava alfabetizar adultos se estes não empregassem suas habilidades em novas técnicas, as esquecendo por desuso ou se deslocando do local de origem para as grandes cidades: "quando se oferece educação para população agrária sem alterar o regime e a tecnologia da produção, tal educação se transforma em fator de imigração do agro para as cidades" ${ }^{486}$ Seria um desperdício, portanto, pretender erradicar o analfabetismo sem alterar as condições estruturais de sua existência, relacionadas com um sistema de escolas primárias rurais deficitário e sem recursos, tanto quanto com o sistema latifúndio-minifúndio, que reproduzia a dependência do camponês frente ao patrão e o "atraso". Assim, além de defender uma educação apropriada aos adultos, que fosse "crítica", "comunitária" e acompanhada de mudanças na estrutura produtiva, Carabantes também indicava a necessidade da alfabetização chegar aos locais de trabalho (haciendas, assentamentos, fábricas). A presença de Paulo Freire no Chile e o impulso eleitoral de Eduardo Frei, permitiram a Carabantes arquitetar uma política que atendesse a essas preocupações.

Entre 1965 e 1967, um total de 168.267 adultos foram alfabetizados pelos círculos de cultura com o método psicossocial no âmbito dos Planos Extraordinários do Mineduc. ${ }^{487}$ Para atuar no meio rural, a Chefatura criou parcerias com CORA, INDAP e SAG na formação de alfabetizadores, mas também com o setor privado (IER) e com o mundo sindical (FEES e confederações). "Conseguimos incorporar funcionalmente o programa de educação de adultos às tarefas da reforma agrária", declarou Carabantes,

\footnotetext{
482 Id. ibid.

483 "Faz alguns anos que denunciamos o absurdo pedagógico de aplicar ao estudante noturno as mesmas finalidades, planos, programas e regimes de trabalho das crianças e adolescentes do liceu diurno, fator em que reside fundamentalmente as causas da enorme deserção escolas". Waldemar Cortés Carabantes, Formas muertas y dinámicas en nuestra educación de adultos. Revista de Educación, n. 93, 1963. Em outra oportunidade, repetiu: "até 1964, o problema específico do analfabetismo foi enfrentado através de campanhas baseadas na ação voluntária, sem métodos didáticos adequados aos interesses psicológicos e sociais do adulto (...), sem texto de leitura para neoleitores, nem meios audiovisuais para ensino; com escassa ou nula participação estatal". Waldemar Cortés Carabantes, Los planes extraordinarios de educación de adultos. Revista de Educación, n. 7, 1968.

${ }^{484}$ Waldemar Cortés Carabantes, Formas muertas y dinámicas en nuestra educación de adultos, op. cit.

${ }^{485}$ Id. ibid.

${ }^{486}$ Id. ibid.

${ }^{487}$ Sendo 14.552 em 1965; 63.995 em 1966; e 89.720 em 1967. Waldemar Cortés Carabantes, Los planes extraordinarios de educación de adultos. Revista de Educación, n. 7, 1968.
} 
"fomos com Paulo Freire a setores rurais, nos reuníamos com professores e o Paulo os motivava". ${ }^{488}$ Segundo Maria Antonieta Saa, supervisora de alfabetização da CORA, era difícil alterar a cultura didática dos professores rurais para incorporar a filosofia educacional que substanciava o método. Muitos professores rurais mostravam uma tendência hierárquica frente aos camponeses analfabetos, o que se pretendia dissipar com a proposta freiriana. Em uma entrevista em 1996, Saa disse: “posteriormente, mudamos os professores rurais por filhos de camponeses com educação primária (...) porque a relação entre o professor rural e o camponês se dava de forma um pouco autoritária, de professores muito acostumados a trabalhar com crianças. Queríamos horizontalizar a relação" ${ }^{489}$ lembra. "A campanha de alfabetização estava inserida no programa da reforma agrária, para que os camponeses se tornassem donos da terra e da sua administração". 490

\section{La raiz y la espiga}

O material de alfabetização psicossocial do Mineduc, La raiz y la espiga, era formado por 25 imagens, sendo 17 delas acompanhadas de palavras geradoras escolhidas por equipes internas ao ministério, enquanto outras oito retratavam situações existenciais propícias ao debate sobre o conceito antropológico de cultura. "Um tema central, indispensável, é o do conceito antropológico de cultura", escreveu Paulo Freire em Santiago: "Sejam homens camponeses ou urbanos, em programa de alfabetização ou pós-alfabetização, o começo de suas das discussões em busca de mais conhecer (...) é o debate desde conceito" (Freire, 2018: p. 165). Na Pedagogia do oprimido, obra repleta de diálogos com camponeses chilenos, Freire relatou:

Certa vez, num dos círculos de cultura do trabalho que se realiza no Chile, um camponês a quem a concepção bancária classificaria de 'ignorante absoluto', declarou, enquanto discutia, através de uma 'codificação' o conceito antropológico de cultura: "descubro agora que não há mundo sem homem". E quando o educador lhe disse: 'Admitamos, absurdamente, que todos os homens do mundo morressem, mas ficasse a terra, ficasse as árvores, os pássaros, os animais, os rios, o mar, as estrelas, não seria isso o mundo?'. "Não!", respondeu enfático, "faltaria quem dissesse: isto é o mundo". O camponês quis dizer exatamente que faltaria a consciência do mundo que, necessariamente, implica o mundo da consciência (Freire: 2018: 99).

Em outro texto, após contar a mesma anedota, Freire completava: "o filósofo camponês, que a concepção elitista classificaria de 'ignorante absoluto', colocou a questão dialética da subjetividadeobjetividade" (Freire, 1968d). A fase anterior à "leitura das palavras", marcada por sessões que priorizavam a "leitura do mundo", era marcada por uma valorização profunda dos saberes camponeses. Seu objetivo era demonstrar que a cultura escrita representava apenas um ramo da cultura humana,

\footnotetext{
${ }^{488}$ Entrevista de Waldemar Cortés Carabantes para Robert Austin, janeiro de 1993 (Austin, 2004: 6)

${ }^{489}$ Entrevista de Maria Antonieta Saa para Robert Austin, agosto de 1995 (Austin, 2004: 46).

${ }^{490}$ Idem.
} 
certamente importante, mas que todos os seres humanos, sem exceção, eram produtores e praticantes da cultura. "Para que os homens simples sejam considerados como absolutamente ignorantes, é necessário que exista aqueles que os considerem assim", escrevia Freire em Santiago (Freire, 1969: 36).

As imagens de La raiz y la espiga destinadas a essa desconstrução eram transformadas em slides (filminas) e projetadas para círculos camponeses em setores rurais que pouco conheciam a eletricidade, o que gerava um efeito tecnológico atrativo. Como se vê a seguir, as imagens não estão destituídas de marcas de hierarquia étnica uma vez que associam o homem branco à tecnologia e o indígena aos instrumentos rústicos, "atrasados". Além de problematizar a questão das ferramentas de caça e trabalho (Quem as constrói? Para quê? Como se utiliza?), as imagens também propunham um debate sobre o uso de animais como "parceiros" de trabalho, bem como as diferenças entre trabalhar sozinho ou em grupo. A série de imagens (a seguir) era concluída com duas ilustrações sobre a cultura imaterial: uma festa típica do mundo rural e uma representação metalinguística da própria decodificação de imagens realizada nos círculos anteriores. Além de propor que os camponeses conversassem sobre o processo pedagógico que eles mesmos estavam protagonizando, a última imagem servia como gancho para se passar às palavras geradoras. ${ }^{491}$
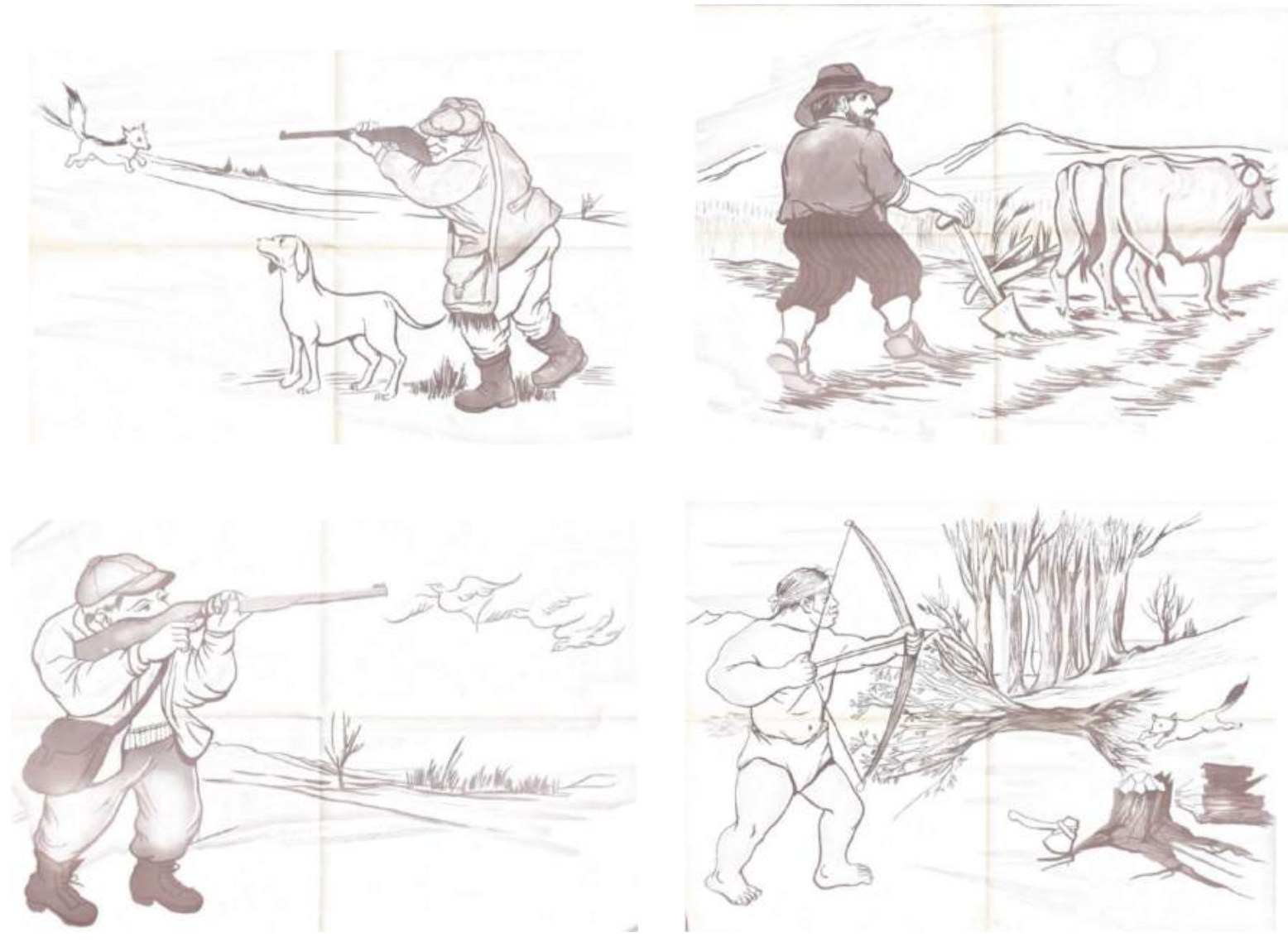

491 Mineduc (Chile). La raiz y la espiga. Manual del método psico-social para la enseñanza de adultos. Santiago: Mineduc, 1966. 

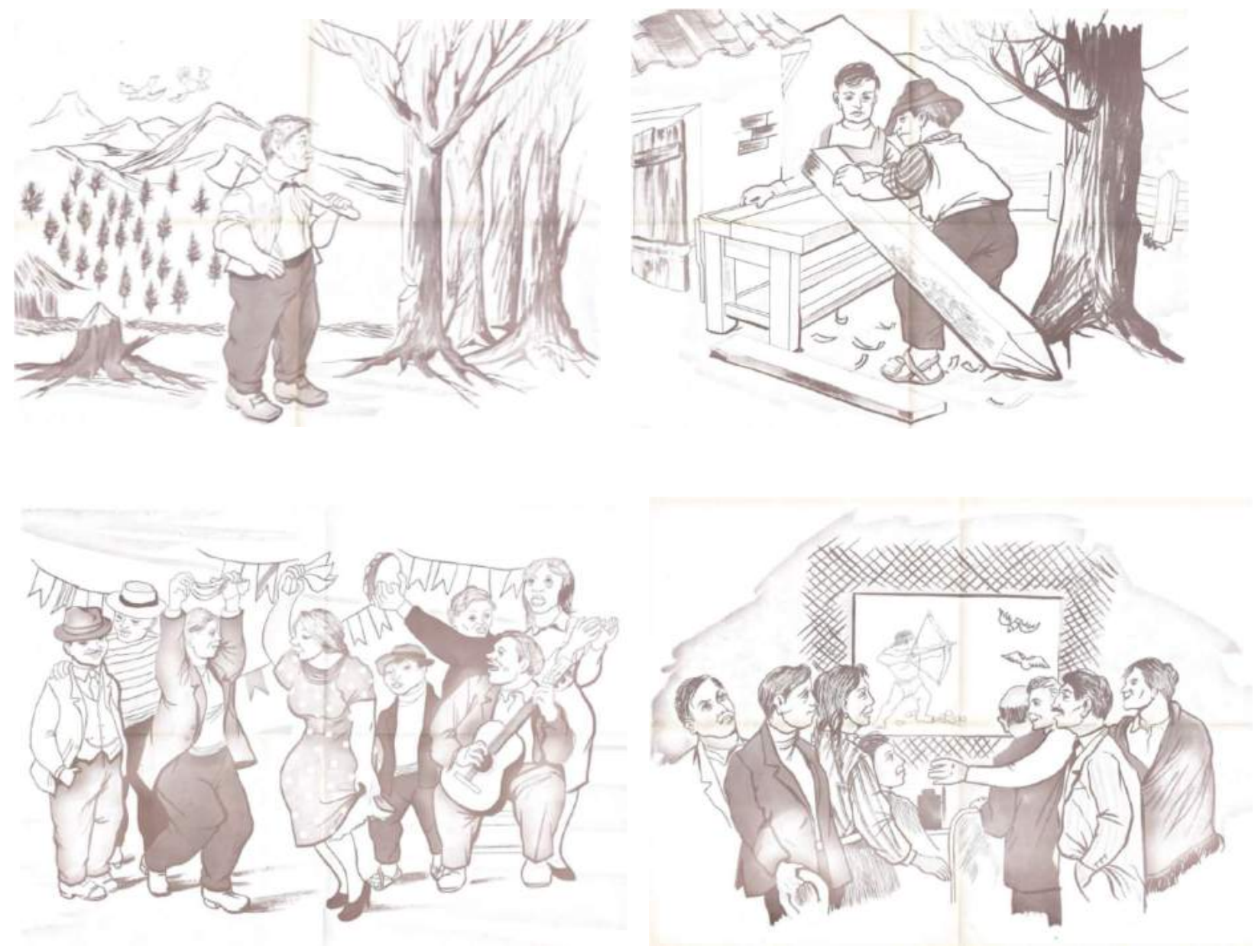

Oito imagens produzidas pelo Ministério da Educação do Chile em 1966 para etapa da pré-alfabetização do método psicossocial, destinadas ao debate sobre o conceito antropológico de cultura.

O educador Guillermo Williamsom (1989) criticou o fato de que o Mineduc havia ignorado a etapa da investigação temática para produzir seus materiais de alfabetização, o que violava o processo dialógico da produção dos temas e palavras geradoras: "o país estava em condições de receber as ideias de Freire e as necessitava com urgência para impulsionar com êxito a mudança cultural necessária à mudança agrária", analisou Williamson (1989: 15). No Mineduc, contudo, "o método foi aplicado massivamente a partir do aparato de Estado, com materiais elaborados e sem realizar, em cada grupo, o trabalho de investigação temática" (Williamsom, 1989: 24).

Embora isso a priori não violasse completamente o processo dialógico das sessões de alfabetização, a ausência da investigação temática demonstrava que as etapas do método podiam ser puladas e recombinadas com diferentes incidências do protagonismo camponês, a depender das intenções dos partidos condutores da política alfabetizadora. As 17 palavras desenhadas a partir do escritório do Mineduc seriam utilizadas para contextos urbanos e rurais, já que o Ministério tinha pressa para mostrar resultados ainda durante o mandato democrata cristão. As palavras eram: casa-pala-camino-vecino 
-zapato - escuela - ambulancia - sindicato - compañero - radio - harina - chiquillo-yugo-trabajo - guitarra - fábrica - pueblo. Ao serem codificadas em imagens, 7 delas eram representativas do contexto rural, outras 5 do contexto urbano, enquanto 4 eram compatíveis com ambos os contextos, como se pode observar a seguir.
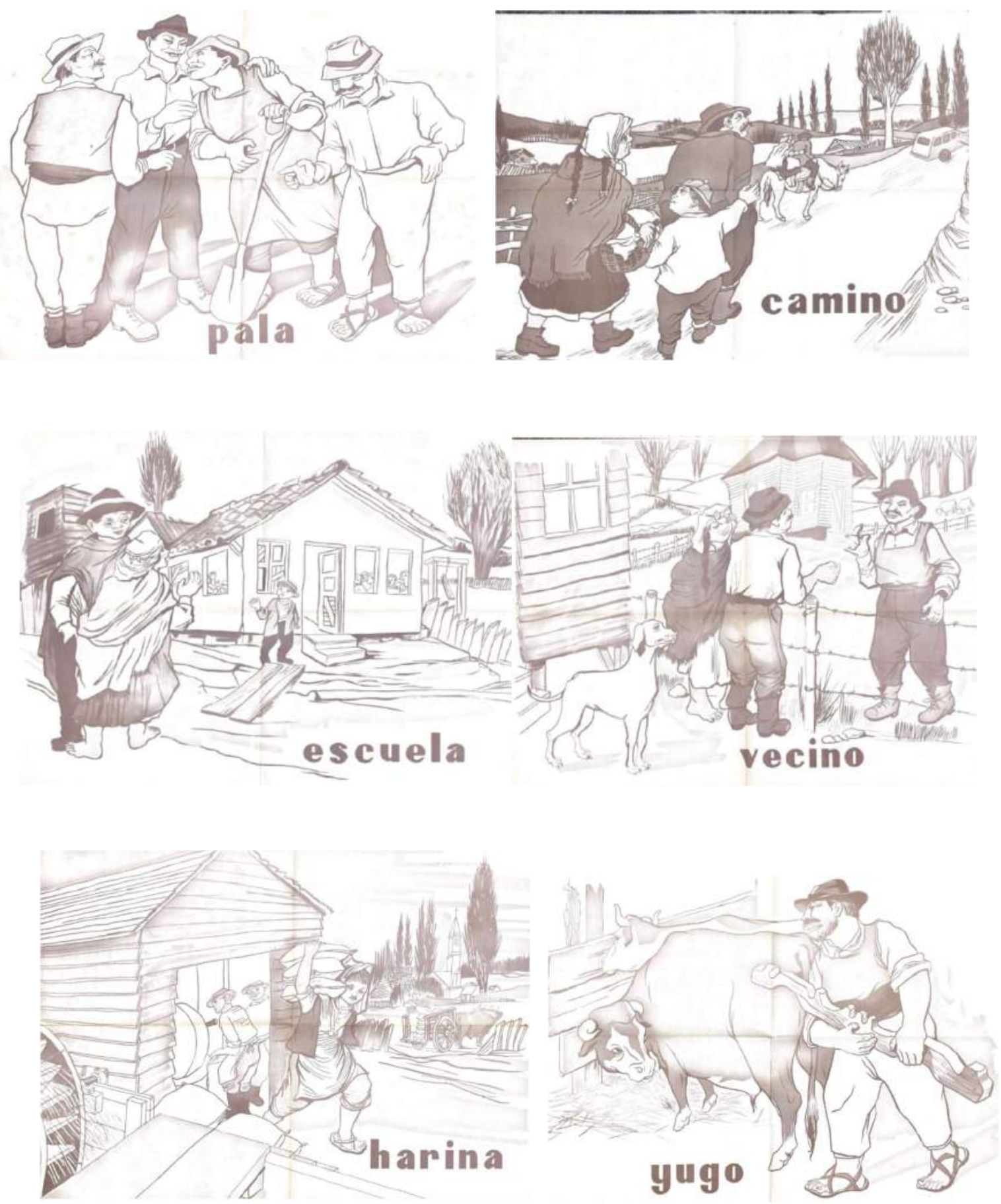


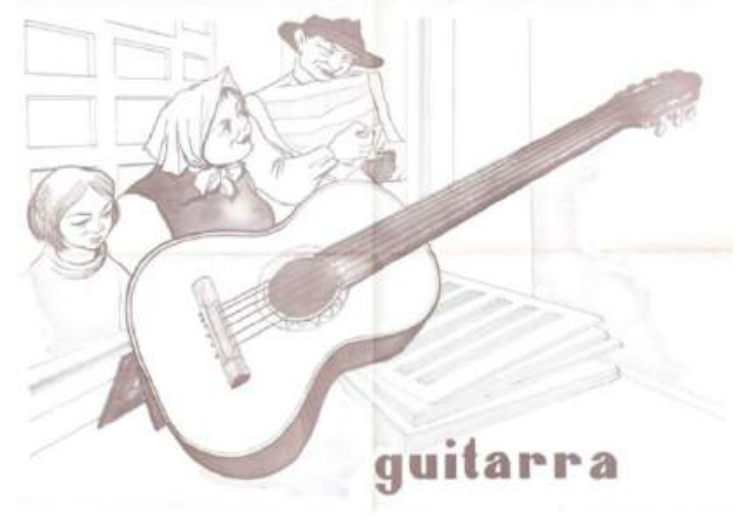

Em uma breve análise das imagens, notam-se aspectos interessantes sobre as realidades $\mathrm{e}$ problemas do camponês, junto com os valores culturais que poderiam ser desdobrados nos diálogos dos círculos de alfabetização. A primeira palavra (pala) evoca a amizade e o companheirismo entre os homens do campo, que parecem trocar impressões ou confidências com intimidade. A mesma intimidade com que se relacionam com seu instrumento de trabalho (a enxada), formada por um pau que é apontado por um dos quatro homens. Como analisado por Tinsman (2009), a camaradagem entre homens camponeses na reforma agrária muitas vezes se materializava de maneira restritiva aos direitos das mulheres, convocadas para a participação social, mas impedidas de ser titulares de propriedades e participar de assembleia dos assentamentos. A segunda palavra (camino) convida ao debate sobre distâncias e meios de transporte, e induz uma conversa sobre o significado do progresso: o que significava caminhar a pé, a cavalo ou de carro na mesma estrada?

A terceira imagem (vecino) é nítida no retrato da propriedade individual, em contraponto à propriedade coletiva. Um casal camponês conversa com seu vizinho, separados por uma cerca de arame farpado, a mesma que foi arrancada nas "corridas de cerco" mapuche em 1970, em um processo de retomada popular das terras e recoletivização. ${ }^{492}$ A mulher está descalça, como na próxima palavra (escuela), na qual um possível pai parece tentar apaziguar a insegurança de uma mãe ao deixar seu filho na escola. É possível pensar, nessa imagem, como a escola rural não era uma instituição completamente consolidada no imaginário camponês, o que gerava eventual insegurança materna sobre sua necessidade. A quarta palavra (harina) evoca o trabalho coletivo e de caráter já não puramente agrícola, concatenando o plantio do trigo com o moinho, processamento e ensacamento. Aqui, seria possível discutir a divisão social do trabalho e a complexificação dos processos produtivos. A quinta (yugo), evoca o debate sobre a relação entre homem e animais e o papel dos animais na produção. Na sexta palavra (guitarra), nota-se que a roupa do homem é um poncho tipicamente rural. Aparentemente, esse homem saca um dinheiro da carteira para comprar o violão em uma vitrine, possivelmente destinada a presentear seu/sua filho/a, que observa o instrumento com interesse.

\footnotetext{
492 Sobre a corridas de cerco organizadas pelos mapuche e pelo Movimento Campesino Revolucionário (MCR), ver Redondo,
} (2017) e Navarrete Vergara (2018). E no capítulo 1 desta tese, a entrevista com Gustavo Marin, Santiago, 20/04/2017. 
Imagens e palavras geradoras do Mineduc compatíveis com o contexto rural ou urbano (a seguir). ${ }^{493}$
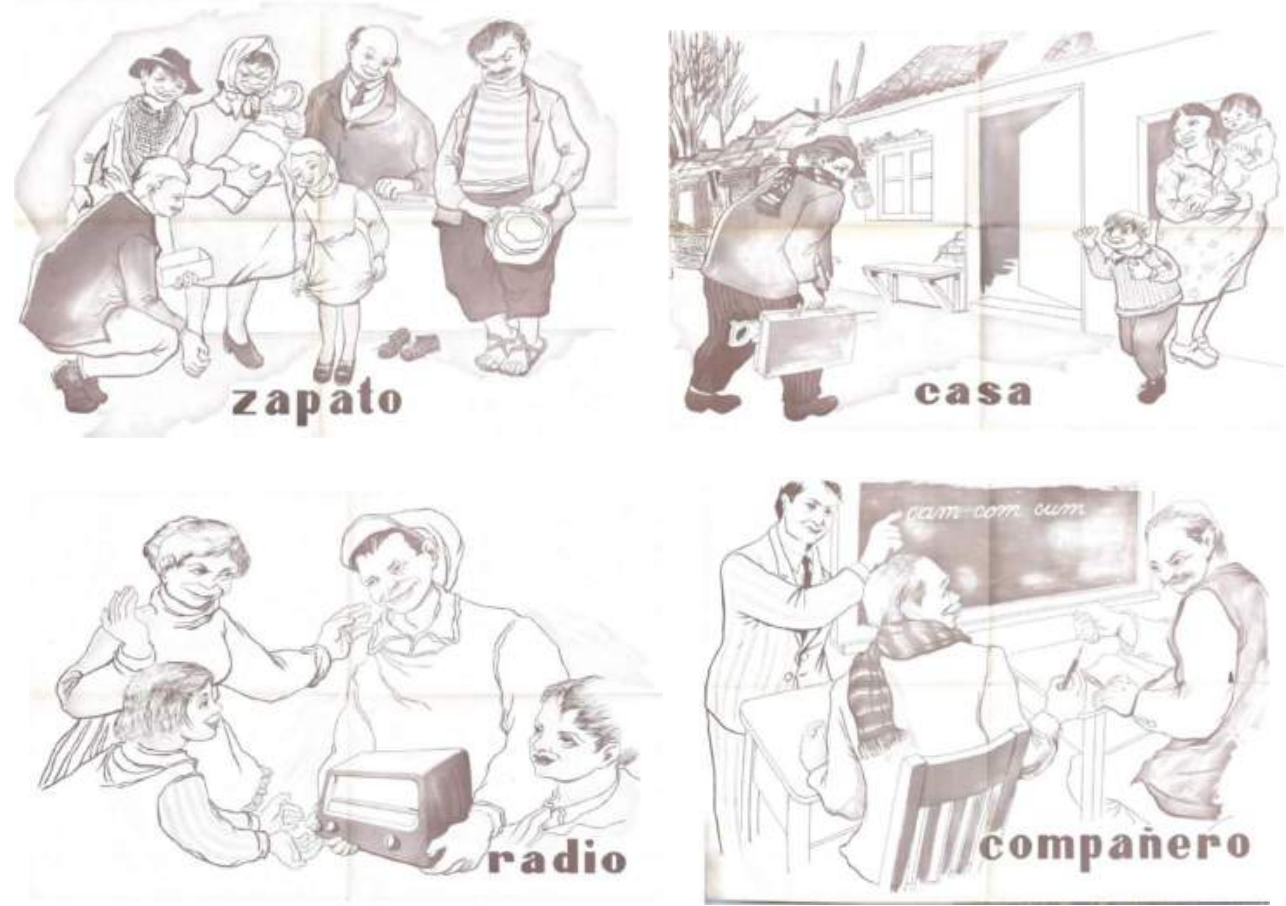

Imagens e palavras geradoras do Mineduc representativas do contexto urbano (a seguir) ${ }^{494}$
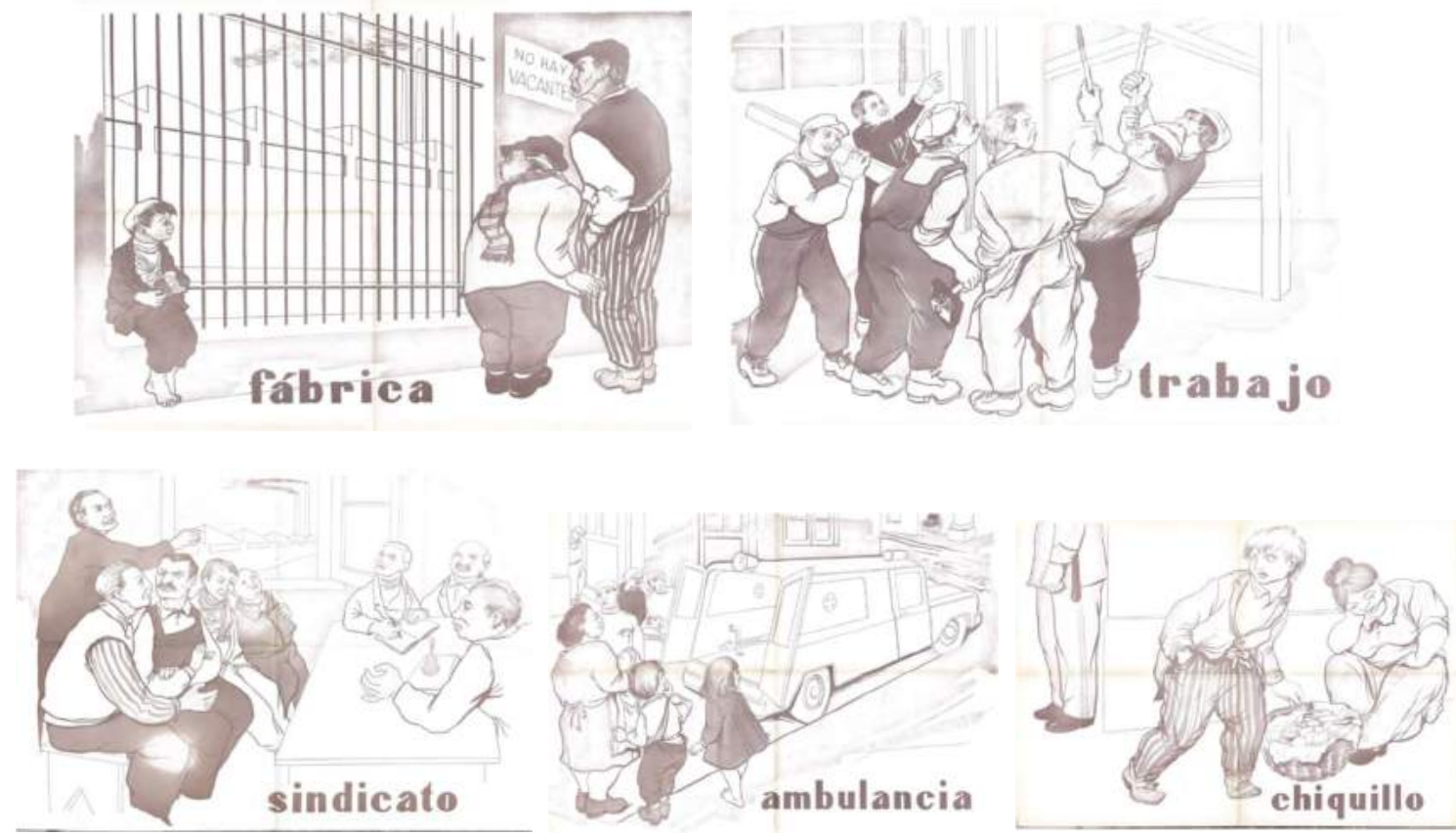

${ }^{493}$ Idem.

${ }^{494}$ Id. ibid. 
No Manual do método psicossocial entregue pelo Mineduc aos alfabetizadores, cada palavra representava um jogo de cinco lâminas (ilustrações): a lâmina situacional, que continha apenas a imagem; a lâmina da palavra, que introduzia a palavra sobre a imagem (como retratado); a lâmina silábica, que separava as sílabas da palavra; a lâmina com as famílias silábicas em sequência; e a lâmina do descobrimento, com as famílias silábicas dispostas na forma de anagrama, para facilitar a visualização e criação de palavras "novas", baseadas nas famílias silábicas da palavra estudada. Foi com a lâmina do descobrimento, como Paulo Freire sempre se recordava, que um trabalhador de Brasília transformou a palavra "ti-jo-lo" em "tu-ja-le" em 1962, emocionando os educadores presentes. 495 Depois da formação com Paulo Freire, os jovens alfabetizadores recebiam uma pasta com cerca de 85 lâminas, que consistia basicamente em todo seu material.

O Mineduc orientava que cada círculo de alfabetização durasse três horas, divididas em três sessões de 45 minutos, com pequenos intervalos de descanso. Como as sessões ocorriam após a jornada de trabalho, já depois de anoitecer, enfrentava-se uma realidade de exaustão dos camponeses, que só poderia ser rompida com o entusiasmo dos próprios alfabetizandos pelo seu poder de protagonizar o método e descobrir as palavras, como um jogo de adivinhação. A ludicidade do método psicossocial era uma chave fundamental do seu sucesso. As primeiras sessões se dedicavam ao diálogo sobre as situações existenciais (para se chegar ao conceito antropológico de cultura) e as seguintes percorriam as palavras geradoras. Nos cursos do verão de 1967, cada alfabetizador permanecia três semanas, de segunda a sexta, com seu círculo; depois era deslocado para outro ciclo de três semanas em outra localidade (Zubicueta, 2019: 86, 88). Rolando Pinto partiu de Salamanca para Puerto de Los Vilos, onde alfabetizou um círculo de pescadores.

No manual do Mineduc, cada palavra estava acompanhada de um conjunto de perguntas, que sugeriam as possibilidades de debate no círculo, antes que se passasse a lâmina silábica. No caso da palavra yugo, por exemplo, o manual sugeria:

Por que se veem cada vez menos bois arando os campos ou transportando carretas? Antes, uma junta de bois emparelhados proporcionava a força necessária para arar o campo. Por que se prefere agora o trator? (...) O homem é um ser fisicamente débil, mas foi capaz de dominar animais tão corpulentos como o boi, o cavalo, o camelo e o elefante e os faz trabalhar para si. Por que e como pode dominá-los? O homem (...) também faz trabalhar a água, o vento, a eletricidade. Por que consegue aproveitar em seu benefício as forças da natureza? Por sua inteligência? (...) É mais inteligente hoje do que quando capturou o fogo e inventou a roda? Ou vai acumulando conhecimentos que o tornam mais poderoso? (...) Se usa a palavra jugo para significar escravidão, domínio, opressão e se diz que os povos oprimidos lutam para sacudir seu jugo. Por que e para que defendemos a liberdade? (...) A liberdade deve ter limites ou não? (...) O Chile é um país verdadeira e completamente livre? ${ }^{496}$

\footnotetext{
495 Em Educação como prática da liberdade, conta Freire: "um analfabeto de Brasília, para emoção de todos os presentes, inclusive do ex-Ministro da Educação, Paulo de Tarso, cujo interesse pela educação do povo o levava à noite, no término do seu expediente, a assistir aos debates dos Círculos de Cultura, que disse: tu já lê, que seria em bom português: tu já lês. E isto na primeira noite em que iniciava a sua alfabetização" (Freire, 1967: 118).

${ }^{496}$ Mineduc (Chile). La raiz y la espiga, op. cit.
} 
Como se nota, a pedagogia da pergunta, tipicamente freririana, era conduzida por uma filosofia política ocidental que funcionava como um guarda-chuva relativamente comum para a doutrina socialcristã da DC, o reformismo estruturalista da CEPAL e setores mais tecnicistas do marxismo. Essa filosofia política pressupunha a superioridade dos seres humanos sobre a natureza; as vantagens absolutas da máquina moderna sobre as técnicas tradicionais; a necessidade da busca pela liberdade individual e nacional; sem, contudo, aglutinar conceitos classistas. Para a lâmina da palavra "escola", o ministério sugeria:

O que seria das crianças daquele local se não houvesse escolas? A escola deve se preocupar só de ensinar conhecimentos ou deve ensinar boas maneiras, formar bons hábitos, ou seja, educar? Por que se deve proceder assim? A escola deve atender somente às crianças, seus alunos, ou deve atender à educação da comunidade e ajudar a resolver seus problemas? A escola da localidade dispõe de mobiliário e materiais adequados? Se não, o que se pode fazer para que os obtenha? (...) As escolas da localidade conseguem atender a todas as crianças ou algumas ficam sem matrícula? Por que algumas crianças não se matriculam, embora haja vagas e por que faltam nas aulas? (...) A educação contribui para o desenvolvimento da economia? ? $^{497}$

O método psicossocial propunha uma construção da leitura totalizante do mundo e partia das experiências locais e efetivamente orgânicas aos participantes do círculo. As perguntas evoluíam de descrições da realidade para criação de hipóteses sobre aquela descrição, até chegar a termos mais abstratos como "desenvolvimento". Evidentemente, embora os coordenadores fossem orientados a nunca discorrerem sua opinião diretamente sobre assunto nenhum, era inevitável que perguntas também fossem condutoras sutis de alguns posicionamentos políticos.

No Vale de Salamanca, em 1967, Rolando Pinto encontrou alguns camponeses que vinham das minas de salitre e tinham vivido experiências de luta sindical, além de terem estabelecido contato com o universo de partidos políticos. Eram os federados (Bengoa, 2016). A leitura de mundo dos federados já não era tão oprimida quanto a de muitos camponeses chilenos que, como investigado pelos sociólogos Maria Edy Ferreira (1968), David Lehman (1970), James Petras e Hugo Zemelman (1972), naturalizavam a superioridade patronal ou buscavam reproduzir hierarquias rígidas de poder nas novas configurações de propriedade. Os camponeses federados se encontravam em um "modelo de consciência" que possivelmente Lehman chamaria "consciência de classe", em contraponto à consciência dependente, de traço paternalista, ou a consciência camponesa, baseada nas raízes da propriedade da terra (Lehman, 1970: 39-40). Em entrevista à Zubicueta, Rolando Pinto recordou como os campesinos de Illapel dialogaram sobre a lâmina "trabalho":

Muitos dos camponeses tinham duas ou três experiências de trabalho, isso lhes permitia comparar o que era seu trabalho na mineração e seu trabalho na agricultura. Então diziam “(...) apesar de sermos tão explorados como lá, aqui temos nossas galinhas, nossos gansos, nossos animaizinhos (...). Ou seja, o trabalho aqui, apesar de que ganhamos menos, é melhor". Se

${ }^{497}$ Idem. 
lançaram à discussão sobre a natureza, o trabalho e a exploração do trabalho. Se Marx estivesse vivo ali, teria saltado de alegria, porque havia compreensão do trabalhador sobre o sentido do trabalho ter de ser sempre exploração (...). E começa essa discussão maravilhosa (Pinto Contreras apud Zubicueta, 2019: $85)$.

Na mesma zona, contudo, outros grupos de alfabetizadores comentaram com Rolando Pinto que a mistura de alfabetizandos que eram ex-mineiros do salitre com camponeses inquilinos nem sempre resultava bem, pois os segundos se entediavam com a leitura politizada dos primeiros. Paulo Freire também recordou situações em que o método precisava flexionar a rigidez da pedagogia dos opressores, dominante na visão de mundo arraigada à realidade dos oprimidos. Um camponês, certa vez, perguntou a Paulo em um círculo de cultura no Chile: "Por que o senhor não explica primeiramente os quadros (codificações)? Assim nos custará menos e não nos dói a cabeça" (Freire, 2010: p. 69). O exercício de pensar sobre a própria realidade e dialogar sobre aquilo que se pensava não era tão óbvio e simples como se poderia imaginar.

O Mineduc também produziu materiais para a pós-alfabetização, analisados por Zubicueta (2019). Eram três livros de leitura para adultos recém-alfabetizados, que tinham como principal objetivo reduzir o analfabetismo funcional, permitindo a continuidade do desenvolvimento leitor. ${ }^{498}$ Carabantes alertava que os desequilíbrios da estrutura social e econômica, típicos do subdesenvolvimento, tornava comum que os trabalhadores alfabetizados que não exercitavam a leitura em seu cotidiano laboral se tornavam analfabetos por desuso. "O analfabeto não é culpado da sua condição", alegava o democrata cristão, "apenas reflete, em seu estado, a evolução geral da sua comunidade (...). É aquele indivíduo que por suas condições de vida e trabalho não necessitou saber ler e escrever". ${ }^{499}$ Estava convencido que "o sujeito da alfabetização é o próprio analfabeto" e que "após alfabetizado, [era desejável que] participasse como fator ativo e criador das mudanças da sua comunidade". ${ }^{500}$ Embora reivindicasse o método psicossocial, os livros de pós-alfabetização produzidos pelo Mineduc estavam já bastante distantes das orientações de Paulo Freire. Diferentemente das primeiras etapas alfabetizadoras, mais fiéis aos princípios dialógicos, os livros de pós-alfabetização La raiz y la espiga obedeciam a uma pedagogia mais diretiva. Neles, o ponto de interrogação que convidava ao diálogo era substituído pela afirmação, que evocava a memorização.

O primeiro livro era uma coletânea de pequenos contos ilustrados, que deveriam ser lidos em voz alta pelo grupo recém-alfabetizado, em sessões de 70 minutos. Após um intervalo, os alunos vivenciavam mais 40 minutos de exercícios de cálculo matemáticos básicos. Um dos contos do Primer Nivel se intitulava "Os apuros de um analfabeto" e contava a história de José, habitante de um pequeno povoado, que por não saber ler perdia oportunidades (se necesitan peones, dizia uma placa) e se

\footnotetext{
${ }^{498}$ Mineduc (Chile). Lectura para Adultos, Primer Nivel. La raiz y la espiga. Santiago: Mineduc, 1966. Seguidos de Lectura para Adultos, Segundo Nivel; e Comunidad, Tercer Nivel.

${ }^{499}$ Waldemar Cortés Carabantes, Perspectivas actuales de la educación de adultos en Chile. Revista de Educación, n. 2, 1967. ${ }^{500}$ Idem.
} 
colocava em risco (peligro, prohibido el passo, alertava outra). O conto não convocava o adulto a refletir sobre sua própria sabedoria pouco letrada, não convocava o diálogo sobre problemas experimentados em sua realidade de trabalhador (como se os alfabetizados tivessem atingido a meta final) e muito menos sobre o conceito antropológico de cultura.

O livro do Segundo Nivel continha textos ensaísticos e não ficcionais, carregados dos democratacristãos. No texto Los oficios de la mujer, por exemplo, lia-se: "hoje, no Chile, a mulher tem direitos iguais ao homem. Pode aspirar a qualquer emprego, menos a carreira militar e a diplomática. Teme-se, quiçá com exagero, que uma mulher vai soltar muito a língua, comprometendo segredos de Estado com outros países". E ao final concluía: "no campo, na fábrica, no escritório, a mulher trabalha cada dia mais. Porém seu melhor ofício será sempre o de mãe". ${ }^{501}$ A ideologia do mutualismo de gênero, analisada por Tinsman (2009), estava nitidamente presente, convocando as mulheres para uma participação ativa, porém, não sem lhes reservar um lugar circunscrito à sua constante coadjuvância frente ao homem nos assuntos estratégicos; e seu eterno dever maternal.

O terceiro nível da pós-alfabetização se baseava no livro Comunidad. Nele, o perfil ideológico da DC se tornava explícito e percorria temas como nação, trabalho e desenvolvimento: "Chile tem uma história de glórias que devemos conhecer e amar. O povo chileno tem traços próprios e inconfundíveis (...). O trabalho de seus homens e mulheres criaram nossa nação, que se mantem unida por um ideal comum de grandeza". ${ }^{502}$ Um olhar romântico e homogeneizador da história do país alcançava, em seguida, a pregação política explícita de apoio ao governo de Eduardo Frei: "Precisamos trabalhar com incessante decisão de promover o desenvolvimento econômico e cultural do nosso país. Devemos apoiar os governos honrados que estão dirigindo nosso destino". ${ }^{503}$ Nesse volume, as ilustrações foram substituídas por fotos, o que criava um efeito de realismo ao acompanhar um texto que não escondia bem suas pretensões partidárias.

Assim, de um processo de alfabetização freiriano, com uma metodologia dialógica e aberta ao protagonismo camponês, saltava-se para uma pós-alfabetização transmissora (de ideologia; de valores; de apoio a governos), tanto quanto antidialógica, cujo proselitismo recompunha a cultura do silêncio descontruída na etapa anterior dos círculos de cultura. Em 1991, Carabantes insistiu na "neutralidade humanista" do método psicossocial aplicado durante o governo Frei:

Se você analisar o método psicossocial que te entrego e encontrar alguma tendência democrata-cristã ganharia um prêmio porque não há nenhuma. Não há. (...) A alguém ocorreu acusar que era um método marxista. A análise da realidade era um assunto objetivo: não havia marxismo, nem proselitismo em favor de um governo. (...) Mas se você analisar os textos do método psicossocial durante o governo de Allende verá que era um método prómarxista. Era um instrumento a serviço de uma política contingente. Não havia mais o respeito ao homem que nós propúnhamos. O método

\footnotetext{
${ }^{501}$ Mineduc (Chile). Lectura para Adultos, Segundo Nivel. La raiz y la espiga. Santiago: Mineduc, 1966.

${ }^{502}$ Mineduc (Chile). Comunidad. Tercer Nivel. La raíz y la espiga. Santiago: Mineduc, 1966.

503 Idem.
} 
psicossocial com Allende se 'Allendizou', no sentido de que se 'Marxistizou', foi um método marxista. ${ }^{504}$

Se Williamson (1989) já havia considerado os materiais da alfabetização uma forma incompleta de adotar o método freiriano, com palavras geradoras "de escritório", ausente a etapa fundamental da investigação temática em terreno, os materiais da pós-alfabetização se distanciavam bastante da proposta original de Paulo Freire. "Observa-se o caráter 'integrador' e não 'subversivo' com que se descrevem os materiais", examinou Williamson (1989: 23). "Por exemplo, define-se como a essência da conscientização a resposta, com consciência crítica, aos estímulos do meio. Nada mais longe das propostas de Freire", prosseguiu. Não por acaso, mais de 30 páginas da Pedagogia do oprimido estão dedicadas à investigação temática e sua importância para o método. Já no INDAP, contudo, onde Paulo Freire tinha sua própria sala e exercia seu trabalho cotidianamente, essa etapa não foi desprezada e o processo refletiu outras prioridades.

\subsection{Paulo Freire no INDAP: ação cultural com comitês camponeses}

\section{Os indapinos e a promoção popular camponesa}

A pedagoga Carmen Gloria Aguayo era jovem quando trabalhou no INDAP com Paulo Freire, durante o governo Frei. "Seu método era revolucionário, por isso o perseguiram no Brasil e ele teve que entrar refugiado aqui", ${ }^{505}$ assinalou. "Uma vez que o oprimido compreende, já não aceita sua situação e vai buscar maneiras de sair. No fundo, isso é a revolução: mudar a situação em que vive", ${ }^{506}$ refletiu Carmen. Na sua militância cristã, ela já havia trabalhado antes como educadora de mulheres pobladoras, nas periferias de Santiago, ${ }^{507}$ mas nunca no campo e tampouco com um método dialógico. Com Chonchol no comando do INDAP, Carmen foi chamada para compor a equipe de capacitação em abril de 1967, especificamente com a tarefa de formular uma política de promoção popular para mulher camponesa. Aí estreou seu contato com o mundo rural. "O método do Paulo exigia que primeiro se conhecesse muito bem o ambiente no qual vivia o camponês. Não começávamos trazendo nossas ideias, mas sim íamos observar. Era muito respeitoso. Primeiro íamos em equipe ver como era a vida dos camponeses, seus desejos, suas aspirações", 508 enfatizou, mostrando uma diferença perante a aplicação do método psicossocial pelo Mineduc, que prescindia da investigação temática. Carmen nunca esqueceu os "cafecinhos" que tomava com Freire no meio das manhãs.

\footnotetext{
${ }^{504}$ Entrevista de Waldemar Cortés Carabantes para Robert Austin, janeiro de 1993 (Austin, 2004: 7-9).

${ }^{505}$ Entrevista com Carmen Gloria Aguayo, Santiago, 28/11/2018.

${ }^{506}$ Idem.

507 "A experiência vivida com pobladores foi muito importante para o resto da minha vida. Aqueles que nunca viram crianças descalças não podem imaginar o que era a pobreza", disse Aguayo em Mujer y Política (Aguayo, 2014: 11).

${ }^{508}$ Idem.
} 
A missão institucional do INDAP, expressa na lei 15.020, incluía "outorgar assistência técnica gratuita e ajuda creditícia aos pequenos e médios agricultores, incluindo os que exploram minifúndios e os indígenas, e as respectivas cooperativas" (Chile, 1962). A maior inovação da diretoria de Chonchol foi priorizar a coletivização dos pequenos agricultores em comitês campesinos, que eram cooperativas de créditos e serviços formadas por associação de pequenos proprietários individuais. Embora nunca tenha "importado" modelos estrangeiros, é certo que Chonchol conhecia a experiência bem-sucedida de cooperativas daquele formato em $\mathrm{Cuba}^{509}$ e apostou na sua viabilidade no Chile, afinal, conhecia profundamente o campesinato do seu país. O crédito prioritário, então, passou de individual a coletivo, conforme os campesinos se organizavam em comitês. O próprio Chonchol se dedicou a percorrer as zonas rurais explicando diretamente aos camponeses a nova política, como retratado na foto a seguir.

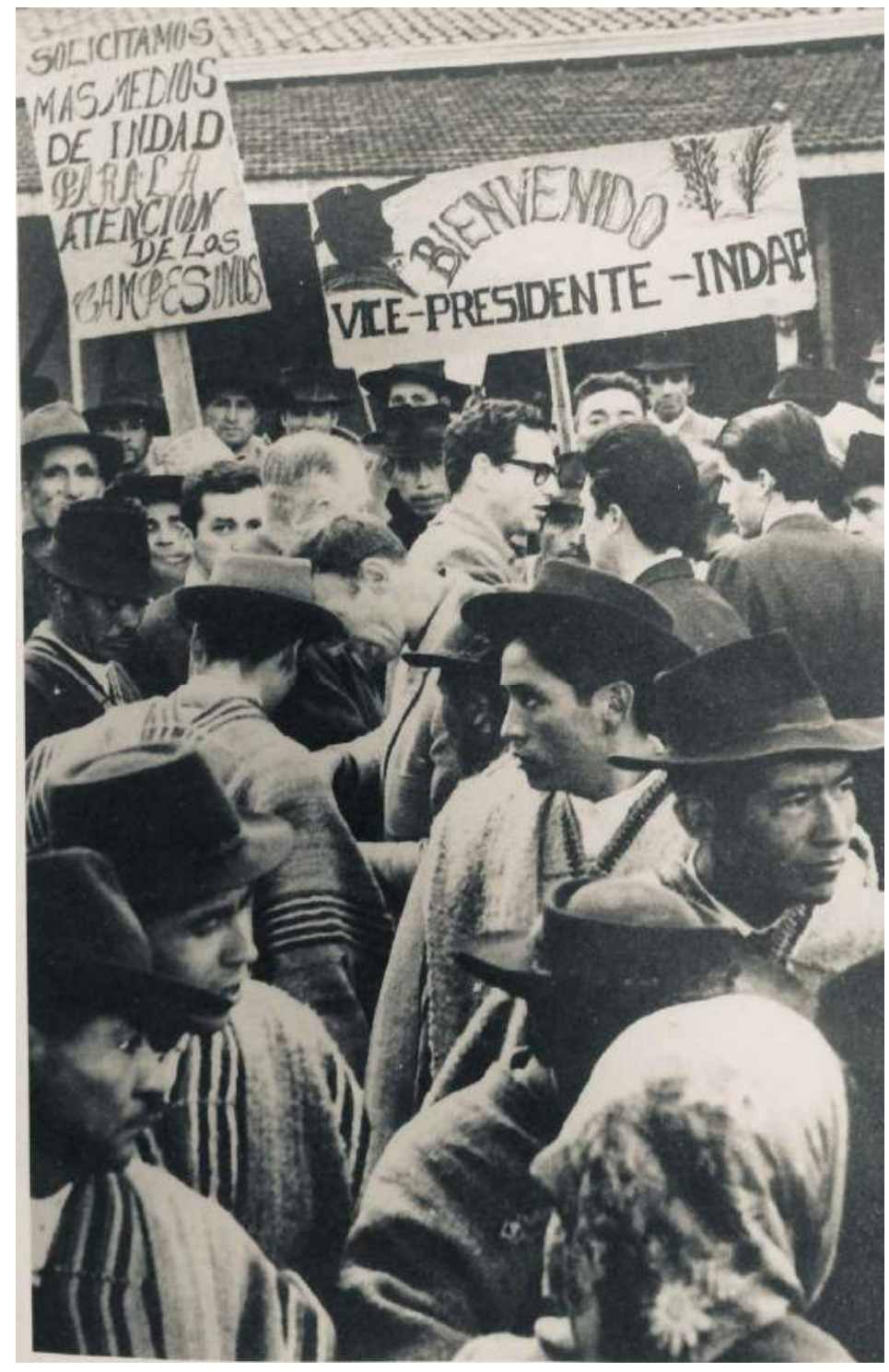

"Bem-vindo Vice-Presidente INDAP!" e "Solicitamos mais recursos do INDAP para atender aos camponeses", dizem os cartazes em 1966. Ao centro, Jacques Chonchol é o único que usa óculos. Fonte: Arquivo pessoal de Jacques Chonchol.

Além disso, durante a administração democrata-cristã, o escopo do INDAP se ampliou para políticas culturais e educacionais, que visavam três novos eixos: “(a) formação de um movimento camponês como instrumento de participação e desenvolvimento; (b) a criação de uma economia camponesa para aumentar a produtividade; e (c) promover e orientar a mudança dos valores sociais e culturais que obstaculizam a unidade e a economia camponesa" (Aguayo, 2014: 65-66). Para executar suas novas

\footnotetext{
${ }^{509}$ Sobre as cooperativas camponesas em Cuba, ver: Vasconcelos, 2015 e 2016. Sobre a passagem de Chonchol pela ilha em
} 1959 e 1961, ver Vasconcelos \& Chonchol, 2012. 
atividades-fim, era necessário contratar funcionários da área educacional, sociológica e cultural para o Ministério da Agricultura, de maneira antes impensável. Isso alterava o perfil dos funcionários do INDAP, predominantemente de áreas técnico-econômicas (comercial, administrativo, creditício), a eles reunindo-se os profissionais do mundo cultural. "O primeiro que fizemos foi buscar pessoal para o INDAP, e para isso recorremos muito às pessoas que vinham do IER", disse Chonchol para Faiguenbaum (2017: 85). "Para o INDAP, o IER foi uma importante fonte e recrutamento de jovens que tinham uma educação e um trabalho camponês", ${ }^{510}$ confirmou. Como já sinalizei em todo capítulo 3, o IER era pioneiro na educação camponesa e formava, desde os anos 1950, milhares de "delegados", agentes comunitários e professores nascidos organicamente do mundo rural. Os delegados do IER foram os primeiros a serem incorporados ao governo democrata-cristão como "promotores populares campesinos". O promotor era um funcionário "todoterreno" (Faiguenbaum, 2017: 86), ou seja, passava sua jornada laboral completa em contato direto com os camponeses, percorrendo propriedade em propriedade. Os promotores "se espalharam pelo campo conversando com os camponeses, para que se organizem em sindicatos, cooperativas, comitês para defender seus direitos", recordou o dirigente camponês Orlando Céspede. ${ }^{511}$ Sergio Faiguenbaum sintetizou:

Os primeiros indapinos [de 1962] (...) percorriam os campos como missionários do progresso técnico (...). Diferentemente, o promotor [de 1964], já não tão pobre de recursos - dispunha de caminhonetes e jeeps -, representava a épica da promoção popular, do cristianismo pós-Concílio Vaticano II, que lutava contra as injustiças sociais (2017: 86).

Foi nesse contexto de inflexão progressista, que Freire se incorporou ao Departamento de Estudos e Metodologias do INDAP, embora a capacitação fosse uma missão transversal. "Vínhamos selecionados de todo o país para fazer seu curso", relatou Hernán Kohnenkantf, ex-funcionário do INDAP de Valparaíso, ao lembrar do pedagogo brasileiro. ${ }^{512} \mathrm{O}$ departamento em que Freire se localizou era coordenado por Raul Velozo e composto de David Downey, Juan Carlos Poblete, Carmen Aguayo, José Antonio Fernández e a brasileira Evelyn Zingue, além dos pintores Paz Vial e Julio Zuñiga, que criavam as obras de arte dos temas geradores dos círculos de cultura (Zubicueta, 2019: 149). Velozo chegou a escrever com Freire o texto Sugerencias para la aplicación del método en terreno, no qual expressavam doze "sugestões práticas" e seis "sugestões gerais" para o coordenador do círculo de cultura do INDAP. A sugestão que abria o texto, dizia:

Suponhamos que haja uma pessoa que seja líder ou cacique da comunidade onde se vai aplicar o método; o caráter livre do Círculo de Cultura, onde todos devem poder dialogar e criticar livremente, poderia ser perturbado pela presença de uma pessoa autoritária (...). O coordenador deve encontrar a forma de neutralizá-la (...). Desnecessário dizer que deve ser feito com prudência. ${ }^{513}$

\footnotetext{
${ }^{510}$ Entrevista com Jacques Chonchol, Santiago, 26/11/2018.

${ }^{511}$ Em entrevista a Faiguenbaum, 2017: 86.

512 Id., p. 87.

${ }^{513}$ Paulo Freire \& Raul Velozo, Sugerencias para la aplicación del método en terreno. Santiago: ICIRA (mimeo), 1968.
} 
As sugestões tratavam de diferentes temas práticos, que revelavam os desafios concretos surgidos da própria experiência de círculos realizados até 1968. Entre eles, os autores propunham formas de abrir um círculo; como evitar que problemas estritamente pessoais se tornassem foco do diálogo, como coletivizar a compreensão dos temas; como coordenar um círculo com uma notícia de jornal no lugar da imagem; como proceder diante de camponeses que se recusavam a falar; como desdobrar as respostas camponesas em novas perguntas. Além disso, advertiam que o coordenador deveria evitar expressar sua opinião, a não ser quando o clima estivesse desinibido o bastante para que aquela se tornasse somente "uma entre as demais". "O papel do coordenador não é, pois, conduzir o grupo de qualquer maneira, mas simplesmente favorecer sua expressão livre e espontânea (...). Um dos requisitos fundamentais de um bom coordenador é a humildade", 514 pontuavam. Enfatizavam, por fim, que o coordenador deveria mostrar que todas as experiências de vida eram válidas e ricas, que todos os camponeses tinham algo importante a dizer. Para encorajar os mais tímidos, se recomendavam conversas privadas que identificassem seus temas geradores "pessoais".

\section{Ação cultural para reforma agrária}

Durante o governo Frei, o INDAP criou 11 centrais de capacitação, espalhadas pelo país: em La Serena, Viña del Mar, Rancagua, Linares, Chillán, Los Angeles, Arauco, Temuco, Osorno, Ancud e Punta Arenas. ${ }^{515}$ Lá ocorriam jornadas de capacitação três enfoques: cursos técnicos, cursos sindicais e cursos sociais. Também havia uma diferenciação formal entre cursos para camponeses da base, para dirigentes e para funcionários. Entre 1965 e 1969, o INDAP capacitou 94.126 pessoas, sendo 80\% camponeses das bases, 15\% camponeses dirigentes e 5\% funcionários do INDAP (Faiguenbaum, 2017: 88-89).

Diferentemente do Mineduc e da CORA, a equipe de Freire no INDAP se dedicou menos à tarefa da alfabetização camponesa e mais à pós-alfabetização e à ação cultural. "A ação cultural como a entendemos", escreveu Freire, em 1968:

...não pode, de um lado, sobrepor-se à visão do mundo dos camponeses e invadi-los culturalmente; de outro, adaptar-se a ela. Pelo contrário, a tarefa que ela coloca ao educador é a de, partindo daquela visão, tomada como um problema, exercer, com os camponeses, uma volta crítica sobre ela, de que resulte sua inserção, cada vez mais lúcida, na realidade em transformação. ${ }^{516}$

A ação cultural do INDAP era uma atuação pedagógica vinculada à concepção de reforma agrária expressada por Freire em seus textos: "o assentamento, como unidade de produção, é também uma unidade cultural ou de ação cultural (...). Essa compreensão da reforma agrária, da qual não pode

\footnotetext{
${ }^{514}$ Id. ibid..

515 Bom lembrar que o IER possuía 20 centrais de capacitação, em 1964, coincidindo com o INDAP em cinco comunas: Rancagua, Chillán, Arauco, Osorno e Ancud (ver capítulo 3).

${ }^{516}$ Paulo Freire, Ação cultural e reforma agrária (Santiago, 1968) em Freire, 1981: 30. Esse capítulo é uma versão ligeiramente diferente do relatório de Freire à Unesco, La alfabetización funcional en Chile, op. cit.
} 
estar ausente a ação cultural, baseia todo o plano de trabalho que apresentamos". ${ }^{517}$ Parte da promoção camponesa via ação cultural do INDAP ocorria no trabalho do Departamento de Teatro e Folclore. Os folcloristas investigavam as práticas culturais camponesas de cada localidade e realizavam festivais abertos para livre expressão comunitária. $\mathrm{O}$ objetivo era galvanizar a subjetividade camponesa do folclore à reforma agrária e expandir informações práticas e sentimentos comunitários sobre as mudanças que estavam em curso. Ao mesmo tempo, surgia no Chile um conceito novo de "teatro campesino", promovido por um grupo itinerante de artistas, que chegaram a realizar quatro turnês de 9 meses e a passar por uma diversidade de territórios rurais com peça e aulas de teatro. Duas peças de teatro marcantes do INDAP foram Un hombre llamado Chile, de Victor Labarca, que retratava o camponês do norte, do centro e do sul do país em três atos; e Con el sol en la redes, de Fernando Cuadra, que narrava um conflito entre uma comunidade de pescadores e os comerciantes intermediários que lhes extorquiam e na qual o protagonista exclamava: "a única alternativa é fazer uma cooperativa!" (Faiguenbaun, 2017: 90-91).

Segundo Zubicueta, "diferentemente do Mineduc ou da CORA, que produziram materiais para massificação do método, as equipes do INDAP tinham maior independência sobre a gestão de seus recursos, no sentido de poder definir os grupos camponeses a assistir e gerar maior constância e profundidade nestes processos" (Zubicueta, 2019: 149). Por isso os materiais produzidos pela equipe freiriana do INDAP eram baseados em investigação temática e na especificidade de cada território subjetivo encontrado. Paz Vial e Julio Zuñiga pintaram uma série chamada El hombre y la cultura, com situações existenciais camponeses para diálogos sobre o conceito antropológico de cultura. Infelizmente, as pinturas da série não foram encontradas em nenhum acervo público: uma delas, pintada por Zuñiga, foi encontrada no acervo pessoal de Jacques Chonchol; e duas delas, pintadas por Paz Vial, foram disponibilizadas do acervo privado de Carmen Aguayo para a historiadora Daniela Zubicueta. As três pinturas estão reproduzidas a seguir.

\footnotetext{
${ }^{517}$ Id., La alfabetización funcional en Chile, op. cit. p. 6-7.
} 


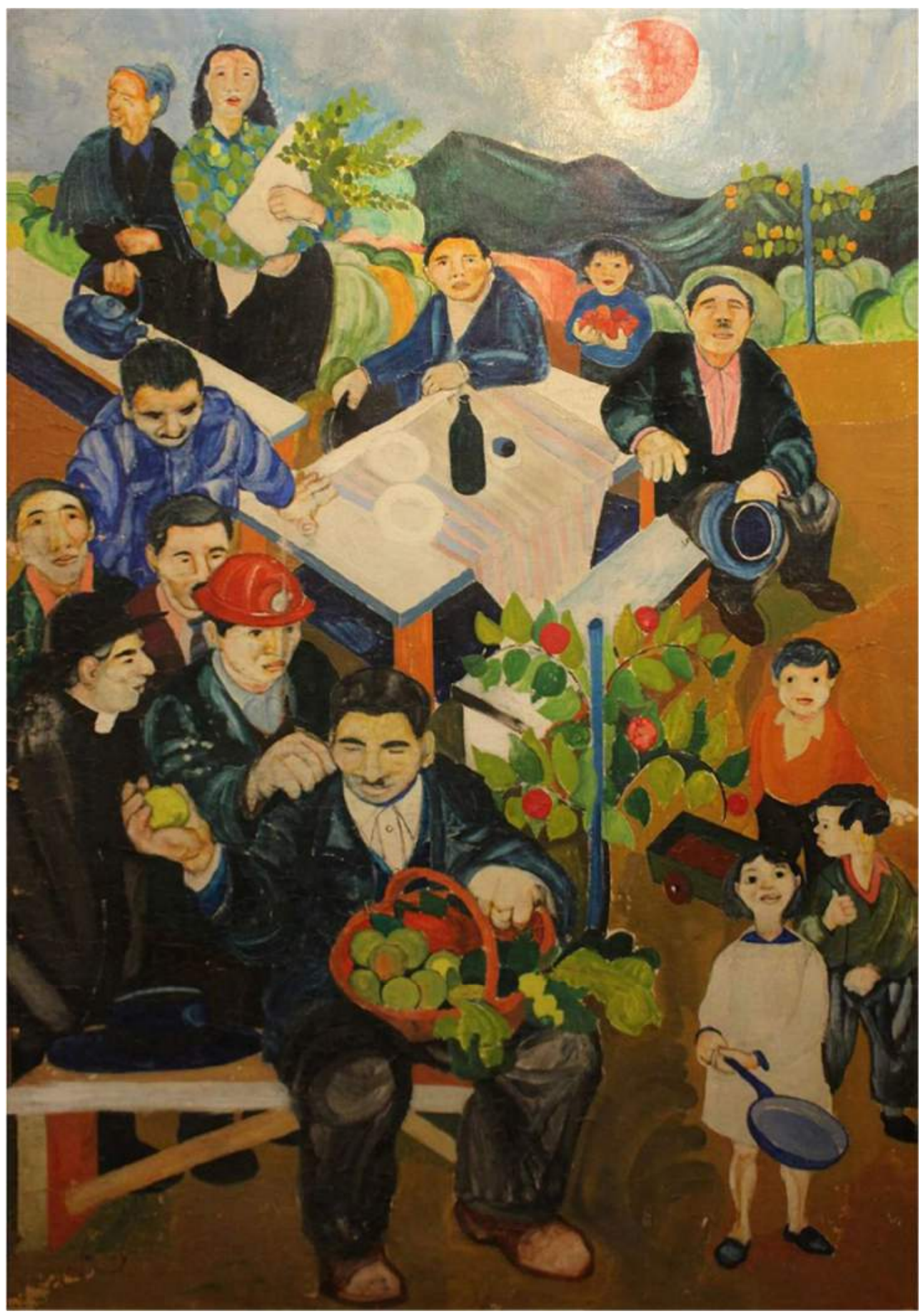

Pintura de Julio Zuñiga (INDAP), utilizada em círculos sobre o conceito antropológico de cultura. Fonte: Acervo pessoal de Jacques Chonchol 


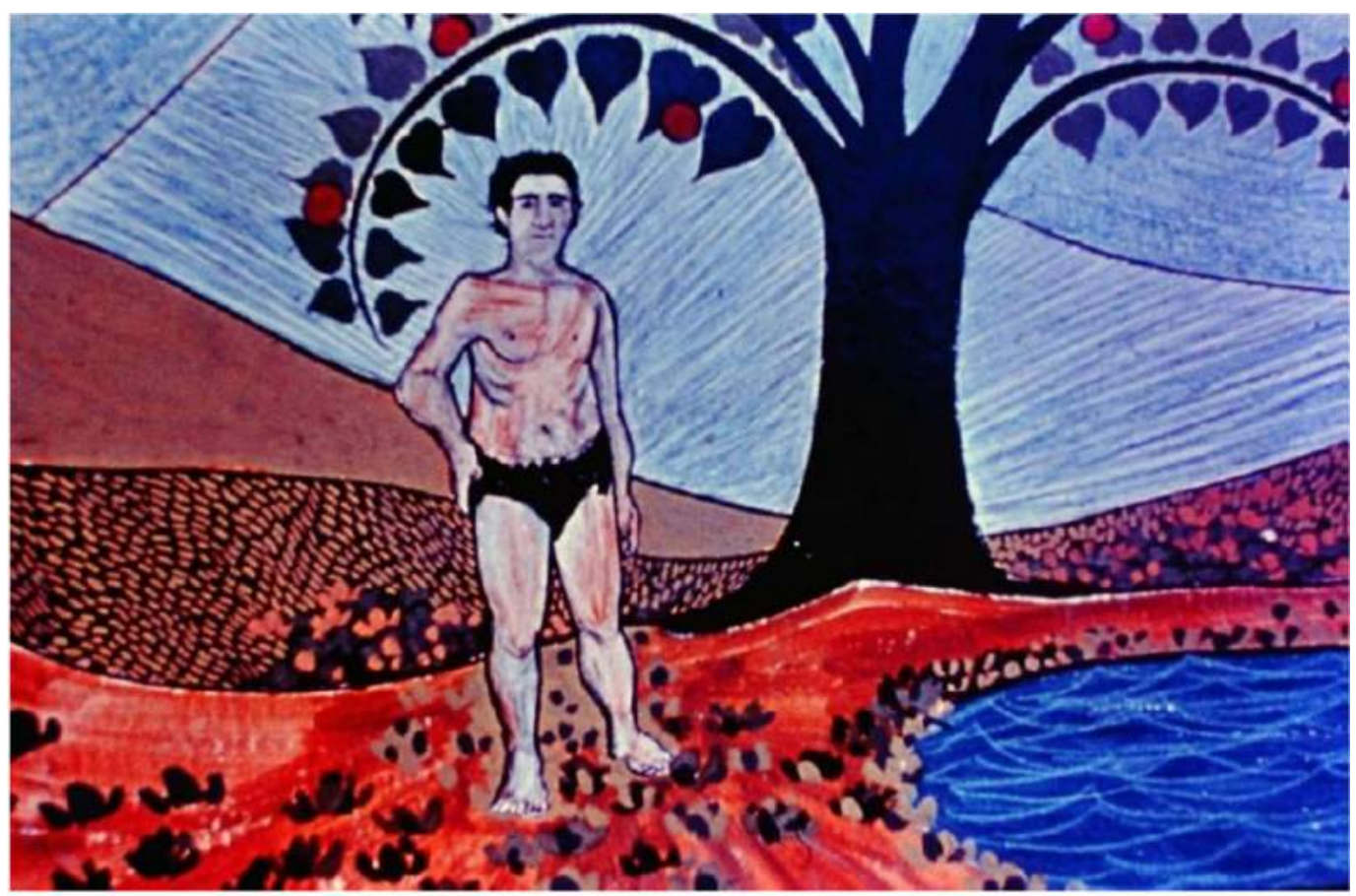

Pintura de Paz Vial (INDAP), utilizada em círculos sobre o conceito antropológico de cultura Fonte: Zubicueta, 2019: 155. Acervo pessoal de Carmen Aguayo

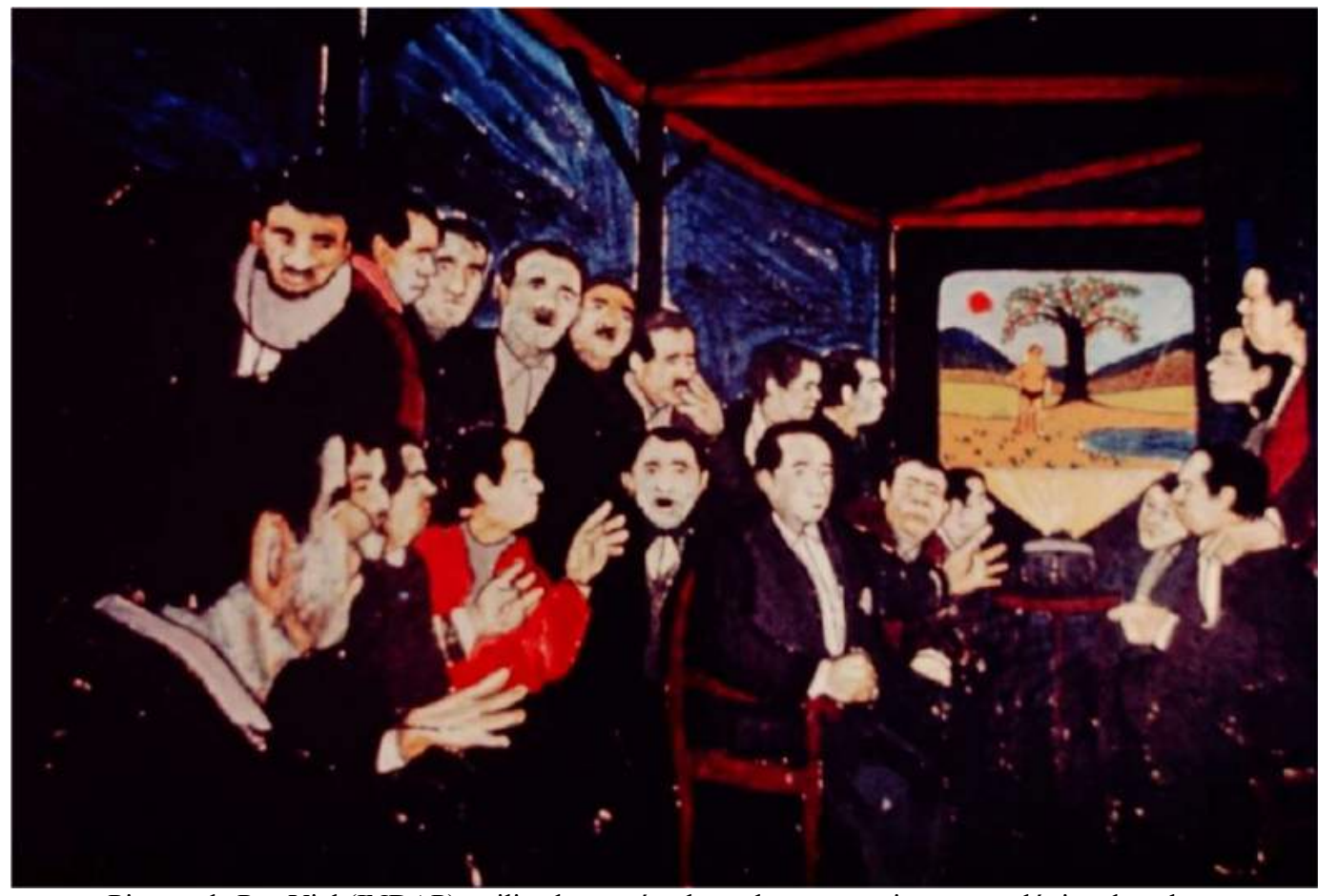

Pintura de Paz Vial (INDAP), utilizada em círculos sobre o conceito antropológico de cultura Fonte: Zubicueta, 2019: 156. Acervo pessoal de Carmen Aguayo

Nas viagens realizadas a cargo do INDAP pelo mundo rural chileno, os pintores Julio Zuñiga e Paz Vial participavam diretamente de círculos de cultura e experienciaram a abertura de diálogos 
horizontais entre educadores e campesinos. Em entrevista à historiadora Zubiecueta, o pintor testemunhou:

Paulo dizia que o problema metodológico que tínhamos era gerar uma instância de diálogo que permitisse [aos camponeses] extrovertir (sic) sua cultura, sua visão de mundo (...). Eu me lembro como era emocionante ver grupos de homens e mulheres, que começavam a dizer coisas, e quando eles concluíam aquilo que Paulo queria que concluíssem: que nós, seres humanos, somos os autores da história, que somos nós que (...) fabricamos tudo, não só as enxadas, mas todas as relações que existem entre nós são obra nossa. Uma descoberta extraordinária. Seguindo as lâminas, você estabelecia firmemente esse critério: que somos nós, cada um de nós e o conjunto de nós, que fazemos a história (Zuñiga apud Zubicueta, 2019: 154-55).

Julio Zuñiga também se lembrou quando o latifundiário Máximo Errázuriz tentou impedir que a equipe do INDAP, incluindo Freire, entrasse em uma escola pública rural que ficava dentro da sua propriedade, nas cercanias de Santiago. "Chegamos de noite e era uma escola no interior de um latifúndio. Na entrada, já estava o dono, com uma escopeta na mão e seus capatazes: "na minha propriedade não entra"', narrou o pintor (Zuñiga apud Zubicueta, 2019: 159). A equipe, que vinha em carro oficial do INDAP com projetor e slides, respondeu com uma pergunta: "Senhor Máximo, de quem é a escola, sua ou do Estado?”. Conseguiram entrar. Aquele latifundiário teve participação ativa no golpe de 1973.

\section{Pedagogia da mulher camponesa}

No arquivo pessoal de Carmen Aguayo, Faiguenbaun (2017) e Zubicueta (2019) encontraram lâminas do INDAP para círculos de mulheres camponesas, pintadas por Paz Vial. Responsável pela elaboração de uma política de promoção da mulher campesina, Aguayo mesclava a concepção democrata cristã da promoção popular com a educação libertadora de Paulo Freire, e sintetizou:

A promoção é a libertação do ser (...). Há diferenças na promoção feminina, pois é preciso partir de uma tomada de consciência de sua própria situação, que é inferior à do homem. Ambos estão oprimidos pelos mesmos opressores, mas ela está ainda mais oprimida, já que o está pelos opressores e pelos oprimidos. ${ }^{518}$

Quase sempre os círculos de homens e mulheres ocorriam separadamente, o que contribuía para evitar "inibições de gênero" que reforçassem a cultura do silêncio. Na investigação temática, Paz Vial encarregou-se especialmente de observar as mulheres rurais, produziu obras de arte originais, à tinta no papel, reproduzidas a seguir a partir do trabalho de Zubicueta (2019).

${ }^{518}$ Carmen Aguayo, La mujer en la promoción campesina. Santiago: INDAP (mimeo): 7. 


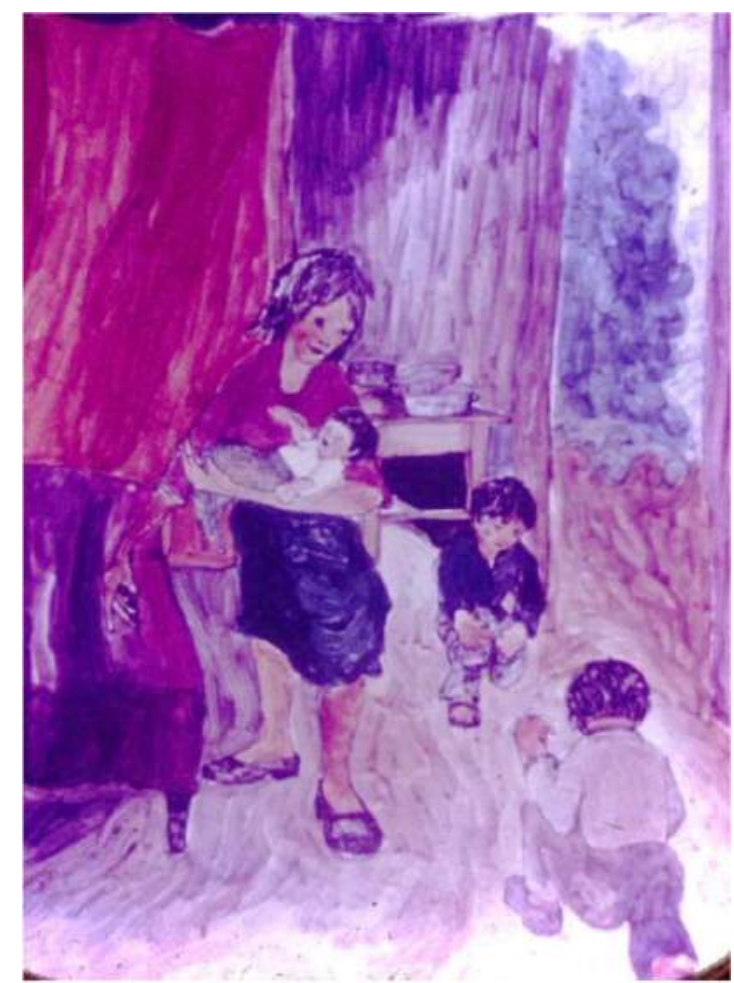

La niña, de Paz Vial. Série La Mujer Campesina (círculos de cultura, INDAP). Fonte: Zubicueta, 2019 163. Acervo pessoal de Carmen Aguayo

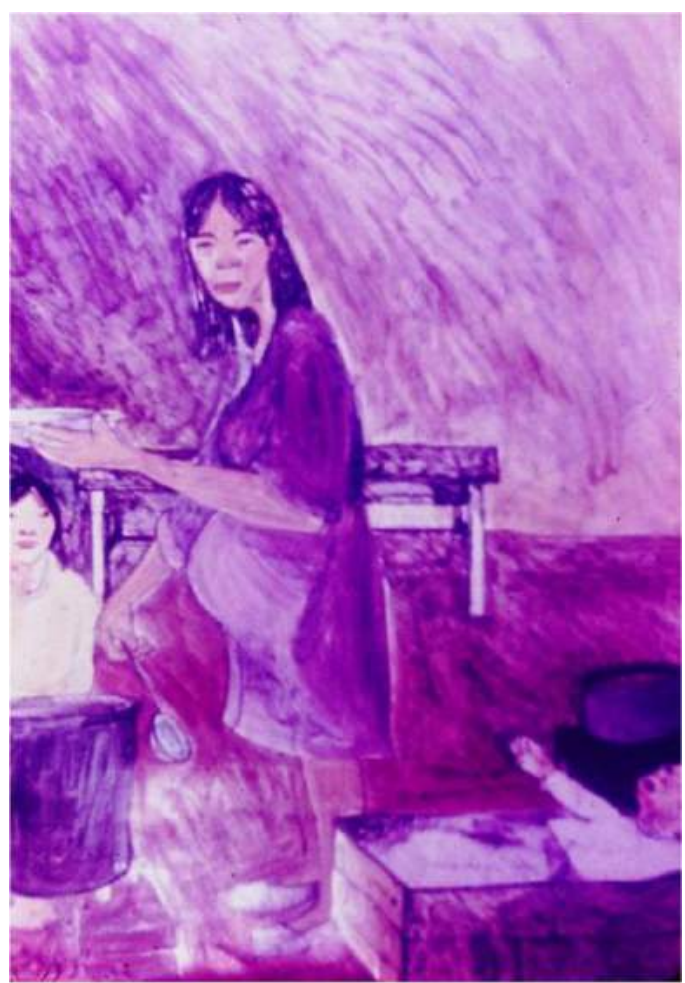

La madre, de Paz Vial. Série La Mujer Campesina (círculos de cultura, INDAP). Fonte: Zubicueta, 2019. 166. Acervo pessoal de Carmen Aguayo

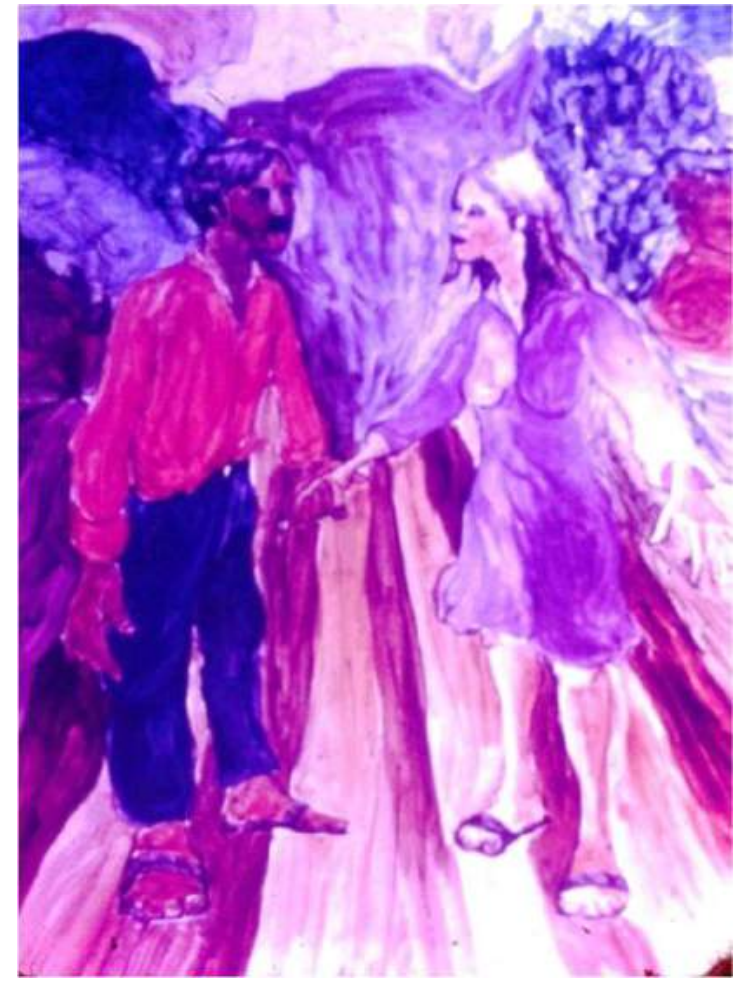

La pareja humana, de Paz Vial. Série La Mujer Campesina (círculos de cultura, INDAP). Fonte: Zubicueta, 2019: 172. Acervo pessoal de Carmen Aguayo

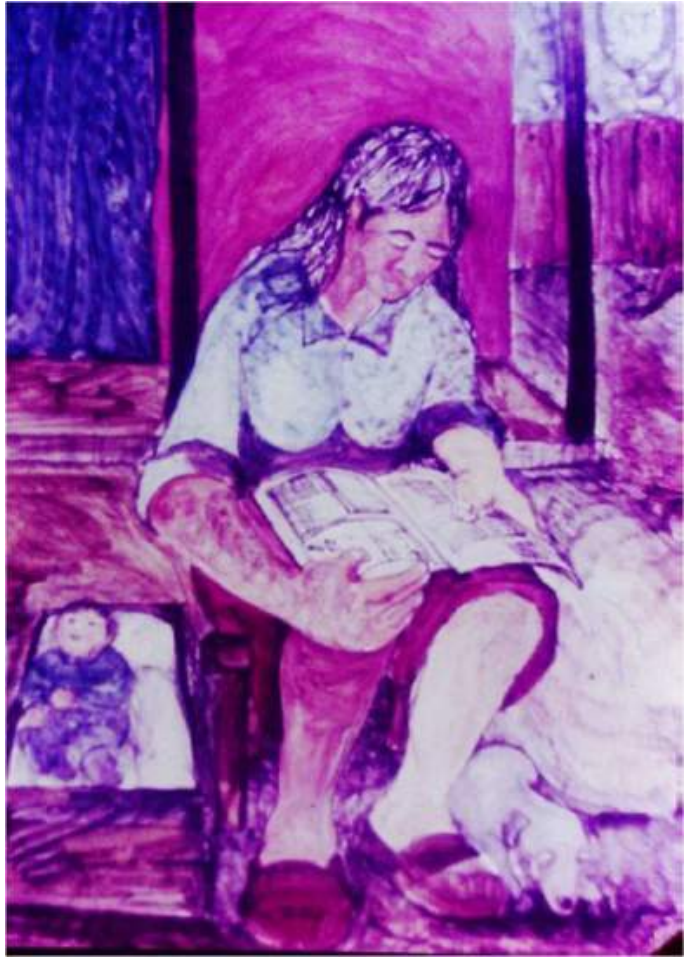

La mujer, ser humano, de Paz Vial. Série La Mujer

Campesina (círculos de cultura, INDAP). Fonte:

Zubicueta, 2019: 170. Acervo pessoal de Carmen Aguayo 


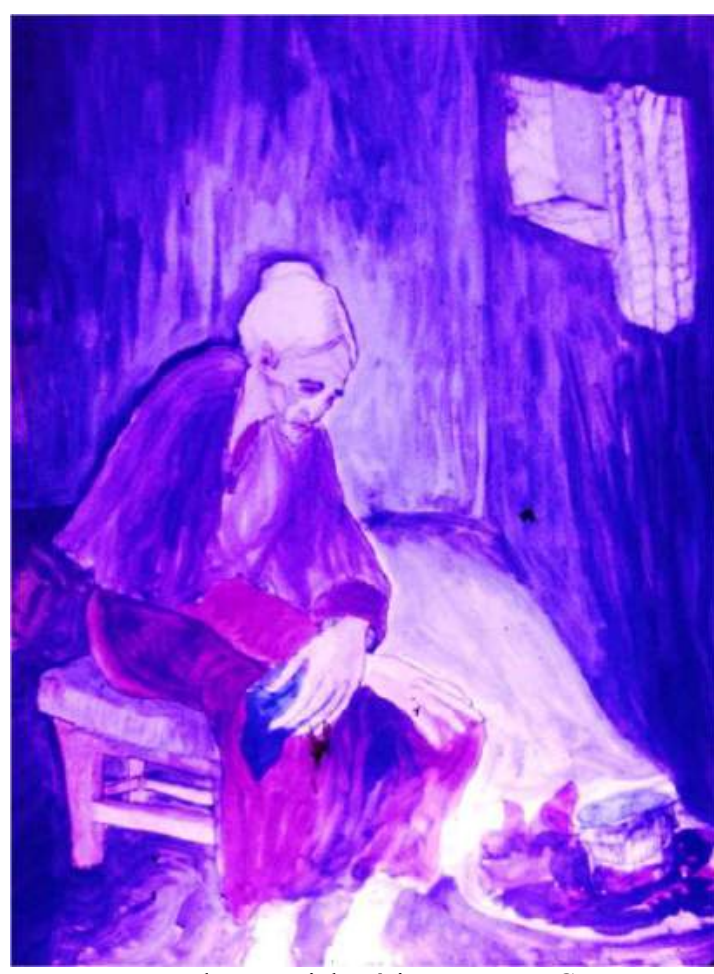

La anciana, de Paz Vial. Série La Mujer Campesina (círculos de cultura, INDAP). Fonte: Zubicueta, 2019: 168. Acervo pessoal de Carmen Aguayo

Além disso, Carmen Aguayo redatou um guia para coordenadoras de círculos de mulheres camponesas, com perguntas de condução dos diálogos em cinco sessões, correspondentes às cinco pinturas. As perguntas mais significativas, suficientes para analisarmos a diferença frente ao material do Mineduc, estão indicadas a seguir.

Para a pintua La niña, o Guia perguntava, por exemplo: "De que brincam os meninos? De que brincam as meninas? Por que são diferentes suas brincadeiras? Os homens cuidam dos bebês? Por quê? Poderiam cuidar? Poderia uma mulher manejar um trator?" (Apud Zubicueta, 2019: 163). Para a pintura La mujere, o guia sugeria, entre outras questões: "o controle de natalidade está ao alcance da mulher camponesa? Ela o aceita? O rechaça? Que atitude tem o marido frente à gravidez da mulher? Sua vida muda quando está grávida?" (Apud Zubicueta, 2019: 165). Para a pintura La anciana, o guia propunha: "que motivos [a idosa] tem para estar triste? Como foi sua vida quando jovem? Com qual idade se casou? Conheceu o homem antes de [com ele] se casar? Por que se casa? Tem atividades fora da sua casa? Quem acolhe suas dores? (...) Qual é sua esperança?” (Apud Zubicueta, 2019: 168). A quarta pintura, La mujer, ser humano, Aguayo problematizava: "Que tipo de vida leva essa mulher? (...) Que coisas faz? Está obrigada a levar essa vida? Por que lê? (...) Em que o cachorro se diferencia da mulher? É livre para escolher seu destino? É livre para ter ou não ter filhos? (...) Pode pensar sobre o destino da sua vida?” (Apud Zubicueta, 2019: 170). E por fim, para o círculo da quinta pintura se perguntava: "Para que se juntam o homem e a mulher? Somente para ter filhos? Há outra finalidade para o casamento? (...) Existem outras formas de união conjugal? O que é poligamia? (...) O que entendemos por amor? Que tipos de amor conhecemos?" (Apud Zubicueta, 2019: 172).

É visível o potencial disruptivo que essas perguntas lançavam em direção ao esquema patriarcal camponês convencional. Diferentemente dos materiais pós-alfabetização do Mineduc, que evocavam o mutualismo de gênero para delimitar os papeis da mulher na promoção popular (Tinsman, 2009), aqui, o guia de perguntas para os círculos de cultura do INDAP, por meio do método de Paulo Freire, tinha viabilidade de serem desdobrados em conversas questionadoras dos fundamentos da ordem patriarcal no campo. Não por acaso, a autora do guia, Carmen Aguayo, foi parte da ruptura com a DC e criação do MAPU em 1969. "Ainda sinto emoção quando recordo o grito do MAPU, que nos identificava junto 
a nossas bandeiras verdes e vermelhas", ${ }^{519}$ rememorou. Suas perguntas propunham horizontes mais amplos do que a quadratura da revolução de Eduardo Frei poderiam oferecer.

Da mesma maneira, a potência subjetiva dos círculos do conceito antropológico de cultura vivenciados pelas equipes do INDAP evocava uma proposta pedagógica só aparentemente compatível com aquela enunciada pelos livros de pós-alfabetização camponesa do Mineduc. O que o Mineduc nomeava como método psicossocial era um processo pedagógico constituído de duas etapas: primeiro, a alfabetização com palavras geradoras "de escritório", escolhidas sem investigação temática, acompanhadas de uma pedagogia da pergunta no manual do alfabetizador, que centrava atenção nas melhores formas de problematizar a palavra; e segundo, os círculos de pós-alfabetização baseados em textos de leitura "de escritório" que expressavam, do nível um ao três, não apenas valores morais específicos do projeto democrata-cristão (a família cristã, a homogeneidade da nação, o progresso econômico sem conflito de classe), como também uma convocatória governista que se tornava explícita.

Do outro lado, a experiência de ação cultural do INDAP tinha menor escala e seu propósito estava mais voltado à problematização do conceito antropológico de cultura do que à alfabetização. A intimidade entre as equipes do INDAP e Paulo Freire, o fato de que todos os dias se encontravam e se reuniam no escritório, permitiu o desenvolvimento de uma disciplina coletiva para escuta, voltada para a necessidade do camponês efetivamente "aprender a dizer sua palavra", como propunha Ernani Fiori no prefácio da Pedagogia do oprimido. As imagens do conceito antropológico de cultura (El hombre y la cultura) foram pintadas por artistas jovens com base em investigação temática. Paulo Freire e Raul Velozo tiveram especial dedicação em orientar os coordenadores de círculo do INDAP sobre a horizontalidade essencial do método, que abria a possibilidade do campesinato se perceber sujeito da história, sem que a piori se anunciasse o tipo de "protagonismo" que deveria exercer, muito menos que tipo de apoio se devia ao governo. Essas diferenças, de certa forma, já ecoavam as cisões que viriam depois, em 1969.

\section{A revolução verde como invasão cultural}

Por fim, é preciso sublinhar que as iniciativas pedagógicas do INDAP não estavam exclusivamente comandadas pela presença de Paulo Freire. A Oficina de Capacitação e Difusão seguia uma agenda de publicações atrelada aos cursos técnicos, sobre os quais Paulo Freire tentou incidir quando estava no ICIRA (como se verá adiante), mas nem sempre conseguiu. Duas séries de 1966, os Manuais Campesinos, com temas econômicos amplos (desenvolvimento/progresso), e as Cartilhas Campesinas, que ensinavam assuntos práticos variados: de técnicas agrícolas aos cuidados com a gravidez; de valores a adubos; dos direitos laborais ao alcoolismo. Esses materiais eram fornecidos aos camponeses alfabetizados pela assistência técnica do INDAP, de maneira nitidamente desatrelada da

\footnotetext{
${ }^{519}$ Carmen Aguayo, Mujer y Politica, op. cit, p.72.
} 
pedagogia freiriana. Entre os Manuais, obtivemos três exemplares que tratavam de Agricultura y desarrollo (n. 1), Necesidades, trabajo y economia (n. 2) e Técnica y progresso (n. 3). Entre as Cartilhas, os temas ensinados estão listados a seguir, sublinhados os únicos três obtidos na Biblioteca Nacional: ${ }^{520}$ 1) La Siembra; 2) Valores de la Persona; 3) El Seguro; 4) El Trabajo; 5) La Leche; 6) Asignación Familiar; 7) La Epizotia; 8) Cuidados durante el embarazo; 9) Los Abonos; 10) Cultivos sin malezas; 11) Rotación de cultivos; 12) El tizón de la papa; 13) El alcoholismo; 14) Como funciona el País; 15) La erosión; e 16) El hombre, sociable por natureza. Todos datam de 1966, produzidos pela Oficina de Capacitação e Difusão do setor de assistência técnica do instituto, que funcionava paralela mente ao Departamento de Estudos e Metodologias no qual estavam as equipes de Paulo Freire. As Cartilhas de assistência técnica eram introduzidas com uma carta do INDAP aos camponeses, que em tom solene e ligeiramente paternalista anunciava que o país dependia da sua produção de alimentos e que o camponês era importante para a nação, mesmo que assim não se sentisse:

\begin{abstract}
"Senhor camponês, ainda que você não saiba, ainda que custe acreditar, você é um homem muito importante para todo Chile (...). O trigo que você agora semeia, cuida e colhe será o pão que comem os mineiros, os pescadores, os trabalhadores, os soldados, os empregados (...). O INDAP trabalha para você. Agora lhe entregamos esta publicação. Preparada pensando em você, na sua família, no seu trabalho. Queremos pedir que a leia com atenção. Se é útil a você, também servirá a todos os chilenos". ${ }^{521}$
\end{abstract}

Na última página, havia uma lista de 15 escritórios zonais do INDAP e um convite para que o camponês pedisse a coleção completa de Cartilhas ao chefe zonal mais próximo. O material poderia ser utilizado por assistentes técnicos do instituto, tanto quanto ser apenas um suporte individual para o camponês alfabetizado. Era um material que buscava instruir de maneira convencional e "bancária" 522 os segmentos escolarizados do campo, com informações diretivas e afirmações indubitáveis sobre questões técnicas e econômicas, com uma forma pedagógica distantes da pedagogia da pergunta estimulada pela equipe de Freire na sala ao lado. As duas prioridades visíveis nesses materiais eram, por um lado, aumentar a produtividade com uso de "técnicas modernas" e, por outro, incentivar a criação de comitês campesinos.

O Manual Agricutura y Desarrollo, por exemplo, dizia: "se seguirmos trabalhando o campo com técnicas usadas por nossos avós, não vamos progredir nunca. É preciso buscar a melhor maneira

\footnotetext{
${ }^{520}$ A lista da coleção completa está em INDAP, (1966d) Cultivos sin malezas. Cartilla n. 10.

${ }^{521}$ Idem.

522 Paulo Freire escrevia em 1967, de Santiago: “Se para a concepção 'bancária' a consciência é este recipiente que deve ser preenchido, é este espaço vazio à espera do mundo, a educação é então este ato de depositar fatos, informações semimortas nos educandos. A estes nada mais resta a não ser, pacientemente, receber estes depósitos, arquivá-los, memorizá-los, para depois repeti-los. Na verdade, a concepção bancária termina por arquivar o próprio homem: tanto o que faz o depósito, como o que recebe, posto que não há homem fora da busca inquieta. Fora da criação, da recriação. Fora do risco da aventura de criar". Paulo Freire, La concepción 'bancaria' de la educación y la deshumanización. La concepción problematizadora de la educación y la humanización. (Resumen de charlas realizadas para un grupo de señoras latinoamericanas en una conferencia realizada en mayo de 1967, en Santiago, bajo patrocinio de la OEA, del Gobierno de Chile y de la Universidad de Chile). Santiago: ICIRA (mimeo.), 1967, p. 6.
} 
de mudar o trabalho na nossa pequena propriedade (...). Para isso devemos trabalhar com novas técnicas". ${ }^{523} \mathrm{O}$ material ensinava que o Chile era um país fértil, com terras boas e água em abundância. Se os camponeses não conseguiam alimentar adequadamente seus filhos e estabelecer uma vida saudável, isso se devia a dois fatores: o atraso técnico, que seria superado se os camponeses aceitassem a ajuda do INDAP; e a má distribuição da terra. "Os camponeses com esforço podem ajudar a melhorar as condições da agricultura", afirmavam, "porém (...) o grande problema é que poucas pessoas têm a maioria das terras. Muitos deles não sabem trabalhá-las já que nunca foram agricultores (...). Nessas condições não temos nenhuma possibilidade de progresso ou desenvolvimento". 524 O Manual prescrevia, em seguida, três medidas para que o campesinato alcançasse o progresso: incorporar melhorias técnicas; formar comitês camponeses; e fazer uma "verdadeira" reforma agrária. Para que a cooperativização de minifundistas em comitês campesinos fosse funcional, era preciso convencer as bases populares de que a associação era vantajosa em relação ao trabalho individual:

Trabalhando sozinhos podemos adiantar muito. Porém, organizadamente progredimos mais rápido. (...) 'A união faz a força'. Organizados vendemos mais facilmente nossos produtos. Também compramos pesticidas e adubos mais baratos. Se somos inquilinos, podemos nos organizar para pedir justiça aos que abusam de nós (...). Assim, nos desenvolvemos mais rapidamente do que se lutamos cada um por conta própria. ${ }^{525}$

Era nítida a opção pela coletivização parcial dos pequenos proprietários em comitês de crédito e serviços, uma proposição emanada do pensamento político e técnico de Jacques Chonchol. Simultaneamente, a reforma agrária era defendida como um caminho para "dar oportunidade de ser proprietários a todos os camponeses que saibam trabalhar a terra". A figura do merecimento da terra aos mais capazes aparecia nos Manuais, alinhados com as regras de titulação por puntajes da lei 16.640. "O Chile vai investir muito capital e trabalho para realizar tal reforma. Não haverá êxito, se os camponeses não façamos um esforço para melhorar a técnica (...). Para que tudo caminhe bem, precisamos ter responsabilidade" ${ }^{526}$ concluíam. Assim, o Manual se alinhava a uma economia moral do sacrifício e ao princípio do merecimento da terra para selecionar os futuros proprietários, o que trazia ecos de uma pedagogia do IER, mas ao mesmo tempo, abria uma narrativa própria sobre capital e trabalho, misturando a promoção campesina do social-cristianismo com conceitos marxistas: "para poder produzir necessitamos de trabalho e capital. (...) Temos o TRABALHO porque nós mesmos o colocamos com nossas próprias mãos, mas não contamos com o CAPITAL (...) Graças ao trabalho se forma o capital", ${ }^{527}$ difundiam. "Nós sempre colocamos o trabalho e o patrão, o capital, mas os lucros ficaram nas mãos dos patrões. Existe uma injustiça econômica muito grande". ${ }^{528} \mathrm{Em}$ termos marxistas,

\footnotetext{
${ }^{523}$ INDAP, (1966a) Agricultura y Desarrollo. Manuales Campesinos n. 1.

${ }^{524}$ Idem.

525 Id. ibid.

526 Id. ibid.

${ }^{527}$ INDAP (1966b), Necesidades, trabajo y economía. Manuales Campesinos n. 2.

528 Idem.
} 
prometiam que o governo democrata-cristão pretendia resolver a injustiça produzida pela contradição entre capital e trabalho em uma chave mais sacrificial que combativa: "O governo atual, através da reforma agrária e das leis sociais, (...) pretende solucionar essa injustiça (...). Mas todo esse labor não terá êxito se nós não aumentarmos nosso trabalho (...), planejarmos nossa empresa", dizia em primeira pessoa o Manual Necesidades, trabajo y economía ${ }^{529} \mathrm{Na}$ última página, estava estampado o trecho de um discurso de Eduardo Frei para camponeses de Temuco, exaltando a ideia de merecimento da terra que, como mostrou o capítulo anterior, era um contraponto à ideia do direito à terra: "Para que estamos fazendo esta Reforma? Para dar terra ao camponês que seja capaz de trabalhar e produzir (...). Reforma agrária não é apenas repartir terras, mas fazer com que essas terras produzam mais". 530

A associação entre campesinato alfabetizado e aumento da produtividade ficava explícita na Cartilha Cultivos sin malezas (Cultivos sem pragas), que ensinava detalhadamente ao camponês como usar diferentes tipos de matamalezas (herbicidas, pesticidas, fungicidas etc). Em uma das muitas ilustrações que acompanhavam tais materiais, pode-se ver um camponês lendo o rótulo de um produto cuja embalagem está sinalizada com uma caveira cruzada por dois ossos (símbolo da toxidade e da morte). Na ilustração, o camponês tem traços indígenas e aproxima o dedo indicador no texto, um gesto comum entre aqueles que aprenderam a ler recentemente. Na página ao lado, há uma lista de instruções numeradas sobre como utilizar o agrotóxico e a importância das instruções escritas no rótulo.

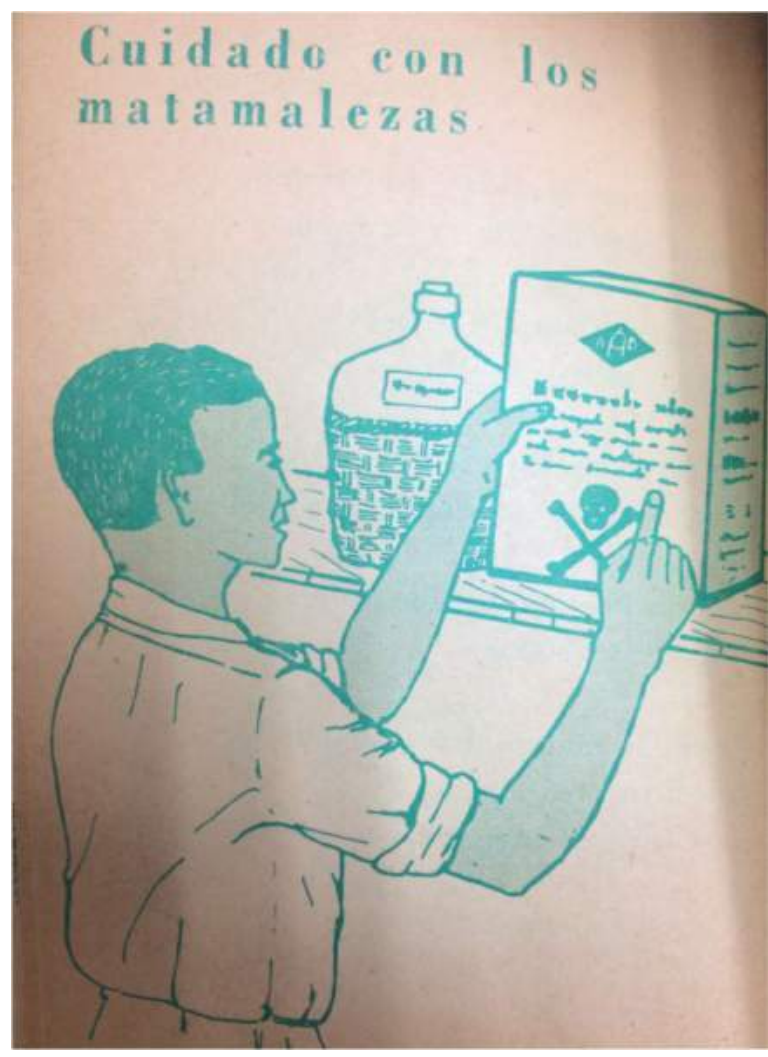

Ilustração de um trabalhador rural lendo o rótulo de um veneno. Aqui a alfabetização camponesa ganha uma conotação diretamente produtiva, atrelada à revolução verde. O INDAP recomenda: "ler bem as indicações dos recipientes e os folhetos antes de usar qualquer matamalezas" e "limite-se estritamente à dose recomendada nos rótulos". Fonte: INDAP, Cultivos sin malezas, 1966d.

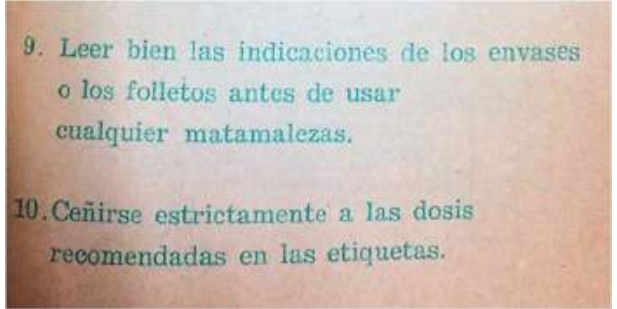

${ }^{529}$ Id. ibid.

${ }^{530}$ Id. ibid. 
"Os camponeses as conhecem bem", enfatizava o texto da cartilha, "sempre teve que lutar contra as pragas. Agora há meios modernos para eliminá-las e é bom conhecê-los. Nunca é demais saber a ciência certa (...). Peça a um especialista que diga qual é o matamalezas que seu cultivo necessita". 531 A tensão entre saber e não saber do camponês estava presente nas cartilhas da assistência técnica. Nos materiais, notava-se um relativo esforço de reconhecimento do trabalho e do saber camponês, ainda mais pela conjugação na primeira pessoa do plural, o que gerava uma percepção de intimidade entre o texto e seu leitor ("nós"). Mas, ao mesmo tempo, enfatizava-se a necessidade imprescindível da técnica moderna trazida de fora, pelo funcionário do Estado, como uma receita que se adota mecanicamente. Entre os pesticidas recomendados estavam ESTER 2, 4-D; ESTER 2, 4, 5-T (formador do agente laranja); AMINA M.C.P.A.; SHELL 10; SHELL 20; e entre os fungicidas Dithane, Polyran, Parzate, Ziran, Zineb, Maneb. ${ }^{532}$ "Se não sabemos controlar a praga. Se não sabemos que cultivo convém para o próximo ano. Se não sabemos qual o rendimento do cultivo", dizia o Manual Técnica y Progreso:

Devemos recorrer a uma pessoa que saiba mais (um técnico agrícola, um engenheiro agrônomo ou um vizinho experimentado). Não há por que se envergonhar. Nenhum homem pode saber tudo e todos necessitamos os demais (...). Se não os conhecemos, devemos pedir ajuda a outras pessoas. ${ }^{533}$

No mesmo INDAP, a humildade que a equipe de Paulo Freire pedia aos educadores e coordenadores de círculos, para que soubessem aprender com os camponeses, aparecia invertida nas cartilhas do setor técnico, que encorajavam a humildade camponesa diante do saber do especialista técnico. "Lembre-se que qualquer que seja sua dúvida, você pode consultar um técnico do INDAP, que com prazer vai colaborar com você". ${ }^{534}$ Além do uso de herbicidas, pesticidas e fungicidas, as cartilhas também ensinavam técnicas de rotação de cultivos com estratégias de planejamento para diferentes tipos de solos: "o solo é a maior riqueza dos camponeses (...). Os técnicos do INDAP serão muito úteis nesse sentido (...) o programa de semeadura deverá servir para 3 ou 4 anos". 535

O esforço da ilustração dos folhetos não era trivial, mas uma tentativa de tornar o material mais agradável para trabalhadores que não tinham o hábito da leitura. Mas ao contrário da metodologia de Paulo Freire, aqui as imagens eram meras ilustrações de uma prescrição técnico-econômica e não situações existenciais para debates em círculos por meio da pedagogia da pergunta. Algumas delas estão reproduzidas a seguir.

\footnotetext{
${ }^{531}$ INDAP, Cultivos sin malezas. Cartilla n. 10, 1966d.

532 INDAP, 1966d, 1966f. Sobre os herbicidas 2, 4-D e 2, 4, 5-T, se escreveu: "Embora o herbicida tenha sido sintetizado em 1942 e já comercializado na década de 40, existem, ainda hoje, lacunas de informações relativas aos efeitos à saúde humana e riscos ao ambiente" (Amarante Jr et al, 2003).

533 INDAP, Técnica y progreso. Manuales Campesinos n. 3, 1966c.

${ }^{534}$ INDAP, Rotación de cultivos. Cartilla n. 11, 1966e.

535 Id. ibid.
} 

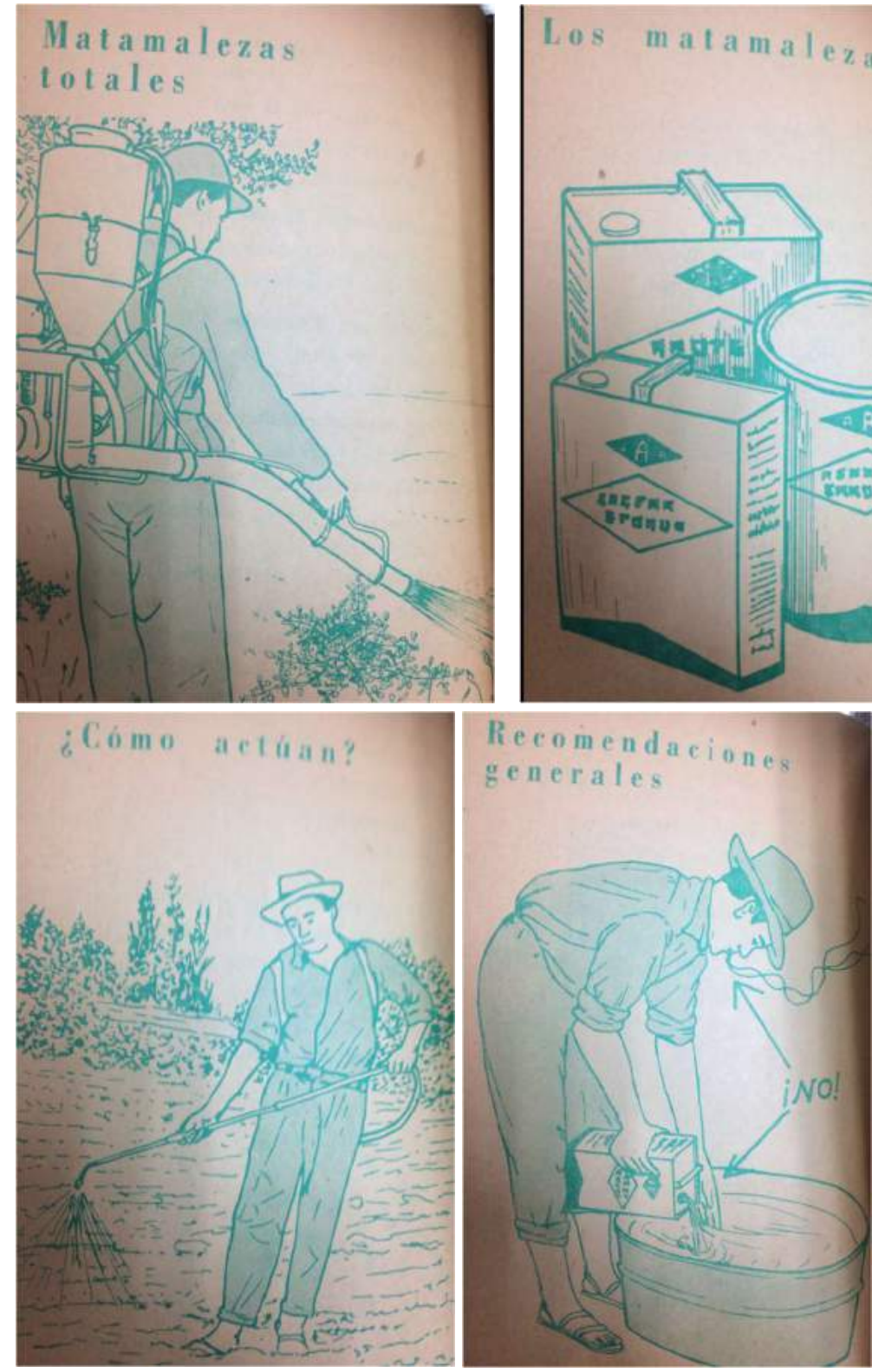

"Estes venenos servem para eliminar todo tipo de vegetação. Podem ser usados na folhagem ou no solo. Se empregam em casos muito especiais (...) quando se quer destruir pragas difíceis de combater. Um dos mais conhecidos é o éster 2, 4, 5-T". Fonte: INDAP, Cultivos sin malezas, $1966 \mathrm{~d}$.

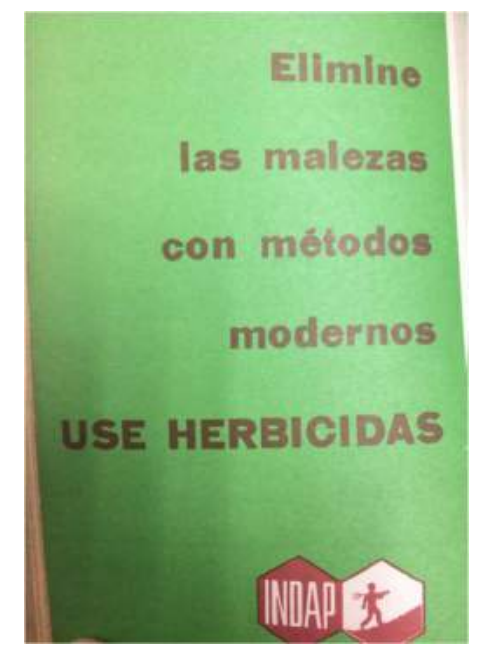

A estratégia discursiva da assistência técnica incluía verbos no imperativo: "elimine as pragas com métodos modernos. Use herbicidas", "Use fungicidas" etc. Ou seja, embora o INDAP tenha formado equipes orgânicas à pedagogia de Paulo Freire, coordenadas pelo próprio brasileiro e criadoras de materiais originais de ação cultural para reforma agrária, na sala ao lado do mesmo organismo o setor da assistência técnica não havia incorporado o método e se empenhava na missão da produtividade com materiais que evocavam a "educação bancária". 


\subsection{Paulo Freire na CORA: o assentamento como totalidade econômico-cultural}

\section{Os freirianos da CORA}

O funcionário da CORA Pablo Garrido foi coordenador do assentamento La Higuera, na província de Aconcágua (V região) e alfabetizador de camponeses durante vários anos: "a maior dívida do sistema do latifúndio com as pessoas que trabalhavam e entregavam sua vida ao trabalho foi, sem dúvida, a falta de educação", ${ }^{536}$ afirmou. "Uma das coisas que perguntávamos ao preparar as primeiras listas de futuros assentados era se sabiam ler e escrever. A resposta majoritária era 'não', que apenas sabiam desenhar sua assinatura... Mas queriam aprender? Sim, com certeza". ${ }^{537}$ Em 1966, Garrido foi aluno de um curso de capacitação no método psicossocial oferecido pela CORA e tornou-se admirador de Paulo Freire:

Tive a sorte de ser enviado a um curso de educação de adultos junto com um grupo de professores (...). Essa sorte se transformou em privilégio, pois tínhamos um professor que por essas coisas de ditadura no Brasil, chegou ao Chile para oferecer sua sabedoria. (...) Para mostrar e conversar sobre um método que era tremendamente perigoso para o regime. Era Paulo Freire, o grande educador brasileiro, criador do método psicossocial. ${ }^{538}$

Foram formados dois grupos de alfabetização no assentamento coordenado por Pablo. Ele ficou encarregado de um deles e a professora primária da escola local de outro. As sessões ocorriam durante a noite, depois das jornadas de trabalho: "os camponeses chegavam em silêncio e quase com vergonha. Escondiam debaixo das suas roupas os cadernos onde praticavam a escrita". 539 Pablo registrou em um livro de memórias o entusiasmo das sessões de decodificação:

A primeira surpresa para eles era que não começamos a ensinar o "P" com "A", "PA"... Penduramos uma grande cartolina com um desenho que representava uma tradicional COSECHA. Homens colhendo, outros carregando um caminhão em um pasto, outros vigiando o trabalho... (...) E começou a primeira aula! Pedi que me contassem: o que enxergam aí? Pouco a pouco todos participavam ativamente, descrevendo o que viam e se sentindo representados em alguns desenhos. (...) Falávamos do trabalho, dos salários, da propriedade da terra, das férias, da educação... de tudo. ${ }^{540}$

O caráter inovador da reforma agrária de 1967 demandou que a CORA formasse novas mentalidades entre seus funcionários com cursos de especialização. Entre 1965 e 1968, o ICIRA ofereceu 85 cursos para 2.192 alunos do pessoal da CORA. Em 1968, entre seus aproximados 1500 funcionários, 243 eram práticos agrícolas, 143 eram engenheiros, 60 eram advogados, 41 eram técnicos

\footnotetext{
${ }^{536}$ Zuñiga et al, 2008, p. 143-149.

537 Id. ibid.

538 Id. ibid.

539 Id. ibid.

${ }^{540}$ Id. ibid.
} 
agrícolas, mas somente 12 eram pedagogos, 18 assistentes sociais e 6 sociólogos. ${ }^{541}$ Além dos professores rurais, portanto, os técnicos e práticos também foram recrutados para as tarefas pedagógicas nos assentamentos.

A CORA era o organismo mais estratégico da reforma agrária chilena: exercia o poder expropriador, fundamentado em visitas de técnicos a haciendas e averiguação das causas legais, posteriormente ratificadas por seu Conselho, por meio de um Acordo de Expropriação embasado na lei 16.640, os valores da indenização ao proprietário e a nova divisão territorial entre assentamentos e reserva patronal (de até $80 \mathrm{HRB}$ ). Além disso, a CORA era corresponsável pelo bom funcionamento do setor reformado: formava a SARA, uma sociedade entre CORA e assentados, que alavancava o processo de reorganização produtiva; fornecia créditos, sementes e insumos para a produção no assentamento; além de ofertar assistência técnica e capacitação em uma escala exigente, que crescia junto com a superfície do setor reformado. As dificuldades de relação entre a CORA e os assentados eram representativas das contradições do processo de mudança estrutural da agricultura: a maior delas, como já mencionado anteriormente, era a confusão entre salário e anticipo (ou adelanto), isto é, a dificuldade dos assentados de aceitarem que o crédito oferecido pela CORA não era um salário, mas sim um empréstimo que precisava ser devolvido. ${ }^{542}$

Além de uma direção nacional centralizada, a CORA funcionava com base em uma estrutura descentralizada de Direções Zonais (abarcando duas a quatro províncias) e Chefaturas de Áreas (que atuavam no nível das comunas). Seus 11 Conselhos Zonais possuíam em média 7 supervisores, todos implicados nas mudanças econômico-culturais: de educação básica, de organizações camponesas, de cooperativas (em geral), das cooperativas da reforma agrária, de cooperativas regionais (de segundo grau), de organizações juvenis e da Central de Capacitação. ${ }^{543}$ Um organograma simplificado da estrutura da CORA mostra (abaixo) os segmentos encarregados da educação.

\footnotetext{
${ }^{541}$ Mario Perez Barraza, CORA: Informe de Práctica para Optar al título de técnico administrativo. Universidad de Chile: La Serena, 1969.

${ }^{542}$ No Diagnóstico de la reforma agraria chilena, Barraclough e Fernández contabilizaram que em 1971 somente $15 \%$ do crédito ao setor reformado retornou devidamente à CORA; e em 1972, o retorno melhorou para 40\% (Barraclough e Fernández, 1974: 47). Estudos da Universidade Católica demonstraram que $87 \%$ da renda dos assentados era composta pelo antecipo estatal e somente $13 \%$ decorria dos ganhos da produção. Criticaram esse procedimento com o termo "antecipo automático", que desvinculava a remuneração das horas realmente trabalhadas (Collarte e Pérez, s/f: 83).

${ }_{543}$ Id. ibid.
} 


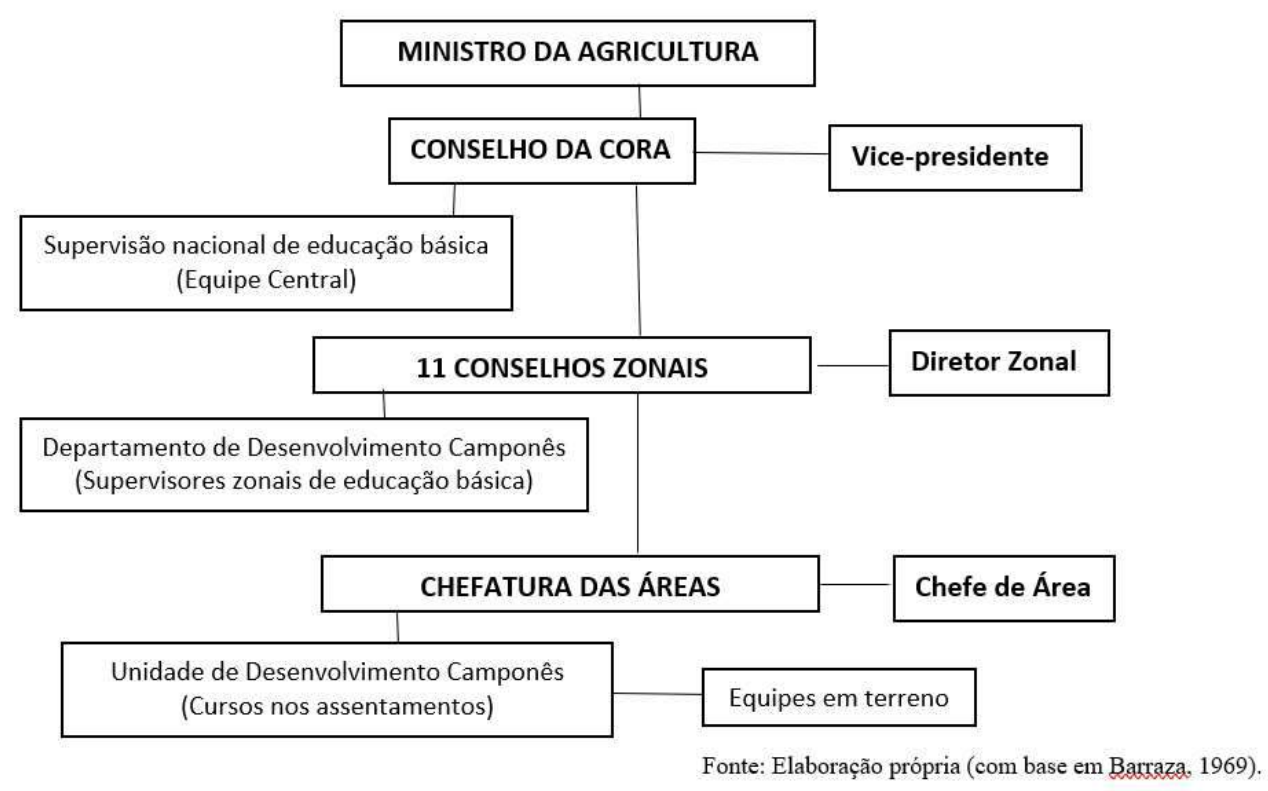

O nível da Área era estratégico, eram aqueles funcionários que garantiam o contato mais direto e constante com o campesinato. Marta Rodriguez Flores, secretária de área em Cauquenes, testemunhou: "minha função era bastante integral, pois a área estava formada pelo Chefe da Área e eu. Portanto, eu fazia trabalho no escritório e em terreno (...). Atendíamos o camponês a cavalo (...). Éramos jovens e tínhamos um ideal comum" (Zuñiga et al, 2008:180). O funcionário da CORA Aldo Zuñiga, da zona III, valorizava o trabalho tecido nas bases da reforma agrária: "quase silenciosamente mantínhamos a rede de contatos e serviços ao camponês e aos funcionários de terreno. $\mathrm{O}$ diretor zonal Gonzalo Puga sempre nos estimulava a comparecer aos atos de instalação do assentamento" (Zuñiga et al, 2008:174) contou.

Durante o governo Frei, cada assentamento garantiu um espaço apropriado para atividades educacionais: às vezes, uma escola local dentro da hacienda, que agora pertencia ao terreno do assentamento; às vezes uma sede social construída a partir da expropriação. O camponês Luis Enrique Aguillera, presidente do Comitê de Assentamento de Cuncumén, do Vale de Choapa, afirmava em 1965 que "os assentamentos camponeses se manterão como uma verdadeira escola de capacitação por dois anos, em casos excepcionais por três". ${ }^{544}$ Nesse mesmo sentido, Paulo Freire ocupou-se em formular sobre a importância do assentamento como totalidade econômica e cultural, como um laboratório pedagógico para prática da liberdade.

"O assentamento aparece, na reforma agrária chilena, como o lugar onde se deve verificar a mudança de seu estado [do camponês] de objeto ao de sujeito. Esta passagem, que não se verificaria sem a transformação estrutural, exige, contudo, algo mais", escreveu Paulo Freire em 1968: ${ }^{545}$ "exige o estabelecimento de uma relação eminentemente dialógica (...) entre quem detêm o poder político, sem

\footnotetext{
${ }^{544}$ CORA, Asentamientos de la reforma agraria, una realidad. Santiago, s/d.

${ }^{545}$ Paulo Freire, Algunas sugerencias en torno de una labor educativa que vea el asentamiento como una totalidad. Santiago: ICIRA (mimeo.), 1968b.
} 
o qual não se faria a reforma agrária, e os camponeses". Apesar de Paulo Freire não haver trabalhado diretamente na CORA, foram muitas as marcas deixadas pelo seu método na atuação do órgão durante aqueles anos. Em 1965, foi criado o Departamento de Desenvolvimento Camponês da CORA, que se encarregou da tarefa da capacitação, organizada em quatro ramos: primeiro, a "capacitação técnica, agrícola e empresarial", com a função de garantir o aumento da produtividade no setor reformado; segundo, a "capacitação organizacional”, com objetivo de estabelecer as instâncias de direção e decisão e tornar o assentamento eficiente em termos administrativos; terceiro, a "educação familiar", que misturava diretrizes de educação moral, higiene, práticas no huerto e indústria caseira, em geral focalizada às mulheres; e quarto, um ramo de "educação básica" (que no INDAP foi chamada "capacitação social"), para "proporcionar ao camponês beneficiário da reforma os conteúdos instrumentais necessários que lhe permitam ter uma base fundamental de conhecimentos para se incorporar melhor à capacitação técnico-empresarial e organizacional (...). A educação básica abre o mundo da cultura letrada aos analfabetos", ${ }^{546}$ explicou Darío Salas, supervisor nacional de educação básica da CORA.

O segmento de educação da CORA que incorporou o método psicossocial com maior organicidade estava formado pelos 3 Supervisores Nacionais de Educação Básica (Darío Salas, María Antonieta Saa e Julio Salgado) e por 9 equipes zonais, compostas por 22 coordenadores que atuavam espalhados pelo país. ${ }^{547}$ As zonas IV e V, que coincidiam com o território do Vale Central, tinham as maiores equipes zonais de educação básica. Não custa lembrar que as regras de expropriação da lei 16.640 estavam calibradas para esse território, que os Hectares de Riego Básico (HRB) eram uma unidade de medida funcional para fertilidade do Vale Central, onde mais assentamentos foram formados durante o governo de Eduardo Frei (sendo disfuncional para territórios da Araucanía, por exemplo).

Darío Salas defendia que a CORA tinha a missão de permitir ao camponês "não apenas adquirir a técnica em função de seu papel de empresário agrícola, mas também adquirir uma nova mentalidade e um sentido solidário perante a comunidade e o país". ${ }^{548}$ A missão educacional da CORA, portanto, era tão estratégica para a transformação estrutural, quanto o processo expropriador e reorganização produtiva do trabalho. Da missão educacional dependia a coesão subjetiva indispensável ao êxito econômico da nova agricultura. Assim como no INDAP, muitos coordenadores de educação da CORA foram recrutados do IER, entre eles Elba Bruna, Rogelio Correa e Julio Salgado. "Em 1965, sai direto do IER para CORA", 549 nos contou Correa:

\footnotetext{
546 Darío Salas, Informe del programa de educación básica. In: Paulo Freire, Alfabetización Funcional en Chile. Informe UNESCO, op. cit., p. 37.

547 Os supervisores zonais de educação básica da CORA eram: I Zona: Enrique Soto; II Zona: Raúl Arancíbia; III Zona: Barbara Larraín, Patrício Hernandez, María Rojas; IV Zona: Paz Goycolea, Juana Aravena Vargas, Enriqueta Jerez, Helia Espinoza, Emma Luisa Riveros; V Zona: Miguel Valladares, Elba Bruna, María Eugenia Contreras, Mónica Betancourt, Clarisa Valdés; VI Zona: Reinaldo Guerrero, Christian Castro, Julio Ibsen; VII Zona: Ricardo Alvarado; VIII Zona: Aníbal Veneciano; IX Zona: Oscar Belmar. (Paulo Freire, Alfabetización Funcional en Chile. Informe UNESCO, op. cit., p. 53. ${ }^{548}$ Darío Salas, op. cit., p.36.

${ }^{549}$ Entrevista com Rogelio Correa, Santiago, 30/05/2019.
} 
Fui despedido do IER (...) e convidado a trabalhar na CORA em razão da minha experiência com os camponeses, sobretudo em capacitação e formação (...). Meu primeiro trabalho foi ajudar a preparar e formar os funcionários que seriam chefes de assentamento da reforma agrária, em geral, técnicos agrícolas, os prácticos (...). Mas também se incorporam na mesma equipe assistentes sociais, trabalhadores sociais, estudantes que fazem seus estágios nos assentamentos, os próprios engenheiros agrônomos, toda essa gente precisava ser capacitada (...). A principal dificuldade, um ponto de conflito entre os formadores sociais (nós) e os técnicos, era convencê-los do protagonismo camponês. Eles eram protagonistas, mas assumir isso na prática significa que os técnicos devem consultá-los, partir daquilo que [os camponeses] sabem, não devem se impor, nem se converter em uma autoridade, em um outro patrão. Isso foi muito difícil. E Paulo Freire aconselhava: "vocês estão tratando o camponês como se fosse da vanguarda (...). Mas esse camponês ainda tem vivo o patrão dentro da sua consciência". Era o espectro, dizia Paulo. O patrão estava vivo na sua espiritualidade (...). "Portanto", aconselhava, "ele necessita do patrão. E como necessita, e vocês o eliminaram, já não existe patrão, ele que terá que ser o patrão de vocês, ou o dirigente". 550

A ausência abrupta de um comando patronal e a inversão de hierarquias sociais da hacienda ao assentamento mostrava que, naquele contexto específico, a transformação do regime de propriedades era uma operação mais ágil que a transformação cultural. As subjetividades camponesas, contudo, eram estruturantes do cotidiano do trabalho e consequentemente implicadas na capacidade de mudança econômica. Nesse sentido, o trabalho pedagógico da CORA era diretamente produtivo e atuava simultaneamente sobre as formas de conhecer, sentir e produzir dos assentados. Em outras palavras, se todo processo de trabalho se sustenta em uma economia moral, era preciso que a CORA atuasse pedagogicamente em prol de uma economia moral que promovesse a forma de propriedade assentamento, desenvolvendo o sentimento de corresponsabilidade dos assentados sobre o novo processo de trabalho. A prática de assembleias decisórias de assentados, por exemplo, inaugurava a necessidade de uma nova cultura política entre os ex-inquilinos, que pouco a pouco deveriam desenvolver um cotidiano baseado em instâncias de decisão totalmente coletivas, o exato oposto do que até ali experimentavam na sua condição social subordinada à ordem de um patrão. "O processo de conversão do dominado em protagonista é muito lento", 551 explicou o professor Correa.

Esse desafio foi encarado com entusiasmo pelos "freirianos da CORA". Em entrevista a Zubicueta, Julio Salgado recordou seus anos como supervisor da educação básica da CORA:

Foi um cargo que gostei muito. (...) Eu tinha que percorrer todo o Chile, onde houvesse um assentamento, era preciso organizar, buscar professores, preparar metodologias básicas. No começo, usamos material já existente, como o Silabário. $\mathrm{Eu}$ já tinha experiência em preparar camponeses nesta área (...). Mas estava interessado em criar um vínculo com o Mineduc para conseguir a validação dos cursos que estávamos oferecendo nos assentamentos. E Waldemar [Cortés Carabantes] me apresentou Paulo Freire (Salgado apud Zubicueta, 2019: 103).

\footnotetext{
${ }^{550}$ Idem.

${ }^{551}$ Id. ibid.
} 
Antes de ser contratado pela CORA, Salgado havia sido professor de espanhol em Curacaví e Talca. O Silabario ao qual se referiu era o material alfabetizador convencional usado no Chile desde 1942, inspirado na pedagogia de John Dewey, que exerceu forte influência entre educadores chilenos desde os anos 1930. O Silabario possuía uma versão urbana (Mi tesoro) e uma versão rural (Mi Tierra) e seu uso na alfabetização de adultos só foi substituído com a presença de Paulo Freire no país. ${ }^{52} \mathrm{O}$ material deweyano dos anos 1940 foi diretamente criticado por Freire em seu relatório à Unesco: “o Silabário é um instrumento que satisfaz a concepção antidialógica da educação", 553 escreveu. O método psicossocial substituía os silabários pela ficha da descoberta, buscando despertar no educando um sujeito criador.

\section{Alfabetização nos assentamentos}

Em 1965, a CORA assinou um convênio com o Mineduc, que passou a validar os cursos oferecidos nos assentamentos e compartilhar a autoria de materiais para camponeses. O convênio CORA-Mineduc estava diretamente vinculado ao método de Paulo Freire e abarcou $56 \%$ de todos os camponeses e funcionários capacitados pela corporação entre 1965 e 1969, como mostra a tabela 12 a seguir.

\begin{tabular}{|c|c|c|}
\hline \multicolumn{3}{|c|}{ Tabela 12 - Convênios entre CORA e instituições para capacitação camponesa (1965-1970) } \\
\hline Instituição & Alunos (1965-1969) & Programa 1970 \\
\hline CORA - ICIRA & $\begin{array}{l}1.840 \text { dirigentes camponeses; } \\
1.947 \text { funcionários da CORA }\end{array}$ & $\begin{array}{ll}11.380 \text { camponeses em alfabetização; } & 831 \\
\text { em capacitação cooperativa; } & 57 \\
\text { funcionários da CORA. }\end{array}$ \\
\hline CORA - INACAP & 105 instrutores; 5.000 assentados & 4.500 assentados \\
\hline CORA - SAG & 1.800 assentados & 8.000 camponeses \\
\hline CORA - IER & $\begin{array}{lllll}\text { Entre } 575 & \text { (a) } & \text { e } & 3.126 & \text { (b) } \\
\text { assentados }\end{array}$ & Sem convênio \\
\hline CORA - MINEDUC & $\begin{array}{l}11.089 \text { alfabetizados (nível 1); } \\
4.412 \text { educação básica (nível 2) }\end{array}$ & Alfabetização com ICIRA \\
\hline CORA diretamente & $\begin{array}{l}1.020 \text { camponeses em educação } \\
\text { básica até } 1966\end{array}$ & Só convênios \\
\hline te: CORA, Reforma & chilena, 1965-1970. Santiago, 1970: 57. & ode septiembre de 1968: 73. \\
\hline
\end{tabular}

A partir de 1970, o convênio de alfabetização camponesa da CORA foi transferido do Mineduc para o ICIRA, junto com a meta de, em um único ano, alfabetizar a mesma quantidade de 11 mil

\footnotetext{
552 Segundo Rodrigo Mayorga, no silabário de 1942 três novidades representavam uma proposta que à época era considerada reformista: 1) a presença de uma ideologia higienista e patriótica, associando temas morais com o comportamento higiênico e exaltando a nação; 2) a condução da criança para sentir-se em harmonia com a realidade, com exemplos da vida campesina, do trabalho, das relações rurais; e 3) o deslocamento da centralidade do conteúdo para o protagonismo do professor, sendo dois terços do livro composto por sugestões. O problema, afirma o autor, é que a precariedade da escola rural era incompatível com o método. Circulares do Mineduc de 1931 e 1951 constatavam precariedades idênticas: falta de mobília, escassez de materiais, professores sem diploma e falta de professores. Nesse cenário, deslocar a centralidade do livro para o professor era ou idealismo ou estrangeirismo (Mayorga, 2018: 245-250).

${ }^{553}$ Paulo Freire, Alfabetización Funcional en Chile. Informe UNESCO, op. cit.,p. 25-26).
} 
camponeses que o convênio CORA-Mineduc havia feito em cinco. O Convênio CORA-IER também foi desfeito em 1970, em contraponto com a abertura de 8 mil vagas no Servicio Agrícola Ganadero (SAG). É possível que tais mudanças tivessem relação com as eleições.

O Convênio CORA-Mineduc estava baseado especificamente no método psicossocial de alfabetização, mas também incluía cursos de artesanato do lar (costura, cabelereiro, eletricidade, folclore). Muitos dos educadores contratados nas bases da CORA eram professores primários rurais, "capacitados no método psicossocial do sr. Paulo Freire e nas técnicas correspondentes", ${ }^{554}$ reportou Darío Salas. Contudo, "se elaborou um material didático muito rudimentar", ${ }^{555}$ considerando a opção governamental de centrar forças na mobilização humana. Em 1968, o convênio CORA-Mineduc nos assentamentos havia adquirido a escala de 252 cursos de pós-alfabetização no nível 1, com 2.357 alunos; 166 cursos de pós-alfabetização no nível 2, com 1.516 alunos; um total de 306 profissionais educadores capacitados no método psicossocial (sendo 184 professores rurais), junto com 52 camponeses que se tornaram alfabetizadores. ${ }^{556}$

Como supervisor de educação básica da CORA, Julio Salgado passou a viajar com Paulo Freire pelos assentamentos chilenos em diferentes partes do país. Uma anedota contada por Freire em Pedagogia da esperança ilustrou uma dessas incursões do brasileiro en terreno. Constantemente, ao visitar assentamentos, Freire permanecia silencioso e observador, concentrando seu esforço de diálogo junto aos funcionários e não aos camponeses (tanto por sua condição de exilado, como pela barreira do idioma). Mas dessa vez, abriu uma exceção. Foi "uma visita que fiz com um companheiro chileno a um assentamento de reforma agrária algumas horas distante de Santiago", escreveu Freire. O companheiro era Julio Salgado. ${ }^{557}$ Freire seguiu:

Funcionavam à tardinha vários círculos de cultura e fomos para acompanhar (...). No segundo ou terceiro círculo a que chegamos, senti um forte desejo de tentar um diálogo com o grupo de camponeses. De modo geral, evitava fazê-lo por causa da língua. Temia que meu "castanhês" prejudicasse o bom andamento dos trabalhos. Naquela tarde resolvi deixar de lado a preocupação e, pedindo licença ao educador que coordenava a discussão do grupo, perguntei se aceitavam uma conversa comigo. (...) Começamos um diálogo vivo, com perguntas e respostas de mim e deles a que, porém, se seguiu rápido um silêncio desconcertante.

Eu também fiquei silencioso. Dentro do silêncio, recordava experiências anteriores no Nordeste brasileiro e adivinhava o que aconteceria. Eu sabia e esperava que de repente um deles, rompendo o silêncio, falaria em seu nome e no de seus companheiros. Eu sabia até o teor de seu discurso. (...)

"Desculpe, senhor", disse um deles, "que estivéssemos falando. O senhor é que podia falar porque o senhor é o que sabe. Nós, não.” (...)

"Muito bem", disse em resposta à intervenção do camponês. "Aceito que eu sei e vocês não sabem. De qualquer forma gostaria de lhes propor um jogo que, para funcionar bem, exige de nós absoluta lealdade. Vou dividir o quadro-negro em dois pedaços, em que irei registrando, do meu lado e do lado de vocês, os gols que faremos eu em vocês; vocês em mim. O jogo consiste em cada um perguntar algo

\footnotetext{
${ }^{554}$ Darío Salas, op. cit., p. 38.

${ }_{555}^{55}$ Idem.

${ }^{556}$ Id. ibid..

${ }^{557}$ A anedota foi lembrada por Salgado em entrevista para Zubicueta (2019: 103).
} 
ao outro. Se o perguntado não sabe responder, é gol do perguntador. Começarei o jogo fazendo uma primeira pergunta a vocês". A essa altura, precisamente porque assumira o 'momento' do grupo, o clima era mais vivo do que quando começamos, antes do silêncio.

Primeira pergunta:

- O que significa a maiêutica socrática?

Gargalhada geral e eu registrei o meu primeiro gol.

- Agora cabe a vocês fazer a pergunta a mim - disse.

Houve uns cochichos e um deles lançou a questão:

- Que é curva de nível?

Não soube responder. Registrei um a um.

- Qual a importância de Hegel no pensamento de Marx?

Dois a um.

- Para que serve a calagem do solo?

Dois a dois.

- Que é verbo intransitivo?

Três a dois.

- Que relação há entre curva de nível e erosão?

Três a Três.

- Que significa epistemologia?

Quatro a três.

- O que é adubação verde?

Quatro a quatro. Assim sucessivamente, até chegarmos a dez a dez.

Ao me despedir deles fiz uma sugestão: "Pensem no que houve essa tarde aqui. Vocês começaram discutindo muito bem comigo. Em certo momento ficaram silenciosos e disseram que só eu poderia falar porque só eu sabia e vocês não. Eu sabia dez coisas que vocês não sabiam e vocês sabiam dez coisas que eu não sabia. Pensem sobre isso (Freire, 2010: 63-64; 66-67).

A descontração e a leveza com a qual Freire desconstruiu hierarquias e demonstrou sua tese, de que não havia ignorância absoluta, nem tampouco sabedoria absoluta, se colocando ele mesmo como um "relativo ignorante" em questões camponesas, fascinou os educadores chilenos que com ele conviveram. "Foi muito impressionante para mim, o reconhecimento dos valores, da cultura, dos conhecimentos. Para eliminar a ideia de que [os assentados] eram ignorantes", recordou Julio Salgado (apud Zubicueta, 2019: 103). Essa mesma hierarquia era reforçada por alguns professores de escolas rurais que, habituados com aulas para crianças, tratavam analfabetos de maneira infantilizada. Esse problema foi constatado por Darío Salas: "por atender às crianças, não conseguem ter uma atitude diferente com os adultos, que seguiram tratando como crianças. Ademais, não estavam compenetrados na nova realidade vivida no assentamento". ${ }^{558}$ Para o supervisor da CORA, essa atitude criava um "grave perigo de invasão cultural" e deveria ser rapidamente corrigida com a abertura de contratação de alfabetizadores camponeses que, com um "mundo cultural comum, podia compreender melhor sua linguagem e proporcionar o manejo das técnicas (...) de uma maneira mais horizontal". ${ }^{559}$ Essa proposta

${ }^{558}$ Darío Salas, Informe del programa de educación básica. In: Paulo Freire, Alfabetización Funcional en Chile. Informe UNESCO, op. cit., p. 38.

${ }^{559}$ Idem. 
foi desenvolvida particularmente bem na Zona IV, mas antes de narrar esse caso, vale mostrar quais eram as palavras geradoras da CORA e suas imagens.

A CORA aproveitava o La Raiz y La Espiga do Mineduc, mas também produziu suas próprias palavras geradoras e lâminas de desenhos. Entre as 17 palavras geradoras escolhidas pela CORA para seus cursos de alfabetização seis coincidiam com as palavras do Mineduc e outras onze foram determinadas pela Equipe Central (sem investigação temática). Na ordem em que apareciam no Guia para el alfabetizador produzido pela equipe da Zona VII, Maule-Linares, as palavras eram: cosecha, cocina, vacuna, arado, escuela, família, ambulancia, compañero, gallina, riqueza, herramientas, gobierno, yugo, guitarra, patrones, bicicleta e trabajo. ${ }^{560}$ O Guía orientava aos educadores: "existem três valores fundamentais sobre os quais é necessário tornar os participantes conscientes: 1) domínio da natureza; 2) sentido comunitário; 3) projeção para o futuro". ${ }^{561}$ A seguir, é possível observar as lâminas das palavras geradoras produzidas pela CORA para seus cursos de alfabetização nos assentamentos. ${ }^{562}$
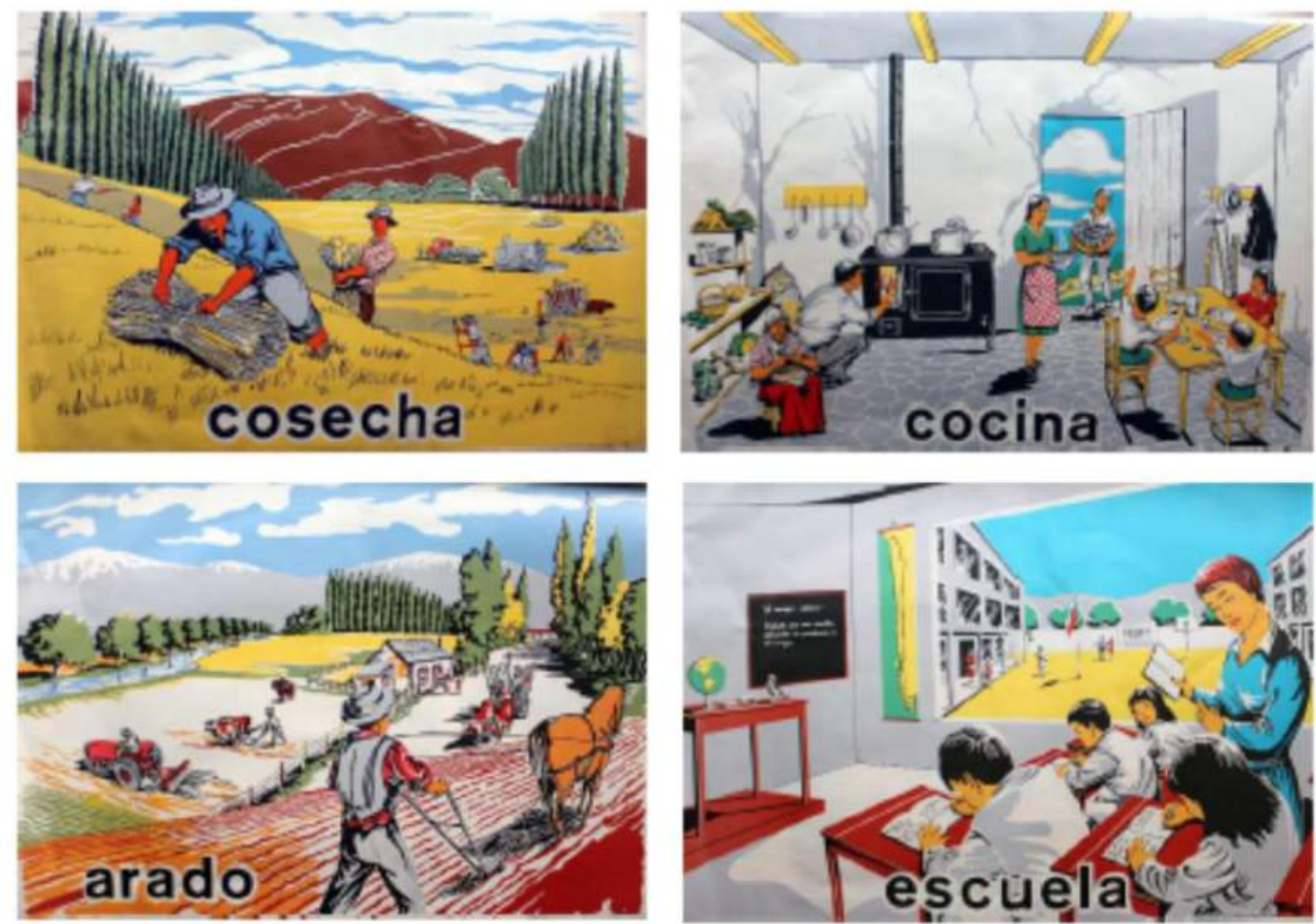

\footnotetext{
${ }^{560}$ CORA, Guía del Alfabetizador según Método Psicosocial de Paulo Freire. CORA VII Zona, Maule-Linares, 1970.

${ }^{561}$ Idem, p. 3.

${ }^{562}$ As imagens estão no Arquivo da Casa Museo Eduardo Frei Montalva. O material foi encontrado originalmente por Daniela Zubicueta (2019: 110-111), publicados em sua dissertação de mestrado na USACH. Agradeço a autora por compartilhar a descoberta.
} 

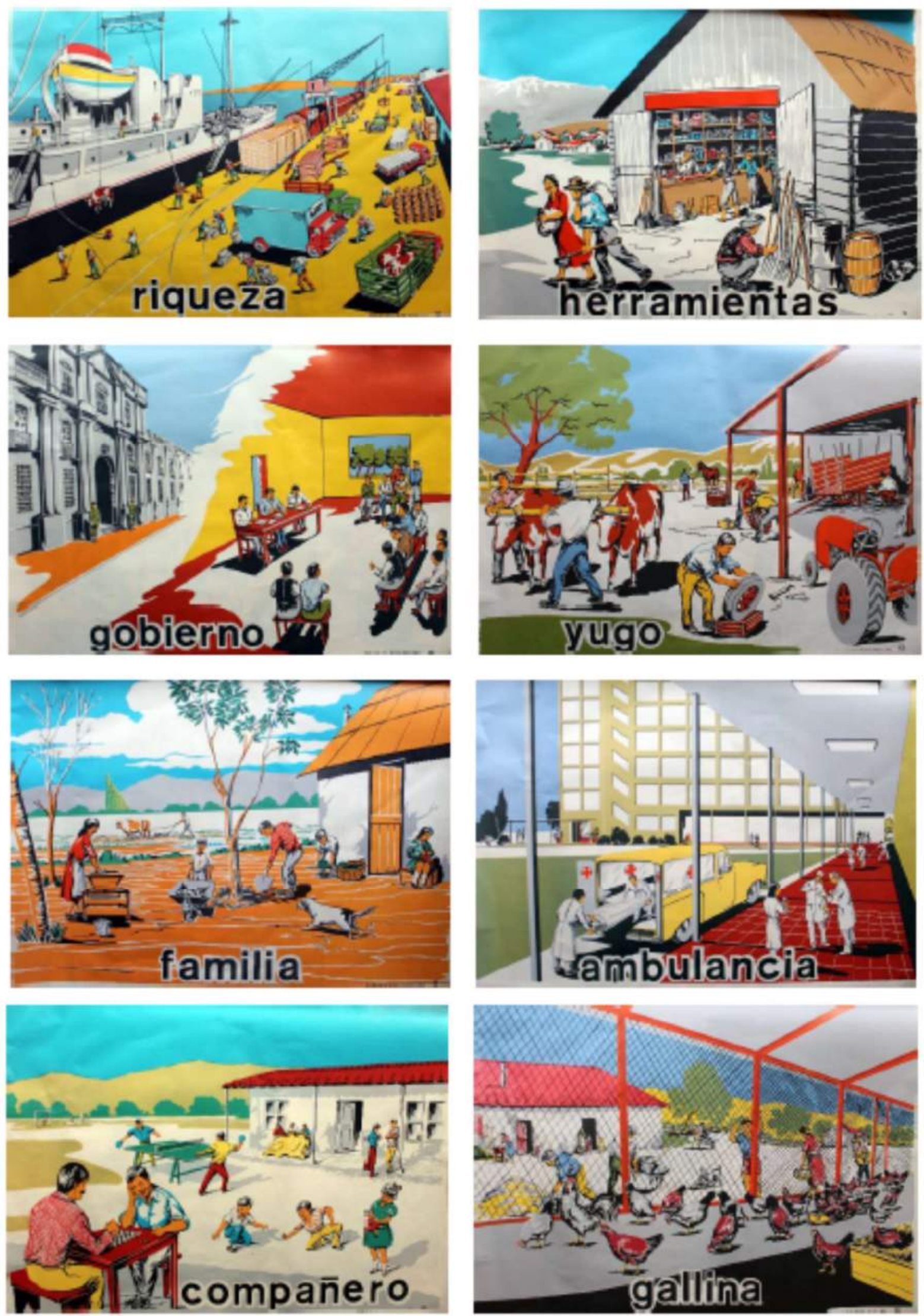

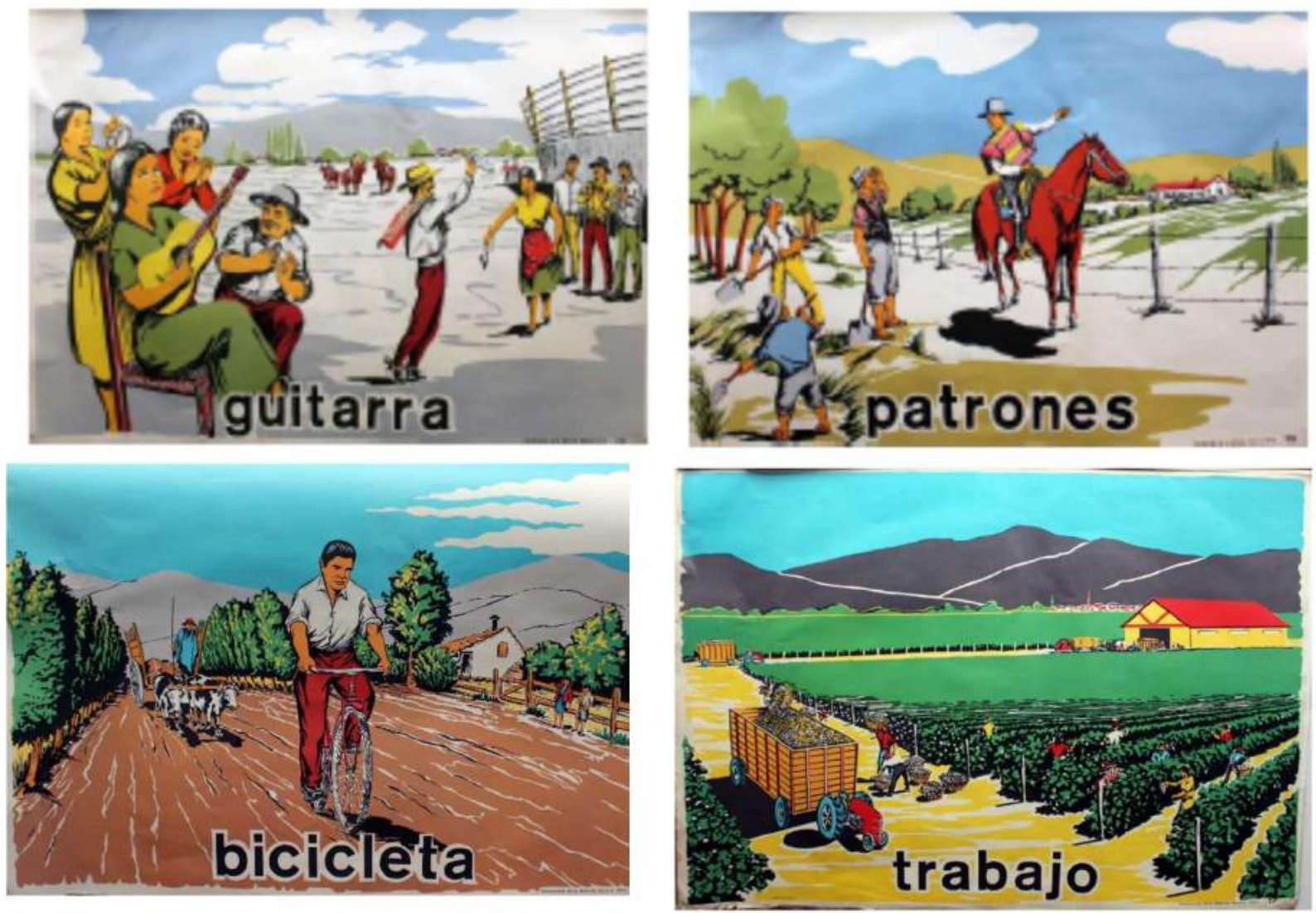

Observando as imagens das palavras geradoras da CORA, chama atenção em primeiro lugar sua principal característica comum: a presença invariável do convívio social e do trabalho comunitário. É possível dizer que todas as imagens da CORA apontavam para uma ontologia coletivista e afirmavam o caráter intrinsecamente social da existência humana. Na cosecha ou na cocina, na produção agrícola ou na reprodução da vida, as palavras eram representadas por cenas de convívio harmônico, que poderiam ser desdobradas em debates nos círculos de alfabetização que tratassem, por exemplo, da divisão do trabalho, das tarefas de cada um na sociedade, das vantagens (e desvantagens) da vida comunitária, das formas moralmente apropriadas de convívio, da reforma agrária e da vida coletiva no assentamento, entre outros. Ao mesmo tempo, um segundo aspecto que se destaca é que nas ilustrações de arado, yugo herramienta e cosecha, as ferramentas de trabalho motorizadas ou de tração animal apareciam como peças complementares da produção, e não contraditórias; como se a técnica moderna encontrasse paz e sintonia com a rusticidade dos métodos tradicionais da agricultura camponesa. Sugere-se imageticamente que não haveria conflito entre técnicas de produção, mas sim uma continuidade natural.

Um terceiro elemento que se nota é que a palavra compañero aparecia relacionada à ludicidade, aos jogos, ao tempo livre e ao divertimento, diferente do material do Mineduc, em que compañero 
remetia a trabalho e sindicalismo. Seguia-se a ênfase na importância da comunidade para reprodução da vida. Em quarto lugar, chama atenção que a lâmina patrones além de ser uma das poucas palavras no plural, não parecia evocar a realidade da hacienda ou do poder patronal da estrutura agrária latifúndio-minifúndio. Embora o homem a cavalo possa ser interpretado como um mayordomo (capataz), seu gesto não é de comando ou ordem, mas de sinalização e informação. Talvez o plural patrones, junto com a serenidade comunicada pelo desenho, pudesse abrir o debate sobre a nova estrutura, isto é, os "novos patrões" representados pelos próprios assentados.

A beleza do convívio, a serenidade do trabalho coletivo e a harmonia das técnicas modernas e tradicionais transmitidas pelas imagens da CORA sinalizavam também para uma importante ausência: nenhuma das cenas evocava conflito ou tensão. Por trás das comunidades rurais pacíficas das ilustrações, é possível adivinhar uma agenda reformista que enaltecia o caráter pacato do desenvolvimento, e se esquivava dos conflitos de classe inerentes à reforma agrária e as contradições geradas pelas mudanças técnicas. O contexto rural no qual se produzia a narrativa pacífica das imagens da CORA, entretanto, era de acirramento do conflito. Entre 1960 e 1966, o ciclo crescente de lutas camponesas acumulava um total de 1.001 pliegos de peticiones ( $74 \%$ das petições feitas por inquilinos por mais terras de regalia); os sindicatos camponeses com personalidade jurídica saltaram de 17 para 169; foram realizadas 826 greves camponesas ( $73 \%$ delas com causas salariais); e 22 tomas (Affonso et al, tomo 2, 1970: 21, 36, 58, 133). O material da CORA, portanto, sublimava a tensão social do campo que desembocou na reforma agrária de 1967 e que seguia crescendo exponencialmente rumo às eleições de 1970.

\section{Camponeses professores: autocapacitação como hipótese}

A interação pedagógica efetivamente ocorrida com os materiais da CORA nos territórios, porém, poderia ser das mais diversas. A supervisora zonal Juana Aravena Vargas contou sobre sua experiência em um assentamento da comuna de Lampa, por exemplo, onde coordenou um curso de alfabetização com 50 camponeses provenientes de vários assentamentos. $\mathrm{O}$ curso exigia dedicação integral dos assentados, com aulas das $8 \mathrm{~h}$ às $12 \mathrm{~h} 30$ e depois das $16 \mathrm{~h}$ às $19 \mathrm{~h}$. Os camponeses que participaram, segundo reportou Vargas, atravessaram uma experiência transformadora. "Antes estávamos cegos, agora a venda dos nossos olhos caiu", disse um deles. ${ }^{563}$ "Eu vim somente aprender a assinar, nunca acreditei que pudesse ler na minha idade", confessou um senhor. "Estamos cansados, nos doí a cabeça, mas não queremos ir embora sem aprender a ler e escrever", explicou outro. "O lápis é mais pesado que a enxada, mas nós nos esforçamos de qualquer forma" e "Já não seremos um peso morto no assentamento", ${ }^{564}$ comentaram.

\footnotetext{
563 Juana Aravena Vargas, Algunas experiencias en la supervisión de educación básica. In: Paulo Freire, Alfabetización Funcional en Chile. Informe UNESCO, op. cit., p. 42.

${ }^{564}$ Id. ibid.
} 
A escuta dos camponeses feita pela educadora Juana Vargas, da CORA, deu origem ao que ela chamou de Projeto de Autocapacitação como Hipótese, um experimento pedagógico estabelecido na IV zona (ao norte de Santiago), que tinha um precedente bem-sucedido em Curicó, sob supervisão de Cristian Castro. Em Lampa, Juana Vargas havia constatado um problema: os camponeses não se sentiam à vontade diante dos professores, nem estabeleciam com eles vínculos horizontais de confiança: "temos vergonha do professor", "não confiamos no professor", "ele não nos entende”, "ele vem na hora que estamos trabalhando", foi algumas dos incômodos expressados pelos assentados de Lampa, registradas por Vargas. Para dirimir essa dificuldade, Vargas criou uma estratégia de formação de camponeses-professores, que começava com uma eleição direta: os alfabetizandos do assentamento passaram a eleger seus professores entre camponeses que tinham concluído do $3^{\circ}$ ao $6^{\circ}$ ano da escola secundária. Depois de eleitos, esses camponeses com mais estudo que aceitassem a tarefa eram capacitados com o método psicossocial e se tornavam professores de grupos de 2 a 10 alunos. ${ }^{565} \mathrm{O}$ Projeto de Autocapacitação como Hipótese foi debatido no conselho do assentamento em Lampa, no qual os assentados sugeriram linhas programáticas: "foram os conselhos [de assentamento] que, em seu mundo, em seu valor, conseguiram refletir com o grupo e realizar a alfabetização entre eles, ou seja, "quem sabe ensina a quem não sabe", ${ }^{566}$ relatou Vargas, reproduzindo a consigna criada pelos próprios camponeses. "Sendo o processo de reforma agrária um processo de autogestão, a alfabetização deveria seguir a mesma linha", ${ }^{567}$ defendeu. Sua meta era criar, com apoio da CORA, brigadas de "camponeses que se autodenominem professores", considerando ainda que "essa experiência pode abrir um novo caminho para alfabetização. (...) São reencontros consigo mesmo; é descobrir novas energias, caminhos antes desconhecidos. É tudo maravilhoso", concluía entusiasmada a supervisora zonal. O passo seguinte, nesse novo caminho, era aplicar o sistema de alfabetização por autogestão ou autocapacitação como hipótese com ajuda das organizações sindicais em outros assentamentos de Lampa, Colina e Quillicura.

Julio Salgado, por outro lado, reportou algumas inquietações. Salgado havia expandido a formação de camponeses alfabetizadores em um curso exitoso sobre o método psicossocial com 56 alunos de diferentes assentamentos de Lampa. Em relatório para Unesco, contudo, ele explicou que teve dificuldades de aplicar a formação em outros locais, porque a comunicação entre formadores e camponeses parecia desimplicada e distante. Para compreender o problema, Salgado resolveu conversar com os camponeses-professores formados no curso de chefes de assentamento de Lampa: todos com $4^{\circ}$ ou $5^{\circ}$ ano da escola secundária. No relatório, lembrou a resposta que recebeu de alguns desses camponeses, que explicava a distância cultural entre os técnicos da CORA e seus pares de outros assentamentos. Dos camponeses professores de Lampa, Salgado escutou algo assim:

A razão [para as dificuldades] é que vocês, funcionários, estão em um mundo distinto do nosso e não conseguem se comunicar conosco porque pertencem a outra

\footnotetext{
565 Idem, p. 46-47.

${ }^{566}$ Id. ibid.

${ }^{567}$ Id. ibid., p. 45
} 
cultura. Os companheiros podem dizer a vocês que está muito bem, mas seguirão pensando outra coisa. O único que alcança o camponês é o próprio camponês, que entende sua linguagem e que pode servir de intérprete entre vocês e esse mundo particular do analfabeto. Por isso, o melhor é que os companheiros [assentados de outras comunas] venham ver o que nós fizemos [em Lampa], ou nós irmos para lá contar. Nós, que já entendemos a importância de que o camponês abra os olhos, temos uma responsabilidade muito grande perante o país e nossos companheiros. ${ }^{568}$

Salgado conversou com a supervisora zonal de Quillota (a $150 \mathrm{~km}$ de Santiago) e colocou em prática as duas sugestões recebidas. Primeiro, dirigentes de assentamentos de Quillota visitaram Lampa. O encontro, presenciado por Salgado, tinha mais de 40 pessoas, sendo cinco camponeses-professores, um grupo de camponeses alfabetizandos de Quillota e toda direção do assentamento de Lampa, junto com a supervisora da CORA. "Naquela ocasião, assisti à melhor demonstração de descodificação de uma lâmina (feita por uma camponesa, Eufrosina Sarmiento) e a uma discussão muito interessante sobre a importância da alfabetização", relatou. "O curioso é que eles prescindiram totalmente de nós, os técnicos em alfabetização, e expressaram suas próprias convicções. Nossa intervenção seria excessiva: eles já sabiam o que deviam fazer". Julio Salgado se viu diante da entrega do papel de alfabetizador para o próprio campesinato, passando a apostar com otimismo na auto-alfabetização camponesa. $\mathrm{O}$ Projeto Autocapacitação como Hipótese parecia ser reproduzível em outras comunas e zonas, o que de fato já estava acontecendo. Salgado prosseguiu o relato:

Três semanas depois, pedi a camponeses de San Felipe (também ao norte de Santiago), que me contassem como haviam realizado sua própria alfabetização. Eles se prepararam e me expuseram, com lâminas e com uma linguagem cheia de imagens e exemplos de experiência. Empregaram técnicas pedagógicas que só um especialista conhece: demonstração de métodos, demonstração de resultados, descodificação, problematização... O camponês, quando não duvida, é um pedagogo nato. (...). Sua linguagem vai menos para a conceitualização e mais para os exemplos concretos. Já não cabia dúvida de que se podia confiar plenamente no camponês alfabetizador (...). Terminada a exposição, prescindiram de nossa qualidade de supervisores de alfabetização e só perguntaram aos seus companheiros sobre as dificuldades de aprendizagem que eles tiveram. ${ }^{569}$

Na mesma direção, estava a proposta de Paulo Freire sobre a produção de textos de autoria camponesa para pós-alfabetização de camponeses, que considerava mais adequados e eficientes do que textos "de escritório", tais como havia produzido o Mineduc em seus materiais La Raiz y La Espiga para nível 1 e 2. Em 1968, o brasileiro escreveu o ensaio Los campesinos también pueden ser los autores de sus propios textos de lectura, argumentando em defesa do "aproveitamento dos redigidos pelos camponeses" para que fossem usados como material de pós-alfabetização. Para produzi-los, os educadores precisariam estar permanentemente atentos às formas de registro da voz camponesa. "Os

\footnotetext{
${ }^{568}$ Fala camponesa lembrada de memória por Julio Salgado, em seu relatório sem título dentro de Paulo Freire, Alfabetización Funcional en Chile. Informe UNESCO, op. cit., p. 51.

${ }^{569}$ Idem, p. 52.
} 
educadores devem aproveitar toda oportunidade para estimular os camponeses a que exponham suas observações, suas dúvidas, suas críticas", pontuou Freire:

Durante a discussão de uma situação problemática - codificação - os educadores devem solicitar aos camponeses que redijam, primeiramente no quadro-negro, depois, numa folha de papel, suas observações - uma simples frase, não importa. Estes dois momentos da redação têm objetivos distintos. O primeiro tem por finalidade propor ao grupo a discussão do conteúdo do texto redigido por um de seus companheiros. (...) O segundo, no qual o educando redige seu pequeno texto numa folha de papel, tem como fim seu aproveitamento posterior numa espécie de antologia de textos camponeses a ser organizada pela Equipe Central, com a participação de educadores de base e, também, de alguns camponeses. Antologia não somente de textos dos participantes do Centro de Educação de um assentamento, mas dos participantes dos Centros de todos os assentamentos de uma zona ${ }^{570}$ (Freire, 1981: 22).

Aderindo à sugestão, Darío Salas, supervisor de educação da Equipe Central da CORA, reportou que "em algumas zonas, se recolheu material escrito pelos próprios camponeses e que servirá para confeccionar um livro de leitura". ${ }^{571}$ Embora essa proposta diferisse consideravelmente dos livros de pós-alfabetização do Mineduc, estes seguiriam sendo utilizados pela CORA, e não foi possível encontrar nos arquivos uma antologia camponesa anterior aos anos $1980 .{ }^{572}$

A gravação de círculos de cultura foi uma das formas de registros orais dos camponeses realizados durante aquele período pela CORA e pelo ICIRA: "uma maneira de recolher o discurso camponês, convertendo-o em textos de leitura, seria a de gravar as discussões nos Centros de Educação ou Círculos de Cultura. A existência deste material abre à Equipe Central uma série de possibilidades que não podem ser desprezadas", alertava o pedagogo: "As sugestões que farei em torno de tais possibilidades desafiarão, certamente, a Equipe Central a perceber outras que me tenham passado despercebidas" (Freire, 1981: 22). Entre as missões da Equipe Central (supervisores nacionais da educação do Departamento de Desenvolvimento Camponês da CORA) era costurar, por meio de constantes visitas a campo, uma relação realista e orgânica entre equipes zonais que, por sua vez, deveriam estar atentas aos educadores das bases. A gravação dos círculos de cultura camponeses, indicou Freire, seria parte da formação contínua dos educadores e técnicos de todos os organismos envolvidos na capacitação camponesa: "um primeiro emprego deste material, antes mesmo de transcritos os debates em torno das codificações, poderia ser o da realização de seminários de avaliação em que os educadores de uma área, escutando as gravações, discutiriam entre si, com representantes da Equipe Central", propôs Freire, como parte da avaliação do método:

No contexto do seminário de avaliação, os educadores estariam tomando distância de sua prática anterior, percebendo, assim, seus acertos e seus equívocos. (...) Seria

\footnotetext{
${ }^{570} \mathrm{O}$ original é mimeografado do ICIRA. Foi publicado em espanhol por Ivan Illich em Cuernavaca (Freire, 1968e). Em 1975, foi publicado em português como capítulo, "Os camponeses e seus textos de leitura (Santiago, 1968)", do livro Ação cultural para liberdade (1981).

${ }^{571}$ Darío Salas, op. cit., p. 41.

572 A ideia completa das Antologias Campesinas, proposta por Freire no ensaio de 1968, só foi executada pelo GIA (Grupo de Investigaciones Agrarias) e pelo CEM (Centro de Estudios de la Mujer) nos anos 1980, com base em relatos autobiográficos.
} 
fundamental que educadores, trabalhando na área "A", escutassem as gravações dos debates realizados nos Círculos de Cultura da área "B" e vice-versa (Freire, 1981: 23).

Um segundo uso das gravações dos círculos camponeses, segundo indicava Paulo Freire, era como material de intercâmbio entre os próprios camponeses. A escuta de círculos entre camponeses de territórios diferentes, ou seja, assentados de Choapa que ouviriam, por exemplo, um círculo com assentados de Cautín sobre temas codificados que eles próprios também haviam debatido "ajudaria a alfabetizandos e alfabetizadores a ir superando o que costumo chamar de visão focalista da realidade e ir ganhando a compreensão da totalidade" (Freire, 1981: 23). Essa conscientização sobre a diversidade das realidades camponesas era um desafio, inclusive, para os próprios dirigentes políticos do país, que frequentemente minimizavam as nuances socioterritoriais e a heterogeneidade de situações para aplicação de uma única lei de reforma agrária.

Freire também incentivou que os camponeses produzissem peças de teatro e programas de rádio, para que pudessem circular entre diferentes assentamentos determinados artefatos culturais de autoria camponesa, em uma ação cultural efetivamente protagonizada por eles. "Podemos imaginar o alcance político-pedagógico que o intercâmbio do discurso camponês poderia ter”, escreveu (Freire, 1981: 23). Um programa de rádio do INDAP, por exemplo, poderia "transmitir alguns dos debates gravados [dos círculos de cultura], seguidos por comentários, em linguagem simples, feitos pela Equipe Central". Eram muitas as possibilidades criativas desencadeadas pelo método, que fomentavam o protagonismo pedagógico camponês e, portanto, seu protagonismo político.

Mas as metodologias para a autoria camponesa de materiais pedagógicos na pós-alfabetização e na ação cultural imaginadas por Freire pareciam encontrar maior resistência em relação à alfabetização em si, considerando os materiais produzidos pelo Mineduc e usados também pela CORA. Havia diferença entre materiais de pós-alfabetização criados com a matéria-prima dos próprios círculos ou aqueles feitos de "conteúdos externos", típicos da invasão cultural. Nesse embate, o pragmatismo pendia contra Freire, que parece ter sido minoritário. Suas propostas mais ousadas encontraram adesão entre profissionais mais orgânicos e próximos do seu trabalho e da sua filosofia educacional, sem alcançar, porém, a massividade dos sistemas de ensino promovidos pelo Mineduc. Freire argumentava:

Por que, ao pensar-se no que deve vir depois da alfabetização, se pensa sempre no programa da escola primária, na sua seriação tradicional? É como se a alfabetização dos adultos, mais rápida ou menos rápida, fosse um "tratamento" necessário que se lhes aplicasse para que depois atravessassem a monotonia da escola primária convencional. Uma alfabetização de adultos que rompe com os esquemas tradicionais não pode, por isso mesmo, prolongar-se numa pós-alfabetização que a negue (...). A análise das descodificações gravadas proporciona a apreensão de temas básicos, capazes de ser desdobrados em unidades de aprendizagem nos mais variados campos. No da agricultura, no da saúde, no da matemática, no da ecologia, no da geografia, no da história, no da economia (Freire, 1981: 24). 


\section{O assentado e sua cultura}

Em algum ponto intermediário entre os materiais "de escritório" do Mineduc La Raiz y La Espiga e as propostas mais ousadas de materiais de autoria camponesa feitas por Paulo Freire, a CORA produziu manuais próprios, específicos de pós-alfabetização para o contexto dos assentamentos, com apoio do Mineduc. O Guia do Método, nível 2, por exemplo, era um Manual para educadores que indicava 55 sessões de pós-alfabetização com embocadura freiriana: "o processo de conscientização, pois, leva o homem a refletir criticamente sobre as condições atuais e a submergir nessa realidade, a fim de que emerja conscientemente comprometido e assuma seu papel de sujeito ativo e criador de seu próprio mundo", anunciava a introdução do Guia. ${ }^{573}$ Feito para guiar professores de assentamentos, o Guia tinha três unidades programáticas: "O assentamento", "O assentado e sua cultura" e "A família". Seu objetivo era construir os "valores culturais adequados à mudança estrutural", além de "proporcionar o domínio funcional das técnicas de leitura, escritura e cálculo, para permitir a incorporação do adulto à cultura letrada através de conhecimentos sistematizados" e também "proporcionar ao camponês os instrumentos fundamentais de incorporação consciente no processo de reforma agrária em uma nova escala de valores". ${ }^{574}$ As metodologias e práticas de aprendizado da leitura misturavam ferramentas convencionais, como "leia em silêncio (...); leia agora em voz alta; se desconhece o significado de alguma palavra, pergunte ao coordenador (ou consulte seu dicionário); volte a ler em silêncio; responda as perguntas sobre o conteúdo", ${ }^{575} \mathrm{com}$ a descodificação de lâminas (imagens) com situações existenciais de tipo freiriano.

Para o aprendizado da escritura, se recomendava a ainda mais convencional "cópia" de parágrafos de um livro e os muitas vezes enfadonhos ditados. Enfim, o Guía era uma mescla de procedimentos e valores freirianos com procedimentos e valores da educação convencional, amarrados pelo social-comunitarismo. A recomendação de Freire sobre textos de autoria camponesa estava lá: “os textos escritos em folha de papel serão aproveitados para uma espécie de antologia de textos camponeses, que será enviada do supervisor zonal para equipe central (...) e depois devolvida às zonas como texto de leitura". ${ }^{576}$ Além disso, o material solicitava que os educadores deixassem claro aos camponeses que os encontros eram "um conjunto de pessoas tentando aprender algo (...), sem diferenças entre professor e aluno (...), partindo das experiências dos camponeses para chegar a uma compreensão crítica da realidade". Ressaltava-se que era importante "evitar que os líderes monopolizem a discussão". ${ }^{577}$ Tal como orientavam Freire e Velozo (1968), o Guía explicava que o coordenador da educação básica "deve ter uma atitude humilde, capaz de dialogar com o camponês; (...) deve renunciar a toda exposição verbalista; (...) não deve aparecer como impondo sua opinião ao grupo; deve

\footnotetext{
573 CORA-Mineduc, Guia del Método, nível 2. Santiago, (mimeo.), 1968.

574 Idem, p. 1.

575 Idem.

576 Idem, p. 2.

${ }^{577}$ Idem, p. 5
} 
problematizar as repostas; (...) não deve pensar que é dono da verdade, nem assumir atitudes paternalistas". ${ }^{578}$

Cada uma das 55 sessões do Guia, representava duas páginas com diretrizes para os educadores sobre problematizações e valores a serem trabalhados a partir do tema. A tabela 13 a seguir é uma síntese das 55 sessões. Na coluna Tema estão os títulos das sessões; em Pontos a destacar/Valores, foram selecionados trechos representativos do Guía para orientar coordenadores; na coluna Recursos, estão os materiais a serem utilizados que sinalizam a mistura do método convencionais com o método freiriano:

\begin{tabular}{|c|c|c|c|}
\hline \multicolumn{4}{|c|}{ Tabela 13 - CORA-MINEDUC, GUÍA PARA EL MÉTODO, NÍVEL 2} \\
\hline & TEMA & PONTOS A DESTACAR / VALORES & RECURSOS \\
\hline \multicolumn{4}{|c|}{ UNIDADE I: O ASSENTAMENTO } \\
\hline 1 & $\begin{array}{l}\text { O assentamento } \\
\text { como unidade física }\end{array}$ & $\begin{array}{l}\text { "Valorização do esforço coletivo, consciência de ser } \\
\text { sujeito capaz de transformar a natureza (...). Capacidade } \\
\text { para compreender que a capacitação é indispensável para } \\
\text { cumprir os objetivos da reforma agrária (camponês - } \\
\text { empresário agrícola - atitude crítica" }\end{array}$ & $\begin{array}{l}\text { Lâmina para } \\
\text { descodificação: } \\
\text { assentamento, homens } \\
\text { e mulheres trabalhando, } \\
\text { cartaz de assentamento. }\end{array}$ \\
\hline 2 & $\begin{array}{l}\mathrm{O} \text { porquê } \\
\text { reforma agrária }\end{array}$ & $\begin{array}{l}\text { "Solidariedade com o país (...). A reforma agrária tem uma } \\
\text { relação com o desenvolvimento socioeconômico do país". }\end{array}$ & 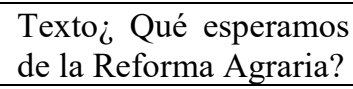 \\
\hline 3 & $\begin{array}{l}\text { O assentamento } \\
\text { como unidade social } \\
\text { (participação no } \\
\text { poder) }\end{array}$ & $\begin{array}{l}\text { "O assentamento é uma organização democrática (...). } \\
\text { Solidariedade com os demais camponeses como modo de } \\
\text { adquirir poder; (...) responsabilidade na participação do } \\
\text { assentamento, nas decisões e eleição de dirigentes. } \\
\text { Solidariedade com os companheiros de trabalho, busca do } \\
\text { trabalho em comum" }\end{array}$ & \begin{tabular}{lr}
\multicolumn{3}{l}{ Lâmina: assembleia de } \\
assentados e mesa \\
diretiva com mulheres e \\
homens. \\
Lâmina \\
organograma ram \\
assentamento. Toxto: \\
Funciones del Consejo \\
de Administración \\
\end{tabular} \\
\hline 4 & Comitê de Consumo & $\begin{array}{l}\text { "O comitê de Consumo é uma organização que responde } \\
\text { às necessidades de abastecimento (...). Funciona com } \\
\text { abportes de capital de cada um dos sócios (...). } \\
\text { Valorização do espírito cooperativo". Se acrescentam } \\
\text { conteúdos de matemática (soma). }\end{array}$ & $\begin{array}{l}\text { Lâmina } \\
\text { descodificação }\end{array}$ \\
\hline 5 & $\begin{array}{l}\text { Números decimais } \\
\text { (soma) }\end{array}$ & "Aplicar a operações do Comitê de Consumo" & Livro Mineduc \\
\hline 6 & $\begin{array}{ll}\text { Unidades } & \text { de } \\
\text { medidas } & \text { de } \\
\text { longitude, } & \\
\text { capacidade e peso }\end{array}$ & "Aplicar a operações do Comitê de Consumo" & Livro Mineduc \\
\hline 7 & Multiplicação & $\begin{array}{l}\text { Operação de multiplicar. "Aplicar a operações do Comitê } \\
\text { de Consumo". }\end{array}$ & Livro Mineduc \\
\hline 8 & Tabuada de 3 e 4 & "Aplicar a operações do Comitê de Consumo" & $\begin{array}{ll}\begin{array}{l}\text { Livro } \\
\text { (exercícios) }\end{array} & \text { Mineduc } \\
\end{array}$ \\
\hline 9 & Tabuada de 5 e 6 & "Aplicar a operações do Comitê de Consumo" & $\begin{array}{ll}\begin{array}{l}\text { Livro } \\
\text { (exercícios) }\end{array} & \text { Mineduc } \\
\end{array}$ \\
\hline 10 & \multicolumn{3}{|c|}{ O Guia saltou a sessão 10.} \\
\hline 11 & Tabuada de 7 e 8 & "Aplicar a operações do Comitê de Consumo" & $\begin{array}{ll}\begin{array}{l}\text { Livro } \\
\text { (exercícios) }\end{array} & \text { Mineduc } \\
\end{array}$ \\
\hline$\frac{12}{13}$ & \multirow{2}{*}{$\begin{array}{l}\text { Tabuada de } 9 \text { e } 10 . \\
\text { A correta disposição }\end{array}$} & \multirow{2}{*}{$\begin{array}{l}\text { Problemas de multiplicação e exposição de uma tábua de } \\
\text { multiplicar. }\end{array}$} & \multirow{2}{*}{$\begin{array}{ll}\text { Livro } & \text { Mineduc } \\
\text { (exercícios) }\end{array}$} \\
\hline 14 & & & \\
\hline
\end{tabular}

\footnotetext{
578 Id. ibid.
} 


\begin{tabular}{|c|c|c|c|}
\hline & $\begin{array}{l}\text { dos termos da } \\
\text { multiplicação. }\end{array}$ & & \\
\hline 15 & $\begin{array}{ll}\text { Multiplicação } & \text { com } \\
\text { números de } & \text { dois } \\
\text { dígitos. } & \end{array}$ & $\begin{array}{l}\text { Usar problemas práticos. "Aplicar a operações do Comitê } \\
\text { de Consumo" }\end{array}$ & $\begin{array}{l}\text { Livro } \\
\text { (exercícios) }\end{array}$ \\
\hline 16 & $\begin{array}{l}\text { Sociedade Agrícola } \\
\text { (CORA- } \\
\text { Camponeses) }\end{array}$ & $\begin{array}{l}\text { SARA: "essa sociedade dirige a vida econômica do } \\
\text { assentamento: produção, comercialização, capitalização". } \\
\text { "Valorização do esforço coletivo, sentido de poupança } \\
\text { para investimento e capitalização; sentido de } \\
\text { responsabilidade" }\end{array}$ & $\begin{array}{l}\text { Lâmina: edifício da } \\
\text { CORA, camponeses } \\
\text { olhando um campo bem } \\
\text { explorado. }\end{array}$ \\
\hline 17 & Deveres dos sócios & $\begin{array}{l}\text { "Respeito pelos acordos assumidos em conjunto. Cuidado } \\
\text { e conservação da propriedade" }\end{array}$ & $\begin{array}{l}\text { Texto sobre deveres dos } \\
\text { sócios. }\end{array}$ \\
\hline 18 & $\begin{array}{ll}\text { Conselho de } \\
\text { Administração }\end{array}$ & $\begin{array}{l}\text { "O conselho de administração dirige e é responsável por } \\
\text { todos os aspectos econômicos do assentamento"; } \\
\text { "valorização de um sistema adequado de planificação; } \\
\text { valorização da tomada de decisões" }\end{array}$ & $\begin{array}{l}\text { Descodificação do } \\
\text { organograma da SARA }\end{array}$ \\
\hline 19 & $\begin{array}{l}\text { Medidas } \\
\text { superfície }\end{array}$ & Hectares & Livro Mineduc \\
\hline 20 & Gráficos & $\begin{array}{l}\text { Conceito e aplicação de gráficos. "valorizar o esforço } \\
\text { comunitário". }\end{array}$ & Livro Mineduc \\
\hline 21 & Avaliação & $\begin{array}{l}\text { "Os camponeses escreverão um pequeno texto } \\
\text { expressando o que aprenderam e o que mais interessou. } \\
\text { Estes textos serão entregues ao supervisor e servirá } \\
\text { posteriormente como material de leitura" }\end{array}$ & REDAÇÃO \\
\hline \multicolumn{4}{|c|}{ UNIDADE II: O ASSENTADO E SUA CULTURA } \\
\hline 22 & Natureza e cultura & $\begin{array}{l}\text { "Destacar como a antiga estrutura condicionava a um tipo } \\
\text { de homem que não participava na tomada de decisões (...). } \\
\text { Manifestar os valores que o camponês tinha". } \\
\text { "Assentamento como nova estrutura (...), necessidade de } \\
\text { nova escala de valores" }\end{array}$ & $\begin{array}{lr}\text { Lâmina 1: } & \text { latifúndio } \\
\text { com patrão e e capataz } \\
\text { ordenando, } \\
\text { trabalhando. } \\
\begin{array}{l}\text { Lâmina } \\
\text { assentamento. }\end{array} \\
\end{array}$ \\
\hline 23 & Natureza e cultura & "Domínio da natureza. Consciência de sujeito da ação" & $\begin{array}{l}\text { Lâmina 3: campo } \\
\text { virgem. Lâmina } 4: \\
\text { campo trabalhado. }\end{array}$ \\
\hline 24 & $\begin{array}{l}\text { A técnica como } \\
\text { parte da cultura }\end{array}$ & $\begin{array}{l}\text { "Utilização da técnica, racionalização do trabalho, } \\
\text { valorização do esforço coletivo, aproveitamento dos } \\
\text { recursos disponíveis" }\end{array}$ & $\begin{array}{l}\text { Lâmina 5: Técnica } \\
\text { primitiva. Lâmina } 6: \\
\text { técnica moderna. }\end{array}$ \\
\hline 25 & $\begin{array}{l}\text { A técnica como } \\
\text { parte da cultura }\end{array}$ & $\begin{array}{l}\text { "Emprego de maquinaria, como colaboradoras entre o } \\
\text { homem e a produção. Valorização da técnica" }\end{array}$ & 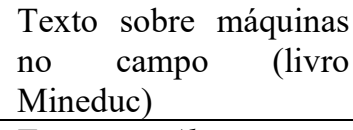 \\
\hline 26 & $\begin{array}{l}\text { A técnica como } \\
\text { parte da cultura }\end{array}$ & $\begin{array}{l}\text { "Destacar o valor do uso de abonos e inseticidas no } \\
\text { assentamento" }\end{array}$ & $\begin{array}{l}\text { Texto Abonos } e \\
\text { inseticidas } \\
\text { Mineduc) }\end{array}$ \\
\hline 27 & $\begin{array}{l}\text { A técnica como } \\
\text { parte da cultura }\end{array}$ & $\begin{array}{l}\text { "Importância da seleção de boas sementes. Valorização da } \\
\text { técnica" }\end{array}$ & $\begin{array}{lrr}\text { Texto } & \text { Empleo } & \text { de } \\
\text { semillas. } & \text { Leitura } & \\
\text { redação. } & & \end{array}$ \\
\hline 29 & Multiplicação & "Propor um caso prático" & Livro Mineduc \\
\hline 31 & $\begin{array}{l}\text { Sentido } \\
\text { comunitário: o } \\
\text { camponês solidário } \\
\text { com os outros }\end{array}$ & $\begin{array}{l}\text { "Destacar o trabalho em comum, (...) cooperativismo. } \\
\text { Sindicalização como solidariedade camponesa dentro do } \\
\text { sistema patronal. Organizações regionais de assentados } \\
\text { em sistemas de reforma agrária. Contato entre assentados } \\
\text { e outros camponeses. Solidariedade com os companheiros } \\
\text { de trabalho, solidariedade com outros camponeses" }\end{array}$ & $\begin{array}{lr}\text { Lâmina } 7: & \text { campo } \\
\text { trabalhado, grupo de } \\
\text { camponeses } \\
\text { trabalhando } r \\
\text { diferentes } & \text { em } \\
\text { Folheto: "A } & \text { aldeia } \\
\text { camponesa" } & \\
\end{array}$ \\
\hline 32 & $\begin{array}{l}\text { Camponês solidário } \\
\text { com o país }\end{array}$ & $\begin{array}{l}\text { "Trabalho camponês contribuindo ao desenvolvimento } \\
\text { socioeconômico do país" }\end{array}$ & $\begin{array}{l}\text { Lâmina 8: trabalho do } \\
\text { camponês e entrega de } \\
\text { produtos para fábrica, } \\
\text { mercados, portos }\end{array}$ \\
\hline
\end{tabular}




\begin{tabular}{|c|c|c|c|}
\hline 33 & $\begin{array}{l}\text { Solidariedade com o } \\
\text { país }\end{array}$ & & $\begin{array}{l}\text { Texto La Patria (livro } \\
\text { Mineduc) }\end{array}$ \\
\hline 34 & \multirow{2}{*}{$\begin{array}{l}\text { Orientação para o } \\
\text { futuro: planificação }\end{array}$} & \multirow{2}{*}{$\begin{array}{l}\text { "Importância da consciência da situação presente para } \\
\text { planificar e orientar o futuro com responsabilidade. } \\
\text { Destacar a importância da programação e da planificação } \\
\text { da produção futura do assentamento. Destacar o futuro } \\
\text { do assentamento como cooperativa camponesa (...). } \\
\text { Refletir sobre evolução social do assentado, seus meios de } \\
\text { produção, seus gastos. Capital fixo e capital de } \\
\text { exploração. Utilização do solo. Comercialização dos } \\
\text { produtos" }\end{array}$} & \multirow{2}{*}{$\begin{array}{l}\text { Lâmina com dados do } \\
\text { assentamento. } \\
\text { Investigação } \\
\text { realidade. Projeção } \\
\text { dessa realidade ao } \\
\text { futuro. }\end{array}$} \\
\hline 35 & & & \\
\hline 36 & \multirow{2}{*}{$\begin{array}{l}\text { Poupança } \quad \text { e } \\
\text { capitalização }\end{array}$} & \multirow{2}{*}{$\begin{array}{l}\text { "Em um primeiro momento de melhoria econômica, a } \\
\text { compra de bens de produção tem primazia sobre outros. } \\
\text { Valorização da capitalização e da poupança (...). Debate } \\
\text { sobre ideias principais: por que a poupança tem } \\
\text { importância para o futuro? (segurança econômica). Por } \\
\text { que é necessário se preocupar com o investimento? (...) Os } \\
\text { camponeses (...) analisarão os cartazes (...) e se } \\
\text { encarregarão de colocá-los e explica-os aos demais" }\end{array}$} & \multirow{2}{*}{$\begin{array}{lr}\text { Texto: } & \text { La } \\
\text { capitalización em el } \\
\text { asentamiento }\end{array}$} \\
\hline 37 & & & \\
\hline 38 & Multiplicação & "Aplicada à poupança e à capitalização" & $\begin{array}{l}\text { Texto de matemática } \\
\text { aplicado ao } \\
\text { assentamento. }\end{array}$ \\
\hline 39 & $\begin{array}{l}\text { Erosão } \\
\text { Florestação }\end{array}$ & $\begin{array}{l}\text { "Destacar a importância da florestação na conservação do } \\
\text { solo agrícola" }\end{array}$ & Texto: Protejer el suelo \\
\hline 40 & Avaliação & $\begin{array}{l}\text { "Controle de rendimentos da II unidade. (...) Redação } \\
\text { sobre o que mais interessou" }\end{array}$ & REDAÇÃO \\
\hline \multicolumn{4}{|c|}{ UNIDADE III: A FAMÍLIA } \\
\hline 41 & $\begin{array}{l}\text { Conceito e função } \\
\text { da família }\end{array}$ & $\begin{array}{l}\text { "As funções da família: socializar, transmissão cultual, ser } \\
\text { unidade econômica, procriar. Valorização da família } \\
\text { como grupo primário de socialização" }\end{array}$ & $\begin{array}{l}\text { Lâmina } 1: \text { família } \\
\text { reunida em torna de } \\
\text { uma fogueira }\end{array}$ \\
\hline 42 & Lar & "Valorização do diálogo familiar" & Texto: La casa \\
\hline 43 & $\begin{array}{l}\text { Relações } \\
\text { interfamiliares }\end{array}$ & $\begin{array}{l}\text { "Relações homem-mulher. Amor (...). Busca da felicidade } \\
\text { de ambos (...). Valorizar a tomada de decisões em comum. } \\
\text { Destacar a igualdade de direitos e deveres entre a mulher } \\
\text { e o homem." }\end{array}$ & 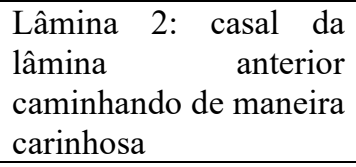 \\
\hline 44 & $\begin{array}{l}\text { A importância da } \\
\text { mulher }\end{array}$ & $\begin{array}{l}\text { "Papel da mulher na sociedade não como pessoa } \\
\text { previsora, mas sim trabalhando ativamente na comunidade } \\
\text { (labores da produção). Valorizar a presença da mulher nos } \\
\text { trabalhos do assentamento" }\end{array}$ & $\begin{array}{l}\text { Texto: La mujer en el } \\
\text { asentamiento }\end{array}$ \\
\hline 45 & $\begin{array}{l}\text { Relação entre pais e } \\
\text { filhos }\end{array}$ & $\begin{array}{l}\text { "Os filhos têm suas próprias características de } \\
\text { personalidade (...). Os pais têm os seguintes deveres com } \\
\text { seus filhos: (a) Educação (...); (b) Segurança (...); (c) } \\
\text { Cuidado" }\end{array}$ & $\begin{array}{l}\text { Lâmina 3: pai } \\
\text { ensinando ao filho e } \\
\text { mãe ensinando uma } \\
\text { filha a tecer }\end{array}$ \\
\hline 46 & Leitura sobre filhos & "Importância da educação dos filhos" & Texto: Los hijos \\
\hline 47 & $\begin{array}{l}\text { Leitura sobre } \\
\text { trabalho dos filhos }\end{array}$ & $\begin{array}{l}\text { "Importância da orientação dos filhos para o trabalho. } \\
\text { Projeção ao futuro" }\end{array}$ & $\begin{array}{l}\text { Texto: El trabajo de los } \\
\text { hijos }\end{array}$ \\
\hline 48 & $\begin{array}{l}\text { Responsabilidade } \\
\text { da sociedade com a } \\
\text { família (direitos da } \\
\text { família) }\end{array}$ & $\begin{array}{l}\text { "Serviços que a sociedade proporciona à família. A } \\
\text { sociedade como macroestrutura, tem responsabilidade de } \\
\text { atender às necessidades dos indivíduos e grupos: (...) } \\
\text { trabalho digno e remuneração respeitável (...); saúde } \\
\text { individual e coletiva (...); educação sistemática: escolas } \\
\text { para todos (...); educação assistemática: bibliotecas, } \\
\text { museus, concertos, rádio, televisão; sufrágio (...); } \\
\text { segurança" }\end{array}$ & $\begin{array}{l}\text { Lâmina } 4: \text { o que a } \\
\text { sociedade proporciona } \\
\text { à família }\end{array}$ \\
\hline 49 & Vacinas & "Valorização da técnica" & $\begin{array}{l}\text { Texto: La higiene y las } \\
\text { vacunas }\end{array}$ \\
\hline 50 & Deveres da família & $\begin{array}{l}\text { "A família como unidade de produção e consumo. (...) } \\
\text { Valorizar o esforço coletivo e de cada membro da família } \\
\text { no processo de produção" }\end{array}$ & $\begin{array}{l}\text { Lâmina 5: família em } \\
\text { um mesmo trabalho de } \\
\text { produção }\end{array}$ \\
\hline
\end{tabular}




\begin{tabular}{|c|c|c|c|}
\hline 51 & Multiplicação & "Destacar o bom uso da renda familiar" & Livro Mineduc \\
\hline 52 & \multirow[t]{2}{*}{$\begin{array}{l}\text { Família } \\
\text { comunidade }\end{array}$} & \multirow{2}{*}{$\begin{array}{l}\text { "A comunidade é o conjunto de famílias e pessoas de uma } \\
\text { área determinada, com costumes, sentimentos, tradições, } \\
\text { preocupações, interesses e objetivos comuns. A família } \\
\text { campesina está integrada em uma comunidade rural (...). } \\
\text { A família deve participar com sua ação na criação de uma } \\
\text { ordem social mais justa que atende ao bem coletivo" }\end{array}$} & $\begin{array}{l}\text { Lâmina 6: várias } \\
\text { famílias trabalhando em } \\
\text { uma estrada do } \\
\text { assentamento. }\end{array}$ \\
\hline 53 & & & $\begin{array}{l}\text { Lâmina 7: cooperação } \\
\text { escola-família. }\end{array}$ \\
\hline 54 & Avaliação & $\begin{array}{l}\text { "Textos expressando o que aprenderam e o mais } \\
\text { interessante" }\end{array}$ & REDAÇÃO \\
\hline 55 & \multicolumn{3}{|c|}{ Avaliação do nível II } \\
\hline
\end{tabular}

A Unidade I se dedicava ao conceito de assentamento, sua organização e sua centralidade para o processo de reforma agrária e o desenvolvimento econômico do país. Nota-se que a "valorização do esforço coletivo", do "espírito cooperativo", do "trabalho comum", o "sentido de responsabilidade na participação do assentamento", da "planificação", da "tomada de decisões" e da "eleição dos dirigentes" formam diretrizes contundentes no sentido de uma cultura democrática, solidária e comunitária para o campesinato chileno. Apesar da lei 16.640 determinar que a titulação das terras pós-assentamento deveria ocorrer em forma individual, cooperativa ou mista, aqui a CORA e o Mineduc atuaram de maneira direta em favor da opção coletiva da propriedade. Efetivamente, não constava no Guía nenhuma tendência ou indicação sobre a possibilidade da propriedade individual. Nas sessões 34 e 35, chamadas "Orientação para o futuro", o educador era orientado de maneira explícita a "destacar o futuro do assentamento como cooperativa camponesa". Curioso notar como a mesma Democracia Cristã, cujo governo produziu tais materiais, acusou o governo seguinte, da Unidade Popular, de "coletivização das terras".

$\mathrm{Na}$ Unidade II, dedicada ao assentado e sua cultura, a diretriz comunitária permeava quase todas as sessões, por meio das diretrizes da "solidariedade com os demais camponeses", da "solidariedade com os companheiros de trabalho", da "sindicalização como solidariedade camponesa dentro do sistema patronal" e da "solidariedade com o país". Assim como nas imagens das palavras geradoras, valores coletivistas apareciam por toda parte. O material era pragmático e atrelava tais valores às formas imediatas de organização econômica do setor reformado, como os comitês de consumo (sobre o qual se dirigiu quase todas as sessões de matemática); a organização do trabalho coletivo; a participação na assembleia do assentamento; o respeito às decisões da assembleia e às eleições de dirigentes; a compreensão de que a produtividade da SARA (a sociedade entre CORA e assentamentos) seria determinante para o destino da reforma agrária. É curioso notar que o material não tocava nas diferentes interpretações conflitivas que circulavam sobre o adelanto da CORA como salário camponês. É possível que nas sessões sobre capitalização e poupança fosse necessário definir com maior nitidez que o adelanto era crédito, ou seja, empréstimo e dívida; e não um salário. O cerne do conflito sobre a identidade de classe do assentado se acomodava nesse aparente detalhe: empresários ou assalariados?

Outra unanimidade do Guía era a "valorização da técnica" (típico das narrativas da modernização) e compreensão da "técnica como parte da cultura" (postulado do conceito antropológico 
de cultura do método de Freire). Na prática, isso significava uma tentativa de reduzir a resistência camponesa aos métodos da agricultura moderna, que decorria, de um lado, da escassez de recursos para compra de insumos, e de outro, de uma mentalidade camponesa pouco aderentes às novidades da revolução verde, essa sistemática invasão cultural que impactou o campesinato latino-americano dos anos 1960 e 1970. Instruir o campesinato sobre a necessidade de inseticidas e pesticidas fazia parte da pós-alfabetização da CORA, assim como as técnicas de seleção de sementes, o uso da maquinaria, a importância da poupança e da capitalização.

Por último, a Unidade III abordava a importância da família na sociedade, os deveres da sociedade perante a família, o matrimônio e o amor, as relações entre pais e filhos, os deveres de cuidado dos pais com as crianças e alguns valores notavelmente progressistas sobre a "valorização do diálogo familiar", a autonomia da personalidade dos filhos e a "igualdade de direitos e deveres entre a mulher e o homem". Chama atenção, por exemplo, que as imagens da sessão 3, eram uma assembleia de assentados e uma mesa diretiva de assentamento "com mulheres e homens". Na prática, porém, tal participação feminina não correspondia sequer com a lei em vigor, que proibia as mulheres (especialmente as solteiras) de se tornarem assentadas titulares (isto é, com direito a voz, voto e candidatura) na estrutura de poder do assentamento. Sobre isso também chama atenção a sessão 44, que solicitava "valorizar a presença da mulher nos trabalhos do assentamento", com um destaque explícito para os "labores da produção", o que correspondia, na realidade prática, ao huerto familiar, ao artesanato camponês e às indústrias caseiras.

A polifonia pedagógica presente nas instituições educacionais da reforma agrária é visível nos diferentes enfoques dos materiais, muitas vezes produzidos no mesmo ano. Em 1968, a CORA publicou uma cartilha cujo título dispensa interpretações: Que sería del campesino sin su mujer? Nela, se lia: "ela ajuda nos trabalhos do campo, além de manter a casa em ordem e as crianças limpinhas (...). Ela organiza os gastos domésticos". ${ }^{579} \mathrm{O}$ objetivo da cartilha, porém, era explicar como organizar um Comitê de Consumo no assentamento, indicado como solução para evitar intermediários e baratear preços. Como o problema do abastecimento doméstico e da gestão dos alimentos era considerado parte dos labores da mulher camponesa, uma política de gênero se misturava com a proposta de coletivizar o consumo. Era preciso fazer uma Lista Geral de Compras, que permitiria um abastecimento de um armazém do assentamento, limpo e higiênico, com atento registro dos gastos coletivos e aportes familiares. A alfabetização e a capacitação entravam, mais uma vez, como um elemento estruturante da nova forma de propriedade coletiva. De novo, também, a cartilha finalizava ignorando a possibilidade da propriedade individual: "ao término do assentamento, quando se forme a cooperativa de reforma agrária, o comitê de consumo continuará funcionando". ${ }^{580}$ A seguir reproduz-se algumas ilustrações da cartilha.

\footnotetext{
${ }^{579}$ CORA, ¿Que sería del campesino sin su mujer? Santiago: CORA, 1968.

${ }^{580}$ Idem.
} 

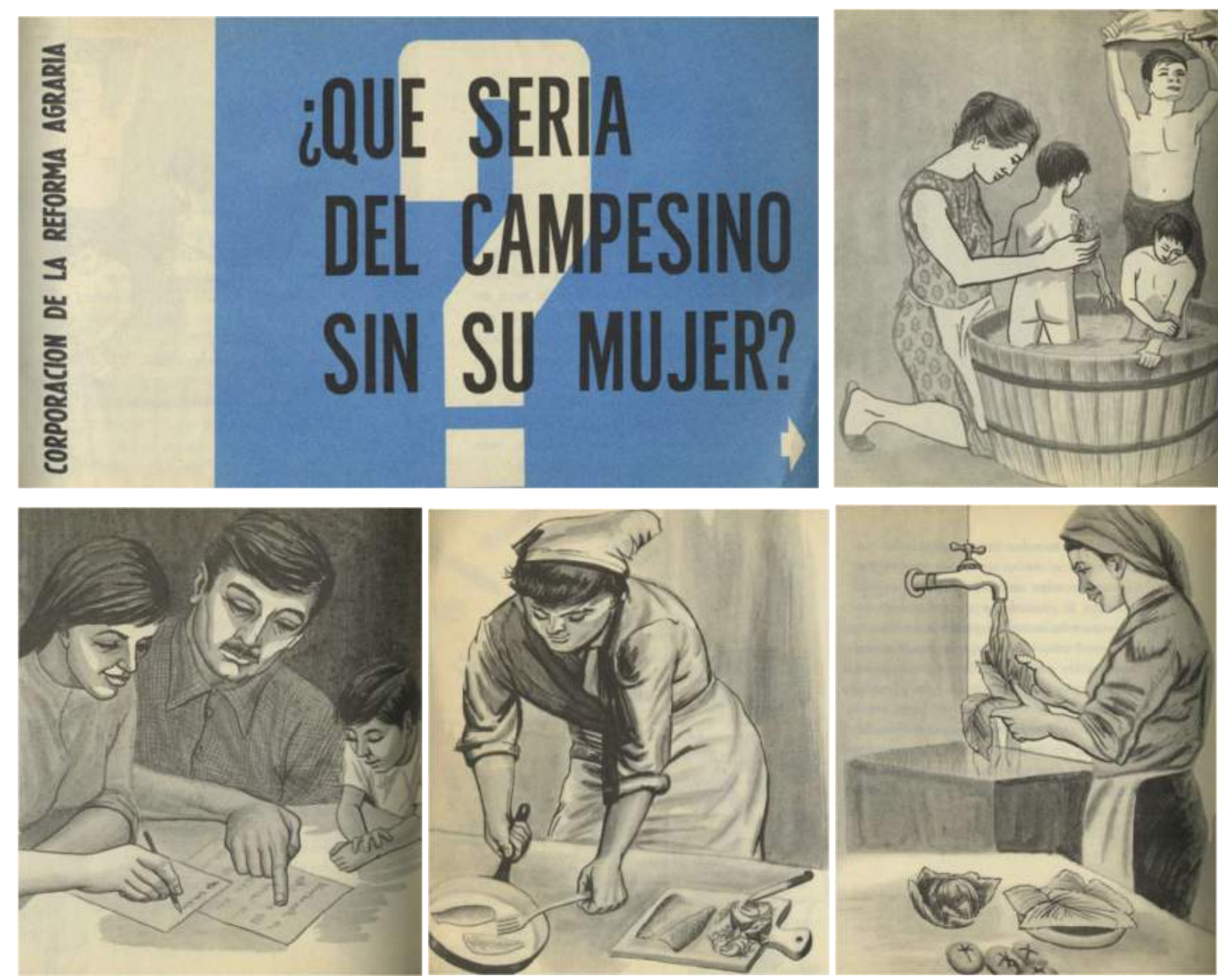

No $1^{\circ}$ Congresso do Trabalhadores da CORA, em agosto de 1968, o Grupo de Trabalho sobre Capacitação Campesina registrou que "a função da capacitação foi adquirindo paulatinamente maior importância dentro do nosso trabalho". ${ }^{581}$ Nos anais do Congresso, a subjetividade política daquela parcela de trabalhadores organizados da CORA demonstrava uma linguagem mais conflitiva do que as imagens das palavras geradoras da alfabetização. Naturalmente, as transformações estruturais dependiam diretamente da sua atuação sem mediações, no corpo a corpo das expropriações, na sua assertividade contra a resistência patronal que inúmeras vezes se insurgia contra aqueles funcionários. "Os inimigos da mudança", registraram nos anais do Congresso, "não apenas controlam a imprensa, rádios e outros meios (...), mas também são capazes de desatar a violência. (...) É necessário que os trabalhadores da Reforma Agrária organizem sua defesa (...) em feitos diários". ${ }^{582}$ Havia algo que unificava o espírito do método de Paulo Freire com a defesa material da reforma agrária, concebida pelos funcionários da CORA em seu $1^{\circ}$ Congresso por meio de uma mensagem de identificação classista com o campesinato: "os inimigos da causa popular não devem ser admitidos em organizações de trabalhadores", ${ }^{583}$ pontuaram. Foi documentalmente definido que a reforma agrária, para a categoria de

\footnotetext{
${ }^{581}$ CORA, $1^{\circ}$ Congreso Nacional de Trabajadores de CORA. Adelante con la reforma agraria. 30 de agosto a $1^{\circ}$ de septiembre de 1968. Santiago: CORA, 1968, p. 72.

582 Id. ibid., p. 78.

583 Id. ibid., p. 79.
} 
trabalhadores da CORA, deveria ser defendida desde uma atitude freiriana perante o campesinato, que o des-objetificasse: "através de um tratamento de igualdade com o camponês; não paternalista; (...) não sentindo-se ajudando o pobre camponês; não olhando-o, medindo-o para conseguir meus objetivos pessoais; mas em um diálogo de igual para igual". E seguiam com um poema:

Tú, campesino, eres pueblo, yo también

Tú vives de tu trabajo, yo también

Tú quieres un mundo mejor, yo también

Yo defiendo mi clase trabajadora

Tú también porque es tu clase s84 $^{584}$

\subsection{Considerações finais}

Não foi possível, nesse capítulo, analisar todos os desdobramentos da pedagogia de Paulo Freire na reforma agrária chilena, o que também nos ajuda a demonstrar como a multiplicação da pedagogia do oprimido naquele contexto foi um processo complexo e repleto de nuances. No próximo capítulo ainda tratarei do assunto a partir de uma perspectiva territorial, que unifica pedagogia, território e poder camponês. Neste capítulo, realizei uma análise pormenorizada dos desdobramentos do método psicossocial nos programas de educação camponesa do Ministério da Educação, do INDAP e da CORA, o que suponho ter sido suficiente para consolidação de três argumentos, identificados a seguir.

Primeiro, que a influência de Paulo Freire na reforma agrária chilena alcançou grandes proporções e representou uma tecnologia político-pedagógica fundamental para as transformações econômicas do regime de propriedade e de trabalho em curso na agricultura. A novidade do método foi recebida com entusiasmo por funcionários dos mais variados setores, permitindo a articulação entre segmentos do governo de Eduardo Frei que antes mal se comunicavam.

Em segundo lugar, que Paulo Freire foi incorporado com diferentes matizes, em composições variadas da pedagogia do oprimido com pedagogias convencionais. As palavras geradoras e os círculos de cultura, que viabilizaram um processo de alfabetização por conscientização em larga escala no campo, foram combinados com práticas da educação bancárias, produtoras de invasão cultural. $\mathrm{O}$ Mineduc, como se viu, adotou palavras geradoras sem investigação temática e criou materiais proselitistas de pós-alfabetização. O INDAP, ao contar com a presença direta de Paulo Freire, organizou a experiência de ação cultural para reforma agrária mais orgânica ao método, com priorização radical do protagonismo camponês (o que também foi o caso do ICIRA, analisado no próximo capítulo). Entretanto, ao mesmo tempo, o mesmo órgão produzia invasão cultural por meio de seu braço de capacitação técnica, com materiais que não respondiam aos mesmos critérios e metodologias das equipes de Freire ao adotar um modelo produtivo da revolução verde como paradigma moderno, benéfico, consensual e pouco questionável. Na CORA, ao mesmo tempo que as palavras geradoras

${ }^{584}$ Id. ibid., p. 80. 
foram representadas por imagens pacificadas do processo conflitivo da reforma agrária e repletas de valores comunitários, os educadores das bases desenvolveram experiências inéditas de autoalfabetização por meio da formação de camponeses alfabetizadores pelo método psicossocial, os quais, por sua vez, demonstraram sua autonomia e sabedoria pedagógica em plena prática. Além disso, os funcionários da CORA pouco a pouco se organizavam com uma perspectiva classista, propondo uma identidade entre sua categoria e a dos camponeses ao apontar para uma aliança entre trabalhadores rurais e funcionários do Estado contra os "inimigos do povo". Ou seja, cada instituição possuía diferentes camadas de incorporação do método de Freire, refletindo em composições contraditórias entre emancipação e invasão cultural no processo de reforma agrária.

Em terceiro lugar, busquei argumentar que a pedagogia de Paulo Freire representava, ao fim e ao cabo, uma concepção e uma estratégia específicas para reforma agrária chilena, atuando na transformação cultural como um enlace dialético da transformação econômica. Em outras palavras, por priorizar a conformação dos sujeitos populares do campo, Paulo Freire propunha combater a invasão cultural e a tecnocracia, o que colocava os freirianos em uma posição muito particular no cenário das disputas políticas. Todo olhar mecanicista ou tecnicista sobre a reforma agrária foi criticado por Freire em seus textos chilenos. Apesar da sua discrição e sua condição de exilado, a pedagogia do oprimido representava uma compreensão específica da subjetividade política dos processos de mudança social. Por isso, a proposta pedagógica freiriana para reforma agrária, se levada às últimas consequências (como se verá no próximo capítulo), poderia gerar uma quebra das hierarquias tradicionais mais profunda do que aquela que os próprios propagadores da reforma agrária da DC pretendiam produzir. A pedagogia freiriana foi apropriada por diferentes atores políticos e pedagógicos da reforma agrária chilena e se multiplicou de maneira multifacetada. Seguindo a documentação dos ensaios de Paulo Freire e das equipes que estavam mais afinadas com sua presença, nota-se que sua pedagogia concatenava uma estratégia de consolidação do sujeito popular camponês e do seu poder produtivo, cognitivo e político. O que, a depender da correlação de força, quebrava hierarquias de modo a incomodar a vanguarda dirigente do progressismo e da reforma. Nos parece, enfim, que as equipes mais orgânicas à pedagogia do oprimido formaram uma espécie de "corrente freiriana" de disputa da reforma agrária chilena: invisível, pluripartidária, constituída por educadores e ativistas que priorizavam a radicalidade lenta do diálogo com as bases e evitavam as disputas sectárias e velozes da vanguarda. 


\section{Capítulo 5 - Pedagogia do território: protagonismo camponês, poder e produção}

"O camponês que consegue um pouco de inteligência, ao patrão não convém nunca que seja estudioso, porque seria ele quem levantaria uma guerra".

- Camponês do assentamento El Recurso, Buin, 1968 $^{585}$

"Agora, por onde passe, o camponês pode falar sem tirar o chapéu. Antes tinha que tirar o chapéu primeiro e falar com o administrador e pedia permissão para falar com o patrão"

- Camponês do assentamento El Recurso, Buin, 1968

"Na comunidade há mais poder. Quanto mais comunidade, mais trabalho e mais produção. É isso que vemos aqui. A união faz a força"

- Camponês do assentamento El Recurso, Buin, 1968 587

"A comunidade é boa para os preguiçosos, não para os mais trabalhadores"

- Camponesa do assentamento El Recurso, Buin, 1968

"Uma pessoa que não sabe ler fica desorientada e passa vergonha. Tem que assinar seu nome e não sabe. Tem que colocar seu dedo toda hora, é uma vergonha para nós que não sabemos nada"

- Camponesa do assentamento El Recurso, Buin, $1968^{589}$

"Roubar dos ricos não é nenhum pecado".

- Camponesa do assentamento El Recurso, Buin, 1968

"Essa lei tem muitos erros porque foi feita para os camponeses, mas os camponeses não participaram de sua elaboração"

Camponês de Peralillo, Colchagua, $1969^{591}$

\subsection{Introdução}

Em janeiro de 1968, Paulo Freire se deslocou da consultoria no INDAP para trabalhar no ICIRA (Instituto de Capacitação e Investigação em Reforma Agrária), onde esteve até abril de 1969, quando deixou o Chile para uma temporada na Universidade de Harvard. Uma elite de brasileiros exilados já atuava no ICIRA desde antes, como Plinio Sampaio, Paulo de Tarso e Almino Affonso. Criado em 10 de junho de 1964, por meio de um convênio entre FAO e governo chileno, o órgão se mantinha com financiamento da ONU. Freire se incorporou ao Departamento de Planificação e Métodos de Educação Rural e, no decorrer do seu último ano no país, criou uma equipe interdisciplinar, com forte vocação

\footnotetext{
${ }^{585}$ ICIRA, Investigación temática. Asentamiento El Recurso, 1968. Caja FPF ACP 01. Centro de Referência Paulo Freire (CRPF), São Paulo.

I Idem.

I Idem.

${ }^{588}$ Idem.

${ }^{589}$ Idem.

590 Idem.

${ }^{591}$ Maria Edy Ferreira \& Liliana Barria. Hacia un método de programación campesina. ICIRA/INDAP: Santiago de Chile, 1971.
} 
experimental e atração pelo trabalho en terreno, com quem desenvolveu duradouros vínculos de amizade.

Segundo o historiador Andrew Kirkendall, "apesar do ICIRA ser uma organização afiliada ao governo chileno e Freire continuar seu trabalho com outras agências do governo, seu envolvimento com a FAO lhe proporcionava maior grau de independência" (Kirkendall, 2010: 82). O historiador destacou que foi ao longo de 1968 que a tensão entre o governo Frei e a crescente projeção do trabalho de Paulo Freire na reforma agrária se tornou cada vez mais visível. Entre julho de 1968, quando Waldemar Cortés Carabantes escreveu seu primeiro relatório sobre a campanha de alfabetização na Revista de Educación, e maio de 1969, quando entregou sua versão final, o nome de Paulo Freire havia simplesmente desaparecido. ${ }^{592}$ No discurso de balanço de seu governo, em 1970, o presidente Eduardo Frei propagandeou a alfabetização de adultos como grande mérito de seu governo, descrevendo as etapas do método psicossocial, mas sem mencionar o nome do brasileiro (Kirkendall, 2010: 86). O ano de 1968 foi chave na cisão interna da Democracia Cristã e, foi neste mesmo período, que Freire conseguiu ter mais tempo para escrever e debater criativamente com seus colegas do ICIRA.

Não foi circunstancial, portanto, que os experimentos mais ousados do método psicossocial ocorressem no ICIRA em 1968 e 1969, como ensaios do que aqui chamei de pedagogia do território. Neste capítulo argumento que os experimentos freirianos no ICIRA se distinguiram dos outros programas rurais por onde penetrou o método psicossocial porque apontavam para essa pedagogia do território, isto é, metodologias de autogestão comunitária que extrapolavam o setor educacional e se transformavam em uma agenda mais radicalizada de poder popular camponês.

No Departamento de Planificação e Métodos de Educação Rural do ICIRA, formou-se uma equipe freiriana com ímpeto experimental, que desenvolveu uma longa e detalhada investigação temática no assentamento El Recurso entre junho e novembro de 1968, com a atuação em campo de pelo menos oito pesquisadores: Maria Edy Ferreira, Sergio Villegas, Odilo Friedrich, Clara Arce R., Martine Hugues, Margarita Depetris, Marcela Gajardo e José Luis Fiori. ${ }^{593}$ Logo em seguida, em 1969, Maria Edy Ferreira, Liliana Barria e Sergio Villegas experimentaram novos desdobramentos do método psicossocial como ferramenta do planejamento territorial "desde abajo", em uma estratégia de capacitação para o poder popular nomeada como "programação campesina", desenvolvida nas comunas de Palmilla e Peralillo, em Colchagua. ${ }^{594}$ A primeira e a segunda experiências eram etapas encadeadas

\footnotetext{
592 No relatório de julho de 1968, Carabantes registrou: "O programa adotou o método do professor brasileiro Paulo Freire (...). A contribuição deste educador consiste em possuir uma técnica adequada para proporcional os elementos da linguagem escrita, mas de forma que representem a realidade dos alfabetizados e sejam reconhecidos por eles. (...). O papel do professor é apenas incentivador, estimulador de uma reação que deve ser produzida no íntimo da consciência do alfabetizado". Posteriormente, esse trecho sumiu. Waldemar Cortés Carabantes, Los planes extraordinarios de educación de adultos, op. cit. ${ }^{593}$ As fontes dos círculos de cultura da investigação temática no assentamento El Recurso são: ICIRA, Investigación temática. Asentamiento El Recurso, 1968. Fundo Paulo Freire, Centro de Referência do Instituto Paulo Freire. Caixa FPF-ACP-01. São Paulo. 303p.; e Maria Edy Ferreira \& José Luis Fiori, Investigación temática cultural de los campesinos de El Recurso. Santiago: ICIRA, 1969 (mimeo).

${ }_{594}$ As fontes da programação campesina são dois relatórios: Maria Edy Ferreira; Liliana Barria \& Sergio Villegas, Hacia un método de capacitación campesina: el diagnóstico como un camino para la acción. Santiago: ICIRA, 1969; e Maria Edy Ferreira \& Liliana Barria. Hacia un método de programación campesina. ICIRA/INDAP: Santiago de Chile, 1971.
} 
daquilo que conceituei como "pedagogia do território". É muito provável, como argumentarei neste capítulo, que o experimento da pedagogia do território coordenado por Maria Edy Ferreira no ICIRA durante o governo Frei tenha influenciado a formulação do decreto que Jacques Chonchol assinou em 21 de dezembro de 1970, já na qualidade de ministro da Agricultura do governo da Unidade Popular, com o qual criava os Conselhos Campesinos em esfera comunal, provincial e nacional (Chile, 1970).

Os experimentos freirianos do ICIRA, que analisarei neste capítulo, utilizavam a investigação temática não só como prática de ação cultural, mas também como estratégia de desenvolvimento territorial, com objetivo de alavancar a organização do sujeito popular camponês. Para que isso fosse possível, alguns pesquisadores, destacadamente a socióloga Maria Edy Ferreira, produziram análises fundamentadas em centenas de sessões de escuta e entrevistas com camponeses de territórios específicos, como Culiprán, ${ }^{595}$ Melipilla, Paine, Buin, Maipú e San Pedro, ${ }^{596}$ além de 80 assentamentos espalhados por 12 zonas do país. ${ }^{597} \mathrm{O}$ método sociológico de Maria Edy estava organicamente atrelado à pedagogia freiriana a partir de uma perspectiva territorial que enfatizava as "aspirações", as "expectativas" e as "tendências" nascidas diretamente da voz do campesinato em territórios determinados. Não por acaso, seus relatórios frequentemente estavam acompanhados de mapas.

No ICIRA, Freire viu sua pedagogia aflorar possibilidades mais ousadas de desconstrução das hierarquias sociais, e irem além da horizontalidade entre educadores e educandos. A "programação campesina", por exemplo, propunha reinventar a lógica do poder sobre o território rural com métodos freirianos, não apenas no setor reformado dos assentamentos, mas também na integração entre minifundistas, sindicatos e cooperativas no mesmo esforço de conscientização territorial. Assim, se a investigação temática de El Recurso foi um mergulho na subjetividade particular de um assentamento, como forma de inventar e estimular novas estratégias de produção e reprodução comunitária da vida, a programação campesina propunha um diagnóstico dos problemas e das aspirações camponesas em nível intercomunitário, ampliando o empoderamento popular para o planejamento regional da reforma agrária. Dois anos antes, Plinio de Arruda Sampaio havia identificado a descoordenação regional da reforma agrária, isto é, como as instituições agrárias sobrepunham funções e deixavam vazios de planejamento no nível das comunas e das províncias. ${ }^{598}$ Os grupos freirianos do ICIRA conheciam o estudo. É visível, através dos documentos, que formulavam estratégias para uma coordenação territorial popular da reforma agrária. O corpus documental mobilizado me permitiu escutar as vozes dos camponeses que participaram desses experimentos, porque a equipe do ICIRA se preocupou em transcrever círculos de cultura gravados.

\footnotetext{
${ }_{595}$ Maria Edy Ferreira, Expectativas campesinas y asignación de tierras de Culiprán. Santiago (mimeo), 1968.

${ }^{596}$ Oscar Domínguez, Aspiraciones de los inquilinos de la provincia de Santiago. ICIRA (mimeo), 1966.

${ }^{597}$ Maria Edy Ferreira, Tendencias del poder entre los campesinos asentados. ICIRA, (mimeo), 1970.

598 Plínio de Arruda Sampaio; Jorge Medina; Alfredo Urrutia \& Jaime Duhart. Organización, Planificación y Coordinación de las instituciones del sector público agrícola de Chile, a nivel de terreno. Departamento de Administración en Reforma Agraria. Santiago: ICIRA, 1966. (borrador de circulación restringida).
} 
O cotidiano de Freire no ICIRA foi especialmente entusiasmado por seus "dois grandes amigos (...), Marcela Gajardo (...) e José Luis Fiori” (Freire, 2011: 72). Com cerca de 20 anos, eram os mais jovens do grupo, que na época ainda cursavam os anos finais na universidade. "As horas que passávamos juntos discutindo achados (...), debatendo dúvidas, interrogando-nos, desafiando-nos, sugerindo-nos leituras, surpreendendo-nos, espantando-nos", registrou Freire: "exerciam em nós um tal encanto que, quase sempre, nossa fala, a partir de certa hora, era a única a ser ouvida no prédio. Todos haviam deixado o escritório e lá estávamos nós, procurando compreender melhor o que havia por trás da resposta de um camponês (...) em um círculo de cultura” (Freire, 2011: 72-73). A distância geracional não se interpôs sobre aquela cumplicidade: "não tenho porque negar o bem que a amizade de ambos [Marcela e José Luis] me fez e a contribuição que a inteligência arguta deles me trouxe", comentou Paulo Freire, em Pedagogia da esperança (2011: 73).

Marceja Gajardo, à época estudante da Universidade Católica, contou que começou a trabalhar com Paulo Freire voluntariamente em 1968, porque o admirava e compactuava com sua filosofia: "Paulo andava buscando uma pessoa que o ajudasse a ter uma relação mais fluente com o espanhol, para poder falar com os chilenos. (...) Isso abriu a possibilidade de que eu me incorporasse voluntariamente à sua equipe do ICIRA. Foi assim que eu entrei", ${ }^{599}$ recordou. Mais tarde, uma liberação de recursos permitiu que ela fosse remunerada como estagiária. "Conheci José Luis e Maria Edy, esse foi meu entorno acadêmico (...). Todo esse grupo se manteve como uma comunidade de amigos, além de uma comunidade acadêmica, intelectual", ${ }^{600}$ recordou Gajardo. Fiori também foi contratado pelo ICIRA no começo de 1968 graças a uma solicitação direta de Paulo Freire. ${ }^{601}$

A missão pedagógica do ICIRA era bastante apropriada ao trabalho que Freire realizava até ali: "planificar, realizar e coordenar programas para capacitar profissionais e pessoal técnico da reforma agrária em todos os níveis", bem como os "programas de investigação e avaliação da reforma agrária" (Gajardo, 1973c: 86). Seus cursos se destinavam a todos os níveis do staff da reforma agrária, da burocracia dos ministérios aos profissionais da ponta: coordenadores de assentamento, técnicos e práticos agrícolas, comitês zonais do INDAP e da CORA, supervisores de educação básica, assistentes sociais, agrônomos, extensionistas e pessoal administrativo. Desde 1965, o ICIRA já ensinava o método psicossocial, tanto para alfabetizadores, como para extensionistas rurais e técnicos. Entre 1964 e 1967, foram 3.230 pessoas formadas, sendo 1.627 funcionários do estado (CORA, INDAP, Minagri, Mineduc) e 1.603 estudantes universitários (Gajardo, 1973b: 86-96). "Em geral (...), eram curso de 5 dias", relatou Marcela Gajardo: "Tratavam de temas como reforma agrária na América Latina e no Chile, análise do setor agrícola do Chile (diagnósticos econômico, social, cultural e político), reforma

\footnotetext{
${ }^{599}$ Entrevista com Marcela Gajardo, Santiago, 04/12/2018.

${ }^{600}$ Idem.

${ }^{601}$ Freire escreveu: "Sugerimos a contratação em tempo parcial do estudante de sociologia José Fiori, de quem nos fazemos absolutamente responsáveis por suas qualidades morais e intelectuais". Paulo Freire, Plan de Trabajo para el año. Una visión sintética. Santiago: ICIRA (mimeo.), 1968c: 20.
} 
agrária e processo de mudança social, medidas e mecanismos da reforma agrária (...) e treinamentos específicos”, escreveu (Gajardo, 1973b: 96).

O ano de 1968 foi marcado pela expansão da base de alunos do ICIRA, tanto quanto pelos experimentos freirianos que evocavam a pedagogia do território. O órgão formou 1.770 pessoas naquele ano, sendo 93\% funcionários do Estado e 7\% universitários. No ano seguinte, como reflexo das experimentações pedagógicas freirianas ao largo do país, especialmente o projeto de autocapacitação camponesa da CORA, o ICIRA enfim incorporou os camponeses em seus cursos: foram 1.625 alunos camponeses em 1969; 1.222 em 1970; e em 1971, já no governo da UP, 4.159 camponeses formados como alfabetizadores (Gajardo, 1973b: 97). Almino Affonso lembrou-se com emoção das aulas que ministrou naquele contexto. Havia muito reconhecimento aos brasileiros que lecionavam assuntos agrários no ICIRA. Nos seus cursos, como nos de Plínio Sampaio e Paulo de Tarso, "terminávamos as aulas com aplausos", recordou. "A gente irradiava algo, que era a nossa frustração de não termos avançado na reforma agrária aqui [no Brasil]. Estávamos vivendo paradoxalmente uma parte de um projeto que nós havíamos amado ter. Não era banal para mim. Acabava com palmas!", ${ }^{602}$ recordou Affonso.

A equipe freiriana do ICIRA levou a sério as transcrições dos círculos da investigação temática. Talvez por isso os únicos registros de círculos integralmente acessíveis foram as 210 páginas de diálogos camponeses ocorridos em 27 círculos de cultura da investigação temática no assentamento El Recurso, na comuna de Buin, a 40 quilômetros ao sul de Santiago, bem como as aulas e diálogos gravados no experimento de programação campesina, coordenado por Maria Edy Ferreira, Liliana Barria e Sergio Villegas. Embora tenham sido localizados e ensaísticos, tais experimentos apontavam metodologias alternativas para constituição do poder popular camponês e constituíram uma corrente freiriana invisível nas disputas posteriores da revolução chilena. Ao respeitar os ritmos da subjetividade camponesa, a lenta temporalidade da pedagogia do território talvez fosse incompatível com as exigências do progresso ou com a velocidade da revolução. Mas, sem dúvida, apresentavam um olhar alternativo sobre as temporalidades da luta de classes, indicando a centralidade da ação cultural como ferramenta do poder popular territorial.

\subsection{Investigação temática no assentamento El Recurso}

Na Pedagogia do oprimido, Paulo Freire dedicou quase 50 páginas para explicar os fundamentos dialógicos da investigação temática. No entanto, a investigação temática foi a parte mais descartada nas diferentes aplicações do método no Chile, sobretudo pelo fato de que desaceleraria a velocidade da alfabetização prometida pelo governo. Na proposta original, a investigação temática era uma ação cultural prévia à escolha das palavras geradoras, ou seja, um processo de pesquisa

${ }^{602}$ Entrevista com Almino Affonso, São Paulo, 07/08/2018. 
coordenado por equipes multidisciplinares que tinha como objetivo promover o diálogo entre mundo letrado dos pesquisadores e o universo cultural e vocabular dos analfabetos, por meio de visitas de escuta e observação, produção de imagens codificadoras e círculos decodificadores. No contexto da reforma agrária chilena, a investigação temática permitiria a criação de vínculos mais constantes entre esses dois mundos, estreitando a distância entre as expectativas camponesas e os caminhos oficiais oferecidos pela reforma agrária dos organismos de Estado.

A investigação temática pretendia criar um espaço de diálogo entre pesquisadores e camponeses. Buscava identificar coletivamente os principais problemas e conflitos enfrentados num território determinado. Isso requeria a dissolução de hierarquias convencionais entre campo/cidade e letrados/iletrados, permitindo a criação de vínculos horizontais novos, que transformassem pesquisadores em aprendizes empáticos dos camponeses e camponeses em pesquisadores ativos da sua realidade. "Os riscos da investigação não estão em que os supostos investigados se descubram investigadores e, desta forma, corrompam os resultados da análise", alertava Freire: "o risco está exatamente no contrário. Em deslocar o centro da investigação, que é a temática significativa, a ser objeto da análise, para os homens mesmos, como se fossem coisas, fazendo-os assim objetos da investigação" (Freire, 2018: 138). Afinal, complementava em outro texto, "investigadores profissionais e povo, nesta operação simpática, que é a investigação do tema gerador, são ambos sujeitos deste processo" (Freire, 2018: 140). Os pesquisadores não deveriam investigar os camponeses, mas sim aprender sua cultura guiados pelas suas mãos.

Entendida como uma estratégia de ação cultural, a investigação temática poderia ser préalfabetizadora ou, no caso de El Recurso, pré-programadora. E o que era a "programação camponesa"? Tratava-se de uma ideia original das equipes freirianas do ICIRA que não aparecia em nenhum texto de Paulo Freire. Segundo Fiori e Ferreira, o processo de pesquisa no assentamento El Recurso teria que cumprir três etapas: a etapa investigadora, que basicamente correspondia à investigação temática descrita por Paulo Freire na Pedagogia do oprimido; a etapa programadora, que consistia em utilizar estratégias freirianas para aprimorar a auto-organização camponesa e sua consciência territorial, por meio da elaboração de um diagnóstico dos principais problemas do território feito pelo próprios camponeses, com apoio dos pesquisadores; e por fim, a etapa pedagógico-ativadora, que mobilizava os camponeses auto-organizados para desenvolver instâncias de poder comunal, a fim de tornar plausível a solução comunitária dos problemas. Assim, se a investigação temática de Paulo Freire era o preâmbulo da alfabetização, a investigação temática do ICIRA oferecia outra agenda: era um preâmbulo para auto-organização camponesa e para o empoderamento territorial. Nesse caso, a ação cultural (etapa investigadora) seria seguida pela atuação dos camponeses como pesquisadores do seu território (etapa programadora) e então pela construção de uma instância de poder nova, que abarcasse diversos atores camponeses de um território determinado e viabilizasse a ação comunitária (etapa pedagógicoativadora). "O caminho da ação se coloca no fim da pesquisa como exigência da continuidade (...), não um relatório puramente acadêmico. Essa continuidade se operacionaliza seguindo caminhos que a ação 
real do campesinato possibilite e imponha, para a realização dos objetivos propostos", ${ }^{603}$ sublinhavam Ferreira e Fiori.

O único experimento registrado no Chile que testou todos os passos sugeridos por Freire para etapa investigadora (a investigação temática) foi o projeto do ICIRA junto ao assentamento El Recurso, embora isso correspondesse somente à primeira das três etapas inventadas pelas equipes freirianas que atuavam no órgão. ${ }^{604}$ Nessa experiência, quase dez pesquisadores visitaram por 7 meses o assentamento, em atividades de escuta e diálogo sobre seus conflitos, sofrimentos, memórias e aspirações acerca da reforma agrária. Foi uma espécie de imersão e de registro direto da subjetividade coletiva de um assentamento. O tempo lento da investigação de El Recurso permitiu a construção de um contato mais constante entre pesquisadores e camponeses. "A metodologia da investigação do tema gerador precisa ser, em si mesma, conscientizadora", registrou Freire: "O que se investiga não é o camponês, como ele se fosse um cadáver (...), mas sua temática significativa. Sua participação como sujeito da investigação temática é, pois, uma exigência básica", ${ }^{605}$ reportou à Unesco. "[No ICIRA] estamos realizando a primeira delas em colaboração com a CORA, em um dos assentamentos da reforma agrária", 606 registrou Freire em 1968 se referindo ao experimento.

O assentamento El Recurso, escolhido com ajuda da CORA, se localizava a 40 quilômetros ao sul de Santiago, o que permitia visitas de um dia inteiro dos pesquisadores que viviam na capital. Os croquis a seguir compunham os relatórios de visitas da investigação temática.

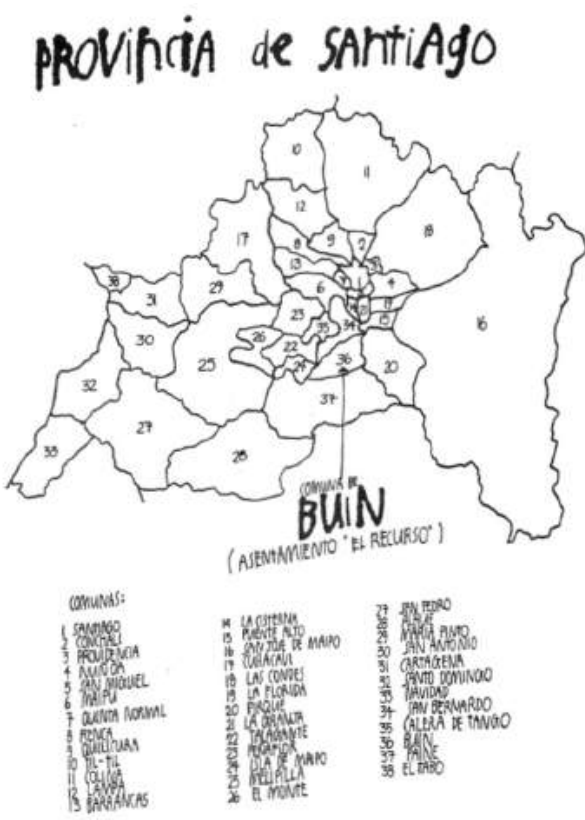

Croqui das Região Metropolitana e suas comunas, localizando Buin (36). Fonte: Ferreira \& Fiori, 1969

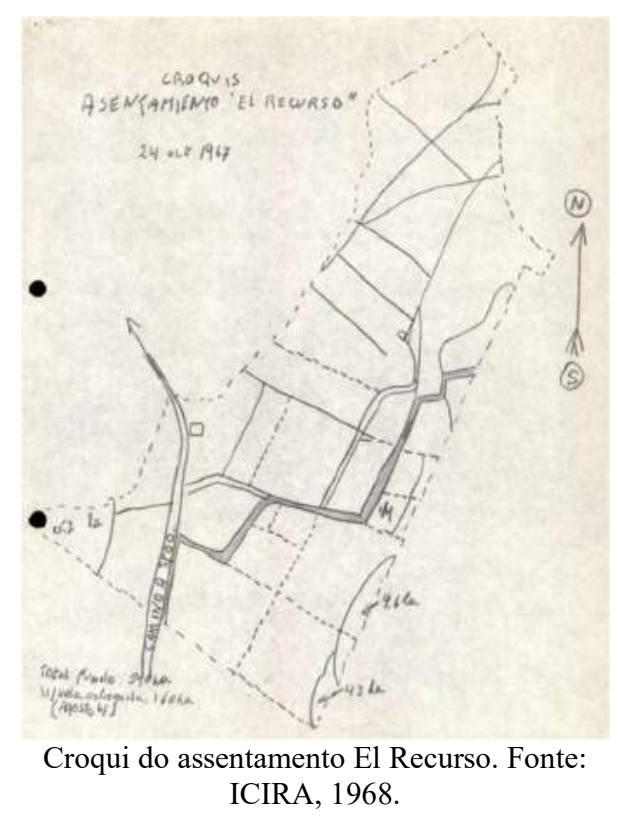

ICIRA, 1968.

\footnotetext{
${ }^{603}$ Maria Edy Ferreira \& José Luis Fiori, Investigación temática cultural de los campesinos de El Recurso. op. cit.

${ }^{604}$ A ideia de que qualquer "programa" de aulas deve ser construído conjuntamente entre educador e educando, que aqui se aplicou ao processo de alfabetização de camponeses, causou espanto e resistência de alguns professores municipais de São Paulo, quando Freire, como secretário de educação municipal propôs uma nova estratégia de construção curricular. Tais conflitos foram recuperados em Haddad (2019), p. 200.

${ }^{605}$ Paulo Freire, Alfabetización Funcional en Chile, informe UNESCO. Santiago: ICIRA (mimeo.), 1968a, p. 13-14.

${ }^{606}$ Id. ibid., p. 14.
} 
El Recurso era uma comunidade heterogênea, que se encontrava em processo transitório para reforma agrária. No fim de 1967, o proprietário da hacienda El Recurso, Vicente Iñiquez, não conseguiu evitar que seus 601 hectares de riego fossem parcelados em três setores (hijuelas), em função da "má exploração", uma causa expropriatória da lei 16.640. O antigo dono mantinha somente 120 hectares de cultivo de trigo, com metade do rendimento potencial que a fertilidade da sua terra permitia. Uma das hijuelas se tornou o assentamento El Recurso, com 150 hectares de riego da fazenda original, que passaram a ser usados para produção chacareira. Enquanto isso, ainda estava em curso um conflito sobre a expropriação de outro setor da superfície restante e a delimitação da reserva patronal de até $80 \mathrm{HRB}$ (hectares de riego básico). Em 1968, o assentamento pertencia a 19 famílias (125 pessoas), que correspondiam a apenas $33 \%$ da população original de trabalhadores da hacienda, cujo total alcançava quase 400 habitantes. Para as 19 famílias assentadas, havia somente 10 casas, com uma média de 2 famílias (12 pessoas) por moradia. Somente 10\% destas casas tinham água encanada e $4 \%$, saneamento básico.

Frequentemente, os inquilinos não incluídos no assentamento eram contratados como trabalhadores temporários (afuerinos) pelos assentados, que se tornaram então empregadores de seus antigos colegas. O patrão seguia controlando o restante da propriedade, onde ficava sua mansão. Por isso, ainda exercia poder efetivo e simbólico sobre o assentamento. Efetivo porque dom Iñiquez controlava os canais de água e irrigação, o que intimidava seus ex-empregados, de acordo com o relatório do ICIRA: "o dono ainda tem controle sobre a maioria das fontes de água e não permite que aos assentados acessem e usem a água" ${ }^{607}$ A fonte de água mais próxima e acessível ao assentamento ficava há 300 metros de distância das casas. O poder simbólico também era relevante: muitos assentados ainda temiam o patrão, desconfiavam da CORA e sentiam-se inseguros sobre o futuro da reforma agrária.

Entre 24 de junho e 14 de julho de 1968, os pesquisadores do ICIRA realizaram 6 visitas de escuta dos assentados e observação das dinâmicas do assentamento. Depois, foram elaboradas imagens com situações existenciais baseadas nas visitas. Entre 3 de outubro e 20 de novembro foram realizados os círculos. A seguir, narrarei esse processo.

\section{Visitas de escuta e observação}

Na primeira visita realizada pela equipe do ICIRA ao assentamento El Recurso, em 24 de junho, Villegas, Fiori e Odilo Friedrich conversaram com Antonio Catalán, o dom Tuco, presidente do assentamento, e David Serrano, vice-presidente. ${ }^{608}$ Estiveram também com Armando Domínguez, coordenador de assentamento da CORA, que acabava de voltar de uma viagem oficial a Israel, onde se encantou com os kibutzim. Os dirigentes eram entusiastas do trabalho cooperativo. Naquela segunda-

\footnotetext{
${ }^{607}$ ICIRA, Investigación temática. Asentamiento El Recurso, op. cit. ${ }^{608}$ Id., ibid.
} 
feira, os pesquisadores apresentaram aos três homens seus objetivos com a investigação temática e escutaram uma breve história da comunidade.

$\mathrm{O}$ assentamento tinha nove meses quando os pesquisadores do ICIRA chegaram. Entre os 125 habitantes, $26 \%$ eram mulheres adultas, $31 \%$ homens adultos e $43 \%$ crianças. Entre os 71 assentados maiores de 15 anos, 45 tinham cursado parcialmente o primário e 26 eram analfabetos. Somente $22 \%$ da população assentada era economicamente ativa na produção agrícola comum, sem contar as mulheres que trabalhavam no huerto e em atividades produtivas domésticas, como conservas de alimentos, artesanatos e costura. ${ }^{609}$ Entre os 39 trabalhadores ativos na produção comum naquele momento, 19 eram assentados titulares, 8 eram seus filhos e 12 eram afuerinos. Todos os sócios do assentamento estavam inscritos como aspirantes à propriedade após a transição, mas os não assentados também constavam na lista. Essa tensão sobre a terra gerava um impulso de luta para que o restante da hacienda fosse expropriado o quanto antes, ampliando as chances de todos. O presidente do assentamento, dom Tuco, reconhecia que às vezes contratavam os afuerinos apenas para que tivessem trabalho, mesmo que não houvesse o que fazer, como acontecia durante aquela visita. Os temporários trabalhavam na retirada de raízes e troncos de árvores cortadas para replantio de 5.000 álamos. "Comentou-se que esse trabalho era feito para que as pessoas tivessem algo a fazer. Os 'não assentados' se declararam muito contentes com a oportunidade de ter trabalho", ${ }^{10}$ registrou a equipe em seu diário.

A memória coletiva do assentamento remetia à greve salarial de 1962. O assentado Luiz Meza, por exemplo, comentou com os pesquisadores em uma das visitas que sempre havia tido uma péssima relação com o patrão, porque ele fraudava contratos com regalías que nunca entregava aos empregados. "Os camponeses tinham medo de cobrar o contrato" disse Meza. Ele foi participante ativo na greve em 1962, que exigiu mais salários e realização completa dos contratos. Os inquilinos saíram vitoriosos, mas, no ano seguinte, o patrão os retaliou e demitiu 24 famílias em duas semanas. Naquela ocasião, os camponeses de El Recurso lembravam ter sido ajudados pelo deputado Juan Acevedo, do Partido Comunista de San Bernardo. Apesar do patrão Iñiquez acusá-los de comunistas, afora esse contato, os assentados alegavam que não havia militantes de partidos políticos na propriedade.

As visitas de escuta e observação foram agendadas para as quintas-feiras e ocorreram semanalmente. A estratégia de escuta partia de algumas perguntas básicas: como era sua vida na época do antigo patrão? O assentamento melhorou sua situação? Quais são os principais problemas do seu dia a dia? O que você espera do futuro? Com isso, recebiam respostas variadas, das mais preocupadas com infraestrutura coletiva até o sofrimento de conflitos conjugais. Na visita de 4 de julho, Villegas, Friedrich e Margarita Depetris conversaram com a assentada dona Marta Soza, secretária e expresidenta do Centro de Madres, casada com Gabriel Soza e mãe de dois filhos. Marta chamava de "bicho" o antigo patrão. Muito ativa na comunidade, ela havia proposto uma cooperativa de consumo

${ }^{609}$ Maria Edy Ferreira, Algunas observaciones sobre el asentamiento El Recurso In: ICIRA, Investigación temática. Asentamiento El Recurso, op. cit.

${ }^{610}$ ICIRA, ibid. 
para resolver o problema do abastecimento, mas sua ideia ainda não tinha sido levada adiante pelo coletivo. Como outras assentadas, Marta gerava uma renda complementar ao antecipo de 170 escudos que era recebido pelo marido, ao produzir e comercializar pães, tortas e empanadas. Aos pesquisadores do ICIRA, lamentou que com a renda familiar só conseguiam comprar comida e não sobrava para roupas. Seu marido era responsável pelo plano de produção de hortaliças, exercia liderança na produção. Marta também relatou que a condições das casas dos assentados era precária, com piso de terra e eletricidade racionada. Também se queixou do transporte: o único ônibus disponível parava a 3,5 quilômetros do assentamento, trecho que costumavam percorrer a pé. Embora houvesse alguns produtores de vestuários na propriedade, era preciso comprar roupas e mantimentos em Buin. A viagem era custosa. Dona Marta também se queixou que o professor não fazia reuniões de pais e mestres na escola da hacienda há mais de dois anos. Ela sentia falta.

Na visita de 11 de julho, Villegas e Friedrich conversaram com Inéz Martínez, esposa do assentado Manuel Rojas, e com suas filhas, cujos nomes não foram mencionados. Pela hora vespertina das visitas, a equipe do ICIRA acessava mais as mulheres que os homens, e logo entraram em contato com as tensões de gênero dentro do assentamento. Dona Marta queixara-se de que os homens não entendiam nada do trabalho das mulheres na casa e no huerto, e que as mulheres precisavam participar das assembleias para, de uma vez por todas, explicar aos homens a importância daquilo que faziam. Ela reivindicava esse direito junto às mulheres organizadas no CEMA: "querem participar das reuniões feitas pelos homens", reportaram os pesquisadores no diário, “mas os maridos não permitem. (...) Há muitas coisas que precisam dizer a eles", ${ }^{611}$ escreveram. As jovens camponesas eram particularmente afetadas por interdições de gênero. As filhas do assentado Manuel Rojas, por exemplo, relataram que não tinham permissão para sair de casa, a não ser para um curso noturno de corte e costura oferecido pelo CEMA. Elas tinham conseguido uma máquina de costura doada. Por outro lado, Inéz Martinez reclamou que as mulheres eram muito conflitivas entre si, e havia uma briga em curso sobre o sumiço de mil escudos pertencentes ao CEMA.

Outra conversa marcante foi com a senhora Zoila de Larco, que expressou uma forte depressão decorrente dos maus-tratos que sofria do marido. Zoila tinha cinco filhos, incluindo um bebê de 4 meses e uma criança com deficiência mental. Quando perguntada sobre o assentamento, lamentou que preferia como era antes: o patrão era bom e lhe dava mantimentos e roupas às crianças. Com o assentamento, apesar da renda ter aumentado para 250 escudos (antecipo), não conseguiam comprar as coisas que o patrão entregava. Quando lhe perguntaram sobre que ela mais gostaria no futuro, Zoila se pôs a chorar desconsoladamente. O que mais queria era mudar de casa, porque o marido tinha um caso com a vizinha e ela vivia uma rotina desesperadora, entre violência e humilhações públicas. Ele lhe batia todos os dias, irritava-se com o choro do neném e só aparecia em casa para comer. Além de sentir-se deprimida, Zoila contou que tinha a vista embaçada de tanto apanhar durante a gravidez. Mas não conseguia ir ao médico

611 Id., ibid. 
em Buin porque não tinha com quem deixar as crianças. Ela estava tão solitária que sentia vergonha de pedir ajuda às mulheres do assentamento: "todas sabem", ${ }^{612}$ chorou. Sua consciência sobre a reforma agrária era a de alguém efetivamente excluída do processo: não sabia qual era o trabalho do marido e ignorava o que fazia a CORA. Por último, confessou que a última vez que havia colocado os pés para fora de casa havia sido para dar à luz ao filho de 4 meses. Para evitar a fúria do marido, parou de frequentar o CEMA. Disse que "seria lindo" se um médico viesse ao assentamento, já que ela tinha muitas demandas de saúde. Não queria mais ter filhos, mas desconhecia como: apenas confiava em Deus.

Uma noite, a equipe esteve presente em uma assembleia dos assentados, que ocorreu na escola, onde também aconteciam uma aula de alfabetização da CORA e o curso de moda do CEMA. O presidente dom Tuco prontamente informou a todos que as mulheres do CEMA haviam pedido de novo para participar da assembleia, mas ele de novo as impediu. Justificou dizendo que era melhor que se reunissem separadamente para as mulheres não "meterem a pata" ${ }^{\prime 13}$ nos seus assuntos. Na socialização pré-assembleia, rolavam piadas pejorativas contra o patrão, nas quais o chamavam de homossexual.

Na sala da escola onde ocorreu a assembleia, havia uma foto do presidente Frei, um crucifixo e fotos da equipe de futebol do assentamento. O secretário da reunião relatou que Rafael Moreno, diretor da CORA, lhes havia prometido pessoalmente que em quinze dias a expropriação do restante da hacienda El Recurso estaria concluída e os inquilinos excluídos do assentamento seriam assentados. Depois, foi colocada em pauta uma proposta da CORA de que o assentamento comprasse árvores do antigo dono. Instalou-se uma polêmica, pois alguns pensavam que era preciso assinar o quanto antes o contrato de expropriação e as árvores passariam a pertencer ao assentamento, mas outros pensavam que era arriscado herdar dívidas do patrão com uma assinatura precipitada. O contrato da expropriação foi então lido pelo presidente do assentamento, interrompido por queixas de que era incompreensível: "não se entende nada!", exclamaram. Quando um assentado propôs convocar um funcionário da CORA que lhes explicasse, outro rebateu que aquilo lhes tomaria horas de trabalho. Um terceiro alegou que se fosse necessário, deviam perder até mesmo uma semana de trabalho para entender o contrato.

A equipe do ICIRA observou que havia uma distância desproporcional entre a mesa diretiva e os assentados, encolhidos no fundo da sala. Era um indício de concentração de poder, pensaram. Posteriormente, Maria Edy escreveu no relatório de observação: “depois da explicação do funcionário da CORA se produz um grande silêncio, apesar dos esforços do presidente e do coordenador para que a assembleia opine e participe", ${ }^{614}$ registrou: "os camponeses se encurralam nos últimos bancos, não falam e estão no escuro. A única lâmpada que há, ilumina apenas a mesa diretiva (...). Os verdadeiros

\footnotetext{
${ }^{612}$ Id., ibid.

${ }^{613}$ Id., ibid.

${ }^{614}$ Maria Edy Ferreira, Algunas observaciones sobre el asentamiento El Recurso In: ICIRA, Investigación temática. Asentamiento El Recurso, op. cit.
} 
atores são os líderes da direção. Os demais camponeses seguem espectadores, que ainda não compreenderam seu papel”.

Maria Edy se especializou em observar as relações de poder entre os camponeses em suas pesquisas. Apostava no espaço da assembleia como forma de autoeducação camponesa: "as reuniões da assembleia contêm em si mesmas a possibilidade de uma capacitação e pouco a pouco podem ajudar os assentados a compreender o funcionamento da sociedade (...), conhecer seus direitos". Ela também percebeu que Antonio Catalán, que havia sido eleito presidente com $25 \%$ dos votos, era quem mais tinha trabalhado naquele ano (215 jornadas). Sua liderança poderia resultar da sua disciplina laboral: "o critério da eficiência do trabalho parece ser uma pauta que orienta a eleição dos líderes, pois todos os membros da direção estão bem colocados no quadro das jornadas de trabalho comunitárias", ${ }^{615}$ observou. Como mostraram os diálogos dos círculos, a economia moral dos assentados e assentadas não poupava críticas aos flojos.

Ainda da assembleia, Villegas tomou a palavra para explicar a proposta da investigação temática. Contou o que era o método psicossocial dos círculos, pediu colaboração de todos e utilizou o exemplo do contrato: se topassem aquela experiência pedagógica, argumentou Villegas, a compreensão do contrato seria facilitada e a organização do assentamento poderia melhorar. Um camponês, Ignacio Larco, respondeu com pragmatismo: "tudo bem, se aquilo lhes trouxesse algum benefício". Villegas registrou: "o secretário da reunião disse que, com esse método, parecia que nós serviríamos de intérpretes da realidade deles e que estavam dispostos a cooperar. Parecem intimidados. Nós nos retiramos para que seguissem tratando de outros pontos". ${ }^{616} \mathrm{Na}$ semana seguinte, um funcionário da CORA passou 5 horas com os assentados debatendo os termos do contrato de expropriação. Foi aprovado.

Em 11 de julho, Margarita Depetris foi à casa da família Meza. Margarita conversou com Isabel Meza, antes da chegada de seu marido, Luiz. Isabel se sentia diferente dos inquilinos excluídos do assentamento pelo critério da educação. Afirmava que "as pessoas do fundo [não assentadas] eram mais ignorantes que eles, quase ninguém sabe ler e escrever direito". ${ }^{17}$ Disse também que a letra do patrão era pior que a dos seus filhos e ele, além de mal-educado, era malvado e havia nascido "com os dois sexos", mito hermafrodita que corria entre os assentados. Quando perguntada sobre qual seria seu principal problema, alegou que o assentamento completo (com a expropriação da outra hijuela) demorava a sair. Aquilo, para ela, nada mais era que um direito seu, já que havia nascido ali. Opinou também que era "ruim que nem todos trabalhassem igual, pois alguns, por serem de direita, atuam como patrãozinhos e trabalham menos". ${ }^{618}$ Depois, disse que tinha medo do cunhado, Gonzalo Meza, capataz do antigo patrão. O irmão de Gonzalo era Luiz Meza, ativo na greve de 1962. Ao falar do passado, Luiz

\footnotetext{
${ }^{615}$ Id., ibid.

${ }^{616}$ ICIRA, Investigación temática. Asentamiento El Recurso, op. cit.

${ }^{617}$ Id., ibid.

${ }^{618}$ Id., ibid.
} 
opinou que "eram bobos de ter tantíssimo medo do patrão, que é um pobre velho que se assusta com tudo. Agora é nossa revanche", ${ }^{619}$ bradou. Ao mesmo tempo, confessou que ainda sentia aquele medo quando o encontrava - e logo se recompunha. "Estamos livres dele", ${ }^{620}$ comemorou.

A última visita da equipe ocorreu no domingo, 14 de julho, com Maria Edy, Fiori e Margarita. A proposta era visitar os camponeses jogando futebol e conhecer esse momento de sociabilidade. Naquela tarde, ocorria um jogo entre as crianças de El Recurso contra crianças de uma propriedade vizinha. Antes de chegar ao campo, passaram pela casa patronal. Apesar do medo persistente dos assentados com relação ao proprietário, reportaram que dom Vicente vivia na capital. A casa estava praticamente abandonada, ocupada somente por seus criados. No entanto, "sua presença existe na propriedade, sua casa é olhada com respeito pelos camponeses que ainda se referem a ele como 'o verdadeiro patrão"”. Observaram que havia uma relação entre a onipresença patronal e o poder divino, perceptível pela disposição espacial da casa grande. "É importante observar o conjunto da casa patronal", descreveram, "onde capela e casa formam um todo, dentro de um mesmo cercado e rodeado pelo mesmo jardim. (...) Visitar a casa de Deus era vir à casa do patrão". ${ }^{621}$ Uma das descobertas das primeiras visitas foi que o capelão da hacienda era amigo íntimo e aliado do patrão, lhe contando os detalhes das confissões dos seus inquilinos. O tema foi retomado nos círculos.

No campo de futebol, conversaram com o capataz Gonzalo Meza, que criticou seu irmão grevista e os líderes do assentamento. O futebol era um momento chave da vida social da comunidade. Foi no campo de futebol que os inquilinos de El Recurso organizaram sua greve em 1962. Antes do assentamento, o Clube Desportivo era uma das mais importantes organizações coletivas dos camponeses, já que ali não havia sindicato, nem comitê, nem partido. A centralidades dos Clubes Desportivos e campeonatos de futebol para organização das demandas camponesas foi posteriormente estudada por Maria Edy em uma pesquisa sobre organizações comunitárias camponesas. Entre os 80 assentamentos pesquisados, encontrou que 64\% deles tinham Clubes Desportivos antes da expropriação, mais do que os $58 \%$ que tinham sindicatos e os $23 \%$ que tinham CEMAs. Depois da expropriação, os Clubes Desportivos dos assentamentos se expandiram para $86 \%$ da mostra, os CEMA foram organizados em $81 \%$, ao passo que os sindicatos decaíram para somente $24 \%$ dos assentamentos. Os Clubes Desportivos eram mais populares entre os assentamentos do que os sindicatos. ${ }^{622}$

No final daquela tarde, no campo de futebol de El Recurso, concluíram a visita conversando com José Moya, um senhor de 70 anos que já morava na hacienda antes do patrão nascer. Ele acreditava que Vicente estava sofrendo um castigo divino, porque havia sido mesquinho e explorador. Moya lembrou que o patrão usava os pacos (policiais) para amedrontar os camponeses e demonstrou certeza de que sua família tinha feito um pacto com o diabo.

\footnotetext{
${ }^{619}$ Id., ibid.

${ }^{620}$ Id., ibid.

${ }^{621}$ Maria Edy Ferreira \& José Luis Fiori, Investigación temática cultural de los campesinos de El Recurso, op. cit., p. 42.

${ }^{622}$ Maria Edy Ferreira, Tendencias del poder entre los campesinos asentados. Santiago: ICIRA, 1970. (mimeo), p. 7.
} 
Após as visitas de escuta e observação, a equipe de investigação temática criou imagens codificadas com temas diretamente vinculados à essa história comunitária.

\section{Círculos de cultura}

A imagens produzidas especialmente para os círculos temáticos no assentamento El Recurso buscavam representar conflitos cotidianos, que Fiori e Ferreira dividiram em quatro eixos e quinze contradições, sintetizados na tabela 14 a seguir.

\begin{tabular}{|l|l|}
\hline \multicolumn{2}{|c|}{ Tabela 14 - Temas geradores da investigação temática do assentamento EI Recurso } \\
\hline \multirow{4}{*}{ Produção e relações de produção } & Camponês $\times$ Terra \\
\cline { 2 - 2 } & Patrão $\times$ Camponeses \\
\cline { 2 - 2 } & Trabalho coletivo da terra $\times$ Trabalho individual da terra \\
\cline { 2 - 2 } Processo de socialização & Trabalho $\times$ Diversão \\
\hline \multirow{2}{*}{ Gestação e estruturação do poder } & Pais $\times$ Filhos \\
\cline { 2 - 2 } & Mulhere $\times$ Homens \\
\cline { 2 - 2 } & Educação escolar $\times$ Educação extra escolar \\
\cline { 2 - 2 } Religiosidade camponesa & CORA $\times$ Assentados \\
\hline & Deus $\times$ Crentes \\
\cline { 2 - 2 } & Padres $\times$ Fiéis \\
\hline & Fonte: elaboração própria, com base em Ferreira \& Fiori, 1969: 51-66. \\
\hline
\end{tabular}

Enquanto Paulo Freire utilizava o conceito antropológico de cultura como recurso para iniciar o diálogo pedagógico decodificador, os pesquisadores do ICIRA enfatizaram diretamente a noção de "conflito" e "contradição" para criar imagens baseada na vida dos camponeses de El Recurso. Tratavase de uma declinação nitidamente marxista do método psicossocial. A filosofia da história por trás dessa abordagem, embora não explícita, indicava que os conflitos e contradições eram os componentes mobilizadores dos processos sociais, tanto quanto do diálogo político-pedagógico e da consciência sobre a realidade. Ademais, era bastante central para a equipe a abordagem das hierarquias de poder entre os atores em contradição e as maneiras como os assentados imaginavam estratégias de futuro que perpetuassem, deslocassem, remodelassem ou destruíssem tais hierarquias. Conhecendo as tensões de gênero latentes no assentamento, a equipe do ICIRA escolheu realizar círculos separados de homens e mulheres. A agenda de encontros seguiu o calendário a seguir. ${ }^{623}$

${ }^{623}$ ICIRA, Investigación temática. Asentamiento El Recurso, op. cit. 


\begin{tabular}{|c|c|c|c|}
\hline \multicolumn{4}{|c|}{ Agenda de círculos de cultura na investigação temática de El Recurso } \\
\hline & Situação & Data & Gênero \\
\hline 1 & Inquilino e Mayordomo (capataz) & $3 / 10 / 68$ & Ambos \\
\hline 2 & Conflito / Greve & $3 / 10 / 68$ & “" \\
\hline 3 & Capela / Igreja & 3/10/68 (a) & “" \\
\hline 4 & Situação familiar: pai, mãe, filhos & $10 / 10 / 68$ & “ \\
\hline 5 & Trabalho da mulher na casa & $10 / 10 / 68$ & Só mulheres \\
\hline 6 & Trabalho e diversão & $10 / 10 / 68$ & Ambos \\
\hline 7 & Futebol & $10 / 10 / 68(b)$ & “" \\
\hline 8 & Cueca & $10 / 10 / 68(b)$ & "“ \\
\hline 9 & Assembleia & $16 / 10 / 68$ & “" \\
\hline 10 & Televisão & $16 / 10 / 68$ & "“ \\
\hline 11 & Comercialização e consumo & $13 / 11 / 68$ & Só homens \\
\hline 12 & $\begin{array}{lll}\begin{array}{l}\text { Trabalho } \\
\text { comunitário }\end{array} & \text { individual } & \text { e } \\
\end{array}$ & 13 e $20 / 11(c)$ & Ambos \\
\hline 13 & Comitê de consumo & 13 e $20 / 11$ & “" \\
\hline 14 & Sala de Aula / Educação & 20/11/68 (d) & “" \\
\hline 15 & Inovação técnica & $20 / 11 / 68$ & Só homens \\
\hline
\end{tabular}

(a) Ferreira \& Fiori (1969) registram outra data: 7/10; (b) Idem: 3/11; (c) Idem: 23/10; (d) Idem: 10/11

O encontro sobre a situação 1, "Inquilino e Mayordono" (também chamada "situação de trabalho no latifúndio"), trouxe à tona o tema da preguiça e da disciplina laboral, assunto crucial na composição da economia moral dos assentados. O círculo aconteceu na noite de 3 de outubro de 1968 . Na primeira, a hierarquia entre o "homem a cavalo" (capataz) e os outros, foi percebida de imediato, por homens e mulheres, como a diferença entre quem não trabalha, porque só manda, e quem trabalha obedecendo. A imagem da situação 1 pode ser vista a seguir.

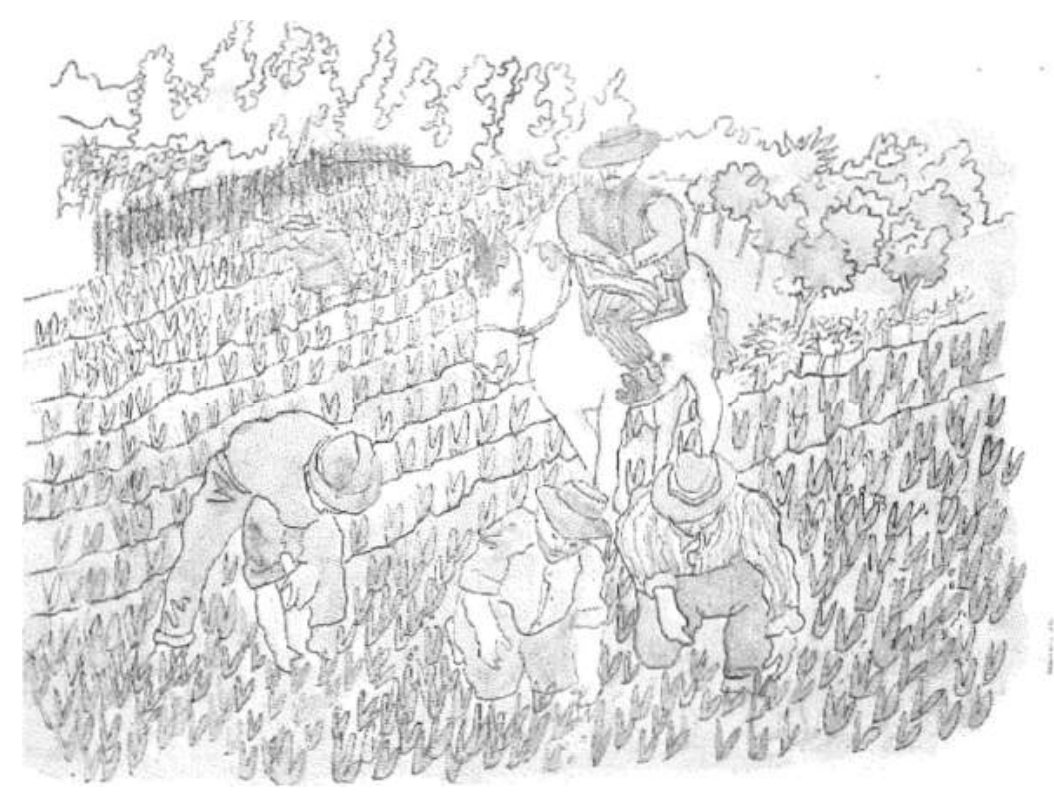

Situação 1: Inquilino e Mayordomo. Fonte: Ferreira \& Fiori, 1969: 76 
"É flojazo o homem que está aí", ${ }^{24}$ disse rapidamente um assentado sobre o capataz, quando o coordenador Sergio Villegas solicitou que explicassem a primeira situação no círculo de homens. "O mayordomo não serve para o trabalho!", exclamou outro. Em seguida refletiu: "na verdade, nós trabalhamos menos do que quando trabalhamos sozinhos. Se trabalhamos sozinhos, nos apressamos por nós mesmos. Mas se nos relacionamos mal com o mayordomo nos apressamos menos, temos menos motivação", disse o assentado. O coordenador então perguntou se a ausência do capataz poderia fazer com que trabalhassem mais. "Bom", respondeu o presidente do assentamento, "há pessoas que não precisam de capataz e outras precisam". O coordenador estimulou que continuasse: e de que depende? "Da responsabilidade. Se você é consciente... É consciente para o trabalho", completou dom Tuco. Para ele, ser consciente para o trabalho significava que "estando sozinhos ou não, [os camponeses] trabalhem e pronto, não esperem que o capataz se vire de costas para descansar. Seguir trabalhando, a isso chamo uma pessoa consciente", definiu.

O coordenador perguntou, então, como era o trabalho no assentamento. "Nós aqui já não temos capataz", disse um assentado. "Agora quando produzimos menos, temos menos lucro e se trabalhamos mais, há mais produção e mais dinheiro. Antes o lucro ia para o patrão. Esse homem que está a cavalo deveria estar juntinho conosco, trabalhando igual", opinou outro. "Sim, e que descanse o cavalo!", brincou um terceiro.

Diferente dos homens, as mulheres iniciaram uma conversa descritiva, com muito mais momentos de silêncio e necessidade de estímulo do coordenador. Sua postura sobre o capataz era menos crítica e mais condescendente: “o administrador está cuidando dos trabalhadores", explicou uma. E por quê? "Porque alguns não sabem trabalhar e outros sabem", respondeu. Mas logo outra senhora compartilhou a ideia de que o capataz não trabalhava: "era costume de antes, dos patrões ter uma pessoa ali que está ganhando mais e não trabalha nada", lembrou: "Quem trabalha é este, que está ganhando menos. O do cavalo, que não trabalha, é mais considerado por seu patrão, tem melhores regalías e melhores condições de vida, além de ser mais bem tratado", afirmou. Ao final, chegaram a conclusões parecidas sobre as vantagens da reforma agrária, mas sem deixar de usar o gênero masculino e a terceira pessoa: "no assentamento, eles sabem que [o trabalho] é para eles, mas no latifúndio não trabalham com gosto, porque sabem que toda produção vai parar nas mãos do patrão".

$\mathrm{Na}$ mesma noite, debateram acaloradamente a situação 2, chamada Conflito. Os camponeses se identificaram logo como os homens que portavam bandeiras do Chile e ferramentas. Também identificaram que estavam em greve e as mulheres e crianças os observavam de longe, demarcando a masculinidade da luta. "Se isso é uma greve, pensam que as mulheres deveriam se integrar ao grupo ou ficar atrás?", perguntou o coordenador. "Integrar-se ao grupo", respondeu o primeiro. "Se a greve é por economia, por mais dinheiro, elas devem nos seguir", disse o segundo, "são elas que levam o gasto da

\footnotetext{
${ }^{624}$ A partir daqui, todas as falas de camponeses nos círculos pertencem ao mesmo documento e não seguirei indicando em nota. Optei por retirar as marcas de interrupção com reticências para garantir a fluência oral do texto: ICIRA, Investigación temática. Asentamiento El Recurso, 1968, op. cit.
} 


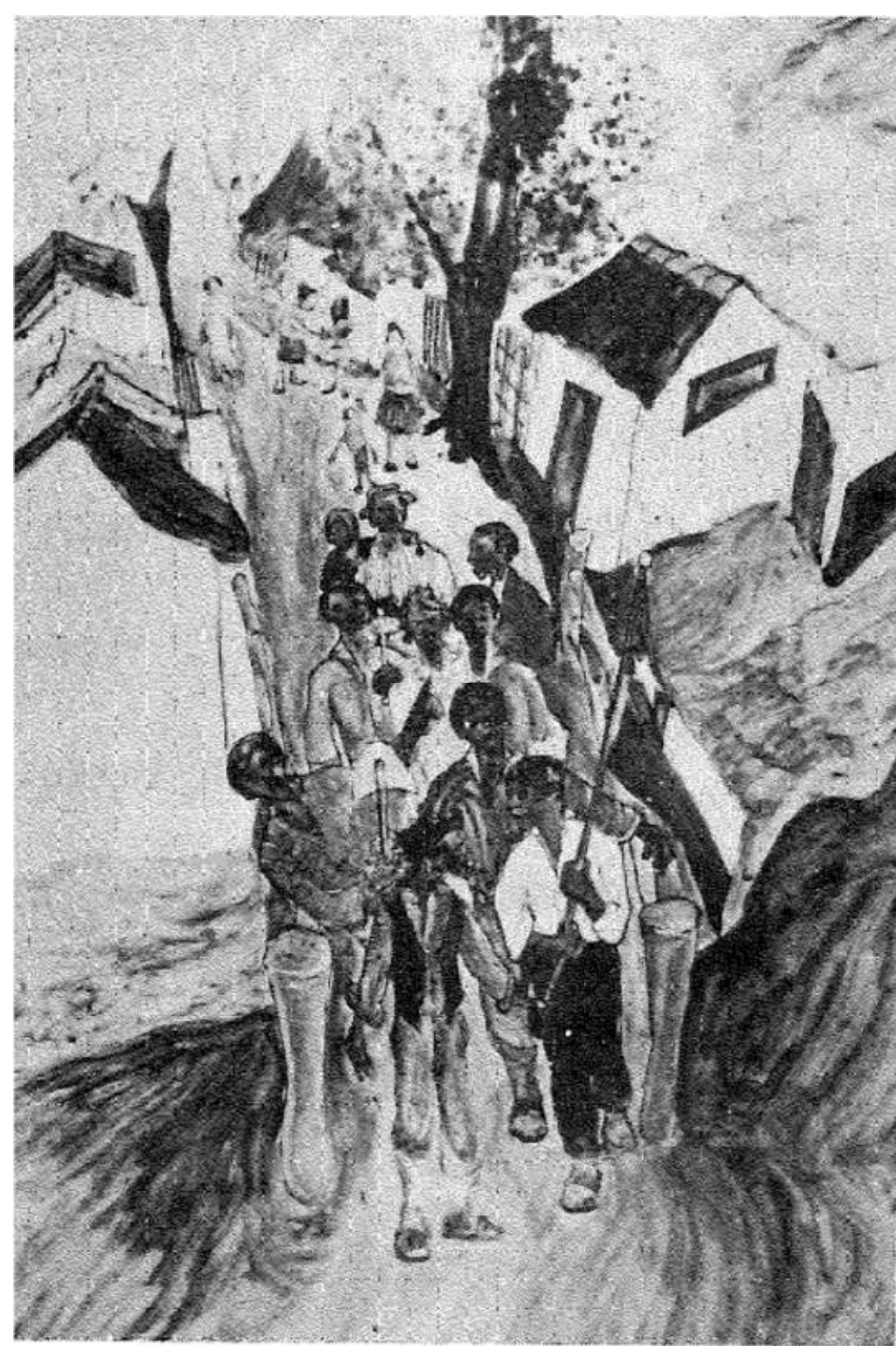

Situação 2: Conflito. Fonte: Ferreira \& Fiori, 1969: 82

casa, não recebem o dinheiro se não lhes damos e têm que se virar. Por isso tem que nos acompanhar pelo salário", completou. "Mas elas também têm arrumar as casas, que estão feias", emendou outro, seguido de risos.

Dom Tuco, o presidente, começou a contar sobre a greve de 1962. "Naquele tempo, ganhávamos uma miséria. Trabalhávamos de sol a sol e nos pagavam quando tinham vontade. E aí fizemos a primeira greve", lembrou. "A semana corrida não era reconhecida, não se reconhecia nada. Aí começaram a pagar a semana corrida. Começaram os aumentos de salários, fomos agarrando um pouquinho mais, as férias de inquilinos e voluntários", ${ }^{25}$ outro camponês seguiu. Depois contaram da participação do deputado Juan

Acevedo (PC) na conquista dos direitos trabalhistas na região. Reclamaram dos maus tratos do patrão, da sua má vontade, das suas terras ociosas. "Por ele, não tínhamos nem o que comer", denunciou um assentado.

O tema da participação feminina foi retomado. Um assentado disse que as mulheres e crianças deveriam participar se a greve fosse pacífica, "sem usar armas, mas com palavras", argumentou. O coordenador perguntou o que pensavam dos protestos violentos. "Acho que aí entra a política", se isentou um assentado. E outro ponderou: "mas às vezes vamos reclamar aos inspetores [do trabalho] $\mathrm{e}$ eles ficam ao lado do patrão e aí sentimos que precisamos fazer justiça por nós mesmos". Vários concordaram: "o inspetor do trabalho se vende aos ricos", "se vende", "se vende". Outro assentado pegou a palavra para criticar militantes radicalizados: "às vezes vem uma pessoa de um partido e diz: 'olha, vamos fazer assim'. Alguns têm razão, mas nem sempre”, ponderou. "Nos dizem: 'vamos com armas'. E depois os camponeses têm que andar fugindo pelas montanhas, escondidos. Isso eu condeno!

${ }^{625}$ A "semana corrida" era o direito ao descanso de domingo remunerado, depois de seis dias trabalhados, garantido pela lei 8.961 de 1948. 
Depois ninguém mais vê os líderes que induziram. E o camponês fica em situação ruim, porque foi contra a autoridade", denunciou. Em seguida, o coordenador consultou a opinião deles sobre os “agitadores políticos". Em geral, os assentados criticaram a atitude dos militantes de partidos que chegavam de repente e queriam convencer os camponeses a realizar ações que eles sequer sabiam se eram ilegais: "se aproveitam de nós", disse um. Concordaram também que o camponês era desconfiado porque já havia sido enganado demais: "o camponês é receoso. E muitos estão com o patrão porque têm medo". E o outro completou: "sofremos o complexo de inferioridade, essa é a verdade.

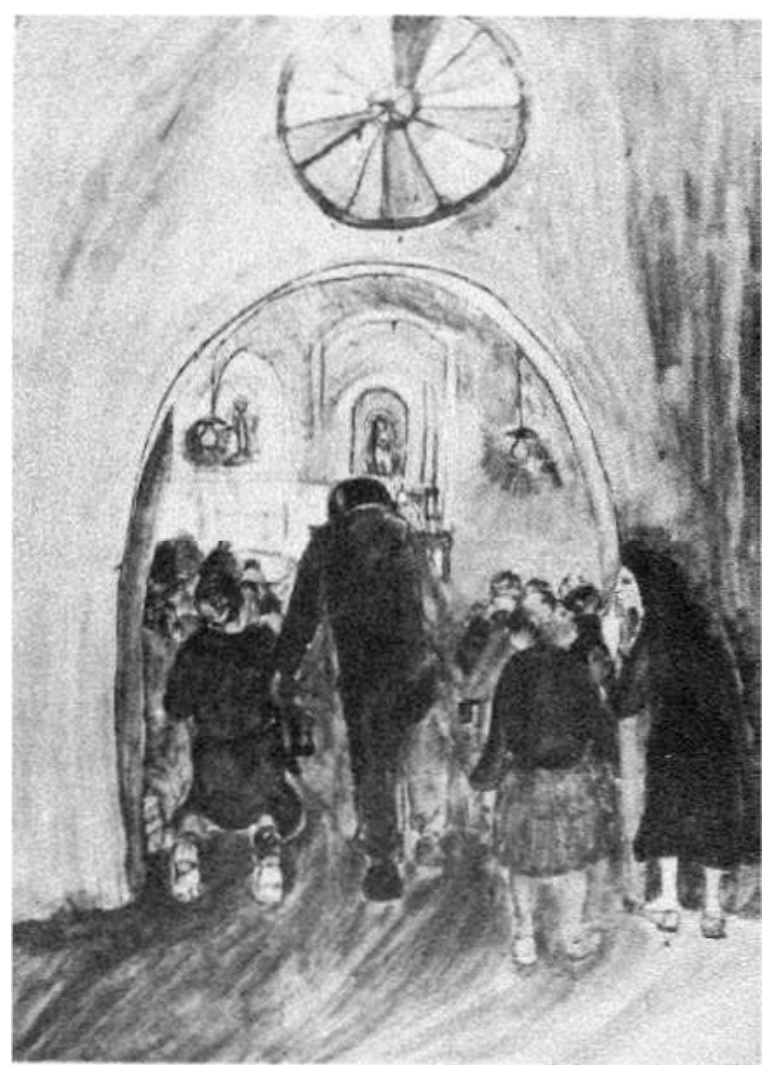

Situação 3: Igreja. Fonte: Ferreira \& Fiori, 1969: 163 Qualquer pessoa que inspira um pouco mais de respeito já nos faz tremer. Mas agora não: nós pelo menos, que somos assentados, já nos acostumamos a nos relacionar com gente de fora. Como vocês mesmos", referindo-se ao coordenador do ICIRA: "já não temos medo de nada".

As mulheres custavam mais tempo a se sentir à vontade e, no início, falavam menos. "Aqui estão em greve", disseram. "Ou então é um latifúndio que vai ser ocupado". E por quê? "Porque os patrões não são bons", "para trabalhar en lo próprio, porque estão cansados de ser escravizados". O coordenador pediu que compartilhassem os murmúrios do fundo: "é preciso quebrar os vidros e forçar a porta", disse uma. "Sim”, concordaram, "porque o patrão não quer se mexer, não quer ir embora", "também não quer pagar". Outra inseriu uma referência à esperança de expropriação do restante da hacienda: "o grupo está esperando que venha a força pública tirar dom Vicente para fora. Assim estaremos todos juntos quando vier a força pública". "Dizem que vem na segunda", disse outra.

Sobre as mulheres e crianças no fundo da imagem, exclamaram: "as senhoras também devem ir, como vamos deixar que eles vão sozinhos?!". "Temos que dar nossa opinião", "seja como for, a perder ou ganhar, é preciso entrar na luta”, concordaram. "Às vezes algo dá errado com os homens e para alguma coisa vamos servir, mesmo que seja assim, atrás", disse outra: "há muitas coisas que os homens se esquecem".

Ainda na mesma noite, os círculos analisaram a situação 3, da Igreja. Os assentados reclamaram da qualidade do desenho, mas seguiram conversando sobre a capela de El Recurso, construída nos primeiros anos do século XX. Segundo eles, a capela servia "para atemorizar os inquilinos, para que 
não roubassem. Todo patrão que tem igreja e traz missões, é para isso, para comprovar quem rouba, porque o padre não esconde nenhum pecado, os torna público al tiro" ${ }^{626} \mathrm{Um}$ camponês seguiu a denunciar o padre: seu cunhado, que tinha confessado roubar ferramentas do patrão, no dia seguinte perdeu as regalias e na mesma noite o sermão dizia "não roubarás". Outro assentado discordou: "uma igreja serve para muitas coisas! Casar, batizar as crianças". Outro emendou: "até nos casarmos na igreja, não nos entregam a mulher para que nos deitemos com ela", seguido de risos. "Eu acredito que os ricos e os padres, que nascem dos ricos, criam ocasiões para atemorizar as pessoas, gente humilde como nós", insistiu outro. "Mas se não houvesse crença viveríamos como os animais. Se não houvesse Deus, o que seríamos nós? Não seríamos nada", alegou um. "Tal como és", provocou outro, gerando risos. Ao terminar a sessão às oito da noite, os assentados insistiram que falassem de mais uma situação: "a gente gosta de conversar".

Embora não tenha seu nome registrado nos relatórios da investigação temática, Rolando Pinto lembrou de atuar nos círculos de El Recurso. Pediu aos camponeses, em certa ocasião, que desenhassem sua realidade no passado, presente e futuro. "Os camponeses chilenos têm uma grande capacidade de expressão oral e expressão gráfica”, pontuou Pinto, “o desenho se convertia em um instrumento de expressão do conhecimento camponês". ${ }^{627}$ Os desenhos de autoria dos camponeses propiciaram ao ICIRA um prêmio da FAO e participaram de uma exposição. Rolando Pinto se recordou de desenhos que revelavam as mudanças do papel da igreja no processo de transformações agrárias. Eram duas imagens: a primeira, o padre escutava os camponeses com uma orelha, enquanto falava ao patrão aquilo que lhe diziam. Na segunda, o padre aparecia reunido junto aos camponeses e o patrão desaparecia. "E na visão do futuro, desaparecia o padre", descreveu. ${ }^{628}$

Entre as mulheres também apareceu o argumento de que a igreja servia para que o patrão controlasse seus empregados. "Dom Vicente pode até ter fé, ser católico, mas não cumpre como católico quando engana seus inquilinos", acusou uma camponesa. Também desconfiavam do padre: "um parente confessou que roubou um saco de trigo" e o patrão ficou sabendo. "Mas roubar é pecado", criticou outra. "Mas roubar dos ricos não é nenhum pecado", argumentou a primeira. "O patrão não vai à missa, joga os cachorros em cima da gente e temos que sair correndo porque eles mordem", denunciou. Discordavam sobre o patrão: "pelo menos nos deu bons conselhos", defendeu uma. "À sua maneira, nem ele nem a Igreja tem caráter", repudiou outra.

\footnotetext{
${ }^{626}$ Al tiro é uma maneira muito chilena de dizer: na mesma hora, naquele instante.

${ }^{627}$ Entrevista com Rolando Pinto Contreras, Santiago, 23/05/2018.

628 Idem.
} 
No dia 10 de outubro, foram debatidas outras cinco imagens. Começaram pela situação familiar, número 4, que no caso das mulheres se desdobrava depois em duas outras imagens sobre o trabalho doméstico feminino (situação 5). Nos registros dos círculos, eram anotados alguns períodos de silêncio, tal como requeria a pedagogia freiriana. O silêncio anotado no começo do círculo dos homens sobre a "situação familiar" foi constrangedor: quinze minutos gravados em que o coordenador se manteve quieto. No conjunto das transcrições de círculo em El Recurso, foram registrados 37 momentos de silêncio. Quando conseguiram começar a descrever a imagem, os homens disseram que o suposto marido parecia uma criança ou parecia estar bêbado. Depois, chegaram à conclusão que o casal estava brigando porque o marido gastou o dinheiro no bar e a mulher não conseguiu comprar comida para os filhos, situação que não era incomum na vida deles. Juntos concordaram que "na casa faltam muitas coisas e os bêbados gastam mal seu dinheiro". Em seguida, um deles notou: "ela está com um olho roxo", "ele lhe bateu". O coordenador perguntou qual seriam os motivos para que um homem batesse em sua mulher. Um deles rapidamente falou: "quando existe um motivo, podemos dar uns cascudos". Todos riram. "Quando é um motivo grave", ponderou outro. "Claro, quando não é grave, com palavras se consegue ajeitar, mas quando há motivo grave e justificado, é preciso dar um pequeno corretivo". Mais risos. Para quebrar o clima tenso, outro então disse: "mas nesse quadro, está demonstrado que ela tem razão". Sim, concordou outro: "e os filhos pequenos estão pagando o pato, escutando problemas". "Sempre acontece isso nos lares", constatou um assentado. O coordenador puxou então o tema do alcoolismo. "Os mais viciados morrem com seus vícios mesmo quando a mulher suplica", refletiu um camponês. Outro ponderou: "muitas vezes tem poucas possibilidades, escassez de trabalho, leva uma vida injusta. Também não conversa com outro companheiro, para refletir sobre essa questão". Foram chegando à conclusão que os homens

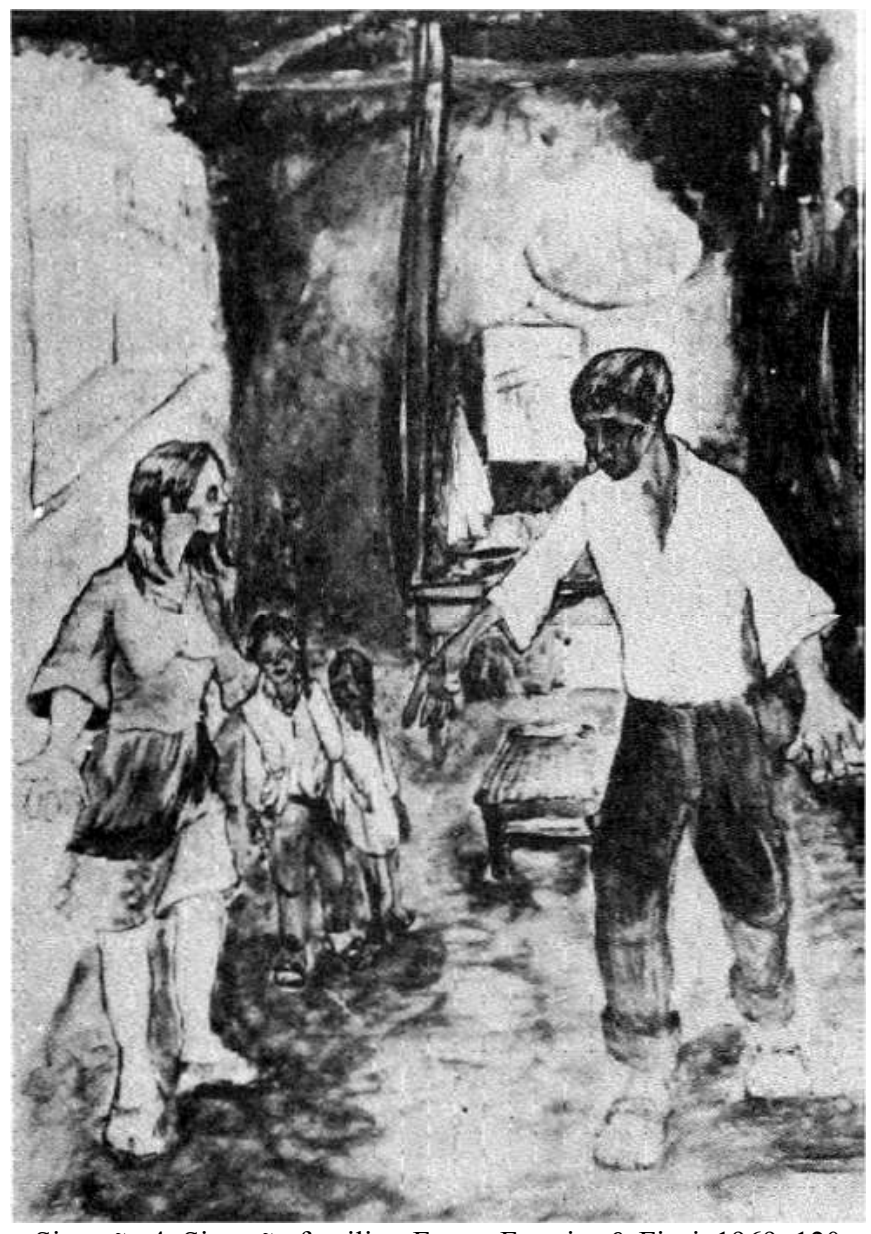

Situação 4: Situação familiar. Fonte: Ferreira \& Fiori, 1969: 120 precisavam conversar mais sobre seus problemas; de que isolados não era fácil resolvê-los. 
Aquele círculo revelava o reflexo de uma família camponesa em crise. Logo a situação da mulher que tem razão se reverteu para a reclamação contra a mulher impertinente: "na casa temos somente problemas", reclamou um assentado. Outro emendou: "Não se pode tomar uma xicara de chá, que a mulher vem dizer que acabou o açúcar, acabou o chá, acabou o pão". Abria-se um espaço para que os maridos criticassem o que chamaram de "más esposas". "Vamos supor que esse cara [da imagem] não está bêbado e está chegando para tomar once. A senhora não tem fogo na casa", ${ }^{629}$ disse um. "Claro", concordou outro, "elas têm que deixar as coisas prontas! Estou dando para que me prepare tudo e se não prepara é uma má esposa". Muitos quiseram falar: "pode ser que ela passou a manhã ou a tarde toda na casa do vizinho e esqueceu que o marido está trabalhando e que vai chegar cansado, morto de fome, com sede e não vai encontrar coisa alguma na casa". E outro completou: "pode ser que o homem não esteja bêbado e nós estamos julgando". Em seguida, o clima beligerante foi quebrado por um camponês que trouxe o tema da pobreza: "o camponês sofre com o econômico, porque na realidade não ganha o que precisa para viver com dignidade. Por isso o camponês está sempre aflito". E o coordenador perguntou: "E por que pensam que o camponês é pobre?". "Porque foi explorado por muitos anos pelos seus patrões, num sistema injusto. Não teve acesso à educação", "os salários são baixos”. Um assentado seguiu explicando: "o camponês que consegue um pouco de inteligência, não convém ao patrão nunca que seja estudioso, porque é este quem vai travar com ele a guerra". Outro completou: "Qualquer pessoa que tinha ideia sobre organização, era um perigo para o dono e era eliminado e perseguido. Por isso o camponês nunca podia levantar sua cabeça".

As mulheres também chegaram ao tema da violência doméstica a parti daquela imagem. "Ela está criticando o homem", diz uma camponesa. "Pode ser que o esteja reprovando porque não lava a cara esse muchacho-hombre", inventou outra. "Ou o muchacho está chamando a atenção dela porque anda mal penteada". Outra camponesa notou: "vejam o punho cerrado que ele tem para dar uma porrada na mulher". Risos. O coordenador perguntou por que ele poderia querer bater na mulher. "Porque está mal penteada, desarrumada". Mais risos. "De vez em quando acho que é bom que um homem bata na mulher", arriscou uma delas, recebendo respostas que concordavam e novos risos. Mas outra contestou: "Não. A mulher não se casou para apanhar". Surgiu um debate: "eu opino que não há nenhum direito de um homem bater na mulher. $\mathrm{O}$ homem e a mulher são iguais, com os mesmos direitos. Eu, frente ao meu marido, como vou deixar que me bata porque está de mau humor? Não!”, protestou. A primeira camponesa rebateu: "sim, quando a mulher dá motivos. O que acontece aqui mesmo no assentamento". Silêncio. "Acontece, mas está mal, a mulher não deve deixar bater", insistiu outra. O clima se tensionou e o coordenador perguntou sobre as crianças da imagem. "Estão assustados". "Quando as crianças veem o pai bravo, ficam perto da mãe, porque ela lhes defende", comentou outra. "É um mau exemplo discutir na frente dos filhos, eles se atemorizam", uma opinou. O coordenador então perguntou qual seria o

${ }^{629}$ Once é uma refeição leve de pão com abacate que todos os lares chilenos costumam fazer no fim da tarde ou à noite. 
motivo da briga. Várias responderam que provavelmente o marido não encontrou a casa arrumada como gostaria, a comida que ele queria, ou que discutiam por falta de dinheiro.

Na mesma noite, foram debatidos os temas "Trabalho e diversão" (situação 6) e "Futebol" (situação 7). Eram duas imagens para uma mesma conversa.

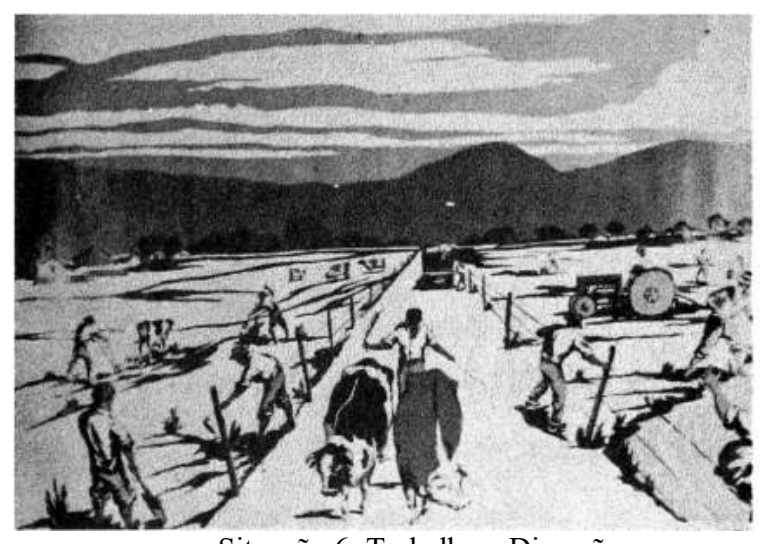

Situação 6: Trabalho e Diversão.

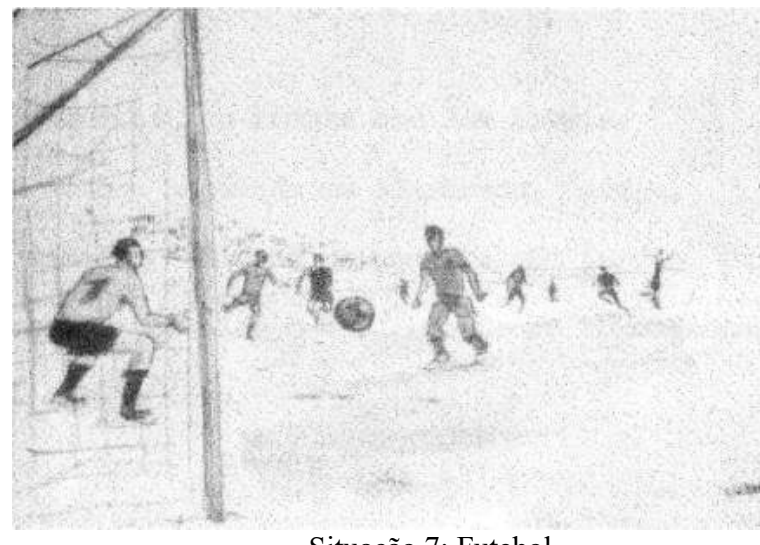

Situação 7: Futebol.

(Fonte: Ferreira \& Fiori, 1969: 110)

Na imagem do Trabalho, os assentados compararam com o primeiro slide, sobre a relação entre o inquilino e o capataz: "totalmente diferente do outro". Identificaram aqui o assentamento, devido à ausência do capataz a cavalo: "aqui cada um trabalha com empenho, contente". A comparação proposta pelo coordenador, contudo, era com o quadro do futebol. O tema do tempo livre era estratégico, embora evitado pelas correntes mais produtivistas da reforma agrária: "é preciso haver diversão, nem tudo é trabalhar!", defendeu um camponês. O coordenador então perguntou por que os homens precisavam do esporte. Naquela comunidade, como em outras, o futebol era forte gerador de coesão social e organização política entre os camponeses. Antes da lei de sindicalização 16.625 de 1967, era um dos poucos momentos em que podiam conversar livremente, articular a resistência ao patrão. Greves, tomas e comitês sindicais foram construídos nos campos de futebol das haciendas aos domingos, em campeonatos entre trabalhadores de diferentes latifúndios. "Serve espiritualmente também, porque relaxa os nervos. A gente se sente satisfeito depois de uma tarde esportiva, com mais tranquilidade. Se esquece dos problemas", alegou um camponês. O outro emendou: "é um meio de reunir-se, conversar, comunicar-se mais, conhecer-se melhor, todas essas coisas boas". O coordenador questionou o que mais gostavam de fazer para divertir-se, além do futebol. "Tantas coisas que desejamos e não podemos ter", suspirou um assentado. Um deles disse que queria ter um carro para "andar com uma muchacha para cima e para baixo". Outro comentou que gostaria de ter uma biblioteca "onde a gente se oriente". Um assentado então lembrou que conseguiram a televisão coletiva porque pouparam por meio do Clube Desportivo. Outro queria instrumentos musicais.

Entre as mulheres imediatamente saiu um comentário sobre a flojera: "os flojos estão brincando e os trabalhadores estão trabalhando", julgou uma camponesa, ao comparar as imagens do trabalho com 
a diversão. Na reflexão sobre a importância do futebol disseram que "as pessoas sentem raiva, não comem bem, preocupada com o trabalho, mas chega domingo e jogam para se divertir e dissipar tantas dores". Uma camponesa propôs um ângulo original: "às vezes o mesmo trabalho serve de diversão". Sim, concordou outra em tom de lamento: "às vezes os homens ficam mais entediados em casa do que no trabalho". Quando perguntadas sobre outras formas de diversão, lembraram dos filmes trazidos pelo padre às sextas-feiras, mas estavam cada vez mais caros e já não conseguiam pagar. Outra lembrou da festa do dieciocho. Ao fim da conversa, uma camponesa disse: "é interessante dar nossa opinião a outra pessoa".

No dia 16 de outubro, foram realizados círculos sobre o tema "Assembleia". Esse registro foi o único que continha os nomes dos 13 assentados homens que participaram. ${ }^{630} \mathrm{O}$ desenho reproduzia a distância física entre dirigentes do assentamento e outros membros notados pela equipe do ICIRA na primeira visita. Na imagem, um grupo de homens se mantinha no fundo da sala, distante da direção. "É quase igual ao que vemos aqui", disse um camponês. "Mas acho que os detrás não têm direito, e os assentados estão sentados na frente". Outro elocubrou: "se é uma reunião da CORA, vem só os assentados, mas se é qualquer outra reunião podem estar os outros". Um camponês disse, então, que o desenhista errou, porque pareciam trabalhadores de fábrica, estavam com sapatos, e os camponeses vestem sandálias. Também notou que estavam muito bem penteados: "nós somos mais desgrenhados, esse aí parece um sindicato". Sim, concordou outro: "se vê que são bastante avançados porque tem um televisor".

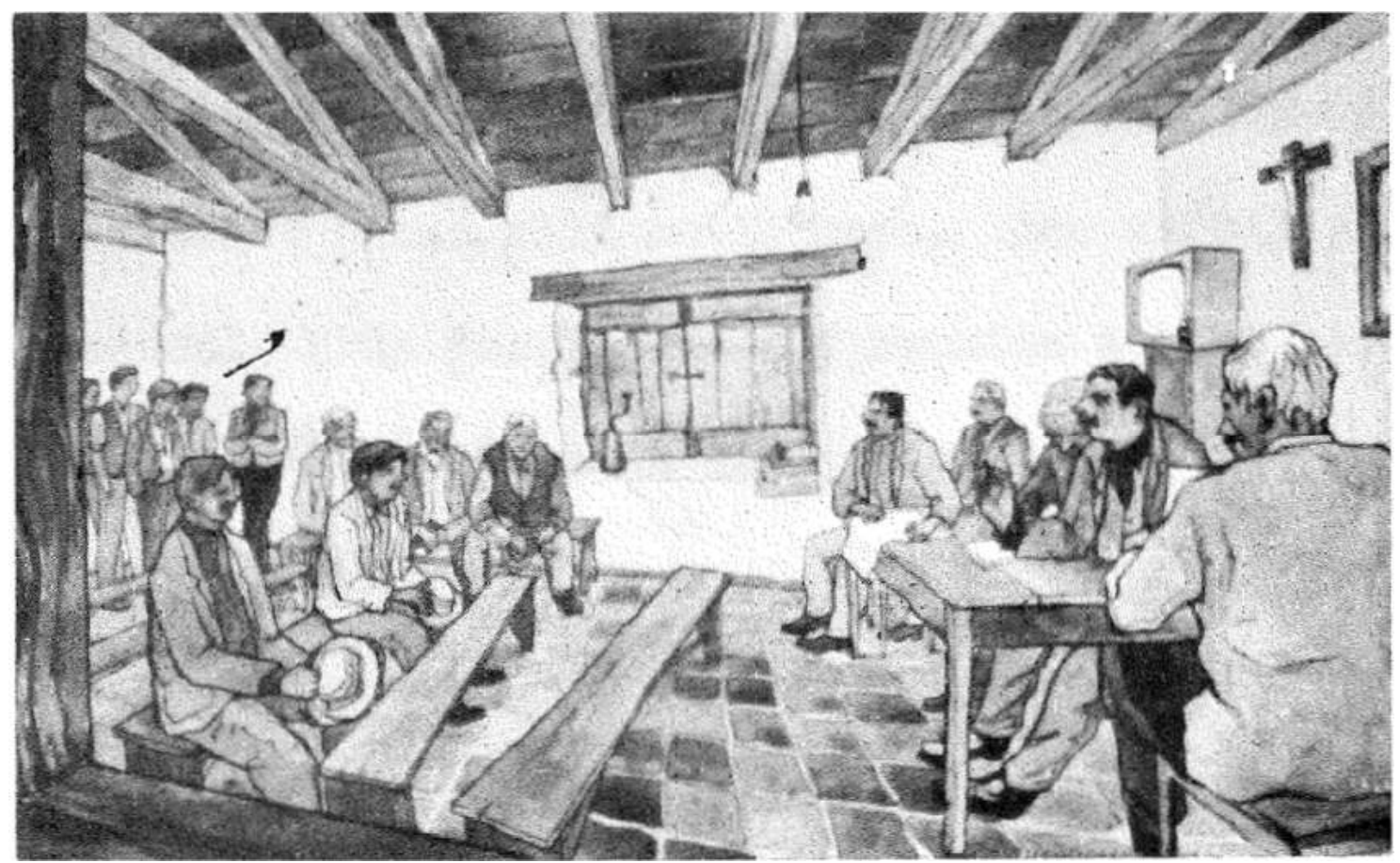

Situação 9: Assembleia de assentados. Fonte: Ferreira \& Fiori, 1969: 150

${ }^{630}$ Eram Victor Villablanca, José Tobar, Ignácio Lorca, Ramón Barrientos, Eugenio Berrios, Renato Serrano, Segundo Martinez, Gabriel Soza, Antonio Catalán, Alejandro Petit, Miguel Moraes, Patrício Mesa, Atilio Vidal. 
A conversa caminhou para um debate geracional. Um senhor disse que eram os mais velhos que falavam na frente e os mais novos que deveriam escutar. Porém, um jovem discordou: "acho que o jovem e o velho têm que unir suas ideias porque aqui no assentamento, no campo, temos as mesmas responsabilidades". Recebeu apoio: "estão os cinco membros da direção na frente, o presidente está explicando os problemas e os jovens têm os mesmos direitos e estão na reunião". Um camponês perguntou então por que os da direção se sentavam separados. Alguns disseram que é porque precisavam falar primeiro e só depois os demais. Outros assentados chegavam atrasados e ficavam atrás. O coordenador aproveitou para questionar o motivo do distanciamento dos homens no fundo da sala. "Para tirar o corpo da responsabilidade", analisou um camponês. E outro emendou: "as pessoas não estão acostumadas a falar na reunião. Nesse momento, não são capazes de dizer. Mas depois quando saem lá fora, aí sim, são capazes de falar o que não falaram na frente dos funcionários da CORA e do presidente. Não foram capazes, mas lá fora dizem”. O tema do silêncio e das hierarquias internas entre eles foi colocado em questão. Um deles criticou: "é comodismo. Vêm na reunião e não dizem nada, só escutam, mas depois criticam. Não são capazes de dizer aqui quando discordam da direção”. Instalouse um longo silêncio. O coordenador decidiu mudar de assunto: e por que há um crucifixo na parede? "Somos católicos. Se fôssemos evangélicos, não haveria crucifixo", disseram entrando em consenso.

Outras questões interessantes que apareceram no círculo foram a do analfabetismo e a do registro no livro de atas. A alfabetização aparecia como uma diferença interna de poder decisiva entre os assentados. "O secretário é o único que sabe escrever", disse um. "O que está anotando deve ser o chefe", completou outro. Depois a ata seria lida em voz alta para todos, que "apenas escutam. Aprovam e desaprovam um ponto ao escutar", explicou. Entre eles, funcionava assim: antes de começar cada reunião, o secretário lia os acordos da reunião anterior. "Sobre trabalho, principalmente", detalhou um assentado. $\mathrm{O}$ coordenador questionou, então, quais deveriam ser as qualidades de um dirigente do assentamento. "Deve ser mais atento que todos para se desenvolver mais e saber mais que os outros", respondeu um camponês. Outro refletiu: "mesmo que eu seja muito amigo da pessoa, não vou votar nela só por isso se não tem condições. E se o outro for meu inimigo, mas é capacitado, eu voto", mostrando simpatia pela noção de impessoalidade política. Um terceiro disse: "[o dirigente] precisa saber do trabalho no campo, saber mandar e fazer com que todos trabalhem. Precisa ter um pouco de conhecimento de leitura e escritura também".

Em seguida, a tensão cresceu quando um camponês resolveu enfrentar o presidente: "às vezes os companheiros se enganam para escolher [o dirigente], porque o presidente que temos aqui é bem tonto", agrediu: "bem apagadinho, parece que nos enganamos muito". O coordenador rapidamente disse: "não acho" e tentou desfazer a provocação perguntando sobre o papel dos estudos na direção do assentamento. Um camponês respondeu: "nos faltam pessoas com mais conhecimentos de leis, que tenham mais estudos. Às vezes por essas coisas nós não podemos tomar uma decisão e o [coordenador] da CORA diz 'olha isso aqui'", se referindo à dependência que sentiam do Estado: "Como tem mais conhecimento, nos mostra o que é bom e o que é ruim, porque nós às vezes tomamos uma decisão sem 
saber o que pode acontecer depois, sem conhecimentos capacitados". Por fim, o coordenador, não desavisado, chamou atenção para ausência das mulheres na assembleia. "É reunião para homens apenas, não para mulheres", sustentou um assentado rapidamente. "Assim como nós aqui: quando nos reunimos não entra mulher e quando estão as mulheres reunidas, não entra homem". Outro assentado descontraiu: "mas quando estamos de festa, aí sim...”. Um deles criticou a personalidade das mulheres: "as mulheres não devem escutar o que nós falamos. Elas são infantis", generalizou. O coordenador nitidamente insistiu na tentativa de desnaturalizar a ausência das mulheres: "mas não pode acontecer que na reunião dos assentados se conversem de temas que são de interesse das senhoras dos assentados e que elas devam estar presentes?”. Um assentado considerou a possibilidade da participação das mulheres de maneira instrumental: "sim, quando precisamos delas para fazer alguma coisa, lhes convidamos para reunião". E outro emendou: "quando precisamos fazer uma festa, receber pessoas de fora, convidamos as mulheres, que são melhores para fazer as coisas”. Ou seja, a comida e a faxina. Outro camponês, isolado, inverteu a compreensão do grupo: "não há nenhum comitê desse assentamento que uma mulher não possa fazer melhor que um homem". Concluíram a conversa falando das hierarquias entre assentados e não assentados. Concordaram, a partir de sua situação privilegiada, que eram iguais: "todos jogamos no mesmo clube de futebol, somos quase todos familiares aqui, só que alguns estão no assentamento e outros não. Não temos brigas, nem divisões".

As mulheres questionaram se a imagem representava o Clube Desportivo ou uma assembleia do assentamento, identificando que ambas reuniam homens. "Devem estar falando que o assentamento não anda bem, porque não estão satisfeitos", afirmou uma assentada. E outra concordou: "devem estar fazendo o balanço, porque estão amargurados". E "ficaram devendo, estão mais vendidos que uma ferramenta", completou uma camponesa. Expressavam assim certa desconfiança sobre a capacidade do assentamento fechar seus balanços no positivo. Outra assentada rapidamente discordou: "não, não acho que estão devendo, nem que estão vendidos, porque antes não tínhamos o que temos agora. Agora temos cavalos, ferramentas, estamos muito melhor que antes", constatou com otimismo. "Então talvez algumas estejam de acordo com o assentamento, ou seja, com a CORA, e outras não. E assim será", sustentou outra camponesa. Em seguida, uma delas explicou sua insatisfação com as diferenças internas do assentamento: não eram todas as famílias que estavam melhor, porque cada casa tinha quantidade diferente de força laboral e havia desigualdade da renda familiar: "algumas casas têm só um trabalhador, o dinheiro não é suficiente". "A culpa é da CORA", acusou outra, "que admite tantos trabalhadores em uma casa e dois ou três em outra". E de quem depende essa divisão? Uma assentada criticou a direção do assentamento, porque contratavam os afuerinos sem consultá-las sobre os familiares desempregados, que nunca eram chamados. "Esse foi um erro", alegou outra assentada, "que contrataram muita gente [de fora] que roubava". Elas acusavam os afuerinos de roubarem ferramentas e sementes do assentamento. "A culpa é deles [dirigentes] de escolher as pessoas que roubavam. E quando se deram conta de que estavam errando já não havia solução e não havia dinheiro", se indignou outra. Rapidamente, uma camponesa defendeu a direção: “mas então onde essa gente ia trabalhar? Me parece 
que é a CORA que os paga e não vem dos bolsos dos assentados, como muitos pensam”, argumentou. "Não, não. Isso sai do assentamento mesmo", enfatizou outra, "e por isso no fim do ano estamos devendo, porque usamos o dinheiro para pagar essa gente". As camponesas não sabiam se os afuerinos eram pagos pela CORA ou pelo assentamento, e divergiam sobre a qualidade da direção.

Nesse momento, o coordenador convidou às mulheres silenciosas que participassem também. "Vocês, que estão atrás, têm uma opinião diferente?". Uma delas respondeu assertiva: "Nós não pertencemos à CORA e por isso não temos direito a dar opinião". Camponesas de fora do assentamento estavam presentes no círculo. As hierarquias entre assentadas e não assentadas se explicitava quando as segundas diziam não ter direito à palavra. O coordenador insistiu: "mas essa é uma reunião de todas, não só das pessoas que estão assentadas, todas as senhoras que quiserem conversar sobre isso podem falar”. Uma não assentada questionou: “não é preciso ser assentada para dizer algo?”. "Ninguém está proibido de falar", respondeu outra camponesa. Mas logo o círculo foi finalizado.

Nos dias 13 e 20 de novembro, os camponeses e camponesas debateram um assunto central nos conflitos da reforma agrária e da economia moral: o "Trabalho individual e coletivo". Numa primeira imagem, havia uma casa camponesa isolada, com uma plantação e duas pessoas que trabalhavam no cultivo familiar. Na segunda, aproveitou-se uma ilustração da CORA com a palavra geradora cosecha, em uma cena harmônica de trabalho coletivo. A diferença da qualidade técnica dos desenhos foi interpretada como se a plantação familiar individual estivesse mais "feia" e a plantação coletiva mais "bonita". Essa interpretação se sintonizava com a inclinação da equipe do ICIRA em favor da propriedade coletiva, que coincidia com a opinião da maioria dos homens de El Recurso, embora não fosse unânime entre as mulheres.

Sobre o primeiro desenho, do trabalho individual, após um silêncio de 20 segundos, um camponês opinou que que a plantação estava mal cuidada: "ele tem muito pouca ajuda, teve que colocar a mulher para trabalhar". Outro completou: "a casa está triste, parece abandonada". Consideraram triste a família não ter filhos que ajudassem no trabalho. Com filhos "ficamos mais tranquilos e esquecemos várias coisas ruins da vida". Com filhos, outro opinou, "damos mais valor à vida e tratamos de batalhar para deixar algo a eles". Um componente interessante da economia moral também se revelava aí, no sentido do trabalho dado pelo futuro dos filhos.

Em seguida, passaram a comentar a situação atual do trabalho no assentamento: "agora temos mais organização, mais casas, vivemos mais perto uns dos outros. Antes as casas estavam quilômetros distantes", comentou um assentado: "agora somos vizinhos, temos mais união, não nos sentimos mais abandonados". Outro prosseguiu concordando: "união é quando estamos todos unidos, trabalhando contentes, aí tiramos boas ideias e formamos uma boa organização. Cada um dá sua opinião e a opinião melhor é escolhida. Mas assim, separados, não temos união". Era consensual o sentimento de que o 

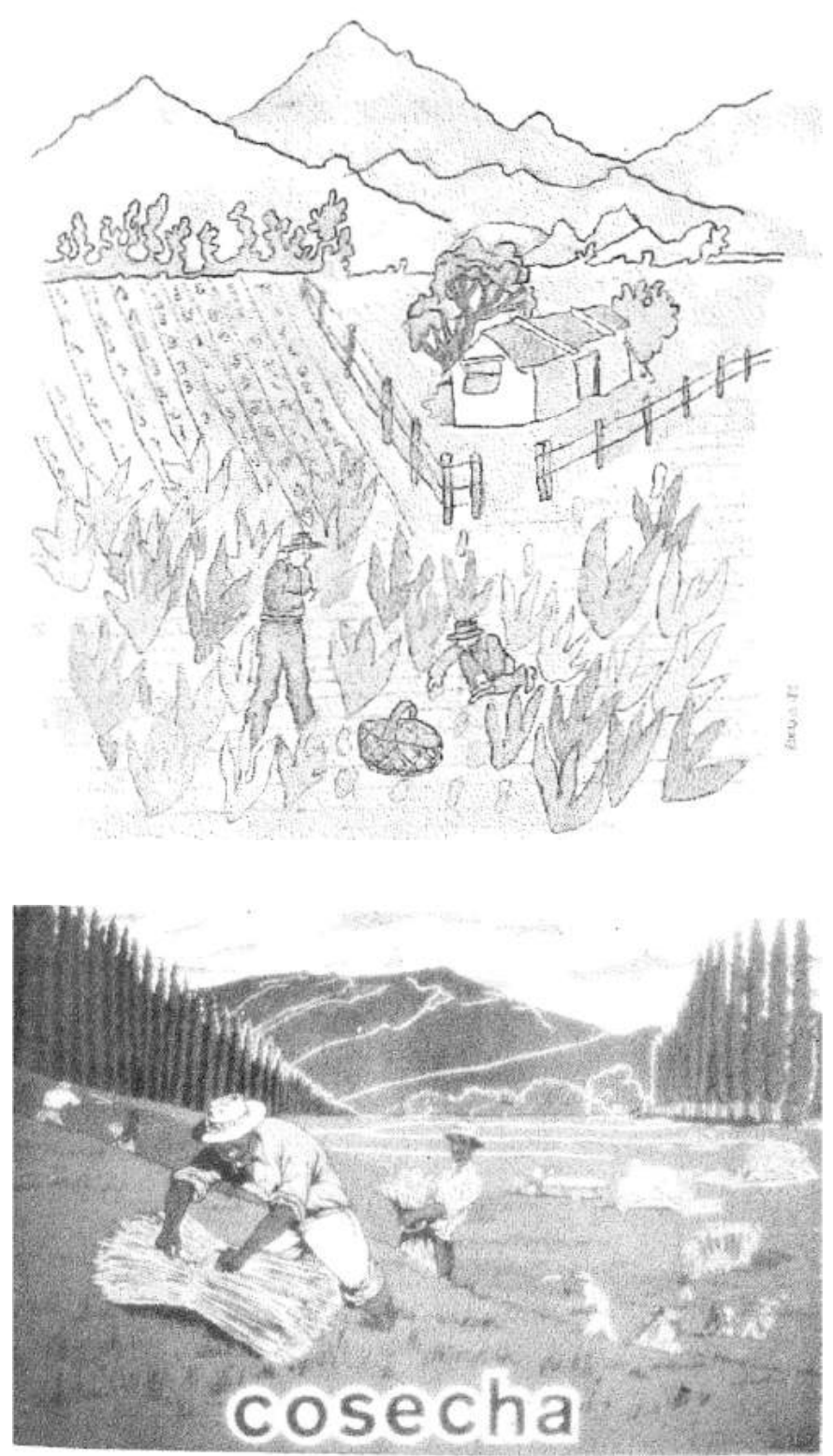

Situacão 12: Trabalho individual $\times$ Trabalho coletivo.

assentamento permitia uma vida comunitária que na hacienda não era possível. "Antes os terrenos estavam todos nas mãos dos patrões e eles não tinham interesse em avançar, limpar, dar para gente trabalhar. Mas agora, há muito entusiasmo, nos deram facilidades e conhecimento", avaliou.

Diante da imagem do trabalho coletivo, um camponês evocou a ideia de continuidade e progresso individual entre o primeiro e o segundo quadro: "esse homem foi muito capacitado até que virou empresário", disse um assentado. "Quando começou era muito pequeno, mas depois de trabalhar e trabalhar fez uma fortuna", concordou outro. Será que sonhavam que poderiam se transformar em grandes proprietários a partir de uma pequena parcela e do esforço familiar?

Um assentado comentou a presença do caminhão ao fundo e da maquinaria para colheita: "estão avançados. Parece muito melhor que a situação anterior". Por isso estavam contentes, disse. "Vamos ver como estão as contas...", brincou outro.

Risos sobre o endividamento. Havia a percepção de que a máquinas e prosperidade vinham sempre acompanhadas de dívidas. Então pela primeira vez, em todo registro, o presidente Eduardo Frei foi citado e elogiado por um camponês: "sozinho não se pode fazer nada, mas aqui, que somos vários, sim. Então aqui eles já tinham o senhor Frei na presidência”, disse um assentado, ao referir-se à segunda imagem: "Frei foi o único que prestou ajuda. Alessandri não gostava de ajudar", opinou. Outro camponês emendou: "os ricos sempre dizem que foram bons patrões. Mas quando tinham os latifúndios, negavam essas facilidades e não emprestavam nem o telefone. E agora o camponês pode falar sem tirar o chapéu. Antes tínhamos que tirar o chapéu para falar com o administrador e pedir permissão para falar com o patrão". O gesto de tirar o chapéu e segurá-lo na altura da barriga era carregado de submissão. Não ter que fazê-lo era um sinal importante da quebra de hierarquias. Ao comentar sobre as melhorias da nova vida, um deles disse: "agora temos mais educação. Nossos filhos serão mais habilidosos que 
nós". Um dos camponeses, nesse momento, pediu que os companheiros silenciosos também falassem, pois se repetiam sempre os mesmos. "Muito bem!", estimulou o coordenador. Um dos silenciosos resumiu: "Na comunidade há mais poder (...). Quanto mais comunidade, mais trabalho e mais produção. É isso que vemos aqui. Pouco trabalho e pouca produção aqui, porque eram pequenos e pouco sabiam, e depois a união faz a força". Sim, concordou outro: "aqui todos estão com vontade de trabalhar".

Por fim, debateram sobre o trabalho da mulher: "não acho bom que a mulher trabalhe, para mim pessoalmente ela não deve", afirmou um. "A mulher tem muito o que fazer com os filhos, tomar conta da casa, para que vá trabalhar no pasto também. Quem deve se sacrificar e prover a casa é o homem", reforçou. Já outro discordava: "não estou de acordo com o que disse o cavalheiro. A mulher tem que ajudar a comunidade para que seja uma comunidade decente. Para prosperar, a mulher precisa ajudar no que seja", comentou. Outro especificou qual seria o trabalho das mulheres: "podem ter um Centro de Madres, mas não no campo". E foi seguido pelo clichê: "claro, no campo os trabalhos são duros e a mulher, pelo que escuto por aí, é mais frágil. Talvez. Não sei”. O coordenador perguntou quais trabalhos as mulheres poderiam fazer. "Cortar as vagens, limpar a cenoura, coisas leves. Arrumar mudas", disse um camponês. O outro completou: "podem conseguir um crédito e comprar uma máquina de tecer". Um senhor mais velho disse: "antes as mulheres trabalhavam muito no campo". "Mas uma mulher, com vestido?", provocou outro. "Sempre podem usar calças", disse o velho. Um assentado mais informado então encerrou ao assunto: "as mulheres são a segunda força de trabalho do país, aqui no Chile a mulher trabalha muito: na indústria, no campo, trabalha muito. Não temos por que dizer que a mulher não deve trabalhar no campo, ela já faz certos trabalhos mais leves".

As camponesas de El Recurso, diferente dos homens, não tinham consenso sobre as vantagens do trabalho coletivo. "O camponês que tem sua parcelita está tranquilo, trabalha sozinho, ninguém manda nele", disse uma. Diante da segunda imagem, elogiaram a alegria do trabalho comunitário, mas uma delas insistiu: "o que estava sozinho estava melhor do que o que está em comunidade. Em comunidade um trabalha mais que o outro e ficam reclamando: 'olha, você trabalha menos e eu mais'. Que posso dizer? Trabalhamos igual e temos partes iguais. Mas o que está sozinho trabalha para ele mesmo". Outra camponesa concordou com o problema das brigas sobre as quantidades de trabalho: "se um trabalha mais ou menos ficam protestando, que é flojo. E é verdade", concluiu. Mas havia divergência: "eu opino que na comunidade trabalham melhor. Porque tudo o que fazem é para ganhar, para eles". "Não", contestou outra assentada, "em comunidade não, porque o trabalhador que trabalha mais não se dá bem. A comunidade é boa para oflojo. Não para o mais trabalhador". Outra camponesa concordou: "o que a senhora diz é verdade. Em comunidade se vê o trabalho bem feito, mas o mais largado não faz nada, não trabalha muito porque sabe que também vai ganhar igual ao que trabalha. E enquanto o senhor que está sozinho, tem que saber trabalhar, porque se ele não trabalha, ninguém o fará por ele”. A competição entre trabalhadores flojos e trabalhadores verdadeiros era o cerne mais representativo do conflito entre economias morais diferentes. A crítica ao flojo guiava os sentimentos camponeses para a propriedade individual; mas o elogio da solidariedade entre iguais no trabalho, os guiava para a propriedade coletiva. 
O coordenador, na sua intervenção mais diretiva, resolveu abrir argumentos sobre as vantagens do trabalho comunitário, e disse: "agora pergunto, depois que me dizem que o segundo quadro é mais bonito. Vocês veem a maquinaria, um caminhão, uma debulhadora... Acreditam que esse senhor que está sozinho pode comprar tudo isso?". "Não", disse uma. "Sim, pode também", discordou outra. "Para isso está batalhando, para comprar as ferramentas que precisa", afirmou outra. Não havia consenso. Por último, também dialogaram sobre a participação das mulheres no trabalho do campo. "Eu gostaria de ajudar", expressou uma delas. "Eu sempre ajudei meu marido fazendo hortas", disse outra. "Mas ir trabalhar na comunidade, que uma mulher vá junto com o homem, isso não", rechaçou outra. "Em um pedaço de terra que seja próprio, muitas coisas podemos ajudar. Limpar cebola, arrancar matos, quebrar milho...", prosseguiu, dentro da hegemonia do trabalho feminino no huerto que o grupo parecia expressar. As palavras utilizadas eram "ajudar o marido". "O campo não é para mulher. Podemos ir quando vai o marido, mas não sozinhas", insistiu uma delas. Mas como sempre, houve desacordo: "olha, uma mulher que ande sozinha pode ser muito respeitada sim. Há certas horas que temos que trabalhar com todos", divergiu uma camponesa.

Em 20 de novembro de 1968, por fim, último dia de círculos da equipe do ICIRA com a comunidade de El Recurso, um dos temas foi "Educação". A conversa contou com novos camponeses que acabavam de ser incorporados no assentamento, por isso o coordenador explicou novamente como seria a dinâmica. Nessa ocasião, explicitou as distâncias e enganos que podiam existir entre camponeses e educadores da reforma agrária: "com essas gravações nós vamos nos dando conta de que aquilo que realmente é importante para vocês, nem sempre são coisas importantes para nós. Não tenham vergonha, nem medo de falar. Se vocês não falam, faltará um aspecto do camponês que nós não vamos entender", sustentou. A primeira observação sobre a imagem da sala de aula foi que havia homens e mulheres misturados.

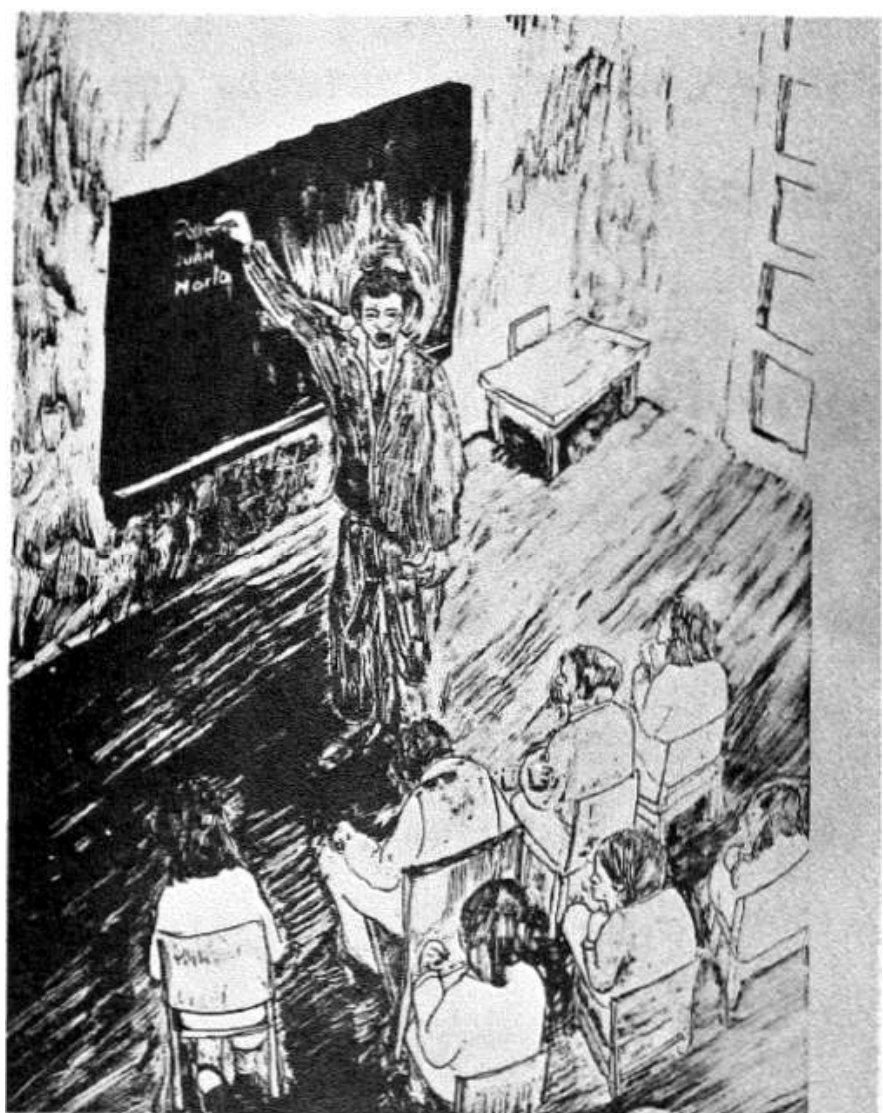

Situação 14: Sala de aula. Fonte: Ferreira \& Fiori, 1969: 134.

Mas o coordenador conduziu o debate para outro lado, perguntando por que pessoas adultas estavam na escola. Começou-se então uma conversa sobre o trabalho infantil dos camponeses, impedidos de estudar. "Não queriam que eu estudasse", disse um. "Nos mandavam trabalhar, porque fazia falta na família", lembrou outro. Um camponês argumentou que não era de fato que os pais não queriam mandar 
os filhos à escola: "Nesse tempo era o patrão que exigia do pai que mandasse os filhos trabalharem, não interessava [ao patrão] que estudassem, não the convinha", explicou. "Nem que a gente soubesse ler", reforçou outro. Os camponeses se lembraram como ganhavam pouco, e que eles também precisavam que os filhos trabalhassem. "Para tantas coisas precisamos saber ler e escrever, saber as quatro operações!", lamentou um assentado analfabeto: "não posso ter um cargo, nada, por isso agora estou tratando de aprender algo". Outro concordou sobre a relação entre estudo e poder: "quem está aprendendo agora está se defendendo dos peixes grandes, agora não nos enganam fácil”. Outro lembrou que escrever era importante para namorar e escrever cartas de amor.

O coordenador então perguntou que tipo de educação ele precisavam. "Cursos que sejam rápidos", disse um assentado. "Cursos técnicos", disse outro, "eletricidade, motores". Outro queria aprender matemática: "o que mais atrasa o camponês é a matemática. Não sabemos contar e depois no fim do ano não sabemos fechar a conta”. O coordenador lembrou que no assentamento já existia cursos de alfabetização. "Eu vou", disse um, "com a condição de aprender a assinar, porque atualmente sou um tiritón" ${ }^{631}$ Outro explicou: "ele fica nervoso". "Realmente. Se tenho um lápis e me dizem 'assine aqui', começo com uma letrinha pequena e depois sigo", explicou um. Outro contam suas estratégias para aliviar o nervosismo ao tentar assinar o nome. "Dá vergonha ir à escola na nossa idade, os outros zombam", confessou um deles. Mas o outro ajudou: "quando a gente está aprendendo, não deve ter vergonha". "Mas os alunos aqui estão com vergonha", disse um se referindo ao quadro. "Os que sabem menos devem estar todos juntos, porque aí não sentem vergonha", propôs outro. "E os que sabem mais, do outro lado". Temiam as diferenças de aprendizado entre si, as hierarquias produzidas por isso. Em seguida, outro propôs: "Ou então, juntamos um companheiro que não sabe e outro que sabe muito. E o companheiro que sabe ensina ao que não sabe”.

Perguntados sobre que educação esperavam que tivessem seus filhos, um deles disse: "que chegue a ser ministro" e riu. "Não pode haver filhos de pobres que sejam deputados, senador, presidente, porque eles não têm educação. Nunca haverá um que seja totalmente camponês, que conheça a terra, que defenda os camponeses", negou em resposta outro assentado. O coordenador aproveitou para perguntar se eles queriam que seus filhos fossem camponeses. "Não, para que trabalhem mais aliviados", respondeu um assentado. Outra polêmica se abriu: alguns defendiam que os filhos estudados deveriam voltar e ajudar a família a progredir no campo. Um deles contou uma cena triste de discriminação que havia sofrido com seu filho, que foi trabalhar em um escritório com gravata. O camponês foi visitá-lo, mas todos eram muito bem vestidos e o próprio filho o expulsou: "e esse velho? Sai daqui. Estou com gente honrada aqui", teria dito. Falaram sobre como o modo de se vestir e trabalhar na cidade era um indicador de poder: "como poderíamos ir à universidade com sandálias? Descalços? Camisa de manga? Morto de fome? Tremendo? Não se pode ir assim à universidade", opinou um deles. "Mas se o pai educa, o jovem pode ir bem preparado à universidade, chegar bem vestido e discutir com os ricos

${ }^{631}$ Tiritar é tremer, isto é, ele tremia ao tentar escrever. 
também", comentou outro. Todos concordaram que havia uma relação imediata entre educação e poder, que inclusive influenciava na maior ou menor capacidade dos camponeses para defenderem seus interesses e se protegerem da repressão policial. Um dos assentados resumiu:

Sendo bem-educado não sentimos vergonha de enfrentar qualquer um, discutir coisas e ter razão. Mas quando não temos educação, não temos também as palavras para nos defender e nos expulsam. Se vamos com boas palavras, terão que nos escutar. Um carabinero, se você não sabe responder, te levam preso. Mas se sabe defender-se, dizem: 'bom, esse gallo parece que tem razão'. O carabinero, quando pensa que você tem menos educação, te leva preso. Quantas vezes levarão preso um senador, um deputado? Não levam porque podem até perder o emprego.

Entre as mulheres, o tema da educação também gerou debates interessantes sobre hierarquias e poder. Tal como aos homens, contaram suas histórias de criança, que não puderam estudar e foram obrigadas a trabalhar. Comentaram sobre as escolas muito distantes e as dificuldades de transporte, ainda mais para as meninas. "Meus pais me mandaram ao colégio, mas por pouco tempo. Era uma distância que eu precisava atravessar uma propriedade. Muito longe", narrou uma camponesa: "Uma vez veio um touro bravo e matou uma criança que não conseguiu atravessar a cerca. $\mathrm{O}$ animal a fez em pedaços. Meus pais nunca mais me deixaram ir à escola. Era perigoso". Outra então comemorou: "mas a educação agora é mais fácil". O coordenador perguntou se pensavam ser uma obrigação colocar os filhos na escola: “claro, hoje não posso dizer 'essa criança não vai na escola porque eu não quero'. Não". Algumas, ao contrário, contaram que ensinavam seus filhos em casa: "eu dou aulas para minha filha em casa. No colégio, tem muitas coisas que não dão atenção". Narrou que era exigente: "me faço de polícia", disse a mãe, "se fez mal feito, tem que refazer".

O coordenador então questionou sobre por que existia a necessidade de estudar. "Para trabalhar em qualquer lugar, e porque se vamos na rua sabemos para onde ir, e uma pessoa que não sabe ler precisa ficar perguntando", respondeu uma camponesa. "Se sabemos ler, chegamos a qualquer lugar sem incomodar ninguém", completou. Outra concordou: “uma pessoa que não sabe ler fica desorientada e passa vergonha. Tem que assinar seu nome e não sabe. Tem que colocar seu dedo toda hora, é uma vergonha para nós que não sabemos nada". Outras acrescentaram que uma pessoa educada sabe respeitar, sabe tratar bem os outros, sabe ajudar os outros. Relacionaram a educação com a solidariedade. "Uma pessoa que não tem educação é como um animalzinho. Vê o outro e não se importa, porque não tem critério, não tem respeito". Outras concordaram: "a educação é para saber respeitar, aprender tantas coisas que ignoramos". O coordenador convidou uma camponesa silenciosa a falar. Ela disse: "eu não tenho nada a opinar, porque não teria paciência para ensinar a ler e escrever". "É uma egoísta então", tensionou a colega. Refletiram sobre a paciência das professoras e das mães no ato de educar, e concluíram que ensinar exigia muito respeito e tranquilidade.

Por último, o coordenador perguntou como gostariam que seus filhos progredissem com educação. "Com um emprego melhor pela educação que vai ter", disse uma delas. "Eu gostaria de lhes 
dar alta educação, mas sou uma mulher sozinha", lamentou outra camponesa. "Sofrem demais os homens do campo, de sol a sol, com fome, com chuva, tem que sair a trabalhar. Não podem dizer, 'hoje não vou'. Enquanto o homem com educação tem seu escritório, trabalha, ganha salário com muito mais facilidade. O trabalhador sofre muito", comparou uma delas. Concordaram que queriam que seus filhos trabalhassem em um escritório. Mas outra lembrou que é possível ser educado e trabalhar no assentamento: "tem cursos de mecânica, poderia ser no assentamento. Ou ser dono da parcela, ter um trator e pagar a outra pessoa de fora", comentou.

Após 27 encontros da equipe do ICIRA com os assentados e assentadas de El Recurso, a primeira etapa da investigação temática havia sido concluída. Ainda restavam outras duas, que nunca chegaram a acontecer.

\section{Experimento inconcluso}

O brasileiro José Luis Fiori, que teve um papel destacado na elaboração de relatórios a respeito da experiência no assentamento El Recurso, registrou junto com Maria Edy Ferreira que a investigação temática era uma "tarefa pedagógica com vistas a uma ação mobilizadora e organizadora do campesinato". ${ }^{632}$ A investigação temática almejava alavancar a capacidade de organização territorial, produtiva e política dos camponeses por meio do exercício cotidiano do diálogo e da problematização comunitária. Oferecia metodologias democráticas de autogestão, mas também aflorava diferenças e conflitos. O relatório da equipe do ICIRA mostrava que a investigação temática tinha como horizonte alterar as relações de poder sobre o território com os recursos oferecidos pela pedagogia do oprimido.

A partir da análise dos círculos, Maria Edy produziu um diagrama sobre a percepção camponesa das hierarquias no assentamento. A socióloga tinha como método a identificação das hierarquias importantes para o camponês e analisava as margens de disponibilidade para mudança e quebra dessas hierarquias, as tensões inerentes a elas e as expectativas de futuro. No caso de El Recurso, Maria Edy identificou três hierarquias principais: do latifúndio, da família e da Igreja: “o camponês de El Recurso se localiza na época do latifúndio. (...). Seu marco natural de referência é o latifúndio, visto como quadro das relações de trabalho (...). A referência ao novo sistema, a presença da CORA como instituição, o papel dos funcionários, são ainda realidades pouco compreendidas", ${ }^{633}$ analisou.

\footnotetext{
${ }^{632}$ Maria Edy Ferreira \& José Luis Fiori, Investigación temática cultural de los campesinos de El Recurso, op. cit., p. 9.

${ }^{633}$ ICIRA, Investigación temática. Asentamiento El Recurso, op. cit.
} 


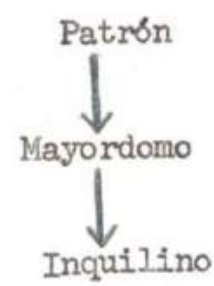

In la Familia*

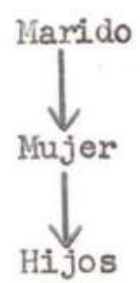

En la Iglesia*

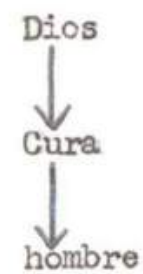

Para ela, a subjetividade de El Recurso ainda estava parametrizada pela experiência préassentamento. "O camponês de El Recurso", escreveu, "não chega a criticar a gestação do poder existente, mas critica a delegação desse poder ao capataz, que não desempenha nenhuma utilidade para o sistema. Critica igualmente o padre, a serviço do patrão, a serviço dos ricos, que se presta para atemorizar os camponeses". ${ }^{634}$ Faltava, na sua opinião, o desenvolvimento de uma consciência coletiva sobre as responsabilidades autogestionárias do assentamento e um sistema consensual de organização do trabalho.

A experiência da pedagogia do território não foi concluída em El Recurso e ficou estacionada em 1968, talvez em função da crise interna pela qual passava a DC, o desmonte das equipes da investigação temática, comprometidas com a ala de Chonchol (que em 1969 formou o MAPU). "No assentamento El Recurso só foi realizada a primeira etapa", lamentaram Ferreira e Fiori, "as duas últimas não foram levadas a cabo. Várias circunstâncias alheias à vontade da equipe impediram sua realização. Sem sua efetivação, porém, o primeiro passo perde seu sentido de radicalidade", ${ }^{635}$ reconheceram. O material produzido, enraizado na subjetividade de um território (um "assentamento visto como uma totalidade"), acabou engavetado. Apesar disso, o manancial de subjetividade camponesa registrado nos círculos de cultura permitia a compreensão apurada dos conflitos mais determinantes no decorrer da reforma agrária nos anos seguintes: entre assentados e não assentados, entre críticos ou aderentes às autoridades clericais conservadoras, entre os defensores do assentamento e os saudosos do "bom patrão", entre as mulheres participativas e as mulheres que preferiam se limitar às funções de gênero pré-estabelecidas, entre as mulheres e os homens, a violência doméstica, o conflito geracional, a propriedade comunitária ou individual, o preguiçoso e o trabalhador, entre tantos outros. $\mathrm{Na}$ mistura de todos estes conflitos e na sobreposição desses sentimentos, forjavam-se expectativas sobre o futuro, que dividiriam os assentados entre aqueles que desejavam a propriedade comunitária, pela via de uma economia moral coletivista, e aqueles que desejavam a propriedade individual, pela via de uma economia moral da desconfiança.

${ }^{634} \mathrm{Id}$., ibid.

${ }^{635}$ Maria Edy Ferreira \& José Luis Fiori, Investigación temática cultural de los campesinos de El Recurso, op. cit., p. 9. 
A etapa da programação, que demandava mobilização camponesa para diagnóstico e resolução de problemas comunitários, foi realizada em um território diferente da investigação temática. Em 1969, em Palmilla, Peralillo e Chépica, uma experiência de programação campesina foi coordenada por Maria Edy e Liliana Barria, que deixaram em seus registros outro conjunto de círculos transcritos por uma pedagogia do território. É o que tratarei a seguir.

\subsection{Território e poder: a programação campesina}

Em 1973, o historiador José Bengoa alertou para a tensão existente entre a narrativa da modernização agrária das vanguardas políticas e a subjetividade camponesa na luta pela terra: "a lógica do campesinato não é a mesma da reforma agrária, ainda que ambas tenham um ponto de partida em comum: a expropriação" (Bengoa, 1973: 234). Referia-se ao fato de que o governo da Unidade Popular tentava canalizar a energia mobilizadora do campesinato para um determinado rumo, mas vivenciou contradições com as expectativas de segmentos do campesinato. "A expropriação é, para o movimento camponês, a forma concreta que assume a luta pelo poder e o fim da exploração na agricultura hoje. É a apropriação da terra pelo camponês", prosseguiu Bengoa:

O processo de reforma agrária não tende a alterar substancialmente a situação de poder na agricultura e na sociedade (...). Portanto, o fato concreto da expropriação se situa em dois contextos diferentes, em dois movimentos distintos, o que resulta na apropriação da força implícita da mobilização camponesa pelo sistema (Bengoa, 1974: 234-235).

A preocupação de Bengoa com a distância entre expectativas camponesas e projeto de reforma agrária no contexto da via chilena ao socialismo havia sido antecipada por Maria Edy Ferreira em seus estudos sobre as aspirações e expectativas camponesas entre 1965 e 1970. A sintonia dos estudos de Maria Edy com a pedagogia freiriana partia de um ponto crucial: a escuta como método. Foi treinada por esses estudos que Maria Edy formulou a proposta da programação camponesa, junto com a Federação de Cooperativas Camponesas de Colchagua e com equipes do ICIRA e do INDAP. A programação seria a segunda etapa do movimento que aqui nomeamos como pedagogia do território.

A seguir, pretendo recuperar o processo investigativo de Maria Edy Ferreira que, pela via de uma sociologia freiriana, chegou ao método da programação. Ao utilizar repertórios filosóficos e metodológicos da pedagogia do oprimido, Maria Edy coordenou um programa que buscava entrelaçar as expectativas camponesas com as possibilidades oficiais abertas pela reforma agrária, considerando novos arranjos de propriedade, trabalho e poder. O repertório freiriano garantiria que esse entrelaçamento não se desse pela via do legalismo, do paternalismo ou da tutela, mas ao contrário: pela via do poder popular camponês pedagogicamente ativado, territorialmente organizado e consciente.

\section{Expectativas camponesas: a escuta como método}


Entre julho de 1965 e março de 1967, Maria Edy Ferreira esteve em contato constante com os camponeses de Culiprán para escutar e registrar suas expectativas sobre a reforma agrária no seu território. "Dentro de poucos meses, as terras de Culiprán serão designadas aos camponeses membros do assentamento", apontava o relatório de Ferreira. "O estudo de suas expectativas, um ano antes da possível designação das terras, pode ajudar a compreender o processo de reforma agrária, do ponto de vista de seu verdadeiro ator, o camponês assentado", 636 explicou. A investigação fazia parte de um projeto mais amplo, em conjunto com Alberto Peña e Maria Raquel Ugarte, intitulado Estudio Descriptivo de la Comunidad Agrícola de Culiprán. Nos agradecimentos, Ferreira deu destaque "a Paulo Freire, cujos escritos foram uma ajuda para compreender o homem camponês em sua visão de mundo e em sua 'forma de pensá-lo'; e cujas ideias fundamentam nosso marco teórico". O estudo identificou quais eram as expectativas camponesas sobre as formas de propriedade pós-assentamento e suas justificativas, demandando, portanto, uma escuta empática e profunda, sem pré-julgamentos.

A hacienda Culiprán se localizava a 12 quilômetros de Melipilla e a 90 quilômetros ao sul de Santiago. Eram 7.126 hectares, sendo $27 \%$ de riego, com pecuária e cultivos extensivos de trigo, batata e milho. Em junho de 1965, os trabalhadores formaram um comitê camponês e organizaram uma petição por maiores salários e melhores regalias. Um mês depois, a CORA expropriou a hacienda por "má exploração", amparada na lei 15.020 do governo Alessandri. Porém, o assentamento demorou a sair porque a reforma constitucional do artigo 10 ainda não havia ocorrido, obrigando a indenização em dinheiro. Diante da lenta tramitação, em novembro os inquilinos pegaram em armas e protestaram no centro de convívio social da hacienda, como um "símbolo da posse da terra", obstruindo a estrada até os cultivos com um piquete. A toma funcionou: semanas depois, a CORA comprou as terras e instituiu o assentamento Culiprán, com 133 famílias e 854 pessoas.

Ferreira realizou o processo de escuta durante o período transitório do assentamento, momento chave da capacitação. Em 1966, um ano depois de formado o assentamento, 93\% dos assentados dizia que preferiam seguir no campo e não ir para cidade. "Uma nova etapa de mudanças ocorrerá em breve entre os assentados: o processo de titulação das terras entre quem as trabalha", registrou Ferreira. $\mathrm{O}$ estudo investigava a "orientação dos camponeses diante desse fato fundamental e como planejam sua vida em torno dessas expectativas da terra. As expectativas dos camponeses não se estabelecem em um plano, nem sob a forma de regramentos", alertava: "No entanto, (...) ainda que não tenham a forma de um plano de ação, não deixam de ser uma orientação dentro do processo". ${ }^{637}$

A socióloga brasileira também enfatizou que "os camponeses estavam em situação de vida muito precária devido à exploração inadequada das suas terras, baixo rendimento e utilização insuficiente de recursos naturais". ${ }^{638}$ Segundo ela, havia espaço para mais 59 famílias na propriedade. A população assentada em Culiprán era jovem: 50\% eram menores de 21 anos. Entre os maiores de 15

\footnotetext{
${ }^{636}$ Maria Edy Ferreira, Expectativas campesinas y asignación de tierras de Culiprán, op. cit. ${ }^{637}$ Id., ibid., p. 8-9.

${ }^{638}$ Id., ibid., p. 1.
} 
anos, $29 \%$ dos homens e $21 \%$ das mulheres eram analfabetos. Entre todos as famílias assentadas, $65 \%$ eram nascidos em Culiprán, 35\% em Melipilla, o que mostrava um importante grau de enraizamento territorial. O contato com o "exterior" da hacienda, agora assentamento Culiprán, era relativamente escasso: $40 \%$ das famílias nunca tinham saído da propriedade para visitar amigos ou familiares e $34 \%$ deles nunca tinham recebido visitas. Porém, $53 \%$ possuíam rádio e $60 \%$ dos alfabetizados liam jornais. A força de trabalho do assentamento correspondia a $28 \%$ da sua população e era formada por 16 assentados ex-empleados (vigilância), que na hacienda tiveram regalias de uma quadra; 66 assentados ex-inquilinos, que tiveram regalias de $1 / 2$ quadra; e 145 voluntários (não assentados), que nunca tiveram regalia. A exploração individual da terra de regalia era precária e com poucas ferramentas. A antiga hacienda, contudo, era provida de estradas, casas, escolas, capela e armazém, devido ao auge de investimentos ocorrido nos anos 1930.

Durante dois anos, Maria Edy elencou e quantificou as expectativas dos assentados de Culiprán com relação à propriedade individual e coletiva, junto a vários outros temas de interesse dos planificadores da reforma. Era nítido que seu trabalho buscava ser uma ponte entre a linguagem camponesa e a linguagem do Estado, viabilizando um diálogo muitas vezes truncado e conflitivo, em decorrência de uma mútua indecifrabilidade. Para Ferreira, era preciso escutar, costurar as expectativas camponesas em um plano de ação que compatibilizasse linguagens díspares. "Diante dos projetos da CORA, frente aos planos do governo, como o camponês assentado vai construindo as linhas de seu próprio projeto?”, questionava Ferreira: "são orientações convergentes? São dois projetos afins? (...) Que valores guiam o camponês, quais as suas metas? (...) Seus planos são individualistas ou (...) captam também o mundo dos outros?". ${ }^{639}$ A hipótese de Ferreira era que "a expectativa dos assentados de Culiprán diante da reforma agrária é uma forma de orientação para o futuro que depende da percepção da mudança atual no período do assentamento", ${ }^{640}$ ou seja, a propriedade individual ou coletiva seria preferida de acordo com a experiência concreta da transição.

Perguntados sobre o que era a reforma agrária, no entanto, $28 \%$ dos assentados responderam que não sabiam: "não sei nada pois ninguém nunca me explicou"; "não sou capaz de dizer"; "não sei para que pode servir", escutou a socióloga brasileira. Outros $31 \%$ sabiam que era a distribuição de terras ao camponês pelo governo e $41 \%$ definiram como uma "ajuda" aos camponeses, associada a mais trabalho e mais produção. ${ }^{641}$ Quando questionados sobre a relação entre a CORA e a reforma agrária, expressivos 38\% dos assentados não sabiam, enquanto 9\% responderam que não havia relação. Outros $44 \%$ avaliavam corretamente que a CORA era administradora e dava assistência técnica à reforma e 9\% que CORA e reforma agrária eram exatamente "a mesma coisa". ${ }^{642}$

\footnotetext{
${ }^{639}$ Id., ibid., p. 16.

${ }^{640}$ Id., ibid., p. 18.

${ }^{641}$ Id., ibid., p. 27.

${ }^{642}$ Id., ibid., p. 28.
} 
Sobre as formas de propriedade futuras, $63 \%$ dos assentados de Culiprán acreditavam que depois do assentamento as terras seriam parceladas entre eles. Enquanto isso, 18\% não sabia o que ocorreria, $11 \%$ acreditava que o patrão voltaria a mandar e $8 \%$ que seriam terras do governo. ${ }^{643}$ As definições sobre "assentamento" também variavam: $31 \%$ dos assentados o definia como "trabalho em comunidade"; $26 \%$ pensava que era "o que acontece agora, diferente de antes"; $16 \%$ associava assentamento ao direito à terra e às obrigações para não ser expulso do coletivo; dois grupos de $9 \%$ definiam como a liberação do patrão e aquilo que vem com a reforma agrária, enquanto outros $9 \%$ dos assentados ignoravam o conceito de assentamento. Ferreira observou que a definição era ainda bastante apegada às referências do sistema haciendal: "o novo sistema tende a ser interpretado nos termos do sistema tradicional da inquilinaje", ${ }^{644}$ explicou. Isso porque a definição de muitos era referenciada na existência do patrão: "estamos trabalhando sozinhos", "é como se fôssemos patrões" e "um latifúndio sem patrão". O organismo decisório da nova estrutura ainda era pouco conhecido: 63\% dos assentados não tinham informação sobre as reuniões do comitê do assentamento. Maria Edy notou que as casas eram demasiado distantes e havia "grande dispersão da população dentro da propriedade". ${ }^{645}$ Apesar disso, Ferreira considerou que "os camponeses de Culiprán estão bem informados sobre a estrutura de poder regulamentar do assentamento". ${ }^{646}$ Isso porque a percepção de $76 \%$ dos assentados era que o "novo dono" da propriedade era a CORA ou o Estado, tal como dizia o texto da lei. Enquanto isso, 9\% pensava que o dono do assentamento era o presidente Eduardo Frei e outros 9\%, os camponeses ${ }^{647}$ Ao mesmo tempo, 55\% deles identificaram que eram os camponeses quem "mandavam" no assentamento. "Antes o patrão mandava sozinho e agora a direção é decidida por nós", ${ }^{648}$ testemunhou um assentado. A percepção sobre os direitos dos assentados ainda estava bastante ancorada no sistema anterior: $81 \%$ deles afirmou que seus direitos atuais eram regalias ampliadas, enquanto $72 \%$ acreditava que seus deveres de assentado consistiam em trabalhar 10 a 12 dias ao mês na produção comum e depois se dedicar en lo propio. "As terras trabalhadas em comunidade são justamente o aspecto básico da mudança do sistema de trabalho. Da experiência atual depende sua expectativa da mudança futura", ${ }^{649}$ alertava Ferreira. Porém, 46\% dos assentados, "ao mostrar que não conhecem o sistema de antecipo serão conduzidos a se considerar ainda como assalariados", sublinhou a socióloga: "Essa falta de informação pode criar um sentimento de frustração no trabalho, assim como uma não participação na empresa, na qual o assentado já não deveria mais se sentir como simples trabalhador, mas sim como sócio da corporação". ${ }^{650}$ Assim, entre 1965 e 1967, ao escutar os camponeses de Culiprán, Maria Edy

\footnotetext{
${ }^{643}$ Id., ibid., p. 29.

${ }^{644}$ Id., ibid., p. 32.

${ }^{645}$ Id., ibid., p. 33.

${ }^{646}$ Id., ibid.

${ }^{647}$ Id., ibid., p. 35.

${ }^{648}$ Id., ibid., p. 39.

${ }^{649}$ Id., ibid., p. 44.

${ }^{650}$ Id., ibid., p. 45.
} 
previa antecipadamente o fundamento do conflito entre campesinato e Estado que se desdobrou durante o governo da Unidade Popular, compreensão que custou a ser decifrada entre militantes da esquerda.

Quando investigadas as expectativas sobre as formas de propriedade, Ferreira notou a forte presença de um sentimento basal expresso na frase "quero apenas ter onde viver", afirmação que ecoava a economia moral que James Scott (1976) mais tarde chamaria de "ética da subsistência". Isso se refletia em que $61 \%$ dos assentados de Culiprán pretendiam a propriedade individual, 27\% preferiam a propriedade cooperativa e $12 \%$ a cooperativa mista ${ }^{651}$ Ferreira analisou a subjetividade e os sentimentos camponeses que explicavam as preferências de propriedade, oferecendo elementos para uma compreensão das tensões entre diferentes economias morais nas bases camponesas:

Entre os que preferem a propriedade individual, alguns expressam o desejo de poder (...) tomar decisões em sua própria terra sem ter que obedecer às ordens de um patrão. Outros dizem que a propriedade individual é economicamente mais conveniente, um incentivo para mais investimentos e produção. Ademais, ainda alegam que nem todos trabalham igual e, portanto, não se prejudicariam aqueles que realmente se esforçam. Já a propriedade em comunidade vem acompanhada de um sentimento da necessidade de se unir para poder avançar. (...) Justificam seu desejo pela propriedade em comunidade por não dispor das ferramentas necessárias para o trabalho, por não ter como pagar pela parcela ou por não ter filhos que colaboram como mão de obra no trabalho agrícola, ou ainda por se sentirem doentes e sem forças para assumir a responsabilidade [da parcela individual]. Outros temem que as parcelas sejam muito pequenas. (...) Estes camponeses não estão acostumados com o emprego de insumos, se mostram temerosos diante de uma restrição da sua área de cultivo. Aqui se nota como o possível emprego de novas técnicas (...) poderia transformar a atitude sobre a propriedade (...). Os camponeses que indicam uma preferência pela forma mista de propriedade, individual e comunitária, desejavam que as melhores terras fossem parceladas, deixando as demais para pastagem. ${ }^{652}$

No passo seguinte, Maria Edy perguntou quais eram a famílias que deveriam receber prioridade nas parcelas. Os motivos listados pelos camponeses foram hierarquizados em três opções: 43\% consideravam o tamanho da família critério prioritário para parcela individual; $29 \%$ consideravam a antiguidade da família no território; e 27\% o empenho no trabalho. Isto é, apesar do recorrente juízo contra os flojos, os assentados de Culiprán sentiam que o tamanho da família e sua legitimidade histórica no território eram hierarquicamente mais importantes que o desempenho laboral e produtivo na decisão sobre merecimento da terra. Além disso, "a grande maioria dos assentados (74\%) pensa que devem pagar pelas terras", ${ }^{653}$ constatou Maria Edy. "Só pagando se conquista um direito", disse um camponês. "Hoje em dia, não se presenteia ninguém", expressou outro. Além disso, 62\% esperavam contar com parcelas maiores que 10 hectares, "ou seja, podem se desiludir com a reforma", apontou Ferreira. ${ }^{654}$

Por fim, outra descoberta relevante de Maria Edy foi que os assentados de Culiprán dissociavam forma de propriedade e forma de trabalho, o que poderia ser representativo de muitos conflitos futuros

\footnotetext{
${ }^{651}$ Id., ibid., p.64.

652 Id., ibid., p. 65.

${ }^{653}$ Id., ibid., p. 70.

${ }^{654}$ Id., ibid.
} 
entre campesinato e Estado. Embora 27\% preferissem a propriedade cooperativa, "os que preferem o trabalho em comunidade são muito poucos". ${ }^{655} \mathrm{Na}$ realidade, somente $7 \%$ dos $27 \%$ associavam sua preferência pela propriedade cooperativa ao trabalho coletivo, enquanto $20 \%$ dissociavam, isto é, desejavam a propriedade cooperativa como território para o trabalho individual. Queriam compartilhar ferramentas e pastos, nada mais. $\mathrm{O}$ resto do território da cooperativa seria ocupado majoritariamente por parcelas, goces, huertos individuais.

Entre suas conclusões, Ferreira argumentou que "os camponeses que captam o período do assentamento de forma dinâmica tendem a se orientar para a comunidade (...), como um valor novo que significa uma reformulação de metas para o grupo". ${ }^{656}$ No entanto, "chama atenção a falta de relação entre propriedade em comunidade e exploração comunitária das terras: $70 \%$ dos assentados que preferiam propriedade comunitária se declarava, por outro lado, inclinado à exploração individual", argumentou Ferreira. E prosseguiu: "Parece que 'comunidade', para muitos camponeses, não vai além dos limites da sua família ampliada". ${ }^{657}$ Havia diferentes conceitos de comunidade em jogo na mesma palavra. Por último, no seu metódico processo de escuta, a socióloga percebeu que "o movimento dos camponeses de Culiprán, ao ocupar as terras do latifúndio, pode ter sido uma rebelião dentro do sistema: queriam ser donos da terra, transformar-se em novos patrões". Os camponeses aspiravam ser proprietários porque "mandariam em si mesmos", "não estariam submetidos ao patrão", "seriam mais livres", "teriam mais poder sobre a terra", mas também porque "se fariam respeitar como patrões" e "seriam chamados de patrão". Um deles pensava que "a pessoa tem mais personalidade" quando é proprietário. Ou seja, para muitos assentados, "o parcelamento das terras simbolizava a multiplicação dos papeis de patrão, meta e aspiração de cada camponês" e "foi difícil aceitar e compreender seu mundo sem o patrão", ${ }^{658}$ o que os fazia deslocar a figura de autoridade para CORA como "novo patrão". A ideia freiriana do oprimido hospedeiro das concepções de mundo do opressor e a dificuldade do oprimido de se livrar do espectro da autoridade que o transformou em objeto, isto é, de vivenciar na prática seu próprio papel como sujeito consciente, requeria um processo de mudanças econômicas e culturais sincronizadas, que determinariam o futuro da reforma agrária.

Essa batalha cultural pelas "aspirações" e "expectativas" dos camponeses passava pelo problema da reprodução dos valores da hacienda no assentamento, pelo desafio de se criar as condições para a quebra da cultura do silêncio, da "autodesvalia" 659 e a dificuldade de transformar relações verticais em horizontais, impedindo que assentados, funcionários e dirigentes se tornassem patroncitos.

\footnotetext{
${ }^{655}$ Id., ibid., p. 85.

${ }^{656}$ Id., ibid., p. 180.

${ }^{657}$ Id., ibid., p. 183.

${ }^{658}$ Id., ibid.

${ }^{659}$ Em Pedagogia do oprimido, Freire escreveu: “A autodesvalia é outra característica dos oprimidos. Resulta da introjeção que fazem eles da visão que deles têm os opressores. De tanto ouvirem de si mesmos que são incapazes, que não sabem nada, que não podem saber, que são enfermos, indolentes, que não produzem em virtude de tudo isso, terminam por se convencer da sua 'incapacidade'" (Freire, 2018: p. 69-70).
} 
Esses desafios foram encarados pela experiência da programação camponesa na província de Colchagua.

\section{Programação camponesa em Colchagua}

Nomeou-se como "programação camponesa" o processo de empoderamento territorial camponês por meio de uma combinação entre métodos freirianos e as ciências do desenvolvimento que apostavam na elaboração de um diagnóstico da realidade como alavanca política para transformação das relações de poder. "O método da programação, em sua prática, está ligado à ação camponesa na província de Colchagua", reportaram Maria Edy e Liliana Barria ${ }^{660} \mathrm{~A}$ unidade territorial do método era a comuna. Três delas, em Colchagua, o experimentaram: Palmilla, Peralillo e Chépica. A programação continha "todos os instrumentos considerados básicos para um diagnóstico geral da comuna" ${ }^{661}$ a ser conduzido diretamente por camponeses capacitados como pesquisadores. Identificando a distância entre as técnicas do Estado na condução da reforma agrária e a agência camponesa no nível do seu território, a programação propunha um fio condutor que oferecesse às organizações camponesas certas metodologias de pesquisa e luta: "o campo da planificação deixaria seu caráter burocrático e vertical para se transformar no impulso da organização massiva do campesinato como expressão e implementação de seu nascente poder", ${ }^{662}$ advogavam. A publicação de 1971, que reuniu registros de círculos realizados em 1969, expressava já os ventos da Unidade Popular: "A planificação participante aparece como fundamental dentro de um processo de transição ao socialismo", ${ }^{663}$ apostaram.

Em 1969, a Federação de Cooperativas Camponesas de Colchagua firmou uma parceria com INDAP e ICIRA para conduzir a experiência pedagógica da programação, cujo objetivo seria fortalecer a organização camponesa no território. A Federação de Colchagua era formada por 11 cooperativas, que somavam 4 mil sócios da província da VI região. ${ }^{664} \mathrm{O}$ mapa a seguir, desenhado em um dos relatórios do experimento, ${ }^{665}$ ajuda a localizar as três comunas onde a programação ocorreu: Palmilla, Peralillo e Chépica.

\footnotetext{
${ }^{660}$ Maria Edy Ferreira \& Liliana Barria. Hacia un método de programación campesina, op. cit.

${ }^{661}$ Id., ibid., p. 6

${ }^{662}$ Id., ibid., p. 7.

${ }^{663}$ Id., ibid.

${ }^{664}$ As cooperativas pertenciam às seguintes comunas: Marchigue; Peralillo; Paredones; Lolol; Santa Cruz; Palmilla; Chépica; Nancagua; Placilla; Chimbarongo; San Fernando. Ver Ferreira, Barria \& Villegas, 1969.

${ }^{665}$ Maria Edy Ferreira \& Liliana Barria. Hacia un método de programación campesina, op. cit.
} 


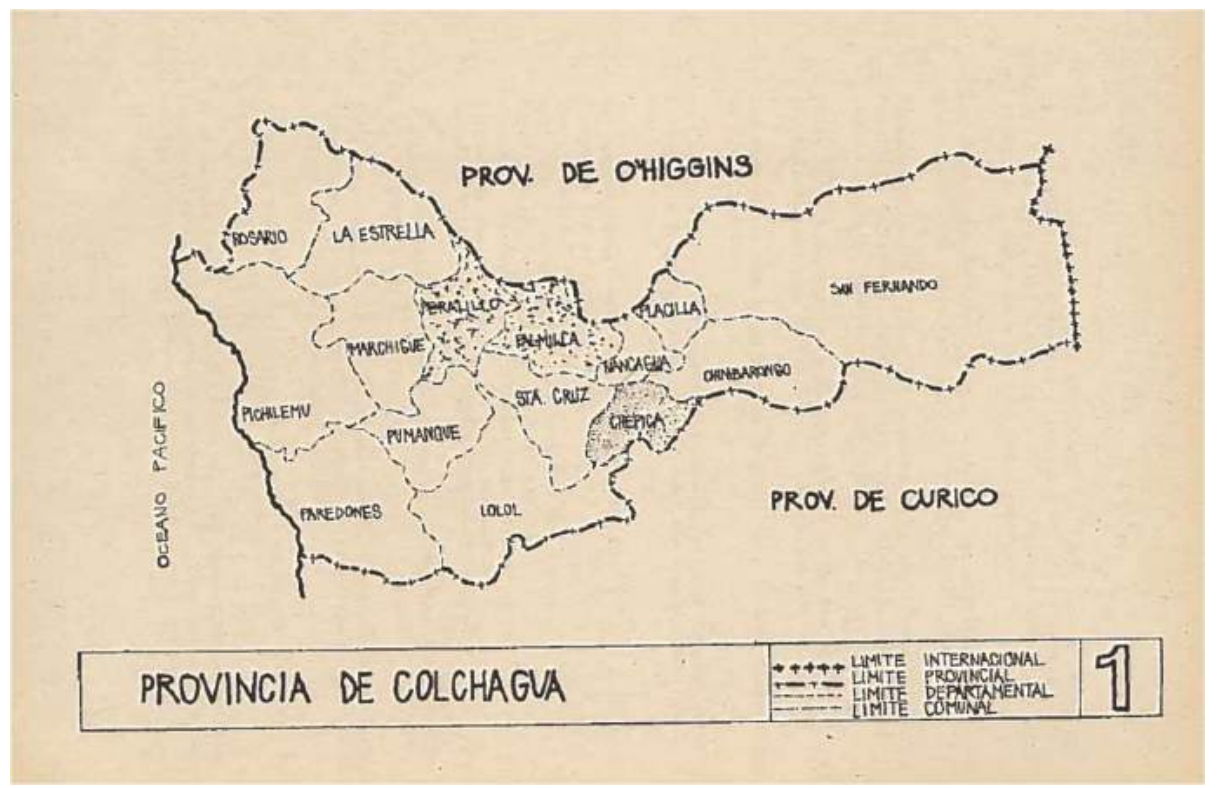

Palmilla e Peralillo foram primeiro, depois Chépica. Assessorados pelo INDAP e pelo ICIRA, cerca de 60 camponeses dirigentes de cooperativas e sindicatos nas comunas de Palmilla e Peralillo produziram uma pesquisa territorial sobre múltiplas dimensões da realidade camponesa e agrária, acompanhados por círculos de cultura. O processo de pesquisa era constituído por um curso de 5 semanas, durante o qual os camponeses pesquisadores foram dispensados de suas tarefas produtivas e sindicais e remunerados pelo INDAP, ainda dirigido por Jacques Chonchol. O curso envolvia o aprendizado sobre como planejar e realizar enquetes, como contabilizar dados, produzir gráficos, tabelas e mapas, além da análise em círculos que posteriormente resultaria em um diagnóstico da realidade agrária da comuna, de autoria coletiva dos próprios camponeses. O diagnóstico era compreendido como um "conhecimento crítico da realidade", no qual camponeses se apropriavam de ferramentas e linguagens do Estado para desenvolver a sua leitura do mundo. Durante o curso, três semanas eram dedicadas à formação de alfabetizadores no método psicossocial. "O método proposto pretende que os camponeses façam um diagnóstico de sua realidade para usar, posteriormente, o conhecimento dessa realidade como base para ação do grupo", indicava-se no relatório: "Nesse sentido, (...) orienta os camponeses a um conhecimento sistemático e crítico da sua realidade, para motivá-los para uma ação programada", ${ }^{666}$ orientavam.

Nos encontros introdutórios, 60 camponeses de Palmilla e Peralillo juntaram-se à coordenadores do ICIRA e INDAP para explicações sobre o método de programação e debates sobre o conceito de diagnóstico, sua utilidade prática para os camponeses. Para verificar a apropriação camponesa do método, o coordenador recapitulava cada etapa. Onde se coletariam os dados, por exemplo. "De toda comuna", "de nós mesmos", "das organizações", "de cada moradia", "do próprio campo", responderam. E o coordenador complementava: "da própria realidade. Se queremos conhecer

${ }^{666}$ Id., ibid.. 
dados sobre escolas, temos que ir até a escola". ${ }^{667}$ Diferente da dinâmica aberta do círculo, em que os coordenadores mais escutavam que falavam, o método de programação exigiu encontros iniciais mais diretivos: "o diagnóstico não é feito de todas as coisas ao mesmo tempo, porque não seria possível. Tomamos a realidade em partes", explicava o coordenador: "Quando juntamos os dados sobre uma coisa, podemos ter representado um aspecto da realidade. Essa forma de unir os dados, chamamos CODIFICAÇÃO”, prosseguiu.

Os camponeses de cada comuna se dividiriam em cinco equipes menores, responsáveis por cinco codificações: (1) população e organização camponesa; (2) terra e propriedade; (3) produção, comercialização e consumo; (4) educação; e (5) moradia e saúde. A tarefa era que os camponeses verificassem e quantificassem esses aspectos da realidade, de maneira autônoma e direta, munidos de enquetes, fichas e tabelas a serem preenchidas com dados coletados em campo. A imagem ao lado, por exemplo, quantificava quantos trabalhadores e quais tipos de relações de trabalho existiam em cada propriedade agrária visitada. Liliana Barria se lembrou que "a intenção era formular um diagnóstico para que as pessoas conhecessem sua situação. Então fizemos uns cartões onde iam anotando para contabilizar quantas pessoas eram e diversos dados". ${ }^{668}$ E sintetizou: "Era uma metodologia para que as pessoas identificassem seus problemas e pudessem, depois, tomar decisões e tomar consciência dos problemas". ${ }^{669}$ Depois, as equipes se juntavam, apresentavam seus dados, relacionavam suas

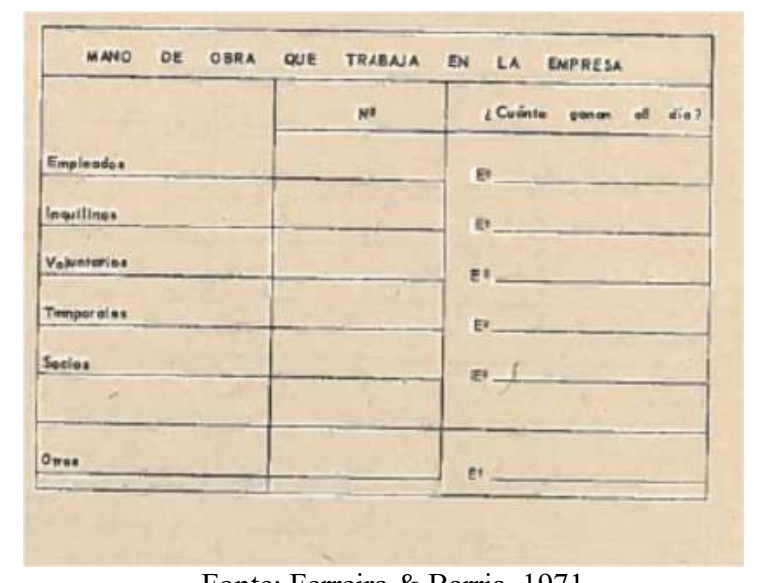

Fonte: Ferreira \& Barria, 1971 experiências, analisavam o resultado e, assim, compunham em conjunto o diagnóstico da comuna, base para o plano de ação. A essência da programação era $\mathrm{o}$ processo de conscientização e não propriamente $\mathrm{o}$ diagnóstico: "para fazer um diagnóstico, poderíamos chamar alguém capacitado que faria facilmente. Mas nós queríamos que eles pesquisassem sua situação, para tomar consciência e analisar", explicou Barria. ${ }^{670}$

Era uma agenda pedagógica territorial bastante ambiciosa. As categorias abstratas apresentadas pelo coordenador, por exemplo, intimidavam os camponeses e eram, à sua maneira, uma forma de invasão cultural. "Alguém poderia dizer, então, com palavras próprias, o que é uma codificação?”, solicitou o coordenador, seguido de um longo silêncio. O coordenador modificou a pergunta: "Se juntamos várias pessoas para estudar a realidade, não podemos trazer todas as coisas no mesmo lugar onde estamos reunidos. O que podemos fazer?",

\footnotetext{
${ }^{667}$ A partir daqui, todo diálogo de aulas e círculos entre coordenadores e camponeses estão em: Maria Edy Ferreira \& Liliana Barria. Hacia un método de programación campesina, op. cit., p. 16-76.

${ }^{668}$ Entrevista com Liliana Barria, Santiago, 15/12/2018.

${ }^{669}$ Idem.

${ }^{670}$ Idem.
} 
tentou. "É preciso fazer um diálogo entre todos", arriscou um camponês. "Por codificação", disse outro. O coordenador seguiu preenchendo o silêncio com sua resposta: "a codificação são os dados sobre uma parte da realidade, que nós representamos por escrito, desenhamos. São os dados representados (...), uma fotografia da realidade", resumiu: "a partir de amanhã vocês vão estudar quais são esses dados (...) coletados por vocês mesmos". ${ }^{671}$ Nos encontros introdutórios, o coordenador também definia decodificação: "estudar os dados, interpretá-los. (...) Juntos vamos estudando, relacionando uns com outros e disso vamos tirar o plano para mudar nossa realidade", ${ }^{672}$ sintetizou. Consequentemente, retomava ele, "a ação tem várias partes. É como dizíamos: diagnóstico, estudo, plano e a própria ação", ${ }^{673}$ explicou. E "a ação tem que ser de todos", destacou o coordenador. Em abstrato, debateu com os 60 camponeses os limites de um plano de ação, suas chances de fracasso, e concluiu com a lição: "temos que estar dispostos a fazer um novo diagnóstico sempre que se perceba que a realidade mudou. (...) A ação não se detém, continua sempre, mesmo quando temos um plano para 20 anos. É preciso seguir refazendo, adaptando às exigências da realidade".

Na etapa seguinte, os 60 camponeses foram divididos em 5 comissões temáticas para cada comuna, correspondentes aos eixos de codificação definidos pelo ICIRA. Durante duas semanas as comissões coletaram dados em campo, que foram codificados em gráficos e tabelas. Nem todos os dados eram encontráveis em camp, e era permitido complementá-los com dados oficiais do censo, por exemplo.

Em Palmilla, a comissão de população e organização soube que a comuna tinha 14.020 habitantes, o que representava $8 \%$ da população da província de Colchagua. Os habitantes de Palmilla eram $83 \%$ rurais e se dividiam em $29 \%$ homens, $24 \%$ mulheres e $47 \%$ crianças. "Vocês sabiam qual era a população de Palmilla?", perguntou o coordenador. "Não sabíamos nada", disse um camponês: "isso é muito interessante, muito importante para nós", enfatizou. Entre os adultos, 77\% eram assalariados, $10 \%$ assentados e 3\% trabalhadores independentes. Sobre o grau de organização, se computou que apenas $12 \%$ dos trabalhadores rurais eram organizados (em cooperativas, sindicatos, assentamentos ou comitês) e $88 \%$ ainda não o eram. As instituições da auto-organização camponesa propostas pela reforma agrária ainda abarcavam poucos camponeses em Palmilla. Já a comissão da propriedade da terra concluiu que havia uma superfície de 34.295 hectares na comuna, sendo $54 \%$ de riego. A comissão da educação, descobriu que, em Palmilla, 37\% dos maiores de 15 anos eram ainda analfabetos. Os dados mais essenciais foram resumidos e apresentados antes de qualquer debate.

\footnotetext{
${ }^{671}$ Maria Edy Ferreira \& Liliana Barria, Hacia un método de programación campesina, op. cit., p. 21. ${ }^{672}$ Id., ibid., p. 18.

${ }^{673}$ Id., ibid..
} 

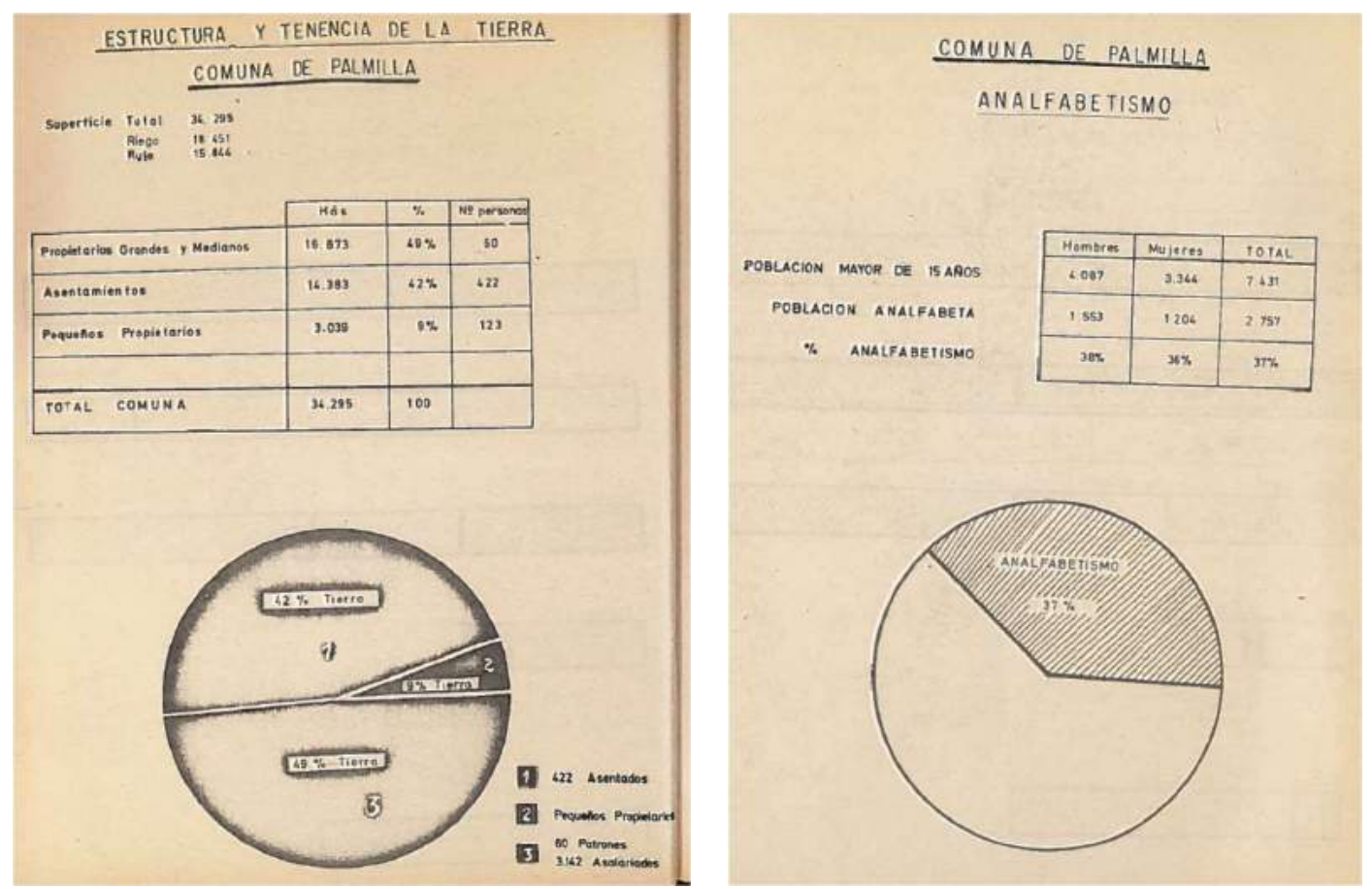

Codificações dos camponeses pesquisadores em Palmilla. Fonte: Ferreira \& Barria, 1971.
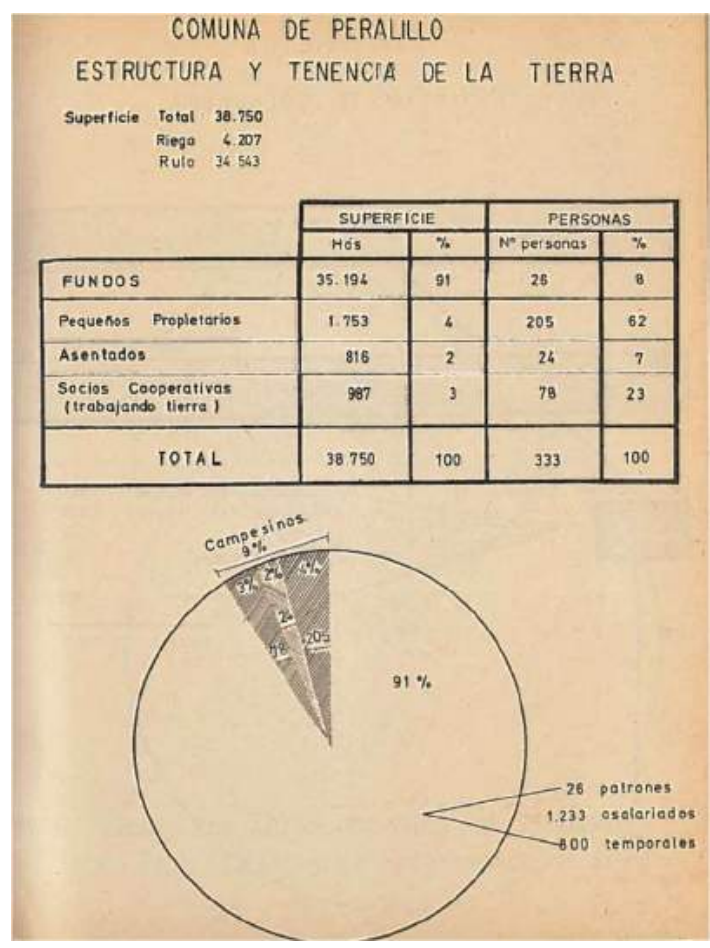

Codificações dos camponeses pesquisadores em Peralillo. Fonte: Ferreira \& Barria, 1971.
Em Peralillo, contabilizou-se uma população de 9.190 pessoas ( $5 \%$ da população da província), sendo $51 \%$ rurais. Eram $27 \%$ homens, $24 \%$ mulheres e $49 \%$ crianças. Entre os trabalhadores, $50 \%$ eram assalariados, somente $1 \%$ era assentado, $3 \%$ cooperativistas e $8 \%$ trabalhadores independentes. Faltaram categorias apropriadas, pois $38 \%$ dos trabalhadores estavam em "outros". Assim como em Palmilla, somente $13 \%$ dos trabalhadores rurais estavam organizados, fora de qualquer organismo coletivo da reforma agrária. Calcularam que a comuna possuía 38.750 hectares, sendo apenas $11 \%$ de riego. Constataram também que $27 \%$ das crianças estavam fora da escola e $25 \%$ dos maiores de 15 anos eram analfabetos. O analfabetismo "foi considerado uma limitação para o acesso do campesinato para exploração direta da terra", dizia o relatório: "os camponeses argumentaram que se quisessem explorar a terra em uma economia camponesa, deviam se capacitar. Saber ler e escrever eram 
feitos fundamentais e muito necessários para melhorar sua organização". ${ }^{674}$ Com os dados mais básicos, os camponeses produziram codificações gráficas mais sofisticadas.

Os círculos de decodificação foram separados por comuna, já que o diagnóstico e o plano de ação seriam construidos com base no território comunal. Em Palmilla, os camponeses pesquisadores chamaram a atenção para seu baixo índice de organização. "Organizados, unidos, é como conseguimos as coisas", defendeu um deles, "individualmente não se consegue nada. Em toda comuna, devíamos estar organizados, sem ninguém para fora", enfatizou um camponês no círculo de decodificação. "Se estivéssemos todos organizados, as coisas iam sair bem", concordou outro. "Em muitos aspectos, o próprio camponês tem culpa", problematizou um deles, "parece difícil para ele entender que não é para o bem estar de cada um. Acham que assim com o patrão está bom, porque é uma tradição de 150 anos". Os camponeses organizados em defesa da reforma agrária sentiam o obstáculo dos outros camponeses resistentes à mudança. "Isso não é coisa que se pode mudar em pouco tempo... Até a consciência está metida nisso", refletiu um. "E ao mesmo tempo, as organizaçoes camponesas não realizaram uma ação para produzir as mudanças no processo de reforma agrária", constatou outro identificado como dirigente. O coordenador questionou: “e qual seria, nesse cenário, a função de um dirigente?”. "Seguir insistindo, demonstrando com fatos, porque não conseguimos nada com mostrar papeis. Temos que mostrar com fatos", argumentou o camponês. A ofensiva patronal era um obstáculo: "os patrões aconselham as pessoas que não se metam porque vão morrer de fome. Quantas vezes escutamos calúnias de que os assentamentos estão morrendo de fome? Essas pessoas estão acostumadas a viver sob os patrões e se convencem do que os patrões lhes dizem", explicou outro: "mas nós estamos vivendo muito melhor!", exclamou o cooperativista. O coordenador apontou para lousa, indicando um gráfico: "não lhes parece que o patrão está defendendo isso? Este enorme dado: 72\% não estão organizados (...). Que ele quer manter essa situação? E por que o patrão consegue convencer o camponês e nós não?", desafiou ao grupo. "Nós não os convencemos porque ainda não temos um verdadeiro plano de ação", respondeu assertivamente um camponês: "Os capatazes de latifúndios, quando defendem o patrão, estão defendendo sua posição acomodada, que ganha mais que um camponês e trabalha muitissimo menos", completou. Ao analisar o tema da propriedade da terra, alguns dos camponeses de Palmilla viram pela primeira vez um mapa da sua comuna. A distribuição da terra encontrada pela comissão da propriedade está sintetizada na tabela 15 a seguir.

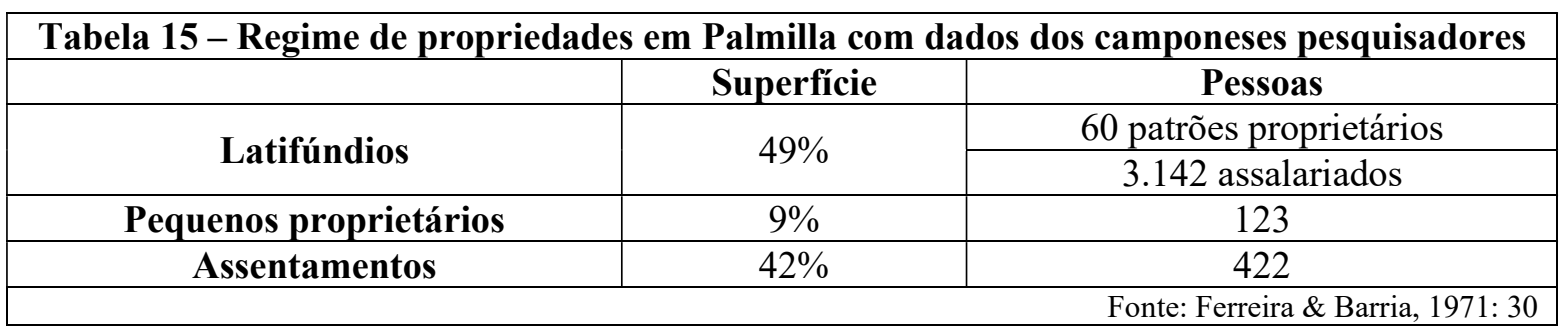

${ }^{674}$ Id., ibid., p. 8. 
O objetivo do plano de ação, para alguns, deveria ser transferir a terra dos patrões aos seus trabalhadores. "O que precisamos verificar é se conseguimos seguir avançando na forma cooperativa. Ou seja, mudar a terra, a estrutura, das mãos dos 60 patrões para os trabalhadores", propôs um camponês. "São 60 patrões e 3.142 assalariados", especificou outro: "E devem ter uns 150 a 200 que trabalham contratados pelos assentamentos". Abordaram no círculo as desigualdades entre camponeses assentados e afuerinos de assentamentos. "São 800 trabalhadores. Os assentados, que podem ser donos da terra, são 422, os outros estão igual aos nos latifúndios: assalariados", identificou um camponês. Outro agarrou o problema: “[os assentados] pagam pouco a cada trabalhador. É o caso do assentamento El Huique, onde tenho um familiar", alertou. Houve divergência sobre o número de afuerinos contratados nos assentamentos. A discussão que se seguiu passou pelas vantagens e desvantagens entre o sócio do assentamento e o afuerino. Embora uns denunciassem que o segundo era mal remunerado pelo primeiro, outros diziam que era o primeiro que arcaria com as dívidas e custos de produção, caso não houvesse bons rendimentos.

"Só um entre os assentamentos tem bom rendimento. Todos os outros tem déficit nesse ano, no balanço geral que fazem", constatou um deles: "isso porque eles não trabalham como deveriam, trabalham muito pouco. Eu sei porque tenho familiares ali que começam a trabalhar às $8 \mathrm{~h} 30$ da manhã e depois das $12 \mathrm{~h}$ já não trabalham mais", acusou um deles. Entre eles, havia divergência sobre quem, afinal, estava mais bem posicionado na reforma agrária: o assentado que se endividava, mas era potencialmente proprietário; ou o temporário que não seria dono, mas ganhava um salário fixo (baixo) e não se endividava com créditos da CORA.

No limite, o dilema vivido por aqueles camponeses era sobre a economia moral do empresário ou do assalariado. A condição híbrida da transição gerava também uma crise de expectativas e aspirações, em que se temia o endividamento da produção assentada, tanto quanto se rechaçava os baixos salários dos excluídos. "O contratado sai sempre perdendo", sustentou um camponês. Os assentados "estão sendo como os patrões", criticou outro. O coordenador perguntou, então, qual era a diferença entre o assentamento e a cooperativa. "Queremos trabalhar por cooperativa para podermos trabalhar todos", respondeu um deles: "Não haveria distinção entre nós e um gallo que mandaria em nós". Curiosamente, via-se a cooperativa como órgão de mais igualdade interna que o assentamento. "E todos participamos dos lucros", outro completou. "O mais interessante de uma organização cooperativa é que todos temos esperança", refletiu um deles. Por isso, o nome da cooperativa de alguns deles era Nueva Esperanza. "Todos esperamos algo, por exemplo, participar do poder econômico", indicou. "Com uma cooperativa, respiramos um pouco mais", prosseguiu outro. "A capacitação ainda pode ajudar", sugeriu um camponês, que participava de uma cooperativa em fase de formação. "Eu não me desenvolvi bem como secretário", confessou, "me faltam... digamos, os cadernos".

Analisando ainda o problema da distribuição das terras, um deles concluiu: "poderíamos ter essa estrutura de terra de $49 \%$ para cooperativas, com 6.589 crianças que podem ter outra vida, um 
pouquinho superior que a nossa. Estamos muito oprimidos". Outro camponês então criticou diretamente os funcionários da CORA e os identificou como os novos patrões: "em resumo, $49 \%$ das terras são dos momios e a outra parte, $42 \%$ são dos pequenos momios, que são os da CORA". Um camponês respondeu com uma reflexão histórica, alegando que o problema começou com os espanhóis, porque os indígenas trabalhavam por eles mesmos. Colocaram-se, enfim, diante do problema do plano de ação. Um deles sugeriu que buscassem "apoio de um autêntico representante nosso no parlamento". Mas logo um camponês respondeu convocando a responsabilidade para a auto-organização camponesa: "nós aqui vamos ajudar a realizar essa mudança". "O que precisamos fazer para mudar a estrutura atual?”, indagou outro. "Vai ser um pouco difícil, porque os donos da terra não nos permitem", notou um deles. Outro campones concluiu: "é dessa oportunidade roubada do camponês que nasce o poder econômico e dele vem o poder político. Os ricos têm dinheiro para tudo, inclusive para pagar a propaganda. E disso nasce o poder político", analisou. "Teríamos que conseguir esses poderes. Depende de nós, porque uma vez conseguido isso, mudaríamos a estrutura da terra", desfechou outro.

Ao chegar ao ponto crucial do poder popular camponês, o coordenador lhes questionou sobre como então pretendiam “conseguir esses poderes”. Algumas das respostas camponesas coincidiam com a concepção freiriana: "com uma ação cultural que determina a mudança de consciência, uma maior participação, uma boa organização. A organização estuda e elege seus representantes", disse um deles. "Através da organização ou de uma cooperativa, ou tendo mais estudo", propôs outro. "Precisamos ter dinheiro para estudar e nos capacitar e depois com unidade dos camponeses e organização, como sindicatos, cooperativas, federações e confederações", pensou outro. Falou-se também em criar "meios camponeses de comunicação de massas" e na "base da educação e da união". Correlacionava-se, de maneira complexa, poder econômico, poder político e educação. "Somos usados porque nos prometem muita coisa para conseguir se eleger, mas depois esquecem dos camponeses", criticaram. Não havia camponees no governo, explicou um deles, "por falta de dinheiro e estudo, porque só os ricos chegavam à universidade e têm dinheiro suficiente para se capacitar", analisou. Após uma semana final de debates, os camponeses de Palmilla não conseguiram elaborar um plano de ação, porque ainda não possuía uma cooperativa comunal e suas organizações ainda estavam pulverizadas. $\mathrm{O}$ processo de programação, contudo, incentivou o surgimento de uma coopeerativa comunal que rapidamente alcançou 300 membros.

Os camponeses de Peralillo conseguiram elaborar seu plano de ação também depois de muitos círculos de decodificação do diagnóstico. "Estamos de acordo que é a realidade da terra que determina todos os problemas", resumiu um camponês dirigente. "Fizemos uma análise do avanço da CORA e percebemos que demoraria 99 anos para expropriar todas as terras", acusou outro: "nós, camponeses, não podemos esperar mais tramitações". O coordenador lembrou: "outro problema vital é que $82 \%$ da terra está nas mãos de 30 pessoas". Sim, confirmou um membro da comissão da propriedade: "isso nossa comissão chamou de estrutura patronal. É o problema mais grave que existe". Outro camponês hierarquizou três problemas a serem resolvidos pelo plano de ação: primeiro, a estrutura patronal; 
segundo, a lentidão da reforma agrária; e terceiro, a necessidade de organizar os camponeses, que com $7 \%$ da terra, eram $87 \%$ desorganizados. "Somos 1.233 assalariados, 800 temporários, ou seja, toda essa gente não tem terras", contabilizou um deles. A comissão que coletou dados sobre propriedades da terra apresentou uma tabela (16) com a distribuição fundiária na comuna, tal como se verá.

\begin{tabular}{|c|c|c|}
\hline Tabela 16 - Regime de propriedades em Peralillo com dados dos camponeses \\
pesquisadores
\end{tabular}

Nos latifúndios, trabalhavam 1.403 assalariados sem terra. "A CORA, em quatro anos, avançou $1 \%$ ao ano na expropriação", calcularam os camponeses. "Pode o camponês esperar meio século?", perguntavam-se impacientes. Um dos camponeses apontou: "essa lei [de reforma agrária] tem muitos erros porque foi feita para os camponeses, mas os camponeses não participaram de sua elaboração". Outro emendou: "não podemos esperar mais tramitações, seja devido à lentidão da reforma agrária ou das nossas próprias debilidades. Precisamos (...) lutar para que todos se organizem, construir uma central camponesa [na comuna], lutar para modificar a lei de reforma agrária", sintetizou. A palavra de ordem do grupo passou a ser a mudança de uma reforma agrária "lenta e tramitada" para uma reforma agrária "rápida, intensa e drástica", parafraseando o conhecido slogan de Jacques Chonchol. Em seu plano de ação, a meta era conquistar a expropriação de sete latifúndios em 1969, que somavam 5.353 hectares e abarcavam 291 assalariados. ${ }^{675}$ Segundo a coleta de dados, os trabalhadores rurais se distribuíam na comuna como mostra a tabela 17 a seguir.

Tabela 17 - Trabalhadores do campo em Peralillo, dados dos camponeses pesquisadores

\begin{tabular}{|c|c|c|}
\hline Tipos & $\mathbf{N}^{\mathbf{0}}$ de pessoas & $\mathbf{\%}$ \\
\hline Camponeses com terra, cooperativados & 78 & 5 \\
\hline Camponeses com terras, assentados & 24 & 2 \\
\hline Trabalhadores independentes (afuerinos) & 205 & 14 \\
\hline Assalariados (inquilinos) & 1.239 & 79 \\
\hline \multicolumn{2}{|r}{} & Fonte: Ferreira \& Barria, 1971: 38 \\
\hline
\end{tabular}

Como síntese, as comissões de organização e de propriedade estabeleceram cinco problemas, com suas respectivas soluções, na forma de plano de ação. O primeiro era a falta de organização camponesa: "o patrão rouba seu trabalho", disse um deles, mas os trabalhadores não sabiam como responder. Organizar os desorganizados foi uma tarefa que assumiram: "que as organizações se unam

${ }^{675}$ Os latifúndios eram Puquillay, El Llano, Riconada de Palmilla, San Javier Lihueimo, Parrones, San Jorge La Blanca, Mercedes. Ferreira \& Barria. Hacia un método de programación campesina, op. cit., p. 41. 
para conseguir o máximo proveito dessa mudança de estrutura", acordaram. Definiram que a meta era que $90 \%$ dos camponeses da comuna estivessem organizados até o fim de 1969. O segundo problema era a má distribuição da terra. A solução que construíram passava por acelerar a reforma agrária pela pressão das suas organizações, "para que a terra seja do camponês". O terceiro problema lançava luz sobre as hierarquias de gênero: "as mulheres têm um problema de não participar das organizações que os homens participam. São tratadas como uma máquina reprodutora de filhos e de tarefas domésticas", registraram. Infelizmente, não se conhece a quantidade de mulheres participantes da programação. Mas resolução apontava para uma agenda progressista no direito político das mulheres camponesas, mais igualitária que os camponeses de El Recurso: "a mulher deve participar das mesmas reuniões que os homens, ser sócias, se organizar", defenderam em Peralillo. Um quarto problema era a necessidade de garantir o cumprimento das leis sindicais e laborais. A solução era garantir a eleição de dirigentes camponeses que representassem o coletivo para pressionar o poder público. O quinto problema era o desemprego dos temporeros. A solução passava também pelo aumento da superfície de cultivo, indicada pela comissão de produção.

A comissão de moradia e saúde concluiu que, em média, moravam 10 pessoas por casa camponesa, 99\% delas sem água potável, 95\% sem luz, 33\% sem banheiro e 60\% das moradias em estado ruim ou inabitável. O único hospital da comuna, com 20 leitos, contava apenas com dois médicos e seis enfermeiros para uma população de mais de 9 mil pessoas. ${ }^{676} \mathrm{~A}$ pobreza, a insalubridade da moradia e má capacitação dos profissionais de saúde gerava uma alta mortalidade infantil. Propuseram um plano de construção de casas para os camponeses e a ampliação da infraestrutura de saúde.

A comissão de produção elaborou um minucioso estudo de cultivos por superfície em toda comuna. Perceberam que ainda era possível expandir cultivos por mais 17.353 hectares, criar pastos em 9.513 hectares e reflorestar 16.773 hectares com eucalipto e pino. "A má exploração da terra ocorre porque está nas mãos de 30 patrões que exploram os camponeses”, definiram. Junto com a mudança de propriedades, planificaram um aumento da produção que ampliasse em 150\% o rebanho bovino, em $60 \%$ o rebanho ovino, em $188 \%$ o rebanho porcino, em 18 vezes a produção de leite, em $550 \%$ a criação avícola, em $150 \%$ a produção de ovos, em $200 \%$ a superfície de milho, em $100 \%$ a superfície de arroz, em $170 \%$ a superfície frutícola e vinícola, se inaugurasse o cultivo de beterraba com 7.800 hectares, em $35 \%$ a superfície de hortaliças, em $33 \%$ a superfície para trigo, entre outros. ${ }^{677}$ Diante da pergunta “como faremos?", responderam "com a unidade camponesa”, “conquistando o poder”, “pressionando as autoridades" e "através do trabalho comunitário".

A comissão de educação dos camponeses pesquisadores de Peralillo verificou que existiam 11.278 crianças fora da escola na província de Colchagua, entre as quais 600 estavam na comuna, o que correspondia a $27 \%$ das 4.503 crianças de Peralillo. Para ela, a comuna contava com 10 escolas e 44

${ }^{676}$ Id., ibid., p. 44.
${ }^{677}$ Id., ibid., p. 43. 
professores. Entre os adultos, 52\% eram analfabetos. ${ }^{678}$ "Na codificação, saiu $15 \%$ de analfabetismo entre adultos. Isso é falso. São 2.423 pessoas que não sabem ler, nem escrever, ou seja, 52\% da população rural adulta”, corrigiram. É possível que o dado anterior se baseasse no censo, que desconsiderava os analfabetos funcionais. Ao se apropriar da realidade com enquetes em campo, os camponeses descobriram que o problema do analfabetismo era mais profundo. "O Estado tem grande culpabilidade. Para as pessoas que estavam no poder não interessava que a cultura do camponês fosse igual à deles", registraram. "Não há quantidade necessária de escolas e professores", denunciaram. E diagnosticaram: "Um só professor atende a muitas crianças (...). A solução seria que um professor não atendesse a mais de 35 ou 40 crianças. O baixo salário dos professores faz com que prefiram seguir outra profissão". Os baixos salários dos pais agravavam o ciclo de falta de educação, como analisaram: "os pais preferem mandar as crianças ao trabalho para que ajudem economicamente na casa. Nisso são irresponsáveis e não pensam no futuro do filho". Também alegaram que a distância das comunidades até a escola e a falta de transporte adequado desencorajava o estudo. "Será necessário que as organizações, como a cooperativa, sindicato ou assentamento, transportem as crianças para escola em algum meio. Será proveitoso para seus filhos", propuseram no plano de ação. Por fim, criticaram a ausência de oportunidades de estudo técnico para os camponeses: "sempre foram os filhos dos patrões que tiveram a oportunidade de estudar para uma profissão técnica, jovens da cidade. Mas eles não conhecem os problemas do campo e se fixam no que aprenderam na escola, não na prática", criticaram. "Os filhos dos patrões que conseguiram um diploma não se interessam pelo camponês, apenas querem possuir um cartão de visitas", zombaram.

Finalizaram anunciando: "acreditamos que as organizações camponesas precisam conseguir que os pais tomem responsabilidade de buscar um futuro melhor para seus filhos e, ainda que seja com grande sacrifício, lhes deem educação". Consideravam-se também agentes da alfabetização futura: "pensamos que através de um bom estudo que nos deu esse curso, poderemos eliminar o analfabetismo na comuna". Sintonizados com a autocapacitação camponesa, os participantes da Peralillo propunham que "a tarefa de alfabetizar poderia contar com a participação dos sócios da cooperativa e dos sindicatos. Estes alfabetizadores, eleitos pela comunidade, se capacitarão não só para alfabetizar, mas também para dar educação em sentido mais amplo, incluindo a capacitação básica e empresarial”. Como meta, propuseram uma campanha de alfabetização massiva, organizada pela cooperativa com apoio do Estado.

Por último, geraram também metas específicas para sua cooperativa comunal, inclusive saltar de 300 para 1000 sócios em 1969, atingindo 42 comunidades camponesas. ${ }^{679}$ Os camponeses de Peralillo sintetizaram, então, suas cinco obrigações políticas do plano de ação:

1) Lutar para que todos os camponeses se organizem em sindicatos e em cooperativas, formando uma força única para mudar a estrutura da terra;

2) Criar uma central camponesa na comuna de Peralillo;

\footnotetext{
${ }^{678}$ Id., ibid.

${ }^{679}$ Id., ibid., p. 46.
} 
3) Lutar para produzir mudanças na lei de reforma agrária;

4) Lutar pela Federação de Cooperativas Camponesas de Colchagua;

5) (...) Temos que passar de uma reforma agrária lenta e tramitada para uma reforma rápida, intensa e drástica. (...) Uma reforma agrária revolucionária. ${ }^{680}$

Eram ecos antecipados da eleição de Allende que se escutavam em 1969 em setores organizados do campesinato. Em novembro de 1969, a Federação de Cooperativas Camponesas de Colchagua enviou uma carta ao ICIRA, a qual solicitava assessoria para aplicar o método em Chépica: "que os camponeses organizados incorporem a planificação agropecuária" ${ }^{681}$ vislumbravam. A pedagogia do território dava frutos.

\subsection{Considerações finais}

Em novembro de 1968, a juventude da DC emitiu um documento entusiasta da construção do socialismo, no qual explicitava a influência de Paulo Freire sobre as mudanças de consciências vividas pelos próprios militantes do partido. Segundo Kirkendall, "muitos dos jovens envolvidos nos programas de alfabetização e outros que trabalharam no campo tiveram, eles próprios, sua consciência transformada, como Freire previu que ocorreria" (Kirkendall, 2010: 81). Para o historiador, existem mais evidências do impacto da pedagogia de Paulo Freire entre os jovens educadores que se lançaram ao aprendizado de alfabetizar camponeses, do que entre próprios os camponeses (o que obviamente se relaciona com o desequilíbrio de registros e vestígios dos alfabetizadores urbanos em relação aos alfabetizandos rurais).

Com as experiências do ICIRA de 1968 e 1969 narradas neste capítulo, busquei identificar o grupo de freirianos que amplificou a radicalidade da pedagogia do oprimido, de maneira a conduzi-la para o cerne do poder territorial, experimentando as fronteiras das quebras de hierarquias enraizadas em subjetividades específicas, além de apontar para uma pedagogia da ação e da organização do poder popular. A partida de Paulo Freire do Chile, em abril de 1969, e o surgimento do Movimento de Ação Popular Unitário (MAPU) em maio de 1969, ruptura anticapitalista da DC, eram, ao fim e ao cabo, acontecimentos correlacionados. O contrato de Freire não foi renovado pelo governo de Eduardo Frei, quando rumores acusavam o brasileiro de "escrever um livro" perigoso para a imagem democrata-cristã. Acusavam-no também de promover a agitação irresponsável da juventude pró-guerrilha do MIR. Sem negar que escrevia seu livro, mas recusando veementemente ter cumprido qualquer papel de agitador, o pedagogo brasileiro aceitou o convite para trabalhar como pesquisador visitante na Universidade de Harvard em 1969 e, em seguida, se comprometeu com o Departamento de Educação do Conselho Mundial de Igrejas, em Genebra, para onde partiu em 1970.

A equipe de freirianos do ICIRA, via de regra, se aglutinou no MAPU, liderado por Jacques Chonchol. No programa fundacional do partido se lia: "é preciso aprofundar a reforma agrária. A terra

\footnotetext{
${ }^{680}$ Id., ibid.

${ }^{681}$ Id., ibid., p. 98.
} 
deve estar nas mãos dos camponeses" (apud Aguayo, 2014: 75). Rapidamente o MAPU se integrou à Unidade Popular, estabelecendo um horizonte estratégico comum com comunistas e socialistas. O problema do poder territorial seguiu sendo uma preocupação do MAPU. No relatório da programação em Colchagua, constatava-se: "faltava uma organização em nível comunal que reunisse a totalidade dos camponeses, como trabalhadores da comuna, geograficamente incorporados na luta da sua classe, localizados em uma realidade física, econômica e social definida”, diagnosticavam. A pedagogia do território encontrava seus limites intransponíveis: o poder patronal, as instituições morosas da reforma agrária, os camponeses apatronados. "Sente-se um vazio de uma instância em nível comunal que possa organizar os camponeses no nível da comuna" ${ }^{682}$ recomendaram após o experimento de programação. Era preciso uma instância apta a enfrentar os obstáculos diagnosticados pelos camponeses de Colchagua.

Argumentamos, nesse sentido, que o decreto 481 de dezembro de 1970, escrito por Jacques Chonchol em seu primeiro mês como ministro da Agricultura, era, ao menos em parte, uma consequência e uma continuidade da pedagogia do território. $\mathrm{O}$ decreto determinava um sistema de representação camponesa que reunisse todas as organizações em três instâncias geográficas: conselhos comunais, conselhos provinciais e o conselho nacional camponês. "Constitui-se o conselho comunal camponês, encarregado de informar e representar, perante o conselho provincial, os acordos do conselho comunal (...). No conselho comunal devem se integrar todas as organizações camponesas existentes", dizia o decreto (Chile, 1971). Além disso, “o ministro da agricultura nomeará seu representante perante cada conselho comunal camponês" (Chile, 1971).

Por ter sido publicado em 1971, o relatório da programação incorporou, em sua introdução, um parecer sobre a criação do conselho comunal campesino: "é a organização que mais pode aproveitar os resultados do diagnóstico, usando como base informativa de seu trabalho e ponto de apoio para o planejamento das tarefas do conselho". ${ }^{633}$ Fiori, integrado às correntes freirianas do ICIRA, sintetizou a pedagogia do território: "o campesinato se educa quando planifica e produz. Ao mesmo tempo, planifica e produz quando se educa. E assim surge progressivamente o homem novo e a nova cultura que supõe e impõe a construção do socialismo". ${ }^{684}$

É certo que a corrente freiriana da pedagogia do território formulou um trabalho revolucionário silencioso, até agora não iluminado pela bibliografia, que era criativo na sua metodologia e ousado diante dos obstáculos. O caráter extraordinário e pontual dos experimentos de El Recurso e de Colchagua não nos impedem de perceber sua potência. Com os recursos da pedagogia do oprimido e do diagnóstico popular, a pedagogia do território identificava os flancos de poder camponês por organizar, palmo a palmo, ao ritmo da subjetividade política daqueles que trabalhavam a terra.

\footnotetext{
${ }^{682}$ Ferreira \& Barria, Hacia un método de programación campesina, op. cit., p. 41.

${ }^{683}$ Id., ibid., p. 5.

${ }^{684}$ José Luis Fiori, Educación y programación campesina. Santiago: ICIRA (mimeo), 1970.
} 


\title{
Capítulo 6 - Pedagogia da reivindicação: sindicalismo camponês e educação política
}

\begin{abstract}
"Nas confederações campesinas, se intensificou a preparação de dirigentes em todos os níveis. Se divulgam os conteúdos da Reforma Agrária, da sindicalização camponesa (...). Demos início a projetos experimentais de alfabetização (...). Os camponeses exigem com urgência que sejam proporcionados os rudimentos básicos que os coloquem a altura dos novos tempos"

- José Campusano, Presidente da Ranquil (1967-1969), dirigente do PC ${ }^{685}$

"Por diferença de educação, não estávamos conscientes da classe social (...). A política de uma organização sindical é para que a gente vá conhecendo nossos inimigos de classe"

- Camponês em depoimento a Marcela Gajardo, 1972 686

"Esse multitudinário movimento exige cada vez mais e melhores dirigentes em todos os seus níveis, exige bases melhor preparadas para poder levar a cabo a grande meta de todos os camponeses chilenos: a Reforma Agrária. Grande é a responsabilidade do FEES"
\end{abstract}

- FEES, Proyectos, Convenios y Programas ${ }^{67}$

\subsection{Introdução}

Na tarde de 22 de janeiro de 1968, a família Benavente Palma, proprietária do latifúndio Cunado Bajo, na comuna de Longaví, em Linares, recebeu a visita de dois funcionários do INDAP, Guillermo Quinteros e Roberto Guzmán. Eles teriam uma reunião com o comitê sindical formado por camponeses daquela propriedade, especificamente com o inquilino Eugenio Garay, que fora escolhido presidente. Mas a matriarca da família, ao escutar a razão da visita, começou a "dar grandes gritos, tentando em seguida agredi-los com pontapés". ${ }^{688}$ Diante daquela desconcertante situação, o filho dos proprietários, Gabriel Benavente Palma, entrou na casa patronal para buscar uma pistola, saiu e disparou sem avisar à queima roupa contra Quinteros, que estava desarmado e ficou gravemente ferido. Em choque, Guzmán carregou seu colega até o veículo do INDAP, para buscar um hospital com urgência. Mas o herdeiro Benavente não se deu por satisfeito: "saiu disparando outros cinco tiros contra a caminhonete" e "absolutamente fora de si, na presença da mãe e com outros dois irmãos, quebrou um dos vidros da caminhonete a coronhadas, na tentativa de liquidar Quinteros". ${ }^{689}$ Os indapinos conseguiram escapar do ataque, mas testemunhas relataram que Benavente prosseguiu seu acesso de fúria, espancando dois trabalhadores agrícolas "pelo delito de haver conversado com os funcionários". No dia seguinte, o jovem proprietário foi preso em flagrante por homicídio frustrado. Dois anos depois, em abril de 1970,

\footnotetext{
${ }^{685}$ Campusano, 2013: 197.

${ }^{686}$ Apud Gajardo, 1973c: 57.

${ }^{687}$ FEES, 1970: 2 .

${ }^{688}$ A balazos tratan de impedir que se reúnan los campesinos, La Nación, 25/01/1968.

${ }^{689}$ Idem.
} 
na mesma propriedade da família Benavente foi assassinado Hernán Mery, funcionário da CORA, que executava seu trabalho de expropriação legal da terra.

Agressões como essa se tornaram cada vez mais comuns depois da aprovação da lei de sindicalização camponesa (16.625, abril/1967) e da lei da reforma agrária (16.640, julho/1967). A consolidação e garantia legal dos direitos dos trabalhadores rurais chilenos, incluído o direito inalienável à sindicalização e à greve, despertou reações violentas de segmentos das classes proprietárias, que não aceitavam a reconfiguração das relações de poder no campo. Intermediários e agentes da transformação estrutural, funcionários de Estado eram frequentemente vítimas da agressão, mas como mostra a anedota, raramente os camponeses saiam ilesos da violência. Na mesma comuna de Longaví, dois anos depois, ocorreu o emblemático assassinato de Hernán Mery em abril de 1970. Mery era funcionário da CORA e foi morto com uma marretada na cabeça quando visitava o latifúndio La Piedad, de 600 hectares, para uma expropriação absolutamente dentro da lei (Avendaño, 2017: 316).

Como demonstraram Affonso (et.al., 1970) e Loveman (1976), a luta dos camponeses do Chile por melhores condições de vida e trabalho, por terra, pelo direito à organização sindical e à liberdade econômica datavam pelo menos da década de 1910. A diversidade dos seus métodos de luta (petições, greves, tomas de fundos, marchas, ocupações de edifícios públicos, pequenas transgressões no uso das regalias), se contrastava com a grave precariedade organizacional do campesinato. Os direitos de sindicalização e greve dos trabalhadores chilenos, assegurado pelo Código do Trabalho de 1931, nunca havia efetivamente vigorado no campo até 1967. Ao contrário, desde 1939, com a Ordem Ministerial $\mathrm{n}^{\mathrm{o}} 34$ do governo Pedro Aguirre Cerda, os direitos sindicais camponeses foram oficialmente suspensos e tal interdição foi confirmada pela lei 8.811 de 1947, conhecida como lei de travas, do governo Gabriel Gonzalo Videla (Loveman, 1976: 124-127; Affonso et al., 1970: 49-52). Foram os governos da Frente Popular que obstruíram os direitos sindicais camponeses no Chile, que por isso adentraram na década de 1960 sem jornada definida, sem salário garantido, nem férias, obrigados a trabalharem "de sol a sol". Como argumentou Loveman (1976), o pacto entre burguesias rurais, latifundiários e burguesias urbanoindustriais chilenas pela exclusão dos trabalhadores rurais da cidadania salarial, viabilizou o rebaixamento geral dos salários, em razão dos baixos custos de produção dos alimentos, o que favorecia todas as frações das classes dominantes. Na base dessa pirâmide, alertou Garret $(1976,1978)$, estava o trabalho reprodutivo não remunerado das mulheres no huerto familiar, que alimentava e viabilizavam a existência da força de trabalho masculina e das crianças. A sindicalização camponesa de 1967 significou, nesse sentido, a quebra de um pacto intra-classes dominantes de longo prazo, o que despertou todo tipo de violências proprietárias e desconfigurou as relações de poder rural estabelecidas durante 150 anos.

Tanto a violência proprietária, como a luta pela sindicalização camponesa não eram fenômenos novos. Loveman conta que o próprio Luis Emilio Recabarrén, fundador do PCCh, levava as petições rurais da Federação Obreira do Chile (FOCH) ao parlamento nas décadas de 1910 e 1920, nas quais os camponeses denunciavam demissões em massa, atrasos de pagamentos, baixos salários, exaustão, falta 
de tempo para produzir para si mesmos, pediam liberdade para vender seus produtos, fim da retaliação aos camponeses peticionários, entre outras pautas. A pressão camponesa aumentou com a criação da Inspetoria do Trabalho pelo Código de 1931, mas ainda assim "os movimentos de trabalhadores rurais careciam de coordenação e orientação ideológica, ou mesmo a colaboração financeira e organizativa de seus aliados de classe e ideologia" (Loveman, 1976: 145). Segundo Bengoa (2016), foram os camponeses afuerinos, com sua itinerância, que mais contribuíram para multiplicação rural da cultura política proveniente das experiências sindicais das minas de salitre. Nos períodos de baixa empregabilidade da agricultura, esses camponeses peregrinavam para o Norte, onde participavam de movimentos sindicais, e depois retornavam aos territórios rurais com novas ferramentas e conhecimentos de luta dos "federados" da FOCH.

Assim como a reforma agrária, a lei de sindicalização camponesa de 1967 resultou da combinação entre a crescente pressão dos trabalhadores rurais de baixo para cima e o advento de uma nova hegemonia reformista, que articulou as elites políticas ao ethos modernizador, também impulsionado pela Aliança para o Progresso e CEPAL. Em 1965, junto ao projeto de lei da sindicalização camponesa enviado ao congresso, o presidente Eduardo Frei denunciava que "a lei 8.811 de 1947 (...) concedeu ao campesinato o direito de sindicalizar-se condicionando-o de tal maneira que na prática o tornou impossível", o que se comprovava porque "em 17 anos (...) só se formaram 24 sindicatos agrícolas em todo país, com um total de 1.647 associados, dos quais 14 com 1.174 sócios se encontram atualmente em atividade" ${ }^{690}$ Frei alertava, ademais, que a exigência de alfabetização de um porcentual dos sindicalizados era "uma notória discriminação", ainda mais considerando que "mais da metade da população analfabeta do país vive nos campos" ${ }^{691}$ Depois de dois anos de debates parlamentares a sindicalização foi aprovada, para entusiasmo da DC e dos partidos da FRAP, temporariamente aliados contra as oligarquias da SNA. Essas mantinham os inquilinos de fundo em condições miseráveis, subordinadas e dependentes - para alguns, "feudais" ou "semifeudais".

A nova lei estabelecia que camponeses tinham direito a formar sindicatos "sem autorização prévia", quando juntassem 100 trabalhadores interessados da mesma ou de várias propriedades, o que poderia ser reduzido a 25 pessoas em circunstâncias específicas autorizadas pela Direção do Trabalho. Tanto a "mulher casada", como os trabalhadores "menores de 18 anos", antes interditados, conquistaram o direito à sindicalização sem autorização prévia de ninguém. Apesar disso, como investigou Tinsman (2009), o poder da "masculinidade sindical" predominou largamente no campo, sendo excepcionais e raras as mulheres engajadas nessa frente. Em 1972, 94\% dos camponeses sindicalizados eram homens (Barraclough, 1974: 178). Os Centros de Madres continuaram a ser naturalizados como espaço aceitável para o civismo das mulheres rurais. Camponesas solteiras tendiam a ser excluídas ou discriminadas da sindicalização, assim como na lei da reforma agrária. Os novos

${ }^{690}$ Mensaje del S. Ex. Presidente de la República. Diario de Sesiones. Cámara de Diputados, Legislatura Extraordinaria, Sesión $3^{\mathrm{a}}$, en miércoles 13 de octubre de 1965, p. 388.

${ }^{691}$ Idem. 
sindicatos, pela lei, deveriam se agrupar em Federações Provinciais, que por sua vez se articulavam em Confederações Nacionais Campesinas. Estava regulamentado, portanto, um sistema sindical camponês, que cresceu exponencialmente entre 1967 e 1973, e foi interrompido e reprimido pela ditadura como mostra o gráfico a seguir. ${ }^{692}$

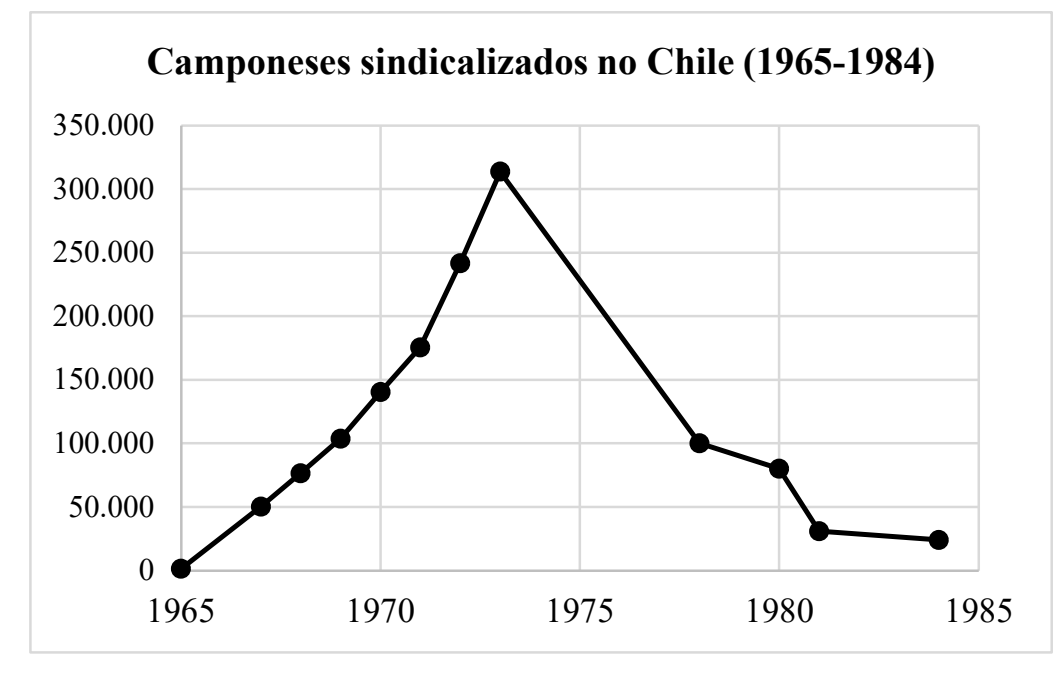

Em 1970, os camponeses sindicalizados representaram de $25 \%$ do total dos trabalhadores rurais (Castillo \& Larraín, 1971: 175), com salto organizativo para 45\% em 1973. A efervescência representada pelo processo de sindicalização foi organicamente atrelada à profusão de cursos e de capacitações sobre os direitos do trabalhador rural, normas para fundação de um sindicato e o papel do sindicato camponês na reforma agrária. Como sinalizou Gajardo (1973a), a capacitação camponesa foi parte orgânica do crescimento do movimento social e sindical camponês daqueles anos. A lei 16.625 atribuía ao sindicato a finalidade de "promover a educação gremial, técnica e geral de seus associados, por meio da criação de escolas profissionais ou da concessão de bolsas a seus afiliados e familiares para estudar e aperfeiçoar-se" (Chile, 1967a). Além de cursos de capacitação, seminários e jornadas, os sindicatos tinham a missão de construir bibliotecas rurais e oferecer serviços culturais e educacionais. Os sindicatos camponeses e seu poder educacional foram compreendidos como peça chave no processo de transformações estruturais, tanto pela DC, como pela FRAP, que consideravam a participação camponesa requisito condicionante da mudança.

Outro consenso consolidado na nova lei era que os patrões tinham o dever de viabilizar a educação do campesinato. Os latifundiários, que durante décadas retiraram as crianças rurais da escola e as obrigaram a trabalhar precocemente, deveriam, a partir dali, "conceder as facilidades convenientes aos dirigentes sindicais, para que possam cumprir adequadamente (...) os fins da educação sindical" (Chile, 1967a). Isso significava não só garantir liberdade sindical aos seus empregados, como também prover instalações adequadas para sua organização e aceitar a presença do Estado em suas propriedades para

${ }^{692}$ Elaboração própria. Números e fontes do gráfico: em 1965, 1.500 camponeses sindicalizados; em 1967, 50.309 (Loveman, 1976: 131, 264-5); em 1968, 76.356; em 1969, 103.544; em 1970, 140.293; em 1971, 175.373; em 1972, 241.610 (Salinas, 1985 apud Tinsman, 2002: 212); em 1973, o auge de 313.700; em 1978, cerca de 100.000 (Gómez, 2002: 5). Em 1980, 80.132 (Silva, 1992: 225); em 1981, 31.000 (Bengoa, 1983: 187-188). Em 1984, 24.000 (Vicaría de la Solidaridad, 1978: 171). 
prestar assessoria - o que, como mostrou a tentativa de homicídio em Longaví, não era bem recebido pela classe patronal.

A medida educacional mais importante da nova sindicalização camponesa constava no artigo $14^{\circ}$, que instituía o Fundo de Educação e Extensão Sindical (FEES), um fato político sem precedentes na história do campesinato e do Estado. O FEES era um organismo público que centralizaria recursos para educação de camponeses adultos em uma escala inédita no país, emanando o objetivo "integracionista" igualmente presente na reforma agrária. Até aquele momento da história chilena, a única instituição especificamente destinada a educação de camponeses adultos estava no setor privado religioso: o IER (ver capítulo 3). O FEES seria a primeira instituição pública destinada exclusivamente à educação de camponeses adultos. Sua missão era ainda mais específica, vinculada à "educação gremial", em uma conjuntura de greves, transformações estruturais e acirramento da polarização no campo.

Os recursos do FEES provinham dos trabalhadores e dos patrões. Todo assalariado rural (sindicalizado ou não) deveria contribuir $2 \%$ de seu salário ao FEES, tanto quanto os empregadores, que destinavam $2 \%$ dos salários da sua propriedade. A Direção do Trabalho seria a autoridade fiscal que arrecadava o imposto nos primeiros 15 dias de cada mês, ${ }^{693}$ sendo metade destinado ao FEES e metade às Confederações e Federações camponesas, que recebiam valores proporcionais à sua base de filiados. Mas a lei também criava sindicatos patronais rurais: além dos $2 \%$ compulsórios, os empregadores agrícolas podiam optar por contribuir mais $1 \%$ da massa salarial da sua propriedade para o sindicato patronal da sua comuna, valor que opcionalmente também poderia ser direcionado ao FEES. As multas e sanções devidas por patrões para Direção do Trabalho devido ao descumprimento da legislação laboral também eram destinadas o fundo.

De certa maneira, o FEES era o primeiro mecanismo de reparação histórica do Estado chileno em favor do campesinato adulto, criado após um século e meio de subjugação dos trabalhadores, exploração e exclusão de gerações de crianças rurais da escolarização formal. O FEES também alterava radicalmente as dimensões do processo capacitador. Se entre 1960 e 1969, o IER havia formado cerca de 29 mil camponeses em seus cursos de capacitação, configurando-se como a maior iniciativa da década para educação camponesa, em 1970, a meta das três confederações nacionais (Triunfo Campesino, Ranquil e Libertad) em convênios com o FEES era capacitar 43.645 camponeses em um único ano. ${ }^{694}$ A capacitação sindical foi parte estratégica da mudança da estrutura agrária no intervalo de 1967 a 1973.

Nesse capítulo, nos propomos a contar a história do FEES, isto é, identificar como seus recursos foram organizados em uma série de novos programas de capacitação para o campesinato, e como participaram dos confrontos do mundo do trabalho rural, da reforma agrária e da reconfiguração das relações de poder no campo. Analisarei qual o papel da educação camponesa no processo de sindicalização; quais conteúdos e materiais didáticos eram utilizados nos cursos; e quais foram os

${ }^{693}$ Chile, Decreto con Fuerza de Ley $n^{\circ} 6$ sobre el Fondo de Educación y Extensión Sindical. Santiago, 12/01/1968.

${ }^{694}$ FEES, Proyectos, Convenios y Programas. Santiago, 1970. 
convênios estabelecidos pelo FEES com cada confederação, bem como outras instituições, como o Instituto Nacional de Capacitação Profissional (INACAP) e a Universidade Católica. Em alguns casos, quando as fontes nos permitirem, examinarei como o campesinato recebia e se organizava em torno dessa avalanche de novas relações culturais e políticas com milhares de professores. Identifico também como a filosofia educacional freiriana esteve presente no mundo sindical camponês, às vezes em composição contraditória com estratégias da educação bancária, outras vezes de maneira a potencializar uma educação marxista para luta de classes.

Argumento que tanto a DC como a FRAP/UP, por meio dos seus braços sindicais rurais, fortaleceram uma "pedagogia da reivindicação", isto é, uma filosofia da ação coletiva como único caminho possível para solução dos problemas vividos pelo campesinato. Uma pedagogia que estimulava o campesinato a organizar comitês sindicais (no nível da propriedade), sindicatos comunais, federações provinciais, a gerenciar a burocracia sindical com competência, a formar cooperativas, a compreender as próprias demandas com consciência crítica e solidária, a conhecer as ferramentas de luta camponesa e a história do seu movimento. Pela pedagogia da reivindicação, estimulava-se a luta coletiva e cada vez mais profissional com a criação de uma camada de dirigentes destacados, formados em cursos longos e aprofundados. Nesse sentido, analiso a importância que a educação sindical exercia na diferenciação interna do próprio campesinato, com o desenvolvimento de saberes burocráticos e administrativos requeridos para gestão sindical, que aos poucos aumentavam as distâncias internas de uma classe estruturalmente diversa.

Por fim, considerando as trajetórias subalternas da maioria dos camponeses, não é demais recordar que o ato de reivindicar representava, em si mesmo, uma revolução subjetiva de grandes proporções, abrindo espaço e dando novo aspecto ao sujeito coletivo mais determinante para a história agrária da revolução chilena. Aprender a se auto-organizar e reivindicar coletivamente seus direitos em nível comunal, provincial e nacional transformavam a disponibilidade subjetiva de amplos setores do campesinato para mudar sua realidade, proporcionando um novo sentido de autodeterminação histórica. Se por um lado o aparato educacional do FEES e das confederações ficou aquém do crescimento das bases sindicalizadas, por outro, os documentos estudados mostram que a capacitação sindical teve um lugar estratégico na mudança cultural dos camponeses educandos e dos funcionários educadores, fermentando a luta de classes e fortalecendo uma subjetividade de combate.

\section{2. "Éramos itinerantes": os primeiros passos do FEES}

A jovem Maria Emília era socióloga recém-formada na Universidade Católica quando foi contratada pelo FEES, em 1968, onde trabalhou até o golpe de 1973. "Cheguei ao FEES como pesquisadora, mas a verdade é que fiz de tudo", ${ }^{695}$ lembrou. A sede do Fundo foi estabelecida na rua

${ }^{695}$ Entrevista com Maria Emília Palma. Santiago, 29 de maio de 2019. 
Dieciocho, 270, em uma mansão santiaguina do século XIX. A mansão foi dividida em duas partes, uma para escritório e outra para funcionamento de atividades pedagógicas. "Necessitávamos criar uma escola camponesa, mas não havia recursos para alugar outra casa", contou Maria Emilia: "então reduzimos o escritório. Era uma mansão antiga, dividida em espaço da família e dos empregados. Deixamos o escritório na parte dos empregados e fizemos salas de aula e dormitórios no melhor espaço da casa. Nos apertamos", ${ }^{696}$ contou. Foi ela mesma quem saiu para comprar camas, móveis, pratos e talheres para viabilizar um dormitório aos camponeses de outras regiões que vinham estudar em Santiago.

Em 1969, o orçamento do FEES alcançou 23 milhões de escudos, dos quais 35\% foram entregues às Confederações por meio de convênios de capacitação sindical, outros $35 \%$ foram destinados a convênios diretos do FEES com outros organismos educacionais (como o INDAP e a Universidade Católica) e $10 \%$ à administração geral. ${ }^{697} \mathrm{O}$ órgão estava proibido por lei de gastar mais de um décimo de seu orçamento com administração interna, o que gerou um paradoxo: gerenciavam recursos abundantes, mas com austeridade interna. Por atuar predominantemente junto às confederações e ter um orçamento próprio restrito, o FEES não chegou a ter sedes nos campos onde atuava. "Nós chegávamos para trabalhar nos territórios rurais em sedes que não eram nossas. Nos emprestavam salas", ${ }^{698}$ explicou Maria Emília, que além de atuar na unidade de estudos e pesquisas do FEES, viajava para dar aulas aos camponeses: "Dávamos aula de maneira muito precária. Éramos itinerantes (...). Fomos um pouco invisíveis [para a repressão, após o golpe] porque éramos itinerantes, não tínhamos lugar físico, além da casa da Dieciocho. Éramos nômades, mas isso não quer dizer que tínhamos escassez de recursos", ${ }^{699}$ analisou.

Certa vez, a professora Maria Emília teve que dormir em uma sede sindical rural sobre estreitas banquetas de madeira, com frio e acompanhada de ratazanas no chão. Em outra viagem, lembra-se de dormir no andar de cima de uma casa de prostituição, onde passou a noite desperta, com receio que abrissem a porta. "Para buscar outro lugar era preciso dirigir 100 quilômetros a noite, mas chovia e era perigoso. As estradas eram péssimas. Então ficávamos onde precisávamos estar para dar as aulas no dia seguinte", conta: "éramos austeros". 700

Na maioria dos campos onde ocorriam as aulas do FEES não havia eletricidade nem outras formas de iluminação para aulas noturnas. Por isso, junto aos livros e materiais didáticos o FEES entregava recursos de iluminação das aulas noturnas. "Contratamos dezenas de professores nos campos para cursos vespertinos e noturnos”, explicou Torres (2020): “entregávamos lampiões para iluminação”. Maria Emília também chegou a dar aulas dentro de tomas. "Nós chegávamos e havia uma toma, por exemplo. Nem sabíamos. E aí precisávamos dar aulas lá mesmo. Os patrões, quando sabiam, não

\footnotetext{
696 Idem.

${ }^{697}$ FEES, Proyectos, Convenios y Programas. Santiago, 1970.

698 Entrevista com Maria Emília Palma. Santiago, 29 de maio de 2019.

699 Idem.

${ }^{700}$ Id., ibid.
} 
gostavam". ${ }^{701}$ Também lecionou dentro de assentamentos, quando neles havia comitês sindicais, embora a CORA se encarregasse da educação no setor reformado.

A existência do FEES consolidava a ideia de que o direito à sindicalização requeria "por parte dos trabalhadores camponeses, conhecimento das verdadeiras finalidades do sindicato, preparação suficiente e meios adequados"702 e que os trabalhadores deviam "participar nas orientações e realizações em matéria de educação e extensão sindicais”. Para promover a educação gremial, técnica e geral dos camponeses, o órgão trabalhava em convênios com as confederações e federações camponesas, junto às quais deveria fomentar centrais de capacitação, bibliotecas, escolas técnicas e oferecer bolsas de estudo aos camponeses. O Fundo supervisionava os programas das confederações, que lhes apresentavam relatórios pedagógicos e prestações de contas periódicas.

A dinâmica criativa do FEES fez com que seus funcionários trabalhassem em múltiplas funções, o que também ocorria em decorrência da necessidade política da transformação agrária. Para Maria Emília, "tinha a ver com a urgência. De repente, por exemplo, alguém precisava ir a Puerto Montt entregar materiais. Na época, mulheres não podiam conduzir carros oficiais, então eu precisava ir com um motorista. Aproveitavam para distribuir tarefas a quem viajava", ${ }^{703}$ explicou. Ela mesma se incumbiu diversas vezes de viagens para lecionar cursos e difundir materiais didáticos territórios adentro: "Eu tinha que ir distribuindo livros no caminho, para que os camponeses estudassem. Sempre fazia viagem multipropósitos, parando em vários pontos", 704 recorda-se. Entre os materiais distribuídos por Maria Emília e outros itinerantes do FEES, estavam as cartilhas laborais.

Para que os camponeses encontrassem informações sobre a nova legislação laboral e sindical, o FEES distribuiu dezenas de milhares de cartilhas laborais entre 1970 e 1971. Eram nove livretos com textos e ilustrações, com objetivo de informar e conscientizar trabalhadores rurais sobre seus novos direitos laborais e ferramentas sindicais. As capas das cartilhas eram artísticas e chamativas, como se visualiza a seguir. ${ }^{705}$

\footnotetext{
${ }^{701}$ Id., ibid.

${ }^{702}$ Chile, Decreto con Fuerza de Ley $n^{\circ} 6$ sobre el Fondo de Educación y Extensión Sindical. Santiago, 12/01/1968.

${ }^{703}$ Entrevista com Maria Emília Palma. Santiago, 29 de maio de 2019.

${ }^{704}$ Idem.

${ }^{705}$ As fotos dos documentos foram autorizadas e supervisionadas pela Biblioteca Nacional do Chile.
} 

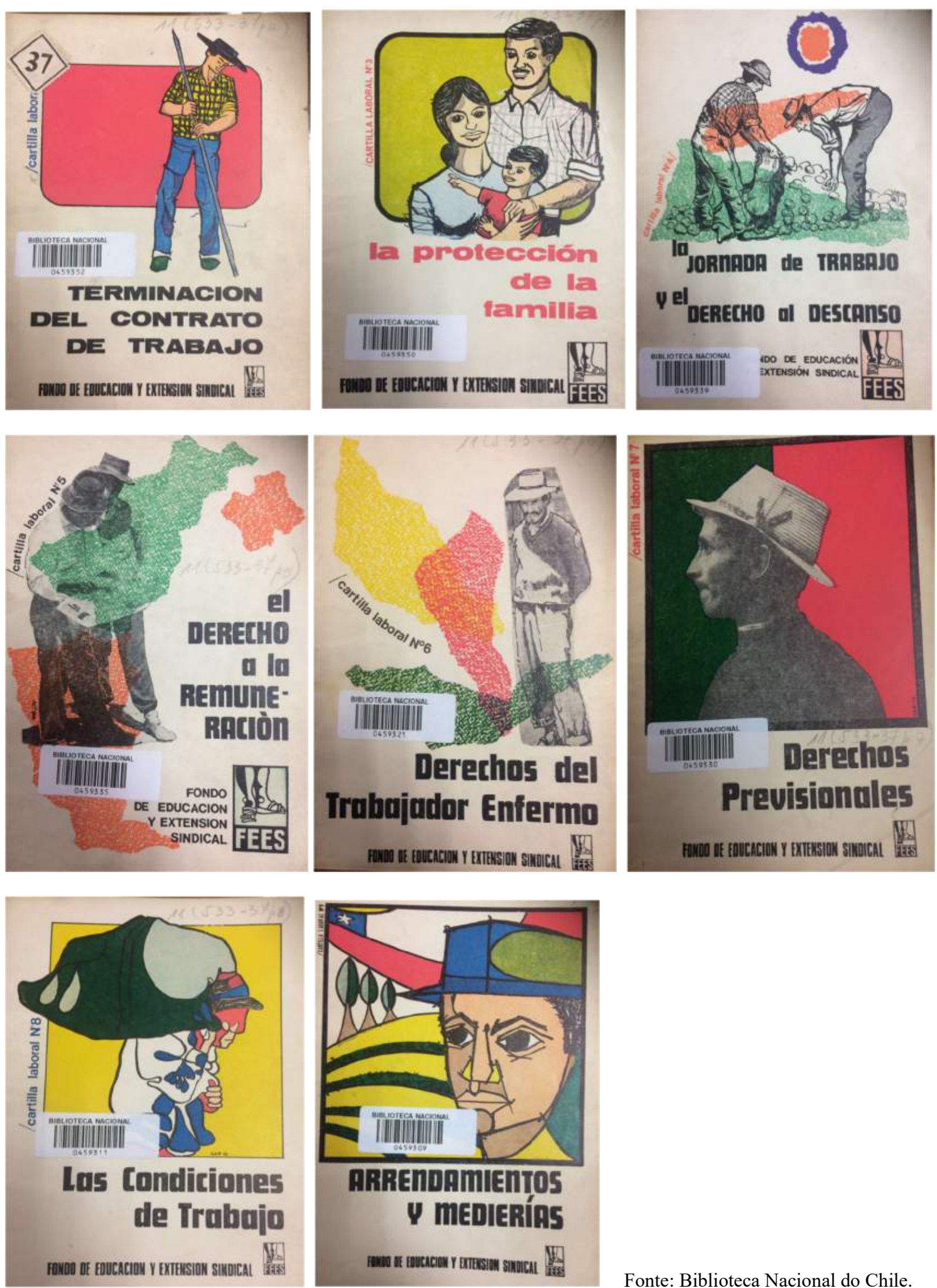

Fonte: Biblioteca Nacional do Chile.

A seguir, analisarei os conteúdos desses materiais. 
Não pude encontrar a Cartilha Laboral $\mathrm{n}^{\circ} 1$, portanto começarei da $\mathrm{n}^{\mathrm{o}} 2$, Terminación del contracto de trabajo, na qual eram resumidas as novas normas para demissão, com ênfase nas garantias de "inamovilidade geral" e "inamovilidade sindical". A inamovilidade geral protegia os camponeses da demissão sem justa causa, enquanto a sindical proibia a demissão do dirigente sindical enquanto compusesse a diretoria. O FEES reproduzia trechos da lei 16.455 de 1966, que definia as normas para rompimento de contratos, e descrevia situações consideradas ilegais de assédio laboral, como agressões e humilhações, que deveriam ser denunciadas aos Inspetores do Trabalho.

Apesar das ilustrações presentes nas cartilhas, era necessário ser alfabetizado para compreender seu conteúdo, predominantemente textual. Ou seja,

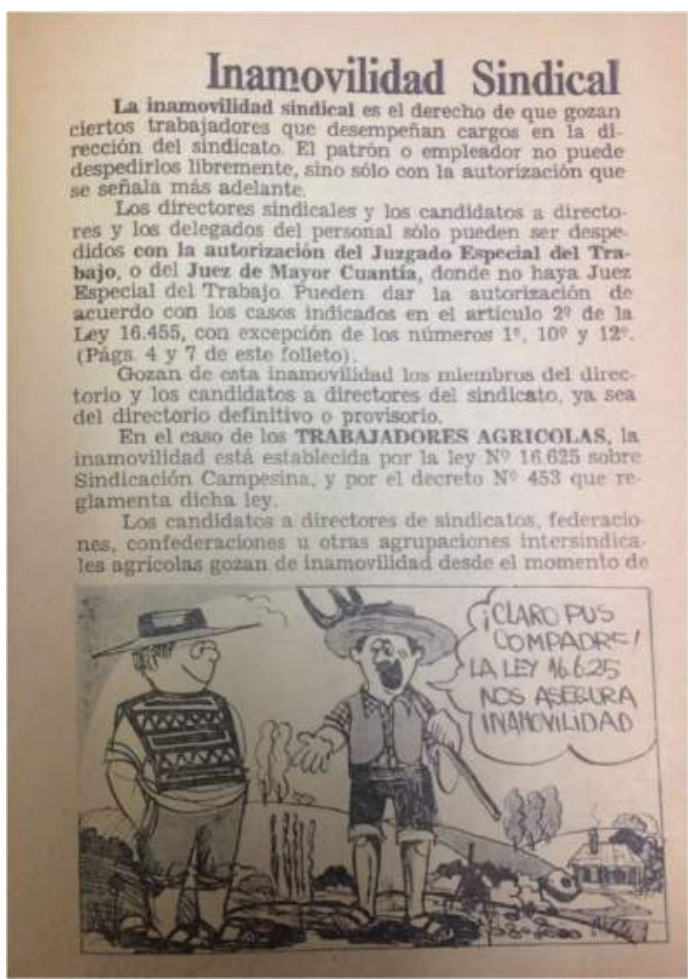

"No caso do trabalhador agrícola, a inamovilidade está estabelecida pela lei 16.625 de Sindicalização

Campesina". Fonte: FEES, Terminación del contracto de trabaio. o material era destinado às direções sindicais alfabetizadas, como apoio para suas lutas cotidianas: "a presente cartilha é distribuída gratuitamente aos sindicatos, federações e confederações agrícolas e podem também ser solicitadas diretamente ao FEES", 706 informava uma delas.

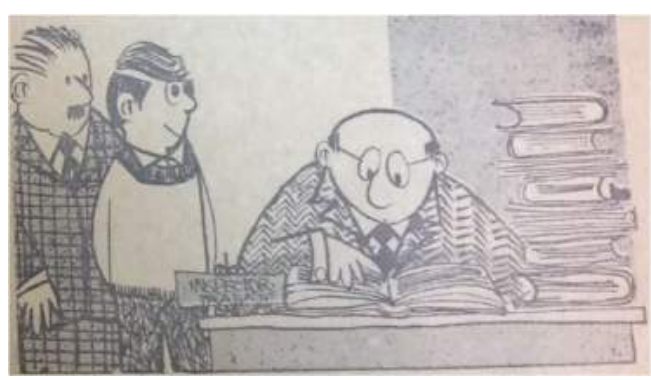

"Quando não há acordo, decidirá a Inspeção do Trabalho". Fonte: FEES, Terminación del contracto de trabajo.

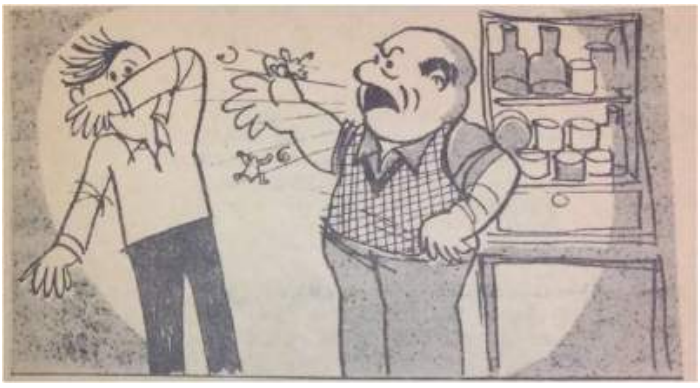

"Trato grosseiro ou conduta imoral grave comprovada" eram causas justas para ruptura contratual. Fonte: FEES, Terminación del contracto de trabajo.

Na cartilha $n^{\circ}$ 2, o Estado aparecia como mediador neutro dos conflitos laborais, tal qual determinava a lei. Entretanto, na experiência camponesa de décadas de lutas nem sempre os inspetores do trabalho se desempenharam de maneira independente

\footnotetext{
${ }^{706}$ FEES, Derechos del trabajador enfermo. Cartilla Laboral no 6. Santiago: FEES, 1970.
} 
do poder patronal. ${ }^{707}$ Nesse sentido, conhecer os direitos do trabalhador camponês e acionar a inspetoria do trabalho diante de injustiças era tão fundamental, quanto insuficiente. Em 1965, segundo Loveman (1976: 249), existiam em todo país apenas 225 inspetores do trabalho para campo e cidade. Cinco anos depois, a situação não era muito melhor. A zona de conflitos agrários representava uma área de 21 milhões de hectares cultivados em mais de 75 mil unidades produtivas, com mais de 330 mil contratos de trabalho ativos. A própria Direção do Trabalho calculou, naquele ano, que seriam necessários ao menos 235 inspetores exclusivos para agricultura para dar vazão ao número de conflitos. Além disso, entre 1966 e 1970, as demissões ilegais foram massivas, grande parte delas como retaliação patronal contra a sindicalização e a mudança de postura do campesinato, que passou a demandar, em nível coletivo ou individual, o pagamento dos salários atrasados e jornadas de até 8 horas.

Em fevereiro de 1967, o jornal comunista El Siglo denunciou uma "onda de demissões" na comuna de Colina, próxima de Santiago. Camponeses de nove propriedades e diferentes modalidades de contratação se reuniram num domingo para organizar a luta contra demissões arbitrárias. Estavam presentes dirigentes comunistas da Federação de Camponeses e Indígenas ${ }^{708}$ e "choveram denúncias de maus tratos e abusos patronais". ${ }^{709}$ Romilio Ramirez, trabalhador rural com sete filhos pequenos, por exemplo, foi cobrar sua patroa que lhe remunerasse a asignación familiar ${ }^{710}$ que lhe era devida: "com os 3 escudos ao dia que recebo, sem refeição e casa muito ruim, não me dá para nada. Mas aquilo [a cobrança] the pareceu errado e ela me informou que já não havia mais trabalho para mim", ${ }^{711}$ relatou o camponês. Na reunião também estavam cinco inquilinos do latifúndio Nueva Esperanza ameaçados de demissão sem justa causa, um deles pai de dez crianças, que perderiam sua casa e sua regalia de terra e tampouco tinham recursos para morar no povoado.

Em setembro de 1967, El Siglo reportou outra onda de demissões ilegais contra 102 camponeses da empresa florestal Siberia, em Ñuble. Eles estavam em luta por melhorias salariais e pelo direito à formação de um sindicato comunal camponês, cuja oficialização era protelada desde junho pela direção do trabalho local. A demora na legalização do sindicato se devia, segundo o jornal, "ao apoio que os empresários possuem das autoridades do trabalho na província". ${ }^{712}$ Outros 83 trabalhadores da mesma empresa entraram em greve em solidariedade contra as demissões. Em dezembro, 21 camponeses de um comitê sindical foram demitidos na comuna de Cabildo, em Petorca, como retaliação por reivindicarem a posse pela CORA do latifúndio El Carmen, já expropriado, com 6.283 hectares.

\footnotetext{
${ }^{707}$ Loveman (1976) analisou dezenas de relatórios de inspetores do trabalho dos anos 1930 a 1960, indicando algumas mediações bem-sucedidas, mas também uma grande quantidade de experiências em que o campesinato perdia confiança nessa instituição.

${ }^{708}$ A Federação Nacional de Campesinos e Indígenas (FNCI) foi formalmente criada em 1961, em um Congresso Nacional Campesino convocado por organizações de trabalhadores rurais ligadas aos socialistas e comunistas, entre elas: a Fundação de Trabalhadores Agrícolas; a Associação Nacional de Indígenas; e a Federação dos Trabalhadores da Terra (Affonso et. Al, 1970: 128). Em fevereiro de 1968, a FNCI adotou o nome Confederação Nacional Campesina e Indígena Ranquil, em homenagem aos trabalhadores mortos de 1934, e passou a usufruir dos direitos organizativos da lei 16.625 (Campusano, 2013). ${ }^{709}$ Ola de despidos y abusos en los fundos de Colina. El Siglo, 21/02/1967.

${ }^{710}$ A asignación familiar consistia em um acréscimo salarial para os trabalhadores rurais de acordo com a quantidade de filhos.

${ }^{711}$ Ola de despidos y abusos en los fundos de Colina, op. cit.

712 Despiden ilegalmente a 102 campesinos. El Siglo, 13/09/1967.
} 
Também exigiam o cumprimento da ata de conciliação da inspetoria do trabalho, que reestabelecia salários atrasados. ${ }^{713}$ Contra as demissões, o sindicato comunal de Cabildo convocou um ato público e dois assentamentos doaram 450 escudos para manutenção dos demitidos.

Nada se comparou, porém, à onda de retaliações vivida em 1968, ano crucial da fundação dos sindicatos camponeses. Só naquele ano, El Siglo denunciou 2.269 demissões ilegais de camponeses, incluindo dezenas de dirigentes sindicais, a maior parte como resposta patronal à onda organizativa dos trabalhadores rurais. No latifúndio La Perla, em Los Angeles, foram 88 demitidos por participarem de uma paralisação convocada pelo sindicato. $\mathrm{O}$ administrador chegou a agredir um trabalhador em público. ${ }^{714}$ Outros 80 camponeses foram demitidos da propriedade Santa Lucía, por organizarem uma paralisação em solidariedade aos demitidos de La Perla. ${ }^{715} \mathrm{Na}$ hacienda La Primera, em Longaví, toda direção do sindicato foi demitida ilegalmente junto com 132 camponeses, motivo pelo qual o ministro do Trabalho solicitou a intervenção na propriedade, como previsto no artigo 171 da lei de reforma agrária. ${ }^{716} \mathrm{O}$ presidente da CUT, Luis Figueroa, alertou em agosto que mais de 112 mil camponeses contratados temporariamente corriam riscos de demissão e desemprego de Coquimbo a Talca, o que já estava concretizado para 7 mil trabalhadores da colheita de beterraba em Ñuble. ${ }^{717}$

Naquele contexto, Jacques Chonchol (INDAP) e o departamento camponês da DC denunciaram que os latifundiários utilizavam a forte seca que acometia os cultivos como pretexto para demissões ilegais massivas, ignorando o direito sindical, a legislação laboral e sabotando a produção. ${ }^{718}$ Em Rengo, onde 1500 camponeses foram demitidos ilegalmente, mais de 440 demandas camponesas foram abertas no Juizado do Trabalho, mas até setembro "nenhuma delas teve resultado positivo, pois os latifundiários contam com a cumplicidade da justiça, que ampara seus privilégios", ${ }^{719}$ reportava El Siglo. A recémcriada Confederação Nacional Campesina Ranquil, em alguns casos, conseguiu reverter demissões, mas o comportamento dos Juizados do Trabalho parecia uma armadilha resistente à nova legislação. ${ }^{720} \mathrm{O}$ jornal oficial do governo, La Nación, deu menor ênfase à onda de demissões ilegais de 1968, embora as tenha denunciado nos latifúndios El Carmen, Limanche e Bonanza. ${ }^{721}$

Era nesse contexto, de retaliação patronal contra a organização sindical camponesa, que as cartilhas do FEES eram confeccionadas e espalhadas de norte a sul, proporcionando legitimidade e informação

\footnotetext{
${ }^{713}$ Matonaje y despidos en fundo 'El Carmen'. El Siglo, 06/12/1967.

71488 campesinos despedidos por dos latifundistas. El Siglo, 10/02/1968.

${ }^{715}$ Despedidos campesinos de 2 fundos de Bío Bío. El Siglo, 17/02/1968

${ }^{716}$ Diz o artigo: "Em caso de lock-out patronal ou de paralisação ilegal que por qualquer motivo suspendam as atividades de exploração de uma propriedade agrícola, o Presidente da República poderá decretar a retomada destas, com intervenção das autoridades civis, que poderão requerer auxílio da Força Pública. O interventor terá todas as faculdades necessárias para continuar a exploração da propriedade" (Chile, 1967b).

717112 mil campesinos amenazados con despidos. El Siglo, 09/08/1968.

${ }^{718}$ Latifundistas usan sequía de pretexto para despidos masivos, dice departamento campesino del PDC. El Siglo, 29/08/1968. Denuncian despidos masivos en el campo. El Siglo, 11/09/1968.

7191500 campesinos despedidos en Rengo. El Siglo, 05/09/1968.

${ }^{720}$ Forman Confederación Nacional de Campesinos. El Siglo, 03/02/1968. Gestiones de dirigentes impidió despido arbitrario de campesinos. El Siglo, 15/06/1968.

${ }^{721}$ Fundo de Limanche fue intervenido. La Nación, 27/06/1968; Latifundistas de Pirque se burlan de sus inquilinos. La Nación, 28/05/1968; Administrador de fundos baleó a campesinos em Puerto Montt. La Nación, Dez./1970.
} 
para luta. A cartilha laboral n ${ }^{\circ}$, Protección de la Familia, se apoiava nos mecanismos da promoção popular campesina defender direitos familiares e as normas da maternidade, mas também para explicar o destino dos impostos. A asignación familiar era "um dos benefícios mais importantes outorgados pelo Serviço de Seguro Social [SSS]", ${ }^{722}$ uma renda obrigatória devida pelos patrões aos trabalhadores de acordo com a quantidade de filhos que tivessem. Havia sido legalmente estabelecida no governo de Pedro Aguirre Cerda, por iniciativa do então ministro da saúde, Salvador Allende. Segundo Oscar Torres, a asignación familiar "para os camponeses tinha um significado muito grande, porque foi a primeira vez que receberam uma remuneração obrigatória em dinheiro, num tempo em que lhes pagavam em espécie (pão, alimentos, huertos, pastagem)". ${ }^{723}$

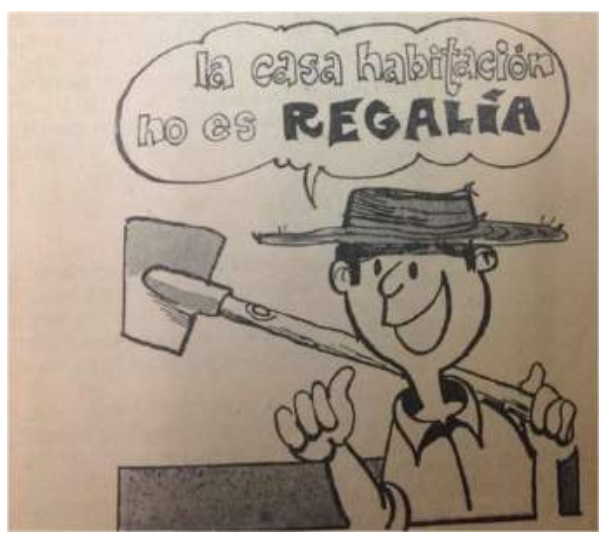

Fonte: FEES, La protección de la familia.

Desde 1964, exigia-se que a remuneração camponesa estivesse composta $50 \%$ por dinheiro, $30 \%$ por regalias produtivas e $20 \%$ por regalias de consumo. Em 1967, o governo Frei determinou que o salário rural fosse integralmente pago em dinheiro, o que não agradou aos camponeses, impactados pela perda das regalias, que afinal eram estruturantes do seu modo de vida (Ramírez, 1968). A cartilha do FEES explicava o mecanismo de arrecadação do SSS e a origem dos recursos da asignación familiar, que "deveriam ser entregues ao trabalhador pelo empregador uma vez ao mês". ${ }^{724} \mathrm{O}$ livreto também detalhava os benefícios do Seguro Social para maternidade, como a licença maternidade remunerada de 3 meses e o subsídio prenatal.

Ademais, ensinava que a moradia camponesa era um direito: "o patrão tem obrigação de dar aos trabalhadores agrícolas uma casa adequada" e "a casa onde vive o camponês e sua família não constitui uma regalia: é uma obrigação patronal". ${ }^{725}$ Segundo o Ministério de Obras Públicas, as casas camponesas não podiam estar em terrenos expostos a inundações periódicas, precisavam ter no mínimo dois cômodos, com paredes de adobe, tijolo, madeira ou cimento e tetos de zinco ou argila (proibidas as paredes, muros e telhados de totora, bambus ou cana). O piso não poderia ser de terra e deveria estar obrigatoriamente ao mínimo de 30 centímetros acima do solo. Obrigava-se que tivessem uma latrina de 1,5 metro de profundidade que não contaminasse a água de beber e cozinhar. A cartilha do FEES incentivava que "o não cumprimento destes requisitos mínimos de moradia por parte do patrão deveriam ser reclamados à Inspeção do Trabalho". 726

Dois anos antes, a mera denúncia das condições ilegais de moradia camponesa causava demissões, como mostrou o caso de afuerinos do latifúndio Lo Infante, contratados para semeadura e colocados

\footnotetext{
${ }^{722}$ FEES, La protección de la familia. Cartilla Laboral n 3. Santiago: FEES, 1970.

${ }^{723}$ Conversa com Oscar Torres por e-mail, 03/08/2020.

${ }^{724}$ FEES, La protección de la familia, op. cit.

${ }^{725}$ Idem.

${ }^{726}$ Id., ibid.
} 
para dormir nas manjedouras juntos com os animais. Ao reclamar na Inspeção do Trabalho, foram ilegalmente despedidos. O mesmo ocorreu com inquilinos do latifúndio Santa Filomena de Nos, demitidos ao reivindicar o pagamento atrasado de seis meses de asignaciones familiares; ou na hacienda Cinco Pinos, onde um trabalhador foi demitido por recusar-se a trabalhar mais de 8 horas ao dia. $^{727}$

Este era o tema da cartilha laboral $n^{\circ}$ 4, La Jornada de Trabajo y el derecho al descanso, que introduzia: "não é raro encontrar casos em que se impõem aos trabalhadores agrícolas jornadas de trabalho superiores à fixada pela lei, ou que não se paga a semana corrida, ou as férias anuais a que todos os trabalhadores têm direito". ${ }^{728}$ Os três conceitos que o livreto introduzia aos seus leitores eram a jornada diária; a semana corrida; e as férias anuais. A jornada não poderia ultrapassar 8 horas diárias e 48 horas semanais, a não ser em casos excepcionais, previamente acordados em um Regulamento Interno da empresa agrícola aprovado pela Inspeção do Trabalho. A jornada obrigatoriamente deveria ser interrompida por 2 horas de descanso. Esse direito ainda estava bem distante da realidade dos camponeses da década de $1960 . .^{729}$ A semana corrida consistia basicamente no direito ao descanso remunerado de domingo, no caso do cumprimento correto das 48 horas semanais de trabalho. Não havia pagamento da semana corrida se houvesse paralisação das atividades por

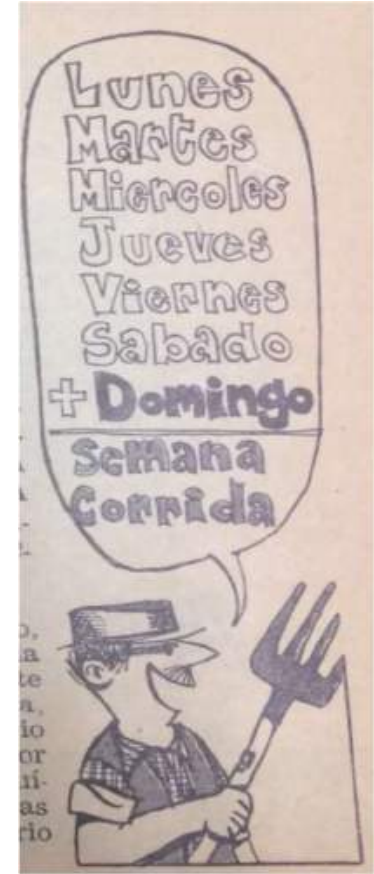

Fonte: FEES, La Jornada de Trabajo y el derecho al descanso. movimentos petitórios, mas sim por casos de impedimento climático.

Conceitos simples como esses ainda não eram realidade para uma grande quantidade de camponeses.

Em um patamar relativamente ingênuo de comunicação, o livreto assegurava que no caso do

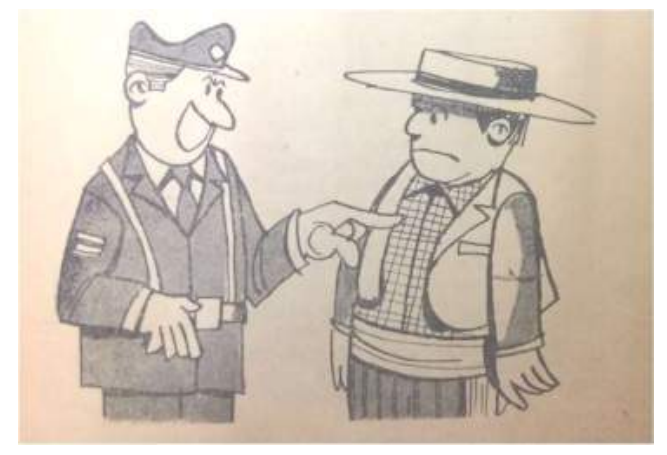
descumprimento da jornada e das remunerações pelos patrões rurais, um inspetor do trabalho "exigirá o imediato fechamento do estabelecimento (...) e se houver resistência

Carabineiro repreendendo um patrão que descumpre o direito ao descanso dos empregados. Fonte: FEES, $L a$ Jornada de Trabajo y el derecho al descanso.

727 Despiden a campesinos de fundos de Nos. El Siglo, 11/06/1968.

${ }^{728}$ FEES, La Jornada de Trabajo y el derecho al descanso. Cartilla Laboral no 4. Santiago: FEES, 1970.

${ }^{729}$ Dueños de fundo tratan como animales a campesinos. El Siglo, 01/03/1968; Trato inhumano contra mapuches heridos en Lumaco. El Siglo, 27/03/1968. 
poderá impor com a força pública". ${ }^{730}$ Aqui, vê-se uma ilustração de um policial repreendendo um patrão por descumprimento do direito ao descanso de seus trabalhadores. O livreto também explicava que a cada 288 dias trabalhados ao ano, o camponês tinha direito a 15 dias de férias remuneradas e se trabalhasse 220 dias, seriam 7 dias de férias. "São irrenunciáveis", dizia a lei, não passíveis de venda ou troca. Igualmente irrealista, ao lado, na cartilha, estava a ilustração de um trabalhador agrícola apresentando uma papelada comprobatória do seu trabalho, demandando direito a férias, embora na prática não existissem sistemas de registros efetivamente controlados pelos camponeses.

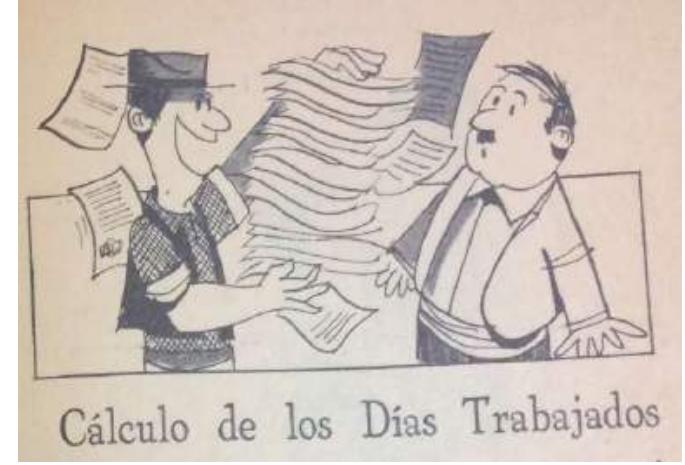

Trabalhador agrícola apresenta comprovação do seu ano de trabalho para pedir férias. Fonte: FEES, La Jornada de Trabajo y el derecho al descanso.
A cartilha $\mathrm{n}^{\circ} 5, E l$ derecho a la remuneración, descrevia os direitos estabelecidos pela lei 16.611 , de fevereiro de 1967, sobre o Pagamento do Salário Agrícola. Desde logo, o material alertava: "é fundamental que $o$ trabalhador tenha conhecimento pleno dos direitos que a lei the oferece (...). Todo pagamento de salário deve reunir as seguintes condições: ser feita em dia de trabalho; no lugar da atividade, na hora seguinte à jornada". ${ }^{731} \mathrm{O}$ livreto explicava que

o patrão deveria ser multado em caso de descumprimento de prazos e valores de remuneração, incluindo o antecipo de até $25 \%$ do salário recebido pelo trabalhador com contrato fixo nos primeiros dez dias mensais. A palavra antecipo era a mesma utilizada pelos assentados para se referir ao crédito da CORA ao assentamento, o que gerou confusões e mal-entendidos relacionados à natureza da remuneração nos assentamentos (ver próximo capítulo). Além disso, as regalias deveriam ser explicitadas no contrato de trabalho, embora na realidade tenham sido historicamente objeto de negociação constante e oral entre patrões e camponeses. A lei também estabelecia que em dias de chuva, neve ou granizo, o camponês tinha direito a não trabalhar "por impedimento climático" e caso o patrão não o dispensasse, o trabalhador poderia se recusar e comprovar a circunstância na Inspetoria de Trabalho, sem prejuízo de seu descanso remunerado da semana corrida. Ao não trabalhar por impedimento climático, o trabalhador receberia metade do seu salário (de Tarapacá a Maule) ou 40\% de seu salário (de Linares a Magallanes, onde chuvas são mais frequentes), porém as asignaciones familiares deveriam estar completas.

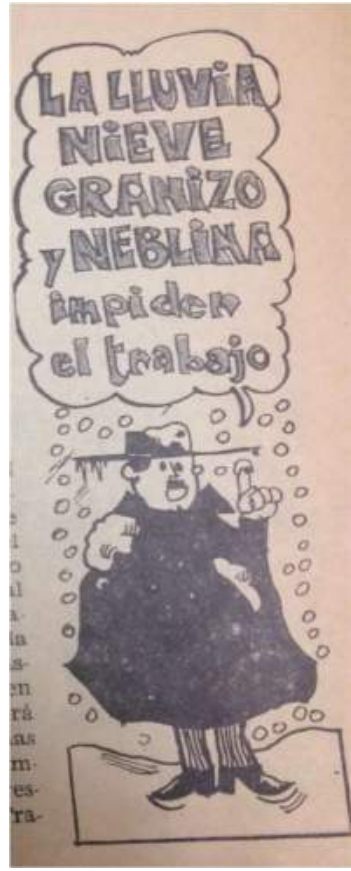

Fonte: FEES, El derecho a la remuneración

${ }^{730}$ FEES, La Jornada de Trabajo y el derecho al descanso, op. cit.

${ }^{731}$ FEES, El derecho a la remuneración. Cartilla Laboral n ${ }^{\circ}$ 5. Santiago: FEES, 1970. 


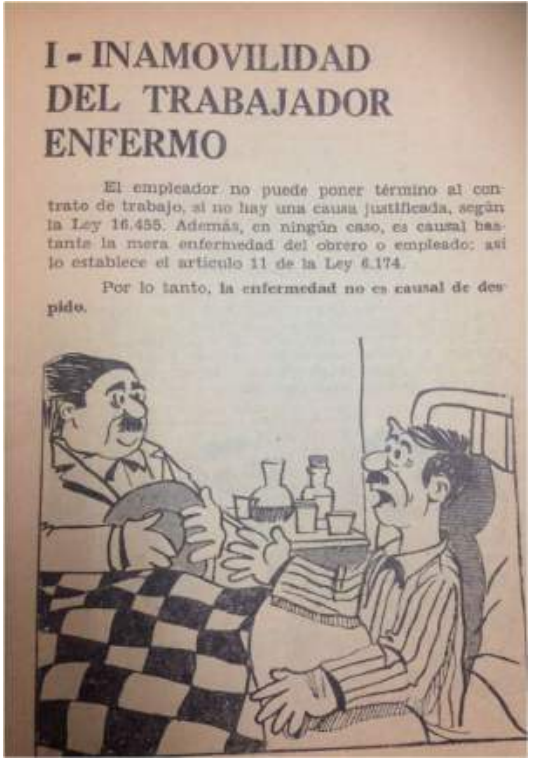

"Em nenhum caso a doença é causa suficiente" para demissão. Fonte: FEES

Derechos del trabajador enfermo.
A cartilha laboral $\mathrm{n}^{\mathrm{o}} 6$ foi especificamente produzida para divulgação dos Derechos del trabajador enfermo. Novamente recorrendo à lei 16.455, o material explicava a inamovilidade do trabalhador doente, que não poderia ser demitido, já que a falta ao trabalho por doença não poderia ser considerada "justa causa". Explicavam também o funcionamento do Serviço Nacional de Saúde (SNS) para o trabalhador rural. Para que os camponeses tivessem direito ao subsídio do SNS, o patrão precisava manter atualizados os carimbos da libreta social, em que se comprovavam os pagamentos patronais de $1 \%$ da massa salarial dos trabalhadores contratados. Mas não bastava: para acessar o benefício, era preciso que o patrão estivesse em dia durante seis meses consecutivos, além de comprovar 13 meses de impostos trabalhistas contínuos ao SSS. Mas era tão comum que patrões sonegassem ou descontinuassem impostos, que uma das petições camponesas mais frequentes no período entre $1931 \mathrm{e}$ 1964, era o preenchimento atualizado da libreta social (Loveman, 1976). Por isso, a cartilha do FEES alertava: "não ter carnê de identidade ou certidão de nascimento não é desculpa para falta de inscrição ou inscrição fora do prazo" no SNS e SSS.

Se o trabalhador beneficiário do subsídio à saúde não pudesse voltar ao trabalho durante um ano e meio, era considerado "inválido" e seu subsídio era convertido em uma aposentadoria por invalidez do SSS. Outro dado interessante do sistema de saúde do trabalhador rural era que estava incorporado o conceito de medicina preventiva e os médicos podiam receitar "repouso preventivo" para evitar doenças mais graves. Ou seja, pela lei, patrões eram obrigados a acatar as licenças médicas preventivas. O conceito de acidente de trabalho também era expandido ao mundo sindical: "Considera-se acidente de trabalho o sofrido por dirigentes sindicais na ocasião de seu desempenho gremial" ${ }^{732}$ indicava a cartilha. Prevendo o caráter conflitivo e masculino do sindicalismo, esse direito estava ilustrado pela figura de uma agressão física entre homens.

A cartilha $\mathrm{n}^{\circ} 7$, sobre Derechos Provisionales, detalhava todos os direitos de aposentadoria e proteção social dos trabalhadores rurais contratados, assim como dos assentados

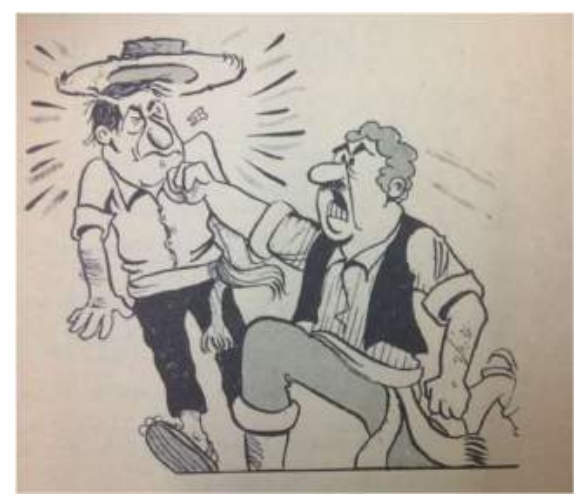

"Considera-se acidente de trabalho o sofrido por dirigentes sindicais na ocasião do desempenho de seu trabalho gremial". Fonte: FEES, Derechos del trabajador enfermo

${ }^{732}$ FEES, Derechos del trabajador enfermo. Cartilla Laboral no 6 Santiago: FEES, 1970. 


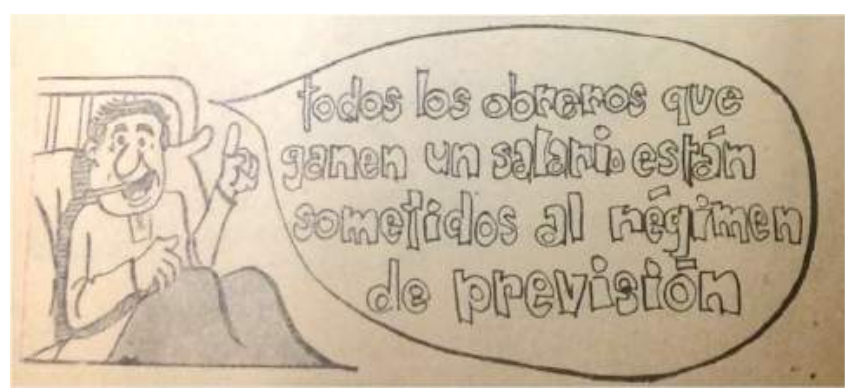

"Todos os trabalhadores que ganham um salário estão cobertos pelo regime de proteção". Fonte: FEES, Derechos del trabajador enfermo da reforma agrária. Os direitos mais significativos eram o seguro desemprego para trabalhadores que durante 156 semanas tivessem contribuído com seus impostos ao SSS; a aposentadoria por velhice aos 65 anos para homens e 60 anos para mulheres, com $70 \%$ de seu salário médio e desde que tivessem contribuído um mínimo de 10 anos; além

das pensões por invalidez, viuvez ou doenças adquiridas por causa da profissão. Para formar o SSS e o SNS, os empregadores contribuíam com uma carga de 39\% dos salários e os trabalhadores rurais com $8 \%$, formando uma base de arrecadação de $47 \%$ sobre o salário base. Mas novamente, a lei estava relativamente distante da realidade, pois a estabilidade contratual era rara mesmo nos casos de inquilinos que passavam a vida inteira dentro da mesma propriedade.

A cartilha também dialogava com a nova situação laboral dos assentados que, "ao se incorporar a uma Sociedade se Reforma Agraria (SARA), perdem a qualidade de trabalhadores agrícolas e, portanto, não recebem salários, nem tem direito à proteção", explicavam: "Mas para remediar esta situação, a lei 16.640 estabeleceu que os assentados estão obrigados a contribuir com o SSS por um salário mínimo enquanto dure o convênio de exploração de terras com a CORA". ${ }^{733}$ As cobranças de impostos sociais, no caso dos assentados, seriam feitas pela própria CORA. Os assentados seguiam tendo direito à asignación familiar, auxílio doença, repouso preventivo, licença maternidade remunerada, aposentadoria por velhice, pensão por invalidez, viuvez ou orfandade, entre outros benefícios. Quando os assentados recebessem seus títulos em propriedade cooperativa e se tornassem pessoas jurídicas separadas da CORA, seriam cobertos pela lei 10.383 de setembro de 1968, e perderiam o seguro desemprego e o subsídio pré-natal. Entre os camponeses que optassem pela propriedade privada, poderiam contribuir com o SNS e o SSS por conta própria, com cotas de $10 \%$ da sua renda, sendo assim reincorporados aos benefícios.

As multas para patrões que não inscrevessem seus trabalhadores na libreta social do SSS variava de $25 \%$ a $400 \%$ da dívida. Aos que não atualizassem a libreta com carimbos da Inspetoria de Trabalho, comprobatórios dos impostos, eram multados com dois salários mínimos. Mas essas multas não pareciam ser suficientes para desincentivar a sonegação. Empregados e empregadores que simulassem situações para obter benefícios também poderiam ser presos.

\footnotetext{
${ }^{733}$ FEES, Derechos prtovisionales. Cartilla Laboral no 7 Santiago: FEES, 1970.
} 
A cartilha $n^{\circ} 8$ do FEES, Las condiciones de trabajo, tratava de temas tão fundamentais como estranhos à realidade camponesa, como a salubridade dos locais de trabalho, a atenção médico-farmacêutica, a higiene, a segurança física, entre outros direitos que pareciam ainda distantes do mundo rural. Pela lei, as condições de trabalho deveriam ser pactuadas entre patrões e empregados no Regulamento Interno da empresa, o que estava ilustrado por uma ingênua figura de negociação pacífica entre as partes. O regulamento deveria conter: a hora de entrada e saída do trabalhador; as horas de descanso; os salários e regalías pré-

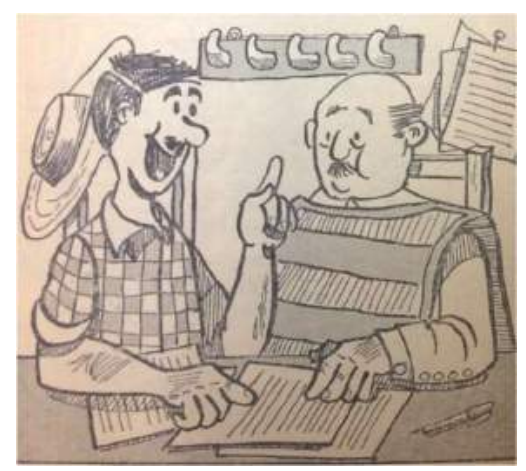

Empregado e empregador debatem regulamento interno da empresa. Fonte: FEES, Las condiciones de trabajo.

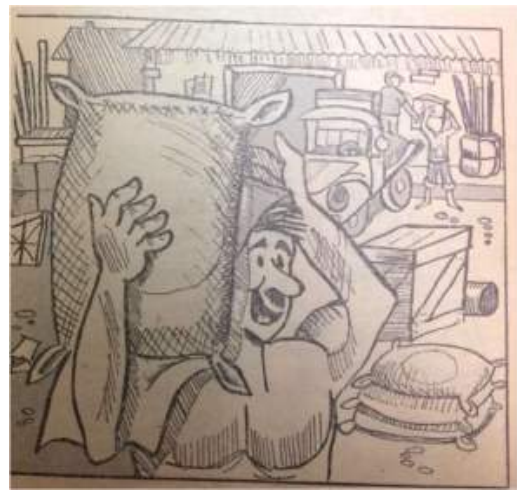

Fonte: FEES, Las condiciones de trabajo.

"Os trabalhadores devem exigir que o Regulamento Interno seja com eles pactuado", ${ }^{734}$ dizia o livreto. Aquele conjunto de detalhes parecia ter sido escrito com inspiração do trabalho urbano industrial, onde as formas de registro e controle do tempo das máquinas permitissem uma maior racionalização das relações de produção. No campo, estabelecer procedimentos de segurança para trabalhos pesados, por exemplo, requeria um nível de modernização técnica, pacificação social e identidade dialógica entre patrões e trabalhadores que era simplesmente

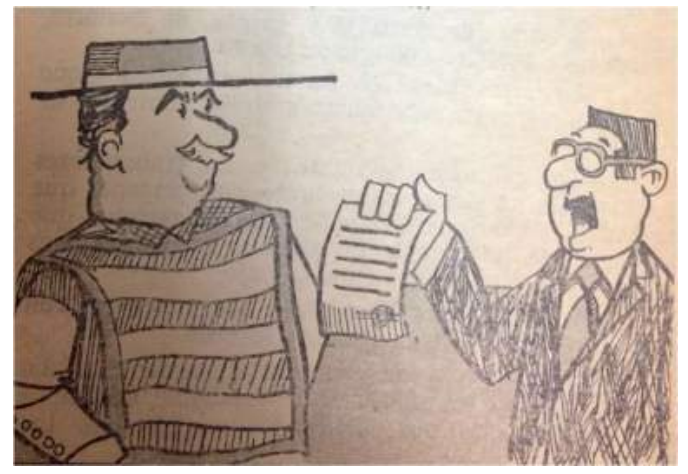

Inspetor do Trabalho aplica multa a patrão. Fonte: FEES, Las condiciones de trabajo. inexistente. Por fim, o patrão seria multado com $2 \%$ do salário base da sua propriedade caso não comunicasse sobre petições e paralisações de seus funcionários à Inspeção do Trabalho. Novamente, ilustrações com trabalhadores alegres e inspetores do trabalho multando patrões davam ao material um clima ingênuo e pouco realista, o que não anulava seu caráter informativo para consulta dos dirigentes sindicais alfabetizados.

\footnotetext{
${ }^{734}$ FEES, Las condiciones de trabajo. Cartilla Laboral no 7 Santiago: FEES, 1970.
} 
A última cartilha laboral $\left(\mathrm{n}^{\circ}\right.$ 9) tratava dos Arrendamientos y medierías, e buscava informar aos camponeses submetidos a contratos diretamente vinculados à terra. Os contratos de arrendamentos e meações deveriam ser supervisionados pelo SAG, não pela Direção do Trabalho. O camponês que arrendasse uma terra estava obrigado a produzir, podendo ser multado e perder a terra caso não o fizesse. A renda deveria ser paga em duas parcelas anuais, sendo que a primeira delas só poderia ser cobrada depois de seis meses de produção. Havia um tempo mínimo de 10 anos para o arrendamento, sendo o

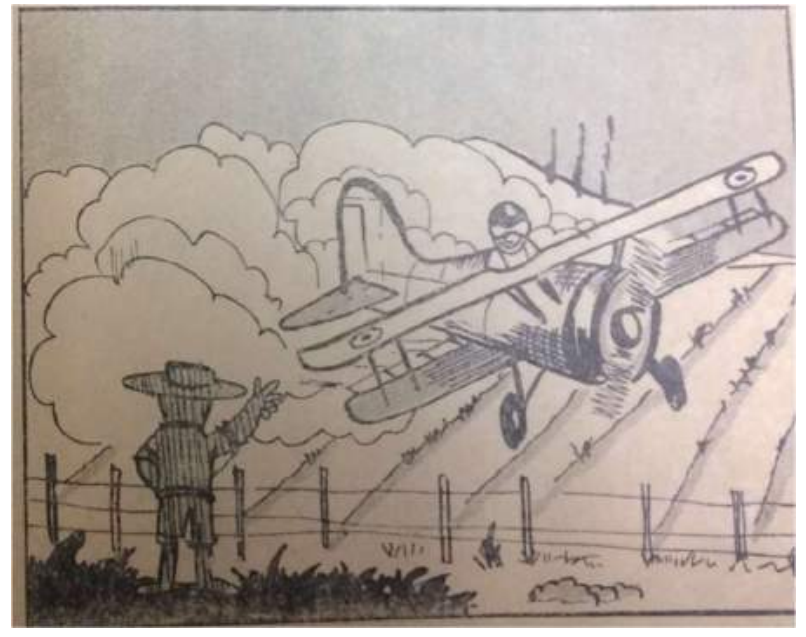

O proprietário tem obrigação de investir no aumento da produtividade da terra arrendada. Fonte: FEES, Arrendamiento y mediería. dono da terra obrigado a investir nas melhorias da propriedade ao menos $10 \%$ da renda cobrada, com objetivo de aumentar a produtividade. Esse conceito vinha acompanhado de uma ilustração com um avião fumigador de fertilizantes e pesticidas, o que revelava o ideário comum da modernização naquele contexto.

Já no contrato da mediería (meação), “as duas partes aportam elementos necessários para explorar as terras e os custos da produção, dirigem conjuntamente a exploração e participam igualmente dos riscos", 735 ensinava o livreto. No contrato, era preciso estipular um número máximo de trabalhadores que seriam contratados ao ano de comum acordo. A disponibilidade hídrica para produção era de responsabilidade do proprietário, junto com metade das sementes, os fertilizantes e pesticidas; enquanto o mediero (meeiro) era responsável pelo trabalho, junto com a outra metade das sementes e insumos, além das máquinas e ferramentas. Se o mediero não produzisse, estaria também sujeito a multas. $\mathrm{O}$ produto final seria dividido ao meio. Os benefícios sociais do mediero estariam garantidos pelas mesmas condições de um trabalhador assalariado, sendo o aporte do proprietário equivalente ao do patrão. Diante de uma expropriação pela CORA, a mediería poderia ser compulsoriamente encerrada pela reforma agrária, com direito a indenizações para proprietários e medieros, sendo que os segundos poderiam ser incorporados como assentados.

Todos esses conteúdos circularam nos sindicatos camponeses pelas mãos itinerantes do FEES.

Segundo a Unidade de Difusão e Publicações, “cartas escritas ao nosso escritório”, indicaram "que as publicações (...) foram acolhidas favoravelmente". ${ }^{736}$ Ademais, os materiais estavam sistematizados e atrelados a capacitação social e gremial dos convênios que o Fundo estabelecia com as confederações camponesas e universidades, para onde se destinava a maior parte do seu investimento.

\footnotetext{
${ }^{735}$ FEES, Arrendamiento y mediería. Cartilla Laboral nº. Santiago: FEES, 1970.

${ }^{736}$ Id., ibid., p. 71.
} 
Paralelamente, um número de agosto 1969 da revista El Campesino, da SNA, trazia uma cartilha para patrões com título Normas Prácticas sobre Legislación del Trabajo. Se isso demonstrava alguma intenção em informar aos proprietários as novas condições do trabalhador rural, evidentemente não aplacava a agressividade patronal. Eram 25 páginas com informações legais sobre as novas leis: a obrigatoriedade do contrato escrito celebrado nos primeiros 15 dias de trabalho, o salário mínimo e as remunerações em dinheiro, o direito do trabalhador de se ausentar por impedimentos climáticos, a semana corrida, a jornada de 8 horas, a remuneração de horas-extras, as férias remuneradas, o direito de sindicalização camponesa, os impostos devidos pelos patrões para financiar o SSS, o SNS e o FEES, o direito à negociação coletiva, e vários outros temas. Sobre educação, a cartilha da SNA, alertava que era obrigação patronal "conceder as facilidades (...) para fins de educação sindical”, bem como permitir que trabalhadores se ausentassem do trabalho para "assistir cursos, seminários e conferências de educação sindical". ${ }^{737}$ De comum acordo, patrões e trabalhadores deveriam fixar quem participaria e qual duração das jornadas educacionais, que não poderia "ser inferior a seis dias por ano por cada trabalhador de uma mesma propriedade". ${ }^{738}$ Ou seja, cada trabalhador rural tinha direito a pelo menos seis dias de aulas por ano, com liberação obrigatória do trabalho. Na impossibilidade de acordo, a decisão caberia ao inspetor do trabalho.

A exclusão educacional, que até ali era um componente-chave da hierarquia de classe entre proprietários e camponeses, estava com seus dias contatos. O ódio de classe despertado por esse aspecto da transformação agrária foi imensurável. Os trabalhadores que pretendessem participar de cursos teriam de enfrentá-lo. Como veremos, os convênios do FEES previam uma ampla variedade de conteúdos e cursos para os camponeses.

\subsection{Educação sindical camponesa: os convênios do FEES}

Em 1967, Oscar Torres se tornou uma importante liderança interna do FEES e atuou como chefe de gabinete do órgão até 1973. Seu trabalho consistia na construção de convênios educacionais com as confederações sindicais e outras instituições, bem como na formulação de estratégias políticopedagógicas que ampliassem a eficácia e o alcance da luta sindical camponesa. Ele compunha o Conselho do FEES junto com o Diretor do Trabalho do ministério do trabalho, o ministério da educação, o conselho de reitores, a ODEPA, dois representantes de Confederações Camponesas e dois representantes da presidência. ${ }^{739}$ Foi no Conselho do FEES que se instaurou, pela primeira vez, uma interlocução direta entre confederações camponesas e Estado, ainda anteriormente à criação do Conselho Nacional Campesino em dezembro de 1970 pelo governo Allende. Torres, de certa maneira, estava se especializando nessa mediação.

\footnotetext{
${ }^{737}$ Normas Prácticas sobre Legislación del Trabajo. El Campesino, v. C, n. 8, Ago/1969: 60. ${ }^{738}$ Idem.

${ }^{739}$ Chile, Decreto con Fuerza de Ley $n^{\circ} 6$ sobre el Fondo de Educación y Extensión Sindical. Santiago, 12/01/1968.
} 
Quando Oscar Torres ainda era estudante de Direito da Universidade do Chile, em fins de 1963, teve sua primeira experiência como professor voluntário de camponeses do Instituto de Humanismo Cristão. Daria aulas sobre a doutrina social da igreja e o Concílio Vaticano II. Numa tarde de sábado, o novato foi para a paróquia de Aconcágua carregando papéis e anotações. "Quando entrei no salão com os camponeses, me dei conta que nada do que eu tinha preparado ia me servir. Perguntei se sabiam ler e escrever e só dois ou três levantaram as mãos. Eram muito pobres, não tinham sapatos... Então pensei: 'mudou tudo'. Nada de anotações. Comecei a aprender na prática", ${ }^{740}$ relembrou Torres: "Aprendi que era preciso dizer coisas simples, repeti-las e ir entrando no diálogo aos poucos, perguntando se compreendiam certas palavras", contou. Sua intuição pedagógica ganhou consistência quando entrou em contato com o trabalho de Paulo Freire, um ano depois, época em que ainda era militante da DC.

Outra experiência que marcou sua trajetória foram os trabalhos voluntários de verão de 1965, no Vale Choapa, onde viviam camponeses "federados", ligados à experiência mineira, ao PC e ao PS. Naquele ano, Choapa foi o berço dos primeiros assentamentos do governo Frei, criados por meio de uma negociação entre camponeses da esquerda e governo da DC, acordo plasmado na lei de 1967. Ao chegarem os primeiros estudantes em Choapa para trabalhos voluntários, os camponeses desconfiaram. Eram jovens da cidade, que além de aparentarem pertencer a extratos sociais mais altos, queriam entrar em reuniões sindicais quase clandestinas.

Oscar Torres lidou com essa desconfiança ao participar de uma reunião sindical com 50 camponeses, convocada pelo sinal de uma bandeira vermelha. "A maioria era analfabeta", lembrou Torres, "hasteavam uma bandeira porque não havia como colocar uma placa escrito "REUNIÃO". ${ }^{741}$ Os dirigentes comunistas do sindicato justificaram a presença dos estudantes, que eram aliados dos camponeses. Oscar então pediu a palavra: "os saudei ao estilo sindical e usei toda minha experiência do momento para fazer um discurso amável sobre quem éramos e porque estávamos ali”, ${ }^{742}$ lembrou. E para desfazer maus entendidos, foi direto ao ponto: "não somos representantes do governo norteamericano, muito menos da CIA, nem tampouco representantes do governo. Estamos fazendo um trabalho de verão porque queremos facilitar o processo de reforma agrária para que os camponeses tenham terra", 743 esclareceu. Em seguida, a permanência dos estudantes foi colocada em votação e a maioria dos camponeses os aprovou. Mal sabia Oscar que passaria todas as décadas seguintes trabalhando com educação camponesa e sindicalização.

Um dos desafios iniciais do FEES foi garantir a arrecadação dos novos impostos para formar o fundo. Havia resistência patronal contra o novo imposto. Na unidade de pesquisas do FEES, Maria Emília participou do primeiro estudo chamado Rol Patronal Agrícola, ${ }^{744}$ coordenado pelo sociólogo brasileiro Wilson Cantoni. A partir de informações do SSS, foi criado um banco de dados com 34 mil

\footnotetext{
${ }^{740}$ Entrevista com Oscar Torres. Santiago, 21/04/2017.

${ }^{741}$ Entrevista com Oscar Torres. Maipo, 26/05/2019.

${ }^{742}$ Idem.

${ }^{743}$ Id., ibid.

${ }^{744}$ Rol Patronal Agrícola. FEES, Proyectos, Convenios y Programas. Santiago: FEES, 1970.
} 
proprietários da base de arrecadação do FEES. Foi também criada uma lista de patrões inadimplentes, que deveriam ser multados por descumprir leis laborais. Para gerenciar as listas patronais, foi desenvolvido um programa computacional moderno. "Precisávamos fazer um cadastro dos proprietários que deviam pagar e quais sonegavam", ${ }^{745}$ lembra Maria Emília.

Os funcionários do FEES se juntaram aos Inspetores do Trabalho e ao INDAP para realizar cobranças de impostos en terreno e, assim, garantir o surgimento do fundo. "Nós assumimos um papel para além do que a lei nos pedia. Cobrar impostos era uma função da Direção do Trabalho", ${ }^{746}$ contou Torres: "Começamos a sair a campo para fiscalizar. Quando percebemos que era preciso ainda mais gente, chamamos o INDAP, que disponibilizou inspetores ad hoc. (...) Foi assim que multiplicamos os inspetores do trabalho", ${ }^{747}$ recorda. A arrecadação do primeiro ano fiscal do FEES foi garantida, em 1968, muito mais pela mobilização dos funcionários da base do Estado do que por uma ordem burocrática: mais de 300 inspetores improvisados saíram a campo cobrando impostos dos patrões, nem sempre com autoridade formal para isso. O estatuto jurídico do FEES o colocava em uma posição ambígua: era um organismo autônomo e misto, isto é, pertencia aos camponeses, mas era operado pelo Estado. ${ }^{748} \mathrm{Na}$ prática, o FEES passou a ganhar autoridade pública conforme cobrava impostos dos patrões acompanhado de outras autoridades. Segundo Maria Emília, em alguns locais onde o Estado não chegava, os próprios sindicatos passaram a cobrar os $2 \%$ patronais, o que obviamente acirrava conflitos. A situação ficou menos tensa depois de 12 de junho de 1968, quando foi fundada a Confederação Nacional do Sindicato dos Empregadores Agrícolas do Chile (CONSEMACH). O sindicato patronal passou a apoiar a arrecadação, pois era financiado por $1 \%$ opcional dos patrões, arrecadado dentro do mesmo mecanismo. Ao integrar os patrões ao novo sindicalismo rural, a CONSEMACH lhe emprestou legitimidade (Gómez, 1972: 45).

Um sistema semioficial de arrecadação foi se consolidando ao longo de 1968. A primeira vez que Oscar Torres entregou um cheque do FEES nas mãos do presidente da confederação Ranquil, da oposição socialista e comunista, em 1969, ficou atento à reação da DC e do governo. Parecia tão extraordinário aquele mecanismo de financiamento da luta sindical que, por um instante, desconfiou se, ao cumprir a lei, seria repreendido pela ala mais anticomunista do governo. ${ }^{749}$ Mas não foi. Entre 1968 e 1973, a correlação de forças dos setores sindicais camponeses se desenvolveu como mostra a tabela 18.

\footnotetext{
${ }^{745}$ Entrevista com Maria Emília Palma. Santiago, 29/05/2019.

${ }^{746}$ Entrevista com Oscar Torres. Santiago, 29/05/2019.

${ }^{747}$ Idem.

748 Entrevista com Oscar Torres. Santiago, 21/04/2017.

${ }^{749}$ Idem.
} 


\begin{tabular}{|c|c|c|c|c|c|c|c|}
\hline \multicolumn{8}{|c|}{ Tabela 18 - Camponeses sindicalizados por Confederação, 1965-1973 } \\
\hline Confederação & Partido & 1968 (a) & 1969 (a) & 1970 (a) & 1971 (a) & 1972 (b) & 1973 (c) \\
\hline $\begin{array}{l}\text { Triunfo } \\
\text { Campesino }\end{array}$ & $\mathrm{DC}$ & 39.288 & 47.609 & 64.003 & 44.901 & 62.073 & \multirow{5}{*}{$\begin{array}{l}\text { Não } \\
\text { especific } \\
\text { ado }\end{array}$} \\
\hline Ranquil & PC/PS & 18.253 & 30.912 & 43.867 & 100.591 & 132.294 & \\
\hline $\begin{array}{l}\text { Unidad Obrero } \\
\text { Campesina }\end{array}$ & MAPU & \multicolumn{3}{|c|}{ Não existia } & 32.552 & 39.675 & \\
\hline Libertad & Cristã* & 17.421 & 23.204 & 29.132 & 34.715 & 43.798 & \\
\hline $\begin{array}{l}\text { Províncias } \\
\text { Agrarias Unidas }\end{array}$ & SNA & -- & 355 & 1.593 & 1.219 & 1.788 & \\
\hline \multicolumn{2}{|c|}{ TOTAL } & 92.383 & 102.080 & 138.595 & 213.978 & 279.628 & 313.700 \\
\hline \multicolumn{8}{|c|}{$\begin{array}{l}\text { Fontes: (a) Barrera, 1973: 271; (b) Gómez, 1981: 11; (c) Gómez, 2002: } 5 \text {. } \\
\text { * A Libertad era formada por movimentos católicos independentes, que flutuavam entre a DC e a patronal SNA: a UCC } \\
\text { (União de Camponeses Cristãos); o MCI (Movimento Camponês Independente); e ANOC (Associação Nacional de } \\
\text { Organizações Camponesas). }\end{array}$} \\
\hline
\end{tabular}

Foi a partir de 1969 que os convênios entre FEES e confederações foram oficializados. No início de 1970, as confederações entregaram um relatório com resultados do primeiro ano de capacitação e o projeto pedagógico para o ano seguinte. Em dois anos de trabalho, o FEES tinha firmado quatro convênios sindicais, com a Triunfo Campesino, Ranquil e Libertad, e com a Federação Provincial Sargento Candelária, de Santiago. Em 1969, foram gastos 4.279.415 escudos com financiamento dos convênios. A projeção para 1970 era mais que duplicar o investimento para 10.007 .498 escudos, sinal do êxito das arrecadações. Além dos convênios sindicais, o FEES criou programas de alfabetização camponesa em parceria com o Mineduc e INDAP; um programa de formação de dirigentes em convênio com o Centro de Estudos Agrários (CEA) da U. Católica, fundado por Gonzalo Arroyo e dirigido por Jaime Guzmán (ambos mapucistas); e um convênio de capacitação profissional com o Instituto Nacional de Capacitação (INACAP). ${ }^{750}$ A seguir, analisarei os programas pedagógicos dos convênios.

\section{Triunfo Campesino: a busca da consciência crítica}

A confederação Triunfo Campesino foi fundada em abril de 1968, formada por doze federações provinciais em Coquimbo, Aconcágua, Santiago, O’Higgins, Colchagua, Curicó, Talca, Linares, Ñuble, Cautín, Valdivia e Osorno. Em seu congresso de fundação, mais de 2 mil pessoas estiveram presentes, inclusive o então democrata-cristão Jacques Chonchol e 60 dirigentes camponeses provinciais. Uma direção com dez homens foi escolhida, junto com a aprovação de uma carta de princípios e o estabelecimento de três eixos de luta imediata: a denúncia contra a perseguição de sindicalistas camponeses; a expropriação imediata dos latifúndios com conflitos deflagrados; e a não redução de recursos para reforma agrária. ${ }^{751}$

\footnotetext{
${ }^{750}$ FEES, Proyectos, Convenios y Programas. Santiago: FEES, 1970.

751 A direção sindical estava formada por camponeses filiados à DC: o presidente Pedro Montecinos (O’Higgins); o vice Sofanor Cifuentes (Talca); o secretário geral Rodolfo Haverbeck (Colchagua); o $2^{\circ}$ secretario Abel Sepúlveda (Ñubles); o tesoureiro Nicomedus Hormazábal (Curicó); e os diretores Andrés Tapia (Santiago), Ricardo Muñoz (Cautín), José Jara
} 
Apesar da ruptura da DC com a figura de Paulo Freire em 1969 e das acusações que circularam contra o brasileiro no governo de Eduardo Frei (ver capítulo 4), a Confederação Triunfo Campesino apresentou um projeto pedagógico para 1970 bastante sintonizado com alguns pressupostos da filosofia educacional freiriana. Entre seus objetivos, pretendiam desenvolver "a participação ativa, consciente, crítica e solidária dos camponeses" além de promover "a consciência crítica para analisar sua realidade individual e o mundo" e fortalecer uma "consciência solidária da classe trabalhadora (...) para realizar uma nova forma de sociedade". Os conceitos de "consciência crítica", "consciência solidária" e uma pedagogia focada na problematização da realidade camponesa eram nitidamente inspirados em Freire.

Ao atuar do Atacama a Magallanes, a Triunfo apresentou a meta de realizar 954 eventos pedagógicos em 1970, de três tipos: Cursos de Base e Jornadas em Campo; Cursos de Dirigentes; e Seminários em Internato. O plano era garantir a participação de 14.870 camponeses nas atividades educacionais, o que representava $23 \%$ do total da sua base sindical naquele ano. Os três tipos de cursos se estruturavam como mostra a tabela 19.

\begin{tabular}{|l|l|l|l|l|l|}
\hline \multicolumn{2}{|c|}{ Tabela 19 - Metas da Confederação Triunfo Campesino - 03/1970 a 02/1971 } \\
\hline Cursos & $\begin{array}{l}\text { Alunos/ } \\
\text { curso }\end{array}$ & $\begin{array}{l}\text { Dias/ } \\
\text { Curso }\end{array}$ & $\begin{array}{l}\text { Horas/ } \\
\text { Curso }\end{array}$ & $\begin{array}{l}\text { Cursos/ } \\
\text { ano }\end{array}$ & $\begin{array}{l}\text { Alunos/ } \\
\text { Ano }\end{array}$ \\
\hline 1. Cursos de base e jornadas & 15 & 4 & 8 & 900 & 13.500 \\
\hline 2. Cursos de dirigentes & 25 & 4 & 32 & 50 & 1.250 \\
\hline 3. Seminários Nacionais & 30 & 5 & 40 & 4 & 120 \\
\hline Totais & & \multicolumn{4}{|c|}{ FEES, 1970:156 } \\
\hline
\end{tabular}

Sendo a maior confederação camponesa daquele momento, a Triunfo Campesino analisava que "a magnitude e profundidade dos conflitos do trabalho que estão ocorrendo ao redor do país demonstra (...) a presença ativa de numerosos dirigentes e bases camponesas, comprometidos e capacitados na concretização (...) da organização sindical", mas, ao mesmo tempo, prognosticava como "cada vez mais necessário dispor de mais e melhores serviços técnicos que permitam aos dirigentes ter uma visão total, precisa e clara dos fatos". ${ }^{752}$ Para isso, o Departamento de Capacitação da Triunfo criou quatro unidades pedagógicas.

A unidade conscientizadora visava despertar o sentido crítico sobre a realidade "partindo do nível da propriedade para etapas sucessivas (província, país, continente) até (...) o ‘diagnóstico crítico"”.753 Consistia na unidade freiriana da capacitação da Triunfo. A unidade de conhecimentos gremiais se dedicava a que os camponeses dominassem a nova ferramenta da luta sindical com "sentido de classe, unidade de propósitos e ação", ${ }^{754}$ focada no ensino das leis trabalhistas e sindicais. A terceira era a

(Coquimbo), Raúl Urtuia (Aconcagua) e Gilberto Hernández (Valdívia). Ver: En Curicó, 50 mil campesinos formaron su confederación. La Nación, 16/04/1968.

${ }^{752}$ Confederación Nacional Sindical de Trabajadores Agrícolas El Triunfo Campesino, Proyecto de Capacitación y Servicios. In: FEES, 1970, op. cit., p. 150.

${ }^{753}$ Id., ibid., p. 153.

${ }^{754}$ Id., ibid. 
unidade de conhecimentos econômicos, que ensinava dois ramos: administração e contabilidade sindical, por um lado, e economia camponesa, reforma agrária e cooperativismo, por outro. E a quarta era a unidade de comunicação social, que pretendia "ensinar técnicas mínimas de condução de grupos, meios de expressão, sistemas de comunicação", além de se preocupar especificamente com "atividades orientadas (...) à mulher, com capacitação específica". ${ }^{755} \mathrm{O}$ ensino de comunicação social foi uma originalidade da Triunfo, inexistente em outras confederações.

Sobre a capacitação para mulher camponesa, o projeto pedagógico da Triunfo evidenciava influência de Carmen Aguayo e do INDAP (ver capítulo 4). Por exemplo, estava expressa a preocupação com o fato da "mulher camponesa ver como único papel possível (...) ser mãe e esposa", o que significa uma "relegação psicológica e social à função meramente doméstica" ${ }^{756}$ Viam como um problema a exclusão das mulheres do mundo sindical, sobretudo as trabalhadoras temporárias da colheita e armazenamento de frutas, que seriam "legalmente obrigadas a pertencer ao sindicato". ${ }^{757}$ Para mudar esse quadro, a confederação propunha uma "ação capacitadora feminina" para que as mulheres se integrassem ao mundo sindical, proposta que articulava dois interesses: por um lado, a promoção popular da mulher camponesa, que deveria participar de organizações, na esteira do socialcomunitarismo da DC; e por outro, uma estratégia pragmática de expansão da própria base. Sindicalizar mulheres camponesas significava uma política progressista de gênero, tanto quanto uma instrumentalização prática das listas de filiados, resultando em maior arrecadação.

É interessante notar como algumas diretrizes pedagógicas da Triunfo Campesino evocavam a experiência da pedagogia do território desenvolvida em Palmilla e Peralillo em 1969 (ver capítulo 5). Entre os conteúdos dos seus 900 cursos/jornadas de base, estavam a produção de "conhecimento sobre os indicadores socioeconômicos da comuna" e "estudos agropecuários e econômicos da propriedade em que atua o comitê sindical", 758 em uma nítida intenção de transformar a propriedade e a comuna em territórios de aprendizagem ativa dos camponeses, apostando no empoderamento popular por meio do conhecimento territorial. Os cursos/jornadas de base também tratavam da lei de sindicalização camponesa, da lei da reforma agrária, de administração sindical e cooperativismo.

Nos 50 cursos para dirigentes, que ocorriam em nível regional, os conteúdos conformavam diretamente o que conceituei como pedagogia da reivindicação, com aulas sobre "Negociação coletiva", "Técnicas de organização e comunicação social", "Métodos de programação de atividades", além de "Contabilidade sindical" e "Economia agrária". A negociação coletiva correspondia a uma das maiores conquistas camponesas da lei de sindicalização, porque forçava os patrões a responderem às demandas em nível comunal ou provincial. A seguir, narrarei alguns casos em que a negociação coletiva foi uma importante ferramenta de luta dos camponeses da Triunfo.

\footnotetext{
755 Id., ibid.

${ }^{756}$ Id., ibid., p. 159.

757 Id., ibid.

${ }^{758}$ Id., ibid.
} 
Em março de 1968, a Federação Campesina de Ñuble, que agrupava dez sindicatos comunais posteriormente integrados à Triunfo, anunciaram uma paralisação provincial contra a "intransigência dos latifundiários em reação à reforma agrária". ${ }^{759} \mathrm{O}$ dirigente Afonso Soto foi até Santiago reunir-se com Rafael Moreno, Jacques Chonchol e o deputado Alberto Jaramillo (DC) para denunciar a retaliação de patrões contra os sindicatos. No mesmo mês, camponeses de 50 latifúndios em Melipilla organizaram uma paralisação de $24 \mathrm{~h}$, apoiada por camponeses de oito assentamentos, reivindicando condições dignas de trabalho e a expropriação. ${ }^{760}$ Em junho de 1968, a Federação Provincial Gabriela Mistral, da Triunfo, com dez sindicatos em Coquimbo, anunciou que seus 2.400 filiados declarariam uma greve camponesa provincial, caso não se resolvesse a negociação coletiva com 600 filiados do sindicato Unión y Progreso, parados há 7 dias em defesa do aumento do salário mínimo agrícola para $10 \mathrm{E}^{\circ}$ ao dia. O protagonismo da Triunfo não impediu que comunistas e socialistas manifestassem: a "Ranquil oferece todo seu apoio, o mesmo feito pela CUT" ${ }^{761}$ Os Inspetores do Trabalho da província foram denunciados pela Triunfo por violar a lei de sindicalização ao autorizar que patrões contratassem substitutos aos grevistas.

Em alguns casos, conflitos despertavam uma reação armada dos patrões, demandando rápida solidariedade sindical de outras comunas. Em julho de 1968, uma greve camponesa foi declarada em San Fernando, em um latifúndio com 700 hectares mal explorados, cujo proprietário era Intendente de Colchagua. Os proprietários reagiram com uma barricada ao redor da casa patronal: "os latifundiários têm em seu poder quatro metralhadoras de tambor, alguns revólveres, carabinas e pistolas de caça. Em cada um dos seus postos tem radiotransmissores nos quais se comunicam sobre o movimento dos camponeses". Tudo isso para enfrentar 35 inquilinos que, somados às mulheres e crianças, estavam em 212 pessoas. ${ }^{762}$ A solidariedade dos sindicatos camponeses em apoio à greve foi fundamental para que a situação não resultasse em tragédia. $\mathrm{O}$ acirramento da luta de classes no campo demandava dos sindicatos cada vez mais estrutura e estratégia coletiva.

Em setembro de 1968, 146 camponeses de seis propriedades declararam greve juntos, organizados pela Federação Provincial Camponesa Eduardo Frei Montalva, pertencente à Triunfo. Tinham apresentado uma petição para a CONSEMACH, sem resposta. ${ }^{763}$ Dois anos depois, a coletivização das greves camponesas se mostrava cada vez maior: em outubro de 1970, mais de 400 camponeses articularam uma greve em 16 latifúndios do vale central, comandados pela Confederação Libertad, e tomaram uma hacienda de 12 mil hectares em Colchagua. ${ }^{764}$ No mesmo mês, em Linares, 3.500 trabalhadores rurais de 158 latifúndios ficaram mais de 12 dias paralisados por melhores condições econômicas, o que levou o Ministro do Trabalho do último mês de governo de Eduardo Frei

\footnotetext{
${ }^{759}$ Federación Campesina de Nuble respalda ampliamente la reforma agraria del gobierno. La Nación, 22/03/1968.

760 Campesinos de 50 fundos protestan contra ataques derechistas a la Reforma Agraria. La Nación, 29/03/1968.

7613 mil campesinos irán a la huelga. El Siglo, 14/06/1968.

762 Colchagua: barricadas contra los campesinos. El Siglo, 02/07/1968.

763 En huelga seis fundos de El Monte. El Siglo, 02/10/1968.

764 Campesinos de 16 fundos en huelga: zona central. El Siglo, 17/10/1970.
} 
determinasse intervenção e nomeasse inspetores do trabalho como interventores ${ }^{765}$ Esse tipo de luta organizada por camponeses de diversos sindicatos comunais tornou-se cada vez mais frequente. Os cursos de negociação coletiva indicavam uma profissionalização para esta tática, que naquele momento ainda abarcava tanto a Triunfo, quanto a Ranquil.

Se antes da sindicalização já existiam as greves camponesas de solidariedade a trabalhadores de outras propriedades (Affonso et. al, 1970), com a sindicalização, a greve de solidariedade evoluía para uma unificação de pautas e imposição da negociação coletiva. Para que os dirigentes se apropriassem dos conhecimentos da luta sindical, a Triunfo Campesino também planejava quatro Seminários Nacionais para 1970, que tratariam das "Orientações e resultados das negociações coletivas", junto com "Orientações técnicas da capacitação sindical" (para formar capacitadores sindicais para as bases) e "Economia agrária", incluindo os conteúdos da reforma agrária, crédito camponês, inamovilidade, jornada e remuneração.

O Convênio do FEES com a Triunfo também contemplava assessoria jurídica, contábil, agronômica e comunicacional aos filiados. A assessoria jurídica assumia a defesa dos camponeses perante os tribunais e formulava a capacitação sobre leis do trabalho. A assessoria contábil auxiliava tesoureiros dos sindicatos e ensinava normas da burocracia sindical, mas também explicava aos comitês sindicais como elaborar uma petição tecnicamente correta contra atrasos de salários e violação de direitos. A assessoria agronômica relacionava o trabalho sindical com o problema produtivo, recompilando informações agropecuárias dos locais de atuação dos sindicatos. Em 1970, a Triunfo já comandava 22 federações, para quem a assessoria de comunicação prestava serviços, além de ser responsável pela relação com a imprensa, pela comunicação interna (como o jornal Triunfo) e pela capacitação camponesa em comunicação social. ${ }^{766}$

Contemplando capacitação e serviços, a Triunfo solicitava ao FEES 4.230.820 escudos para 1970, o que incluía o pagamento de professores, materiais didáticos, viagens, alimentação e alojamento para os alunos camponeses, além de bolsas para que os trabalhadores não perdessem seus dias de trabalho enquanto estudavam. Um professor era remunerado com 60 escudos a hora aula pela confederação da DC.

No projeto pedagógico da Triunfo Campesino para os anos 1971-1972, as quatro unidades de capacitação permaneceram as mesmas, com a meta ampliada de 17.228 alunos camponeses, sendo 13.500 em jornadas de base; 1.500 em jornadas de dirigentes de comitês sindicais; 2.162 em internatos de dirigentes provinciais e comunais; e 66 dirigentes nacionais em internatos em Santiago. ${ }^{767}$ Apesar do aumento da meta, um relatório interno da Triunfo lamentava que o desempenho da capacitação sindical do convênio anterior havia ficado aquém do esperado. Em janeiro de 1971, a participação nas

\footnotetext{
${ }^{765}$ Reanudación de 158 fundos en Linares. La Nación, Out.1968.

${ }^{766}$ Confederación Nacional Sindical de Trabajadores Agrícolas El Triunfo Campesino, Proyecto de Capacitación y Servicios. In: FEES, 1970, p. 160-161.

767 FEES \& Triunfo Campesino, Informe sobre Capacitación y Servicios entre la Confederación Nacional Sindical de Trabajadores Agrícolas “El Triunfo Campesino” y el Fondo de Educación y Extensión Sindical, 1971.
} 
jornadas de base en terreno foi $86 \%$ da meta. Dos 50 cursos de dirigentes provinciais idealizados só $37 \%$ foram realizados. No caso da formação de dirigentes nacionais, ao contrário, a meta foi superada em $20 \%$. Em termos de distribuição territorial, $48 \%$ dos camponeses capacitados estavam entre O’Higgins e Curicó; e outros 20\% apenas em Cautín e Valdivia. ${ }^{768}$

O avaliador anônimo dizia que o maior problema da Triunfo havia sido a conscientização dos capacitadores: "para conscientizar (...) é preciso que a pessoa que realiza este trabalho esteja conscientizada e tenha os meios culturais e materiais para desenvolver esta importante missão", analisou. Com tom duro, criticou professores e capacitadores da Triunfo, alegando "ausência total de conhecimentos pedagógicos mínimos necessários para entabular a relação ensino-aprendizagem". ${ }^{769} \mathrm{~A}$ crítica de fundo era que a capacitação sindical da Triunfo havia adquirido aspecto instrumental, fragilizando o programa conscientizador. "Fica claro que os objetivos propostos no Convênio de 1970, de criar consciência crítica e consciência solidária de classe NÃO FORAM ALCANÇADOS", ${ }^{770}$ dizia o relatório anônimo: "foram entregues conhecimentos parciais (...), mas não se conseguiu que o camponês tomasse uma verdadeira posição crítica perante o momento histórico político" e, portanto, "a capacitação se converteu em um mero instrumento reivindicativo". ${ }^{771} \mathrm{O}$ relatório concluía ainda mais severo: "isso contradiz a linha da confederação e faz dos capacitadores seres inúteis (sic) para cumprir uma função conscientizadora". 772

Em janeiro de 1971, quando o parecer interno anônimo foi escrito, avaliou-se que os temas das aulas eram apropriados, porém somente para a ação sindical reivindicativa, o que entrava em contradição com o que se compreendia como "conscientizar o camponês para que este seja um elemento vital de mudança". ${ }^{773}$ Não se sabe se a derrota eleitoral da DC em 1970, meses antes do relatório, teria algo a ver com a irritação do avaliador, que parecia demandar uma "pedagogia de resultados" pouco compatível com os valores freirianos. Como solução, propunha-se formações sistemáticas para capacitadores, a planificação do trabalho em nível provincial e "o trabalho pedagógico com temas de aulas unificados às linhas e critérios da confederação". 774

Por fim, vale destacar que no novo convênio FEES e Triunfo para 1971-1972, foi acrescentado um módulo de história do movimento camponês chileno, baseado nos recém-publicados tomos do Movimiento Campesino Chileno, resultado de 5 anos de pesquisas do exilado brasileiro Almino Affonso, ex-ministro do trabalho do presidente João Goulart, junto aos jovens sociólogos chilenos Emilio Klein, Sergio Gómez e Pablo Ramirez no ICIRA (Affonso et al., 1970). O livro teve grande impacto nas formas de ensinar história camponesa nos departamentos de capacitação dos sindicatos.

\footnotetext{
${ }^{768}$ Anônimo, Análisis Crítico del Departamento de Capacitación, Difusión y Estudios de la Confederación Triunfo Campesino de Chile. In: FEES \& Triunfo Campesino, Informe sobre Capacitación y Servicios entre la Confederación Nacional Sindical de Trabajadores Agrícolas “El Triunfo Campesino” y el Fondo de Educación y Extensión Sindical, 1971.

${ }^{769}$ Idem.

${ }^{770}$ Id., ibid. Grifo do original.

${ }^{771}$ Id., ibid.

772 Id., ibid.

${ }^{773}$ Id., ibid.

${ }^{774}$ Id., ibid.
} 
Pela primeira vez, o movimento camponês chileno e suas organizações foram historiografados e analisados com grande volume de dados empíricos, informações de jornais, arquivos e entrevistas, fazendo com que a ação dos novos sindicatos camponeses parecesse uma continuidade prática da narrativa daqueles livros. Não apenas na Triunfo Campesino, como em outras confederações, a obra se tornou uma referência para a educação sindical camponesa.

\section{Ranquil: educação para luta de classes}

A Confederação Ranquil, dirigida por comunistas e socialistas e inaugurada com este nome em fevereiro de 1968, inicialmente articulava cinco federações provinciais recém-criadas em Coquimbo, Aconcágua, Santiago, Talca e Magallanes, além de assessorar a formação de novos sindicatos comunais em Valparaíso, Maule, Malleco, Cautín, Osorno e Llanquihue. ${ }^{775}$ A Ranquil criou seu Departamento de Capacitação, com uma estrutura piramidal que passava pelo Diretor de Capacitação, o conselho nacional, diretores zonais de capacitação e capacitadores da ponta, que lidavam diretamente com os camponeses. Para 1970 e 1971, planejou-se um programa de capacitação que contemplaria 11.480 camponeses, ou seja, $26 \%$ da sua base de filiados daquele ano. O conjunto do convênio demandava ao FEES a soma de 3.013.080 de escudos. ${ }^{776}$ Seus objetivos pedagógicos incluíam "resgatar (sic) o trabalhador agrícola para que participe no processo social e econômico do país", além de "formar seu sentido de classe social para que (...) atue nos processos cívicos e econômicos”. Também pretendiam conscientizar o trabalhador agrícola de que "a organização sindical é um valioso instrumento na defesa de seus interesses", e denunciar "os setores que se aproveitam do seu desconhecimento (...) para se opor a que se organizem ou afastá-los dos sindicatos". ${ }^{777}$ Ecoavam algo da pedagogia freiriana, pretendiam que o camponês problematizasse sua realidade, e de modo mais diretivo, estimulavam que se relacionasse com outros sujeitos da luta social, sinalizando a amplitude da sua luta: "o camponês não é uma unidade isolada, nem como individuo, nem como classe, nem como organização sindical" e necessitava desenvolver uma "estreita ligação com outros organismos da classe trabalhadora". ${ }^{778}$

Além disso, falavam sobre "armar teoricamente os trabalhadores agrícolas", compartilhar conhecimento sobre sindicalização e leis do trabalho, proporcionar saberes sobre a "utilização racional da tecnologia econômica e agropecuária moderna, considerando que a (...) luta pela (...) reforma agrária (...) sinaliza ao camponês um papel muito mais importante do que simples mão de obra”. Finalizavam com o horizonte de "formar um novo tipo de trabalhador agrícola, cujas aspirações sejam superar as velhas formas de trabalho e exploração da terra". ${ }^{779}$ As palavras socialismo e revolução não apareciam

\footnotetext{
${ }^{775}$ Forman Confederación Nacional de Campesinos. El Siglo, 03/02/1968.

776 Confederación Nacional Sindical Campesina e Indígena Ranquil, Proyecto de Capacitación y Servicios. In: FEES, 1970, p. 254.

777 Id., ibid., p. 243-245.

${ }^{778}$ Id., ibid.

${ }^{779}$ Id., ibid.
} 
no programa da Ranquil. Ademais, entre o projeto e o Convênio assinado pelo FEES, a expressão "classe social” foi substituída por "grupo social".

A capacitação da Ranquil combinava um repertório marxista relativamente tímido com aspectos metodológicos freirianos, embora fosse mais diretiva que dialógica na capacitação para o confronto classista. Alertavam que os camponeses até então tinham sido instrumentalizados por interesses alheios e a capacitação lhes permitiria identificar os próprios interesses de classe, garantindo o aprendizado organizativo da luta sindical, expandindo seu mundo e ampliando seu arco de alianças com outros trabalhadores. O camponês Martim Vasquez lembra-se até hoje que na sua primeira aula, em um sindicato comunal da Ranquil, "nos contaram do massacre da Escola de Santa Maria e de todas as matanças de trabalhadores que ocorreram ao longo da história do Chile, inclusive de outros países". ${ }^{780}$ Depois, nas aulas seguintes, falaram "coisas sobre o $1^{\circ}$ de maio, as leis que estavam criando em defesa dos trabalhadores... Quando começamos a aprender, estudávamos as leis para aplicá-las", 781 recordou.

O projeto da Ranquil abarcava territórios de Coquimbo a Llanquihue, e contemplava quatro modalidades: cursos de capacitação nível I, nível II, charlas-diálogo e formação de capacitadores. Enquanto as duas primeiras eram especificamente para dirigentes sindicais de nível comunal, provincial e nacional, as charlas-diálogo eram mais amplas, destinadas às bases dos sindicatos como se vê na tabela 20.

\begin{tabular}{|l|l|l|l|l|}
\hline Tabela 20 - Metas da Confederação Ranquil - 07/1970 a 04/1971 \\
\hline Tipo & Qtde & Horas/Curso & Alunos/Curso & Alunos \\
\hline Curso Nível I & 30 & 30 & 20 & 600 \\
\hline Curso Nível II & 9 & 30 & 20 & 180 \\
\hline Formação de Capacitadores & 5 & 45 & 20 & 100 \\
\hline Charlas-Diálogo & 530 & 2 & 20 & 10.600 \\
\hline Total & 574 & -- & -- & 11.480 \\
\hline \multicolumn{7}{|l|}{} \\
\hline
\end{tabular}

Chama atenção a enorme quantidade de conteúdos indicados para cada um desses cursos, aparentemente desproporcionais às suas horas de trabalho pedagógico. Enquanto as correntes freirianas davam valor ao tempo pedagógico compassado pelo próprio camponês, ao ritmo de um diálogo lento sobre as imagens e temas geradores, era evidente que as correntes marxistas sindicais propunham uma pedagogia mais acelerada e conteudista, embora igualmente atreladas à realidade das vanguardas camponesas em luta. A grade de conteúdo dos cursos da Ranquil pode ser vista na tabela 21.

\footnotetext{
${ }^{780}$ Entrevista com Martim Vásquez, Santiago, 28/04/2017.

781 Idem.
} 


\begin{tabular}{|c|c|c|c|c|}
\hline Nível & Curso & Duração & Alunos & Conteúdos \\
\hline \multirow{4}{*}{1} & $\begin{array}{l}\text { Questões } \\
\text { sindicais e } \\
\text { sociais }\end{array}$ & $\begin{array}{c}5 \mathrm{~h} \\
(1 \mathrm{dia})\end{array}$ & \multirow{4}{*}{20} & $\begin{array}{l}\text { (a) História da organização sindical nacional e internacional. } \\
\text { (b) Motivos que exigem a mudança da propriedade da terra e } \\
\text { novas formas de relações econômicas e técnicas no campo. }\end{array}$ \\
\hline & $\begin{array}{l}\text { Capacitação } \\
\text { Legislativa }\end{array}$ & $\begin{array}{c}10 \mathrm{~h} \\
(2 \mathrm{dias})\end{array}$ & & Leis trabalhistas e sindicalização (lei 16.625). \\
\hline & $\begin{array}{c}\text { Reforma } \\
\text { agrária }\end{array}$ & $\begin{array}{c}10 \mathrm{~h} \\
(2 \mathrm{dias})\end{array}$ & & Aspectos fundamentais da reforma agrária (lei 16.640). \\
\hline & $\begin{array}{l}\text { Admin. } \\
\text { Sindical }\end{array}$ & $\begin{array}{c}5 \mathrm{~h} \\
(1 \mathrm{dia}) \\
\end{array}$ & & Administração e direção de um sindicato. \\
\hline $\begin{array}{c}\text { Tota } \\
1\end{array}$ & & $\begin{array}{c}30 \mathrm{~h} \\
(6 \text { dias })\end{array}$ & 20 & \\
\hline \multirow{3}{*}{2} & $\begin{array}{l}\text { Admin. } \\
\text { sindical e } \\
\text { orientação }\end{array}$ & $\begin{array}{c}10 \mathrm{~h} \\
(2 \text { dias })\end{array}$ & \multirow{3}{*}{20} & $\begin{array}{l}\text { (a) Contabilidade sindical: papel do tesoureiro. } \\
\text { (b) Desempenho de cada um dos postos de direção. } \\
\text { (c) Conflitos coletivos: petições, negociações, greves. } \\
\text { (d) O que é representatividade e sua importância. }\end{array}$ \\
\hline & $\begin{array}{l}\text { Admin. de } \\
\text { empresas } \\
\text { agrícolas }\end{array}$ & $\begin{array}{c}10 \mathrm{~h} \\
(2 \text { dias })\end{array}$ & & $\begin{array}{l}\text { (a) Função dos Conselhos de Assentamentos. } \\
\text { (b) Etapas da reforma agrária e nova condição camponesa: } \\
\text { de explorado a sócio } \\
\text { (c) Organização e manejo de cooperativas. } \\
\text { (d) Cooperativas: tipos e formas (individual, mista, } \\
\text { coletiva), vantagens e desvantagens. } \\
\text { (e) Distribuição dos rendimentos em assentamentos e } \\
\text { cooperativas. } \\
\text { (f) Sistemas de crédito e formas de operar. } \\
\text { (g) Técnicas de planificação produtiva. }\end{array}$ \\
\hline & $\begin{array}{l}\text { Noções } \\
\text { elementares } \\
\text { de economia } \\
\text { política }\end{array}$ & $\begin{array}{c}10 \mathrm{~h} \\
(2 \text { dias })\end{array}$ & & $\begin{array}{l}\text { (a) Conhecimentos elementares de economia política. } \\
\text { (b) Características especiais da economia política em } \\
\text { sociedades de distintas estruturas econômicas. } \\
\text { (c) Projeções econômicas de programas políticos } \\
\text { confrontados com a realidade social do país. }\end{array}$ \\
\hline $\begin{array}{c}\text { Tota } \\
1\end{array}$ & & $\begin{array}{c}30 \mathrm{~h} \\
(6 \text { dias })\end{array}$ & 20 & \\
\hline \multirow{4}{*}{\multicolumn{2}{|c|}{$\begin{array}{l}\text { Curso para } \\
\text { Capacitadores e } \\
\text { Orientadores }\end{array}$}} & $\begin{array}{c}10 \mathrm{~h} \\
(2 \text { dias })\end{array}$ & \multirow{4}{*}{20} & História da organização sindical. \\
\hline & & $\begin{array}{c}10 \mathrm{~h} \\
(2 \mathrm{dias})\end{array}$ & & $\begin{array}{l}\text { Economia política e problema do regime de propriedade da } \\
\text { terra. }\end{array}$ \\
\hline & & $\begin{array}{c}10 \mathrm{~h} \\
(2 \mathrm{dias})\end{array}$ & & Organização sindical campesina. \\
\hline & & $\begin{array}{c}10 \mathrm{~h} \\
(3 \text { dias })\end{array}$ & & $\begin{array}{c}\text { Lei de reforma agrária: assentamentos, cooperativas, planos } \\
\text { de produção, programas de produção, orçamentos. Comitês } \\
\text { de pequenos proprietários e sua participação na reforma } \\
\text { agrária; problemas de crédito. } \\
\end{array}$ \\
\hline & Total & $\begin{array}{c}45 h \\
\text { (9 dias) } \\
\end{array}$ & 20 & \\
\hline \multicolumn{5}{|c|}{ Elaboração própria. Fonte: FEES, 1970: 249-252 } \\
\hline
\end{tabular}

Em síntese, é possível dizer que o nível 1 tratava do centro dos conflitos da reforma agrária e da luta sindical no campo, priorizado o entendimento popular das leis 16.625 e 16.640 . No nível 2, esse mesmo conteúdo se aprofundava. Sobre a sindicalização, o aprofundamento estava na história do movimento camponês, nas variadas táticas de luta e no funcionamento da administração sindical. Já sobre a reforma agrária, o aprofundamento se dava no debate sobre a organização econômica do 
assentamento, as formas de propriedade posteriores (parcela individual, cooperativas, cooperativas mistas), a planificação produtiva, sistemas de crédito e a nova condição do camponês, que passava de explorado a sócio. Foi essa passagem que em muitos casos engendrou a identidade dos assentados com uma espécie de nova classe patronal, fenômeno que conformou o centro das observações da Pedagogia do oprimido. O curso de Economia política era uma particularidade marxista do projeto pedagógico da Ranquil. Embora não estivesse explícito, é possível inferir que tratava de conceitos como mais-valia e lucro, relações sociais de produção e modo de produção, examinando as lutas cotidianas dos camponeses com categorias do materialismo histórico. Para estudar no nível 2, camponeses seriam selecionados pela confederação "entre os alunos mais destacados dos cursos passados, para desenvolver ao máximo suas capacidades". ${ }^{782}$

Também era notável que no curso para capacitadores camponeses da Ranquil, uma espécie de nível 3, não havia nenhuma matéria de pedagogia, filosofia educacional ou comunicação social, em contraste com a Triunfo. A prioridade da Ranquil era que os capacitadores fossem especialistas no conteúdo das aulas (o que) e não em métodos educacionais (como). Por isso, a formação de capacitadores tematizava a história das lutas camponesas, a questão agrária chilena, a economia política do capitalismo periférico e, sobretudo, os caminhos da mudança e os programas para o futuro, para além das leis de reforma agrária e de sindicalização. Aqui também as palavras socialismo ou revolução estavam ausentes.

Sobre a questão da mulher camponesa, a Ranquil sinalizava uma especificação de charlas para mulheres, que segundos eles, "coparticipavam" (sic) dos problemas socioeconômicos "que afetam seus companheiros, devendo conhecê-los e participar da mudança". ${ }^{783}$ A ideia de uma "coparticipação" mostrava bem como era difícil, para os capacitadores da Ranquil, enxergar as mulheres como seres inteiros, e não complementares à vida dos homens. Entre os temas indicados para as camponesas estavam a "História da participação da mulher nas lutas sociais até nossos dias", "Organização da mulher em Centros de Madres", "Participação nos Centros de Padres e Apoderados das Escolas", "Direitos cívicos da mulher", "Direitos previdenciários", "Cargas familiares e subsídio pré-natal”, entre outros assuntos considerados femininos, o que confirmava a masculinidade sindical camponesa e o mutualismo de gênero (Tinsman, 2002).

Os cursos estavam uniformemente distribuídos pelo território chileno, um pouco mais concentrados nas províncias de Biobío, Malleco, Cautín (26\%). Na região mais concentrada da Triunfo, entre Aconcágua, Valparaiso e Santiago ocorreriam apenas 16\% dos cursos da Ranquil em 1970. No ano seguinte, a confederação abriu centrais de capacitação regionais nas cidades de Ovalle, Santiago, San Fernando, Talca, Chillán, Temuco, Valdívia e Punta Arenas, destinadas aos cursos e internatos. Já as charlas-diálogo ocorreriam dentro das propriedades rurais, sendo 34\% delas em Aconcágua, Valparaiso e Santiago; 26\% em Ñuble, Concepción e Arauco; e 18\% em Valdivia, Osorno, Llanquihue,

\footnotetext{
${ }^{782}$ Id., ibid., p. 246.

${ }^{783}$ Id., ibid., p. 247.
} 
Chiloé, Aysén: ${ }^{784}$ "se dará grande importância a esta forma educacional", ${ }^{785}$ pontuaram, em um sentido expansivo da formação de base.

O mote conteudista era visível na pedagogia da Ranquil e, consequentemente, seus fundamentos metodológicos e pedagógicos pareciam rudimentares se comparados com os acalorados debates sobre estratégias de educação camponesa impulsionados pelas correntes freirianas no INDAP, CORA e ICIRA desde 1965. Nas considerações metodológicas do seu projeto, recomendavam uma "linguagem adequada, simples e direta" 786 aos capacitadores, que deveriam "acostumar o aluno a entregar sua opinião, ajudá-lo a adquirir confiança na exposição diante do grupo" ${ }^{787}$ mas sem indicar como isso poderia ser feito. "A metodologia será a nível elementar, de acordo com a pouca prática de leitura e escrita dos camponeses e sua pouca ou nula experiência nesse sentido", indicavam apenas. Entre as formas didáticas propostas, não havia nada além de exposições do professor (até 45 minutos), atividades em quartetos e uso de meios audiovisuais. Ao fim dos cursos, os dirigentes camponeses seriam avaliados oralmente em uma lógica bancária, com exigência de respostas sobre "toda matéria". Na prática, a possibilidade dialógica dependeria da sensibilidade dos professores para estabelecer escuta e comunicação real com seus alunos. Pelo volume de conteúdo, não parecia pequena a possibilidade de monólogos seguidos de avaliação por memorização, o que não significa que estivesse desprovido de profundo sentido histórico.

\section{Libertad: organizar a comunidade}

A Confederação Libertad foi uma construção de movimentos católicos independentes, que embora no mundo partidário estivessem na zona de influência da DC, mantinham sua diferenciação no mundo sindical em razão da força paralela da Igreja no campo. Em seu projeto pedagógico para o FEES, a Libertad informava estar entre Aconcagua e Valdivia e estabelecia como objetivos fomentar a "formação do homem como pessoa humana" e a "promoção do homem como membro de uma organização de uma comunidade". ${ }^{788}$ Demandavam do FEES um orçamento de 2.243 .262 escudos e privilegiavam as jornadas de difusão massiva para bases, bem mais que os cursos de dirigentes. Por isso, para 1970, prometiam 17.295 camponeses capacitados, ou seja, 59\% da sua base sindical. Eram quatro tipos de cursos propostos pela Libertad: jornadas de difusão; cursos de introdução; cursos básicos; e cursos especializados. A quantidade de camponeses participantes de cada modalidade está na tabela 22.

\footnotetext{
${ }^{784}$ Id., ibid., p. 253, 257.

${ }^{785}$ Id., ibid., p. 247.

${ }^{786}$ Id., ibid., p. 248

${ }^{787}$ Id., ibid.

${ }^{788}$ Confederación Nacional Sindical Campesina Libertad, Proyecto de Capacitación y Servicios. In: FEES, 1970, p. $202-227$.
} 


\begin{tabular}{|l|l|l|l|l|}
\hline \multicolumn{5}{|c|}{ Tabela 22 - Metas da Confederação Libertad - 03/1970 a 03/1971 } \\
\hline Tipos de Cursos & Qtde & Horas/curso & Alunos/curso & Total de Alunos \\
\hline Jornadas de Difusão & 435 & $2 \mathrm{~h}$ & 35 & 15.225 \\
\hline Cursos de Introdução & 54 & $8 \mathrm{~h}(2$ dias $)$ & 30 & 1.620 \\
\hline Cursos Básicos & 9 & $33 \mathrm{~h}(6$ dias $)$ & 25 & 225 \\
\hline Cursos Especializados & 9 & $33 \mathrm{~h}(6$ dias $)$ & 25 & 225 \\
\hline Total & $\mathbf{5 0 7}$ & \multicolumn{3}{|c|}{ Fonte: FEES, 1970: $202-208,232$} \\
\hline
\end{tabular}

A confederação tinha nove centrais de capacitação, distribuídas em três zonas de capacitação (norte, do Aconcagua a O’Higgins; centro, de Curicó a Maule; e sul, de Ñuble a Valdivia). O conteúdo dos cursos estava conectado com o comunitarismo e a doutrina social da igreja, e ensinava a construir diferentes tipos de organização, não somente o sindicato. Nas jornadas de difusão, se pretendia "motivar a comunidade para que se organize, seja em sindicatos, cooperativas, CEMAs, ou outras organizações camponesas" ${ }^{789}$ Nos cursos introdutórios visavam "promover uma organização" (não necessariamente sindical), bem como mostrar ao "beneficiário" (sic) quais problemas poderiam ser resolvidos comunitariamente, estimulando o grupo para "ampliar o raio de ação da organização e criar outras". 790 O curso básico tampouco identificava o sindicato como prioridade, e pretendia "capacitar ao beneficiário sobre sua organização específica, explicando seus direitos e obrigações como associado", junto com proporcionar "conhecimentos que os habilitem a desempenhar-se em qualquer cargo do sindicato ou organização" ${ }^{791}$ Somente o último tipo de curso, de especialização, que tinha como meta a formação de dirigentes especificamente sindicais. Assim como as outras, a Confederação Libertad também oferecia serviços de assessoria jurídica, de contabilidade e organização, além possuir uma unidade de pesquisas própria.

Em 1970, o FEES também consolidou convênio com outras duas organizações não sindicais para capacitação camponesa: o INACAP e a Universidade Católica.

\section{FEES-INACAP: educação produtiva e realidade chilena}

Oscar Torres foi também responsável por coordenar o convênio do FEES com o INACAP. Em 1969, seu amigo Augustín Alberti voltou ao Chile, depois de trabalhar no CINTERFOR, o Centro Internacional de Formação Profissional da OIT. Tornou-se funcionário da CORFO. "Alberti propôs criar um ramo especial de formação profissional na CORFO, que foi o INACAP (...). Ele era do MAPU também, isso nos aproximou", 792 conta Torres, que já tinha rompido com a DC, embora nunca tenha comunicado seu chefe sobre sua filiação ao MAPU. Torres e Alberti formularam três eixos para formação profissionalizante do convênio: fruticultura em Los Andes; maquinária agrícola em San

\footnotetext{
${ }^{789}$ Id., ibid., p. 231.

${ }^{790}$ Id., ibid.

${ }^{791}$ Id., ibid., p. 232.

792 Entrevista com Oscar Torres. Maipo, 26/05/2019.
} 
Fernando; e pecuária em Osorno. ${ }^{793}$ "Mas nada fazíamos se não fosse com as organizações", explicou Oscar, "então o convênio era com INACAP, só que também com as confederações sindicais", 794 responsáveis por selecionar e enviar os camponeses para os cursos. Assinaram o convênio, no fim de 1970, o FEES, o INACAP, Triunfo Campesino, Ranquil e Libertad. Em 1972, foi incorporada a Unidad Obrero-Campesina (UOC), a cisão mapucista no meio sindical camponês.

O convênio estabelecia o objetivo de que o setor camponês se convertesse "em fator determinante do desenvolvimento integral do país, mediante sua participação ativa nas organizações representativas de seus direitos econômicos e sociais", o que ocorreria ao se "proporcionar instrumentos necessários para que possam cumprir com êxito as tarefas (...) do processo de mudanças da estrutura agrária". Nesse sentido, o convênio propunha unir capacitação técnica moderna com conscientização, ou seja, "preparar autênticos dirigentes capazes de motivar e propender a um autodesenvolvimento e a organização do setor rural", o que era sintetizado pela proposta de "uma capacitação massiva do campesinato nas modernas técnicas de produção, sem prejuízo de dotá-lo de um nível básico de conhecimentos gerais, culturais e sociais". 795

Torres se recorda de ter sido o autor da proposta de misturar formação técnica e social. "O INACAP tinha um princípio tecnológico e tecnocrático, com aquelas profissionalizações medidas internacionalmente: passo 1, pegue a chave de fenda; passo 2, aperte o parafuso; passo 3, façam o orifício", criticou. "Nem se chamavam "professores", mas 'instrutores"" ${ }^{796}$ Segundo Oscar, as cartilhas profissionalizantes eram feitas pelas mesmas empresas que vendiam a maquinaria agrícola. "Mas fizemos uma contraproposta”, relatou, afinal “já estávamos na Unidade Popular, estávamos em revolução", pois Allende tinha acabado de ganhar as eleições. Argumentou que os trabalhadores do campo eram muito diferentes dos trabalhadores da cidade, que não sabiam ler e escrever e tampouco estavam acostumados com máquinas. Por isso, antes da capacitação tecnológica propôs "dois níveis prévios: um de nivelação, para que todos partissem de um lugar próximo de leitura e escrita; e o segundo sobre realidade nacional. Colocamos este nome, mas era conscientização. Na verdade, mais que Paulo Freire, era um marxismo encarnado", ${ }^{797}$ resumiu Torres.

Por isso, o que começou como uma proposta tecnocrática profissionalizante acabou se convertendo em uma formação com três níveis, sendo que para se alcançar o último degrau da especialização era obrigatório ter percorrido a capacitação histórico-social. As três etapas do convênio estão condensadas na tabela 23.

\footnotetext{
793 Idem.

${ }^{794}$ Id., ibid.

${ }^{795}$ FEES-INACAP, Proyecto de Convenio. In: FEES, 1970, p. 26-43.

${ }^{796}$ Entrevista com Oscar Torres. Maipo, 26/05/2019.

797 Idem.
} 


\begin{tabular}{|c|c|c|c|}
\hline \multicolumn{4}{|c|}{ Tabela 23 - Convênio FEES-INACAP e Confederações - 1970/1971 } \\
\hline Etapas & $\begin{array}{l}\text { Alunos } \\
\text { /turma }\end{array}$ & $\begin{array}{l}\text { Horas } \\
\text { /curso }\end{array}$ & Conteúdos \\
\hline Nivelação & 40 & $\begin{array}{c}170 \mathrm{~h} \\
(4 \text { semanas })\end{array}$ & Espanhol, Matemática e História \\
\hline Realidade Nacional & 40 & $\begin{array}{c}80 \mathrm{~h} \\
(2 \text { semanas })\end{array}$ & $\begin{array}{l}\text { Estrutura econômica, política, cultural e } \\
\text { agrária do Chile. }\end{array}$ \\
\hline Técnico-profissional & 15 & $\begin{array}{c}250 \mathrm{~h} \\
(6 \text { semanas })\end{array}$ & $\begin{array}{l}\text { Fruticultura ou Maquinaria Agrícola ou } \\
\text { Pecuária. }\end{array}$ \\
\hline
\end{tabular}

No tópico de Espanhol, se considerava a necessidade de redigir e manejar documentos "de uso corrente na vida social, laboral e gremial". ${ }^{798}$ No tópico de História, se buscava desenvolver a consciência histórica do camponês, isto é, uma "visão problematizadora da história da cultura, com ênfases em aspectos geográfico-culturais". Também se preocupavam com a localização da cultura chilena dentro da cultura latino-americana e da América Latina no mundo, junto com a "análise das experiências vividas pelo camponês ressaltando suas raízes históricas". ${ }^{799} \mathrm{Na}$ etapa de nivelação, o projeto utilizava o método psicossocial.

No curso de Realidade nacional, os alunos entrariam em contato com debates mais aprofundados da história do Chile no contexto latino-americano, junto com tópicos de análise estrutural da realidade. $\mathrm{Na}$ aula sobre estrutura econômica, se explicariam os conceitos de "modo de produção; consumo; dependência estrutural; tensões e obstáculos ao desenvolvimento", 800 indicando uma abordagem marxista/estruturalista da realidade chilena. $\mathrm{Na}$ aula sobre estrutura política, explicava-se a organização do Estado e a estratificação social. A aula sobre estrutura cultural trataria de temas como desigualdade educacional e papel dos meios de comunicação. E por fim, sobre estrutura agrária seriam pautados os dois eixos organizadores da transformação: a reforma agrária e a sindicalização camponesa. Os materiais indicados para o curso eram recortes de jornal, ilustrações temáticas (com método psicossocial) e entrevistas gravadas com dirigentes sindicais. Aparentemente, a metodologia de Paulo Freire e a análise marxista encontravam uma combinação harmônica neste convênio.

Por fim, a fase mais longa da formação era a técnico-profissional, que durava seis semanas. Somente alunos que já tinham passado pelos cursos anteriores chegariam nessa fase. O método indicado era "essencialmente prático", entrando aí a expertise do INACAP. A inserção de agrotóxicos nas práticas de produção estava presente em no mínimo $12 \%$ do curso de maquinaria agrícola e em $50 \%$ das aulas de fruticultura, nas disciplinas sobre "controle de pragas e pesticidas". Tratava-se de uma educação produtiva afinada ao consenso técnico da revolução verde, que naquele período unia todas as correntes do espectro político, inclusive as inimigas mortais no campo ideológico. "As esquerdas não tinham uma

\footnotetext{
798 FEES-INACAP, Proyecto de Convenio. In: FEES, 1970, p. 29.

${ }^{799}$ Id., ibid.

${ }^{800}$ Id., ibid, p. 29-30.
} 
consciência ecológica naquela época. Não se falava nada sobre meio ambiente", ${ }^{801}$ constatou Oscar Torres.

Para todos os alunos, o FEES disponibilizava uma bolsa no valor de um salário mínimo agrícola em cada etapa, de modo que os camponeses pudessem se dedicar exclusivamente ao estudo durante três meses, alojados em Los Andes, San Fernando ou Osorno. Era pré-requisito que já fossem alfabetizados, estivessem sindicalizados e fossem assalariados ou assentados. A cada ano, os ciclos de cursos se reproduziram por quatro vezes, coordenados conjuntamente por FEES, INACAP e confederações.

Conforme se acirrou a polarização política, durante o governo Allende, os alunos de confederações camponesas rivais seguiam colegas de cursos. Mas na memória de Oscar Torres, a polarização ideológica não interpelou as atividades: "nunca estive em uma situação de conflito aberto ou discriminação ideológica entre alunos em sala de aula. Talvez tenha ocorrido. Mas estava estabelecida uma espécie de divisão territorial entre as confederações", ${ }^{802}$ cada uma ocupada em ampliar sua base de filiados nas fronteiras de um campesinato majoritariamente desorganizado.

\section{FEES-Universidade Católica: intelectuais e camponeses}

Depois da reforma universitária de 1968, que engendrou importantes transformações em muitas universidades, foi criado um Departamento de Cultura Popular na Universidade Católica, com objetivo de desenvolver iniciativas que vinculassem a atividade acadêmica "com os interesses e projetos dos grupos populares", formando "professores e alunos capazes de desenvolver métodos de trabalho nesta linha" ${ }^{803}$ Em janeiro de 1970, como parte dessa mudança, foi fundado o Centro de Estudos Agrários dirigido pelo mapucista Gonzalo Arroyo e, posteriormente, por outro mapucista, Jaime Guzmán.

Um convênio foi firmado entre FEES e CEA justamente para desenvolver parcerias da universidade com o mundo popular. A finalidade desse convênio era capacitar o camponês na educação gremial e social, para habilitá-lo a utilizar "sua organização (...) dentro do desenvolvimento integral do país". ${ }^{804}$ Ao unir o vocabulário social-comunitarista da esquerda cristã com conceitos-chave do marxismo e o método psicossocial, o convênio da U. Católica compunha elementos dos convênios anteriores, mas avançava em novas áreas de especialização. Este se propunha a criar um sistema de capacitação "de alto nível, (...) uma formação especializada em uma série de técnicas que são necessárias para dirigir eficientemente as organizações sindicais". ${ }^{805}$ Para Oscar Torres, o objetivo era criar um "trampolim para a universidade", 806 ou seja, aproximar ao máximo os dirigentes camponeses

\footnotetext{
${ }^{801}$ Entrevista com Oscar Torres. Santiago, 21/04/2017.

${ }^{802}$ Entrevista com Oscar Torres. Maipo, 26/05/2019.

${ }^{803}$ Convenio FEES-U. Católica - Programa de Capacitación Gremial FEES - Confederaciones Nacionales de Trabajadores Agrícolas - Universidad Católica de Chile. In: FEES, 1970, p. 45-69.

${ }^{804}$ Id., ibid.

${ }^{805}$ Id., ibid.

${ }^{806}$ Id., ibid.
} 
de um curso universitário.

Os cursos tinham o mesmo formato do convênio com INACAP, com diferenças na terceira etapa das especializações profissionalizantes, que substituíam a educação produtiva, por uma formação social atrelada à pedagogia da reivindicação, com saberes e habilidades práticas fortalecedoras da luta camponesa. O curso de nivelação durava quatro semanas; o curso sobre realidade nacional durava três; e os cursos de especialização duravam cinco semanas cada: três meses de curso, sete horas diárias. Os alunos também tinham bolsas de um salário mínimo pagas pelo FEES. Era um pré-requisito que fossem camponeses assalariados e dirigentes sindicais (de comitês a confederações). A seleção era feita pelas organizações. A terceira etapa oferecia cinco especialidades, duas delas particularmente inovadoras: Instrutores de Base; Relações Laborais; Programação e administração de um sindicato; Contabilidade sindical; e Comunicação. O conteúdo dos cursos está na tabela 24.

\begin{tabular}{|c|c|c|}
\hline \multicolumn{3}{|c|}{ Tabela 24 - Convênio FEES-Universidade Católica para 1970 e 1971} \\
\hline Especialização & Objetivos & Conteúdos \\
\hline \multirow{7}{*}{$\begin{array}{l}\text { Instrutores de } \\
\text { base }\end{array}$} & \multirow{7}{*}{$\begin{array}{l}\text { "Formar dirigentes camponeses que } \\
\text { dominem técnicas de trabalho e } \\
\text { organização de grupo, (...) capazes de } \\
\text { compartilhar conhecimentos, } \\
\text { organizando atividades culturais e } \\
\text { pedagógicas." } \\
\text { "Conseguir que os camponeses } \\
\text { controlem e dirijam todos os aspectos } \\
\text { do movimento laboral agrário." } \\
\text { "Formar conscientizadores que } \\
\text { eliminem os obstáculos de ordem } \\
\text { cultural. (...) E que o camponês } \\
\text { controle as atividades culturais que } \\
\text { hoje diferentes agentes externos } \\
\text { realizam" }\end{array}$} & (a) Reflexão sobre homem e natureza. \\
\hline & & (b) Reflexão sobre homem e sociedade. \\
\hline & & (c) Reflexão sobre educação e sociedade. \\
\hline & & $\begin{array}{l}\text { (d) A cultura camponesa: família camponesa } \\
\text { com ênfase na mulher e na juventude. Cultura } \\
\text { camponesa em sua relação com a estrutura } \\
\text { agrária. Cultura camponesa e cultura nacional. }\end{array}$ \\
\hline & & $\begin{array}{l}\text { (e) História do movimento camponês. História } \\
\text { do movimento obreiro e estudantil em suas } \\
\text { relações com a cultura e movimento camponês. }\end{array}$ \\
\hline & & $\begin{array}{l}\text { (f) Metodologia de alfabetização, de leitura e } \\
\text { escrita crítica e compreensiva. Metodologias de } \\
\text { matemática, geografia e história. }\end{array}$ \\
\hline & & $\begin{array}{l}\text { (g) Princípios e técnicas de programação de } \\
\text { atividades culturais e didáticas, ligadas à vida } \\
\text { camponesa e efemérides nacionais. }\end{array}$ \\
\hline \multirow[t]{4}{*}{$\begin{array}{l}\text { Relações } \\
\text { Laborais }\end{array}$} & \multirow{4}{*}{$\begin{array}{l}\text { "Proporcionar ao camponês os } \\
\text { conhecimentos jurídicos, sociais, } \\
\text { econômicos que incidam em suas } \\
\text { relações de trabalho (...), que o } \\
\text { instrumentalize para um melhor } \\
\text { desenvolvimento do movimento } \\
\text { camponês" }\end{array}$} & $\begin{array}{l}\text { (a) Instrumentos Jurídicos: análise da lei } \\
\text { 16.625 e Lei de Inamovibilidade. }\end{array}$ \\
\hline & & $\begin{array}{l}\text { (b) Instrumentos econômicos: Análises da } \\
\text { empresa; metodologia para calcular } \\
\text { remunerações e fatores produtivos. }\end{array}$ \\
\hline & & $\begin{array}{l}\text { (c) Conceitos para instrumentalização da ação } \\
\text { sindical camponesa: métodos de luta, petições, } \\
\text { paralisações, marchas, greves. Instância de } \\
\text { solução de conflitos: ata de consenso, } \\
\text { intervenção, intervenção com administração, } \\
\text { expropriação. }\end{array}$ \\
\hline & & $\begin{array}{l}\text { (d) Avaliação do movimento camponês: } \\
\text { pressão camponesa nos últimos anos; } \\
\text { conquistas, impactos, reforma agrária. Estudos } \\
\text { de caso de conflitos camponeses: extensão, } \\
\text { duração, relação com grupos urbanos, papel do } \\
\text { dirigente, instâncias de decisão. }\end{array}$ \\
\hline \multirow{3}{*}{$\begin{array}{l}\text { Administração } \\
\text { sindical }\end{array}$} & \multirow{3}{*}{$\begin{array}{l}\text { "Entregar conhecimentos integrais de } \\
\text { administração e programação para o } \\
\text { bom funcionamento do sindicato e sua } \\
\text { projeção sobre outras organizações }\end{array}$} & Educação sindical. \\
\hline & & Técnicas de programação. \\
\hline & & Técnicas em grupo. \\
\hline
\end{tabular}




\begin{tabular}{|c|c|c|}
\hline & camponesas" & \\
\hline \multirow{5}{*}{$\begin{array}{l}\text { Contabilidade } \\
\text { sindical }\end{array}$} & \multirow{5}{*}{$\begin{array}{l}\text { "Outorgar conhecimentos sobre } \\
\text { manejo contábil a fim de que o } \\
\text { camponês consiga utilizar os recursos } \\
\text { financeiros do sindicato da melhor } \\
\text { forma possível" }\end{array}$} & Patrimônio sindical. \\
\hline & & Obtenção de recursos (cotas, aportes, doações). \\
\hline & & Orçamento (entradas e saídas, imprevistos). \\
\hline & & $\begin{array}{l}\text { Tesouraria (funções do tesoureiro, trâmites } \\
\text { bancários) }\end{array}$ \\
\hline & & $\begin{array}{l}\text { Contabilidade sindical (livros de contabilidade, } \\
\text { balanços, sistemas de fiscalização). }\end{array}$ \\
\hline \multirow[t]{6}{*}{ Comunicação } & \multirow{6}{*}{$\begin{array}{l}\text { "Capacitar o campesinato } \\
\text { especialmente seus dirigentes, sobre o } \\
\text { sentido e valor da comunicação na } \\
\text { sociedade moderna, o domínio de } \\
\text { técnicas e o papel que lhes corresponde } \\
\text { na realidade camponesa chilena". } \\
\text { "Criar comunicadores camponeses, } \\
\text { conscientes da importância de seu } \\
\text { trabalho, do sentido comunitário de } \\
\text { estar informado; (...) do valor de suas } \\
\text { pautas culturais, linguagem, modo de } \\
\text { vida. } \\
\text { (...) Entregar elementos práticos para } \\
\text { tornar real essa comunicação" }\end{array}$} & (a) Sentido e valor da comunicação \\
\hline & & $\begin{array}{l}\text { (b) Importância da comunicação na sociedade } \\
\text { (jogos de poder nas comunicações; meios de } \\
\text { comunicação do campo e da cidade). }\end{array}$ \\
\hline & & $\begin{array}{l}\text { (c) Comunicação como fator de integração ou } \\
\text { desintegração. }\end{array}$ \\
\hline & & $\begin{array}{l}\text { (d) Comunicação como fator de estabilização } \\
\text { ou mudança social. }\end{array}$ \\
\hline & & $\begin{array}{l}\text { (e) Impacto da imprensa no ambiente } \\
\text { campesino. }\end{array}$ \\
\hline & & $\begin{array}{l}\text { (f) Práticas: técnicas de escrever, comunicação } \\
\text { oral, técnicas de reportagem; responsabilidade } \\
\text { do trabalho no mimeografo; possibilidade de } \\
\text { fazer um jornal; mecanismos de distribuição; } \\
\text { rádio; teatro; títeres. }\end{array}$ \\
\hline
\end{tabular}

Os programas do convênio mostravam a combinação do método psicossocial com o marxismo, junto de uma ênfase na centralidade da cultura para as transformações econômicas agrárias. $\mathrm{O}$ curso para Instrutores de Base, por exemplo, além de mobilizar o conceito antropológico de cultura e o
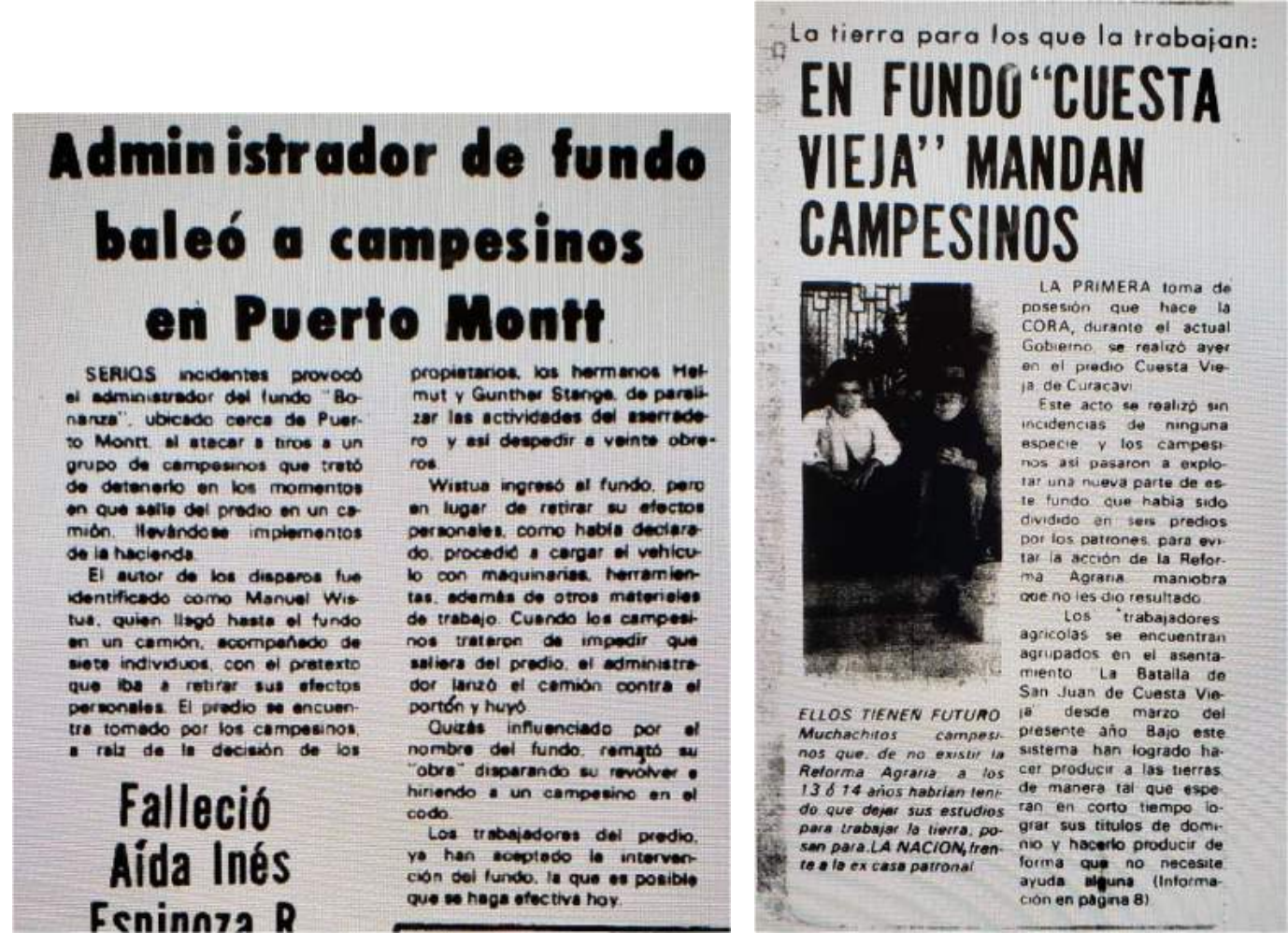

Fonte: La Nación, Dez/1970. 
princípio filosófico dos temas geradores em seus conteúdos iniciais, indicava um objetivo bastante estratégico e específico na luta pela emancipação camponesa: a substituição dos agentes externos de ação cultural por camponeses, que deixassem de depender de profissionais urbanos. O propósito era multiplicar camponeses professores, atores, comunicadores, organizadores culturais, artistas, e fomentar o potencial criativo dos camponeses com base em sua própria cultura, por meio de técnicas básicas de organização popular, com objetivo de "remover os obstáculos culturais" da reforma agrária. De igual importância, o curso sobre Relações laborais era uma espécie de especialização em luta de classes (a pedagogia da reivindicação), que oferecia ferramentas legais, jurídicas e econômicas para compreensão e ação nos conflitos rurais, junto com a análise dos métodos de luta e o estudo de casos concretos de petições, greves e tomas, utilizando notícias de jornal e documentos do mundo real, como estes mostrados aqui.

As notícias permitiam o debate sobre como fazer uma petição, em quais casos uma ata de conciliação da inspetoria do trabalho era vantajosa para os trabalhadores rurais. Ou ainda, o que as leis 16.625 e 16.455 garantiam para melhorar as condições de trabalho; ou como desenvolver uma negociação coletiva, mobilizar diferentes trabalhadores de uma comuna ou de uma província; quando organizar uma paralisação e quando declarar greve; quais eram as causas legais de expropriação da reforma agrária e como estar preparado para a retaliação proprietária. Essas questões eram despertadas e frutificadas com jornais e documentos da Inspetoria do Trabalho.

Oscar Torres, cuja esposa, à época, era professora desse convênio, se recorda que "ali liam os jornais, liam as notícias e coletivamente criticavam. Que pensam disso?". ${ }^{807}$ Era comum também analisarem criticamente a imprensa da direita, como El Mercurio: "No começo, os camponeses acreditavam de pés juntos no que estava escrito. Não devem acreditar sem questionar, diziam os professores. Quem está dizendo isso?”. Então, “os dirigentes camponeses iam criando ferramentas para serem críticos. Depois diziam: ‘essa é opinião do El Mercurio! E quem é o dono de El Mercurio?’”.808 A crítica aos latifundiários fazia parte de um universo comum entre camponeses da Triunfo, da Ranquil e da UOC. Contudo, com o tempo, as clivagens internas da reforma agrária iam tornavam-se cada vez mais visíveis. Em aulas mais críticas contra a direita, os professores refletiam: "Será que os da Triunfo estão gostando tanto quanto os da Ranquil e da UOC?" ${ }^{809}$ Entre os professores do CEA, "estava muito presente o MAPU", explicou Torres. ${ }^{810}$ De fato, o engajamento dos professores à esquerda às vezes causava desconforto entre camponeses com posições mais centristas ou conservadoras: "entre dirigentes democrata-cristãos, começaram a dizer: 'Aqui há um acordo do FEES com a esquerda, estão nos levando para esquerda. Para isso fizeram esse programa'. Começaram a surgir certas resistências em mandar gente da Triunfo para U. Católica. Mas nada escandaloso", ${ }^{811}$ contou Torres.

\footnotetext{
${ }^{807}$ Entrevista com Oscar Torres. Maipo, 26/05/2019.

${ }^{808}$ Id., ibid.

${ }^{809}$ Id., ibid.

${ }^{810}$ Id., ibid.

${ }^{811}$ Id., ibid.
} 
O curso para comunicadores camponeses, com técnicas modernas de jornalismo crítico, era único no país. A ideia era acelerar as ferramentas de comunicação independente produzida pelos camponeses, criar a possibilidade de jornais exclusivamente camponeses, ou programas de rádio ou boletins em centros de capacitação. A aposta era que técnicas básicas de comunicação no mundo urbano, quando transportados para o mundo rural e ativados pela sabedoria camponesa, poderiam agir sobre a disposição subjetiva das lutas estruturais.

O programa da U. Católica parecia mais exigente, pois requisitava dos camponeses um repertório maior de conhecimentos prévios formais. O nível de exigência dos cursos poderia dar a impressão de que eram relativamente elitistas, destinado a camponeses que tiveram acesso à escolarização acima da média rural. Isso não era totalmente falso. Porém, era também notável que a metodologia freiriana representava um sincero esforço de aproximação dos professores universitários com relação ao universo temático e cultural do camponês. Novamente, no rastro da pedagogia freiriana aparecia o MAPU. Os idealizadores do convênio escreveram: "nesse trabalho de ensino estão integrados dois mundos diferentes e contraditórios: o universitário e o camponês (...). Se produz uma dicotomia entre a cultura universitária (abstrata-teórica) e a do camponês (essencialmente prática, concreta)". 812 Consequentemente, o "método a empregar será o método psicossocial, que permitirá ao camponês refletir sobre sua realidade e a realidade universal. Isso se consegue mediante a reflexão crítica que tende a formar pessoas conscientes, que atuem criticamente". ${ }^{813}$

Reconheciam, por fim, a necessidade de que os professores universitários aprendessem com os camponeses: "outro aspecto importante a considerar na utilização do método se resume a ensinar aprendendo; utilizar perguntas e respostas" em uma formação "com base na experiência do camponês". ${ }^{814}$ Era um tremendo desafio para professores habituados com a tradição de ensino bancário e o convívio orgânico com as elites do país.

\subsection{Sindicalismo camponês e analfabetismo}

A estrutura de capacitação dos convênios FEES representava uma oferta sem precedentes de educação e formação para camponeses adultos. Ao se considerar a heterogeneidade do campesinato, porém, é compreensível que muitos dos cursos atingissem segmentos específicos dos trabalhadores rurais, dirigentes alfabetizados ou sindicalizados com protagonismo nas bases e maior facilidade de comunicação com o mundo urbano. Não é possível calcular a dimensão de camponeses sindicalizados analfabetos, mas as atas de fundação dos sindicatos de trabalhadores rurais estavam repletas de digitais daqueles que não sabiam assinar o próprio nome. Por meio da observação de 12 atas de fundação de sindicatos das províncias de Talca e Curicó, entre 1967 e 1973, encontrei casos com 94\% de camponeses

\footnotetext{
812 FEES, 1970, p. 58

${ }^{813}$ Id., ibid., p. 58-59.

${ }^{814}$ Id., ibid.
} 
não alfabetizados entre os seus fundadores, que assinaram a ata com suas impressões digitais, até sindicatos com $30 \%$ de analfabetos. Tampouco é certo se aqueles que sabiam assinar o nome eram plenamente alfabetizados, sendo essa a conquista primária de um alfabetizando.

O Sindicato Agrícola de Trabalhadores El Despertar de Chile, da província de Curicó, por exemplo, foi fundado em julho de 1967 com 483 membros, sendo que 77\% assinaram a ata com impressões digitais. O Sindicato Agrícola Independiente San Cristóbal de Teno, em Curicó, foi fundado em agosto de 1967 com 337 membros, dos quais 66\% assinaram a ata com digitais. No mês seguinte, setembro de 1967, Sindicato de Trabalhadores Agrícolas Unión Campesina de Licanten, também em Curicó, foi fundado em setembro de 1967 com 132 membros, sendo que 34\% assinaram com os dedos. O Sindicato de Trabalhadores Agrícolas La Frontera, em Romeral (Curicó), foi fundado em outubro de 1967 com 207 membros, dos quais $49 \%$ assinaram com suas digitais. Entre as atas pesquisadas, a mais reveladora foi a do Sindicato de Trabalhadores Agrícolas El Libertador, em Molina (província de Talca), fundado em outubro de 1967 com nada menos que 997 membros, dos quais 932, ou seja, 94\% utilizaram impressões digitais para comprovar filiação. ${ }^{815}$ As atas pesquisadas estão na tabela 25.

\begin{tabular}{|c|c|c|c|c|c|}
\hline \multicolumn{5}{|c|}{ Tabela 25 - Impressões digitais na ata de fundação de sindicatos camponeses } \\
\hline Sindicato & Confederação & $\begin{array}{c}\text { Comuna, } \\
\text { Província }\end{array}$ & $\begin{array}{c}\text { Data } \\
\text { fundação }\end{array}$ & Membros & $\begin{array}{c}\text { \% impressões } \\
\text { digitais }\end{array}$ \\
\hline $\begin{array}{c}\text { Sindicato de } \\
\text { Trabalhadores Agrícolas } \\
\text { Union Campesina de } \\
\text { Licanten }\end{array}$ & $\begin{array}{c}\text { Triunfo } \\
\text { Campesino }\end{array}$ & $\begin{array}{c}\text { Licanten, } \\
\text { Curicó }\end{array}$ & $24 / 09 / 1967$ & 132 & $34 \%$ \\
\hline $\begin{array}{c}\text { Sindicato de } \\
\text { Trabalhadores Agrícolas } \\
\text { La Frontera }\end{array}$ & $\begin{array}{c}\text { Triunfo } \\
\text { Campesino }\end{array}$ & $\begin{array}{c}\text { Romeral, } \\
\text { Curicó }\end{array}$ & $29 / 10 / 1967$ & 207 & $49 \%$ \\
\hline $\begin{array}{c}\text { Sindicato Agrícola } \\
\text { Independente San } \\
\text { Cristóbal de Teno }\end{array}$ & $\begin{array}{c}\text { Triunfo } \\
\text { Campesino }\end{array}$ & $\begin{array}{c}\text { Temo, } \\
\text { Curicó }\end{array}$ & $19 / 08 / 1967$ & 337 & $66 \%$ \\
\hline $\begin{array}{c}\text { Sindicato Agrícola de } \\
\text { Trabalhadores EI } \\
\text { Despertar de Chile }\end{array}$ & $\begin{array}{c}\text { Triunfo } \\
\text { Campesino }\end{array}$ & $\begin{array}{c}\text { Curicó, } \\
\text { Curicó }\end{array}$ & $22 / 7 / 1967$ & 483 & $77 \%$ \\
\hline $\begin{array}{c}\text { Sindicato Agrícola El } \\
\text { Copihue }\end{array}$ & $\begin{array}{c}\text { Não registrada } \\
\text { em ata }\end{array}$ & $\begin{array}{c}\text { Rauco, } \\
\text { Curicó }\end{array}$ & $30 / 07 / 1967$ & 114 & $35 \%$ \\
\hline $\begin{array}{c}\text { Sindicato Agrícola de } \\
\text { Trabalhadores El Surco }\end{array}$ & Ranquil & $\begin{array}{c}\text { Curicó, } \\
\text { Curicó }\end{array}$ & $16 / 07 / 1967$ & 231 & $31 \%$ \\
\hline $\begin{array}{c}\text { Sindicato Agrícola de } \\
\text { Trabalhadores Lautaro }\end{array}$ & Ranquil & $\begin{array}{c}\text { Hualañe, } \\
\text { Curicó }\end{array}$ & $16 / 10 / 1967$ & 103 & $35 \%$ \\
\hline $\begin{array}{c}\text { Sindicato de } \\
\text { Trabalhadores Agrícolas } \\
\text { El Libertador }\end{array}$ & Libertad & $\begin{array}{c}\text { Molina, } \\
\text { Talca }\end{array}$ & $16 / 10 / 1967$ & 997 & $94 \%$ \\
\hline $\begin{array}{c}\text { Sindicato de } \\
\text { Trabalhadores Agrícolas } \\
\text { La Unión }\end{array}$ & $\begin{array}{c}\text { Não registrada } \\
\text { em ata }\end{array}$ & $\begin{array}{c}\text { Rio Claro, } \\
\text { Talca }\end{array}$ & $05 / 05 / 1968$ & 102 & $69 \%$ \\
\hline
\end{tabular}

815 Archivo Nacional de la Administración (ARNAD), Fundo DIRELA (Dirección Laboral), cx.174, pastas 2850, 2851, 2852, 2858, 2859, 2860, 2861, 2862, 2863, 2864, 2865. 


\begin{tabular}{|c|c|c|c|c|c|}
\hline $\begin{array}{c}\text { Sindicato de Pequenos } \\
\text { Agricultores La } \\
\text { Alborada }\end{array}$ & $\begin{array}{c}\text { Não registrada } \\
\text { em ata }\end{array}$ & $\begin{array}{c}\text { Pelarco, } \\
\text { Talca }\end{array}$ & $08 / 07 / 1972$ & 29 & zero \\
\hline $\begin{array}{c}\text { Sindicato de } \\
\text { Trabalhadores Agrícolas } \\
\text { EI Despertar Campesino }\end{array}$ & $\begin{array}{c}\text { Não registrada } \\
\text { em ata }\end{array}$ & $\begin{array}{c}\text { Curepto, } \\
\text { Talca }\end{array}$ & $10 / 08 / 1972$ & 105 & $51 \%$ \\
\hline $\begin{array}{c}\text { Sindicato de } \\
\text { Trabalhadores Agrícolas } \\
\text { Liberación Campesina }\end{array}$ & $\begin{array}{c}\text { Não registrada } \\
\text { em ata }\end{array}$ & $\begin{array}{c}\text { Sagrada } \\
\text { Familia, } \\
\text { Curicó }\end{array}$ & $28 / 06 / 1973$ & 114 & $33 \%$ \\
\hline Fonte: ARNAD, Fundo DIRELA, cx.174, pastas 2850, 2851,2852,2858,2859,2860,2861,2862, 2863,2864,2865. \\
\hline
\end{tabular}

Hierarquias entre camponeses alfabetizados e não alfabetizados no processo de sindicalização e reforma agrária foram percebidas pelo sociólogo Ian Roxborough, quando circulou por dez assentamentos da província de Santiago a fim de compreender a percepção camponesa sobre as transformações e os debates da revolução chilena, já em 1971 e 1972. Nas fazendas expropriadas El Porvenir e San José, constituídas como assentamentos em 1971, os camponeses atravessavam conflitos internos entre lideranças para assumir os cargos de direção. Como a CORA enviava gestores, os assentamentos receberam pessoas externas à propriedade nomeadas como tesoureiros (cajeros). "Em ambos os casos, os tesoureiros foram acusados de fraude", narrou Roxborough (1977: 501): "Em ambos os casos, os tesoureiros eram agentes externos com nível educacional ligeiramente mais alto (...). Para completar, em El Porvenir a tesoureira era uma mulher, o que, como ela mesma constatou, em si mesmo causava problemas com os camponeses". Os camponeses que acusavam os tesoureiros de fraudes, porém, eram analfabetos e não sabiam ler o livro-caixa. Os tesoureiros eram as únicas pessoas alfabetizadas disponíveis. O papel dos alfabetizados como controladores das contas revelava o poder do conhecimento no controle produtivo e na gestão das relações de produção, tanto quanto a desconfiança de outros camponeses que, por serem analfabetos, se sentiam incapazes de se apropriar verdadeiramente da gestão dos regimes de trabalho e de renda na nova estrutura. Nos mesmos assentamentos havia conflitos e críticas com relação aos presidentes.

No entanto, quando duas educadoras, capacitadas como alfabetizadoras, chegaram para lecionar em El Porvenir, não conseguiram formar um grupo de alunos porque a vergonha em expor dificuldades era maior que a vontade de aprender. Começaram a lecionar individualmente. Mas logo o presidente do assentamento se opôs à continuidade dos cursos e fez o que pode para impedir o trabalho das educadoras, com receio de ver ampliada a crítica ao seu poder de chefe. "Talvez, mais do que qualquer outra coisa", concluiu Roxborough, "a falta de habilidades empresariais e organizativas, junto com o baixo nível de alfabetização, compunha os principais problemas que surgiram na fase inicial [do assentamento]" (1977: 508). Evidenciava-se o papel chave da capacitação na reconfiguração do micropoder entre os próprios camponeses.

No âmbito sindical, a hierarquia entre camponeses alfabetizados e não alfabetizados se expressava, por exemplo, no fato de que as direções empossadas eram sempre capazes de escrever seu nome. Mesmo que isso não significasse alfabetização plena, nas atas que examinei não havia impressões digitais nas 
assinaturas das direções. Um exemplo pode ser visto a seguir, na página com as assinaturas da direção do Sindicato Agrícola de Trabalhadores de Lautaro, em Curicó.

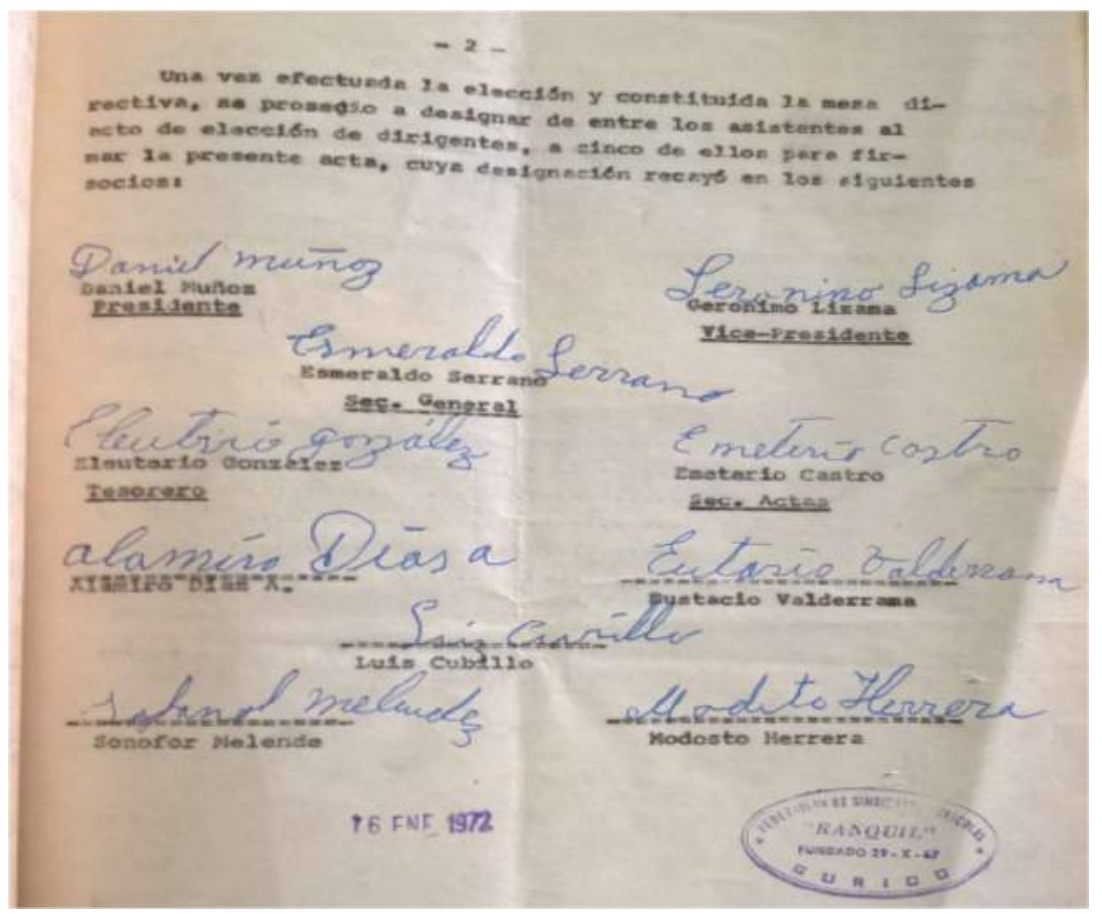

Direção assina ata de fundação do Sindicato Agrícola de Trabalhadores de Lautaro, em 16/10/1967. Fonte: ARNAD, Fundo DIRELA, Cx. 174, Cp. 2859

Também é notável que todos os estatutos sindicais pesquisados possuíam o mesmo texto, oferecido pela Inspetoria do Trabalho no momento da fundação. O estatuto era trazido por agentes externos ao mundo camponês, nunca formulada pelos próprios. Todos os estatutos diziam, com as mesmas palavras, que era missão do sindicato "promover a educação gremial, técnica e geral de seus associados, especialmente pela criação de escolas profissionais ou concessão de bolsas aos seus filiados e familiares para estudar e se aperfeiçoar em escolas e universidades". ${ }^{816}$ Também era sua função "proporcionar a organização de bibliotecas" e oferecer "assessorias técnicas, educacionais, culturais, de promoção socioeconômica e outras", 817 além de inaugurar uma Comissão Educacional do Sindicato "que procurará instalar escolas primárias e Institutos de Capacitação Agrícola para os sócios e seus familiares (...), com cursos, conferências de legislação social e de educação cívica". ${ }^{818}$

O idêntico estatuto para todos os sindicatos mostrava um grande alheamento dos seus fundadores com o que significava aquele documento, desprovido de qualquer subjetividade ou particularidade daqueles trabalhadores que o firmavam com seus dedos. A seguir, algumas imagens das atas de fundação repletas de impressões digitais.

\footnotetext{
${ }^{816}$ Estatuto sindical de diversos sindicatos. ARNAD, Fundo DIRELA, Cx. 174.

${ }^{817}$ Id., ibid.

${ }^{818}$ Id., ibid.
} 

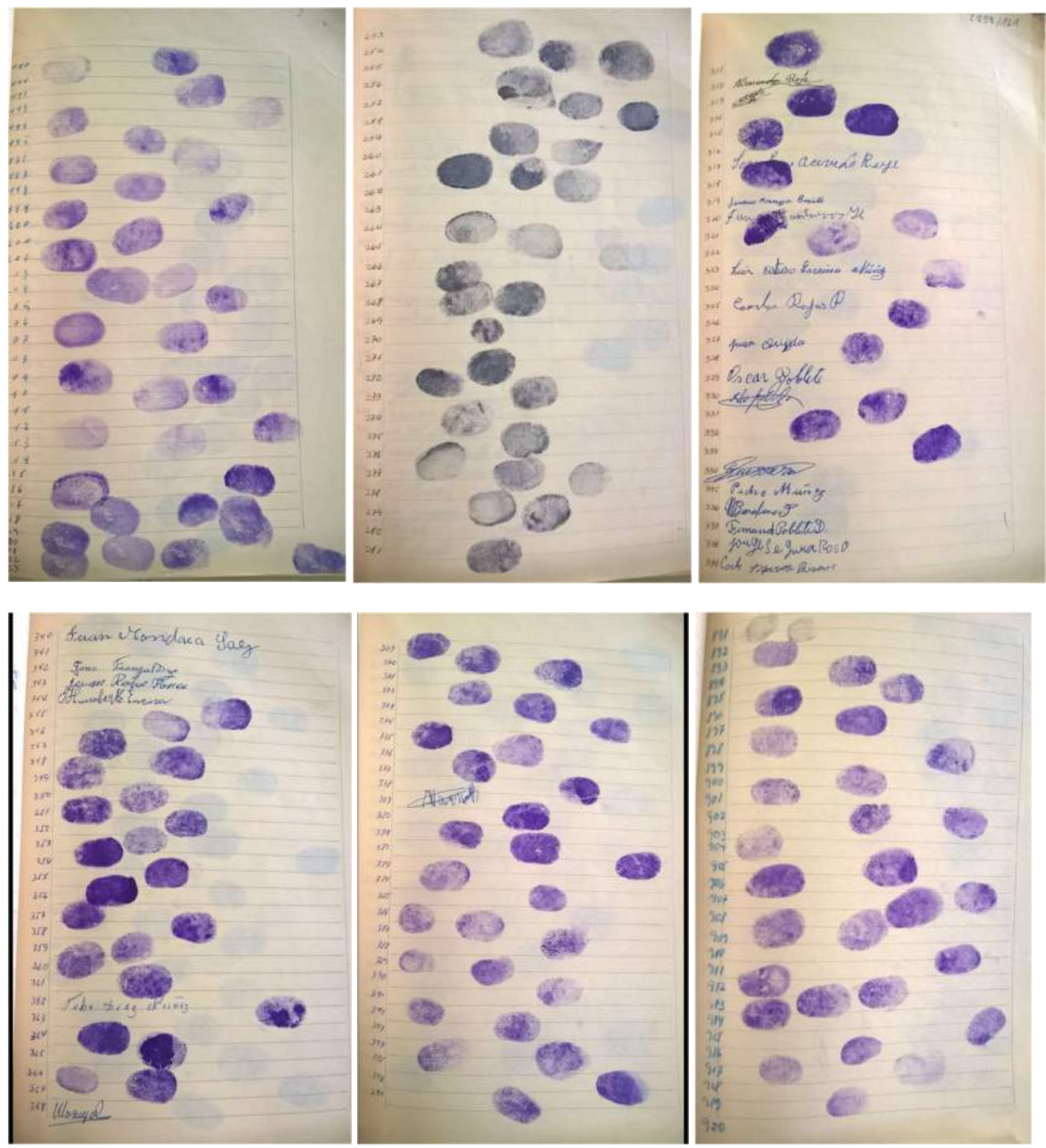

Assinaturas de ata de fundação do Sindicato El Libertador. Fonte: ARNAD, Fundo DIRELA, Cx. 174, Carpeta 2858.

Um exemplo de esforço metodológico para que camponeses analfabetos estivessem incluídos na educação sindical foi o uso do método psicossocial para ensino sobre os novos direitos camponeses pela Confederação Triunfo Campesino. Em seu projeto de convênio com o FEES para 1971 e 1972, apresentava um plano com alguns exemplos de aulas. Na unidade de conscientização, por exemplo, propunham uma aula sobre alienação, com o uso de uma nova versão da lâmina da CORA para o círculo sobre JUGO ${ }^{819}$ A aula consistia em um debate sobre hierarquia, submissão e incultura, em contraste com a importância de conhecer seus próprios direitos, de entender a realidade em seu em torno e localizar-se nela de maneira consciente e crítica. Os materiais escritos que acompanhavam a aula eram destinados aos "senhores capacitadores", não aos camponeses. Entre eles, um texto intitulado

819 Triunfo Campesino, Proyecto de Convenio Triunfo Campesino 1971-1972. Santiago: FEES, 1971. 
Alienação, caracteristica de nossos tempos, com citações de Paulo Freire e Eric Fromm, outro com nome História Crítica, com uma narrativa sobre a história de exclusão do campesinato; e outro ainda chamado Movimento patronal. Movimentos camponeses, que definia conceitualmente o sistema capitalista e as relações de classe no campo, além de explicar o significado do termo momio com tom científico: "é o beneficiado pelo capitalismo. Não precisa trabalhar para viver, mas fazer trabalhar o seu dinheiro ou capital (...) Momiaje é a classe social dona dos meios de produção. A outra classe é a TRABALHADORA $" .820$

Esse projeto da Triunfo trazia elementos teóricos marxistas desalinhados com a DC, o que mostra como os processos educacionais nas bases nem sempre correspondiam à linha das direções partidárias, ou talvez como se sentiam pressionados pela ruptura à esquerda da UOC, que em 1971 gerou uma queda de 32\% do número de filiados da Triunfo. "Existe um grupo de trabalhadores", dizia o material para capacitadores: "que não têm consciência desta divisão e acredita que seus interesses são os da momiaje. Eles são os alienados ou amarillos". ${ }^{821}$ Outros elementos do texto mostravam que seus autores estavam à esquerda da DC: “o protótipo do neocapitalista é, em essência, tão explorador como o empresário tradicional (...). São eles que dirigem os movimentos patronais agrícolas (SNA, CONSEMACH). São extremamente habilidosos", dizia o texto para capacitadores da Triunfo.

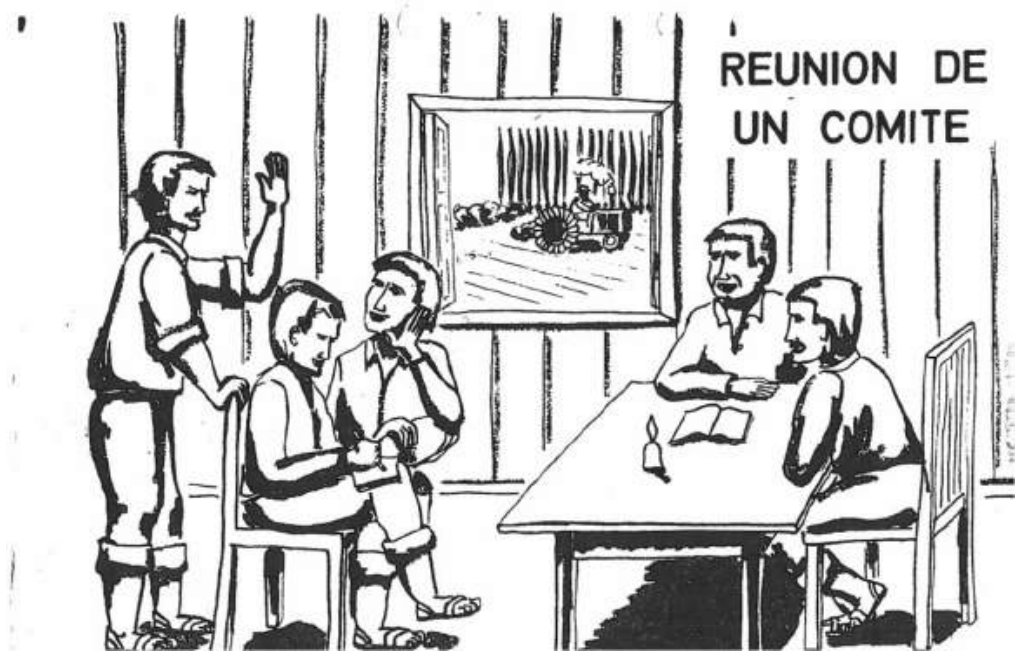

Fonte: Triunfo Campesino, Proyecto de Convenio Triunfo Campesino 1971-1972.

Um segundo esquema de aula da Triunfo, que considerava a necessidade de ensinar os direitos dos camponeses com imagens, para analfabetos, tratava justamente do tema Organização sindical. Os objetivos eram básicos: compreender o que era um sindicato e sua importância; saber o que é um comitê sindical e como organizá-lo. O método era o círculo de cultura com base em imagens, com uma pedagogia da pergunta que se orientava para as questões: "se percebem problemas na libreta, o que fazem? Falam direto com o patrão? Se reúnem com outros que tem o mesmo problema? Em qual destes casos obteve mais rápida e justa solução?"” ${ }^{822}$ Dessa conversa, o capacitador deveria deduzir, junto aos camponeses, a necessidade da organização sindical. Propunha-se a utilização da ilustração aqui reproduzida como mote do debate.

\footnotetext{
${ }^{820}$ Id., ibid..

${ }^{821}$ Id., ibid..

822 Id., ibid.
} 
O tema seguinte relacionava a necessidade de autoridade paterna na família com a necessidade de autoridade sindical em um comitê. As questões sugeridas eram: "Quem forma a família? Todos mandam igual? Todos têm a mesma responsabilidade? Que papel corresponde a cada membro?". ${ }^{823}$ Com isso, o capacitador deveria concluir junto aos camponeses que o comitê sindical, assim como a família, precisava de uma autoridade. A diferença era que no comitê a autoridade deveria ser eleita. Outra estratégia imagética de ensino para camponeses analfabetos era sobre o sistema sindical da Lei 16.625, esquematizado em organogramas que facilitavam a compreensão visual da sindicalização.

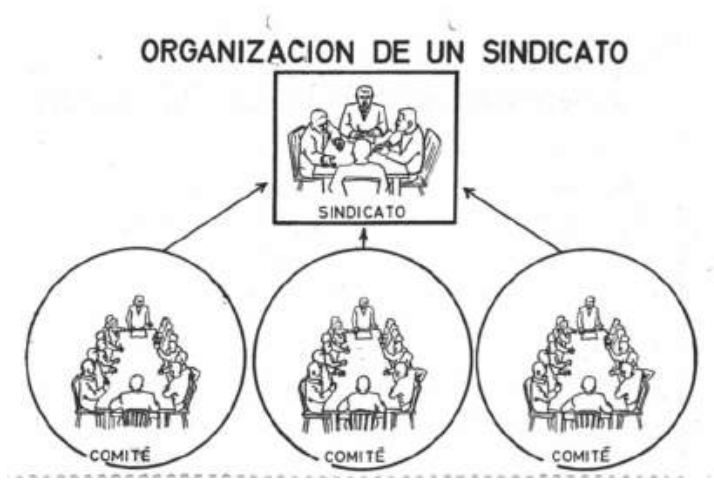

Fonte: Triunfo Campesino, Proyecto de Convenio Triunfo Campesino 1971-1972.
Entre os educadores que trabalhavam diretamente no FEES, também se criavam métodos de educação camponesa para se driblar textos e permitir que camponeses com alfabetização precária ou incompleta adentrassem na análise sobre a realidade chilena, dispensando a leitura pela oferta de imagens. Maria Emília, que lecionava tanto na escola camponesa da sede do FEES, como em viagens itinerantes pelas regiões, contou ao menos duas atividades pedagógicas que desenvolveu em suas aulas para camponeses sem linguagem textual.

A primeira ocorria nas escolas camponesas na sede do FEES em Santiago, pois demandava equipamento audiovisual inexistente nas sedes locais emprestadas. A proposta era um debate sobre o filme El Chacal de Nahueltoro, lançado em 1969, primeiro longa-metragem do diretor Miguel Littín, que logo se tornou diretor da Chile Films no governo Allende e um dos cineastas mais consagrados da revolução chilena (Cornejo, 2015: 127). El Chacal de Nahueltoro era um documentário dramatizado sobre a história verídica de Jorge del Carmen Valenzuela Torres, um pobre migrante rural, solitário, que desde a infância vagava de trabalho em trabalho, sem perspectivas e sem nunca ter entrado em uma escola. O afuerino ficou conhecido como Chacal de Nahueltoro depois de cometer um crime selvagem em 1960: o assassinato brutal de uma mãe e seus

\footnotetext{
${ }^{823}$ Id., ibid.
}

\section{ORGANIZACION SINDICAL CAM,PESINA}

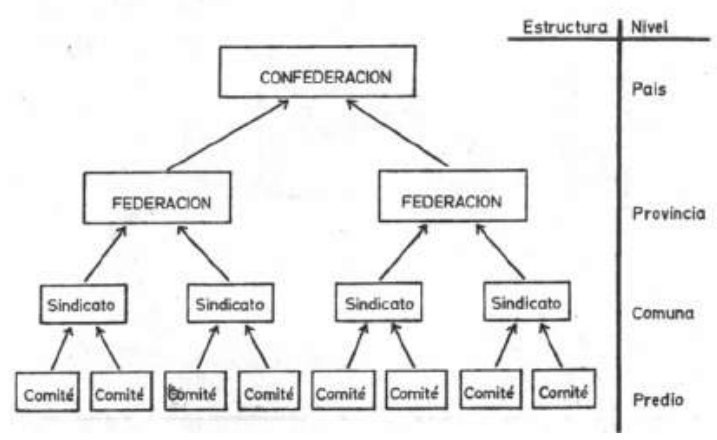
Triunfo Campesino 1971-1972.
Fonte: Triunfo Campesino, Proyecto de Convenio 
cinco filhos, incluindo um bebê. O crime havia chocado a sociedade chilena da época. Depois de passar meses no presídio, Valenzuela foi condenado à pena capital e fuzilado.

Miguel Littín captou uma série de problemas profundos da sociedade rural chilena na reconstituição fílmica da história do crime e do seu perpetrador, em uma sequência com 5 partes: infância, andar, prisão, educação e amansamento e morte. Com trechos narrados em primeira pessoa e elementos reais dos autos do processo, como a voz da juíza e a reconstituição de entrevistas de Valenzuela para imprensa, o filme incorporava, segundo Cornejo (2015) alguns dos procedimentos mais sofisticados da historiografia social vista de baixo. Valenzuela havia sido uma criança rural pobre, que perdeu o pai cedo e não frequentou a escola. Aos 6 anos fugiu de casa, percorrendo mais de 40 quilômetros de San Carlos a San Fabián. A inexistência de infância era uma das marcas da sua trajetória e entre as primeiras frases do filme está um policial dizendo à criança de 6 anos: "seja homem!". A partir dali sua vida foi um constante caminhar solitário, de trabalho em trabalho, no limiar da sobrevivência.

Um dia, Valenzuela chega à casa de uma pobre camponesa com cinco filhos, cujo marido acabava de falecer. Ela estava ameaçada de despejo pelo patrão: "senhora, necessito dar a casa a um inquilino que trabalhe", escutou. A camponesa alegou que seu marido morto havia trabalhado o suficiente, que ela tinha cinco filhos e não tinha para onde ir. Mas não adiantou: "agora ele está morto. Preciso da casa e se você não sair, lhe tiro a força". Despejada violentamente por carabineiros, a viúva ficou desamparada com seus 5 filhos pelos campos, e por azar se juntou à itinerância de Valenzuela. $\mathrm{Na}$ manhã seguinte, depois de tomar um garrafão de vinho, o forasteiro entrou em surto e assassinou a camponesa e seus 5 filhos. $O$ cortejo fúnebre da família assassinada era acompanhado por uma multidão camponeses. Depois de ser quase linchado pela população, o assassino era capturado e preso. Na cadeia, era ressocializado: cortavam seu cabelo, ofereciam refeições regulares, o integravam em um time de futebol, o catequizavam e o alfabetizavam. A cadeia é retratada como uma oportunidade de regeneração, sobretudo em função da inédita oportunidade educacional. Além de se alfabetizar, Valenzuela assistiu aulas de história chilena, sobre o orgulho pátrio da Batalha de Iquique em 21 de maio de 1879 e era assim convidado ao pertencimento. Nos meses da prisão, o Chacal atravessa uma grande transformação, e deixa de ser um pobre brutalizado para se tornar um humilde trabalhador "civilizado". No entanto, a pena é capital.

Antes de ser fuzilado, Chacal é entrevistado por um repórter que lhe pergunta: "você aprendeu coisas novas na prisão? Se sentiu mais tranquilo? Está arrependido?". E ele diz: “Aprendi a trabalhar em vários trabalhos, tive como me vestir e como comer. Me senti mais tranquilo. Me dei mais conta da vida. Estou arrependido, naquele momento não tive consciência do que fiz". O repórter então lhe perguntava se culpava o álcool pelo crime, e Valenzuela dizia: "Culpo ao álcool, sim. Mas também porque nunca tive ensino de ninguém, não tive educação nenhuma" Agora pretendia "ser um homem humilde e trabalhador, útil à sociedade". A narrativa do filme conduzia à compreensão idealista de que 
o Chacal de Nahueltoro era parte de uma sociedade adoecida pela pobreza, dramática no campo, mas que poderia ser curada com educação. Apesar disso, é fuzilado.

O filme rendeu muitos debates com os alunos camponeses de Maria Emília: "sempre havia toda uma discussão sobre como as pessoas podem mudar sua postura, sua percepção do mundo, ter um olhar diferente a partir de um processo de capacitação (...). O problema de fundo do filme era um dilema ético e o sentido da justiça", ${ }^{824}$ explicou a professora. O filme fazia parte do movimento de cinema experimental da Universidade do Chile, e inaugurava uma linguagem expressionista e realista, que ia ao cerne dos problemas sociais e da questão agrária.

Sua fotografia era densa de sentido e sua história estimulava o debate sobre o poder da alfabetização junto aos camponeses. A seguir alguns fotogramas do filme.
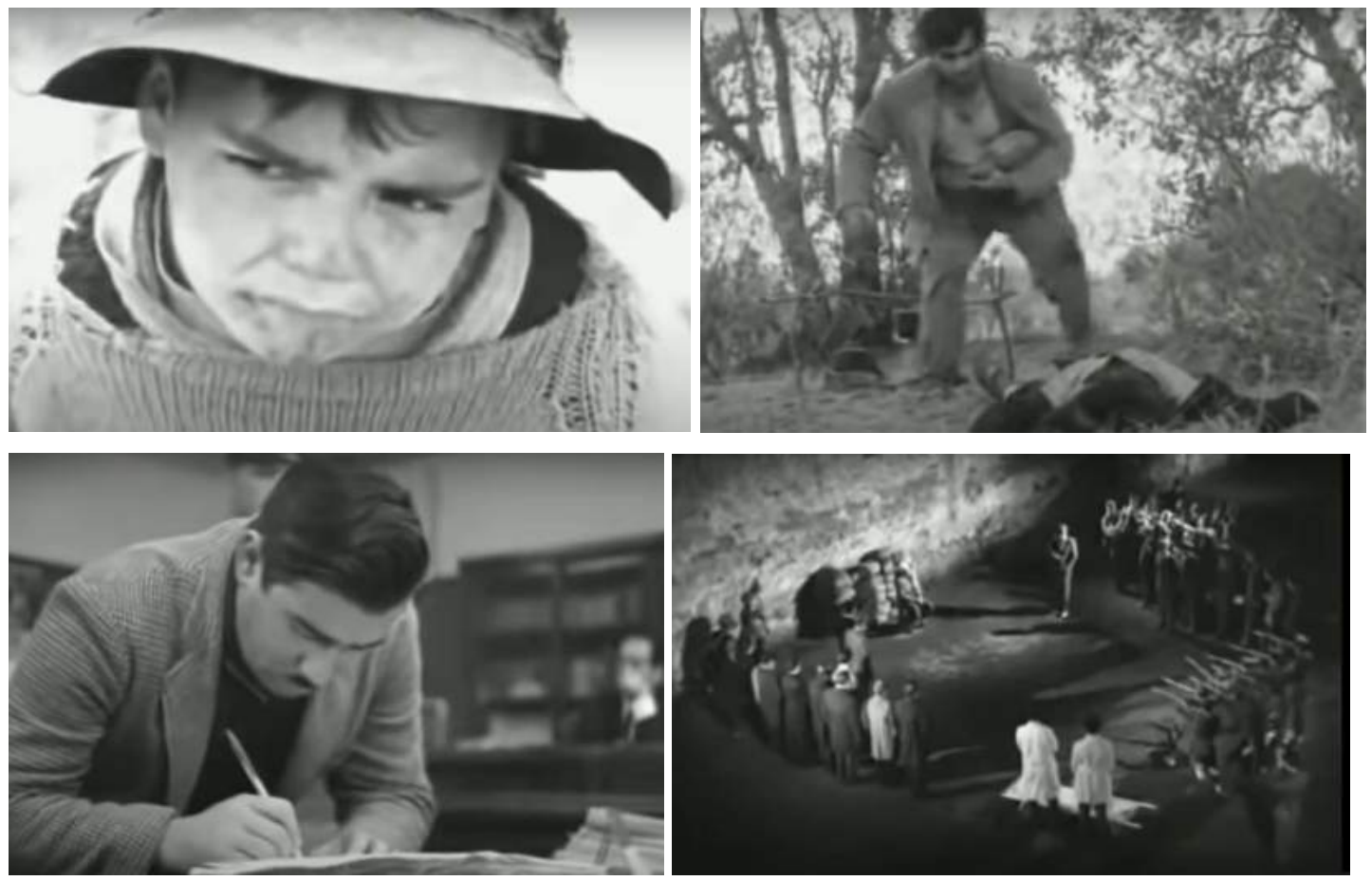

A trajetória de Jorge Valenzuela: criança rural pobre, assassino brutal, regenerado pela educação prisional, mas fuzilado. Fonte: El Chacal de Nahueltoro.
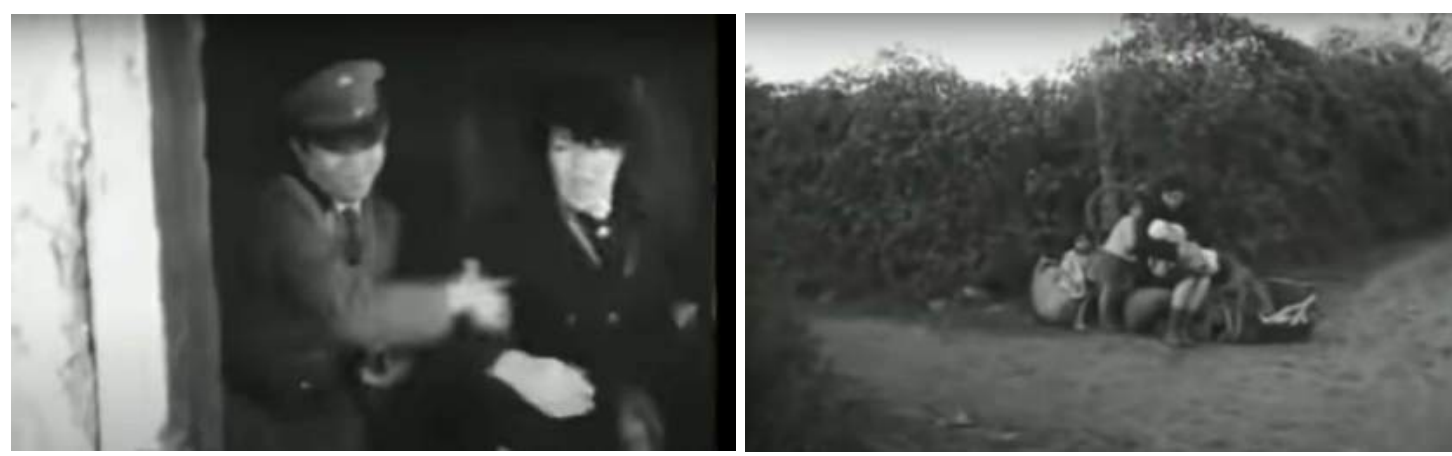

Viúva camponesa e seus cinco filhos despejados por carabineiros por ordem do patrão. Fonte: El Chacal de Nahueltoro.

${ }^{824}$ Entrevista com Maria Emília Palma. Santiago, 29/05/2019. 

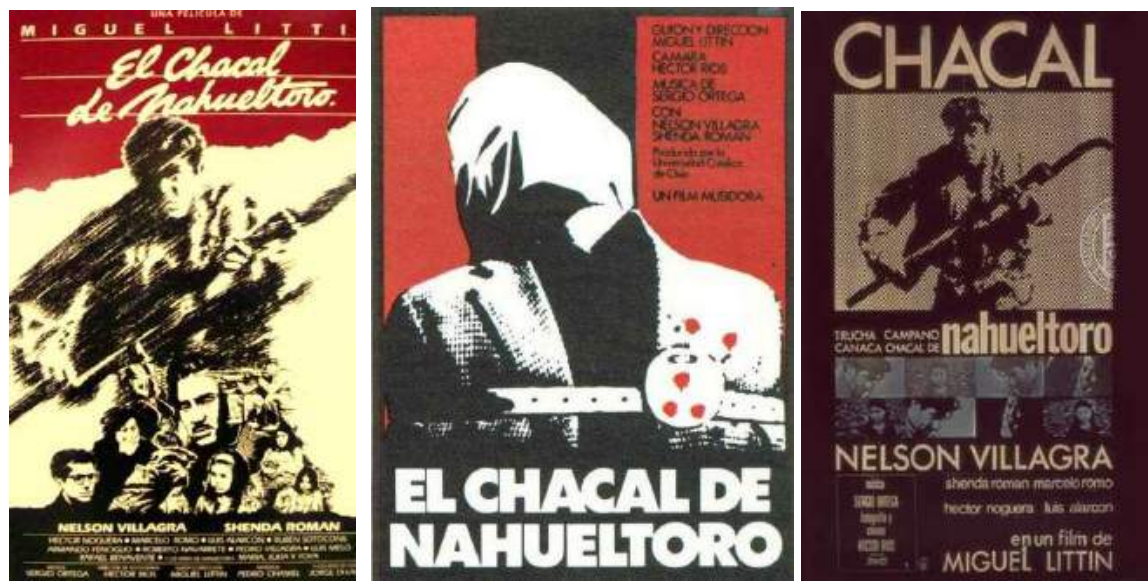

Cartazes do filme (1969).

A segunda estratégia não textual da professora Maria Emilia eram exercícios teatrais de encenação que simulavam situações de conflitos laborais entre camponeses e patrões. "Eu me lembro perfeitamente de fazer rol playing. Cada aluno encenava como o trabalhador teria que enfrentar ao empregador na Direção do Trabalho", ${ }^{825}$ relatou: "Quem estava encenando tinha que pensar como se fosse o patrão, depois a Direção do Trabalho e o trabalhador. Tinham que fazer os três papeis. Se colocar no papel do outro, para depois saber como atacá-lo". ${ }^{826}$ A ideia era ensaiar o conflito, fazendo o exercício de pensar como o patrão para saber enfrentá-lo melhor no mundo real. Maria Emília adorava que convívio com os alunos. Na sua memória, era afetuoso o clima das escolas camponesas do FEES. "Todos estes cursos eram jornadas longas, concentradas e terminavam em festa, comida comum, música... Era maravilhoso", se lembra: "Criávamos um vínculo muito além da relação professoraluno". 827

\subsection{Considerações finais}

Neste capítulo busquei mostrar a importância da educação sindical camponesa na reconfiguração das relações de poder no campo chileno a partir de 1967, especificamente a capacitação atrelada à luta dos trabalhadores rurais por seus direitos laborais, por melhores condições de vida e pelo fim do vínculo de submissão com os patrões. Os cursos e convênios do Fundo de Educação e Extensão Sindical estavam organicamente atrelados ao processo de sindicalização camponesa, a partir da ruptura do pacto entre as frações das classes dominantes que excluíram o campesinato dos direitos sindicais e salariais básicos.

\footnotetext{
${ }^{825}$ Id., ibid.

${ }^{826}$ Id., ibid.

${ }^{827}$ Id., ibid.
} 
Por isso, a atuação do FEES representou um processo de reparação histórica, no qual o Estado criou um mecanismo de transferência de renda proprietária para a educação camponesa, obrigando que os mesmos patrões que impediam a escolarização das crianças rurais passassem a garantir o direito de seus trabalhadores adultos ao estudo. Esse processo gerou reações proprietárias de diferentes tipos: desde a SNA, que institucionalmente publicou uma cartilha para patrões com as novas leis e a CONSEMACH que se beneficiou do mesmo sistema de arrecadação que os sindicatos dos trabalhadores, até os proprietários vingativos e agressivos, que impediam a presença de funcionários de Estado para assessorar camponeses em suas propriedades e tiravam do armário suas metralhadoras intimidar greves e paralisações rurais. Vimos também que a sindicalização camponesa e a reforma agrária eram dois movimentos de um mesmo processo de transformação estrutural, presentes em todos os programas pedagógicos da educação sindical camponesa como horizonte desejável, que demandava dos trabalhadores rurais um impulso de novos conhecimentos e saberes de novo tipo.

Os novos sindicatos, federações e confederações se fortaleceram com os cursos financiados por meio do FEES, orientados para uma pedagogia da reivindicação, na qual o método psicossocial e o marxismo se combinaram de diferentes maneiras. Tanto a confederação Triunfo Campesino como a Ranquil, com suas diferentes estratégias pedagógicas, valorizavam a formação de uma consciência crítica, propunham que os camponeses se tornassem sujeitos da transformação e se dedicavam a que conhecessem as leis da sindicalização, do trabalho e da reforma agrária, que aprendessem a administrar um sindicato e a conduzir negociações coletivas.

Mas, como notou Marcela Gajardo em 1973, "a capacitação de trabalhadores, urbanos e rurais, vem aparecendo de forma cada vez mais clara como um instrumento da luta ideológica. A capacitação camponesa, em particular, apresenta (...) uma paulatina localização na perspectiva do poder" (Gajardo, 1973c). Embora conceitos como socialismo e revolução não estivessem explicitados nos programas pedagógicos da Ranquil, por exemplo, o contexto da eleição de Allende em 1970 torna o debate da revolução e da luta anticapitalista inescapável a todos os chilenos. Vimos que a pedagogia da reivindicação conformava um ponto de partida semelhante ao mundo sindical conduzido por diferentes partidos políticos que valorizavam a organização camponesa contra os abusos históricos do poder patronal. Contudo seu desdobramento em um processo revolucionário gerou clivagens conflitivas, nas quais as ferramentas de luta camponesa ensinadas nos cursos, como greves e paralisações, se deslocam para fins mais ideológicos. No próximo capítulo analisarei essas batalhas durante governo da Unidade Popular.

Embora não haja evidências imediatas do uso dos aparelhos de capacitação nos processos eleitorais, é certo que as redes de confiança e amizade criada entre camponeses nos cursos e seus professores ampliavam como nunca a zona de contato entre o mundo camponês, o universo educacional e a política, e expandia também as redes de politização e mobilização. Para criar e fortalecer tais redes, o processo pedagógico era um elo fundamental. Se não pode haver verdadeira educação sem a formação de vínculos de confiança, tais vínculos se transformavam em ativos políticos atuantes nas correlações 
de forças. Isso não quer dizer que o FEES ou as confederações instrumentalizassem seus alunos camponeses para fins de campanha de maneira vulgar, mas que o processo social da educação era trabalho de base que rendia frutos e tinha consequências eleitorais.

Por fim, como busquei demonstrar, a ampliação das diferenças internas do campesinato também é um tema-chave desse processo. Tais diferenças se aprofundam com o processo de polarização política ao longo da revolução chilena do triênio 1970-1973. Mas antes disso, foi necessária uma massiva interação entre camponeses e educadores, que galvanizava e viabilizava a ruptura representada pela sindicalização e a consequente reconfiguração das relações de poder no campo. Educação sindical e formação política camponesa, luta de classes no campo e quebra de hierarquias foram processos sociais dinâmicos, imprevisíveis e entrelaçados. Como procurei narrar, nesse contexto, o FEES cumpria um papel extraordinário como agente intermediário entre campesinato e Estado, entre diferentes organizações sindicais do campesinato e, principalmente, como um agente de reparação histórica contra a exclusão dos trabalhadores rurais da educação e do poder, já que atuava pedagogicamente na transformação estrutural das relações sobre a terra e o trabalho agrícola. 


\section{Capítulo 7 - Unidade Popular e a reforma agrária: batalha da produção, batalhas da capacitação}

"O fundamento da capacitação é a efetiva participação camponesa nas decisões governamentais sobre as diferentes políticas agrárias".

- Salvador Allende, $1970^{828}$

"Minha capacidade veio nada mais que por sofrimentos, companheiros, não por ter estudos, nem por ter feito cursos de capacitação. (...) A capacitação da luta contra o momio e em benefício dos companheiros. Agora é a primeira vez que venho a um curso de capacitação e (...) estou aqui quase à força bruta”.

- Camponês em depoimento, $1972^{829}$

“As metas de produção (...) são as metas da capacitação".

- Solon Barraclough, $1973^{830}$

“Os programas de capacitação não serão um apoio ao processo de transição ao socialismo, enquanto sua planificação não se descentralize para as comunas rurais e não se transforme seu conteúdo e metodologia, para a qual a participação camponesa é imprescindível".

- Manuel Peñafiel e Klaus Bethke, 1973

"O grande fracasso da reforma agrária foi a falta de educação"

- Manuel Herrera, professor de camponeses, $\mathbf{2 0 1 7}^{\mathbf{8 3 2}}$

\subsection{Introdução}

Em agosto de 1970, José Campusano, dirigente camponês que havia presidido a Ranquil entre 1962 e 1968, visitou a casa de Luis Ibacache, inquilino de um latifúndio em Colchagua. Lá viviam 12 pessoas: 6 adultos, todos analfabetos, e mais seis crianças. Campusano era um experiente militante comunista e estava encarregado da campanha de Salvador Allende nas bases dos trabalhadores rurais. Percorreu por meses o país e dialogou com a população pobre do campo, apresentando o programa agrário da UP. "Em sucessivas reuniões convocadas por Jacques Chonchol, numerosos dirigentes camponeses elaboraram a estratégia agrícola (...) do governo da UP”, narrou em suas memórias (Campusano, 2013: 190). Além de articular as linhas políticas da cúpula da esquerda, ele cumpria o papel de costurar a estratégia com os camponeses dos mais diversos recantos do mundo rural. "Tínhamos a missão de

\footnotetext{
${ }^{828}$ Allende, 1970, p. 29-30.

${ }^{829}$ Revista Agraria, n. 5. Chile Hoy, n. 51, Maio/1973 e Gajardo, 1973c: 30.

830 "Hay que ponerse metas realistas". Entrevista a Solón Barraclough. Revista Agraria, n. 5. In: Chile Hoy, n. 51, Maio/1973.

${ }^{831}$ Manuel Peñafiel e Klaus Bethke. Capacitación: ¿Privilegio de la burocracia? Revista Agraria, n. 5. In. Chile Hoy, n. 51, Maio/1973.

${ }^{832}$ Entrevista com Manuel Herrera Castro, San Clemente, 27/05/2017.
} 
propor novos quadros que realizassem o trabalho nos lugares mais distantes do país", explicou. Uma das dificuldades que encontravam, contudo, era que "muitos camponeses não sabiam ler e escrever e, portanto, não estavam nos registros eleitorais, mesmo que simpatizassem com Allende" (Campusano, 2013: 191).

Por serem analfabetos, o inquilino Luis Ibacache, sua esposa Juanita e seus quatro filhos adultos eram desprovidos da cidadania eleitoral. 833 "Não perca tempo, companheiro", teria dito o trabalhador, "por ser escravo deste fundo, não podemos votar por Allende. Nenhum de nós está inscrito" (apud Campusano, 2013: 191). Naquela tarde de 1970, Ibacache relatou que na hacienda somente três trabalhadores votavam, sempre no candidato do patrão. Mas o dirigente da Ranquil tinha uma visão estratégica sobre o papel dos sujeitos analfabetos naquelas eleições: "Dom Lucho", respondeu, "você, sua mulher e seus filhos podem fazer um trabalho muito mais importante do que este que eu faço" (Campusano, 2013: 192). Propôs ao casal que pensassem em todos os parentes e amigos que tinham na região e organizassem um ato público, com carne assada, chicha e a presença de lideranças comunitárias. "Suas amizades valem muito mais que a dos patrões", argumentou o comunista, "você e sua família, especialmente a dona Juanita, vão conseguir a maioria dos votos deste setor. (...) Essa mesma conversa, vocês devem repetir em cada casa e multiplicar", instruiu (Campusano, 2013: 193).

Algumas semanas depois, uma carta de dom Lucho a Campusano o convidava para o evento de campanha no último domingo do mês. A lista inicial de 80 amigos e parentes dos Ibacache consolidouse em um ato público festivo com mais de 200 camponeses em apoio a Allende, incluindo eleitores históricos dos candidatos patronais. "Muitos atos semelhantes ocorreram", lembrou Campusano (2013: 194), "os ranchos camponeses se povoaram de cartazes com nome do Allende". Naquele instante, Luis e Juanita Ibacache comprovaram que, embora o analfabetismo os proibisse de votar, não os impedia de influenciar o voto da sua comunidade.

A participação política de analfabetos, rurais e urbanos, foi igualmente convocada pela UP por meio da canção popular e da nueva canción chilena, como no emblemático Canto al Programa (1970) interpretado por Inti-Illimani; ou nas 40 medidas cantadas (1971), do grupo Lonqui. ${ }^{834}$ A medida 24 dizia: "Reforma Agrária de Verdade. Aprofundaremos a reforma agrária, que beneficiará também a médios e pequenos agricultores, minifundistas, medieros, empleados e afuerinos. Estenderemos o crédito agrário. Asseguraremos mercado para a totalidade dos produtos agropecuários" (UP, 1970).

Compositores e músicos comprometidos com o programa da UP demonstravam ter consciência sobre a importância de dialogar com os pobres não letrados e convocá-los a apoiar Allende por meio da canção. Na abertura do Canto al Programa, ${ }^{835}$ um narrador se apresentava como Peyuco Pueblo e dizia:

\footnotetext{
${ }^{833} \mathrm{O}$ voto dos analfabetos foi aprovado como emenda constitucional nos últimos meses do governo Frei, mas não a tempo de ser garantido nas eleições de 1970. Estava previsto que a primeira participação eleitoral dos analfabetos ocorreria nas eleições presidenciais de 1976, que nunca aconteceu (Austin, 2003: 144).

${ }^{834}$ Natalia Schmiedecke (2017) analisou o papel da nueva canción na política cultural da revolução chilena.

${ }^{835}$ Canto al Programa (1970). Música: Sergio Ortega e Luis Advis. Letra: Julio Rojas. Narrador: Alberto Sendra. Interpretação: Inti-Illimani.
} 
Si me miran en el campo soy peón de cuerpo moreno.

Si me ven en la ciudad, puedo ser cualquier obrero.

Si me buscan en la costa, me encuentran en los pesqueros.

Si van a buscarme al norte, voy vestido de minero.

Así, desde norte a sur, aunque sea sin quererlo, me verán en todas partes, con el sudor en el cuerpo.

Peyuco Pueblo falava com linguagem e sotaque camponês, mas se identificava como um trabalhador múltiplo, que poderia estar em qualquer lugar do país, pronto a incentivar a cumplicidade entre diferentes frações da classe popular. Sua linguagem também evocava a matriz rural de toda classe trabalhadora chilena que, sendo mineira, industrial ou pescadora, provavelmente teria algum passado ou antepassado camponês. Entre as músicas programáticas anunciadas por Peyuco, estava a Canción de la reforma agrária, que dizia:

$$
\begin{aligned}
& \text { Con arados se despiertan } \\
& \text { Tierras que estaban dormidas } \\
& \text { Por eso hagamos, compadre, } \\
& \text { Las formas cooperativas. } \\
& \text { ¡Ya se acaba el latifundio! } \\
& \text { ¡El campo al que lo trabaja! } \\
& \text { ¡Se hace la reforma agraria! } \\
& \text { El momento es importante, } \\
& \text { Nadie se ponga delante. } \\
& \text { Y los técnicos agrarios } \\
& \text { Ya se ponen al servicio } \\
& \text { Del campesino chileno } \\
& \text { Que ha encontrado su destino. } \\
& \text { Con el pueblo en el gobierno } \\
& \text { Se descubren mil caminos } \\
& \text { Aceleran la reforma } \\
& \text { Los consejos campesinos. }
\end{aligned}
$$

Essa canção delineia, na forma e no conteúdo, alguns dos assuntos a serem analisados neste capítulo. Primeiro, a forma popular e oral de convocação camponesa à participação, e superava os obstáculos do analfabetismo, dava pistas de que a revolução chilena faria transbordar a gradual "integração camponesa" e a "capacitação social" para o âmbito do engajamento e do protagonismo das bases populares. Como o próprio Canto al Programa, a revolução chilena foi um processo dialógico massivo, no qual o fundamento da capacitação foi a participação. Em segundo lugar, a centralidade do 
programa agrário da UP estava posta em três eixos presentes na canção: o fim do latifúndio; o aumento da produção no setor reformado por meio da forma cooperativa, viabilizado pela interação virtuosa entre técnicos e trabalhadores rurais; e a luta popular organizada pelos conselhos camponeses, o novo organismo criado pelo governo Allende, em diálogo com dirigentes sindicais, para acelerar as transformações. A relação dos técnicos com os camponeses era um tema sensível, como alertava Paulo Freire em Extensión o Comunicación?, ainda em 1968. A canção trazia uma ênfase peculiar no fato de que os técnicos estariam "a serviço" dos camponeses, o que invertia as hierarquias estabelecidas do conhecimento produtivo, já um pouco estremecidas pela pedagogia do oprimido e potencialmente invertidas pelo processo revolucionário. Reforçar ou desequilibrar tais hierarquias, como vimos, eram forças opostas que atuavam de maneira concomitante no seio da capacitação camponesa, visíveis na tensão entre métodos pedagógicos tradicionais ou emancipadores presentes nos diferentes programas educacionais.

O incentivo de Campusano ao engajamento de camponeses analfabetos na campanha de 1970 era representativo de uma concepção ampliada da "participação camponesa", cujo desenvolvimento máximo conformava o "poder popular" da via chilena ao socialismo. Como mostram Winn (1986) e Cury (2017), a revolução chilena experimentou zonas de autonomia do protagonismo popular (a revolução desde abajo), junto com articulações entre movimentos, sindicatos, comunidades e governo; tanto quanto tensões entre tais autonomias e o governismo (a revolução desde arriba). Nesse caso específico, Campusano se posicionava como o articulador eleitoral dos debaixo com os de cima; ele não apenas convidou muitos camponeses a superar as inibições geradas pelo analfabetismo, como também os ajudou a demonstrar o valor que tinham nos destinos da sua comunidade e do país.

Havia uma disposição revolucionária da UP em superar a "promoção popular" para muito além de uma "integração dos marginalizados", substituindo as expressões-chave do programa da DC por outras, como luta de classes, poder popular, socialismo e revolução. Convocar a participação política dos analfabetos rurais invertia a lógica desenvolvimentista predominante, que entendia a educação como requisito da participação, inclusive das decisões econômicas da reforma agrária. A doutrina social-cristã da "integração", criticada pelas correntes marxistas e por Paulo Freire na época, ${ }^{836}$ havia revelado seu limite no processo lento e cauteloso de expropriações de terras no governo Frei. ${ }^{837}$ Tal lentidão decorria tanto dos compromissos da DC com a classe proprietária, como da visão cronológica sobre capacitarse (primeiro) e participar (depois). Tal cronologia eventualmente era invertida pela práxis pedagógica freiriana, tanto quanto pela maneira como a UP fez política nas bases camponesas, convidando os

\footnotetext{
${ }^{836} \mathrm{Na}$ Pedagogia do oprimido, Freire escreveu: "Os chamados marginalizados, que são os oprimidos, jamais estiveram fora de. Sempre estiveram dentro de. Dentro da estrutura que os transforma em 'seres para outro'. Sua solução, pois, não está em 'integrar-se', em 'incorporar-se' a esta estrutura que os oprime, mas em transformá-la para que possam fazer-se 'seres para si'” (Freire, 2018: 84-85). Para críticas à teoria da marginalidade aplicada pelo governo Frei, ver Pascal-Allende, 1971; Gajardo, 1973c; Garret, 1976; Freire, 2018; Marini, 2019, entre outros.

${ }^{837}$ Em 6anos, Frei expropriou 3,5 milhões de hectares de 1.408 propriedades. Em um ano e meio de governo, em junho de 1972, Allende já havia expropriado quase 5,3 milhões de hectares de 3.282 propriedades (Barraclough \& Fernández, 1974: 75).
} 
trabalhadores rurais a se capacitar por meio da luta. Por isso, a UP entrava em consonância com o sentimento de urgência dos camponeses: "não podemos esperar mais tramitações", ${ }^{838}$ diziam no círculo de cultura de Peralillo.

Ao propor uma filosofia da práxis, isto é, uma capacitação pela participação, a UP se conectava também com a valorização dos saberes camponeses advindos da sua experiência cotidiana de resistência. Em 1972, um camponês que participava de um curso da confederação Unidad ObreroCampesina escreveu: "minha capacidade veio nada mais que por sofrimentos, companheiros, não por ter estudos, nem por ter feito cursos de capacitação (...). A capacitação da luta contra o momio" ${ }^{839}$ Um recorte deste depoimento foi publicado na Revista Agrária do hebdomadário Chile Hoy, visível a seguir.

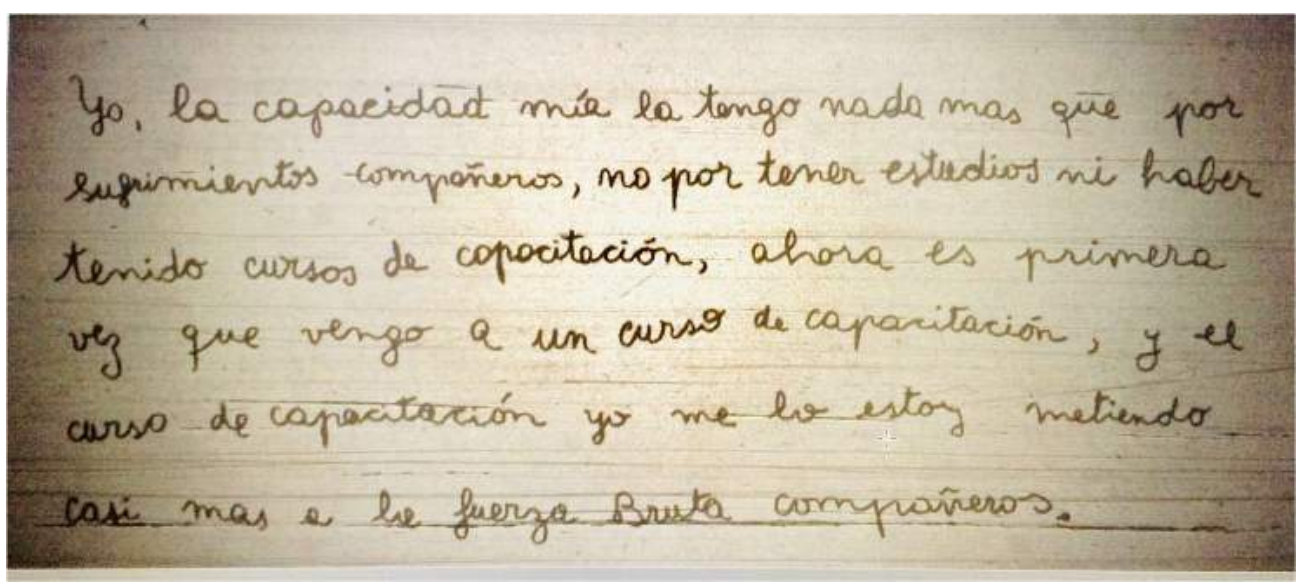

Depoimento camponês em curso de 1972. Fonte: Revista Agraria, n. 5. Chile Hoy, n. 51, Maio/1973.

Tendo tudo isso em vista, discutirei neste capítulo os seguintes temas: primeiro, o papel da mobilização camponesa na garantia do triunfo eleitoral de Allende; segundo, as novas políticas da UP para reforma agrária e suas relações com a capacitação; em terceiro, a nova política de capacitação camponesa da UP, com a formação do Comitê Técnico de Capacitação Nacional Camponesa (CTNC), seus cursos e desafios; e quarto, a relação entre a batalha da produção e a batalha da capacitação, ou seja, como os desafios da produtividade agrárias também se refletiam nos desafios da capacitação. Com isso, argumentarei que havia uma contradição entre a temporalidade econômica da revolução, que tinha pressa para garantir seu próprio processo de acumulação, e a temporalidade pedagógica da revolução, que demandava mais tempo para que o campesinato se convencesse da importância coletiva de aumentar sua autodisciplina laboral. Os estímulos materiais da reforma agrária, como será analisado, não favoreciam a produção coletiva: havia uma contradição entre o discurso da batalha da produção e os mecanismos concretos de sua realização. No entanto, a capacitação era um estímulo moral que poderia atuar no aumento da produtividade, contanto que o tempo econômico se articulasse ao tempo pedagógico. Com tudo isso, ainda não será esgotada a análise da capacitação camponesa durante o

\footnotetext{
${ }^{838}$ Apud Ferreira \& Barría, 1971. Ver capítulo 5.

${ }^{839}$ Gajardo, 1973c, p. 30.
} 
triênio da UP, que merecerá mais um capítulo sobre a alfabetização camponesa, a relação entre marxistas e Paulo Freire durante o triênio, e os conselhos camponeses.

\subsection{Unidade Popular e o voto camponês}

Quando os resultados eleitorais favoráveis a Allende foram anunciados, em setembro de 1970, uma grande inquietação tomou conta das elites econômicas, proprietários rurais e setores conservadores das classes médias. Como explicou Joan Garcés (1993: 41), assessor de Allende, o eleitorado camponês havia sido um elo fundamental dessa vitória, cuja distância em relação ao segundo colocado foi de apenas 39 mil votos $(1,3 \%$ do eleitorado $) .{ }^{840}$ Diferentes tentativas de golpe buscaram impedir que Allende tomasse posse ao longo dos 60 dias que transcorreram entre as eleições ( 4 de setembro) e a transição do poder (4 de novembro). Vários níveis de boicotes e manobras políticas foram articuladas pela CIA e a International Telephone and Telegraph (ITT) junto a ala direita da DC, fosse para orientar a vitória a Alessandri, fosse para impor novas eleições. ${ }^{841} \mathrm{O}$ Comitê Quarenta, grupo governamental/empresarial dos EUA para política externa, aprovou a liberação extraordinária de 250 mil dólares da CIA naqueles meses para que o então presidente Eduardo Frei garantisse que o Congresso votasse por Alessandri no segundo turno parlamentar (etapa estabelecida pela constituição chilena quando o primeiro colocado não obtivesse maioria absoluta). ${ }^{842}$ Foram diversas pressões militares, econômicas e psicológicas, promovidas pela articulação CIA-ITT-Frei para golpear Allende antes da posse.

Num cenário em que a UP possuía 38\% de deputados e 46\% de senadores (Garcés, 1993: 63), Allende dependia exclusivamente da ala esquerda da DC para fazer valer sua vitória, especialmente do acordo com Radomiro Tomic, que como candidato teve dificuldade de se diferenciar do allendismo. Naquele momento crítico, há um aspecto pouco iluminado pela historiografia: o campesinato ligado à DC cumpriu um papel fundamental de pressão popular em favor da posse do presidente socialista. Não porque se identificasse com a esquerda, mas porque sabiam o que a volta de um governo oligárquico representava para o futuro da reforma agrária. Essa contradição, Frei não pode evitar.

Entre setembro e outubro de 1970, diversas organizações camponesas dirigidas pela DC manifestaram seu apoio à posse de Allende, o que certamente teve algum peso nas dificuldades encontradas por Frei para viabilizar o plano CIA-ITT. A Federação de Assentamento de Linares, por

\footnotetext{
840 Joan Garcés (1993) explicou que os dados eleitorais de 1970 nas comunas agrárias de que dispunha foram "roubados no saque da minha biblioteca, que se deu logo após o golpe militar", não sendo possível reconstruí-los. Os dados históricos do SERVEL (Servicio Electoral de Chile) estão disponíveis somente a partir de 1989 e tampouco a Biblioteca do Congresso do Chile dispõe destas informações em detalhe.

${ }^{841}$ Ver capítulo "O plano ITT-CIA-Frei de 1970" (Garcés, 1993).

${ }^{842}$ Garcés (1993: 64-65) narra que: "O Comitê Quarenta, organismo governamental de maior autoridade em matéria de Segurança dos Estados Unidos autorizou a CIA a investir não menos que US\$ 11 milhões entre 1962 e 1970 para impedir que Allende fosse eleito presidente (...). Em uma reunião presidida por H. Kissinger, em 14 de setembro de 1970 (...) um extraordinário de US\$250 mil foi aprovado para o 'apoio clandestino dos projetos que Frei ou sua gente de confiança estimasse oportuno"”.
} 


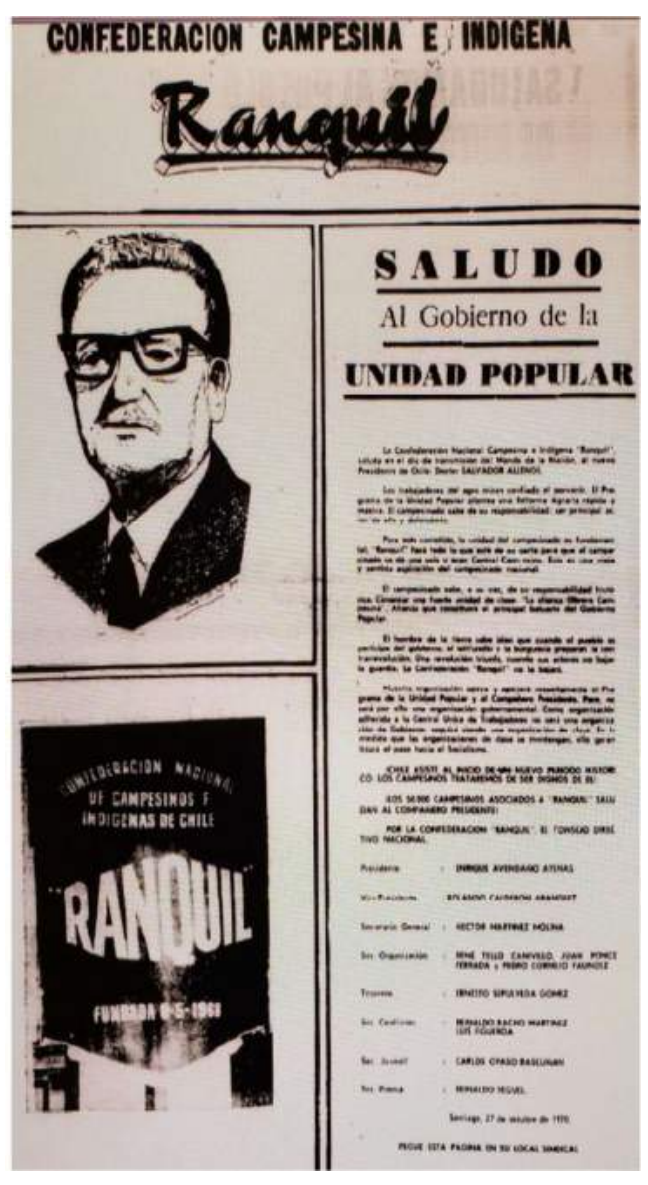

Ranquil saúda o triunfo de Allende. El Siglo, Nov./1970. exemplo, cuja direção de sete membros era composta por democrata-cristãos, declarou que "o setor camponês, antes postergado, respeitoso da vontade popular, exige respeito ao triunfo do candidato $d r$. Salvador Allende", além de fazer "um chamado a todas as organizações camponeses a que se pronunciem (...) para ratificar o dr. Salvador Allende como presidente". ${ }^{843}$ E completavam: "estamos à espera dos acontecimentos, caso o capitalismo fracassado queira arrebatar o triunfo dos trabalhadores". ${ }^{844}$ Em 8 de outubro, o Comitê Sindical da Sociedad Agrícola Ganadera Los Cerrillos decidiu por unanimidade "oferecer seu apoio incondicional e até as últimas consequências a nosso presidente eleito" 845 e declarou: "somos integrantes de um sindicato dirigido pela DC e apesar disso reconhecemos no companheiro Allende um verdadeiro representante dos anseios camponeses". 846 Enquanto as bases da Triunfo Campesino se movimentavam para proteger a vitória de Allende, a direção permaneceu calada.

Já o presidente da Confederação Libertad, Gustavo Díaz Fabre, menos de uma semana após as eleições se reuniu com o presidente da Ranquil, Enrique Avedaño, e reconheceu a vitória de Allende. O líder da Ranquil, com tom excessivamente otimista, comemorava: "os resultados das eleições demonstram, pela votação da UP nas comunas rurais, que esse importante setor compartilha plenamente as medidas propostas pela UP sobre a reforma agrária". 847 Enquanto isso, o dirigente da Libertad, historicamente ligada à Igreja, além de reconhecer Allende como novo presidente, alegava que "sempre se manifestaram para que as reservas [patronais] de terra sejam abolidas por completo", uma vez que "em todas as partes (...) se registram provocações dos latifundiários expropriados" e que "os camponeses vizinhos são verdadeiramente oprimidos pelo dono da propriedade ao lado" ${ }^{848}$ A Libertad se posicionou, naquele instante, em defesa de uma nova lei de reforma agrária que garantisse a maior

\footnotetext{
${ }^{843}$ Campesinos dicen: $63 \%$ de Chile votó por los cambios. El Siglo, Set/1970.

844 Id., ibid.

${ }^{845}$ Campesinos y obreros junto a la victoria del pueblo. El Siglo, Out/1970.

846 Id., ibid.

${ }^{847}$ Los campesinos debemos tomar las riendas del campo. El Siglo, set/1970. Grifo da autora.

848 Id., ibid.
} 
profundidade do processo expropriatório. Ambas as Confederações representavam mais de 100 mil camponeses. A Triunfo demorou a emitir sua opinião.

A assertividade dos partidos da UP para defender Allende nas bases, naquele momento, gerou frutos positivos entre os camponeses. Em Collipulli, foi criado um sindicato comunal em setembro, com mais de 200 presentes, presidido pelo comunista Manuel Castillo Curinao, que discursou: "o novo governo é o único capaz de levar adiante uma verdadeira e profunda reforma agrária, que entregue a terra aos que por gerações a fizeram produzir como servos". ${ }^{849} \mathrm{O}$ dirigente convocava os presentes a "cerrar fileiras junto ao governo popular e deter qualquer manobra dos momios". 850 Em outubro, a Confederação de Pequenos Agricultores declarou apoio ao novo governo e apresentou uma carta de demandas: "viemos dizer ao presidente eleito que terá nossa colaboração para produzir mais e melhor. Somos capazes de solucionar qualquer tipo de crise de alimentos. Há 300 mil famílias catalogados no Chile como pequenos agricultores", ${ }^{851}$ afirmaram. Poucos dias depois, 16 organizações camponesas anunciaram de maneira unificada seu apoio contundente à posse de Allende junto a uma lista de demandas para aceleração da reforma. Entre elas, oito Federações de Assentamentos dirigidas pela DC (Arauco, Linares-Maule, Talca, O’Higgins, Aconcágua, Colchagua, Valparaíso, Curicó). ${ }^{852}$ Pressionado pela base, Enrique Mellado, presidente da Triunfo Campesino, declarou no fim de outubro que "desde o primeiro momento reconheceram o triunfo de Salvador Allende". 853

Em 1973, José Bengoa publicou um artigo na Revista Agrária (Chile Hoy) sobre o voto camponês entre 1970 e 1973, em quatro pleitos: as eleições presidenciais (set./1970), municipais (abril/1971), complementares (jan./1972) e parlamentares (mar./1973). O pesquisador selecionou 17 comunas rurais com quatro perfis: o primeiro tipo, eram comunas com predomínio do setor reformado e reservas patronais de $80 \mathrm{HRB}$ (antigo predomínio do latifúndio), cuja produção era exportadora e também abastecia o mercado interno; o segundo tipo, eram comunas com predomínio da média propriedade entre 20 e $80 \mathrm{HRB}$, onde não houve reforma agrária, cuja produção se direcionava à subsistência e ao mercado nacional; o terceiro tipo, com predomínio da pequena propriedade (entre 5 e $20 \mathrm{HRB}$ ), produção para subsistência e pequeno comércio local; e o quarto tipo, com predomínio de minifúndios menores que $5 \mathrm{HRB}$ e baixa produtividade ${ }^{854} \mathrm{~A}$ polarização entre UP e oposição nesses quatro tipos de comuna rural nas quatro eleições mencionadas, podem ser visualizadas na tabela $26 .^{855}$

\footnotetext{
${ }^{849}$ Campesinos de Collipulli formaron sindicato comunal. Defienden el triunfo popular. El Siglo, Set./1970.

${ }^{850}$ Id., ibid.

${ }^{851}$ Pequeños agricultores ofrecemos apoyo al gobierno popular El Siglo, Out./1970.

${ }^{852}$ Llevar adelante sin vacilaciones el proceso de reforma agraria. Acuerdo entre máximos dirigentes campesinos y Salvador Allende. El Siglo, Out./1970.

${ }^{853}$ Triunfo Campesino refuta cargos de publicaciones. El Siglo, Out./1970.

${ }^{854}$ As comunas rurais de tipo 1 eram Peumo e Requinoa (O'Higgins), Palmilla e Peralillo (Colchagua) e Longaví (Linares). As comunas rurais de tipo 2: Quinita de Tilcoco (O’Higgins), Lolol, La Estrella e Nancagua (Colchagua). Tipo (3): Las Cabras e Olivar (O’Higgins), Pumanque e Rosario Lo Solis (Colchagua). Tipo 4: Malloa (O’Higgins), Paredones e Pichilemu (Colchagua), Colbun (Linares). Ver José Bengoa, Las elecciones en el campo. Revista Agraria, n. 4. In: Chile Hoy, n. 44, Abr/1973.

855 Os votos da oposição correspondem a DC e PN somados em 1970 e 1971; depois coligados como Confederação da Democracia (CODE) em 1972 e 1973.
} 


\begin{tabular}{|c|c|c|c|c|c|c|}
\hline \multicolumn{6}{|c|}{ Tabela 26 - Votos em Comunas Rurais por Tipo, 1970-1973 (\%) } \\
\hline \multirow{2}{*}{ Eleições } & Tipo 1 & Tipo 2 & Tipo 3 & Tipo 4 & Média \\
\hline \multirow{2}{*}{1970} & UP & 32,2 & 24,8 & 23,8 & 26,5 & 26,8 \\
\cline { 2 - 7 } & PN+DC & 69 & 72,8 & 75,8 & 72,8 & 72,6 \\
\hline \multirow{2}{*}{1971} & UP & 44,4 & 44 & 29,2 & 44 & 40,4 \\
\cline { 2 - 7 } & PN+DC & 54,6 & 56,3 & 62,5 & 55 & 57,1 \\
\hline \multirow{2}{*}{1972} & UP & 43,8 & 36 & 33,8 & 37,5 & 37,8 \\
\cline { 2 - 7 } & CODE & 55,4 & 63 & 65,5 & 61,8 & 61,4 \\
\hline \multirow{2}{1973}{} & UP & 46,8 & 38,3 & 33,3 & 38 & 39,1 \\
\cline { 2 - 7 } & CODE & 52,4 & 60,8 & 65,3 & 61 & 59,9 \\
\hline \multirow{2}{*}{$\begin{array}{c}\text { Média 1970- } \\
1973\end{array}$} & UP & 41,8 & 35,8 & 31,8 & 36,5 & 36,5 \\
\cline { 2 - 7 } & PN+DC & 57,9 & 63,2 & 67,3 & 62,6 & 62,7 \\
\hline Elaboração própria com base em Revista Agraria, n. 4. In: Chile Hoy, n. 44, Abr/1973. \\
\hline
\end{tabular}

A UP obteve melhor desempenho médio nas comunas tipo 1 (com predomínio do setor reformado, territórios das expropriações), mas é visível que o apoio camponês à esquerda cresceu em todos os tipos de comunas rurais durante o triênio da UP, em média de 26\% (1970) para 39\% (1973). Enquanto isso, a soma de votos da DC e do PN, durante o mesmo período nas mesmas comunas rurais, caiu de 72,6\% para 59,9\%. Se bem a UP ainda não lograva representar uma maioria eleitoral absoluta nas comunas rurais selecionadas, também é certo que a disputa política nestes territórios tendia nitidamente ao crescimento do apoio camponês ao governo, pois a UP consolidou uma marca 10\% maior que seu "terço" inicial do eleitorado. De modo geral, o apoio camponês à UP foi mais forte nas comunas rurais de tipo 1 (setor reformado), em seguida nas comunas rurais de tipo 2 (médias propriedades, entre $20 \mathrm{e}$ $80 \mathrm{HRB}$ ) e 4 (minifúndios); e menor nas comunas tipo 3 (pequenas propriedades, entre 5 e $20 \mathrm{HRB}$ ), onde o campesinato não era beneficiário da reforma agrária e ainda bastante vulnerável às pressões dos grandes proprietários. No nível do detalhe, se desagregamos o comportamento eleitoral entre as comunas de mesmo tipo, também existiam disparidades, ${ }^{856}$ o que evidencia que o engajamento político camponês era heterogêneo e estava longe de obedecer a uma lógica linear da relação entre formas de propriedade, estratificação camponesa e preferência ideológica.

Num primeiro momento, como vimos, Allende obteve forte apoio das bases camponesas da DC, não apenas para garantir sua posse, mas também para uma reforma agrária contundente. Ao longo de três anos de governo, o voto camponês ampliou sua opção pela esquerda, sem que isso fosse suficiente para obter maioria absoluta ou para neutralizar a agitação anti-UP feita por setores camponeses orgânicos à oposição. Nesse sentido, entre 1970 e 1973, a relação entre UP e campesinato foi estremecida pelas batalhas ideológicas acirradas em torno da política agrária da via chilena ao

${ }^{856}$ Por exemplo, nas comunas de tipo 3, onde a UP teve pior desempenho, havia grande diferença interna. Em Quinita de Tilcoco, a UP obteve $31 \%$ nas presidenciais de 1970 e $66 \%$ nas parlamentares de 1971; enquanto em Lolol, respectivamente 13\% e 31\%; em La Estrella, 14\% e 22\%; e em Nancagua, 41\% e 57\%. Eram províncias de mesmo tipo. 
socialismo. Como veremos, no decorrer do triênio, o governo popular nunca deixou de convidar as organizações camponesas da oposição ao diálogo, de escutar suas demandas, incorporar seus dirigentes em organismos amplos (como o CTNC) e buscar pactos. A proposta de capacitação camponesa da UP foi, nesse sentido, atravessada pelo turbilhão do processo revolucionário de maneira paradoxal: ao mesmo tempo que a participação camponesa (na produção, nas lutas e no poder) passou a ser encarada como parte do processo capacitador, a própria capacitação se mostrou insuficiente para garantir uma comunicação transparente e contínua entre governo e campesinato. Ao fim e ao cabo, a política de capacitação camponesa da UP se transformou em uma ferramenta fundamental, mas insuficiente, para combater as cortinas de fumaça das campanhas ideológicas anticomunistas que penetravam especialmente entre os assentados.

\subsection{Política agrária da Unidade Popular: três dilemas desafiam a capacitação}

A política da UP para a reforma agrária foi inovadora em diversos aspectos, dos quais destaco três eixos estratégicos: a aceleração das expropriações até a completa eliminação do latifúndio e esgotamento das possibilidades legais em junho de 1972; a criação de novas formas de propriedade no setor reformado, os Centros de Reforma Agrária (CERA) e os Centros de Produção (CEPRO); e a criação dos conselhos campesinos em nível comunal, provincial e nacional. Para implementar tais mudanças e favorecer um sistema misto de planificação produtiva entre Estado e campesinato, iniciouse uma reorganização territorial das instituições do agro, o que afetou diretamente as diretrizes da capacitação camponesa. Cada uma dessas políticas, contudo, foi desencadeada com métodos diferentes e em momentos não coincidentes, e originaram focos próprios de apoio entusiasmado ou desgaste entre trabalhadores rurais e governo.

$\mathrm{Na}$ caracterização oficial da UP, era preciso transformar a reforma agrária capitalista de Frei em uma revolução agrária da via chilena ao socialismo. Na prática, era consensual que isso se materializasse na aceleração das expropriações; no aumento da produtividade do setor reformado; na criação de novas formas de propriedade camponesa coletiva, que incluíssem mulheres, indígenas e afuerinos com direitos iguais aos homens, winkas e inquilinos; na priorização das cooperativas de reforma agrária com relação à parcela individual; na criação de propriedades estatais; e na criação de um sistema de conselhos camponeses, ferramenta dos trabalhadores rurais para unificar suas demandas e construir poder popular. As ênfases e a operacionalização política desse consenso, como avaliou Manuel Barrera, encontrou diversos obstáculos: "apesar do programa agrário emanar acordos táticos entre os partidos da UP, a sua implementação prática evidenciou mais claramente as posições divergentes dos partidos" (Barrera, 1973: 225)

Os imbróglios do debate interno da Comissão Nacional Agrária da UP dificultaram um anúncio simultâneo e cristalino desses três eixos estratégicos. Antes de entrar no mérito de como os três eixos se relacionavam com a capacitação, a ordem em que as políticas e polêmicas apareceram foi a seguinte. 
Primeiro, em novembro de 1970, foram anunciados os conselhos camponeses. Após um diálogo aberto com todas as confederações, o decreto dos conselhos foi firmado em 21 de dezembro de 1970. Segundo, vieram as novas formas de propriedade do setor reformado (CERA/CEPRO), anunciadas em setembro de 1971, após um ano de debates internos. Os decretos do Centro de Reforma Agrária (CERA) e dos Centros de Produção (CEPRO) deram à oposição uma oportunidade de disseminar a falsa ideia de que a UP não entregaria a terra efetivamente aos camponeses, como prometido, mas sim criaria fazendas estatais. $^{857}$ E terceiro, em junho 1972, a UP anunciou o fim do latifúndio e o esgotamento das expropriações da lei de reforma agrária, o que deu início ao dilema interno sobre como avançar em direção à socialização e a necessidade de uma nova lei de reforma agrária. Cada uma dessas três políticas ocorreu com ritmo próprio e com estratégias de comunicação polifônicas, nem sempre coordenadas com a capacitação camponesa. Por isso, antes de analisarmos os caminhos da política de capacitação da UP, parece-me necessário explicar o contexto dessas políticas e os desafios agrários da revolução chilena. Afinal, era no contexto desses desafios que a capacitação se desenrolava.

\section{A aceleração das expropriaç̃̃es}

Entre setembro de 1970, o ministro da agricultura Jacques Chonchol explicou a política agrária do novo governo aos veículos de imprensa e afirmou: "já temos uma lei de reforma agrária. Não é necessário criar uma nova", ${ }^{858} \mathrm{em}$ sintonia com o comunista David Baytelman que, ao assumir a CORA, disse que "a lei de reforma agraria existente permite fazer as transformações fundamentais no campo". ${ }^{859}$ O próprio Chonchol, no entanto, enunciava que a reserva patronal de $80 \mathrm{HRB}$ era um problema, pois fortalecia o latifúndio e emperrava o processo de mudanças: "isso sem dúvida deve ser modificado", 860 declarou, o que implicava mudar a lei. A esquerda radical, dentro e fora da UP, alertava que não se devia demorar a reduzir o limite máximo da propriedade privada de 80 para $40 \mathrm{HRB}$, abolir a reserva patronal e expropriar os bens de capital, do contrário a própria reforma agrária alimentaria $\mathrm{o}$ setor econômico que frearia a revolução chilena, composto por uma média burguesia agrária ultracapitalizada. E para isso era necessário modificar a lei.

O agrônomo Jorge Echeñique, da comissão agrária do MAPU, era um dos que alertava que a lei 16.640 fortalecia a média burguesia. ${ }^{861} \mathrm{Em}$ razão do coeficiente de conversão entre hectares físicos e hectares de riego básico, algumas reservas patronais alcançavam 360 hectares físicos, além de reter os bens de capital. Em Cautín, onde centenas de comunidades indígenas se organizavam pela recuperação das terras usurpadas, as reservas patronais de 340 hectares físicos geravam incompreensão e indignação (Steenland, 1977: 229). Para setores da esquerda, as reservas ameaçavam o projeto

\footnotetext{
${ }^{857}$ Diario de Sesiones, Cámara de Diputados, Legislatura Ordinaria, Sesión 30a , 01/09/1971, p. 2737-2836.

${ }^{858}$ Chonchol explica nueva reforma agraria, El Siglo. Set/1970.

859 "Reforma agraria rápida y profunda", anunció Baytelman, nuevo vice de la CORA. El siglo, Nov./1970.

${ }^{860}$ Chonchol explica nueva reforma agraria, El Siglo. Set/1970.

${ }^{861}$ Jorge Echeñique. La batalla contra el latifundio. Revista Agraria, n. 1. Chile Hoy, n. 25, Dez/1972. E Alaluf et.al., 1972.
} 
socialista, argumento compartilhado por pesquisadores militantes como Arroyo (1972), Gómez (1973) e Kay (1976). Segundo mapeamento de Ian Roxborough (1974), a posição dos partidos da esquerda com relação à política de expropriações e ao tamanho da propriedade privada se dividia como mostra a tabela 27.

\begin{tabular}{|c|c|c|c|c|c|}
\hline \multicolumn{5}{|c|}{ Tabela 27 - Posições dos partidos políticos de esquerda frente às expropriações } \\
\hline Partido & $\begin{array}{c}\text { Necessidade } \\
\text { imediata de } \\
\text { uma nova lei }\end{array}$ & $\begin{array}{c}\text { Setor } \\
\text { privado de } \\
\mathbf{4 0} \text { a 80 HRB }\end{array}$ & $\begin{array}{c}\text { Setor privado } \\
\text { de 20 a 40 } \\
\text { HRB }\end{array}$ & $\begin{array}{c}\text { Reserva } \\
\text { patronal com } \\
\text { bens de capital }\end{array}$ & Indenizações \\
\hline PC & Não & Aliados na batalha da produção & Mantida & Manter \\
\hline PS & Sim & $\begin{array}{c}\text { Expropriar } \\
\text { por tamanho }\end{array}$ & $\begin{array}{c}\text { Expropriar se } \\
\text { mal explorada }\end{array}$ & $\begin{array}{c}\text { Só para } \\
\text { proprietários } \\
\text { produtivos }\end{array}$ & Eliminar \\
\hline MAPU & Sim & Expropriar & Não expropriar & Expropriar & Manter \\
\hline MIR & Sim & Expropriar & Caso a caso & Expropriar & Eliminar \\
\hline \multicolumn{7}{|r|}{} \\
\hline
\end{tabular}

Embora com posições diferentes, no começo do governo, os partidos da esquerda confluíram com as demandas camponesas ao acelerar o processo expropriatório. Entre novembro e dezembro de 1970, Baytelman se reuniu com centenas de camponeses e garantiu que a CORA tomaria posse de todas as terras expropriadas pelo governo anterior, que ainda não estavam sob controle camponês, emperradas em "tramitações" nos tribunais agrários, quando proprietários questionavam o valor das indenizações ou o tamanho das reservas. ${ }^{862} \mathrm{O}$ diretor da CORA anunciou que seriam 3 mil propriedades expropriadas no governo de Allende, o que se cumpriu mais rápido que o previsto, pois em junho de 1972 já eram 3.282 propriedades expropriadas pela lei (Barraclough \& Fernández, 1974: 75).

A aceleração da reforma agrária foi impulsionada debaixo para cima pelas tomas. Em Cautín, uma onda de corridas de cerco e tomas entre 1970 e 1971 ficou conhecida como Cautinazo, promovida por camponeses e mapuches independentes ou organizados no Movimento Campesino Revolucionário (MCR). ${ }^{863}$ As corridas de cerco foram ações noturnas de deslocamento das cercas das propriedades privadas localizadas em terras usurpadas dos indígenas. Gustavo Marín, estudante e dirigente do MIR em Lautaro que participou das corridas, lembrou que cada macieira antiga dentro de uma propriedade privada era vista pelos indígenas como marco do seu território, plantadas no centro das aldeias ancestrais, que usavam as maçãs para chicha. Muito mais efetivas do que as macieiras, eram os títulos de propriedade das reduções invadidas, guardadas como um tesouro pela maioria das comunidades indígenas, mas ignoradas pelas instituições, até a eleição de Allende (Correa, Molina \& Yáñez, 2005). Em setembro de 1970, depois da onda de mais de 30 corridas de cerco, em uma reunião com cerca de 70 pessoas no subterrâneo da Igreja Metodista de Temuco, líderes miristas e indígenas desenvolveram

\footnotetext{
862 Campesinos asumirán control de 155 fundos expropiados por CORA a partir de la próxima semana. El Siglo, Nov/1970. 863 O cautinazo e a reforma agrária na Araucanía foram temas pesquisados por Saavedra (1972), Cantoni (1972b), Berdichewsky (1977), Mallon (2004), Correa, Molina \& Yáñez (2005), Suazo (2013), Redondo (2017) e Navarrete Vergara (2018), entre outros.
} 
o Manifesto do MCR. ${ }^{864}$ Ao solicitar o espaço para o pastor Helmuth Knatt, o militante Victor Gavilán alegou a realização de um curso de capacitação (Suazo, 2013: 197), o que não deixava de ser coerente com a dialética capacitação/participação.

A insurreição indígena e camponesa de Cautín e a crescente tensão com a classe proprietária local fez com que Chonchol deslocasse o Ministério da Agricultura a Temuco durante os meses de janeiro e fevereiro de 1971. "Os camponeses sofrem com uma urgência que é necessário satisfazer", 865 afirmou. Em dezembro, La Nación contabilizava mais de 50 propriedades tomadas em Cautín, que parecia à beira de um enfrentamento armado. ${ }^{866}$ Uma das tomas era na propriedade do deputado da DC, Jorge Exequiel Lavanderos. Concomitante ao II Congresso Mapuche, que aglutinou de mais de 250 comunidades indígenas pela recuperação das terras, "no âmbito da UP, foram constituídas 16 equipes técnicas para convidar os trabalhadores ao diálogo" e "evitar que a ação camponesa e indígena seja aproveitada pelos extremistas de direita" ${ }^{867}$ Rolando Pinto Contreras, educador de camponeses formado por Paulo Freire em 1966, havia sido convidado por Chonchol para chefiar o recém-criado Comitê Técnico Nacional de Capacitação Camponesa (CTNC) e viajou a Temuco para compor as equipes de diálogo da UP.

Rolando Pinto conta que Chonchol pretendia "dar um sentido político à escuta do setor mapuche" $\$ 68$, e para isso criou um "conselho da reforma agrária" em Lautaro, ou seja, um fórum de diálogo entre governo e participantes das tomas. "Estava tudo tomado, era uma grande luta mapuche", recordou o pedagogo: "eles cortavam a cabeça de touros reprodutores e encaixavam em um pau na entrada da propriedade, rodeada por bandeiras mapuche, que simbolizavam a destruição do poder winka". ${ }^{869} \mathrm{O}$ diálogo horizontal, base da pedagogia freiriana, foi naquele momento o método do governo para escutar as demandas mapuches. Nada melhor que criar equipes com freirianos en terreno. Nesse intuito, Rolando Pinto e outros cinco dirigentes ministeriais foram enviados a conversar com lideranças indígenas em Lautaro. De lá, porém, não voltaram: "os líderes mapuche nem nos deixaram falar, nos agarraram, nos levaram como reféns para uma toma". ${ }^{870} \mathrm{O}$ mapucista Rolando Pinto e seus colegas da UP ficaram presos na bodega do latifúndio ocupado, bem tratados e bem alimentados. Os indígenas exigiram: "não queremos Jacques Chonchol, queremos Allende".

\footnotetext{
${ }^{864}$ Entrevista com Gustavo Marín, Santiago, 20/04/2017.

${ }^{865}$ A Temuco se irá el Ministerio de Agricultura. La Nación. Dic/1970; Nuevo enfoque dará el gobierno de la UP al problema de mapuches. La Nación, Dez/1970.

${ }^{866}$ Extremistas de derecha buscan enfrentamiento armado en Cautín. La Nación, Dez/1970.

${ }^{867}$ Dicen indígenas a diputado Lavandero: “Momio, ¡devuélvenos nuestras tierras!". La Nación, Dez/1970.

${ }^{868}$ Entrevista com Rolando Pinto Contreras, Santiago, 11/12/2018.

${ }^{869}$ Id., íbid.

${ }^{870}$ Id., ibid.
} 
O presidente chegou quatro dias depois em Temuco para o fechamento do Congresso Mapuche e só então liberaram os reféns das "equipes de diálogo". Como apoiava as tomas, Rolando Pinto foi um refém otimista. Com o trabalho de Chonchol, Allende e as equipes de diálogo formadas pela UP, o governo conseguiu contornar a tensão e atender a demanda camponesa nos marcos da via chilena ao socialismo, ao "legalizar" a rebelião popular, respaldando cada toma dentro das causas de expropriação previstas na lei. O Cautinazo foi um dos momentos em que a revolução desde abajo e a revolução desde arriba se fortaleceram mutuamente.

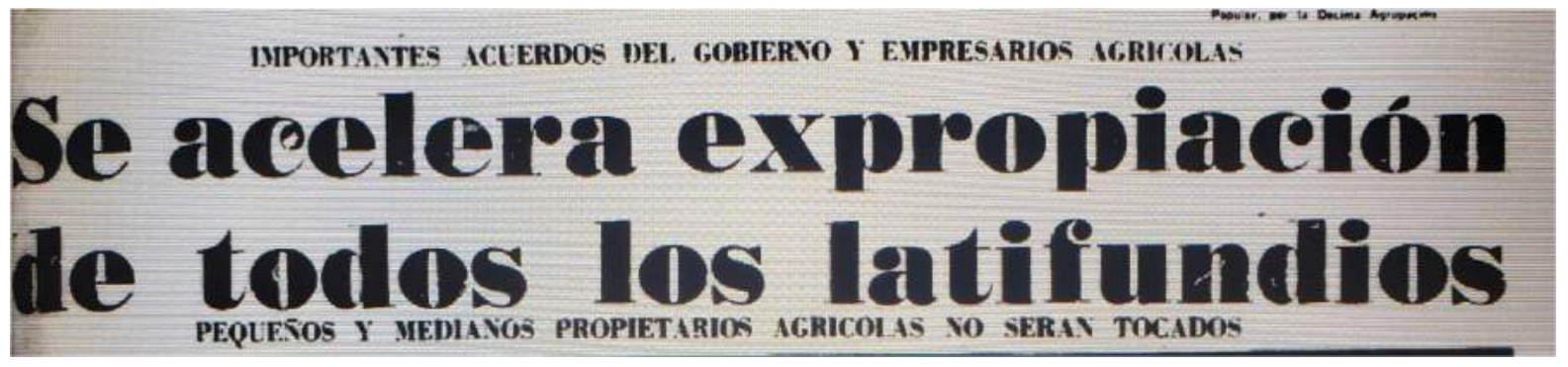

A imprensa comunista assegurava que pequenos e médios não seriam “tocados”. El Siglo, 16/02/1971.

Naquele período, tomas também aconteceram em Ñuble. O jornal La Segunda, da oposição, denunciou "caos e violência" da província, e Baytelman (CORA) se deslocou para região para averiguar 8 ocupações: 6 em propriedades hipotecadas por sonegação de impostos, que já estavam praticamente sob controle do Banco de Estado, e 2 por descumprimento patronal da ata de conciliação [acta de avenimiento] da Inspetoria do Trabalho. Baytelman, que adotava uma linha crítica às tomas pelo PC, deu razão aos ocupantes, mas alertou: "modestamente peço aos camponeses que cuidem destas propriedades, que são patrimônio de todos os chilenos". ${ }^{871} \mathrm{O}$ artigo 171 da reforma agrária permitia ao Estado nomear interventores em propriedades com conflitos não solucionados pela Direção do Trabalho, o que foi feito. Em seguida, Baytelman se reuniu com dirigentes das três confederações e prometeu que as prioridades de expropriação seriam definidas pelos próprios camponeses, assim como as terras das reservas, já que os patrões sempre ficavam com as mais férteis, o que prejudicava os assentamentos. ${ }^{872}$ Conforme o processo expropriatório se acelerava, se agigantava a demanda por capacitação camponesa do setor reformado.

\section{Desafios do setor reformado}

Sobre as formas de propriedade do setor reformado houve anúncios imediatos, porém incompletos, do governo popular. Segundo as diretrizes da Comissão Agrária da UP de outubro de

\footnotetext{
${ }^{871}$ Baytelman: campesinos participaran realmente en la reforma agraria. El Siglo, Nov./1970.

${ }^{872}$ Id., ibid.
} 
1970, seriam "três tipos de propriedade: estatal, cooperativa e privada", ${ }^{873} \mathrm{com}$ forte prioridade às cooperativas mistas de reforma agrária: propriedade coletivas com "a casa e o goce ou huerto (...) garantidos como propriedade individual". ${ }^{874}$ A prioridade da cooperativa mista foi confirmada por Chonchol: "o grosso da agricultura vai estar nas mãos das cooperativas de camponeses, com propriedade familiar do huerto e da casa. (...) Em certos casos pode ser individual, mas a preferência, como indica o programa, é a propriedade cooperativa". ${ }^{875}$ No plano das formas transitórias de propriedade, que duravam entre 3 e 5 anos antes de se consolidar a titulação, o governo popular anunciou que os CERA substituiriam os assentamentos em setembro de 1971. À diferença dos assentamentos, os CERA incluíam mulheres e afuerinos como beneficiários da reforma, agrupava unidades expropriadas em territórios maiores (em nome de uma nova racionalidade da planificação), restringia o tamanho do huerto (considerado cada vez mais um adversário ao aumento da produtividade coletiva), e criava um fundo coletivo de excedentes para o desenvolvimento comunal. Muitas dessas medidas não agradaram aos assentados. Um dos primeiros CERA criados em 1971 foi chamado de Fidel Castro, em meio à visita do líder cubano pelo Chile, e seria dirigido por Luz Escalona, uma mulher camponesa, mãe de 7 filhos, o que invertia as usuais hierarquias de gênero da reforma agrária até ali. ${ }^{876}$

Em setembro de 1971, Chonchol foi ao Congresso e participou de uma longa sessão parlamentar sobre o CERA e o CEPRO, fortemente criticados por políticos da DC e PN. ${ }^{877} \mathrm{O}$ anúncio gerou polêmicas entre governo popular e campesinato, especialmente a Confederação de Assentamentos, que ao longo do triênio foi se inclinando ao golpismo e utilizando o CERA como objeto de agitação política contra Allende e Chonchol. A UP não conseguiu estabelecer uma comunicação fluente com a classe camponesa sobre os CERA, interpretados como uma tentativa de eliminação dos goces internos ao assentamento, o que acabou abrindo um flanco de hostilidade contra o governo. A rejeição de setores do campesinato ao novo formato de propriedade reformada deu origem aos Comitês, uma mediação prática entre assentamento e CERAs. As diferenças entre as propriedades transitórias da reforma agrária estão resumidas na tabela 28.

\footnotetext{
${ }^{873}$ Pequeños y medianos agricultores no serán expropiados por la CORA. El Siglo, Out./1970. A proposta das três formas de propriedade agrária foi confirmada pelo dirigente sindical e ex-deputado Bernardo Araya no Pleno do Partido Comunista de novembro de 1970. Sobre as cooperativas, enfatizou: "o goce ou huerto é propriedade individual de cada grupo familiar". Ver: Plena participación de los campesinos en el desarrollo de la producción. El Siglo, Nov./1970.

${ }^{874}$ Idem.

875 Chonchol explica nueva reforma agraria, El Siglo. Set/1970

${ }^{876}$ Madre de siete hijos preside CERA "Fidel Castro". El Siglo, 14/11/1971.

${ }^{877}$ Diario de Sesiones, Cámara de Diputados, Legislatura Ordinaria, Sesión 30a , 01/09/1971, pp. 2737-2836. No dia 3, ocorreu a primeira aparição do termo CERA no El Siglo: “Apoyamos creación de los CERA”. El Siglo, 03/09/1971.
} 


\begin{tabular}{|c|c|c|c|}
\hline \multicolumn{4}{|c|}{ Tabela 28 - Diferenças entre propriedades transitórias do setor reformado } \\
\hline & $\begin{array}{c}\text { Assentamento } \\
\text { (lei 16.640 de 1967) }\end{array}$ & $\begin{array}{c}\text { CERA } \\
\text { (decreto ministerial, 1971) }\end{array}$ & $\begin{array}{l}\text { Comitê Camponês } \\
\text { (mediação prática) }\end{array}$ \\
\hline $\begin{array}{c}\text { Participação nas } \\
\text { decisões }\end{array}$ & Chefes de família & $\begin{array}{c}\text { Homens e mulheres } \\
\text { assentados }\end{array}$ & $\begin{array}{c}\text { Homens casados ou } \\
\text { solteiros }\end{array}$ \\
\hline $\begin{array}{c}\text { Organização } \\
\text { estrutural }\end{array}$ & $\begin{array}{c}\text { Simples: assembleia e } \\
\text { direção }\end{array}$ & $\begin{array}{l}\text { Complexa: assembleia, } \\
\text { comitês, equipes }\end{array}$ & $\begin{array}{l}\text { Simples: assembleia } \\
\text { e direção }\end{array}$ \\
\hline $\begin{array}{c}\text { Goces individuais } \\
\text { e pastagem }\end{array}$ & Definidos internamente & $\begin{array}{c}\text { Limitados pela CORA a } 1 / 2 \\
\text { ha por pessoa }\end{array}$ & $\begin{array}{c}\text { Definidos } \\
\text { internamente }\end{array}$ \\
\hline $\begin{array}{c}\text { Anticipo ou } \\
\text { adelanto }\end{array}$ & Remuneração igual & $\begin{array}{c}\text { Incentivos diferenciados } \\
\text { por trabalho }\end{array}$ & Remuneração igual \\
\hline Lucros & Integral dos assentados & $\begin{array}{c}\text { Fundo excedente para } \\
\text { comuna }\end{array}$ & $\begin{array}{c}\text { Integral dos } \\
\text { assentados }\end{array}$ \\
\hline Tamanho & Fazenda expropriada & $\begin{array}{c}\text { Agrupamento de fazendas } \\
\text { expropriadas }\end{array}$ & Fazenda expropriada \\
\hline $\begin{array}{l}\text { Unidades criadas } \\
\text { em } 1971 \text { e } n^{0} \text { de } \\
\text { famílias }(*)\end{array}$ & 25 CERA, 1060 famílias & 10 CEPRO, 697 famílias & $\begin{array}{l}628 \text { Comitês, } 12.611 \\
\text { famílias }\end{array}$ \\
\hline
\end{tabular}

Elaboração própria com base em Roxborough, 1977: 286 e (*) Barrera, 1973: 232

Junto com os CERA, em setembro de 1971, foram criados os CEPRO, haciendas estatais com trabalhadores assalariados, mas em número reduzido e localizadas sobretudo nas estâncias pecuárias de Magallanes. A hacienda estatal, até então inexistente na lei de reforma agrária, era considerada pela Comissão Agrária da UP como uma empresa "com objetivo de servir de modelo", porque "demonstrará as vantagens da exploração de larga escala, do emprego de técnicas modernas e da especialização da produção". ${ }^{878}$ Mas a estatização da terra, assegurou Chonchol, chegaria apenas "a certos setores industriais" e "granjas experimentais". 879

No início, a maioria da UP parecia concordar com a anunciada priorização das cooperativas mistas, um caminho autogestionário para agricultura socialista, coerente com o slogan "a terra para quem a trabalha". Porém, alguns setores se inclinavam à estatização plena, tema que deu margem para acusações diversas da oposição e do próprio campesinato. O militante socialista e pesquisador agrário Eugenio Maffei, por exemplo, pensava que a "condição necessária para que se constitua uma Área Socializada na Agricultura é o controle dos meios de produção pelo Estado e as organizações autênticas da luta de classes", criticando os “modelos de autogestão, (...) [que] debilitam o proletariado agrícola, sempre minoritário, como também produzem (...) um proletariado muito mais indefeso e frágil (...), marginalizado do movimento sindical" ${ }^{880}$ Embora minoritário, o setor da UP que defendia a estatização plena da terra corroborou o argumento da oposição sobre a captura das propriedades camponesas pelo Estado, o que gerou uma cortina de fumaça sobre os reais problemas do setor reformado, ou seja, a organização e controle do trabalho coletivo, as remunerações diferenciais e os planos de exploração.

\footnotetext{
878 Pequeños y medianos agricultores no serán expropiados por la CORA. El Siglo, Out./1970.

${ }^{879}$ Chonchol explica nueva reforma agraria, El Siglo. Set/1970

${ }^{880}$ Eugenio Maffei, Los centros de producción y la reforma agraria. Revista Agraria, n. 5. In: Chile Hoy, n. 51, Maio/1973.
} 
Esses desafios reais do setor reformado foram objetivo da capacitação camponesa, mas não de maneira suficientemente massificada e coerente para vencer a cortina de fumaça.

No âmbito da propriedade privada, o comité agrário da UP chamava atenção para o fato de que "não haverá expropriação de médios e pequenos agricultores (...) sempre que sua atividade principal seja a exploração da sua terra e se submetam aos planos nacionais de produção" ${ }^{881}$ Embora a imprensa pró-governo tenha enfatizado a garantia de não expropriação aos pequenos proprietários em diversas ocasiões, ${ }^{882}$ isso não assegurou completo apoio político do setor. ${ }^{883}$ Para os pequenos e médios proprietários (até $40 \mathrm{HRB}$ ) nem sempre ficou claro o que significava "se submeter a planos nacionais de produção", nem como isso deveria ocorrer.

\section{Poder popular e Conselhos Camponeses}

As primeiras declarações de Chonchol para imprensa prometiam: "os camponeses estarão dentro do governo, e não abaixo dele" $" 884 \mathrm{e}$ "os Conselhos Campesinos mandarão na reforma agrária". 885 O governo popular não demorou a realizar reuniões com organizações camponesas de todos os matizes para dar partida ao projeto dos Conselhos Campesinos. Em novembro, Chonchol se encontrou com Hugo Silva, presidente da Triunfo Campesino, que criticou a demora da CORA em tomar posse de terras já expropriadas em O'Higgins e acusou um funcionário do INDAP de se apropriar do excedente da produção trigueira de um assentamento ${ }^{886}$ Conflitos entre camponeses e funcionários do agro eram muito comuns e se tornaram ainda mais constantes dali em diante. Poucos dias depois, Chonchol se reuniu com cinco confederações - Ranquil, Triunfo Campesino, Libertad, além da Confederação de Assentamentos e a recém-criada Confederação de Cooperativas da Reforma Agrária - a convite do ministério.

O ministro abriu a reunião com as palavras: "a política da reforma agrária (...) esteve sempre dirigida por técnicos de governo e os camponeses estavam à margem de todo tipo de participação (...). Os conselhos devem ter uma participação fundamental na condução dos programas do agro". 887 Chonchol não desconsiderava os conselhos de seu amigo Paulo Freire, ao colocar em pauta a delicada tensão entre técnicos e camponeses. Em seguida, apresentou um projeto de decreto que criava o Conselho Nacional Camponês e os Conselhos Zonais Camponeses, baseados na nova estrutura

\footnotetext{
${ }^{881}$ Pequeños y medianos agricultores no serán expropiados por la CORA. El Siglo, Out./1970.

${ }^{882}$ Id., ibid.; No expropian a pequeños y medianos agricultores. El Siglo, 04/02/1971; La derecha siempre gobernó contra los pequeños agricultores. El Siglo, 22/02/1971

${ }^{883}$ José Bengoa, Las elecciones en el campo. Revista Agraria, n. 4. In: Chile Hoy, n. 44, Abr/1973.

884 "Campesinos estarán dentro del gobierno y no debajo de él”, Chonchol en su primera reunión con la prensa. El Siglo, Nov./1970.

${ }^{885}$ Chonchol: Consejos Campesinos mandarán en la reforma agraria. El Siglo, Nov./1970.

${ }^{886}$ Dirigentes de la Triunfo plantearon problemas a Chonchol. El Siglo, Nov./1970.

${ }^{887}$ Campesinos junto a su ministro le ponen el hombro a la gran tarea. El Siglo, Nov./1970. Estudian Proyecto sobre Consejos Nacionales Campesinos. La Nación, Out./1970.
} 
territorial da reforma agrária, na qual todas as instituições do agro se estruturariam pelas mesmas zonas. Os dirigentes camponeses escutaram a proposta e levaram o assunto aos seus pares.

Em menos de duas semanas, um novo encontro ocorreu para que o governo escutasse as organizações camponesas sobre os conselhos: "vasta e profunda foi a reunião de trabalho da tarde de quarta-feira entre Ministro da Agricultura, Jacques Chonchol e representantes máximos das confederações camponesas, de cooperativas e assentamentos e do setor de trabalhadores do agro", 888 dizia uma reportagem. As propostas camponesas foram basicamente quatro. Primeiro, algumas confederações defenderam que os conselhos fossem criados por lei, e não por decreto, alegando que isso os tornaria mais perenes e institucionalizados. A isso, Chonchol respondeu que a criação dos conselhos era urgente, pois sobre eles se apoiava a totalidade da política do governo e, portanto, não havia tempo para esperar a tramitação da lei. Baytelman já havia declarado que as prioridades de expropriação seriam conduzidas pelos conselhos campesinos e que o governo aceleraria o processo. ${ }^{889}$ Só um decreto daria a agilidade necessária. Em segundo lugar, a Ranquil propôs que o "Conselho Zonal" fosse substituído pelo "Conselho Comunal", ao que a Triunfo acrescentou a proposta de "Conselhos Provinciais". A territorialidade das novas zonas da reforma agrária era ainda abstrata, não possuía significado concreto, ao contrário da comuna e da província. A proposta foi acatada pelo governo, que desistiu dos Conselhos Zonais e decretou três níveis de participação: os Conselhos Camponeses Comunais, Provinciais e Nacional. ${ }^{890}$

Um terceiro aspecto, defendido por todas as confederações, era que o Conselho Nacional Campesino tivesse poder de decisão e não apenas de aconselhamento ou assessoria, ou seja, que se tornasse um órgão de poder efetivo. Ponto sensível da própria via chilena ao socialismo, esse pleito mostrava até que ponto o governo popular delegaria seus poderes a organizações dos trabalhadores. Chonchol respondeu que isso seria impossível, pois o "Estado, como organismo representativo das grandes maiorias do país, não podia renunciar ao seu direito de decidir sobre o avanço dos seus planos para cumprir o programa da UP" ${ }^{891}$ Essa mesma divergência repercutiu na realidade prática dos conselhos comunais, que nem sempre tinham efetivo poder de deliberação sobre as expropriações, como anunciado originalmente. ${ }^{892}$ Por fim, uma última demanda, também consensual entre as organizações, era que os funcionários do agro não participassem dos conselhos camponeses: "sua presença poderia constituir uma força de pressão sobre a opinião dos trabalhadores do campo, que dispõem de menor conhecimento técnico da agricultura" ${ }^{893}$ argumentaram os dirigentes. Um repórter que acompanhou a

\footnotetext{
${ }^{888}$ El campesino en el centro de las decisiones agrarias El Siglo, Nov./1970.

${ }^{889}$ Garantizada participación de campesinos en expropiación La Nación, Nov./1970.

${ }^{890}$ Consejos Campesinos a nivel comunal plantea la Ranquil. El Siglo, Nov./1970.

${ }^{891}$ El campesino en el centro de las decisiones agrarias. El Siglo, Nov./1970.

892 Segundo a crítica de Sérgio Gómez, da Comissão Agrária do MAPU: "A expropriação segue sendo um procedimento burocrático. (...) Não ganhamos nada com camponeses assistindo a um teatro ou a um 'show' que consiste na leitura de propriedade a propriedade, seus proprietários, tamanho, o artigo e inciso da lei de causa para expropriação e o conselheiro dizer: "aprovado"". Para ele, aquele rito servia somente para "dar um marco camponês a um ato burocrático, mas sem participação real” (Gómez, 1973: 190).

${ }^{893}$ Idem. Grifo desta tese.
} 
reunião descreveu que os trabalhadores rurais queriam se organizar com plena autonomia no novo organismo, "sem técnicos que os coloquem nas mil armadilhas de sempre para manipulá-los". 894 Reconheciam a importância e o papel dos funcionários de Estado, mas pediam que atuassem em outro espaço. Estariam os técnicos "a serviço" dos camponeses, como na Canción de la reforma agraria?

$\mathrm{O}$ conhecimento dos técnicos era uma ferramenta de poder bastante importante no âmbito micropolítico da reforma agrária e os camponeses de todos os partidos mostravam identificar essa presença como um obstáculo para a conformação do seu próprio poder popular. O próprio ministro reconhecia: "muitos funcionários que têm relação com o camponês mantêm com eles uma atitude patronal. (...). Não deve ser assim". 895 A Confederação dos Trabalhadores do Agro estava na reunião, mas não se manifestou. Já Chonchol, apesar de reconhecer o problema, expressou seu desacordo porque "eram eles [os funcionários] que aplicam as decisões em nível técnico e isso poderia gerar mais conflitos entre camponeses e funcionários, que o contrário". ${ }^{896}$ Nesse sentido, os conselhos deveriam ser plenamente autônomos em relação ao governo, mas a UP não abdicava da presença dos técnicos nas reuniões como consultores sem voto. ${ }^{897}$ Talvez se subestimasse o poder dos funcionários do agro para obstruir as decisões camponesas ou dificultar a materialização das políticas da UP nas bases da reforma, como ocorreu quando o chefe zonal da CORA, Juan Enrique Waler, ordenou a divisão de um assentamento em Huáquen e pretendia entregar 4.500 hectares a 26 trabalhadores que, segundo denunciavam os assentados, estavam sendo usados como laranjas do antigo patrão Heriberto Mussen ${ }^{898}$. A UP construiu hegemonia nos órgãos sindicais dos trabalhadores do agro, mas isso não impedia sabotagens individuais. ${ }^{899}$

O decreto 481 dos conselhos camponeses determinava que "a participação camponesa no processo de reforma agrária deve ter uma expressão orgânica, que canalize, em todos os níveis, as aspirações, interesses e inquietudes dos camponeses" (Chile, 1970). Imediatamente, foi criado o primeiro conselho comunal campesino em Loncoche, "cujo exemplo servirá de ponto de partida para a criação de outros organismos similares", dizia o jornal comunista. ${ }^{900}$ O Conselho de Loncoche representava o setor camponês e indígena mais dinâmico daquele instante, em pleno cautinazo, e foi criado como ferramenta política dos protagonistas da onda de tomas. Seria um dos experimentos de poder popular que, ao longo de 1971 e sobretudo 1972, causaria contradições com a ala do governo UP que pretendia manter as energias insurgentes mais controladas.

\footnotetext{
${ }^{894}$ Los campesinos en primer plano. El Siglo, Nov./1970.

${ }^{895}$ Chonchol explica nueva reforma agraria, El Siglo. Set/1970.

${ }^{896} \mathrm{El}$ campesino en el centro de las decisiones agrarias. El Siglo, Nov./1970.

897 A Comissão Agrária da UP delineava: "todos os profissionais agrários deverão servir de elementos consultivos aos Conselhos Campesinos e prestar toda atenção técnica necessária”. In: Pequeños y medianos agricultores no serán expropiados por la CORA. El Siglo, Out./1970.

898 Jefe zonal de CORA crea divisionismo en Huaquen. El Siglo, Set./1970.

${ }^{899}$ Aplastante triunfo UP en trabajadores de CORA. El Siglo, 18/12/1971.

900 Temuco: Se crean los primeros consejos campesinos. El Siglo. Dic/1970.
} 
O comunista Bernardo Araya supunha que os conselhos mostrariam uma "definida tendência de classe" o que os permitiria "deixar de lado a divisão partidária" e lutar por "interesses comuns". 901 Na prática, contudo, surgiram três tipos de conselhos, correspondentes a diferentes táticas partidárias: os Conselhos do Decreto, em que só participavam organizações camponesas, defendidos pelo oficialismo e pelo PC; os Conselhos Ampliados, em formato de assembleia, com voz e o voto a todos os camponeses não organizados que quisessem participar, defendidos pela ala do PS de Carlos Altamirano, pelo MAPU e pelo MIR; e os Conselhos Mistos, fruto de uma negociação interna na esquerda, que combinava um lote para camponeses dos sindicatos e outro para representantes eleitos espontaneamente. A polêmica dos conselhos se desenvolveu ininterruptamente entre 1971 e 1973, o que afetava a capacitação camponesa em dois sentidos. Primeiro, porque conselhos se tornaram um espaço político educador e capacitador para revolução chilena; e segundo, porque a comuna era potencialmente a unidade territorial do poder popular para planificar a produção, como experimentado pela pedagogia do território (ver capítulo 5), o que se misturava diretamente ao processo capacitador.

\section{A política de capacitação camponesa}

Segundo Marcela Gajardo e Alberto Silva, em um artigo de 1973, “o governo popular herdou um aparato de capacitação camponesa (...) estava altamente burocratizado. Considerava-se a capacitação como transmissão de conhecimentos realizada de cima para baixo, e se havia suprimido toda problemática conjuntural como ponto de partida", criticavam. ${ }^{902}$ A saída de Freire da consultoria ao governo em fins de 1968, segundo Gajardo, gerara uma deterioração do processo capacitador e a desconstrução das linhas de trabalho tecidas a partir das equipes freirianas. $\mathrm{O}$ aparato capacitador da DC havia atravessado uma "luta interna entre o velho e o novo", ${ }^{903}$ sendo o primeiro representado pela concepção integracionista e o segundo pela concepção mobilizadora da capacitação camponesa. Luta esta que refletia a cisão do próprio partido, e o que culminava no surgimento do MAPU. Não por acaso, no governo da UP, os militantes do MAPU se destacaram na capacitação camponesa, sendo a corrente política mais diretamente influenciada por Paulo Freire, que mais experimentou dentro da sua pedagogia.

O governo popular possuía o desafio de integrar os objetivos da capacitação camponesa às três grandes tarefas da sua reforma agrária: a necessidade de uma nova lei que radicalizasse as expropriações; o aumento da produção no setor reformado; e o fortalecimento dos conselhos camponeses. Os três processos dependiam, para seu sucesso, de uma política de capacitação camponesa

\footnotetext{
${ }^{901}$ Plena participación de los campesinos en el desarrollo de la producción. El Siglo, Nov./1970.

902 Marcela Gajardo e Alberto Silva, Capacitación: un problema por resolver. Revista Agraria, n. 5. In: Chile Hoy, n. 51, Maio/1973.

903 Id., ibid.
} 
transparente e coerente com tais objetivos. Se não era a única, era uma das mais importantes ferramentas disponíveis.

Para isso, a UP se preocupou em reterritorializar e reestruturar o funcionamento da capacitação. A Comissão Agrária da UP anunciou que era preciso eliminar "todo paralelismo atual, que distorce as políticas do setor" (Barraclough \& Fernández, 1974: 230), e centralizar o poder capacitador no Estado, o que foi oficializado em maio de 1971 com a criação do CTNC. O CTNC nasceu de um decreto ministerial da agricultura, como parte da reorganização territorial das instituições do agro. ${ }^{904}$ "Cada instituição tinha sua própria unidade de capacitação (só na CORA, existem cinco)", alertaram Barraclough e Fernández (1974: 230). O ministro Chonchol deu início a uma reorganização territorial das instituições agrárias por áreas e zonas, o que permitiria uma divisão melhor de tarefas capacitadoras entre as instituições e um método de planificação econômica com participação popular. A proposta articulava centralização e descentralização: por um lado, instalava o Comitê Nacional para centralizar o processo capacitador; por outro, dava importância aos conselhos camponeses como sujeitos ativos do processo capacitador, ecoando alguns aspectos da pedagogia do território. A seguir, analisarei o papel do Comitê Técnico Nacional de Capacitação Camponesa na política agrária da UP.

\subsection{O CTNC e a arquitetura da capacitação camponesa da UP}

Antes que o Ministério da Agricultura se deslocasse a Temuco, Rolando Pinto foi encarregado por Chonchol da política de capacitação camponesa da UP, como chefe do CTNC. Ambos eram companheiros do MAPU e amigos de Paulo Freire, e haviam convivido intensamente com o brasileiro. O governo pretendia unificar desenvolver um Programa Nacional de Capacitação Camponesa, alinhado aos objetivos da via chilena ao socialismo e, consequentemente, às necessidades produtivas do setor reformado. O plano era coordenar a rápida expansão do território da reforma agrária com os novos planos de capacitação para a Área de Propriedade Social da agricultura. O CTNC foi o principal organismo para capacitação camponesa durante os anos da UP. Contudo, como veremos, enfrentou obstáculos quase intransponíveis.

\footnotetext{
904 Resposta ao diagnóstico coordenado por Plinio de Arruda Sampaio, que problematizava a sobreposição de funções governamentais nas pontas das instituições do agro: "Não existe, em nível territorial, uma boa coordenação entre as instituições do setor público agrícola. Essa coordenação só conseguirá por uma reformulação da estrutura de organização da maioria delas", diziam os autores do ICIRA: "a estrutura de organização das distintas instituições (...) não favorece um sistema de operação por Planos Regionais de Desenvolvimento Agropecuário". Ver Sampaio et. al. Organización, Planificación y Coordinación de las instituciones del sector público agrícola de Chile, a nivel de terreno. Departamento de Administración en Reforma Agraria. Santiago: ICIRA, 1966. Ver também o capítulo de Sampaio em Alaluf et. al, 1972.
} 


\section{Centralizar a capacitação?}

O Comitê Técnico Nacional de Capacitação Camponesa (CTNC) foi formalizado em maio de 1971, quando o Ministério da Agricultura voltou a Santiago. Estava composto de 20 instituições: os organismos do agro (CORA, INDAP, ICIRA, INACAP, SAG), o Ministério da Educação, três Universidades (U. Chile, U. Católica, U. Técnica do Estado), confederações sindicais (Ranquil, Triunfo Campesino, Libertad, UOC, Departamento Camponês da CUT e, inclusive, a patronal Províncias Agrárias Unidas, além do FEES), órgãos estatais de fomento (CORFO, Banco do Estado) e o IER. O ICIRA foi definido como coordenador dessa improvável mistura. Tratava-se de um "esforço para orientar o aparato estatal de capacitação camponesa (...) sob a coordenação do ICIRA"905 e "dar maior dinamismo e racionalidade aos múltiplos programas de capacitação do agro, assim como integrar o técnico e o ideológico em função da política agrária do governo", ${ }^{906}$ na síntese de Gajardo e Silva.

Junto com o Comitê Nacional foram criados 3 Comitês Regionais de capacitação (Norte, Centro, Sul) e 11 Comitês Zonais de Capacitação (Barraclough \& Fernández, 1974: 230). A proposta era unificar programas, produzir materiais e atuar em "zonas capacitadoras" via Comitês Zonais e conselhos campesinos. ${ }^{907} \mathrm{O}$ plano territorial que conectava capacitação, participação camponesa, reforma agrária e produção planificada estava baseado no reordenamento territorial com conceito de zonas. Concebia-se participação camponesa nas instâncias zonais de capacitação, em uma espécie de tensão dialética entre a centralização e a descentralização das pedagogias e metodologias. O mais importante era que todos, de cima a baixo, buscassem o aumento da produção. Disciplinar o trabalho recém "liberado", porém, seria o maior desafio de todo processo revolucionário no campo. ${ }^{908}$

A função do Comitê era desenvolver um Programa Nacional de Capacitação Campesina, produzir linhas de trabalho educacional e confeccionar materiais que seriam transmitidos até a ponta: os comitês zonais. No entanto, cada instituição que compunha o CTNC já possuía suas próprias estratégias de capacitação, além de materiais, educadores e práticas acumuladas nos anos anteriores, orçamento próprio e "clientelas" específicas. A CORA capacitava assentados, o INDAP trabalhava com pequenos proprietários e comitês campesinos, o FEES e INACAP com os camponeses sindicalizados em convênios com as confederações, as universidades tinham seus próprios departamentos de extensão, enquanto o ICIRA priorizava, até aquele momento, a capacitação dos funcionários. Reunir essa complexidade de processos educacionais sob um único comando se mostrou uma missão complicada e logo Rolando Pinto se deu conta do problema.

\footnotetext{
${ }^{905}$ Marcela Gajardo e Alberto Silva, Capacitación: un problema por resolver, op. cit.

${ }^{906}$ Id., ibid.

907 Como vimos, na primeira versão do decreto que Chonchol apresentou para os conselhos camponeses da base, estes eram "zonais" e se tornaram "comunais" por demanda das organizações.

${ }^{908} \mathrm{O}$ grande desafio dos processos revolucionários da periferia do capitalismo era como disciplinar o trabalho na agricultura no contexto da eliminação da figura do capataz, tema investigado para o caso de Cuba em Vasconcelos (2016a).
} 
Inicialmente, foram determinadas 5 linhas de capacitação. Para cada uma, grupos de trabalho aglutinavam as instituições em equipes, como mostra a tabela 29 a seguir.

\begin{tabular}{|l|l|}
\hline \multicolumn{1}{|c|}{$\begin{array}{c}\text { Tabela 29 - Linhas de Capacitação do Comitê Técnico Nacional de Capacitação } \\
\text { Campesina do governo da UP (1971-1973) }\end{array}$} \\
\hline \multicolumn{1}{|c|}{ Linha } & \multicolumn{1}{c|}{ Equipes } \\
\hline (1) Capacitação Sindical & INDAP, FEES, Confederações \\
\hline (2) Educação Básica de Adultos e Jovens Rurais & Mineduc, CORA \\
\hline (3) Técnico-Produtiva e Gestão Socioeconômica & CORA, SAG, INDAP, INACAP \\
\hline (4) Assistência à Pequena Propriedade & INDAP, SAG \\
\hline (5) Mecanização Agrícola & CORFO, CORA \\
\hline \multicolumn{2}{|c|}{ Fonte: Pinto Contreras, 2020.} \\
\hline
\end{tabular}

Centralizar a capacitação correspondia, entre outras intenções, à planificação econômica na área de propriedade social do campo. Mas em termos políticos, a centralização deveria ser acompanhada de uma descentralização do poder capacitador nas comunas. Era isso que defendiam alguns pesquisadores e militantes. Por um lado, que "toda ação de capacitação (...) através do sistema de planificação aprovado para o setor agrícola, [tivesse] como objetivo central aumentar a produção agropecuária até os níveis que sejam necessários". ${ }^{909}$ Simultaneamente, que "os programas de capacitação não serão um apoio ao processo de transição ao socialismo, enquanto sua planificação não se descentralize para as comunas rurais", 910 diziam Peñafiel e Bethke. A tensão entre centralização/descentralização do processo capacitador camponês se expressou na distância entre CTNC e as realidades locais da capacitação.

As dificuldades atravessadas pelo CTNC advinham da sua própria composição. Estava formado por instituições públicas com propósitos distintos entre si, e partidos políticos inimigos, que logo manifestaram rivalidades ideológicas intransponíveis. O "loteamento político" do Comitê, como alertavam Gajardo e Silva, "motivou (...) a disputa setorial das organizações e suas clientelas políticas, com a conseguinte dificuldade de fixação de linhas comuns de ação". ${ }^{911}$ Como exemplo, lembravam que em 1973 ainda havia materiais de capacitação do CNTC em caráter preliminar, que "nunca chegaram a ser aprovados (...) por divergências internas sobre seu conteúdo". 912

As organizações sindicais ou privadas eram representativas de classes em conflito e de perspectivas diferentes para a reforma agrária. Enquanto a Triunfo Campesino cada vez mais se inclinava à defesa da parcela individual, para se diferenciar da UP, denunciando que o governo fugiria à sua responsabilidade de entregar a terra aos camponeses, a Ranquil se inclinava a apoiar Allende, sem com isso perder independência. O IER, como vimos, era convictamente anticomunista; a confederação Províncias Agrárias Unidas, mesmo que pouco representativa, era patronal (SNA). Os demais órgãos

\footnotetext{
${ }^{909}$ Manuel Peñafiel eKlaus Bethke, Capacitación: ¿Privilegio de la burocracia?, op. cit.

${ }^{910}$ Id., ibid. Esses pesquisadores pareciam ter uma solução teórica, sem problematizar a tensão prática do próprio enunciado: "a unidade de comando deve ser uma linha hierárquica central (Ministro - Diretor Zonal de Agricultura - Chefe de Área), que implica respeito às decisões, uma centralização horizontal em nível nacional e uma descentralização vertical para as zonas e áreas". Não fica claro o que seria "descentralização vertical".

${ }_{911}$ Marcela Gajardo e Alberto Silva, Capacitación: un problema por resolver, op. cit.

912 Id., ibid.
} 
estavam dirigidos por lideranças da UP que tampouco concordavam plenamente sobre a tática agrária. O INDAP era presidido pelo socialista Adrian Vásquez, a CORA pelo comunista David Baytelman, o ICIRA representado pelo mapucista Rolando Pinto, o FEES pelo mapucista Oscar Torres. "Logo começaram as brigas", relatou Rolando Pinto, que presidiu o Comitê durante um ano. "Havia duas grandes tendências", ele resumiu:

Uma, podemos chamar mais revolucionária, que propunha que não haveria mudança política sem participação popular e, portanto, no seio do Comitê deveriam estar as correntes camponesas, mesmo que fossem contraditórias. Seria possível, com maior participação, dar às decisões do Comitê uma centralidade camponesa. Eu vocalizava esse pensamento. Na outra tendência, os comunistas pensavam que o comitê deveria assegurar a política do Estado. $^{913}$

Arnaldo Cáceres Vildós, comunista que trabalhou com alfabetização e capacitação de camponeses no ICIRA durante o governo UP, sendo secretário de José Campusano, recordou-se da polêmica: "se o PC dirigia uma confederação, para que juntar com outra que não tinha os mesmos objetivos? Muita gente não gostava disso", explicou: "Mas a ideia de Allende e do governo popular era que todas estas diferenças fossem discutidas, analisadas e se chegasse a acordos para não se transformar em pugna. Por isso, nesse espaço da capacitação camponesa participavam todas as tendências, inclusive a direita". ${ }^{914}$ A produção de pactos para política de capacitação, contudo, não era nada simples.

Os choques entre as vanguardas que ocupavam o Comitê nublaram o debate sobre metodologias pedagógicas para reforma agrária. O desafio prático do diálogo entre educadores urbanos e camponeses e os problemas da "invasão cultural", por exemplo, foram temas quase ausentes nas reuniões, diferente do que ocorreu no INDAP, CORA e ICIRA durante a presença de Paulo Freire, quando a questão dos métodos pedagógicos foi alçada ao centro do debate da capacitação. Isso não queria dizer, contudo, que a questão não fosse praticada e pensada "nas linhas de trabalho" en terreno. Segundo Rolando Pinto, havia um hiato entre o Comitê e as bases da capacitação. Enquanto o Comitê nunca deu importância à polêmica levantada em Extensión o comunicación?, o tema da invasão cultural e da metodologias pedagógicas era um assunto latente para quem trabalhava como educador na ponta: "era o eterno problema da UP: enquanto a estrutura do Estado discutia problemas da cota de poder, na linha de trabalho [nas bases] se seguia avançando dentro dos princípios do próprio plano de governo", 915 analisou. O mesmo hiato foi diagnosticado por outros analistas. ${ }^{916} \mathrm{Ou}$ seja, a ocorrência de zonas de paralisia institucional no governo, em função de impasses partidários e rivalidades, não interrompia o processo revolucionário desde baixo.

\footnotetext{
${ }^{913}$ Entrevista com Rolando Pinto Contreras, Santiago, 11/12/2018.

${ }^{914}$ Entrevista com Arnaldo Cáceres, Santiago, 29/06/2017.

915 Id., ibid.

916 "Se observou frequentemente uma dissonância entre a planificação do comitê e a ação regional, fruto de uma crescente burocratização central e falta de recursos que (...) conduziu à paulatina deterioração desta atividade em várias zonas", escreveram Gajardo \& Silva. Capacitación: un problema por resolver, op. cit.
} 


\section{Cursos do CTNC}

Apesar dos obstáculos, o Comitê conseguiu desenvolver cursos próprios unificados, sem que a capacitação paralela dos organismos fosse suspensa. Em agosto de 1971, no sentido oposto da rivalidade paralisante, as três confederações sindicais propuseram um "Programa Único de Capacitação" formulado em conjunto, voltado para área reformada e com a estrutura tripartite dos convênios do FEES: uma etapa de nivelação (castelhano e matemática); a capacitação social sobre realidade nacional; e uma etapa técnica-profissional voltada para a economia do assentamento. As confederações se encarregariam da capacitação social, isto é, a alfabetização e conscientização com o método psicossocial. Representava um "esforço notável de união camponesa", segundo Barraclough \& Fernández (1974: 232). Seriam cursos de três meses, quatro vezes ao ano, para 2.900 camponeses sindicalizados, com custo de mais de 8 milhões de escudos, representando uma escala mais massificada do que os convênios FEES-INACAP ou FEES-U. Católica. A proposta foi aprovada: em 1971, o programa unificado das confederações capacitou 4.159 camponeses em cursos executados pelos Comitês Zonais, e foi além da base de sindicalizados inicialmente proposta, distribuídos territorialmente como na tabela 30 .

\begin{tabular}{|c|c|c|c|c|c|c|}
\hline \multicolumn{7}{|c|}{ Tabela 30 - Cursos dos Comitês Zonais/CTNC (1971) } \\
\hline Zona & $\begin{array}{c}\mathrm{N}^{0} \\
\text { cursos }\end{array}$ & $\begin{array}{c}\text { Semanas/ } \\
\text { Curso }\end{array}$ & $\begin{array}{l}\text { Participantes } \\
\text { (total) }\end{array}$ & $\begin{array}{c}\text { Campesinos } \\
(\%)\end{array}$ & $\begin{array}{c}\text { Funcionários } \\
(\%)\end{array}$ & Outros (\%) \\
\hline La Serena (II) & 12 & 11 & 453 & $38 \%$ & $47 \%$ & $14 \%$ \\
\hline Quilota (III) & 28 & 22,5 & 1.023 & $36 \%$ & $46 \%$ & $16 \%$ \\
\hline Santiago (IV) & 35 & 27 & 1.886 & $28 \%$ & $22 \%$ & $49 \%$ \\
\hline Rancagua (V) & 13 & 9,5 & 387 & $44 \%$ & $51 \%$ & -- \\
\hline Talca (VI) & 42 & 42,5 & 1.794 & $41 \%$ & $77 \%$ & $7 \%$ \\
\hline Linares (VII) & 7 & 6 & 306 & $22 \%$ & $83 \%$ & -- \\
\hline Chillán (VIII) & 9 & 7,5 & 367 & $16 \%$ & $30 \%$ & -- \\
\hline $\begin{array}{c}\text { Los Angeles } \\
\text { (X) }\end{array}$ & 23 & 22,5 & 748 & $64 \%$ & $30 \%$ & - \\
\hline Temuco (XI) & 61 & 55 & 2.140 & $71 \%$ & $28 \%$ & -- \\
\hline Valdívia (XII) & 2 & 2 & 65 & -- & $100 \%$ & -- \\
\hline $\begin{array}{l}\text { Puerto Montt } \\
\text { (XIII) }\end{array}$ & 3 & 3 & 85 & -- & $100 \%$ & -- \\
\hline $\begin{array}{l}\text { Magallanes } \\
\text { (XIV) }\end{array}$ & 1 & 1 & 50 & -- & $100 \%$ & -- \\
\hline Total (\%) & 237 & 210,5 & 9.333 & $4.159(45 \%)$ & $3.858(41 \%)$ & $\begin{array}{l}1.316 \\
(14 \%)\end{array}$ \\
\hline
\end{tabular}

Em 1971, entre os 9.333 participantes dos cursos dos Comitês Zonais, 45\% eram camponeses, $41 \%$ eram funcionários do agro e $14 \%$ “outros", sendo a maior parte estudantes universitários, cada vez mais engajados nos trabalhos de verão para reforma agrária. Entre os 237 cursos, 139 foram de capacitação social (que combinava temas da realidade chilena, reforma agrária e mundo laboral, com 
estratégias do método psicossocial); 79 foram cursos agroeconômicos, focados na formação administrativa para os assentamentos; e 19 agrotécnicos, sobre técnicas de produção. ${ }^{917}$

Além dos cursos, em 1971 ocorreram 67 jornadas curtas organizadas pelos comitês zonais, com 35.155 participantes. Entre eles, 96\% camponeses, 1,8\% funcionários e 2,2\% “outros” (universitários) (Barraclough \& Fernández, 1974: 239). A grande maioria destas jornadas (63) foram de capacitação social para Conselhos Comunais Campesinos, nas quais se dialogava sobre as funções do conselho, sua composição e as estratégias de avanço da reforma agrária. Nesse caso, notou-se uma articulação entre a capacitação camponesa e a política agrária da UP para fortalecimento do poder popular dos trabalhadores rurais.

No fim de 1971, o CTNC parecia ter estabilizado um pouco melhor seu funcionamento, e traçara a meta de capacitar 14.470 camponeses em cursos de verão, entre novembro de 1971 e fevereiro de 1972. ${ }^{918}$ Em seguida, em fevereiro de 1972, o Comitê aprovou o Programa Nacional de Capacitação Camponesa, cuja meta era formar 40.000 camponeses ao ano, nas cinco linhas de trabalho estabelecidas. Mas novamente a realidade ficou bastante aquém da meta. No primeiro semestre de 1972, foram 200 cursos dos Comitês Zonais com 4.599 beneficiários, sendo 89\% camponeses; e 439 jornadas para 6.826 participantes, sendo $90 \%$ camponeses. ${ }^{919}$ Naqueles meses, vários comitês zonais deixaram de funcionar em razão da falta de coordenação entre funcionários do CTNC e dos territórios, além da crise de financiamento. Entre os 12 Comitês Zonais de Capacitação ativos em 1971, somente sete permaneceram em 1972 (de La Serena a Chillán). As jornadas do $1^{\circ}$ semestre de 1972 foram 95\% de capacitação social para conselhos camponeses en terreno, beneficiando um total de 6.826 participantes. Ou seja, embora não cumprissem a meta quantitativa, atuavam para impulsionar o programa da UP, "capacitando" para o poder popular camponês (Barraclough \& Fernández, 1974: 233, 243, 245).

No Diagnóstico que entregaram ao ministro da agricultura Rolando Calderón em novembro de 1972, Barraclough \& Fernández alertaram sobre a "multiplicação de erros do CTNC". Para começar, "não se explicitou o que se entendia por coordenação do ICIRA" (Barraclough \& Fernández, 1974: 230). Cada instituição do agro "seguia organizando seus próprios programas (...), que defendiam com bastante interesse porque se tratava de atender a uma clientela não só política, mas institucional" (Barraclough \& Fernández, 1974:230), e não se engajaram suficientemente ao Programa Nacional. Tudo isso fez com que os acordos do Comitê tivessem "escasso respaldo e, portanto, as instituições não se comprometem em cumpri-los" (Barraclough \& Fernández, 1974: 231). A transmissão das diretrizes do Comitê aos capacitadores da ponta não acontecia na prática e as decisões eram tomadas em nível local, desorganizando as intenções unificadoras da UP sobre a capacitação camponesa. Às vezes, um

\footnotetext{
917 Dos 9.333 alunos, 61\% cursaram a capacitação social, organizada pelas confederações; 33\% cursaram a capacitação agroeconômica com educação básica; e 6\% cursaram a capacitação agrotécnica e produtiva (Barraclough \& Fernández, 1974: 240).

${ }_{918}$ Para isso, foram requisitados 42 milhões da CORA, 2 milhões do INDAP e 2 milhões do FEES (Barraclough \& Fernández, 1974: 233).

${ }^{919}$ Dos 4.599 alunos, 35,2\% cursaram a capacitação social; 17,6\% a capacitação agrotécnica; e 47,2\% cursaram capacitação agroeconômica com educação básica (Barraclough \& Fernández, 1974: 244).
} 
funcionário era designado para ser coordenador da capacitação de 4 ou 5 províncias pelo CTNC, viajava desde Santiago e ao chegar gerava mal-estar entre as instituições locais, que já atuavam na ponta com seus próprios programas e materiais. Segundo o Diagnóstico, foi criada assim uma estrutura “inoperante" e "impossível” (Barraclough \& Fernández, 1974: 232).

Além disso, diagnosticaram que era "um erro conceber a capacitação como um processo com fim em si mesmo. A capacitação é um dos meios necessários para cumprir certos objetivos externos a ela mesma, objetivos concretos de uma política agrária" (Barraclough \& Fernández, 1974: 235). Eram favoráveis a uma capacitação pragmática, que servisse ao aumento da produtividade do setor reformado com resultados visíveis. Nesse sentido, criticaram a capacitação social, diretamente influenciada pela pedagogia freiriana e pelas estratégias de conscientização do CEREN, que ocupou a maior parte dos cursos dos comitês zonais, por serem "muito gerais", supostamente sem efeito prático na produção. Subestimavam, possivelmente, a alavanca moral e o engajamento subjetivo para o aumento da produtividade nas unidades reformadas, em que a ausência do capataz e do patrão gerava afrouxamento do trabalho coletivo. Uma visão mecanicista entre capacitação e produção, em confronto com a visão freiriana.

\section{Disputa ideológica e guerra orçamentária do agro}

Apesar de milhares de camponeses estarem contemplados nos cursos e jornadas do CNTC, a desorganização e as rivalidades internas instaladas no Comitê de alguma maneira corroboraram para o não cumprimento das metas das batalhas da produção no setor reformado. Um dos indicativos das dificuldades do CTNC foi o fracasso na confecção dos materiais de capacitação do Programa Nacional. Desde 1971, uma proposta de material foi escrita, mas nunca aprovada nas reuniões, e então permaneceu estancada nos emaranhados de conflitos ideológicos da superestrutura, cada vez mais descolada da realidade capacitadora local. Um Manual Nacional de Alfabetização Campesina permaneceu estancado, e os alfabetizadores de camponeses utilizavam o Sugerencias para la Alfabetización, analisado no próximo capítulo. ${ }^{920}$

Segundo lembra Rolando Pinto, na superestrutura do Comitê, os posicionamentos diretivos dos partidos sobre as formas de propriedade e os rumos da reforma agrária se sobrepuseram ao debate sobre a capacitação, dificultando a tomada de decisões pedagógicas. ${ }^{921}$ Enquanto PC e setores do PS insistiam na propriedade cooperativa como diretriz predominante da política agrária do governo, a DC cada vez mais transitava para a defesa do huerto familiar e da parcela individual, apesar de seu histórico incentivo ao cooperativismo. No acirramento da polarização, a DC realçou seu discurso anticomunista, difundindo a denúncia de que a UP era contra o huerto familiar e contra a entrega das terras tituladas

920 “Os textos de capacitação social, por exemplo, estão elaborados há muito tempo, mas o CTNC não conseguiu aprová-los em sua totalidade. Através dos textos (...) que se especificam os conteúdos dos cursos” (Barraclough \& Fernández, 1974: 233). ${ }^{921}$ Entrevista com Rolando Pinto Contreras, Santiago, 11/12/2018. 
aos trabalhadores, e dessa forma enganavam os camponeses com o slogan "a terra para quem a trabalha”. A DC e o PN alinharam seu discurso alegando que as verdadeiras intenções do governo eram promover uma agricultura estatal de tipo soviético. As polêmicas transbordavam dos partidos e do parlamento para o Comitê. ${ }^{922}$

Para comprovar essas "verdadeiras intenções" da UP, senadores e deputados da DC citavam um informe da Comissão Nacional Agrária do PS (CONAS) vazado para imprensa em meados de 1971, que dizia que "a substituição do Estado burguês pelo Estado proletário é impossível sem uma revolução violenta" 923 e que "o governo da UP deve (...) levar adiante uma tática de estrangulamento para destruição definitiva do poder da burguesia e deste modo abrir caminho para instauração da ditadura do proletariado". ${ }^{924} \mathrm{O}$ vazamento do relatório da CONAS repercutiu com tanta intensidade em meados de 1971, que o PS expôs a público suas fissuras. O Comitê Central dos socialistas desautorizou sua Comissão Agrária a falar em nome do partido, e publicou no El Mercurio uma declaração oficial: “o documento [da CONAS] constitui a opinião de alguns militantes do Setor Agrário, manifestada internamente no seio do partido. Essas opiniões não são compartilhadas pela Direção do PS".925 Enquanto isso, o MAPU permanecia defendendo que a decisão sobre a propriedade reformada pertencia aos camponeses, caso a caso, como previsto na lei. ${ }^{926}$ Precisamente por isso, na interpretação do mapucista Rolando Pinto, o MAPU estaria mais preocupado em dialogar com os camponeses por meio do processo de capacitação do que em disputar a forma de propriedade do setor reformado. A questão pedagógica, portanto, seria bem mais relevante que os enfrentamentos pouco frutíferos da vanguarda. ${ }^{927}$

A DC, por meio do IER e da Triunfo Campesino, passou a denunciar a incompetência do CTNC, que estaria desmontando os programas de capacitação camponesa do governo anterior sem substitui-los. Tais acusações irritavam os partidários da UP, porque o verdadeiro desmonte dos programas de capacitação era realizado pelos próprios parlamentares da $\mathrm{DC}$ e do $\mathrm{PN}$, que se empenharam em cortar orçamentos das instituições do agro na Lei Orçamentária para 1971 e emperrar a capacidade política do Executivo. Em novembro de 1970, Chonchol havia anunciado que o orçamento do Minagri seria 115\% maior que o ano anterior, e que saltaria de 930 milhões a 2 bilhões de escudos, com objetivo de acelerar a reforma agrária. ${ }^{928}$ Ele esclareceu que os organismos do agro operavam em déficit. ${ }^{929} \mathrm{Um}$ dos motivos era o custo das indenizações aos proprietários rurais, mas também o fato de que os camponeses do setor reformado não retornavam os créditos do Banco do Estado e da CORA,

\footnotetext{
${ }_{922}$ Diario de Sesiones del Senado. Legislatura ordinaria 313a . Sesión 15a , 30/06/1971. Sesión 26a , 27/07/1971; Cámara de Diputados, Legislatura Ordinaria, Sesión 30a, 01/091971.

${ }^{923}$ CONAS apud Senador Julio Von Muhlenbrock (PN). Diario de Sesiones del Senado. Legislatura ordinaria $313^{\mathrm{a}}$. Sesión 15, 30/06/1971: 1122 .

${ }^{924}$ Id., ibid.

${ }^{925}$ PS apud Senador Julio Von Muhlenbrock (PN). Diario de Sesiones del Senado. Legislatura ordinaria 313 ${ }^{\mathrm{a}}$. Sesión $15^{\mathrm{a}}$, 30/06/1971: 1123 .

${ }^{926}$ Artigo 67: "O Conselho [da CORA] poderá titular as terras em qualquer uma das formas apontadas neste inciso, quando os camponeses selecionados para ser beneficiários assim o solicitem de comum acordo" (Chile, 1967b). As formas apontadas eram três: parcela individual, cooperativa e cooperativa mista.

${ }_{927}$ Entrevista com Rolando Pinto Contreras, Santiago, 11/12/2018.

${ }_{928}$ Aumentarán el presupuesto para el sector agrícola. La Nación, Nov./1970.

${ }^{929}$ Fuerte déficit sufren organismos agrícolas. La Nación, Nov./1970.
} 
confundindo o antecipo com um salário. Em 1971, somente 15\% do crédito ao setor reformado retornou aos cofres públicos, situação melhorada em 1972, com 40,8\% de retorno. Uma parte do investimento produtivo das instituições do agro ao setor reformado escorria, sem contabilidade ou registro, como um subsídio à produção individual camponesa dentro das propriedades coletivas (Barraclough \& Fernandez, 1974: 47).

Mas o plano de gastos de Chonchol com a reforma agrária foi inviabilizado desde o primeiro ano de governo. O ministro denunciou, em dezembro de 1970, que o Legislativo havia reduzido a verba da ODEPA em 32\% (de 14,5 a 9,9 milhões de escudos) e do ICIRA em 57\% (de 13,9 a 6,5 milhões), o que estava em contradição com o discurso dos parlamentares da DC "que defenderam a necessidade de se criar maior coordenação no setor agrário". ${ }^{930}$ As dificuldades do CTNC eram políticas e financeiras, criadas pelo estrangulamento dos recursos para reforma agrária e capacitação camponesa imposto pela oposição parlamentar. O problema básico era ausência de orçamento próprio, que tornava o Comitê dependente de repasses das instituições participantes. Durante todo o período, o Comitê funcionou com 2 milhões de escudos repassados pela CORA e com verbas do ICIRA, o órgão mais pobre.

A DC se aproveitava da redução de recursos que ela mesma ajudava a aprovar para denunciar o governo nas reuniões do Comitê. Apesar disso, Rolando Pinto defendia a permanência da oposição dentro do organismo. Dizia aos comunistas: "é preferível ter o IER aqui dentro, com água morna (...). Vamos preservar o diálogo, não vamos gerar essa ruptura". 931 O IER dispunha de legitimidade histórica sobre a capacitação camponesa, com real base social e com a aura do pioneiro, pois completava 16 anos em uma atividade que os outros órgãos executavam a menos de 5. Apesar dos choques, o MAPU defendia que o Comitê se preservasse como organismo amplo, não exclusivo da UP. Segundo se recorda Rolando Pinto, o comunista José Campusano lhe respondia: "você é muito idealista e romântico, os processos políticos são duros". 932

O estrangulamento orçamentário das instituições do agro piorou em 1972. A DC tentou chantagear o governo com uma lista de exigências relacionadas a cargos públicos de seus correligionários, mas o governo recusou-se a aceitar qualquer uma delas. "O PDC cortará os recursos para reforma agrária", ${ }^{933}$ denunciavam os comunistas. Em janeiro de 1972, Chonchol qualificou como "vingança" o gesto da oposição, que estrangulou ainda mais os orçamentos ministeriais para agricultura e educação. Cortava-se 10 milhões de escudos do Fundo de Fomento Lechero, e se buscava inviabilizar uma das políticas mais populares de Allende: a entrega de $1 / 2$ litro de leite diário a todas as crianças chilenas. ${ }^{934}$

No caso do INDAP, em 1971 o governo havia aumentado de 120 mil para 250 mil a base de pequenos proprietários beneficiados com assistência técnica e crédito. Na realidade, suas demandas de

\footnotetext{
930 Ministro Chonchol: Disminución de fondos a organismos agrícolas creará serios problemas. La Nación, Dez./1970.

931 Entrevista com Rolando Pinto Contreras, Santiago, 11/12/2018.

932 Id., ibid.

933 Chantaje contra el país: destrozan el presupuesto. El Siglo, 28/12/1971

934 Reducción de presupuesto paraliza planes educacionales y agrarios. La Nación, Jan./1972.
} 
crédito cresceram em 150\%, mas seu orçamento foi sequestrado para 1972, com um corte de 400 para 100 milhões de escudos, recursos que permitiriam apenas 3 meses de funcionamento, ou a demissão de 3500 funcionários para atravessar o ano. ${ }^{935}$ Os trabalhadores do agro logo começaram um movimento de protestos contra os cortes orçamentários, que mutilavam a capacitação. Em uma marcha de servidores públicos em defesa do orçamento do governo, "chamou atenção o grande número de funcionários democrata-cristãos", ${ }^{936}$ dizia uma matéria.

A situação do orçamento de 1972 era tão grave, que Chonchol escreveu uma "Carta aos camponeses chilenos", na qual explicava que o ministério da agricultura deveria dispor de 2,8 bilhões de escudos em 1972, mas a oposição cortou $88 \%$, aprovando 1/8 dos recursos para política agrária. Isso significava 310 milhões a menos para INDAP; 50 milhões a menos para Fundo de Infraestrutura do Minagri; 7 milhões a menos para ICIRA; 100 milhões a menos para Empresa de Comercialização Agrícola; e 551 milhões a menos para CORFO Agrícola. No caso do ICIRA, o governo seria obrigado a demitir metade dos funcionários, "não podendo cumprir os programas de capacitação agrícola (...), convênios já aprovados com as confederações sindicais camponesas". ${ }^{937}$ Aniceto Rodrigues, líder da ala allendista do PS, declarou: "os camponeses e pequenos proprietários de Linares devem saber que a aliança do PN com a DC no parlamento mutilou o orçamento público, especialmente do INDAP". 938 Toda essa novela se repetiu em 1973, quando um corte de $42 \%$ no orçamento da CORA conduzido pela oposição (que totalizava quase 3 bilhões de escudos a menos), sequestrou 307 milhões do programa de produção no setor reformado, 704 milhões das obras de escolas rurais e casas camponesas, além de comprometer quase completamente o programa de capacitação. Muitos educadores seguiram trabalhando com salários atrasados. ${ }^{939}$ A CORA retrucou anunciando que $73 \%$ dos recursos para indenização dos patrões expropriados foram cortados pela oposição.

A guerra orçamentária atingiu também o FEES. Com o triunfo de Allende a sonegação dos patrões rurais cresceu. Uma reunião entre ministério da agricultura e do trabalho em maio de 1971 constatou que $55 \%$ dos proprietários não pagava o que devia. No primeiro trimestre, o fundo recebeu apenas $20 \%$ dos aportes patronais. Para reduzir danos, o governo anunciou a suspensão de crédito e assistência técnica a todos os proprietários que estivessem inadimplentes. "O governo, em completo acordo com as organizações sindicais camponesas, enfrentará decididamente a resistência dos latifundiários em cumprir a lei 16.625", narrava El Siglo: "no ano passado todos os camponeses chilenos realizaram uma paralisação nacional de 24 horas demandando este direito, que permite elevar seu nível de consciência dos trabalhadores do campo e sua capacitação técnica para enfrentar as novas responsabilidades da produção agropecuária". ${ }^{940}$ Em junho de 1971, foi ativado um plano de fiscalização do pagamento

\footnotetext{
${ }^{935}$ Reducción de presupuestos: “Perjuicio irreparable para los pequeños agricultores”. La Nación, Jan./1972.

${ }_{936}$ Movimiento nacional de protesta inician trabajadores del agro. La Nación, Jan./1972.

937 Carta de Chonchol a los campesinos chilenos: oposición derechista intenta paralizar desarrollo agrícola. La Nación, Jan./1972.

${ }^{938}$ Aniceto Rodrigues: "Los planes de desarrollo del país paralizaran”. La Nación, Jan./1972

${ }^{939}$ Corte al presupuesto de CORA dificulta el proceso agrario. La Nación, Fev./1973.

940 Batida a fondo contra latifundistas que no pagan $2 \%$ del Fondo de Educación. El Siglo, 11/05/1971.
} 
patronal ao FEES, que deviam ao fundo 75 milhões de escudos. ${ }^{941}$ Em uma reunião coordenada por Oscar Torres (diretor do FEES) e Juan Arredondo (diretor do Trabalho), foi anunciado um plano de emergência, com a publicação da lista de patrões inadimplentes e obstrução dos benefícios das instituições do agro à burguesia agrária. Um curso para Inspetores do Trabalho e funcionários do INDAP foi ministrado pelo FEES para garantir que quatro fiscais por província garantissem a operação. "Os representantes da Direção do Trabalho irão de propriedade em propriedade cobrar a fatura aos senhores momios", ${ }^{942}$ anunciavam.

Enquanto isso, dentro do FEES a disputa orçamentária repercutiu em tentativas da Triunfo Campesino e da Libertad em dispor de uma fatia maior do seu orçamento para as confederações camponesas. Em uma reunião do Conselho do FEES em fevereiro de 1972, Enrique Mellado, presidente da Triunfo, apelava: "ou restringimos o programa de capacitação, ou despedimos funcionários (...). As organizações sindicais dão vida ao Fundo (...) e o Fundo deve estar a serviço dos camponeses, porque lhes pertence". ${ }^{943} \mathrm{Um}$ dos Conselheiros, Arturo Sáenz retrucou que as confederações "atuam obedecendo a um partido político", ${ }^{944}$ o que irritou os dirigentes camponeses: "insulto gratuito", ${ }^{945}$ disse Gustavo Diaz, da Libertad. Naquela ocasião, a Triunfo devia ao FEES a prestação de contas de $25 \%$ do convênio de $1971 .{ }^{946}$

A luta pelo orçamento do FEES durou meses, até que o dirigente da Ranquil, Luis Cossío, se posicionou junto aos sindicalistas camponeses pelo aumento dos recursos repassados às organizações. A situação era crítica, porque as bases sindicais não paravam de crescer, enquanto o orçamento se apertava. Cossío cobrou que "as organizações devem ter mais participação nos programas do FEES", em vez de apenas demandar recursos. O CTNC era criticado pelos dirigentes camponeses, que defendiam reduzir o repasse. O representante da Triunfo se opôs a que o FEES entregasse recursos ao Comitê em 1972, “por não funcionar bem". ${ }^{947} \mathrm{Na}$ ocasião, Oscar Torres defendeu a política da UP de unificação da educação camponesa, dizendo que "o Comitê Técnico (...) causa um grande benefício ao campesinato, pois a experiência nos mostra que os programas de capacitação isolados têm benefícios limitados e os recursos são mais bem aproveitados e um programa integrado". ${ }^{448}$ Os representantes da Libertad e da Triunfo questionavam a efetividade do Comitê, enquanto as confederações estavam passando por dificuldades, obrigadas a cortar cursos de capacitação.

\footnotetext{
${ }^{941}$ Les caerá la teja a latifundistas que no cumplen con el 2\% del "FEES". El Siglo, 17/06/1971.

942 Id., ibid.

${ }^{943}$ ARNAD, Ministério do Trabalho, v. 2706. Acta de la 6 6 a sesión extraordinaria del honorable consejo del FEES, 15/02/1972. ${ }^{944}$ Id., ibid.

${ }^{945}$ Id., ibid.

${ }^{946} \mathrm{Na}$ reunião, Oscar Torres pediu que o presidente da Triunfo desmentisse uma notícia do jornal La Prensa, que acusava o FEES de irregularidades no repasse a essa confederação. O próprio Luis Cossío, presidente da Ranquil, ponderou sobre as dificuldades da prestação de contas, pois muitas vezes realizavam cursos em campos distantes, lugares que não ofereciam recibos. ARNAD, Ministério do Trabalho, v. 2706. Acta de la $8^{\text {a }}$ sesión extraordinaria del honorable consejo del FEES, 04/04/1972.

947 Id., ibid.

948 Id., ibid.
} 
Em síntese, o estrangulamento orçamentário operado pela oposição (DC e PN) e a sonegação dos aportes patronais aos organismos do agro responsáveis pela capacitação comprometiam o funcionamento feral da capacitação camponesa no governo da UP, que além de tudo sofria com desgaste do debate ideológico. O governo lutou pela recomposição do financiamento da capacitação camponesa e não é por acaso que recorreu ao trabalho voluntário para alfabetização de camponeses.

\section{De volta às bases}

A experiência política que mais dava sentido ao trabalho do educador Rolando Pinto era o diálogo com os camponeses e o trabalho nas bases. "Me lembro de sair das reuniões do Comitê, que às vezes duravam um dia inteiro, com enxaqueca. Até que disse: já chega, me cansei”, lembrou: "Quando vi que aquele trabalho se tornava algo burocrático, sai do Comitê e fui para CORA". ${ }^{949} \mathrm{Na}$ CORA, desceu de volta ao terreno para trabalhar dentro da linha de capacitação empresarial ou técnicoprodutiva, nos cursos para camponeses do setor reformado. Era uma ação pedagógica colada às equipes de produção e das assembleias de assentamentos. Essa foi, segundo Barraclough e Fernández, uma das linhas de capacitação que mais se desenvolveu no CNTC, com cursos de planificação produtiva e para cajeros-bodegueros, que cuidavam da contabilidade da empresa coletiva. O princípio era "que os camponeses fizessem o manejo produtivo de acordo à concepção socialista", ${ }^{950}$ explicou Rolando Pinto. Para isso, era necessário "entregar instrumentos ao produtor beneficiário para que, em sua gestão produtiva e em sua gestão econômico-social, tivessem em vista que se tratava de um poder camponês. Daí a importância dos planos de exploração". ${ }^{951}$

Seguindo o percurso do professor Rolando Pinto, descerei às bases da capacitação no setor reformado, para analisar a batalha da produção e as batalhas da capacitação.

\subsection{Batalha da produção, batalhas da capacitação}

\section{Batalha da produção}

"No Chile de Allende, as revoluções verde e vermelha são agora vistas como interdependentes, e poder e produção, como inseparáveis", escreveram Kay \& Winn (1972: 22) à época. Durante o governo da UP, a pedagogia para aumentar a produtividade da reforma agrária aderia plenamente à modernização oferecida pelo capitalismo internacional, ao mesmo tempo que extrapolava os programas técnicos de capacitação, tornando-se uma questão central da luta política em toda sociedade. Entre as narrativas da modernização, o tema da produtividade era a pedra angular e a razão de ser da reforma

\footnotetext{
${ }^{949}$ Entrevista com Rolando Pinto Contreras, Santiago, 11/12/2018.

950 Idem.

951 Idem.
} 
agrária. Foi com o argumento da produtividade que Alessandri entregou terras estatais em forma de colônias para médios proprietários em 1962; foi com o mesmo argumento que Frei construiu uma reforma agrária estrutural em 1967. O aumento da produtividade sustentava a reforma agrária da CEPAL, da FAO e da Aliança para o Progresso, cujo programa se materializou no relatório CIDA (1966), dirigido por Solon Barraclough.

Consequentemente, a batalha da produção agrária anunciada por Allende tornou-se o centro da guerra política da via chilena ao socialismo na agricultura. Por meio da produtividade agrária as esquerdas lutavam para demonstrar que o setor reformado era a maneira superior de organização social do trabalho, que a propriedade coletiva do campesinato era mais produtiva que a propriedade capitalista. Em suma, a produtividade agrária era uma chave mestra para todos os projetos de transformação, e se tornara o avatar das batalhas ideológicas da revolução chilena. Consequentemente, uma das principais ferramentas de deslegitimação da política agrária do governo popular foi a denúncia da queda da produtividade, sistematicamente realizada pela SNA, pela DC, pelo PN, entre outros.

A estratégia retórica da SNA, contudo, era sofisticada. A oligarquia rural explorava as fissuras da própria esquerda por meio de um pragmatismo produtivista. Por um lado, nos primeiros meses de governo, a SNA buscou dialogar com Allende em reuniões, cartas e gestos de trégua, o que incluiu a viagem do seu presidente Benjamin Matte a Cuba. ${ }^{952}$ Matte fez questão de se mostrar distante das rivalidades ideológicas, e construiu a imagem de alguém exclusivamente preocupado com a produção. "A delegação da SNA que viajou recentemente a Cuba (...) tinha por objetivo abrir os mercados cubanos para a exportação de produtos agropecuários chilenos", dizia El Campesino em janeiro de 1971: "o resultado foi amplamente positivo". 953 Por outro lado, a SNA acusava veementemente o MIR e as tomas, os classificando de "gangsters" e "sabotadores da produção", 954 jogando com as tensões internas da UP.

Embora nem todos os setores do governo popular simpatizassem com o processo de tomas, quando a direita acusava a esquerda radical de sabotagem produtiva, a UP unia vozes para defender sua própria capacidade de aumentar a produção. No começo de 1971, Chonchol "desmentiu contundentemente uma série de falsidades disseminadas pelos elementos latifundiários (...) de que a aplicação da lei de reforma agrária significaria uma inevitável crise da produtividade". ${ }^{955} \mathrm{O}$ ministro garantia que as colheitas iam bem na Araucanía durante o cautinazo, e a Empresa de Comercialização Agrícola (estatal) estava pronta para comprar todo trigo. Também assegurava a "ótima produção leiteira de Temuco", 956 mostrando que nem a reforma agrária, nem as tomas geravam queda da produtividade.

\footnotetext{
952 Em novembro de 1970, a SNA entregou um memorando a Salvador Allende e pediu que se "definisse as regras do jogo". Ver Actividades de la SNA: Memorándum a Salvador Allende; El Campesino. Nov/1970, v. CI, nº 11; Editorial: Necesidad de definir las reglas del juego. El Campesino. Nov/1970, v. CI, nº 11.

${ }^{953}$ Actividades de la SNA. El Campesino. Ene/1971, v. CII, nº 1; La SNA en Cuba. El Campesino. Jan/1971, v. CII, no 1.

954 Gagsterismo en Cautín. El Campesino, Abril/1971, v. CII, no 4; Editorial: ¿Quién sabotea la producción? Abril/1971, v. CII, $\mathrm{n}^{\circ} 4$.

${ }^{955}$ No hay problemas con cosechas: el momiaje miente de puro miedo. El Siglo, 09/02/1971.

956 Id., ibid.
} 
Em novembro de 1970, Baytelman já havia respondido acusações de que os assentamentos estavam desperdiçando recursos e que sua produtividade era baixa, à deriva de um caos econômico. Para justificar a dificuldade de muitos assentamentos em arcar com suas dívidas frente à CORA, o comunista responsabilizou o governo anterior: "o processo de reforma agrária até aqui foi feito de forma paternalista, os camponeses não têm conhecimento de algumas decisões (...) e não sabem qual é o processo financeiro que estão vivendo", ${ }^{957}$ argumentou Baytelman: "se um assentamento tem saldo negativo, isso não desmerece a reforma agrária. O importante é a consciência da capacidade empresarial. Se os camponeses sabem que estão perdendo dinheiro, a comunidade tomará as medidas necessárias para afrontar a situação", completava. Desde o começo da reforma agrária, Chonchol explicava seu caráter deficitário para o Estado: era preciso arcar com indenizações aos proprietários e subsidiar a adaptação camponesa à nova organização do trabalho. Ou seja, subsidiar o tempo da capacitação. Mas qual era o tempo da capacitação? Não seria a aceleração do tempo pedagógico um problema central no alerta de Paulo Freire (1969) contra a invasão cultural dos técnicos extensionistas ao mundo camponês? A batalha da produção era a batalha da capacitação e no seio do processo revolucionário havia uma contradição entre acelerar o aumento da produtividade e respeitar os ritmos do poder popular camponês, isto é, seguir os pressupostos da pedagogia freiriana.

A batalha da produção agrária era também, por essência, a batalha política. A imprensa de esquerda atravessou o triênio demonstrando que os latifundiários promoviam ações sabotadoras em diferentes territórios. Autoridades de Santa Cruz (O’Higgins) denunciaram, em março de 1971, que um latifundiário de Chépica, Jorge Dacaret, provocou um incêndio proposital em seu cultivo de trigo, denunciado por cinco trabalhadores que receberam a ordem para tocar fogo. ${ }^{958}$ Nas propriedades intervenidas pelo artigo 171 devido a conflitos entre patrões e camponeses, havia grande tensão sobre a questão produtiva. Os trabalhadores rurais da província de Santiago, se reuniram em março de 1971, para alertar que os proprietários estavam realizando ações de sabotagem da produção e pediram apoio das confederações sindicais..$^{959}$

Naquele mês, o problema mobilizou autoridades máximas do governo: "o plano de sabotagem à produção agrícola, lançado pelo $\mathrm{PN}$ e a direita da $\mathrm{DC}$, foi denunciado ontem em conferência de imprensa oferecida pelas mais altas autoridades do agro, encabeçadas pelo ministro Chonchol e os dirigentes agrários dos partidos da UP”, dizia El Siglo. O ministro anunciava o Plano de Produção Agrária para 1971-1972, como primeiríssima prioridade do governo, com endosso de Allende. ${ }^{960} \mathrm{~A}$ produção agrária era estratégica para alimentar os trabalhadores urbanos, cujo poder de consumo crescia rapidamente, e sobretudo para liberar divisas de importação de alimentos. Tais divisas eram indispensáveis no projeto de desenvolvimento revolucionário, tanto para investimentos sociais, como

\footnotetext{
${ }^{957}$ No se está botando la leche en asentamientos. La Nación, Nov./1970.

${ }^{958}$ Latifundista incendió intencionalmente 40 hectáreas de trigo. El Siglo, 12/03/1971.

${ }^{959}$ Sabotaje y sedición patronal, denuncian los campesinos. El Siglo, 13/03/1971.

${ }^{960}$ Chonchol: Plan para derrotar el sabotaje momio en la agricultura. El Siglo, 25/03/1971.
} 
para industrialização. O governo convocava não apenas os camponeses, mas também os pequenos e médios proprietários, os trabalhadores da CUT, os pescadores, os estudantes voluntários, os profissionais do agro, e até mesmo os latifundiários remanescentes, para a batalha da produção agrária: "todo mundo vai trabalhar" 961 pela agricultura, anunciava o governo.

Na conferência de março de 1971, Baytelman garantiu: "esse governo não apenas entregará a terra aos camponeses, como também eles mesmos que se encarregarão dos planos de produção e do aspecto financeiro e administrativo, coisa que jamais fez a CORA dirigida pelo senhor Rafael Moreno". 962 Vencer o paternalismo da DC no quesito administração do setor reformado significava entregar aos camponeses o poder produtivo e simultaneamente garantir o aumento da produção. O elo desse processo era a capacitação que, como vimos, sofria com escassez de recursos e impasses políticos graves.

Ao longo de 1971, a relação do governo com organizações camponesas da DC passou a se deteriorar. A produção do setor reformado foi questionada e denunciada pela oposição para deslegitimar as políticas agrárias da via chilena ao socialismo, o que se agravou com a criação dos CERA e CEPRO. Se inicialmente o campesinato da DC apoiou a escolha de Allende pelo Congresso e se mostrou disposto a dialogar com o governo em diferentes reuniões, com um dirigente da Triunfo (Victoriano Zenteno) presidindo o Conselho Nacional Campesino, ${ }^{963}$ ao longo de 1971 a Triunfo Campesino, a Libertad e a Confederação de Assentamentos assumiram um discurso cada vez mais pessimista e denuncista, diversas vezes vocalizado pelo deputado Emilio Lorenzini (DC). O divisor de águas da relação entre Allende e o campesinato da DC foi a criação dos CERA e CEPRO em setembro de 1971.

No dia 14 de setembro, Lorenzini leu em plenário uma carta das três confederações camponesas de oposição (Triunfo, Libertad, Assentamentos), acusando o governo de trair o campesinato com uma suposta estatização da terra, por meio de novas formas propriedade. Segundo a carta, o agrupamento de múltiplas unidades produtivas num único CERA iria "dificultar tremendamente a administração das propriedades, que por essa razão ficam sujeitas aos funcionários do Estado". ${ }^{964} \mathrm{Ou}$ seja, denunciavam o governo da UP exatamente daquilo que o comunista Baytelman acusava ter sido característico no governo da DC: a tutela dos funcionários do agro sobre o setor reformado. Além disso, denunciavam que a incorporação dos afuerinos (desempregados) ao CERA "deixará totalmente descapitalizado o conjunto das propriedades", e entregaria "a administração e planificação (...) à CORA". Alegavam também que no CERA, a propriedade da maquinária agrícola pertencia ao Serviço de Mecânica Agrícola (SEAM) do Estado, que submetia os camponeses a contratos superfaturados: "com um ano que os camponeses pagam de aluguel por um trator, poderiam comprar dois tratores", denunciava a carta. Por fim, alegavam que "os excedentes obtidos pelo CERA serão destinados ao Estado, sem participação dos camponeses", o que criava um sistema de absorção da renda camponesa que

\footnotetext{
${ }^{961}$ Todo Chile se movilizará por el plan de aumento de la producción agrícola. El Siglo, 25/03/1971.

962 Id., ibid.

963 Dirigente de la "Triunfo" es presidente del Consejo Campesino. El Siglo, 12/01/1971.

964 Referência de todas as citações do parágrafo: Diario de Sesiones, Cámara de Diputados, Legislatura Ordinaria, Sesión 30a , 14/09/1971, pp. 3360-3361.
} 
corroborava com a tese do "novo patrão Estado", difundida pela DC. O deputado Lorenzini arrematava a carta das confederações com o discurso agrário que se galvanizou na oposição camponesa até o golpe: "Se os camponeses só terão salários e não podem obter lucros, como vão pagar a compra da terra? (...) A vontade do Estado não é entregar jamais a terra aos camponeses, mas sim reservá-las para si”. A tensão se acirrou ainda mais quando, em novembro de 1971, o congresso da confederação de assentamentos ignorou as posições dos delegados camponeses da UP e o jornal freista La Prensa anunciou em manchete que os assentados exigiam a renúncia de Chonchol. Para a imprensa comunista, tratava-se de uma "resolução politiqueira de alguns dirigentes e de costas para as massas camponesas, que durante todo o período do governo UP respaldaram a reforma agrária e seu ministro". 965

Apesar da tensão sobre as formas de propriedade reformada, no fim de 1971, predominava um tom otimista do governo sobre a batalha da produção. Em termos quantitativos, a produtividade agrária efetivamente aumentou, e, no entanto, a percepção sobre a oferta de alimentos foi afetada pelo crescimento concomitante do consumo devido às melhorias salariais. O governo da UP executou uma política de reajustes salariais diferenciais, que beneficiava os mais pobres com aumentos maiores. Isso gerou aumento da renda per capita, que se combinou com a redução do desemprego, o rebaixamento de preços de produtos de consumo massivo pelo governo e outras políticas sociais, que desencadearam um

\begin{tabular}{|c|c|}
\hline $\begin{array}{c}\text { Tabela 31 - Aumento da } \\
\text { disponibilidade alimentar per capita } \\
\text { (1970 a 1972) }\end{array}$ \\
\hline Trigo & $16,5 \%$ \\
\hline Arroz & $21,6 \%$ \\
\hline Açúcar & $23,8 \%$ \\
\hline Leite & $53,8 \%$ \\
\hline Carne & $25,6 \%$ \\
\hline Ovos & $13,5 \%$ \\
\hline Batata & $8,1 \%$ \\
\hline Óleo & $8,6 \%$ \\
\hline Revista Agrária $\mathrm{n}^{\circ}$ 1, Chile Hoy, $1972: 10$ \\
\hline
\end{tabular}
rápido aumento do poder de compra das populações periféricas. Essas gastavam $50 \%$ da sua renda em alimentos. ${ }^{966}$

Articulistas do Chile Hoy chamavam esse fenômeno de paradoxo do abastecimento. Entre 1965 e 1970, havia ocorrido um aumento de $14,8 \%$ da oferta global de alimentos no Chile. Comparativamente, entre 1970 e 1972, o aumento da disponibilidade alimentar foi de $27 \%$ (tabela 31). ${ }^{967}$ Os autores constatavam, porém, que a oferta alimentar fora puxada pelas importações, mais que pela produção interna. Em 1972, a importação real de alimentos era o dobro em relação a 1970 e o preço dos alimentos importados saltou em 8\% em 1971 e em 41\% em 1972 frente aos anos anteriores. Nesse contexto, apesar do aumento da produção agrícola interna durante a reforma agrária, a importação de alimentos sobre a oferta alimentar global saltou de 21,3\% (1965-1970) para 33,2\% (1972). Os autores defendiam que antes da eleição de Allende havia um "racionamento invisível", naturalizado pelo capitalismo, que entrou em evidência quando a revolução chilena promoveu o acesso popular a um padrão alimentar mais digno.

Como era previsível, esse processo originou um desequilíbrio na balança comercial. Em 1972, mais de $30 \%$ das divisas de exportações eram usadas para importação de alimentos e outros $15 \%$ para

\footnotetext{
965 PDC utiliza a campesinos para atacar al gobierno popular. El Siglo, 01/11/1971.

${ }^{966}$ Gerson Gomez \& Ivan Ribeiro, Paradojas del Abastecimiento. Revista Agraria n.1, Chile Hoy n. 25, Dez/1972.

967 Id., ibid
} 
matérias-primas agropecuárias à indústria. Isso fazia com que a UP diagnosticasse que $45 \%$ da sua capacidade importadora estava comprometida com produtos agroalimentares. A revolução chilena na agricultura tinha a missão de resolver esse problema. Também por isso, a UP seguiu denunciando as sabotagens dos proprietários privados ao longo de todo triênio, de incêndios propositais às reduções das superfícies cultivadas, de soltura de animais dos patrões para pastar nos cultivos dos assentamentos à paralisia produtiva de alguns setores privados. ${ }^{968}$

Uma das estratégias da UP para o incentivo à produção foi a amizade entre trabalhadores urbanos e rurais. Os sindicatos promoviam encontros de capacitação e entretenimento para estimular a aliança afetiva entre operários e camponeses, além de reforçar o sentido moral do esforço produtivo. "Jogaram futebol, cantaram e dançaram, almoçaram juntos e transmitiram suas experiências", relatava uma matéria sobre um dia de encontro entre os operários da Industria Têxtil El Progreso, a qual operava sob controle dos trabalhadores há 5 meses, e os camponeses da propriedade San Ramón, em Melipilla: "operários têxteis e trabalhadores agrícolas se confundiram, uma vez mais, em um abraço fraternal". ${ }^{669}$ Uma cerimônia de prêmios aos operários têxteis mais produtivos era uma forma de incentivo ao campesinato. O interventor da fábrica, Heriberto Molina, explicava: "vocês, companheiros do campo, tem que produzir a terra (...), semear e colher batatas, feijão, arroz... Tudo o que o povo necessita para se alimentar. E nós temos que produzir os tecidos para vesti-los. Temos que trabalhar mais, elevar a produção". ${ }^{970}$

O governo, os organismos do agro, a CUT, os dirigentes sindicais e os partidos, todos conclamavam o campesinato a produzir mais. ${ }^{971} \mathrm{Se}$ o camponês conhecesse o trabalhador urbano que deveria alimentar e com ele estabelecesse vínculos afetivos, poderia encarar a tarefa com mais empenho coletivista. $\mathrm{O}$ esforço de produtividade da reforma agrária foi visível também quando, em novembro de 1971, na Feira Internacional de Santiago (FISA) da SNA, o maior evento de exposição agropecuária do país, a CORA e os assentados apresentaram stands inéditos que concorriam com as exposições patronais: "uma inusitada ofensiva do setor reformado no coração da exposição anual da SNA surpreende a muitos visitantes", ${ }^{972}$ relatava uma matéria: "a mostra da CORA comprova que o camponês, fora do regime feudal tradicional, em propriedades administradas por eles mesmos, conseguem aumentar a produção e recuperar todos os índices". ${ }^{973}$

\footnotetext{
${ }^{968}$ Cómo opera el sabotaje a la producción agrícola. El Siglo, 03/04/1971; El complot del agro. El Siglo, 28/03/1971; Dueños de fundos queman cultivos. El Siglo, 01/12/1971.

${ }^{969}$ Frente común para ganar la batalla de la producción. El Siglo, 26/10/1971.

970 Id., ibid.

${ }^{971}$ El campesino: primer actor en la lucha por producir más. El Siglo, 03/11/1971.

972 FISA: Campesinos muestran sus realizaciones en Stands de CORA. El Siglo, Nov./1971.

${ }^{973}$ Id., ibid.
} 
Naquele mesmo mês, Fidel Castro estava visitando o Chile em uma viagem que durou 24 dias.

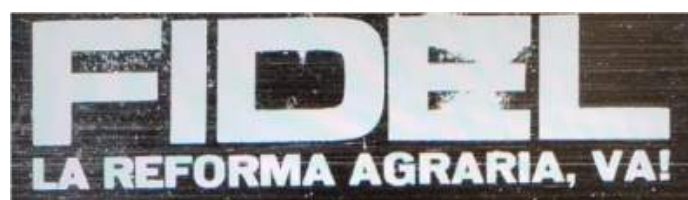

la tierra es el pan de Chile...

... con'el trabajo

y la abnegación

de nuestros campesinos,

estamos ganando

la batalla de la producción

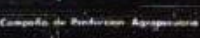

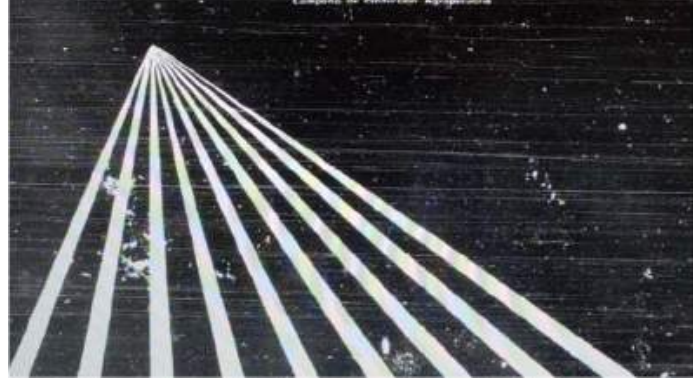

El Siglo relaciona Fidel Castro à batalha da produção. 10/11/1971.

Allende aproveitou as aglomerações massivas de trabalhadores diante do líder cubano para fortalecer o sentimento moral da batalha da produção. A importância da disciplina laboral para a revolução foi um dos três principais assuntos de Fidel em seu diálogo com as multidões chilenas de norte a sul do país. O cubano explicava incansavelmente, em todos os seus discursos, que os sacrifícios dos trabalhadores feitos para a revolução geravam benefícios coletivos, ao contrário dos sacrifícios feitos anteriormente, sob a coerção dos capitalistas e para enriquecer oligarquias e elites (Borges \& Vasconcelos, 2019: 246-273).

Em 1971, a CORA declarou que a área reformada conseguiu poupar 17 milhões de dólares em importações agroalimentares, o que ainda era extremamente pouco perto dos 350 milhões de dólares gastos em importação de alimentos naquele ano, ${ }^{974}$ ainda mais estrangulados pela queda do preço do cobre, que gerava prejuízos de 100 milhões de dólares anuais (Huerta, 1989: 363). No Plano Agropecuário da ODEPA para 1972/1973, a batalha da produção prometia cultivar 1.709.000 hectares novos, sendo 814.000 no setor reformado (Huerta, 1989: 365). Na tabela 32 a seguir, se compara a meta de produção em relação ao efetivamente alcançado em 1972 em três setores: o reformado, os pequenos proprietários e a burguesia agrária.

\begin{tabular}{|c|c|c|c|}
\hline \multicolumn{5}{|c|}{ Tabela 32 - Batalha da produção: expansão da superfície cultivada (1972/1973) } \\
\hline & Meta (hectares) & Realidade (hectares) & Realidade (\%) \\
\hline CORA & 814.000 & 450.700 & 34 \\
\hline INDAP & 895.000 & 194.700 & 14,7 \\
\hline Setor privado & -- & 678.400 & 51,3 \\
\hline Total & 1.709 .000 & 1.323 .800 & 100 \\
\hline \multicolumn{4}{|r|}{ Fonte: Barraclough \& Fernandez, 1974: 108; Huerta, 1989: 366.} \\
\hline
\end{tabular}

Segundo Huerta (1989), o setor privado teria sido responsável por 51\% dos cultivos em 1972 e 1973, em consequências de dois fenômenos. Por um lado, proprietários improdutivos decidiram se proteger da reforma agrária por "má exploração", frequentemente utilizada pela UP para expropriações, e colocaram terras baldias para produzir pela primeira vez na sua história. Nesse sentido, a pressão

${ }^{974}$ Editorial: Acuerdo con las confederaciones. Revista Agraria n.1, Chile Hoy n. 25, Dez/1972 
produtivista da reforma agrária teria funcionado para disciplinar uma fração da classe proprietária. Por outro lado, as reservas patronais entre 40 e $80 \mathrm{HRB}$ estavam ultracapitalizadas, devido a não expropriação dos bens de capital, problema sinalizado nos debates da comissão agrária da UP. Isso tornava o ponto de partida das reservas patronais muito mais favorável do que o dos assentamentos.

Os esforços para levantar a produção do setor reformado foram inúmeros. Em novembro de 1971, uma reunião geral de Chefes Zonais da CORA com Baytelman na comuna de Padre Hurtado, fixou metas de produção próprias aos assentamentos, CERA e CEPRO, que deveriam expandir em 4 mil hectares frutícolas nos dois anos seguintes, preservar o gado em idade reprodutiva, ampliar a reprodução pecuária endógena e aumentar a produção leiteira. Apesar do estrangulamento orçamentário, a CORA anunciou 8 milhões de escudos em infraestrutura produtiva (irrigação, silos, galpões, bodegas) e social (casas camponesas, escolas rurais, policlínicas). Na reunião, falava-se em "aproveitamento máximo de todos os recursos" e "exploração produtiva de novas e amplas zonas", e sempre se levava em conta o caráter coletivo do setor reformado. ${ }^{975}$

A ausência do campesinato em uma reunião de planificação produtiva dos chefes zonais da CORA, contudo, mostrava uma contradição interna da UP: a batalha de produção parecia desintegrada dos conselhos camponeses. Em um curso de capacitação da UOC, em fins de 1972, um camponês formulou o problema da seguinte forma: "Deixaremos de estar explorados quando conseguirmos o poder". ${ }^{976} \mathrm{Em}$ outras palavras, o poder popular camponês encontrava um limite no imperativo da produtividade, quando um plano nacional de produção era determinado de cima para baixo com base na decisão dos técnicos. Diferentemente da pedagogia do território, na qual metodologias freirianas eram usadas para que as demandas produtivas e a criação de um plano agropecuário comunal surgissem de baixo para cima, por meio da pesquisa camponesa do território, o Plano Nacional Agropecuário de 1971 e 1972 foi construído no âmbito da tecnoestrutura do Estado. Essa tensão latente entre técnicos, que elaboravam o plano, e camponeses, que deveriam executá-lo, precisava ser resolvida pela capacitação, através dos chamados planos de explotación ou planos de produção. Cada assentamento necessitava aprovar em assembleia um plano de produção que se orientasse pelas diretrizes do plano nacional. A planificação geral vinha de cima, mas os próprios camponeses precisavam aprender a planificar coletivamente dentro da sua unidade produtiva por meio das assembleias e debates entre os trabalhadores nas bases. Evidentemente, os ritmos desses dois processos planificadores paralelos, de cima e de baixo, podiam se desencontrar. Por isso a missão da capacitação camponesa no setor reformado era mais complexa do que se poderia imaginar. Nela estavam depositadas as possibilidades de engajamento e protagonismo camponês na batalha da produção, tanto quanto o sentimento camponês de haver sido enganado, pois lhe ofereceram a terra e a liberdade do jugo patronal e lhe entregaram uma enorme pressão produtiva. A horizontalidade ou verticalidade do processo capacitador em cada assentamento variava, mas os imperativos da batalha da produção pautavam a vida nacional e pareciam inescapáveis.

\footnotetext{
975 Aumento de la producción analizan en CORA. El Siglo, 24/11/1971.

976 Gajardo, 1973c.: 45
} 
Em junho de 1972, quando a UP eliminou o latifúndio e expropriou 5,3 milhões de hectares, essa tensão se tornou mais evidente e a divisão das esquerdas se acirrou. Enquanto o allendismo identificava na batalha da produção o objetivo principal da continuidade da revolução, o que exigia estabilidade social no agro e foco nas tarefas produtivas; o setor da esquerda radical, priorizava a questão do poder e alertava que era preciso derrotar a burguesia agrária, pois seria ela a articuladora da contrarrevolução. ${ }^{977}$ Todos esses dilemas estavam simultaneamente ativos em múltiplas batalhas da capacitação, nas multidões de capacitadores e camponeses que interagiram naquele período.

O que se constata é que o governo popular oferecia espaços de diálogo no âmbito dos conselhos camponeses, porém no processo planificador da produção do setor reformado predominava uma tensão entre a decisão dos funcionários da CORA e a metodologia freiriana voltada para as tarefas técnicoeconômicas.

\section{Batalhas da capacitação}

Nas narrativas da modernização, inúmeras vezes a capacitação camponesa aparecia como um "momento mágico", no qual as heranças subjetivas não eram problematizadas como obstáculos para a nova estrutura. A ausência de uma compreensão antropológica sobre a economia pode ter prejudicado a revolução chilena na agricultura, que viveu uma cisão entre a racionalidade econômica dos planejadores e a realidade do campesinato. A capacitação dos planificadores era mecânica, como se ao receber determinadas instruções, o camponês se convertesse automaticamente naquilo que precisava ser: um empresário coletivo. As possibilidades de aumento produtivo, portanto, na maior parte das vezes estava relacionada com o convencimento político do campesinato a respeito da importância social do seu trabalho. Isso porque os estímulos materiais individuais, naquele momento, terminaram concentrados no goce ou huerto familiar; enquanto os rendimentos coletivos cresciam de maneira irregular e incerta, através de uma prática de organização econômica experimental e nova.

A territorialidade da reforma era bastante heterogênea: houve assentamentos que aumentaram sua produtividade; outros que diminuíram os registros coletivos, mas aumentaram a produtividade dentro dos goces individuais; outros que reduziram a produção em decorrências de conflitos internos. Às vezes, o camponês se comportava como um pequeno empresário subsidiado dentro de um contexto formal de propriedade coletiva, como se "todo latifúndio fosse a nova regalia. Sobre isso, no prefácio do Diagnóstico, Fernández formulava uma pergunta chave para a revolução chilena na agricultura: "porque é tão segura a pequena exploração no âmbito da reforma agrária, sendo um modo de produção estancado e decadente fora dela?” (apud Barraclough \& Fernández, 1974: 11). Chonchol (1976) sintetizou o problema escrevendo que "a contabilidade da produção era conduzida por funcionários da CORA em seus longínquos escritórios e sofria atrasos, de modo que ao fim do ano não se sabia se havia

\footnotetext{
${ }^{977}$ Etapa de consolidación: segundo “pie” de la RA. La Nación, Jul./1972.
} 
benefícios ou perdas". Além disso, continua, "como os adelantos salariais eram iguais a todos (...), os camponeses mais esforçados perceberam que a melhor maneira de aumentar sua renda era dar mais importância ao cultivo individual. O interesse pela exploração coletiva ia diminuindo em benefício da individual" (Chonchol, 1976). Para resolver o problema era necessário articular duas ações: primeiro, criar um sistema diferencial de remunerações vinculado ao trabalho dos cultivos coletivos nas unidades reformadas, ou seja, um incentivo material à propriedade coletiva; e segundo, conduzir essa mudança no seio dos processos de capacitação e da transformação subjetiva do campesinato, alterando a prática da sua economia moral da regalia, pela demonstração das vantagens materiais da economia coletiva. Em outras palavras, atrelar de maneira mais orgânica a batalha da produção e a batalha da capacitação aos incentivos materiais e morais requeridos pela revolução.

Com base em pesquisas empíricas, a brasileira Maria Edy Ferreira (que liderou as equipes freirianas do ICIRA) alertava desde 1968 que tanto os padrões de resistência camponesa pela expansão da regalia, como as hierarquias laborais da hacienda se reproduziam subjetivamente na nova estrutura de propriedades. Se os camponeses lutaram por décadas para ampliar sua produção autônoma no interior do latifúndio, a tendência era que seguissem buscando essa meta individual no interior dos assentamentos. Ao mesmo tempo, as antigas hierarquias patronais se refletiam na "formação de uma oligarquia burocrática constituída por dirigentes camponeses reeleitos para cargos de autoridade dentro do assentamento" (Ferreira, 1970: 22). Ao estudar as expectativas camponesas e as tendências de poder entre os assentados, Ferreira $(1968$; 1970) argumentava que os desejos e aspirações dos camponeses não apareciam na forma de "plano ordenado", como requerido pela CORA. Desde o governo anterior, a socióloga se perguntava: "frente aos projetos da CORA e planos de governo, como o camponês assentado vai construindo as linhas de seu próprio projeto? São orientações convergentes?" (Ferreira, 1968: 16). Como construir uma democracia produtiva no seio de uma subjetividade marcada pela autoridade patronal ou do mayordomo? ${ }^{978}$ As lideranças da UP e os funcionários do agro tinham pressa para o aumento da produtividade e apostavam nos camponeses para desatar o nó do subdesenvolvimento e sustentar a estratégia econômica da revolução, lhes apresentando planos de produção nem sempre compatíveis com a subjetividade camponesa.

Alguns obstáculos subjetivos ao aumento da produção estavam relacionados ao aprendizado democrático, ao uso das assembleias de assentamento como ferramenta organizativa dos planos de produção. Nisso consistiu a atuação capacitadora de Rolando Pinto, depois que saiu do CTNC e se tornou chefe nacional do Departamento de Capacitação Agropecuária da CORA. "Havia dois grandes departamentos de capacitação, que eu unifiquei”, explicou: "a capacitação agroeconômica, que

\footnotetext{
978 “O mayordomo que foi a figura autoritária mais criticada no fundo, aquele a quem se atribuía a função não justificada de controlar os trabalhos dos inquilinos, agora passa a ver legitimada sua função pelos canais democráticos que reestruturam o antigo sistema (...). Quem exerce a função de autoridade patronal para o camponês assentado? Seria a própria CORA? (...) O presidente do assentamento estaria unicamente localizado em seu antigo papel de delegado de um poder máximo confundido com aquele que possui a terra e orienta o processo de produção da empresa?" (Ferreira, 1970: p. 25-26), questionava a pesquisadora.
} 
elaborava os planos de produção (...); e a capacitação social, com educação sobre as leis, a alfabetização, o programa da mulher". ${ }^{979}$ Isso ocorreu em fins de 1971. O novo ramo se chamou Capacitação Socioprodutiva e fundia as técnicas da pedagogia freiriana com os cursos de gestão e administração dos assentamentos e CERA. Pinto se recorda que alguns dos participantes do experimento pedagógico de El Recurso atuaram junto com ele nessa linha, buscando unificar a pedagogia freiriana com a capacitação técnico-econômica. Mas essa fusão não agradou a todos. Entre os pedagogos, por exemplo, Júlio Salgado não gostava de trabalhar com os agrônomos. ${ }^{980}$ Por outro lado, muitos agrônomos e extensionistas rejeitavam usar a pedagogia freiriana para ensinar técnicas produtivas e administração. Rolando Pinto contou que alguns agrônomos com quem trabalhava na capacitação socioprodutiva da CORA, certo dia "apresentaram uma acusação para me expulsar do Colégio de Agrônomos, alegando que eu não levava em conta os indicadores de qualidade do solo para impulsionar certos cultivos", relatou em tom de anedota: "Necessitávamos expandir! Eu realmente não me preocupava com a qualidade de solos. Nosso tema era a ocupação agrícola do terreno, um conceito político distinto". ${ }^{981} \mathrm{O}$ que os agrônomos não sabiam é que Rolando Pinto não era agrônomo e, consequentemente, não poderia ser expulso do Colégio. Mas não eram todos. Segundo ele, "muitos técnicos viam com bons olhos essa integração, porque sabiam que muitos problemas produtivos dos camponeses estavam relacionados a problemas sociais". 982

O trabalho da capacitação socioprodutiva da CORA consistia em utilizar as ferramentas dialógicas freirianas para desenvolver o plano de produção junto aos "grupos de explotación" dos assentamentos e CERA. Os grupos de explotación eram as equipes de trabalho internas à unidade reformada, que se responsabilizavam por diferentes tipos de tarefas. Havia quatro tipos de equipes: primeiro, as equipes responsáveis pelo ciclo completo de um único cultivo específico ao longo de todo ano; segundo, as equipes encarregadas de uma etapa de da produção (a preparação do solo, a semeadura, o crescimento, aplicação de pesticidas, ou a colheita), dividindo a produção de diferentes cultivos com outras equipes; terceiro, havia as equipes especializadas em máquinas agrícolas, que pilotavam tratores, garantiam a manutenção e a limpeza das máquinas; e quarto, havia as equipes administrativas do assentamento, nos quais se destacavam os dirigentes alfabetizados, os camponeses capacitados em cursos do CTCN para cajeros-bodegueros, os dirigentes sindicais e aqueles camponeses com facilidade de circulação na cultura urbana (Gómez, 1994). Segundo o Diagnóstico, os cursos para cajerosbodegueros teria sido um dos poucos êxitos do CTNC (Barraclough \& Fernández, 1974: 236).

Sergio Gómez (1994), mapucista que trabalhava na ODEPA com a planificação agrária, alertava que não existia uma norma de trabalho padronizada para organização das remunerações no setor reformado e isso gerava uma série de problemas. Via de regra, desde o início da reforma agrária,

\footnotetext{
${ }^{979}$ Entrevista com Rolando Pinto Contreras, Santiago, 23/05/2019.

980 Id., ibid.

${ }^{981}$ Id., ibid.

982 Id., ibid.
} 
os assentados recebiam os mesmos valores de antecipo a cada mês, independente das horas trabalhadas. Esse sistema originava insatisfação entre camponeses, que passaram a defender, por meio das suas organizações, remunerações diferenciais de acordo com a norma de trabalho e jornadas efetivas. Em muitas unidades reformadas, a ausência do poder coercitivo do mayordomo (capataz) desorganizava o trabalho. Os camponeses passaram a se dedicar muito mais às suas parcelas familiares internas do que à produção coletiva, o que criava conflitos internos dentro dos assentamentos e CERA. Alguns camponeses acusavam seus companheiros de não trabalhar no cultivo coletivo, mas de se beneficiar dos subsídios e créditos comuns. As fronteiras entre o individual e o coletivo no interior do assentamento pareciam borradas, como alertavam Barraclough \& Fernández (1974), e isso dava margem para que muitos camponeses se dedicassem mais dias na parcela interna, usufruindo de sementes, fertilizantes e outros recursos produtivos coletivos. O Estado, portanto, estava financiando uma economia privada de subsistência no interior da propriedade coletiva, o que gerava desorganização produtiva durante a batalha de produção. Reorganizar o trabalho e criar um sistema de remunerações padronizado era uma tarefa urgente para garantir a batalha da produção, mas não era nada simples.

Trabalhando na ODEPA, Gómez (1994) percebia que a planificação produtiva interna ao setor reformado continha três tipos de situação. Primeiro, os camponeses que apreciavam a igualdade de remuneração independente das horas trabalhadas, sintetizado no sentimento "aqui somos todos iguais". Nessa situação, ocorria um relaxamento da disciplina laboral e um conflito com lideranças engajadas na batalha da produção, que criticavam o antecipo igualitário por desestimular o trabalho, mas perdiam nas assembleias quando propunham a remuneração diferencial. Na segunda situação, sintetizada pela frase "aqui somos todos iguais, mas trabalhamos mais ou menos iguais", o coletivo do assentamento percebia os problemas do antecipo igualitário, a assembleia estabelecia sistemas de controle e remunerações vinculadas ao trabalho, junto com sanções ao ausentismo. Nesses casos, um sistema de remuneração diferenciada surgia nas bases, criado pelos camponeses. Essa situação, segundo Gómez, refletia maior consciência da batalha de produção e da necessidade de criar controles coletivos do trabalho. Numa terceira situação, os assentados criavam remunerações diferenciais e normas de trabalho para algumas tarefas, mas não para o conjunto da cadeia produtiva, em um híbrido da primeira e da segunda.

Como não existia um regulamento geral que organizasse as remunerações diferenciais no setor reformado, cada unidade encontrou uma forma de resolver (ou não resolver) o problema da relação trabalho/produtividade. Eram múltiplas tensões internas: trabalhadores que aumentavam a produtividade no seu goce com empenho, mas não colaboravam na produção coletiva; assentados que trabalhavam menos em geral, descomprometidos com a batalha de produção; camponeses preocupados e engajados na batalha da produção, que quando eram maioria conseguiam estabelecer normas de trabalho específicas para sua unidade, ante a inexistência de uma orientação geral a esse respeito; camponeses engajados que eram minoria em seus assentamentos e não podiam vencer a desorganização laboral sem ajuda do Estado. Lembrando do IER e sua economia moral do sacrifício, é possível dizer 
que dessa vez quem se voltava contra os "flojos" era a própria UP, principalmente os comunistas, os mais entusiastas da batalha de produção. Mas a UP não chegou a implementar uma política de remuneração diferenciada pelo trabalho no setor reformado, capaz de "disciplinar os flojos" e criar incentivos materiais para a produção coletiva, atraindo camponeses da parcela familiar interna para a plantação comum. Era justamente nisso que Sergio Gómez (1994) trabalhava quando ocorreu o golpe em 1973. Enquanto isso, restava aos partidários da batalha da produção a propaganda, o engajamento e os estímulos morais.

A criação de um sistema de trabalho para as unidades reformadas foi objeto de acordos incipientes entre governo e confederações camponesas. Em abril de 1971, um documento assinado pela CORA, e pela Confederação de Assentamentos e lideranças de Cooperativas Multi-Ativas Regionais (MULTIRECOOPS) criava uma proposta de remunerações calibradas pelo trabalho. ${ }^{983}$ Contudo, o modelo não foi adotado em escala significativa, já que tampouco estava devidamente atrelado aos processos de capacitação.

Rolando Pinto se recorda que um grupo de técnicos franceses do IRAM (Institut de Recherches et d'Applications des Méthodes de Développement), ligados à esquerda cristã, participava ativamente da tentativa de criar um modelo de capacitação empresarial para que os camponeses aprendessem a formular planos de produção. Os franceses do IRAM, que estiveram no Chile entre 1966 e 1971, eram favoráveis às cooperativas autogestionárias. Convidados por Chonchol antes do triunfo de Allende, trabalharam próximos dos mapucistas Rodrigo Ambrósio e Manuel Antonio Garretón (Durán Cid, 2017). Atuavam com capacitação produtiva no Departamento de Desenvolvimento Camponês da CORA, em diversos territórios, influenciados pelo método psicossocial. Facilitavam as assembleias de assentamento na condução dos planos por meio de uma metodologia de cálculo econômico interno à unidade reformada, registro de jornadas, divisão do trabalho e remuneração diferenciada. Também assessoravam a contabilidade dos assentamentos, e ensinavam como calcular custos de produção, entradas de insumos e planificar canais de comercialização comuns à cooperativa.

Nesse sentido, os franceses do IRAM atuavam em prol da propriedade coletiva camponesa, alinhados à tendência autogestionárias do MAPU. Segundo Durán Cid (2017: 254), "formaram parte da tecnoestrutura, como muitos funcionários da CORA", sendo bem recebidos pelos técnicos chilenos do agro. Entre as metodologias de contabilidade interna do assentamento que propunham, estavam "fichas técnico-econômicas" para registros de custos de produção. Organizar a divisão social do trabalho e a capacitar para especialização técnica eram dois desafios sentidos pela CORA. Em seus informes, os voluntários do IRAM davam conta que "o campesinato tinha (...) arraigada a ideia de que o 'bom camponês' é aquele que sabe fazer de tudo e, portanto, resistiu à especialização em termos culturais" (Durán Cid, 2017: 257-258). Muitos deles coordenaram jornadas de capacitação do CTNC.

983 Além disso, o documento também definia que "a casa e o huerto serão entregues em propriedade familiar; e o resto do assentamento será entregue como cooperativa", e que a superfície do huerto poderia variar entre 0,5 e 2 hectares (apud Gómez, 1994). 
"Os franceses, como muitos funcionários chilenos do agro, estavam conscientes da dimensão sociocultural das transformações promovidas com a reforma agrária e as possíveis resistências do campesinato", explicou Durán Cid (2017: 258). Um dos franceses dizia: "não conheci funcionários burocratas" (Durán Cid, 2017: 260) e descreveu o clima de efervescência que movia a capacitação socioprodutiva.

$\mathrm{Na}$ Capacitação Socioprodutiva, Rolando Pinto Contreras auxiliou muitos assentados a preencher as fichas técnico-econômicas e os planos de produção. Os planos eram pendurados na sala da direção do assentamento, que se incumbia de distribuir os trabalhos para dar conta das metas. Idealmente, cada assentamento estava acompanhado por técnicos regionais e nacionais, mas isso nem sempre ocorria. Pinto Contreras utilizou círculos de cultura para construção de planos de produção nos assentamentos, no entanto não havia nenhum tipo de institucionalização do método, tampouco havia material pedagógico nacional. Por um lado, as condições locais eram cambiantes e demandavam pedagogias específicas; por outro, o CTNC tinha materiais de capacitação empresarial emperrados nas polêmicas da cúpula. Nas bases, o acúmulo de desafios da capacitação produtiva precisava ser resolvido com improviso e criatividade.

Rolando Pinto Contreras assegurou que as fichas técnico-econômicas criadas pelos franceses foram utilizadas em todos os assentamentos: "eu coordenava isso, e sei que funcionou. Foi uma contribuição dos franceses sobre como gerar um plano de desenvolvimento coletivo". ${ }^{984}$ Mas completou: "não aplicávamos essa proposta francesa exatamente como diziam os franceses. A ODEPA fez uma adaptação". O pedagogo explicou que a metodologia da capacitação socioprodutiva estava conduzida pelo trabalho coletivo, pela autogestão e a busca da autonomia camponesa, associadas à luta pelo socialismo agrário. Naquele contexto, Rolando Pinto também relembra que o Capacitação ou Extensão? de Freire "era o livro que tínhamos como guia para comunicação tecnológica, que permitia uma descentralização e a construção de conhecimento produtivo a partir do diálogo entre técnico e camponês". 985

Paulo Freire voltou ao Chile três vezes durante o governo Allende, nas quais trabalhou diretamente com Rolando Pinto na capacitação socioprodutiva da CORA. Embora não estivesse contratado, chegou a lecionar algumas aulas informais para técnicos do agro em 1971 e $1972 .{ }^{986} \mathrm{O}$ brasileiro viajou pelos campos novamente, e ao observar a capacitação, ofereceu formações aos capacitadores. Os militantes do MAPU foram os mais entusiastas de Paulo Freire, mas alguns miristas e socialistas da CORA também pensavam em estratégias dialógicas para o aumento da produtividade. Já os comunistas, segundo Rolando Pinto, militavam pela planificação central e não apostavam em planos de produção construídos em escala local, no diálogo paciente com os camponeses das bases. $\mathrm{O}$ plano de produção, afinal, não era apenas um imperativo produtivista, mas também uma agenda a

\footnotetext{
${ }^{984}$ Entrevista com Rolando Pinto Contreras, Santiago, 23/05/2018.

${ }^{985}$ Id., ibid.

${ }^{986}$ Id., ibid.
} 
serviço do socialismo autogestionário, do poder produtivo camponês por meio da capacitação. Construir um plano de produção exercitava a coletividade do assentamento, criava identidade entre os camponeses e os engajava em objetivos comuns, de maneira que superassem a subjetividade hierárquica que predominou em toda sua experiência anterior: "queríamos demonstrar como se progredia melhor coletivamente do que individualmente", ${ }^{987}$ confirmou Rolando Pinto. Os planos de produção eram também "planos de socialização", construídos através do cultivo de uma economia moral coletivista para alavancar a batalha da produção de baixo para cima.

$\mathrm{Na}$ atuação de Rolando Pinto e dos freirianos que estavam na CORA, havia uma tentativa genuína de unir através da "comunicação tecnológica" estes dois polos tensos da reforma agrária da UP: o imperativo econômico e o poder camponês para decidir sobre suas formas de trabalho e cultivo. "A maior dificuldade é que os planos eram muito técnicos. Os técnicos os explicavam tecnicamente aos trabalhadores", ponderou Rolando Pinto:

Não incluíam nos planos de produção, os conceitos de participação camponesa, a apropriação do conhecimento técnico pelos assentados, que era o que nós queríamos introduzir como Departamento de Capacitação. Muitos técnicos aplicavam os planos de produção como uma receita, entregavam os formulários e diziam como preencher. Nem sempre havia um processo formativo. ${ }^{988}$

Em 1972, uma das vezes que Freire foi ao Chile, esteve com Rolando Pinto em um assentamento e dialogou com os camponeses sobre a importância de que se apropriassem da técnica da planificação, mas sem a ela se submeter. O pedagogo lembra-se que Freire teria dito aos assentados algo como: "Vocês precisam se apropriar do instrumento, e não deixar que o instrumento os engula". Como resposta, um dos camponeses pediu para olhar as mãos de Freire. Vendo como eram finas e delicadas, disse. "Este viejo no sabe de nada", ${ }^{989}$ arrancando risos do brasileiro.

Anedotas à parte, Rolando Pinto concluiu que as tensões entre individualidade e coletividade, bem como entre os planos de produção locais, nacionais ou individuais no seio da reforma agrária foram problemas nunca resolvidos. Na capacitação da CORA pela lógica "socioprodutiva" e freiriana da comunicação tecnológica, possivelmente, localizava-se um importante elo perdido entre o imperativo econômico e o poder popular camponês, capaz de mediar a polarização agrária interna às esquerdas, e se diluía, por meio do diálogo paciente, a contradição entre campesinato e desenvolvimento nacional. O tempo dessa outra revolução na subjetividade camponesa, contudo, era muito lento frente às exigências da própria revolução chilena.

\footnotetext{
987 Id., ibid.

988 Id., ibid.

${ }^{989}$ Id., ibid.
} 


\section{Dois professores em campo}

O desafio cultural da produtividade no campo foi vivido diretamente pelo professor Manuel Herrera, de San Clemente, na província de Talca. Herrera se filou ao PC com 18 anos, mesma época em que se graduou na Escola Normal. Desde jovem, alternava suas aulas para crianças rurais com cursos que ministrava para adultos camponeses nas jornadas sindicais da Ranquil e da CUT. Em 1970, cursou uma formação de educadores sobre o método psicossocial. "Sacrifiquei o verão de 1970 a 1971 e fui estudar em Santiago", ${ }^{990}$ contou, quando aprendeu a alfabetização freiriana e logo tornou-se professor de professores. "Participei de vários cursos da CORA (...). Efetivamente, eram cursos muito bons (...). A ideia era mudar a mentalidade do trabalhador, para que ele soubesse que o patrão já não estava lá, mas a ausência do patrão não significava não ter mais que trabalhar", ${ }^{991}$ sintetizou Herrera. Muitos camponeses, segundo o professor, pensavam que ao liberar-se do patrão, passariam a fazer o que bem entendessem, sem responder a nenhuma outra autoridade ou coletividade. Outros pensavam que por serem dirigente, ou presidentes do assentamento, deveriam apenas ordenar o trabalho dos outros, reproduzindo as antigas hierarquias patronais na nova estrutura. "Essa parte falhou", considerou Herrera: "muitos se queixavam de ter que trabalhar mais, mas era natural que tivessem, porque agora a terra era deles". 992

Herrera vinha de uma família pobre e rural. Na infância, chegou a passar frio, fome e não tinha recursos para comprar sapatos. Sua mãe morreu analfabeta. Ao se filiar ao PC, Herrera foi escalado direto ao comitê comunal de San Clemente, sem passar pela juventude (a Jota). Os dirigentes argumentaram: "você maneja bem o lápis". Desde então, trabalhou com alfabetização e educação política de camponeses. Atuou como professor do sindicato Cajón del Maule, da Ranquil. Nas suas aulas, defendia a aceleração da reforma agrária e explicava a importância da sindicalização como ferramenta de luta coletiva. Antes da eleição de Allende, lecionava também às crianças do latifúndio San Clemente: "eram crianças mirradas, desnutridas. A exploração era terrível”, ${ }^{993}$ recorda. Quando Allende foi eleito, as questões social e produtiva tornaram-se o centro das preocupações comunistas na região. O latifúndio onde Herrera ministrava aulas tinha 400 hectares ociosos.

Mas a expropriação do latifúndio San Clemente só ocorreu depois de uma toma coordenada pelo sindicato comunal. Apesar de ser comunista, Herrera participou da toma, na qualidade de professor daqueles camponeses: "eu não estava lutando por terras para mim", esclareceu. Foi formado o assentamento Luis Emílio Recabarrén, com 150 hectares e 30 trabalhadores. "Foi muito comentada a toma, porque ocorreu nos tempos de Allende e Allende não estava muito a favor da tomas", recordou Herrera, que apesar de ser alinhado às diretrizes do partido, apoiou ativamente a ação. Nos anos da UP,

\footnotetext{
${ }^{990}$ Entrevista com Manuel Herrera Castro, San Clemente, 27/05/2017.

${ }^{991}$ Id., ibid.

992 Id., ibid.

${ }^{993}$ Id., ibid.
} 
o profe Herrera foi capacitador da CORA em assentamentos, professor em sindicatos camponeses e escolas rurais, e lecionou para todas as idades e em diversas situações.

Ele se recorda que o assentamento Recabarrén "chegou a ser a propriedade mais importante e de maior produtividade em San Clemente (...). Era o melhor da região". ${ }^{994}$ Digamos que foi um caso de produtividade coletiva bastante bem-sucedido no setor reformado. Herrera explicou que a hegemonia comunista no assentamento viabilizou uma experiência extraordinária da aliança econômica entre operários urbanos e camponeses. Os assentados do Recabarrén vendiam diretamente sua produção alimentar aos sindicatos de Santiago, escapando dos atravessadores. Isso lhes permitia cobrar um pouco mais pelos seus produtos e permanecer com valores abaixo do mercado especulativo e, portanto, favoráveis aos trabalhadores urbanos. Um dos símbolos da prosperidade desse assentamento foi a compra do primeiro aparelho televisor da comuna, identificado com êxito e modernização. Os operários da Fensa (fábrica de geladeiras) recebiam alimentos do assentamento e ofereciam aos camponeses eletrodomésticos de última geração.

Como professor e militante, Herrera se empenhou em explicar aos camponeses que, uma vez expropriada a terra, era preciso priorizar a batalha da produção: "para Allende, se a terra era expropriada, tinha que aumentar sua produção, não diminuir". ${ }^{995}$ A toma do latifúndio San Clemente resultou em uma divisão em três partes: a reserva patronal de $80 \mathrm{HRB}$, o assentamento Recabarrén, hegemonizado pelos comunistas, e o assentamento Manuel Larraín, hegemonizado pela DC. Herrera se lembra da rivalidade entre os dois assentamentos: "foi uma grande inveja, porque a produtividade e o progresso dos companheiros do Recabarrén foram notórios e reconhecidos por todo povo. Não era comum: eles chegaram a ter um caminhão próprio, onde transportavam os produtos", ${ }^{996}$ contou o professor: "Na época da colheita de batata, colhiam e não perdiam nada, porque levavam diretamente a Santiago e entregavam aos sindicatos (...). Estavam dentro da linha do partido", explicou. O PC desenvolveu canais próprios de crescimento da economia popular obreiro-campesina ao assegurar que assentamentos comunistas entregassem sua produção aos sindicatos comunistas, e recebessem em troca bens de consumo urbanos. Por outro lado, o discurso anticomunista teve alta penetração entre os camponeses vizinhos da DC, assentados do Manuel Larraín: "era fácil ganhar um católico", reclamou Herrera, "bastava dizer que os comunistas eram contra Deus". 997

$\mathrm{O}$ aumento produtivo do assentamento Recabarrén estava acima da média do setor reformado. Ali, os camponeses eram empenhados e comandados por uma moral revolucionária alinhada ao partido. Herrera atribuiu o sucesso extraordinário daquele assentamento à disciplina comunista: "houve alguns assentamentos bem orientados e respaldados por partidos políticos, nesse caso, o PC, cujos dirigentes pediam aos camponeses que não tirassem os pés do acelerador, ou seja, quando mais produzir, sempre

\footnotetext{
${ }^{994}$ Id., ibid.

995 Id., ibid.

${ }^{996}$ Id., ibid.

997 Id., ibid.
} 
melhor". ${ }^{998} \mathrm{Na}$ percepção do professor, a batalha da produção foi mais contundente nas unidades reformadas com a presença de partidos, sobretudo quando priorizavam a linha do governo. Neles, diz Herrera, "as pessoas trabalhavam com muito mais vontade, porque sabiam que o esforço que faziam era em benefício próprio, não para o patrão, mas para o coletivo. Alguns entenderam, e na medida em que foram entendendo, se tornaram militantes". 999

Outros assentamentos ou CERAs não funcionavam da mesma forma. Para Herrera, "esse foi um dos grandes fracassos da reforma agrária no Chile: a maioria dos companheiros não entendeu que ao liberar-se do jugo do patrão, não era para que descansassem (...). Era para que trabalhassem até mais, pois o fruto do trabalho iria para sua família. O camponês chileno não estava preparado, não estava educado", ${ }^{1000}$ concluiu. Para exemplificar, conta que muitos assentamentos consumiram suas vacas leiteiras descontroladamente, sem contabilidade, nem registro, em asados e festas. Herrera circulava cotidianamente pela região, pois dava aulas em diferentes propriedades. Certa vez, chegou a um sindicato dentro de um assentamento e seus dirigentes tinham matado um novilho para comer: "perguntamos aos dirigentes por que tinham matado o novilho e eles responderam: é que estamos contentes! Mas o repuseram? Não". Então, Herrera ensinava: "companheiros, se vocês mataram um animal do assentamento, precisam repor outro ao coletivo". Alguns camponeses não recebiam bem a advertência e mostravam forte resistência à moral coletivista. Numa ocasião, o profe Herrera escutou: "pois é, nós nos libertamos do patrão, mas agora temos outros patrões", ${ }^{1001}$ em referência ao próprio professor.

Em San Clemente, Herrera deu aulas sobre o conceito da propriedade coletiva e explicava por que os assentados não deveriam usufruir individualmente, sem registro, do patrimônio dos assentamentos ou CERAs. Dizia que o descontrole contábil do setor reformado era aproveitado pela direita, que acusava o "caos econômico". Ao mesmo tempo, as tentativas da CORA em determinar planos de produção acelerados, eventualmente com pedagogias tecnocráticas, corroborava com a tese do "Estado patrão". Quando perguntei se Herrera considerava que suas aulas influenciavam ou não o comportamento camponês sobre a produção, ponderou: "não era possível mudar a mentalidade de um camponês, de um dia para o outro. Eles foram durante anos, décadas, educados de uma maneira. Precisavam entender qual era o objetivo de entregar-lhes a terra (...). Não era para benefício individual, mas coletivo", refletiu. Portanto, suas aulas pretendiam explicar quais eram os objetivos do governo e porque a batalha da produção era tão importante à coletividade nacional. Os camponeses precisavam estar politicamente convencidos da solidariedade de classe que precisavam exercer, trabalhando mais para alimentar melhor a todo país e economizar divisas para um processo nacional de socialização do

\footnotetext{
998 Id., ibid.

${ }^{999}$ Id., ibid.

1000 Id., ibid.

1001 Id., ibid.
} 
bem-estar. Isso ocorreria, possivelmente, com custos de curto prazo à sua individualidade, mas em benefício do longo prazo.

Outro professor que experimentou os desafios da educação produtiva no campo foi Arnaldo Cáceres. Durante os anos da UP, foi alfabetizador de camponeses e dirigente nacional de capacitação do ICIRA, acompanhando José Campusano. ${ }^{1002}$ Cáceres viajava pelo país para assessorar a formação dos planos de produção dos assentamentos e organizar o aumento da produtividade por meio da capacitação. "Naquele tempo, trabalhávamos sábado e domingo, sem descanso. Íamos às propriedades em distintos lugares, conhecer realidades cada vez mais distantes. Se precisássemos ir a Valdivia, por exemplo, só nos pagavam a passagem", ${ }^{1003}$ recordou. O entusiasmo revolucionário gerava um empenho redobrado de alguns funcionários de Estado, comprometidos com o projeto agrário da UP, mesmo quando as instituições do agro estavam sem orçamento: "havia uma mística. Deixávamos nossos lares um pouco abandonados para trabalhar mais por esse setor camponês, que tinha sido tão explorado e tinha uma vida tão difícil", ${ }^{1004}$ contou o professor. A lembrança de Arnaldo mostra que a escassez de recursos da capacitação foi contrapesada pelo compromisso voluntário e revolucionário de alguns dos próprios capacitadores que, em nome da revolução, trabalhavam mais horas do que estipulado em seus contratos, ainda que atrasassem seus salários. Além disso, "faltavam muitos funcionários. Nas regiões agrícolas, contávamos com o professorado rural que nos apoiava e com os voluntários de alfabetização camponesa," 1005 narrou Cáceres. A onda de solidariedade voluntária pela educação camponesa aproximava as pessoas nos territórios rurais, unindo funcionários do agro e professores de escola para acelerar a capacitação e fazer valer a reforma.

Arnaldo se recorda que a batalha pela propriedade coletiva era fundamental na capacitação: "estávamos na tarefa de influenciar o campesinato para a cooperativa", mas havia outras forças presentes nas bases "com um discurso de que era a propriedade privada que permitiria progredir". ${ }^{1006}$ Cáceres contou que havia uma quantidade importante de camponeses defensores da parcela individual: “eles tinham o exemplo do patrão, que era um só. O patrão não precisava ter organização e fazer eleições [para direção da cooperativa] (...). Muitos tinham essa ideia. Era uma tarefa difícil alterá-la”, ${ }^{1007}$ rememorou. Por outro lado, pela prática produtiva do assentamento, "cada vez mais o campesinato ia compreendendo que as tarefas da exploração se realizavam melhor conjuntamente (...). Nós percebíamos que conseguíamos influenciar o aumento do uso de máquinas, por exemplo, ou a construção de pequenas vilas de casas (...)", se recordou Arnaldo. Tal qual disse Rolando Pinto, o melhor convencimento pela propriedade coletiva era o exercício prático do plano de produção como plano de socialização. Se o plano produtivo tivesse ampla participação camponesa, gerava maior

\footnotetext{
1002 Quando Rolando Pinto Contreras saiu da chefia do CTNC, José Campusano assumiu.

1003 Entrevista com Arnaldo Cáceres, Santiago, 29/06/2017.

1004 Id., ibid.

1005 Id., ibid.

1006 Id., ibid.

1007 Id., ibid.
} 
compromisso comum e, consequentemente, mais trabalho, mais excedente coletivo. Assim, as batalhas da produção e da capacitação se complementavam e se retroalimentavam. "Aos poucos os camponeses tinham melhores condições, melhores salários, melhor retribuição ao seu esforço e viam que era melhor trabalhar em conjunto", ${ }^{1008}$ reforçou Cáceres.

Mas ele também entrou em contato com a narrativa de denúncia do "novo patrão Estado", ${ }^{1009}$ que aos poucos se disseminou entre camponeses, especialmente depois da criação do CERA e CEPRO. Essa crítica, repetida incansavelmente pelo deputado Emilio Lorenzini (DC), que advogava para camponeses, e por Juan Chacón (presidente da Confederação de Assentamentos), reverberava na experiência prática do campesinato. Por vezes, funcionários da CORA moralmente imbuídos de cumprir a tarefa do plano nacional agropecuário, abdicavam de uma abordagem dialógica junto aos camponeses, e tendiam a uma invasão cultural malsucedida. Ou seja, quando metas produtivas eram burocraticamente construídas, quando o técnico da CORA virava as costas, elas já não valiam.

Como comunista, o professor Arnaldo Cáceres criticou as tomas pelo viés produtivo. Disse que muitas delas absorviam ao setor reformado terras pouco férteis, que prejudicavam a comprovação prática da tese da propriedade coletiva. Além disso, como capacitador, era pragmático ao perceber que já havia mais terra expropriada do que a estrutura capacitadora era capaz de alcançar: "nós precisávamos que houvesse organização forte em cada propriedade reformada, que se orientasse a melhorar a produção", 1010 expressou: "A mim coube visitar várias propriedades expropriadas, resultantes dessas mobilizações em 1972 e 1973, que estavam abandonadas", criticou. Exemplificou com uma visita a uma terra expropriada perto de Valparaíso, onde encontrou o campo coberto de ervas daninhas. "Perguntei aos trabalhadores quando iam limpar a maleza do terreno e começar a produzir. Me responderam: não é maleza, aí embaixo há uma vinha" ${ }^{1011}$ Debaixo da erva daninha havia uma uva de ótima qualidade abandonada pelos camponeses depois da expropriação. "A alguns não interessava a produção, mas sim a agitação", ${ }^{1012}$ arrematou. Nesse sentido, o pragmatismo produtivista do PC demonstrava a tese de que as tomas eram contraditórias com a batalha da produção, o que ecoava alguns aspectos dos discursos da oposição proprietária. Esse tipo de situação ajudava a oposição a exemplificar suas denúncias. Para outros setores da esquerda, porém, a produção não era o elo fundamental da revolução, e era mais importante conquistar um poder popular camponês palmo a palmo, mesmo que isso custasse a redução da produtividade.

Pinto também se recordou de um assentamento instalado em Rancagua, que fracassou na produtividade com protagonismo camponês. Antes, produzia flores em escala industrial: "Era um excelente produtor, mas era um milionário e se dedicava a exportar rosas", ${ }^{1013}$ lembrou o educador, que

\footnotetext{
1008 Id., ibid..

${ }^{1009}$ Id., ibid.

${ }^{1010}$ Id., ibid.

1011 Id., ibid.

1012 Id., ibid.

${ }^{1013}$ Entrevista com Rolando Pinto Contreras, Santiago, 23/05/2019.

1013 Id., ibid.
} 
à época estava na CORA. "Expropriamos e o entregamos aos camponeses, mas eles destruíram a produção. São erros que se cometeram", ${ }^{1014}$ analisou Rolando Pinto.

Outro caso contado por Cáceres foi o chamado "boicote técnico". Na província de Aconcágua, havia uma importante produção de cítricos. Ele recorda que em 1972, naquela zona, "em distintos lugares os laranjais lamentavelmente tinham perdido produção, estavam queimados". ${ }^{1015}$ Os funcionários do Minagri iniciaram uma investigação e se deram conta que o mesmo engenheiro trabalhou em todos os lugares em que os cítricos queimaram. Um funcionário do ministério foi escutar uma capacitação do tal engenheiro, a respeito de desinfetante de cítricos e descobriu-se que o engenheiro recomendava uma dose muito mais alta do que a indicada do desinfetante, induzindo a queima de vários hectares de laranjais. "Foi um enfrentamento tão grande que mesmo uma pessoa como essa, que passou pela universidade, era capaz de indicar uma sobredose (...). A este extremo chegou o Chile naquele momento". ${ }^{1016}$ Nesse caso, tratava-se de uma ação individual. Foi em outubro de 1972 que ocorreu o ápice do enfrentamento produtivo, com a ofensiva da oposição e o boicote sistemático à produção e ao abastecimento representado pelo paro patronal de 1972.

\section{O campesinato não parou em outubro de 1972}

Quando a oposição à UP atingiu seu maior grau de organização gremial, em outubro de 1972, caminhoneiros e comerciantes protagonizaram um dos maiores locautes da história do Chile, que ficou conhecido como o paro nacional. O paro afetou tremendamente o escoamento da produção agrícola, gerou desabastecimento e caos econômico, e expandiu rapidamente um mercado inflacionado de produtos alimentares clandestinos. Naquele contexto, os camponeses foram disputados pela tensão política e produtiva que se instalou no país. "O paro obedece a um plano formulado e financiado pelo imperialismo norte-americano, como fica claro pelos documentos da ITT (..), impulsionado pelos setores mais reacionários do país", ${ }^{1017}$ acusou o camponês Pascual Salinas, presidente da Ranquil. Para a confederação, o paro era a resposta organizada dos patrões e proprietários: "os latifundiários sonham em recuperar sua terra (...), por isso, caem em desespero", 1018 explicou. Mas Salinas estava seguro que a ampla maioria dos camponeses não tinham caído na armadilha. Efetivamente, foi intensa a mobilização de "contra-paro" dos trabalhadores rurais, que criou um Comando Nacional Campesino de emergência, formado por Ranquil, UOC e Confederação Mapuche, a "linha unificada dos camponeses para afrontar o paro nacional". ${ }^{1019}$

\footnotetext{
${ }^{1014}$ Id., ibid.

1015 Entrevista com Arnaldo Cáceres, Santiago, 29/06/2017.

1016 Id., ibid.

${ }^{1017}$ Entrevista a Pascual Salinas (Ranquil). Revista Agraria n.1, Chile Hoy, n. 25, Dez./1972.

1018 Id., ibid.

1019 Enrique Ponce de León, Los comandos. Revista Agraria n.1, Chile Hoy, n. 25, Dez./1972.
} 
No início de outubro, o novo Comando se reuniu com o general Prats, Comandante do Estado Maior das Forças Armadas, para definir diretrizes de ação conjunta entre campesinato e governo sobre como contornar a situação. Segundo o repórter do Chile Hoy, Prats teria dito que "era um orgulho conversar com camponeses e era a primeira vez na história que isso ocorria", ${ }^{1020}$ e que estava contente com a consciência camponesa a respeito do significado do paro. Os camponeses desse setor também se articularam à Direção Nacional de Abastecimento e Comércio (DINAC), sob a chefia do brigadeiro Alberto Bachelet. O Comando Nacional se replicava em comandos de níveis regional e local, com a finalidade de garantir o abastecimento de alimentos às cidades e insumos produtivos aos agricultores, especialmente no setor reformado, além de assegurar a vigilância produtiva no campo e denunciar qualquer sabotagem. Diante da situação em que "produtos estavam apodrecendo por não ter como sair ao mercado", ${ }^{1021}$ os comandos locais organizavam feiras populares, canais de comercialização de carne, hortaliças, frangos, ovos, com seus próprios caminhões e tratores. Caravanas de tratores foram realizadas em diferentes partes do país para buscar insumos, sementes e adubos. Apesar das crescentes rivalidades ideológicas internas à esquerda, os comandos alcançaram um grau de unidade popular surpreendente.

A imprensa de esquerda confrontou a versão do El Mercurio, que afirmava que 400 mil camponeses tinham paralisado em outubro, o que representaria $57 \%$ das forças de trabalho rural nacional. Mas esse número estava longe dos dados oficiais e da experiência vivida por muitos funcionários do agro naquelas semanas. Segundo Carabineros e ODEPA, somente 107 propriedades agrárias paralisaram suas atividades no início do mês, sem demorar a retomá-las dentro de alguns dias, em um universo de 239.200 unidades produtivas rurais, das quais 4.700 pertenciam ao setor reformado e 185.500 eram minifúndios. ${ }^{1022}$ Comparativamente, a Direção do Trabalho contabilizava que em 1971, os camponeses haviam paralisado atividades em 1.758 propriedades em favor da reforma agrária, ou seja, um índice de adesão 16 vezes maior. Em outubro de 1972, "muitos patrões foram às comissarias denunciar paros em suas terras, sem que estes existissem", ${ }^{1023}$ segundo apurou José Bengoa. E arrematou: "Em solidariedade aos transportistas não pararam mais de 4 mil camponeses. Os dois zeros que sobram, devemos colocar na conta do desespero da oposição". ${ }^{1024}$

Àquela altura, o setor reformado controlava $35 \%$ da superfície agrícola do país, mas como avaliou o presidente da Ranquil: "o latifúndio acabou (...), mas segue aqui no campo de outra forma, através da reserva e das relações com monopólios industriais". ${ }^{1025}$ Perguntado se afinal o paro de outubro havia fortalecido ou enfraquecido a organização camponesa da Ranquil, Salinas não titubeou em dizer que saíram mais fortalecidos. Enquanto isso, Enrique Mellado, presidente da Triunfo

\footnotetext{
${ }^{1020}$ Id., ibid.

${ }^{1021}$ Id., ibid.

1022 José Bengoa, El paro de los conchencos. Revista Agraria n.1, Chile Hoy, n. 25, Dez./1972.

${ }^{1023}$ Id., ibid.

1024 Id., ibid

${ }^{1025}$ Entrevista a Pascual Salinas (Ranquil). Revista Agraria n.1, Chile Hoy, n. 25, Dez./1972.
} 
Campesino declarou que realizaram um paro de 24 horas em solidariedade aos transportistas, mas sem explicitar uma agenda própria de lutas da sua agremiação. A contradição do discurso de Mellado ficava nítida quando, apesar da polarização, não conseguia evitar uma constatação: "fomos sempre duros para exigir que a reforma agrária fosse mais rápida, mais drástica e esse governo (...), em grande medida, o realizou. Estamos satisfeitos", admitiu: "celebramos e aplaudimos essa medida do governo". ${ }^{1026}$ Perguntados então por que apoiaram o paro, Mellado dizia que a Triunfo tinha uma lista de reivindicações para que a terra fosse garantida efetivamente ao campesinato e que o paro também servia para visibilizar essa pauta: "nos deixaram as portas abertas", falou em referência ao governo. O líder sindical camponês da DC precisava mediar entre a oposição denuncista do seu partido, que aderiu ao paro, e a realidade da sua base, que poderia ser prejudicada por ele. Em nível nacional, as organizações camponesas se posicionaram da forma como mostra a tabela 33 .

\begin{tabular}{|c|c|c|c|}
\hline \multicolumn{4}{|c|}{$\begin{array}{l}\text { Tabela } 33 \text { - Confederações Campesinas no paro de outubro de } \\
\qquad 1972\end{array}$} \\
\hline Confederação & Partido & Sócios & $\begin{array}{l}\text { Posição frente } \\
\text { ao paro }\end{array}$ \\
\hline Triunfo Campesino & $\mathrm{DC}$ & 51.092 & Favorável ativo \\
\hline $\begin{array}{c}\text { Províncias Agrária } \\
\text { Unidas }\end{array}$ & PN & 1.219 & Favorável ativo \\
\hline $\begin{array}{l}\text { Confederação de } \\
\text { Assentamentos }\end{array}$ & $\mathrm{DC}$ & 20.976 & Favorável ativo \\
\hline Ranquil & $\mathrm{PC} / \mathrm{PS}$ & 100.299 & Contrário ativo \\
\hline UOC & MAPU & 29.355 & Contrário ativo \\
\hline Libertad & Igreja & 34.715 & Contrário passive \\
\hline $\begin{array}{c}\text { Confederação de } \\
\text { Cooperativas } \\
\text { Campesinas }\end{array}$ & $\mathrm{DC}$ & 42.642 & $\begin{array}{l}\text { Base descola da } \\
\text { direção }\end{array}$ \\
\hline
\end{tabular}

A recém-criada UOC, dirigida pelo MAPU que fracionou a Triunfo Campesino, na voz de seu secretário geral Raul Aravena, defendeu que os comandos campesinos deveriam seguir funcionando, mesmo com o término do paro, ${ }^{1027}$ como ferramenta de poder popular camponês e aliança econômica direta entre campesinato e trabalhadores da cidade, organizados nas Juntas de Abastecimento e Preços. Os Comandos e as JAPs formaram uma aliança emergencial, que potencialmente poderia representar a nova substância da economia socialista.

No âmbito dos técnicos e funcionários do agro, houve uma cisão. O Colégio de Agrônomos foi ativo apoiador dos transportistas, articulado ao Comando Unido de Colégios Profissionais, que assinaram o Pliego de Chile. Seu presidente, José Garrido, sancionou Jacques Chonchol e cancelou sua carteira profissional por seis meses. O ministro, que caiu em novembro de 1972 como consequência das pressões promotoras do paro, acusou Garrido de estar "mais preocupado em obstruir o governo do que velar pelo exercício da profissão". ${ }^{1028}$ Por outro lado, Rolando Pinto se recorda que "em 1972, quando ocorreu o paro nacional, os agrônomos e técnicos da CORA seguiram trabalhando pelos camponeses.

\footnotetext{
${ }^{1026}$ Entrevista a Enrique Mellado (Triunfo Campesino). Revista Agraria n.1, Chile Hoy, n. 25, Dez./1972.

${ }^{1027}$ Entrevista a Raúl Aravena (Unidad Obrero-Campesina). Revista Agraria n.1, Chile Hoy, n. 25, Dez./1972.

1028 Andanzas de la Orden Agronómica. Revista Agraria n.1, Chile Ho, n. 25, Dez./1972.
} 
Por causa da greve, não recebiam pelas viagens, mas foram trabalhar nos assentamentos que lhes foram designados". ${ }^{1029}$

Em outubro de 1972, o professor Arnaldo Cáceres estava em Cautín. O desabastecimento, segundo se lembra, foi muito grave: "não havia pão nas padarias", ${ }^{1030}$ relatou. Lembra-se que os fertilizantes precisavam ser aplicados em uma determinada data para assegurar a batalha da produção do trigo, mas havia muita dificuldade que tais produtos viajassem do Norte ao Sul. "Ficamos em uma situação muito complicada, muito difícil (...). Começamos a importar de outros países ou fazer traslados dos nitratos do norte em pequenos barcos, até a enseada de Cautín”. ${ }^{1031}$ A lembrança de Gustavo Marín, do MCR, sobre o paro nas terras mapuche evocava outro paradoxo do abastecimento. Os assentamentos formados na Araucanía, com as tomas do cautinazo, estavam com alta produtividade, e substituíam a economia minifundistas do período anterior: "as terras ocupadas em 1971 começaram a entrar realmente em produção massiva em 1972, e ainda mais em 1973”, contou Marín, ${ }^{1032}$ que vivia em Loncoche. Com o paro patronal de outubro de 1972, não havia como escoar a produção e o desabastecimento das cidades se contrastava com a abundância produtiva de alimentos, grãos e leite estancado nos assentamentos indígenas do sul. "O período foi sumamente caótico", lembrou Marín: "se produziu um gargalo produtivo dramático. Houve uma tentativa de acordo entre camponeses e sindicatos urbanos, mas o ciclo natural de produção e venda foi interrompido". ${ }^{1033} \mathrm{O}$ paro evidenciava seu aspecto de sabotagem à economia popular no momento em que a abundância agroalimentar da produção na Araucanía era desproporcional à capacidade de escoamento estatal ou sindical. "Os camponeses não podiam tomar todo leite que produziam, nem comer todas as vacas que dispunham, nem comer toda farinha”, lembrou Gustavo Marín. Havia desabastecimento nas cidades e abundância produtiva no campo.

Passado o locaute, em novembro de 1972, um novo acordo foi assinado entre o ministro da Agricultura (o socialista Rolando Calderón, de origem camponesa) e as confederações Triunfo Campesino, Ranquil, UOC, Libertad e a Confederação de Assentamentos. O acordo indicava 9 diretrizes comuns que poderiam garantir a unidade do movimento camponês em torno às regras da produção no setor reformado. Segundo documentação disponibilizada por Sergio Gómez (1994), que como funcionário da ODEPA participou da reunião que elaborou o acordo, os 9 compromissos entre governo e organizações eram: (1) elevar a produção; (2) combater a especulação e os mercados clandestinos de alimentos; (3) lutar contra os funcionários que prejudicam a produção, qualquer que seja sua ideologia; (4) combater o alcoolismo e o ausentismo dos camponeses (promover a disciplina laboral); (5) alterar o regulamento dos assentamentos, estabelecendo normas de trabalho, estímulos à produção e sanções internas, através de uma comissão com as organizações camponesas; (6) assignar as terras de

\footnotetext{
1029 Entrevista com Rolando Pinto Contreras, Santiago, 23/05/2019.

${ }^{1030}$ Entrevista com Arnaldo Cáceres, Santiago, 29/06/2017.

1031 Id., ibid.

1032 Entrevista com Gustavo Marín, Santiago, 20/04/2017.

1033 Id., ibid,
} 
acordo com a lei de reforma agrária, ou seja, seguindo a vontade dos camponeses (nesse ponto, todas as confederações subscreveram que a parcela individual exclusiva não é a melhor forma; (7) garantir que o huerto familiar tivesse 2 hectares dentro da propriedade coletiva, mas sem prejudicar o trabalho comum; (8) que as unidades reformadas adquirissem maquinarias agrícolas em pools de cooperativas; (9) que as organizações camponesas participassem da política de crédito, da fixação de preços agrícolas com a ODEPA e dos organismos de comercialização do Estado (ECA). Outros seis pontos foram debatidos, mas não houve acordo.

Passados sete meses, em agosto de 1973, um terceiro acordo sobre a regulação do trabalho no setor reformado foi assinado entre ministério e confederações camponesas. Às vésperas do golpe, o problema da organização produtiva do setor reformado ainda não estava resolvido. Tampouco havia uma orientação clara sobre como a capacitação camponesa deveria incorporar formalmente o tema em cursos e jornadas. A reunião de agosto demonstrava que mesmo quando a polarização política alcançava sua máxima tensão ainda existia um espaço de diálogo vivo entre UP e as confederações camponesas da oposição, incluindo o presidente da confederação de assentamentos, que em 11 de setembro apoiou o assassinato de Allende (Gómez, 1982, 1994; Bengoa, 2016). Não houve tempo e condições políticas para que o sistema de incentivos ao trabalho pactuado com as entidades fosse implementado no setor reformado. Os desafios revolucionários vividos na batalha da produção e na batalha da capacitação foram soterrados pelo golpe.

\subsection{Considerações finais}

Nesse capítulo, avaliei qual era o lugar estratégico da capacitação camponesa nas políticas agrárias da UP, bem como a tentativa frustrada de criação de um Programa Nacional de Capacitação Camponesa, pactuado entre instituições do governo e da oposição. O CTCN, como todas as instituições do agro, foi afetado por rivalidades ideológicas e cortes orçamentários promovidos pela mesma oposição que acusava a UP de gerar "caos econômico". Assim, a oposição inviabilizou a expansão de programas de capacitação camponesa planejados pelo governo e obstruiu as políticas públicas e os recursos da revolução chilena. Apesar disso, quatro linhas de ação pedagógica para reforma agrária foram estabelecidas, e os comitês zonais chegaram a capacitar, em um ano e meio, 13.932 pessoas em cursos de três meses, das quais 8.353 eram camponeses; e 41.981 pessoas participaram das jornadas curtas de capacitação (2 horas), das quais 39.882 eram camponesas e a grande maioria direcionada aos conselhos camponeses (Barraclough \& Fernández, 1974: 238-39, 242-43). Como outros documentos do triênio o UP, os registros sobre a capacitação camponesa também sofreram com queimas de arquivos durante a ditadura, sobretudo relacionados ao ano de 1973, o que dificultou uma agregação mais completa. 
Nesse capítulo, também analisei o elo fundamental entre a batalha da produção agrária e as batalhas da capacitação, e identifiquei que a capacitação socioprodutiva da CORA buscou unificar o diálogo horizontal da pedagogia do oprimido com os imperativos técnico-econômicos da produção. Argumento que a temporalidade da revolução econômica entrou em contradição com a temporalidade da mudança subjetiva, gerando problemas de disciplina laboral, engajamento coletivista do campesinato e organização do trabalho. A capacitação não poderia dar conta desse problema automaticamente, embora sobre ele tenha se debruçado com atenção, como mostra o relato de Rolando Pinto. A revolução prometeu a emancipação dos trabalhadores rurais pela reforma agrária acelerada, mas também exigiu seu máximo empenho para alcançar um desenvolvimento econômico nacional. Essa tensão interna à revolução se desdobrou nas mais diversas e heterogêneas situações de conflito ou de prosperidade. Os freirianos que atuavam na CORA aproveitaram a metodologia dos planos de produção dos missionários franceses do IRAM, a adaptação chilena da ODEPA e o método dialógico de círculos de cultura para ampliar e fortalecer as assembleias das unidades reformadas e democratizar ao máximo as decisões econômicas. No entanto, a velocidade desse trabalho de base era mais lenta do que as exigências revolucionárias da planificação nacional.

A subjetividade coletiva dos trabalhadores rurais não se ajustaria automaticamente às necessidades do desenvolvimento econômico nacional. Era também sobre isso que Paulo Freire falava na Pedagogia do oprimido: a mudança subjetiva não seria instantânea e aqueles que tivessem uma visão mecanicista sobre o problema cultural da reforma agrária encontrariam obstáculos insuperáveis. Era preciso ter paciência para construir um diálogo revolucionário com os oprimidos. A ausência dessa perspectiva, dizia Freire, poderia desembocar em uma invasão cultural produtivista, por meio de uma "extensão" sem "comunicação" pelas vanguardas de esquerda. A ferramenta estratégica para que a batalha da produção fosse bem-sucedida era a capacitação. Quando a reforma agrária escalou à velocidade revolucionária, a capacitação sofreu uma enorme exigência, e encontrou no caminho não apenas o estrangulamento orçamentário de todas as instituições do agro, como também os obstáculos enunciados pela Pedagogia do oprimido e pelas pesquisas empíricas de Maria Edy Ferreira (1968, 1970).

Como mostram os relatos de dois professores de camponeses, no âmbito do setor reformado era possível encontrar alianças inovadoras entre assentados e sindicatos urbanos que driblavam intermediários privados, havia produções coletivas muito bem-sucedidas e unidades reformadas que produziam uma visível prosperidade; mas também existiam diversos problemas relacionados com a dificuldade de delimitar as fronteiras entre prioridades individuais e coletivas no dispêndio do tempo de trabalho e nas possibilidades de consumo. Muitos camponeses optavam por priorizar seu huerto familiar, e consumiam insumos coletivos e descapitalizavam o próprio assentamento ou CERA; outros, dirigentes sindicais ou de assentamentos, aproveitavam a nova liberdade para consumir carne em eventos festivos, sem repor ao coletivo. Essa diversidade de situações da subjetividade camponesa entrava em confronto com a racionalidade econômica da revolução, que apresentava planos de produção 
ousados, em decorrência da necessidade de liberação de divisas com redução das importações agroalimentares.

A capacitação ocupava um lugar estratégico, porque era o único espaço de encontro sistemático entre as múltiplas subjetividades camponesas e os planos de produção propostos no âmbito da racionalidade econômica da revolução. Em uma entrevista em 1973, Solón Barraclough afirmou que "as metas de produção (...) são as metas da capacitação" e que era "necessário começar com uma análise realista das unidades de produção e dos seus problemas. Com base nisso, programar junto às organizações camponesas um plano realista de capacitação comunal para conquistar metas que os próprios camponeses reconheçam". ${ }^{1034}$ Diante do fracasso de um programa nacional de capacitação, Barraclough conclui que a comuna poderia ser uma unidade territorial estratégia para unificar a batalha da produção à capacitação. Essa conclusão, porém, tinha sido desenvolvida na prática pela pedagogia do território, quando os experimentos freirianos do ICIRA em 1969 utilizavam recursos dialógicos da pedagogia do oprimido para promover o desenvolvimento socioeconômico por meio do protagonismo camponês em nível local.

Mas a batalha da capacitação produtiva para reforma agrária não era a única batalha educacional camponesa impulsionada pela revolução chilena. No próximo e último capítulo, analisarei a experiência de alfabetização camponesa nos anos da UP, os diálogos entre marxistas e Paulo Freire, o trabalho voluntário e a capacitação para os conselhos camponeses.

1034 “Hay que ponerse metas realistas”. Entrevista a Solón Barraclough. Revista Agraria, n. 5. In: Chile Hoy, n. 51, Maio/1973. 


\section{Capítulo 8 - Alfabetização camponesa e trabalho voluntário na Unidade Popular: diálogos entre marxistas e freirianos}

"A redefinição da nossa educação se nutrirá de duas fontes: o conhecimento
crítico da realidade educacional chilena (...) e a vontade de incorporar nossa
educação ao processo de transição à nova sociedade, o que implica
compromisso com as metas nacionais."

- Salvador Allende para professores e alunos, $1971^{1035}$

"Os trabalhos voluntários de 1971 entregaram uma resposta clara e contundente. Mais de 50 mil jovens tomaram em suas mãos a inadiável responsabilidade, a grande tarefa da construção do Chile Novo (...). Seu esforço e sacrifício desinteressado mostram o temperamento generoso da juventude chilena."

- Alberto Ríos, presidente da Federação Estudantil da UTE, $1971^{1036}$

"Antes pensávamos que a Universidade devia nos ensinar, mas agora sabemos que devem fazer práticas conosco, conviver conosco."

- Osvaldo Cruz, camponês, assentamento General Schneider, 1973 ${ }^{1037}$

"Para abrir o caminho ao socialismo (...), a participação dos trabalhadores nas decisões governamentais implica conhecimento dos problemas e reflexão sobre estes."

- Autores de Sugerencias para la Alfabetización, 1971

"Consciência de classe implica prática de classe e saber de classe. E por essa razão, a revolução é um ato de conhecimento"

- Paulo Freire, Santiago, $1972^{1038}$

"O Chile é uma grande codificação e a pedagogia é um grande instrumento para mobilizar as massas".

- Universitário do Instituto Pedagógico da U. Chile, $1972^{1039}$

\subsection{Introdução}

Durante os três verões do governo de Salvador Allende, uma multidão de jovens engajados na revolução se deslocou para as zonas rurais para participar das jornadas de alfabetização camponesa e fazer trabalho voluntário. Realizavam todo tipo de atividade: de "comitês de cultura" de alfabetização

\footnotetext{
${ }^{1035}$ Del presidente Allende a los profesores y alumnos. Revista de Educación, n. 34, Mar./1971.

1036 Apud Lily Vega, Los trabajos voluntarios del verano de 1971, una gran jornada juvenil. Revista de Educación, n. 32-33, 1970.

${ }^{1037}$ Es bueno que la universidad llegue a los campesinos. Dice campesino por Escuela de Verano de la UTE. La Nación, Ene/1973.

1038 ¿Una dimensión política de la educación? Una conversación con Paulo Freire. In: Cuadernos de Educación, Serie Orientaciones (1971-1973). Santiago: Universidad de Chile, 1972.

${ }^{1039}$ Entrevistador de Paulo Freire em: ¿Una dimensión política de la educación? Una conversación con Paulo Freire, op. cit.
} 
com o método psicossocial até o trabalho de colheita nos cultivos, a construção de casas, escolas rurais e obras de infraestrutura agrícola. Uma dessas jovens era a comunista Francisca Rodriguez, apelidada de Pancha. Nascida na comuna de Lo Espejo, um pequeno povoado perto da capital, Francisca não era propriamente camponesa, mas sempre manteve contato frequente com o meio rural. Nas suas andanças militantes, estava acostumada a pegar o trem em sentido contrário a Santiago e se embrenhar nas propriedades rurais e assentamentos da zona, além de conversar com os trabalhadores do campo em campanhas de agitação política. Nas eleições de 1970, dedicou quase todos os fins de semana a fazer panfletagens no campo, distribuindo volantes que explicavam as 40 medidas da UP e as políticas revolucionárias para reforma agrária. Quando perguntada sobre como os panfletos poderiam se comunicar com os analfabetos rurais, ela lembrou: "sempre vinham com muitos desenhos e tinham letras bem grandes". ${ }^{040}$

No verão de 1972, Francisca se juntou aos quase 2 mil jovens voluntários que instalaram um acampamento na província de Tarapacá para construir um sistema de irrigação agrícola no Pampa de Tamarugal, em pleno deserto. "Era uma represa subterrânea que irrigaria uma grande quantidade de superfície da reforma agrária”, contou (Rodríguez, 2020), cerca de 6 mil hectares. Ao término daquele verão, em março, os brigadistas que fizeram o "dreno do Cabildo", como ficou conhecida a obra no deserto, se concentraram no Estádio Nacional e foram recebidos pelo presidente Allende. Pancha recorda que foi ao ato "de peito cheio, com orgulho por haver construído a drenagem para os camponeses". ${ }^{1041}$ Como jovem dirigente do Departamento Feminino do PC, durante os mil dias de Allende, Francisca não parou de viajar entre campo e cidade, como representante da Frente de Mulheres da UP. Tornou-se uma "mulher nexo", que costurava os vínculos entre a política de Santiago e as mulheres camponesas dos recantos rurais. ${ }^{1042}$ Seu companheiro, Carlos Opazo, era diretor do departamento juvenil da Ranquil, e também atuava nas brigadas voluntárias.

Os trabalhos voluntários de verão e as jornadas de estudantes solidários ao campesinato não eram propriamente uma novidade, porém ganharam proporção e importância sem precedentes durante o governo da UP. Ambos os governos, de Frei e Allende, incentivavam esse tipo de mobilização, mas a aceleração das mudanças trazida pela via chilena ao socialismo era acompanhada da expansão do engajamento da juventude em todas as esferas. Desde 1967, o governo chileno havia criado a Oficina Nacional de Serviços Voluntários (ONSEV) do Ministério da Educação. ${ }^{1043}$ Com base nessa estrutura, os governos da DC e da UP criaram convênios com federações estudantis. Estas, de maneira autônoma ou atrelada aos partidos, se mostravam cada vez mais interessadas em participar das decisões e ações sobre os rumos do país. Francisca Rodríguez explicou que "nos tempos da Unidade Popular, várias brigadas eram para salvar a produção da sabotagem. Fizemos muitíssimas jornadas de trabalho

\footnotetext{
1040 Entrevista com Francisca Rodríguez Huerta, Santiago, 14/05/2017.

${ }^{1041}$ Id., ibid.

1042 Até hoje, a militância de Francisca Rodríguez acontece nesse âmbito: é dirigente da Associação Nacional de Mulheres Rurais e Indígenas do Chile (ANAMURI), vinculada à Via Campesina.

${ }^{1043}$ Cerca de 3 mil jóvenes salen este verano al trabajo voluntario. Revista de Educación, n. 3, 1967.
} 
voluntário no campo: plantar, semear, colher, carregar caminhões de alimentos", recordou. "Em todas as férias estudantis, organizávamos os trens da solidariedade". ${ }^{1044}$ Eram chamados de trens da solidariedade os vagões que de Santiago em dezembro lotados de estudantes e espalhavam brigadas voluntárias a lo largo y ancho del país.

De 1970 a 1973, foram organizados quatro tipos de brigadas voluntárias, com dezenas de milhares de jovens que se esparramavam pelos territórios rurais: da educação, da agropecuária, da saúde e da construção civil. ${ }^{1045}$ Para o governo, os trabalhos de verão cumpriam várias funções, inclusive a contenção de crises, como expressou o ministro Humberto Martones durante o cautinazo, em dezembro de 1970: "durante a próxima temporada de trabalhos voluntários, serão deslocados milhares de estudantes, médicos, enfermeiros, dentistas e técnicos do INDAP e ICIRA, com objetivo de encontrar uma rápida solução ao assunto mapuche" ${ }^{1046}$ prometeu. Naquele mês, a Ranquil anunciou que era necessário aumentar em cinco vezes o número de 600 bolsas de estudos outorgadas aos filhos de indígenas para seus cursos de capacitação sindical. ${ }^{1047}$

Os brigadistas da educação dos estudantes voluntários eram capacitados em jornadas rápidas para aprender o método e tinham a incumbência da alfabetização camponesa, para a qual utilizavam a pedagogia do documento Sugerencias para la alfabetización. ${ }^{1048}$ Era uma dedicada adaptação do método psicossocial produzida por profissionais do Mineduc em 1971. Esse documento será um dos objetos centrais de análise deste capítulo, uma vez que é a a principal fonte disponível que explicita a estratégia pedagógica da via chilena ao socialismo para alfabetização camponesa, bem como as alianças e tensões dos marxistas com Paulo Freire. Como já vimos, a demora do CTNC em criar um material exclusivo para alfabetização camponesa fez com que as Sugerencias do Mineduc fossem difundidas como principal suporte dos alfabetizadores no campo. É desse material que se recordam Victor Yañez, ${ }^{1049}$ secundarista e alfabetizador voluntário em San Carlos; e Manuel Herrera, ${ }^{1050}$ professor normalista de San Clemente. Como contou Marcela Gajardo (1991: 85), “o Manual Nacional de Alfabetização Camponesa não chegou a ser publicado" durante o governo UP permaneceu emperrado nas cúpulas do CTNC. ${ }^{1051}$

A meta de alfabetização do governo popular era ousada, mas não impossível: erradicar o analfabetismo em seis anos de mandato. Em março de 1971, Allende convocou professores e estudantes a participar ativamente desse enfrentamento, mencionando que ainda existiam 900 mil analfabetos, ou

\footnotetext{
1044 Entrevista com Francisca Rodríguez Huerta, Santiago, 14/05/2017.

1045 Lily Vega, Los trabajos voluntarios del verano de 1971, una gran jornada juvenil. Revista de Educación, n. 32-33, 1970.

${ }^{1046}$ Nuevo enfoque dará el gobierno de la UP al problema de mapuches. La Nación, Dez./1970.

1047 Partió escuela sindical de tercera zona Ranquil. El Siglo, Dez./1970.

${ }^{1048}$ Emma Espina Reyes; Sergio Arévalo; Arnulfo Rubilar; Nelson Severino, Sugerencias para la Alfabetización. Programa de Educación de los Trabajadores. Nuestra adaptación del Método Psicosocial. Santiago: Ministerio de Educación Pública, 1971. Ver: Reedición Conmemorativa: Revista NuestrAmérica, número especial, 2014.

1049 Entrevista com Victor Yañez, San Carlos, 19/05/2017.

1050 Entrevista com Manuel Herrera Castro, San Clemente, 27/05/2017.

${ }^{1051}$ Embora não tenha sido publicado, Gajardo teve acesso ao material do CTNC. Tinha seis palavras geradoras iguais à CORA do governo Frei (cosecha, gobierno, guitarra, trabajo, patrón, compañero), quatro palavras que coincidiam com o La Raiz y la Espiga, do Mineduc do governo Frei (radio, sindicato, compañero, guitarra) e nove palavras novas (horqueta, feria, educación, desayuno, sindicato, tierra, enfermo, juventude, pobreza). Ver Gajardo, 1991: 84, e o capítulo 4 desta tese.
} 
seja, $14 \%$ da população maior de 15 anos. ${ }^{1052}$ Objetivamente, o analfabetismo rural permanecia sempre mais alto: 26,5\%, segundo o censo de 1970, ${ }^{1053}$ embora recenseamentos do Mineduc apontassem para $30 \%$. ${ }^{1054}$ "Tenho a satisfação de ter sido um lutador universitário", lembrou Allende, que pretendia sensibilizar professores e estudantes para a urgência do problema social rural: "um pai analfabeto não pode ensinar a linguagem ao seu filho (...). Há crianças que caminham quilômetros nas zonas rurais, chegam famintos em escolas deterioradas, nas quais o professor se empenha inutilmente para que aprendam, crianças (...) cuja memória é pior do que daquelas que se alimentaram normalmente", ${ }^{1055}$ argumentava o presidente.

Allende convidava atores sociais da educação para erradicar o analfabetismo em velocidade revolucionária, inspirado na campanha cubana de 1960 a 1962: "vamos fazer certo, aquilo que Cuba fez certo", discursou: "Faremos uma grande cruzada para nossos compatriotas que sequer aprenderam a ler, não por culpa própria, mas sim de um regime". ${ }^{1056}$ Entre as experiências mais relevantes de alfabetização camponesa do governo Allende estava o Programa Nacional de Educação Camponesa, coordenada em conjunto pelo CTNC e pelo Mineduc, inaugurado em jornadas de alfabetização na comuna de Monte Patria. Esse programa teve início em novembro de 1971 e tinha como meta alfabetizar 400 mil camponeses. ${ }^{1057}$ A estratégia desse programa era que os próprios camponeses de alfabetizassem, tal qual foi ensaiado pelos educadores da CORA em 1967, no projeto "autocapacitação como hipótese" (ver capítulo 4).

Para a UP, a educação de adultos deveria ser um processo orgânico à própria revolução, fundamentada em uma pedagogia socialista para "formar o homem novo" e "defender os valores da solidariedade social frente ao individualismo característico do sistema burguês", ${ }^{1058}$ como definiu Iván Nuñez, um dos formuladores da Escola Nacional Unificada (ENU). Nuñez defendia a "integração dos programas educacionais aos de saúde, moradia e desenvolvimento social", que se desdobraria concomitantemente a "um melhoramento substantivo dos níveis de vida (...), resultante da construção socialista" ${ }^{1059}$ Dentro do conceito de uma educação de adultos para a solidariedade socialista, os alfabetizadores voluntários adquiriam um peso específico, porque encarnavam a demonstração prática do sentimento revolucionário de generosidade universal. $\mathrm{O}$ empenho da juventude em ajudar compatriotas desconhecidos em todas as regiões do país, movidos pela convicção no direito universal à alfabetização e a uma vida digna, era um exemplo prático da batalha de valores, que moldavam estruturas de sentimento, economias morais e lutas políticas.

\footnotetext{
1052 Del presidente Allende a los profesores y alumnos. Revista de Educación, n. 34, Mar./1971. O governo Frei alegava ter reduzido o analfabetismo de $16 \%$ a $11 \%$ em cinco anos. Cinco años de revolución educacional Revista de Educación, n. 20, 1969

${ }^{1053}$ Chile. Indicadores Económicos y Sociales. 1960-1988. Santiago: Banco Central de Chile, 1989, p. 418.

${ }^{1054}$ Hoy se inicia programa para capacitar a 400 mil campesinos. El Siglo, 21/11/1971.

${ }^{1055}$ Del presidente Allende a los profesores y alumnos. Revista de Educación, n. 34, Mar./1971.

1056 Id., ibid.

${ }^{1057}$ Hoy se inicia programa para capacitar a 400 mil campesinos. El Siglo, 21/11/1971.

${ }^{1058}$ Ivan Nuñez, Política y educación. Revista de Educación, n. 32-33, 1970.

1059 Id., ibid.
} 
Como veremos, as posições político-pedagógicas da UP (documentadas nas Sugerencias) e de Paulo Freire encontravam importantes convergências relacionadas com a luta pela emancipação social e pela dignidade popular, mas também nítidas diferenças sobre a forma de condução do diálogo no processo pedagógico. As Sugerencias eram compostas por uma etapa de codificações e debates sobre "natureza e cultura", seguida de 22 palavras geradoras acompanhadas de imagens fotográficas e um extenso conteúdo textual direcionado aos alfabetizadores, propondo objetivos e sugestões para reflexão, conteúdos auxiliares com uma lista de informações sobre a realidade chilena, além de orientações técnicas sobre os fonemas e exercícios silábicos. As Sugerencias tampouco eram unânimes entre as correntes da esquerda chilena. Se havia diferenças entre Sugerencias e Paulo Freire, também dentro da UP existiam olhares divergentes sobre os fundamentos políticos do material.

Nesse capítulo, discutirei as políticas de alfabetização camponesa da Unidade Popular, os diálogos entre marxistas e freirianos na conformação de um método pedagógico que combinava o diálogo decodificador com a diretividade da revolução, bem como a importância do trabalho voluntário dos jovens urbanos na reforma agrária e nas atividades de alfabetização no campo. Particularmente relevante é o diálogo crítico ocorrido entre Paulo Freire e as vanguardas políticas da esquerda chilena naquele triênio, o qual nos permite compreender as convergências e fissuras entre formas leninistas e freirianas de tecer a revolução, ambas no interior do campo marxista.

Como já anunciado em capítulos anteriores, compreendo que a pedagogia freiriana foi uma espécie de tendência política invisível da revolução chilena, que jamais se aglutinava como um partido, mas que atuava nas bases de maneira radicalmente dialógica e se diferenciava de práticas dirigistas muito comuns a todos os segmentos e partidos da esquerda da época. Por fim, também analisarei brevemente como os Conselhos Comunais Camponeses se atrelavam (ou não) a esta onda de educação camponesa revolucionária que ocupou o Chile nos anos da UP. Nesse último tópico, trarei alguns elementos sobre a educação política do MIR e sua relação com Paulo Freire.

\subsection{Voluntários para alfabetização rural: a aliança camponesa-estudantil}

O envolvimento estudantil com questões agrárias vinha desde 1968, quando foi criada a Frente Unida de Defesa da Reforma Agrária (FUDRA), uma articulação anunciada em abril em uma conferência de imprensa com seis dirigentes estudantis e doze dirigentes camponeses, ${ }^{1060}$ de correntes marxistas e cristãs. Na ocasião, Sergio Martínez, presidente do assentamento de Pullahue, manifestou: "assim como os estudantes lutaram por reformar as estruturas das universidades (...), os camponeses lutam para transformar o sistema de propriedades da terra". ${ }^{1061}$ Jorge Navarrete, presidente da Federação

1060 Campesinos y estudiantes defenderán Reforma Agraria. El Siglo, 03/04/1968; Se unieron estudiantes y campesinos en defensa de la reforma agraria. La Nación, 03/04/1968; Frente Urbano de Defensa de la Reforma Agraria. La Nación, 06/04/1968.

1061 Id., ibid. 
de Estudantes da Universidade do Chile (FECH), complementou: "a FUDRA se oporá a todos que queiram acabar com a reforma agrária, seja o próprio governo ou não". ${ }^{1062}$ Essa aliança camponesaestudantil ganhou enorme importância durante o processo revolucionário.

\section{Trabalhos voluntários de verão}

Os trabalhos voluntários durante a UP foram encarados como "uma oportunidade de tomada de posição da juventude para contribuir de modo significativo (...) à construção de uma sociedade sobre novas bases". ${ }^{1063}$ Todos os partidos da esquerda acreditavam que o sentimento solidário da juventude, seu idealismo e busca de justiça eram alavancas morais para o processo revolucionário. Além disso, se apostava que "os estudantes, em contato dinâmico com os camponeses, principalmente aqueles das camadas mais modestas do povo, ganharão em sua condição humana o que nenhum tipo de ensino pode oferecer", ${ }^{1064}$ de modo que os próprios voluntários seriam conscientizados e conquistariam uma compreensão mais profunda da realidade chilena por meio do contato cotidiano com os camponeses.

A participação estudantil nas brigadas de trabalho voluntário rural de dezembro $1970 \mathrm{cresceu}$ $340 \%$ em relação a 1965 e 70\% em relação a 1969. Foram 5.225 estudantes cadastrados pela Oficina Nacional de Serviços Voluntários (ONSEV) do Mineduc no primeiro verão do governo da UP. ${ }^{1065}$ Os estudantes organizaram em 142 acampamentos espalhados em 15 províncias do país. ${ }^{1066}$ A ONSEV realizou convênios com 28 Centros e Federações estudantis, entre elas a FECH, a FEUC (U. Católica), a FEUTE (U. Técnica do Estado), a Federação de Estudantes Secundários (FESECH), de Estudantes Técnico-Industriais (FEITECH), a Confederação de Estudantes Normalistas (CONFECH) e de Estudantes Agrícolas (FEDEACH), além de grupos comunais de juventudes voluntárias. ${ }^{1067} \mathrm{O}$ aprendizado do trabalho voluntário era uma via de mão dupla, e ampliava a visão de mundo dos estudantes e lhes proporcionava uma compreensão prática da realidade camponesa durante 3 meses consecutivos. Era a ONSEV que arcava com os $90 \%$ custos de transporte, habitação e alimentação dos voluntários, como um subsídio público para solidariedade juvenil. ${ }^{1068}$

\footnotetext{
1062 Id., ibid.

${ }^{1063}$ Lily Vega, Los trabajos voluntarios del verano de 1971, una gran jornada juvenil. Revista de Educación, op. cit. 1064 Id., ibid.

${ }^{1065}$ Cerca de 3 mil jóvenes salen este verano al trabajo voluntario. Revista de Educación, n. 3, 1967; Balance de la labor de estudiantes voluntarios en los trabajos de verano de 1968: nuevos proyectos. Revista de Educación, n. 4, 1968; Lily Vega, Los trabajos voluntarios del verano de 1971, una gran jornada juvenil. Revista de Educación, n. 32-33, 1970.

1066 Tarapacá, Atacama, Coquimbo, Valparaíso, Santiago, Maule, Nuble, Biobío, Concepción, Malleco, Cautín, Valdivia, Osorno, Llanquihue e Chiloé.

${ }^{1067}$ A lista de organizações estudantis participantes do trabalho é enorme, algumas delas listadas aqui: FECH, FEUC (e FEUC Valparaíso), FEUTE (e FEUTE Valdívia), FESECH, FEITECH, FEDEACH, Centro de Alunos do Instituto Pedagógico da UTE, Centro de Estudantes Geógrafos da U. do Chile, Centro de Estudantes de Odontologia da U. Chile, Centros de Alunos de Construção Civil da UTE, Centro de Estudantes de Educação da U. Católica, Centro de Estudantes de Ciências Políticas da U. Chile, Federação de Estudantes Secundários de Santiago, Federação de Estudantes de Comércio (FECOCH), Federação de Estudantes Profissionais e Técnicos (FETEPRO), entre muitas outras. Lily Vega, Los trabajos voluntarios del verano de 1971, una gran jornada juvenil. Revista de Educación, op. cit.

${ }^{1068}$ Lily Vega, Los trabajos voluntarios del verano de 1971, una gran jornada juvenil. Revista de Educación, op. cit.
} 
O clima de engajamento promovia uma mistura de entusiasmos entre camponeses e estudantes, sujeitos coletivos que passaram a se encontrar com frequência em marchas e concentrações de apoio a Salvador Allende. O alfabetizador Arnaldo Cáceres, que trabalhava no ICIRA, se lembrou de ver, em 1972, que seus alunos camponeses testavam suas primeiras palavras escritas nos cartazes que pintavam para levar às marchas de apoio ao governo da UP. ${ }^{1069}$ Quando Allende viajava aos campos mais remotos, multidões de camponeses se preparavam para recebê-lo e apoiá-lo. Alicia Muñoz, camponesa que tinha sido retirada da escola aos 9 anos para servir como empregada na casa patronal, se lembra de preparar cartazes com seus companheiros de CERA e descer na carroceria de um caminhão até Molina para assistir à passagem de Allende: "eu vivia em uma propriedade muito isolada e distante, lá na Cordilheira. Tínhamos somente um transporte, um caminhão que enchíamos de panos com 'Viva Presidente Allende!", lembrou: "Descíamos a Cordilheira em direção ao pueblo pegando as pessoas pelo caminho para participar dos eventos e marchas" (Muñoz, 2020).

A jovem Camila Montecinos não era filiada a nenhum partido e fez parte das brigadas de trabalho voluntário durante dois verões da UP, quando era estudante de agronomia da Universidade do Chile: "em 1972 estive três meses na comuna de Rengo, em Rancagua. Depois, no primeiro semestre de 1973, estive no Sul, na zona camponesa de Victoria", ${ }^{1070}$ contou. Embora não fosse militante partidária, Camila se lembra de presenciar uma solenidade de filiação de um grupo de camponeses ao PC, em um assentamento na Araucanía em 1973. Conforme recebiam seus carnês, contou, "as pessoas se emocionavam". ${ }^{1071}$ A cerimônia de entrada em um partido disciplinado como o PC, naquele contexto, era um gesto de responsabilidade e pertencimento maior a uma grande causa. A presença dos partidos da UP no campo se tornava cada vez mais intensa e o campesinato se integrava a essa onda de mobilizações voluntárias com uma crescente confiança nos novos "agentes externos" vindos das universidades. Não à toa, a base organizada em sindicatos camponeses saltou $223 \%$ somente no triênio de Salvador Allende.

No verão de 1970-1971, a FECH organizou 1.625 voluntários em 69 acampamentos espalhados em sete províncias (Coquimbo, Colchágua, Talca, Ñuble, Cautín, Valdívia e Osorno). Eram quatro tipos de brigadas: saúde, educação, construção civil e agropecuária. Segundo relatório da FECH para ONSEV, suas Brigadas de Educação identificaram 7.710 camponeses iletrados nas suas zonas de atuação. Nos redutos indígenas, foram encontradas taxas de analfabetismo ainda mais altas que a média rural $(26 \%$ a $30 \%)$ que alcançavam de $40 \%$ a $46 \%$. Além disso, foram realizados 30 cursos de contabilidade, 205 palestras sobre direitos sindicais camponeses, 41 conversas sobre educação sexual, além de terem sido inaugurados 33 novos CEMAs e promovidos 37 atos culturais entre estudantes e camponeses. A Brigada de Saúde da FECH reportou 2 mil atendimentos médicos, aplicaram 2.144 doses de vacinas, conduziram 524 palestras sobre diarreia infantil e entregaram meio litro de leite diário

\footnotetext{
1069 Entrevista com Arnaldo Cáceres, Santiago, 29/06/2017.

1070 Entrevista com Camila Montecinos, Santiago, 14/05/2017.

1071 Id., ibid.
} 
a 3.450 crianças, além de oferecerem atendimento odontológico a 760 pessoas e 261 palestras sobre higiene. Entre os feitos das Brigadas de Construção Civil, estavam a construção de onze escolas rurais, dez policlínicas, 28 jardins infantis, 19 praças, três pontes, dois caminhos e uma roda hidráulica. Nos mesmos três meses, a Brigada de Agropecuária realizou atenção veterinária a 2.022 animais, aplicou 3.442 vacinas, conduziu palestras sobre a reforma agrária para 580 pessoas, ofereceram 810 horas de trabalho em assistência técnica agronômica e 6.120 horas de trabalho em colheitas e cultivos. ${ }^{1072}$ Esses números, embora um pouco enfadonhos, ajudam-nos a ter a dimensão do impacto que os trabalhos voluntários tiveram na vida de muitos camponeses chilenos.

A Revista de Educación do Mineduc recebeu uma carta de um leitor de Chiloé que dizia: "houve uma notória melhoria nos trabalhos de verão, tanto em seu aspecto técnico, como na quantidade de obras tão generosamente realizadas". ${ }^{1073}$ No entanto, o mesmo leitor advertia sobre a "necessidade de realizar reuniões de preparação antes que os grupos saiam para as províncias, que incluam informações cabais sobre o caráter e os costumes das populações com as quais vão trabalhar, um estudo sobre as zonas". ${ }^{1074}$ Para ele era necessário "preparar o voluntário até mesmo no conhecimento da linguagem regional". ${ }^{1075}$ É muito possível que os jovens urbanos, com seus hábitos próprios de linguagem, consumo e formas de se relacionar gerassem constrangimentos em algumas comunidades camponesas, nada habituadas com as formas de ser do estudante urbano. A impetuosidade da juventude comprometida com o processo revolucionário também poderia criar mal-entendidos e atritos entre culturas urbanas e rurais. De toda forma, os relatórios das Federações seguiam a indicar que os impactos positivos eram muito maiores que os negativos.

A FEUTE reportou 2 mil voluntários no verão de 1970-1971, sendo 1.600 vindos de Santiago e 400 de Valdívia, espalhados por nove províncias: Osorno, Llanquihue, Chiloé, Arauco, Aysén, Valdívia, Isla de Santa María e Temuco ao Sul, e La Serena e Antofagasta ao Norte. Entre suas principais atividades, presentes em quase todas as atuações, estava a alfabetização. Também construíram escolas rurais, policlínicas, fizeram mutirões para embelezamento das praças dos povoados, pintaram murais, ofereceram serviços de saúde, eventos culturais e até criaram assentamentos. ${ }^{1076}$ Ofereceram os cursos de educação fundamental, nutrição, higiene, moda e tecido, agricultura, mecânica, eletricidade, sindicalismo e cooperativismo. Além disso, realizaram um trabalho de recenseamento do analfabetismo das zonas em que atuaram: "os voluntários participaram dos objetivos do Programa de Educação dos Trabalhadores para a mudança, como propôs o Mineduc. Uma das tarefas foi a o mapeamento censitário dos focos de analfabetismo", ${ }^{1077}$ reportou-se. Além de iniciar trabalhos de alfabetização, os voluntários mapearam as taxas de analfabetismo no campo, e guiaram as prioridades

\footnotetext{
1072 Lily Vega, Los trabajos voluntarios del verano de 1971, una gran jornada juvenil, op. cit.

1073 Apud Lily Vega, ibid.

1074 Id., bid.

1075 Id., ibid.

1076 Id., ibid.

1077 Id., ibid.
} 
do governo na sua política de alfabetização. Por fim, realizavam também trabalhos diagnósticos comunais e territoriais, que a ONSEV chamou de "estratégias microrregionais de desenvolvimento", mas não se sabe se houve uso ou não de círculos de cultura dialógicos para essa atividade.

Entre os voluntários daquele verão, 271 eram estrangeiros, sendo 121 membros dos Corpos de Paz dos Estados Unidos, cuja atuação no Chile já vinha de longa data (como mostra o capítulo 3). Aparentemente, a esquerda passou a conviver com os estadunidenses de uma maneira menos incômoda do que no governo anterior, embora não desavisada sobre o viés geopolítico daquelas missões. Efetivamente, o espírito dos trabalhos voluntários parecia combater a cultura do sectarismo entre as juventudes partidárias, pois essas inevitavelmente se misturavam em tarefas concretas e precisavam se ajudar em trabalhos bastante práticos. Evidentemente, o trabalho educativo era mais suscetível às inclinações partidárias. De toda forma, em janeiro de 1971 um evento aglomerou mais de três mil jovens da DC e da UP em Temuco, "um massivo ato juvenil em apoio à reforma agrária e aos trabalhos voluntários". ${ }^{1078}$ Ao mesmo tempo, algumas medidas muito identificadas com a UP eram parte integrada dos trabalhos voluntários, como a entrega do $1 / 2$ litros de leite para cada criança chilena, prometida incansavelmente por Salvador Allende desde a campanha. Em março de 1971, em Chillán, 649 estudantes voluntários repartiram mais de 61 mil litros de leite em benefício de 26.140 pessoas, o que resultou em um aumento de $115 \%$ do consumo de leite na comuna. ${ }^{1079}$

Ao fim dos trabalhos de verão de 1971, o presidente da FEUTE, Alberto Ríos, discursou:

As jornadas de trabalho voluntário demonstram a multifacetada capacidade da juventude chilena, seu alto espírito para enfrentar milhares de inconvenientes, dificuldades de toda índole e orientar seu trabalho às mais variadas gamas do conhecimento. A juventude aprendeu da melhor escola da vida. Esses meses não serviram apenas para ensinar práticas e técnicas e para cooperar trabalhando, mas sim contribuiu para que conhecêssemos o povo chileno de maneira vital, (...) vivendo suas inquietações e dramas, e aprendêssemos junto a trabalhadores e camponeses, que são os personagens principais da nossa revolução. São coisas infantis do vanguardismo (...) querer dar lições de como ser revolucionário aos trabalhadores chilenos, de um anarquismo febril querer fazê-lo de acordo com esquemas próprios (...). Cada ação, por pequena que seja, deve ser medida de acordo a como afeta os interesses do povo. ${ }^{1080}$

E concluía seu discurso com uma citação de Lênin, em defesa de "uma moral internamente subordinada aos interesses da luta dos trabalhadores". ${ }^{1081}$

Em julho de 1971, os voluntários se organizaram também na Operação Inverno: "tão logo que começam as férias, milhares e milhares de estudantes marcham ao campo para abrir sulcos e canais de irrigação. Muitos se inscreveram na sua federação estudantil e há também os jovens trabalhadores, que organizam seu tempo e querem participar", ${ }^{1082}$ dizia uma matéria. Manuel Guerrero, encarregado de

\footnotetext{
1078 Toda la juventud chilena por la reforma agraria, El Siglo, 05/01/1971.

1079 En Chillán, 649 voluntarios reparten más de 61 mil kilos de leche. El Siglo, Mar/1971.

1080 Apud Lily Vega, op.cit.

${ }^{1081}$ Id., ibid.

${ }^{1082}$ Los jóvenes van al campo a elevar la producción agrícola. El Siglo, 04/07/1971.
} 
Trabalhos Voluntários da JJCC, declarou: "São muitas tarefas e notamos com satisfação a massiva participação do nosso partido". ${ }^{1083}$ No total, dois mil jovens se deslocaram ao campo pela batalha da produção, trabalhando no setor reformado em O’Higgins, Colchagua, Nuble, Aconcagua, Valparaíso, Valdívia e Arica. "Os muchachos valdivianos cortaram madeira das serralherias, em Cañete a muchachada se dedicou à colheita de batatas, em Arica foram preparados centenas de hectares de solo para cultivo", ${ }^{1084}$ dizia a notícia, considerando a "limpeza dos feijões de exportação nos assentamentos" 1085 uma das principais atividades.

Nos anos de 1972 e 1973, houve uma relativa inflexão nos trabalhos de verão, que embora seguissem tarefas de alfabetização, passaram a se engajar de modo mais emergencial nas atividades produtivas: "os estudantes não estarão alheios a esta batalha por aumentar a produção, pela qual está passando o país", ${ }^{1086}$ dizia a imprensa do governo. A ONSEV direcionou 594 jovens para trabalhar na construção de 37 pavilhões avícolas durante o verão. ${ }^{1087}$

Em fevereiro de 1972, a oposição de Concepción acusou os estudantes de "veranear" durante o trabalho voluntário. A imprensa do governo os defendeu: "não estão veraneando, estão ajudando a construir um Chile novo (...), com trabalhos de conscientização". ${ }^{1088}$ O Chefe Zonal da CORA de Concepción, elogiou os estudantes, que trabalharam em mais de 60 assentamentos da região. Com os estudantes, dizia o funcionário, "a organização dos camponeses melhora a olhos vistos". ${ }^{1089}$ Ao mesmo tempo, admitia-se alguns problemas: na primeira semana de trabalho, os estudantes ficaram sem ferramentas e sem tarefas, além de haver uma descoordenação inicial. Mas o problema foi corrigido e ao final todos sentiram sobrecarga de trabalho, entendido como dado positivo.

No verão de 1972-1973, a UTE realizou sua VI Escola de Verão itinerante, e com ela inaugurou pela primeira vez brigadas de professores e estudantes voluntários diretamente dedicadas aos camponeses: "A UTE sai ao campo", dizia uma notícia, "chegará às comunas de Talagante, Huchún e Maria Pinto, entre 8 e 26 de janeiro, que junto com numerosas comunas da Grande Santiago, que receberão dezenas de professores". ${ }^{1090}$ Era a primeira vez que a UTE incluía comunas camponesas em seus cursos anuais. ${ }^{1091}$ O programa de Escolas de Verão da UTE havia se convencidos de que "a Universidade deve chegar aos setores rurais para capacitação dos trabalhadores". ${ }^{1092} \mathrm{O}$ curso se instalou em assentamentos da reforma agrária. Pedro Quintanilla, dirigente do sindicato Despertar Campesino que representava trabalhadores de 50 propriedades, deu seu depoimento: "para nós é muito importante

1083 Id., ibid.

1084 Id., ibid.

1085 Id., ibid.

1086 Trabajos de verano: convenio FECH-CORA. La Nación, Jan./1972.

1087594 universitarios se suman a proceso de reforma agraria. La Nación, Jan/1972.

1088 Trabajos de verano: aumenta la solidaridad campesino-estudiantil. La Nación, Fev./1972.

1089 Id., ibid.

1090 Es bueno que la universidad llegue a los campesinos. Dice campesino por Escuela de Verano de la UTE. La Nación, Jan./1973.

1091 A luta pela função social da universidade deu origem a novos Departamentos de Extensão e Educação Popular na Universidade do Chile, na Universidade Técnica do Estado e na Universidade Católica, alguns dos quais começaram a operar em convênios com o FEES.

1092 Idem. 
assistir a esses cursos, porque nos convém saber como administrar as propriedades expropriadas". O camponês comentou que era a primeira vez que recebia cursos e os atribuiu ao "governo que temos agora". ${ }^{1093}$ Quando perguntado se as mulheres camponesas também participavam, ele respondeu: "acho que algumas vão participar, ao menos na área avícola, precisamos aprender a aplicar vacinas. Na área agrícola também, na fruta, há muito trabalho que as mulheres podem fazer, como colher e descarregar pêssegos e uvas". ${ }^{1094}$

Os cursos da UTE eram sobre Melhoramento da produção agrícola, Melhoramento da leiteria e pecuária, Recursos naturais, Reforma agrária, Planificação agropecuária do governo e Responsabilidade da classe trabalhadora na batalha da produção. No assentamento General Schneider, com 8 mil hectares e 96 assentados, na comuna de Maria Pinto, foi criado um Comitê de Disciplina que Controla do Trabalho. O vice-presidente do assentamento, Osvaldo Cruz, declarou: “antes pensávamos que a Universidade devia nos ensinar, mas agora sabemos que devem fazer práticas conosco, conviver conosco". ${ }^{1095}$ No entanto, as condições das aulas para os camponeses não eram fácies, porque nem sempre deixavam de trabalhar nos cultivos durante os cursos: "é muito sacrificado", disse Cruz, "temos muito trabalho. Nesse momento, temos escassez de gente para trabalhar. Antes vinham veterinários e faziam muitas coisas. Agora nos ensinam a vacinar. Por isso os cursos da universidade são importantes", ${ }^{1096}$ completou. Em 1972, a UTE também firmou um Convênio com o FEES para capacitação e difusão cultural. "A ideia era exibir peças de teatro social aos camponeses e suas comunidades e motivá-los a criar grupos de teatro e peças com conteúdo social rural”, explicou Oscar Torres (2020).

Em março de 1973, entre os mais de 5 estudantes mobilizados nos trabalhos de verão, 250 voluntários da FECH, FEUT e CUT foram financiados pela CORA e fizeram colheitas no setor reformado de Linares a Valdívia. O governo anunciava que o trabalho voluntário foi fundamental para economia de divisas durante aquela colheita. Os voluntários custeados pela CORA também atuavam nas áreas de medicina veterinária, odontologia, enfermaria, nutrição, psicologia, eletricidade, topografia e mecânica. ${ }^{1097}$ Embora não existam dados completos de voluntários do último verão de Allende, só a Ranquil exclusivamente mobilizou 5.270 voluntários para trabalhos produtivos em CERAs, assentamentos e construção de escolas rurais, uma quantidade parecida de voluntários que toda ONSEV havia cadastrado em 1970. ${ }^{1098}$ Como indicava a concepção revolucionária da educação de Iván Nuñez, os trabalhos produtivos, sociais, de infraestrutura, saúde e educação ocorriam de modo orgânico à transformação da vida. A totalidade destas transformações era a revolução.

\footnotetext{
1093 Idem.

1094 Idem.

1095 Es bueno que la universidad llegue a los campesinos. Dice campesino por Escuela de Verano de la UTE. La Nación, Jan./1973.

${ }^{1096}$ Id., ibid.

${ }^{1097}$ Voluntarios en el campo: economía y producción. La Nación, Mar/1973.

1098 Cinco mil voluntarios trabajaran en el Agro. La Nación, Maio/1973.
} 


\section{De Monte Pátria aos professores voluntários}

Em novembro de 1971, teve início o Programa Nacional de Educação Campesina na comuna de Monte Pátria, na região de Coquimbo. O Programa era a política da UP para erradicar o analfabetismo rural no país. Era, portanto, prioritário para CORA e Mineduc, que se encarregaram dessa linha no interior do CTNC. CORA e Mineduc tinham as vantagens do enraizamento, tanto com a estrutura de capacitação por zonas da primeira, como as escolas rurais do segundo. A meta era alfabetizar todos os 618 mil camponeses ainda iletrados em um ano, focando na pós-alfabetização a partir dos anos seguintes. O Programa foi inaugurado com um evento que reuniu mais de 1.300 camponeses. Eram quatro etapas de formação: (1) educação básica para 40 mil camponeses, ou seja, cursos de alfabetização, matemática e contabilidade e ciências sócio-históricas; (2) "educação familiar e feminina", que reforçava o aspecto patriarcal da divisão sexual do trabalho; (3) "educação juvenil e recreativa", ligada às artes e aos esportes; e (4) "capacitação em saúde", ramos coordenados pelo SNS. ${ }^{1099}$ O plano inicial do CTNC, a essa altura já presidido por Campusano, era confecção de três materiais didáticos diferentes, um para cada zona do país dividido entre Norte, Centro e Sul. No entanto, como sabemos, o manual de alfabetização camponesa nunca chegou a ser publicado e o material utilizado para ocupar o vazio eram as Sugerencias.

A grande inovação do programa era a nacionalização da "autocapacitação como hipótese", ou seja, eram os camponeses que seriam os principais sujeitos alfabetizadores de seus companheiros. "Os alfabetizadores serão agora os próprios camponeses que foram previamente preparados e ensinarão aos seus companheiros não apenas a ler e escrever, mas também (...) compreender o processo de mudanças que vivemos" ${ }^{1100}$ anunciava El Siglo. Hector Reyes, chefe do Departamento de Educação Básica da CORA, reforçou: "Na aprendizagem ativa que agora colocamos em marcha, o próprio camponês irá descobrir o método para analisar e sistematizar os problemas que mais lhe interessam". ${ }^{1101}$

O educador da CORA Julio Salgado estima que 20 mil camponeses foram alfabetizados em oito meses em Monte Pátria (Austin, 2003: 178). Arnaldo Cáceres, que alfabetizou dentro do Programa, lembra-se que a escolha simbólica de Monte Pátria se justificava por ser o local com maior taxa de analfabetismo do país: “organizávamos equipes, conversávamos com instituições de trabalhadores da educação e fazíamos capacitações de professores" 1102 para o método psicossocial contou. Cáceres valorizava muito a parceria com professores das escolas rurais em cada localidade que lecionava. Os professores capacitados iam trabalhar em diferentes locais, não apenas na sua própria zona: "tinham nosso apoio, do ICIRA, para se deslocar para lugares onde os camponeses estivessem mais agrupados". ${ }^{1103}$ Cáceres alfabetizou na comuna de Renca, nos arredores de Santiago, e depois em

\footnotetext{
1099 Hoy se inicia programa para capacitar a 400 mil campesinos. El Siglo, 21/11/1971.

1100 Id., ibid.

1101 Id., ibid.

1102 Entrevista com Arnaldo Cáceres, Santiago, 29/06/2017.

1103 Id., ibid.
} 
Cautín, onde trabalhava quando ocorreu o golpe. Cáceres também lembra que a capacitação de camponeses alfabetizadores em Monte Patria teve um impulso da politização dos "camponeses federados", aqueles que tinham trabalhado no salitre e desenvolvido uma cultura política bastante combativa: "isso chamou muito minha atenção, havia um trabalho político nessas comunidades". Lembrou Arnaldo: "as cooperativas se conectavam aos serviços públicos com mais facilidade, conseguiam créditos. (...) Enquanto nas zonas mais ao sul, a imagem do patrão era mais forte entre os camponeses. O que era uma dificuldade para nós". ${ }^{1104}$ Afinal, se a tarefa dos alfabetizadores era também impulsionar a consciência da reforma agrária, quanto mais forte a interiorização do patrão nos camponeses (a "aderência ao opressor", nas palavras de Freire), mais custoso era o trabalho.

Ao mesmo tempo, conta Arnaldo, "a alfabetização com o método Paulo Freire tornava a tarefa mais leve. Era recordar parte da vida de cada pessoa. Cada um dos alunos tinha uma experiência (...). Essa conversa nos facilitava, porque nos mostrava a nós e a eles, as condições em que se trabalhava e se vivia no campo, que eram duríssimas". ${ }^{1105}$ Cáceres descreveu materiais de alfabetização que correspondiam às imagens criadas no assentamento El Recurso, quando as equipes freirianas do ICIRA realizaram a investigação temática em 1968 (ver capítulo 5). Ele se lembrava da imagem da Igreja, que sempre gerava muitas anedotas por conta dos padres que viviam nas zonas rurais, suas relações com os patrões, seu comportamento. "Os alunos iam se animando e contavam coisas. Como histórias de uma pessoa que roubou um saco de trigo e se confessou na Igreja, mas no dia seguinte o patrão o demitiu por ser ladrão, ou recebia uma surra", ${ }^{1106}$ lembrou Arnaldo, mostrando que a experiência de El Recurso era comum a muitas outras haciendas, em que os padres violavam sua função espiritual e usavam a confissão camponesa como arma do patrão. Nessas conversas, conta Arnaldo, "os camponeses iam se dando conta, sem que nós disséssemos muita coisa". ${ }^{1107}$

Para Arnaldo, a principal batalha política no processo de alfabetização durante o Programa de Educação Camponesa, não era entre os partidos, mas sim a batalha contra o peso da simbologia do patrão e do padre, que eram as figuras predominantes no imaginário dos camponeses. Ele se recorda de conversar com camponeses sobre como seria a melhor forma de organizar a espacialidade das suas casas no assentamento, indicando que se estavam mais próximos, podiam ter eletricidade, um centro cultural e conviver mais entre si. Ao passo que na forma como o patrão organizava a espacialidade das casas camponesas, eram tão distantes umas das outras que não era possível que combinassem nada: "o sistema patronal impedia que eles se encontrassem e criassem acordos sobre salários", ${ }^{1108}$ explicava o professor. "Mas alguns ficavam muito temerosos e pensavam que de repente ia aparecer um novo patrão, que os ia castigar e despedir, deixá-los nas margens dos caminhos", recordou. Essa fantasia do "retorno do patrão", desafortunadamente, encontrou-se com aspectos da realidade depois do golpe de 11 de

\footnotetext{
1104 Id., ibid.

${ }^{1105}$ Id., ibid.

${ }^{1106}$ Id., ibid.

${ }^{1107}$ Id., ibid.

1108 Id., ibid. .
} 
setembro de 1973. Alguns camponeses, segundo se lembra Arnaldo, diziam: "se essas terras são do patrão, porque vocês vêm até aqui tirar dele?". Como conversar pedagogicamente com os amarillos? Nem sempre os camponeses "apatronados" eram financiados ou comprados por razões econômicas. Às vezes, eram aderentes ao opressor por razões de ordem histórica-antropológica. "Já outros se atreviam mais e propunham greves, tomas, mobilizações e inclusive marchar a Santiago para exigir", ${ }^{1109}$ explicou Arnaldo. Na lembrança do professor Cáceres, o processo de alfabetização era efetivamente um processo de conscientização, que se deparava com obstáculos subjetivos à mudança, de ordem estrutural.

O professor Herrera também trabalhou como alfabetizador da CORA durante a UP. "Saía a organizar centros de educação e de alfabetização nas escolas rurais (...). Meu irmão me dizia: você está agarrado a isso tudo, precisa trabalhar menos. E eu respondia: não, companheiro, não se trata de trabalhar menos. Se trata de trabalhar mais", ${ }^{110}$ contou Herrera. Com isso, se reforça a compreensão de que mesmo entre os profissionais, havia uma grande dose de tempo de trabalho voluntário que era oferecido para a tarefa da alfabetização. Herrera abria a escola bem cedo, dava aulas no turno da manhã para crianças rurais, e depois dava aulas no turno da noite para alfabetizar os camponeses. Voltava depois de meia-noite. Nos fins de semana, aulas em sindicatos e assentamentos. Herrera era um profissional voluntário, conduzido pelo estímulo moral geral da própria revolução: "era uma vida absolutamente comprometida e entregue à causa", ${ }^{1111}$ resumiu. Herrera se tornou professor de coordenadores do método psicossocial: "aos professores das escolas normais, não the ensinavam o método", contou, "era preciso que o conhecessem através da CORA". ${ }^{1112}$ Esse trabalho era feito no Centro Porvenir, entre Talca e San Clemente, pela mobilização voluntária dos professores. A capacitação durava uma semana inteira, na qual tinham alimentação e habitação dadas pela CORA. "Eu mesmo buscava os professores", recordou Herrera, "os tirávamos das escolas e eles eram transformados. Até criavam seus próprios centros de alfabetização". ${ }^{1113}$ Segundo Herrera, a CORA tinha veículos, mas não funcionários comprometidos - "muita gente da DC". Portanto, como professor e dirigente comunista, fez um acordo com a CORA de pegar um veículo emprestado toda semana e "hacer la pega con gente de afuera". Ou seja, segundo Herrera, enquanto os funcionários da CORA da DC ficavam em seus escritórios e se preocupavam exclusivamente com a formação dos "novos chefes de assentamento", militantes de diferentes organizações da UP, realizavam voluntariamente o trabalho educacional camponês que deveria ser da CORA. "Depois eles apresentavam como trabalho próprio", ${ }^{1114}$ acusou, "mas isso não nos interessava. O que nos interessava era fazer a política de alfabetização, que a educação chegasse nos trabalhadores rurais. Não importava como". ${ }^{115}$ O profe

\footnotetext{
${ }^{1109}$ Id. ibid.

${ }^{1110}$ Entrevista com Manuel Herrera Castro, San Clemente, 27/05/2017.

${ }^{1111}$ Id., ibid.

1112 Id., ibid.

1113 Id., ibid.

1114 Id., ibid.

1115 Id., ibid.
} 
Herrera contou que os funcionários da CORA que permaneciam no escritório se referiam aos professores mobilizados dizendo: "essa gente aqui são os voluntários que andam dando aulas".

Por fim, a proximidade e a dedicação que alguns professores voluntários chegaram a ter com os camponeses, para Herrera, era um importante fator político nas bases da revolução: "nós íamos visitálos e ficar com eles. Ganhávamos a amizade e a confiança dos camponeses, e estávamos sempre por perto. Quando outros chegavam com discursos, o camponês dizia: e quem é esse?", explicou. "O camponês sempre viveu à base de mentiras. $\mathrm{O}$ que se prometeu ao camponês, nunca se cumpriu. Se você diz que na semana seguinte, no próximo encontro, vai levar um livro ou dois, tem que chegar com os livros, com chuva ou com neblina. (...) Mas nem todos criavam essa proximidade e compromisso com o camponês. Por isso fracassamos". 1116

Segundo os autores Diagnóstico, o Programa Nacional de Educação Camponesa começado em Monte Patria, junto com os cursos de cajero-bodeguero, teriam sido as experiências de maior sucesso do CTNC (Barraclough \& Fernández, 1974: 233).

\section{Operação casa patronal}

Os estudantes e professores voluntários, milhares de alfabetizadores que se espalharam pelo país nos anos da UP, encontraram para sua atividade um novo território de apropriação: as casas patronais das haciendas. Logo na primeira expropriação da CORA do governo Allende, em novembro de 1970, a demanda surgiu dos próprios camponeses. O latifúndio Cuesta Vieja tinha sido dividido em seis pedaços pelos seus donos, que tentaram driblar a lei. Com a expropriação, foi criado o assentamento La Batalla de San Juan de Cuesta Vieja, com 262 hectares irrigados e 267 de secano. Pelo simbolismo da ocasião, Baytelman foi ao assentamento e comunicou aos camponeses que a CORA lhes oferecia duas vagas para um curso de contabilidade, que ocorreria no mês seguinte em Santiago. Os camponeses responderam que gostariam de criar uma Escola Agrícola na casa patronal.

Segundo Oscar Torres, essa ideia já circulava desde 1969 no FEES. Como o fundo não tinha sedes locais e regionais, seus professores sentiam falta de locais de educação fixos nos próprios assentamentos, onde pudessem ministrar suas aulas com mais facilidade. Notaram que muitas casas patronais estavam inutilizadas, pois os patrões se retiravam, mas os camponeses não tinham autorização formal para se apropriar, e a CORA tampouco tomava uma iniciativa. "Fui falar com Rafael Moreno em 1969, para conseguir que a CORA passasse as casas patronais dos assentamentos ao FEES. Muitas ficavam desocupadas", ${ }^{1117}$ contou Torres. E prosseguiu: "Moreno disse que ia pensar e passou o tema a um assessor. $\mathrm{O}$ assessor reclamou com o chefe: 'como você vai fazer um convênio com Oscar Torres?

\footnotetext{
${ }^{1116}$ Id., ibid.

1117 Entrevista com Oscar Torres. Maipo, 26/05/2019.
} 
Ele é do MAPU! Não percebe que entregaria as casas patronais para esquerda?'. Aí Moreno nunca me respondeu". 1118

A ideia de Torres foi consolidada pelo governo da UP em julho de 1972, quando foi criada a Operação Casa Patronal: "de forma intuitiva, as casas patronais começaram a ser usadas pela CORA como centrais de capacitação camponesa, mas até agora não havia planificação nacional", ${ }^{1119}$ dizia uma matéria. Segundo a imprensa oficial, um ano e meio de governo popular teria sido suficiente para derrubar a mortalidade infantil em $10,5 \%$ com a política do leite e aumentar a escolaridade infantil em $5,5 \%$. A criação de escolas nas casas patronais acabaria de vez com o problema das distâncias das escolas rurais e daria inédita capilaridade à educação camponesa. Nem todas seriam escolas. A Operação Casa Patronal contemplava postos de saúde e centros de veraneio para trabalhadores urbanos. Em meados de 1972, 300 casas patronais já estavam em transformação. "O analfabetismo é maior no campo, porque a ignorância dos camponeses foi uma preocupação importante dos latifundiários", explicava La Nación: "Tão logo a criança tinha idade para trabalhar, o patrão lhe exigia que abandonasse os estudos e ajudasse seu pai, obtendo outro trabalhador sem necessidade de pagar nada mais". ${ }^{1120}$

Foi exatamente essa a história de Alicia Muñoz (ver capítulo 1). Os patrões do latifúndio Água Fria (província de Curicó), onde morava Alicia, eram assediadores sistemáticos das mulheres camponesas. Com 9 anos, a pequena Alicia foi retirada compulsoriamente da escola para trabalhar na casa patronal. Os donos eram alguns irmãos com a mesma mentalidade: "os patrões se sentiam donos de nós", contou Alicia (Muñoz, 2020). Estabeleceram uma dominação abusiva cotidiana com aqueles trabalhadores. Em 1971, encorajados pela eleição de Allende, os camponeses do latifúndio organizaram uma toma e conquistaram a expropriação, formando um CERA. O sindicato Marcha de Molina, da Ranquil, participou e apoiou a luta. Temendo uma revanche, todos os patrões se retiraram da terra menos um. Aquele que ficou sofreu um atentado: "os jovens tinham muito ódio dele. Não medo, como eu. Ódio. Quem o baleou foi um sobrinho meu. Depois ele foi detido, com outros quatro ou cinco jovens camponeses daquela terra. O patrão foi levado ao hospital e não morreu. Mas nunca mais voltou ao latifúndio", ${ }^{1121}$ relatou Alicia. Depois dessa circunstância, a casa patronal foi ocupada e transformada em escola: "íamos pela noite estudar, fazer alfabetização e reforço. Eu tinha cursado só até o $3^{\circ}$ ano", lembrou Alicia: "São recordações bonitas que tenho desse processo, os sindicatos, as reuniões. Era maravilhoso". ${ }^{1122}$ Por outro lado, Alicia também se recorda que as mulheres que estudavam às vezes sofriam discriminação dos homens: "Eram poucas mulheres que estudavam alfabetização. Éramos um pouco mal vistas. 'En que andan?', pensavam algumas pessoas". ${ }^{1123}$ A principal capacitação que Alicia se recorda eram as aulas de corte e costura no Centro de Madres: "falávamos de tecidos, mas também

\footnotetext{
${ }^{1118}$ Id., ibid.

1119 Escuelas y postas en ex casas patronales. La Nación, 30/07/1972.

1120 Id., ibid.

${ }^{1121}$ Entrevista com Alicia Muñoz, Santiago, 14/05/2017.

1122 Id., ibid.

${ }^{1123}$ Id., ibid.
} 
conversávamos sobre o presidente, sobre como melhorar a escola e os professores, como fazer uma escola maior, que não tivesse apenas uma sala". ${ }^{1124}$ Com a toma e o governo Allende, também chegou pela primeira vez um posto de saúde naquela propriedade, algo inimaginável para quem viveu a dominação patronal anterior: "foi maravilhoso! Ali podíamos buscar o leite das crianças, que havia sido dado pelo presidente Allende. Era meio litro por criança. Foi uma mudança brutal". ${ }^{1125}$

A Operação Casa Patronal pretendia resolver o problema educacional de adultos e crianças. A grande maioria das crianças rurais não alcançava a escola secundária (Liceus), porque para isso necessitava mudar-se para o povoado, para a capital e morar bem longe da família. "A reforma agrária conseguiu incorporar mais crianças na educação ao terminar com a exploração de menores", explicava uma matéria. "Contudo, o problema não terminou. A criança camponesa está estudante até o $8^{\circ}$ ano básico, mas daí não pode continuar, porque os Liceus não estão no campo". ${ }^{1126} \mathrm{Se}$ as casas patronais oferecessem educação secundária, o acesso dos jovens camponeses à escolarização se alterava substancialmente. A Operação não demandava grandes mudanças na estrutura das casas, porque muitas delas eram "verdadeiros palácios de magnatas da terra, construído com todo luxo e vários banheiros e condições irreparáveis para serem utilizadas como escolas de concentração de internatos, onde as crianças camponesas podem terminar seus estudos secundários", ${ }^{1127}$ anunciava a imprensa oficial. Em San Felipe, uma mansão rural seria incorporada à Escola Técnica Agrícola, sob comando da Universidade do Chile.

No assentamento El Siglo, próximo da comuna de Talagante, na região metropolitana, o camponês José Ravanal expressou: "nas casas patronais, queremos fazer cursos de capacitação. Aqui precisamos de aulas de todo tipo. Eu por exemplo, somente sei ler", ${ }^{1128}$ comentou durante a Escola de Verão da UTE, em janeiro de 1973.

A apropriação das casas patronais para educação camponesa poderia resolver um problema ainda mais estrutural, relacionado à distância dos organismos do agro em relação à realidade camponesa. O governo da UP se dedicou sobremaneira a uma reforma administrativa que obrigaria os funcionários técnicos a conviver mais com os camponeses com os quais trabalhassem. A distância cultural entre técnicos e camponeses também eram uma distância geográfica. Por isso, o ministério de Chonchol deu início a uma reestruturação do agro que envolvia, entre outras medidas, a ruralização dos técnicos, para que tivessem "permanente contato com o campesinato", ${ }^{1129}$ por meio da "incorporação dos funcionários às unidades reformadas". ${ }^{1130}$ A orientação gera era que, a partir de 1973, os técnicos do agro deveriam se mudar para viver dentro das propriedades rurais, junto aos camponeses, nos CERA

\footnotetext{
1124 Id., ibid.

${ }^{1125}$ Id., ibid.

${ }^{1126}$ Ex casa patronales son ahora salas de clases. La Nación, 01/08/1972.

${ }^{1127}$ Id., ibid.

1128 Es bueno que la universidad llegue a los campesinos. Dice campesino por Escuela de Verano de la UTE. La Nación,Jan./1973.

${ }^{1129}$ Funcionarios del agro deberán vivir y trabajar en el campo. La Nación, Jun./1972.

${ }^{1130}$ Id., ibid.
} 
e assentamentos. O governo considerava que "a necessidade de maior contato dos funcionários com os camponeses se transformou em uma necessidade vital e urgente, devido à aceleração do processo de reforma agrária. A ideia é deslocar os funcionários das cidades, para levá-los a viver no campo", ${ }_{1131}$ propunha Chonchol em meio à crise de outubro de 1972. A proposta do governo envolvia absorver mais camponeses ao setor reformado, além de todos os desempregados rurais existentes entre o total de 350 mil famílias camponesas, que estavam do lado de fora da reforma. ${ }^{1132}$ Chonchol insistia que era preciso integrar os serviços do agro o mais rápido possível à realidade camponesa e anunciou: "os funcionários devem ir viver no campo, já que 30\% deles está em Santiago e 60\% nas cidades capitais de províncias e somente $10 \%$ deles vive no campo". ${ }^{1133}$

Sem dúvida, a Operação Casa Patronal, ao oferecer uma sede educacional nova dentro de cada unidade reformada, poderia também facilitar a transição dos funcionários da cidade ao campo, para que se misturassem melhor aos camponeses e diluíssem os problemas de hierarquia produtiva e cultural, ainda muito fortes nas relações da reforma agrária. "A reforma agrária deixou os camponeses sozinhos em matéria técnica", insistiu o ministro Chonchol durante o paro, "é urgente que os técnicos se desloquem para viver no campo. Isso significa romper com a atual estrutura burocrática". ${ }^{1134} \mathrm{~A}$ crise de outubro derrubou Chonchol, mas seu sucessor, Rolando Calderón, deu continuidade à política. Os funcionários do Minagri foram obrigados a vincular-se de maneira imediata com os técnicos das bases e os próprios Conselhos Comunais Camponeses, muitos dos quais estavam desassistidos. Era preciso garantir, segundo Calderón, uma "integração rápida e eficaz dos funcionários do agro ao campo". ${ }^{135}$ Em março de 1973, Carlos Espinoza, Chefe Nacional do Programa de Capacitação dos Trabalhadores do Agro, elogiou a iniciativa: "pela primeira vez se desenvolve um programa orgânico para capacitar o pessoal desse setor, como consequência da integração dos serviços e políticas do governo popular", ${ }^{1136}$ registrou, em apoio à ruralização dos funcionários. Evidentemente, houve resistência e a política levaria alguns anos para ser concluída. A intenção era revolucionária, porque aproximava ao máximo o trabalho manual do intelectual, até que fosse possível efetivamente fundi-los em um só corpo de trabalhadores, com diferentes funções, mas sem hierarquias.

Os voluntários estudantes, professores, a Operação Casa Patronal, bem como o deslocamento dos funcionários do agro ao campo, eram processos concomitantes que ampliavam enormemente a zona de diálogo e conflito entre cultura camponesa e urbana. O material Sugerencias para Alfabetización foi sem dúvida um dos principais registros que nos permite compreender a fundo a política pedagógica da UP junto aos camponeses. A seguir, analisarei em detalhes esee documento.

\footnotetext{
1131 Id., ibid.

${ }^{1132}$ Estado de la agricultura, dio a conocer Chonchol. La Nación, Out./1972.

1133 Id., ibid.

${ }^{1134}$ Id., ibid.

${ }^{1135}$ Consejos comunales campesinos, herramientas de lucha y poder. La Nación, Dez./1972.

${ }^{1136}$ Impulsan perfeccionamiento de funcionarios agrarios. La Nación, Mar./1973.
} 


\subsection{Pedagogia freiriana e adaptações marxistas: o guia da UP para alfabetização}

O governo da UP se engajou na educação de adultos trabalhadores com prioridade, em sintonia e diálogo com a CUT. Em fins de 1971, o Mineduc criou um Programa de Alfabetização Funcional e de Educação Básica Politécnica de Trabalhadores, inspirado na pedagogia socialista que buscava unificar educação e trabalho orientados pela perspectiva socialista (Austin, 2003: 153). Em conjunto com a CUT, o Mineduc estabeleceu uma Direção Nacional Autônoma de Educação de Trabalhadores e Adultos, que coordenou campanhas de alfabetização principalmente urbanas, mas também rurais. $\mathrm{Na}$ ausência do Manual Nacional de Alfabetização Campesina, que nunca chegou a ficar pronto no CTNC, as Sugerencias para la Alfabetización, elaboradas pelo Mineduc para todos os trabalhadores adultos, foi amplamente utilizado no campo. Era uma adaptação do método psicossocial às demandas do programa da UP. A seguir, analisarei este documento em detalhes, buscando encontrar similaridades e tensões com a pedagogia freiriana, reveladoras de estratégias político-pedagógicas distintas, bem como da compreensão conflituosa sobre a temporalidade, os saberes e os sujeitos da revolução.

\section{Sugestões para alfabetização: uma adaptação marxista do método psicossocial}

A linha de Educação Básica do CTNC era desenvolvida pelo Ministério da Educação Pública e pela CORA. Se os materiais de capacitação do Comitê ficaram emperrados devido às rivalidades políticas e escassez de recursos, isso não ocorreu com o Programa de Educação dos Trabalhadores do Mineduc, que promoveu uma ampla campanha de alfabetização e conscientização no campo e na cidade, e que adaptou o método psicossocial ao programa da Unidade Popular. O guia Sugerencias para la alfabetización. Nuestra adaptación del Método Psicossocial foi publicado em 1971 como material principal de alfabetização do governo Allende, com autoria de Emma Espina Reyes, Sergio Arévalo, Arnulfo Rubilar e Nelson Severino. ${ }^{1137}$ O guia oferecia 11 imagens para círculos sobre o conceito antropológico de cultura (embora não utilizasse essa expressão) e 22 palavras geradoras, todas acompanhadas por fotos, em vez de pinturas. A busca pelo realismo fotográfico e pela representação mais fiel e técnica das situações de vida era, sem dúvida, uma marca das Sugerencias que o diferenciava dos materiais freirianos do governo anterior.

O Guia foi confeccionado com dupla função: oferecer um método de alfabetização coerente com a luta da UP pela emancipação dos trabalhadores do campo e da cidade, e, ao mesmo tempo, oferecer ao alfabetizador um livro de repertórios, argumentos e informações que lhe permitissem atuar como educador crítico do capitalismo, das injustiças sociais e das classes dominantes chilenas ao longo da história. Os autores do Guia justificavam a importância do método psicossocial e sua potencialidade

${ }^{1137}$ Emma Espina Reyes; Sergio Arévalo; Arnulfo Rubilar; Nelson Severino. Sugerencias para la Alfabetización. Programa de Educación de los Trabajadores. Nuestra adaptación del Método Psicosocial. Santiago: Ministerio de Educación Pública, 1971. Ver: Reedición Conmemorativa: Revista NuestrAmérica, número especial, 2014. 
alfabetizadora em um contexto revolucionário: "escolhemos este método porque não reduz a aprendizagem da leitura e escrita a um simples ler e escrever, mas o vincula à discussão e à reflexão sobre problemas interessantes aos iletrados e importantes para o país", ${ }^{1138}$ introduziam em Sugerencias. Elogiavam o sentido humanista da pedagogia freiriana e seu combate contra a alienação, colocando a própria realidade popular como centro das relações pedagógicas. No preâmbulo do Guia, apresentavam o conceito de "consciência transitiva" de Educação como prática da liberdade, sem, contudo, citar a Pedagogia do oprimido. A partir do conceito freiriano de alienação, apresentavam uma interpretação marxista da relação entre trabalho e consciência humana: "se a atividade do homem perde o caráter de criação, se seu trabalho se faz para outrem e não lhe pertence, o homem já não se pertence a si mesmo, mas sim como instrumento a serviço de quem compra sua força de trabalho", definiam: "a alienação não é um fato psíquico, mas sim uma relação social". ${ }^{1139}$

Nesse sentido, tratava-se de uma adaptação mais diretiva e conteudista do método psicossocial, preocupada em oferecer estratégias de diálogo crítico contra o capitalismo, informar as medidas do governo popular e seu programa, e consequentemente menos preocupada, digamos assim, com a escuta do silêncio dos analfabetos durante um círculo. Em outras palavras, no Sugerencias encontrava-se mais informações e conteúdos para preencher o silêncio, do que considerações socioeducativas sobre a escuta. O educador escutava, mas também precisava falar - e na sua fala, eventualmente, traria mais dados da realidade do que perguntas sobre a percepção a respeito dela.

A adaptação também partia de um olhar crítico sobre Paulo Freire, como explicitavam seus autores: “o autor do método psicossocial dá à alienação um enfoque psicológico (...). Não compartilhamos dessa posição, mas igual a ele, acreditamos que o esclarecimento e a autoformação da consciência crítica contribuem para fortalecer a luta pelo fim da sociedade capitalista alienante". ${ }^{1140}$ Consideravam, portanto, que o enfoque de Freire se delimitava ao âmbito psicológico da desalienação da consciência, enquanto o que realmente poderia garantir tal desalienação seria somente a mudança substantiva das relações sociais de produção. ${ }^{1141}$ Mesmo assim, admiravam a "rebeldia contra os dogmas" 1142 e a valorização da cultura popular que fundamentavam o método.

Em 1970, o Chile possuía mais de 618 mil trabalhadores analfabetos absolutos, sendo metade destes camponeses. $\mathrm{O}$ analfabetismo absoluto alcançava $26,7 \%$ da população rural, uma queda de cerca de $8 \%$ ocorrida durante o governo Frei. $\mathrm{O}$ analfabetismo funcional seguia massificado e difícil de contabilizar (Austin, 2003: 137). Nas Sugerencias, foram escolhidas palavras geradoras em conjunto com trabalhadores urbanos, a partir de encontros prévios realizados em todo país, diferentemente do governo anterior, que escolheu as palavras geradoras dentro do ministério, como criticou Williamson (1989).

\footnotetext{
${ }^{1138}$ Espina Reyes et.al., Sugerencias..., op.cit., p. 94.

1139 Id., ibid, p. 96.

1140 Id., ibid.

${ }^{1141}$ Como mostram capítulos anteriores, Freire também estava preocupado com as relações sociais de produção e com o assentamento como território material da mudança cultural. Possivelmente, a crítica se direcionava mais propriamente à obra Educação como prática da liberdade.

${ }^{1142}$ Espina Reyes et.al., Sugerencias..., op. cit., p. 97.
} 
Eram elas: leche; casa; camisa; voto; teléfono; embarazo; enfermo; compañero; cesante; hogar; sindicato; salario; gobierno; educación; máquina; calle; desayuno; juventud; guitarra; tierra; cobre; teatro. Com exceção de duas palavras mais urbanas (telefono e calle), as outras vinte palavras pertenciam igualmente às realidades urbana e rural. $O$ fato de que o mesmo material fosse utilizado para alfabetização de trabalhadores urbanos e rurais também evocava o empenho da UP em articular a luta obreiro-camponesa a partir de um mesmo processo de politização e mobilização.

Antes da alfabetização, as Sugerencias propunham uma "etapa motivadora", inspirada nos círculos sobre o conceito antropológico de cultura da pré-alfabetização, mas tocavam em temas mais diversificados. A etapa motivadora era formada por quatro unidades: a primeira tratava da "Condição Humana - Diferenciação entre Natureza e Cultura" (cujo fundamento estava em Freire); a segunda tratava da "Redução do Homem à Qualidade de Coisa", fundamentada em Marx; a terceira abordava a "Libertação Social", e buscava refletir sobre as lutas populares e os desafios das revoluções na reorganização da sociedade; e a quarta, "Comitê de Cultura", apresentava uma proposta de autoeducação aos trabalhadores alfabetizandos, incentivados a formar núcleos de estudo e alfabetização com autonomia. A palavra freiriana "círculo" foi substituída por "comitê", escolha que evocava um vocabulário mais próximo do mundo sindical.

Nas próximas páginas, é possível conhecer as 11 imagens que compunham as 4 unidades da etapa motivadora, junto com excertos dos enunciados do Guia, com objetivos e procedimentos, e observações analíticas sobre tais enunciados. Nota-se em todos os enunciados da etapa motivadora a ausência da pedagogia da pergunta, muito presente nos materiais do INDAP quando Freire esteve por lá. A ausência da pergunta era um indício político-pedagógico e metodológico de uma adaptação mais diretiva do método.

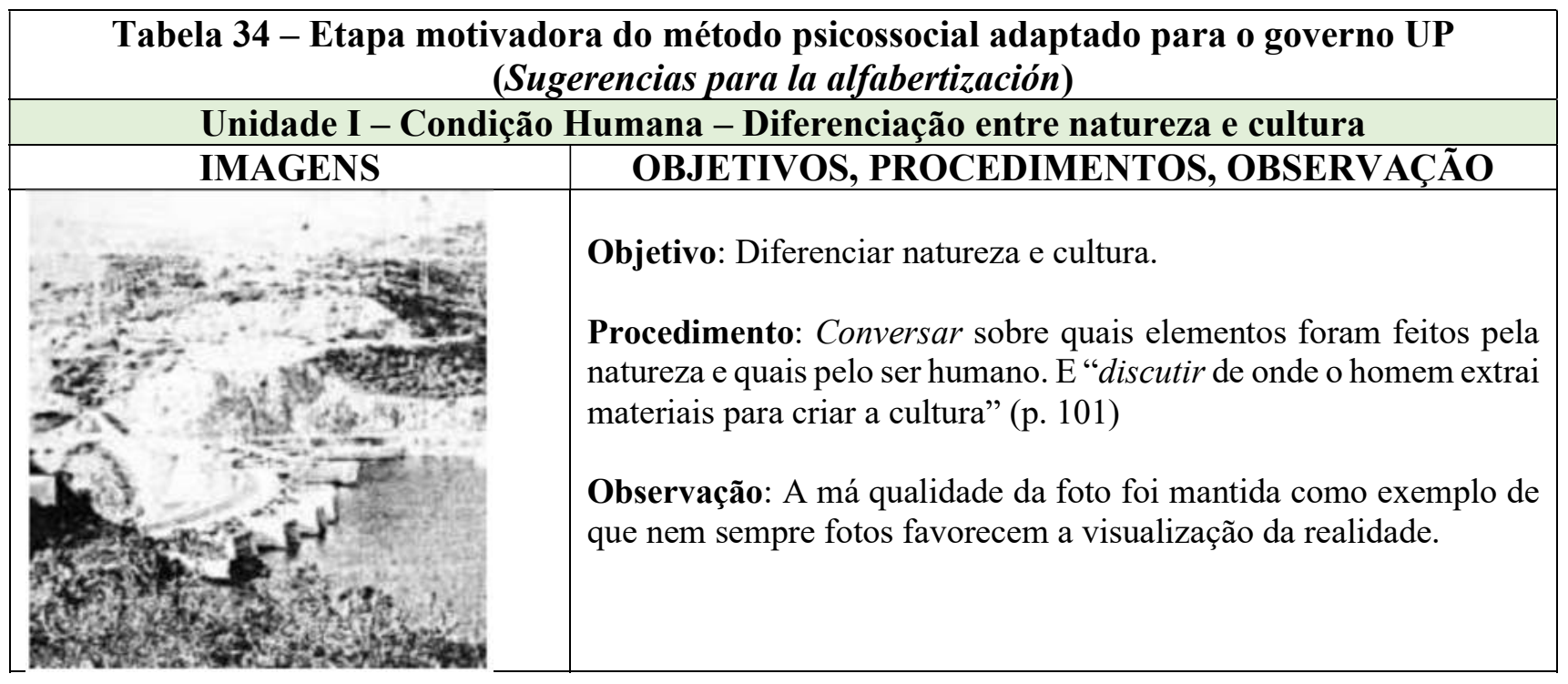




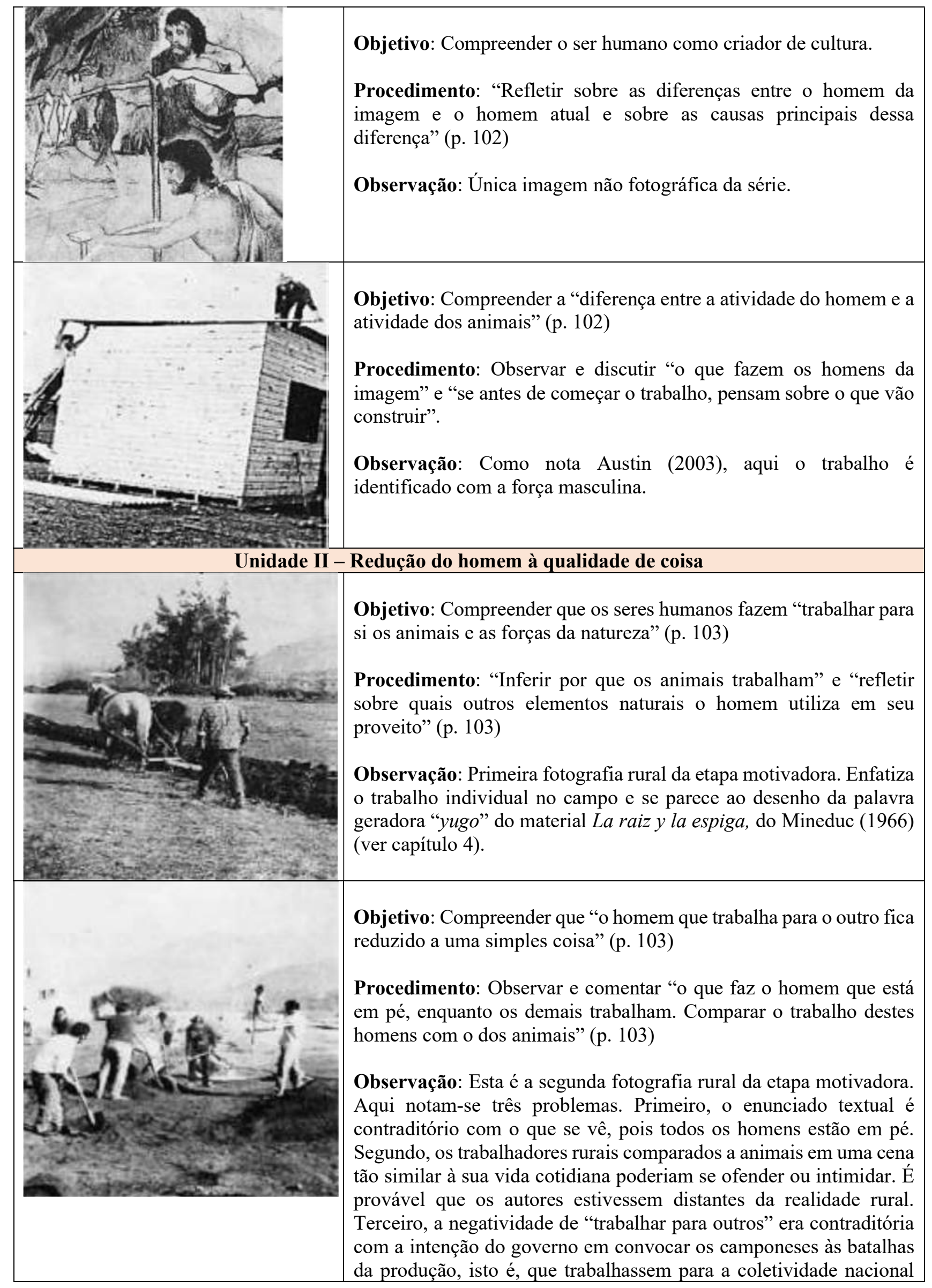




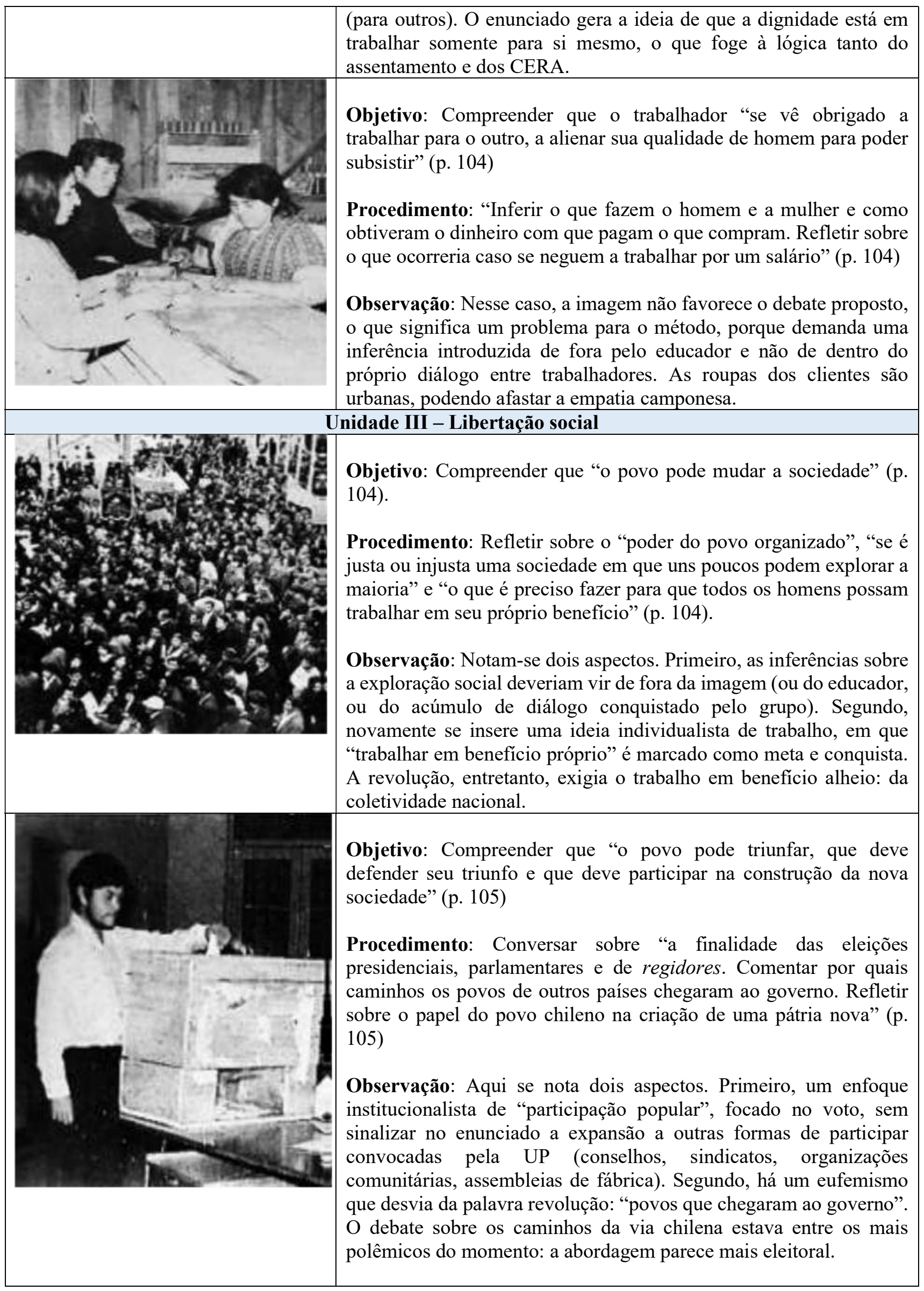




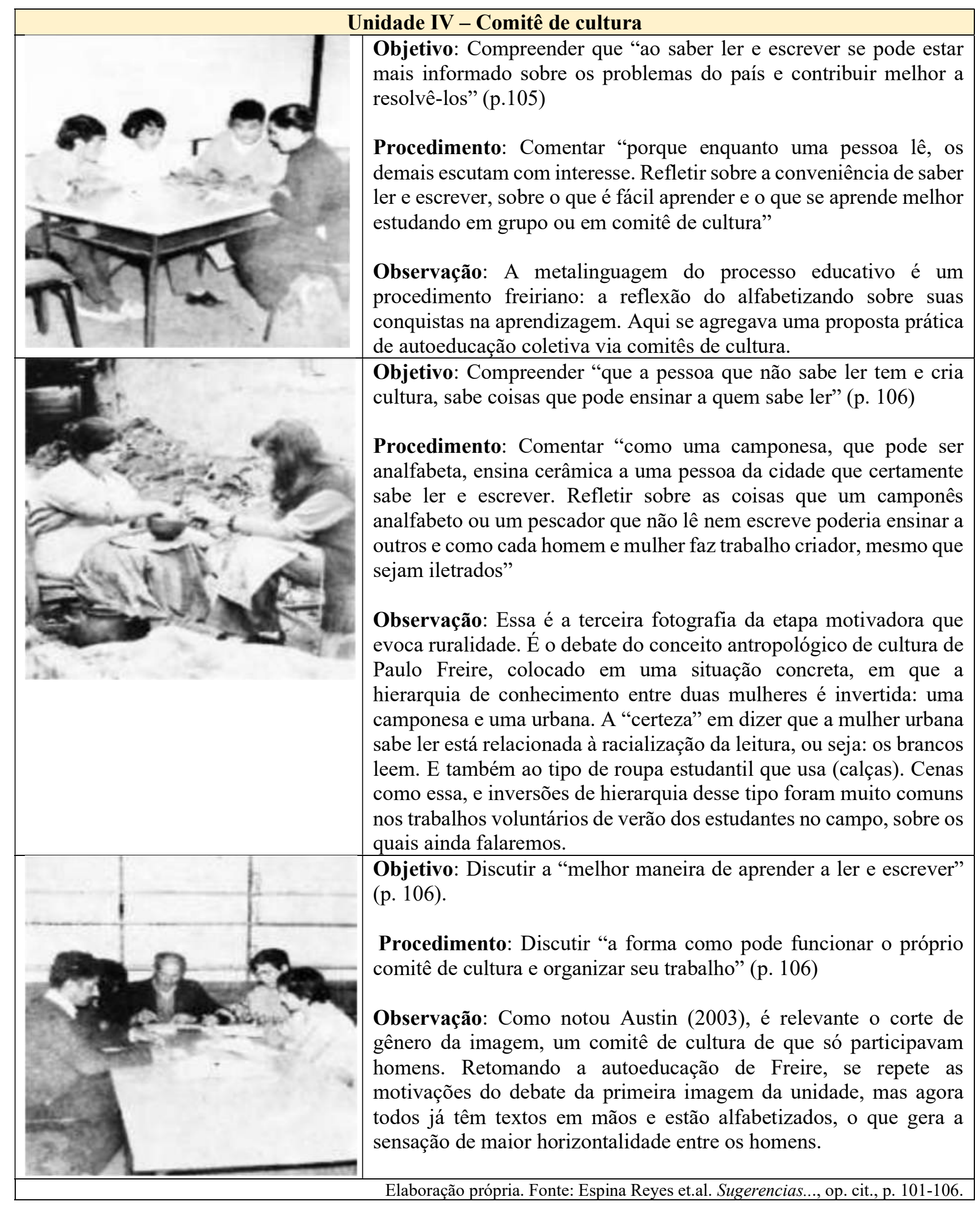

Nas orientações metodológicas e de conduta do educador, o guia sinalizava que este deveria "ter calma e esperar que cada participante diga tudo o que estime necessário"1143 sobre cada imagem.

${ }^{1143}$ Espina Reyes et.al., Sugerencias..., op. cit., p. 120. 
Ou seja, enquanto uma das principais preocupações de Freire era com o silêncio, a necessidade de escutá-lo e a gradual ruptura da cultura do silêncio imposta às classes oprimidas, o guia do governo UP supunha que haveria mais verborragia que silêncio dos trabalhadores, nas atividades de análise das imagens. Ademais, como nos cursos do FEES que utilizavam a imprensa como material de politização, sugeria-se uma conexão entre as imagens, as palavras geradoras e o debate político instalado no país: "se o coordenador considerar oportuno, em algum momento da análise dos problemas pode contribuir com informações ou dados, por exemplo, do programa de governo, dos discursos de seus líderes e dos adversários, da imprensa, cuidando que o grupo entenda a linguagem", ${ }^{1144}$ recomendavam os autores.

Nas Sugerencias, as palavras geradoras vinham acompanhadas das fotos para análise, junto de uma lista de objetivos de reflexão, objetivos de leitura e escritura; sugestão de temas para reflexão e conteúdos auxiliares, contendo uma série de informações estatísticas e dados sobre a realidade chilena, que aportavam ao educador elementos para informar o grupo sobre questões políticas candentes. Os conteúdos que acompanhavam as palavras tinham forte inspiração humanista na defesa da justiça social, o que se articulava à crítica marxista da realidade, ressaltando constantemente a questão de classe, da luta popular, a importância das alianças entre diferentes frações de trabalhadores e, invariavelmente, os caminhos de dignidade abertos pelo novo governo. Além disso, cada palavra estava acompanhada de sugestões técnicas para codificação, indicando as possibilidades de trabalho silábico e fonético. Os procedimentos silábicos eram idênticos ao método psicossocial de Freire, com as fichas que promoviam a progressão das sílabas até a "ficha da descoberta". Com ela, o coordenador deveria "esperar com tranquilidade que algum participante possa ler a palavra" e "evitar mostras as sílabas que podem ser unidas para formar palavras". ${ }^{1145}$

A primeira palavra geradora do Sugerencias expressava forte carga simbólica: leche. O objetivo de reflexão tratava da importância do leite para a saúde nutricional das crianças, dos problemas de desnutrição e mortalidade infantil no Chile e na América Latina, o vínculo da má alimentação com dificuldades de aprendizagem e evasão escolar, junto com o "conhecimento da política do atual governo para solucionar o problema da desnutrição infantil" e o papel da "participação consciente e ativa da comunidade" 1146 na solução do problema. Entre os conteúdos auxiliares, o educador era estimulado a lembrar que " $50 \%$ das crianças menores de 15 anos estão desnutridas" no Chile e explicar que "o latifúndio é o grande culpado dos problemas alimentícios de todos os chilenos e responsável da situação de atraso e miséria características do campo". ${ }^{1147}$ Nota-se que uma pedagogia defensora da reforma agrária se colocava no centro de um material também usado para alfabetizar classes trabalhadoras urbanas, estimulando a empatia destas com as lutas do campesinato. Ao conhecer que uma das causas da desnutrição infantil era o latifúndio, o trabalhador urbano passava a entender a causa camponesa

\footnotetext{
${ }^{1144}$ Id., ibid.

1145 Id., ibid., p. 138.

${ }^{1146}$ Id., ibid, p. 112-116.

1147 Id., ibid.
} 


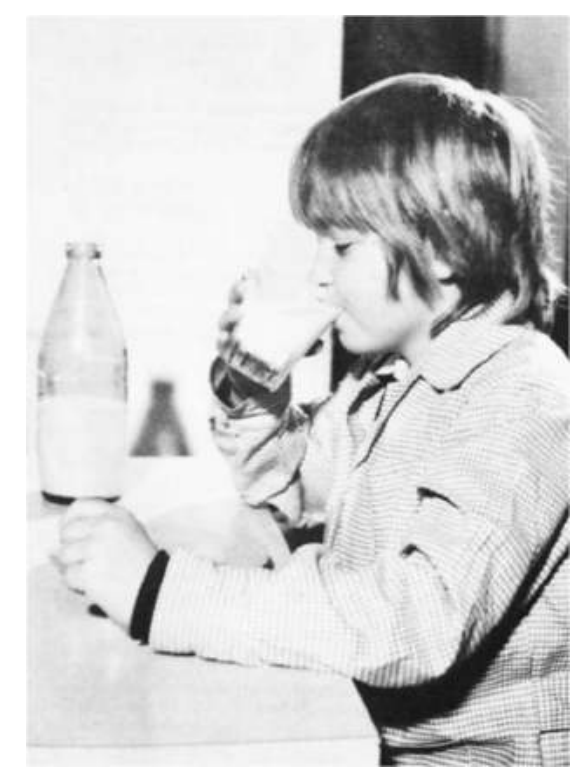

Foto da palavra geradora n. 1 .

Fonte: Sugerencias.... (p. 112).

como uma forma de proteger a saúde de todas as crianças, ou seja, como uma causa popular universal. Essa universalização do sujeito camponês em luta pela terra era, sem dúvida, um componente diferencial e revolucionário do Sugerencias.

Além disso, o educador recebia conteúdos auxiliares sobre as políticas do governo UP: a campanha do "meio litro de leite para todas as crianças do Chile" foi uma das bandeiras mais importantes do governo Allende junto à população mais pobre, com grande eficácia em ampliar sua base de apoio. Não era tudo: "o plano nacional do leite beneficiará os menores de 15 anos, as grávidas, as mães que amamentam e as mães de crianças menores de um ano", ${ }^{1148}$ cotas que deveriam ser distribuídas pelo SSS, SNS, Forças Armadas, Carabineros e outras instituições. O material alertava que o plano seria abastecido pelos 15 milhões de litros de leite produzidos no Chile junto com mais 48 milhões de quilos de leite em pó importado, o que implicava um gasto de 300 milhões de escudos ao ano. Mas "com a reforma agrária, que está introduzindo a tecnificação do agro, se procurará produzir o total de leite que o país necessita", ${ }^{1149}$ anunciava o guia.

O leite era um tema-dobradiça, como dizia Paulo Freire, pois conseguia articular diretamente o cotidiano popular com uma consciência totalizante e crítica da sociedade, buscando demonstrar aos trabalhadores alfabetizandos que o direito ao leite e a saúde das crianças estavam diretamente relacionadas com a reforma agrária. O leite passava a simbolizar a busca por uma sociedade mais digna, participativa, igualitária e socialista: "a comunidade deve desenvolver um sentido de sanção coletiva perante aqueles que compram leite para fins comerciais", ${ }^{1150}$ propunham. Entre outros temas, propunham debater o plano nacional do leite como "primeira medida do governo da UP"; a "atitude dos adultos frente à primeira medida"; as condições de produção leiteira no país; a "participação da comunidade no cumprimento da primeira medida" e o "status da criança no governo UP". ${ }^{1151}$

Victor Yañez foi um dos jovens alfabetizadores com guia Sugerencias para la alfabetización e lembrou-se bastante bem da relação entre as palavras geradoras e o programa da UP. Ele era filho de minifundista e ainda adolescente se organizou na Frente Estudantil do MIR, quando estava no secundário. Participou de quatro trabalhos de verão, entre 1969 e 1973, alfabetizando camponeses. "A alfabetização era superbonita, porque os camponeses gostavam de escutar o desenvolvimento da explicação das lâminas”, contou Yáñez: “Chegávamos na casa dos camponeses e dávamos aula ao redor

\footnotetext{
1148 Id., ibid.

1149 Id., ibid.

${ }^{1150}$ Id., ibid.

${ }^{1151}$ Id., ibid.
} 
do fogo", ${ }_{1152}$ recordou. Quase sempre, o momento da alfabetização era uma atividade de empoderamento masculino, que excluía as mulheres: "participavam as esposas somente daqueles que não eram muito machistas. Se não, mandavam a senhora para dentro. Mas elas olhavam pelos buraquinhos e escutavam a aula de qualquer forma", ${ }^{1153}$ explicou Victor. Depois os próprios camponeses se afeiçoavam do alfabetizador e os convidavam para voltar, "para aprender mais". As imagens tinham $40 \mathrm{~cm} \times 30 \mathrm{~cm}$ : "falávamos da política do Allende, que era o meio litro de leite por criança chilena. Explicávamos todo o processo. No fundo, nas lâminas estavam as 40 medidas de Allende. Essa era a conscientização", recordou. Victor também se lembrava da palavra "Cobre", com a qual se explicava aos alfabetizandos a política da UP para estatização do cobre: "el sueldo de Chile", dizia Allende.

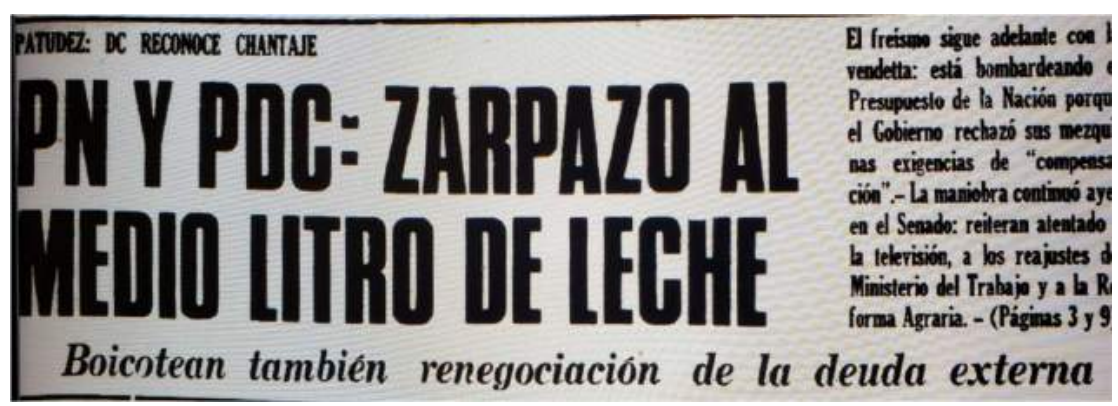

El Siglo denuncia oposição através do simbolismo político do leite.
A politização do leite era forte também na imprensa. Frequentemente, os partidos de esquerda acusavam os proprietários e patrões de desperdício de leite ou de crueldades relacionadas ao leite. "Latifundiários preferem jogar leite fora do que dar aos camponeses", ${ }^{1154}$ dizia uma matéria do El Siglo de setembro de 1970. Em novembro de 1971, a acusação se inverteu: David Baytelman precisou desmentir que os assentamentos de Nuble estavam jogando leite fora: "aqui não se derrama leite", disse na visita a assentamentos acusados pela oposição. ${ }^{155}$ Em janeiro de 1971, a imprensa comunista voltou a acusar os patrões: "Latifundiários preferem dar leite aos porcos". ${ }^{1156}$ Em novembro de 1971, com o estrangulamento orçamentário do Legislativo contra o governo ainda mais duro, os comunistas denunciaram uma "pancada no meio litro de leite", ${ }^{1157}$ dada por PN e DC (manchete na imagem). O leite era um símbolo que veiculava a luta política na chave generosidade versus crueldade, ainda mais porque se tratava do alimento das crianças chilenas. Não era por acaso que se tratava da palavra geradora $n^{0} 1$, bastante prolífica ao debate conscientizador.

O professor Herrera também sem recordou da memorável palavra geradora leche: "era a primeira palavra que ensinávamos aos camponeses, diretamente associada à campanha do meio litro de leite",

\footnotetext{
1152 Entrevista com Victor Yañez, San Carlos, 19/05/2017.

${ }^{1153}$ Id., ibid.

${ }^{1154}$ Latifundistas prefieren botar la leche y no dársela a campesinos. El Siglo, Set./1970

${ }^{1155}$ No se está botando la leche en asentamientos. La Nación, Nov./1970

${ }^{1156}$ Latifundista prefiere darles la leche a los chanchos. El Siglo, 29/01/1971.

${ }^{1157}$ PN y PDC: zarpazo al medio litro de leche. El Siglo, 29/12/1971.
} 
explicou Herrera: "Começávamos pedindo que os companheiros contassem sobre a produção de leite e terminávamos falando da política do governo popular, que era fundamental para as crianças do Chile". ${ }^{158}$ Também se lembrou da palavra "cobre", que os fazia debater a nacionalização do cobre, a palavra "sindicato", que trazia à tona o tema da organização popular. "O método psicossocial (...) permite aprender a família silábica (...), mas vai acompanhado de uma etapa de reflexão para conscientizar". Quando perguntado se o método, na sua opinião, funcionava, Herrera exclamou: "Sim, funcionava! Teve muito êxito. Mas dependia também do monitor, que precisava ser capaz de transformar a aula em uma aula conscientizadora". ${ }^{1159}$

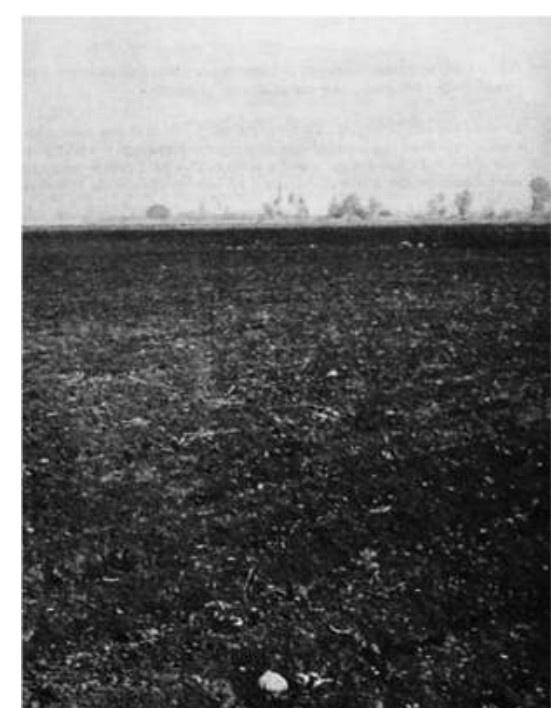

Foto da palavra geradora $\mathrm{N}^{\circ} 20$.

Fonte: Sugerencias...., op. cit., p. 202.

Outra palavra geradora importante das Sugerencias era tierra. Curiosamente, a imagem não evocava produção, nem trabalho humano: um pedaço de terra descampada e erma. Aliás, a ausência de sujeitos era uma característica da maioria das imagens do Sugerencias, que parecia contradizer o texto, que invariavelmente evocava o protagonismo popular para todas as 22 palavras. Além de aprender o fonema " $t$ " e o duplo "rr", entre os objetivos principais da palavra Tierra estava a importância da reforma agrária, o que recolocava o tema camponês no centro do desenvolvimento nacional. A redistribuição da terra e melhor aproveitamento produtivo era uma questão de justiça social e benefício da maioria. "A terra em nosso país foi o grande bastião do setor mais ganancioso e explorador da oligarquia", diziam os conteúdos auxiliares do Guia: "A ignorância e a miséria a que foram submetidos os camponeses durante dezenas de anos pelos senhores da terra foram fazendo do trabalhador do campo e sua família um grupo que vivia em condições de quase escravidão". ${ }^{1160}$ Além disso, em 5 páginas de textos, o material descrevia a política agrária do governo da UP, e com isso oferecia aos educadores um repertório detalhado sobre as mudanças em curso. Assegurava-se que a reforma agrária da UP estava integrada ao projeto de transição ao socialismo, mas isso não significava prejudicar os pequenos e médios proprietários. Ao contrário, buscava-se atrair essas frações de classe alertando que já eram beneficiárias diretas da reforma, pois receberiam mais créditos e assistência técnica, melhores condições produtivas no setor privado. Eles tinham o "direito de não ser expropriados", ${ }^{1161}$ embora não estivesse dito o que se entendia por média propriedade em termos objetivos. Os autores indicavam que proprietários improdutivos poderiam perder o direito a reserva e que tampouco a localização daquelas

\footnotetext{
${ }^{1158}$ Id., ibid.

1159 Id., ibid.

${ }^{1160}$ Espina Reyes et.al., Sugerencias..., op. cit., p. 204.

${ }^{1161}$ Id., ibid., p. 206.
} 
seria escolha preferencial dos patrões, como havia anunciado Baytelman nos primeiros meses de governo: "poderá ser dada em outras terras, caso necessário, para reestruturar as explorações camponesas". ${ }^{1162}$

Fazendo coro com as lideranças do governo, outra preocupação do material era assegurar que os camponeses teriam incondicional direito ao huerto familiar dentro da propriedade cooperativa: "Cada camponês terá direito à propriedade familiar, consistindo em sua casa e o huerto. A produção se organizará de preferência sob sistema cooperativo". ${ }^{1163}$ Não havia nenhuma palavra sobre os CERA no guia, provavelmente porque o material foi confeccionado enquanto a Comissão Nacional Agrária da UP ainda estava debatendo e formulando a nova propriedade transitória que substituiria os assentamentos, anunciada apenas em setembro de 1971. O que estava explicitado no Sugerencias era que a reforma agrária seria feita por zonas, não por propriedades, e agruparia expropriações em unidades maiores, além de criar uma nova racionalidade territorial. Também se informava que o governo incluía os afuerinos como beneficiários da reforma agrária (nada se dizia sobre as mulheres camponesas), o que se consolidou com o surgimento dos CERAs. O Guia também anunciava que um novo projeto de lei para avançar a reforma agrária estava sendo confeccionada pelo Conselho Nacional Campesino, que o enviaria ao Congresso em razão da necessidade de se modificar aspectos da lei anterior (sem, contudo, especificar quais). A comunicação educacional sobre essas questões sensíveis das formas de propriedade, da reserva e da nova lei de reforma agrária, porém, pareciam pecar por dois problemas: por um lado, continham informações em excesso, que muitos educadores poderiam não manejar à vontade; e por outro, eram informações pouco definitivas, o que gerava eventuais dificuldades para dar respostas diretas aos questionamentos camponeses.

Já o tema do sistema de conselhos camponeses estava mais bem definido, também porque era o assunto sobre o qual a UP foi mais rápida e contundente. Ensinava-se o que era o Conselho Nacional Camponês e seu papel de representar o campesinato perante o governo e dialogar constantemente com o Minagri. Mas a ideia de conselhos comunais, propostas pelas organizações camponesas durante a negociação com o ministro, não estavam ali, e, em seu lugar, havia a proposta de conselhos zonais, que fora substituída no decreto. Pode parecer um detalhe, mas é relevante o fato de que o Sugerencias falasse sobre os conselhos zonais camponeses, que na prática nunca chegaram a existir, já que o próprio governo os substituiu por conselhos comunais no decorrer do diálogo com as organizações. Isso indicava que os autores do material tinham uma proximidade bastante importante com o centro das formulações políticas da UP, mas não necessariamente acompanharam o processo de negociações com os movimentos ou as minúcias das polêmicas partidárias a respeito da política agrária do governo. Descreviam, além disso, que conselhos zonais eram compostos por "camponeses eleitos pelas bases", uma informação aparentemente imprecisa, já que este era justamente um foco de polêmicas entre os partidos da UP. Ao longo de 1971, o MIR e a ala mais radical do PS, liderada por Carlos Altamirano,

1162 Id., ibid.

1163 Id., ibid. 
passaram a defender que os conselhos comunais deveriam ser compostos de todos os camponeses que deles participassem, em forma de assembleia popular livre. Já o PC e a ala allendista do PS defendiam a forma do decreto, isto é, que os conselhos estivessem compostos de representantes das organizações (sindicais, cooperativas, assentamentos, comitês). Essa polêmica se prolongou ao longo de alguns meses, até que o ministro da agricultura propôs uma mediação entre os conselhos pela base e os conselhos do decreto: os conselhos ampliados (ou mistos), cuja composição era parcialmente das organizações, parcialmente livre (Roxborough, 1974), fórmula que passou a ser defendida pelo MAPU. ${ }^{1164} \mathrm{O}$ tema dos conselhos camponeses estava atravessado pelas polêmicas táticas da revolução chilena. O material de alfabetização do governo, embora fosse um importante suporte para conscientização popular sobre o processo revolucionário, não alcançava esse nível de especificidade.

De maneira metalinguística, o Sugerencias ainda aproveitava a palavra tierra para falar sobre o papel da alfabetização camponesa na reforma agrária e a política educacional rural da Unidade Popular. Anunciava que haveria programas educativos de rádio aos camponeses, cursos de tecnologia agropecuária ajustados às necessidades do setor reformado e aos planos de produção, além de "teatro, arte e outras atividades culturais que permitem o desenvolvimento da personalidade nas comunidades camponesas". ${ }^{1165}$ Victor Yáñez, estudante secundário e alfabetizador, lembrava que "se falava do trigo, que era a base do pão, que na mesa de nenhum trabalhador chileno deveria faltar o pão. Por isso, era necessário produzir e já se aumentava os hectares em produção comparado a outros governos". ${ }^{1166}$ Ele recordava também de ensinar sobre a importância da estatização de uma grande empresa fornecedora de arame e outros insumos, para baixar o preço das sementes; bem como da comercialização, que se fosse estatal poderia remunerar camponeses com preços mais adequados.

Além de leche e terra, selecionei outras 9 palavras geradoras do Sugerencias para uma análise panorâmica da estratégia de alfabetização da UP, igualmente utilizada no campo e na cidade. Na tabela 35 a seguir, as palavras selecionadas estão acompanhadas da foto do guia, que tinha um papel central no estímulo ao debate dos alfabetizandos, junto com temas e ênfases sugeridas para o processo educacional e as medidas do governo da UP atreladas explicitamente à palavra geradora e indicadas ao educador.

\footnotetext{
${ }^{1164}$ Em janeiro de 1972, um censo empreendido por pesquisadores do INDAP, FEES e ICIRA, do Atacama a Llanquihue, constatou que 177 das 235 comunas agrícolas do país fundaram conselhos comunais, sendo $63 \%$ na forma do decreto, $25 \%$ da forma ampliada e $12 \%$ pela base (Gómez \& Klein, 1972).

${ }^{1165}$ Espina Reyes et.al., Sugerencias..., op. cit., p. 207.

${ }^{1166}$ Entrevista com Victor Yañez, San Carlos, 19/05/2017.
} 


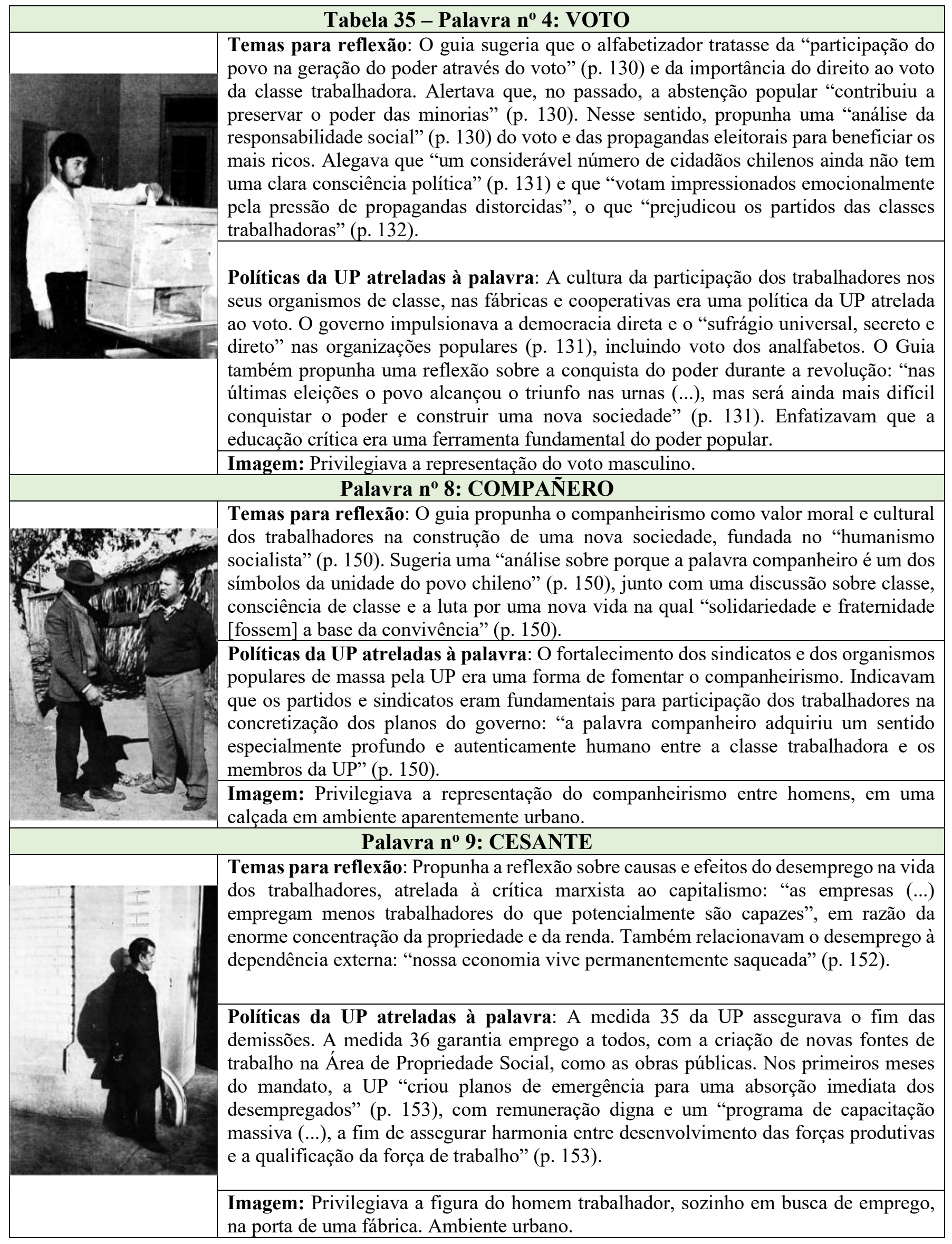




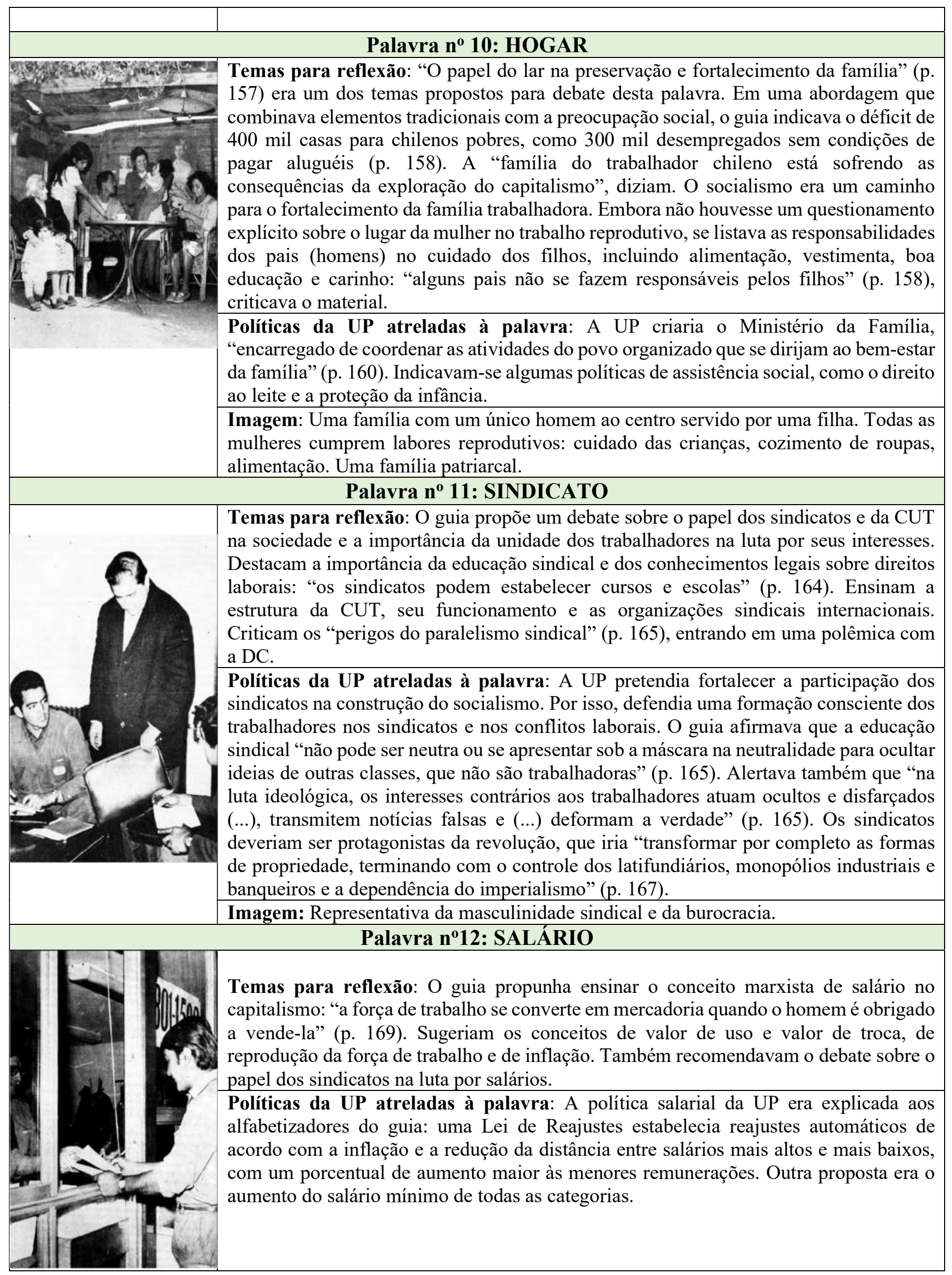




\begin{tabular}{|c|c|}
\hline & $\begin{array}{l}\text { Imagem: Novamente, a opção pelo gênero masculino para representar a classe } \\
\text { trabalhadora, em um ambiente urbano, no guichê de recebimento de salário. }\end{array}$ \\
\hline \multicolumn{2}{|r|}{ Palavra n¹3: GOBIERNO } \\
\hline \multirow{3}{*}{$\frac{1}{1}$} & $\begin{array}{l}\text { Temas para reflexão: "O Estado, e como consequência o governo, apareceu quando a } \\
\text { sociedade se dividiu em classes", narrava o Guia: "é o instrumento da classe dominante } \\
\text { para preservar sua dominação" (p. 173). Sugeriam discutir o Estado capitalista como } \\
\text { "ditadura de classe". Por outro lado, o socialismo era "uma forma aperfeiçoada de } \\
\text { democracia, em que a imensa maioria do povo participa efetivamente do governo" (p. } \\
\text { 173). Propunha-se o debate sobre os partidos políticos e os problemas do sistema politico } \\
\text { chileno. }\end{array}$ \\
\hline & $\begin{array}{l}\text { Políticas da UP atreladas à palavra: "No Chile há atualmente um governo popular. A } \\
\text { classe endinheirada perdeu as eleições e agora quem governa é o povo" (p. 174), definia } \\
\text { o guia. A UP implementava uma democratização de todos os espaços de poder na } \\
\text { sociedade e a "incorporação do povo no poder estatal" (p. 174). Mas o governo só seria } \\
\text { bem com apoio popular ativo. A UP teria uma dupla tarefa: aprofundar os direitos } \\
\text { democráticos dos trabalhadores e alterar as instituições capitalistas, o que dependia de } \\
\text { reformas constitucionais. Aos trabalhadores caberia também garantir o aumento da } \\
\text { produtividade da Área de Propriedade Social. }\end{array}$ \\
\hline & $\begin{array}{l}\text { Imagem: Apesar da orientação ao poder popular e ao sujeito trabalhador, a foto } \\
\text { representava o governo pelo palácio, um símbolo tradicionalista. }\end{array}$ \\
\hline \multicolumn{2}{|r|}{ Palavra n¹4: EDUCACIÓN } \\
\hline \multirow{4}{*}{ (3) } & $\begin{array}{l}\text { Temas para reflexão: Sugerem o debate sobre os "valores predominantes na sociedade } \\
\text { capitalista" (p. 177), na qual o lucro se sobrepõe à coletividade. O guia ensina que há } \\
\text { uma correlação entre forças produtivas e educação: o capitalismo depende da expansão } \\
\text { das escolas para formar trabalhadores qualificados para manipular máquinas. Essa } \\
\text { educação "eleva o nível cultural", porém segue conservadora (p. 178). Por outro lado, os } \\
\text { valores socialistas implicam uma "nova educação" para "a consciência de que o trabalho } \\
\text { é fonte de todas as conquistas materiais e culturais das sociedades" (p. 179). O socialismo } \\
\text { requer "um povo consciente e solidário, educado para exercer e defender seu poder } \\
\text { político" (p. 179). }\end{array}$ \\
\hline & $\begin{array}{l}\text { Políticas da UP atreladas à palavra: Era uma situação metalinguística, tematizar a } \\
\text { educação durante a alfabetização. Para construir o socialismo, diz o guia, a UP formaria } \\
\text { "trabalhadores capacitados, técnicos e profissionais para superar os atuais problemas (...) }\end{array}$ \\
\hline & $\begin{array}{l}\text { de um país subdesenvolvido e dependente" (p. 179). Sem mencionar a Escola Nacional } \\
\text { Unificada (ENU), enfatizava os valores da nova educação, mais que o programa } \\
\text { concreto: "a nova cultura surgirá da luta da fraternidade contra o individualismo; da } \\
\text { valorização do trabalho humano; (...) contra a colonização cultural" (p. 179). Tampouco } \\
\text { há qualquer reflexão freiriana sobre o espelhamento dos valores do opressor nos } \\
\text { pensamentos e sentimentos do oprimido, ou sobre os desafios da transformação da } \\
\text { consciência para uma revolução. }\end{array}$ \\
\hline & $\begin{array}{l}\text { Imagem: Uma das cinco fotos com representação feminina, junto com hogar, casa, } \\
\text { embarazo e teléfono. A educação é trabalho atribuído às mulheres por seu aspecto de } \\
\text { cuidado. }\end{array}$ \\
\hline \multicolumn{2}{|r|}{ Palavra nº 15: MÁQUINA } \\
\hline & $\begin{array}{l}\text { Temas para reflexão: Sugere o debate sobre o "duplo papel da máquina na sociedade } \\
\text { moderna", como libertadora e exploradora, bem como a necessidade de "trabalhadores e } \\
\text { técnicos qualificados para acelerar o desenvolvimento nacional" (p. 181). Apresenta uma } \\
\text { visão essencialista sobre o trabalhador chileno, indicando traços positivos e negativos } \\
\text { gerais, enfatizando "a falta de educação" (p. 182). O tema principal é educação e } \\
\text { desenvolvimento, com uma compreensão otimista do progresso tecnológico, que } \\
\text { "exigirá cada vez mais conhecimentos" e, portanto, "o trabalhador deverá adquiria maior } \\
\text { cultura básica e sistematizada", e se adaptar às "exigências da produção" (p. 183). }\end{array}$ \\
\hline
\end{tabular}




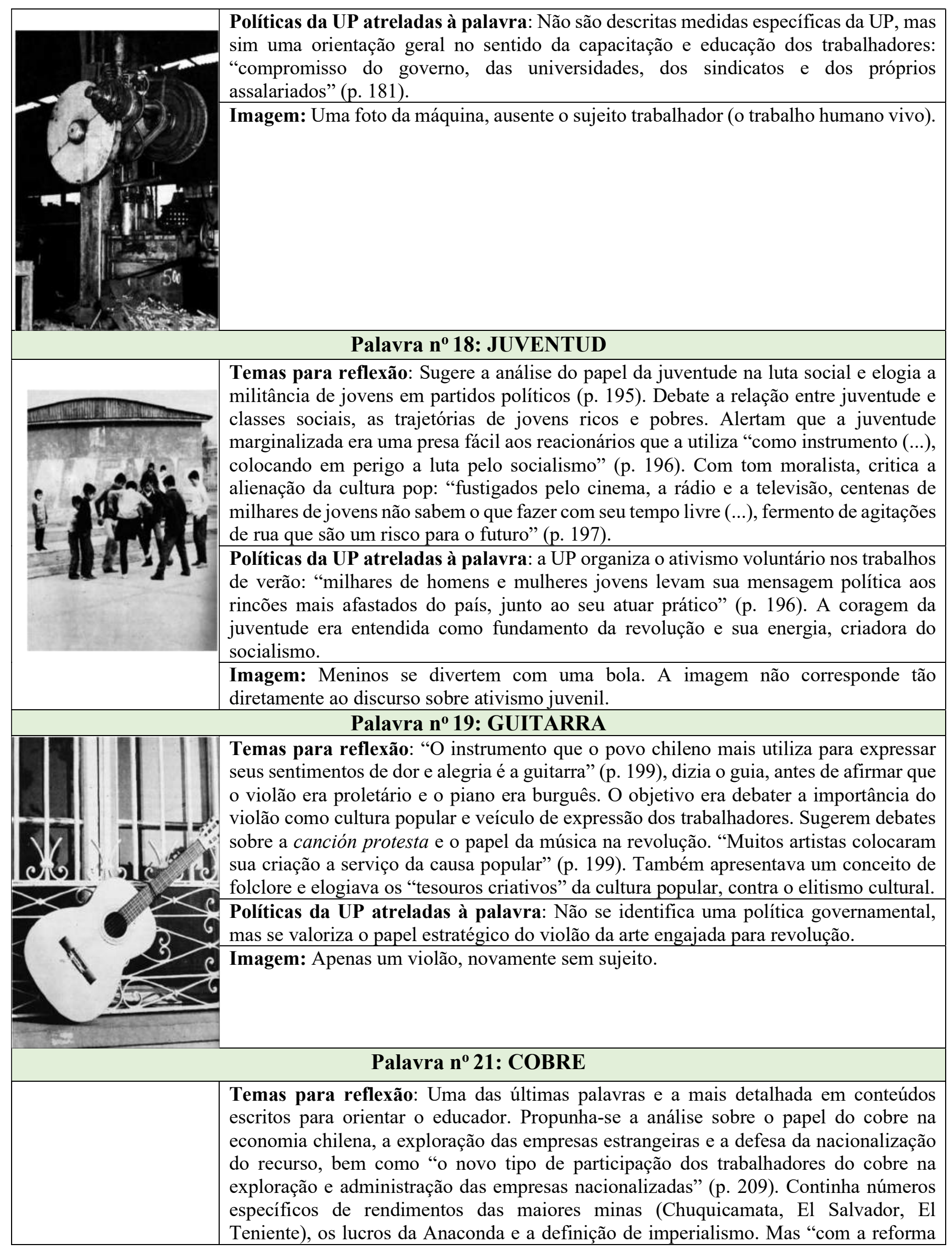




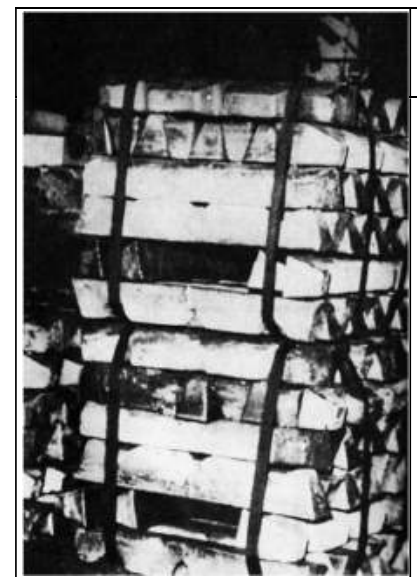

constitucional, fica definitivamente estabelecido o domínio absoluto do Estado sobre as jazidas" (p. 212).

Políticas da UP atreladas à palavra: "A política do governo da UP para o cobre obedece a uma concepção ideológica que busca o caminho ao socialismo" (p. 210), registrava o guia. O cobre era o lastro da transição. Aproveitando a palavra "cobre", o guia define conceitualmente o que é o socialismo: "os movimentos e doutrinas que perseguem o controle consciente de todas as forças econômicas, industriais e políticas em benefício da sociedade inteira; o que implica a (...) abolição das classes" (p. 211), de modo que "trabalhadores manuais e intelectuais adquiram a propriedade coletiva e cooperativa de grandes recursos naturais e dos principais meios de produção e distribuição" (p. 211). Nessa palavra também indicam as tarefas dos trabalhadores: "produzir o máximo aproveitamento dos recursos humanos, materiais e tecnológicos, (...) coordenar a atividade de uma empresa em um plano geral de tipo nacional" (p. 212) e a "participação dos trabalhadores no nível diretivo" com a representação de operários eleitos pelas bases em equipes de direção empresarial. Indicavam que a CUT defendia metade de trabalhadores eleitos pelas bases nas direções de todas as empresas do país. Imagem: O objeto cobre, novamente sem sujeitos.

Elaboração própria. Fonte: Espina Reyes et.al., Sugerencias..., op. cit.

Tanto na palavra Calle, como em Juventud, os autores destacavam a importância do trabalho voluntário para revolução. Na primeira, o educador era incentivado a refletir com os alfabetizandos sobre a necessidade, "para a construção do socialismo (...), da efetiva e concreta participação de todos os comprometidos com o processo de mudança", ${ }^{1167}$ e deveria considerar, ademais, que "é preciso estimular e fomentar é o trabalho voluntário". $1168 \mathrm{O}$ material aconselhava que os educadores explicassem como organizar voluntários para melhorias de infraestrutura comunitária, para as quais "cada homem, mulher ou jovem pode aportar sua mão de obra". ${ }^{1169}$ Na palavra juventud, as Sugerencias destacavam que "uma das atividades mais significativas da juventude tem sido a ação social. (...) Milhares de homens e mulheres jovens levam sua mensagem política aos rincões mais afastados do país, junto ao seu atuar prático", elogiava o material. E completava: "Em grande medida, contribuíram para romper o isolamento ideológico e a não participação da população marginal rural do país". ${ }^{1170}$ Nota-se um eco da teoria da marginalidade, o que parecia contradizer sua enfática rejeição por Freire. “Os homens alienados não podem vencer sua dependência ao 'incorporar-se' à mesma estrutura responsável de sua dependência”, criticava um artigo de Freire de 1971: “o analfabeto não é uma pessoa que vive à margem da sociedade, (...) mas sim um representante do estrato dominado da sociedade, em oposição consciente ou inconsciente com aqueles que, na mesma estrutura, o tratam como uma coisa", ${ }^{1171}$ conceituava.

Seria cansativo percorrer a totalidade das palavras geradoras do material de alfabetização da UP. Com essa seleção analítica, é visível uma mescla entre o método psicossocial e o método conteudista

\footnotetext{
${ }^{1167}$ Espina Reyes et.al., Sugerencias..., op. cit., p. 186.

${ }^{1168}$ Id., ibid.

${ }^{1169}$ Id., ibid., p. 187

${ }^{1170}$ Id., ibid., p. 196.

1171 Paulo Freire, El proceso de alfabetización adulta como acción cultural para la libertad. Revista de Educación, n. 34, Mar./1971.
} 
de tipo tradicional, que oferecia a teoria marxista como estratégia de compreensão do mundo. Nota-se também que a pedagogia da pergunta foi substituída por um material que prezava mais o conteúdo informativo e a afirmação, do que metodologias de escuta ativa. As ferramentas entregues ao educador pelas Sugerencias tratavam bem pouco do método e da condução do diálogo alfabetizador, priorizando os conteúdos e repertórios necessários à formação de uma consciência crítica anticapitalista e, consequentemente, se supunha a ampliação da hegemonia revolucionária. A questão da hierarquia entre educadores e educandos tampouco era abordada pelo material dirigido aos educadores, nem a possiblidade de que os conteúdos oferecidos pelo alfabetizador intimidassem os alfabetizandos e reforçassem a cultura do silêncio. Bastante contrastante com os materiais das equipes freirianas do INDAP ou com a metodologia da investigação temática em El Recurso, no Sugerencias o educador não era orientado a perguntar aos camponeses, por exemplo, o que pensavam da reforma agrária, do assentamento, da cooperativa, do trabalho coletivo ou individual. Tampouco era orientado a escutar com paciência e atenção a opinião dos trabalhadores sobre tantos assuntos mobilizados no material. A alfabetização era um veículo de debate sobre a política da UP para o processo revolucionário, mas tal debate parecia estar orientado por uma via afirmativa e informativa. Com isso, não pretendo criticar o programa por falta de neutralidade, pois a neutralidade na educação não existe, como sabiam tanto Freire, como os marxistas, mas sim iluminar a relevância das diferenças no método pedagógico e suas implicações. Enquanto as pedagogias mais estreitamente ligadas a Freire quebravam a hierarquia entre educador e educando, o material da UP corria o risco potencial de não o fazê-lo.

\section{Paulo Freire no Chile em 1972: diálogos com a revolução chilena}

Em março de 1971, a Revista de Educación do Mineduc publicou um artigo no qual Paulo Freire aprofundava o argumento sobre a centralidade da cultura e do diálogo horizontal em um processo revolucionário, reforçando sua crítica à mentalidade mecanicista, "que Marx chama de 'grosseiramente materialista", ${ }^{1172}$ escreveu. Já vivendo em Genebra, o brasileiro voltou ao Chile três vezes durante o governo da Unidade Popular: em fevereiro e junho de 1971, e em fevereiro de 1972. As duas primeiras estadias foram curtas, de apenas uma semana. Reencontrou amigos, conversou com camponeses novamente, deu palestras, mas não chegou a ser convocado para nenhum tipo de política governamental. Em 1972, passou um mês inteiro no país, quando pode observar o trabalho pedagógico da UP mais de perto. Naquela ocasião, ocorreu um debate direto entre Freire e estudantes marxistas engajados nas batalhas teóricas da revolução chilena. Convidado a uma entrevista junto a universitários do Instituto Pedagógico da Universidade do Chile, Freire escutou logo na primeira pergunta que "o pensamento em

1172 Paulo Freire, El proceso de alfabetización adulta como acción cultural para la libertad. Revista de Educación, n. 34, Mar./1971. 
suas obras se apresenta como a-histórico, ou seja, sem uma categoria histórica operando ao fundo", ${ }^{1173}$ em razão da suposta ausência da luta de classes como conceito-chave na sua filosofia educacional, e que "por um livro como este (Pedagogia do oprimido) não o teriam perseguido, nem no Brasil, nem haveria problemas no Chile, nem em nenhuma parte", ${ }^{1174}$ o que dava a entender que se tratava de uma obra inofensiva ou inoperante. Eram críticas que circulavam à época e inclusive estavam expressas na introdução do Sugerencias. Como contou Gajardo, Paulo Huet, um funcionário da CORA, chegou a escrever uma Crítica marxista a Paulo Freire, na qual mirava o próprio Sugerencias, e argumentava que as palavras escolhidas pelos autores do documento tinham caráter "reformista", uma vez que dispensavam conceitos fundamentais do marxismo, como "classe", "partido", "socialismo" e "revolução" (Gajardo, 1991: 84).

Freire aproveitou para dialogar em termos autocríticos, mas também para inverter a crítica e matizar o caráter a-histórico ou abstracionista de algumas alegações. Respondeu que poderia concordar que Educação como prática da liberdade contivesse aspectos de uma consciência ingênua, mas que dentro de seu contexto histórico, isto é, no Brasil antes de 1964, era um livro crítico. Ademais, ressaltava que seus textos guardavam uma relação dialética com sua prática e com os tempos e espaços delimitados em que os escreveu e, portanto, precisavam ser examinados em conjunto, no movimento da sua própria conscientização: "se eu tivesse uma prática idealista no Brasil, não tinha sido preso, nem expulso da universidade, nem meus livros seriam proibidos até hoje, oito anos depois", ${ }^{1175}$ constatou. Concordava, contudo, que o conceito de "conscientização" era paulatinamente apropriado por setores reacionários na América Latina e que nenhuma teoria era imune a apropriações indevidas. Admitia, nesse sentido, certa responsabilidade por não ter desenvolvido seu pensamento de maneira mais nítida a respeito dos limites estruturais do capitalismo.

A pedagogia freiriana se chocava mais com os setores do marxismo chileno que priorizavam a batalha da produção como imperativo máximo do processo revolucionário, o que favorecia hierarquias sociais e laborais em vez de dissolvê-las. Segundo Freire, esses setores subestimavam a conscientização a partir de um olhar mecanicista da transformação da realidade e também incorriam em práticas elitistas de "invasão cultural" pela esquerda ou "colonialismo revolucionário", oferecendo respostas prontas para os problemas, sem necessidade de escutar as respostas nascidas da vida de educandos trabalhadores. Segundo o próprio Freire, alguns de seus detratores marxistas:

[...] não o fazem devido aos meus erros anteriores, mas porque rechaçam (...), no fundo, o processo de conscientização. E ao fazê-lo não fazem outra coisa que cair no equívoco oposto ao equívoco idealista, que é o equívoco mecanicista, objetivista. Em um caso, se arrisca a nomear a consciência como produtora da realidade, e no outro considera que a consciência é uma mera réplica da realidade, não havendo

1173 ¿Una dimensión política de la educación? Una conversación con Paulo Freire. In: Cuadernos de Educación, Serie Orientaciones (1971-1973). v. 4, n. 2. Santiago: Universidad de Chile, 1972, p. 2-25.

1174 Id., ibid., p. 3.

1175 Id., ibid., p. 5. 
base aceitável para a conscientização. Me expresso com clareza que ao criticar a mim mesmo, não renuncio à conscientização. ${ }^{1176}$

A reforma agrária enquanto processo de mudança estrutural totalizante, que demandava esforço de transformação técnico-produtiva e econômico-subjetiva, permitia a visualização prática dessa diferença. O dirigente comunista David Baytelman, por exemplo, pensava que os camponeses do setor reformado, "na maioria dos casos, aceitavam o trabalho coletivo com entusiasmo, até que a ausência de incentivos materiais fazia os melhores trabalhadores recusar a participação no esforço coletivo" (Baytelman, 1979: 152). Ou seja, a dificuldade de estruturação econômica era objetiva, vinculada a limites das forças produtivas na agricultura chilena. Por outro lado, como os freirianos do ICIRA percebiam no trabalho de escuta dos camponeses, o nó subjetivo sobre as vantagens do trabalho individual ou coletivo não era tão simples de desatar. Ou seja, não bastava dispor da máquina mais moderna e do crédito disponível para resolver o conflito entre individualidade e coletividade do trabalho e da propriedade da terra.

Esse conflito sobre o papel da subjetividade na transformação revolucionária também se expressava naquilo que o Sugerencias se distanciava de Freire. Embora o guia impulsionasse a defesa da dignidade popular, dos direitos dos trabalhadores, da luta pela igualdade social, e explicasse as medidas da UP sobre cada palavra geradora em defesa de um horizonte socialista, os autores não consideravam com qual metodologia conduzir o diálogo com os trabalhadores que discordassem de seu conteúdo, ou seja, não davam atenção ao problema central da conscientização na Pedagogia do Oprimido. O que fazer diante de trabalhadores oprimidos, cuja subjetividade é orientada pelos valores da classe dominante ao tal ponto que o desejo de conquistar privilégios e enriquecer é muito mais enraizado do que o desejo de lutar pela igualdade entre todos? Victor Yáñez, ${ }^{1177}$ que alfabetizou com o Sugerencias, utilizou a expressão fachos pobres (fascistas pobres) para falar sobre aqueles que se recusavam a apoiar as mudanças do governo popular, embora fossem beneficiados por elas. No processo revolucionário, a questão dos camponeses amarillos se tornou mais aguda, sobretudo pela postura beligerante da Confederação de Assentamentos contra o governo e pelo avanço da reforma agrária privada (Gómez, 1972), quando proprietários ampliavam regalias internas para angariar apoio de seus inquilinos contra a CORA.

Na conversa de 1972, Freire também sentiu necessidade de explicar que quando escreveu Pedagogia do oprimido: "estava completamente convencido do problema das classes sociais" e que na "dialética do opressor-oprimido está implícito, indubitavelmente, o problema das classes sociais". ${ }^{1178}$ Se houve algum erro nesse sentido, respondeu, foi "não haver explicitado essa obviedade". ${ }^{1179}$ A luta de classes, de certa forma, era o cerne da Pedagogia do oprimido, embora não ostentasse a expressão.

\footnotetext{
1176 Id., ibid.

${ }^{1177}$ Entrevista com Victor Yañez, San Carlos, 19/05/2017.

${ }^{1178}$ ¿Una dimensión política de la educación? Una conversación con Paulo Freire, op. cit.

1179 Id., ibid., p. 5.
} 
Quem não o notava estaria excessivamente apegado ao rótulo, não ao conceito. Sem mencionar o Sugerencias, Freire também criticou diretamente a invasão cultural como procedimento vanguardista da esquerda. Alertou que "todo tipo de invasão cultural é antirrevolucionária (...). Daí a distância que estou observando hoje no Chile, entre a expressão verbalizada de uma opção revolucionária e a prática pequeno-burguesa (...) que nada tem a ver com a revolução". ${ }^{1180}$ É preciso lembrar que Freire estava em diálogo com estudantes, cujo furor verbal muitas vezes ultrapassava a prática.

A centralidade do método pedagógico e do debate sobre como conduzir o diálogo conscientizador, um tema desprezado pelo Sugerencias, era precisamente um recurso para desconstruir a invasão cultural produzida pela educação bancária: "não adianta nada dar cursos de marxismo para camponeses. O que adianta é aproveitar sua prática revolucionária (...). É pela prática revolucionária, que a classe trabalhadora aprende a teoria da revolução", ${ }^{1181}$ advertiu o brasileiro. Freire voltaria a falar sobre a "incontinência verbal", a "discurseira" e o "desmando do palavreado" de alguns setores da esquerda, quando relembrou o Chile da UP em Pedagogia da esperança (2011: 60), e identificou que isso era um problema metodológico e ideológico, uma vez que "não há erro metodológico que não seja ideológico". ${ }^{1182}$

Falando diretamente ao grupo do Instituto Pedagógico, o pedagogo criticou slogans e cartazes produzidos pelo Ministério da Educação do governo Allende, particularmente um cartaz da campanha de alfabetização que ilustrava um homem trabalhador com uma espécie de fenda na cabeça, preenchida por letras despejadas de uma mão, junto ao slogan: Quem semeia, colhe. Ensine a ler. "Péssimo", ${ }^{1183}$ disse Freire aos universitários Mais tarde, ao relembrar o diálogo com os chilenos, o brasileiro reformulou a crítica com as seguintes palavras: "esse é um pôster que, feito por progressistas, implica uma profunda incoerência, pois expressa sem vacilação uma ideologia ostensivamente autoritária. Mas além disso revela também uma profunda ignorância científica em torno do que é a linguagem" (Freire, 2011: 255-6).

O outro slogan criticado por Freire, sem que ele soubesse, era de autoria de um camponês: "quem sabe, ensina, quem não sabe, aprende" do Instituto Pedagógico. A frase estava modificada e descontextualizada, mas sua origem tinha muito mais relação com Freire do que ele mesmo poderia supor. "Quem sabe ensina a quem não sabe", na formulação original, foi o que disse um camponês assentado no contexto do projeto "Autocapacitação como hipótese", conduzido por Juana Aravena, coordenadora educacional da CORA. O camponês expressava que os camponeses poderiam ser alfabetizadores entre si. O registro da sua fala estrava reportado em um relatório de Juana Aravena,

\footnotetext{
${ }^{1180}$ Id., ibid., p. 7

1181 Id., ibid. Retomando o conceito de educação bancária analisado no capítulo 4: "Se para a concepção 'bancária' a consciência é este recipiente que deve ser preenchido, é este espaço vazio à espera do mundo, a educação é então este ato de depositar fatos, informações semimortas nos educandos". Paulo Freire, La concepción 'bancaria' de la educación y la deshumanización. La concepción problematizadora de la educación y la humanización. 1967, p. 6

1182 ¿Una dimensión política de la educación? Una conversación con Paulo Freire, op. cit.

1183 Id., ibid.
} 
interno a um relatório que Paulo Freire enviou à Unesco em 1968. ${ }^{1184}$ Fora de contexto, a frase evocar a prática bancária. "Será que o líder pequeno-burguês, possuindo uma consciência histórica e uma consciência de classes que não é sua, vai formar a consciência de classe daqueles [trabalhadores] que não têm o que deveriam ter?", ${ }^{1185}$ provocou Freire: "o conhecimento revolucionário não é posse da vanguarda. No momento em que uma vanguarda possui conhecimento revolucionário e diz 'vou transferi-lo às bases populares', é elitista". ${ }^{1186}$ Rolando Pinto, que acompanhou Freire e Gajardo na entrevista de 1972, recorda-se que na saída o brasileiro teria comentado a seus amigos do MAPU: "a briga aqui é entre sectarismo e autonomia". ${ }^{1187}$

A passagem de Freire pelo Chile também foi marcada por uma visita a población Nueva La Habana, que o deixou entusiasmado com o MIR. Os pobladores, com apoio dos revolucionários, transformaram carcaças de ônibus destinadas ao ferro-velho em salas de aula para adultos trabalhadores: "é interessante observar como o MIR, que continuamente esteve à esquerda do PC e depois do próprio governo da UP, revelou sempre uma simpatia pela educação popular que aos paridos da esquerda tradicional, lhes faltava" (Freire, 2011: 53), escreveu mais tarde. ${ }^{1188}$ Gajardo, que levou Freire à entrevista de 1972, lembra-se que seu amigo não estava muito feliz ao sair, e disse que criticara algumas escolhas do governo de Allende, as quais indicavam uma política de alfabetização com aspectos bancários: "as cabeças vazias me geravam o mesmo incômodo", ${ }^{1189}$ lembrou-se Marcela sobre o cartaz.

Quando avaliamos, por exemplo, a lista de "tarefas da classe trabalhadora" entregues pelo Sugerencias no debate sobre a palavra cobre, é possível observar uma lógica bancária da esquerda, que ao final era representativa de aspectos bancários da dinâmica revolucionária, na qual o educador entregaria as missões do trabalhador do cobre para viabilizar o processo revolucionário, sem contudo cogitar a possibilidade metodológica de perguntar ao trabalhador quais tarefas ele, como sujeito protagonista da revolução, pensava em assumir para fortalecer a economia chilena. Tendo vivido a experiência prática de todas essas convergências e divergências, Marcela Gajardo escreveu:

Em geral, o método de Paulo Freire e a ideia de conscientização perderam força no contexto de uma sociedade em que a velocidade da mudança e as características do conflito ideológico impediam sequer o diálogo ao nível dos partidos e entidades de governo (Gajardo, 1991: 85).

Seguindo essa avaliação, a revolução produziu uma tensão entre os imperativos econômicos do processo transitório e a temporalidade pedagógica da mudança, que permitisse o protagonismo

\footnotetext{
1184 Juana Aravena Vargas, Algunas experiencias en la supervisión de educación básica. In: Paulo Freire, Alfabetización Funcional en Chile, informe UNESCO. Santiago: ICIRA (mimeo.), 1968a.

1185 ¿Una dimensión política de la educación? Una conversación con Paulo Freire, op. cit., p. 7.

1186 Id., ibid., p. 12.

${ }^{1187}$ Entrevista com Rolando Pinto Contreras, Santiago, 23/05/2019.

1188 Freire seguia: "quando o PC e o PS dogmaticamente recusavam trabalhar com certas poblaciones porque, diziam, sem "consciência de classe", se mobilizariam apenas durante o processo de reivindicação de algo após cuja obtenção se seguiria necessariamente a desmobilização, (...) o MIR desenvolveu um intenso trabalho de mobilização e organização, já em si pedagógico-político, a que se juntou uma série de projetos educativos nas áreas populares" (Freire, 2011: 53). O debate sobre a centralidade da fábrica ou do bairro para luta de classes revolucionária no Chile da UP foi pesquisado por Cury, 2017.

${ }^{1189}$ Entrevista com Marcela Gajardo. Santiago, 29/11/2018.
} 
emancipatório dos camponeses sem que fossem retomassem padrões de hierarquia laboral. O processo pedagógico culminaria com a autodisciplina laboral, baseada em valores solidários, no sacrifício produtivo para a coletividade nacional e em uma "economia moral revolucionária", doadora de tempo de trabalho para o bem-estar de outros trabalhadores. Embora fossem radicalmente distintas da hacienda, as novas hierarquias laborais geradas pelo imperativo econômico da revolução, para muitos trabalhadores rurais, evocavam a experiência da hierarquia patronal e fomentavam a percepção do "novo patrão Estado". Essa percepção alimentou as bases camponesas da DC e das confederações sindicais Triunfo Campesino e de Assentamentos. O desencontro entre transformação pedagógica e econômica se desdobrava em quebra de confiança no projeto da UP entre alguns setores camponeses.

Ainda assim, para o professor Julio Salgado, que trabalhou no Departamento de Educação da CORA entre 1965 e 1974, a experiência do método psicossocial foi bem-sucedida em todos os assentamentos em que alcançou participar, ainda mais naqueles em que os próprios camponeses se tornaram alfabetizadores (Salgado apud Goic \& Sahuenza, 1992: 260). A crise de temporalidades não impedia que a temporalidade pedagógica da transformação estrutural da subjetividade produtiva avançasse, mesmo que mais lentamente.

\subsection{Conselhos Camponeses e os desafios da pedagogia do território}

$\mathrm{O}$ argumento fundacional para criação dos conselhos camponeses era a necessidade de estruturar canais sistemáticos de diálogo entre o governo popular e as múltiplas organizações do campesinato, bem como criar mecanismos de decisão das bases sobre a reforma agrária. Embora não tenha havido tempo suficiente para seu amadurecimento, os conselhos camponeses constituíram uma das mais importantes inovações estratégicas da revolução agrária da UP. Apesar de incipientes, os conselhos comunais evocavam o nexo entre poder e produção, e indicavam que a revolução poderia precisar da pedagogia do território, uma das principais chaves para resolver o descompasso entre imperativo econômico e poder popular camponês. O fenômeno dos conselhos tinha uma força pedagógica, tanto por mobilizarem recursos de capacitação, como por produzirem aprendizagens políticas diversas em nível comunal por meio da interação entre campesinato organizado e desorganizado.

Em outras palavras, os conselhos camponeses permaneceram em estágio germinal, mas eram a chave da revolução no campo e, por meio deles, poderiam prosperar formas criativas de poder popular rural. De certa forma, isso sinalizava no Diagnóstico:

Existem experiências metodológicas isoladas e não conhecidas pelo CTNC. Uma delas é o chamado Plan Comunal, elaborado pela Subdivisão de Planificação da CORA e INDAP em colaboração com SAG e ICIRA, que constitui uma tentativa global de concepção de trabalho com os conselhos comunais campesinos. Partindo do diagnóstico da Comuna se chega a um 
programa de trabalho que se confronta com o marco nacional de planificação, saindo disso um trabalho comum entre camponeses e funcionários de Estado (Barraclough \& Fernández, 1974: 234).

Como os próprios autores indicam, o uso dos conselhos como ferramenta de planificação e desenvolvimento territorial foi excepcional, não alcançando a maioria. Os conselhos comunais, nesse sentido, eram potencialmente uma ferramenta pedagógica de diálogo, aceleração da reforma agrária, planejamento produtivo e de territorialização do poder camponês, mas não houve tempo para que se desenvolvessem todas essas potencialidades. Algumas divergências sobre a composição e organização dos conselhos comunais eram representativas da polêmica central da experiência da UP, em que governo, partidos e organismos de poder popular terminavam disputando o poder entre si, em vez de exercê-lo de maneira compartilhada.

\section{Capacitação para Conselhos Camponeses}

Algumas iniciativas de capacitação buscaram acelerar a formação de conselhos em diferentes territórios. Entre 1971 e 1972, os Comitês Locais do CTNC mobilizaram 39.881 camponeses para jornadas de capacitação exclusivas sobre conselhos camponeses. As atribuições dos conselhos eram bastante amplas e estavam atravessadas por uma ambiguidade a respeito da diferença entre dialogar e decidir. Se o diálogo era um fundamento político-pedagógico importante da revolução e o diálogo territorializado poderia ser uma estratégia de desenvolvimento, o salto necessário para a decisão camponesa, isto é, a transferência do poder do Estado para os organismos de poder popular, não chegou a se completar.

Em julho de 1972, o Departamento de Cultura da Ranquil, em parceria com o Departamento de Folclore e Teatro, realizou o $1^{\circ}$ Curso Nacional de Dirigentes Culturais Camponeses, que contou com 40 alunos. Esses dirigentes culturais seriam lideranças dos novos Centros Culturais Camponeses, que "trabalham em íntima conexão com os Conselhos Comunais Camponeses, chamados a ser os impulsionadores da nova cultura popular no campo, ajudando a descobrir novos artistas populares e trocando o antigo consumidor de arte, que era a burguesia, pelo público criador de sua própria expressão artística". ${ }^{190} \mathrm{O}$ convênio de capacitação cultural camponesa Ranquil/INDAP pretendia "desenvolver uma política cultura verdadeiramente popular", pautando a cultura como centro das batalhas políticas dos conselhos comunais. O conteúdo das aulas teóricas incluía "Política Cultural e Agrária do Governo Popular"; "História do Movimento Camponês Chileno"; "Analfabetismo"; "Alcoolismo" e "Participação da mulher"; enquanto as aulas práticas tratavam de "Técnica artística"; "Jornalismo popular"; "Expressão mural”; “Teatro"; “Títeres”; "Música”; “Artesanato”. Era uma iniciativa que

${ }^{1190}$ Curso para dirigentes de Centros Campesinos. La Nación, Jul./1972. 
vinculava os conselhos comunais à ação cultural para reforma agrária e assim impulsionava a batalha cultural no sentido do socialismo.

Entre 1971 e 1972, a Triunfo Campesino também criou cursos de capacitação sistemática para dirigentes dos conselhos. Também foram incorporadas em seus serviços sindicais, "assessoria à organização de Conselhos Campesinos a nível nacional, provincial e comunal”. Também se propunham a criar, em 1973, um internato para Conselheiros Campesinos, o que desconheço se chegou a ocorrer. ${ }^{1191}$ No primeiro Convênio da Unidade Obreiro-Campesina com o FEES, para 1972, também se planejaram conteúdos de capacitação sobre conselhos. A UOC partiu com $15 \%$ da base sindical da sua ruptura com a DC em 1971. Em seu plano de capacitação entregue ao FEES, estabeleciam a meta de capacitar 36 mil alunos em jornadas rápidas para as bases, 630 camponeses em Seminários para Monitores (cinco dias), 750 alunos em cursos de dirigentes comunais e provinciais, e 60 alunos em cursos para dirigentes nacionais (CTNC). Os Conselhos Camponeses apareciam em quase todos os temários (Gajardo, 1973c: 22). As confederações sindicais se esforçavam em algum grau para incorporar a agenda dos conselhos na sua capacitação.

Como constatou Gajardo, o estrangulamento das instituições do agro, a inoperância do CTNC e a intensidade da disputa ideológica durante a revolução fizeram com que os processos de ação cultural e capacitação encontrassem muitos obstáculos para o cumprimento das suas metas e fossem quase compulsoriamente substituídos por processos de "difusão" de informações. Durante a UP, Gajardo constatou que "se intensificam as jornadas (destinadas a informar seus filiados) e diminuem os cursos de formação de alto nível para dirigentes" (Gajardo, 1973a: 148). A imprensa governista, por exemplo, produziu uma edição especial sobre Conselhos Camponeses. Um material ilustrado chamado "Los Consejos Comunales Costaron Mucho" 1192 era destinado a explicar e informar sobre o peso histórico daquela ferramenta de luta e poder, além de difundir a consciência histórica a respeito das lutas contidas naquela conquista.

${ }^{1191}$ FEES, Proyecto de Convenio, Triunfo Campesino, 1971-1972.

${ }^{1192}$ Los consejos comunales campesinos costaron mucho. La Nación, Fev./1972. 

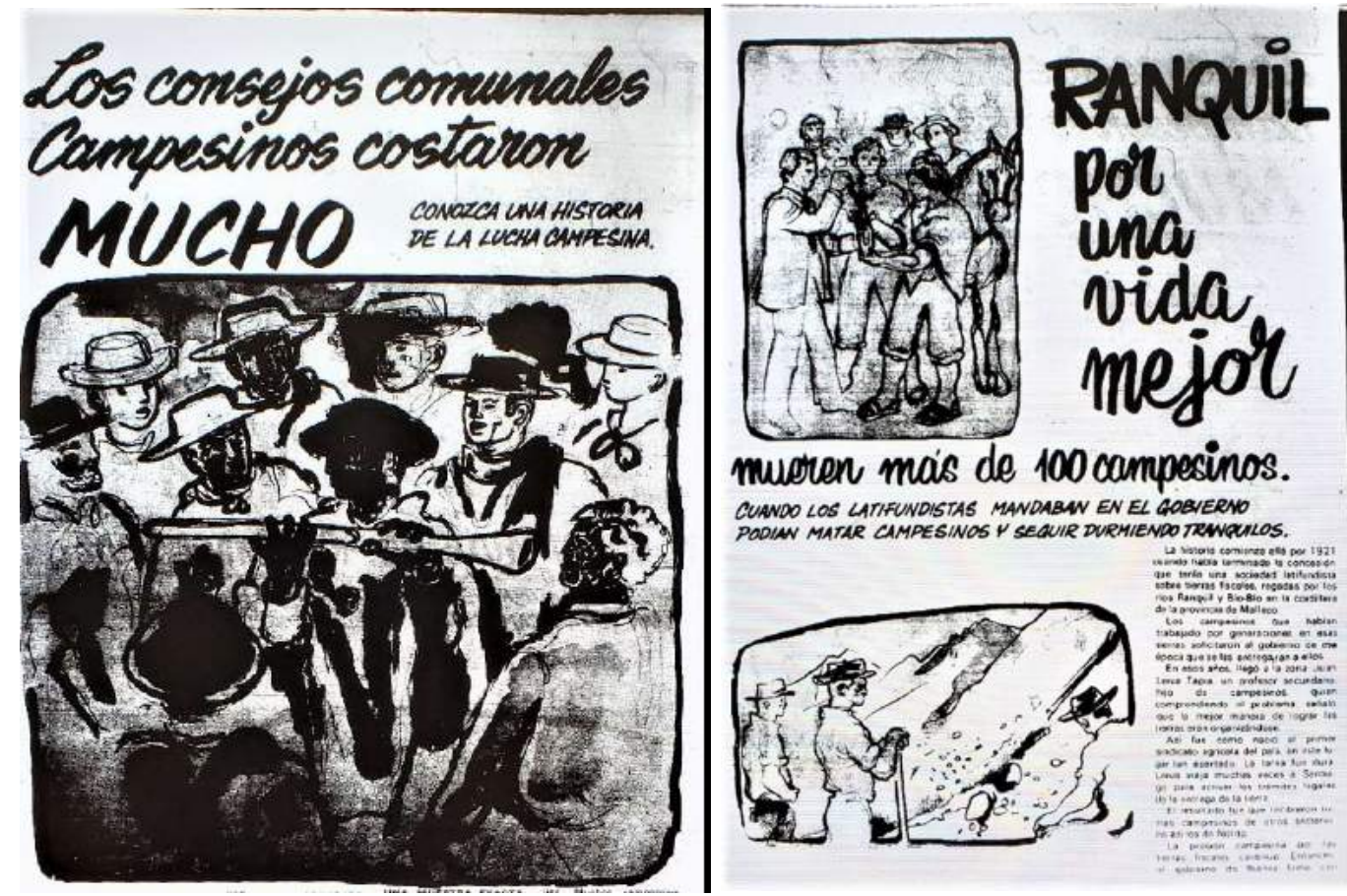

La Nación, Feb./1972.

O material associava a luta camponesa desde o massacre de Ranquil, em 1934, até os Conselhos Camponeses. Depois de descrever a história das lutas passadas, concluíam com as palavras de Ruben Aravena, dirigente campesino do Conselho de Cobquecura (Nuble): "El Consejo Campesino pesa, compañero, y se le están tomando miedo". Ainda havia, contudo, uma tensão latente entre as concepções diferentes sobre o papel dos conselhos na revolução. A seguir explorarei as nuances entre dialogar e decidir, junto com a relação entre camponeses organizados e desorganizados.

\section{Dialogar ou decidir?}

O decreto 481 de 21 dezembro de 1970 foi uma prioridade para Chonchol e Allende. Definia que "a participação camponesa no processo de reforma agrária deve ter uma expressão orgânica que canalize, em todos os níveis, as aspirações, interesses e inquietações dos camponeses" (Chile, 1970). Ainda segundo o decreto, o Conselho Nacional Camponês (CNC) tinha como missão "transmitir a opinião dos camponeses ao Governo em todos os assuntos do agro" (Chile, 1970), especialmente quatro: a) os planos nacionais de desenvolvimento rural, produção agropecuária e reforma agrária; b) as políticas de preços, crédito e comercialização; c) os programas e orçamentos dos organismos do agro; e d) políticas sociais do trabalhador rural. O decreto também determinava que "todos os planos, programas, orçamentos e políticas seriam examinadas e informadas pelo CNC antes da aprovação do Ministério da Agricultura ou Presidente da República" (Chile, 1970). O CNC era constituído por dez membros, dois representantes de cinco organizações nacionais camponesas (Triunfo Campesino, 
Libertad, Ranquil, Confederação de Assentamentos e Confederação de Cooperativas). Tinha a faculdade de fazer "sugestões, propostas e denúncias" (Chile, 1970). Do decreto, portanto, ficava claro que os conselhos eram uma ferramenta garantida de diálogo, mas apenas potencialmente uma ferramenta de decisão e poder. Mais de 300 delegados camponeses de todo país, representando mais de 200 mil camponeses organizados, compareceram à assinatura do decreto. ${ }^{1193}$

$\mathrm{Na}$ reunião entre Chonchol e os dirigentes camponeses que antecedeu à assinatura, em novembro de 1970, as organizações propuseram que o CNC tivesse poder deliberativo, ao que o ministro respondeu que a UP não poderia abrir mão do seu poder governamental delegado pelo voto popular, e assim contornou a polêmica que, mais tarde, inevitavelmente se desdobrou. ${ }^{1194}$ Logo após o decreto, todas as confederações nacionais convocaram suas bases para explicar o decreto e iniciar a estruturação dos conselhos. Um anúncio da Ranquil dizia às suas bases deveriam "tomar contato com as demais organizações de camponeses que existem na província ou comuna (...) o mais rápido possível". ${ }^{1195}$ Alertavam que os conselhos tinham como atribuição "estudar planos de desenvolvimento rural, produção agropecuária e reforma agrária”, opinar sobre orçamentos, políticas de preço/créditos e discutir as aspirações do campesinato. "O governo da UP entregou parte da responsabilidade do desenvolvimento agropecuário aos próprios camponeses", dizia a Ranquil, "e a esta confiança nós saberemos responder através de nossas organizações de massas". ${ }^{1196}$ Os conselhos camponeses impunham a necessidade da unidade entre as mais diversas organizações camponesas em todos os níveis.

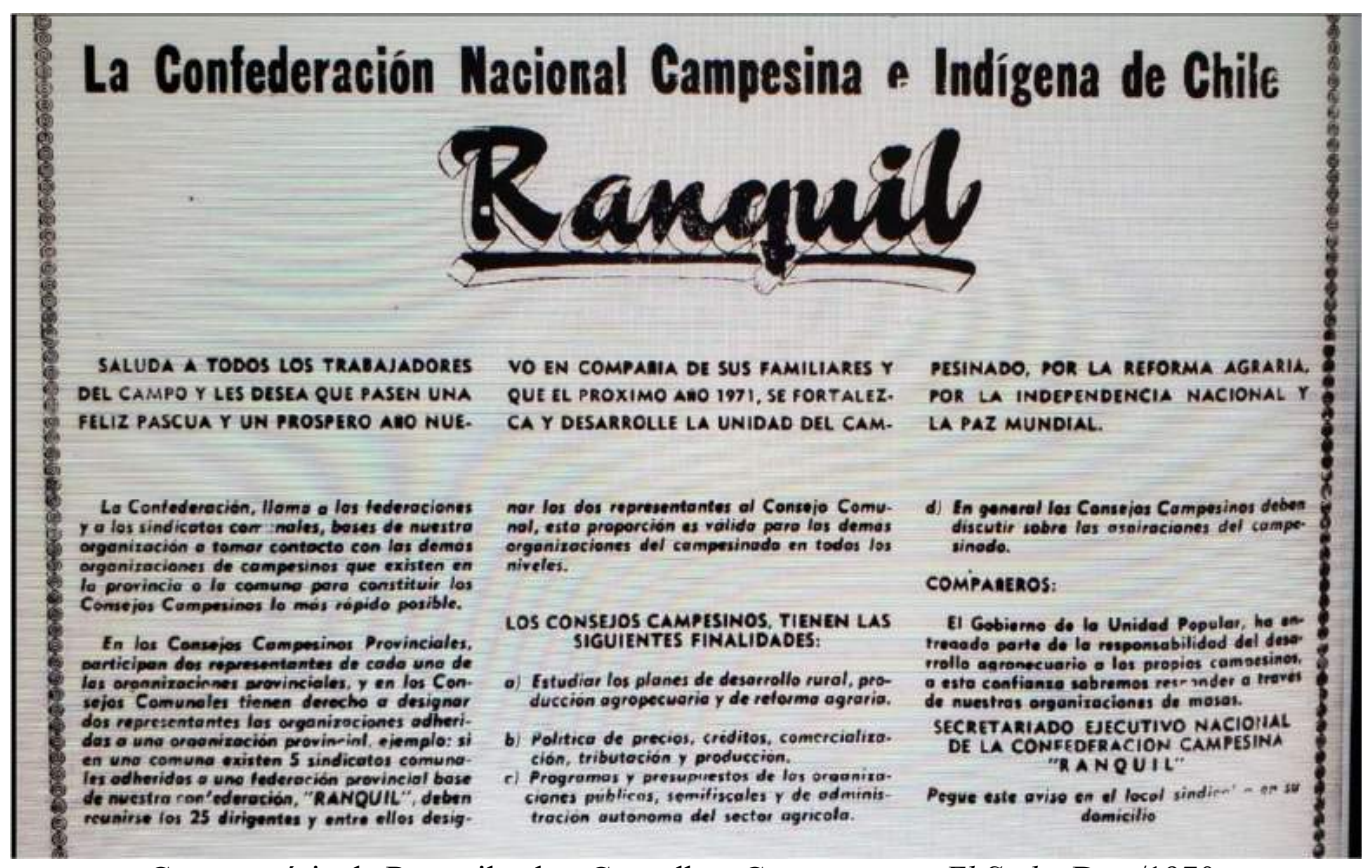

Convocatória da Ranquil sobre Conselhos Camponeses . El Siglo, Dez./1970.

\footnotetext{
${ }^{1193}$ La próxima semana se crea el consejo nacional campesino. El Siglo, Dez./1970.

1194 Dirigentes de la Triunfo plantearon problemas a Chonchol. El Siglo, Nov./1970.

1195 Anuncio Ranquil sobre CNC. El Siglo, Dez./1970.

${ }^{1196}$ Convocatória da Ranquil sobre Conselhos Camponeses. El Siglo, Dez./1970.
} 
O primeiro presidente eleito do CNC foi Victoriano Zenteno, presidente da Triunfo Campesino e militante da DC. O secretário geral foi Dagoberto Ortega, da Federação Provincial de Assentamentos de Linares, que venceu Enrique Avendaño da Ranquil por um único voto. ${ }^{1197}$ Dagoberto, que não pertencia a nenhum partido político, declarou: "queremos que se exproprie a terra do Chile sem que fique um centímetro de reserva a estos momiachos que nos fizeram sofrer a vida toda". ${ }^{1198}$ Além da formação dos Conselhos Provinciais (CPC) e Comunais Camponeses (CCC), em janeiro de 1971, os dirigentes camponeses propunham a constituição de uma Assembleia Nacional Campesina, composta de todos os participantes dos CNC, CPC e CCC. No contexto do Cautinazo e do deslocamento do ministério a Temuco, o primeiro Conselho Comunal Camponês a se constituir foi o de Loncoche. ${ }^{1199}$ Os conselheiros aproveitaram a movimentação para também se deslocar e fomentar o primeiro Conselho Provincial, de Cautín, formado por quatro organizações: a Federação Eduardo Frei, a de Assentamentos, a de Cooperativas e Federação Luis Emilio Recabarren. ${ }^{1200}$ O deslocamento do Minagri a Temuco foi tão significativo que até mesmo o presidente do $\mathrm{CNC}$, militante democrata cristão, o acompanhou. Em seguida, o CNC aproveitou o embalo para realizar um giro com seus dez membros por mais de 15 províncias, o que estimulou a formação dos CPC. O comunista Enrique Avedaño, da Ranquil, elogiou a iniciativa: "esse giro constituirá um aporte muito significativo ao processo de unidade de ação no qual todas as organizações camponeses estão de acordo". ${ }^{1201}$ Havia, segundo ele, um "alto espírito unitário que existe entre as organizações".

A imprensa comunista reforçava que o papel mais significativo dos conselhos era sua "ingerência direta na planificação das medidas de desenvolvimento agropecuário", bem como nas prioridades de expropriações e na "organização do trabalho nas terras expropriadas, no aumento da produtividade", entre outros. ${ }^{1202}$ De maneira hiperbólica, o diretor da ODEPA Juan del Canto declarou que "o CNC é o veículo através do qual 3 milhões de pessoas vão se integrar um trabalho conjunto para programa a reforma agrária", se referindo à totalidade da população rural do país. ${ }^{1203}$ Como chefe da instituição responsável por tornar factíveis os planos de produção dos assentamentos, Del Canto também sublinhou: "em especial, os conselhos deverão planificar a economia camponesa e colaborar com o governo na capacitação da população rural". ${ }^{1204}$ Nesse sentido, os Conselhos tinham um importante papel cultural, tanto no sentido econômico (da cultura produtiva), quanto no sentido artístico (da promoção de uma vida cultural ativa no campo).

\footnotetext{
${ }^{1197}$ Dirigente de la "Triunfo" es presidente del Consejo Campesino. El Siglo, 12/01/1971.

${ }^{1198}$ El trabajador de la tierra decidirá su destino, El Siglo, 11/01/1971.

1199 Temuco: Se crean los primeros consejos campesinos. El Siglo, Dez./1970.

${ }^{1200}$ Consejo Nacional Campesino funcionará también en Cautín, El Siglo, 19/01/1971

${ }^{1201}$ Consejos Campesinos deben constituirse rápidamente. El Siglo, 19/02/1971

1202 Id., ibid.

${ }^{1203}$ Consejo Nacional Campesino deberá integrar a 3 millones de personas, director de ODEPA opina. El Siglo, Dez./1970.

1204 Id., ibid.
} 
Os Conselhos eram promissores e foram elogiados por parlamentares da UP e de uma ala da DC: "os trabalhadores rurais organizados devem dirigir seu próprio destino", ${ }^{205}$ disse o deputado radical Mario Barahona. "Será enorme seu poder de decisão", frisou o socialista Joel Marambio, do PS de Colchagua: "[os conselhos] terão ingerência na planificação da produção agrícola. Receberão a educação necessária para que (...) se incorporem plenamente ao processo". O deputado da DC, Sergio Paez, afirmou: "nós concordamos, estava em nossos esquemas". A senadora Maria Elena Carrera destacou que se tratava de "um grande desejo dos trabalhadores do campo (...). Outorgará poder ao campesinato para que participe ativamente no processo agrário". O presidente da CUT, Luis Figueroa, afirmou que "o CNC é o pilar fundamental da batalha pela reforma agrária". O presidente da FECH, o estudante Alejandro Rojas, discursou que o papel histórico dos conselhos, dizendo que o movimento estudantil "está indissoluvelmente ligado à classe trabalhadora e ao movimento camponês. A criação do CNC (...) cria as condições para que os próprios camponeses, protagonistas da luta contra os latifundiários, assumam a direção das tarefas revolucionárias junto ao governo". Até o deputado do PN, Evaldo Klein, de Llanquihue, admitiu: "Não conheço bem o decreto que cria o CNC, mas creio que é benefício geral tudo o que trate de organizar, educar e planificar o agro".

Na percepção de alguns trabalhadores rurais como Nicanor Cofre, presidente da Confederação de Cooperativas Camponesas e dirigente há 20 anos, o CNC era "o primeiro passo para unidade camponesa". ${ }^{206} \mathrm{O}$ mesmo apostava a Triunfo Campesino, que na voz de Victoriano Zenteno, expressou: "todos tem confiança de que o Conselho não representa só a voz isolada da Confederação Triunfo, Ranquil ou Libertad, mas a voz do campesinato de todas as zonas do país". ${ }^{1207}$ A Triunfo, naquele instante, encabeçava 23 federações provinciais.

Embora a percepção geral fosse positiva, havia efetivamente uma diferença entre transmitir ao governo a opinião dos camponeses e decidir sobre os processos. O próprio governo pareceu variar sua interpretação precisa sobre tal nuance. O ministro Chonchol, por exemplo, afirmou categoricamente que "todas as terras expropriadas serão aprovadas pelos conselhos camponeses" 1208 e que o campesinato iria “ participar desde dentro da condição do governo", enquanto o secretário de Estado matizava que o "CNC é um organismo encarregado de transmitir a opinião dos camponeses ao governo". ${ }^{1209}$ Nesse sentido uma primeira divergência que surgiu no decorrer da expansão dos conselhos foi o caráter real ou performático da decisão camponesa naqueles organismos.

“A expropriação segue sendo um procedimento burocrático", criticou Sergio Gómez, membro da Comissão Agrária do MAPU, em 1973: "Não ganhamos nada com camponeses assistindo a um teatro ou a um 'show' que consiste na leitura de propriedade a propriedade, seus proprietários, tamanho, o

\footnotetext{
1205 Todas as citações deste parágrafo pertencem a esta fonte: Políticos opinan sobre creación del Consejo Nacional Campesino. El Siglo, Dez./1970.

${ }^{1206}$ El trabajador de la tierra decidirá su destino, El Siglo, 11/01/1971.

${ }^{1207}$ Id., ibid.

1208 “Todas las tierras expropiadas serán aprobadas por Consejos Campesinos”, Min. Chonchol El Siglo, Dez./1970

1209 Id., ibid.
} 
artigo e inciso da lei de causa para expropriação e o conselheiro dizer: 'aprovado'" (Gómez, 1973: 190), descreveu. Para ele, aquele rito servia somente para "dar um marco camponês a um ato burocrático, mas sem participação real" (Gómez, 1973: 190). Uma das grandes limitações dos conselhos é que não tinham personalidade jurídica própria e não tinham orçamento autônomo, dependendo da boa vontade das organizações para garantir seu mínimo funcionamento. A ausência de orçamento indicava que o sistema de conselhos, na prática, pendia muito mais para o dialogar do que para o decidir. Para os socialistas Eugenio Maffei e Emílio Marchetti (1972: 6), os conselhos deveriam ser "unidades que permitam aos trabalhadores controlar os meios produtivos, em outras palavras, ter verdadeiramente $\mathrm{o}$ poder" e completavam com a proposta de que a "planificação, execução e controle da política agrária da comuna pode ser um ponto de partida" (Maffei e Marchetti, 1972: 6) para poder popular real.

\section{Conselhos pela base e transferência de poder}

Após o entusiasmo inicial, no decorrer do primeiro ano de experiências, formas alternativas ao conselho do decreto foram criadas pelo próprio campesinato. Uma quantidade significativa de conselhos comunais foi formada não por representantes definidos por organizações camponesas, mas sim por eleições diretas da própria base, que poderia escolher representantes de um campesinato "desorganizado". Esses conselhos foram fomentados pelo PS e chamados "conselhos pela base", e passavam por fora das estruturas organizativas já existentes além de absorver a energia mobilizadora dos movimentos espontâneos. No fim de 1971, pesquisadores do CEREN (Castillo \& Larraín, 1971) alertavam que $75 \%$ dos camponeses eram excluídos da interlocução com o governo no conselho criado na forma do decreto, por não pertencerem a nenhuma organização.

Em dezembro de 1971, mais de 100 camponeses, representantes de milhares de trabalhadores do agro, entregaram ao ministro Chonchol um novo projeto de constituição dos Conselhos Comunais, que continha substancialmente três propostas: primeiro, que os conselhos fossem devidamente financiados. Afinal, como podiam dar conta de tantas atribuições, tais como "propor expropriações, participar dos planos de produção, do desenvolvimento econômico e social das comunas, conservação dos solos, e políticas de comercialização", ${ }^{1210}$ se nem sequer tinham recursos para transportar seus membros para reunião? Segundo, queriam a ampliação do número de camponeses nos conselhos "eleitos pela base". Argumentavam que havia um "vigoroso movimento de criação de $\mathrm{CC}$ e numerosos que já se constituíram por eleições da base". ${ }^{1211}$ Também declaravam que concebiam os conselhos como "gérmen do novo poder que está sendo gestado ao calor das transformações. O poder das massas trabalhadoras, das classes majoritárias do país, do que até agora foram explorados por uma minoria gananciosa" 1212 e isso requeria a máxima incorporação dos desorganizados. A terceira proposta era que as instituições do

\footnotetext{
${ }^{1210}$ Proyecto de constitución de Consejos Comunales Campesinos recibió Chonchol. El Siglo, 23/12/1971.

${ }^{1211}$ Id., ibid.

1212 Id., ibid.
} 
agro criassem um convênio escrito com os conselhos comunais, e lhes transferir formalmente seus poderes e atribuições. "É necessário, companheiro ministro da agricultura, que os organismos do Estado (...) formalizem a autêntica, definitiva e irrevogável participação de todo campesinato no exercício das principais faculdades destes mesmos organismos", insistiam em carta. Diziam que o projeto entregue era uma "uma solução harmônica entre as atuais características dos Organismos Públicos do Agro e a legalidade a que estão sujeitos e as reivindicações camponesas". ${ }^{1213}$ E reiteravam:

Companheiro Ministro de Agricultura e Presidente da Comissão Nacional Agraria da UP: (...) é suficiente, em nosso juízo, que os organismos do agro se comprometam mediante um convênio escrito a reconhecer ao movimento camponês sua verdadeira participação nas principais faculdades correspondentes a estes organismos. Estas faculdades precisam ser entregues aos CCC, que se constituirão de acordo ao projeto adjunto. ${ }^{1214}$

Para que o conselho tivesse poder, precisava necessariamente ter algum grau de autonomia financeira. Mas para que isso fosse "legalizado", era preciso que o governo formalizasse por escrito que os conselhos mandariam mais que o Estado em nível territorial. Um dos problemas era que as rivalidades ideológicas já fervilhavam nos conselhos, que acabaram em alguns casos por se tornar consórcios de organizações camponesas rivais, o que emperrava o seu funcionamento com chantagens financeiras de parte a parte. Alguns conselhos não conseguiam fazer reuniões por falta de dinheiro para transporte e alimentação dos seus membros. Segundo Gómez \& Klein (1972), a falta de autonomia jurídica do conselho revelava que "agentes externos cumprem um papel determinante nos primeiros passos de sua constituição". A falta de autonomia dos conselhos foi duramente criticada por Maffei e Marchetti (1972), que defendiam a transformação dos conselhos em poderes paralelos ao Estado e que o excedente do CERA se convertesse oficialmente em recurso orçamentário do novo poder, alavancando a transição ao socialismo.

Em algumas comunas, a guerra partidária duplicou conselhos paralelos da mesma comuna, como em Molina (Talca) e em Fresa (Llanquihue), onde coexistiram um conselho do decreto dirigido pela DC e um conselho ampliado pelo PS (Maffei \& Marchetti, 1972). Além disso, funcionários de Estado de um partido frequentemente colaboravam com membros do conselho do seu partido, e desconsideravam os demais. "Existe um problema derivado da forma como o aparato de Estado funciona no campo", explicavam Gómez \& Klein (1972): "Foram criados para servir clientelas e não para que tais clientelas se incorporassem na tomada de decisões". Com isso, questionavam a própria estrutura do Estado, indicando os limites da via chilena. Qualquer solução primava pelo financiamento autônomo dos conselhos, com cotas e tributações paralelas ao próprio Estado.

Como resposta à demanda dos conselhos pela base, o Ministério da Agricultura admitiu uma fórmula intermediária, chamada "conselhos ampliados", formados metade a partir de organizações, metade a partir de eleições diretas. Em janeiro de 1972, um censo empreendido por pesquisadores do

${ }^{1213}$ Id., ibid.

1214 Id., ibid. 
INDAP, FEES e ICIRA, do Atacama a Llanquihue, constatou que 177 das 235 comunas agrícolas do país fundaram conselhos comunais, sendo $63 \%$ na forma do decreto, $25 \%$ da forma ampliada e $12 \%$ era pela base. Descobriu-se também que $43 \%$ dos conselhos comunais estavam desacompanhados do Estado; e que $46 \%$ das suas direções eram formadas por assalariados rurais, $27 \%$ por assentados e $27 \%$ por pequenos proprietários (Gómez \& Klein, 1972). Os principais problemas dos conselhos, segundo coordenadores do estudo, eram "a falta de definição clara sobre o que os conselhos devem ser e qual papel devem cumprir" (Gómez \& Klein, 1972), além da falta de financiamento e a falta de uma sede, que impedia que dirigentes camponeses se dedicassem prioritariamente à sua estruturação.

\section{Conselhos, MIR e capacitação mapuche}

Não foi por acaso que o primeiro Conselho Comunal (Loncoche) e o $1^{\circ}$ Congresso Provincial de Conselhos Comunais (Cautín) ocorreram na zona mais deflagrada da reforma agrária, com maior concentração de comunidades indígenas, algumas das quais vinculadas à esquerda radical (MIR). O surgimento do Movimento Campesino Revolucionário (MCR) no processo de lutas do cautinazo representou um encontro entre a radicalidade indígena e a radicalidade mirista, ambas dispostas a conquistar a terra pela ação direta, sem esperar tramitações, e igualmente encorajadas a ultrapassar os limites da lei para acelerar a revolução. Os conselhos camponeses convocavam o campesinato à territorialização do seu poder político e social, o que para as comunidades indígenas correspondia a uma forma de organização social e política ancestral, ao seu modo de vida historicamente constituído de significados espirituais e comunitários do território. Apesar da existência inevitável de conflitos, a vida indígena na Araucanía era mais coletivizada e socializada do que a vida camponesa nas haciendas, o que antecipava a organização territorial comunitária sinalizada pelos conselhos comunais.

O professor Arnaldo Cáceres se recorda da campanha de alfabetização na Araucanía, para qual foi desenvolvida, durante a UP, uma estratégia específica de letramento bilíngue, em castelhano e mapudumgum. "Na Araucanía, a maior parte das pessoas era analfabeta. Ali o ICIRA estabeleceu um programa especial, um projeto tecnicamente bilíngue, que considerava elementos da cultura mapuche, que eram analisados segundo o método do Paulo Freire". ${ }^{1215}$ Até o governo da UP, as escolas rurais da Araucanía ensinavam exclusivamente em espanhol, e a língua originária era desconsiderada pela educação formal, apesar das crianças falarem em mapudumgum entre si. Mas os capacitadores de Santiago não falavam suficientemente bem mapudumgum para executar essa tarefa, que foi viabilizada com capacitadores indígenas. "Eram capacitadores indígenas, de dentro das terras onde viviam as comunidades", ${ }^{1216}$ explicou Cáceres.

1215 Entrevista com Arnaldo Cáceres, Santiago, 29/06/2017.

1216 Id., ibid. 
Segundo o historiador Robert Austin, "a política da UP foi única: prontamente foi desenvolvido um programa de alfabetização bilíngue no Sul (...), que mais tarde se tornou paradigmático da relação entre educadores populares e povos originários na América Latina" (Austin, 2003: 144). A alfabetização bilíngue alfabetizou, entre 1970 e 1973, mais de 10 mil indígenas da Araucanía. Foram ao menos três iniciativas ou programas para educação mapuche durante a UP: foi criado o Instituto de Capacitação e Desenvolvimento Mapuche; o Instituto de Capacitação Indígena; e o Programa de Mobilização Cultural do Povo Mapuche, baseado nas instituições próprias dos povos indígenas e na sua autodeterminação (Austin, 2003: 170). Durante o triênio, foram criados cerca de mil Centros Culturais Mapuche, com milhares de educadores indígenas formados no método psicossocial e encorajados a utilizar suas próprias técnicas internas às tradições educacionais de seu povo. Esse processo implicava o desafio de dar formas gráficas e alfabéticas a uma riquíssima cultura oral, transmitida de geração em geração sem o uso da escrita como ferramenta. Segundo Austin (2003), o trabalho de transposição da oralidade para um processo bilíngue de alfabetização contou com a coordenação da argentina Isabel Hernández e do brasileiro Wilson Cantoni e teria representado o "apogeu” da política de educação popular da UP, pelo seu aspecto revolucionário e inovador. Segundo Gajardo, o Programa de Mobilização Cultural do Povo Mapuche e a alfabetização bilíngue tinham como objetivo "lutar contra a discriminação étnica, redefinir a consciência social e a cultura do povo mapuche, elevar seus níveis de consciência política e fortalecer sua identidade étnica" (Gajardo, 1991: 85).

Havia uma "revolução indígena" no seio da revolução chilena, que impôs ao governo a Comissão de Restituição de Terras Usurpadas por meio de um convênio entre CORA e Direção de Assuntos Indígenas (DASIN) (Correa, Molina \& Yáñez, 2005: 208). Com base na documentação da CORA e do SAG, os autores dimensionaram a totalidade das terras expropriadas em favor de camponeses mapuches pelas duas leis de reforma agrária durante três governos, como mostra a tabela 36.

\begin{tabular}{|c|c|c|c|c|c|}
\hline \multicolumn{2}{|c|}{ Tabela 36 - Expropriações da Reforma Agrária em favor de mapuches (1964-1973) } \\
\hline \multicolumn{2}{|c|}{ Frei (1964-70) } & \multicolumn{2}{c|}{ Allende (1970-73) } & \multicolumn{2}{c|}{ Total } \\
\hline Propriedades & Superfície & Propriedades & Superfície & Propriedades & Superfície \\
\hline 25 & 20.595 & 137 & 129.420 & 162 & 150.015 \\
\hline $15,4 \%$ & $13,7 \%$ & $84,6 \%$ & $86,3 \%$ & \multicolumn{3}{c|}{$100 \%$} \\
\hline \multicolumn{4}{|r|}{ Fonte: Correa, Molina, Yáñez, 2005: 220} \\
\hline
\end{tabular}

Naquele contexto, outra brasileira que atuou como educadora do ICIRA, especificamente no programa de educação mapuche, foi Zilah Branco, exilada no Chile desde 1969. Ao chegar em Santiago, conheceu Almino Afonso e começou a trabalhar como socióloga e educadora na reforma agrária. Por meses viveu em Temuco, onde vivenciou a formação dos conselhos camponeses e atuou junto aos mapuche. Branco narrou sua experiência nas comunidades: "fui dar um curso de história para camponeses de uma localidade no interior de Temuco com a proposta de formar os Conselhos Comunais onde estariam os trabalhadores sem terra ao lado dos camponeses. Li bastante e me muni de mapas 
regionais e gráficos com dados estatísticos". ${ }^{1217}$ No entanto, nos contou, "ao iniciar a exposição sobre a história "deles" abri o mapa para situar o território e me dei conta de que eu estava falando grego e mostrando um quadro de rabiscos ininteligíveis". ${ }^{1218}$ A brasileira percebeu que estava à beira de iniciar um processo de educação bancária, mas corrigiu a rota a tempo de inverter a situação. Depois de uma pausa para tomar um chá e uma conversa informal com seus alunos, mudou de estratégia:

\begin{abstract}
Comecei novamente com o mapa virado de costas para que eles desenhassem os pontos principais da região e passei a perguntar como era a história dos latifúndios, dos trabalhadores, dos pequenos agricultores, quem distribuía a água, o papel do padre - que era mais amigo dos latifundiários do que dos pobres... Discutiam entre si, traçando caminhos, fontes de água, obstáculos naturais, terras boas e más, casas grandes, casinhas camponesas e "rucas mapuches". Com entusiasmo foram contando a história das relações sociais, os sofrimentos, as formas de exploração, o uso da força com a ajuda da igreja e da repressão policial. Abri um gráfico de barras para indicar a população dividida em classes e as terras de cada classe. Ficaram quietos e desinteressados. Redesenhei os gráficos em forma de "queijos", como os que produziam, e eles indicaram o tamanho das fatias que, elas sim, indicavam a dimensão social e do poder. ${ }^{1219}$
\end{abstract}

Zilah lembra que mais tarde Solon Barraclough the comentou que havia sido bem avaliada pelos alunos. Ela lhe contou, então, que "usara a técnica de perguntar o que os alunos sabiam (...), ou seja, a realidade conhecida por eles primeiro, para preencher os quadros da teoria. (...). Na verdade, eu é que aprendia a história com eles, oferecendo uma metodologia de análise". ${ }^{1220}$ Zilah não chegou a fazer formações sobre o método psicossocial, mas já se identificava com a filosofia do Paulo Freire. Essa interação simpática que desenvolveu com seus alunos mapuche gerou ampla aceitação da brasileira entre os indígenas das comunidades onde trabalhou. Branco avaliava que o fato de ela falar castelhano com erros e ser uma estrangeira ajudou a que os indígenas a vissem como "não chilena" e, portanto, "não colonizadora". Suas aulas se tornaram um diálogo sobre a história e a cultura dos seus alunos, protagonizado pelos mesmos e orientado para a formação dos Conselhos Camponeses.

Zilah também se recorda de um conflito entre uma toma mapuche em 1971 e representantes do governo, que tentavam convencê-los de desarmar a ação, pois aquela propriedade não era contemplada pela lei de reforma agrária. Um grupo de técnicos foi convocado a participar desse diálogo, com quem ela partiu como espectadora. Ao chegar na toma, reconheceu alguns de seus alunos e outros rostos de participantes das jornadas de formação do ICIRA que ela ministrou. Depois de um desentendimento entre lideranças indígenas e representantes do governo, os mapuche propuseram que a Zilah explicasse qual era a proposta. Ela entrou na toma: "repeti o que o representante do governo dissera, mas com as minhas palavras simplificadoras. Aliás, num péssimo castelhano que começara a aprender. Eu tinha a impressão de que o que eu dizia não tinha maior importância", ${ }^{1221}$ lembrou. Ao final da conversa, o líder da toma informou que votariam o que fazer em assembleia. Antes de sua saída, lhe disse: "você

\footnotetext{
${ }^{1217}$ Entrevista com Zilah Branco por e-mail, 23/10/2018.

1218 Id., ibid.

1219 Id., ibid.

${ }^{1220}$ Id., ibid.

1221 Id., ibid.
} 
fala verdades". Zilah nunca compreendeu com exatidão o motivo pelo qual seus alunos confiaram tanto nela, mas seguiu atribuindo ao fato de ser estrangeira e diferente do colonizador imediato. A brasileira também se lembra de participar de uma reunião de um Conselho Camponês em Temuco, na qual presenciou o debate entre um mirista e um indígena sobre as prioridades da revolução. Enquanto o primeiro defendeu que o conselho deveria realizar uma preparação militar para defender a população de um futuro golpe, o líder indígena ressaltou que naquele momento era prioritário que o conselho fortalecesse a batalha da produção, e alegava que, quando faltasse o pão, o militante do MIR poderia ir para casa dos seus parentes se alimentar, mas os indígenas dependiam dos recursos alimentares daquele território. Essa visão corroborava um dos apelidos que os indígenas deram aos estudantes do MIR: "los de las arrancás" (Navarrete Vergara, 2017: 61), isto é, os que "arrancavam" e sumiam depois das ações, porque viviam em outros lugares. Steenland, que viveu em Cautín durante a UP, resumiu desta maneira o conflito:

O PC sentia que os Conselhos Camponeses deveriam ajudar no processo produtivo, atuando como mediadores entre a burocracia de Estado e as massas camponesas. O PS, e em grande medida o MIR, sentiam que os Conselhos Camponeses deveriam codirigir o processo produtivo e formar a base da dualidade de poder (que atuaria como representante de um novo governo socialista, no momento em que a classe trabalhadora fosse vitoriosa na sua luta pelo poder do Estado) (Steenland, 1977: 17).

O $1^{\circ}$ Congresso Provincial de Conselhos Comunais Campesinos ocorreu em Cautín em julho de 1972, com 206 delegados eleitos em 16 comunas e mais de 40 camponeses observadores de outras comunas. O conselho provincial foi eleito com 7 representantes, sendo 3 socialistas, 2 do MCR (incluindo Félix Huentelaf), um comunista, um radical e um militante da esquerda cristã. Na ocasião, após de reivindicarem dois representantes comunistas no $\mathrm{CPC}$, os comunistas acabaram rompendo com o evento (Steenland, 1977: 147).

O $2^{\circ}$ Congresso Provincial de Conselhos Comunais Campesinos de Cautín foi entre 30 de novembro e 3 de dezembro de 1972. O evento aconteceu na comuna de Angol, com a presença de 200 delegados eleitos pela base em 11 conselhos comunais que, segundo a imprensa oficial, representavam 15 mil camponeses. O evento foi aberto por Norma Huecho Parada, a presidente indígena do CPC de Cautín, que ressaltou a importância da participação das mulheres indígenas na luta revolucionária pela terra. Diante do novo ministro Rolando Calderón, os CCC de Cautín votaram favoravelmente a doze resoluções, ${ }^{1222}$ representativas do processo de radicalização da revolução agrária em articulação com as demandas indígenas. Tais eram as diretrizes da luta dos conselhos comunais camponeses nascidos no Wallmapu.

1) Os CCC seriam uma "ferramenta de poder camponês", democráticos e eleitos pela base em territórios subcomunais.

${ }^{1222}$ Consejos comunales campesinos, herramientas de lucha y poder. La Nación, Dez./1972. 
2) Lutariam por uma nova lei de reforma agrária, que expropriasse todas as propriedades privadas maiores que $20 \mathrm{HRB}$.

3) Toda expropriação deveria ocorrer a "puertas cerrada", ou seja, sem reserva patronal.

4) Defendiam a expropriação imediata de todos os terrenos abandonados e mal cultivados e a recuperação de 82 mil hectares de terras usurpadas dos mapuche, dos quais somente 7.300 tinham sido devolvidos (Steenland, 1977: 149).

5) Escreveram: "Que os conselhos comunais campesinos sejam a autoridade máxima em seu setor na condução e aplicação da reforma agrária", ${ }^{1223}$ o que os colocava em disputa com os organismos do agro o poder de decisão, para além do diálogo.

6) Dentro da política construída pela UP, defendiam a "integração rápida e eficaz dos funcionários do agro no campo", ou seja, a ruralização dos técnicos que deveriam viver junto aos camponeses com quem trabalhariam.

7) Lutavam pela "plena participação do CCC na planificação da produção agropecuária", evocando as ferramentas exercitadas na pedagogia do território.

8) Advogavam por uma "lei indígena que realmente proteja os interesses mapuches", já que a lei aprovada no congresso distorcia algumas reivindicações indígenas entregues a Allende em dezembro de 1970.

9) Além disso, exigiam que "os encarregados de aplicar a lei indígena sejam todos mapuches".

10) Que os CCC deveriam ser financiados com $1 \%$ do orçamento de todos os organismos do agro.

11) Que os CCC tivessem personalidade jurídica via projeto de lei, para garantir sua perenidade.

12) Que a contabilidade dos assentamentos e CERA fosse controlada pelos CCC, e que se transferisse o poder da assembleia de assentados para o território externo ao assentamento, indo além do excedente do CERA a um fundo comunitário de desenvolvimento comunal.

Em janeiro de 1973, um Encontro Nacional de Conselhos Comunais Camponeses ocorreu em Chillán, organizado pelo Conselho Provincial de Ñuble. Foram mais de 500 delegados de todo país, porém mais de 10 mil camponeses participaram como observadores, sem voto. ${ }^{1224}$ Nesse encontro, foram debatidas as diferentes experiências de funcionamento dos mais de $170 \mathrm{CCC}$ ativos naquele momento, bem como a necessidade de incorporar e aproximar os sindicatos da ação territorial e unitária dos camponeses dos conselhos, junto com diversas reivindicações que apontavam no mesmo sentido das resoluções de Cautín. O movimento indígena, nesse sentido, se tornou uma vanguarda da política camponesa para os conselhos comunais campenses em todo território chileno. O Encontro de CCC, narrado e presenciado por Bastías Rebolledo (2016), revelou o transbordamento das mobilizações

\footnotetext{
1223 Id., ibid.

${ }^{1224}$ En Chillán, encuentro nacional de los consejos comunales campesinos, La Nación, Jan/1973. En Ñuble: Congreso Nacional de Consejos Campesinos La Nación, Jan/1973.
} 
camponesas no sentido da constituição do poder popular territorial, onda que já não poderia ser contida ou controlada por nenhum partido ou força política.

O vínculo dos miristas com os mapuche foi atravessado pelo tema da educação revolucionária. A educação teve um papel fundamental na conformação de nexos políticos entre miristas huincas e indígenas, além de acobertar atividades de conspiração revolucionária, que eram disfarçadas de "aulas" e "escolas". Efetivamente os miristas realizaram "escolas de formação política" na Araucanía, com propósito de fortalecer os conselhos pela base como ferramenta de poder popular e construção da dualidade de poder (o que implicava também a necessidade do treinamento militar, que não chegou a ser sistemático).

As escolas de formação política do MIR propunham uma visão marxista da história, a crítica da ideologia nacional burguesa e a necessidade da luta popular para construção do socialismo. Assim se recorda um líder do MCR, Victor Morfinqueo, que participou como aluno de uma escola de formação ideológica do MIR:

Na escola, tinham nos ensinado história, mas esta que ensinam em todos os colégios: a história burguesa chilena. O professor [mirista] nos deu a entender que a história oficial que havíamos aprendido era parcial. Esse homem nos entregou uma história de outro ponto de vista. (...) Falava que a única maneira que os mapuche poderiam sobreviver era com o trabalho coletivo, que o minifúndio era uma doença das comunidades mapuche e que buscando uma forma de trabalho coletivo e organizado poderíamos superar a miséria (Morfinqueo apud Navarrete Vergara, 2017: 65).

O pesquisador Cristóbal Bize encontrou fotografias no Arquivo Documental do Centro Cultural, Museu e Memoria de Neltume, na província de Panguipulli, que retratam aulas da escola de formação ideológica do MIR. Nas lousas de papel, em casebres de madeira iluminados com lampião, é possível ver rabiscados os conceitos marxistas como "meios de produção", "meios de trabalho" e "maisvalia", ao lado de um pôster com o rosto do Che, do Fidel, do Lênin e do Ho Chi Min. Tais fotos ajudam 
a imaginar o clima das aulas de formação política da esquerda radical no sul do Chile junto aos camponeses indígenas e huincas.
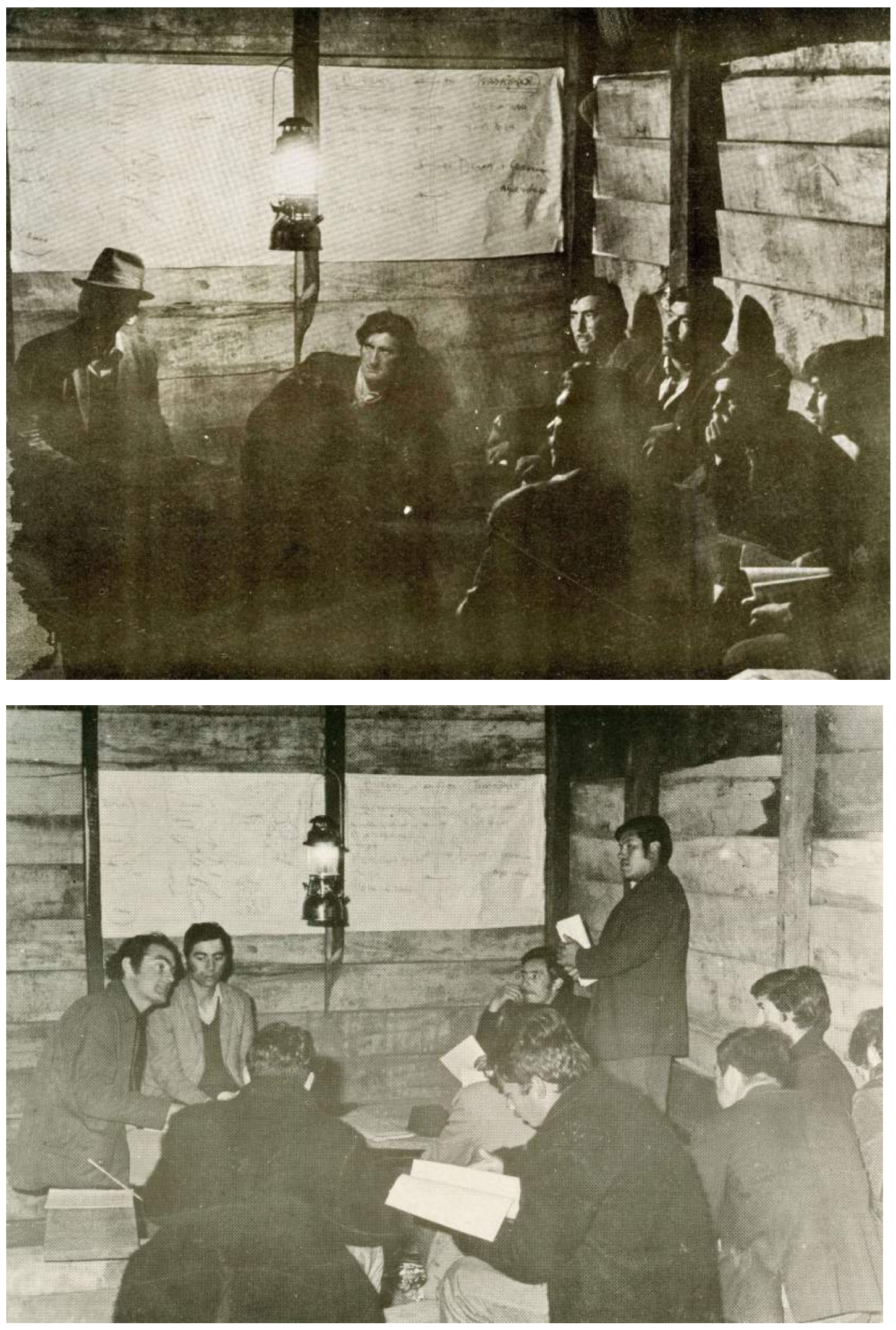

Neltume. 1972. Archivo del Centro Cultural Museo v Memoria de Neltume via Cristóbal Bize. 

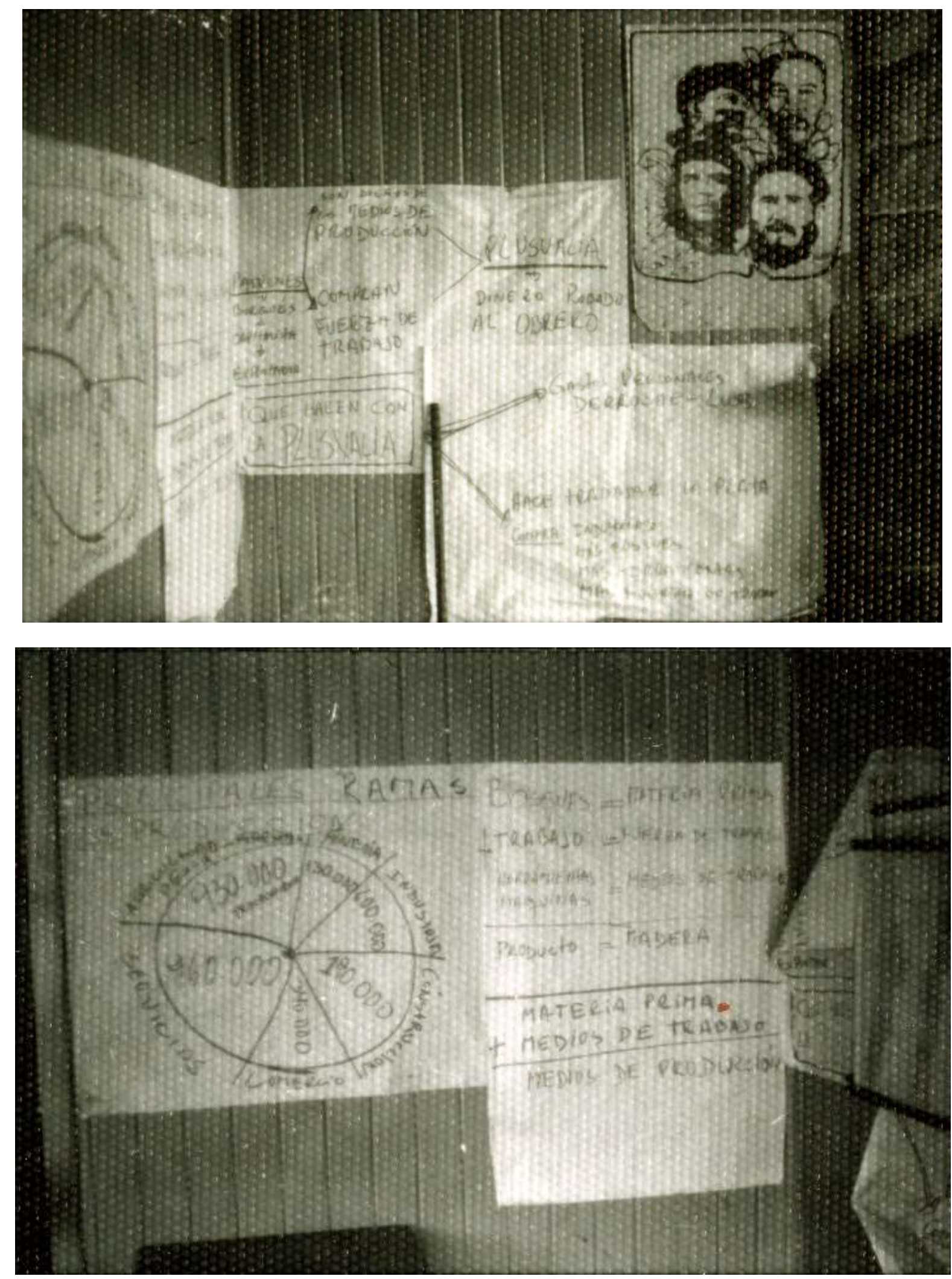

Neltume, 1972. Archivo del Centro Cultural Museo y Memoria de Neltume via Cristóbal Bize. 


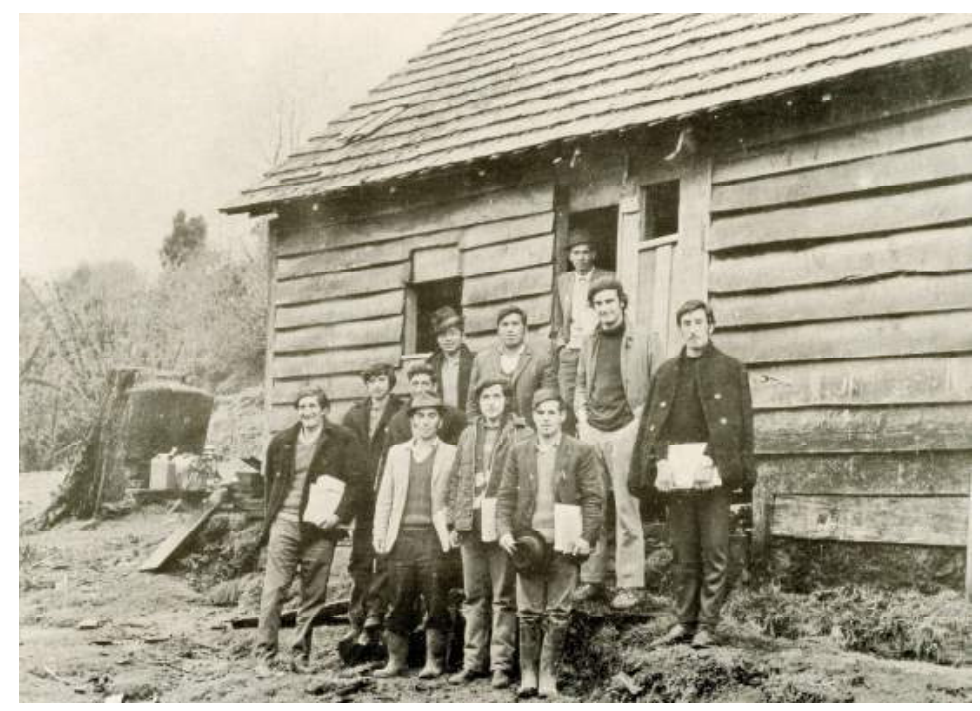

Neltume, 1972. Archivo del Centro Cultural Museo y Memoria de Neltume via Cristóbal Bize.

Como mostram os relatos de Julián Bastías (2009, 2016), muitas vezes a primeira estratégia de aproximação dos miristas com as comunidades mapuche foram pelo "disfarce" do professor. Como explicou Navarrete Vergara (2017: 58), tais militantes buscavam um vínculo orgânico e uma convivência prolongada com as comunidades, vivendo junto delas durante meses ou anos. Foram acolhidos e conquistaram confiança de comunidades mapuche, com uma dedicação militante abnegada, que os fazia abandonar seus cursos universitários e suas vidas urbanas para viver dentro das rucas. Entre as práticas de confiança estavam as escolas de formação política. Segundo Navarrete Vergara (2017: 64), "durante essa aproximação entre camponeses pobres e militantes, foi significativa a constituição de algumas 'oficinas' de formação política, que lhes permitiu ordenar sistematicamente o conjunto de reivindicações e demandas dos trabalhadores agrícolas" e que "aportaram uma perspectiva socialista ao processo de formação de uma frente camponesa em terras mapuche".

A distância da realidade mirista e mapuche era um desafio político pedagógico. Gustavo Marín conta que em 1970, os mapuche com quem vivia em Loncoche escutaram pela primeira vez sobre a CORA e pensaram que se tratava de uma senhora. ${ }^{1225}$ Também se recordou quando estava em uma marcha do MCR em Temuco, acompanhado de amigas jovens indígenas, que quando avistaram um lençol com o rosto do Che desenhado, pensaram que sua boina era um lago: "elas não viam o rosto do Che, porque não estavam acostumadas a esta imagem, não a conheciam e não poderiam fazer essa abstração", ${ }^{1226}$ contou Marín. Miristas e indígenas realizaram um processo mútuo de alfabetização política, no qual os marxistas precisavam aprender da cultura mapuche para dela apreender sua radicalidade territorializada, enquanto os segundos se aproveitavam da cultura política dos primeiros para refletir com novas categorias sobre as injustiças da sua própria realidade e a economia política do capitalismo.

Segundo Florencia Mallon, embora a reforma agrária fosse impulsionada por uma epistemologia classista, a coesão étnica-comunitária e os laços de solidariedade entre os territórios mapuche foram fundamentais para impulsionar a luta camponesa no Sul. No entanto, pela alta

${ }^{1225}$ Entrevista com Gustavo Marin, Santiago, 20/04/2017.
${ }^{1226}$ Id., ibid. 
capacidade de adaptação criativa das comunidades indígenas, o substrato étnico que viabilizava a identidade e a ação coletivas nem sempre esteve visível na superfície, porque a luta classista se sobrepunha pela linguagem do Estado e dos partidos de esquerda (Mallon, 2004). A radicalidade do MCR, que articulava marxismo e luta mapuche, junto da onda de tomas autônomas do sul (Redondo, 2017), originou escolas de formação política concomitantes à luta territorial. O MIR criou escolas de capacitação camponesa, misturando intuição político-pedagógica, imersão nas comunidades e o método de Paulo Freire, com quem se relacionou diretamente antes da eleição de Allende. Algumas das escolas miristas de formação política da Araucanía coincidiram com acusações de focos guerrilheiros inexistentes difundidas pela imprensa patronal, como o Diario Austral de Temuco. Foi o caso da invasão militar ao assentamento Arnoldo Ríos, da comunidade Nicolás Ailío, acusado de comportar uma "escola de guerrilha rural", onde na realidade funcionava uma escola de formação política, na qual existiam armas exclusivas de uso pessoal e defensivo. Lá, como relata Mallon, as torturas começaram antes do golpe de 11 de setembro.

\subsection{Considerações finais}

O impasse da reforma agrária chilena alcançou um grau máximo em 1973, quando um setor significativo da UP e das esquerdas estavam convictos da necessidade de uma nova lei de reforma agrária, sem que houvesse nenhuma condição objetiva de aprovação de qualquer lei, dada a postura cada vez mais sediciosa da oposição no congresso. O boicote patronal e a violência proprietária se intensificaram, o estrangulamento orçamentário do agro tornou o processo capacitador cada vez mais atropelado pela guerra ideológica e territorial. Os camponeses mobilizados seguiram construindo um caminho próprio fortalecendo o poder dos $\mathrm{CCC}$, da maneira como podiam. A quantidade de estudantes disponíveis para o trabalho voluntário rural se expandia conforme se acirrava o processo revolucionário.

Entre 1971 e 1973, 182.733 trabalhadores chilenos foram alfabetizados, o que proporcionou uma queda $29 \%$ do analfabetismo absoluto em relação a 1970 em pouco menos de um terço de governo (Austin, 2003: 178). Havia fortes indícios de que a meta de erradicação do analfabetismo seria alcançada antes dos 6 anos de mandato de Allende.

No caso da alfabetização rural, não se dispõe de dados específicos exclusivos do governo da UP, pois muitos registros se perderam na destruição da ditadura. Em 1973, os militantes da educação e da reforma agrária pareciam perceber a necessidade de mudanças basais na condução da capacitação camponesa da UP. Gajardo e Silva indicavam: "é necessário mudar radicalmente a orientação da educação camponesa para colocá-la a altura do processo que hoje vive o país, especialmente na agricultura". ${ }^{1227}$ A velocidade da revolução ultrapassava a capacitação camponesa, e isso dificultava a

${ }^{1227}$ Marcela Gajardo y Alberto Silva. Capacitación: un problema por resolver. Revista Agraria, n. 5. In: Chile Hoy, n. 51, Maio/1973. 
sincronia entre os tempos pedagógico, o tempo da tomada do poder e o tempo da organização popular. Os autores prosseguiam: "a estruturação do trabalho capacitador foi adquirindo um estilo burocrático, já que se tratava pura e simplesmente da divulgação de mensagens desenvolvimentistas (...) entregues pelas direções políticas". Essa burocratização fomentou um tipo de atividade "tecnicista e desmobilizadora". ${ }^{1228}$ Aparentemente, todos os setores da UP estavam insatisfeitos com os rumos da capacitação camponesa em 1973, possivelmente devido ao desencontro paulatino entre capacitação e revolução e a uma dificuldade de sincronização do tempo pedagógico com a velocidade revolucionária.

Na primeira semana de setembro de 1973, o FEES organizou uma viagem de quase 100 jovens camponeses à União Soviética, em um convênio no qual participariam de cursos de capacitação para aprender a utilizar máquinas agrícolas importadas da Romênia e Bulgária pelo governo Allende. "Chegaram as máquinas dos países socialistas, (...) mas não havia gente capacitada para manejar estas máquinas!”, recordou Oscar Torres: “os partidos, especialmente o PC, criaram essa ideia de mandar jovens camponeses à URSS para que se capacitassem". ${ }^{1229}$ Um desses jovens era sobrinho de Alicia Muñoz, que aos dez anos foi retirada à força da escola para trabalhar sem remuneração na casa patronal do latifúndio Aguar Fria nos anos 1950. Os jovens foram preparados pelo FEES para viagem e Alicia acompanhou seu sobrinho ao aeroporto: "estavam muito alegres", contou Alicia, "sabiam que iam em busca de capacitação para voltar ao processo de construção do socialismo em seu país, com uma missão a cumprir" (Muñoz, 2020). Alicia e seu sobrinho, nascidos inquilinos de fundo, nunca tinham ido ao aeroporto: "tenho a viva lembrança de chegar ao aeroporto e ver pela primeira vez um avião tão de perto" (Muñoz, 2020). O golpe aconteceu poucos dias depois e os jovens já não puderam retornar para sua missão revolucionária no Chile.

A alfabetização rural durante o governo da UP, com a adaptação do método de Paulo Freire a partir de uma perspectiva mais diretiva da revolução, as multidões de jovens nos trabalhos voluntários que proporcionaram a aliança estudantil-camponesa, e os processos de aprendizagem criados nos conselhos comunais camponeses, que ecoavam a pedagogia do território, foram fenômenos sociais complexos, que mobilizaram a estrutura de sentimento da revolução, a batalha da consciência solidária e coletiva e a luta pelo poder popular. Todos esses movimentos, segundo argumentamos, podem ser entendidos como parte da batalha político-pedagógica da revolução chilena no campo, que ocupam centralidade no processo econômico da via chilena ao socialismo.

1228 Id., ibid.

${ }^{1229}$ Entrevista a Oscar Torres, Maipo, 26/05/2019. 


\section{Epílogo}

"Com o golpe militar, foi como se o mundo inteiro tivesse despencado. Eu não conseguia entender: como puderam matar o presidente? Era nosso presidente, o presidente do povo chileno, o único que foi acessível e que visitava os povoados rurais. Nós descíamos a cordilheira no caminhão e víamos o presidente bem perto. Até que o mataram".

- Alicia Muñoz, camponesa de Curicó ${ }^{1230}$

O golpe militar que matou Salvador Allende começou em Cautín no dia 30 de agosto de 1973, quando foram registrados os primeiros casos de tortura contra camponeses e indígenas executados por membros das Forças Armadas, 12 dias antes do bombardeio ao Palacio de La Moneda (Steenland, 1977; Mallon, 2004). A revista Chile Hoy reportou 24 operações militares (allanamientos) em Cautín entre 30 de agosto e 2 de setembro, com militares que invadiram assentamentos, CERA, CEPRO e comunidades indígenas. As FFAA também invadiram a sede do PS, o Comando Comunal Campesino criado em outubro de 1972 para sanar a crise de abastecimento, os escritórios das instituições do agro e indústrias da Área de Propriedade Social. A pretexto da Lei de Controle de Armas, as operações foram comandadas pelo coronel Pablo Iturriaga, da Infantaria de Tucapel, e pelo comandante Rigoberto Pacheco, do Grupo de Helicópteros da Força Aérea, "ambos de conhecida trajetória golpista", ${ }^{1231}$ assegurava a repórter Faride Zerán. Na capa da edição 65 de Chile Hoy, de 7 a 13 de setembro, o rosto expressivo de Margarita Paillal, líder mapuche de 30 anos, mãe de sete filhos, denunciava: "torturas em Cautín". Uma manchete destacava a fala de Paillal: "estamos mais bravos do que nunca e com mais vontade de lutar", dizia a líder indígena. ${ }^{1232}$ A jornalista Faride Zerán, que entrevistou Margarita e produziu a matéria, recorda-se até hoje que naquela semana ficou angustiada com a possibilidade de que a exposição de capa, editada quatro dias antes do golpe, colocasse a dirigente mapuche ainda mais em risco (Zerán, 2020).

No dia 30 de agosto, na comuna de Neuhuentúe, "militares instalaram seu centro de operação na ex-casa patronal do CEPRO Jorge Fernández, utilizando o terceiro andar da mansão para manter camponeses presos e torturá-los", ${ }^{1233}$ explicava a reportagem. Mais de 30 militares participaram da operação só naquela propriedade da reforma agrária, na qual foram violadas casas camponesas de 54 famílias, onde viviam cerca de 300 crianças. Iturriaga acusava o CEPRO de ser um "acampamento

${ }^{1230}$ Entrevista com Alicia Muñoz, Santiago, 14/05/2017.

${ }^{1231}$ Un nuevo montaje de la derecha. Chile Hoy, n. 65, Set./1973.

1232 Id., ibid.

1233 Id., ibid. 
guerrilheiro" do MCR, o que era falso. Enquanto os camponeses eram mantidos presos na casa patronal, helicópteros sobrevoavam a propriedade como forma de intimidação. Alguns dirigentes indígenas

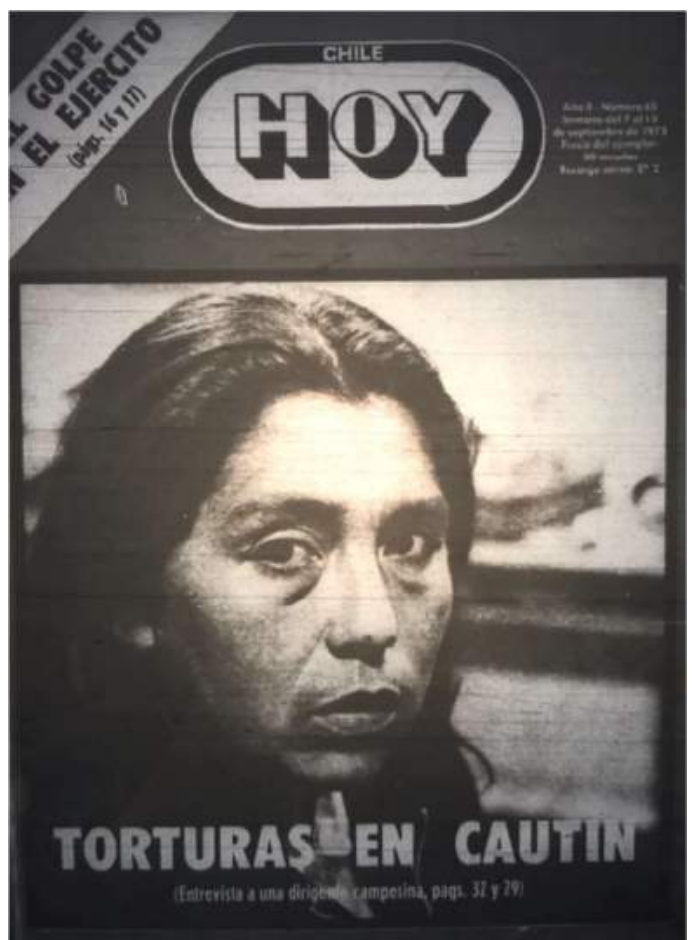

Torturas en Cautín. Chile Hoy, n. 65, 07 a 13/09/1973. foram enlaçados na cintura por uma corda e carregados pelo helicóptero sob ameaça de que seriam arremessados ao chão.

Margarita Paillal era assistente rural voluntária do posto de saúde estabelecido na casa patronal e tinha livros de educação para saúde. Quando os militares invadiram sua casa, encontraram 4,2 mil escudos dentro de um livro e a roubaram. Depois, "se apossaram da casa patronal", contou Paillal: "foram bruscos, companheira. (...) Quando entraram na casa patronal, onde estava o posto de saúde, (...) quebraram tudo. Jogaram os medicamentos no chão", ${ }^{1234}$ contou. Os camponeses foram enfileirados e os dirigentes do CEPRO foram levados ao terceiro andar da casa, onde começaram as torturas. Paillal ficou do lado de fora e escutou os gritos: "os militares vinham trazendo uma máquina elétrica", ${ }^{1235}$ disse. Com os gritos de dor dos seus amigos e do seu marido, Paillal desmaiou: "sou mulher e tenho consciência, senti por todos os meus companheiros de classe", ${ }^{1236}$ explicou. Durante 4 dias e 4 noites, os militares se comportaram como donos de tudo: "faziam o que queriam". Os torturadores pediam informações sobre miristas e armas. Mas "não havia armas", garantia Paillal, "estas armas que saem nos jornais foram postas por eles mesmos (...). Não havia armas nem quando ocorreu a toma no ano passado (...). As armas que usamos eram paus (...). Os jornais mentem!”. E acusava: "Por que não tiram fotos dos companheiros torturados?”. ${ }^{1237}$ As mulheres e crianças ficaram sem comer e sem dormir: "nossa terra ficou regada de lágrimas, companheira, e até agora é preciso seguir assim, porque os companheiros ainda estão presos (...). Os companheiros da comuna de Puerto Saavedra, querem saber se o Presidente permite ou não essas coisas contra o povo que o elegeu". ${ }^{1238}$ Para desgastar Allende e confundir os trabalhadores, os militares golpistas repetiam que tinham ordem presidencial para realizar a operação. Por isso, as vítimas da tortura foram até Santiago cobrar Allende e obrigá-lo a punir os responsáveis. No 11 de setembro, o marido de Margarita já estava ilegalmente preso havia 12 dias.

\footnotetext{
${ }^{1234}$ Id., ibid.

1235 Id., ibid.

1236 Id., ibid.

1237 Id., ibid.

1238 Id., ibid.
} 
A ditadura reprimiu camponeses e funcionários do agro com grande rapidez, e logo passou a identificá-los como parte dos inimigos prioritários. O relatório da Comissão Nacional da Verdade e Reconciliação de 1990 (Informe Rettig) notificou que em três meses e meio de ditadura (de 11 de setembro a 31 de dezembro), 285 camponeses e 31 funcionários do agro foram mortos e desaparecidos. ${ }^{1239}$ As mortes e desaparições de camponeses daqueles meses correspondeu a $85 \%$ do total registrado em toda ditadura (324 vítimas fatais). No caso dos funcionários do agro, corresponderam a $60 \%$ das 51 vítimas fatais do período ditatorial.

A Comissão Valech 1, que investigou prisões e torturas da ditadura, diluiu a condição camponesa em diferentes categorias: "trabalhadores não qualificados" (5.681 presos), "pequenos empresários agrícolas" (357 presos), "trabalhadores qualificados do agro" (153 presos) (Chile, 2004: 563). O mesmo ocorreu na Comissão Valech 2: "trabalhadores não qualificados" (1.596 presos), "pequenos empresários agrícolas" (136 presos) ou trabalhadores qualificados do agro (139 presos) (Chile, 2011: 44). Portanto, não é possível ter certeza sobre a quantidade de camponeses presos e torturados pelos militares, inclusive pela subnotificação.

Os camponeses mais mobilizados e atuantes na reforma agrária, que responderam às convocatórias de participação popular feitas tanto pelo governo da DC, quanto da UP, foram os mais penalizados pelo decreto 208 da ditadura militar, de 19 de dezembro de 1973, que proibia que participantes de greves rurais e tomas de terra fossem beneficiados com parcelas da reforma agrária. Esses foram os primeiros 5 mil camponeses excluídos da terra pela Junta Militar por motivos políticos, junto com os trabalhadores rurais filiados a partidos da esquerda (Lira \& Loveman, 2002: 132). O impacto da contrarreforma agrária, contudo, foi 5 vezes mais amplo contra os trabalhadores rurais. Segundo o relatório de Sergio Fuenzalida, José Maria Bulnes e Victor Toledo, ${ }^{1240}$ a ditadura expulsou das terras da reforma agrária 50.277 camponeses beneficiários, sendo 25.349 vinculados a assentamentos com expropriação revogada, 5 mil eliminados pelo decreto 208 e 19.928 camponeses que postularam parcelas, mas foram rechaçados. O novo sistema de pontuação criado pela ditadura desfavorecia o campesinato e beneficiava empresários, proprietários, burocratas e técnicos agrários do alto escalão, que obtiveram parcelas com facilidade (Bulnes et. al, 2003: 150).

A contrarreforma agrária atuou reconcentrando as terras da reforma agrária de diferentes maneiras: $34 \%$ da superfície da reforma agrária foi devolvida aos seus antigos donos, que recuperaram integral ou parcialmente suas propriedades; $20 \%$ da superfície foi transferida a proprietários privados por leilões

\footnotetext{
${ }^{1239} \mathrm{O}$ relatório Rettig não oferece agregados por tipo de vítima, o número foi verificado manualmente pela autora.

${ }^{1240} \mathrm{O}$ relatório foi elaborado por contrato e encomenda do Minagri do governo de Ricardo Lagos, entre 2000 e 2003. Seu objetivo era fundamentar uma política de reparação camponesa que nunca ocorreu. $\mathrm{O}$ relatório e o estudo piloto anterior (Bulnes et. al., 2000) foram engavetados. A história detalhada desses relatórios e uma argumentação historiográfica a respeito da espoliação da terra como violação de direitos humanos foi sintetizada em artigo que publiquei na revista Historia Agraria (Vasconcelos, 2020c).
} 
e outros procedimentos ilegais; $10 \%$ da superfície foi apropriada por organismos públicos, muitos deles controlados pelos próprios militares, como as Forças Armadas ${ }^{1241}$ ou a Corporação Nacional de Florestas (CONAF), presidida pelo genro de Pinochet, Julio Ponce Lerou. Ao somar-se as terras que permaneceram sem destinação oficial, nota-se que $70 \%$ das terras da reforma agrária foram retiradas dos camponeses pela ditadura, como mostra o gráfico a seguir.

\section{Contrarreforma agrária no Chile (1973-1990)}

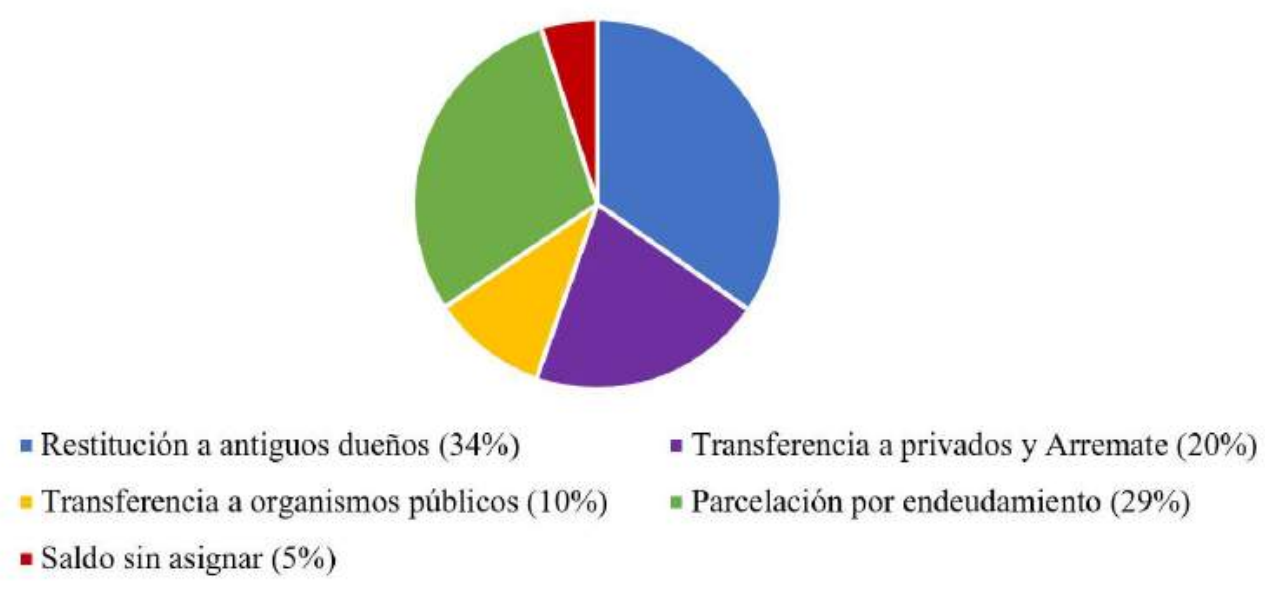

Fonte: Elaboração própria com base em Bulnes et. al., 2003: 121-122). Publicado em Vasconcelos, 2020c.

Os $29 \%$ das terras da reforma agrária parceladas entre camponeses pela ditadura foram suficientes para que Bellisario (2007a, 2007b) caracterizasse a política agrária da Junta Militar como uma “contrarreforma agrária parcial". No entanto, como mostraram Echeñique e Rolando (1991: 16), o livre mercado de terras aberto em 1980 foi avassalador para os camponeses parceleiros. No primeiro ano da redemocratização, em 1991, os autores calculavam que 57\% das parcelas camponeses vendidas pela ditadura já não estavam mais em mãos camponesas, o que correspondia a 21 mil famílias e 10\% das terras da reforma agrária. Os camponeses foram duplamente endividados pela ditadura. Primeiro, as parcelas de terra foram vendidas pela ditadura sem qualquer assistência creditícia ou técnica, o que criou dívidas para famílias camponesas que já estavam seriamente descapitalizadas. Segundo, as grandes dívidas do setor reformado recaíram sobre os bolsos dos assentados individualmente, fossem eles recebedores de parcelas ou não, muito embora todos tenham sido encorajados pelo próprio Estado a se endividar para expandir a produção durante os dois governos anteriores. Por isso, no gráfico anterior utilizei a categoria de "parcela por endividamento", já que a venda de parcelas aos camponeses pela ditadura não deve ser confundida com uma "reforma agrária", mas sim com um processo sistemático de opressão por dívida concomitante ao terrorismo de Estado.

${ }^{1241}$ Sobre as terras da reforma agrária apropriadas pelas Forças Armadas, escrevi duas reportagens com Claudia Urquieta para o CIPER: Urquieta \& Vasconcelos, 2018a, 2018b. 
Milhares de camponeses endividados sofreram toda sorte de abusos, mais tarde investigados por Bulnes et. al. (2000, 2003). Camponeses analfabetos foram forçados a assinar contratos sem que soubessem o que estava escrito; outros contratos eram anunciados como se fossem de arrendamento, mas na realidade eram contratos de venda; camponeses foram forçados por patrões e militares a assinar papéis em branco, que seriam preenchidos depois. Portanto, não me parece plausível o eufemismo "contrarreforma agrária parcial" para descrever o que ocorreu (como argumentei em Vasconcelos, 2020c). Os $29 \%$ de superfície da reforma agrária vendidas aos camponeses pela ditadura rapidamente foram passados para outras mãos, o que fez com que restasse uma pequena minoria de trabalhadores rurais beneficiada, junto de burocratas, técnicos e militares que compraram parcelas.

$\mathrm{O}$ analfabetismo, naquele momento, aprofundava ainda mais a situação de vulnerabilidade do campesinato. Sobre isso, Rogelio Correa, que desde 1958 era professor de camponeses do IER e da CORA, nos relatou uma história. Correa era mapucista, mas continuou no seu emprego da CORA depois do golpe, e ali permaneceu enquanto não foi demitido. Por isso, participou do processo de pontuação e seleção de camponeses para a controversa parcela vendida pela ditadura. "Em todas as zonas, havia um chefe de segurança do agro, que era um militar e estava encarregado de aplicar o 208”, explicou: "o chefe militar ia direto à propriedade conversar com o patrão, que lhe apontava: "este é comunista, este é socialista"”. ${ }^{1242} \mathrm{O}$ trabalho de Correa, naqueles anos, era listar as pontuações dos camponeses. "Compliquei o máximo possível o 208”, narrou Correa:

Me chegavam fichas de camponeses com o 208. Muitas vezes o camponês tinha assinado com seu dedo, vinha um carimbo escrito eliminado e o relatório justificava dizendo que era um marxista-leninista. Eu ia conversar com o capitão: 'Capitão, você já leu O capital, de Marx? Pois para ser marxistaleninista, primeiro é necessário ler O capital. São as obras mais complicadas do mundo. Olhe, aqui há um camponês que não sabe ler nem escrever, mas é marxista-leninista. Isso é impossivel!', eu dizia. E o capitão: 'esses carabineiros huevones'. E eu pedia: 'simplesmente, faça um relatório dizendo 'Sem Antecedentes". E pronto: eu salvava o camponês do 208". ${ }^{1243}$

Ao atuar por dentro de um regime autoritário e ao correr risco de ser perseguido ou muito mal interpretado por seus companheiros da esquerda, Correa assegura que Linares teria sido a província com menos camponeses eliminados da terra pelo 208, em razão da sua arriscada atuação. Em geral, ele não sabia quem eram os camponeses que ajudou. Mas logo foi apelidado pelos próprios militares da CORA em Linares de "pai dos camponeses".

1242 Entrevista com Rogelio Correa, Santiago, 30/05/2019.
${ }^{1243}$ Id., ibid. 
"Neste momento, não podemos dar educação rural, porque não temos como. Devemos ajustar os recursos que temos para alcançar o máximo de eficiência", ${ }^{1244}$ declarou o Almirante José Toribio Merino, um dos mais perigosos articuladores do golpe, em uma reunião da Junta Militar em 14 de setembro de 1974. A educação camponesa dos organismos de Estado foi desmontada durante a ditadura.

Entre 1979 e 1980, a CORA foi convertida na Oficina de Normalização Agrícola (ODENA), que se encarregou dos leilões de $25 \%$ das terras do setor reformado (Bellisario, 2007a). Seu departamento de educação foi destruído. O INDAP seguiu existindo, mas com um setor educacional praticamente nulo, controlado por uma agenda tecnocrática e esmagado por um ajuste fiscal. A repressão custava aos cofres públicos, e ajustes foram promovidos para custeá-la. Os militares sequer sabiam o que era o FEES: "parece-me que o ministério do Trabalho tem um instituto de capacitação camponesa", ${ }^{1245}$ arriscou o ministro da agricultura na reunião da Junta Militar, nitidamente sem saber do que estava falando. O subsecretário do trabalho explicou de onde vinha a arrecadação do FEES. Seu mecanismo distributivo de renda e sua lógica de reparação histórica para o campesinato não teria qualquer possibilidade de existência na ditadura. Na mesma reunião, o ministro da Agricultura argumentou: "o IER tem 32 centrais ao longo do país. É um organismo, até certo ponto, confiável”, ${ }^{1246}$ o que sugeria uma possível parceria. Mas o tema estava longe de ser considerado relevante para os generais.

O desmonte da educação camponesa de adultos na ditadura foi avassalador e deixou desamparados a dezenas de milhares de camponeses engajados em processos educacionais. "O ICIRA desapareceu em 1982, foi cancelado como projeto", ${ }^{1247}$ explicou Rolando Pinto. Nos anos 1980, segundo se recordou Valdemar Cortés Carabantes, um funcionário do Mineduc chamado Hector Urrútia teria criado uma versão do método psicossocial com situações existenciais bíblicas. Obviamente, nenhuma pedagogia libertadora seria compatível com o regime repressivo, que pode ter utilizado fragmentos de técnicas freirianas com propósitos opostos (Carabantes apud Austin, 2004: 18).

Camila Montecinos, estudante de agronomia da U. Chile entre 1972 e 1975, se lembrou que "depois do golpe desapareceu qualquer educação relacionada à agricultura camponesa. Me lembro que em uma das primeiras aulas que tive depois do golpe, o professor disse: 'a primeira coisa que devem aprender é a cobrar pelo seu trabalho", contou a agrônoma. E criticou: "a ditadura criou esses consultores técnicos freelancer, que faziam boletos. Foi uma mudança brutal na nossa escola de agronomia". ${ }^{1248}$ Montecinos também se lembra de um professor de Economia agrícola, que era democrata cristão e dirigente do Colégio de Agrônomos, e para explicar os conceitos de oferta e demanda usava como exemplo debochado as sabotagens patronais para gerar inflação durante o governo de Allende. "O ovo era uma das proteínas mais baratas que o povo conseguia ter", lembrou Montecinos,

\footnotetext{
${ }^{1244}$ Chile, Junta de Gobierno. Acta 172-a, Secreto, 14/11/1974 (p. 17).

1245 Id., ibid.

1246 Id., ibid.

${ }^{1247}$ Entrevista com Rolando Pinto Contreras, Santiago, 23/05/2019.

1248 Entrevista com Camila Montecinos, Santiago, 14/05/2017.
} 
ressaltando a crueldade: "depois do golpe, esse professor contava com orgulho que os proprietários jogavam 200 mil ovos no lixo por dia e assim explicava o conceito de elasticidade de preços. Mas os alunos não podiam dizer nada: estávamos com o golpe sobre nossas cabeças, com gente presa e gente que começava a desaparecer". ${ }^{1249}$

Alicia Muñoz, a camponesa da epígrafe deste epílogo, conta que os militares invadiram o CERA onde ela morava e reprimiram seus companheiros, prendendo alguns e expulsando outros daquela terra onde sempre tinham vivido: primeiro como inquilinos, depois como camponeses livres. "Colocaram minha família na rua, todos tiveram que sair de lá e levaram o que puderam dos seus animaizinhos, porque não conseguiram vendê-los. Os militares foram expulsando os trabalhadores da terra como se fossem lixo", ${ }^{1250}$ lembrou. Alicia estava em Santiago no dia do golpe, pois recém havia deixado seu sobrinho no aeroporto para que partisse à URSS com o FEES e aprendessem a manejar as máquinas agrícolas do bloco soviético. A família de Alicia em Curicó, com numerosos irmãos e sobrinhos, não tinha para onde ir e se protegeu em uma igreja no povoado próximo, que os acolheu durante alguns dias. Estavam desterritorializados e arrancados das suas comunidades, perseguidos pelos militares e amedrontados por torturas. Depois, como ocorreu com muitas outras famílias camponesas, foram obrigados a se espalhar para sobreviver: alguns foram morar de favor, outros buscar trabalho em outra parte da província mais distante dos antigos patrões, outros se tornaram moradores de poblaciones callampa rurais, que receberam este nome porque cresciam como cogumelos nas beiras de estrada. "Hoje, as terras do CERA onde eu vivi estão com os filhos e netos dos primeiros donos, que são da alta elite. Já outra parte da propriedade, ficou com a CONAF", ${ }^{1251}$ explicou Alicia.

A Vicaría da Solidariedade foi criada em janeiro de 1976, como um braço da Igreja que combateu a ditadura de diferentes formas. A primordial e mais importante das suas missões era a amparar as famílias de pessoas desaparecidas e mortas pelo regime, com advogados, serviços jurídicos gratuitos, assistentes sociais e acolhimento psicológico. Ao longo dos anos, ao receber um fluxo de vítimas cada vez maior, a Vicaría formou um valioso arquivo sobre a repressão e seus agentes, que muito incomodou o alto escalão do generalato e dos carabineros. Em março de 1985, José Manuel Parada, o mais destacado advogado da Vicaría, foi encontrado assassinado pelos militares, que queriam ocultar suas descobertas. Por estar oficialmente protegida pelo cardeal Silva Henríquez, a Vicaría tinha conseguido até então expandir seu trabalho com relativa proteção e autonomia.

O Departamento Camponês da Vicaría da Solidariedade surgiu em 1976 e foi extinto em 1984. O órgão se organizava em três linhas de trabalho. Primeiro, a Unidade de Assessoria Jurídica, formada

\footnotetext{
${ }^{1249}$ Id., ibid.

${ }^{1250}$ Entrevista com Alicia Muñoz, Santiago, 14/05/2017.

1251 Id., ibid.
} 
por pouco mais de 30 advogados que recebiam milhares de camponeses ao ano e necessitavam proteção e assistência jurídica. Segundo, a Unidade Produtiva, que tinha como objetivo oferecer terras da igreja para que os camponeses reprimidos pela contrarreforma agrária formassem cooperativas e encontrassem meios de subsistência. Parte da produção alimentar dessas cooperativas (chamadas de "unidades de produção", na linguagem da autocensura) era destinada a refeitórios infantis criados pela Igreja nas poblaciones, nas quais também atuava outro departamento da Vicaría. A Unidade de Produção chegou a contar com entre 70 e 360 famílias camponesas, o que evidenciava o desequilíbrio entre a enormidade do desamparo (mais de 50 mil camponeses expulsos da terra) e a reduzida capacidade de apoio. Em terceiro, havia a Unidade de Capacitação Camponesa, que tinha como principal objetivo a capacitação empresarial para viabilizar a autonomia dos camponeses das unidades de produção, junto com cursos jurídico-sociais que ampliavam a consciência camponesa sobre como se proteger das arbitrariedades. ${ }^{1252}$

Assim, os múltiplos departamentos da Vicaría articulavam uma economia popular muito precária, mas ao mesmo tempo imprescindível para a sobrevivência de milhares de trabalhadores urbanos e rurais. As atividades de capacitação camponesa realizadas pelo Departamento Camponês Vicaría durante a ditadura estão sintetizadas na tabela 37.

\begin{tabular}{|c|c|c|}
\hline \multicolumn{3}{|c|}{$\begin{array}{c}\text { Tabela 37 - Capacitação Camponesa da Vicaría } \\
\text { da Solidariedade durante a ditadura (1976-1983) }\end{array}$} \\
\hline Ano & Jornadas e Cursos & Participantes \\
\hline $\mathbf{1 9 7 6}$ & 9 & 290 \\
\hline $\mathbf{1 9 7 7}$ & 33 & 1.100 \\
\hline $\mathbf{1 9 7 8}$ & 45 & 1.101 \\
\hline $\mathbf{1 9 7 9}$ & 29 & 1.200 \\
\hline $\mathbf{1 9 8 0}$ & 22 & 743 \\
\hline $\mathbf{1 9 8 1}$ & 13 & 279 \\
\hline $\mathbf{1 9 8 2}$ & 7 & 153 \\
\hline $\mathbf{1 9 8 3}$ & 5 & 89 \\
\hline Total & 163 & 4.955 \\
\hline $\begin{array}{l}\text { Vicaría de la Solidaridad, 1976, 1977, 1978, 1979a, 1979b, 1981, } \\
\text { 1982a, 1982b, 1982c, 1983. }\end{array}$ \\
\hline
\end{tabular}

A maioria dos cursos eram voltados para sobrevivência econômica das cooperativas camponesas fomentadas pela Vicaría: a prioridade era capacitação empresarial, técnico-produtiva, administrativa e jurídica. Também se realizavam jornadas de avaliação e criavam-se espaços educacionais que serviam também à cumplicidade de trabalhadores reprimidos. As jornadas de educação básica contemplavam a $5 \%$ a $15 \%$ dos participantes e em geral eram uma etapa niveladora em matemática e alfabetização para prosseguimentos dos cursos técnicos. Em 1981, começaram a ser inseridos cursos de capacitação sindical, produção comunitária e seminários de dirigentes, sobretudo articulados com capacitações juvenis, que recolocavam conceitos como "comunidade" e "dirigentes", que nos anos anteriores pareciam banidos da linguagem.

${ }^{1252}$ Vicaría de la Solidaridad. Ocho meses de labor, agosto 1976. Centro de Documentación. Doc. nº 0001700. Santiago, 1976. 
Num cenário de terra arrasada, a Unidade de Capacitação do Departamento Camponês permitia a criação de uma agenda positiva ao campesinato, ou como apostavam: "o programa de capacitação contribui (...) ao desenvolvimento e fortalecimento das organizações sindicais através de seminários de capacitação jurídica, de análise da realidade agrícola e, sobretudo, através do curso de formação técnicosindical". ${ }^{1253}$

Na recepção do Departamento Camponês, foram atendidas 10.603 pessoas apenas entre 1979 e 1981, mas a Vicaría contava com apenas 33 advogados para todas essas demandas. Foram assumidos não mais do que 2.098 conflitos judiciais, entre os quais $68 \%$ eram trabalhistas, $22 \%$ civil-patrimoniais e $10 \%$ penais, mas todos estavam impreterivelmente ligados à luta pela terra ou contra os abusos da classe proprietária. ${ }^{1254}$ Em 1982, um Simpósio Nacional sobre Sindicalismo Camponês reuniu camponeses traumatizados com a repressão, mas conscientes da necessidade de reorganização da sua luta e da unidade entre diferentes correntes políticas, inclusive aquelas que apoiaram o golpe, como a DC. O campesinato estava fragmentado e maltratado. A DC deixou de apoiar a Junta Militar em 1976 e suas bases camponesas também sofreram os impactos da repressão e da contrarreforma.

O Simpósio foi aberto com leitura de um poema camponês, que expressava de maneira cristalina os traumas que viveram e os desafios que tinham pela frente. ${ }^{1255}$

La contrarreforma agraria Nos causó grandes quebrantos

Emigraciones, por tanto

Y una enorme cesantía.

Pero la gran mayoría Aún se encuentra en el campo.

[...] Como pedir no se puede

Al olmo que nos dé peras

$\mathrm{Ni}$ que flores, la higuera

O las parras den claveles, Soldados ni coroneles

Hablarán nuestro lenguaje Y de capitán a paje

Cumplen la misma doctrina. Legislación campesina No es tela de ese ropaje.
[...] Hay miles de parceleros Que casi ya no producen,

Pues la dispersión conduce

Tan sólo al despeñadero.

El dependiente, el mediero

Y el mapuche están muy mal. En la lucha sindical

Todos debemos unirnos.

Salir de este gran martirio Es un común ideal.

Entonces el crecimiento Del sindicato es posible.

La cuestión es imprimirle Más confianza al movimiento.
[...] Volvemos a encontrarnos Las esperanzas renacen Puede ser que luego pasen Estas penurias del agro. Estos momentos amargos Con su cola de secuelas Cual cicatriz de viruela Aunque duela, pasarán. El humano en su crear Sacará pan de la tierra.

[...] Es del máximo interés $Y$ el futuro no me aterra Que los que labran la tierra Serán grandes otra vez.

A Vicaría foi, possivelmente, um dos espaços mais articulados de capacitação camponesa durante a ditadura, mas não foi o único. Criado em 1978, o Grupo de Investigações Agrárias (GIA) estava abrigado na Academia de Humanismo Cristiano, também sob proteção da Igreja, e tinha como objetivo realizar pesquisas sobre a situação agrária na ditadura e permanecer em contato com os camponeses, além de identificar suas necessidades mais imediatas. O Grupo chegou a contar com mais

\footnotetext{
${ }^{1253}$ Vicaría de la Solidaridad, Cuarto año de labor, doc. 0002608. 1979b, op. cit., p. 70.

1254 Mais detalhes sobre os atendimentos jurídicos da Departamento Campesino da Vicaría estão analisados em Vasconcelos, 2020c.Vicaría de la Solidaridad, Quinto año de labor, FDAVS, doc. 0002700, 1980, p. 70.

1255 Vicaría de la Solidaridad, Sindicato y Sociedad, ponencia en el Simposio Nacional sobre Sindicalismo Campesino, FDAVS, Documento, doc. 2145a. 1982c.
} 
de 50 pesquisadores e educadores e teve grande importância tanto nas ações de amparo de um campesinato violentado, como na pesquisa da situação social de miséria rural gerada pela contrarreforma agrária (Rivera \& Cruz, 1984).

Segundo a economista agrária Maria Elena Cruz, que trabalhou no GIA como pesquisadora durante 15 anos, era uma organização "composta por economistas, agrônomos, sociólogos, veterinários, engenheiros florestais, arquitetos, historiadores, geógrafos, formando um grupo de gente que discutia o modelo imposto, apesar das restrições da época". ${ }^{1256}$ Tais profissionais "produziam uma importante quantidade de publicações que se divulgavam (...) para jovens de distintas profissões e às organizações camponesas que se rearticulavam" nos anos 1980. Segundo Cruz, o GIA manteve uma pós-graduação informal, reunindo os pesquisadores militantes da reforma agrária e camponeses. A pesquisa aos poucos abriu espaço para a educação camponesa, pequenas jornadas de formação em campo e uma rearticulação silenciosa e

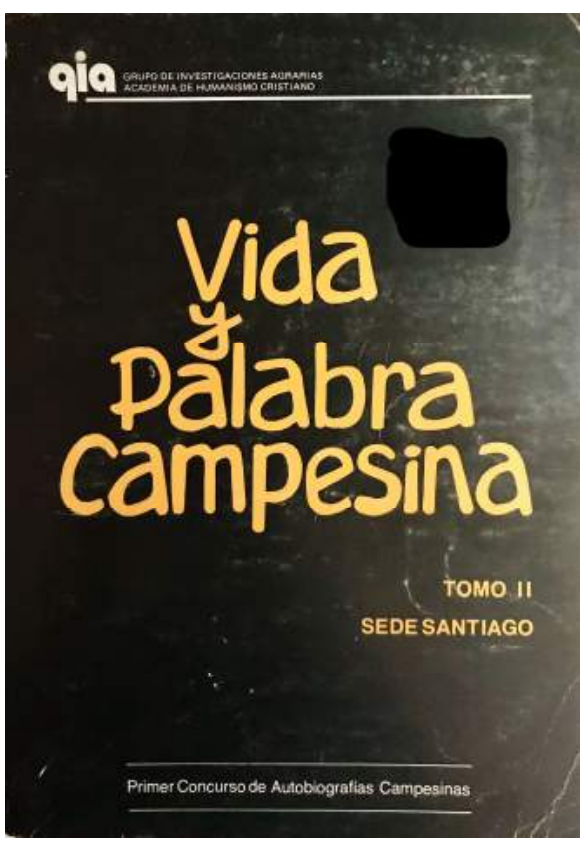

Primeiro Concurso de Autobiografias Campesinas, GIA, 1986. discreta entre pesquisadores e camponeses perseguidos.

“Estive no projeto 'Capitalismo e Campesinato', estudei a zona frutícola, participei de um projeto sobre a expansão florestal, realizei estudos sobre pobladores rurais e uma investigação sobre cidades intermediárias", recordou Cruz: "Como profissional, sempre estive disponível quando me convidavam a colaborar com organizações camponesas que se interessaram por nossas pesquisas". ${ }^{1257}$

Um dos projetos mais interessantes do GIA foi o Concurso de Autobiografias Campesinas, registrados em cinco tomos um total de quase 300 autobiografias de camponeses. Esse projeto evocava a ideia de que os "camponeses podem ser autores dos seus textos de leitura", como recomendava Freire duas décadas antes, e colocava a metodologia dos relatos de vida em prática, como fizeram as pesquisadoras do CEM. O GIA, aliás, tinha vocação freiriana e aos poucos expandiu sua atuação na educação popular.

A educação camponesa foi um componente estrutural dos processos econômicos e culturais de modernização, reforma agrária e revolução no campo chileno entre 1955 e 1973. Na ditadura, o Estado lançou o campesinato a um estado de exploração, perseguição e vulnerabilidade, subjugado pela aliança

${ }^{1256}$ Comunicação com Maria Elena Cruz por e-mail, 05/10/2020.

${ }^{1257}$ Id., ibid. 
orgânica entre proprietários, patrões e militares, que criaram uma versão ditatorial da modernização sem mudança no regime de propriedades. Como relatou um advogado do Departamento Camponês da Vicaría em 1982, na ditadura “o problema laboral adquiriu uma dimensão político-delitual, subversiva da ordem pública (...). Os setores patronais sentem claramente a segurança que lhes dá a autoridade pública, às suas posições e interesses, permitindo-lhes instalar um verdadeiro regime de terror entre os trabalhadores agrícolas". ${ }^{1258} \mathrm{O}$ terrorismo de Estado autorizava o terrorismo proprietário, ambos se fortaleciam reciprocamente para reinstaurar uma ordem de silêncio camponês, concentração fundiária e exclusão educacional.

O encontro cada vez mais amplo, plural e criativo entre agentes urbanos e camponeses, entre estudantes, professores rurais, sindicalistas, artistas, militantes e trabalhadores agrícolas na construção de um "Chile nuevo" foi desfeito com emprego de uma violência catastrófica. Mas como bem sabia a inteligência camponesa: "Aunque duela, pasarán. El humano en su crear sacará pan de la tierra".

1258 Vicaría de la Solidaridad, Departamento Campesino, Sistematización trabajo programa jurídico (octubre 1977-octubre 1982), FDAVS, doc. 0064200. 1983b. 


\section{Bibliografia}

ACUÑA, Lila. Hombres y mujeres en Putaendo: sus discursos y su visión de la historia. Santiago: Centro de Estudios de la Mujer, 1986.

AFFONSO, Almino; GÓMEZ, Sergio; KLEIN, Emilio; RAMÍREZ, Pablo. Movimiento campesino chileno. 2 tomos. Santiago de Chile: ICIRA, 1970.

. Vivemos no Chile o que havíamos amado ter no Brasil, mas não pudemos. In: AUSTIN HENRY, Robert; SALÉM VASCONCELOS, Joana; CANIBILO RAMÍREZ, Viviana (orgs.). La vía chilena al socialismo 50 años después: historia y memoria. Buenos Aires: CLACSO, 2020.

AHUMADA, Jorge. En vez de la miseria. 2a ed. Santiago: Editorial del Pacífico, 1958.

ALALUF, David; BARRAClOUGH, Solon. CORVALÁN, Antonio; ECHEÑIQUE, Jorge; MATTELARD, Armand; SAMPAIO, Plinio. Reforma Agraria Chilena: Seis ensayos de interpretación. Santiago: ICIRA, 1972.

ALtAMIRANO, Carlos \& SALAZAR, Gabriel. Conversaciones con Carlos Altamirano. Memorias críticas. $2^{\mathrm{a}}$ ed. Santiago: Editorial Debate, 2011.

AMARANTE JR., Ozelito; SANTOS, Teresa Cristina; NUNES, Gilvanda. Breve revisão de métodos de determinação de resíduos do herbicida ácido 2, 4-Diclorofenoxiacético (2, 4-D). Química nova, v. 26, n. 2, 223-229, 2003.

ARANTES, Paulo. O novo tempo do mundo e outros estudos sobre a era da emergência. São Paulo: Boitempo, 2014.

ARAVENA, Rodrigo \& DÍAZ-DIEGO, José. Paulo Freire en Chile (1964-1969): testimonios de exdirigentes campesinos durante la reforma agraria. Informes Fondo de Apoyo a la Investigación Patrimonial, n.. 18, 2016, 91-118.

ARROYO, Gonzalo. Después del latifundio, ¿qué? In: Mensaje, n. 113. Santiago, 1972.

AUSTIN, Robert. State, Literacy \& Popular Education in Chile, 1964-1990. Lanham, Md.: Lexington Books, 2003.

AVENDAÑO, Octavio. Los partidos frente a la cuestión agraria en Chile, 1946-1973. Representación de intereses, gradualismo y transformación estructural. Santiago: LOM, 2017.

BARAONA, Rafael; ARANDA, Ximena. \& SANTANA, Roberto. Valle de Putaendo: estúdio de estrutura agraria. Santiago: Instituto de Geografía de la Universidad de Chile, 1961.

BARRALOUGH, Solon. Estructura agraria y educación en América Latina. Santiago: CEPAL/UNESCO, 1962.

- ¿Qué es una reforma agraria? In: DELGADO, O. Reformas Agrarias en América Latina. Procesos y perspectivas. $1^{\mathrm{a}}$ ed. México/Buenos Aires: Fondo de Cultura Económica, 1965a.

Elementos para una teoría del cambio agrario. In: DELGADO, O. Reformas Agrarias en América Latina. Procesos y perspectivas. $1^{\mathrm{a}}$ ed. México/Buenos Aires: Fondo de Cultura Económica, $1965 \mathrm{~b}$.

\& FLORES, Edmundo. Tipos de tenencia de la tierra. In: DELGADO, O. Reformas Agrarias en América Latina. Procesos y perspectivas. $1^{\mathrm{a}}$ ed. México/Buenos Aires: Fondo de Cultura Económica, 1965.

; AFFONSO, Almino.; HERNANDÉZ, Silvia; ZEMELMAN, Hugo; GÓMEZ, Sergio; BENGOA, José. Chile: reforma agraria y gobierno popular. Buenos Aires: Ediciones Periferia, 1973.

. \& FERNÁNDEZ, José Antonio. Diagnóstico de la reforma agraria chilena. Cidade do México: Siglo XXI, 1974.

BARRERA, Manuel. Chile 1970-1972: La conflictiva experiencia de los cambios estructurales. Caracas: ILDIS, 1973.

BAYTELMAN, David. Problems of collective land exploitation in Chilean Agriculture. In: Chile at the turning point. Lesson of the socialists years, 1970-1973. In: GIL, F; LAGOS, R.; LANDSBERGER, H. Filadélfia: Institute for the Study of Human Issues, 1979.

BECA, Carlos Eugenio; RICHARDS, Cecilia; BIANCHETTI, Lucídio. Ernani Maria Fiori: professor brasileiro en tierras chilenas - testemonios. Educação e Realidade. Porto Alegre, v. 38, jul-set./2013, pp. 1021-1034.

BELLISARIO, Antonio, 'The Chilean Agrarian Transformation: Agrarian Reform and Capitalist 'Partial' Counter-Agrarian Reform, 1964-1980. Part 1: Reformism, Socialism and Free Market Neoliberalism', Journal of Agrarian Change, 7 (1), 2007a, p. 1-34.

'The Chilean Agrarian Transformation: Agrarian Reform and Capitalist 'Partial' Counter-Agrarian Reform, 19641980. Part 2: CORA, Post-1980 Outcomes and the Emerging Agrarian Class Structure', Journal of Agrarian Change, 7 (2), 2007b, p. $145-182$.

BENGOA, José. Movilización campesina: análisis y perspectivas. In: Chile: reforma agraria y gobierno popular. Buenos Aires: Ediciones Periferia, 1973, p. 217-244.

. El campesinado chileno después de la reforma agraria. Santiago: Ediciones Sur, 1983. 
. Poder y subordinación. Historia social de la agricultura chilena. Tomo I. 1 ${ }^{\text {a }}$ ed. Santiago: Ediciones Sur, 1988.

. Haciendas y campesinos. Historia social de la agricultura chilena. Tomo II. $1^{\text {a }}$ ed. Santiago: Ediciones Sur, 1990.

. História rural de Chile Central. Tomos I e II. Santiago: Lom, 2015.

. Historia del pueblo mapuche. Siglos XIX y XX. (1ª ed. 1985). $7^{\mathrm{a}}$ ed. Santiago: Lom, 2014.

. Reforma agraria y revuelta campesina. Santiago: Lom, 2016.

BERDICHEWSKY, Bernardo. Reducciones araucanas y su incorpoación en el modo de producción capitalista. Lima: Universidad Nacional Mayor de San Marcos, 1977.

BORGES, Elisa Campos. "Con la unidad popular ahora somos gobierno!” A experiência dos cordones industriales no Chile de Allende. Rio de Janeiro: Luminária Academia, 2015.

. \& VASCONCELOS, Joana Salém. Cuba e Chile: diálogos revolucionários para América Latina. In: SALES, J; ARAÚJO, R.; MENDES, R.; SILVA, T. Revolução Cubana: ecos, dilemas e embates na América Latina. Sergipe: Ed. IFS, 2019, p. 246-273.

BULNES, José María; CELEDÓN, Roberto; COLL, Matías; FUENZALIDA, Sergio \& GONZÁLEZ, Leonso. Identificación y diagnóstico jurídico de casos ilustrativos por regiones de tierras afectadas por la reforma agraria que presentan irregularidades en su adjudicación o tenencia actual, y alternativas de regularización, reparación o indemnización posible a sus beneficiarios originales, por vías administrativas, judiciales o legislativas. Santiago: Ministerio de Agricultura/Universidad Arcis, 2000.

BULNES, José María; FUENZALIDA, Sergio \& TOLEDO LLANCAQUEO, Víctor. Las tierras y los campesinos de la reforma agraria chilena: Leyes, asignatarios y destino: Informe Final. Convenio Ministerio de Agricultura/Universidad Arcis "Catastro Nacional de Tierras derivadas de la reforma agraria que no se adjudicaron a los beneficiarios de este proceso o que las perdieron y estudio de la situación socioeconómica de dichos originales beneficiarios». Santiago de Chile: Ministerio de Agricultura/Universidad Arcis, 2003.

CARSON, Rachel. Primavera silenciosa. $2^{\text {a }}$ ed. São Paulo: Melhoramentos, 1969.

CERECEDA, Luz Eugenia \& DAHSE, Fernando. Dos décadas de cambios en el agro chileno. Santiago: Universidad Católica de Chile, 1980.

CHAYANOV, A. V. Teoria dos sistemas económicos não capitalistas (1924). In: CARVALHO, Horácio Martins (org.), Chayanov e o campesinato. São Paulo: Expressão Popular, 2014a.

. Viagem de meu irmão Alexei ao país da utopia camponesa. In: CARVALHO, Horácio Martins (org.), Chayanov e o campesinato. São Paulo: Expressão Popular, 2014b.

CHILE. Indicadores Económicos y Sociales. 1960-1988. Santiago: Banco Central de Chile, 1989.

CHONCHOL, Jacques. El desarrollo de América Latina y la Reforma Agraria. Santiago: Editorial del Pacífico, 1964.

Razones económicas, sociales y políticas de la reforma agraria. In: DELGADO, Oscar. Reformas Agrarias en América Latina. Procesos y perspectivas. $1^{\mathrm{a}}{ }^{\mathrm{e}}$ ed. México/Buenos Aires: Fondo de Cultura Económica, 1965. Set./1976.

El Campesinado y la Política Agraria de la Unidad Popular (1970-1973). Revista Trimestre Económico, México, Jul-

Por una nueva reforma agraria para Chile. Santiago: LOM, 2018.

\& SOLAR, Julio Silva. Hacia un mundo comunitario. Condiciones de una política social cristiana. Santiago: Colección Estudios Sociales, 1951.

\& ROBLES-ORTIZ, Claudio. Jacques Chonchol: un cristiano revolucionário en la politica chilena del siglo XX. Conversaciones con Claudio Robles Ortiz. Santiago: U. Finis Terrae, 2016.

COLLARTE, Juan Carlos \& PÉREZ, Santos (org.). El problema agrario en 100 asentamientos del Valle Central. Santiago: Ediciones Nueva Universidad, Universidad Católica de Chile, s/f.

CORNEJO, Tomás. El Chacal de Nahueltoro, un capítulo de historia social. Andamios, v. 12, n. 29. Set-Dez./2015.

CORVERA VERGARA, Maria Teresa (org.). Reforma Agraria Chilena, 50 años. Historia y reflexiones. Santiago: Biblioteca del Congreso Nacional de Chile, 2017.

CORREA, Martin; MOLINA, Raúl; YÁÑEZ, Nancy. La reforma agraria y las tierras mapuches. Chile, 1962-1975. Santiago: Lom, 2005.

CORVALÁN, Luis. El gobierno de Salvador Allende. Santiago: LOM, 2003.

COSTA, Emília Viotti da. "Estrutura versus Experiência. Novas tendências da história do movimento operário e das classes trabalhadoras na América Latina: o que se ganha e o que se perde". In: Revista Brasileira de Informação Bibliográfica em Ciências Sociais - BIB n ${ }^{\circ} 29$. ANPOCS: Rio de Janeiro, 1990. 
. “A dialética invertida: 1960-1990”. Revista Brasileira de História. Brasil: 1954-1964. São Paulo: ANPUH/Marco Zero, v. $14, \mathrm{n}^{0} 27,1994$, p. 9-26.

CURY, Márcia. O protagonismo popular: experiências de classe e movimentos sociais na construção do socialismo chileno (1964-1973). Campinas: Editora da UNICAMP, 2017.

DE TARSO, Paulo. Educación y cambio social. La Paz: Ministerio de Educación de Bolivia, 1970.

DURÁN CID, Daniela. Reforma agraria y cooperación francesa en la CORA (1967-1971). In: ROJAS, Álvaro \& MANRÍQUEZ, Paula (orgs.). Reforma agraria 50 años después. Origen y desarrollo del proceso. Talca: Editorial Universidad de Talca, 2017.

IMABLE DURÁN, R. Asentamientos de Choapa: cambios en la tenencia de la tierra y en los ingresos de los campesinos. Revista de Economía de la Universidad de Chile, año XXV, n. 93, 1967.

FAIGUENBAUM, Sergio. La reforma agraria “de macetero". La derecha chilena y la alianza para el progreso durante el gobierno de Jorge Alessandri (1962-1964). Tesis Doctoral en Estudios Americanos con mención en História. Santiago: USACH, 2013

. Toda una vida. Historia de INDAP y los campesinos (1962-2017). Santiago: INDAP/FAO, 2017.

FAURÉ POLLONI, Daniel Esteban. Auge y caída del movimiento de educación popular chileno. De la promoción popular al proyecto histórico popular (Santiago, 1964-1994). Tesis Magíster. Santiago: USACH, 2011.

FREIRE, Paulo. Educação como prática da liberdade. $1^{\text {a }}$ ed. Rio de Janeiro: Paz e Terra, 1967a.

. Ação cultural para liberdade e outros escritos. $5^{\text {a }}$ ed. São Paulo: Paz e Terra, 1981.

. Pedagogia do oprimido. $65^{\mathrm{a}}$ ed. São Paulo: Paz e Terra, 2018.

. Pedagogia da esperança. $17^{\mathrm{a}}$ ed. São Paulo: Paz e Terra, 2011.

. \& GUIMARÃES, Sergio. Aprendendo com a própria história. $3^{\mathrm{a}}$ ed. São Paulo: Paz e Terra, 2010.

GADOTTI, Moacir (org.). Paulo Freire, uma biobibliografia. São Paulo: Cortez/IPF, 1996.

GAJARDO, Marcela. Paulo Freire. Crónica de sus años en Chile. Santiago: FLACSO Chile, 2019.

. La concientización en América Latina: una revisión crítica. DF México: CREFAL, 1991.

GARCÉS, Joan. Allende e as armas da politica. São Paulo: Scritta, 1993.

GARRET, Patricia. Growing Apart: the experiences of rural men and women in central Chile, $\mathrm{PhD}$. Winsconsin: University of Wisconsin-Madison, 1978.

GOIC, Pedro \& SAHUENZA, Enrique. Un camino en la dignificación del campesino. Santiago: Huerta Berenguer L., 1992.

GÓMEZ, Sergio. Los empresarios agrícolas. Santiago: ICIRA, 1972.

. "El rol del sector agrícola y la lucha de clases". In: BARRACLOUGH, S; AFFONSO, Almino; HERNANDÉZ, Silvia; ZEMELMAN, Hugo; GÓMEZ, Sergio; BENGOA, José. Chile: reforma agraria y gobierno popular. Buenos Aires: Ediciones Periferia, 1973.

. Organizaciones rurales y estructura agraria. Chile 1973-1976. Documento de trabajo FLACSO, 1981.

. Instituciones y procesos agrarios en Chile. Santiago: FLACSO/CLACSO, 1982.

. Movimiento campesino, respuesta empresarial y reforma agraria. Una década de profundización democrática en el campo (1964-1973). Tese de Doutorado em Sociologia, São Paulo: FFLCH/USP, 1994.

2002 .

. Organización campesina en Chile: reflexiones sobre su debilidad actual. Revista Austral de Ciencias Sociales, n. 6,

. \& ECHEÑIQUE, J. La agricultura chilena: las dos caras de la modernización. Santiago: FLACSO, 1988.

GÓMEZ, S \& KLEIN, E. Informe sobre el estado actual de los consejos comunales campesinos. Santiago: ICIRA, 1972.

GUNDER FRANK, André. “Tipos de reformas agrarias”. In: DELGADO, O. Reformas Agrarias en América Latina. Procesos y perspectivas. $1^{\mathrm{a}}$ ed. México/Buenos Aires: Fondo de Cultura Económica, 1965.

. The development of underdevelopment. Monthly Review, v. 18, n. 4, Set./1966.

. Capitalismo y subdesarrollo en América Latina. 5a ed. México D.F.: Siglo XXI, 1967.

HOLST, John D. Paulo Freire in Chile, 1964-1969: "Pedagogy of the Oppressed" in Its Sociopolitical Economic Context. Harvard Educational Review, v. 76 n. 2, Sum. 2006, p. 243-270.

HUERTA, Maria Antonieta. Otro agro para Chile: historia de la reforma agraria en el proceso social y político. Santiago: Ediciones Chile-América, CESOC, 1989. 
KAY, Cristobal. Chile, an appraisal of Popular Unity's agrarian reform. Glasgow: Institute of Latin American Studies, University of Glasgow, 1974.

\& WINN, Peter. La reforma agraria en el gobierno da Unidad Popular. Sociedad y Desarrollo, n.3. Santiago: CESO, Universidad de Chile, 1972. p. $135-159$

Agrarian Reform and Rural Revolution in Allende's Chile. Journal of Latin American Studies, v. 6, n. 1, may, 1974, 501

. Chile's Neoliberal Agrarian Transformation and the Peasantry. Journal of Agrarian Change, v. 2, n. 4, 2002, p. 464-

. \& SILVA, Patricio (orgs.) (1992). Development and Social Change in the Chilean Countryside: From the pre-Land Reform Period to the Democratic Transition. Amsterdam: CEDLA, 1992, p. 215-232.

KAUfMAN, Robert. The Politics of Land Reform in Chile. 1950-1970. Public Policy, Political Institutions, and Social Change. Cambridge, Massachusetts: Harvard University Press, 1972.

KIRKENDALL, Andrew J. Paulo Freire and the Cold War Politics of Literacy. Chapel Hill: University of North Carolina Press, 2010.

LANDER, Edgardo, La colonialidad del saber: eurocentrismo y ciencias sociales: perspectivas latinoamericanas. Buenos Aires: CLACSO, 2000.

LÊNIN, Vladimir. O imperialismo: fase superior do capitalismo. 1ª ed. São Paulo: Global, 1979.

LIRA, Elizabeth \& Loveman, Brian. El espejismo de la reconciliación política. Chile, 1990-2002. Santiago: LOM, 2002.

LOVEMAN, Brian. Struggle in the countryside. Political and rural labor in Chile, 1919-1973. $1^{\text {a }}$ ed. Bloomington: Indiana University Press, 1976.

LUXEMBURGO, Rosa. A acumulação do capital. São Paulo: Nova Cultural, 1985.

MALLON, Florencia. La sangre del copihue: la comunidad Mapuche de Nicolás Ailio y el estado chileno, 1906-2001. Santiago: LOM, 2004

MARINI, Ruy Mauro. O reformismo e a contrarrevolução. Estudos sobre o Chile. São Paulo: Expressão Popular, 2019.

MAYORGA, Rodrigo. Las grandes reformas pedagógicas. In: SERRANO, Sol; PONCE DE LEÓN, Macarena; BENGIFO, Francisca; MAYORGA, Rodrigo (orgs.). Historia de la educación en Chile (1810-2010). Tomo III. Democracia, exclusión y crisis (1930-1964). Santiago: Taurus, 2018.

MORENO, Rafael. Introducción. In: CHILE, Ley 16.640 de reforma agraria. Santiago, 28 de julio de 1967.

MUÑOZ TOLEDO, Alicia. Memorias de una mujer campesina. In: AUSTIN HENRY, Robert; SALÉM VASCONCELOS, Joana; CANIBILO RAMÍREZ, Viviana (orgs.). La vía chilena al socialismo 50 años después: historia y memoria. Buenos Aires: CLACSO, 2020.Disponível em: http://biblioteca.clacso.edu.ar/clacso/se/20201201032252/La-via-chilena-alsocialismo-Tomo-II.pdf

NAVARRETE VERGARA, Jaime. Movimiento Campesino Revolucionario. Concepción: Escaparate, 2018.

NUN, José. Superpoblación relativa, ejército industrial de reserva y masa marginal. In: Revista Latinoamericana de Sociologia, v. 5, n. 2, 1969, p. 178-236.

OSZLAK, Oscar. La trama oculta del poder. Reforma agraria y comportamiento politico de los terratenientes chilenos, 19581973. Santiago: Lom, 2016.

OSORIO VARGAS, Jorge (org.). Freire entre nos. A 50 años de Pedagogía del Oprimido. La Serena: Nueva Mirada Ediciones, 2018.

PALMADA LIU, Emiliano. Paulo Freire en Chile: tiempo de siembra. In: Revista NuestraAmerica. Número especial, set. 2014, p. 52-67.

PASCAL ALLENDE, Andrés. Relaciones de poder en una localidad rural. Estudio de caso en el Valle Hurtado, Coquimbo. Santiago: ICIRA/FAO, 1971.

PÉREZ NAVARRO, Camila \& SILVA SALINAS, Camila. Educación y proyectos desarrollistas: Discursos y prácticas de alfabetización popular en Chile, 1960-1970. In: Cuadernos Chilenos de Historia de la Educación, n. 1, Santiago, Jun./2013.

PETRAS, James \& LAPORTE JR, Robert. Cultivating Revolution. The United States and Agrarian Reform in Latin America. Nova Iorque: Random House, 1971.

. \& ZEMELMAN, Hugo. Proyección de la reforma agraria. El campesinado y su lucha. Santiago: Quimantú, 1972.

PINTO, Aníbal. Chile: un caso de desarrollo frustrado. Santiago: Ed. Universitária, 1959.

PINTO CONTRERAS, Rolando. Aportes teóricos y pedagógicos al legado intelectual de Paulo Freire. In: OSORIO VARGAS, Jorge (org.). Freire entre nos. A 50 años de Pedagogía del Oprimido. La Serena: Nueva Mirada Ediciones, 2018. 
. Desafíos y contradicciones en una experiencia inconclusa: la capacitación campesina en la reforma agraria de la UP. In: AUSTIN HENRY, Robert; SALÉM VASCONCELOS, Joana; CANIBILO RAMÍREZ, Viviana (orgs.). La vía chilena al socialismo 50 años después: historia y memoria. Buenos Aires: CLACSO, 2020. Disponível em: http://biblioteca.clacso.edu.ar/clacso/se/20201201032252/La-via-chilena-al-socialismo-Tomo-II.pdf

PISTRAK, Moisey M. Ensaios sobre a escola politécnica. São Paulo: Expressão Popular, 2015.

PONCE DE LEÓN, M. La política y las políticas educativas. In: SERRANO, Sol; PONCE DE LEÓN, Macarena; BENGIFO, Francisca; MAYORGA, Rodrigo (orgs.). Historia de la educación en Chile (1810-2010). Tomo III. Democracia, exclusión y crisis (1930-1964). Santiago: Taurus, 2018.

QUIJANO, Aníbal. Los movimientos campesinos contemporáneos en América Latina. Editorial Latina. Colección Temas Latinoamericanos, n. 2, 1971.

REDONDO, Jesús-Ángel. Tierra, trabajo y libertad Conflictos campesinos e indígenas en la provincia de Cautín (1967-1973). Santiago: LOM, 2017.

RENGIFO, Francisca. El enemigo del niño es el hambre. In: SERRANO, S.; PONCE DE LEÓN, M.; RENGIFO, F.; MAYORGA, R. (eds.). Historia de la educación en Chile (1810-2010). Tomo III. Democracia, exclusión y crisis (1930-1964). Santiago: Taurus, 2018.

RIVERA, Rigoberto \& CRUZ, María Elena (1984). Pobladores rurales: Cambios en el poblamiento y el empleo rural en Chile. Santiago: Academia de Humanismo Cristiano, 1984.

ROBLES ORTIZ, Claudio. Revolution from below in Panguipulli: Agrarian reform and political conflict under the Popular Unity in Chile. Journal of Agrarian Change, v. 18, n. 3, 2017, p. 606-631.

. The agrarian historiography of Chile: Foundational interpretations, conventional reiterations, and critical revisionism. Historia Agraria (SEHA), n. 81, agosto, 2020, p. 1-29.

RODRÍGUEZ HUERTA, Francisca. Evocando la historia. In: AUSTIN HENRY, Robert; SALÉM VASCONCELOS, Joana; RAMÍREZ, Viviana (orgs.). La vía chilena al socialismo a los 50: historia y memoria. Tomo II: Memoria. Buenos Aires: CLACSO, 2020. Disponível em: http://biblioteca.clacso.edu.ar/clacso/se/20201201032252/La-via-chilena-al-socialismoTomo-II.pdf

ROSSET, Peter \& MARTÍNEZ TORRES, María Elena. Agroecología, territorio, recampesinización y movimientos sociales. In: Estudios Sociales, v. 25, n. 47, Jan-Jun/2017, pp. 275-299.

ROXBOROUGH, Ian. Agrarian policy in the Popular Unity government. In: Occasional Paper $n^{\circ}$ 14. Glasgow: Institute of Latin American Studies, University of Glasgow, 1974.

. The political mobilization of farm workers during the Chilean Agrarian Reform, 1971-1973: a case study. PhD. Diss. Winsconsin: University of Wisconsin-Madison, 1977.

SANTOS, Boaventura de Sousa. Para além do pensamento abissal: das linhas globais a uma ecologia de saberes, Novos Estudos CEBRAP, n. 79, 2007.

. Una epistemología del Sur. La reinvención del conocimiento y la emancipación social. México: Siglo XXI, 2009.

SAAVEDRA, Alejandro. La cuestión mapuche. Santiago: ICIRA, 1972.

Capitalismo y lucha de clases en el campo. Chile, 1970-1972. Madrid: Alberto Corazón, 1975.

SALAZAR, Gabriel. Labradores, peones y proletarios. $1^{\text {a }}$ ed. 1985. Santiago: LOM, $3^{\text {a }}$ ed., 2000.

SCHMIEDECKE, Natalia Ayo. "Nuestra major contribución, la hacemos cantando": a nova canção chilena e a questão cultural no Chile na Unidade Popular. Tese de Doutorado, Franca: FCHS-UNESP, 2017.

SCOTT, James C. The moral economy of the peasants. Rebellion and subsistence in Southeast Asia. New Haven/Londres: Yale University Press, 1976.

. Weapons of the weak. Everyday forms of peasant resistance. New Haven: Yale University Press, 1985.

SCOTT, Joan. Gender and the politics of history. Nova Iorque: Columbia University Press, 1999.

SERRANO, Sol; PONCE DE LEÓN, Macarena; BENGIFO, Francisca; MAYORGA, Rodrigo (orgs.). Historia de la educación en Chile (1810-2010). Tomo III. Democracia, exclusión y crisis (1930-1964). Santiago: Taurus, 2018.

SEVILLA GUZMÁN, Eduardo \& MOLINA, Manuel G. Sobre la evolución del concepto de campesinado en el pensamiento socialista: una aportación para vía campesina. In: Seminario Vía Campesina. Brasília, Nov./2004.

SILVA, Patricio. The State, Politics and Peasant Unions. In: KAY, Cristóbal \& SILVA, Patricio (orgs.). Development and Social Change in the Chilean Countryside: From the pre-Land Reform Period to the Democratic Transition. Ámsterdam: CEDLA, 1992, p. 215-232.

SNA, El punto de vista de los terratenientes: Chile. In: DELGADO, O. Reformas Agrarias en América Latina. Procesos y perspectivas. $1^{\mathrm{a}}$ ed. México/Buenos Aires: Fondo de Cultura Económica, 1965. 
SOTOMAYOR, Jorge Rogers. Dos caminos para la reforma agraria, 1945-1965. Santiago: Orbe, 1966.

STEENLAND, Kyle, Agrarian reform under Allende: Peasant revolt in the South. Alburquerque: University of Mexico Press, 1977.

SUAZO, Cristian. “Nadie nos trancará el paso!” Contribución a la historia del Movimiento Campesino Revolucionario (MCR) en la provincia de Cautín (1970-1973). Tesis para optar al grado de licenciado en educación. Concepción: Universidad de Concepción, 2013.

THOMPSON, Edward P. The Moral Economy of the English Crowd in the Eighteenth Century. In: Past \& Present, n. 50 Fev/1971, p. 76-136.

. As peculiaridades dos ingleses e outros artigos. Campinas: Unicamp, 2001.

. A formação da classe operária inglesa: a árvore da liberdade. v. I. Rio de Janeiro: Paz e Terra, 1987.

TINSMAN, Heidi. Partners in conflict. The politics of gender, sexuality and labor in the Chilean Agrarian Reform, 19501973. Durhan/Londres: Duke University Press, 2002.

. La tierra para quien la trabaja. Género, sexualidad y movimientos campesinos en la Reforma Agraria chilena. $1^{\mathrm{a}}$ ed. Santiago: Lom, 2009.

Se compraron el modelo. Consumo, uva y la dinámica transnacional: Estados Unidos e Chile durante la Guerra Fría. 1. ed. Santiago: Ediciones Alberto Hurtado, 2016. 2008

. A paradigm for our own. Joan Scott in Latin American history. The American Historical Review - AHR Forum. Dez./

TORRES, Oscar. Sindicalismo y capacitación campesina en la Unidad Popular. In: AUSTIN HENRY, Robert; SALÉM VASCONCELOS, Joana; CANIBILO RAMÍREZ, Viviana (orgs.). La vía chilena al socialismo 50 años después: historia y memoria. Buenos Aires: CLACSO, 2020. Disponível em: http://biblioteca.clacso.edu.ar/clacso/se/20201201032252/La-viachilena-al-socialismo-Tomo-II.pdf

URQUIETA, Claudia \& SALÉM VASCONCELOS, Joana. Historia de un despojo: Las tierras de la Reforma Agraria que el Ejército arrebató a campesinos. Centro de Investigaciones Periodísticos - CIPER, 2018a. Disponível em: https://ciperchile.cl/2018/03/19/historia-de-un-despojo-las-tierras-de-la-reforma-agraria-que-el-ejercito-arrebato-acampesinos/. Último acesso: 31 jan. 2021.

. Historia de un despojo II: Las tierras de la Reforma Agraria de las que no se habla. Centro de Investigaciones Periodísticos - CIPER, 2018b. Disponível em: https://ciperchile.cl/2018/03/19/historia-de-un-despojo-las-tierras-de-lareforma-agraria-que-el-ejercito-arrebato-a-campesinos/. Último acesso: 31 jan. 2021.

VALDÉS, Ximena. La posición de la mujer en la hacienda. Santiago: CEM, 1988.

.; MACK, Macarena \& MATTA, Paulina, Los trabajos de las mujeres entre el campo y la ciudad. Santiago: Biblioteca de la Mujer, Centro de Estudios de la Mujer, 1986.

VALENZUELA, Esteban. Dios, Marx...y el MAPU. Santiago: LOM, 2014.

VARGAS, María Cristina. En una sociedad en que la tierra está concentrada, está concentrada también la educación. In: Revista NuestraAmerica. Número especial, set. 2014, p. 69-78.

VASCONCELOS, Joana Salém. Dilemas agrários da Unidade Popular: conflitos rurais na via chilena ao socialismo (19671973). In: COSTA, Adriane Vidal; BORGES, Elisa Campos (orgs.). Os 50 anos da Unidade Popular no Chile: um balanço historiográfico. Belo Horizonte: Fino Traço, 2020a.

Revolución chilena y batalla de la producción agraria: sabotajes patronales y estímulos al trabajo campesino. In: AUSTIN HENRY, Robert; SALÉM VASCONCELOS, Joana; CANIBILO RAMÍREZ, Viviana (orgs.). La vía chilena al socialismo 50 años después: historia y memoria. Buenos Aires: CLACSO, 2020b. Disponível em: http://biblioteca.clacso.edu.ar/clacso/se/20201201031842/La-via-chilena-al-socialismo-Tomo-I.pdf

. Tierra y derechos humanos en Chile: la contrarreforma agraria de la dictadura de Pinochet y las políticas de reparación campesina. Revista Historia Agraria, v. 80, 2020c, p. 1-34.

. Reforma agrária e socialismo na América Latina: Cuba e Chile. In: RIBEIRO, Vanderlei Vazelesk \& SECRETO, Maria Verónica (orgs.). Agrarismos. Estudos de história e sociologia do mundo rural contemporâneo. $1^{\text {a }}$ ed. Rio de Janeiro: Mauad/FAPERJ, 2017, p. 187-207.

. História agrária da revolução cubana: dilemas do socialismo na periferia. São Paulo: Alameda, 2016a.

. Trabalho voluntário e socialismo nos canaviais cubanos: uma história da safra de 1970. Revista Eletrônica da $\overline{A N P H L} A C$ (USP), v. 21, 2016b, p. 34-65.

. Propriedade coletiva em debate: caminhos da revolução agrária em Cuba (1959-1964). Revista NERA (UNESP), v. $\overline{27,2015}$, p. $240-258$. 
. \& CHONCHOL. Jacques. Jacques Chonchol em Cuba: reforma agrária e revolução em 1961. Revista Mouro, São Paulo, n. 7, 2012.

WILLIAMS, Raymond. Culture and materialism. Nova Iorque: Verso, 2005.

. Marxismo e literatura. Rio de Janeiro: Zahar, 1979.

WINN, Peter. Weavers of revolution. The Yarur workers and the Chile's road to socialism. Nova Iorque: Oxford University Press, 1986.

. A revolução chilena. São Paulo: UNESP, 2010.

ZEMELMAN, Hugo. El migrante rural. Santiago: ICIRA, 1971a.

ZERÁN, Faride. Otra vez el pueblo (Prefácio). In: AUSTIN HENRY, Robert; SALÉM VASCONCELOS, Joana; CANIBILO RAMÍREZ, Viviana (orgs.). La vía chilena al socialismo 50 años después: historia y memoria. Buenos Aires: CLACSO, 2020. Disponível em: http://biblioteca.clacso.edu.ar/clacso/se/20201201032252/La-via-chilena-al-socialismo-Tomo-II.pdf

ZUBICUETA LUCO, Daniela. De imágenes, palabras y diálogos: alfabetización freiriana y concientización campesina durante la reforma agraria en Chile (1965-1973). Tesis de Magíster en Historia. Santiago: Universidad de Santiago de Chile (USACH), 2018.

\section{Fontes Primárias}

\section{Biblioteca Nacional de Chile}

\section{Instituto de Educación Rural}

IER, Surco y Semilla. Revista de la familia campesina. 1962-1968.

IER, Memoria institucional (1970-1971).

IER, Radio-Escuela Surco y Semilla, folletos para el profesor. 1965.

IER, Curso de Alfabetización y Cultura Popular. Prof. Paulo Freire - INDAP. s/f.

IER, Escuela Agrícola de Adultos Princesa Paola de Bélgica, 1971.

IER, ¿Que es el IER?, 1972.

\section{CEREN}

AFFONSO, Almino. Trayectoria del movimiento campesino chileno. In: Cuadernos de la Realidad Nacional $\mathrm{n}^{\circ}$ 1, Santiago: CEREN, Universidad Católica de Chile, Set. 1969.

BARRACLOUGH, Solon. Sistemas de tenencia alternativos resultantes de reformas agrarias en América Latina. In: Cuadernos de la Realidad Nacional n ${ }^{\circ}$ 2, Santiago: CEREN, Universidad Católica de Chile, Jan. 1970.

. Reforma agraria: historia y perspectivas. In: Cuadernos de la Realidad Nacional $\mathrm{n}^{\circ}$ 7, Santiago: CEREN, Universidad Católica de Chile, Mar.1971.

. \& AFFONSO, Almino. Diagnóstico de la reforma agraria chilena (noviembre 1970 - Junio 1972. In: Cuadernos de la Realidad Nacional $\mathrm{n}^{\circ}$ 16, Santiago: CEREN, Universidad Católica de Chile, Abr. 1973.

CANTONI, Wilson. Poder popular em el agro chileno. In: Cuadernos de la Realidad Nacional $\mathrm{n}^{\circ}$ 11, Santiago: CEREN, Universidad Católica de Chile, Jan. 1972a.

. Fundamentos para una política cultural mapuche. In: Cuadernos de la Realidad Nacional $\mathrm{n}^{\circ}$ 14, Santiago: CEREN, Universidad Católica de Chile, Out. 1972b.

CASTILLO, Fernando \& LARRAÍN, Jaime. Poder obrero-campesino y transición al socialismo em Chile. In: Cuadernos de la Realidad Nacional nº 10, Santiago: CEREN, Universidad Católica de Chile, Dez. 1971.

CHONCHOL, Jacques. Poder y reforma agraria en la experiencia chilena (I). In: Cuadernos de la Realidad Nacional $\mathrm{n}^{\circ} 2$, Santiago: CEREN, Universidad Católica de Chile, Jan. 1970.

CRISPI, Jaime. Consideraciones acerca de una política económica agraria para la fase actual del proceso revolucionario chileno. In: Cuadernos de la Realidad Nacional n 17, Santiago: CEREN, Universidad Católica de Chile, Jul.1973. 
GREBBE, Maria Ester; PACHECHO, Sergio \& SEGURA, José. Cosmovisón mapuche. In: Cuadernos de la Realidad Nacional $\mathrm{n}^{\circ}$ 14, Santiago: CEREN, Universidad Católica de Chile, Out. 1972.

JEANNOT, Bernardo. El problema mapuche. In: Cuadernos de la Realidad Nacional n 14, Santiago: CEREN, Universidad Católica de Chile, Out. 1972.

LEHMAN, David. Hacia un análisis de la consciencia de los campesinos. In: Cuadernos de la Realidad Nacional $\mathrm{n}^{\circ} 2$, Santiago: CEREN, Universidad Católica de Chile, Jan. 1970.

MAFFEI, Eugenio \& MARCHETTI, Emilio. Estructura agraria y consejos comunales campesinos: situación actual, análisis y estrategia. In: Cuadernos de la Realidad Nacional n 14, Santiago: CEREN, Universidad Católica de Chile, Out. 1972.

.\& BILLAZ, René. La reforma agraria chilena y el camino hacia el socialismo. In: Cuadernos de la Realidad Nacional $\mathrm{n}^{\circ}$ 11, Santiago: CEREN, Universidad Católica de Chile, Jan. 1972.

MELLET, Hugo O. \& DAÑíN, Jorge O. Nueva legislación sobre indígenas en Chile. In: Cuadernos de la Realidad Nacional n 14 , Santiago: CEREN, Universidad Católica de Chile, Out. 1972.

RIBEIRO, Ivan. La transición hacia el socialismo en Chile y la planificación del sector agropecuario. In: Cuadernos de la Realidad Nacional n 12, Santiago: CEREN, Universidad Católica de Chile, Abr. 1972.

ZEMELMAN, Hugo. Factores determinantes en el surgimiento de una clase campesina. In: Cuadernos de la Realidad Nacional $\mathrm{n}^{\circ}$ 7, Santiago: CEREN, Universidad Católica de Chile, Mar. 1971b.

\section{Revista de Educación}

ASTORGA, Alberto Aleite. Reformas estructurales y planeamiento educacional. Revista de Educación, n. 95, 1964.

CARABANTES, Waldemar Cortés. Formas muertas y dinámicas de nuestra educación de adultos. Revista de Educación, n. 93-94, 1963.

MENDEZ, Luz Vieira. La situación del maestro en América Latina. Revista de Educación, n.74-75, 1958.

\section{Partido Socialista}

CONAS (Comisión Nacional Agraria del Partido Socialista), Informe al Encuentro de Trabajo de los Comités Regionales sobre el Problema Agrario y las tareas del Partido en el campo. 01/03/1973.

PS, Bases de una Politica Socialista Frente el Problema Agrario. Trabajo presentado por el Departamento de Estudios Técnicos del Comité Central del PS al XIX Congreso General. Los Andes, 7 a 10 dezembro, 1961.

RODRÍGUEZ, Aniceto. 1966, año de la organización y las luchas campesinas. Informe al Pleno Nacional del PS. Santiago, 1966.

\section{Partido Comunista}

PC, La conquista de la reforma agraria será posible mediante la lucha del pueblo. Santiago, 1966.

\section{Jornais e Revistas}

Surco y Semilla (1962-1968)

El Siglo (1967-1973)

La Nación (1967-1973)

Chile Hoy (1971-1973)

Revista Agraria, Chile Hoy (1972-1973)

\section{Ministério de Educación Pública}

ESPINA REYES, Emma; ARÉVALO V., Sergio; RUBILAR S., Arnulfo; SEVERINO M., Nelso. Sugerencias para la Alfabetización. Programa de Educación de los Trabajadores. Santiago: Ministerio de Educación Pública, 1971. In: Revista NuestrAmérica, número especial, Concepción, 2014, p. 91-218.

MINEDUC (Chile). La raiz y la espiga. Manual del método psico-social para la enseñanza de adultos. Santiago: Mineduc, 1966.

MINEDUC (Chile). Lectura para Adultos, Primer Nivel. La raiz y la espiga. Santiago: Mineduc, 1966. 
MINEDUC (Chile). Lectura para Adultos, Segundo Nivel. La raiz y la espiga. Santiago: Mineduc, 1966.

MINEDUC (Chile). Lectura para Adultos, Comunidad, Tercer Nivel. La raíz y la espiga. Santiago: Mineduc, 1966.

\section{Escritos de Paulo Freire no Chile}

FREIRE, Paulo. La concepción 'bancaria' de la educación y la deshumanización. La concepción problematizadora de la educación y la humanización. (Resumen de charlas realizadas para un grupo de señoras latinoamericanas en una conferencia realizada en mayo de 1967, en Santiago). Santiago: ICIRA (mimeo.), 1967b.

. Alfabetización Funcional en Chile, informe UNESCO. Santiago: ICIRA (mimeo.), 1968a.

. Algunas sugerencias en torno de una labor educativa que vea el asentamiento como una totalidad. Santiago: ICIRA (mimeo.), 1968b.

Plan de Trabajo para el año. Una visión sintética. Santiago: ICIRA (mimeo.), 1968c.

. La alfabetización de adultos. Crítica de su visión ingenua: comprensión de su visión crítica. In: Educação e conscientização. Cuaderno n 25, Cuernavaca, México: Centro Intercultural de Documentación (CIDOC), $1968 \mathrm{~d}$.

. Los campesinos también pueden ser los autores de sus propios textos de lectura. In: Educação e conscientização. $\overline{\text { Cuaderno }} n^{\circ}$ 25, Cuernavaca, México: Centro Intercultural de Documentación (CIDOC), Fev. 1968e.

. Investigación y metodología de la investigación del "tema generador" - reducción y codificación temáticas. In:

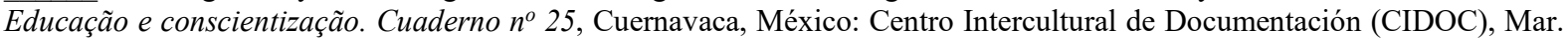
$1968 \mathrm{f}$.

A propósito del tema generador y del universo temático. In: Educação e conscientização. Cuaderno $n^{\circ} 25$, Cuernavaca, México: Centro Intercultural de Documentación (CIDOC), Abr. 1968g.

. Formación pedagógica de los padres. In: Educação e conscientização. Cuaderno $n^{\circ} 25$, Cuernavaca, México: Centro Intercultural de Documentación (CIDOC), 1968h.

Al coordinador de un círculo de cultura. In: Educação e conscientização. Cuaderno $n^{\circ}$ 25, Cuernavaca, México: Centro Intercultural de Documentación (CIDOC), $1968 \mathrm{i}$.

. El rol del trabajador social en el proceso de cambio. In: Educação e conscientização. Cuaderno $n^{\circ} 25$, Cuernavaca, México: Centro Intercultural de Documentación (CIDOC), 1968j.

. El compromiso del profesional con la sociedad. In: Educação e conscientização. Cuaderno $n^{\circ} 25$, Cuernavaca, México: Centro Intercultural de Documentación (CIDOC), 1968k.

. \& VELOZO, Raul. Sugerencias para la aplicación del método en terreno. Santiago: ICIRA (mimeo), 1968.

. ¿Extensión o comunicación? Santiago: ICIRA, 1969.

- ¿Una dimensión política de la educación? Una conversación con Paulo Freire. In: Cuadernos de Educación, Serie Orientaciones (1971-1973). v. 4, n. 2. Santiago: Universidad de Chile, 1972, p. 2-25.

\section{CORA - Corporación de Reforma Agraria}

Los asentamientos de la reforma agraria. Una realidad chilena. S/d.

Chile avanza, Reforma Agraria. Santiago, 1966.

Congreso de Trabajadores de CORA. Santiago, 1968.

Que sería del campesino sin su mujer. Santiago, 1968.

CORA \& MINEDUC (1968), Guia Método, Nível 2. Santiago, 1968.

Informe de Práctica, Mario P. Barraza, 1968.

Guía del Alfabetizador según Método Psicosocial de Paulo Freire. CORA VII Zona, Maule-Linares, 1970.

Reforma agraria chilena, 1965-1970.

Planes de Area. Arauco, Buin, Llaima, Llay Llay, Longaví, Melipilla, Ovalle, Palmilla, Pelarco, Petorca-Ligua, San Carlos, San Felipe y Los Andes, Santa Cruz.

\section{INDAP - Instituto de Desarrollo Agropecuario}

AGUAYO, Carmen Gloria. La mujer en la promoción campesina. INDAP, (mimeo.) s/f. 
ALLENDE, Salvador. Perspectivas de la Reforma Agraria. INDAP, 197-.

INDAP, Agricultura y desarrollo. Manuales Campesinos n. 1. Producidos por Capacitación / Difusión, 1966a. . Necesidades, trabajo y economía. Manuales Campesinos n. 2. Producidos por Capacitación / Difusión, 1966b. . Técnica y progreso. Manuales Campesinos n. 3. Producidos por Capacitación / Difusión, 1966c . Cultivos sin malezas. Cartilla n. 10. Oficina de Difusión de INDAP, 1966d. . Rotación de cultivos. Cartilla n. 11. Oficina de Difusión de INDAP, 1966e. ., El tizón de la papa. Cartilla n. 12. Oficina de Difusión de INDAP, 1966f. . Reglamento interno para obreros agrícolas (Perteneciente al fundo), 1966g. . Manual de Programación para Desarrollo Campesino. Departamento de Planificación, 1966h. . Manual de derechos campesinos (HT), 1968a. . Marco Nacional de Programación. Política de Organizaciones (HT), 1968 b.

\section{ODEPA - Oficina de Planificación Agrícola}

ODEPA, Plan de Desarrollo Agropecuario 1965-1980. Síntesis. Ministerio de Agricultura. Santiago, 1968.

\section{FEES - Fondo de Educación y Extensión Sindical - e sindicatos}

GITAHY, Leda; DONOSO, M. \& ENCINA, Francisco. La organización sindical del sector afuerino. Santiago: FEES, 1972. GASMURI, Jaime M. Gobierno Popular y Reforma Agraria. Santiago: FEES, 1971.

Confederación Libertad, Independencia total frente a partidos politicos. Nuestra Confederación Lucha por Reales Cambios de estructura. (Panfleto). . Ley 16.625 y Reglamento de la Ley 16.625.

$\mathrm{MCI}, A B C$ del sindicalismo campesino, $\mathrm{s} / \mathrm{f}$

PROVOSTE, Patricia \& CANTONI, Wilson. La organización sindical campesina 1968-1969. Santiago: FEES, 1970.

FEES. Proyectos, Convenios y Programas. Santiago, 1970a.

. Terminación del contrato de trabajo, Cartilla Laboral n. 2. Santiago, 1970b.

. La protección de la familia, Cartilla Laboral n. 3. Santiago, 1970c.

. La jornada de trabajo y el derecho al descanso, Cartilla Laboral n. 4. Santiago, 1970d.

. El derecho a la remuneración, Cartilla Laboral n. 5. Santiago, 1970e.

. Derechos del trabajador enfermo, Cartilla Laboral n. 6. Santiago, 1970f.

. Derechos provisionales, Cartilla Laboral n. 7. Santiago, 1970g.

. Las condiciones de trabajo, Cartilla Laboral n. 8. Santiago, 1970h.

. Arrendamientos y medierías. Cartilla Laboral n. 9. Santiago, 1970i.

\& Triunfo Campesino, Informe sobre Capacitación y Servicios entre la Confederación Nacional Sindical de Trabajadores Agrícolas “El Triunfo Campesino” y el Fondo de Educación y Extensión Sindical, 1971.

\section{ICIRA - Instituto de Capacitación e Investigación de Reforma Agraria}

AFFONSO, Almino.; KLEIN, Emilio. Factores condicionantes de la presión campesina. Santiago: ICIRA, 1970. 1970.

.; GÓMEZ, Sergio.; KLEIN, Emilio.; RAMÍREZ, Pablo. Movimiento campesino chileno. 2 tomos. ICIRA, Santiago,

DOMÍNGUEZ, Oscar. Aspiraciones de los inquilinos de la provincia de Santiago. Santiago de Chile: ICIRA, 1966.

GSM, Síntesis de algunos aspectos de la reforma agraria chilena. 1964-1969. Resumen preparado por G.S.M. de un Documento Interno de ICIRA. (mimeo.)

FERREIRA, Maria Edy. Expectativas campesinas y asignación de tierras de Culiprán. ICIRA: Santiago, 1968. (mimeo.) 
Tendencias del poder entre los campesinos asentados. Santiago: ICIRA, 1970. (mimeo).

(mimeo).

\& FIORI, José Luis. Investigación temática cultural de los campesinos de El Recurso. Santiago: ICIRA, 1969

.; BARRIA, Liliana \& VILLEGAS, Sergio. Hacia un método de capacitación campesina: el diagnóstico como un camino para la acción. Santiago: ICIRA, 1969.

. \& BARRIA, Liliana. Hacia un método de programación campesina. Santiago: ICIRA/INDAP, 1971.

FIORI, José Luis. Educación y programación campesina. Santiago: ICIRA (mimeo), 1970.

GAJARDO, Marcela. Educación y concientización: aspectos de una experiencia pedagógica. Santiago: ICIRA, 1969.

LIMA, Lauro de Oliveira. El Método Freire. Método Acelerado de alfabetización de adultos. ICIRA, 1967.

SAMPAIO, Plínio de A.; MEDINA, Jorge; URRUTIA, Alfredo \& DUHART, Jaime. Organización, Planificación y Coordinación de las instituciones del sector público agrícola de Chile, a nivel de terreno. Departamento de Administración en Reforma Agraria. Santiago: ICIRA, 1966. (borrador de circulación restringida)

ZABALETA, Marta. Ejemplo de una nueva concepción educativa: la alfabetización y concientización de adultos para el cambio social. Apuntes basados en clases dictadas por el Profesor Paulo Freire. Informe para ser presentado a discusión en la comisión docente estudiantil de planes de estudio. Escuela de Economía y Administración, Universidad de Concepción. Concepción, Ago/1968.

\section{PIIE - Programa Interdisciplinar de Investigación en Educación (U. Católica)}

GAJARDO, Marcela. El desarrollo de la capacitación campesina en Chile: 1960-1970. Santiago: PIIE, 1973a.

. El desarrollo de la capacitación campesina en Chile: 1960-1970 - Anexos: Descripción de las instituciones que imparten capacitación campesina. Santiago: PIIE, 1973b.

. Educación campesina y cambio cultural: una experiencia piloto. Santiago: Universidad Católica de Chile, 1973c.

Cambios sociales y educación de adultos en Chile: una visión retrospectiva. Santiago: Consejo Internacional para Educación de Adultos/PIIE, 1978.

Capacitación Campesina y Medios de Comunicación: una aproximación a sus alcances y perspectivas. Santiago: PIIE/ICECOOP, 1978.

\& ANDRACA, Ana Maria. Un proceso de aprendizaje colectivo. Programa Interdisciplinario de Investigaciones en Educación / Instituto Chileno de Educación Cooperativa. Santiago: PIIE/ICECOOP, 1979.

\section{ARNAD - Archivo Nacional de la Administración}

Fondo del Ministerio de Educación, Chile.

Fondo del Ministerio de Agricultura, Chile.

Fondo de la Dirección Laboral, Chile.

\section{Vicaría de la Solidaridad}

VICARÍA DE LA SOLIDARIDAD. Ocho meses de labor. Centro de Documentación. Doc. 0001700. Santiago. Fundación de Documentación y Archivo Vicaría de la Solidaridad (FUNVISOL), 1976. . Un año de labor. Doc. 5002500. Santiago, 1977.

Segundo año de labor. Doc. 0002001. Santiago, 1978.

Tercer año de labor. Doc. 0002500. Santiago, 1979a.

Cuarto año de labor. Doc. 0002608. Santiago, 1979b.

. Quinto año de labor. Santiago, 1981.

. Sistematización del Departamento Campesino (octubre/1977 - octubre/1982). Santiago, 1982a.

. Sexto año de labor. Santiago, 1982b.

Séptimo año de labor. Santiago, 1982c.

Simposio Nacional sobre Sindicalismo Campesino. Acción Solidaria por la Justicia Social. Doc. 2145a. Santiago, 
. Sindicato y Sociedad. Simposio Nacional sobre Sindicalismo Campesino. Doc. 2145a. Santiago, 1982e.

. Octavo año de labor. Santiago, 1983.

. Noveno año de labor. Santiago, 1984.

\section{CRPF - Centro de Referência do Instituto Paulo Freire}

ICIRA, Investigación temática. Asentamiento El Recurso, 1968. Fundo Paulo Freire, Centro de Referência do Instituto Paulo Freire. Caixa FPF-ACP-01. São Paulo. 303p.

FERNÁNDEZ, José Antonio. La construcción de un pensamiento inacabado. Cuadernos de Pedagogía, n. 265. Santiago, jan/1998.

WILLIAMSON, Guillermo. Paulo Freire (1965-1969). Su paso por Chile y el Chile por que pasó. Santiago, 1989 (mimeo).

\section{LTC - Land Tenure Center (University of Wisconsin-Madison)}

BAYTELMAN, David. Nutricion y agricultura. Madison: Land Tenure Center, University of Wisconsin-Madison, 1970.

CHINCHILlA, Norma S. Strata and Class Consciousness in the Chilean Peasantry. Unpublished Ph.D. dissertation, University of Wisconsin, Madison, Wisconsin, 1973.

CHINCHILLA, Norma S. \& STERNBERG, Marvin. Agrarian reform and campesino consciousness. Latin American Perspectives v. 1, n. 2, 1974.

DORNER, Peter. Interpretive synthesis and policy implications of Land Tenure Center and related research. Madison: Land Tenure Center, University of Winsconsin Madison, 1966a.

. Land tenure and agricultural development in Latin America. Madison: Land Tenure Center, University of Winsconsin Madison, $1966 \mathrm{~b}$.

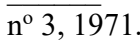

Land reform in Latin America. Wisconsin: University of Wisconsin-Madison -Land Economics. Monograph Series

\& THIESENHUSEN, William. Relevant Research Programs to beConducted in Developing Countries. Journal of

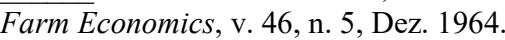

GARRET, Patrícia. Some structural constrains on the agricultural activities of women: the Chilean hacienda. Madison: Land Tenure Center, University of Winsconsin Madison, 1976. 1978.

. Growing Apart: the experiences of rural men and women in central Chile, PhD. University of Wisconsin-Madison,

HAVENS, Eugene A. The Land Tenure Center: its establishment and activities. Madison: Land Tenure Center, University of Wisconsin, 1963.

STANFIELD, David. Methodological notes on evaluating the impact of agrarian reform in Chile's Central Valley. Santiago: Land Tenure Center, 1973.

. \& BROWN, Marion, Proyecto de cambios socio-económicos en cien predios del sector rural en Chile. Santiago:

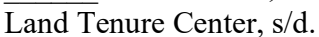

. \& BOSSERT, Tom. The role of participation and campesino Consciousness in the Chilean agrarian reform. Madison: Land Tenure Center, University of Wisconsin, 1974.

TERRY, McCoy. The politics of structural change in Latin America: the case of agrarian reform in Chile. Madison: Land Tenure Center, University of Wisconsin-Madison, 1969.

THIESENHUSEN, William C. Agrarian reform and economic development in Chile: some cases of colonization. Madison: Land Tenure Center, University of Wisconsin, 1965a.

. An experiment in land reform: reform on Chilean church land offers study laboratory. Madison: Land Tenure Center, University of Wisconsin, 1965b.

An experimental cooperative farming plan in Chile. Madison: Land Tenure Center, University of Wisconsin, $1965 \mathrm{c}$.

. Chile's experiment in agrarian reform. Madison: University of Winsconsin Press, 1966a.

. Profit margins in Chilean agriculture: a comment on James O. Bray's fundo B. Madison: Land Tenure Center, University of Wisconsin, 1966b.

Grassroots economic pressures in Chile: an enigma for development planners. Madison: Land Tenure Center, University of Wisconsin, 1966c. 
The possibilities of gradualist turnover of land in agrarian reform programs in Chile. Madison: Land Tenure Center, University of Wisconsin Press, 1966d.

. Chile's experiment in agrarian reform. Madison: Land Tenure Center, University of Wisconsin, 1966e.

. The possibilities of gradualist turnover of land in agrarian reform programs in Chile. Madison: Land Tenure Center, University of Wisconsin, 1966f.

.How big is the brain drain? Madison: Land Tenure Center, University of Wisconsin Press, 1967.

"Agrarian reform in Chile". In: Peter Dorner (org.). Land reform in Latin America. Land Economics Monograph Series, n. 3, 1971, p.105-25.

. Chile's experiment in agrarian reform: four colonization projects revisited. Madison: Land Tenure Center, University of Wisconsin, 1974

\section{RAC - Rockefeller Archive Center}

AIA (AMERICAN INTERNATIONAL ASSOCIATION FOR ECONOMIC AND SOCIAL DEVELOPMENT). The Rural Education Program - Chile - Quarterly Report. Box 42, Folder 310.1962-1963.

FORD FOUNDATION. MANITZAS, Nita R. Discussions on Chile held at various United States government agencies. Ford Foundation Catalogued Reports. Report 001527, 1959.

CLAWSON, Marion. Possibilities and significant studies of land reform in Chile. Report on a reconnaissance trip to Chile in April, 1960. Ford Foundation Catalogued Reports. Report 002533, 1960.

BERG, S.O., HANSON, L.E. \& MARTIN, W.P. Chilean agriculture. A report on Chilean agriculture and agricultural education to the Ford Foundation. Ford Foundation Catalogued Reports. Report 001718, 1963.

MYERS, W. M. Report on a trip to Chile. Ford Foundation Catalogued Reports. Report 000285, 1964.

VIGIER, Francis C. Chilean Community Centers Project - Education and Research Aspects. Ford Foundation Catalogued Reports. Report 000315, 1964.

WILHELM, William E. Agricultural education development in Argentina and Chile. Ford Foundation Catalogued Reports. Report 002626, 1964.

SIMKINS, C.A. Progress Report. Minnesota Agricultural Extension Project in Chile. October 1, 1964 - September 30, 1965. Ford Foundation Catalogued Reports. Report 001703, 1965.

BODDY, Francis; KINGSLEY, James M.; McDIARMID, E.W.; MORSE, H. T. Report of visit to the University of Concepcion, Chile, by a Special Team from University of Minnesota (November 10 to December 5, 1964). Ford Foundation Catalogued Reports. Report 000110, 1965. 000045,1965

LAIRD, William J. Report on visit to Chile, March $24^{\text {th }}-$ April $5^{\text {th }}, 1965$. Ford Foundation Catalogued Reports. Report

FISCHLER, Abraham S. Visit to Chile April 19-30 th. Educational Planning Commission efforts. Ford Foundation Catalogued Reports. Report 000064, 1965.

COCHRANE, Willard W. University of Minnesota Agriculture Extension and Education Project in Chile, 1966-67: proposed work plan and budget. Ford Foundation Catalogued Reports. Report 001697, 1966.

HOWARD, John \& MARRYMANN, John. Report on Howard-Merryman visit to Chile. Ford Foundation Catalogued Reports. Report 000234, 1966.

QUEENAN, Bernard P. Visit to Chile 23 ${ }^{\text {rd }}$ April-15 th May 1967. Letters addressed to John P. Netherton, Ford Foundation representative in Chile \& Confidential Annex. Centre for Educational Television Overseas (CETO). Ford Foundation Catalogued Reports. Report 001921, 1967.

COLLINS, Norman \& VALDÉS, Alberto. The Chilean agricultural economy. Prepared for the workshop on Latin American Agricultural Development, sponsored by the Agricultural Development Council of Ford Foundation, Cuernavaca, México, July 25-27, 1967. Ford Foundation Catalogued Reports. Report 002936, 1967.

NETHERTON, John. University of Chile - University of California Collaboration. Ford Foundation Catalogued Reports. Report 004824, 1968.

NETHERTON, John. The case of Chile-California Program. In: International Division Conference. Ford Foundation

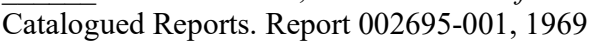

BELL, Peter D. The first year of the transition towards socialism in Chile. Ford Foundation Catalogued Reports. Report 011601, 1971.

VALDES, Alberto. The transition to socialism: observations on Chilean agriculture. Ford Foundation Seminar on Rural Development and Employment, Ibadan, Nigeria. Ford Foundation Catalogued Reports. Report 001275-020, 1973. 
. HAKIM, Peter. Education and transition to socialism in Chile. Foundation Catalogued Reports. Report 004055, 1973.

. HAKIM, Peter \& SOLIMANO, Giorgio. Supplemental Feeding as a Nutritional Intervention: the Chilean experience on the distribution of milk. MIT International Nutrition Planning Program. Discussion Papers n.2. Cambridge, 1975. Ford Foundation Catalogued Reports. Report 0002139, 1975.

ROCKEFELLER FAMILY PUBLIC RELATIONS DEPARTMENT, Chile Rural Education Project of the RBF. Series 13 (FA1193). Box 18, folder 108, 1964.

\section{The Convenio Archive, University of California, Davis}

AGRICULTURAL SUBCOMMITTEE. Minutes of the meeting. The Convenio Archive (box 1, AR 01-05). Shields Library Special Collections. University of California, Davis, 1966.

ALLEN, M.W. \& NOFFSINGER, E.M. Final Report. Nematology Investigation in Chile. The Convenio Archive (box 1, AR 01-02). Shields Library Special Collections. University of California, Davis, 1969.

. Los nematodos, factor limitante en la producción de cítricos. El Mercurio, 17/12/1968. The Convenio Archive (box 1, AR 01-02). Shields Library Special Collections. University of California, Davis, 1968.

ALLEN, Merlin. Los nematodos, factor limitante de la producción de citrus. El Mercurio, 17/12/1968. The Convenio Archive (box 1, AR 01-02). Shields Library Special Collections. University of California, Davis, 1968.

ALLEN, M.W., NOFFSINGER, E.M., VALENZUELA, A., SÁNCHEZ, L., LIZANA, A. Control of citrus nematode (Tylenchulus semipenetrans) on living lemon trees. Nematology Project - Chile. The Convenio Archive (box 1, AR 01-02). Shields Library Special Collections. University of California, Davis, 1968-1969.

BARNES, M. M. Statement of M. M. Barnes to Agricultural Sciences Subcommittee UC-UC Ford Foundation Program, August, 5th, 1969 [classified]. The Convenio Archive (box 1, AR 01-06). Shields Library Special Collections. University of California, Davis, 1969.

BENNET, C.W., HILLS, F.J., EHRENFELD, R., VALENZUELA, J., KLEIN, C. Yellow wilt of sugar beet. Journal of American Society of Sugar Beet Technologists. The Convenio Archive (box 1, AR 01-03). Shields Library Special Collections. University of California, Davis, 1967.

BRINGHURST, R.S., Final Report Projects CC 2458, CC 2459, CC 2460. Department of Pomology, UCD. July, 1,1967 June, 30, 1968. The Convenio Archive (box 1, AR 01-04). Shields Library Special Collections. University of California, Davis, 1968.

. Fruticulture. The Convenio Archive (box 1, AR 01-06). Shields Library Special Collections. UC, Davis, 1968.

BURNS, Michael. Political Atmosphere in Chile in Relation to Agricultural Development. The Convenio Archive (box 1, AR 01-05). Shields Library Special Collections. University of California, Davis.

CARROL, F., PORTE, E., HAARDT, E., GODOY, M., ROBB, J., TORELL, D., GARCIA, Ximena, CASTELLANO, H. The Efficiency of utilization of land and feed resources for livestock production in Chile. The Convenio Archive (box 1, AR 0106). Shields Library Special Collections. UC, Davis, 1968.

CHANCELLOR, William J. Preface. Agricultural Education, Research and Extension in Chile. International Agricultural Development. The Convenio Archive (box 1, AR 01-01). Shields Library Special Collections. University of California, Davis, 1965.

ENGLISH, W. H. Plant Pathology Program. The Convenio Archive (box 1, AR 01-03). Shields Library Special Collections. University of California, Davis, 1967.

., MOLLER, J.W., NOME, S.F. New records of fungus diseases of fruit crops in Chile. Plant Diseases Reporter, v.. 51, n. 3, 1967. The Convenio Archive (box 1, AR 01-03). Shields Library Special Collections. University of California, Davis, 1967.

., TORRES, Adriana P., KIRK, Joyce. Reconocimiento de especies del género Monilinia em frutales de carozo y en trembrillo de flor en Chile. Revista Agricultura Técnica, v. 29, n 2. The Convenio Archive (box 1, AR 01-03). Shields Library Special Collections. University of California, Davis, 1966.

., O'REILLY, H.J. Investigation of fungus and bacterial disease of deciduous fruits (1967-1968). The Convenio Archive (box 1, AR 01-06). Shields Library Special Collections. UC, Davis, 1968.

HAGAN, R. M. Summary Minutes. Agriculture and Veterinary Medicine Subcommittee Meeting, Jan 1st, 1968. The Convenio Archive (box 1, AR 01-05). Shields Library Special Collections. University of California, Davis, 1968.

HARDIN, Charles M. A proposal for a Foreign Service Faculty centered in The College of Agriculture of The University of California [Preliminary - Comments Welcome]. The Convenio Archive (box 1, AR 01-05). Shields Library Special Collections. University of California, Davis, s/d. 
The idea of an International Service Faculty. The Convenio Archive (box 1, AR 01-05). Shields Library Special Collections. University of California, Davis, 1966.

HART, W.H., NOFFSINGER, E.M., ALLEN, M.W. Nematode investigations in Chile. The Convenio Archive (box 1, AR 0106). Shields Library Special Collections. UC, Davis, 1968.

HESSE, Claron. Nursery and Varietal Improvement. 1968-1969 Annual Report, Project CC 2458. The Convenio Archive (box 1, AR 01-04). Shields Library Special Collections. University of California, Davis, 1969.

. Orchard Soil Management. 1968-1969 Annual Report, Project CC 2459. The Convenio Archive (box 1, AR 01-04). Shields Library Special Collections. University of California, Davis, 1969.

Progress Report. Pomology in Chile. Jan/1967, Jan/1968, Aug/1968-Jul/1969, April-May/1979. The Convenio Archive (box 1, AR 01-04). Shields Library Special Collections. University of California, Davis.

. Report on a trip to Chile. UC-UC Program. Jan. 5th to Jan. 30th, 1967. The Convenio Archive (box 1, AR 01-05). Shields Library Special Collections. University of California, Davis, 1967.

HILLS, F. J. Investigación, aplicación y extensión. La clave para mejorar la producción remolachera. Boletin Remolachero, IANSA, v. 10, n.31, The Convenio Archive (box 1, AR 01-03). Shields Library Special Collections. University of California, Davis, 1966.

KIDO, H., HUGUES:, MARIN, A. A study of the biology and control of Margarodes vitium Girad. Sep. 15, 1967 - Feb. 8, 1968. The Convenio Archive (box 1, AR 01-06). Shields Library Special Collections. UC, Davis, 1968.

LEWIS, David C. The case against institutional involvement of the University of California in foreign agricultural research. The Convenio Archive (box 1, AR 01-05). Shields Library Special Collections. University of California, Davis.

MITCHELL, F.G. Report on a trip to Chile, UC-UC Program, Feb. 16th to Mar. 18th, 1967. The Convenio Archive (box 1, AR 01-05). Shields Library Special Collections. University of California, Davis, 1967.

NOME, S. F., LEACH, L.D., Progress Report. Plan Pathology Program. The Convenio Archive (box 1, AR 01-03). Shields Library Special Collections. University of California, Davis, 1967.

NYLAND, G., KRAUSE, R., OCHOA, M., LEGARRAGA, M. Virus Diseas of Stone and Pome Fruits and Nursery Improvement Program. The Convenio Archive (box 1, AR 01-06). Shields Library Special Collections. UC, Davis, 1968.

O'REILly, H. J., KIRK, Joyce, KRAUSE, R., GONZALEZ, R., CAMPOS, L., NOME, F., TORRES, Adriana P., LEGARRAGA, M., LIZANA, A. KOCHER, F., FRITCH, N. Investigation of Fungues and Bacterial Diseases of Deciduous Fruits. Annual Report. UCD, July-Nov/1968. The Convenio Archive (box 1, AR 01-03). Shields Library Special Collections. University of California, Davis, 1968.

PHILLIPS, Allan. Agricultural Research. International Agricultural Development. The Convenio Archive (box 1, AR 01-01). Shields Library Special Collections. University of California, Davis, 1965.

PLATT, R.G. Report of Citrus and Avocado Culture in Chile, UC-UC Program, Jan. 8th to Feb. 3rd, 1967. The Convenio Archive (box 1, AR 01-05). Shields Library Special Collections. University of California, Davis, 1967.

RYUGO, Kay. Final Report CC 2458, CC 2459, CC 2460. The Convenio Archive (box 1, AR 01-04). Shields Library Special Collections. University of California, Davis, 1967.

\& HESSE, C.O. Research Project. The Convenio Archive (box 1, AR 01-05). Shields Library Special Collections. University of California, Davis.

SCHULTZ, Thomas. Agricultural Education. International Agricultural Development. The Convenio Archive (box 1, AR 0101). Shields Library Special Collections. University of California, Davis, 1965.

SEM AUTOR. Project CC 2460, Progress report F. Cordon Meyer. The Convenio Archive (box 1, AR 01-04). Shields Library Special Collections. University of California, Davis, 1967.

SEM AUTOR, A request submitted to the Ford Foundation for a continuation of funding for the UC-UC cooperative program for the period from April, 1st, 1968 to June, 30, 1970. The Convenio Archive (box 1, AR 01-05). Shields Library Special Collections. University of California, Davis, 1968.

SCHLINGER, Evert I. Studies in neotropical agroceridae, part 1. The Convenio Archive (box 1, AR 01-02). Shields Library Special Collections. University of California, Davis, 1967.

TIMM, David. Agricultural Extension. International Agricultural Development. The Convenio Archive (box 1, AR 01-01). Shields Library Special Collections. University of California, Davis, 1965.

THE CONVENIO. 1965-1967 Annual Report. University of California - Universidad de Chile. The Convenio Archive (box 1). Shields Library Special Collections. University of California, Davis.

1969-1970 Annual Report. University of California - Universidad de Chile. The Convenio Archive (box 1). Shields Library Special Collections. University of California, Davis. 
1970-1971 Annual Report. University of California - Universidad de Chile. The Convenio Archive (box 1). Shields Library Special Collections. University of California, Davis.

1971-1972 Annual Report. University of California - Universidad de Chile. The Convenio Archive (box 1). Shields Library Special Collections. University of California, Davis.

1972-1973 Annual Report. University of California - Universidad de Chile. The Convenio Archive (box 1). Shields Library Special Collections. University of California, Davis.

. 1973-1974 Annual Report. University of California - Universidad de Chile. The Convenio Archive (box 1). Shields

Library Special Collections. University of California, Davis.

.1974-1975 Annual Report. University of California - Universidad de Chile. The Convenio Archive (box 1). Shields

Library Special Collections. University of California, Davis.

UC \& UC. A proposal for education and research program between the University of Chile and the University of California presented to Ford Foundation. The Convenio Archive (box 1, AR 01-05). Shields Library Special Collections. University of California, Davis, 1965.

UC-UC, Study Committee. Commission of agricultural sciences. The Convenio Archive (box 1, AR 01-05). Shields Library Special Collections. University of California, Davis, 1964.

URIU, K. Notes from verbal report of Dr. K. Uriu to D.S. Brown on Uriu's visit to Chile in November (1966). The Convenio Archive (box 1, AR 01-05). Shields Library Special Collections. University of California, Davis, 1966.

WEATHERS, L.G., SANCHEZ, L. Distribution of tristeza virus in commercial trees in Chile. 1968-1969 Annual Report. The Convenio Archive (box 1, AR 01-03). Shields Library Special Collections. University of California, Davis, 1969.

La amenaza de la tristeza de los cítricos em Chile. In. Revista Agricultura Técnica, v.30, n.3, s/d. The Convenio

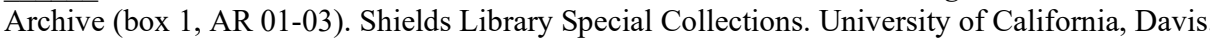

. Tristeza Disease of Citrus in Chile. Plant Disease Reporter, v. 54, n. 7, July/1970. The Convenio Archive (box 1, AR 01-03). Shields Library Special Collections. University of California, Davis, 1970.

. Naturaleza y distribución de las enfermedades virosas de cítricos en Chile. Revista Agricultura Técnica, v. 29, n` 4,

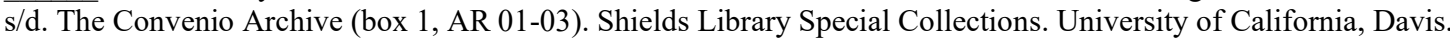

\section{Governo do Chile}

CHILE. Orden Ministerial $N^{\circ} 34$ sobre Organización Sindical en los Campos. Santiago, 28/03/1939.

. Ley 8.811. Agrega disposiciones al Código del Trabajo, relativas a la organización sindical de los obreros agrícolas. Santiago, 29/07/1947.

. Ley $n^{\circ} 16.625$ de Sindicación Campesina. Santiago, 29/04/1967a.

. Ley $n^{\circ} 16.640$ de Reforma Agraria. Santiago, 28/07/1967b.

. História de la Ley $n^{\circ}$ 16.640. Biblioteca del Congreso Nacional de Chile, 1965-1967.

. Decreto con Fuerza de Ley $n^{\circ} 6$ sobre el Fondo de Educación Sindical. Santiago, 12/01/1968.

. Decreto con Fuerza de Ley $n^{\circ} 16$ sobre las Sociedades Agrícolas de Reforma Agraria, Santiago, 31/10/1968.

. Decreto $n^{\circ}$ 481. Crea el Consejo Nacional Campesino. Santiago, 21/12/1970.

. Informe de la Comisión Nacional de Verdad y Reconciliación. Informe Rettig, 1990.

. Informe de la Comisión Nacional sobre Prisión Política y Tortura. Informe Valech 1, 2005.

. Informe de la Comisión Presidencial Asesora para la Calificación de Detenidos Desaparecidos, Ejecutados

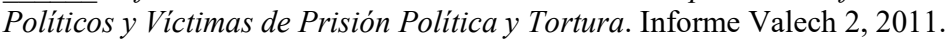

\section{Publicações do sistema ONU}

CIDA, Tenencia de la Tierra y desarrollo socio-económico del sector agrícola. Santiago: CIDA, 1966.

FAO, El rol del la FAO em la reforma agraria chilena. Santiago: FAO, 2017.

OEA, Carta de Punta del Este. OEA: Punta del Este, 1961.

\section{Truman Library}


Harry S. Truman, Inaugural Address. Public Papers, Harry S. Truman. Truman Library, January 20th, 1949. Disponível em: https://www.trumanlibrary.org/publicpapers/index.php?pid=1030 Último acesso: 02 dez. 2018.

Special Message to the Congress Recommending Point 4 Legislation. Public Papers, Harry S. Truman. Truman Library, June 24th, 1949b. Disponível em: https://www.trumanlibrary.org/publicpapers/index.php?pid=1156 Último acesso:02 dez. 2018.

Point Four Information Service. Memorandum. Report of Meeting, Point Four Committee. Pennsylvania, Washington D.C,

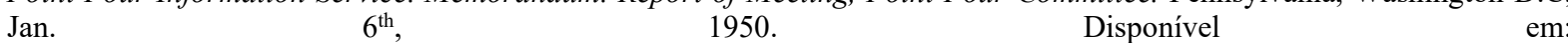
https://www.trumanlibrary.org/whistlestop/study collections/pointfourprogram/documents/B28 $08-06$ 01.jpg Último acesso: 02 dez. 2018

\section{JFK Library}

John F. Kennedy, Inaugural Address, January 20th, 1961. Disponível em: https://www.jfklibrary.org/learn/about-jfk/jfk-inhistory/alliance-for-progress Último acesso: 01 abr. 2019.

Alliance for Progress: Speeches by Teodoro Moscoso, U.S. Coordinator, Alliance for Progress. James S. Bradshaw Personal Papers. JSBPP-001-007-p0002. July $19^{\text {th }}, 1962$ - February, 17 ${ }^{\text {th }}, 1964$. Disponível em: https://www.jfklibrary.org/assetviewer/archives/JSBPP/001/JSBPP-001-007 . Último acesso: 31 jan. 2021.

\section{Autobiografias e memórias}

CAMPUSANO, José A. Sembrando horizontes. Valparaíso: Ediciones Horizontes, 2013.

CORONA, Juan Chacón. El despertar campesino. REF. INCOMPLETA.

DEGEN, Pedro Cardyn. Sangre de baguales. Epopeyas mapuches y obreras en tiempos del Complejo Maderero de Panguipulli. Un efecto mariposa inconcluso. Santiago: Lom, 2017.

DÍAZ, Juan Chacón. Hasta aquí no más llegó su patrón. REF. INCOMPLETA.

MARÍN, Gustavo. Relatos intimos de José Peralta. São Paulo: Escrituras, 2003.

REBOLLEDO, Julían Bastías. Memorias de la lucha campesina. Cristiano, mestizo y tomador de fundo. $1^{\mathrm{a}}$ ed. Santiago: Lom, 2009.

. Memorias de la lucha campesina. Mapuches, mestizos y estudiantes $1^{\mathrm{a}}$ ed. Santiago: Lom, 2016.

ZUÑIGA, Aldo; NARVÁEZ, Afonso; POZO, Antonio; RAMOS, Boris; CASTRO, Héctor; HERREROS, Javier; GALICIA, Jorge; RODRIGUEZ, Marcela; LOBOS, Mario; LEPE, Nancy; DELAHAYE, Olivier; PINO, Osvaldo; GARRIDO, Pablo; DROGUETT, Ramiro; SAIEG, Ramós; RODRIGUEZ, Sonia. Un remezón a la memoria. La reforma agraria en Aconcagua y Valparaíso Chile 1967-1973. Experiencias y anécdotas de quienes trabajaron en ella, en la hoy V Región. San Felipe: Edición Independiente por los autores, 2008. 


\section{Entrevistas}

AUSTIN, Robert (org.). Diálogos sobre Estado y educación popular en Chile: de Frei a Frei (1964-1993). Santiago: CECATP, 2004.

\begin{tabular}{|c|c|c|c|c|}
\hline \multicolumn{2}{|c|}{ ENTREVISTADO } & IDENTIFICAÇÃO & DATA & $\begin{array}{l}\text { COMUNA, } \\
\text { REGIÃO }\end{array}$ \\
\hline 1 & Jacques Chonchol & $\begin{array}{l}\text { Vice-Presidente do INDAP (1965-1969) } \\
\text { e Ministro da Agricultura (1970-1972) }\end{array}$ & $\begin{array}{c}14-15 / 04 / 2016 \\
11 / 4 / 2017 \\
26 / 11 / 2018 \\
22 / 05 / 2019\end{array}$ & Santiago \\
\hline 2 & Gustavo Marín & Dirigente do MIR Lautaro & $20 / 4 / 2017$ & Santiago \\
\hline 3 & Oscar Torres & $\begin{array}{l}\text { Chefe de Gabinete do FEES (1967- } \\
\text { 1973) }\end{array}$ & $\begin{array}{l}21 / 4 / 2017 \\
26 / 05 / 2019\end{array}$ & Santiago, Maipo \\
\hline 4 & Sergio Gómez & $\begin{array}{l}\text { Sociólogo, agrônomo. Foi militante do } \\
\text { MAPU e funcionário da ODEPA }\end{array}$ & $21 / 4 / 2017$ & Santiago \\
\hline 5 & Martim Vasquez & Camponês e dirigente da CONAPROCH & $28 / 4 / 2017$ & Santiago \\
\hline 6 & Leonel Abarca & Camponês e dirigente da Ranquil & $2 / 5 / 2017$ & Santiago \\
\hline 7 & José Bengoa & $\begin{array}{c}\text { Historiador agrário, editou a Revista } \\
\text { Agraria do Chile Hoy }\end{array}$ & $4 / 5 / 2017$ & Santiago \\
\hline 8 & Mario Garcés & Historiador social & $9 / 5 / 2017$ & Santiago \\
\hline 9 & $\begin{array}{c}\text { Francisca Rodriguez } \\
\text { Huerta }\end{array}$ & $\begin{array}{c}\text { Militante do PC, dirigente da } \\
\text { ANAMURI }\end{array}$ & $14 / 5 / 2017$ & Santiago \\
\hline 10 & Camila Montecinos & Agrônoma e dirigente da ANAMURI & $14 / 5 / 2017$ & Santiago \\
\hline 11 & Alice Muñoz & Camponesa e dirigente da ANAMURI & $14 / 5 / 2017$ & Santiago \\
\hline 12 & Hugo Cumsille & Ex-funcionário da CORA & $16 / 5 / 2017$ & Santiago \\
\hline 13 & Juan Aedo & Ex-funcionário da CORA & $31 / 5 / 2017$ & Santiago \\
\hline 14 & Victor Yáñez & $\begin{array}{c}\text { Ex-militante da FER-MIR, alfabetizador } \\
\text { camponês }\end{array}$ & $19 / 5 / 2017$ & San Carlos, Bio Bio \\
\hline 15 & Carlos Contreras & Ex-funcionário da CORA & $21 / 5 / 2017$ & $\begin{array}{l}\text { Los Angeles, Bio } \\
\text { Bio }\end{array}$ \\
\hline 16 & Octavio Fritz & Ex-funcionário da CORA & $21 / 5 / 2017$ & Negrete, Bio Bio \\
\hline 17 & Miguel Mattus & Ex-funcionário da CORA & $21 / 5 / 2017$ & Negrete, Bio Bio \\
\hline 18 & Guillermo Carrasco & Ex-assentado & $21 / 5 / 2017$ & Negrete, Bio Bio \\
\hline 19 & Manuel Torres & Ex-funcionário da CORA & $22 / 5 / 2017$ & $\begin{array}{l}\text { Los Angeles, Bio } \\
\text { Bio }\end{array}$ \\
\hline 20 & Ovídio Diaz Diaz & $\begin{array}{l}\text { Camponês de fazenda não expropriada, } \\
\text { parcelero }\end{array}$ & $27 / 5 / 2017$ & $\begin{array}{l}\text { San Clemente, } \\
\text { Maule }\end{array}$ \\
\hline 21 & $\begin{array}{c}\text { Manuel José Herrera } \\
\text { Castro } \\
\end{array}$ & $\begin{array}{l}\text { Professor de camponeses, militante do } \\
\text { PC. }\end{array}$ & $27 / 5 / 2017$ & $\begin{array}{l}\text { San Clemente, } \\
\text { Maule } \\
\end{array}$ \\
\hline 22 & $\begin{array}{c}\text { Andrés Pascal } \\
\text { Allende } \\
\end{array}$ & Ex-dirigente do MIR & $16 / 6 / 2017$ & Santiago \\
\hline 23 & Arnaldo Cáceres & Ex-dirigente do ICIRA & $29 / 6 / 2017$ & Santiago \\
\hline 24 & Maria Elena Cruz & Economista e ex-funcionária da ODEPA & $29 / 6 / 2017$ & Santiago \\
\hline 25 & Patricio Palma & Diretor da DIRINCO (1971-1973) & $29 / 6 / 2017$ & Santiago \\
\hline 26 & Oscar Valladares & Camponês e dirigente da UOC & $30 / 6 / 2017$ & Santiago \\
\hline 27 & Brian Loveman & $\begin{array}{c}\text { Cientista Político (EUA), Peace Corps no } \\
\text { Chile }\end{array}$ & 03/11/2017 & Solana Beach (CA) \\
\hline 28 & Almino Affonso & $\begin{array}{c}\text { Ex-Ministro do Trabalho do Jango e } \\
\text { pesquisador do ICIRA }\end{array}$ & 07/08/2018 & São Paulo \\
\hline 29 & Zilah Branco & $\begin{array}{c}\text { Simpatizante do PCB e ex-funcionária } \\
\text { do ICIRA }\end{array}$ & Out.-Nov./2018 & Por email \\
\hline 30 & Carmen Aguayo & $\begin{array}{c}\text { Socióloga no INDAP (1964-1968), ex- } \\
\text { MAPU }\end{array}$ & $28 / 11 / 2018$ & Santiago \\
\hline
\end{tabular}




\begin{tabular}{|c|c|c|c|c|}
\hline 31 & Marcela Gajardo & $\begin{array}{c}\text { Socióloga e educadora do ICIRA, equipe } \\
\text { Paulo Freire }\end{array}$ & $29 / 11 / 2018$ & Santiago \\
\hline 32 & Jaime Gazmuri & $\begin{array}{c}\text { Agrônomo, PS, ex-dirigente da CORA, } \\
\text { ex-MAPU }\end{array}$ & $18 / 12 / 2018$ & Santiago \\
\hline 33 & Liliana Barria & Socióloga, trabalhou no INDAP e ICIRA & $15 / 12 / 2018$ & Santiago \\
\hline 34 & $\begin{array}{c}\text { Rolando Pinto } \\
\text { Contreras }\end{array}$ & $\begin{array}{c}\text { Pedagogo, trabalhou na equipe de Paulo } \\
\text { Freire, ICIRA, CNCT, ex-militante do } \\
\text { MAPU }\end{array}$ & $\begin{array}{c}11 / 12 / 2018, \\
23 / 05 / 2019\end{array}$ & Santiago \\
\hline 35 & Maria Emilia Palma & $\begin{array}{c}\text { Socióloga, trabalhou na CORA e no } \\
\text { FEES }\end{array}$ & $26 / 05 / 2019$ & Maipo \\
\hline 36 & Rogelio Correa & $\begin{array}{c}\text { Ex-professor do IER e da CORA, } \\
\text { militante do MAPU, equipe Paulo Freire. }\end{array}$ & $30 / 05 / 2019$ & Santiago \\
\hline
\end{tabular}

